
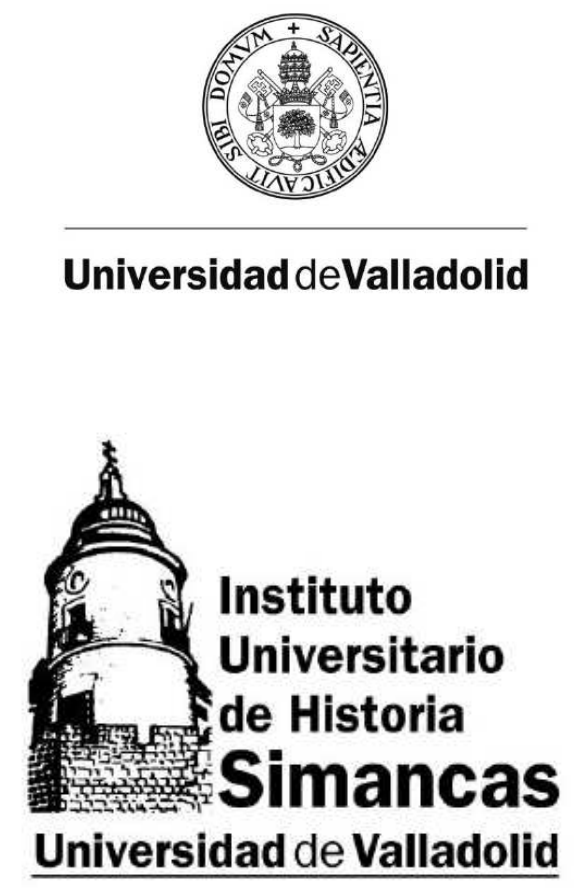

\title{
TERRITORIO, SOCIEDAD Y CONFLICTOS EN EL TRÁNSITO HACIA LA MODERNIDAD \\ La Ribera del Duero burgalesa a finales de la Edad Media
}

Jesús G. Peribáñez Otero

TESIS DOCTORAL

Dirigida por:

María Isabel del Val Valdivieso

\author{
VALLADOLID \\ 2013
}





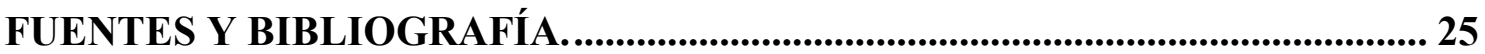

1. FUENTES ARCHIVÍSTICAS.......................................................................... 27

2. FUENTES IMPRESAS............................................................................................ 29

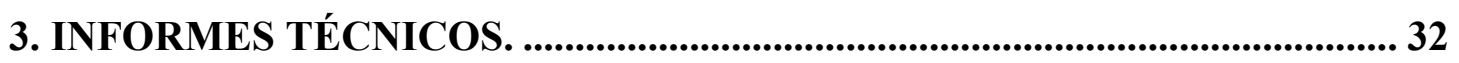

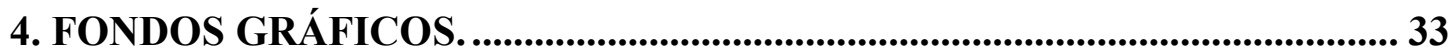

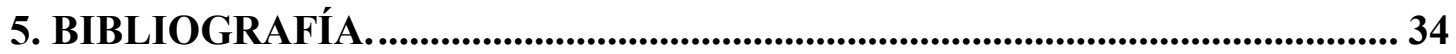

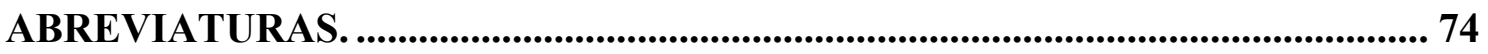

I. LA CONFIGURACIÓN DE UN ESPACIO FEUDAL................................... 75

1. PUNTO DE PARTIDA: EL MEDIO NATURAL DE LA RIBERA DEL

DUERO BURGALESA. .............................................................................................. 77

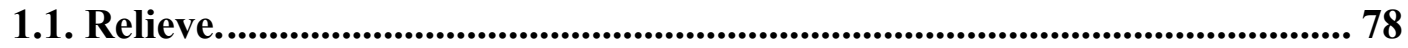

1.1.1. Geología y principales elementos del relieve........................................... 78

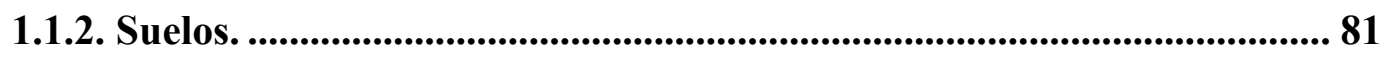

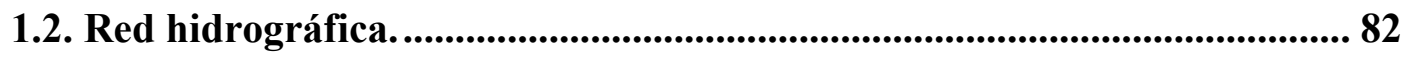

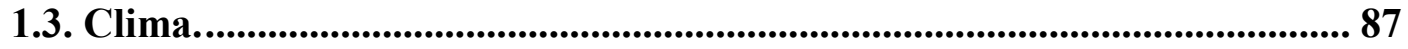

1.4. Vegetación. .................................................................................................................... 90

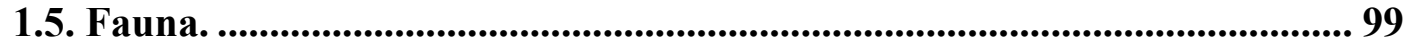

2. LA TRANSFORMACIÓN DEL ESPACIO NATURAL: LA

CONFIGURACIÓN DEL ESPACIO RURAL FEUDAL HASTA LA BAJA

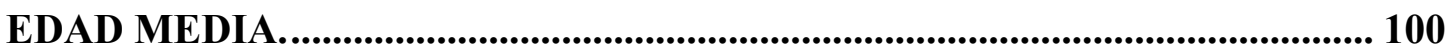

2.1. Poblamiento de la Ribera del Duero en la Alta Edad Media. ................. 102

2.2. Poblamiento Plenomedieval................................................................................ 111

2.3. La crisis del siglo XIV. ......................................................................................... 113

2.4. La recuperación del siglo XV .................................................................... 119

3. EL ESPACIO URBANO: LA VILLA DE ARANDA A FINALES DE LA

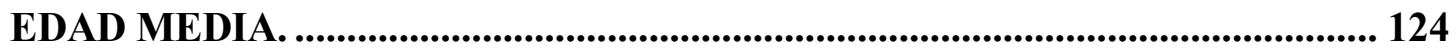

3.1. La configuración del espacio urbano medieval............................................ 125

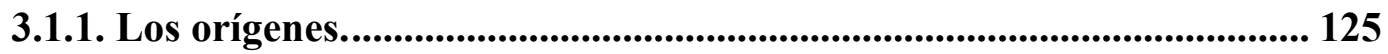


3.1.2. EI núcleo urbano del siglo XIII. ........................................................... 130

3.1.3. El estancamiento del siglo XIV .................................................................. 139

3.1.4. La gran expansión urbana del siglo XV ........................................... 143

3.2. La estructura urbana a finales de la Edad Media...................................... 146

3.2.1. La muralla: cerca, cavas y puertas. .............................................................. 150

3.2.2. Morfología urbana........................................................................................ 165

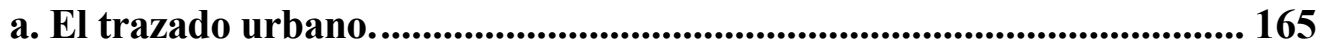

b. Las divisiones internas de la villa: cuadrillas, collaciones y barrios. .... 180

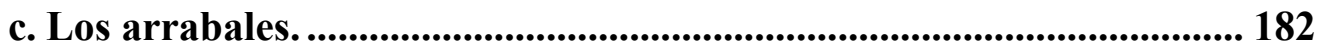

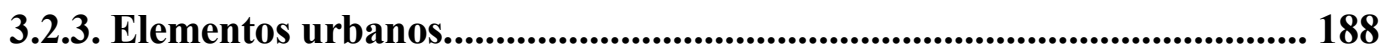

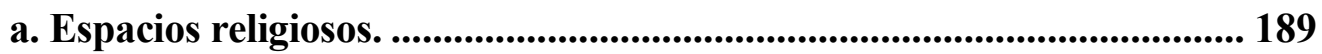

b. Espacios económicos......................................................................................... 206

c. Espacios residenciales: las viviendas........................................................ 222

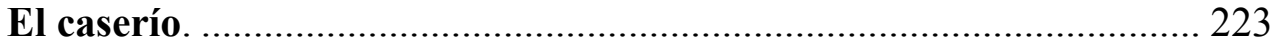

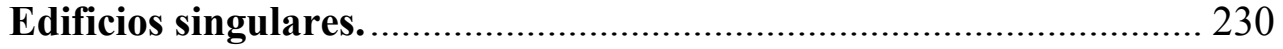

d. Espacios marginales. ......................................................................... 234

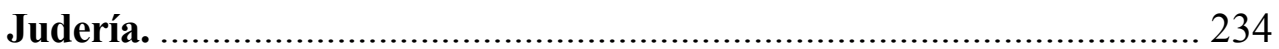

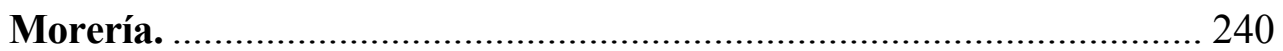

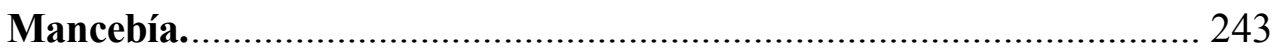

e. Dotaciones e infraestructuras urbanas. ..................................................... 245

Dotaciones sanitarias y educativas....................................................... 245

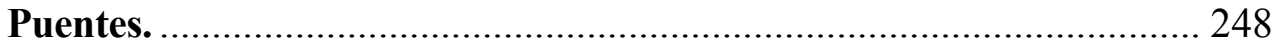

Abastecimiento y evacuación de aguas................................................. 253

3.2.4. El espacio periurbano: la Tierra de Aranda........................................... 262

3.3. La integración en el sistema urbano de la Castilla Septentrional. ............. 267

3.3.1. Factores que explican el desarrollo urbano de Aranda......................... 267

3.3.2. Indicadores del dinamismo urbano. ..................................................... 272

\section{LOS ACTORES POLÍTICOS EN LA_RIBERA DEL DUERO A FINALES}

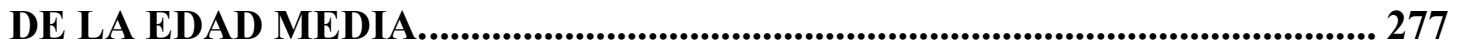

1. LA AUTORIDAD REAL. ............................................................................... 281

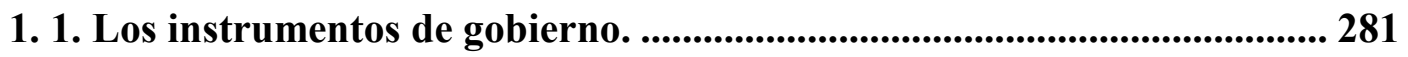

1.1.1. El orden y la justicia: la Santa Hermandad y el Corregimiento........ 282 
a. La Santa Hermandad. ..................................................................... 282

b. El Corregimiento de Aranda de Duero. .............................................. 286

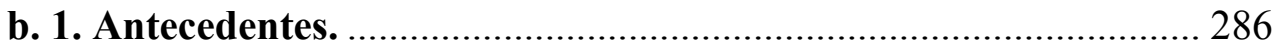

b. 2. La implantación del Corregimiento en Aranda........................... 289

b. 3. La proyección del corregidor sobre la comarca ribereña.............. 294

1.1.2. La Hacienda Real. .................................................................................... 297

1.1.3. La uniformidad religiosa: el Tribunal de la Inquisición en la Ribera302

1. 2. Relaciones con los distintos poderes del reino. ......................................... 305

2. LA VILLA DE ARANDA DE DUERO .............................................................. 308

2. 1. Realengo y enajenaciones.......................................................................309

2. 2. El concejo: el regimiento y los oficiales concejiles................................. 315

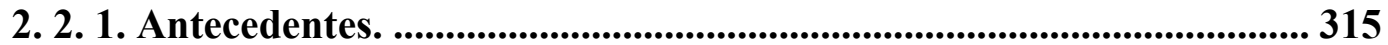

2. 2. 2. La implantación del regimiento en Aranda y la tradición foral. ..... 317

2.2.3. La reforma del Regimiento en el reinado de los Reyes Católicos. ..... 321

2.2.4. Funcionamiento y características del concejo......................................... 328

a. Funcionamiento del concejo. ............................................................... 328

b. La participación del Común en el ejercicio del poder. ......................... 340

c. Injerencia nobiliaria. ....................................................................... 344

2.3. Oligarquía y Comunidad............................................................................. 347

2.3.1. Oligarquía y linajes. ..................................................................................... 348

a. El origen de los linajes en Aranda de Duero.......................................... 348

b. Las principales familias de la oligarquía arandina............................... 356

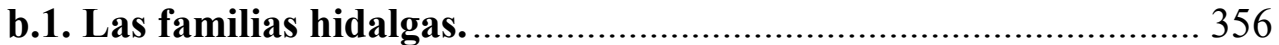

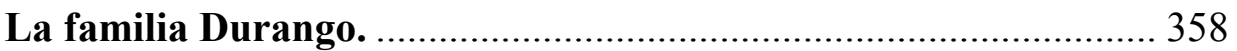

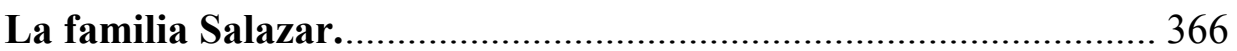

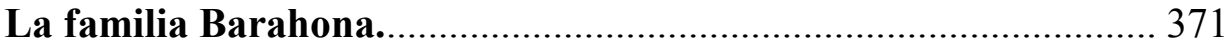

La familia Mora-Aranda. ............................................................. 373

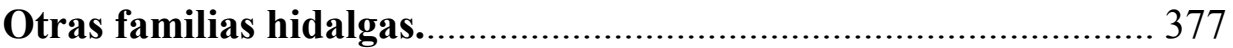

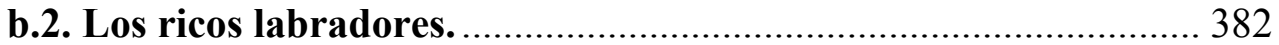

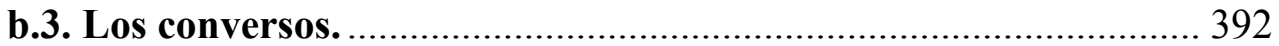

2.3.2. La Comunidad. .......................................................................................... 408

a. El concepto de Comunidad..................................................................409

b. La gran diversidad de la Comunidad........................................................ 412 
c. Corporativismo y solidaridad: gremios y cofradías. ............................ 423

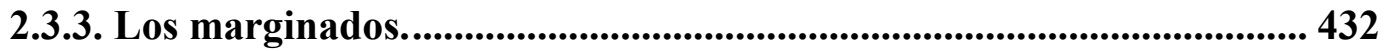

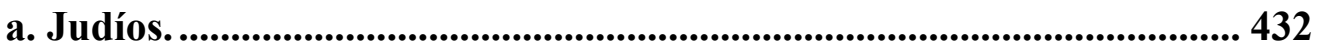

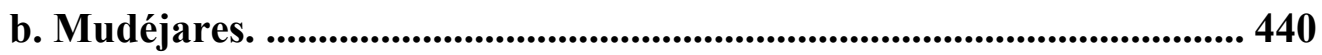

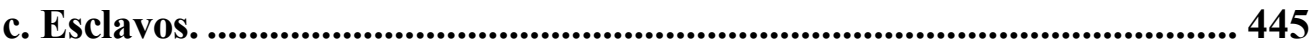

3. LA NOBLEZA...................................................................................................... 447

3. 1. Consolidación territorial de los grandes señores..................................... 448

3. 2. Las grandes familias nobiliarias de la comarca....................................... 452

3. 2. 1. Linaje Zúñiga y Avellaneda: Condes de Miranda............................. 453

3. 2. 2. Linaje Sandoval y Rojas: Marqueses de Denia.................................. 483

3. 2. 3. Linaje de la Cueva: duques de Alburquerque y condes de Siruela. 493

3. 2. 4. Linaje Téllez-Girón: Condes de Urueña. .............................................. 504

3. 2. 5. Linaje Suárez Figueroa y Mendoza: Condes de Coruña................... 517

3. 3. El papel de la pequeña nobleza. ..................................................................... 523

3. 3. 1. La familia Acuña. ...........................................................................524

3. 3. 2. La familia Avellaneda, señores de Valverde. ................................... 535

3. 3. 3. La familia Álvarez Delgadillo, señores de Castrillo. ......................... 538

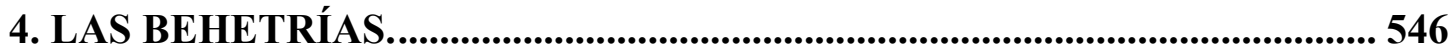

5. LAS INSTITUCIONES RELIGIOSAS. .......................................................552

5. 1. El obispado de Osma: la configuración del sistema diocesano y la red parroquial............................................................................................................................ 553

5. 1. 1. Los orígenes................................................................................................... 553

5. 1. 2. La organización de la Diócesis de Osma............................................... 561

5. 1. 3. Actividad pastoral y religiosidad. ................................................ 565

5. 2. Las órdenes regulares...................................................................... 575

5. 2. 1. Monasterio de Santa María de la Vid............................................. 576

5. 2. 2. Monasterio de San Pedro de Gumiel de Izán........................................ 581

5. 2. 3. Convento de Santo Domingo de Caleruega............................................. 590

5. 2. 4. Convento Domus Dei de La Aguilera. .................................................. 598

5. 2. 5. Convento de San Francisco de Aranda. ..............................................607 607

5. 2. 6. Convento de Santa Isabel o de las Antonias......................................... 616 
III. LOS CONFLICTOS 621

1. LA RIBERA DEL DUERO BURGALESA COMO ESCENARIO DEL

CONFLICTO CIVIL: RECONOCIMIENTO DE LA AUTORIDAD REAL .. 627

2. CONFLICTOS DE CARÁCTER ECLESIÁSTICO Y RELIGIOSO. ........... 638

2. 1. Enfrentamientos entre la jurisdicción regia y la eclesiástica................... 639

2. 2. Conflictividad en el seno de las instituciones religiosas. .......................... 645

2.2.1. Pugna por los beneficios eclesiásticos. ................................................ 645

2.2.2. La proyección reformista en las órdenes religiosas de la Ribera del

Duero burgalesa. 651

2.2.3. Problemas de competencia entre clero secular y regular. 656

2.3. Enfrentamientos derivados del control social de la Iglesia..................... 658

2. 4. Conflictos con las minorías religiosas. ................................................665

2.4.1. Evidencias de violencia contra la comunidad judía. ............................ 665

2.3.2. Conflictos con la comunidad mudéjar................................................... 673

3. EL PODER DE LA NOBLEZA COMARCANA.......................................... 676

3.1. La política expansiva de los grandes señores y los conflictos intranobiliarios 676

3.1.1. El enfrentamiento entre los linajes Sandoval y Téllez-Girón: la villa de Gumiel de Izán y el valle del Esgueva.

3.1.2. Las disputas entre los Zúñiga y los Acuña por el señorío de la villa de Hoyales y Fuentelisendo. 681

3.1.3. El conflicto por un río: los Zúñiga y su villa de La Aguilera contra los Sandoval y su villa de Gumiel del Mercado. 685

3.1.4. Quintanilla de Nuño Pedro y Alcubilla de Avellaneda. 688

3.2. Usurpación de bienes de la Iglesia. 690

3.2.1. Las pretensiones de la nobleza comarcana sobre el monasterio de San Pedro de Gumiel de Izán. 691

3.2.2. La proyección del linaje Zúñiga sobre Santa María de la Vid. 695

3.2.3. Otras agresiones de la nobleza comarcana sobre instituciones religiosas. 698

3.3. Apropiación de behetrías. 701

3.3.1. Hontoria de Valdearados. 701

3.3.2. Las otras behetrías. 702 
3.4. Presión señorial sobre sus vasallos y respuestas antiseñoriales. .............. 704

3.5. Balance: la realidad señorial en la Ribera del Duero burgalesa a principios del siglo XVI........................................................................................... 710

4. CONFLICTIVIDAD URBANA: LA VILLA DE ARANDA. ........................... 718

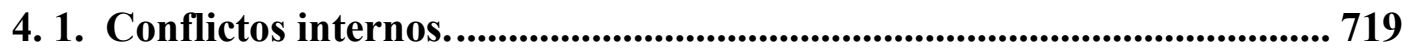

4. 1. 1. Conflictos entre los miembros de la clase dominante......................... 719

4. 1. 2. Enfrentamientos entre oligarquía y Comunidad................................ 724

a. Funcionamiento del concejo................................................................. 726

b. Aplicación de la justicia....................................................................... 732

c. Gestión de los ingresos concejiles........................................................ 735

d. Exención fiscal. ............................................................................................ 741

e. Regulación de la actividad económica. ..................................................... 745

f. Vinculación con los nobles comarcanos. .................................................... 758

4. 2. Conflictos externos. ......................................................................................... 763

4. 2. 1. La pretensión de expansión y hegemonía comarcal............................ 763

4. 2. 2. Injerencia de los poderes vecinos y conflictos.................................. 768

5. COLOFÓN: LAS COMUNIDADES.................................................................. 774

5. 1. Cambio de tendencia desde 1504.......................................................... 774

5. 2. El desarrollo del movimiento comunero en Aranda. ............................... 779

5. 2. 1. Antecedentes. .............................................................................................. 781

5. 2. 2. El estallido de la Revolución en Aranda............................................. 784

5. 2. 3. Los protagonistas......................................................................................... 785

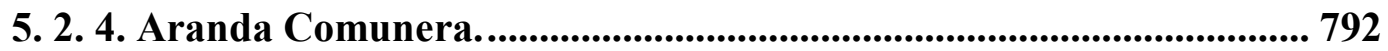

5. 2. 5. La represión. ................................................................................... 802

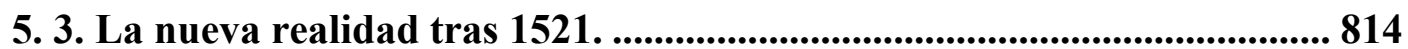

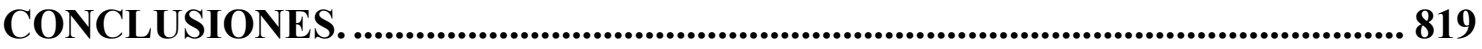

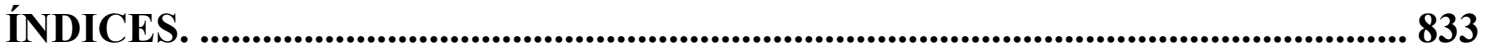

ÍNDICE TOPONÍMICO. .......................................................................................8 835

ÍNDICE DE CUADROS Y GRÁFICOS:...........................................................8 839

ÍNDICE DE IMÁGENES: ...................................................................................8 840

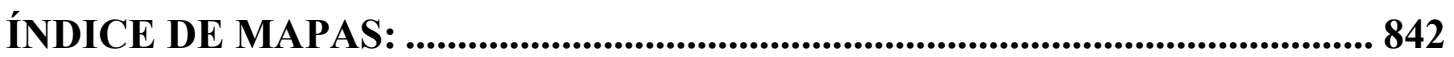

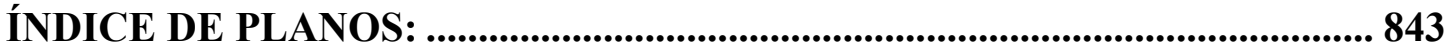


"Papa, explícame para qué sirve la historia”. Así interrogaba, hace algunos años, un muchachito allegado mío a su padre que era historiador. Me gustaría poder decir que este libro es mi respuesta. Porque no imagino mejor elogio para un escritor que saber hablar con el mismo tono a los doctos y a los alumnos. Pero tal sencillez es el privilegio de unos cuantos elegidos...

MARC BLOCH, Apología para la historia o el oficio de historiador. (1941-1949). 
A buen seguro que la princesa Isabel todavía recordaba en aquel otoño de 1473 sus frecuentes estancias años atrás en la tranquila y dinámica villa situada a las orillas del Duero. Sin embargo, a medida que se aproximaba a las primeras casas del arrabal meridional advirtió algunos indicios de los estragos provocados por un pasado cercano lleno de violencia e inestabilidad. En la mirada de los vecinos que salían a su encuentro también se percibía la esperanza y el anhelo de esa paz y tranquilidad que ella recordaba. Junto al puente le esperaba la comitiva encabezada por los cuatro ricos labradores que ostentaban aquel año el oficio de regidores. Aguardaban su llegada engalanados con sus mejores ropas para recibir a la nueva señora de la villa. Los regidores estaban escoltados por don Diego de Rojas y una amplia retahíla de hidalgos a su servicio, auténticos protagonistas del asalto violento que certificó la fidelidad de la villa a doña Isabel. Una vez realizado el protocolario juramento, princesa, corte, autoridades municipales y vecinos cruzaron el puente y franquearon la Puerta de Duero ${ }^{1}$.

Casi cinco décadas después, esta vez en primavera, el nieto de doña Isabel hizo su espectacular entrada en la villa ${ }^{2}$. Las autoridades municipales salieron a recibir al cortejo real engalanados con sus mejores vestidos que en nada tenían que envidiar a los que portaba el séquito real. Entre los regidores destacaba la figura de Pedro de Santa Cruz, acaudalado converso que formaba parte de las compañías de arrendadores más importantes del reino. El resto de los regidores eran destacados miembros de la nobleza local como los Durango, Acuña, Zúñiga o Avellaneda. Siguiendo la costumbre inmemorial el monarca juró los privilegios antes de entrar en la villa. En esta ocasión el representante de la casa Sandoval no estaba presente en la ceremonia ${ }^{3}$, pero sí que se encon-

\footnotetext{
${ }^{1}$ Hipotética reconstrucción basada en varios documentos que hacen referencia a este hecho. El más relevante de todos ellos se encuentra en Archivo Municipal de Aranda de Duero (AMA), leg. 42, doc. 6 y ha sido transcrito por HURTADO QUERO, M., Documentos Reales (siglos XIII al XVI). Colección Diplomática del Archivo Histórico Municipal de Aranda de Duero. Aranda de Duero, 1986, doc. 11, pp. 24-26.

${ }^{2}$ La entrada de Carlos I en Aranda en 1518 fue narrada por el cronista Laurent VITAL en su Relation du premier voyage de Charles-Quint en Espagne. Hemos consultado la transcripción francesa recogida en Collection de Chroniques Belges inédites. Collection des voyages des souveranins des PaysBas. Tomo III, Bruselas 1881. Existe también traducción española Relación del primer viaje de Carlos $V$ a España. Madrid, 1958, reed. 1992. Asimismo se hace referencia a este viaje en GARCÍA MERCADAL, J., Viajes de extranjeros por España y Portugal: desde los tiempos remotos hasta comienzos del siglo XX. Valladolid, 1999.

${ }^{3}$ Don Bernardino de Sandoval y Rojas había recibido el oficio de Gobernador de la Casa de la Reina Juana en Tordesillas por lo que se encontraba desempeñando su cargo en esa población. Precisamente desde Aranda el monarca envío el 29 de abril de 1518 unas instrucciones al marqués (Archivo
} 
traba el noble con mayores intereses en la comarca, don Francisco de Zúñiga y Avellaneda, III conde de Miranda ${ }^{4}$. Don Carlos franqueó las murallas y fue acogido por sus habitantes con gran alegría y los honores propios de la ocasión: ...de los balcones y ventanas de las casas colgaban lienzos y ramajes y las calles estaban tapizadas de verdor. El cronista Laurent Vital confirma la grandiosidad del recibimiento con su comentario: ...no habia visto un lugar donde sus moradores se portasen mejor, ni donde las gentes del rey fuesen mejor ni mas cariñosamente tratadas ${ }^{5}$. Tan solo tres años más tarde ese desbordante entusiasmo popular con que se había recibido al monarca se transformó en una verdadera rebelión que puso en jaque los fundamentos sobre los que se estaba asentando la nueva monarquía moderna.

Precisamente el periodo temporal enmarcado entre estas dos entradas reales es sobre el que se centra nuestro estudio. El objetivo general de esta aproximación a la historia de la Ribera del Duero burgalesa no es otro que tratar de comprender los mecanismos y factores que explican el notable desarrollo y transformación de esta comarca a finales de la Edad Media tanto en el ámbito socioeconómico como en el político. Evidentemente este objetivo no es nada original pues sigue la estela de otros meritorios trabajos que, desde otras perspectivas, han abordado espacios y cronología de similares características.

Antes de proceder con el análisis pormenorizado del sujeto histórico en cuestión, creemos conveniente realizar una serie de apreciaciones de carácter teórico que encuadren metodológicamente este trabajo. Somos conscientes de que cualquier estudio histórico tiene un enfoque que condiciona el desarrollo de la investigación y, en buena medi-

General de Simancas -AGS-, CONSEJO DE ESTADO, leg. 5, doc. 294, transcrito por BERGENROTH G. A. Calendar of Letters, Despatches, and State Papers relating to the negotiations between England and Spain. Suplemento de los volúmenes I y II. Londres, 1868, pp. 156-161, doc. 30).

${ }^{4}$ Muy probablemente él o sus allegados fueron los responsables de las noticias que hicieron llegar al rey cuando pernoctaba en el cercano lugar de San Martín de Rubiales en las que se afirmaba que en Aranda había un brote de peste. Vital no señala a los responsables del bulo pero afirma que las autoridades arandinas ...imaginaron bien de dónde podía venir quien les hiciera tanto daño a propósito, a causa de que habían rechazado a algunos señores argumentado que no querían a otro señor más que al Rey, sabiendo que éstos ejercían gran presión sobre el rey para nombrarles un gobernador; y para conseguirlo mejor le daban a entender que Aranda era un villorrio (VITAL, Relation du premier voyage..., p. 260. Todas las referencias en castellano a esta obra incluidas en este trabajo son traducciones propias).

5 Tanto la descripción de casas y calles como el comentario del cronista son traducciones literales de VITAL, Relation du premier voyage..., p. 261. 
da, tiene su proyección sobre las conclusiones que se obtienen. En este sentido, conviene señalar que nuestro trabajo se centra en dos aspectos que creemos fundamentales dentro del desarrollo histórico de una sociedad.

Por una parte, debemos señalar que el estudio del espacio trasformado por el ser humano, tanto en su vertiente rural como urbana, responde a la intención de comprender cómo vivían los habitantes de la comarca ribereña a finales de la Edad Media. En este sentido partimos de la premisa de que toda organización del espacio es el reflejo de los grupos humanos que sobre ella se desarrollan y que, por lo tanto, el territorio es transformado conforme cambian las necesidades e ideas de una sociedad en constante evolución ${ }^{6}$. Así pues el análisis de los distintos elementos que configuraron la organización territorial no es tan sólo un ejercicio descriptivo que nos presenta el escenario sobre el que se desarrolló la vida y actividad de sus pobladores en un momento concreto; debemos ir más allá y tratar de identificar y analizar las transformaciones que experimentaron estos espacios para así intentar comprender la dinámica propia de los grupos sociales que promovieron los cambios. La principal ventaja que aportan las conclusiones obtenidas de este análisis es que difícilmente están contaminadas por sus productores a diferencia de lo que ocurre con las informaciones transmitidas por la documentación escrita que, al fin y al cabo, fueron producidas por un grupo minoritario muy concreto, en función de unos intereses y con una finalidad que en ocasiones los historiadores no llegamos a identificar. La dependencia exclusiva de la fuente escrita provoca que el historiador reconstruya una realidad bajo la óptica de esa minoría productora de documentos y se dejen de lado los matices y realidades que caracterizaban a la gran masa social que no controlaba los medios escritos. Evidentemente el estudio de la cultura material no es la panacea pero sí un elemento complementario que participa en igualdad de condiciones en la reconstrucción

\footnotetext{
${ }^{6}$ Quisiéramos evitar cualquier encasillamiento dentro de las corrientes historiográficas pero es evidente la deuda que este planteamiento tiene con los principios básicos de la Arqueología Espacial y del Paisaje que concibe el espacio como el escenario de las acciones humanas. Sobre este aspecto existen numerosas referencias bibliográficas que sería imposible señalar en esta nota por lo que nos limitaremos a mencionar algunos artículos que aportan una visión de conjunto sobre esta aproximación historiográfica como son los de OREJAS SACO DEL VALLE, A., "Territorio, análisis territorial y Arqueología del Paisaje", en Studia Historica. Historia Antigua. 13-14, 1996, pp. 61-68; de la misma autora "Arqueología de los paisajes agrarios e historia rural", en Arqueología Espacial. 26, 2006, pp. 7-19; y MARTíN CIVANTOS, J. M., “Arqueología y recursos naturales. Notas para la arqueología del Paisaje”, en Medio Ambiente y Arqueología Medieval. Granada, 2008, pp. 17-39. Asimismo nuestro planteamiento es deudor de alguno de los enfoques que se pergeñaron en las primeras etapas de la escuela francesa de los Annales, sobre todo en lo referente a la interacción entre geografía e historia.
} 
histórica del pasado que tradicionalmente ha dependido excesivamente del documento escrito, con los vicios y peligros que esto conlleva.

El otro aspecto al que prestaremos especial atención en el desarrollo de nuestro estudio es el conflicto. Aunque en principio este concepto es rápidamente identificable por su carácter cotidiano, la moderna sociología ha demostrado que la definición del mismo es sumamente compleja ${ }^{7}$. Sin entrar en detalles que nada tienen que ver con el objeto de nuestro estudio, la conflictividad que nosotros trataremos de analizar está definida por el enfrentamiento entre dos o más colectivos sociales ocasionado por discrepancias sobre todo de orden económico y político. De ningún modo descartamos las diferencias ideológicas como motivo del conflicto; es más, estamos convencidos de que en el fondo subyace una verdadera contraposición entre las diferentes formas de entender las relaciones que configuran una sociedad. Sin embargo, somos conscientes de los problemas que se plantean para identificar estas últimas en un ámbito tan reducido en el espacio y el tiempo como el que hemos planteado en este trabajo de investigación. En nuestro estudio partimos de la premisa de que el conflicto es una realidad inherente a la naturaleza humana y que las relaciones sociales que se desarrollan dentro de una comunidad no se pueden entender sin este fundamental elemento que, lejos de constituir por sí mismo un factor negativo, se define como un factor dinamizador clave en los procesos de creación, consolidación y crisis de las estructuras básicas sobre las que se asientan las diferentes sociedades históricas. En consecuencia, el análisis de los diferentes conflictos que se desarrollaron en el seno de determinadas sociedades permite al historiador llegar a una serie de conclusiones que posibilitan la reconstrucción y comprensión del sujeto analizado. En este sentido, se aprecia claramente en nuestro planteamiento el papel protagonista que tiene el conflicto en la dinámica interna de una sociedad, aunque hemos de reconocer que no estamos en condiciones de afirmar a través de un estudio tan limitado en el espacio y el tiempo si la conflictividad actúa como motor de los cambios sociales o si bien es un síntoma o consecuencia de la evolución particular de los grupos humanos ${ }^{8}$.

\footnotetext{
${ }^{7}$ Una visión general sobre los diferentes enfoques sobre la Teoría del Conflicto se puede consultar en DOMÍNGUEZ BILBAO, R. y GARCÍA DAUDER, S., Introducción a la Teoría del Conflicto en las organizaciones. Madrid, 2003.

${ }^{8}$ Sin ánimo de entrar en polémicas y asumiendo nuestras limitaciones en el campo de la sociología, es evidente que nuestro planteamiento es deudor en lo básico de los postulados estructuralistas entre los que cabe destacar la obra de DAHRENDORF (Clases sociales y su conflicto en la sociedad industrial. Madrid, 1970; y "Hacia una teoría del conflicto social", en Los cambios sociales. Fuentes, tipos y conse-
} 
Esta última consideración nos permite enlazar con otro de los puntos que deseábamos abordar en esta introducción y que está en relación con la propia condición del historiador.

En primer lugar, queremos poner de manifiesto nuestro absoluto convencimiento de que, a pesar de haber actuado con todo el rigor, profesionalidad y espíritu crítico del que nos creemos capaces, el análisis histórico que presentamos no ha sido concebido como un reflejo de la realidad histórica en su sentido categórico sino que es el resultado del análisis de los escasos y parciales vestigios que nos han llegado de una sociedad compleja. En consecuencia, este resultado está necesariamente mediatizado por la precariedad de las fuentes, la manifiesta intencionalidad que proyectaron sus productores sobre alguna de ellas y, en gran medida, por el tamiz aplicado por quien esto escribe que conscientemente ha optado por introducir unos determinados parámetros a la crítica sobre las fuentes, ha desarrollado una metodología con una inevitable carga personal y ha interpretado los datos en función de una serie de modelos teóricos heredados. Así pues, necesariamente debemos reconocer que, a pesar de nuestro rotundo compromiso con la objetividad, el resultado final, y sobre todo las conclusiones, lleva implícito un cierto grado de subjetividad. De todo ello se deduce que nuestro estudio no nace con la vocación de dar por zanjado el estudio de la Ribera del Duero a finales de la Edad Media, sino que más bien se plantea como una aproximación a la realidad histórica de la sociedad castellana en el tránsito hacia la Modernidad. Nos proponemos contribuir a poner un poco más de luz sobre el comportamiento de las pequeñas villas y su entorno rural y, sobre todo, potenciar la apertura de nuevas puertas para otros estudios, bien gracias al alumbramiento de nuevos datos, o bien como consecuencia de la crítica constructiva de nuestros planteamientos y conclusiones. En definitiva, nuestra intención no es sólo incrementar el conocimiento de una realidad histórica que ya cuenta con excelentes trabajos, sino sobre todo invitar a la reflexión y a continuar profundizando en este tema desde una perspectiva crítica y constructiva.

En este sentido, creemos necesario en este punto de nuestra exposición poner de manifiesto nuestro claro convencimiento de que una de las principales funciones del

cuencias. México, 1968, pp. 97-107). Tampoco podemos olvidar a otros autores más próximos como el maestro VALDEÓN BARUQUE y los innumerables estudios de numerosos historiadores que tuvieron en don Julio un indudable referente. Ante la imposibilidad de citar a todos en esta introducción nos parece conveniente mencionar su obra Los conflictos sociales en el reino de Castilla en los siglos XIV y XV. (Madrid, 1975) y "Los conflictos sociales en los siglos XIV y XV en la Península Ibérica”, (en Historia Medieval. Anales de la Universidad de Alicante. 3, 1984, pp. 131-142). 
historiador es tratar de transmitir a la sociedad el contenido y las conclusiones de las investigaciones históricas de una manera clara y precisa ${ }^{9}$. Bien es cierto que la precisión se sobreentiende en el trabajo del historiador, pero no es tan evidente que los historiadores hayamos superado la fase en la que el lenguaje específico y en ocasiones gregario convierte al estudio histórico en un mensaje críptico al que solo acceden los iniciados. De esta manera cualquier aspirante a reputado historiador debe hacerse eco de este lenguaje para ser admitido y reconocido por el grupo. Esta dinámica degenera obligatoriamente en una espiral que empuja a los miembros del grupo a innovar continuamente con la creación y definición de nuevos vocablos que nacen para sustituir o matizar otros ya existentes. En ocasiones los historiadores nos dejamos arrastrar por un atractivo canto de sirenas epistemológico que nos hace introducir nuevos términos y perspectivas según las modas y desechar planteamientos catalogados como obsoletos o desfasados. Con esta apreciación personal tampoco queremos hacer apología del inmovilismo ni de la vulgarización del lenguaje y los contenidos históricos, sino más bien proponemos la apuesta por una expresión normalizada del conocimiento histórico ajustada a la realidad social en la que el historiador desempeña su trabajo. En definitiva, lo que nos proponemos es socializar el conocimiento histórico, apostando rotundamente por una narrativa que permita la comprensión de los resultados de la investigación histórica ${ }^{10}$.

Dejando a un lado los aspectos teóricos, creemos lógico que antes de seguir adelante es necesario señalar los criterios empleados para establecer el ámbito cronoespacial en el que se centra el presente estudio.

\footnotetext{
${ }^{9}$ No es nuestra intención entrar en el tema de la función social del historiador sobre todo teniendo en cuenta la gran cantidad de ensayos y estudios que ha generado este aspecto. Nos remitimos a dos que han tenido una proyección notable: IBÁÑEZ ALONSO, J., Del algoritmo al sujeto. Perspectivas de la investigación social. Madrid, 1985; y FLORESCANO, E., "La función social del historiador", en La Historia y el historiador. México, 1997, pp. 63-87.

${ }^{10}$ LOZANO HERNÁNDEZ ya apuntaba hace varias décadas la narración "como una forma de inteligibilidad que afecta tanto a la producción del texto histórico como a su recepción" (El discurso histórico. Madrid, 1987, pp. 173 y ss.). Sobre la necesidad de buscar el equilibrio entre teoría y narrativa ver VAL VALDIVIESO, M. I., "Aspiraciones y actitudes socio-políticas. Una aproximación a la sociedad urbana de la Castilla bajomedieval", en La ciudad medieval. Aspectos de la vida urbana en la Castilla bajomedieval. Valladolid, 1996, pp. 213-254, en concreto pp. 214-216.
} 


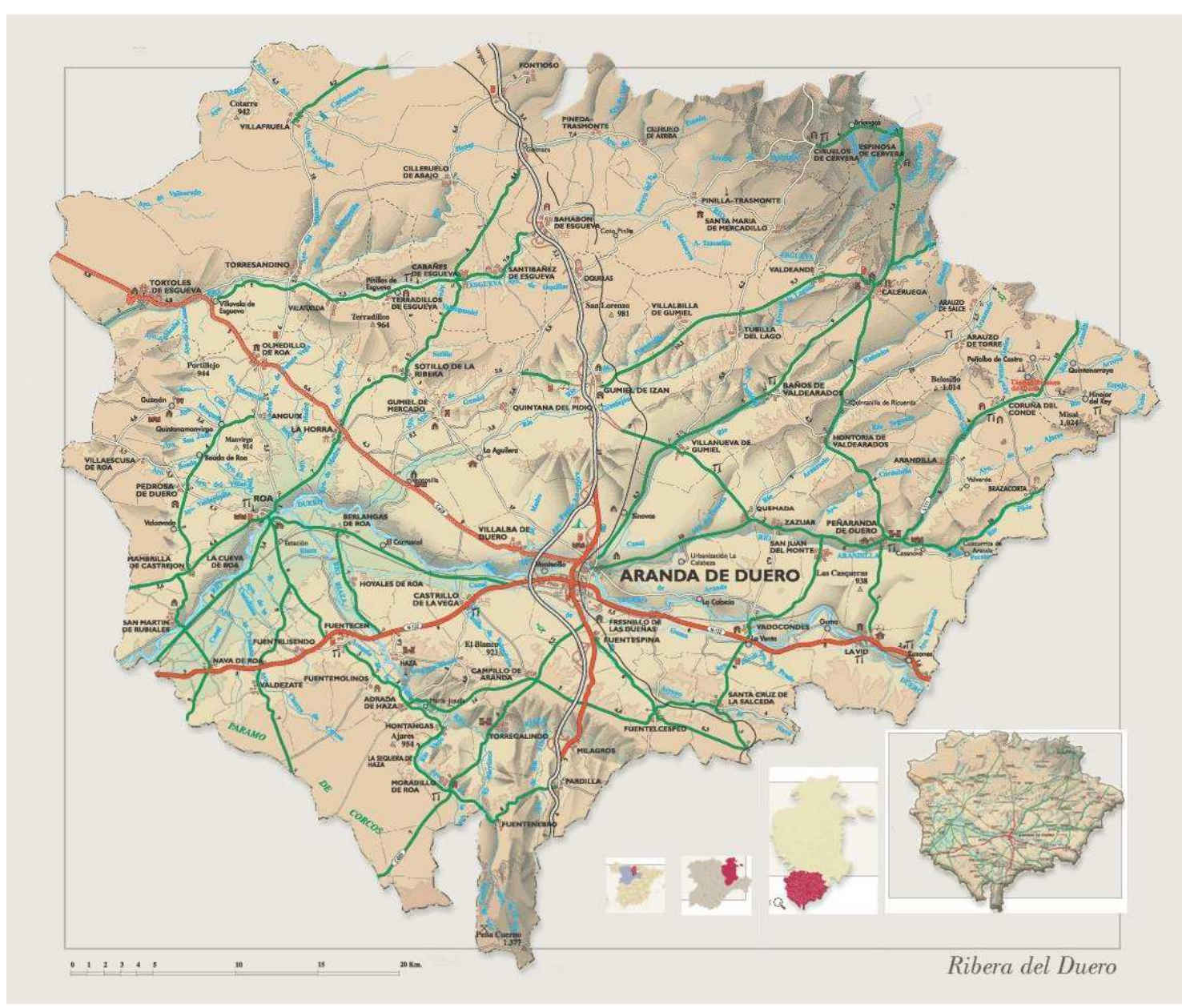

Mapa 1: La Ribera del Duero burgalesa en la actualidad.

Si bien es cierto que el término Ribera del Duero ${ }^{11}$ tal y como lo entendemos en la actualidad es bastante nuevo, ya encontramos alguna referencia altomedieval que, lejos de servir como argumento para defender la existencia de una realidad histórica antiquísima, no es más que la constatación de que este término aparece vinculado al elemento geográfico que entonces y ahora define este espacio: la tierra por la que discurre el Duero. Así debemos entender la referencia que aparece en un documento de donación de Ermengol VI, conde Urgel, al monasterio de Retuerta en que se dice: ...quam habeo in Retorta de Riba de Doro ${ }^{12}$. A tenor de la información de la que disponemos,

${ }^{11}$ El uso contemporáneo de este término para designar a la comarca comienza a generalizarse a partir de los años 80 del siglo XX al amparo de la implantación de la Denominación de Origen Ribera del Duero y el rápido y espectacular desarrollo vitivinícola que experimentó la comarca.

${ }^{12}$ CORREDERA GUTIÉRREZ, E., “Los condes soberanos de Urgel y los premostratenses”, en Analecta Sacra Tarraconensia 36 (1963), pp. 258-59; citado por VALLEJO PENEDO, J. J., "El monasterio de Santa María de la Vid. Fundación, formación y consolidación del señorío abacial. Colección diplomática (1132-1299)", en El monasterio de Santa María de la Vid. 850 años. Madrid, 2004, nota 7, p. 227. Resulta cuanto menos curioso que una de las primeras referencias a esta comarca natural haga alusión a un espacio que en la actualidad no se encuentra amparado por la Denominación de Origen. 
no fue hasta finales del siglo XVIII cuando el término adquirió su actual dimensión territorial y así Loperráez señala: Esta (tierra) ocupa los Arciprestazgos de Aranda, Aza, y Roa, llamándola por lo comun tierra de la Ribera ${ }^{13}$.

El marco espacial objeto de nuestro estudio viene delimitado por una serie de condicionantes. Así, desde un punto de vista administrativo actual, la comarca arandina se corresponde con el núcleo central de lo que hoy conocemos como Ribera del Duero, englobando todos los municipios burgaleses del Sur de esta provincia, más algunos de las actuales provincias de Segovia y Soria encuadrados bajo esta denominación.

No obstante, los fundamentos que hemos utilizado para definir el territorio de esta comarca han sido básicamente geográficos e históricos.

Desde un punto de vista geográfico ${ }^{14}$ los criterios aplicados para establecer los límites son básicamente geomorfológicos (elementos significativos del relieve) e hidrográficos (cuencas y vertientes). Sobre estos primeros criterios se ha solapado una serie de referentes de carácter histórico como la existencia de organizaciones territoriales previas al momento que se aborda (Alfoces, Merindades y Comunidades de Villa y Tierra básicamente) o las zonas de influencia de las distintas realidades políticas contemporáneas al periodo estudiado (corregimientos o centros de poder señoriales y eclesiásticos). El resultado ha sido el establecimiento de un marco espacial delimitado de la siguiente manera:

- Por el Norte, la superficie de páramo y las sierras que actúan como divisoria de aguas con la cuenca del Arlanza y sus ríos subsidiarios.

- Por el Este, las sierras y páramos que enmarcan las vertientes de los ríos Arandilla, Pilde y Perales, al Norte del Duero; y el páramo de Castrillejo y Santa Cruz de la Salceda, al Sur de este río.

- Por el Sur, el conjunto de la Sierra de Pradales.

- Por el Oeste, el páramo de Corcos, al Sur del Duero, de San Martín, al Norte de este río, y de Torresandino, respecto al Cerrato.

13 LOPERRÁEZ CORVALÁN, J., Descripción histórica del Obispado de Osma. Madrid, 1788. Reed. Madrid, 1978, Tomo II, p. 6.

${ }^{14}$ Para Fernando Molinero “...la Ribera, como comarca, arranca de un hecho morfológico: del relieve de un valle entre páramos, abrigado, con suelos sueltos y marginales, dedicados a la producción de uva" (MOLINERO, F., "Origen y evolución de la Ribera del Duero", en Ponencias del I Curso de Viticultura y Enología Denominación de Origen Ribera del Duero 2001. Aranda de Duero, 2002, pp. 9-14). 
En conclusión, la comarca arandina se vería configurada por un basto territorio con epicentro en la villa de Aranda de Duero y que limitaría septentrionalmente con las tierras de Lerma; la Comunidad de San Esteban de Gormaz por Oriente; la Tierra de Sepúlveda y Maderuelo por el Sur; y por Occidente con la zona de influencia de Peñafiel y, marginalmente, la comarca del Cerrato ${ }^{15}$.

No obstante, y a pesar de estos límites, se ha de señalar que hay dos espacios significativos que mantienen una dinámica relativamente autónoma del resto: las tierras de Roa y el curso medio, que no la cabecera, del valle del Esgueva.

Por otra parte este estudio se enmarca en una cronología bajomedieval. El periodo final del siglo XV y las primeras décadas de la decimosexta centuria nos permiten situarnos en ese atractivo ámbito de transición hacia la Modernidad. En concreto, nos proponemos estudiar la realidad histórica de la Ribera del Duero entre dos momentos claves en la evolución de la Historia de Castilla: el estudio arranca con el análisis de los convulsos episodios que rodearon el acceso de doña Isabel al trono castellano y culmina en los momentos inmediatamente posteriores a la revolución comunera. La elección de este corto periodo de tiempo se fundamenta en las importantes transformaciones que experimentó el territorio ribereño a raíz del último conflicto sucesorio del siglo $\mathrm{XV}$ y que condujeron al dramático desenlace que tuvo lugar durante los primeros años veinte del Quinientos de la mano del conflicto comunero y la posterior represión.

En consonancia con los planteamientos anteriormente desarrollados y el marco cronoespacial que acabamos de definir, hemos optado por organizar la exposición de este trabajo en tres grandes capítulos. El primero de ellos está dedicado al estudio del espacio físico sobre el que se desarrolla la actividad humana. Comenzaremos este apartado con la definición de los elementos naturales del marco territorial para después pasar a analizar las sucesivas transformaciones que este espacio ha sufrido de la mano del ser humano hasta configurar el poblamiento que se definió a finales de la Edad Media. Este primer capítulo concluye con el estudio en profundidad de la realidad urbana más importante de la comarca en este periodo, la villa de Aranda. El objetivo de este apartado no es tanto reconstruir el urbanismo de esta villa sino, a través del análisis de las no-

${ }^{15}$ No en vano una demarcación más o menos similar ha sido utilizada en otros trabajos de carácter histórico (NUÑO GONZÁLEZ, J., "Pautas de ocupación territorial y conformación urbana en la Ribera del Duero burgalesa durante la Edad Media", en Biblioteca 16. Estudio e Investigación. 2001, pp. 79104, en concreto p. 82) e incluso artístico (ZAPARAÍN YAÑEZ, M. J., Desarrollo artístico de la comarca arandina siglos XVII y XVIII. Salamanca, 2002, Vol. I, pp. 50-51). 
tables transformaciones que experimentó, tratar de comprender la realidad socioeconómica que se desarrolló en este núcleo urbano.

El segundo bloque se centra en identificar y definir las principales características de los actores que protagonizaron las relaciones de poder en la comarca ribereña a finales de la Edad Media. En este sentido hemos organizado la exposición en cinco apartados que agrupan a colectivos relativamente homogéneos que acogen en su seno realidades notablemente diferentes. En primer lugar, analizamos el papel de la Corona inmersa en su objetivo de consolidar su poder en el reino en general y en esta comarca en particular. Nos detendremos especialmente en los diferentes instrumentos que sobre este territorio se utilizaron para hacer efectiva su política de afianzamiento de la institución. Seguidamente estudiaremos con detenimiento la realidad política y social de la villa de Aranda. Comenzaremos con el análisis del concejo arandino como institución política para después identificar y definir los principales actores políticos que desarrollaron su actividad en el seno de este núcleo urbano. Como en otros ámbitos urbanos castellanos, la sociedad arandina experimentó una marcada polarización en torno a dos grupos fundamentalmente: la oligarquía local y la Comunidad. La compleja realidad de la sociedad feudal urbana obliga a finalizar este apartado con el estudio de los grupos sociales que se encontraban al margen de las categorías anteriormente señaladas, bien fuera por su condición religiosa o jurídica.

Otro gran bloque dentro de este capítulo está dedicado al estudio de la nobleza comarcana. Para abordar la realidad nobiliaria de este periodo nos remontaremos al momento en que se comenzó a fraguar la presencia de estos linajes en el territorio ribereño. Seguidamente analizaremos las bases de su poder y su evolución para culminar con la situación de este grupo privilegiado en el tránsito hacia la Modernidad. Conscientes de la heterogeneidad que presenta este grupo hemos optado por organizar la explicación abordando en primer lugar la realidad de los grandes linajes comarcanos y a continuación señalar el papel de la pequeña nobleza.

Un epígrafe más modesto ocupa la exigua relación de behetrías que sobrevivieron a finales de la Edad Media en el territorio ribereño. En este punto nos detendremos en su identificación y en la constatación de ciertas dinámicas particulares.

El último apartado de este segundo capítulo está dedicado a la realidad que presentan las diferentes instituciones religiosas que desarrollaron su actividad en la comarca ribereña. En primer lugar, se analiza la situación de la extensa red parroquial y el 
papel de las diferentes autoridades diocesanas sobre el territorio y sus gentes. A continuación nos detendremos en las comunidades monásticas que se asentaron a lo largo de la Edad Media en la comarca y que en el periodo estudiado se encuentran en términos generales en franca decadencia tanto en lo que se refiere a sus bases económicas como en su capacidad de proyectarse en el ámbito político.

El último capítulo de este trabajo está consagrado a la identificación y análisis de los múltiples conflictos que tuvieron lugar en la comarca ribereña a finales de la Edad Media. Con la intención de sistematizar la información recogida y aplicar un método analítico coherente, hemos optado por agrupar los conflictos en cuatro categorías. La primera de ellas se ocupa del conflicto sucesorio con el que se abre el periodo estudiado y que supuso el reconocimiento de la autoridad real. Este punto se centra en la proyección que tuvo la disputa sucesoria a escala comarcal.

El segundo ámbito de conflictividad tiene como nexo común el cariz religioso de los enfrentamientos. El primero y más significativo se centra en los problemas derivados de la colisión entre la jurisdicción regia y la eclesiástica. Un segundo bloque aborda los conflictos que se desarrollaron en el seno del estamento clerical y se concretan en la pugna por los beneficios eclesiásticos; en los problemas derivados de la aplicación de las reformas en las diferentes comunidades regulares; y las controversias surgidas entre clero secular y regular por el solapamiento de sus competencias. Este apartado dedicado a los conflictos religiosos finaliza con el análisis de los que tuvieron como protagonistas a las minorías religiosas.

El tercer bloque analiza la conflictividad que tuvo como actores principales a los diferentes linajes nobiliarios de la comarca. Como en otras partes del Occidente medieval, la política expansiva de las grandes familias de la nobleza provocó una serie de enfrentamientos que en el ámbito de nuestro estudio hemos sistematizado en cuatro epígrafes. El primero de ellos estudia los principales enfrentamientos intranobiliarios protagonizados por la nobleza ribereña. El segundo epígrafe analiza las agresiones sufridas por las instituciones religiosas comarcanas por parte de alguna de las familias nobiliarias. El tercero se centra en las características del proceso de señorialización experimentado por las behetrías de este territorio. La presión ejercida por los señores sobre sus vasallos y las débiles respuestas antiseñoriales será el cuarto de los epígrafes de este apartado. Finalmente, este bloque dedicado a la conflictividad nobiliaria finaliza con la 
descripción del panorama señorial a comienzos del siglo XVI en la Ribera como resultado de la política expansiva de los linajes.

La conflictividad urbana es otro de los grandes apartados que desarrollaremos en el tercer capítulo. En esta ocasión el estudio se centra en la sociedad civil de la villa de Aranda de Duero. El análisis de la situación se articula en dos grandes epígrafes. El primero de ellos se centra en la conflictividad interna. En este apartado se abordará en primer lugar los conflictos que atañen a los miembros de la clase dominante. Un segundo punto analizará el enfrentamiento entre la oligarquía y la Comunidad, intentando sistematizar la continua tensión que se vivió entre ambos grupos en una serie de categorías que agrupan diferentes situaciones sintomáticas de una problemática concreta. El segundo de los epígrafes está destinado a identificar las principales líneas de enfrentamiento entre la sociedad urbana arandina en cuanto entidad colectiva política y los diferentes poderes comarcanos. Esta conflictividad se centró fundamentalmente en la colisión de intereses a causa de la política expansiva que intentó llevar a cabo la villa arandina y su defensa de la autonomía política frente a injerencias foráneas.

El último apartado de nuestro trabajo está dedicado a valorar y analizar la incidencia de la Revolución Comunera en la comarca de la Ribera del Duero y sobre todo en el principal núcleo urbano de este territorio: la villa de Aranda de Duero. Este capítulo comenzará con la identificación de los cambios que ya se percibían en los primeros años del Quinientos. Después abordaremos detenidamente el desarrollo de los acontecimientos en la capital de la Ribera, enmarcándolos dentro del desarrollo general del movimiento comunero en el reino de Castilla. Para ello, en primer lugar se analizarán los antecedentes que abocaron al estallido del conflicto en la villa arandina. Seguidamente identificaremos y definiremos a los principales protagonistas que capitalizaron la sublevación y analizaremos las líneas de actuación del gobierno comunero. Por último, finalizaremos con la valoración del fracaso de la iniciativa comunera, la posterior represión realista y las consecuencias que se siguieron de este desenlace.

El punto final de este trabajo está reservado para la presentación de una serie de conclusiones que tratan de sintetizar someramente los principales rasgos de la interrelación de la sociedad y el territorio en la comarca de la Ribera del Duero burgalesa a finales de la Edad Media. No obstante, este trabajo y sus conclusiones no se conciben como un estudio cerrado. Para alcanzar nuestro último objetivo es necesaria la colaboración del lector aportando la valoración y crítica que estime conveniente y así, mediante la 
interacción del trabajo del investigador y las propuestas de los lectores, contribuiremos al desarrollo de la ciencia histórica.

Llegados a este punto creo del todo necesario culminar esta introducción con unos merecidos agradecimientos a todas aquellas personas e instituciones que han hecho posible la realización de esta investigación.

Quiero agradecer y felicitar por su exquisita profesionalidad a todo el personal de los diferentes archivos en los que he estado trabajando durante todos estos años. Han sido muchos los archivos a los que he tenido que acudir en las fases previas de este proyecto, pero sería injusto no mencionar especialmente a los trabajadores del Archivo General de Simancas y de la Real Chancillería de Valladolid sin cuya ayuda y disponibilidad este trabajo hubiera sido bastante más áspero. Asimismo es necesario mencionar al personal del Archivo Municipal y de la Biblioteca Municipal de Aranda de Duero que me ha permitido trabajar en sus dependencias como si estuviera en mi casa y me ha agasajado con su amable atención. También debo agradecer su disponibilidad a la hora de facilitarme el acceso a la espléndida colección fotográfica que ha recopilado el personal de la Biblioteca.

A lo largo de mi periplo personal y profesional he contado con la inestimable ayuda de un gran número de maestros en el sentido pleno de la palabra. Algunos comenzaron a enseñarme hace mucho tiempo y todavía lo hacen, otros me encaminaron hacia lo que hoy se ha constituido en mi profesión, y otros han moldeado la innata curiosidad que apuntaba hacia la investigación histórica. A todos ellos les debo lo que hoy soy.

En este sentido, es absolutamente imprescindible reconocer la labor de María Isabel del Val Valdivieso. En primer lugar, y como corresponde en este punto, le agradezco enormemente que aceptara la dirección de este trabajo de investigación. Sin lugar a dudas, hubiera sido imposible llevar a buen puerto esta tesis doctoral sin su ayuda, sus inestimables recomendaciones y, sobre todo, su paciencia y apoyo en los largos y arduos años durante los que se ha gestado. No puedo por menos que reconocer que su aliento, sobre todo en los momentos difíciles, su disponibilidad absoluta y la constante oferta de oportunidades han fructificado en esta investigación. No obstante, mi mayor gratitud se expresa en el plano personal pues he sido agraciado con el privilegio de gozar de su amistad. Muchas gracias Maribel. 
También es necesario reconocer la ayuda prestada por muchos compañeros de fatigas tanto del Área de Historia Medieval de la Universidad de Valladolid como de otros centros universitarios y docentes por los ha discurrido mi vida académica, investigadora y docente. En este sentido, creo necesario mostrar gratitud también a los numerosos alumnos que a lo largo de estos años me han enseñado a enseñar y han ampliado mis perspectivas en la tarea de la investigación histórica.

Por último, y seguramente porque son los primeros, quiero mostrar mi agradecimiento a los amigos y familiares que han sufrido, padecido y soportado durante tanto tiempo mi incontrolable necesidad de investigar. Especialmente agradecido estoy a mis padres que se sacrificaron por mí y mi futuro. Mi mayor deuda la he contraído a lo largo de estos años con mis tres soletes a los que he privado durante muchas horas de un marido y un papi. Después de tantos años de trabajo soy consciente de que el único sacrificio ha sido el vuestro. Muchas gracias por permitirme concluir este trabajo y por vuestra presencia constante. Gracias Irene, gracias María, gracias Isabel. 
FUENTES Y BIBLIOGRAFÍA. 


\section{FUENTES ARCHIVÍSTICAS.}

Archivo de la Real Chancillería de Valladolid (ARChV)

Cédulas y Pragmáticas.

Pergaminos.

Planos y Dibujos.

Pleitos Civiles.

Registro de Reales Ejecutorias (RRE).

Sala de Hijosdalgo.

Archivo Diocesano de Burgos (ADB)

Libro de Fábrica de Santa María la Real de Aranda.

Archivo Ducal de Alba

Montijo.

Archivo Ducal de Medinaceli (ADM)

Archivo Histórico.

Denia-Lerma.

Archivo General de Simancas (AGS)

Cámara de Castilla (CC)

Cédulas.

Diversos.

Memoriales.

Personas.

Pueblos.

Casa y Descargos de los Reyes Católicos.

Casa y Sitios Reales.

Consejo de Estado.

Consejo Real (CR).

Consejo y Juntas de Hacienda. 
Contaduría Mayor de Cuentas (CMC).

Escribanía Mayor de Rentas (EMR).

Expedientes de Hacienda (EH).

Guerra Antigua.

Mapas, Planos y Dibujos (MPD).

Mercedes y Privilegios.

Patronato Real (PR).

Registro General del Sello (RGS).

Archivo General de Indias (AGI)

Casa de Contratación.

Catálogo de Pasajeros a Indias.

Gobierno. Indiferente General.

Justicia.

Archivo Histórico Nacional (AHN)

Clero Regular.

Clero Secular.

Consejo de Órdenes.

Consejo.

Archivo Provincial de la Diputación de Burgos (APDB)

Catastro del Marqués de la Ensenada.

Archivo Histórico Provincial de Burgos (AHPB)

Protocolos Notariales.

Archivo Municipal de Aranda de Duero (AMA)

Biblioteca Nacional (BN)

Biblioteca de la Real Academia de la Historia (BRAH)

Colección Salazar y Castro. 
Sección Nobleza del Archivo Histórico Nacional (SNAHN)

Duques de Fernán Núñez.

Duques de Frías.

Duques de Osuna.

Familia Moncada.

Señores de los Cameros.

\section{FUENTES IMPRESAS.}

AMALRIC, J. P., Aranda de Duero 1752 según las Respuestas Generales del Catastro de Ensenada. Madrid, 1990.

BERGENROTH G. A., Calendar of Letters, Despatches, and State Papers relating to the negotiations between England and Spain. Suplemento de los volúmenes I y II. Londres, 1868.

BLANCO LOZANO, P., Colección Diplomática de Fernando I. León, 1987.

BRAUM, G. y HOGENBERG, F., Civitates orbis terrarum. Colonia, 1588.

BURRIEL, A. M., Memorias para la vida del santo rey Don Fernando III. Madrid, 1800. Versión digital en http://www.cervantesvirtual.com, consultada el $12 / 05 / 2011$.

CARRETE PARRONDO, C., Fontes Iudaeorum Regni Castellae II. El tribunal de la Inquisición en el Obispado de Soria (1486-1502). Salamanca, 1985.

CARRILLO DE HUETE, P., Crónica del Halconero de Juan II. Madrid, 1946.

Crónica anónima de Enrique IV. Edición de SÁNCHEZ-PARRA, M. P., Madrid, 1991.

Crónica de don Álvaro de Luna, condestable de los reynos de Castilla y de León. FLORES, J. M. (Ed.), Madrid, 1784.

Crónica de Don Sancho el Bravo. En ROSELL, C. (Ed.), Crónicas de los Reyes de Castilla. Madrid, 1953, Tomo I.

Crónica del rey don Enrique, Tercero de Castilla é de Leon. En ROSELL, C. (Ed.), Crónica de los Reyes de Castilla. Madrid, 1953, Tomo II.

DE LAS CASAS, B., Vida de Cristóbal Colón. Edición Biblioteca Ayacucho, 1992. 
DEL CASTILLO RUIZ DE MOLINA, S., Noticias genealogicas de la antigua familia de Aranda de la que justifica su descendencia don Joachin de Aranda y Amezaga. Madrid, 1741.

DÍAZ MEDINA, A. (Ed.), Relación del discurso de las Comunidades. Valladolid, 2003.

ENRÍQUEZ DEL CASTILlO, D., Crónica del rey don Enrique IV. En ROSELL, C.

(Ed.), Crónicas de los reyes de Castilla. Madrid, 1953, Tomo III.

ENRIQUEZ FERNÁNDEZ, J., HIDALGO DE CISNEROS, C. y MARTÍNEZ

LAHIDALGA, A., Fuentes documentales del País Vasco. Colección documental del Archivo histórico de Bilbao (1473-1500). San Sebastián, 1999.

FERNÁNDEZ ÁLVAREZ, M., Corpus Documental de Carlos V. Salamanca, 1975.

GALÍNDEZ DE CARVAJAL, L., Crónica de Enrique IV. En ROSELL, C. (Ed.), Crónicas de los reyes de Castilla, Madrid, 1953, Tomo III.

GONZÁLEZ DE TORRES, E., Chronica Seraphica. Octava parte. Madrid, 1737.

GONZÁLEZ, J., Reinado y Diplomas de Fernando III. Córdoba, 1980, 3 Vol.

GONZÁlez, T., Censo de Población de las provincias y partidos de la Corona de Castilla en el siglo XVI. Madrid, 1829, red. 2009.

HURTADO QUERO, M., Documentos Reales (siglos XIII al XVI). Colección Diplomática del Archivo Histórico Municipal de Aranda de Duero. Aranda de Duero, 1986.

HURTADO QUERO, M., y PERIBÁÑEZ OTERO, J. G., Los Reyes Católicos en el Archivo de Aranda de Duero. Aranda de Duero, 2004.

Índice de los documentos procedentes de los monasterios y conventos suprimidos que se conservan en el Archivo de la Real Academia de la Historia. Tomo I (Monasterios de Nuestra Señora de la Vid y San Millán de la Cogolla), Madrid, 1861.

Las siete partidas del Rey Don Alfonso el Sabio. Ed. Real Academia de la Historia, 1973.

LOPERRÁEZ CORVALÁN, J., Descripción histórica del Obispado de Osma. Madrid, 1788. Reed. Madrid, 1978. 3 Vol.

LÓPEZ DE AYALA, P., Crónica del rey Don Pedro. En ROSELL, C. (Ed.), Crónicas de los reyes de Castilla. Madrid, 1953. Tomo I.

LÓPEZ DE HARO, A., Nobiliario genealógico de los reyes de España. Madrid, 1622.

MADOZ, P., Diccionario Geográfico-Estadístico-Histórico de España. Madrid, 18451850, Reed. Ámbito, 1984. 
MANSILla REOLlO, D., Catálogo Documental del Archivo de la Catedral de Burgos (804-1416). Madrid-Barcelona, 1971.

MARTÍNEZ LIÉBANA, E., Colección Diplomática del Real Convento de Santo Domingo de Caleruega. Vergara, 1931.

MENÉNDEZ PIDAL DE NAVASCUES, F. (edit.), El Libro de la Cofradía de Santiago de Burgos. Bilbao, 1977.

MORO, Th, Utopia.. Edición de MEDINILLA Y TORRES, G., Madrid, 1805.

PADILlA, L., Crónica de Felipe I, llamado el Hermoso. En Colección de Documentos Inéditos para la Historia de España. Tomo VIII, Madrid, 1846.

PALENCIA, A. Crónica de Enrique IV. Edición y traducción de PAZ Y MELIA, A., Madrid, 1904-1908, 4 vol.

- Cuarta Década. Edición LÓPEZ DE TORO, J., Madrid, 1974.

PELLICER DE TOVAR, J., Justificacion de la grandeça y cobertura de primera clase en la casa y persona de Don Fernando de Zúñiga, noveno Conde de Miranda. Madrid, 1668.

PÉREZ DE GUZMÁN, F., Crónica del serenísimo príncipe Don Juan, segundo rey de este nombre en Castilla y en León. En ROSELL, C. (Ed.), Crónicas de los Reyes de Castilla. Madrid, 1953. Tomo II.

PUlGAR, H. Crónica de los Reyes Católicos. En ROSELL, C. (Ed.), Crónicas de los reyes de Castilla. Madrid, 1953, Tomo III.

RIAÑO RODRÍGUEZ, T. y GUTIÉRREZ, M. C., "Documentos de los siglos XII y XIII del archivo de la Catedral de Burgo de Osma", en Archivo de Filología Aragonesa. XVIII y XIX, 1976, pp. 217-284.

ROMANO DE THUESEN, E. A. Transcripción y edición del Catálogo Real de Castilla, autógrafo inédito de Gonzalo Fernández de Oviedo y Valdés. Edición digital a partir del texto original de la tesis doctoral. http://www.cervantesvirtual.com, consultada 01/09//2011.

SANTA CRUZ, A., Crónica del Emperador Carlos V. Real Academia de la Historia, Madrid, 1920.

SERRANO, L., El Cartulario del Infantado de Covarrubias. Valladolid, 1907.

- Cartulario de San Pedro de Arlanza. Madrid, 1925.

— El Obispado de Burgos y Castilla Primitiva. Madrid, 1935. 2 Vol. 
TORO CEBAlloS, F., El discurso genealógico de Sancho de Aranda. Alcalá la Real, 1993.

UBIETO ARTETA, A., Cartulario de San Juan de la Peña. Valencia, 1962, 2 vol.

VALERA, D., Memorial de diversas hazañas. En ROSELL, C. (Ed.), Crónicas de los Reyes de Castilla. Madrid, 1953, Tomo III.

- Crónica de los Reyes Católicos. Edición y estudio de CARRIAZO, J. M., Madrid, 1927.

VILLAR GARCÍA, L. M., Documentación medieval de la Catedral de Segovia (11151300). Salamanca, 1990.

VITAL, L., Relation du premier voyage de Charles-Quint en Espagne. Collection de Chroniques Belges inédites. Collection des voyages des souveranins des PaysBas. Tomo III, Bruselas, 1881.

- Relación del primer viaje de Carlos V a España. Madrid, 1958.

VIVANCOS GÓMEZ, M., Documentación del monasterio de Santo Domingo de Silos (954-1254). Burgos, 1988.

\section{INFORMES TÉCNICOS.}

ABAD ÁlVAREZ, I. y PALOMINO LÁZARO, A. L., Informe técnico del sondeo arqueológico realizado en el solar $n^{\circ}$ 13-15 de la Plaza de Santa María. Aranda de Duero (Burgos). Febrero 1997. Depositado en el Servicio Territorial de Cultura de Burgos.

CRISTÓBAL VILLANUEVA, E., Informe técnico sobre el seguimiento arqueológico llevado a cabo en el inmueble $n^{\circ} 6$ de la calle de Santa Lucía, en Aranda de Duero (Burgos), con motivo del desmantelamiento de 13 metros de la muralla que circundaba su casco histórico. Febrero-abril de 1992. Depositado en el Servicio Territorial de Cultura de Burgos.

- Informe técnico del seguimiento arqueológico realizado en la Plaza de San Juan de Aranda de Duero (Burgos). Febrero, 1994. Depositado en el Servicio Territorial de Cultura de Burgos. 
- Informe técnico del seguimiento arqueológico realizado durante el derribo y vaciado del inmueble $n^{o} 38$ de la calle Puerta Nueva, de Aranda de Duero (Burgos). Febrero 1994. Depositado en el Servicio Territorial de Cultura de Burgos.

— Informe técnico de los sondeos y seguimiento arqueológico realizados en el solar $n^{\circ} 6$ de la Plaza de San Juan, en Aranda de Duero (Burgos). Junio 1994. Depositado en el Servicio Territorial de Cultura de Burgos.

- Informe técnico sobre el seguimiento arqueológico llevado a cabo en el solar $n^{\circ}$ 43 de la calle Postas de Aranda de Duero (Burgos). Julio 1998. Depositado en el Servicio Territorial de Cultura de Burgos.

MARTÍN, M. A. y GARCÍA, J. T., Informe Arqueológico. Seguimiento arqueológico en la Iglesia de San Juan de Aranda de Duero (Burgos). 2002.

PALOMINO LÁZARO, A. L., Informe del Inventario Arqueológico del Término Municipal de Aranda de Duero. 1993. Depositado en el Servicio Territorial de Cultura de Burgos.

- Informe técnico de los sondeos y seguimiento arqueológico realizados en el solar $n^{\circ} 4$ de la Plaza de San Juan, en Aranda de Duero (Burgos). Junio 1994. Depositado en el Servicio Territorial de Cultura de Burgos.

- Informe Técnico. Documentación arqueológica Casa de los Juzgados Aranda de Duero (Burgos). 1998. Depositado en el Servicio Territorial de Cultura de Burgos.

PALOMINO LÁZARO, A. L., y ABAD ÁlVAREZ, I., Informe Técnico. Documentación del solar $n^{\circ} 5$ de la Plaza de San Juan. 1998. Depositado en el Servicio Territorial de Cultura de Burgos.

\section{FONDOS GRÁFICOS.}

- Archivo personal de Juan Gabriel Abad Zapatero.

- Biblioteca Digital de la Real Academia de la Historia (http://bibliotecadigital.rah.es/).

- Colección Fotográfica de la Biblioteca Municipal de Aranda de Duero (CBMAD).

- Colección Fotográfica de Máximo López Sanz.

- Infraestructura de Datos Espaciales de Castilla y León (Base de datos cartográfica: http://www.idecyl.jcyl.es). 


\section{BIBLIOGRAFÍA.}

ABAD ÁlVAREZ, I. y PERIBÁÑEZ OTERO, J. G., "El control social del agua en la villa de Aranda de Duero. El aprovechamiento del río Aranzuelo a principios del siglo XVI", en Usos sociales del agua en la ciudades hispánicas de la Edad Media. Valladolid, 2002, pp.113-156.

— "La pesca fluvial en el Reino de Castilla durante la Edad Media", en Vivir del agua en las ciudades medievales. Valladolid, 2006, pp. 147-180

ABAD LICERAS, J. M., "El ocaso de la presencia franciscana en Aranda de Duero a través de la documentación jurídica: los conventos de San Francisco y San Antonio en los siglos XVIII y XIX”, en Biblioteca 11. Estudio e Investigación. 1996, pp. 207-256.

ABAD ZAPATERO, J. G., Aranda Industrial. Valladolid, 1981.

- Caminos de Silos. Valladolid, 1982.

- Apuntes para una Historia de Aranda. Aranda de Duero, 1984-1988.

ABAD ZAPATERO, J. G. y ARRANZ ARRANZ, J., Las Iglesias de Aranda. Pamplona, 1989.

ABÁSOlo ÁlVAREZ, J. A., Comunicaciones de la época romana en la provincia de Burgos. Burgos, 1975.

ABÁSOlO ÁlVAREZ, J. A. y GARCÍA ROZAS, R., Carta arqueológica de la provincia de Burgos. Partido judicial de Salas de los Infantes. Burgos, 1980.

AGUADÉ NIETO, S. “Alfonso X y las órdenes mendicantes” en Könige, Landesherren und Bettelorden. Konflikt und Kooperation in West-und Mitterleuropa bis zur Frühen Neuzeit. Werl, 1998, pp. 288-292.

AGUADO GONZÁLEZ, F. J., "La sucesión en el Ducado de Medina Sidonia a la muerte de don Juan de Guzmán y el linaje de los Téllez-Girón”, en Anuario de Estudios Medievales. 19, 1989, pp. 689-708.

- El ascenso de un linaje castellano en la segunda mitad del siglo XV: los TéllezGirón, condes de Urueña. Tesis Doctoral de la Universidad Complutense de Madrid, 1990.

ALCALÁ, A., "La política religiosa de los Reyes Católicos. La Inquisición. La expulsión de los judíos", en Isabel la Católica y la política. Valladolid, 2001, pp. 117156. 
ALEXANDRE, P., Le climat en Europe au Moyen Âge. Contributions à l'histoire des variations climatiques de 1000 à 1425, d'après les sources narratives de l'Europe occidentale. París, 1987.

ALONSO GARCÍA, D., Fisco, poder y monarquía en los albores de la modernidad: Castilla 1504-1525. Tesis de la Universidad Complutense de Madrid, 2004. Disponible en formato digital en http://eprints.ucm.es/tesis/ghi/ucm-t27728.pdf. Consulta realizada el 30/04/2012.

— "El sistema fiscal castellano (1503-1536). Elementos de análisis, palabras de discusión", en Entre Clio y Casandra. Poder y sociedad en la Monarquía Hispánica durante la Edad Moderna. Murcia, 2005, pp. 233-255.

- El erario del reino. Fiscalidad en Castilla a principios de la Edad Moderna.1504-1525. Valladolid, 2007.

ALONSO PONGA, J. L., La Arquitectura del Barro. Valladolid, 1994.

ALONSO RUIZ, B., "Un modelo funerario del tardogótico castellano: las capillas treboladas", en Archivo español de Arte. 311, 2005, pp. 277-295.

ALVAR EZQUERRA, A., Fernando I (1503-1564): socialización, vida privada y actividad pública de un Emperador del Renacimiento. Madrid, 2004.

ALVARADO PLANAS, J., De la ideología trifuncional a la separación de poderes. Madrid, 1993.

ÁlVAREZ ÁlVAREZ, C., La ciudad de León en la Baja Edad Media: el espacio urbano. León. 1992.

ÁLVAREZ BORGE, I., "Poder condal y organización territorial en Castilla en la Alta Edad Media. El alfoz de Clunia”, en Burgos en la Alta Edad Media II Jornadas Burgalesas de Historia. Burgos, 1991, pp. 571-586.

- Monarquía feudal y organización territorial. Alfoces y merindades en Castilla (siglos X-XIV). Madrid, 1993.

- Poder y Relaciones Sociales en Castilla en la Edad Media. Los territorios entre el Arlanzón y el Duero en los siglos Xal XIV. Salamanca, 1996.

ÁlVAREZ MORALES, A, Las Hermandades: expresión del movimiento comunitario en España. Madrid, 1974.

ÁlVAREZ PALENZUELA, V. A., Monasterios cistercienses en Castilla (siglos XIIXIII). Valladolid, 1978. 
AMADOR DE LOS RÍOS, J., Historia social, politica y religiosa de los judios de España y Portugal. Madrid, 1875-76 (reed. 1973).

ANDRÉS ORDAX, S., "Escultura monumental castellana en el tránsito del siglo XV al XVI: la portada de Santa María de Aranda de Duero", en Biblioteca 17. Estudio e Investigación. 2002, pp. 315-347.

APARICIO DE ANDRÉS, D., "Donaciones al monasterio de La Vid en el término de Alcozar (1160-1190)", en Celtiberia. 91, 1997, pp. 135-144.

ARAM, B., La reina Juana: gobierno, piedad y dinastía. Madrid, 2001.

ARAMBURU-ZABALA HIGUERA, M. A., Las obras públicas de Castilla entre 1575 y 1650: los puentes. Madrid, 1990, 2 Vol.

— La arquitectura de puentes en Castilla y León, 1575-1650. Valladolid, 1991.

ARANDA PÉREZ, F. J. (Coord.), Sociedad y élites eclesiásticas en la España Moderna. Cuenca, 2000.

ARAUZO BRIONES, E., "Catálogo de árboles singulares de la Ribera del Duero en la provincia de Burgos”, en Biblioteca 12. Estudio e investigación. 1997, pp. 117210.

ARÍZAGA BOLUMBURU, B., Urbanística medieval (Guipúzcoa). San Sebastián, 1990.

— "La recuperación del paisaje urbano medieval: propuesta metodológica", en $L a$ ciudad medieval: aspectos de la vida urbana en la Castilla bajomedieval. Valladolid, 1996, pp. 13-33.

- La imagen de la ciudad medieval: la recuperación del paisaje urbano. Santander, 2002.

ARMENTEROS ARMENTEROS, I. et álii, “Geología e Hidrogeología del Terciario en el sector de Aranda de Duero (Burgos)-Peñafiel (Valladolid), Sureste de la Cuenca del Duero", en Biblioteca, 11. Estudio e Investigación. 1996, pp. 45-66.

ARRANZ GUZMÁN, A., "El Clero", en Orígenes de la Monarquía Hispánica. Propaganda y legitimación (1400-1520). Madrid, 2004, pp. 141-175.

ARREGUI ZAMORANO, P., Monarquía y Señoríos en la Castilla moderna: Los Adelantamientos de Castilla, León y Campos (1474-1643). Valladolid, 2000.

ASENJO GONZÁLEZ, M., Segovia. La ciudad y su Tierra a fines del medievo. Segovia, 1986. 
— "El ritmo de la comunidad. Vivir en la ciudad, las artes y los oficios en la Corona de Castilla”, en La vida cotidiana en la Edad Media. Logroño, 1998, pp. 169200.

— "Las ciudades", en Orígenes de la Monarquía Hispánica: propaganda y legitimación (ca. 1400-1520). Madrid, 1999, pp. 105-140

— "Demografía. El factor humano en las ciudades castellanas y portuguesas a fines de la Edad Media", en Las sociedades urbanas en al España Medieval. Pamplona, 2003, pp. 97-150.

— "Acerca de los linajes urbanos y su conflictividad en las ciudades castellanas a fines de la Edad Media”, en Clio y Crimen: Revista del Centro de Historia del Crimen de Durango. 6, 2009, pp. 52-84.

— "La aportación del sistema urbano a la gobernabilidad del Reino de Castilla durante la época de los reyes católicos (1474-1504)", en Anuario de estudios medievales. 39/1, 2009, pp. 307-328.

ASENJO GONZÁLEZ, M. y MONSALVO ANTÓN, J. M., "Dos visiones de las villas de la Extremadura. Sector occidental y oriental de la cuenca meridional del Duero (siglos XI-final XV), en Boletín Arkeolan. 14, 2006, pp. 239-266.

ATIENZA HERNÁNDEZ, I., "La aristocracia en tiempos de Isabel I de Castilla: una aproximación cuantitativa y cualitativa", en Sociedad y Economía en tiempos de Isabel la Católica. Valladolid, 2002, pp. 133-149.

AZCONA, T., La elección y reforma del episcopado español en tiempo de los Reyes Católicos. Madrid, 1960.

- Isabel la Católica. Madrid, 1964.

— "Reformas del Episcopado y del clero de España en tiempo de los Reyes Católicos y de Carlos V”, en Historia de la Iglesia de España. Madrid, 1980. Vol. III1, pp. 115-210.

BARBERO, A. y VIGIL, M., La formación del feudalismo en la Península Ibérica. Barcelona, 1978.

BARRIENDOS VALLVÉ, M., "El clima histórico de Catalunya (siglos XIV-XIX). Fuentes, métodos y primeros resultados", en Revista de Geografía. 30 y 31, 1996-97, pp. 69-96

— "La climatología histórica en el marco de la antigua Monarquía Hispánica", en Scripta Nova, 3, 1999, pp. 32-54. 
BARRIOS GARCÍA, A., "Notas sobre la Diócesis de Osma en la Edad Media”, en Orígenes del Obispado de Osma. Arte e Historia en la Diócesis de Osma. El Burgo de Osma, 1998, pp. 229-258.

BARRÓN GARCÍA, A., "La platería arandina en el siglo XVI”, en Biblioteca 10. Estudio e Investigación. 1995, pp. 39-65.

— "Platería y artes decorativas medievales en la Ribera del Duero", en Biblioteca 17. Estudio e Investigación. 2002, pp. 233-67.

— "Platería y artes decorativas en el Renacimiento del Duero", en Biblioteca 18. Estudio e Investigación. 2003, pp. 177-215.

BARROS GUIMERANS, C., "Violencia y muerte del señor en Galicia a finales de la Edad Media”, en Studia Historica. Historia Medieval. 9, 1991, pp. 111-158.

BARTOLOMÉ HERRERO, B., "Una visita pastoral a la diócesis de Segovia durante los años 1446 y 1447”, en En la España Medieval. 18, 1995, pp. 303-349.

— "La Iglesia de Osma-Soria”, en Historia de las diócesis españolas. Madrid, 2004, vol. 20, pp. 321-492.

BEAULANDE, V., Le malheur d'être exclu? Excommunication, réconciliation el société à la fin du Moyen Âge. Paris, 2006.

BELTRÁN DE HEREDIA, V., Historia de la Reforma de la Provincia de España (1450-1550). Roma, 1939.

BENITO MARTÍN, F., La formación de la ciudad medieval. La red urbana en Castilla y León. Valladolid, 2000.

BENITO RUANO, E., Los orígenes del problema converso. Barcelona, 1976.

BERMÚDEZ AZNAR, A., El Corregidor de Castilla durante la Baja Edad Media (1348-1474). Murcia, 1974.

— "Los concejos y la administración del reino", en Concejos y ciudades en la Edad Media hispánica. Madrid, 1990, pp. 569-600.

BERZAL DE LA ROSA, E. Los Comuneros: de la realidad al mito. Madrid, 2008.

BIETENHOLZ, P. y DEUTXCHER, Th., Contemporaries of Erasmus. A Biographical Register of the Renaissance and Reformation. Toronto, 1995.

BLÁZQUEZ MIGUEL, J., Inquisición y criptojudaismo. Madrid, 1988.

BLICKLE, P., "El principio del bien común como norma para la actividad política: La aportación de campesinos y burgueses al desarrollo del Estado Moderno temprano en Europa Central”, en Edad Media: revista de historia. 1, 1998, pp. 29-46. 
BLOCH, M., Apología para la historia o el oficio de historiador. México, 2001.

BONACHÍA HERNANDO, J. A., El concejo de Burgos en la Baja Edad Media ((13451426). Valladolid, 1978.

- El Señorio de Burgos durante la Baja Edad Media (1255-1508). Valladolid, 1988.

- (Dir.), La ciudad medieval. Aspectos de la vida urbana en la Castilla bajomedieval. Valladolid, 1996.

— "Mas honrada que ciudad de mis reinos...: la nobleza y el honor en el imaginario urbano (Burgos en la Baja Edad Media)", en La ciudad medieval. Aspectos de la vida urbana en la Castilla bajomedieval. Valladolid, 1996, pp. 169-212.

— "El agua en la documentación municipal: los Libros de Actas", en El Agua en las ciudades castellanas durante la Edad Media. Valladolid, 1998, pp. 41-70.

— "La justicia en los municipios castellanos bajomedievales", en Edad Media. Revista de Historia. 1, 1998, pp. 145-182.

— "El desarrollo urbano de la villa de Aranda de Duero en la Edad Media", en Biblioteca 24. Estudio e Investigación. 2010, pp. 9-35.

— "La Iglesia de Castilla, la reforma del clero y el Concilio de Aranda de 1473", en Biblioteca 25. Estudio e Investigación. 2011, pp. 269-298.

BORRERO FERNÁNDEZ, M., "El papel social de la vid en un mundo dominado por la gran propiedad", en Historia, Instituciones, Documentos. 36, 2009, pp. 11-26.

— "Violencia entre vecinos: las tensiones cotidianas en el ámbito rural medieval", en Homenaje al profesor Eloy Benito Ruano. 2010, vol. 1, pp. 145-158.

CABEZUELO PLIEGO, J. V., "Guerra y violencia en un espacio frontero", en Canelobre. 52, 2007, pp. 42-57.

CABRILlANA, N., "La crisis del siglo XIV en Castilla: La Peste Negra en el obispado de Palencia", Hispania. 109, 1968, pp. 245-258.

CADIÑANOS BARDECI, I., Arquitectura fortificada en la provincia de Burgos. Madrid, 1987.

— "Judíos y moros en Aranda de Duero y sus contornos" en Sefarad. 50/1 y 2. 1990, pp. 47-66 у 289-318.

— "Judíos y moros en Aranda de Duero y sus contornos", en Biblioteca 7. Estudio e Investigación. 1992, pp. 23-51. 
— "Peñaranda de Duero: notas de historia y arte", en Biblioteca 8. Estudio e Investigación. 1993, pp. 111-131.

— "Los puentes del Sur de la provincia de Burgos durante la Edad Moderna", en Biblioteca 11. Estudio e Investigación. 1996, pp. 7-44.

— "Judíos y moros en el Duero arandino", en Biblioteca 18. Estudio e Investigación. 2003, pp. 57-74.

CALDERÓN CONCHA, P., "Teoría de conflictos de Johan Galtung”, en Revista Paz y Conflictos. 2, 2009, pp. 60-81.

CALDERÓN ORTEGA, J. M., "En torno al origen y las causas de los primeros pleitos del Estado de Monterrey en Galicia”, en Hispania. 168, 1988, pp. 49-78.

- Álvaro de Luna: riqueza y poder en la Castilla del siglo XV. Madrid, 1998

- El Ducado de Alba: la evolución histórica, el gobierno y la hacienda de un estado señorial (siglos XIV-XVI). Madrid, 2005.

CALLEJAS, F., El Fuero de Sepúlveda. Madrid, 1837.

CALVO PÉREZ, J. J., "Las ordenanzas de la villa de La Aguilera”, en Biblioteca 11. Estudio e Investigación. 1996, pp. 137-159.

— "La vida rural en Quintana del Pidio según las ordenanzas de los siglos XV y XVI", en Cuadernos del Salagar. Revista de Investigación Histórica y Cultura Tradicional, 2000, pp. 1-31.

CALVO PÉREZ, J. J. y HERNANDO GARCÍA, M., “Aranda de Duero y su comarca en el siglo XVIII según la relación de textos geográfico-históricos enviados a Tomás López”, en Biblioteca 8. Estudio e Investigación. 1993, pp. 67-110.

CALZADA TOLEDANO, J. J., Iconografía en el artesonado mudéjar de Sinovas. Burgos, 2009.

CANTERA MONTENGRO, E., "Pleitos de usura en la diócesis de Osma en el último tercio del siglo XV", en Anuario de Estudios Medievales. 12, 1982, pp. 597-624.

— "El apartamiento de judíos y mudéjares en las diócesis de Osma y Sigüenza a fines del siglo XV”, en Anuario de Estudios Medievales. 17, 1987, pp. 501-510.

— "Relaciones judeocristianas en la diócesis de Osma en el último tercio del siglo XV", en Encuentros en Sefarad. Actas del Congreso Internacional sobre los Judios en la Historia de España. Ciudad Real, 1987, pp. 103-136. 
— "Las comunidades mudéjares de las diócesis de Osma y Sigüenza a fines de la Edad Media”, en Espacio, tiempo y forma. Historia Medieval. 4, 1989, pp. 137173.

— "Una familia prestamista y arrendadores judíos en tiempos de la expulsión: los Soto de Aranda de Duero", en Espacio, tiempo y forma. Historia Medieval, 12, 1999, pp. 11-46;

— "Notas acerca de la expulsión de los judíos de la diócesis de Osma (Soria)", en Espacio, tiempo y forma. Historia Medieval. 13, 2000, pp. 57-84.

— "Las comunidades judía y mudéjar de Aranda de Duero a finales del siglo XV", Biblioteca 25. Estudio e Investigación. 2011, pp. 127-152.

CARANDE, R., Carlos Vy sus banqueros. Barcelona, ed. 2004.

CARBÓ, L., "Aproximación al conflicto bajomedieval castellano”, en Cuestiones de Historia Medieval. Buenos Aires, 2011, Vol. II, pp. 373-403.

CARCELLER CERVIÑO, P., Realidad y representación de la nobleza castellana del siglo XV: el linaje de la Cueva y la casa ducal de Alburquerque. Tesis de la Universidad Complutense de Madrid, 2006. Disponible en formato digital en http://eprints.ucm.es/tesis/ghi/ucm-t29153.pdf. Consulta realizada el 31/01/2012.

— "Los bandos nobiliarios y la carrera política: ascenso y privanza de Beltrán de la Cueva", en Anuario de Estudios Medievales. 36, 2006, pp. 783-801.

— "Nobleza cortesana, caballería y cultura: la casa ducal de Alburquerque", en $T i$ tulos, grandes del reino y grandeza en la sociedad política: sus fundamentos en la Castilla medieval. Madrid, 2006, pp. 215-263.

— "El privado como eje vertebrador del partido regio durante la época de Enrique IV: Beltrán de la Cueva", en El contrato político en la Corona de Castilla: cultura y sociedad política entre los siglos Xy XVI. Madrid, 2008, pp. 355-390.

CARLÉ, M. C., "El bosque en la Edad Media (Asturias-León-Castilla)", en Cuadernos de Historia de España. LIX-XL, 1976, pp. 297-334.

CARRASCO GARCÍA, G., "Judeoconversos de Jerez y el obispado de Cádiz a fines del siglo XV”, en En la España Medieval. 29, 2006, pp. 311-345.

CARRETERO ZAMORA, J. M., La averiguación de la Corona de Castilla, 1525-1540. Los pecheros y el dinero del reino en la época de Carlos V. Salamanca, 2008.

CARRIÓN GONZÁLEZ, L., Historia documentada del convento Domus Dei de La Aguilera. Madrid, 1930. 
CASADO ALONSO, H., Señores, mercaderes y campesinos. La comarca de Burgos a fines de la Edad Media. León, 1987.

— "Crecimiento económico y redes de comercio interior en la Castilla Septentrional (siglos XV y XVI)", en Imágenes de la diversidad. El mundo urbano en la Corona de Castilla (s. XVI-XVIII), Santander, 1997, pp. 283-322.

— "El movimiento comunero antes de la Revolución de las Comunidades", en Introducción a la Historia de Castilla. Burgos, 2001, pp. 711-729.

— "El Duero oriental a finales de la Edad Media y principios del siglo XVI: crecimiento económico y transformaciones", en Biblioteca 25. Estudio e Investigación. 2011, pp. 25-37.

CASTRILlO DE LA FUENTE, J. M., "Medidas contra la violencia que rodea a la prostitución clandestina en las ciudades medievales", en La convivencia en las ciudades medievales. Logroño, 2008, pp. 503-514.

- "Conflictividad social alrededor de la prostritucion ilegal en la Castilla bajomedieval", en Conflictos y sociedades en la historia de Castilla y León: aportaciones de jóvenes historiadores. Valladolid, 2010, pp. 317-326.

CÁTEDRA GARCÍA, P., La "Historia de la Casa de Zúñiga”: otrora atribuida a Mosén Diego de Valera. Salamanca, 2003.

CEBAS HERnANDO, J. A., Callejero comentado de Aranda de Duero. Aranda de Duero, 2000.

CEREZO MARTÍNEZ, R., La Cartografía Náutica Española en los Siglos XIV, XV y XVI. Madrid, 1994, p. 51.

CIUDAD RUÍZ, M., “El maestrazgo de Don Rodrigo Téllez Girón”, en En la España Medieval. 23, 2000, pp. 321-365.

CLÉMENT, V., "Frontière, reconquête e mutation des paysages végétaux entre Duero et Système Central du XI au milieu du XV siècle", en Melanges de la Casa de Velásquez, 29, 1993, pp. 87-126.

— "La forêt et les hommes en Castille au XIII siècle: l'exemple du territoire de Sepúlveda”, en Melanges de la Casa de Velásquez, 30, 1994, pp. 253-274.

CLEMENTE RAMOS, J. (Ed.), El medio natural en la España medieval: actas del I congreso sobre ecohistoria e historia medieval. Cáceres, 2001. 
COLLANTES DE TERÁN SÁNCHEZ, A., "Solidaridades laborales en Castilla", en Cofradias, gremios y solidaridades en la Europa medieval. Pamplona, 1993, pp. 113-126.

CONTRERAS, J., "Judíos, judaizantes y conversos en la península Ibérica en los tiempos de la expulsión”, en Judios. Sefarditas. Conversos. La expulsión de 1492 y sus consecuencias. Madrid, 1995, pp. 457-477.

CONTRERAS, J. y DEDIEU, J. P., "Estructuras geográficas del Santo Oficio en España”, en Historia de la Inquisición en España y América. Madrid, 1993. Vol. II, pp. 3-47.

CÓRDOBA DE LA LLAVE, R., “Adulterio, sexo y violencia en la Castilla medieval”, en Espacio, Tiempo y Forma. Historia Moderna. 7, 1994, pp. 153-184.

— "A una mesa y una cama: barraganía y amancebamiento a fines de la Edad Media”, en Saber y vivir: mujer, antigüedad y medievo. 1996, pp. 127-154.

— "Violencia cotidiana en Castilla a fines de la Edad Media", en Conflictos sociales, políticos e intelectuales en la España de los siglos XIV y XV. Logroño, 2004, pp. 393-444.

CORREDERA GUTIÉRREZ, E., "Los condes soberanos de Urgel y los premostratenses”, en Analecta Sacra Tarraconensia. 36, 1963, pp. 258-59.

CRESPO ORTIZ DE ZÁRATE, S., "Conflicto religioso entre paganismo y cristianismo en la Diócesis de Osma durante la Antigüedad Tardía Hispana", en Hispania Antiqua. XXVIII, 2004, pp. 179-196.

CRIADO MAMBRILLA, R., Historia de la imagen, cofradia y ermita de Nuestra Señora de las Viñas. Aranda de Duero, 2006.

CUÑAT CISCAR, V. M.,'La memoria del poder concejil: el documento escrito", en $L a$ gobernanza de la ciudad europea en la Edad Media. Logroño, 2011, pp. 517547.

DAHRENDORF, R., Clases sociales y su conflicto en la sociedad industrial. Madrid, 1970.

— "Hacia una teoría del conflicto social", en Los cambios sociales. Fuentes, tipos y consecuencias. México, 1968, pp. 97-107.

DÁNVILA COLLADO, M., Historia crítica y documentada de las Comunidades de Castilla. Madrid, 1897-1900. 
DÁVILA JALÓN, V., Historia y nobiliario de Gumiel de Mercado, Sotillo de la Ribera y Ventosilla. Madrid, 1958.

DE AYALA MARTÍNEZ, C., Las órdenes militares hispánicas en la Edad Media (siglos XII-XV). Madrid, 2007.

DE FRANCISCO OLMOS, J. M., "La moneda de la Castilla bajo medieval. Medio de propaganda e instrumento económico", en II Jornadas Científicas sobre Documentación de la Corona de Castilla (siglos XIII-XV). Madrid, 2003, pp. 278348.

DE LA CRUZ GONZÁlEZ, A., Historia de Nuestra Señora de las Viñas. Madrid, 1795 (reed. Aranda de Duero, 1983).

DE LA CRUZ, V., La abadía cisterciense de Bujedo de Juarros. S. XII-XIX. Burgos, 1990.

DE LAS HERAS MOLINOS, F. J., "El Medio Físico de la Comarca de la Ribera”, en Biblioteca 4. Estudio e Investigación. 1989, pp. 55-71.

DIAGO HERNANDO, M., "El comercio de la lana en Soria en época de los Reyes Católicos", en Celtiberia. 77-78, 1989, pp. 25-75.

— “Arrendadores arandinos al servicio de los Reyes Católicos", en Historia, Instituciones, Documentos. 18, 1991, pp. 71-99.

— "Caballeros e hidalgos en la Extremadura castellana medieval (siglos XII-XV)", en En la España Medieval. 15, 1992, pp. 31-62.

— "Linajes navarros en la vida política de la Rioja bajomedieval. El ejemplo de los Estúñiga”, en Príncipe de Viana. 197, 1992, pp. 563-582.

- Estructuras de poder en Soria a fines de la Edad Media. Valladolid, 1993.

— "El papel de los linajes en las estructuras del gobierno urbano en Castilla y en el Imperio alemán durante los siglos bajomedievales", en En la España Medieval. 20, Madrid, 1997, pp. 143-177.

— "Introducción al estudio del comercio entre las coronas de Aragón y Castilla durante el siglo XIV: las mercancías objeto de intercambio", en En la España Medieval. 24, 2001, pp. 47-101.

— "El papel de los corregidores en los conflictos políticos en las ciudades castellanas a comienzos del siglo XVI", en En la España Medieval. 27, 2004, pp. 195223. 
— "Las corporaciones de caballeros hidalgos en las ciudades castellanas a fines de la edad media. Su participación en el ejercicio del poder local”, en Anuario de Estudios Medievales. 36/2, 2006, pp. 803-838.

— "Cambios políticos e institucionales en Aranda de Duero desde el acceso al trono de los Reyes Católicos hasta la Revuelta Comunera", en Edad Media. Revista de Historia 9. 2008, pp. 299-342.

— "Hidalgos y pecheros en la lucha por el ejercicio del poder en Aranda de Duero durante el periodo bajomedieval", en Biblioteca 25. Estudio e Investigación. 2011, pp. 109-126.

DÍAZ DE DURANA, J. R., "El fenómeno urbano medieval en Álava y Vizcaya”, en El fenómeno urbano medieval entre el Cantábrico y el Duero. Santander, 2002, pp. 59-109.

DÍAZ IBÁÑEZ, J., "Simbología y ritual en torno a las relaciones y conflictos sociales del clero burgalés durante la baja Edad Media”, en Espacio, Tiempo y Forma, Historia Medieval. 22, 2009, pp. 91-121.

DÍAZ MARTÍNEZ, P. C., "La Diócesis de Osma en la Antigüedad”, en Arte e Historia de la Diócesis de Osma. El Burgo de Osma, 1998, pp. 205-230.

DÍEZ FERNÁNDEZ-LOMANA, J. C. y RODRÍGUEZ MARCOS, J. A., Las raíces de nuestra historia. De Atapuerca al Neolítico. Burgos, 2009.

DOMINGO ZAPATERO, E., La Comunidad de Villa y Tierra de Haza. Hoyales. Fuentelisendo. Madrid, 2002.

DOMÍNGUEZ BILBAO, R.,y GARCÍA DAUDER, S., Introducción a la Teoría del Conflicto en las organizaciones. Madrid, 2003.

DOMÍNGUEZ CASAS, R., Arte y etiqueta de los Reyes Católicos. Madrid, 1993.

— "Heráldica en el arte del Renacimiento: Burgos y el Sur Provincial", en Biblioteca 18. Estudio e Investigación. 2003, pp. 219-61.

DURANY CASTRILLO, M., "El paisaje rural medieval a través del ejemplo berciano", en Paisajes rurales y paisajes urbanos: métodos de análisis en Historia Medieval. Zaragoza, 1994, pp. 29-64.

EGIDO LÓPEZ, T., "El problema histórico de los judeo-conversos españoles”, en Las tres culturas en la Corona de Castilla y los sefardies. Salamanca, 1990, pp. 165178.

— (Coord.), Fernando I. Un infante español Emperador. Valladolid, 2004. 
ESCALONA MONGE, J., "Comunidades, territorios y poder condal en la Castilla del Duero en el siglo X”, en Studia Histórica. Historia Medieval. 18-19, 2000-2001, pp. 85-120.

ESCUDERO CHICO, S., Organización del espacio y poblamiento en la Tierra de Roa (Burgos) siglos V al XIII. Tesis inédita, Valladolid, 2001.

ESCUDERO CHICO, S. y MARTÍN MARTÍN, A. "Toponimia y Repoblación en el territorio burgalés durante la Alta Edad Media”, en Burgos en la Alta Edad Media. Burgos, 1991, pp. 521-537.

ESTEBAN RECIO, M. A., Palencia a fines de la Edad Media. Una ciudad de señorío episcopal. Valladolid, 1989.

ESTEBAN RECIO, M. A. e IZQUIERDO GARCÍA, M. J., "Pecado y marginación. Mujeres públicas en Valladolid y Palencia durante los siglos XV y XVI”, en La ciudad medieval: aspectos de la vida urbana en la Castilla bajomedieval. Valladolid, 1996, pp. 131-168.

ESTEBAN VAlLEJO, J. L., Historia documentada de Tórtoles de Esgueva. Burgos, 2011.

ESTEPA DÍEZ, C., Estructura social de la ciudad de León (s. XI-XIII). León, 1977.

- Las Behetrías castellanas. Valladolid, 2003, 2 Vol.

EZQUERRA REVILLA, I. J. y PIZARRO LLORENTE, H. P., "Los consejeros de Carlos V. Pedro de Acuña y Avellaneda" en La Corte de Carlos V. (Coord. MARTÍNEZ MILLÁN, J.), vol. 2, pp. 13-16.

FACI, J., "La reforma gregoriana en Castilla y León", en Historia de la Iglesia en España. Madrid, 1980, vol. II-1, pp. 262-275.

FERNÁNDEZ CONTI, S. (Coord.),. "Los servidores de las casas reales", en La Corte de Carlos V. Madrid. 2000. Vol. 3.

— "La organización de la Casa del príncipe Felipe (1535-1546), en La Corte de Carlos V. Madrid, 2000, vol. 1, Tomo II, pp. 97-120.

— "Los consejeros de Carlos V. Don Juan de Zúñiga y Avellaneda", en La Corte de Carlos V. (MARTÍNEZ MILLÁN coord.), Madrid, 2000, vol. 2, pp. 477-479.

— "Los consejeros de Carlos V. Francisco de Zúñiga y Avellaneda", en La Corte de Carlos V. (MARTÍNEZ MILLÁN coord.), Madrid, 2000, vol. 2, pp. 472-476 FERNÁNDEZ DE CÓRDOVA MIRALLES, A., Alejandro VI y los Reyes Católicos. Relaciones político-eclesiásticas. Roma, 2005. 
FEROS, A., El Duque de Lerma. Realeza y privanza en la España de Felipe III. Madrid, 2002.

FLORESCANO, E., "La función social del historiador", en La Historia y el historiador. México, 1997, pp. 63-87.

FONT ARELLANO, J., “Técnicas medievales de construcción con tierra”, en Construir la ciudad en la Edad Media. Logroño, 2010, pp. 335-356.

FONT TUllOT, I., Historia del clima en España. Cambios climáticos y sus causas. Madrid, 1988.

FRANCO SILVA, A., "El linaje Sandoval y el señorío de Lerma en el siglo XV", en El Pasado Histórico de Castilla y León. Edad Media. Salamanca, 1984. Vol. I, pp. 133-149.

— "El linaje Sandoval y el señorío de Lerma en el siglo XV", en Anales de la Universidad de Cádiz, I, 1984, pp. 45-61.

- La fortuna y el poder. Cádiz, 1996.

- Entre los reinados de Enrique IV y Carlos V: los Condestables del linaje Velasco (1461-1559). Jaén, 2006.

— "Juan Pachecho. De doncel del príncipe de Asturias a marqués de Villena (14401445)", en Anuario de Estudios Medievales. 39/2, 2009, pp. 723-775.

GALTUNG, J., Tras la violencia, 3R: reconstrucción, reconciliación, resolución. Afrontando los efectos visibles e invisibles de la guerra y la violencia. Bilbao, 1998

- Violencia cultural. Guernica, 2003.

GARCÍA CAMINO, I., "La vivienda medieval: perspectivas de investigación desde la arqueología", en La vida cotidiana en la Edad Media. Logroño, 1998, pp. 77110.

GARCÍA CÁRCEL, R., “Orígenes y naturaleza de la Inquisición”, en 1490, en el umbral de la modernidad: el Mediterráneo europeo y las ciudades en el tránsito de los siglos $X V$-XVI. Valencia, 1994, vol. 1, pp. 425-436.

GARCÍA DE CORTAZAR, J. A., Organización social del espacio en la España medieval. La Corona de Castilla en los siglos VIII al XV. Barcelona, 1985.

- La sociedad rural en la España medieval. Madrid, 1988. 
GARCÍA DE VALDEAVELLANO, G., "Carta de hermandad entre los concejos de la Extremadura castellana y del arzobispado de Toledo en 1295”, en Revista Portuguesa de Historia. XII, 1969, pp. 56-76.

GARCÍA FERNÁNDEZ, E., "Las cofradías de oficios medievales del País Vasco (1350-1550)", en Studia Historica, Historia Medieval. 15, 1997, pp. 11-40.

- Gobernar la ciudad en la Edad Media. Oligarquías y elites urbanas en el País Vasco. Vitoria, 2004.

- El linaje de los Ayala, Vitoria, 2007.

GARCÍA GRINDA, J. L., "La arquitectura popular castellana en sus tipos básicos. El ejemplo burgalés como encrucijada de influencias", en Aproximación etnográfica a Castilla y León. Barcelona, 1988, pp. 333-376.

GARCÍA IZQUIERDO, I., "Propuestas sobre la configuración territorial altomedieval de la cuenca del Duero: un estudio sobre la génesis de las comunidades de villa y tierra en el valle del Riaza", en Biblioteca 23. Estudio e Investigación. 2009, pp. 247-263.

GARCÍA MANSO, E., "El vino en época medieval en la Ribera del Duero”, en El vino en época tardoantigua y medieval. 2009, pp. 227-252.

GARCÍA MARCO, F. J., Las comunidades mudéjares de la Comarca de Calatayud en el siglo XV. Zaragoza, 1993.

GARCÍA MARÍN, J. M., El oficio público en Castilla durante la baja Edad Media. Madrid, 1987.

GARCÍA MERCADAL, J., Viajes de extranjeros por España y Portugal: desde los tiempos remotos hasta comienzos del siglo XX. Valladolid, 1999.

GARCÍA MERINO, C., Población y poblamiento en Hispania Romana. El Conventus Cluniensis. Valladolid, 1975.

— "Las raíces históricas de la sede episcopal oxomense: aproximación a la etapa tardoantigua de Uxama”, en I Semana de Estudios históricos de la Diócesis de Osma-Soria. Soria, 2000, vol. I, pp. 179-196.

GARCÍA ORO, J., Cisneros y la reforma del clero en España en tiempos de los Reyes Católicos. Madrid. 1971.

— "Conventualismo y Observancia. La reforma de las órdenes religiosas en los siglos XV y XVI”, en Historia de Iglesia en España Madrid, 1980, vol. III-1º, pp. 211-349. 
- Cisneros: un cardenal reformista en el trono de España (1436-1517). Madrid, 2005.

GARCÍA RÁMILA, I., El INEM Cardenal López de Mendoza. Burgos, 1958, reed. 1995.

GARCÍA SIMÓN, A., Castilla y León según la visión de los viajeros extranjeros. Siglos XV-XIX. Salamanca, 1999.

GARCÍA VILLOSLADA, R. (Dir.), Historia de la Iglesia en España. La Iglesia en la España de los siglos VIII-XIV. Madrid, 1980, Vol. II-1.

GARCÍA Y BELLIDO, et álii., Resumen Histórico del Urbanismo Español. Madrid, 1968.

GARCÍA Y GARCÍA, A., Synodicon Hispanum. VIII: Calahorra-La Calzada y Pamplona. Madrid, 2007.

GARCÍA, H., "El reformismo del Pastor Bonus de Juan Maldonado", en Hispania Sacra. $\mathrm{N}^{\mathrm{o}} 71,1983$, pp. 193-218.

GLICK, Th., Cristianos y musulmanes en la España medieval (711-1250). Madrid, 1991.

GOICOLEA JULIÁN, F. J.,’Los judíos y mudéjares de Haro a finales de la Edad Media: análisis del proceso de exclusión social de ambas comunidades en el siglo XV”, Historia, instituciones, documentos. 23, 1996, pp. 317-332.

— "Expansión territorial de los núcleos urbanos y la articulación de las relaciones con sus aldeas en la Rioja alta medieval", en Anuario de Estudios Medievales. 32/1, 2002, pp. 293-331.

- El gobierno urbano en La Rioja en época medieval e inicios de la Edad Moderna (s. XIII-mediados del XVI. Logroño, 2004.

— "'Los más nobles y honrados': caballeros e hidalgos en las ciudades y villas riojanas (s. XV-inicios s. XVI)", en Brocar: Cuadernos de investigación histórica. 31, 2007, pp. 411-440.

— "El vino en el mundo urbano riojano a finales de la Edad Media", En la España medieval. 30, 2007, pp. 217-244.

GÓMEZ BÁRCENA, M. J., "Escultura gótica funeraria en Burgos. La Ribera del Duero", Biblioteca 17. Estudio e Investigación. 2002, pp. 269-292.

GÓMEZ GÓMEZ, A., "La techumbre mudéjar de Sinovas", en Biblioteca 17. Estudio e Investigación. 2002, pp. 71-90. 
GONZÁLEZ ALONSO, B., "Sociedad urbana y gobierno municipal en Castilla (14501600)", en Sobre el Estado y la administración de la Corona de Castilla en el Antiguo Régimen. Madrid, 1981, pp. 57-84.

— "La reforma del gobierno de los concejos en el reinado de Isabel", en Isabel la Católica y la política. Valladolid, 2001, pp. 293-312.

GONZÁLEZ ARCE, J. D., Gremios, producción artesanal y mercado: Murcia, siglos $X I V y X V$. Murcia, 2000.

GONZÁLEZ CRESPO, E., Elevación de un linaje nobiliario castellano en la Baja Edad Media: los Velasco. Tesis leída en la Universidad Complutense de Madrid, 1981

GONZÁLEZ ECHEGARAY, M. C. et álii, Artistas cántabros de la Edad Moderna: su aportación al arte hispánico. Diccionario biográfico-artístico. Santander, 1991.

GONZÁleZ GONZÁLEZ, C., Real monasterio de Santo Domingo de Caleruega. Salamanca, 1993.

GONZÁLEZ JIMÉNEZ, M., El mundo urbano en la Castilla del siglo XIII. Sevilla. 2006.

GONZÁLEZ MÍNGUEZ, C., “Algunos datos sobre la población de Castilla durante el reinado de Fernando IV", en El Pasado Histórico de Castilla y León. Edad Media. Salamanca, 1984. Vol. I, pp. 87-99.

GONZÁLEZ, J., El reino de Castilla en la época de Alfonso VIII. Madrid, 1960. 3 Vol.

- Reinado y diplomas de Fernando III. Córdoba, 1983.

GOÑI, J, “López de Mendoza y Zúñiga, Ínigo”, en Historia Eclesiástica de España. Madrid, 1972, pp. 452-454.

GROIZARD Y CORONADO, C., Ensayo de investigación histórica. La Diócesis de Calahorra en el siglo XV. Don Juan de Quemada, obispo auxiliar (1478-1492). Madrid, 1913.

GUERRERO NAVARRETE, Y., Organización y gobierno en Burgos durante el reinado de Enrique IV de Castilla (1453-1476). Madrid, 1986.

— "La política de nombramiento de corregidores en el siglo XV: entre la estrategia regia y la oposición ciudadana", en Anales de la Universidad de Alicante. 10, 1994-1995, pp. 99-124.

— “Élites urbanas en el siglo XV: Burgos y Cuenca", Revista d'Història Medieval. 9, 1998, pp. 81-104. 
— “Orden público y corregidor en Burgos (siglo XV)", Anales de la Universidad de Alicante. 13, 2000-2002, pp. 59-102.

— "Poder patricio e identidad política en Burgos", en Anales de la Universidad de Alicante. 16, 2009-2010, pp. 63-91.

GUIJARRO GONZÁLEZ, S., "Los centros de cultura urbana en el siglo XV: las escuelas de gramática castellano-leonesas", en 1490, en el umbral de la modernidad: el Mediterráneo europeo y las ciudades en el tránsito de los siglos XV-XVI. Valencia, 1994, vol. 2, pp. 243-256.

GUILARTE, A. M., El obispo Acuña. Historia de un comunero. Valladolid, 1983.

GUTIÉRREZ GONZÁLEZ, J. A., Fortificaciones y Feudalismo en el origen y formación del Reino Leonés (siglos IX-XIII). Zaragoza, 1995.

GUTIÉRREZ NIETO, J., "La semántica del término comunidad antes de 1520. Las asociaciones juramentadas de defensa", en Hispania. 136, 1977, pp. 316-379.

HARO ÁlVAREZ, M. L. e IGLESIAS AGÜERA, P., "Restauración de la iglesia de San Juan Bautista por el módulo de piedra-mármol de la Escuela-Taller", en Restauración Iglesia de San Juan Bautista. Aranda de Duero. Aranda de Duero, 1990, pp. 15-19.

HERNÁNDEZ ÍÑIGO, P., “Aproximación al utillaje agrícola bajomedieval a través de los protocolos notariales: el caso de Córdoba", en Vida cotidiana en la España medieval. Madrid, 1998, pp. 281-302.

HERNANDO GALLARDO, J. L., "Pintura gótica en la Ribera del Duero: el arte de contar historias", en Biblioteca 17. Arte e Investigación. 2002, pp. 145-186.

— "Notas sobre la pintura del siglo XVI en la Ribera del Duero: párvulos hallazgos y otras apostillas", en Biblioteca 18. Arte e Investigación. 2003, pp. 315-355.

HERNANDO SÁNCHEZ, C. J., Castilla y Nápoles en el siglo XVI. El Virrey Pedro de Toledo. Salamanca, 1994.

HIGOUNET, C., Paysages et villages neufs du Moyen Âge. Burdeos, 1975.

HILTON, R., Conflicto de clases y crisis del feudalismo. Barcelona, 1988.

HOPFNER, H., "La evolución de los bosques de Castilla la Vieja en tiempos históricos”, en Estudios Geográficos. 56, 1954, pp. 415-430.

HUETZ DE LEMPS, A., Vinos y viñedos de Castilla y León. Segovia, 2004.

IBÁÑEZ ALONSO, J., Del algoritmo al sujeto. Perspectivas de la investigación social. Madrid, 1985. 
IGLESIAS BERZOSA, J., "Importancia del vino en el desarrollo económico de la villa y tierra de Aranda (s. XVI). Estudio de las bodegas", en Biblioteca 18. Estudio e Investigación. 2003, pp. 75-116.

IGLESIAS BERZOSA, J. y VILLAHOZ GARCÍA, A., Viñedo, vino y bodegas en la Historia de Aranda de Duero. Aranda de Duero, 1982.

IZQUIERDO BENITO, R., Un espacio desordenado. Toledo a fines de la Edad Media. Toledo, 1996.

— "Los conflictos socio-religiosos en las ciudades medievales castellanas", en $L a$ convivencia en las ciudades medievales. Logroño, 2008, pp. 81-111.

IZQUIERDO, P., "La Ribera del Duero en la Literatura española”, en Biblioteca 10. Estudio e Investigación. 1995, pp. 209-230.

JARA FUENTE, J. A., "Posiciones de clase y sistemas de poder: vinculación y contradicciones en la construcción del 'común de pecheros' en la baja Edad Media”, en Los espacios de poder en la España medieval. Logroño, 2002. pp. 511-532.

— "Estructuras formales de poder y de organización de las clases dominantes urbanas en Castilla. El regimiento: una crisis del siglo XIV en el siglo XV”, en Edad Media. Revista de Historia. 8, 2007, pp. 225-241.

— "Con mucha afección e buena voluntad por seruir a bien publico: la noción de ‘bien común’ en perspectiva urbana”, en Studia historica. Historia Medieval. 28, 2010, pp. 55-82.

— "Negociando la dominación: las elites urbanas castellanas en el siglo XV (el ejemplo de Cuenca)", en La gobernanza de la ciudad europea en la Edad Media. Logroño, 2011, pp. 399- 425.

JERÉZ CALDERÓN, J. J., Pensamiento político y reforma institucional durante la Guerra de las Comunidades de Castilla (1520-1521). Madrid, 2007.

JIMÉNEZ ALCAZAR, J. F., Un concejo de Castilla en la frontera de Granada. Lorca 1460-1521. Granada, 1997.

— "Con el qual deseo murieron todos los nuestros antepasados: propaganda, legitimidad y pasado como factores de gobierno en los concejos castellanos (siglos XIII-XVI), en La gobernanza de la ciudad europea en la Edad Media. Logroño, 2011, pp. 487-515.

KAGAN, R. L., Ciudades del siglo de Oro: las vistas españolas de Anton Van den Wyngaerde. Madrid, 1986. 
— Imágenes urbanas del mundo hispánico: 1493-1780. Madrid, 1998.

KEMP, M., Leonardo da Vinci. Las maravillosas obras de la naturaleza y el hombre. Madrid, 2011.

KLEIN, J. La Mesta. Madrid, 1979.

LADERO QUESADA, M. A., Los mudéjares de Castilla en tiempo de Isabel I. Valladolid, 1969.

- La Hacienda Real en Castilla en el siglo XV. La Laguna, 1973.

— “Los mudéjares en Castilla", en Historia. Instituciones. Documentos. 5, 1978, pp. 257-304.

— "La caza en la legislación municipal castellana. Siglos XIII a XVIII", en En la España Medieval. 1, 1980, pp. 193-221.

— “Aspectos de la política económica de Alfonso X”, en Revista de la Facultad de Derecho de la Universidad Complutense. 9, 1985, pp. 69-82.

— "Corona y ciudades en la Castilla del siglo XV", en En la España Medieval. 8, 1986, pp. 551-574.

- "Estado y Hacienda en Castilla durante la Baja Edad Media"; en Estado, Hacienda y Sociedad en la Historia de España. Valladolid, 1989, pp. 13-43.

- Castilla y la Conquista de Granada. Granada, 1993.

- Las ferias de Castilla: siglos XII al XV. Madrid, 1994.

— "Monarquía y ciudades de realengo en Castilla siglos XII a XV", en Anuario de Estudios Medievales. 24, 1994, pp. 718-773.

— "El sistema impositivo en Castilla y León (siglos X-XIII)", en I Jornadas sobre Documentación jurídico-administrativa, económico financiera y judicial del reino castellano-leonés (siglos X-XIII). Madrid, 2002, pp. 283-302.

— "Castilla a comienzos del siglo XVI: sociedad y poder", en Entorno a las comunidades de Castilla. Cuenca, 2002, pp. 27-44.

- La Hermandad de Castilla: cuentas y memoriales, 1480-1498. Madrid, 2005.

— "Deudas y bienes de judíos del obispado de Burgos en 1492", en Aragón en la Edad Media. 19, 2006, pp. 285-300.

LADERO QUESADA, M. F., Las ciudades de la Corona de Castilla en la Baja Edad Media (siglos XIII-XV). Madrid, 1996.

— "La vivienda: espacio público y espacio privado en el paisaje urbano medieval", en La vida cotidiana en la Edad Media. Logroño, 1998, pp. 111-128. 
LAURENT, P. et álii, Bastides, villes nouvelles du Moyen Âge. Toulouse, 1988.

LAVADO PARADINAS, P., "El palacio fortaleza de los Delgadillo en Castrillo de don Juan”, en Publicaciones de la Institución Tello Téllez de Meneses. 41, 1979, pp. 217-231.

LAVEDAN, P., L'Urbanisme au Moyen Âge. Géneve, 1974.

LAYNA SERRANO, F., Historia de Guadalajara y sus Mendozas en los siglos XV y XVI. Madrid, 1942.

LÁZARO PALOMINO, F. e IGLESIAS BERZOSA, J., Restauración Iglesia de San Juan Bautista. Aranda de Duero, 1990.

LE GOFF, J., Tiempo, trabajo y cultura en el occidente medieval. Madrid, 1983.

LE ROY LADURIE, E., Le territoire de l'historien. París, 1973.

LECANDA ESTEBAN, J. A. y PALOMINO LÁZARO, A. L., "Dos modelos de ocupación del territorio en época visigoda en la provincia de Burgos: la región montañesa septentrional y la comarca ribereña del Duero", en Actas del V Congreso de Arqueología Medieval Española. Valladolid, 2000, vol. I, pp. 37-48.

LINAJE CONDE, A., "Memorias de La Vid”, en Cor Unum, 1979, n 195-196, p. 48.

LINDE, L. M., Don Pedro Girón, duque de Osuna. La Hegemonía española en Europa a comienzos del siglo XVII. Madrid, 2005.

LLORENTE, J. A., Historia Crítica de la Inquisición Española. Barcelona, ed. 1870.

LOBATO CEPEDA, B. et álii, "Arquitectura de adobe en la Ribera del Duero", Narria, 28, 1982, pp. 10-13.

LÓPEZ DE GUEREÑO SANZ, M., Monasterios medievales premostratenses. Reinos de Castilla y León. Salamanca, 1997, 2 Vol.

LÓPEZ MARTÍNEZ, N., Judaizantes e Inquisición en la Ribera del Alto Duero (14861502), Burgos, 2005.

LÓPEZ MATA, T., Geografía del Condado de Castilla a la muerte de Fernán González. Madrid, 1957.

LÓPEZ PITA. P. "Nobleza y monarquía en el Tránsito a la Edad Moderna. Títulos y Grandes en el movimiento comunero", en Títulos, grandes del reino y grandeza en la sociedad política: Fundamentos en la Castilla medieval. Madrid, 2006, pp. $163-213$.

LÓPEZ SANZ, M. "Las fuentes públicas en Aranda de Duero", en Siglo XXI. Sept. de 1998, pp. 18 y 19. 
LOSADA VAREA, C., La arquitectura en el otoño del Renacimiento: Juan de Naveda, 1590-1638. Santander, 2007.

LOSADA, A., Epistolario de Juan Ginés de Sepúlveda. Madrid, 1979.

LOZANO HERNÁNDEZ, J., El discurso histórico. Madrid, 1987.

LUNENFIELD, M., Los corregidores de Isabel la Católica. Barcelona, 1989.

MACKAY, A., "Hacienda y Sociedad en la Castilla Bajomedieval", en Estado, Hacienda y Sociedad en la Historia de España. Valladolid, 1989, pp. 47-78.

MANSILLA REOYO, D., "Obispado y monasterios", en Historia de Burgos. Burgos, 1986, vol. II, pp. 295-356.

MANZANO MANZANO, J., "Fray Antonio de Marchena, principal depositario del gran secreto colombino", en Andalucía y América en el siglo XVI. Sevilla, 1983, vol. II, pp. 501-516.

MARÍN DE SAN MARTÍN, L., El monasterio de Santa María de la Vid. 850 años. Madrid, 2004.

MÁRQUEZ VILLANUEVA, F., "Conversos y cargos concejiles en el siglo XV”, en Revista de Archivos, Bibliotecas y Museos. Tomo LXIII, 2, 1957, pp. 503-540.

MARTÍN CEA, J. C., "Una pequeña contribución al conocimiento del campesinado castellano: el yuguero", en El pasado histórico de Castilla y León. Salamanca, 1984, Tomo I, pp. 101-112.

- El campesinado castellano de la Cuenca del Duero. Aproximaciones a su estudio durante los siglos XIII al -XV). Zamora, 1986.

— El mundo rural castellano a fines de la Edad Media. Valladolid, 1991.

— "El modelo testamentario bajomedieval castellano y su reflejo en los diferentes grupos sociales", en Edad Media. Revista de Historia. 6, 2003-2004, pp. 103156.

— "Violencia y conflictividad social en Castilla, vista desde el prisma de la historia local (siglos XIV y XV), en Conflicto, violencia y criminalidad en Europa y América. Vitoria, 2004, pp. 105-144.

— "La intervención política concejil en el mantenimiento de la convivencia. Castilla siglos XIV y XV", en La convivencia en las ciudades medievales. Logroño, 2008, pp. 393- 425.

MARTÍN CEA, J. C. y BONACHÍA HERNANDO, J. A., "Oligarquías y poderes concejiles en la Castilla Bajomedieval: balance y perspectivas", en Oligarquías polí- 
ticas y elites económicas en las ciudades bajomedievales (siglos XIV-XVI). Revista d'Història Medieval, 9, Valencia, 1998, pp. 17-40.

MARTÍN CIVANTOS, J. M., “Arqueología y recursos naturales. Notas para la arqueología del Paisaje", en Medio Ambiente y Arqueología Medieval. Granada, 2008, pp. 17-39.

MARTÍN CRIADO, A., La ornamentación en la arquitectura tradicional de la Ribera del Duero. Ávila. 2008.

MARTÍN VISO, I., “Organización episcopal y poder entre la Antigüedad Tardía y el Medievo (siglos V-XI): las sedes de Calahorra, Oca y Osma", en Iberia. 2, 1999, pp. 151-190.

— "Una frontera casi invisible: los territorios al norte del Sistema Central en la Alta Edad Media (siglos VIII-XI)”, en Studia Histórica. Historia Medieval. 23, 2005, pp. 89-114.

— "Repoblaciones, territorios, iglesias y santos: los valles del Duratón y del Riaza (siglos X-XII)", en Biblioteca 23. Estudio e Investigación. 2009, pp. 265-292.

MARTÍNEZ DÍEZ, G., Libro Becerro de las Behetrías. Estudio y texto crítico. León, 1981.

- Fueros locales en el territorio de la provincia de Burgos. Burgos, 1982.

- Las Comunidades de Villa y Tierra de la Extremadura castellana. Madrid, 1983.

— "La época condal”, en Historia de Burgos. Vol. II Edad Media (1), Burgos, 1986, pp. 48-49.

— Pueblos y alfoces burgaleses de la repoblación. Valladolid, 1987.

— “Algunos aspectos de la Diócesis de Osma en la Edad Contemporánea", en Arte e Historia de la Diócesis de Osma. El Burgo de Osma, 1998, pp. 281-317.

MARTÍNEZ GARCÍA, L., "Los campesinos solariegos en las behetrías castellanas durante la Baja Edad Media”, en Los señorios de Behetría. 2001, pp. 187-226.

— "El señorío abadengo en Castilla: consideraciones sobre su formación y desarro1lo (ss. XI-XIV)", en Historia Medieval: Revista de Historia. 8, 2007, pp. 243277.

MARTÍNEZ LLORENTE, F. J., Régimen jurídico de la Extremadura Castellana medieval. Las Comunidades de Villa y Tierra (s. X-XIV). Valladolid, 1990. 
MARTÍNEZ MARTÍNEZ, M. J., "Aproximación iconográfica de la fachada de Santa María la Real de Aranda de Duero", en Biblioteca 10. Estudio e Investigación. 1995, pp. 23-37.

— "Orgullo, miedos y esperanzas del pueblo de Aranda a finales de la Edad Media: la fachada de Santa María la Real”, Biblioteca 25. Estudio e Investigación. 2011, pp. 153-186.

MARTÍNEZ MiLlÁN, J. (Dir.), La Corte de Carlos V. Madrid, 2000. 3 Vol.

MARTÍNEZ MiLlÁN, J. y DE CARLOS MORALES, C., Felipe II. La configuración de la monarquía hispánica. Valladolid, 1998.

MARTÍNEZ MORO, J. La renta feudal en la Castilla del siglo XV: Los Stúñiga. Valladolid, 1977.

MARTÍNEZ SOPENA, P., La Tierra de Campos Occidental. Poblamiento, poder y comunidad del siglo X al XIII. Valladolid, 1985.

— "Réorganisation de l'espace et conflits de pouvoir: les pueblas reales au Nord du Duero", en Genèse médiévales de l'Espagne Moderne. Du refus a la révolte: les résistences. Niza, 1991, pp. 7-20.

— “Logroño y las villas riojanas entre los siglos XII y XIV”, en Historia de la ciudad de Logroño. Logroño, 1994, pp. 279-322.

— "Repoblaciones interiores, villas nuevas de los siglos XII y XIII", en IV Congreso de Estudios Medievales. León, 1995, pp. 163-87.

— "Villas nuevas y planificación urbana en la Castilla medieval", en Castilla y el mundo feudal. Valladolid, 2009, vol. I, pp. 469-484.

MARTÍN-VIDE, J. (Ed.), Avances en Climatología histórica en España. Barcelona, 1997.

MENDOZA, J. A., "El cardenal D. Íñigo López de Mendoza y el monasterio de La Vid", en Archivo Agustiniano. 44, Madrid, 1950, pp. 67-84.

MENÉNDEZ PIDAL, R., "Repoblación y tradición en la cuenca del Duero", en Enciclopedia Lingüística Hispánica. Madrid, 1960, Tomo I, pp. XXIX-XLVII.

MENJOT, D. y SÁNCHEZ MARTÍNEZ, M. (coord.), Fiscalidad de Estado y fiscalidad municipal en los reinos hispánicos medievales. Madrid, 2006.

MERINO GAYUBAS, C., Genealogía del solar de Guzmán. Salamanca, 2001. 2 Vol. 
MÍNGUEZ FERNÁNDEZ, J. M., "Feudalismo y concejos. Aproximación metodológica al análisis de las relaciones sociales de los concejos medievales castellanoleoneses”, en En la España medieval. 3, 1982, pp. 109-122.

MOLINERO, F., “Origen y evolución de la Ribera del Duero", en Ponencias del I Curso de Viticultura y Enología Denominación de Origen Ribera del Duero 2001. Aranda de Duero, 2002, pp. 9-14.

MONSALVO ANTÓN, J. M., “La formación del sistema concejil en la zona de Burgos (siglo XI-mediados del siglo XIII)", en Burgos en la Plena Edad Media. Burgos, 1984, pp. 127-210.

— "Herejía conversa y contestación religiosa a fines de la Edad Media. Las denuncias a la Inquisición en el Obispado de Osma”, en Studia Historica. Historia Medieval. 2, 1984, pp. 109-138.

- El Sistema político concejil: el ejemplo del señorío medieval de Alba de Tormes y su concejo de Villa y Tierra. Salamanca, 1988.

— "La participación política de los pecheros en los municipios castellanos de la Baja Edad Media. Aspectos organizativos”, en Studia Historica. Historia Medieval. 7, 1989, pp. 37-94.

— "Concejos castellano-leoneses y feudalismo (Siglos XI-XIII). Reflexiones para un estado de la cuestión", en Studia Historica. Historia Medieval. 10, 1992, pp. 203-243.

— "Parentesco y sistema concejil. Observaciones sobre la funcionalidad política de los linajes urbanos en Castilla y León (siglos XIII-XV)", en Hispania. Revista Española de Historia. 53/185, 1993, pp. 937-969.

— "Solidaridades de oficio y estructuras de poder en las ciudades castellanas de la Meseta durante los siglos XIII y XV (aproximación al estudio del papel político del corporativismo artesanal)", en El trabajo en la Historia. Salamanca, 1996, pp. 39-90.

— "Los territorios de las villas reales de la Vieja Castilla, ss. XI-XIV: (estudio a partir de una docena de sistemas concejiles entre el Arlanza y el alto Ebro)", en Studia Historica. Historia Medieval. 17, 1999, pp. 15-86.

— “Centralización monárquica castellana y territorios concejiles (algunas hipótesis a partir de las ciudades medievales de la región Castellano-Leonesa)", en Anales de la Universidad de Alicante. Historia medieval, 13, 2000-2002, pp. 157-202. 
— “Aproximación al estudio del poder gremial en la Edad Media castellana. Un escenario de debilidad", en En la España Medieval. 25, 2002, pp. 135-176.

- "Aspectos de las culturas políticas de los caballeros y los pecheros en Salamanca y Ciudad Rodrigo a mediados del siglo XV. Violencias rurales y debates sobre el poder en los concejos", en Lucha política. Condena y legitimación en la España medieval. Lyon, 2004, pp. 237-296.

— "En torno a la cultura contractual de las élites urbanas: pactos y compromisos políticos (linajes y bandos de Salamanca, Ciudad Rodrigo y Alba de Tormes)", en El contrato político en la Corona de Castilla: cultura y sociedad políticas entre los siglos Xy XVI . Madrid, 2008, pp. 159-209.

— "Luchas de bandos en Ciudad Rodrigo durante la época Trastámara", en Castilla y el mundo feudal. Valladolid, 2009, vol. III, pp. 201-221

— "Violence between Factions in Medieval Salamanca: some Problems of Interpretation", Imago temporis. Medium Aevum. 3, 2009, pp. 139-170.

MONTOYA GARCÍA-REAL, E, La Ribera del Duero burgalesa. El vino y su Denominación de Origen. Burgos, 2006, pp. 17-20

MORAL GARCÍA, J., "Evolución de la población de Aranda de Duero en los primeros tiempos de la Edad Moderna", en Biblioteca 6. Estudio e Investigación. 1991, pp. 159-190.

- Milagros. Su pasado histórico. Burgos, 2004.

MORATINOS GARCÍA, M. y VILLANUEVA ZUBIZARRETA, O., “Consecuencias del decreto de conversión al cristianismo de 1502 en la aljama mora de Valladolid”, en Sharq al-Andalus. 16-17, 1999-2002, pp. 117-139.

MORENO PEÑA, J. L., "Burgos en su espacio geográfico", en Historia de Burgos I (Edad Antigua). Burgos, 1984, pp. 39-82.

MORETA VELAYOS, S., Rentas monásticas en Castilla: problema de método. Salamanca, 1974.

- Malhechores feudales: violencia, antagonismos y alianzas en clases en Castilla siglos XIII-XIV. Madrid, 1978.

MOXÓ, S., "De la nobleza vieja a la nobleza nueva. La transformación nobiliaria castellana en la Baja Edad Media", en Cuadernos de Historia. Anexos de la revista Hispania. 3, 1969, pp. 1-210.

— Los antiguos señoríos de Toledo. Toledo, 1973. 
NARBONA VIZCAÍNO, R., "El método prosopográfico y el estudio de las élites de poder bajomedievales", en El Estado en la Baja Edad Media: nuevas perspectivas metodológicas. Zaragoza, 1999, pp. 31-49.

— "La introducción de la Inquisición en las ciudades de Castilla y de la Corona de Aragón”, en Tolerancia y fundamentalismo en la Historia. Salamanca, 2007, pp. 53-98.

NETANYAHU, B., Los marranos españoles desde finales del siglo XIV a principios del XVI según las fuentes hebreas, Valladolid, 1994.

— Los orígenes de la Inquisición en la España del siglo XV, Barcelona, 1999.

— “Causas y fines de la Inquisición española", en Isabel la Católica y la política. Valladolid, 2001, pp. 315-331.

NIETO SORIA, J. M., "Las relaciones Monarquía-Episcopado en Castilla, siglos XIIIXIV. Definición de sus caracteres e interpretación de conjunto", en El Pasado Histórico de Castilla y León. Edad Media. Salamanca, 1984, vol. I, pp. 285-294.

- Iglesia y génesis del Estado Moderno en Castilla (1369-1480). Madrid, 1994.

- (Dir.), Orígenes de la Monarquía Hispánica. Propaganda y Legitimación (ca.1400-1520). Madrid, 2004.

NUÑO GONZÁLEZ, J., "Pautas de ocupación territorial y conformación urbana en la Ribera del Duero burgalesa durante la Edad Media", en Biblioteca 16. estudio e Investigación. 2001, pp. 79-104.

— "La Ribera del Duero burgalesa entre los siglos XIII y XIV”, en Biblioteca 17. Estudio e Investigación. 2002, pp. 11-41.

— "Aranda y sus tierras en el siglo XVI: ambiente histórico en un tiempo de grandes empresas", en Biblioteca 18. Estudio e Investigación. 2003, pp. 9-37.

— "Las iglesias rurales en la Ribera del Duero en época románica: un variado papel dentro de una sociedad en formación”, en Biblioteca 23. Estudio e Investigación. 2009, pp. 137-159.

OLIVA HERRER, H. R., La Tierra de Campos a fines de la Edad Media. Economía, sociedad y acción política campesina. Valladolid, 2002.

— "El mundo rural en tiempos de Isabel I", en Sociedad y economía en tiempos de Isabel La Católica. Valladolid, 2002, pp. 41-75.

- Justicia contra señores. El mundo rural y la política en tiempos de los Reyes Católicos. Valladolid, 2004. 
— "El mundo rural y la política en tiempos de los Reyes Católicos", en Isabel La Católica y su época. Valladolid, 2007, vol. 1, pp. 299-318.

— "Reacciones a la crisis de 1504 en el mundo rural castellano", en Crisis de subsistencia y crisis agrarias en la Edad Media. Sevilla, 2007, pp. 259-276.

— "Conflictos antiseñoriales en el reino de Castilla a fines de la Edad Media: viejas preguntas, ¿nuevas respuestas?”, en Historia, instituciones, documentos. 36, 2009, pp. 313-331.

— "La crisis del siglo XIV en el valle del Duero Oriental. Notas para una evaluación de la crisis del siglo XIV”, en Biblioteca 24. Estudio e Investigación. 2010, pp. 105-120.

OLIVA HERRER, H. R. y CHALLET, V., "La sociedad política y el mundo rural a fines de la Edad Media”, en Edad Media. Revista de Historia. 7, 2005-2006, pp. 75-98.

OLIVERA SERRANO, C., "Los señores y el estado de Monterrey", en Cuaderno de Historia de España. LXXX, 2006, pp. 147-170.

OLMOS HERGUEDAS, E., "Urbanística medieval en una villa de la cuenca del Duero. Cuéllar durante la Baja Edad Media”, en La ciudad medieval. Aspectos de la vida urbana en la Castilla bajomedieval. Valladolid, 1996, pp. 53-81.

- La Comunidad de Villa y Tierra de Cuéllar a partir de las ordenanzas de 1546. Valladolid, 1997, pp. 92-102.

- La Comunidad de Villa y Tierra de Cuéllar a fines de la Edad Media. Poder político concejil, ordenanzas municipales y regulación de la actividad económica. Valladolid, 1998.

- Agua, paisaje y ecohistoria. La comarca de Cuéllar a partir del siglo XIII. Valladolid, 2011.

ONTORIA OQUILLAS, P., "El Concilio de Aranda. Aportaciones para su historia externa”, en Boletín de la Institución Fernán González. 187, 1976, pp. 999-1046.

- "Aportaciones bibliográficas al Concilio de Aranda", en Biblioteca. Estudio e Investigación. 3 y 4, 1985-86, pp. 79-84 y101-118.

— "El arcipreste de Gumiel, Don Gonzalo García de Aza, tutor de Santo Domingo de Guzmán”, en Santo Domingo de Caleruega. Jornadas de Estudios Medievales. Salamanca, 1994, pp. 277-297. 
OREJAS SACO DEL VALLE, A., “Territorio, análisis territorial y Arqueología del Paisaje", en Studia Historica. Historia Antigua. 13-14, 1996, pp. 61-68.

— “Arqueología de los paisajes agrarios e historia rural”, en Arqueología Espacial. 26, 2006, pp. 7-19.

ORTEGA VALCÁRCEL, J., "Geografía histórica de Burgos Altomedieval”, en Burgos en la Alta Edad Media. Burgos, 1991, pp. 181-228.

— "El microcosmos humanizado: los núcleos urbanos y las comunicaciones", en Historia de la Ciencia y de la Técnica en la Corona de Castilla. Valladolid, 2002, vol. I, pp. 277-443.

PALACIOS MADRID, F., "El monasterio de Gumiel de Izán, panteón de los Guzmanes”, en Boletín de la Institución Fernán González. 119, 1952, pp. 179-190.

— "Abaciologio del monasterio de San Pedro de Gumiel de Izán” en Boletín de la Institución Fernán González. 171, 1968, pp. 266-275 y 172, pp. 89-99.

PALOMINO LÁZARO, A. L., “Aproximación a la situación actual de la investigación arqueológica en la burgalesa Ribera del Duero", en Biblioteca 11. Estudio e Investigación. 1996, pp. 257-272.

PASTOR DÍAZ DE GARAYO, E., Castilla en el tránsito de la Antigüedad al Feudalismo. Poblamiento, poder político y estructura social del Arlanza al Duero. 1996, Valladolid.

PEÑA PÉREZ, F. J., "Protesta popular y violencia institucional en la ciudad e Burgos a comienzos del siglo XVI: ingredientes de un conflicto sociorreligioso", en Castilla y el mundo feudal. Valladolid, 2009, pp. 189-199.

PÉREZ CELADA, J. A., "El mundo monástico entre el Duero y el Arlanza a fines de la Edad Media”, en Biblioteca 25. Estudio e Investigación. 2011, pp. 205-225.

PÉREZ DE URBEL, J., "Los primeros siglos de la Reconquista (711-1038)", en Historia de España. La España Cristiana. Comienzo de la Reconquista (711-1038). T. VI, Madrid, 1964.

- El Condado de Castilla. Madrid, 1969.

PÉREZ EMBID, J., El Cister en Castilla y León. Monacato y dominios rurales (s. XII$X V)$. Salamanca, 1986.

PÉREZ GONZÁLEZ, C., El Concilio de Aranda (1473). Segovia, 2007.

PÉREZ, J., La revolución de las comunidades de Castilla (1520-1521). Madrid, 1978.

- Isabel y Fernando: los Reyes Católicos. Hondarribia, 1988. 
— “Los Reyes Católicos 1476-1516”, en Tuñón de Lara (Dir.) Historia de España. Vol. V. Barcelona, 1989, pp. 139-75.

- Los Comuneros. Madrid, 2001.

— "Las comunidades de Castilla", en Entorno a las comunidades de Castilla. Cuenca, 2002, pp. 133-145.

PERIBÁÑEZ OTERO, J. G., La ocupación del suelo en Béarn. Siglos XIII y XIV. Bastidas y núcleos de nueva fundación. Valladolid, 1998.

— "Violencia y espacio urbano. La percepción espacial de las relaciones sociales entre judíos, mudéjares y cristianos en la Ribera del Duero burgalesa”, en Castilla y el mundo feudal. Valladolid, 2009, Vol. II, pp. 25-42.

— "El control del territorio en la Ribera del Duero en la Baja Edad Media", en Biblioteca 25. Estudio e Investigación. 2011, pp. 39-65.

— "La pugna por el poder en la villa de Aranda de Duero a finales de la Edad Media: Élites, comunidad e injerencia nobiliaria”, en La gobernanza de la ciudad europea en la Edad Media. Logroño, 2011, pp. 131-161.

— "La Revolución Comunera en Aranda de Duero", en Biblioteca 26. Estudio e Investigación. 2012, pp. 55-78.

PERIBÁÑEZ OTERO, J. G. y ABAD ÁLVAREZ, I., "El agua como fuente para el estudio del poblamiento", en El agua en las ciudades castellanas durante la Edad Media. Valladolid, 1998, pp. 257-282.

— "El fenómeno urbano medieval en Burgos y La Rioja", en El fenómeno urbano medieval entre el Cantábrico y el Duero. Santander, 2002, pp. 175-209.

- Aranda de Duero, 1503. Aranda de Duero, 2003.

PINTO CEBRIÁN, M. A., Más allá del Vino. Fauna y Flora de la Ribera del Duero. Aranda de Duero, 2003.

POLO MARTÍN, R., El régimen municipal de la Corona de Castilla durante el reinado de los Reyes Católicos (Organización, funcionamiento y ámbito de actuación). Madrid, 1999.

PORRAS GIL, M. C., "Estética y humanismo en la Familia Zúñiga-Avellaneda", en Biblioteca 18. Estudio e Investigación. 2003, pp. 117-141.

PORTILLO CAPILLA, T., “D. Pedro Montoya, obispo de Osma (1454-1474)”, en Celtiberia. 50, 1975, pp. 231-244.

— Instituciones del Obispado de Osma. Soria, 1985. 
PUYOL Y ALONSO, J., Las hermandades de Castilla y León: estudio histórico seguido de las ordenanzas de Castronuño. Madrid, 1913.

QUINTANILLA RASO, M. C., "Política ciudadana y jerarquización del poder. Bandos y parcialidades en Cuenca”, en En la España Medieval. 20, 1997, pp. 219-250.

- "Sociabilidad nobiliaria y solidaridad jerárquica en la Castilla del siglo XV", Cuadernos de Historia de España. 76, 2000, pp. 155-184.

— “La Nobleza", en Orígenes de la Monarquía Hispánica. Propaganda y Legitimación (ca. 1400-1520). Madrid, 2004, pp. 63-104.

— "Los Grandes Nobles", en Medievalismo. Boletín de la Sociedad Española de Estudios Medievales, 2004, pp. 127-142.

— "El engrandecimiento nobiliario en la Corona de Castilla. Las claves del proceso a finales de la Edad Media”, en Título, grandes del reino y grandeza en la sociedad política. Fundamentos en la Castilla medieval. Madrid, 2006, p. 17-102.

— "Élites de poder, redes nobiliarias y monarquía en la Castilla de fines de la Edad Media”, en Anuario de Estudios Medievales. 37/2, 2007, pp. 957-981.

— "Fórmulas y prácticas de la cultura política nobiliaria: los Grandes en la crisis dinástica castellana (1498-1507)", en Gobernar en tiempos de crisis. Las quiebras dinásticas en el ámbito hispánico (1250-1808). Madrid, 2008, pp. 199-220.

RÁBADE OBRADÓ, M., "Los judeoconversos en tiempos de Isabel la Católica”, en Sociedad y Economía en tiempos de Isabel la Católica. Valladolid, 2002, pp. 201-228.

RAMBLA, P., "Historia del dogma de la Inmaculada Concepción”, en Archivo Franciscano Digital. http://franciscanos.org. Consulta realizada el 01/07/2012.

RAMOS, N., "La Iglesia a través de las Cortes castellanas. Uso y abuso de la excomunión (siglos XIII-XIV)", en Cuadernos de Historia de España. 69, 1987, pp. 97108.

REGLERO DE LA FUENTE, C., "El obispado de Osma hasta mediados del siglo XIII: génesis y problemática", en Santo Domingo de Caleruega: contexto eclesial religioso. Salamanca, 1996, pp. 183-224.

— "El fenómeno urbano medieval en las actuales provincias de Valladolid y Palencia”, en El fenómeno urbano medieval entre el Cantábrico y el Duero. Santander, 2002, pp. 210-40. 
— "Poder regio y dominios monásticos en la Ribera del Duero (s. XI-XIV)", en Biblioteca 24. Estudio e Investigación. 2010, pp. 169- 186.

RETUERCE VELASCO, M., “Testimonios materiales del Madrid andalusí,, en Testimonios del Madrid medieval. El Madrid musulmán. Madrid, 2004, pp. 81-116.

REYES TÉLLEZ, F., “Arqueología Medieval Burgalesa: estado de la cuestión”, en Introducción a la Historia de Burgos en la Edad Media. I Jornadas burgalesas de Historia. Burgos, 1990, pp. 177-229.

— "Arqueología Altomedieval en el Valle del Duero", en Biblioteca 6. Estudio e Investigación. 1991, pp. 9-26.

RIESCO DE ITURRI, M. B., Nobleza y Señoríos en la Castilla Centro-Oriental en la Baja Edad Media (Siglos XIV y XV). Tesis doctoral de la Universidad Complutense de Madrid, 2002. Disponible en formato digital en http://eprints.ucm.es/2453/1/H0030101.pdf. Consulta realizada el 30/08/2012.

RÍOS DE LA LLAVE, R., Mujeres de clausura en la Castilla medieval: El Monasterio de Santo Domingo de Caleruega. Madrid, 2007.

RODRÍGUEZ RODRÍGUEZ, M. C., "El monasterio de San Pedro de Gumiel. Notas históricas (s. XII-XIII)", en Santo Domingo de Caleruega. Jornadas de estudio Medieval 1992-1993. Salamanca, 1994, pp. 299-324.

ROMERO MARTÍNEZ, A., "El asociacionismo del poder: las cofradías de hidalgos y caballeros”, en En la España Medieval. 18, 1995, pp. 135-162.

ROMERO PORTILLA, P., "Exiliados en Castilla en la segunda mitad del siglo XIV: origen del partido portugués", en Poder y sociedad en la Baja Edad Media hispánica: homenaje al profesor Luis Vicente Díaz Marín. Valladolid, 2002, vol. I, pp. 519-540.

— “El peso de la familia Acuña en el nacimiento del partido portugués", en Homenaje al profesor Eloy Benito Ruano. Murcia, 2010, vol. II, pp. 683-692.

RUBIAL GARCÍA, A., "Isabel de Castilla y los movimientos religiosos en España durante su reinado. Su impacto en América”, en Isabel la Católica y la política. Valladolid, 2001, pp. 351-362.

RUCQUOI, A, "Del concejo a la comunidad", en Valladolid en la Edad Media. La villa del Esgueva. Valladolid, 1993, pp. 75-101.

- Valladolid en la Edad Media. El mundo abreviado. Valladolid, 1997, 2 vol. 
RUÍZ DE LA PEÑA, J. L., "Repoblaciones urbanas tardías en las tierras del Norte del Duero (siglos XII-XIV)”, en Revista del Derecho Español. 1, 1976, pp. 71-124.

- Las 'polas' asturianas en la Edad Media: estudio y diplomatario. Oviedo, 1981.

— "La formación de la red urbana en el tramo riojano del Camino de Santiago y las colonizaciones francas (s. XI-XIII)", en El fuero de Logroño. Logroño, 1996, pp. 209-210.

RUÍZ VÉLEZ, I. y PAMPLIEGA PAMPLIEGA, R., El Colegio de San Nicolás Instituto Cardenal López de Mendoza (1538-1967). Burgos, 2007.

RUÍZ, T., Historia social de España, 1400-1600. Barcelona, 2002.

SABATÉ, F. (Ed.), Natura y desenvolupament. El medi ambient a l'Edat Mitjana. Lleida, 2007.

SACRISTÁN DE LAMA, J. D., La Edad del Hierro en el Valle Medio del Duero. Rauda (Roa, Burgos). Valladolid, 1986.

— "Escombros bajo nuestros pies", en Biblioteca 2. Estudio e Investigación. 1987, pp. 40-45.

— “Arqueología: Raíces y cimientos”, en Biblioteca 3. Estudio e Investigación. 1988, pp. 9-15.

SÁEZ, C., "Diego Gómez de Sandoval y la escritura precortesana en Sicilia (14151416)", en Signo. Revista de Historia de la Cultura Escrita. 2, 1995, pp. 9-18.

SÁINZ GUERRA, J. L., La génesis de la plaza en Castilla durante la Edad Media. Valladolid, 1990.

— "Desarrollo urbanístico de Aranda. Estudio del plano de 1503", en Biblioteca 18. Estudio e Investigación. 2003, pp. 41-56.

SALAZAR Y CASTRO, L., Historia genealógica de la Casa de Haro. Madrid, reed. 1959.

— Historia Genealógica de la Casa de Lara. Madrid, reed. 2009.

SALVÁ, A., Burgos en las Comunidades de Castilla, Burgos, 1895 (reed. 2002).

SÁNCHEZ ALBORNOZ, C., Despoblación y repoblación del valle del Duero. Buenos Aires, 1966.

— Viejos y nuevos estudios sobre las instituciones medievales españolas. Madrid, 1976. 
SÁNCHEZ BENITO, J. M., "Notas sobre la Junta General de la Hermandad en tiempos de los Reyes Católicos", en Anales de la Universidad de Alicante. 8. 1991, pp. 147-168.

SÁNCHEZ DE MORA, A., Los Lara. Un linaje castellano de la Plena Edad Media. Burgos, 2007.

SÁNCHEZ DEL BARRIO, A., Arquitectura popular, Valladolid, 1987.

— "Las construcciones populares medievales: un ejemplo castellano de comienzos del XIV”, en Studia Historica. Historia Medieval. 7, 1989, pp. 127-153.

SÁNCHEZ DONCEL, G., Presencia de España en Oran (1509-1792). Toledo, 1991.

SÁNCHEZ HERRERO, J., "El clero en tiempos de Isabel I de Castilla", en Sociedad y Economía en tiempos de Isabel la Católica. Valladolid, 2002, pp. 151-181.

- “Amantes, barraganas, compañeras, concubinas clericales", en Clio y Crimen. 5, 2008, pp. 106-137.

SÁNCHEZ HERRERO, J. y LÓPEZ BAHAMONDE, R., "La geografía eclesiástica en León y Castilla. Siglos XIII al XVI”, en El Pasado Histórico de Castilla y León. Edad Media. Salamanca, 1984, vol. I, pp. 295-313.

SÁNCHEZ LEÓN, P., "La constitución histórica del sujeto comunero: orden absolutista y lucha por la incorporación estamental en las ciudades de Castilla (13501520)", en En torno a las comunidades de Castilla. Cuenca, 2002, pp., 159-208.

SÁNCHEZ RIVERA, J. I., "Ermitas, rollos y humilladeros en la comarca ribereña”, en Biblioteca 18. Estudio e Investigación. 2003, pp. 143-176.

— "Los asentamientos medievales en el eje del Duero: de la cabaña a la plaza del mercado", en Biblioteca 23. Estudio e Investigación. 2009, pp. 103-135.

- Los puentes de la Ribera burgalesa. Vitoria, 2010.

— "La torre de Gumiel de Izán y las iglesias encastilladas en la Ribera del Duero", en Biblioteca 25. Estudio e Investigación. 2011, pp. 67-88.

SANZ ABAD, P., "Aranda de Duero en la primera mitad del siglo XVI", Boletín de la Institución Fernán González, Burgos, 1967, pp. 5-25.

- Historia de Aranda de Duero. Burgos, 1975.

SCHELLING, Th., La estrategia del conflicto. Madrid, 1964.

SEGURA, S., La idea de ciudad en la cultura hispana de la Edad Moderna. Barcelona, 1992. 
SERRANO, L., "Los Armíldez de Toledo y el monasterio de Tórtoles", en Boletín de la Real Academia de la Historia. 1933, pp. 60-140.

SOLA LANDA, T., El virreinato de Navarra en la etapa de los Austrias. Gobierno político y administración (siglos XVI-XVII). Tesis inédita. Universidad de Navarra, 1997.

SOLER NAVARRO, A. M., El Ducado de Peñaranda. Su origen y desarrollo hasta la desaparición del linaje de los Zúñiga. Tesis doctoral, Universidad Complutense de Madrid, 2009. Disponible en http://eprints.ucm.es/9818/1/T31471.pdf, consulta realizada 28/03/2011.

SOLER SALCEDO, J. M., Nobleza española: nobleza inmemorial, 1520. Madrid, 2008.

SOLÓRZANO TELECHEA, J. A., Santander en la Edad Media. Patrimonio, parentesco y poder. Santander, 2002.

— "Violencia y conflictividad política en el siglo XV: el delito al servicio de la élite en las Cuatro Villas de la Costa de la Mar", en Anuario de estudios medievales. 35/1, 2005, pp. 159-184.

— "Elites urbanas y construcción del poder concejil en las Cuatro Villas de la Costa de la Mar (siglos XIII-XV)”, en Ciudades y villas portuarias del Atlántico en la Edad Media. 2005, pp. 187-230.

— "De "Todos los más del pueblo" a la "Republica e comunidad": el desarrollo y la consolidación de la identidad del común de Laredo en los siglos XIV y XV”, en Anales de historia medieval de la Europa atlántica. 1, 2006, pp. 61-106.

— “La fundación y promoción de las 'villas nuevas' en el litoral Atlántico del Norte peninsular durante el reinado de Alfonso X", en El mundo urbano en la Castilla del siglo XVIII. Sevilla, 2006, vol. 2, pp. 315-328.

— "Linaje, comunidad y poder: desarrollo y consolidación de identidades urbanas contrapuestas en la Castilla bajomedieval", en Familia y sociedad en la Edad Media (siglos XII-XV). Zaragoza, 2007, pp. 71-94.

SOLÓRZANO TELECHEA, J. A. y ARÍZAGA BOLUMBURU, B., El fenómeno urbano medieval entre el Cantábrico y el Duero. Santander, 2002.

SUÁREZ FERNÁNDEZ, L., Nobleza y monarquía. Puntos de vista sobre la historia política castellana del siglo XV. Valladolid, 1975.

- Judios españoles en la Edad Media. Madrid, 1980. 
- Historia del reinado de Juan I de Castilla. Madrid, 1982. 2 Vol.

- Fundamentos de la monarquía. Madrid, 1989.

- Los Reyes Católicos. La conquista del Trono. Madrid, 1989.

— Los Reyes Católicos: El tiempo de la guerra de Granada. Madrid, 1989.

- Enrique IV. Barcelona, 2001.

- Nobleza y monarquía. Entendimiento y realidad. El proceso de construcción de la Corona española. Madrid, 2003.

TOMÁS Y VALIENTE, F., "Origen bajomedieval de la patrimonialización y la enajenación de oficios públicos en Castilla", en Actas del I Symposium de Historia de la Administración. Madrid, 1970, pp. 132-154.

TORRES FONTES, J. "El alcalde mayor de las aljamas de moros en Castilla", en Anuario de Historia del Derecho Español. XXXII, 1962, pp. 131-182.

UROSA SÁNCHEZ, J., Politica, seguridad y orden público en la Castilla de los Reyes Católicos. Madrid, 1998.

VACA LORENZO, A., "Recesión económica y crisis social de Castilla en el siglo XIV”, en Las crisis en la Historia. Salamanca, 1995, pp. 33-56.

VAL VALDIVIESO, Mª. I., Isabel la Católica, princesa (1468-1474), Valladolid, 1974.

— "Resistencia al dominio señorial durante los últimos años del reinado de Enrique IV”, en Hispania. Revista Española de Historia. 34, 1974, pp. 53-104.

— "Los bandos nobiliarios durante el reinado de Enrique IV", en Hispania. Revista Española de Historia. 35/130, 1975, pp. 249-294.

— "Introducción al estudio del Obispado de Osma en la Baja Edad Media", en Celtiberia. 70, 1985, pp. 211-252.

— "Dinámica social en las ciudades castellanas en torno a 1494", en El Tratado de Tordesillas y su época. Salamanca, 1993, vol. I, pp. 113-130.

— "Ascenso social y luchas por el poder en las ciudades castellanas del siglo XV", en En la España Medieval. 17, 1994, pp. 157-184.

— “Oligarquía versus Común. Consecuencias sociopolíticas del triunfo del regimiento en las ciudades castellanas", en Medievalismo: Boletín de la Sociedad Española de Estudios Medievales. 4, 1994, pp. 41-58.

— "El abastecimiento de agua a Segovia en el contexto bajomedieval castellano". Estudios Segovianos. 94, 1996, pp. 731-52. 
— "Aspiraciones y actitudes socio-políticas. Una aproximación a la sociedad urbana de la Castilla bajomedieval", en La ciudad medieval. Aspectos de la vida urbana en la Castilla bajomedieval. Valladolid, 1996, pp. 213-254.

— "La revolución comunera como punto de llegada de las luchas por el poder en las ciudades castellanas del siglo XV", en Scripta. Estudio en homenaje a Élida García García. Gijón, 1998, Vol. II, pp. 617-633.

— "Elites urbanas en la Castilla del siglo XV (Oligarquía y Común), en Elites e redes clientelares na Idade Media. Lisboa, 2001, pp. 71-89.

— "Las líneas maestras de la obra política isabelina en Castilla", en Sociedad y Economía en tiempos de Isabel la Católica. Valladolid, 2002, pp. 263-283.

- Agua y poder en la Castilla bajomedieval. Valladolid, 2003.

— "La identidad urbana al final de la Edad Media", en Anales de historia medieval de la Europa atlántica. 1, 2006, pp. 5-28.

— "Élites populares urbanas en la época de Isabel I de Castilla", en La sociedad política a fines del siglo XV en los reinos ibéricos y en Europa. París, 2007.

— "La Farsa de Ávila en las crónicas de la época", en Espacios de poder y formas sociales en la Edad Media. Madrid, 2007, pp. 355-367.

— "La perturbación de la paz urbana en la Castilla del siglo XV", en La convivencia en las ciudades medievales. Logroño, 2008, pp. 23-52.

- "Río y vida urbana en la Castilla del siglo XV", en Biblioteca 24. Estudio e Investigación. 2010, pp. 47-62.

— "El reinado de los Reyes Católicos y su repercusión en la comarca de Aranda de Duero", en Biblioteca 25. Estudio e Investigación. 2011, pp. 9-24.

— "Cruelty in Medieval Castile. War, Towns an Monarchy in te XV Century", en On Cruelty. Sur la cruaté. Über Grausamkeit. Colonia. 2011, pp. 492-510.

VALDEÓN BARUQUE, J. Los conflictos sociales en el reino de Castilla en los siglos $X I V y X V$. Madrid, 1975.

— "Un despoblado medieval castellano del siglo XIV: Fuenteungrillo", en En la España Medieval. 3, 1982, pp. 705-716.

— "Los conflictos sociales en los siglos XIV y XV en la Península Ibérica", en Anales de la Universidad de Alicante. 3, 1984, pp. 131-142.

— "Crisis y recuperación (Siglos XIV y XV)", en Historia de Castilla y León. Tomo V, Valladolid, 1985. 
— "Las oligarquías urbanas", en Concejos y Ciudades en la Edad Media Hispánica. Madrid, 1990, pp. 509-535.

— "Revueltas en la Edad Media castellana", en Revueltas y revoluciones en la historia. Salamanca, 1990, p. 9-20.

— "Reflexiones sobre las murallas urbanas de la Castilla medieval", en La ciudady sus murallas. Madrid, 1991, pp. 67-88.

— "Motivaciones socio-económicas de las fricciones entre viejocristianos, judíos y conversos”, en Judios. Sefarditas. Conversos. La expulsión de 1492 y sus consecuencias. Valladolid, 1995, pp. 69-88.

— "Señoríos y nobleza en la Baja Edad Media (El ejemplo de la Corona de Casti1la)", en Les Senyories medievals. Una visió de les formes del poder feudal. Revista d'Història Medieval. 8. Valencia, 1997, pp. 15-24.

— "Resistencia antiseñorial en la Castilla medieval", en El chivo expiatorio. Judíos, revueltas y vida cotidiana en la Edad Media. Valladolid, 2000, pp. 132-161.

VALDEÓN BARUQUE, J., y ESTEBAN RECIO, A., "Esbozo de una geografía social: Palencia a fines de la Edad Media”, en Studia Historica. Historia medieval. 2, 1985, pp. 117-141.

VALLEJO PENEDO, J. J., “D. Íñigo López de Mendoza, abad comendatario del monasterio", en Cor Unum, 1979, nº 195-196, pp. 60-65.

— "El monasterio de Santa María de la Vid. Fundación, formación y consolidación del señorío abacial. Colección diplomática (1132-1299)”, en El monasterio de Santa María de la Vid. 850 años. Madrid, 2004, pp. 99-240.

— "Monjes y libros: 850 años de Historia”, en El monasterio de Santa María de la Vid. 850 años. Madrid, 2004, pp. 291-348.

VÁZQUEZ DE PARGA, L., La división de Wamba. Contribución al estudio de la historia y geografía eclesiástica de la Edad Media española. Madrid, 1943.

VÁZQUEZ GARCÍA, F. y MORENO MENGÍBAR, A., Poder y prostitución en Sevilla. Tomo I (Edad Moderna). Salamanca, 1995.

VELA SANTAMARÍA, F. J.,"El sistema urbano del Norte de Castilla en la segunda mitad del siglo XVI", en Ciudad y mundo urbano en la Época Moderna. Madrid, 1997, pp. 15-43.

VELASCO PÉREZ, S, Aranda. Memorias de mi Villa y de mi Parroquia. Madrid, 1925 (red. 1983). 
VICENS VIVES, J., Juan II de Aragón, 1398-1479. Barcelona, 1953.

- Fernando II de Aragón. Zaragoza, 1962.

VILAR Y PASCUAL, L., y VILAR PSAYLA, J. J., Diccionario histórico, genealógico y heráldico de las familias ilustres de la monarquía española. Madrid, 1886.

VILLALOBOS Y MARTÍNEZ-PONTREMULI, M. L., "Los Estúñiga. La penetración en Castilla de un linaje de la nobleza nueva", en Cuadernos de Historia. Anexos de la Revista Hispania. 6, 1975, pp. 327-357.

VILLANUEVA ZUBIZARRETA, O., “Agua y patrimonio en Castilla: el puente de Itero del Castillo en Burgos y las tenerías de la ciudad de Zamora", en Musulmanes y Cristianos frente al Agua en las Ciudades Medievales. Santander, 2008, pp. 17-45.

— "Regulación de la convivencia con los mudéjares en las ciudades de la cuenca del Duero", en La convivencia en las ciudades medievales. Logroño, 2008, pp. $351-367$.

VILLAR GARCÍA, L. M., La Extremadura castellano-leonesa: guerreros, clérigos y campesinos (711-1252). Salamanca, 1986.

— "La formación de las Comunidades de Villa y Tierra en las fronteras del Duero", en Biblioteca 24. Estudio e Investigación. 2010, pp. 77-103.

VIÑA BRITO, A. C., "Don Pedro Girón y los orígenes del señorío de Usuna”, en Historia, instituciones, documentos. 17, 1990, pp. 267-285.

— “Gumiel de Izán, una villa en litigio entre el conde de Urueña y el de Castro", en Historia, instituciones, documentos. Sevilla, 1994, nº 21, pp. 501-513.

VOGEL, C., "Penitencia y excomunión en la Iglesia antigua y alta Edad Media", en Concilium. 107, 1975, pp. 9-21.

YARWOOD, D., La Arquitectura en Europa. La Edad Media (650-1550). Madrid, 1996.

YEVES, J. A., "Aranda de Duero en los libros de viajes y guías de viajeros", en Biblioteca 12. Estudio e Investigación. 1997, pp. 95-116.

YUN CASALILLA, B., "El mercado del vino en Córdoba durante la crisis de 15041508: Aproximación al estudio de las bases económicas de un grupo social", en Investigaciones históricas: Época moderna y contemporánea. 1, 1979, pp. 7-42.

- Sobre la transición al capitalismo en Castilla. Economía y sociedad en Tierra de Campos (1500-1830). Salamanca, 1987. 
ZALAMA, M. A., Vida cotidiana y arte en el palacio de la reina Juana I en Tordesillas. Valladolid, 2000.

- Juana I. Arte poder y cultura en torno a una reina que no gobernó. Madrid, 2010.

ZAMORA LUCAS, F., La villa de Roa. Madrid, 1965.

ZAPARAÍN YÁÑEZ, M. J., El monasterio de Santa María de la Vid: arte y cultura, del medievo a las transformaciones arquitectónicas de los siglos XVII y XVIII. Madrid, 1994.

- Desarrollo artístico de la comarca arandina siglos XVII y XVIII. Salamanca, 2002, 2 Vol.

— "El Monasterio de la Vid en el Arte de la Ribera", El Monasterio de Santa María de la Vid 850 años. Madrid, 2004, pp. 33-97. 


\section{ABREVIATURAS.}

ADB

ADM

AGI

AGS

AHN

AHPB

AMA

APDB

ARChV

$\mathrm{BN}$

BRAH

CBMAD

$\mathrm{CC}$

CC CÉDULAS

CC DIVERSOS

CC MEMORIALES

CC PUEBLOS

$\mathrm{CMC}$

$\mathrm{CR}$

doc./docs

$\mathrm{EH}$

EMR

fol./fols.

leg.

MPD

p./pp.

PR

RGS

RRE

SNAHN

vol.
Archivo Diocesano de Burgos.

Archivo Ducal de Medinaceli.

Archivo General de Indias.

Archivo General de Simancas.

Archivo Histórico Nacional.

Archivo Histórico Provincial de Burgos.

Archivo Municipal de Aranda de Duero.

Archivo Provincial de la Diputación de Burgos.

Archivo de la Real Chancillería de Valladolid.

Biblioteca Nacional.

Biblioteca de la Real Academia de la Historia.

Colección de la Biblioteca Municipal de Aranda de Duero.

Cámara de Castilla.

Cámara de Castilla Cédulas.

Cámara de Castilla Diversos.

Cámara de Castilla Memoriales.

Cámara de Castilla Pueblos.

Contaduría Mayor de Cuentas.

Consejo Real.

Documento/documentos.

Expedientes de Hacienda.

Escribanía Mayor de Rentas.

Folio/folios.

Legajo.

Mapas, Planos y Dibujos.

página/páginas

Patronato Real.

Registro General del Sello.

Registro de Reales Ejecutorias.

Sección Nobleza del Archivo Histórico Nacional.

Volumen. 


\section{LA CONFIGURACIÓN DE UN ESPACIO FEUDAL.}

Cerca la ciudad una muralla alta y gruesa con muchas torres y parapetos. El foso es seco, pero profundo y ancho,... Las plazas están fabricadas, así para el comercio, como para el abrigo cómodamente; los edificios no son deslucidos, antes en todos los barrios se continúa un modelo,... Las calles tienen veinte pasos de latitud, y a las espaldas de ellas todo lo que tiene de ancho el barrio es jardín cercado en contorno...

TOMÁS MORO, Utopía. Capítulo Primero. 1516. 
Sin lugar a dudas, el espacio es el escenario sobre el que se desarrollan las actividades humanas en cualquiera de los periodos de la historia de la Humanidad. Evidentemente este marco físico tuvo su origen en periodos geológicos que se encuentran fuera de los objetivos de este trabajo, pero es patente que las características naturales de este espacio condicionaron en gran medida la vida de los grupos humanos que sobre él se desarrollaron por lo que parece lógico indagar sobre sus características.

En este primer capítulo intentaremos definir este marco físico partiendo en primer lugar de la identificación de sus elementos naturales definitorios como son el relieve, el clima, la hidrología y los seres vivos que acompañaron a los grupos humanos. La reconstrucción del entorno natural será el punto de partida para tratar de analizar las principales transformaciones que experimentó el espacio y que lo convirtieron en un medio cada vez más alterado por las actividades humanas. En este sentido, nos detendremos en la conformación del poblamiento medieval en sus diferentes fases hasta que se definió el asentamiento del periodo bajomedieval.

Dentro del contexto urbanizador que experimentó la Corona de Castilla, concluiremos este apartado con el estudio del espacio más antrópico de la comarca que no es otro que la villa de Aranda de Duero. Este núcleo urbano experimentó a finales de la Edad Media un desarrollo significativo, convirtiéndose en el centro dinamizador de la comarca.

\section{PUNTO DE PARTIDA: EL MEDIO NATURAL DE LA RIBERA DEL DUERO BURGALESA.}

Evidentemente la Ribera del Duero que nosotros conocemos hoy es notablemente diferente a la que conocieron nuestros antepasados hace más de quinientos años. Sin embargo, partiendo de los elementos naturales que hoy perviven y de las distintas fuentes históricas de las que disponemos, pretendemos hacer una reconstrucción del medio que nos permita aproximarnos a la realidad espacial en la que se desarrollaron las actividades de los ribereños a finales de la Edad Media ${ }^{16}$.

\footnotetext{
${ }^{16}$ En este sentido nos parecen muy interesantes las aportaciones metodológicas que se recogen en la obra colectiva editada por CLEMENTE RAMOS, J. (Ed.), El medio natural en la España medieval:
} 
La comarca de la Ribera del Duero se encuentra en la Meseta Septentrional, enmarcada geológicamente en lo que viene en denominarse la Cuenca Terciaria del Duero. A continuación analizaremos los principales rasgos definidores de la geomorfología de este espacio, así como las principales características de los ríos que lo surcan, las peculiaridades climáticas y las variedades vegetales y faunísticas más significativas.

\subsection{Relieve.}

Las características que presenta el aspecto exterior de la corteza terrestre son fundamentales a la hora de configurar el paisaje sobre el que se asientan los grupos humanos. El paisaje natural de la comarca ribereña a finales de la Edad Media es el resultado de una serie de episodios geológicos que configuraron determinados elementos de relieve y unos suelos que trataremos de definir a continuación con la intención de comprender el marco natural en el que se desarrollaron unas estrategias de supervivencia de la sociedad feudal perfectamente adaptadas a su entorno.

\subsubsection{Geología y principales elementos del relieve.}

La comarca natural de la Ribera del Duero se ha configurado en diferentes momentos geológicos, si bien es cierto que la era Terciaria jugó un importante papel en el resultado final ${ }^{17}$. Los escasos materiales paleozoicos y mesozoicos se circunscriben bá-

actas del I congreso sobre ecohistoria e historia medieval. Cáceres, 2001; así como la coordinada por SABATÉ, F. (Ed.), Natura y desenvolupament. El medi ambient a l'Edat Mitjana. Lleida, 2007. No obstante, somos conscientes de las limitaciones que supone un estudio de este tipo a escala local y el peligro que corremos de caer en generalizaciones carentes de valor, pero consideramos que es absolutamente necesario aproximarnos a este espacio físico sobre el que se desarrolló la sociedad ribereña medieval. Nuestro análisis no es más que una modesta aportación al más que deseable análisis a escala regional como fue planteado en su momento por ORTEGA VALCÁRCEL, J., "Geografía histórica de Burgos Altomedieval”, en Burgos en la Alta Edad Media. II Jornadas burgalesas de Historia. Burgos, 1991, pp. 181-228, especialmente p. 216. Recientemente OLMOS HERGUEDAS ha presentado un excelente trabajo que reconstruye el paisaje medieval de la comarca de Cuéllar (Agua, paisaje y ecohistoria. La comarca de Cuéllar a partir del siglo XIII. Valladolid, 2011).

17 Para la realización de este apartado hemos utilizado las siguientes publicaciones: SAN MIGUEL DE LA CÁMARA, M, Explicación de las hojas 314, 345, 346 y 375. Mapa Geológico de España. Escala 1:50.000. Instituto Geológico y Minero de España, Madrid, 1952; PARDO, M. y VILlarinO, T. (dir.), Análisis del Medio Físico. Delimitación de unidades y estructura territorial. Burgos. Valladolid, 1987; PALÁ BASTARÁS, J. M. (dir.) Análisis del Medio Físico. Delimitación de unidades y estructura territorial. Soria. Valladolid, 1988; ARENILLAS PARRA et álii, Análisis del Medio Físico. Delimitación de unidades y estructura territorial. Segovia. Valladolid, 1988; DE LAS HERAS MOLINOS, F. J., "El Medio Físico de la Comarca de la Ribera", en Biblioteca 4. Estudio e Investigación, Aranda de Duero, 1989, pp. 55-71; ARMENTEROS ARMENTEROS, I. et álii, "Geología e Hidrogeología del Terciario en el sector de Aranda de Duero (Burgos)-Peñafiel (Valladolid), Sureste de la 
sicamente a los extremos meridional y nororiental del área de estudio, en la sierra de Pradales e inmediaciones (Valdevacas, Montejo,...) y en las Peñas de Cervera respectivamente. La actividad geológica del Cuaternario se manifiesta en la continua actividad de los agentes erosivos sobre el relieve y la labor de sedimentación apreciada sobre todo en depósitos aluviales de los fondos de valle.

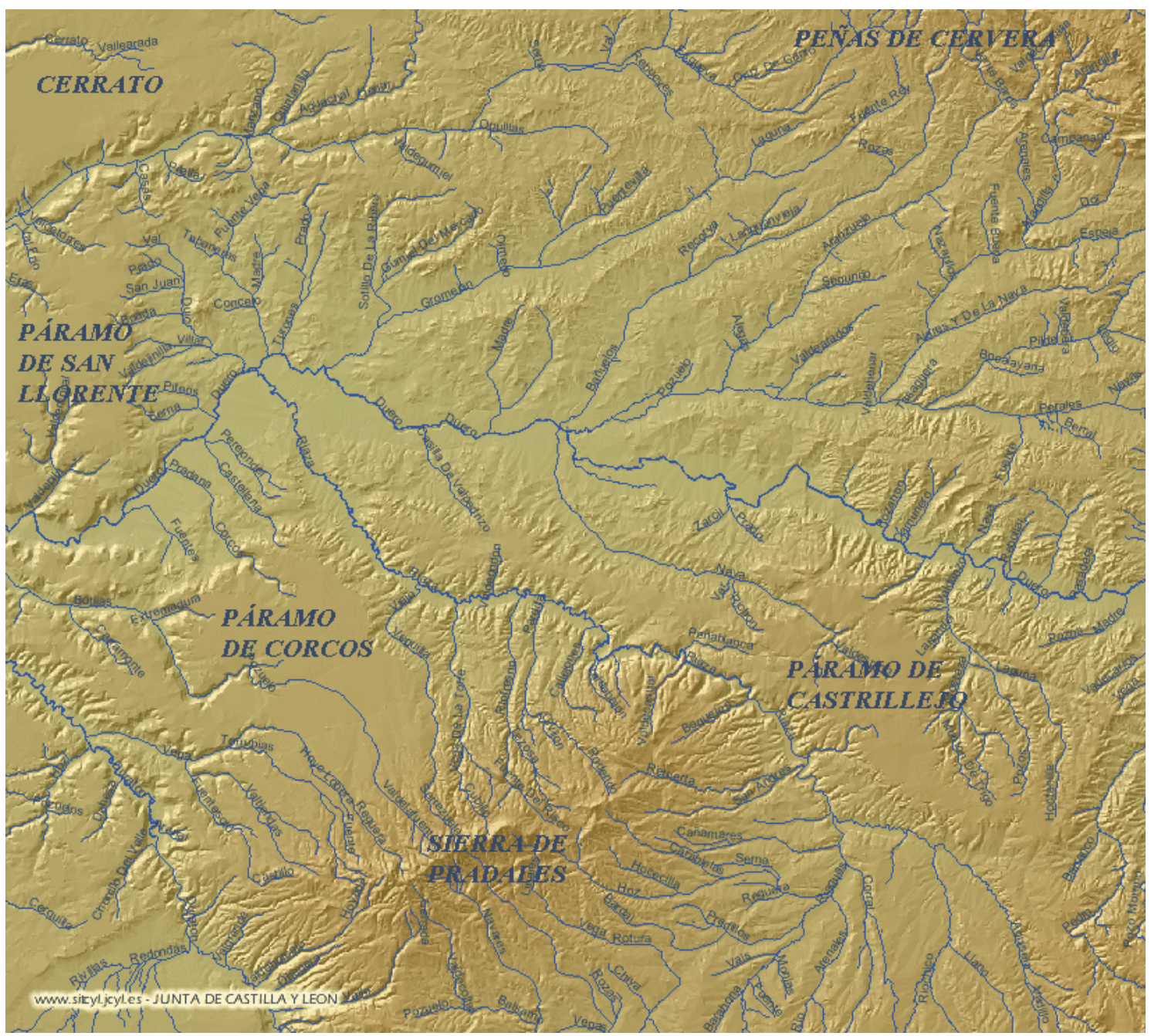

Mapa 2: Principales elementos del relieve en la Ribera del Duero.

Desde un punto de vista morfológico en la Ribera del Duero distinguimos una serie de elementos de relieve bastante significativos:

Cuenca del Duero", en Biblioteca 11. Estudio e Investigación. Aranda de Duero, 1996, pp. 45-66; MORENO PEÑA, J. L., "Burgos en su espacio geográfico", en Historia de Burgos I (Edad Antigua). Burgos, 1984, pp. 39-82; MONTOYA GARCÍA-REAL, E, La Ribera del Duero burgalesa. El vino y su Denominación de Origen. Burgos, 2006, pp. 17-20; y MOLINERO, “Origen y evolución..., pp. 9-14. 
1. Las sierras: se trata de los conjuntos paleozoicos y mesozoicos de la Sierra de Pradales o Serrezuela y el zócalo de Honrubia en el extremo meridional y los materiales mesozoicos de las Peñas de Cervera, Huerta del Rey y Espejón en el borde nororiental. Las principales cumbres de estas sierras son el Pico Valdosa (1.412 m.) y el Pico Castro (1.265 m.) en la zona de Cervera y la Peña del Cuerno $(1.377 \mathrm{~m}$.) y el Cueto $(1.253 \mathrm{~m}$.) en la Sierra de Pradales.

2. Los páramos: llanuras elevadas de gran extensión, de origen terciario y naturaleza calcárea. En el espacio estudiado encontramos dos conjuntos diferenciados por su altitud y origen. Por una parte, los páramos que oscilan entre los $900 \mathrm{y}$ los 960 m. y que se configuraron en el tránsito del Mioceno Medio al Superior. En este grupo de páramos de altitud media encontraríamos los altos de Milagros, Gumiel de Izán y Gumiel del Mercado. El segundo conjunto paramero se formó al final del Mioceno Superior y se caracteriza por una altitud que varía entre los 980 y los 1.050 m. Entre éstos destaca, al Sur del Duero, la gran extensión paramera que desde Castrillejo de Robledo se extiende hasta Sacramenia, incluyendo el páramo de Corcos. Al Norte del Duero, estos páramos altos se adosan a las estribaciones del Sistema Ibérico, formando un piedemonte plano inclinado hacia el Duero ${ }^{18}$ (los Arauzos, Caleruega, Valdeande, etc.). Este elemento adquiere una típica forma de páramos rotos, seccionados por una red de riberas muy tupida.

3. Campiña o laderas: terrenos de transición entre los páramos y los fondos de valle. Son llanuras suavemente onduladas e inclinadas ligeramente hacia los ríos. En algunas ocasiones esta transición es bastante brusca y presenta fuertes pendientes que suele recibir el nombre de cuesta. En estos espacios predominan los suelos de tipo arcilloso-arenoso y margoso, recubiertos con una fina película de elementos de arrastre y se caracterizan por ser bastante pobres en general.

4. Cerros: elevaciones de reducidas dimensiones que destacan entre la suave ondulación de las laderas. Se formaron por la acción diferencial de los agentes erosivos que han encontrado un elemento de resistencia a su paso. Los cerros testigos son los de mayor altura, con una cima plana o mesa y escarpes pronunciados. Los más destacados son el Manvirgo (938 m.), el Cerro Gallego (1.014 m.) o el

\footnotetext{
${ }^{18}$ ARMENTEROS ARMENTEROS, "Geología e Hidrogeología..., p. 52.
} 
Cerro de Castro $(1.023 \mathrm{~m}$.) que alberga la ciudad romana de Clunia Sulpicia. Los de menor entidad presentan una forma cónica con una cima redondeada debido a la pérdida de las capas duras que la protegían.

5. Fondos de valle: son anchos y de fondo plano con materiales aluviales cuaternarios depositados en terrazas. En la comarca reciben el nombre de "vegas". La más significativa es la vega del Duero que no sobrepasa los 4 kilómetros de anchura en la comarca. Otras vegas significativas son las del Riaza, Esgueva, Gromejón y Arandilla. Cabe destacar dentro de estos fondos de valle la existencia de una garganta excavada por el río Riaza en su recorrido por los materiales cretácicos del macizo de Honrubia que ha dado lugar a unas hoces con paredes verticales.

\subsubsection{Suelos.}

En la comarca de la Ribera del Duero predominan los suelos pardo-calizos más o menos consolidados dependiendo de su localización topográfica y su exposición a los agentes erosivos. Así, podríamos señalar tres tipos de suelo asociados a los tres elementos de relieve más significativos: páramo, ladera y fondo de valle.

En los páramos encontramos una formación edáfica resultado de la descalcificación de las calizas y dando lugar a suelos de mediana evolución, con abundante carbonato cálcico y pobres en humus. Han tenido tradicionalmente un aprovechamiento secano cerealístico que rápidamente agota las potencialidades de estos débiles suelos ${ }^{19}$.

En las laderas o cuestas, sobre el horizonte de las blandas capas de margas y arcillas, se encuentran suelos arenoso-arcillosos, muy porosos, con escasa materia orgánica y alto contenido en carbonato ${ }^{20}$. Son suelos fácilmente erosionables aunque las pendientes no son muy destacadas.

Los fondos de valle o vegas se caracterizan por unos suelos formados sobre los sedimentos aluviales del Duero y sus afluentes. Son suelos jóvenes, con alternancia de lechos de grava con texturas limo-arcillosas y la presencia de materia orgánica es notable. Generalmente son profundos, de textura de media a gruesa, buena permeabilidad y

\footnotetext{
${ }^{19}$ No obstante, el aprovechamiento cerealístico de estos espacios parameros se produjo en la comarca al amparo del proceso desamortizador a partir de mediados del siglo XIX. Anteriormente, como ya se mencionará más adelante, estos espacios estaban cubiertos en su mayor parte por monte bajo.

${ }^{20}$ IGLESIAS BERZOSA, J. y VILLAHOZ GARCÍA, A., Viñedo, vino y bodegas en la Historia de Aranda de Duero. Aranda de Duero, 1982, pp. 18-19.
} 
aireación. Todas estas características han condicionado la aparición de un horizonte antrópico causado por el aprovechamiento agrario al que ha estado sometido desde la $\operatorname{antigüedad~}^{21}$.

\subsection{Red hidrográfica.}

Como no podía ser de otra manera, el río Duero es el protagonista fundamental en la comarca arandina, articulando todo el territorio. Éste recorre el espacio estudiado de $\mathrm{E}$ a $\mathrm{O}$ en su parte central durante más de 70 kilómetros y en él vierten sus aguas los principales afluentes que transitan por estas tierras: Riaza, Arandilla, Gromejón y Bañuelos.

El Duero a su paso por la comarca arandina es un río con un caudal notable ${ }^{22}$ y con un régimen relativamente regular y de tipo pluvio-nival. Sus máximos se alcanzan en la primavera (deshielo y lluvias de primavera) y el otoño (entrada de frentes atlánticos) lo que ha provocado a lo largo de la historia innumerables episodios de crecidas ${ }^{23}$ que han continuado durante el siglo XX a pesar de la regulación del caudal en su cabecera.

El resto de la red hidrográfica la podemos organizar en dos rangos en función de su significación hídrica.

Los dos principales afluentes del Duero en la comarca arandina son dos ríos que no transcurren en su totalidad por estas tierras. El Riaza nace en la vertiente N de la Sierra de Ayllón, en las inmediaciones de La Quesera. Su entrada en la comarca ribereña se hace a través de la Garganta de Montejo de la Vega y vierte sus aguas al Duero en las inmediaciones de Roa. Por su parte, el río Esgueva nace en el término de Briongos en las Peñas de Cervera y discurre por el $\mathrm{N}$ de la comarca hasta que entra en tierras vallisoletanas a la altura de Encinas de Esgueva, para después desembocar en el Pisuerga.

${ }^{21}$ La mayor parte de la información sobre las características de los suelos de la Ribera del Duero han sido obtenidas de PARDO y VILLARINO, Análisis del Medio Físico... Burgos. pp. 29-30, y PALÁ BASTARÁS, Análisis del Medio Físico... Soria. p. 15-16.

$2215 \mathrm{~m}^{3} / \mathrm{seg}$. según PARDO y VILLARINO, Análisis del Medio Físico... Burgos. p. 43.

${ }^{23}$ Son numerosas las noticias que tenemos de crecidas e inundaciones del Duero o sus afluentes desde el siglo XV como se pueden observar en ABAD ÁLVAREZ, I. y PERIBÁÑEZ OTERO, J. G., "El control social del agua en la villa de Aranda de Duero. El aprovechamiento del río Aranzuelo a principios del siglo XVI", en Usos sociales del agua en la ciudades hispánicas de la Edad Media. Valladolid, 2002, pp. 113-156, en concreto p. 122. 


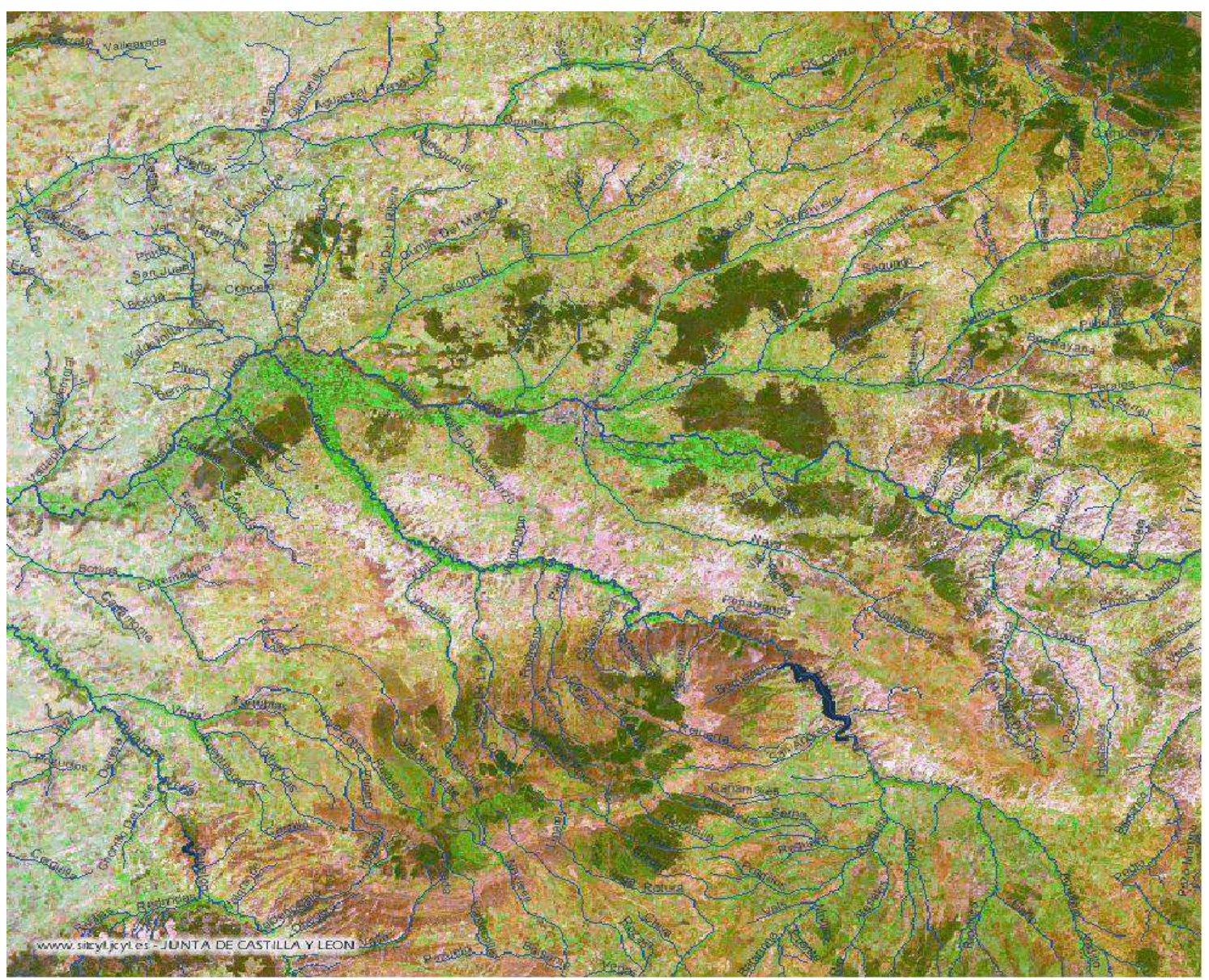

Mapa 3: Red hidrográfica de la Ribera del Duero.

El segundo rango de afluentes del Duero en esta comarca estaría formado por una serie de ríos mucho más modestos que los anteriores y que se caracterizan por su reducido caudal además de un régimen muy irregular con frecuentes crecidas y fuertes estiajes. Todos ellos vierten al Duero por su margen derecha y presentan un curso paralelo entre sí en dirección NE-SO ${ }^{24}$. Entre estos ríos el más significativo es el Arandilla que nace en el término de Huerta del Rey y, tras más de 40 kilómetros de recorrido, desemboca al E de la villa de Aranda. Cuenta entre sus principales afluentes con el Espeja, Pilde, Perales y Aranzuelo. El río Bañuelos nace el término de Arauzo de Miel y discurre cerca de 34 kilómetros hasta desembocar en las inmediaciones de Aranda. Por último, el río Gromejón tiene sus fuentes en el municipio de Caleruega, fluye durante 44 kilómetros y vierte sus aguas en las cercanías de Berlangas de Roa.

${ }^{24}$ Esta situación, junto a la dirección SE-NO del Riaza, dan a la red hidrográfica una disposición de punta de flecha apuntando hacia el Oeste (DE LAS HERAS, “El Medio Físico..., p. 60). 
Además de estos ríos con un caudal continuo durante todo el año, la comarca ribereña está jalonada por una serie de cursos de agua menores como arroyos o simples regatos que tan solo llevan agua estacionalmente. Entre los primeros debemos nombrar el arroyo de la Nava, que nace en Castrillejo de Robledo y desemboca en el Duero en su margen izquierdo junto a Aranda de Duero; los arroyos de Pardilla, Riofresno, Vega de la Torre, y Chorrón que manan de la sierra de Pradales y vierten en el Riaza por su margen izquierdo; y por último, los arroyos de San Andrés y El Dujo que desembocan directamente en el Duero en su margen derecho a la altura de Roa.

A pesar de la existencia del topónimo "Lago" (Tubilla del Lago), no hay constancia histórica de la existencia de acumulaciones de agua lo suficientemente significativas como para ser designadas con este nombre. Sin embargo, si que tenemos constancia de varias lagunas de posible origen endorreico en las proximidades de Aranda de Duero, Campillo de Aranda, Moradillo de Roa y Caleruega. En la periferia de la capital de la Ribera se localizaba un conjunto de media docena de pequeñas lagunas a poco más de un kilómetro al Oeste de la villa, en el término conocido como El Montecillo, junto al Camino Real de Valladolid ${ }^{25}$. No obstante, la laguna de mayor tamaño se localizaba al Este de la villa, a poco más de dos kilómetros, y era conocida como la laguna de San Juan por encontrarse próxima a la ermita del mismo nombre. Todas ellas han sido desecadas a lo largo del siglo XX para su posterior aprovechamiento agrícola o industrial. Por suerte, las dos balsas de agua que se encuentran en las proximidades de Campillo de Aranda todavía se conservan en la actualidad, así como la denominada de las Tenadas en Moradillo de $\mathrm{Roa}^{26}$. La laguna de Caleruega se encuentra en el límite con el término de Arauzo de Miel como se constata ya en un apeo fechado en $1272^{27}$. También son habituales las referencias a pequeñas acumulaciones naturales de agua o "poças" que

\footnotetext{
${ }^{25}$ Madoz describe en su Diccionario Geográfico-Estadístico-Histórico de España: ... lagunas de corta extensión hay a la distancia de $1 / 2$ legua al final del Montecillo. También señala: ... al O como a 200 pasos de la villa se forman algunas balsas pequeñas en diferentes barrancos que hay junto al camino de Valladolid (Reed. Ámbito, 1984; prov. de Burgos, vol. II; p. 50). Estas lagunas se desecaron no hace muchos años tras la canalización de la Nava, siendo su espacio posteriormente nivelado para la instalación de un polígono industrial.

${ }^{26}$... hay en el término dos estanques grandes, uno al $N$ y otro al E (MADOZ, Diccionario Geográfico..., vol. II, p. 267). PINTO CEBRIÁN, M. A., Más allá del Vino. Fauna y Flora de la Ribera del Duero. Aranda de Duero, 2003, p. 30.

${ }^{27}$ Apeo de los términos de la villa de Caleruega hecho por orden del rey Alfonso el Sabio y confirmado por él en Murcia el 26 de mayo de 1272 (MARTÍNEZ LIÉBANA, E., Colección Diplomática del Real Convento de Santo Domingo de Caleruega. Vergara, 1931. Doc. XIX, pp. 22-24).
} 
eran utilizadas ocasionalmente para regar como en Quintanilla del Pidio, Roa de Duero o Berlangas de Roa ${ }^{28}$.

Para completar el panorama hídrico de la comarca, a las aguas superficiales debemos añadir las subterráneas. En la comarca encontramos varios niveles de acuíferos que todos ellos han sido o son aprovechados por el hombre.

En un primer nivel encontraríamos un acuífero multicapa que se recarga en la superficie del páramo y se descarga a lo largo de diferentes manantiales situados a diferente altura (calizas, arcillas, margas o materiales detríticos del cuaternario ${ }^{29}$. A este primer nivel pertenece el significativo manantial de Tubilla que todavía hoy abastece parcialmente a la villa de Aranda.

Un segundo nivel se establece en los fondos de valle, en el nivel detrítico existente entre los materiales cuaternarios y las arcillas, a unos escasos cuatro o cinco metros de la superficie ${ }^{30}$. De este acuífero es del que se nutre la mayoría de los pozos que desde la Edad Media han sido utilizados para el riego de los huertos domésticos ${ }^{31}$.

Fuentes o manantiales de ambos niveles aparecen referidos en la documentación medieval. En La Aguilera conocemos la Fuente Casalara, la fuente de Fuenfaças y la fuente del Tiñoso; en Aranda, junto al monasterio de San Francisco, hay una fuente cave el dicho monasterio que mana de una huerta; en el término de Mataranda en lo alto hay cuatro fuentes que manan mucho agua sobre todo en invierno; y en la linde con Torregalindo está la fontanilla de Martín García; la fuente de Valdetorrezuela en Aldehorno; la fuente de prado maça, fuente garvias y fuente Rey en Caleruega ${ }^{32}$.

${ }^{28}$ Hordenaron que Barrolin y las poças que son la de La Peñuela y la de Santa Maria que ninguno sea osado a la ronper para regar ni para hotra cosa... Capítulo XXVIII de las ordenanzas de 1554 de Quintana del Pidio, transcritas por CALVO PÉREZ, J. J., "La vida rural en Quintana del Pidio según las ordenanzas de los siglos XV y XVI", en Cuadernos del Salagar. Revista de Investigación Histórica y Cultura Tradicional, 2000, pp. 1-31. Otras lagunas o humedales han sido identificadas en las inmediaciones de Roa y en Berlangas de Roa (NUÑO GONZÁLEZ, J., "Pautas de ocupación..., p. 82).

${ }^{29}$ ARMENTEROS ARMENTEROS, “Geología e Hidrología..., p. 55-56. Este artículo muestra un estudio hidrogeológico que identifica cuatro grupos de manantiales dentro de este acuífero multicapa en función de las formaciones geológicas que drenan y del caudal que descargan estos manantiales.

${ }^{30}$ DE LAS HERAS, “El Medio Físico..., p. 60.

${ }^{31}$ El monasterio de San Francisco de Aranda contaba con varios pozos que un testigo dice que son menos hondo de media lia -soga de esparto- (AGS, Consejo Real -CR-, leg. 40, doc. 8). Sobre la profusión de pozos en los huertos del arrabal de Carraquemada en Aranda a finales de la Edad Media ver ABAD ÁLVAREZ y PERIBÁÑEZ OTERO, “El control social..., pp. 125-126.

${ }^{32}$ AMA, leg. 1199, doc. 19; AGS, CR, leg. 40, doc. 8; AMA, leg. 40, doc. 2; AGS, CR, leg. 34, doc. 17; Apeo de los términos de la villa de Caleruega de 26 de mayo de 1272 en MARTÍNEZ LIÉBANA, Colección Diplomática...., Doc. XIX, pp. 22-24.. 
Por último, un tercer nivel de aguas subterráneas se localiza por debajo de los 15 metros de profundidad. Su aprovechamiento sólo se ha producido a partir del siglo XX para la captación de aguas tanto para el abastecimiento urbano como para usos agrícolas e industriales ${ }^{33}$.

Todos estos recursos hídricos estuvieron a disposición de la sociedad de la Baja Edad Media, pero con toda seguridad sus características y comportamientos eran muy diferentes de los actuales. A falta de estudios concretos sobre la Ribera del Duero en este aspecto podemos extrapolar algunas consideraciones referidas a espacios próximos. A escala regional Ortega Valcárcel constata la importancia, frecuencia y extensión de los humedales en Castilla, sobre todo en la Castilla Vieja, ya desde el periodo Altomedieval. En la cercana Comunidad de Villa y Tierra de Cuéllar se nos presenta un aumento del volumen de agua que transportaban los ríos respecto a la actualidad y algo parecido se señala para Paredes de Nava aunque se hace referencia a la transición entre los siglos XIV y XV $\mathrm{XV}^{34}$. Sea como fuere, y a falta de más estudios específicos, lo que parece cierto es que la Ribera del Duero a finales de la Edad Media presentaba un ambiente más húmedo que en la actualidad debido a condicionantes climáticos $\mathrm{y}$, sobre todo, a la inexistente sobreexplotación de los recursos hídricos que se ha producido durante el último siglo con la generalización de los cultivos de regadío ${ }^{35}$ y las infraestructuras hidráulicas de regulación ${ }^{36}$. Buena prueba de ello son las aguas de los ríos Gromejón y

${ }^{33}$ DE LAS HERAS, “El Medio Físico..., p. 60-61.

34 ORTEGA VALCÁRCEL, "Geografía histórica..., p. 217; OLMOS HERGUEDAS, E., La Comunidad de Villa y Tierra de Cuéllar a fines de la Edad Media. Poder político concejil, ordenanzas municipales y regulación de la actividad económica. Valladolid, 1998, p. 30; Y MARTÍN CEA, J. C., El mundo rural castellano a fines de la Edad Media. Valladolid, 1991, pp. 20-24.

${ }^{35}$ Nos parece significativo que a mediados del siglo XIX los manantiales en los fondos de valle eran muy habituales. En la villa de Aranda se documentan varios en las inmediaciones del río Duero: los manantiales del Montecillo, a poco más o menos dos kilómetros al O de la villa en una zona de recreo; el manantial de la Virgen, junto a la ermita de la Virgen de las Viñas; y los caños de Mansilla, a un kilómetro al E de la villa (MADOZ, Diccionario Geográfico..., p. 50). Todos ellos están secos en la actualidad.

${ }^{36}$ La red hidrográfica del espacio que estudiamos se ve afectada por una serie de obras hidráulicas que han modificado notablemente el comportamiento de dos de los principales ríos. Por una parte el Duero ha sido regulado en su cabecera con la construcción en 1941 del embalse de la Cuerda del Pozo y además son numerosos los canales de riego construidos desde el siglo XVIII, destacando el Canal de Guma o de la Reina Victoria (1873) y el canal de Aranda (1936). Por su parte el Riaza está regulado por el embalse de Linares del Arroyo desde 1951. 
Aranzuelo, hoy en día casi inexistentes, y que a finales del siglo XV se convirtieron en la causa del grave enfrentamiento entre vecinos y comunidades ${ }^{37}$.

En este evidente contexto de irregularidad y dentro de una sociedad eminentemente agraria la percepción colectiva de los recursos hídricos siempre ha estado presidida por la disconformidad y, así, no faltan las quejas de los vecinos tanto por la falta de agua como por el exceso, siendo casi imposible encontrar testimonios que muestren una situación de óptimo hídrico.

\subsection{Clima.}

Las condiciones climáticas de la Ribera del Duero participan de las características generales del clima predominante en la Submeseta Norte y que podríamos denominar de tipo Mediterráneo Continentalizado. Este clima está notablemente condicionado por la elevada altitud media $(800 \mathrm{~m}$.) y la disposición del reborde montañoso (Cordillera Cantábrica, Sistema Ibérico y Sistema Central) que rodea la Cuenca del Duero provocando la disminución de las precipitaciones y fomentando los contrastes térmicos.

Desde el punto de vista térmico nuestra comarca se caracteriza por unos veranos cortos y no muy cálidos, con máximas en julio $\left(21,2^{\circ} \mathrm{C}\right.$ de media), e inviernos largos y rigurosos, con mínimas en enero (ronda los $3,5^{\circ} \mathrm{C}$ de media) ${ }^{38}$. La presencia persistente de anticiclones, cálidos en verano o fríos en invierno, sobre la masa continental meseteña impide la entrada de masas de aire más templadas y húmedas de origen atlántico. Las estaciones equinocciales son cortos periodos de tránsito a verano o invierno. La amplitud térmica en consecuencia es elevada. Las heladas son frecuentes y se suceden de octubre a abril, aunque es habitual que se prolonguen a lo largo de mayo. Las horas de sol anuales oscilan entre las 2.400 y las 2.500 .

La pluviometría es moderada-baja, rondando los $450 \mathrm{~mm}$. anuales y con una distribución estacional muy desequilibrada, con máximos en primavera y otoño cuando los

${ }^{37}$ El agua del Aranzuelo fue el centro de las disputas entre los vecinos de Aranda, el convento de San Francisco y los dueños de los molinos del Arandilla durante más de treinta años a principios del siglos XVI (ABAD ÁLVAREZ y PERIBÁÑEZ OTERO, “El control social...). Las comunidades de La Aguilera y Gumiel del Mercado disputaron entre 1487 y 1501 por las aguas del Gromejón (AGS, Registro General del Sello -RGS-, 148708, fol. 160 y AMA, leg. 1198, doc. 4 y leg. 1199, doc. 19).

${ }^{38}$ Los datos térmicos y pluviométricos han sido obtenidos de la web del Consejo Regulador de la Denominación de Origen Ribera Del Duero (www.riberadelduero.es, consulta realizada el 01/06/2012) y hacen referencia a la media de los últimos 30 años. 
anticiclones pierden peso y permiten el paso de las borrascas atlánticas. Los mínimos se producen en verano, siendo frecuente la ausencia total de precipitaciones sólo rota por tormentas de ámbito local. También presenta un mínimo secundario en invierno pues el frío potencia las situaciones anticiclónicas siendo habituales las nieblas que a veces evolucionan hacia esporádicos fenómenos de cencella. Es escasa la incidencia de las nevadas que se concentra de forma puntual en las zonas de sierra. Más habitual es el granizo o pedrisco en primavera y verano que arruina frecuentemente las cosechas ${ }^{39}$.

No obstante, también a nivel local observamos unas diferencias en el ámbito térmico y pluviométrico, siendo el centro de la comarca y el fondo de valle más cálido y menos húmedo que la periferia ${ }^{40}$.

Los vientos predominantes son el "cierzo" de componente N o NE y muy frío; los vientos del NO o "regañón" suelen ser húmedos y acompañan a las lluvias; el "solano" es un viento del SE, cálido, seco y sofocante; y por último, los provenientes del SE o "ábrego" traen a Castilla templanza y humedad atlántica pero no tiene gran incidencia en nuestra comarca debido al lago trayecto continental recorrido ${ }^{41}$.

Evidentemente este retrato climático de la Ribera del Duero corresponde a la época actual y es lógico pensar que habría algunas diferencias respecto al periodo medieval. Son muy escasas y fragmentadas las noticias que hemos obtenido de la documentación medieval referentes a la climatología de nuestra comarca pero sí que evidencian unas características muy próximas a las comentadas anteriormente.

La mayor parte de las incidencias meteorológicas tienen su origen en pérdidas de las cosechas. En este sentido, son habituales las referencias a las heladas como las que arruinaron la vendimia del año $1521^{42}$. También aparece reflejada en la documentación

\footnotetext{
${ }^{39}$ Las crónicas medievales nos transmiten siempre el pedrisco como un grave problema, a menudo relacionado con otros fenómenos naturales que vaticinan desgracias. Así, en la Crónica de Enrique IV se señala que ...en el qual año (1459) muchas señales parecieron, que se mostró en un dia muy sereno una muy gran llama en el cielo, la qual se partió en dos partes, la una paresció quedar, y la otra corrió al oriente en tierra de Burgos y de Valladolid; en el Estio muchas aves y bestias de gran piedra e agua perecieron; los panes e árboles fueron gastados (Mosén Diego de VALERA, Memorial de diversas hazañas. Cap. XVII, en ROSELL, C. (Ed.), Crónicas de los Reyes de Castilla. Madrid, 1953, Tomo Tercero, p. 21).

40 PARDO y VILLARINO, Análisis del Medio Físico... Burgos. pp. 19-26 y PALÁ BASTARÁS, Análisis del Medio Físico... Soria. pp. 59-71.

${ }^{41}$ PARDO y VILLARINO, Análisis del Medio Físico... Burgos. p. 26.

${ }^{42}$ AGS, CONTADURÍA MAYOR DE CUENTAS (CMC), leg. 355. Esta noticia la transmiten las declaraciones de los depositarios de los bienes confiscados de los exceptuados del perdón general por lo que debe ser tomado con cierta cautela. El recurso al pedrisco para justificar el descenso del rendimien-
} 
el efecto contrario como se aprecia en el argumento del arandino Martín Tamarón que en 1489 justificaba el retraso en el pago de un préstamo por ...que el vyno que en ella avia dis que se perdio con el solano que fiso este verano, circunstancia que hace una clara referencia a lo que hoy denominamos una ola de calor por la llegada de una masa de aire africano que empuja el viento del $\mathrm{Sur}^{43}$. Posiblemente una hola de frío siberiano es lo que narra la Crónica de don Juan Segúndo cuando señala que, estando éste en Guadalajara presto a iniciar su viaje a Roa en el mes de enero de 1437 ,...hizo un viento tan frio, que heló la tierra de tal manera que muchos caminantes perescieron... y ...el Rey partió de allí para la villa e Roa, é hizo aquel día tan gran viento é nieve, que el Rey se hubo de volver. Como era urgente acudir a Roa, se ordenó que 300 hombres abrieran el camino con palos y azadas y ...quando el Rey pasó hecho el camino, estaba tan alta de cada parte, que pujaba dos codos sobre los que iban cabalgando ${ }^{44}$.

De igual manera se refleja en la documentación el carácter irregular de las precipitaciones. Tan pronto encontramos referencias a largos periodos de sequía como documentamos las quejas por ...las grandes aguas que ha hecho este ynvierno ${ }^{45}$. Esta situación repercutía irremediablemente sobre el caudal de los ríos provocando severos estiajes, pero también destructoras avenidas e inundaciones ${ }^{46}$.

Dentro de los fenómenos atmosféricos también documentamos episodios incalificables pero, cuanto menos, curiosos. El cronista Pérez de Guzmán narra como en 1438, ... estando el Rey allí en Roa en el dicho año, le fue dicho como en Maderuelo... habia acaescido... que veian por el ayre venir piedras muy grandes como de tova, livianas, que no pesaban mas que plumas, é que aunque daba á algunos en la cabeza no hacian daño ninguno: y destas cayeron muy gran muchedumbre en la dicha villa é cerca della. El rey, extrañado, mandó un hombre de su confianza para verificarlo, ...el qual

to de las viñas bien pudo estar motivado por el interés de los depositarios de abonar una menor cantidad de rentas al factor real. No obstante, aunque la noticia no fuera cierta, este recurso a la helada certifica la cotidianeidad de este fenómeno meteorológico.

${ }^{43}$ AGS, RGS, 148909, fol. 106, transcrito por CANTERA MONTENGRO, E., "Pleitos de usura en la diócesis de Osma en el último tercio del siglo XV", en Anuario de Estudios Medievales. 12, 1982, pp. 620-621.

44 PÉREZ DE GUZMÁN, F., Crónica del serenísimo príncipe Don Juan, segundo rey de este nombre en Castilla y en León, en ROSELL, C. (Ed.), Crónicas de los Reyes de Castilla. Madrid, 1953. Tomo II, p. 532.

\footnotetext{
${ }^{45}$ AGS, RGS, 149901, fol. 188.

${ }^{46}$ AGS, CR, leg. 40, doc. 8.
} 
fue, é no solamente fue certificado ser así, mas traxo algunas de quellas piedras, tan grandes como una pequeña almohada, é tan livianas como pluma, é todas huecas y floxas $^{47}$.

En conclusión, y a falta de estudios concretos sobre el espacio castellano, parece sensato extrapolar los estudios del ámbito europeo o ibérico a nuestra comarca ${ }^{48}$. Éstos muestran que durante buena parte del siglo XV se produjo un aumento generalizado de temperaturas y precipitaciones. No obstante, un estudio realizado en la cercana comarca de Burgos, en el que se analizan las fechas de inicio de la vendimia, muestra un clima muy parejo al actual ${ }^{49}$. Por lo tanto nos encontraríamos con unas condiciones climáticas bastante apacibles y óptimas para el crecimiento de una población, sobre todo si las comparamos con las provocadas por la gran oscilación climática que se produjo a partir de 1550 y que estuvo acompañada de un incremento de las inundaciones, además de frecuentes e intensos episodios de frío junto a grandes nevadas ${ }^{50}$.

\subsection{Vegetación.}

La vida vegetal se encuentra íntimamente asociada a la climatología y a las características del relieve y los suelos. La vegetación de la Ribera del Duero se puede in-

\footnotetext{
${ }^{47}$ PÉREZ DE GUZMÁN, Crónicas del serenísimo..., Tomo II, p. 547.

${ }^{48}$ En este sentido destacan las investigaciones europeas de LE ROY LADURIE, E., Le territoire de l'historien. París, 1973; y ALEXANDRE, P., Le climat en Europe au Moyen Âge. Contributions à l'histoire des variations climatiques de 1000 à 1425, d'après les sources narratives de l'Europe occidentale. París, 1987, o las ibéricas de FONT TULLOT, I., Historia del clima en España. Cambios climáticos y sus causas. Madrid, 1988. En los últimos años se han producido avances significativos en el estudio del paleoclima español como aparecen reflejados en la Red Española de Reconstrucción Climática a partir de fuentes documentales (www.ucm.es/info/reclido). Son significativos los trabajos sobre Cataluña de MARTÍN-VIDE, J. (Ed.), Avances en Climatología histórica en España. Barcelona, 1997; BARRIENDOS VALLVÉ, M., "El clima histórico de Catalunya (siglos XIV-XIX). Fuentes, métodos y primeros resultados", en Revista de Geografía, 30 y 31 (1996-97), pp69-96; "La climatología histórica en el marco de la antigua Monarquía Hispánica", en Scripta Nova, 3, 1999, pp. 32-54; y la base de datos pluviométrica para Andalucía desde el año 1500 (RODRIGO, F. S. et álii, "A 500-year precipitation record in southern Spain”, en Internacional Journal of Climatology. 19, 1999, pp. 1233-1253).

${ }^{49}$ CASADO ALONSO, H., Señores, mercaderes y campesinos. La comarca de Burgos a fines de la Edad Media. León, 1987, pp. 30-32.

${ }^{50}$ BARRIENTOS VALLVÉ, “La climatología histórica... pp. 20-21.
} 
cluir dentro de la gran región biogeográfica mediterránea y está enmarcada en un piso bioclimático supramediterráneo seco ${ }^{51}$.

Las principales masas vegetales que se observan en la comarca forman verdaderas asociaciones que se vinculan a espacios $\operatorname{concretos}^{52}$.

Las sierras presentan hasta los $1.000 \mathrm{~m}$. de altitud una vegetación con predominio de manchas de encinas (Quecus ilex) y quejigos (Quercus faginea), sabinas (Juniperus thurifera) aisladas y abundante matorral de escaso porte. Tan sólo en la Serrezuela encontramos pequeños robledales (Quercus ruber) mezclados con quejigos y matorrales de brezos (Erica lusitanica) y aulagas (Genista scorpius). En la zona silícea al S de la comarca aparecen rebollos (Quercus pyrenaica) dentro de extensas masas de matorrales bajos como el tomillo (Thymus mastichina), torvisco (Daphne gnidium) o cantueso (Lavandula stoechas).

En las parameras calizas, la sabina -popularmente identificado como enebroforma bosques poco densos y más o menos degradados, bien acompañado de encinas chaparras o carrascas (Quercus ilex rotundifolia), quejigos y enebros (Juniperus communis), o bien de matorral con predominio de matas espinosas como las aulagas o estepa (Cistus laurifolius) y plantas aromáticas como el espliego (Lavandula latifolia), el romero (Rosmarinus officinalis) y la salvia (Salvia lavandulifolia).

En los fondos de valle encontramos fresnedas (Fraxinus angustifolia) y olmedas (Ulmus minor) en compañía de escaramujo (Rosa canina), zarzamora (Rumus ulmifolius), aligustre (Ligustrum vulgare) y endrino (Prunus spinosa). En una franja paralela a los cauces de los ríos se sitúa la vegetación propiamente de ribera con protagonismo de sauces (Salix fragalis, atrocinera, alba o purpurea), chopos (Populus nigra), álamos (Populus alba), alisos (Alnus glutinosa), majuelos (Crataegus monogyna) y cornejos (Cornus sanguinea) junto a lúpulo (Humulus lupulus), jabonera (Saponaria officinalis), dulcamara (Solanum dulcamara) o juncos (Juncus inflexus).

Al margen de esta vegetación vinculada a determinados espacios, las dos formaciones vegetales más abundantes en la Ribera del Duero son el encinar y el pinar, ambas

${ }^{51}$ ARAUZO BRIONES, E., "Catálogo de árboles singulares de la Ribera del Duero en la provincia de Burgos”, en Biblioteca 12. Estudio e investigación. 1997, pp. 117-210.

${ }^{52}$ La información sobre las especies vegetales que se señalan a continuación ha sido obtenida del referido artículo de ARAUZO BRIONES “Catálogo de árboles..., p. 128; PARDO y VILLARINO, Análisis del Medio Físico... Burgos, pp. 31-37; PALÁ BASTARÁS, Análisis del Medio Físico... Soria, pp. 7681; ARENILLAS, Análisis del Medio Físico... Segovia, pp. 71-73; MORENO PEÑA, "Burgos en su espacio..., pp.71-75; y PINTO CEBRIÁN, Más allá del vino... 
desarrolladas fundamentalmente en la campiña. El encinar es la vegetación potencial de estas tierras pero la puesta en valor del espacio ha hecho que quede relegado a una situación casi marginal en la actualidad. La encina crece asociada a los quejigos, sabinas, enebros, pinos, majuelos y endrinos. En los encinares también encontramos matorral formado de estepa, aulagas, salvia y espliego.

Por el contrario, el pinar tiene todavía hoy una notable presencia, aunque la mayor parte de estas masas forestales tienen su origen en las repoblaciones forestales. Los pinares que hoy podemos ver en nuestra comarca están formados fundamentalmente por el pino resinero o negral (Pinus pinaster) junto al pino carrasco (Pinus halepensis) y en menor medida por el pino piñonero o doncel (Pinus pinea). Acompañan a estas formaciones encinas, quejigos, sabinas, enebros y matorrales como jaras (Cistus ladanifer) y gayubas (Arctostaphyllos uva-ursi), posibles reminiscencias de las especies originales de estas zonas repobladas.

Ahora bien, ¿este paisaje vegetal tiene algo que ver con el que se podía observar en el periodo medieval? Evidentemente sí. En su mayor parte las especies eran casi con total seguridad las mismas, pero lo que sin lugar a dudas era diferente era la extensión y características de las diferentes masas forestales.

Varios autores ya han planteado la posibilidad de reconstruir los espacios vegetales medievales, sea a través fuentes documentales (sobre todo a través de los apeos), topónimos, información oral, obras literarias o análisis polínicos ${ }^{53}$. Pero lo cierto es que recomponer el paisaje vegetal de hace más de 500 años se convierte en algo casi imposible por lo que nos limitaremos a aproximarnos a lo que debió ser, siendo consciente de las grandes limitaciones con las que nos encontramos ${ }^{54}$.

Para ello vamos a recurrir a fuentes escritas, no sólo contemporáneas a la época medieval que analizamos, sino también aquellas que nos permitan tener una visión del

${ }^{53}$ SÁEZ, C. y CASTRILlO, A., "Los deslindes de Sepúlveda (siglo XV): Estudio Diplomático", en Anuario de Estudios Medievales, 23 (1993) pp. 473-491; GARCÍA DE CORTAZAR, J. A., La sociedad rural en la España medieval. Madrid, 1988; GLICK, Th., Cristianos y musulmanes en la España medieval (711-1250). Madrid, 1991; RETUERCE VELASCO, M., "Testimonios materiales del Madrid andalusí", en Testimonios del Madrid medieval. El Madrid musulmán. Madrid, 2004, pp. 81-116, en especial pp. 109-112.

${ }^{54}$ Ejemplos de reconstrucción del paisaje vegetal, sobre todo de las masas de pinar, lo encontramos en OLMOS HERGUEDAS, Agua, paisaje,..., pp. 49-118. Una reconstrucción del paisaje rural en general se puede ver en DURANY CASTRILLO, M., "El paisaje rural medieval a través del ejemplo berciano", en Paisajes rurales y paisajes urbanos: métodos de análisis en Historia Medieval. Zaragoza, 1994, pp. 29-64. 
paisaje del periodo preindustrial. Así tendremos una percepción del medio sin las grandes alteraciones que se produjeron en las tierras castellanas a partir del siglo XIX (desamortización, mecanización, reparcelación, repoblación...).

A mediados del siglo XIX las masas boscosas se desarrollaban sobre todo en los cerros y presentaban pinos, enebros, encinas o carrascas, robles y sabinas junto a plantas aromáticas como el tomillo, cantueso y salvia, además de tintóreas como el pastel, rubia y gualda. Para el caso concreto de la villa de Aranda sabemos que había al menos cinco montes propiedad del ayuntamiento con encinas, enebros y pinos en la periferia del término municipal ${ }^{55}$. Es significativo que en el XVIII estos montes de la villa eran siete y los materiales gráficos contemporáneos sobre la comarca nos muestran un espacio densamente poblado de arbolado sobre todo en la zona Este como se aprecia en los mapas de La Vid y de la provincia de Burgos contenidos en la obra de Tomás López (Ver Mapa 4$)^{56}$. De la misma manera el mapa del monte de la Calabaza que se encuentra en el Archivo de la Real Chancillería de Valladolid confirma esta densidad de monte en la comarca (Ver Mapa 5) ${ }^{57}$. No obstante, Loperráez en 1778 muestra su disgusto por la casi total ausencia de vegetación en las riberas de los ríos de la comarca ${ }^{58}$.

${ }^{55}$ MADOZ, Diccionario Geográfico..., Vol. II, pp. 46-47 y 50. En la información sobre el partido judicial de Aranda de Duero señala: En los cerros hay bosques de pastos y leña..., encontrándose en ellos arbolado de pinos, enebros, encinas ó carrascas, robles y sabinas cuyas maderas han servido en otros tiempos para la construccion, solo se usan en el dia para el combustible y el carboneo, y para alguna que otra pieza de instrumentos agrícolas: también abundan de plantas aromaticas y medicinales, siendo los principales el tomillo, el cantueso y la salvia de superior calidad; la yerba pastel, la rubia y la gualda para los tintes y varias otras útiles para las artes que los naturales apenas se aprovechan.... Esta misma localización de los montes en los bordes de páramo la identifica SÁNCHEZ RIVERA en el valle medio del Esgueva ("Los asentamientos medievales en el eje del Duero: de la cabaña a la plaza del mercado", en Biblioteca 23. Estudio e Investigación. 2009, pp. 103-135).

${ }^{56}$ La referencia a los montes de Aranda se ha obtenido de AMALRIC, J. P., Aranda de Duero 1752 según las Respuestas Generales del Catastro de Ensenada. Madrid, 1990, pp. 42-43. El mapa de La Vid es el que presentó Mateo de Arana en 1771 junto a las respuestas al formulario enviado por Tomás López (Biblioteca Nacional -BN-, Mss 7307, h. 268r.) y el de la provincia de Burgos es el de 1784 (BN, Mr/35/1377). Más información sobre el Diccionario Histórico Geográfico de España de Tomás López referido a la Ribera del Duero en el trabajo de CALVO PÉREZ, J. J. y HERNANDO GARCÍA, M., “Aranda de Duero y su comarca en el siglo XVIII según la relación de textos geográfico-históricos enviados a Tomás López”, en Biblioteca 8. Estudio e Investigación. 1993, pp. 67-110.

57 Archivo de la Real Chancillería de Valladolid (ARChV), PLANOS Y DIBUJOS, ÓLEOS, doc. 90. No existen referencias al pleito originario en el que se encuadró este plano pero por las características técnicas del óleo todo parece indicar que se trata de un documento del siglo XVIII.

${ }^{58}$ ¿Quién creerá que en un país húmedo, y que le baña el rio Duero, y otros muchos, no habian de estar todas sus márgenes pobladas de árboles?. Pues nada de esto se vé... (LOPERRÁEZ CORVALÁN, Descripción histórica..., Tomo II, p. 14). 
De finales del XVII data la descripción que un viajero anónimo hizo de la vegetación que encontró a su paso por nuestra comarca: ...partimos de esa pequeña ciudad (Lerma), pasando tres leguas largas de bosque de encinas, sabinas, enebros y otras especies de árboles que, a pesar de la mucha niebla y del frío, no dejaron de esparcir un olor grande y suave. Entramos a continuación en un país de landas llenas de espliego, de tomillos y de alhucema, al fin de las cuales encontramos un pueblo llamado Mercadero (¿Gumiel del Mercado o Santa María del Mercadillo?) donde comimos... El país que atravesamos esa tarde no me pareció mucho mejor que el de la mañana. Llegamos anochecido a una ciudad bastante grande, que es Aranda... A la salida de Aranda los viajeros encontraron ...un terreno bastante cubierto de encinas, sabinas y otros $y$, por lo demás, un terruño muy ingrato ${ }^{59}$.

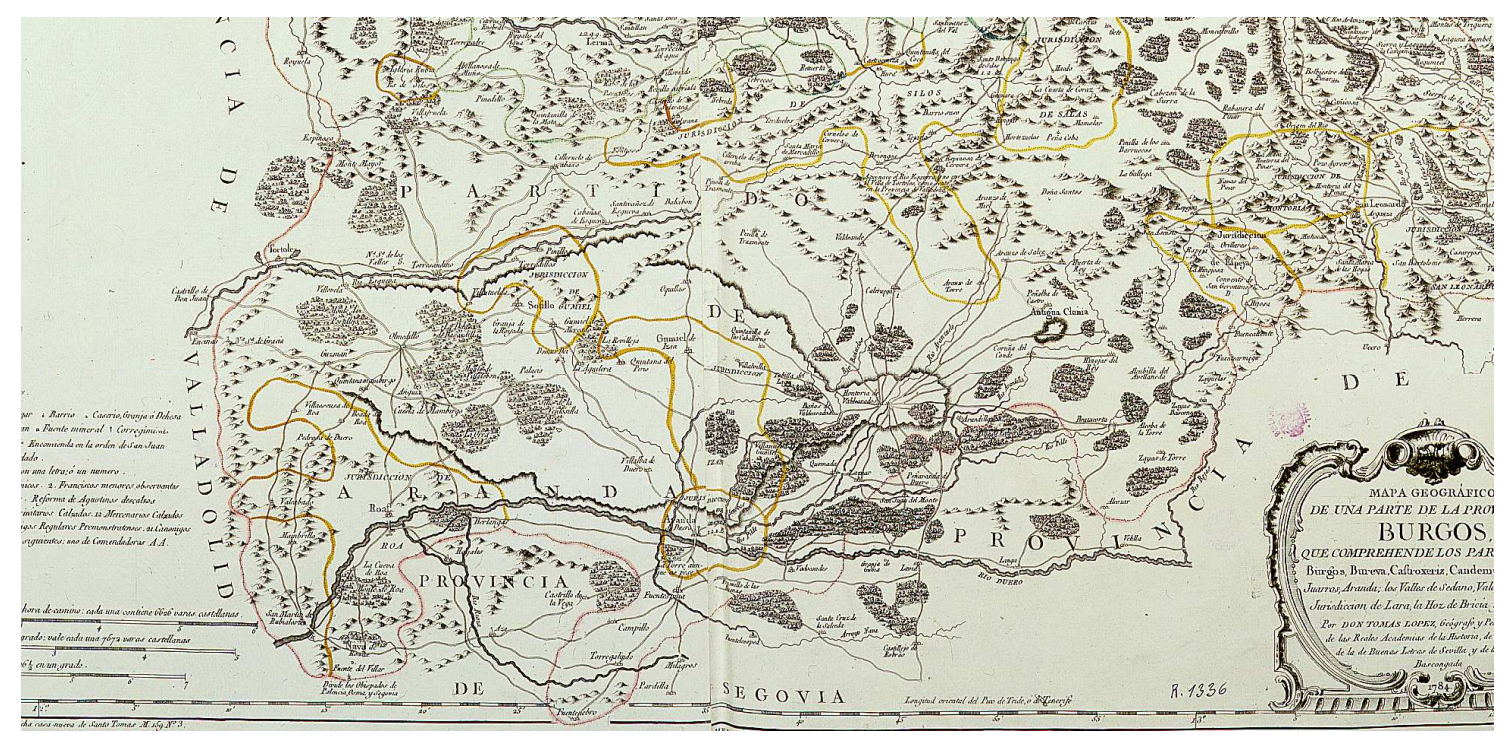

Mapa 4: Detalle del Sur de la provincia de Burgos según Tomás López.

El testimonio del viajero Bartolomé Joly en 1604 relata su viaje desde El Burgo de Osma hasta Peñafiel, apuntando algunas notas sobre el paisaje: A lo largo de sus orillas (el Duero antes de llegar a La Vid) crece voluntariamente el jazmín, esa olorosa y blanca flor tan soberana contra la tiña,... Por un terreno de pinares, extraviados en la noche, llegamos a Barderonde (Vadocondes)... Al día siguiente, por una cuesta de viña, donde las aguas estaban fuera de los pueblos, cavadas en la roca, llegamos a comer a Aranda... Después, por Hoyales, recomendado por producir los mejores garbanzos de

${ }^{59}$ YEVES, J. A., “Aranda de Duero en los libros de viajes y guías de viajeros”, en Biblioteca 12. Estudio e Investigación. 1997, pp. 95-116, en especial pp. 105-106. 
toda España; luego, por San Martín de Rubiales, buen país, donde los almendros están por las tierras plantados como en el Delfinado. Las cigüeñas son allí tan frecuentes, que anidan en todos los campanarios ${ }^{60}$.

Tan solo hemos localizado un testimonio de un viajero contemporáneo al periodo de nuestro estudio. Se trata de León de Rosmithal de Blatna, cuñado del rey de Bohemia, que viajó por España entre 1465 y 1467. A través de la relación de Shaschek, uno de sus secretarios, se relata el viaje: De Lerma a Roa hay siete millas... Para llegar a Roa atravesamos una selva en que no había más árboles que enebros y sabinas,... después fue nuestro camino por tierra yerma en que no había más que salvia y romero en leguas. También hace referencia al pueblo de Nava de Roa, del que dice: Es éste un lugar situado a la falda de unos montes ${ }^{61}$.

Aparte de este testimonio, la reconstrucción del paisaje bajomedieval se nutre de otras noticias bastante dispersas que muestran un panorama muy similar al ya comentado. En términos generales, las referencias a enebrales, robledales, encinares, quejigos y pinares a finales de la Edad Media nos hacen pensar en masas boscosas de cierta entidad con el predominio específico de estas especies a las que se hace referencia ${ }^{62}$. Por otra parte, el vocablo "monte" se utiliza para hablar de formaciones vegetales más o menos densas pero sin identificación de especies predominantes ${ }^{63}$. No obstante, el proceso roturador y el progresivo aumento de la demanda de madera afectó significativamente a la foresta ribereña y así se constata cómo la Reina Juana en 1507, vista la escasez de leña en la villa de Aranda, sugirió a las autoridades que ...podian poner e plantar algunos montes e pinares... e asimismo hagays poner e pongays en las riberas que ay en los terminos desa dicha villa e en las otras partes que a vosotros paresçieses sauçes e alamos e otros arboles ${ }^{64}$.

${ }^{60}$ YEVES, “Aranda de Duero en los libros de viajes..., p. 102.

${ }^{61}$ GARCÍA SIMÓN, A., Castilla y León según la visión de los viajeros extranjeros. Siglos XV$X I X$. Salamanca, 1999, pp. 65-66 y 375.

${ }^{62}$ AGS, RGS, 148809, fol. 114; 149305, fol. 122; 149909, fol. 286; 150101, fol. 258; CÁMARA DE CASTILLA (CC) PUEBLOS, leg. 22, doc. 78; AGS, CR, leg. 22, doc. 1 y leg. 34, doc. 17.

${ }^{63}$ Así, por ejemplo, los vecinos de Hontoria cortaban ...estepa y henebros para sus casas y arados... de un pedaço de monte que se llama San Bartolome (AGS, RGS, 149908, fol. 257). A propósito del mismo monte se señala que no tienen derecho los vecinos ... a cortar leña ni encina ni roble (AGS, CR, leg 6, doc. 5).

${ }^{64}$ AMA, leg. 1222, doc. 16 (Transcrito por HURTADO QUERO, Documentos Reales..., doc. 34, pp. 66-67). Algo similar encontramos en Aldehorno en 1513 (AGS, CR, leg. 34, doc. 17). 


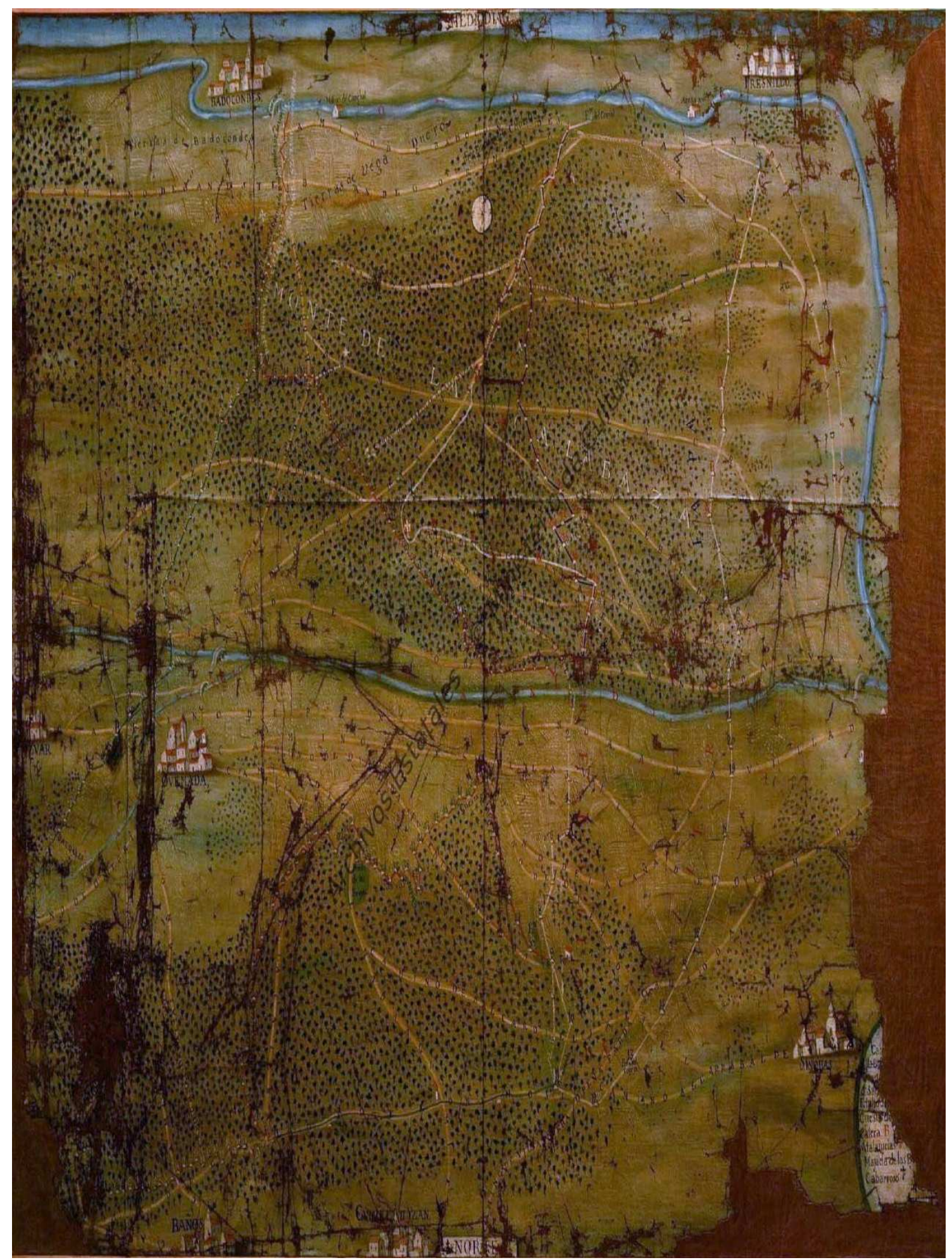

Mapa 5: Representación del monte de La Calabaza en el siglo XVIII (ARChV).

En un intento de reconstrucción del paisaje vegetal más preciso, deberíamos recurrir a otros instrumentos documentales como son la toponimia y los apeos o procesos 
de deslinde de pagos y términos ${ }^{65}$. Sin embargo, las escasas, fragmentadas e imprecisas informaciones obtenidas no nos han permitido obtener resultados dignos de consideración. Mostramos a continuación varios ejemplos que afectan a espacios morfológicamente diferenciados: el páramo (Milagros), la sierra (Aldehorno) y la vega (La Aguilera).

Así, en el apeo de Milagros de 1332 tan solo encontramos una referencia toponímica significativa: Val de Quexijal, localizado en la vertiente Norte de la paramera que actúa de interfluvio entre el Duero y el Riaza. Otros documentos nos muestran vegetación de pinos carrascos y barda pero sin especificar su emplazamiento ${ }^{66}$. Sabemos que hasta finales del siglo XIX las parameras se utilizaron como pasto y monte, sobre todo de enebros y sabinas, y que sólo tras la desamortización se roturaron los llanos y se dedicaron al cultivo cerealístico, configurando el paisaje que presenta en la actualidad ${ }^{67}$.

Más ilustrativo es el apeo de Aldehorno en 1513 realizado con el objeto de que ...señalasen e amojonasen los montes e lugares adonde de nuevo otros se podrian poner e mandar poner e plantar salzes, alamos, e pobos, e pinares e otros arboles ${ }^{68}$. Se trata por lo tanto del amojonamiento de un monte para ser repoblado y en él se hace referencia a salzejos y un carrasco, y además son constantes las referencias a praderas, labranzas e, incluso huertos. Indirectamente, también se hace referencia a la presencia de robles, encinas y quejigos. De toda esta información se infiere que se trataría de un monte bastante despejado, bastante diferente de los densos bosques con los que cuenta la sierra en la actualidad.

En el contexto del enfrentamiento entre La Aguilera y Gumiel del Mercado por el aprovechamiento de términos se describe una significativa abundancia de montes de carrascos, localizados en las cuestas de la periferia de estas localidades. Por la información que aportan los testigos sabemos que una gran masa de monte de pino carrasco se

${ }^{65}$ Aspecto ya abordado por CASADO HERNANDO, Señores, mercaderes..., p. 33 y OLMOS HERGUEDAS, La Comunidad..., p. 33.

${ }^{66}$ AGS, CR, leg. 22, doc. 1 (El apeo aparece transcrito por MORAL GARCÍA, J. Milagros. Su pasado histórico. Burgos, 2004, pp.413-414). La barda son ramas de sabina o enebro utilizadas como combustible, cubiertas o, incluso, se quemaban para protegerse de la peste (PINTO CEBRIÁN, Más allá del Vino..., p. 152).

${ }^{67}$ MORAL GARCÍA, Milagros. Su pasado..., pp. 270-262. Esta misma situación se constata en las parameras occidentales de la provincia de Soria (PALÁ BASTARÁS, Análisis del Medio Físico... Soria, p. 16)

${ }^{68}$ AGS, CR, leg. 34, doc. 17. 
extendía a ambos márgenes del camino que partía desde Aranda. Al Norte, desde el Montehermoso hasta Revilla, junto al Gromejón, se extendía el denominado Monte; y hacia el Sur, hasta La Ventosilla, se encontraba Los Carrascales ${ }^{69}$.

En definitiva, estos relatos, descripciones y documentos nos muestran una vegetación muy similar a la que encontramos hoy: encinares casi por todas partes, enebrales que seguramente eran sabinares, pinares con abundancia de negrales y donceles ${ }^{70}$, matorral estepario y vegetación de ribera junto a los cauces de los ríos. No obstante, da la sensación de que la vegetación en la Baja Edad Media, sobre todo la masa arbórea, alcanzaba una mayor extensión que en la actualidad. Baste como ejemplos las extensas parameras de monte roturadas en el siglo XIX o la presencia del roble en la comarca que en la actualidad se limita a una pequeña mancha en la zona de la Serrezuela, mientras que la documentación medieval lo identifica además en las tierras al Norte del Duero, como en Peñaranda u Hontoria.

Para terminar, no nos resistimos a hacer mención a una fuente literaria de primer orden que hace referencia precisamente al roble $\mathrm{e}^{71}$ :

... a diestro dexan a san Estevan, mas cae aluen; entrados son los ifantes al robredo de Corpes, los montes son altos, las ramas pujan con la nues, e las bestias fieras que andan aderredor.

${ }^{69}$ AMA, leg. 1199, doc. 19.

${ }^{70}$ La identificación de la expansión del pino en Castilla asociada a las repoblaciones posteriores al siglo XV, sobre todo modernas, planteadas por HOPFNER ha sido puesta en cuestión por CARLÉ y VINCENT que documentan la existencia de grandes masas de pinares en Castilla y, sobre todo, en su sector suroriental en épocas anteriores (HOPFNER, H., "La evolución de los bosques de Castilla la Vieja en tiempos históricos", en Estudios Geográficos. 56, 1954, pp. 415-430; CARLÉ, M. C., "El bosque en la Edad Media (Asturias-León-Castilla)", Cuadernos de Historia de España. LIX-XL, 1976, pp. 297-334; y CLÉMENT, V. "Frontière, reconquête e mutation des paysages végétaux entre Duero et Système Central du XI au milieu du XV siècle”, en Melanges de la Casa de Velásquez. 29, 1993, pp. 87-126; y del mismo autor "La forêt et les hommes en Castille au XIII siècle: l'exemple du territoire de Sepúlveda", en Melanges de la Casa de Velásquez. 30, 1994, pp. 253-274). En el caso concreto de nuestra comarca, PINTO CEBRIÁN señala que el pino piñonero y el resinero serían dos especies nativas de la Ribera y hace referencia a restos arqueológicos de carbón de pino resinero y cáscaras de piñones consumidos en el primer milenio a. C. Estos pinos estarían emplazados en ambientes cálidos y arenosos dispersos entre las encinas y sabinas. Según este autor el pino carrasco se introdujo en la Ribera en las repoblaciones forestales de mediados del siglo XX (Más allá del Vino..., pp. 145-155). No obstante, hemos localizado referencias a carrascos en la documentación medieval como hemos señalado anteriormente.

${ }^{71}$ Poema de Mio Cid, edición de Colin Smith (ed. 1987), vs. 2696-2701, p. 234. La localización del Robledal o Robredo de Corpes se ha identificado tradicionalmente con Castillejo de Robledo. Para más información sobre la visión de la Ribera del Duero en la literatura castellana ver IZQUIERDO, P., "La Ribera del Duero en la Literatura española", en Biblioteca 10. Estudio e Investigación. 1995, pp. 209230. 
Falaron un vergel con una limpia fuent,

Mandan fincar la tienda infantes de Carrion;...

\subsection{Fauna.}

Íntimamente unida a la vegetación encontramos la fauna. Son pocos los estudios relativos a la fauna silvestre medieval, sobre todo si los comparamos con otros periodos de la historia de la humanidad ${ }^{72}$.

Las referencias que tenemos a la fauna del periodo bajomedieval en la Ribera del Duero son muy escasas, fragmentarias y casi siempre relacionadas con la alimentación o con la caza o pesca. Sabemos que en los montes de la comarca vivían conejos (Oryctolagus cuniculus), liebres (Lepus granatensis), “puercos” (Sus scrofa) y hasta corzos (Capreolus capreolus) y venados (Cervus elaphus). También eran abundantes las palomas torcaces (Columba palombus), perdices (Alectoris rufa) y, algo menos, codornices (Coturnix coturnix) en los espacios más despejados. A modo de ejemplo, sabemos que en el verano de 1463 se instaló la corte de la reina Isabel en Aranda y le acompañaba el mayordomo Andrés de Cabrera que, tras recuperarse de una enfermedad, ...esta en Aguilera quatro dias a; sano esta y mas gentil, a los codorniçes se anda folgando ${ }^{73}$. Otro ejemplo lo encontramos en el artesonado mudéjar de Sinovas en el que aparecen varias escenas de caza con perros: una de ellas reproduce el acoso de dos perros sobre un oso; en otra se aprecia la persecución de un can a una liebre; y en una tercera escena aparece un perro sobre una perdiz. Asimismo otra escena representa el acecho de un halcón sobre una paloma ${ }^{74}$.

Por otra parte, también constatamos la existencia de truchas (Salmo trutta), barbos (Barbus bocagei), anguilas (Anguilla anguilla), bogas (Chondrostoma duriense), lamprehuela (Cobitis calderon), bermejuelas (Rutilus ascasii), cachuelos (Leuciscus

\footnotetext{
${ }^{72}$ Estos estudios casi siempre están vinculados a los restos encontrados en excavaciones arqueológicas o las ordenanzas sobre la caza. En este sentido son bastante interesantes las indicaciones sobre especies animales recogidas por LADERO QUESADA, M. A., en "La caza en la legislación municipal castellana. Siglos XIII a XVIII", en En la España Medieval. 1, 1980, pp. 193-221. Recientemente OLMOS HERGUEDAS ha realizado una reconstrucción de la fauna del periodo medieval en la comarca de Cuéllar (Agua, paisaje,..., pp. 173-183).

${ }^{73}$ Tomado de AZCONA, T., Isabel la Católica. Madrid, 1964, p. 41.

${ }^{74}$ CALZADA TOLEDANO, J. J., Iconografía en el artesonado mudéjar de Sinovas. Burgos, 2009, pp. 20-23.
} 
cephalus), cangrejos (Austropotamobiues pallipes), mejillones (Unio crassus) y almejas (Spheridae) en los ríos ribereños ${ }^{75}$.

Fuera de estas especies con un evidente aprovechamiento cinegético o pesquero las noticias sobre animales salvajes son casi anecdóticas: así sabemos de la existencia de gorriones (Passer domesticus), cigüeñas (Ciconia ciconia), cuervos (Corvus corax), garzas (Ardea cinerea), buitres (Gips fulvus), alimoches (Neophron pernopterrus), zorros (Vulpes vulpes), lobos (Canis lupus)... y un largo etcétera de animales tan habituales que no había necesidad alguna de mencionarlos. Para hacernos eco de estas especies debemos acudir a otras fuentes como son las literarias o iconográficas. De nuevo en el magnífico artesonado mudéjar de la iglesia de San Nicolás de Bari de Sinovas se muestra la representación de cigüeñas, perdices, águilas, ocas, garzas, conejos o ciervos; si bien es cierto que aparecen en compañía de osos, leones, elefantes, camellos, grifos y dragones ${ }^{76}$.

\section{LA TRANSFORMACIÓN DEL ESPACIO NATURAL: LA CONFIGURACIÓN DEL ESPACIO RURAL FEUDAL HASTA LA BAJA EDAD MEDIA.}

Son muchos y de gran calidad los estudios de diferentes autores que han abordado el desarrollo histórico de la Ribera del Duero. La presencia humana en la comarca se constata desde el Paleolítico y, salvo estos primeros pasos de la vida del hombre por nuestras tierras, todos los periodos de la Historia de la Ribera cuentan con valiosos estudios de contrastada calidad. Una breve enumeración nos permite destacar los realizados por Sacristán de Lama para el periodo celtibérico; los de Abásolo, Palol y el amplio

\footnotetext{
75 Sobre estas especies, técnicas y ámbitos de pesca recomendamos nuestro trabajo (ABAD ÁlVAREZ, I. y PERIBÁÑEZ OTERO, J. G., "La pesca fluvial en el Reino de Castilla durante la Edad Media", en Vivir del agua en las ciudades medievales. Valladolid, 2006, pp. 147-180). Sobre la situación actual de las especies fluviales y la singularidad de los cangrejos autóctonos en el Duero ver ALONSO GARCÍA-AMILIBIA, M., "El Duero, una visión integral desde el río", en Congreso homenaje al Douro/Duero y sus ríos: memoria, cultura y porvenir. Zamora, 2006; y PINTO CEBRIÁN, Más allá del Vino..., pp. 37-42.

${ }^{76}$ Además de la obra de CALZADA TOLEDANO señalada anteriormente, también pueden consultarse ABAD ZAPATERO, J. G. y ARRANZ ARRANZ, J., Las Iglesias de Aranda. Pamplona, 1989, pp. 128-134; y GÓMEZ GÓMEZ, A., "La techumbre mudéjar de Sinovas", en Biblioteca 17. Estudio e Investigación. Arte medieval en la Ribera del Duero. 2002, pp. 71-90.
} 
equipo que trabaja sobre el periodo romano y Clunia; los de Reyes Téllez, Escudero Chico o Pastor Díaz de Garayo dedicados al periodo de transición entre el mundo antiguo y medieval; o el de Álvarez Borge que aborda la realidad plenomedieval. A todos ellos debemos añadir las desiguales aportaciones de los eruditos locales a través de sus meritorias Historias de nuestros Pueblos ${ }^{77}$.

La ocupación humana en la Ribera del Duero está atestiguada desde hace miles de años. El desarrollo de los Inventarios Arqueológicos en los años 90 del siglo XX ha puesto de manifiesto la existencia de población paleolítica en estas tierras, en concreto del Pleistoceno Medio, aunque no se ha documentado todavía continuidad durante el Paleolítico Medio y Superior ${ }^{78}$. Desde el Neolítico se observa una ocupación casi continua del territorio. Significativo en la configuración del poblamiento es el periodo celtibérico en el que se observa una clara articulación del territorio en torno a núcleos de población tan singulares como Roa o Clunia, sin olvidar otros poblados como los localizados en La Vid, Arauzo de Torre, Pinilla-Trasmonte o Langa ${ }^{79}$.

La irrupción romana en las tierras medias de la Meseta supuso un significativo desarrollo de la comarca en todos los sentidos. Tras el proceso de conquista y las guerras civiles del siglo I a. C., la ciudad romana de Clunia Sulpicia se convirtió en un bastión fundamental del proceso de romanización de la Meseta y en "un foco de transformación cultural y de ordenación del entramado poblacional y viario de la comarca" ${ }^{\text {"80 }}$. Clunia, y en menor medida Rauda, articularon un territorio jalonado de numerosas villae de pequeño y mediano tamaño (Baños de Valdearados, Quemada, Arandilla, Quintanamanvirgo, Haza, Milagros,...) y un eje viario integrado completamente en la red de infraestructuras imperia-

${ }^{77}$ A todos ellos haremos mención a lo largo de los siguientes capítulos por lo que estimamos conveniente no cansar al lector con una retahíla bibliográfica casi interminable.

78 SACRISTÁN DE LAMA, J. D., "Escombros bajo nuestros pies", en Biblioteca 2. Estudio e Investigación. 1987, pp. 40-45; PALOMINO LÁZARO, A. L., “Aproximación a la situación actual de la investigación arqueológica en la burgalesa Ribera del Duero", en Biblioteca 11. Estudio e Investigación. 1996, pp. 257-272; y DÍEZ FERNÁNDEZ-LOMANA, J. C. y RODRÍGUEZ MARCOS, J. A., Las raíces de nuestra historia. De Atapuerca al Neolítico. Burgos, 2009, pp 100 y 107.

79 SACRISTÁN DE LAMA, J. D., La Edad del Hierro en el Valle Medio del Duero. Rauda (Roa, Burgos). Valladolid, 1986; y “Arqueología: Raíces y cimientos”, en Biblioteca 3. Estudio e Investigación. 1988, pp. 9-15.

${ }^{80}$ SACRISTÁN DE LAMA, “Arqueología: Raíces..., p. 13. 
les (calzadas, miliarios, puentes...) ${ }^{81}$. Buena parte de estas villas y caminos fueron el germen del poblamiento medieval.

Los vestigios hispanovisigodos en esta comarca son muy escasos, reduciéndose a discretos testimonios funerarios en Clunia, Roa y Valdezate, y los probables de Baños de Valdearados. En este ámbito cultural los investigadores discrepan notablemente sobre la continuidad o no respecto al poblamiento tardorromano. Así Abásolo y García Rozas hablan de continuidad argumentando la identidad de algunos asentamientos y proximidad de hallazgos. Por su parte Pastor Díaz de Garayo señala el abandono sistemático de los asentamientos tardorromanos en el siglo $\mathrm{V}$ y la ruptura poblacional causada por la inestabilidad generalizada y la debilidad demográfica dentro del contexto de la crisis global del mundo antiguo ${ }^{82}$. No obstante, recientemente se ha planteado la posibilidad de una amplia presencia visigoda en nuestra zona a la luz de los resultados de los trabajos de prospección arqueológica realizados durante los últimos veinte años ${ }^{83}$.

\subsection{Poblamiento de la Ribera del Duero en la Alta Edad Media.}

El tránsito entre el mundo antiguo y el medieval ha provocado una intensa y polémica producción historiográfica que afecta de manera significativa a nuestra comarca. Son muchas las teorías que se han formulado sobre este aspecto: desde las olvidadas tesis de Menéndez Pidal que entendía el término populare como el sometimiento de un espacio a una jurisdicción y no como la ocupación de un espacio vacío ${ }^{84}$; pasando por el clásico “desierto estratégico” de Don Claudio ${ }^{85}$; los planteamientos de Barbero y Vigil

${ }^{81}$ Obras de referencia en este sentido son las de GARCÍA MERINO, C., Población y poblamiento en Hispania Romana. El Conventus Cluniensis. Valladolid, 1975; y ABÁSOLO ÁLVAREZ, J. A., Comunicaciones de la época romana en la provincia de Burgos. Burgos, 1975.

${ }^{82}$ ABÁSOlO ÁlVAREZ, J. A. y GARCÍA ROZAS, R., Carta arqueológica de la provincia de Burgos. Partido judicial de Salas de los Infantes. Burgos, 1980, p. 29; PASTOR DÍAZ DE GARAYO, E., Castilla en el tránsito de la Antigüedad al Feudalismo. Poblamiento, poder político y estructura social del Arlanza al Duero. 1996, Valladolid, pp. 35-42 y 60-62.

${ }^{83}$ LECANDA ESTEBAN, J. A. y PALOMINO LÁZARO, A. L., "Dos modelos de ocupación del territorio en época visigoda en la provincia de Burgos: la región montañesa septentrional y la comarca ribereña del Duero", en Actas del V Congreso de Arqueología Medieval Española. Valladolid, 2000. Vol. I, pp. 37-48.

${ }^{84}$ MENÉNDEZ PIDAL, R., "Repoblación y tradición en la cuenca del Duero", en Enciclopedia Lingüistica Hispánica. Madrid, 1960, Tomo I, pp. XXIX-XLVII.

${ }^{85}$ SÁNCHEZ ALBORNOZ, C., Despoblación y repoblación del valle del Duero. Buenos Aires, 1966. Esta interpretación ha sido la predominante hasta hace poco, como puede verse en parte de la histo- 
que definen la repoblación como el "control político y militar ... de población antigua" que nunca llegó a organizarse en un territorio de modo que pudiera alcanzar la cohesión necesaria para formar una unidad política independiente ${ }^{86}$; los trabajos arqueológicos de Reyes Téllez que ponen de manifiesto la continuidad poblacional entre los siglos VIII y $\mathrm{X}$ en la meseta castellana ${ }^{87}$; la tesis de Escudero Chico que analiza la situación de la comarca raudense ${ }^{88}$; el estudio de Álvarez Borge que perfila la configuración de una nueva organización territorial surgida de la desintegración de las "comunidades de aldea" que paulatinamente evolucionaron hacia un complejo sistema de relaciones feudales ${ }^{89}$; o el planteamiento de Martín Viso que presenta un territorio ajeno a un poder centralizado entre los siglos VIII y XI y que a partir de entonces se vio absorbido por la capacidad feudalizadora del poder condal $/ \mathrm{real}^{90}$. Todos ellos han participado sin lugar a dudas en la clarificación de este aspecto tan controvertido de la historiografía altomedieval española, pero a día de hoy no se ha conseguido alcanzar un consenso generalizado sobre este problema histórico.

Polémicas aparte, en el periodo alto medieval la práctica totalidad de las comunidades rurales objeto de nuestro estudio aparecen citadas en los escasos documentos que hacen referencia a la comarca ribereña ${ }^{91}$. Incluso algunas de estas comunidades, en concreto Roa y Fresnillo de las Dueñas, ya contaban con un instrumento de ordenariografia oficial (por ejemplo PÉREZ DE URBEL, J., El Condado de Castilla. Madrid, 1969 o MARTÍNEZ DIEZ, G., "La época condal", en Historia de Burgos. Vol. II Edad Media (1), Burgos, 1986, pp. 48-49).

${ }^{86}$ BARBERO, A. y VIGIL, M., La formación del feudalismo en la Península Ibérica. Barcelona, 1978 , p. 227.

${ }^{87}$ REYES TÉLLEZ, F., “Arqueología Medieval Burgalesa: estado de la cuestión”, en Introducción a la Historia de Burgos en la Edad Media. I Jornadas burgalesas de Historia. Burgos, 1990, pp. 177-229; y del mismo autor "Arqueología Altomedieval en el Valle del Duero", en Biblioteca 6. 1991, pp. 9-26.

${ }^{88}$ ESCUDERO CHICO, S., Organización del espacio y poblamiento en la Tierra de Roa (Burgos) siglos $V$ al XIII. Tesis inédita, Valladolid, 2001; y el mismo autor junto a MARTÍN MARTÍN, A. "Toponimia y Repoblación en el territorio burgalés durante la Alta Edad Media", en Burgos en la Alta Edad Media. Burgos, 1991, pp. 521-537.

89 ÁlvareZ BORGE, I., Poder y Relaciones Sociales en Castilla en la Edad Media. Los territorios entre el Arlanzón y el Duero en los siglos X al XIV. Salamanca, 1996.

${ }^{90}$ MARTÍN VISO, I., "Una frontera casi invisible: los territorios al norte del Sistema Central en la Alta Edad Media (siglos VIII-XI)”, en Studia Histórica. Historia Medieval. 23, 2005, pp. 89-114.

${ }^{91}$ A modo de síntesis podemos consultar NUÑO GONZÁLEZ, "Pautas de ocupación..., pp.79104. Más detalles los encontramos en MARTÍNEZ DÍEZ, G., Las Comunidades de Villa y Tierra de la Extremadura castellana. Madrid, 1983; y Pueblos y alfoces de la repoblación. Valladolid, 1987. 
miento jurídico de primer orden como era el fuero. Esta situación es reflejo del grado de complejidad, no sólo política y organizativa, sino también económica y social, que comienza a pergeñarse en la comarca a la par que en el resto del ámbito castellano ${ }^{92}$.

A la luz de todas estas interpretaciones la identificación del poblamiento altomedieval adquiere un alto grado de complejidad. No es nuestra intención entrar en polémicas por lo que a continuación presentamos una visión general basada exclusivamente en las investigaciones desarrolladas en los últimos años tamizadas por nuestro criterio personal, con todas las precauciones y limitaciones que ello comporta.

La visión clásica de la ruptura ocupacional en la Meseta Norte ligada a la invasión islámica del año 711 está en la actualidad en entredicho. La tradicional interpretación despobladora parece haber sido desmontada con una ingente cantidad de estudios que apuestan por que, efectivamente, la irrupción musulmana supuso una ruptura con la organización sociopolítica y territorial de la realidad hispanovisigoda pero que, sin lugar a dudas, no supuso la despoblación del espacio meseteño. Tras los primeros años de avance islámico, la Meseta septentrional sufrió una desestructuración respecto a los, ya de por sí, débiles lazos de imbricación del aparato político hispanovisigodo ${ }^{93}$. Se deduce por lo tanto un amplio territorio poblado, bien es cierto que con un carácter bastante laxo, que no se articulaba bajo la estructura feudal de los reinos del Norte ni bajo la soberanía del Emirato del Sur. En este territorio no parece que existiera una interrelación ni jerarquización entre los distintos núcleos o comunidades que lo formaban ${ }^{94}$ y además sufría las incursiones de los vecinos septentrionales o meridionales con un marcado significado económico: la obtención de un botín. Pastor Díaz de Garayo mantiene que del siglo VIII al X estas comunidades situadas entre el Duero y el Arlanza mantuvieron una política de pactos o acuerdos con el poder andalusí de carácter netamente económico (parias) que les permitían mantener cierta estabilidad. Esta política se ve refrendada con la inexistencia casi absoluta de razzias agarenas en esta región en contraposición a la situación de inestabilidad en otras zonas cristianas vecinas. Esta situación sólo se vio interrumpida cuando los condes castellanos integraron las poblaciones del Duero bajo su dominio político (912). La respuesta andalusí fue con-

92 MARTÍNEZ DÍEZ, G., Fueros locales en el territorio de la provincia de Burgos. Burgos, 1982; PERIBÁÑEZ OTERO, J. G. y ABAD ÁLVAREZ, I., "El fenómeno urbano medieval en Burgos y La Rioja", en El fenómeno urbano medieval entre el Cantábrico y el Duero. Santander, 2002, pp.175209.

\footnotetext{
${ }^{93}$ PASTOR DÍAZ DE GARAYO, Castilla en el tránsito..., pp. 114 y ss.

${ }^{94}$ MARTÍN VISO, “Una frontera casi invisible..., pp. 89-114.
} 
tundente en forma de campañas de castigo sobre esta comarca que se prolongaron hasta principios del siglo XI por parte de Abd-el-Ramán III, Almanzor y Abd-el-Malik ${ }^{95}$. Ese periodo de inestabilidad finalizó como consecuencia de la crisis califal y tuvo como resultado la integración de estos territorios dentro del engranaje de los triunfantes señores feudales del Norte.

Sean rupturistas o continuistas, la mayor parte de los investigadores del periodo altomedieval parecen coincidir en que la estructura de poblamiento en torno al año 1000 presentaba una red de ocupación bastante densa con proliferación de pequeños núcleos compactos y estables -las aldeas- situados a escasa distancia unos de otros, fruto del crecimiento agrario altomedieval ${ }^{96}$. Un buen ejemplo de este panorama poblacional lo podemos observar en las más de treinta aldeas que conformaban el Campo de Roa como trasmite el documento fechado en 1143 por el que Alfonso VII concedía el Fuero de Sepúlveda a la villa de Roa.

En lo que no parece haber tal acuerdo es en el proceso mediante el cual estas comunidades se integraron en el entramado feudal de los reinos cristianos. Tradicionalmente se explicaba mediante el proceso de reconquista y repoblación pero, una vez superada la idea de la ruptura, parecen más adecuadas las propuestas que hablan de integración de una población ya existente en las redes de poder y organización territorial de los reinos del Norte. En este sentido, Martín Viso pone como ejemplo el caso de la comunidad de Sepúlveda que, quizá en el 940 y con toda seguridad en el 1076, firmaría un pacto de reconocimiento de la autoridad condal/real sobre su territorio a cambio de la garantía de salvaguar-

\footnotetext{
${ }^{95}$ PASTOR DÍAZ DE GARAYO, Castilla en el tránsito..., p. 140. En un texto sobre las campañas organizadas por Almazor a finales del siglo X se dice: la trigesimocuarta, la de Osma y Alcubilla, de Castilla: sometió y arrasó el país de Castilla, llegando hasta el país de los vascones; conquistó la ciudad de Osma y la pobló con musulmanes para hostigar a los cristianos, pues era su punto más avanzado... La trigesimonovena, la de San Esteban; acampó ante ella y la asedió durante cinco días, al cabo de los cuales la conquistó por la fuerza e instaló allí un contingente de musulmanes; de allí marchó hacia Pamplona... habiendo destruido la ciudad, avanzó hacia el castillo de Clunia, que conquistó el mismo día de su llegada (MOLINA, L., "Las campañas de Almanzor a la luz de un nuevo texto", en Al-Qantara, II, 1981, pp. 232-233).

${ }^{96}$ En palabras de GARCÍA DE CORTAZAR, J. A. "hacia el año mil un conjunto de unidades aparentemente homólogas, las aldeas, llenan el espacio" (en Organización social del espacio en la España medieval. La Corona de Castilla en los siglos VIII al XV. Barcelona, 1985, p. 71). También coinciden en esta apreciación ORTEGA VALCÁRCEL : "Es la imagen de la plenitud, del espacio lleno" ("Geografía histórica... p. 197); y PASTOR DÍAZ DE GARAYO (Castilla en el tránsito..., pp. 62-66). El material gráfico presentado por PASTOR es bastante ilustrativo de esta situación (p. 56). No obstante, REYES TÉLLEZ discrepa en cuanto a la estabilidad de estas aldeas en el periodo anterior al siglo XII y señala para los casos de los asentamientos de Valdezate y La Sequera un carácter inestable y semipermanente (“Arqueología Medieval Burgalesa... p. 207; y "Arqueología Altomedieval en el Valle del Duero..., pp. 926).
} 
dar la autonomía local de la que ya disfrutaba y que se reflejó en el Fuero. Los instrumentos básicos de integración de estos territorios del Duero dentro del esquema feudal del condado castellano serían la transformación de las comunidades de aldea en concejos, su vertebración en un espacio jerarquizado y el encuadramiento diocesano ${ }^{97}$. No obstante, otros autores como Álvarez Borge rechazan la idea de la feudalización como elemento exógeno y consideran que los vínculos señoriales propios de las relaciones de dominación feudales son el fruto de la transformación o disolución de las comunidades de aldea ${ }^{98}$.

A lo largo de este periodo se configuraron dos modelos diferentes en lo que a la organización de territorio se refiere. Por una parte, en los territorios situados al Norte del Duero se empleó el alfoz como instrumento de gestión del territorio, auque poco después fue sustituido por Merindades o Adelantamientos. Por otra parte, las Extremaduras experimentaron una nueva forma de organización territorial a través de las Comunidades de Villa y Tierra.

En lo que toca a la plasmación de esta nueva realidad sobre el poblamiento nos encontramos entre los siglos X y buena parte del XII con una clara jerarquización espacial y organización administrativa del territorio llevada a cabo por parte de la autoridad condal y que se articulaba en lo que ha venido en denominarse alfoz. Se trata de una división territorial del Condado de Castilla en pequeños distritos o demarcaciones que contaban con un núcleo central, que generalmente coincidía con un castillo, a cargo del cual, por delegación de la potestas condal, se encontraba un tenente. Este delegado condal concentraba en la cabeza del alfoz las funciones fiscales, militares y judiciales, a la vez que administraba la gestión de las tierras públicas o la propiedad dominical. Prácticamente todo el territorio al Norte del Duero que es objeto de nuestro estudio estaba encuadrado dentro del alfoz de Clunia. No obstante, Álvarez Borge señala también la existencia de un alfoz con centro en Gumiel y Pastor Díaz de Garayo añade sendos alfoces en Roa y San Esteban de Gormaz en los que estaría englobado parte de este espacio ${ }^{99}$.

\footnotetext{
${ }^{97}$ MARTÍN VISO, I., "Repoblaciones, territorios, iglesias y santos: los valles del Duratón y del Riaza (siglos X-XII)”, en Biblioteca 23. Estudio e Investigación. 2009, pp. 265-292.

98 ÁlVAREZ BORGE, I., Poder y relaciones sociales..., pp. 15-24. Este autor define las comunidades de aldea como un colectivo asentado en un territorio con vínculos comunitarios en sus relaciones sociales y económicas. Se trataría por lo tanto de una fase avanzada de desarrollo de las sociedades gentilicias. Frente a la imposición desde fuera del modelo feudal, este autor señala que la formación del feudalismo en los territorios castellanos fue fruto de la propia contradicción en el seno de las comunidades de aldea.

${ }^{99}$ Salvo matices que no vienen al caso, buena parte de los investigadores especializados en el tema coinciden en estas características que hemos señalado, aun partiendo de presupuestos y planteamien-
} 


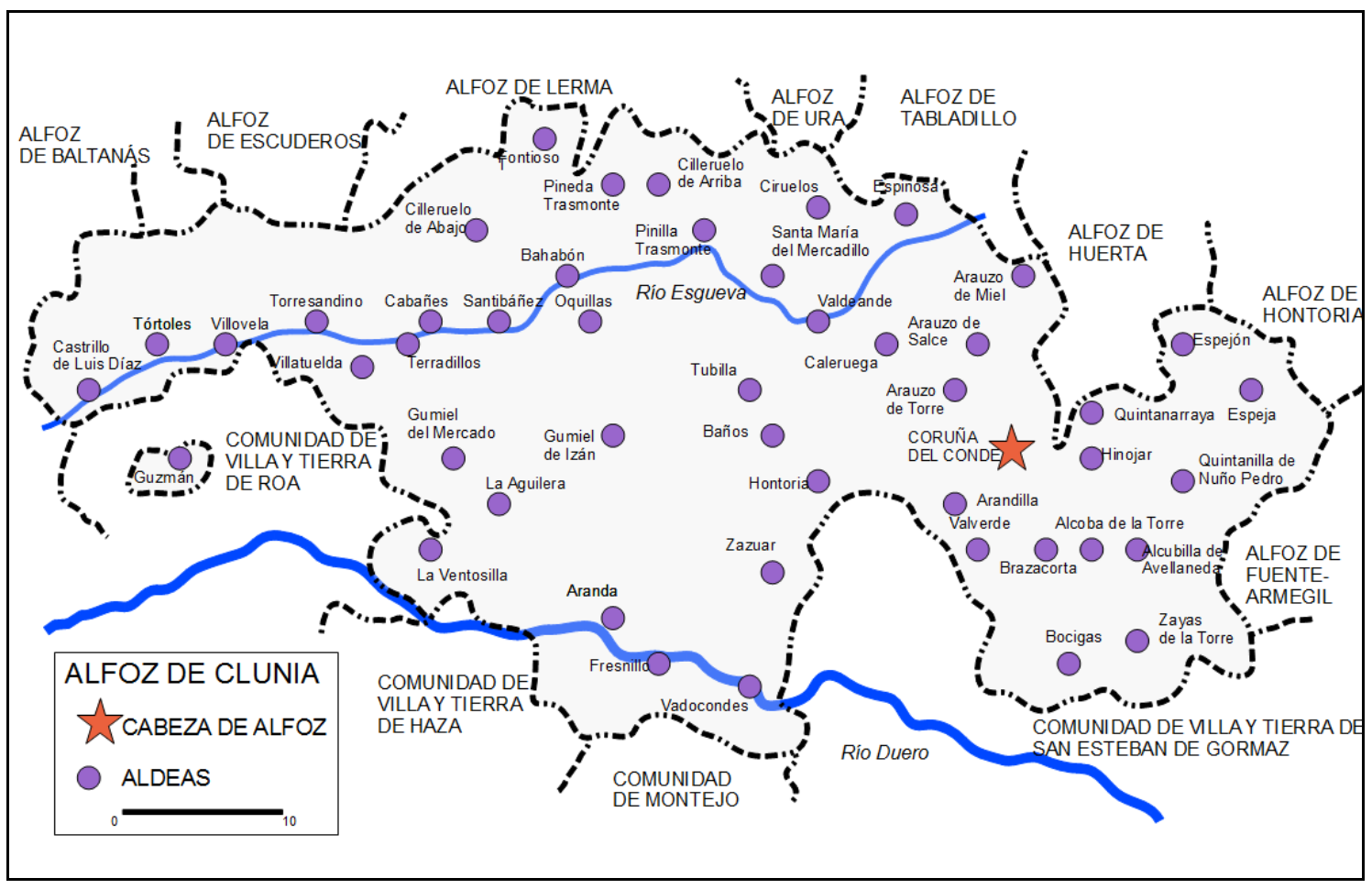

Mapa 6: El alfoz de Clunia según Martínez Díez.

Para las tierras situadas al Sur del Duero el instrumento ideado a partir del siglo XI para organizar el territorio fueron las Comunidades de Villa y Tierra. Estas demarcaciones eran circunscripciones territoriales más o menos amplias dependientes en todos los sentidos de una villa cabeza de la Comunidad y fuera del control de Merinos o Adelantados ${ }^{100}$. En principio poseían una mayor autonomía y dependían directamente del rey. En nuestra

tos radicalmente diferentes. Los principales estudios para el espacio que nos ocupa se deben a MARTÍNEZ DÍEZ, G., Pueblos y alfoces..., pp. 7-16; ÁLVAREZ BORGE, I., Monarquía feudal y organización territorial. Alfoces y merindades en Castilla (siglos X-XIV). Madrid, 1993, pp. 55-96; del mismo autor "Poder condal y organización territorial en Castilla en la Alta Edad Media. El alfoz de Clunia", en Burgos en la Alta Edad Media II Jornadas Burgalesas de Historia. Burgos, 1991, pp. 571-586; y PASTOR DÍAZ DE GARAYO, Castilla en el tránsito..., pp. 201-211.

${ }^{100}$ Para MONSALVO ANTÓN los concejos de Villa y Tierra surgieron por la exigencia de la conquista y la repoblación en zona de frontera. Estas comunidades se caracterizaron por contar con una importante autonomía, poseer una enorme extensión territorial, gozar de importantes comunales y bienes baldíos y tener una especialización económica de carácter ganadero ("Centralización monárquica castellana y territorios concejiles (algunas hipótesis a partir de las ciudades medievales de la región CastellanoLeonesa)", en Anales de la Universidad de Alicante. Historia medieval, 13, 2000-2002, pp. 157-202) MARTÍNEZ LLORENTE, F. J., Régimen jurídico de la Extremadura Castellana medieval. Las Comunidades de Villa y Tierra (s. X-XIV). Valladolid, 1990, pp. 343-53. Las tierras al S del Duero no se incorporaron a la jurisdicción de los Adelantamientos de Campos y Burgos hasta los últimos años del reinado de Felipe II, probablemente entre 1587 y 1589 (ARREGUI ZAMORANO, P., Monarquía y Señorios en la Castilla moderna: Los Adelantamientos de Castilla, León y Campos (1474-1643). Valladolid, 2000, pp. 200 y 223$)$. 
comarca encontramos las Comunidades de Villa y Tierra de Roa, Haza y Montejo ${ }^{101}$. El debate historiográfico sobre el origen de estas Comunidades ha sido muy fructífero en los últimos años por lo que nos remitimos a las obras de Villar García en lo que a la implantación y funcionamiento de esta forma de organización territorial que se fraguó en este periodo en los territorios al Sur del Duero ${ }^{102}$. No obstante, no nos resistimos a citar la interesante interpretación que recientemente ha planteado García Izquierdo sobre la implantación de la estructura territorial de las comunidades de villa y tierra sobre la población preexistente y el espacio concreto del valle del Riaza. Para este autor la nueva organización territorial impuesta por las autoridades cristianas del Norte en este espacio se produjo aprovechando las estructuras castrales autóctonas en torno a las que se movía una población fundamentalmente ganadero-depredatoria ${ }^{103}$.

De forma paralela a esta adscripción de carácter administrativo y político, y de forma nítidamente complementaria, se produjo la imbricación del espacio del valle del Duero en el renovado encuadre diocesano. Parece ser que las tierras de la Ribera formaron parte desde el siglo X de la Diócesis de Burgos. Pero a finales del siglo XI fueron objeto de un dilatado litigio entre ésta y la Provincia Eclesiástica de Toledo, de la cual era sufragánea la recientemente restaurada Diócesis de Osma ${ }^{104}$. El conflicto se intentó solucionar en el concilio provincial de Husillos en 1088 con un compromiso entre las dos partes en el que se establecía la frontera entre ambas diócesis: ... et sicut aqua ipsa currit et labitur in Arandam, aqua quae discurrit per Cluniam, et pertransit ipsam Cluniam, usque Penam de Aranda, donec labitur in fluvium Dorium, et omnes villae ex hac

101 MARTÍNEZ DÍEZ, Las Comunidades de Villa y Tierra..., pp. 301-305; y MONSALVO ANTÓN, J. M., "La formación del sistema concejil en la zona de Burgos (siglo XI-mediados del siglo XIII)", en Burgos en la Plena Edad Media. Burgos, 1984, pp. 127-210.

${ }^{102}$ Son conocidas las numerosas obras que sobre este aspecto han realizado estos autores. Entre ellas destacamos la monografía de VILLAR GARCÍA La Extremadura castellano-leonesa: guerreros, clérigos y campesinos (711-1252). Salamanca, 1986; y la síntesis y estado de cuestión realizado por este mismo autor presentada en "La formación de las Comunidades de Villa y Tierra en las fronteras del Duero", en Biblioteca 24. Estudio e Investigación. 2010, pp. 77-103. Por su parte MONSALVO ANTÓN presenta su propuesta sobre la configuración de las Comunidades de Villa y Tierra al Sur del Duero en El Sistema político concejil: el ejemplo del señorio medieval de Alba de Tormes y su concejo de Villa y Tierra. Salamanca, 1988.

103 GARCÍA IZQUIERDO, I., "Propuestas sobre la configuración territorial altomedieval de la cuenca del Duero: un estudio sobre la génesis de las comunidades de villa y tierra en el valle del Riaza", en Biblioteca 23. Estudio e Investigación. 2009, pp. 247-263.

${ }^{104}$ SERRANO, L., El Obispado de Burgos y Castilla Primitiva. Madrid, 1935, vol. I, pp. 278-9, 336-7 y mapa $n^{\circ} 3$ en p. 448 . 
parte fluminis Arandae ${ }^{105}$. El conflicto no se solucionó pues conocemos una bula papal en 1107 que sancionaba el anterior compromiso y no fue hasta el Concilio de Burgos de 1136 cuando el legado pontificio puso fin al conflicto estableciendo definitivamente la frontera que encuadraba la comarca ribereña en la diócesis oxomense. Finalmente las villas de Aszam, Turrem de Galindo, Fresnelo, Vado de Condes, Baralanguas, Rivales, Rozam, et totum campum de Roza, Guzman, Villamuela, Villamualera, Aquilora, Castellum de Aranda, Cremada, Tovela, Valdefande, Pennela, Pennam de Aranda, entre otras, se adscribieron a la Diócesis oxomense ${ }^{106}$.

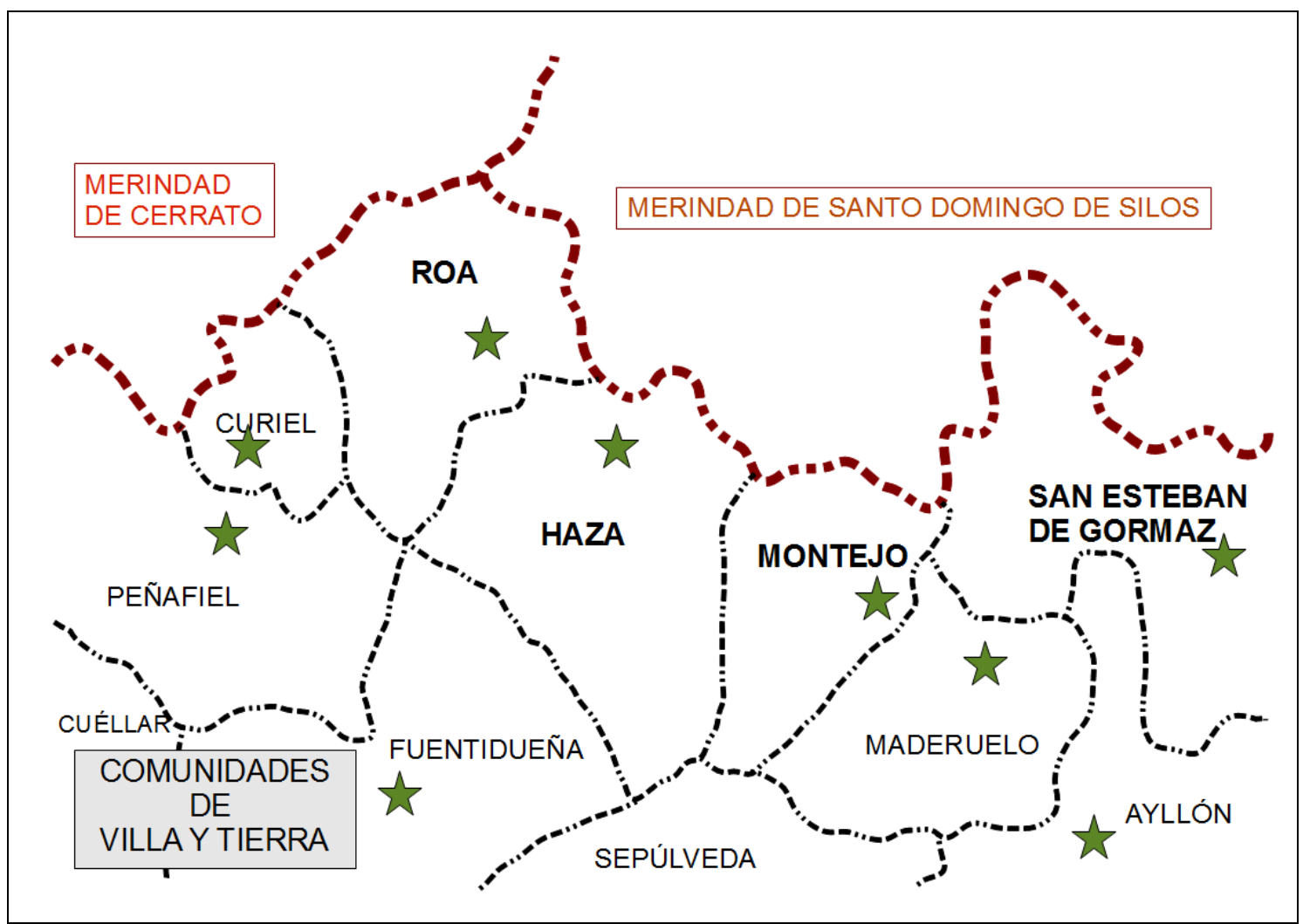

Mapa 7: Las Comunidades de Villa y Tierra en la Ribera del Duero según Martínez Díez.

A partir del siglo XI la estructura diocesana se consolidó como un destacado elemento de vertebración y jerarquización territorial. Esta situación se observa sobre todo a través del establecimiento de los arcedianatos, los arciprestazgos y una extensa red de pa-

${ }^{105}$ El fragmento ha sido tomado de LOPERRÁEZ CORVALÁN, Descripción Histórica... Tomo III, p. 7. La traducción literal del fragmento sería la siguiente: ...y como la propia agua corre y fluye hacia Aranda, el agua que discurre a través de Clunia y atraviesa la propia Clunia hasta Peñaranda, hasta que vierte sus aguas en el río Duero, y todas las villas de esta parte del río de Aranda.

${ }^{106}$ LOPERRÁEZ CORVALÁN, Descripción Histórica..., Tomo III, pp. 16-18. 
rroquias dependientes que además se convirtieron en instrumento de detracción de los excedentes económicos a través del diezmo ${ }^{107}$.

También constatamos en este periodo la ramificación de los intereses de numerosos monasterios sobre esta comarca. Las grandes instituciones monásticas estaban relacionadas con la expansión cluniacense primero (Santo Domingo de Silos y San Pedro de Cardeña) y la implantación de establecimientos cistercienses o premostratenses después ${ }^{108}$. Pero no debemos olvidar la proliferación de pequeños monasterios vinculados a la iniciativa privada familiar ${ }^{109}$, que supusieron una evidente puesta en valor del territorio. En la comarca ribereña, a falta de datos más concluyentes, podríamos incluir dentro de este tipo de monasterios las numerosas referencias altomedievales de pequeños monasterios sin continuidad en el periodo plenomedieval o que fueron absorbidos, gracias a las donaciones reales o nobiliarias, por los grandes cenobios regionales ${ }^{110}$.

${ }^{107}$ SÁNCHEZ HERRERO, J. y LÓPEZ BAHAMONDE, R., "La geografía eclesiástica en León y Castilla. Siglos XIII al XVI", en El Pasado Histórico de Castilla y León. Edad Media. Vol. I, pp. 295313. Sobre las relaciones económicas entre la autoridad real y el Episcopado ver NIETO SORIA, J. M., "Las relaciones Monarquía-Episcopado en Castilla, siglos XIII-XIV. Definición de sus caracteres e interpretación de conjunto", en El Pasado Histórico de Castilla y León. Edad Media. Vol. I, pp. 285-94, especialmente p. 289. Para el caso concreto de la comarca estudiada es interesante el trabajo de NUÑO GONZÁLEZ, J., "Las iglesias rurales en la Ribera del Duero en época románica: un variado papel dentro de una sociedad en formación”, en Biblioteca 23. Estudio e Investigación. 2009, pp. 137-159.

108 El proceso de implantación del señorío de abadengo ha sido abordado por MARTÍNEZ GARCÍA, L., en "El señorío abadengo en Castilla: consideraciones sobre su formación y desarrollo (ss. XI-XIV)", en Historia Medieval: Revista de Historia. 8, 2007, pp. 243-277. Una visión de conjunto sobre la realidad monástica en el territorio que nos ocupa es ofrecida por REGLERO DE LA FUENTE en "Poder regio y dominios monásticos en la Ribera del Duero (s. XI-XIV)", en Biblioteca 24. Estudio e Investigación. 2010, pp. 169-186).

${ }^{109}$ Bajo este epígrafe identificamos los "monasterios propios" que define la historiografía como "monasterios de escasas proporciones, con un número muy limitado de componentes y con una tradición y observancia probablemente derivada de las fructosianas... en manos de laicos y que sirven de eficaz instrumento en las tareas de población y ocupación del espacio". Estos establecimientos eclesiásticos de fundación privada se desarrollaron en el Norte peninsular desde finales del siglo VIII. Supusieron una inagotable fuente de enfrentamientos con las autoridades eclesiásticas a propósito de su dependencia hasta que el III Concilio de Letrán en 1179 reservó únicamente al fundador el derecho de patronato (GARCÍA VILlOSLADA, R. (Dir.), Historia de la Iglesia en España. La Iglesia en la España de los siglos VIII$X I V$. Vol. II-1' ${ }^{\circ}$, pp. 136-39). Para ÁLVAREZ BORGE estas iglesias y monasterios propios fueron un elemento más dentro del proceso de desintegración de las comunidades de aldea, además de un factor fundamental para la consolidación del sistema feudal y el reforzamiento de la autoridad real (Poder y relaciones sociales..., pp. 53-72).

${ }^{110}$ Baste como ejemplo la dotación a la nueva casa cisterciense de Santa María de Haza que hace la condesa Mayor García, viuda del conde Gonzalo Rodríguez de Marañón, con la condición de que su hija Inés fuera su primera abadesa. Esta casa era dependiente del monasterio de Bujedo de Juarros, fundación asimismo de los condes en 1159 (GONZÁLEZ, J. El Reino de Castilla en la época de Alfonso VIII. Madrid, 1960. Vol. I, p. 299; y SÁNCHEZ DE MORA, A., Los Lara. Un linaje castellano de la Plena Edad Media. Burgos, 2007, p. 191) Otros ejemplos son San Andrés de Boada, San Cucufate de Monzón, San Miguel de Quintana del Pidio, Santa María de Cela, San Lorenzo y Santa Eugenia de Gumiel del 
Por último, algunos autores aseveran que ya en el siglo XI estaba plenamente configurada una red de grandes caminos que, desarrollada al amparo de la actividad pastoril y la explotación ganadera, articulaba el espacio formando una verdadera estructura regional que unía los pastos cantábricos con la Extremadura castellana. Esta red de comunicación aprovecharía las antiguas vías romanas, los vados y puentes del Duero (Osma, Roa y San Esteban), los pasos medios del Arlanza y enlazaría con las estribaciones cantábricas a través de la ciudad de Burgos que ya en este momento desviaba y canalizaba las vías de comunicación tanto en dirección N-S (vía castellana) como E-O (Camino de Santiago) ${ }^{111}$.

\subsection{Poblamiento Plenomedieval.}

Desde finales del siglo XII y durante buena parte de la decimotercera centuria se observa en Castilla un franco desarrollo en el sentido amplio de la palabra fruto de la gran expansión territorial que acompañó al reinado de Fernando III. La relativa estabilidad interna permitió el despegue económico del reino como se aprecia en el incremento de la actividad agrícola y sobre todo ganadera; la proliferación de la actividad artesanal y comercial en las florecientes urbes castellanas; y en el desarrollo y consolidación de un verdadero intercambio internacional ${ }^{112}$. Como no puede ser de otra manera, la Ribera del Duero participó de esta situación general. Así se pone de manifiesto también en la villa de Aranda que comenzó a desarrollarse como núcleo urbano a mediados del siglo XIII gracias a la promoción real, iniciando el despegue de una notable actividad comercial como lo muestra la concesión de una feria en 1298. También nos parece revelador de este espectacular crecimiento el hecho de que a finales del siglo XIII se convirtiera en un preciado botín para los grandes señores comarcanos ${ }^{113}$.

Izán, San Pedro de Haza, San Isidoro de Clunia, San Juan de Peñaranda o San Mamés de Gumiel del Mercado (NUÑO GONZÁLEZ, "Pautas de ocupación territorial..., pp.96-97).

111 ORTEGA VARCÁRCEL basa esta afirmación en un privilegio de Sancho II a la iglesia de Oca en 1068 en el que permitía que sus ganados pastaran libremente por buena parte del espacio castellano incluyendo ...in Cerrato et in Bonamatre et in Serrezuela, sive in omnibus extremis partibus ("Geografía histórica..., pp. 214-15).

112 Tomado de MARTín, J. L., Historia de Castilla y León. La afirmación de los reinos (Siglos XI-XIII), Tomo IV, Valladolid, 1985, pp. 34-64.

${ }^{113}$ VELASCO PÉREZ, S, Aranda. Memorias de mi Villa y de mi Parroquia. Madrid, 1925 (red. 1983), p. 52; y PERIBÁÑEZ OTERO, J. G. y ABAD ÁlVAREZ, I., Aranda de Duero, 1503. Aranda de Duero, 2003, pp.27-32. 
En este mismo periodo asistimos asimismo a la creación y consolidación de algunos de los grandes dominios monásticos comarcanos como fueron los de Santa María de La Vid (1132-56), San Pedro de Gumiel de Izán (1194) y Santo Domingo de Caleruega $(1218-66)^{114}$.

La organización política del espacio castellano sufrió desde mediados del siglo XII una reestructuración con la creación de la Merindad Mayor de Castilla que a su vez se dividió en Merindades Menores. Al frente de la primera se encontraba el Merino Mayor designado directamente por el rey. Dirigían las segundas los Merinos Menores. Esta nueva institución supuso la configuración de una organización territorial diferente a la de los alfoces y se expresaba como el señorío jurisdiccional del rey ${ }^{115}$. La mayor parte del territorio encuadrado en el alfoz de Clunia pasó a depender de la Merindad Menor de Santo Domingo de Silos ${ }^{116}$. En la segunda mitad del siglo XIII se produjo una modificación en la configuración administrativa del reino de Castilla pues Alfonso X cambió la figura del Merino Mayor por la del Adelantado Mayor, si bien es cierto que no supuso ningún cambio significativo en los límites espaciales de cada distrito ${ }^{117}$. En este sentido, el único cambio significativo que encontramos en esta organización político-administrativa se produjo ya en los primeros años del Quinientos cuando los monarcas decidieron dividir el extenso Adelantamiento de Castilla en dos partidos, el de Campos y el de Burgos. La mayor parte de la comarca ribereña se encuadró bajo la autoridad del Alcalde Mayor del Adelantamiento de Burgos y tan solo algunos núcleos de la parte oriental pasaron a estar adscritos al Adelantamiento de Campos ${ }^{118}$.

\footnotetext{
${ }^{114}$ REGLERO DE LA FUENTE, “Poder regio y dominios monásticos..., pp. 173 y ss.
}

115 ÁLVAREZ BORGE, Monarquía feudal..., pp. 177 y ss.

${ }^{116}$ MARTÍNEZ DÍEZ, Pueblos y alfoces..., pp. 9-10. Este mismo autor ha estudiado con detalle esta organización territorial a través del análisis del Becerro de las Behetrías en Libro Becerro de las Behetrias. Estudio y texto crítico. León, 1981.

${ }^{117}$ ARREGUI ZAMORANO, Monarquía y Señoríos..., pp. 32-70. No obstante, es necesario remarcar que la merindad menor de Castilla-Vieja se transformó en mayor y el título de Merino Mayor quedó ligado al linaje de los Fernández de Velasco. Este extenso territorio, que aparece singularizado en el Libro Becerro de Behetrías, se segregó desde entonces de la jurisdicción del Adelantado de Castilla y así se mantuvo con los Reyes Católicos (pp.40-41).

${ }^{118}$ Esta división se produjo en 1502 y generó una frontera bastante indefinida en la comarca ribereña. Tal es así que en el inventario de los diferentes lugares de cada uno de los Adelantamientos que se hizo a finales del siglo XVI Roa y su Tierra aparecía bajo la autoridad del Alcalde Mayor del Adelantamiento de Campos pero la villa de Haza era señalada por los alcaldes de uno y otro Adelantamiento dentro de sus respectivas jurisdicciones (ARREGUI ZAMORANO, Monarquía y Señoríos... pp. 97, 200 y Ss.). 
Por otra parte, ya a finales del siglo XIII en el valle medio del Duero aparece claramente perfilada una notable red de núcleos urbanos de cierta entidad que contaban con unos concejos que habían conseguido fortalecer sus atribuciones políticas. Entre ellos se encontraban los primitivos centros del poder condal como Roa, San Esteban de Gormaz u Osma a los que se sumaron otros nuevos como la sede diocesana instalada en El Burgo de Osma u otras villas, como Aranda de Duero, que comenzaban a consolidarse como verdaderos centros comarcales. Un dato que apoya esta situación es una carta de hermandad y defensa mutua firmada en condiciones de igualdad en 1295 por los anteriores concejos junto a los de Soria, Gormaz o Catalañazor ${ }^{119}$. Para Barrios García esta multiplicidad de núcleos urbanos medianos con zonas de influencia notables en el territorio del obispado de Osma se explicaría por la incapacidad de atraer habitantes y actividades tanto de Osma como del Burgo de Osma, lo cual impidió que se configurasen como una verdadera capital de la diócesis ${ }^{120}$.

\subsection{La crisis del siglo XIV.}

En los años a caballo entre el siglo XIII y el XIV se aprecia un progresivo cambio que desembocó en lo que la historiografía tradicional ha denominado la crisis del siglo XIV y que tiene su máxima expresión en la generalización de los tres azotes clásicos: el hambre, la guerra y la peste ${ }^{121}$.

En 1301 las fuentes relatan: ... e este año fue en toda la tierra muy grand fambre; e los omes morianse por las plazas e por las calles de fambre... ${ }^{122}$. Los episodios de hambrunas se repitieron en 1331-33, entre 1343 y 1346 y así sucesivamente. Al hambre se sumó la inestabilidad política en la que se sumió Castilla durante todo el si-

119 GARCÍA DE VALDEAVELLANO, G., "Carta de hermandad entre los concejos de la Extremadura castellana y del arzobispado de Toledo en 1295”, en Revista Portuguesa de Historia, XII, 1969, pp. 56-76.

${ }^{120}$ BARRIOS GARCÍA, A., "Notas sobre la Diócesis de Osma en la Edad Media", en Orígenes del Obispado de Osma. Arte e Historia en la Diócesis de Osma. El Burgo de Osma, 1998, pp. 229-258.

${ }^{121}$ Un estado de la cuestión y la revisión del término crisis, así como su vinculación con la fiscalidad regia la podemos ver en OLIVA HERRER, H. R., "La crisis del siglo XIV en el valle del Duero Oriental. Notas para una evaluación de la crisis del siglo XIV", en Biblioteca 24. Estudio e Investigación. 2010, pp. 105-120.

122 Crónica de Don Sancho el Bravo. En ROSELL, C. (Ed.), Crónicas de los Reyes de Castilla. Madrid, 1953, Tomo I, p. 81. 
glo XIV, que comenzó con las minorías de Fernando IV y Alfonso XI y culminó con la cruenta guerra civil que enfrentó a Pedro I y al futuro Enrique II. A comienzos del siglo XIV la Ribera se convirtió en escenario de las tensiones entre las distintas facciones de la alta nobleza: por una parte el infante don Juan se hizo fuerte en Roa; don Diego López de Haro situó su centro de operaciones en Gumiel del Mercado y Torregalindo; y Aranda fue el escenario de las pretensiones de la familia Haro en 1295 y de un cruento enfrentamiento entre las tropas fieles al monarca y las de Juan Núñez de Lara en $1306^{123}$. Testimonio directo de las consecuencias de la guerra es la información que hizo la priora y el convento de Santo Domingo de Caleruega a Fernando IV en 1306 al afirmar ...que este ssu logar de Caleruega que era despoblado e yermo lo uno por los males e los dannos que rreçivieron los ssus vassallos que moravan en tiempo de guerra e lo al por la muy grant cabeça que tenian en los serviçios e en los pechos ${ }^{124}$. Una evidencia más de esta inestabilidad fue la presencia de Pedro Núñez como encomendero del monasterio de San Pedro de Gumiel en 1304 y, también a partir de ese mismo año, los sucesivos episodios de injerencia judicial de los delegados reales en el señorío del monasterio de Santo Domingo de Caleruega, que actuaron sin el correspondiente permiso y licencia de la priora. A esta situación debemos añadir que el monasterio dominicano se amparó bajo la protección de la familia de los Haro desde $1326^{125}$.

A mediados de la decimocuarta centuria la inestabilidad aumentó sustancialmente a causa del enfrentamiento entre Pedro I y Enrique de Trastamara. En este conflicto la comarca se vio plenamente implicada, entre otras cosas, porque en esos momentos don Tello, hermano del conde de Trastamara, ejercía como señor de Aranda. Éste, además de prestar su apoyo a su hermano, se dedicaba al pillaje por estas tierras como narra el cronista: Cuando el rey partio... para Castilla, don Tello su hermano, fijo del rey don Alfonso y de doña Leonor de Guzmán, estava en la villa de Aranda de Duero, que era suya: e quando supo que el rey venia, ovo grand miedo de el... e partieron de Aranda, e

${ }^{123}$ El episodio de 1295 aparece registrado por LOPERRÁEZ CORVALÁN en su Descripción histórica..., Tomo II, pp. 175-176. Este autor transcribe el contenido de un pergamino que se conservaba en el Archivo Municipal de Aranda de Duero y que en la actualidad se encuentra desaparecido. Los aspectos épicos de ambos acontecimientos han sido narrados magistralmente por VELASCO PÉREZ, en Aranda. Memorias..., pp. 50-56.

${ }^{124}$ MARTÍNEZ LIÉBANA, Colección Diplomática..., doc. LXIV, pp. 70-72.

${ }^{125}$ PÉREZ EMBID, J., El Cister en Castilla y León. Monacato y dominios rurales (s. XII-XV). Salamanca, 1986, p. 564; y GONZÁLEZ GONZÁLEZ, C., Real monasterio de Santo Domingo de Caleruega. Salamanca, 1993, pp. 121-122 y 130. 
robaron la recua que venia de Burgos, e iva para la feria de Alcala de Henares ${ }^{126}$. Otros señores y lugares comarcanos también fueron actores de la contienda y, así, Roa permaneció bajo control del rey Pedro junto a Haza, mientras que los Gumieles apostaron por el Trastamara.

Pero la guerra propiamente dicha no fue la única forma de violencia que los ribereños temían. Más habitual es lo que la historiografía denomina "bandolerismo nobiliario" y que cuenta en la comarca con numerosos ejemplos que se centraron fundamentalmente en las aldeas y granjas propiedad de los dominios monásticos, como veremos con detenimiento más adelante.

La situación se complicó aún más si cabe con la irrupción del tercer azote con efectos mucho más devastadores: la Peste Negra. Esta epidemia asoló los países mediterráneos y llegó a la Península a mediados de siglo causando una terrible mortandad. Los episodios pestilentes se repitieron a lo largo de la segunda mitad del XIV con un rebrote centrado en la ribereña localidad de Roa en el año $1394^{127}$.

Una pequeña prueba del retroceso demográfico y económico que sufrió la Ribera la encontramos de nuevo en la villa de Aranda. A comienzos del siglo XIV Alfonso XI concedió el privilegio de cambiar el día de mercado, pasándolo de sábado a lunes, para que pudiera acudir a él la comunidad judía. Al final del texto el monarca señalaba: ...ca mi voluntad es que el dicho logar de Aranda se pueble asi de cristianos como de judios, en manera que puedan pasar los unos con los otros ${ }^{128}$. No parece muy aventurado concluir que la medida se hizo con la intención de asentar población en el territorio en unos momentos de evidentes dificultades ${ }^{129}$.

También en los señoríos monásticos observamos claros indicios en este sentido. En 1306 la priora y convento de Santo Domingo de Caleruega consiguió la reducción de la cabeza pechera argumentando la merma de población que había sufrido como consecuen-

${ }^{126}$ LÓPEZ DE AYALA, P., Crónica del rey Don Pedro. Año 1352, cap. V. En ROSELL, C. (Ed.), Crónicas de los Reyes de Castilla. Madrid, 1953, Tomo I.

${ }^{127}$ VALDEÓN BARUQUE, J., “Crisis y recuperación (Siglos XIV y XV)”, en Historia de Castilla y León. Tomo V, Valladolid, 1985, p. 28; y VACA LORENZO, A., "Recesión económica y crisis social de Castilla en el siglo XIV", en Las crisis de la Historia. Salamanca, 1995, pp. 33-56, en concreto p. 45 .

${ }^{128}$ VELASCO PÉREZ, Aranda. Memorias..., pp. 61-62.

129 Una visión general de este momento en la comarca ribereña la encontramos en NUÑO GONZÁLEZ, J., "La Ribera del Duero burgalesa entre los siglos XIII y XIV”, en Biblioteca 17. Estudio e Investigación. 2002, pp. 11-41. 
cia de las guerras del momento ${ }^{130}$. Otro indicio más es la desaparición en la segunda mitad del siglo XIV de las dos secciones femeninas premostratenses que el monasterio de Santa María de la Vid tenía en la comarca: la última noticia documental que se tiene del priorato femenino de Santa María del Coro de Fresnillo de las Dueñas está fechada en 1348 y el priorato de Nuestra Señora de Brazacorta dejó de existir entre 1379 y $1390^{131}$. Por otra parte, el monasterio de San Pedro de Gumiel parece que recurrió a la falsificación de una sentencia en 1400 para impedir que sus vasallos cambiaran el abadengo por la behetría como había se había acordado en una sentencia arbitral de $1299^{132}$. Asimismo, como veremos más adelante, la existencia de varias referencias a despoblados en este periodo confirma este retroceso generalizado ${ }^{133}$.

También nos parece revelador del retroceso productivo el hecho de que precisamente en 1336 doña Aldonza, vecina de Lerma y viuda de don Fernando Sánchez de Velasco, rescindiera el contrato de arrendamiento que mantenía con el monasterio de San Pedro de Gumiel por unas heredades de San Martín de Porquera, otras de Villanueva ${ }^{134}$ y las aceñas que el monasterio poseía en el Duero en el término de Aranda ${ }^{135}$. En este senti-

${ }^{130}$... que este ssu logar de Caleruega que era despoblado e yermo lo uno por los males e los dannos que rreçivieron los ssus vassallos que moravan en tiempo de guerra e lo al por la muy grant cabeça que tenian en los serviçios e en los pechos, e que por ende sse yvan dendo del mas de los pecheros que y avian ficado (MARTÍNEZ LIÉBANA, Colección Diplomática..., doc. LXIV, pp. 70-72). La revisión de la cabeza pechera fue una práctica bastante frecuente en Castilla bajo el reinado de Fernando IV y es un claro indicador de la recesión demográfica. GONZÁLEZ MÍNGUEZ lo constata en Valbuena de Duero, San Vicente de la Barquera, Nájera, Briones y Caleruega ("Algunos datos sobre la población de Castilla durante el reinado de Fernando IV", en El Pasado Histórico de Castilla y León. Edad Media. Salamanca, 1984. Vol. I, pp. 87-99).

${ }^{131}$ LÓPEZ DE GUEREÑO SANZ, M. T., Monasterios medievales premostratenses. Reinos de Castilla y León. Vol. I, Salamanca, 1997, pp. 299 y 314.

${ }^{132}$ PÉREZ EMBID, El Cister..., p. 517.

${ }^{133}$ Baste como ejemplo el caso de Villajimeno que es donado por Juan I en 1388 al monasterio de Santo Domingo de Caleruega, señalándose ...damos vos el termino de Villaximeno que es cerca de Caleruega que es lugar dado por yermo. Además se especifica que la corona se reserva ciertas prebendas que nos las den los del dicho termino, si se poblare (MARTÍNEZ LIÉBANA, Colección Diplomática..., doc. XC, pp. 131-33). Muchos más ejemplos de este fenómeno los podemos encontrar en MARTÍNEZ DÍEZ, Pueblos y alfoces..., pp. 223-238.

${ }^{134}$ San Martín de Porquera es un despoblado que se encuentra actualmente en el término municipal de Tubilla del Lago y que perteneció al monasterio de San Pedro de Gumiel al menos desde 1219 (MARTÍNEZ DÍEZ, Pueblos y Alfoces..., p. 232). Esta Villanueva que aparece citada parece ser la actual Villanueva de Gumiel.

${ }^{135}$ AMA, leg. 41, doc. 2. Precisamente este documento de rescisión se redactó en el real sobre Lerma y se señalaba que la carta original del arrendamiento estaba en la villa y, al estar cercada por el rey, no podía destruirla. Estas aceñas son las mismas que había donado Fernando III al monasterio de San Pedro de Gumiel en 1236. 
do, otro indicio significativo es el notable descenso de la cabaña ovina propiedad del monasterio de Santo Domingo de Caleruega que en 1310 contaba con 10.000 ovejas y en 1390 se había reducido a $2.000^{136}$.

El Libro Becerro de las Behetrías es una fuente documental de primer orden que plasma notablemente la realidad del territorio castellano en los años centrales de la decimocuarta centuria ${ }^{137}$. En la comarca ribereña la información ofrecida por este documento es parcialmente limitada pues el territorio de Aranda fue excluido de la descripción de 1352 y al menos 22 núcleos de la Merindad de Silos no aparecen en la relación ${ }^{138}$. La incidencia en la comarca de las behetrías es bastante moderada pues tan solo encontramos catorce behetrías: Arauzo de Salce, Arauzo de Torre, Arauzo de Miel, Baños de Valdearados, Cilleruelo de Arriba, Guzmán, Alcoba de la Torre, Quintanarraya, Pinilla-Trasmonte, Pineda-Trasmonte, Valdeande, Vadocondes, Zazuar y Hontoria de Valdearados. La gran mayoría, al menos once, pervivieron como tales hasta el siglo XVI y otras fueron absorbidas por los señores comarcanos como ocurrió con Guzmán que se convirtió en solariego de los Zúñiga; o Alcoba de la Torre que pasó a la familia Delgadillo ${ }^{139}$.

Al hilo precisamente de estas enajenaciones, el fenómeno que consideramos más relevante en este periodo de crisis es la creación y consolidación de los dominios de los grandes señores laicos que progresivamente fueron acumulando los espacios originariamente vinculados al realengo o incluso los dependientes de las instituciones religiosas. A lo largo del siglo XIV se asistió a una aceleración de la tendencia a la concentración del

${ }^{136}$ Lo mismo ocurre con el resto del ganado, pues de 1.000 vacas, 1.000 puercos y 200 yeguas se pasó 200 vacas, 100 cerdos y 50 yeguas (MARTÍNEZ LIÉBANA, Colección Diplomática..., docs. LXX y LXXVI, pp. 81 y 138).

${ }^{137}$ Recientemente el profesor ESTEPA DÍEZ ha realizado un minucioso análisis de esta realidad en su monografía Las Behetrías castellanas. Valladolid, 2003. También son significativos los trabajos de MARTÍNEZ DÍEZ, G., Libro Becerro de las Behetrías. Estudio y texto crítico. León, 1981. Asimismo encontramos información al respecto y cuadros sinópticos en el capítulo dedicado a las Behetrías de SÁNCHEZ ALBORNOZ, C., Viejos y nuevos estudios sobre las instituciones medievales españolas. Madrid, 1976, Tomo I, pp. 17-194.

${ }^{138}$ Para ESTEPA DÍEZ la exclusión de Aranda, junto a otros espacios, del inventario se debe a que "se trata de circunscripciones con un pleno contenido como señoríos jurisdiccionales y donde se han asumido las cargas de la fiscalidad regia”. La ausencia de los núcleos se atribuye al carácter incompleto de la descripción en la Merindad (Las Behetrías..., vol. I, p. 31).

${ }^{139}$ Las behetrías que hemos citado aparecen relacionadas como tales en el reparto de Galeotes que se realizó en 1508 o 1531 (ESTEPA DÍEZ, Las Behetrías..., vol. II, pp. 360 y 368). El caso de Vadocondes es un poco más complicado pues, aunque no aparece en el reparto de 1508, sabemos que al menos hasta 1480 era behetría bajo la encomienda del duque de Villahermosa, hermano del rey Fernando (AGS, RGS, 148003, fol. 36). 
poder en manos de los sectores más elevados de la nobleza, generalizándose a partir del cambio de dinastía un notable aumento del poder de los señores que se plasma en la creación de verdaderos estados señoriales como veremos confirmado en el periodo que nos ocupa $^{140}$. Baste como ejemplo la significativa presencia de los clanes familiares de los Haro, los Lara, los Leyva o los Guzmán, entre los que destaca el omnipresente Ramir Flórez, como señores de un importante número de lugares en la comarca ribereña ${ }^{141}$. Como veremos más adelante, esta tendencia a la concentración tuvo un momento clave tras el desenlace de la guerra fraticida cuando el linaje de los Avellaneda impuso su dominio sobre buena parte del territorio ribereño.

El mapa señorial de la comarca arandina a mediados del siglo XIV se puede completar con otra fuente bastante reveladora, el Libro de Cuentas de los cenobios benedictinos realizado en 1338. Este documento nos muestra la extensión económica y territorial de los monasterios benedictinos de San Pedro de Arlanza y Santo Domingo de Silos en nuestra comarca ${ }^{142}$, que complementa la aportada por el Becerro sobre las posesiones de los monasterios locales de Gumiel, La Vid y Caleruega.

Mención aparte merece el tema de los despoblados medievales que tradicionalmente se relacionan con este periodo de recesión. Baste como muestra de lo significativo del fenómeno que Martínez Díez ha localizado en el territorio del alfoz de Clunia más de ochenta despoblados, cuarenta en la Comunidad de Villa y Tierra de Roa, cuatro más en la de Haza y cinco en la de Montejo. Poco sabemos sobre la causa de esta abundancia de pueblos abandonados, aunque Martínez Díez señala que la mayor parte de ellos, el 90\%, ya eran calificados como tales a mediados del siglo XIV y achaca este fenómeno al tirón de Andalucía, es decir a la dinámica repobladora sobre las nuevas tierras ocupadas al Sur del Sistema Central a partir del siglo XIII ${ }^{143}$. No obstante, también cabe la posibilidad de que buena parte de estos núcleos no fueran en su origen más

${ }^{140}$ ÁlVAREZ BORGE, Poder y Relaciones... pp. 296-320. Este aspecto es ilustrado por este autor a través de la evolución de las behetrías.

${ }^{141}$ Una visión más completa del panorama del poblamiento que presenta el Becerro de las Behetrías ha sido realizada por NUÑO GONZÁLEZ, "La Ribera del Duero..., pp. 30 y ss.

${ }^{142}$ MORETA VELAYOS, S., Rentas monásticas en Castilla: problema de método. Salamanca, 1974, pp. 61-70. De los registros de los nueve monasterios benedictinos que se recogen en el Libro de Cuentas tan solo los de San Pedro de Arlanza y Santo Domingo de Silos cuentan con intereses en la Ribera del Duero, si exceptuamos la pequeña renta que el monasterio de San Pedro de Cardeña recibe en Torresandino (pp. 56-61).

${ }^{143}$ MARTÍNEZ DÍEZ, Pueblos y alfoces..., p. 18. 
que pequeñas granjas o alquerías que contaban con una reducida población de carácter familiar y sobre la que cualquier adversidad (malas cosechas, epidemias, inestabilidad) incidiera de manera drástica y dramática causando la desaparición de la capacidad productiva y, por lo tanto, impidiendo la supervivencia del núcleo de población ${ }^{144}$. Por otra parte, un buen número de estos despoblados fueron en origen pequeños monasterios, casi con toda seguridad de origen familiar, que a lo largo del periodo altomedieval fueron integrados en los dominios de los grandes monasterios comarcanos como territorios sin población. Baste como ejemplos los de San Lorenzo en Gumiel de Izán (Monasterium Sancti Laurencii et Sancte Eugenie) que pertenecían a San Pedro de Arlanza; o San Cucufate en Gumiel del Mercado (monasterium Sancti Cucufati cum terminies suis) que fue donado a Santo Domingo de Silos ${ }^{145}$. Posiblemente lo mismo sucedía con las granjas de San Martín de Porquera y San Pedro del Pinar que eran propiedad del monasterio de San Pedro de Gumiel ${ }^{146}$.

\subsection{La recuperación del siglo $\mathrm{XV}$.}

En los primeros años del Cuatrocientos se comenzó a vislumbrar un cambio significativo. Las hambrunas, los brotes de peste y la violencia aparejada a la inestabilidad política continuaron; sin embargo, se produjo un proceso de recuperación o, como aseguran algunos autores, de reconstrucción en el campo castellano ${ }^{147}$. La Ribera del Duero

144 ORTEGA VARCÁRCEL constata que las aldeas del siglo XII eran de escasas dimensiones, entre cinco vecinos para las más modestas y cincuenta para las más numerosas. Por otra parte, la inexistencia en la actualidad de restos materiales que identifiquen este tipo de asentamientos es totalmente plausible teniendo en cuenta que estas pequeñas aldeas se construyeron básicamente de madera, barro y paja. En la Ribera en concreto primaría sobre todo el uso del tapial para los elementos sustentantes y bien pudiera ser rematado por cubiertas vegetales (“Geografía histórica..., pp. 197-204). En la Tierra de Campos Occidental se ha constatado la disminución del número de lugares habitados coincidiendo con la guerra civil en el primer tercio del siglo XII, auque el mayor número de despoblados se produjo en la primera mitad del siglo XIII paralelamente a la creación de nuevas villas (MARTÍNEZ SOPENA, P., La Tierra de Campos Occidental. Poblamiento, poder y comunidad del siglo X al XIII. Valladolid, 1985, pp. 55-57).

${ }^{145}$ Ejemplos obtenidos de la obra de MARTÍNEZ DÍEZ, Pueblos y alfoces..., p. 232.

${ }^{146}$ La donación de San Martín de Porquera es la primera referencia documental de la que se tiene constancia del monasterio de San Pedro de Gumiel y que, aunque está fechado en 1064, parece ser un documento de finales del siglo XII (RODRÍGUEZ RODRÍGUEZ, M. C., "El monasterio de San Pedro de Gumiel. Notas históricas (s. XII-XIII)", en Santo Domingo de Caleruega. Jornadas de estudio Medieval 1992-1993. Salamanca, 1994, pp. 299-324). San Pedro del Pinar en Zazuar aparece en la documentación en 1333 como una extensa propiedad del monasterio entre las aldeas de Quemada y Zazuar sin mención alguna a vecinos (AMA, leg. 41, doc. 3).

${ }^{147}$ VALDEÓN BARUQUE, “Crisis y recuperación..., pp. 29-37. 
participó de esta situación como se aprecia a través de una serie de indicios que certifican este cambio de coyuntura.

Las evidencias más significativas las hemos localizado en el principal núcleo urbano de la comarca ya en este periodo: la villa de Aranda de Duero. Como veremos con mayor profundidad en el capítulo dedicado a este núcleo urbano, a partir de finales del siglo XIV el concejo comenzó un proceso de expansión territorial que amplió considerablemente su exiguo territorio con la incorporación de los lugares de Quemada y unos términos comprados al monasterio de $\mathrm{La} \mathrm{Vid}^{148}$. Con la incorporación de estos términos se configuró el territorio de la villa de Aranda y su tierra con las aldeas de Villalba, Prado, Vega Duero, Sinovas, Fuentespina y Casasola, que no variará de forma significativa hasta finales del siglo $\mathrm{XV}^{149}$.

Pero, sin lugar a dudas, el indicio más relevante del gran desarrollo que experimentó la villa arandina durante este periodo fue el gran crecimiento urbano que se materializa en la creación de una nueva cerca que englobó el recinto comercial surgido en los aledaños de la puerta SE del núcleo primitivo así como el gran arrabal desarrollado al E, configurando el espacio intramuros que se observa en el plano de $1503^{150}$.

La documentación nos transmite por otra parte un enorme incremento de las roturaciones en la comarca. De nuevo el ejemplo de la villa arandina ilustra esta situación. En 1433, con la finalidad de mediar en los conflictos entre vecinos que surgieron a consecuencia de las roturaciones, el obispo de Osma, como juez árbitro, estableció una sentencia que las regulaba y en la que se ordenaba que se nombraran dos jueces de entradas e ronpimientos con competencias para solucionar los pleitos e imponer penas, inhibiendo a los alcaldes ordinarios de este asunto. Estos dos jueces eran nombrados anualmente, uno por los regidores de los linajes y otro por los procuradores de la comunidad $^{151}$.

${ }^{148}$ VELASCO PÉREZ, Aranda. Memorias..., pp. 91-92. La venta se produjo en 1366 pero no se hizo efectiva hasta 1396 al faltar la confirmación del Reformador de la Orden Cisterciense.

149 VELASCO PÉREZ, Aranda. Memorias..., pp. 46-47. Don Silverio señala que la tierra de Aranda en el siglo XIII ya estaba formada por estas aldeas. En 1495 se sumó por un corto periodo de tiempo el lugar de Milagros (AGS, CC PUEBLOS, leg. 13, doc. 3)

${ }^{150}$ SÁINZ GUERRA, J. L., La génesis de la plaza en Castilla durante la Edad Media. Valladolid, 1990, pp. 117-119; y PERIBÁÑEZ OTERO y ABAD ÁLVAREZ, Aranda de Duero..., pp. 38-40.

${ }^{151}$ AMA, leg. 43, doc. 27. No conocemos la sentencia en sí sino una declaración del obispo a propósito de las quejas de ciertos vecinos sobre el contenido de la sentencia. Esta declaración sólo habla de dos de las cláusulas de la sentencia: una sobre el nombramiento de los jueces y otra sobre los plazos para el cumplimiento de las sentencias. 
También encontramos en 1404 conflictos relacionados con roturaciones de nuevos espacios entre el monasterio de San Pedro de Gumiel y el concejo de Baños de Valdearados a causa de unas posesiones del cenobio en el término de San Martín de Porquera que fueron labradas por algunos vecinos de Baños sin la pertinente licencia ${ }^{152}$. Este proceso de puesta en valor de nuevas tierras continuó durante todo el siglo XV como lo pone de manifiesto la repoblación tardía del lugar de Cuzcurrita a mediados de la centuria $^{153}$.

Asimismo se observa un destacable crecimiento del aprovechamiento ganadero como se pone de manifiesto en la proliferación de conflictos originados por el uso de montes y pastos. Estos enfrentamientos entre los pueblos de la comarca ya se observan desde mediados del $\mathrm{XIV}^{154}$ y se generalizaron en la primera mitad del XV, llegando a generar en algunos momentos serios brotes de violencia ${ }^{155}$.

Como síntesis, podemos afirmar que la red de poblamiento medieval de la Ribera del Duero se configuró en los siglos XI y XII sobre la base de otro previo desestructurado y sin ningún tipo de jerarquía hasta que se impuso el poder condal sobre el territorio. Sea por imposición o por la propia evolución de las comunidades de aldea, lo cierto es que la feudalización del territorio de la comarca ribereña fue un hecho a finales del siglo XI. Este entramado de núcleos se consolidó a lo largo del siglo XIII y experimentó un ligero retroceso desde mediados del siglo XIV, que en principio se manifestó en el significativo número de despoblados documentados.

${ }^{152}$ PÉREZ EMBID, El Cister..., p. 518.

${ }^{153}$ Yten, se hallo otro lugar del conde de Miranda que se llama la villa de Coscorita, que a mas de ochenta años que esta poblada y nunca pago serviçio ni les fue pedido. Çitamosla, conforme a la ynstruçion, y cunplese el termino de los çien dias en que avian de pareçer a diez e syete de diziembre deste presente año de quinientos e treynta e tres. Y, ansymismo, le repartimos lo que nos paresçio que mereçen pagar (CARRETERO ZAMORA, J. M., La averiguación de la Corona de Castilla, 1525-1540. Los pecheros y el dinero del reino en la época de Carlos V. Salamanca, 2008, Vol. III, p. 1418).

${ }^{154}$ VELASCO PÉREZ, Aranda. Memorias..., p. 93. Se citan acuerdos con Torregalindo en 1357 (AMA, leg. 42, doc. 2), Gumiel de Izán en 1368, Zazuar en 1369, La Aguilera en 1388 y Ventosilla en 1393.

${ }^{155}$ En 1416 se establecía un acuerdo de términos para el aprovechamiento ganadero común entre Aranda y Gumiel de Izán (AMA, leg. 1101, doc. 4). En 1423 se produjo, tras una serie de agravios de los de Aranda a vecinos de Gumiel de Izán, el asalto de la aldea de Sinovas por éstos últimos. El conflicto se solucionó con un compromiso en 1425. También se llegó a un acuerdo en 1432 entre Aranda y la villa de Haza sobre límites y aprovechamiento comunal de ganados (VELASCO PÉREZ, Aranda. Memorias..., pp. 94-97). 
Tras un corto pero intenso periodo de recuperación, la red de poblamiento de la comarca ribereña en la Baja Edad Media se confirmó como heredera del largo proceso de configuración que hemos señalado en los capítulos anteriores. Como veremos con mayor detalle más adelante, a mediados del Cuatrocientos la Ribera del Duero era una comarca muy dinámica desde el punto de vista económico y social. En el ámbito político y territorial destacaba el amplio poder de los señores laicos, entre los que se encontraban los condes de Miranda, Castro o Alburquerque. Esta pujanza señorial contrastaba con la evidente decadencia de las instituciones monásticas como Santa María de La Vid, San Pedro de Gumiel, Santo Domingo de Caleruega, Santa María de Fuencaliente, Santo Domingo de Silos o San Pedro de Arlanza. La presencia del realengo en la comarca tan sólo se percibía, ciertamente de forma discontinua, en la villa de Aranda de Duero, bien de forma directa o bien como señorío de las reinas o algunos familiares reales.

A finales del siglo XV y principios del XVI se aprecia una organización del territorio muy bien definida y que apenas difiere de la que podemos observar quinientos años más tarde como ocurre en otros espacios vecinos ${ }^{156}$. Una visión de la realidad de la comarca en los primeros años del Quinientos la ofrece el censo elaborado por los oficiales reales tras la Guerra de las Comunidades ${ }^{157}$. Aparte del incuestionable valor demográfico de los datos que aporta la Averiguación de la Corona de Castilla, este documento permite vislumbrar claramente la entidad territorial de los grandes poderes que dominaban el espacio ribereño al final del periodo objeto de nuestro estudio, como veremos con mayor profundidad más adelante.

${ }^{156}$ Esta configuración del poblamiento que pervive en la actualidad la podemos observar también en la Tierra de Campos (YUN CASALILLA, B., Sobre la transición al capitalismo en Castilla. Economía y sociedad en Tierra de Campos (1500-1830). Salamanca, 1987, pp. 56-60).

${ }^{157}$ CARRETERO ZAMORA, La averiguación de la Corona... 


\section{Cuadro 1: La población de la Ribera del Duero a principios del siglo XVI según la Averiguación de Castilla.}

\begin{tabular}{|c|c|c|}
\hline TERRITORIO & LOCALIDADES & $\begin{array}{c}\text { POBLACIÓN } \\
\text { vecinos pecheros }\end{array}$ \\
\hline $\begin{array}{l}\text { La villa de Aranda y su } \\
\text { Tierra }\end{array}$ & $\begin{array}{l}\text { Aranda, Sinovas, Fuentespina, Villalba, Prado, } \\
\text { Casasola y Vega Duero }\end{array}$ & $1.318+70$ pobres \\
\hline \multirow{3}{*}{$\begin{array}{l}\text { Señorío de los Condes de } \\
\text { Urueña }\end{array}$} & Gumiel de Izán y su Tierra & 705 \\
\hline & Bahabón, Oquillas y Cilleruelo de Arriba & 81 \\
\hline & Santa María del Mercadillo & $\overline{12}$ \\
\hline \multirow{3}{*}{$\begin{array}{l}\text { Señorío de los Marqueses } \\
\text { de Denia }\end{array}$} & Gumiel del Mercado y su Tierra & 256 \\
\hline & Valdesgueva & 371 \\
\hline & La Ventosilla & 42 \\
\hline \multirow{2}{*}{$\begin{array}{l}\text { Señorío de los Condes de } \\
\text { Coruña }\end{array}$} & Coruña del conde y su Tierra & 288 \\
\hline & San Marcelino de Espeja y Espejón & 148 \\
\hline \multirow{11}{*}{$\begin{array}{l}\text { Señorío de los Condes de } \\
\text { Miranda }\end{array}$} & Hoyales y Fuentelisendo & 52 \\
\hline & Moradillo y Aldehorno & 91 \\
\hline & Haza y su Tierra & 372 \\
\hline & Montejo de la Vega y su Tierra & 336 \\
\hline & Peñaranda y su Tierra & 262 \\
\hline & Bocigas de Perales & 80 \\
\hline & La Aguilera & 97 \\
\hline & Fuentelcésped & 21 \\
\hline & Valverde & 12 \\
\hline & Langa de Duero & 143 \\
\hline & Rejas & 78 \\
\hline \multirow{2}{*}{$\begin{array}{l}\text { Señorío del Condado de } \\
\text { Siruela }\end{array}$} & Roa y su Tierra & 1.602 \\
\hline & Torregalindo y su Tierra & 103 \\
\hline $\begin{array}{l}\text { Dominio de los Señores de } \\
\text { Castrillo }\end{array}$ & $\begin{array}{l}\text { Ciruelos de Cervera, Tejada, Zayas de la Torre y } \\
\text { Alcozar }\end{array}$ & 304 \\
\hline $\begin{array}{l}\text { Dominio de los Señores de } \\
\text { Valverde }\end{array}$ & Alcoba de la Torre y Alcubilla de Avellaneda & 79 \\
\hline \multirow[t]{12}{*}{ Behetrías } & Pinilla de Trasmonte & 124 \\
\hline & Zazuar & 103 \\
\hline & Vadocondes & 140 \\
\hline & Arauzo de Miel & 122 \\
\hline & Valdeande & 91 \\
\hline & Baños de Valdearados & 114 \\
\hline & Arauzo de Torre & 21 \\
\hline & Quintanarraya & 88 \\
\hline & Espinosa de Cervera & 78 \\
\hline & Hinojar del Rey & 31 \\
\hline & Castrillo de Solarana & 95 \\
\hline & Hontoria de Valdearados & 80 \\
\hline \multirow{3}{*}{$\begin{array}{l}\text { Dominio del Monasterio de } \\
\text { Santo Domingo de Silos }\end{array}$} & Quintana del Pidio & 71 \\
\hline & Arauzo de Salce & 48 \\
\hline & Huerta del Rey & 102 \\
\hline \multirow{3}{*}{$\begin{array}{l}\text { Dominio del Monasterio de } \\
\text { Santa María de la Vid }\end{array}$} & Tubilla del Lago & 57 \\
\hline & Fresnillo de las Dueñas & 142 \\
\hline & Zuzones & 14 \\
\hline $\begin{array}{l}\text { Monasterio de Santa María } \\
\text { de Tórtoles }\end{array}$ & Tórtoles de Esgueva & 198 \\
\hline
\end{tabular}




\section{EL ESPACIO URBANO: LA VILLA DE ARANDA A FINALES DE LA} EDAD MEDIA.

Dentro de la red de poblamiento de la Castilla septentrional del periodo bajomedieval encontramos una serie de núcleos de población que presentan una definición claramente urbana como Valladolid, Burgos, Salamanca, Palencia, Segovia, Ávila,... Pero también es cierto que muchos otros núcleos participan de una serie de características físicas, sociales y económicas que permiten identificarlas como ciudades de tamaño medio y que en muchas ocasiones se han agrupado bajo la denominación de villas ${ }^{158}$. Estos centros urbanos además de las características anteriormente citadas también ejercían un importante papel como elementos centrales que dinamizaban el amplio espacio rural circundante, canalizando sus excedentes a través de un activo mercado que en ocasiones sobrepasaba el ámbito comarcal.

En el territorio que nos ocupa la villa de Aranda de Duero participa de estas características y funciones que definen a las ciudades medianas. A lo largo de este apartado intentaremos abordar la configuración de esta villa como un verdadero núcleo urbano y la articulación de su espacio como resultado del desarrollo de una sociedad activa y dinámica a finales de la Edad Media.

${ }^{158}$ Ciertamente el término villa tiene un significado polisémico. El origen de esta palabra se asienta en la unidad de explotación rural romana denominada villa. En el Noroeste peninsular este vocablo se consolidó a lo largo de la Antigüedad Tardía convirtiéndose ya en el siglo VIII en una célula básica de organización del espacio rural que aunaba una entidad de poblamiento, una creciente comunidad y un territorio propio. Este tipo de organización territorial se mantuvo como tal hasta que a mediados del siglo XII fue sustituida por las parroquias (SÁNCHEZ PARDO, J. C., Territorio y poblamiento en Galicia entre la Antigüedad y la plena Edad Media. Santiago de Compostela, 2008). Desde finales del siglo XII, a buen seguro que por influencia franca, en determinados ámbitos del Norte Peninsular vuelve a retomarse el vocablo villa pero esta vez para definir un núcleo de población con una características más o menos comunes: una muralla, un régimen jurídico privilegiado que se expresa por medio de unos fueros, un contingente social heterogéneo y la posesión de un territorio rural sobre el que se proyectaba el domino de la villa (RUIZ DE LA PEÑA I., "La formación de la red urbana en el tramo riojano del Camino de Santiago y las colonizaciones francas (s. XI-XIII)", en El fuero de Logroño. Logroño, 1996, pp. 209-210; y MARTÍNEZ SOPENA P., "Logroño y las villas riojanas entre los siglos XII y XIV”, en Historia de la ciudad de Logroño. Logroño, 1994, pp. 279-322). Ahora bien, a finales de la Edad Media la realidad de las villas era muy diversa pues esta denominación amparaba a entidades poblacionales tan diversas como las pequeñas villas costeras cantábricas junto a algunos de los principales núcleos urbanos del reino como Valladolid o Medina del Campo. Por último, quisiéramos matizar que a lo largo de nuestra exposición emplearemos los términos ciudad y ciudadano no en el sentido estricto que se refiere a la realidad jurídica de la civitas, sino en un sentido laxo como sinónimo de núcleo urbano y sus habitantes. 


\subsection{La configuración del espacio urbano medieval.}

La realidad urbana de la villa de Aranda a finales de la Edad Media se configuró a lo largo de los siglos precedentes sin que conozcamos a ciencia cierta en qué momento histórico se produjo su nacimiento. Son numerosos los autores que se han aproximado a la problemática de la evolución urbana de Aranda desde diferentes puntos de vista, sin que por el momento podamos dar respuesta a este interrogante de manera definitiva ${ }^{159}$.

En este epígrafe trataremos de exponer nuestra hipótesis de trabajo al amparo de las fuentes documentales y arqueológicas de las que disponemos y siendo conscientes en todo momento de que la propuesta planteada está abierta a futuras modificaciones en función de la aparición de nuevos datos que pongan luz sobre esta cuestión. Para ello analizaremos en primer lugar las referencias altomedievales para después articular una hipótesis sobre el posible origen de la villa y continuaremos con el estudio de la evolución del núcleo hasta el periodo bajomedieval.

\subsubsection{Los orígenes.}

A pesar de los diversos intentos que se han producido en los último años por aclarar el origen del núcleo urbano arandino, se mantiene todavía hoy la incertidumbre sobre su origen. La historiografía local ya propuso en su día remontarlo al periodo prehistórico o romano, pero lo cierto es que ni entonces ni por el momento existen datos objetivos que nos permitan hablar de poblamiento previo al siglo $\mathrm{X}$ en el solar que hoy ocupa la villa. El asentamiento del núcleo originario arandino sobre un espacio elevado y enmarcado en la confluencia de dos ríos, más la proximidad a un hipotético vado en el Duero y una discutible identificación etimológica han sido los principales argumentos esgrimidos para justificar su origen antiguo, sin olvidar tampoco la necesidad imperiosa

${ }^{159}$ Una primera aproximación fue realizada por VELASCO PÉREZ, Aranda. Memorias..., pp. 11-31. Mucho más exhaustivo fue el análisis de SANZ ABAD que abrió el camino de otros posteriores (Historia de Aranda de Duero. Burgos, 1975, cap. XV, pp. 99-107). Una visión de conjunto del urbanismo arandino fue aportada por ABAD ZAPATERO, J. G., Aranda Industrial. Valladolid, 1981, pp. 15-50. Desde un punto de vista más técnico se aproximaron a este problema los profesores SÁINZ GUERRA, tanto en su tesis doctoral La Génesis de la Plaza..., pp. 161-200, como en su estudio "Desarrollo urbanístico de Aranda. Estudio del plano de 1503", en Biblioteca 18. Estudio e Investigación. 2003, pp. 41-56; y BENITO MARTÍN, F., La formación de la ciudad medieval. La red urbana en Castilla y León. Valladolid, 2000, p. 118. Hace unos años también participamos junto a ABAD ÁLVAREZ en este debate proponiendo una revisión de lo visto hasta el momento y planteando nuevos interrogantes en la obra Aranda de Duero..., pp. 22-40. Recientemente el profesor BONACHÍA HERNANDO ha realizado un excelente trabajo de síntesis sobre el estado de la cuestión en su estudio "El desarrollo urbano de la villa de Aranda de Duero en la Edad Media”, en Biblioteca 24. Estudio e Investigación. 2010, pp. 9-35. 
que en determinados momentos de nuestra historia hubo de engrandecer el prestigio de un lugar acudiendo a la antigüedad y grandeza del Pueblo en cuestión ${ }^{160}$.

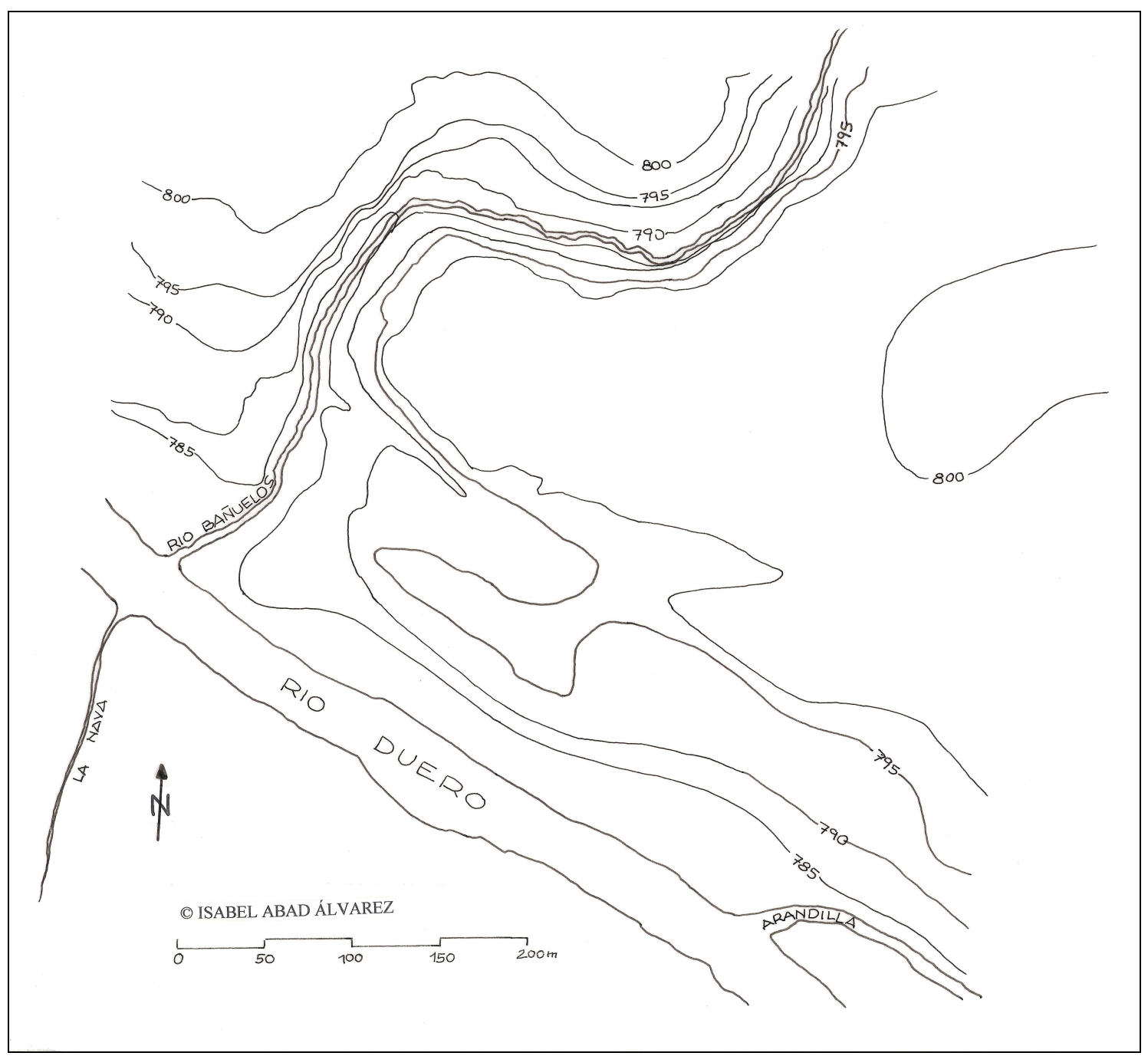

Plano 1: Topografía del terreno sobre el que se asienta Aranda de Duero.

Por el momento la única fuente con la que contamos para aproximarnos a los momentos iniciales de este núcleo urbano sigue siendo la arqueología. Es bastante significativo que todas las intervenciones realizadas hasta ahora en el perímetro urbano aran-

${ }^{160}$ DE LA CRUZ GONZÁLEZ, A., Historia de Nuestra Señora de las Viñas. Madrid, 1795 (reed. Aranda de Duero, 1983), pp. 104-21; VELASCO PÉREZ, Aranda. Memorias..., pp. 11-31; y SANZ ABAD, Historia de Aranda..., pp. 9-26. 
dino han sido poco reveladoras, pues las fechas más antiguas que han aportado sólo llegan hasta el siglo XIII ${ }^{161}$.

En este sentido, llama bastante la atención este déficit de evidencias arqueológicas prerromanas o romanas para el espacio urbano arandino en contraposición a los numerosos testimonios prehistóricos y protohistóricos que se han documentado en el término municipal de Aranda, así como en el resto de la Ribera del Duero burgalesa. También es significativo que ninguno de ellos refleje una continuidad en el espacio y el tiempo que permita relacionarlo con el primitivo origen del núcleo arandino ${ }^{162}$. No ocurre aquí como en la cercana villa de Roa, donde se suceden los asentamientos prehistóricos, protohistóricos, romanos, visigodos y medievales ${ }^{163}$.

Los trabajos de investigación desarrollados en las últimas décadas en los que se ha recurrido al barrido sistemático de las fuentes escritas, a los que se ha sumado el resultado de las investigaciones arqueológicas, parecen confirmar la ausencia de una realidad poblacional en este espacio en el periodo de transición entre la Antigüedad y la Alta Edad Media ${ }^{164}$. Posiblemente, una primera y atrevida aproximación podría plantear la posibilidad de que la primitiva Aranda tuviera su origen en las comunidades de aldea que se configuraron en este periodo de transición pero, por el momento, no contamos con datos ni documentales ni arqueológicos que lo corroboren ${ }^{165}$.

La primera referencia documental en la que aparece mencionado el término Aranda está fechada en el 989. El documento en cuestión procede del monasterio de San Juan de la Peña en Huesca y se refiere a una alianza entre el rey de León, el de Navarra y el conde de Castilla. El dato lo transmite primeramente Loperráez Corvalán,

${ }^{161}$ CRISTÓBAL VILLANUEVA, E., Informe técnico de los sondeos y seguimiento arqueológico realizados en el solar $n^{\circ} 6$ de la Plaza de San Juan, en Aranda de Duero (Burgos). Junio 1994. Depositado en el Servicio Territorial de Cultura de Burgos, p. 19.

162 PALOMINO LÁZARO, A. L., Informe del Inventario Arqueológico del Término Municipal de Aranda de Duero. 1993. Depositado en el Servicio Territorial de Cultura de Burgos.

163 SACRISTÁN DE LAMA, La Edad del Hierro...,; ABÁSOLO ÁLVAREZ, J.A., Comunicaciones de la época romana...; LECANDA ESTEBAN y PALOMINO LÁZARO, "Dos modelos de ocupación..., vol. I, pp. 37-48.

${ }^{164}$ REYES TÉLLEZ, “Arqueología Medieval Burgalesa...., pp. 177-229; y del mismo autor “Arqueología Altomedieval..., pp. 9-26; ÁLVAREZ BORGE, Poder y Relaciones Sociales...; y PASTOR DÍAZ DE GARAYO, Castilla en el tránsito...; GARCÍA IZQUIERDO, "Propuesta sobre la configuración..., pp. 247-264; y MARTÍN VISO, “Repoblaciones, territorios..., pp. 265-292.

${ }^{165}$ A esta misma conclusión llegó hace bastante tiempo LÓPEZ MATA, T., Geografía del Condado de Castilla a la muerte de Fernán González. Madrid, 1957, p. 121. 
quien a su vez lo toma de otros autores anteriores, y posteriormente lo reproduce Sanz $\mathrm{Abad}^{166}$. Por el momento esta información debe ser tomada con mucha cautela pues hasta ahora no hemos tenido acceso a dicho documento para comprobar el contexto en el que se introduce este término, máxime cuando transcurrirá más de un siglo sin que tengamos noticia alguna de Aranda.

La siguiente mención la proporciona el fondo documental del monasterio de San Pedro de Arlanza. En él se recoge que el 27 de abril de 1054 una tal Momadona, su hijo Pedro y su hermano Muño Gustios donaron al monasterio su herencia en ciertas villas localizadas entre el Duero y el Arlanza, incluyendo ...Pennan de Aranda mea porcione, et in Castrillo de Aranda mea porcione ${ }^{167}$. El primer nombre está claro que hace referencia a la vecina localidad de Peñaranda. La atribución del segundo parece un poco más complicada pues el propio autor de la transcripción del documento señala que este Castrillo de Aranda sería Castrillo de la Vega, mientras que otros autores lo identifican con Aranda ${ }^{168}$. En este sentido, es significativo que ya durante todo el siglo XI el nombre de Aranda aparece frecuentemente en la documentación, aunque no hace referencia a un núcleo de poblamiento sino a un río, el que actualmente conocemos como Arandi1la. Así se observa en una donación realizada por Alfonso VI en 1073 al monasterio de Silos en la que se nombraba el río de Aranda a la hora de establecer los límites del territorio donado: ... ubi iuxta decurrit fluvius Aranda (...) de pars occidente, sicut discurrit rivulo Aranda ${ }^{169}$. En nuestra opinión es bastante improbable que el documento de 1054 se refiriera a Castrillo de la Vega ya que la atribución del complemento de Aranda implica que se situaba en las inmediaciones del río Arandilla como ocurre con el caso de Pennam de Aranda. Posiblemente hiciera referencia a un emplazamiento castrense situado en las inmediaciones del río Arandilla sin que por el momento podamos confirmar

${ }^{166}$ LOPERRÁEZ CORVALÁN, Descripción Histórica.... Tomo I, p. 58; BERGANZA, F., Antigüedades de España. Madrid, 1719, libro IV, cap. 12, p. 289; SANZ ABAD, Historia de Aranda..., pp. 37-38. Existen dudas razonables sobre el documento en cuestión pues el mismo PÉREZ DE URBEL señaló en su momento que "la escritura estaba tan borrosa que fue imposible leer su contenido", ("Los primeros siglos de la Reconquista (711-1038)", en Historia de España. La España Cristiana. Comienzo de la Reconquista (711-1038). T. VI, Madrid, 1964, p. 315). En la transcripción realizada por UBIETO ARTETA este documento no aparece (Cartulario de San Juan de la Peña. Valencia, 1962, 2 Vol).

${ }^{167}$ SERRANO, L., Cartulario de San Pedro de Arlanza. Madrid, 1925, pp. 114-16.

${ }^{168}$ MARTÍNEZ DÍEZ, Pueblos y alfoces..., pp. 214-15; PASTOR DÍAZ DE GARAYO, Castilla en el tránsito..., p. 206.

169 VIVANCOS GÓMEZ, M., Documentos del monasterio de Santo Domingo de Silos (9541254). Burgos, 1988, pp. 19-21. 
ni descartar que se tratase del emplazamiento de la actual villa de Aranda, sobre todo a tenor de la ausencia de evidencias arqueológicas y la inexistencia de cualquier referencia a esta propiedad del monasterio en la documentación posterior. El propio padre Serrano expuso en otra de sus obras que este castellum se integraba dentro de una nueva línea defensiva creada en el siglo $\mathrm{X}$ que se extendía por el valle del Esgueva y tenía como puntos avanzados "las torres de Peñaranda y Castillo, cerca de esta población en el monte de la Calabaza", siempre en la línea del río Arandilla ${ }^{170}$.

Nuevamente nos encontramos con esta disyuntiva en la información que nos transmite la disputa entre las diócesis de Burgos y Osma por el control de las tierras de la Ribera del Duero. En 1088 en Husillos, en la actual provincia de Palencia, se celebró un concilio provincial con el fin de solucionar este conflicto. En el compromiso que adquirieron ambas partes se especificaba ...et sicut aqua ipsa currit et labitur in Arandam, aqua quae discurrit per Cluniam, et pertransit ipsam Cluniam, usque Penam de Aranda, donec labitur in fluvium Dorium, et omnes villae ex hac parte fluminis Arandae $e^{171}$. Al margen de a qué diócesis perteneciera el núcleo arandino, lo importante es que se menciona a la vez el lugar de Aranda, fluye hacia Aranda-currit et labitur in Arandam-, así como el río de Aranda -fluminis Arandae-, es decir, el río Arandilla. Prácticamente las mismas palabras se utilizaron en una bula papal de 1107 en la que sólo se añadía: ...et omnes Villae ex Septentrionali parte fluminis Arandae ${ }^{172}$. Tras muchos años de enfrentamientos entre las dos diócesis por la adscripción de la comarca ribereña, en 1136 el legado pontificio puso fin a la disputa con una concordia en la que se enumeraban las villas que pertenecerían desde entonces a la Diócesis de Osma: Aszam, Turrem de Galindo, Fresnelo, Vado de Condes, Baralanguas, Rivales, Rozam, et totum campum de Roza, Guzman, Villamuela, Villamualera, Aquilora, Castellum de Aranda, Cremada, Tovela, Valdefande, Pennela, Pennam de Aranda ${ }^{173}$. La situación del término entre los lugares claramente identificados de Aquilora (La Aguilera) y Cremada (Quemada), más la coincidencia de esta denominación de castellum de Aranda con la que aparecía en el documento de 1054, nos hace pensar que efectivamente en los prime-

\footnotetext{
${ }^{170}$ SERRANO, El obispado de Burgos..., Tomo III, p. 174.

${ }^{171}$ El fragmento ha sido tomado de LOPERRÁEZ CORVALÁN, Descripción Histórica..., Tomo III, p. 7.
}

${ }^{172}$ LOPERRÁEZ CORVALÁN, Descripción Histórica..., Vol. III, p. 555.

${ }^{173}$ LOPERRÁEZ CORVALÁN, Descripción Histórica..., Vol. III, pp. 16-18. 
ros años del siglo XII existía un núcleo de población en el actual emplazamiento de la capital de la Ribera o en sus proximidades.

La denominación castellum apunta a un asentamiento con unas características fundamentalmente defensivo-militares. Atendiendo a esta función y teniendo en cuenta la orografía del terreno es obligado plantearse en qué lugar concreto pudo existir este emplazamiento defensivo. Sanz Abad planteó en su momento que la fundación, o mejor dicho refundación ${ }^{174}$, de Aranda se produjo en dos núcleos: por una parte, uno de ellos se instalaría en el actual emplazamiento de la iglesia de San Juan; mientras que el otro estaría en los aledaños de la desaparecida ermita del Santo Cristo, en una posición intermedia entre el anterior y el río Duero. Al primero le otorgaba un carácter residencial mientras que al segundo le asignaba la función militar refrendada por un hipotético castillo que defendía el vado que permitía franquear el Duero. Sin embargo, la escasez de noticias documentales, así como la inexistencia, por ahora, de evidencias arqueológicas $^{175}$ nos hacen pensar que el núcleo de población que se desarrolló en este espacio antes del siglo XIII debió ser de escasa entidad, limitándose a construcciones de pobres materiales cuyos restos fueron eliminados por el gran crecimiento que se produjo con posterioridad.

\subsubsection{EI núcleo urbano del siglo XIII.}

Lo cierto es que las noticias sobre este pequeño núcleo militar no tienen continuidad a lo largo del siglo XII y no se vuelve a tener referencias sobre Aranda hasta principios del siglo XIII. El primer documento que conservamos en el archivo municipal arandino testimonia la donación que Fernando III hizo en 1236 al monasterio de San

174 Recordemos que SANZ ABAD plantea el origen protohistórico y también se muestra de acuerdo con las tesis que defienden la existencia de un desierto estratégico en la cuenca del Duero (Historia de Aranda..., pp. 9-14 y 29).

${ }^{175}$ Los trabajos arqueológicos realizados en el entorno de San Juan han sido totalmente estériles en cuanto a evidencias anteriores a la segunda mitad del siglo XIII. Y desde luego no se ha documentado ninguna estructura defensiva que sugiera la función militar derivada del término "castellum", salvo el imponente torreón de la propia iglesia. CRISTÓBAL VILLANUEVA, E., Informe técnico del seguimiento arqueológico realizado en la Plaza de San Juan de Aranda de Duero (Burgos). Febrero, 1994; Informe técnico de los sondeos y seguimiento arqueológico realizados en el solar $n^{\circ} 6$ de la Plaza de San Juan, en Aranda de Duero (Burgos). Junio 1994; PALOMINO LÁZARO, A. L., Informe técnico de los sondeos y seguimiento arqueológico realizados en el solar $n^{\circ} 4$ de la Plaza de San Juan, en Aranda de Duero (Burgos). Junio 1994; PALOMINO LÁZARO, A. L., y ABAD ÁLVAREZ, I., Informe Técnico. Documentación del solar $n^{\circ} 5$ de la Plaza de San Juan. 1998; MARTÍN, M. A. y GARCÍA, J. T., Informe Arqueológico. Seguimiento arqueológico en la Iglesia de San Juan de Aranda de Duero (Burgos). 2002. Depositados en el Servicio Territorial de Cultura de Burgos. 
Pedro de Gumiel de Izán de unas aceñas en el río Duero, en termino de Aranda ${ }^{176}$. A partir de este momento encontramos una gran cantidad de referencias que indican que Aranda ya estaba configurada como un núcleo de población de cierta entidad. Además la villa estaba bajo la protección real desde tiempos de Alfonso X y, casi con toda seguridad, también bajo el reinado de Fernando III $^{177}$.

La prosperidad que gozaba la villa es puesta de manifiesto por el hecho de que muchos de los grandes nobles del momento trataron de hacerse con su control, aprovechando la debilidad de unos reyes que accedieron al trono siendo niños ${ }^{178}$.

En los últimos años del siglo XIII y los primeros del XIV este núcleo se convirtió en un próspero centro de intercambio comercial al que María de Molina, viuda de Sancho IV y regente de su hijo Fernando IV, concedió en 1298 una feria anual que debía desarrollarse durante quince días después de Santa María de febrero y eximía de portazgo a los asistentes ${ }^{179}$. Asimismo Alfonso XI en 1326 accedió a la solicitud de los arandinos de trasladar el mercado semanal de los sábados a los lunes para que la comunidad judía de la villa y la comarca pudiera participar sin problemas derivados de la celebración del shabbat ${ }^{180}$.

En definitiva, todos estos indicios muestran que a finales del XIII la villa de Aranda era un centro urbano atractivo y con una vitalidad comercial importante.

Parece lógico en este punto de la exposición plantearse cuál fue el detonante para que un pequeño núcleo militar se convirtiera con el paso del tiempo en un centro de

${ }^{176}$ HURTADO QUERO, Documentos Reales..., doc. 1, pp. 3-4. Se trata de las aceñas de los monjes que aparece en la documentación medieval (AGS, CR, leg. 40, doc. 8). VELASCO PÉREZ identifica esta heredad con la que se encontraba en el término actual de "Los Monjes" (Aranda. Memorias..., p. 46). En este mismo término SANZ ABAD localizó ciertos vestigios arqueológicos (capiteles y restos de columnas) de cronología indefinida (Historia de Aranda..., pp. 51-52).

${ }^{177}$ En la primera confirmación de privilegios que conservamos de Sancho IV en 1291 se señala que la villa era de su padre, el rey Alfonso X. En este documento se confirma el carácter realengo de la villa y el respeto de las franquicias que se concedían a las villas de realengo de la Extremadura (HURTADO QUERO, Documentos Reales..., doc. 3, pp. 4-12). Por otra parte, SANZ ABAD señala que la donación de 1236, a la que hemos hecho referencia anteriormente, demuestra que Aranda era ya villa de realengo con Fernando III (Historia de Aranda..., p. 51).

${ }^{178}$ Las sucesivas contiendas que sufrió la capital de la Ribera en las minorías de Fernando IV y Alfonso XI han sido expuestas por VELASCO PÉREZ en su Aranda. Memorias..., pp. 50-61.

${ }^{179}$ VELASCO PÉREZ, Aranda. Memorias..., p. 56.

${ }^{180}$ VELASCO PÉREZ, Aranda. Memorias..., pp. 61-62. 
atracción de población en el que se desarrolló una notable actividad comercial, además de convertirse en una codiciada posesión para la aristocracia castellana.

Cierto es que la posición geoestratégica del enclave arandino, no tanto por ser un punto intermedio entre la vieja Castilla y los extensos territorios de la Extremadura, sino sobre todo por su posición en el corredor del Duero en un momento en el que comenzaba a despegar el comercio con el vecino reino de Aragón ${ }^{181}$, fue un factor clave en su consolidación como núcleo urbano, aunque no suficiente.

La ausencia de testimonios documentales o arqueológicos que expliquen mínimamente la causa de este cambio tan significativo nos ha llevado a plantearnos una hipótesis de trabajo fundamentada en una serie de indicios que a nuestro entender apuntan a la promoción real del núcleo a través de una nueva fundación. A continuación intentaremos analizar estos indicios con la intención de obtener evidencias que permitan confirmar nuestra hipótesis ${ }^{182}$.

En primer lugar, utilizaremos un recurso de uso generalizado en la reconstrucción de los entramados urbanos y los medievales en particular ${ }^{183}$. Comenzaremos rastreando los vestigios del primitivo parcelario urbano de Aranda y terminaremos poniendo en relación la realidad arandina con la de otras partes del reino castellano en ese mismo periodo cronológico.

Si analizamos el parcelario urbano actual de Aranda y la imagen del plano de 1503 podemos observar que, a pesar de su marcado carácter radiocéntrico, hay una parcela que muestra, tanto en el antiguo como en el actual, una disposición claramente regular. Se trata de lo que hoy conocemos como barrio de San Juan, con las actuales calles de San Juan, Gayubares, Palillos, Barcelona, Aguilera, Centeno, Canaleja y la Plata. Esta disposición regular responde a un tipo concreto de núcleo urbano de nueva funda-

${ }^{181}$ LADERO QUESADA, M. A., “Aspectos de la política económica de Alfonso X”, en Revista de la Facultad de Derecho de la Universidad Complutense. 9, 1985, pp. 69-82; DIAGO HERNANDO, M., "Introducción al estudio del comercio entre las coronas de Aragón y Castilla durante el siglo XIV: las mercancías objeto de intercambio", en En la España Medieval. 24, 2001, pp. 47-101. Este aspecto se confirma arqueológicamente con el hallazgo de un dinero de vellón de Jaime I de Aragón, acuñado desde 1234, en una de las escasas intervenciones arqueológicas que se han realizado en las inmediaciones de la iglesia de San Juan de Aranda (CRISTÓBAL VILLANUEVA, E., Informe técnico de los sondeos y seguimiento arqueológico realizados en el solar $n^{\circ} 6$ de la Plaza de San Juan, en Aranda de Duero (Burgos). Junio 1994. Depositado en el Servicio Territorial de Cultura de Burgos, p. 16).

${ }^{182}$ Esta hipótesis ya la perfilamos en nuestro anterior trabajo Aranda de Duero..., pp. 29-33.

${ }^{183}$ ARÍZAGA BOLUMBURU, B., La imagen de la ciudad medieval: la recuperación del paisaje urbano. Santander, 2002, pp. 71-74. 
ción como la que podemos observar en La Puebla de Arganzón, Labastida, Salvatierra, Aguilar de Campos, Villadiego o la tardía Briviesca ${ }^{184}$.

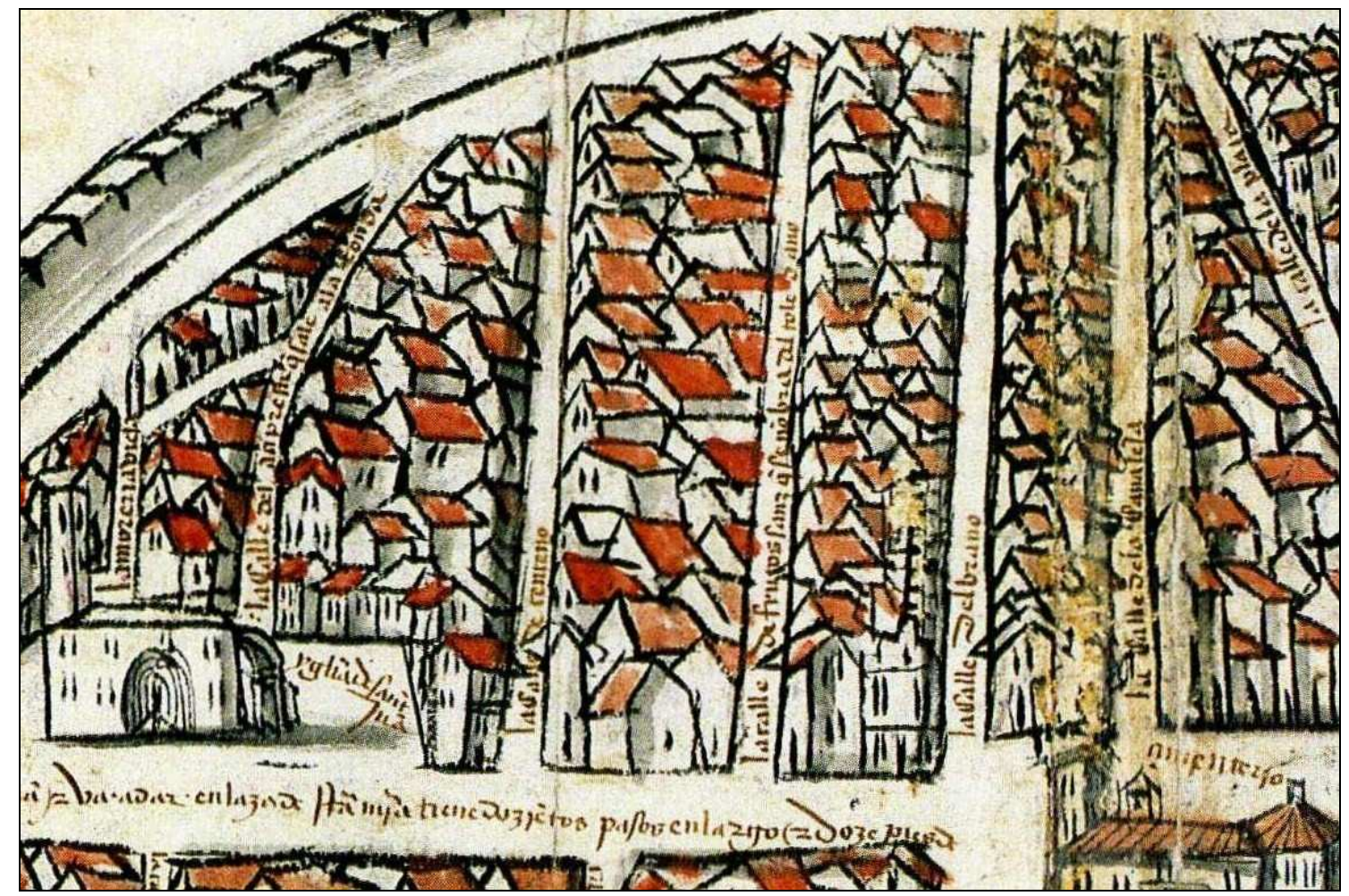

Imagen 1: Detalle del barrio de San Juan según el plano de 1503.

Son varios los estudios que han identificado un significativo proceso de creación de nuevos centros urbanos desde finales del siglo XI y hasta la segunda mitad del siglo XIII a los que se dotó de una cierta autonomía municipal y una serie de privilegios plasmados en un Fuero. Estos núcleos contaban con la protección de una cerca o muralla y cumplían una doble función: por una parte administrativa-territorial, con el control de su entorno próximo; y por la otra económica, con el desarrollo de un mercado de ámbito comarcal. En Castilla fueron escasas las fundaciones ex nihilo y generalmente los núcleos aparecieron asociados a centros primitivos que se pretendía potenciar (fortalezas, monasterios, mercados, vías de comunicación, fronteras,...). Estas nuevas entidades urbanas han sido denominadas por la historiografía como "repoblaciones interiores" y son consideradas la plasmación material del "proceso de transformación del pobla-

${ }^{184}$ SÁINZ GUERRA, La Génesis de la Plaza..., pp. 161-200; DÍAZ DE DURANA, J. R., "El fenómeno urbano medieval en Álava y Vizcaya", en El fenómeno urbano medieval entre el Cantábrico y el Duero. Santander, 2002, pp. 59-109; REGLERO DE LA FUENTE, C., "El fenómeno urbano medieval en las actuales provincias de Valladolid y Palencia", en El fenómeno urbano..., pp. 210-40; y PERIBÁÑEZ OTERO, J. G. y ABAD ÁLVAREZ, I., "El fenómeno urbano medieval..., pp. 175-209. 
miento previo con un sentido claramente urbanizador" ${ }^{\prime 185}$. Muchos de estos núcleos recibieron el calificativo de "villa", en un intento de diferenciar este nuevo asentamiento de la amplia malla de habitats rurales, de las agrupaciones rurales mayores o de las ciudades consolidadas. Otra característica de estos núcleos de nueva fundación es que nacieron de la iniciativa regia, en un intento de plasmar sobre el territorio el proceso de consolidación del poder real ${ }^{186}$. Así se observa en el caso de Logroño en 1095 con Alfonso VI, La Puebla de Arganzón en 1191 con Alfonso VIII, Labastida en 1242 con Fernando III, Salvatierra en 1256 con Alfonso X o Briviesca en 1305 con Fernando IV. También es característico de estas nuevas fundaciones que conservaran el nombre primitivo a pesar de la evidente modificación de su realidad espacial ${ }^{187}$.

En definitiva, se advierte en Castilla un episodio periférico del mismo proceso de reorganización y puesta en valor del territorio que se produjo en Europa Occidental con una cronología similar ${ }^{188}$.

El núcleo de población arandino del siglo XIII participaba de casi todas estas características que definen a los núcleos de nueva fundación o repoblaciones tardías: en su plano existen pervivencias de un trazado regular, premeditado, que seguramente estu-

${ }^{185}$ RUIZ DE LA PEÑA, J. L., "Repoblaciones urbanas tardías en las tierras del Norte del Duero (siglos XII-XIV)”, en Revista del Derecho Español. 1, 1976, pp. 71-124.

${ }^{186}$ MONSALVO ANTÓN señala que en este momento se lleva a cabo la "reorganización del realengo con la fundación de villas nuevas como núcleos a los que se daba autonomía, territorio y competencias en áreas donde el realengo o señorío real necesitaba agrupar sus dominios y competir así con otros señores de la zona o por intereses geoespaciales o bien comerciales ("Centralización monárquica castellana..., p. 170).

${ }^{187}$ MARTÍNEZ SOPENA, P., "Repoblaciones interiores, villas nuevas de los siglos XII y XIII”, en IV Congreso de Estudios Medievales. León, 1995, pp. 163-87; "Logroño y las villas riojanas..., pp. 279-322; y "Réorganisation de l'espace et conflits de pouvoir: les pueblas reales au Nord du Duero", en Genèse médiévales de l'Espagne Moderne. Du refus a la révolte: les résistences. Niza, 1991, pp. 7-20; "Villas nuevas y planificación urbana en la Castilla medieval", en Castilla y el mundo feudal. Valladolid, 2009, vol. I, pp. 469-484. MONSALVO ANTÓN, J. M., "Los territorios de las villas reales de la Vieja Castilla, ss. XI-XIV: (estudio a partir de una docena de sistemas concejiles entre el Arlanza y el alto Ebro)", en Studia Historica. Historia Medieval. 17, 1999, pp. 15-86. ASENJO GONZÁLEZ, M. y MONSALVO ANTÓN, J. M., "Dos visiones de las villas de la Extremadura. Sector occidental y oriental de la cuenca meridional del Duero (siglos XI-final XV), en Boletín Arkeolan. 14, 2006, pp. 239-266. SOLÓRZANO TELECHEA, J. A., “La fundación y promoción de las ‘villas nuevas' en el litoral Atlántico del Norte peninsular durante el reinado de Alfonso X”, en El mundo urbano en la Castilla del siglo XVIII. 2006, vol. 2, pp. 315-328. Una visión de conjunto del proceso repoblador del siglo XIII se puede consultar en la obra colectiva dirigida por GONZÁLEZ JIMÉNEZ, M., El mundo urbano en la Castilla del siglo XIII. Sevilla. 2006.

${ }^{188}$ LAVEDAN, P., L’Urbanisme au Moyen Âge. Géneve, 1974; HIGOUNET, C., Paysages et villages neufs du Moyen Âge. Burdeos, 1975; LAURENT, P. et álii, Bastides, villes nouvelles du Moyen Âge. Toulouse, 1988; PERIBÁÑEZ OTERO, J., La ocupación del suelo en Béarn. Siglos XIII y XIV. Bastidas y núcleos de nueva fundación. Valladolid, 1998, pp. 21-33. 
viera definido por una cerca; la denominación de castellum del siglo XI desaparece y Aranda se identifica como una villa en la documentación del XIII; en este mismo periodo ya cuenta la villa con unas aldeas bajo su jurisdicción ${ }^{189}$; y la actividad comercial del mercado semanal se vio potenciada con la concesión de una feria a partir de 1298. La única característica que no parece cumplir el núcleo arandino es que no parece contar con un marco jurídico propio, el fuero.

En la misma confirmación de Sancho IV, después de renovar su compromiso de no enajenar la villa de la Corona, se comprometía a ...guardar e mantener en todos los fueros e franquisas e libertades que an las otras nuestra çibdades e villas de la Extremadura e fuera de la meryndat de Santo Domingo de Silos ${ }^{190}$. No es de extrañar este carácter ambiguo al no citarse el fuero concreto que se asigna pues los monarcas ya mostraban su interés por unificar el derecho en sus dominios ${ }^{191}$. No obstante, creemos que de concederse un fuero concreto, éste sería el de Sepúlveda ${ }^{192}$. Los argumentos en los que nos basamos se centran en su proximidad y en el hecho de ser también una villa de realengo. A esto debemos añadir que a finales del siglo XV todavía existía entre la población arandina la percepción de que gozaban de este fuero. El ejemplo más sólido es el que transmite la propia administración real al ordenar en 1488 ...que se guarde el fuero de Sepulveda a Aranda de Duero ${ }^{193}$. Asimismo el concejo arandino utilizó como uno de sus principales argumentos en una disputa con los hidalgos de la villa en 1489

${ }^{189}$ En el documento de Fernando III datado en 1236 que se conserva en el Archivo Municipal se cita son en termino de Aranda, sin especificar nada más. Pero en la confirmación de privilegios de Sancho IV en 1291 ya aparece la denominación de villa, entendiéndose que ya era villa con su padre, Alfonso X: ...porque la villa de Aranda era del rey don Alfonso, nuestro padre. Más adelante también se hace referencia a las aldeas de la jurisdicción arandina: ... a vos el conçeio e los omes buenos de Aranda e de sus aldeas (HURTADO QUERO, Documentos Reales..., docs. 1 y 3, pp. 3-12). Esta circunstancia puede ponerse en relación con el fenómeno de conversión del realengo directo en realengo concejil que ha identificado MONSALVO ANTÓN en otros territorios castellanos. De esta manera se conseguía una mayor eficacia en el ejercicio del señorío del rey al implicar a las autoridades locales ("Centralización monárquica castellana..., p. 176).

${ }^{190}$ HURTADO QUERO, Documentos Reales..., doc. 3, pp. 4-12.

${ }^{191}$ BENITO MARTÍN, La formación..., p. 118.

192 Eso mismo ocurrió en 1143 en la vecina Roa cuando Alfonso VII concedió el Fuero de Sepúlveda a esta localidad (MARTÍNEZ DÍEZ, Fueros locales..., pp. 149-150). Este texto lo conocemos a través de una confirmación de Sancho IV en 1291 (LOPERRÁEZ CORVALÁN, Descripción Histórica..., Vol. III, p. 17).

193 AGS, RGS, 148802, fol. 188. En este documento se ordenaba que se cumpliera lo contenido en el fuero de Sepúlveda, en concreto en lo referente a la herencia de los menores o mayores que muriesen sin descendencia. 
...que esa dicha villa esta poblada a fuero $\mathrm{y}$, por lo tanto, los hidalgos debían contribuir a los gastos como el resto de vecinos ${ }^{194}$. También los vecinos aludían con frecuencia a este fuero en sus debates particulares, sobre todo cuando había una herencia por me$\operatorname{dio}^{195}$.

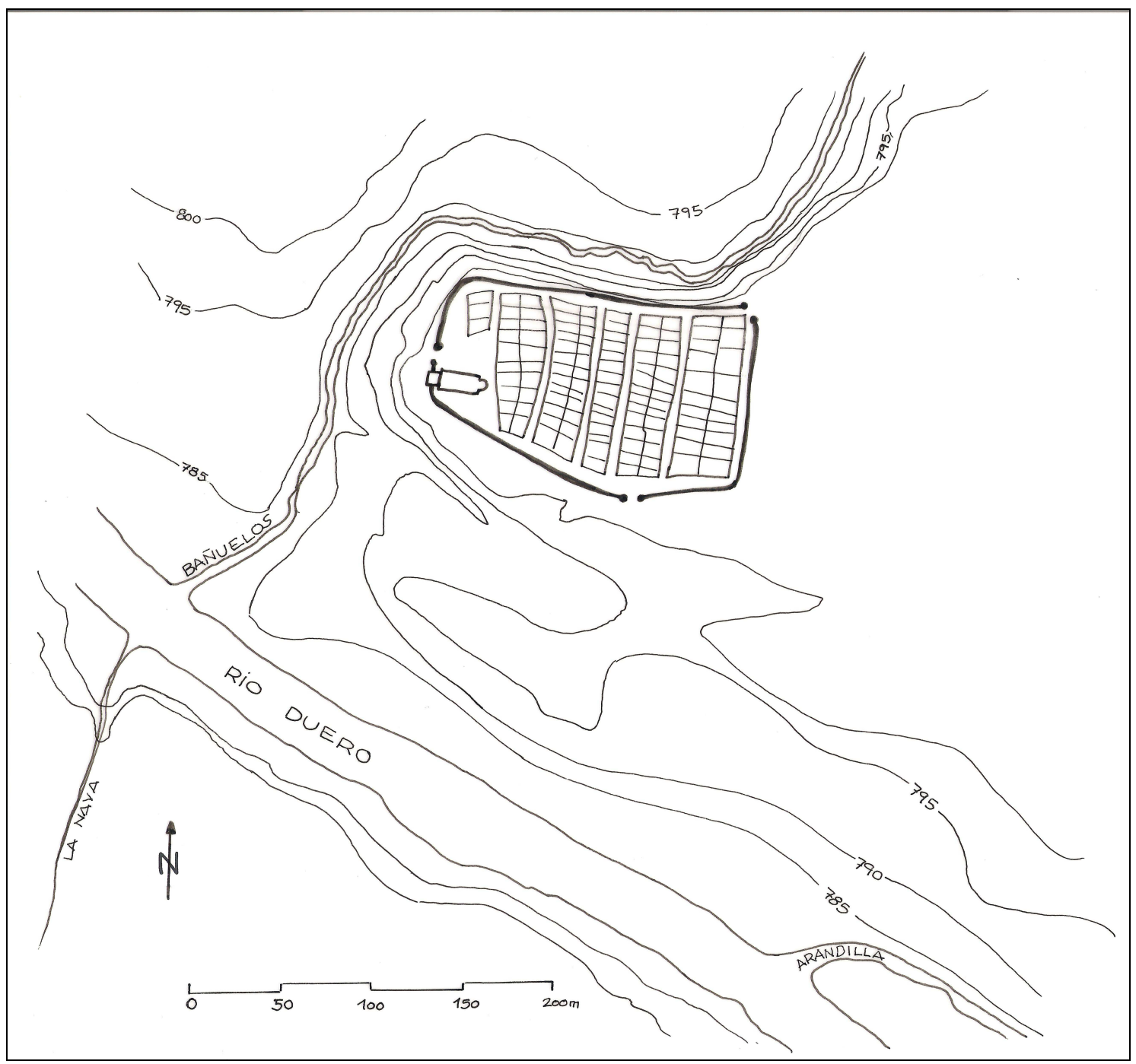

Plano 2: Hipotético trazado del núcleo de nueva fundación arandino.

En conclusión, y a la vista de los datos aportados, pensamos que el origen de la villa de Aranda como núcleo urbano se encuentra en las políticas de reestructuración del

${ }^{194}$ AGS, RGS, 148901, fol. 261.

${ }^{195}$ Los litigantes utilizaban argumentos totalmente opuestos según sus intereses pues mientras una de las partes argumentaba ...e que segud el fuero de Sepulveda usado e guardado en la dicha villa de Aranda y segud la costumbre ynmemorial usada e guardada en la dicha villa...; la contraria manifestaba que ...no aya tal fuero en Aranda ni nunca fuera usado ni ge a dado el dicho fuero en la dicha villa (ARChV, Registro de Reales Ejecutorias -RRE-, Caja 241, doc. 63). 
territorio castellano llevadas a cabo por los monarcas castellanos desde mediados del siglo XI y hasta comienzos del siglo XIV. Creemos que, en un momento indeterminado del siglo XIII, se fundó un núcleo de poblamiento en el espacio elevado delimitado al Norte y Oeste por la fuerte pendiente del río Bañuelos y por el Sur por el vallejo del Hocino (hoy calle Pedraja). Probablemente este nuevo asentamiento se efectuó junto o sobre el primitivo elemento defensivo denominado por las fuentes castellum y que, a falta de pruebas materiales, pensamos que estaría situado bien bajo la iglesia de San Juan, o bien en las inmediaciones de arco del actual Ayuntamiento. La creación de este nuevo núcleo, que recibió la denominación de villa, supuso una profunda transformación del espacio sobre el que se asentó (urbanización), así como del entorno próximo. Esta nueva realidad urbana se convirtió en el centro de los intereses de la Corona en la comarca ribereña ${ }^{196}$. Gracias a la promoción real la villa alcanzó en muy pocos años un gran desarrollo económico que se plasmó en un notable crecimiento del perímetro urbano que sólo se vio frenado por la profunda crisis que asoló Europa y Castilla a lo largo de buena parte del siglo XIV.

La villa se presentaba en estos primeros momentos de vida urbana como un pequeño núcleo asentado sobre una suave colina y protegido por una primitiva cerca. En su extremo occidental contaba con un centro de culto seguramente ya bajo la advocación de San Juan ${ }^{197}$. A partir de este punto la villa se extendió por la plataforma más o menos plana que se encontraba al E de la iglesia siguiendo un modelo de asentamiento regular y planificado compuesto por cinco manzanas rectangulares separadas por callejas con disposición N-S. Una calle perpendicular a las manzanas discurriría por el lado Norte de la villa (actual calle Palillos) y otra por el Sur (actual calle de San Juan). Ambas funcionarían como rondas que comunicaban el extremo occidental con el oriental.

${ }^{196}$ Este mismo fenómeno está perfectamente documentado en otros núcleos castellanos como Frías, Miranda de Ebro, Medina de Pomar o Aguilar de Campoo. Todos ellos compartían una serie de características comunes de las que Aranda es partícipe: no tenían necesariamente un pasado castral o administrativo previo, en ellas se desarrollaron importantes contingentes de artesanos y comerciantes, el territorio que controlaban poseía un importante interés estratégico y se configuraron desde el punto de vista político como un sistema concejil (MONSALVO ANTÓN, J. M., "Los territorios de las villas reales..., pp. 44-47).

${ }^{197}$ Precisamente en el extremo occidental tenemos constancia arqueológica de una escalera que comunicaba la plaza de San Juan con el Bañuelos y que está datada en la segunda mitad del siglo XIII por un "dinero de vellón" de Jaime I de Aragón (1213-1276) situado en uno de los peldaños (CRISTÓBAL VILLANUEVA, E., Informe técnico de los sondeos y seguimiento arqueológico realizados en el solar $n^{\circ}$ 6 de la Plaza de San Juan, en Aranda de Duero (Burgos). Junio 1994. Depositado en el Servicio Territorial de Cultura de Burgos, p. 16). 
Al SE de la villa se abriría probablemente una puerta junto a la cual, no sabemos si intra o extramuros, se situó en un momento posterior un segundo centro de culto: la iglesia de Santa María. Precisamente esta puerta jugó un papel fundamental en el crecimiento de la villa pues su localización la configuraba como un excelente punto de encuentro de los caminos que venían del Norte, del Este, del Sur y también del Oeste, pues seguramente los caminantes que atravesaban el Bañuelos junto a San Juan aprovechaban la ligera pendiente del vallejo del Hocino para entrar en la villa evitando así el desnivel del acceso por la puerta de San Juan. No es de extrañar que con el paso del tiempo este espacio se convirtiera en el centro neurálgico de la población.

Esta hipótesis es totalmente compatible con la preexistencia de un núcleo primigenio de carácter militar, el citado castellum; que bien se vio absorbido por la fundación de la villa, y por lo tanto estaría localizado en la colina de San Juan; o bien se encontraba en la colina del Santo Cristo, junto a la Puerta del Duero. Ambos emplazamientos pudieron convivir hasta que se unieron tras las sucesivas ampliaciones de la cerca. Este carácter polinuclear de las villas no es una novedad dentro del poblamiento peninsular pues ha sido ampliamente constatado en la Galicia plenomedieval ${ }^{198}$. Asimismo el geógrafo Al-Idrisi transmite esta idea de desestructuración en la descripción que hizo de Segovia: ...tampoco es ciudad sino muchas aldeas próximas las unas con las otras ${ }^{199}$. En este sentido, también se ha documentado la fundación de pueblas nuevas junto a castros preexistentes $^{200}$. Los dos núcleos se encontrarían separados por la depresión del Hocino y su vía de comunicación se establecería a través de un pequeño puente del que quedaba constancia todavía a finales de la Edad Media pues una de las calles de la villa recibía el explícito nombre de la Pontecilla, a mitad de camino entre la Puerta de Duero y San Juan a través de la plaza de Santa María ${ }^{201}$. Por otra parte, la observación de la representación de la ermita de San Llorente en la zona Sur de la villa en el plano de

${ }^{198}$ SÁNCHEZ PARDO, Territorio y poblamiento en la Galicia..., p. 451.

${ }^{199}$ GARCÍA MERCADAL, Viajes de..., p. 197.

${ }^{200}$ RUIZ DE LA PEÑA, I., "La formación de la red urbana..., pp. 209-210. Este fenómeno también se produjo en el reino de León como se pone de manifiesto en el caso de Mayorga donde se creó una puebla real junto a un castro sobre el Cea en el siglo XII (MARTÍNEZ SOPENA, La Tierra de Campos..., p. 173-176; y BENITO MARTÍN, La formación..., pp. 171-172).

${ }^{201}$ AGS, CR, leg. 40, doc. 8; y CMC, leg. 355. En el plano de 1503 en esta calle aparece el siguiente rótulo: la calleja de la Pontecilla tras los plateros (Mapas, Planos y Dibujos -MPD-, leg. X, doc. 1). BONACHÍA HERNANDO también hace referencia a este puente interior ("El desarrollo urbano..., p. 24). 
1503 permite apreciar la existencia de un pequeño ábside semicircular y una serie de columnillas adosadas en el presbiterio, que recuerda las cabeceras de las construcciones románicas. Si así fuera, bien podría tratarse de la iglesia de este núcleo del Duero, o bien el vestigio de una ermita situada extramuros.

\subsubsection{El estancamiento del siglo XIV.}

La primera fase expansiva en el desarrollo de la villa arandina llegó a su fin con el comienzo del siglo XIV. Las causas son de todos conocidas. A las sucesivas crisis de subsistencia, se sumaron los continuos enfrentamientos políticos que sacudieron Castilla durante las minorías de Fernando IV y Alfonso XI que culminaron con la cruenta guerra civil que enfrentó a Pedro I y el futuro Enrique II. Como otras muchas ciudades de Castilla, la villa de Aranda se vio inmersa en esta dinámica de violencia durante todo el siglo XIV. La situación se complicó aún más si cabe con la irrupción de un tercer azote con efectos mucho más devastadores, la Peste Negra, que posiblemente tuvo el valle de Duero como una de las vías de propagación desde el Levante del que el episodio que afectó a la villa raudense en 1394 no es más que un ejemplo de lo que debió acontecer en toda la comarca ${ }^{202}$.

Las repercusiones negativas sobre el desarrollo de la comunidad arandina no se hicieron esperar como se puede apreciar en la justificación del traslado del día de mercado concedido por Alfonso XI en 1326 en lo que parece una medida para fomentar el asentamiento de población en el territorio en unos momentos de evidentes dificulta$\operatorname{des}^{203}$.

${ }^{202}$ VALDEÓN BARUQUE, Crisis y recuperación..., Tomo V, p. 28; y CABRILLANA, N., "La crisis del siglo XIV en Castilla: La Peste Negra en el obispado de Palencia", en Hispania. 109, 1968, pp. 245-258, en concreto p. 255.

${ }^{203}$ OLIVA HERRER, "La crisis del siglo XIV..., pp. 107-120. Para el caso concreto de la comarca ribereña NUÑO GONZÁLEZ, "La Ribera del Duero..., pp. 11-41. 


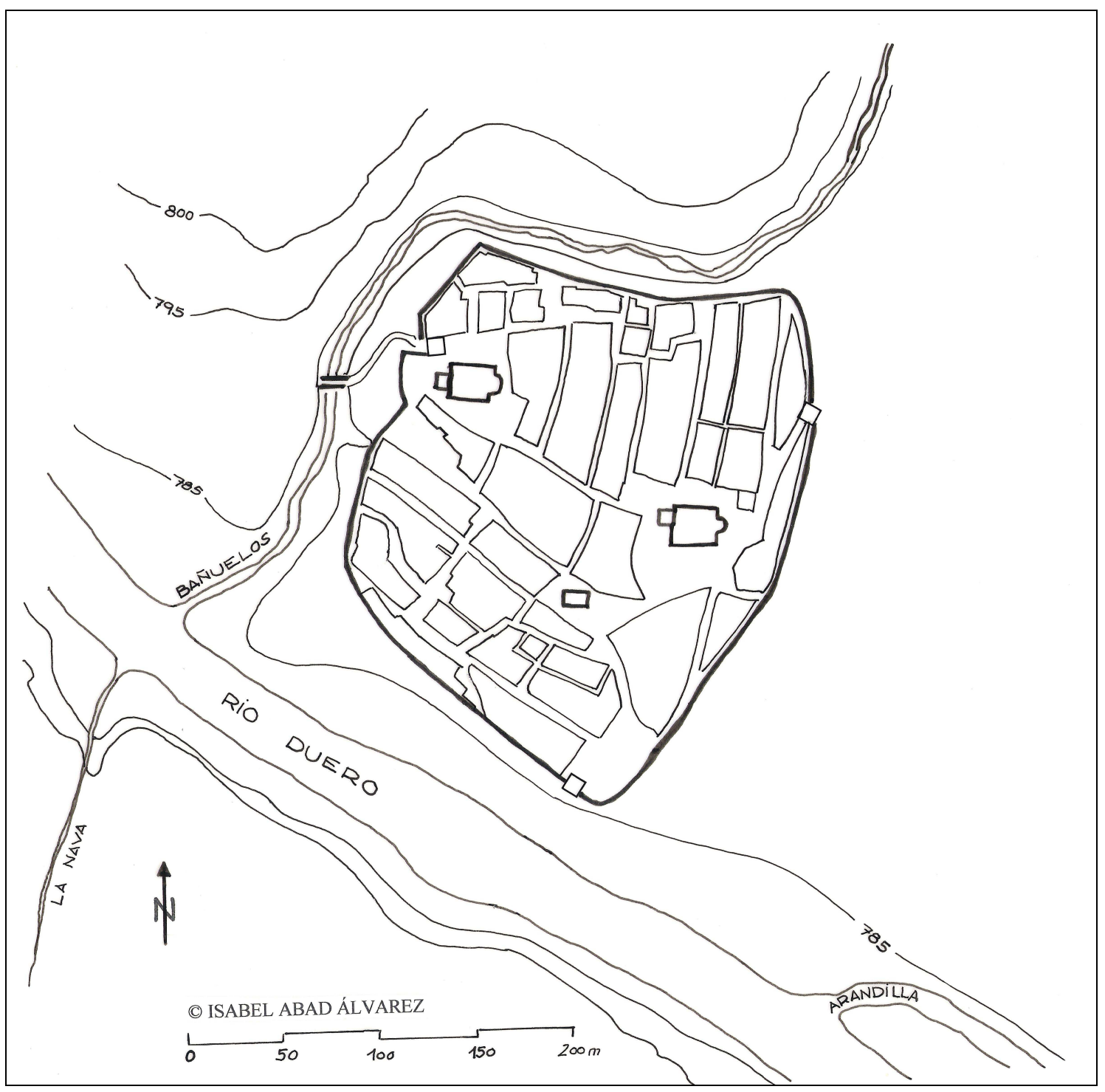

Plano 3: Esquema de la primera cerca según Abad Zapatero.

La merma de población y actividad económica derivada de la crisis en buena lógica tuvo que repercutir en la vida de Aranda, poniendo freno al desarrollo urbano de la villa, sin que podamos precisar con un cierto grado de fiabilidad el espacio que ocupaba la población en este siglo. La historiografía local señala que ya en el XIII se produjo la incorporación dentro de la cerca del espacio comprendido entre el barrio de San Juan y el puente del Duero, estando limitado el contorno de la villa por las riberas de los ríos Duero y Bañuelos por el Norte, Oeste y Sur y cerrándose por el Este por una cerca que iría en línea recta desde la puerta de Cascajar hasta la del Puente, pasando por las inmediaciones de la iglesia de Santa María ${ }^{204}$. Pero lo cierto es que no hay ningún dato que

204 SANZ ABAD, Historia de Aranda..., pp. 99-107; y ABAD ZAPATERO y ARRANZ ARRANZ, Las Iglesias..., pp. 15-20. 
confirme esta disposición. Tan solo contamos con alguna información posterior que asegura que el espacio deprimido entre el barrio de San Juan y la puerta del Puente, el vallejo del Hoçino, era ...ynabitable e donde nunca fue poblado nin se espero poblar ${ }^{205}$. Aunque existe la evidencia de núcleos que incorporan en sus murallas espacios abiertos para albergar el ganado en momentos de peligro, no parece el contexto del siglo XIII especialmente conflictivo en las tierras del Duero como para tomar esta medida, aunque sí que es evidente esta inestabilidad en el siglo posterior. No obstante, es necesario recordar que junto a la puerta Este de la villa, en las proximidades de Santa María existía un término conocido como la Dehesilla que remite directamente al espacio acondicionado para el cuidado del ganado.

Desde nuestro punto de vista, siguiendo la hipótesis planteada por Sáinz Guerra $^{206}$, creemos que a principios del XIV el núcleo urbano experimentó una pequeña ampliación que supondría la incorporación de la actual Plaza de Santa María con su primitivo templo más el espacio adyacente (Cascajar, Pozo, Boticas y un tramo de la Miel y Aceite). En los espacios extramuros inmediatos se desarrollarían unos arrabales de carácter comercial: la Plaza del Pan, donde se establecería el mercado del cereal; la Plaza Nueva, destinada a albergar acontecimientos que requirieran un espacio amplio como podían ser la feria o los actos festivos; y Barrionuevo. En este último caso es bastante significativo que su comunicación posterior con la zona de Santa María fuera a través de una calle en recodo en la que todavía a finales del siglo XV existía un arco de calicanto que bien pudiera ser la reminiscencia de un portillo que comunicara el primitivo recinto intramuros con el nuevo arrabal ${ }^{207}$. También es significativo que precisamente en el arranque de este arrabal se asentó la comunidad judía e instaló allí su sinagoga $^{208}$. En este mismo sentido, llama bastante la atención que junto a este arco de calicanto se emplazara el arranque de la calle de las Quintanas que aunque de significado

${ }^{205}$ AGS, RGS, 148607, fol. 71, transcrito por CADIÑANOS BARDECI, I., "Judíos y moros en Aranda de Duero y sus contornos”, en Biblioteca 7. Estudio e Investigación. 1992, doc. 2, pp. 42-43.

206 SÁINZ GUERRA, La Génesis de..., p. 118; y BENITO MARTÍN, La formación..., p. 258.

${ }^{207}$ Este arco tenía unas dimensiones considerables pues diferentes testigos afirmaban que tenía 15 pies de alto por otros tantos de ancho, lo que supone un vano de algo más de 4x4 metros de luz (AGS, CR, leg. 39, doc. 3).

${ }^{208}$ La información sobre el arco y la presencia de varias familias judías y la sinagoga en el comienzo de la calle Barrionuevo la aportan los diferentes testigos que declaran en el proceso para la apertura de la calle Barrionuevo (AGS, CR, leg. 39, doc. 3, transcrito por PERIBÁÑEZ OTERO y ABAD ÁLVAREZ, Aranda de Duero..., pp. 142 y ss.). 
polisémico se puede identificar claramente con un espacio extramuros cercano a las puertas $^{209}$.

En todo caso, es difícil con la información que tenemos hasta el momento definir con nitidez el perímetro de esta cerca y sus características. Esta hipótesis de trabajo seguramente se verá contrastada con la aparición de nuevos restos arqueológicos y nuevas referencias documentales que pongan algo de luz sobre este periodo en la evolución urbana de la villa arandina.

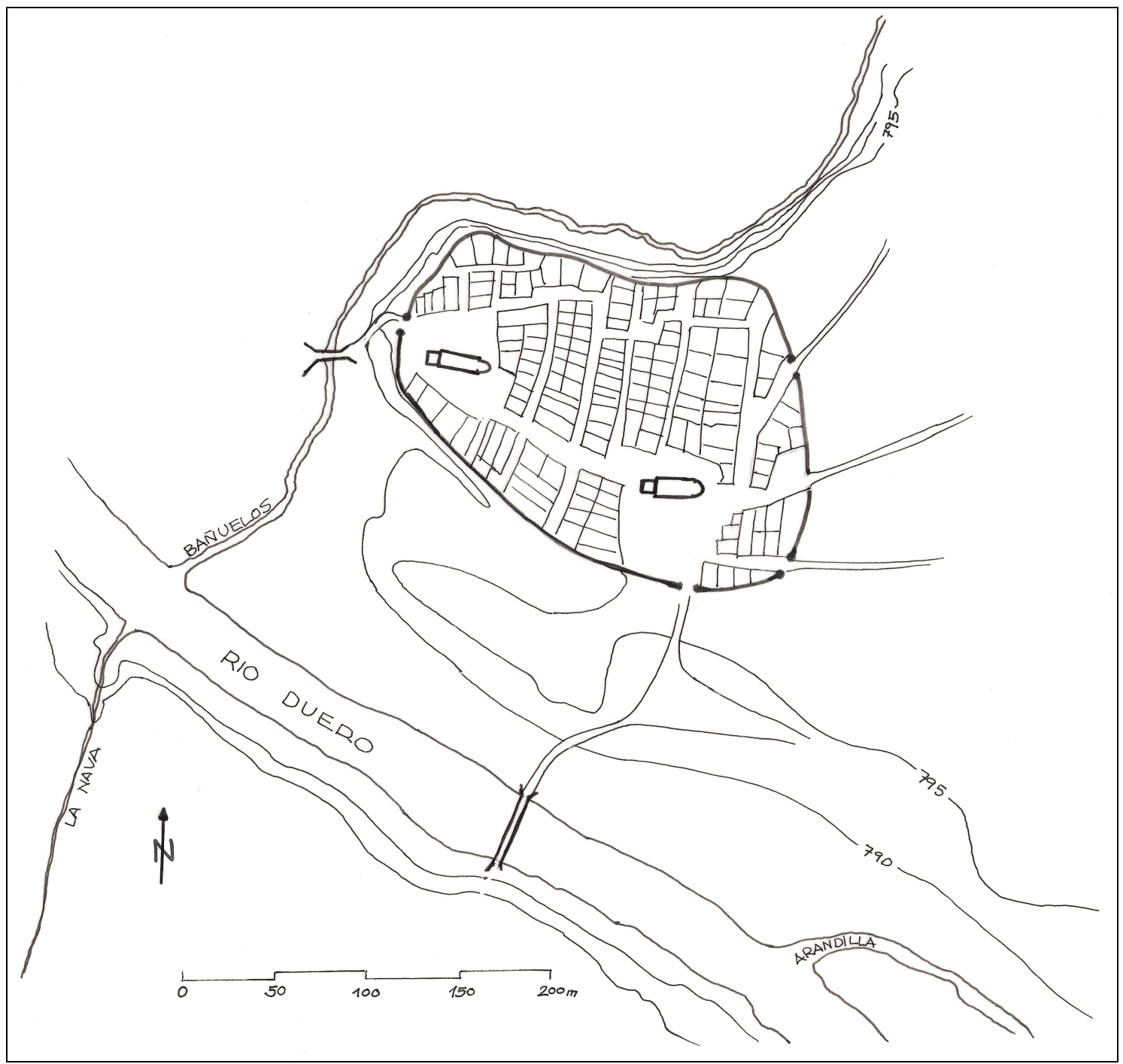

Plano 4: Esquema de la primera ampliación de la cerca según Sáinz Guerra.

${ }^{209}$ Quintana tiene varios significados pero entre ellos destacan dos que bien pudieran identificarse con la calle arandina. Por una parte así se denominaba a las puertas, vías o plaza de los campamentos romanos donde se vendían víveres. Asimismo con esta palabra se designaba a los vertederos o muladares situados en el espacio extramuros. 
Por otra parte, como veremos más adelante con mayor detenimiento, ya desde comienzos del siglo XIV se constata la existencia de un primitivo puente de piedra sobre el Duero ${ }^{210}$. Seguramente en este momento también existía el puente sobre el Bañuelos, aunque no tenemos ningún testimonio que lo confirme.

\subsubsection{La gran expansión urbana del siglo $X V$.}

Durante los primeros años del Cuatrocientos las hambrunas, los brotes de peste y la violencia aparejada a la inestabilidad política continuaron, pero se advierte el comienzo de un proceso de recuperación o reconstrucción en el campo castellano ${ }^{211}$. En el ámbito de la villa arandina observamos en este periodo ciertos indicios que apuntan en esta dirección. Por una parte, el concejo amplió considerablemente su exiguo territorio jurisdiccional con la compra en 1396 del lugar de Quemada ${ }^{212}$ al que en 1426 se sumó la amplia granja de Revilla de Olleros más los términos de la Paliza y Páramo, en el extremo suroriental de su Tierra. ${ }^{213}$.

Pero además de la ampliación de los límites territoriales, la documentación transmite un enorme desarrollo de las roturaciones en el término de la villa que provocó numerosos conflictos entre los vecinos y que obligaron a las autoridades a regular esta actividad. En concreto se nombraron dos jueces de entradas e ronpimientos con competencias para solucionar los pleitos e imponer penas ${ }^{214}$.

${ }^{210}$ En mayo de 1306 Fernando IV, junto al infante don Juan, cercó la villa de Aranda donde se refugia don Juan Núñez de Lara. La crónica de este monarca narra el episodio concreto del enfrentamiento: ...mandó el infante D. Juan que se metiesen so la puente e que derribasen el pilar de la puente que estaba en seco entre el rio e donde estaban peleando porque non pudiesen tornar los de dentro a la villa (tomado de NUÑ̃ GONZÁLEZ, "La Ribera del Duero..., p. 18).

${ }^{211}$ VALDEÓN BARUQUE, Crisis y Recuperación ..., Vol. 5., pp. 29-37.

212 VELASCO PÉREZ, Aranda. Memorias..., pp. 91-92. Esta misma dinámica expansiva tuvo lugar con la misma cronología en otros territorios castellanos como La Rioja (GOICOLEA JULIÁN, F. J., "Expansión territorial de los núcleos urbanos y la articulación de las relaciones con sus aldeas en la Rioja alta medieval", Anuario de Estudios Medievales, 32/1, 2002, pp. 293-331).

${ }^{213}$ La anexión se produjo mediante un censo a perpetuidad que el concejo se comprometió a pagar al monasterio de Santa María de la Vid (AMA, leg. 43, doc. 4). Revilla de Olleros es un despoblado que se encuentra junto a la actual Nacional 111, a mitad de camino entre Aranda y Quemada. El término de Las Palizas todavía es reconocible en la toponimia arandina en la ribera Norte del Duero, frente a Fresnillo de las Dueñas. No conocemos la ubicación exacta del Páramo, pero posiblemente se encuentre entre los dos anteriores, muy cerca del monte de La Calabaza (MARTÍNEZ DÍEZ, Pueblos y Alfoces..., p. 231; mapa 1/50.000 del Instituto Nacional Geográfico, n ${ }^{\mathrm{o}} 375$-Fuentelcésped- $2^{\mathrm{a}}$ Ed. 1960).

${ }^{214}$ AMA, leg. 43, doc. 27. 
Este crecimiento también se manifestó en la proliferación de conflictos con los pueblos del entorno que, aunque ya se documentan algunos desde mediados del $\mathrm{XIV}^{215}$, se generalizaron en la primera mitad del XV e incluso derivaron en episodios de violen$\mathrm{cia}^{216}$.

Sin lugar a dudas, la evidencia más relevante de la recuperación y el dinamismo en este periodo fue el gran crecimiento urbano que experimentó la villa arandina, llegando a duplicar la extensión con la que contaba en la fase anterior. En estos momentos se construyó una nueva cerca que englobó el recinto comercial surgido en los aledaños de la puerta SE del núcleo primitivo, la Plaza Nueva, y el gran arrabal desarrollado al Este, la Plaza del Pan y la Dehesilla.

El profesor Sáinz Guerra ha explicado de manera muy convincente la génesis del amplio espacio público que surgió al mediodía del núcleo originario y que recibió el nombre de Plaza Nueva ${ }^{217}$. Este autor señala que este espacio tuvo un origen comercial y se configuró en unos terrenos extramuros en la prolongación de una hipotética puerta situada en la calle de la Miel, junto a la Plaza de Santa María, enmarcándose por los caminos que se dirigían hacia el puente del Duero y hacia el Este. Al final de una ligera pendiente, en un espacio llano, se consolidó esta plaza con una disposición triangular, típica de las plazas de origen medieval. Señala asimismo que este recinto fue el único capaz de albergar el espacio comercial necesario para el desarrollo de la feria concedida en 1298.

Para este autor la Plaza del Pan o del Trigo, de origen también comercial, se configuró como un simple ensanchamiento de la calle de la Dehesilla en un punto intermedio entre la iglesia y la nueva puerta Este. Esta hipótesis supondría que esta plaza se creó en un momento posterior a la ampliación de la cerca. En este punto no coincidimos con él pues, como ya hemos comentado anteriormente, creemos que la génesis de la Plaza del Trigo fue previa a la ampliación de la cerca como un espacio comercial, especializado en la compraventa de grano. Se encontraría junto a la primitiva puerta Este y se vio absorbido por la misma ampliación de la muralla que afectó a la Plaza Nueva.

${ }^{215}$ VELASCO PÉREZ, Aranda. Memorias..., p. 93. El autor cita acuerdos con Torregalindo en 1357 (AMA, leg. 42, doc. 2), Gumiel de Izán en 1368, Zazuar en 1369, La Aguilera en 1388 y Ventosilla en 1393.

\footnotetext{
${ }^{216}$ Los conflictos se produjeron con Gumiel de Izán (AMA, leg. 1101, doc. 4) y la Comunidad e Villa y Tierra de Haza (VELASCO PÉREZ, Aranda. Memorias..., p. 94-97).

${ }^{217}$ SÁINZ GUERRA, La Génesis de la Plaza..., pp. 229-31.
} 
La hipótesis planteada por el profesor Sáinz Guerra se basa sobre todo en el estudio urbanístico del plano arandino, aunque son escasas las evidencias documentales o arqueológicas que lo corroboran. Posiblemente esta ampliación del espacio intramuros debió producirse a principios del siglo $\mathrm{XV}$, paralelamente al proceso de recuperación demográfica y económica del territorio castellano. Tenemos la certeza de que en 1432 ya hacía un tiempo que esta nueva muralla estaba construida pues el concejo fijó las condiciones de seguridad necesarias para que se construyeran casas adosadas al lienzo en el lado Sur de la Plaza Nueva ${ }^{218}$. Las autoridades fijaron los lotes que podían ser edificados y los subastaron a cambio del pago de un censo perpetuo ${ }^{219}$. Entre las condiciones que debían cumplir estas nuevas construcciones se establecía la obligación de mantener la alineación establecida del portal vano ${ }^{220}$ y permitir la realización de las rondas, respetando el espacio necesario para que pasase un hombre con su escudo y lanza por el adarve. La circunstancia de que en estas fechas se subastaran las parcelas indica claramente que todo el sector Sur de la Plaza Nueva no se encontraba edificado a comienzos del siglo XV, circunstancia que se podía hacer extensiva a otros sectores del espacio intramuros entre los que se encontraría el ya mencionado del Hocino. La existencia de estos vacíos en el interior es bastante habitual en las ciudades castellanas del momento y contrasta con la imagen ciertamente idealizada del lleno absoluto que transmite el plano de 1503. El hecho de que la ampliación incluyera espacios vacíos y que las autoridades municipales incorporaran en la subasta una normativa expresa sobre las características de la construcción permite percibir la existencia de una incipiente planificación urbanística.

${ }^{218}$ VELASCO PÉREZ, Aranda. Memorias..., p. 87. El documento original que transcribe parcialmente este autor es uno de los que lamentablemente ha desaparecido del Archivo Municipal.

${ }^{219}$ El concejo arrendó estos solares a los vecinos a cambio de una renta anual. Este tipo de contratos de arrendamiento eran en realidad simples compraventas pero con la obligación por parte de los vecinos de pagar cierta cantidad de dinero todos los años en reconocimiento del dominio que el concejo tenía sobre estos solares. Con el paso del tiempo, el dominio y el uso efectivo se concentraron en manos del particular.

${ }^{220}$ Este documento certifica la existencia de soportales en las plazas castellanas medievales a comienzos del siglo XV. Esta circunstancia se confirma con la anotación "solosportales" que el autor del plano de 1503 hizo precisamente junto al lado Sur de la Plaza Nueva. Así lo ponen de manifiesto SANZ ABAD (Historia de Aranda..., pp. 103-05) y SÁINZ GUERRA (La Génesis de la Plaza..., p. 230) en contraposición a lo apuntado por TORRES BALBÁS (GARCÍA Y BELLIDO, et álii., Resumen Histórico del Urbanismo Español. Madrid, 1968, pp. 163-166) quien señala que la aparición de los soportales fue tardía en el reino de Castilla. 
Así pues, a mediados del siglo XV la villa de Aranda era un núcleo urbano plenamente desarrollado con una cerca que enmarcaba sus calles, sus plazas, su caserío, sus iglesias,... Además contaba con unos arrabales que preconizan el gran desarrolló que experimentó la sociedad que vivió entre sus muros durante los años finales del siglo XV y el principio del Quinientos.

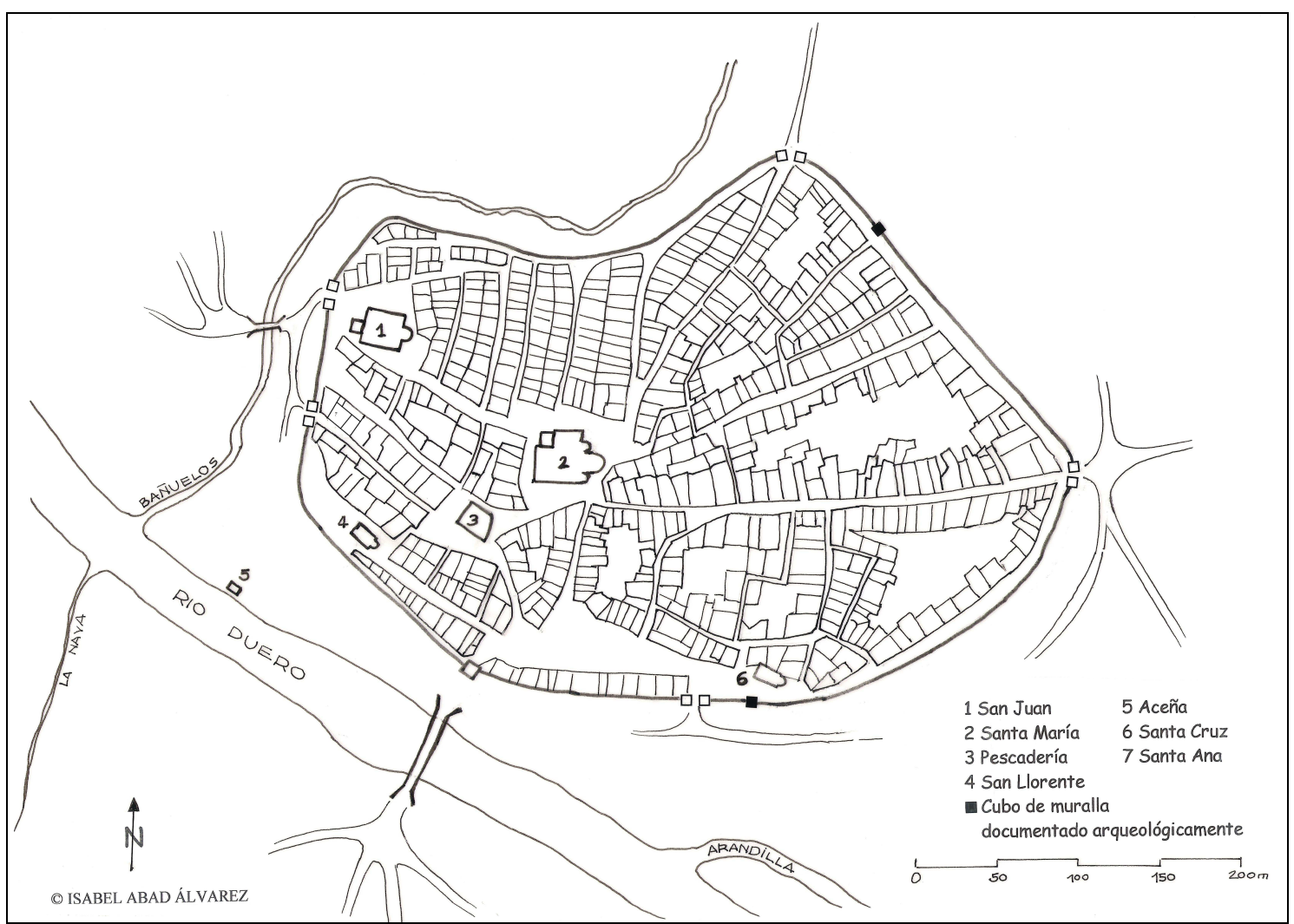

Plano 5: La villa de Aranda de Duero a finales del siglo XV.

\subsection{La estructura urbana a finales de la Edad Media.}

En este capítulo pretendemos reconstruir la estructura urbana del principal núcleo de la Ribera del Duero. Como acabamos de afirmar en el apartado anterior, la villa de Aranda ha de ser considerada una entidad urbana en sentido pleno a finales de la Edad Media a pesar de mantener en su fisionomía y dinámica bastantes rasgos de carácter rural, pues como bien señalan Valdeón Baruque y Esteban Recio “...en el Medievo, resulta prácticamente imposible señalar los límites entre ambos sectores (urbano y rural), pues los que consideramos núcleos urbanos estaban, habitualmente, penetrados de elementos rurales y, por 
su parte, las aldeas poseían a menudo rasgos distintivos que se suponen específicos de las ciudades",221.

Para ello contamos con numerosas fuentes documentales y en menor número arqueológicas. Entre las primeras es necesario destacar una fuente gráfica de primer orden: el plano de la villa de $1503^{222}$. Este documento de tan extraordinaria calidad ha sido objeto de numerosos estudios a los que ya hemos hecho referencia anteriormente y otros muchos que citaremos en las líneas siguientes. Antes de continuar con el análisis de la estructura urbana arandina creemos necesario hacer algunas matizaciones previas sobre esta representación gráfica del espacio urbano arandino.

El plano fue encargado por el corregidor de Aranda Hernando de Gamarra con la intención de ilustrar el contenido de la documentación que se presentó ante el Consejo Real para dirimir el pleito que trataron los vecinos de la calle Barrionuevo con los propietarios de unas casas en la calle del Pozo por la intención de los primeros de derribar las propiedades de los segundos para dar acceso directo desde Barrionuevo a la Plaza Pública o de Santa María, centro neurálgico de la villa. Aunque ni el corregidor ni el concejo eran parte implicada en el proceso, su intervención fue requerida por el Consejo Real que le encomendó recavar la información necesaria para abordar la problemática planteada por los vecinos. Final-

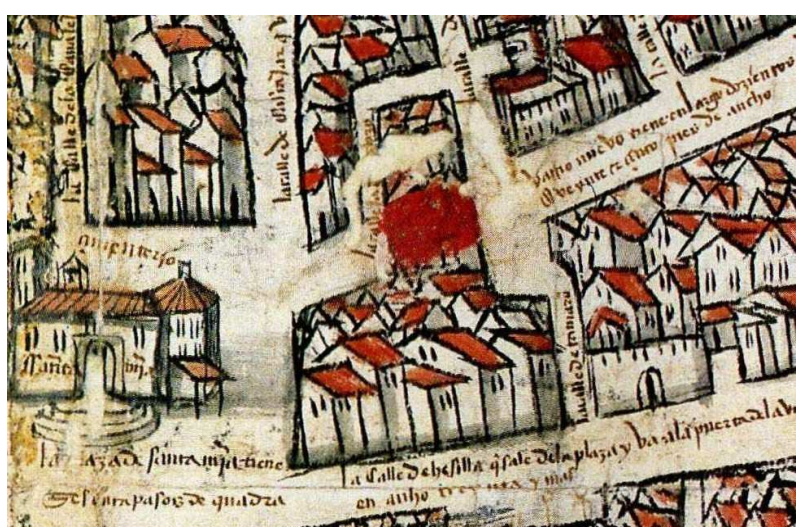
mente Gamarra redactó un informe favorable al derribo y lo acompañó con este plano para ilustrar su posición.

Imagen 2: La calle del Pozo en el plano de 1503.

El plano de Aranda de 1503 muestra una imagen bastante fiable de lo que fue la capital de la Ribera

${ }^{221}$ VALDEÓN BARUQUE, J., y ESTEBAN RECIO, A., "Esbozo de una geografía social: Palencia a fines de la Edad Media”, en Studia Historica. Historia medieval. 2, 1985, pp. 117-141.

${ }^{222}$ El plano se encuentra en el Archivo General de Simancas, en la sección de Mapas, Planos y Dibujos, leg. X, doc 1. Este plano acompañaba a la documentación de un proceso que está depositado en Consejo Real, leg. 39, doc. 3. Ambos documentos fueron estudiados y transcritos por PERIBÁÑEZ OTERO y ABAD ÁLVAREZ en Aranda de Duero. 1503. 
a finales de la Edad Media y, lo que es más importante, de cómo la veían los vecinos de aquellos años, con su cerca, sus calles y plazas, sus iglesias,... Una primera aproximación al trazado urbano de 1503 permite comprobar que su pervivencia es prácticamente completa en la actualidad pues son muy reducidas y de escasa consideración las modificaciones experimentadas desde entonces. Las causas son variadas, pero la más evidente es que este plano muestra la villa en el momento de su máximo apogeo. Desde entonces la pérdida de vitalidad fue continua hasta bien entrado el siglo $\mathrm{XX}^{223}$.

A propósito de la disposición circular observada en este plano, es conveniente señalar, como ya lo hicieran otros autores ${ }^{224}$, que responde a una idealización que tiene dos vertientes. La primera de ellas, dentro de un plano conceptual, se refiere a la idea que tenía el propio dibujante sobre su ciudad: el círculo como elemento geométrico plasmaba la figura perfecta que servía como emblema de la ciudad y la representaba. Esta imagen de la villa arandina en 1503 muestra el concepto de ciudad que tenía la sociedad de la Baja Edad Media. Ligado a este carácter ideal del plano, en los últimos años se ha planteado la posibilidad de que este plano fuera un plano-propuesta en el que las autoridades manifestaban una intención reformadora, precursora del movimiento intervencionista del siglo $\mathrm{XIX}^{225}$. Este carácter de propuesta explicaría la evidente distorsión entre lo representado en el plano y la realidad. Desde nuestro punto de vista la mayor parte de las anomalías que aparecen en el plano se deben a la concepción idealizada de la que hemos hablado y al evidente interés que tenía el corregidor, promotor de este documento, de que se reflejara en el gráfico los argumentos que esgrimía en su informe favorable: ...mi pareçer es, por aquella razon de derecho que dispone que la utilidad publica a de ser preferida a la privada utilidad, que vuestra alteza debe mandar abrir la dicha calle mandando pagar el justo valor de las dichas casas a los señores dellas ... e por que mejor sean informados para lo que sean servidos de mandar, envio a vuestra alteza pintada la dicha villa y las calles de ella. Fernando de Gamarra ${ }^{226}$.

${ }^{223}$ La evolución del urbanismo de Aranda en época moderna ha sido estudiada por ZAPARAÍN YÁÑEZ, M. J., Desarrollo artístico..., vol. I, pp. 94-158 y vol. II, pp. 343-44 y 425-26. Para la evolución urbana hasta el siglo XX son bastante ilustrativas las obras de SANZ ABAD, Historia de Aranda..., pp. 219-24, 293-300 y 311-38; y ABAD ZAPATERO, Aranda Industrial..., pp. 17-60.

${ }^{224}$ SÁINZ GUERRA, La Génesis de la Plaza..., p. 117-18; del mismo autor "Desarrollo urbanístico... pp. 41-56; y IGLESIAS BERZOSA y VILLAHOZ GARCÍA, Viñedo, Vino y Bodegas..., pp. 28-29.

${ }^{225}$ SÁINZ GUERRA, “Desarrollo urbanístico..., pp. 54-55.

${ }^{226}$ AGS, CR, leg. 39, doc. 3, transcrito por PERIBÁÑEZ OTERO y ABAD ÁLVAREZ, Aranda de Duero..., pp. 197-198. 


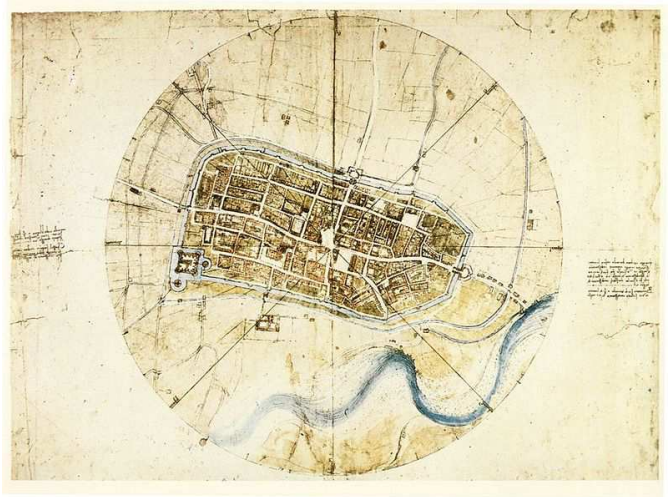

Imagen 3: Plano de Imola de Leonardo Da Vinci.

La segunda vertiente responde a cuestiones materiales. En este sentido, es necesario matizar que el plano, como no podía ser de otra forma, no es perfecto. Esta imperfección es el resultado de lo comentado en el punto anterior y también de las dificultades técnicas, pues a finales de la Edad Media todavía no se dominaba la triangulación matemática y la geometría por lo que la proyección de la realidad en un plano resultaba necesariamente imperfecta ${ }^{227}$. En este sentido, el profesor Kagan señala que hasta la traducción al latín de la Geographia de Ptolomeo en 1410 no llegaron a Europa los conocimientos técnicos necesarios para el desarrollo de la cartografía. En Europa persistía una tradición cartográfica simbólica, en la que sin lugar a dudas se debe encuadrar el plano de Aranda. La diferencia entre la cartografía científica y la simbólica es fácilmente perceptible si comparamos la representación arandina con la impresionante vista icnográfica que realizó por aquellos años Leonardo Da Vinci de la ciudad de Imola ${ }^{228}$. En relación con el desarrollo científico de la cartografía es cuanto menos curioso que precisamente en 1503 se creó en Castilla el primer servicio cartográfico en la Casa de Contratación de Sevilla ${ }^{229}$.

Por otra parte, el plano se centra en un problema concreto por lo que se omiten elementos que el autor considera accesorios como pueden ser los arrabales. Así, a pesar de que en el documento escrito que acompañaba al plano se mencionaban los diferentes arrabales de la ciudad, en el plano aparecen reflejados mínimamente, reduciéndose al dibujo de unas casas al Sur del puente Duero y de otras similares en el extremo Norte del mismo ss.

${ }^{227}$ KAGAN, R. L., Imágenes urbanas del mundo hispánico: 1493-1780. Madrid, 1998, pp. 98 y

${ }^{228}$ Colección de la reina Isabel II, Castillo de Windsor. Más detalles sobre las características de este plano en KEMP, M., Leonardo da Vinci. Las maravillosas obras de la naturaleza y el hombre. Madrid, 2011, pp. 235-236.

${ }^{229}$ CEREZO MARTÍNEZ, R., La Cartografia Náutica Española en los Siglos XIV, XV y XVI. Madrid, 1994, p. 51. 
puente. En definitiva, el resto de los arrabales simplemente no aparecen debido a su intrascendencia en el asunto que motivó la realización del plano que sólo implicaba al espacio intramuros.

Tras estas matizaciones a propósito de una de las principales fuentes para el estudio del urbanismo de la Aranda bajomedieval, pasemos a analizar cada uno de los elementos más significativos de la estructura urbana de la villa.

\subsubsection{La muralla: cerca, cavas y puertas.}

Es un recurso obligado citar al sabio Alfonso X y Las partidas para hacer referencia a la muralla como el elemento diferenciador de una ciudad pues en la Séptima Partida la ciudad es definida como ...todo aquel lugar que es cercado de los muros, con los arrabales et edificios que se tienen con ellos ${ }^{230}$. En la mente del legislador y también en la de los hombres y mujeres del medievo se identificaba claramente espacio urbano con muralla, pero además estos núcleos participaban de otra serie de elementos que los diferenciaba del medio rural predominante.

Estos rasgos diferenciadores se refieren a una cantidad variable de población, cierta densidad de ocupación, el predominio de las actividades artesanales y comerciales sobre las primarias, la presencia de una institución diocesana importante o el disfrute por parte de sus vecinos de un fuero propio. No obstante, ninguno de estos elementos es excluyente como lo demuestra la amplia diversidad de realidades urbanas que conviven en la Europa cristiana en general y en Castilla en particular ${ }^{231}$.

En este sentido, la cerca o muralla se erigió en el emblema de la villa y en símbolo de la unidad lograda por el conjunto de los habitantes. Suponemos que, al igual que ocurrió en la cercana localidad de Roa y en otros núcleos urbanos castellanos, la construcción de la cerca arandina corrió a cargo de los propios vecinos, tanto de los habitantes intramuros como de los moradores de la Tierra arandina ${ }^{232}$.

${ }^{230}$ Séptima Partida, Título 33, ley 6 (Las siete partidas del Rey Don Alfonso el Sabio. Ed. Real Academia de la Historia, 1973, vol. III, p. 720).

${ }^{231}$ RENOUARD, Y., Les villes d'Italie de la fin du X siècle au debut du XV siècle. París, 1969, pp. 43-51; VALDEÓN BARUQUE, J., "Reflexiones sobre las murallas urbanas de la Castilla medieval", en La ciudad y sus murallas. Madrid, 1991, pp. 67-88; y una visión general de la Castilla septentrional se muestra en la obra colectiva de SOLÓRZANO TELECHEA, J. A. y ARÍZAGA BOLUMBURU, B., El fenómeno urbano medieval entre el Cantábrico y el Duero. Santander, 2002.

${ }^{232}$ LOPERRÁEZ CORVALÁN, Descripción Histórica..., vol. III, doc. LXXIX, pp, 231-233; Y GARCÍA BELLIDO et álii, Resumen Histórico del Urbanismo..., p. 138. 
Pero además de hacerse cargo de su construcción, este objeto de orgullo para la villa se convirtió con el tiempo en un penoso, costoso y continuo problema para los arandinos que debían hacerse cargo de su mantenimiento y reparación. En este sentido es bastante significativo que casi todas las referencias documentales con las que contamos sobre la cerca de Aranda se refieran precisamente a las quejas del concejo y los vecinos a propósito de su estado deplorable, la necesidad de su reparación y la precariedad de los propios para hacer frente a este gasto constante.

Bien es cierto que en tiempos de guerra era necesario mantener este elemento de seguridad en buenas condiciones, como ocurrió durante los conflictos bélicos en los que la villa se vio inmersa durante buna parte de la segunda mitad del siglo XV. Así lo reconoció el monarca Enrique IV cuando en 1460 decidió conceder a la villa el privilegio de exención del impuesto de la moneda forera argumentando que los vecinos ...han fecho grandes gastos e costas ansi en el guardar y velar de la dicha villa como en el adobo e reparo de los muros e cerca della por la tener como la tenedes a mi servicio ${ }^{233}$. Pero el dispendio continuó en periodos de paz como lo muestra el hecho de que las autoridades locales solicitaran sendas licencias a los monarcas en 1499 y en 1510 para echar sisa sobre los mantenimientos con el fin de sufragar los reparos de la cerca, argumentando que con los propios no era suficiente para hacer frente a todos los gastos ${ }^{234}$. El elevado coste de este mantenimiento, unido a su importancia, llevó a las autoridades a dividir la muralla en sectores y asignar a los vecinos de esas demarcaciones la obligación de vigilar y mantener el tramo correspondiente en perfectas condiciones. En este sentido, era obligatorio para los vecinos que tenían su casa adosada a la cerca encargarse del mantenimiento del tramo paralelo a su vivienda ${ }^{235}$.

Las murallas son elementos típicos de las civilizaciones que viven una situación de inestabilidad. Obviamente la primera función de la cerca medieval era la de proteger a los vecinos que en ella se cobijaban de los enemigos que, como ya hemos visto, fueron bastante abundantes y diversos en el periodo bajomedieval. Esta protección en ocasiones sobrepasaba el ámbito de nuestra lógica y se trasladaba a ámbitos menos tangibles como el del

${ }^{233}$ AMA, leg. 43, doc. 18 .

${ }^{234}$ AGS, RGS, 149901, fol. 188; CR, leg. 40, doc. 8; y CC PUEBLOS, leg. 13, doc. 7. El elevado coste del mantenimiento de las murallas no fue privativo de la villa de Aranda. Una de las hijas del primer conde de Miranda estimaba que su padre se había gastado ocho cuentos de maravedíes en la reparación de la fortaleza y murallas de Haza (ARChV, RRE, Caja 154, doc. 2).

${ }^{235}$ AGS, RGS, 149901, fol. 188. 
miedo o el temor, siendo habituales los episodios en los que se procedía a reparar la cerca ante las noticias que avisaban de la llegada de la peste.

Las murallas de la villa desempeñaron otras funciones complementarias de la defensiva. Entre éstas destaca en primer lugar la función jurídica pues el recinto murado diferenciaba jurídicamente a los vecinos intramuros, poseedores de una serie de privilegios, de los habitantes extramuros. No obstante, a finales de la Edad Media esta diferencia no estaba tan clara. Así se observa, por ejemplo, en la concesión de la exención de los pedidos y la moneda forera por parte de Enrique IV en 1467. En ella se establece que tanto los vecinos intramuros como los de los arrabales disfrutarían de este privilegio, excluyendo explícitamente a los moradores de la Tierra arandina ${ }^{236}$.

Más definida aparece otra de las funciones de la muralla que tiene que ver con la actividad mercantil y la fiscalidad. El concejo a través de sus fieles o los arrendadores de rentas se encargaban tanto de controlar todos los productos que se introducían a través de las puertas, como de imponer los correspondientes impuestos locales o generales. En este contexto es en el que debemos encuadrar la prohibición de desarrollar actividades comerciales que impusieron los regidores a los moradores del arrabal de Allendeduero en $1490^{237}$.

Los historiadores de la ciudad medieval también han identificado otras funciones menos tangibles pero igualmente significativas. Entre ellas destaca la simbólica, pues la muralla se configura como un elemento de ennoblecimiento del núcleo urbano, transformándose en emblema del poder municipal. En este mismo sentido, conviene tener en cuenta que una torre o fortaleza fue el símbolo empleado en el escudo municipal para representar a la villa ${ }^{238}$. Redundando en este aspecto, no es baladí que cuando la princesa Isabel acudió en 1473 a la villa, las autoridades municipales la recibieron en el arrabal y no le

236 ...que no gocen ni puedan gozar de la dicha merced e franqueza en la dicha mi carta contenida salvo los bezinos e moradores de la dicha villa de Aranda e de los dichos sus arravales según y en la manera que en la dicha mi carta es contenido; e no las otras personas vezinos e moradores assi de los lugares e tierra de la dicha villa de Aranda, como de otras qualesquier ciudades villas e lugares del mi realengo e principado como quier que se vengan e bayan a bivir e bivan e moren en la dicha villa de Aranda y en los dichos sus arravales e las que vengan con cargo (AMA, leg. 43, doc. 18).

${ }^{237}$ AGS, RGS, 149002, fol. 176. Aspecto que veremos con detenimiento más adelante en el apartado dedicado a los conflictos.

${ }^{238}$ PERIBÁÑEZ OTERO, J. G., "La pugna por el poder en la villa de Aranda de Duero a finales de la Edad Media: Élites, comunidad e injerencia nobiliaria”, en La gobernanza de la ciudad europea en la Edad Media. Logroño, 2011, pp. 131-161, en concreto pp. 138-139. 
franquearon el paso de las murallas hasta que no confirmó los antiguos privilegios arandi$\operatorname{nos}^{239}$.

En otro orden de cosas, la muralla también se utilizó como elemento de segregación y así lo observamos en la construcción de una cerca en 1486 que delimitaba la morería arandina ${ }^{240}$.

El sistema defensivo de la villa de Aranda a finales del medievo estaba definido por una cerca con cinco puertas y un postigo, más un foso en aquellas zonas del recinto que no presentaban un desnivel acusado de carácter natural.

La cerca tenía una forma ovalada ligeramente irregular, algo habitual en las villas medievales del occidente europeo ${ }^{241}$. Aproximadamente el recinto murado arandino englobaba una superficie de 13,2 hectáreas $\left(132.000 \mathrm{~m}^{2}\right)^{242}$.

La muralla que se representa en el plano de 1503 aparece continua, sólo interrumpida por las puertas, con lienzos homogéneos rematados por almenas. No se aprecian cubos ni tampoco adarve. Sin embargo, las noticias documentales y arqueológicas testimonian una cerca bastante diferente. Por la información con la que contamos, sabemos que al menos desde 1432 la cerca contaba con un adarve o pasillo por el que se realizaban los servicios de guardia y vigilancia ${ }^{243}$. Además evidencias fotográficas y arqueológicas muestran la existencia de cubos a lo largo de la cerca. Recientes derribos de antiguos edificios han permitido sacar a la luz varios tramos del lienzo de la cerca junto a algunos vestigios de estos cubos.

Entre las actuales calles de Santa Lucía y Postas, con motivo de la demolición del inmueble $\mathrm{n}^{\mathrm{o}} 6$ de la primera de ellas, se documentó arqueológicamente un tramo de muralla y un cubo. El lienzo tenía una longitud de algo más de doce metros con una altura superior a los cinco metros y un grosor que rondaba los dos metros y medio. Para su construcción se utilizaron sillares, mampuesto y tapial. El cubo era de planta rectangular, tenía unas dimensiones de 5 × 3 metros y alcanzaba una altura de tres metros.

\footnotetext{
${ }^{239}$ BONACHÍA HERNÁNDO, "El desarrollo urbano..., p. 23.

${ }^{240}$ AGS, CC MEMORIALES, leg. 163, doc. 57.

${ }^{241}$ GUTIÉRREZ GONZÁLEZ, J. A., Fortificaciones y Feudalismo en el origen y formación del
} Reino Leonés (siglos IX-XIII). Zaragoza, 1995, pp. 55-60.

${ }^{242}$ BENITO MARTÍN, La formación de la ciudad..., p. 103.

${ }^{243}$ VELASCO PÉREZ, Aranda. Memorias..., p. 87. 


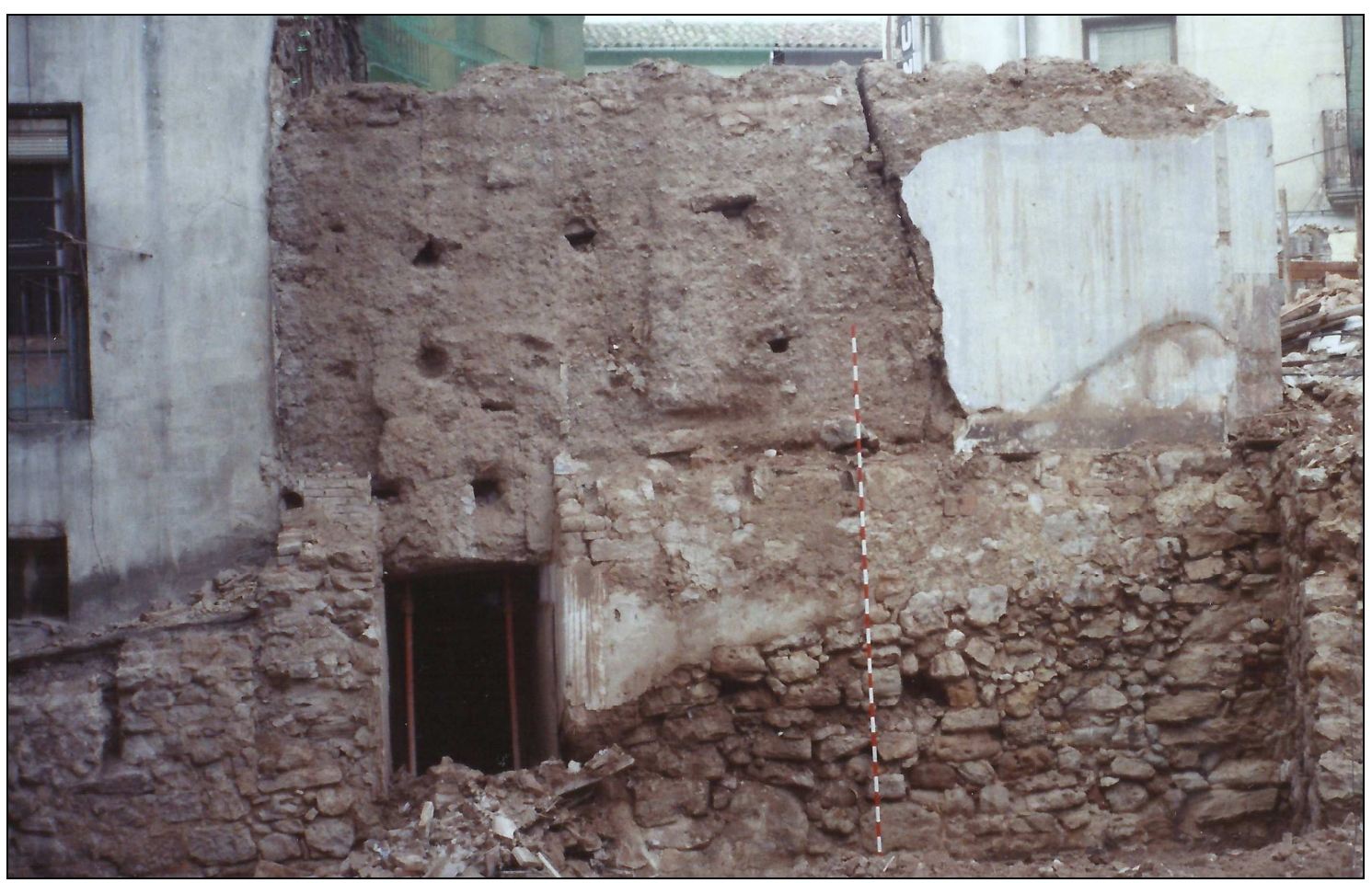

Imagen 4: Detalle del lienzo identificado en la excavación arqueológica de la calle Santa Lucía nº 6.

Este mismo cubo y parte del lienzo se pueden apreciar en una fotografía de Las Traseras que se realizó a principios del siglo XX, antes de la construcción del Cine Aranda. Cabe destacar que en esta intervención no se pudo comprobar la existencia de una zanja de cimentación, pero sí que se documentó un rebaje en el suelo natural por el exterior de la cerca de casi dos metros de profundidad, con lo que la altura hacia el exterior de la cerca sería mucho mayor que hacia el interior ${ }^{244}$.

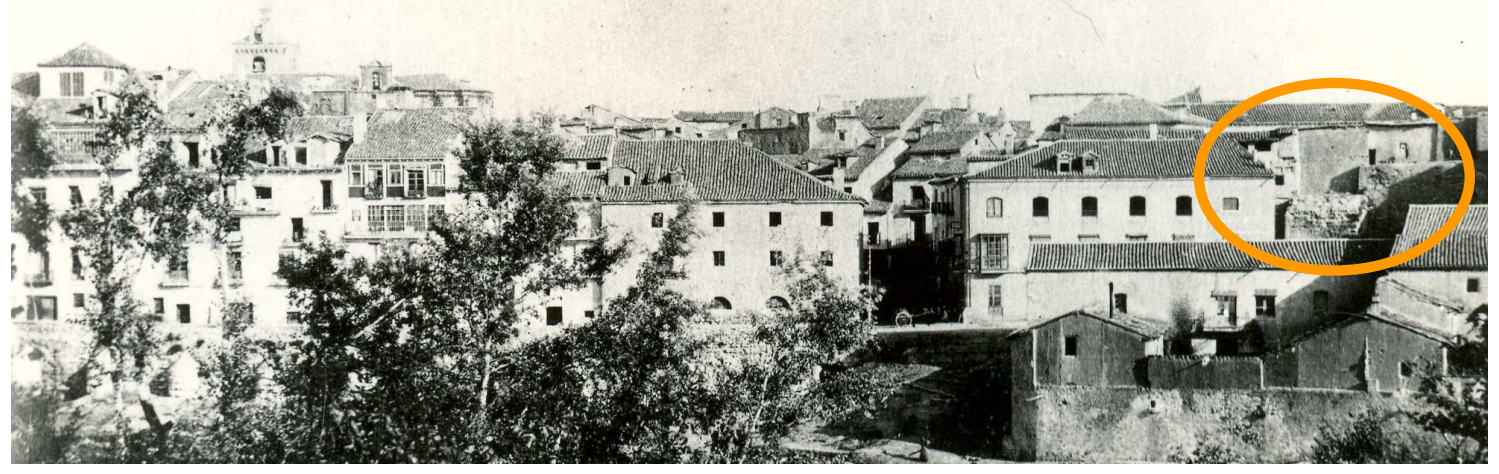

Imagen 5: Fotografía de Las Traseras en la que se aprecia un cubo de la muralla.

${ }^{244}$ CRISTÓBAL VILLANUEVA, E., Informe técnico sobre el seguimiento arqueológico llevado a cabo en el inmueble $n^{\circ} 6$ de la calle de Santa Lucía, en Aranda de Duero (Burgos), con motivo del desmantelamiento de 13 metros de la muralla que circundaba su casco histórico. Febrero-abril de 1992. Depositado en el Servicio Territorial de Cultura de Burgos. 


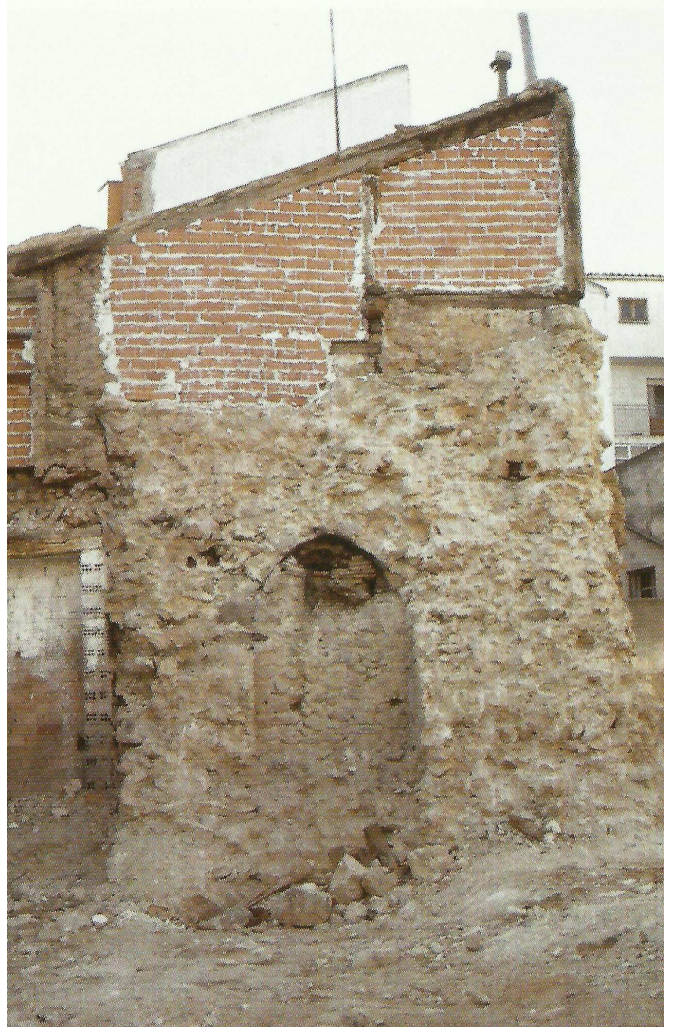

mente metro y medio ${ }^{245}$.
Imagen 6: Detalle del cubo localizado en Puerta Nueva ${ }^{\circ} 38$.

Un nuevo cubo apareció en la demolición del solar $n^{0} 38$ de la calle Puerta Nueva. Este cubo medía cinco metros de ancho por otros cinco de profundidad y una altura máxima hacia el espacio intramuros de casi siete metros, mientras que hacia el exterior superaba los nueve metros. El cubo presentaba la peculiaridad de que estaba horadado por un pasillo cubierto por una bóveda ojival que lo recorría de lado a lado, paralelo a la cerca. Además bajo este pasillo se encontraba un pozo de agua a una profundidad de aproximada-

El lienzo exterior de la muralla también se documentó arqueológicamente en la llamada "Casa de los Juzgados", en la calle Postas. En las obras de rehabilitación de este edificio se constató la existencia de un tramo del lienzo de la muralla de algo más de ocho metros de largo y una altura aproximada de cuatro metros. Este muro tenía una anchura de dos metros y estaba construido mediante dos lienzos paralelos de grandes bloques de mampostería entre los cuales se observa un relleno de piedra y argamasa de calicanto. Este paramento se conserva todavía en la pared Norte del edificio, sirviendo de medianero con el edificio que tiene su fachada en la Plaza Mayor ${ }^{246}$.

Recientemente el derribo de una casa en la calle Ronda $n^{\circ} 10$ ha sacado a la luz lo que parece un tramo del lienzo de la muralla que se encontraba embutido en la construcción. Los restos que se conservan apenas permiten apreciar las características del

${ }^{245}$ CRISTÓBAL VILLANUEVA, E., Informe técnico del seguimiento arqueológico realizado durante el derribo y vaciado del inmueble $n^{\circ} 38$ de la calle Puerta Nueva, de Aranda de Duero (Burgos). Febrero 1994. Depositado en el Servicio Territorial de Cultura de Burgos.

246 PALOMINO LÁZARO, A. L., Informe Técnico. Documentación arqueológica Casa de los Juzgados Aranda de Duero (Burgos).1998. Depositado en el Servicio Territorial de Cultura de Burgos. 
muro ni sus dimensiones originales. A falta de un estudio más riguroso nos limitaremos a considerarlo como un posible resto de la cerca primitiva a tenor de su localización entre las calles Ronda y Ricaposada.

La suma de las referencias documentales y arqueológicas muestran una cerca con unas características que recuerdan las de la cerca que ordenó construir en 1295 doña Violante en la cercana localidad de Roa. En el documento se especifica que ...haian andamio (adarve), e antepecho, e almenas; et el andamio sea atal que pueda hi bien andar omme bien armado, e armar vallesta en todo logar del cerco, e la cerca que sea de seis tapiales de alto (cinco metros aproximadamente), sin el antepecho, e sin las almenas; e el antepecho e las almenas sean encalado, porque se non derroquen ${ }^{247}$.

De todas formas, la cerca no se mantuvo rígida e inmóvil tras su configuración del Cuatrocientos. Un testimonio bastante revelador de esta situación la transmite el regidor arandino Pedro de Mora que en 1499 informó de que varios vecinos de la Plaza Nueva que tenían sus casas adosadas a la muralla pretendían ensancharlas. Para ello solicitaron a las autoridades que les cedieran suelo, ...los quales diz que gelo dieron hazia la parte del Duero con la condición que los dichos dueños ...oviesen de facer e fiziesen la cerca de cal e canto a la medida e altor de la que la dicha villa tiene junto a la dicha puerta de Duero; e que dejasen la ronda hueca e libre en lo alto como de antes estaba para que la dicha villa se pudiese rondar e andar por ella un hombre con lan$c ̧ a^{248}$. De manera que en el sector Sur de la Plaza Nueva la primitiva cerca creada a principios de ese mismo siglo fue derribada, o quizá integrada dentro de las nuevas construcciones, y fue adelantado su emplazamiento unos metros en dirección Sur. A buen seguro que este procedimiento se reprodujo en todo el contorno de la cerca cuando se amortizó bastante tiempo después, como se ha podido comprobar en las escasas intervenciones arqueológicas que se han realizado sobre la muralla arandina.

A pesar de la relativa elasticidad de la cerca, adaptándose al crecimiento de la población, su existencia también comportó una serie de desventajas. Dos son los principales problemas que hemos detectado en este sentido. Por una parte, las noticias documentales que hacen referencia a la cerca de finales de la Edad Media muestran una muralla con

${ }^{247}$ LOPERRÁEZ CORVALÁN, Descripción Histórica..., vol. III, doc. LXXIX, pp, 231-233. Esta descripción poco tiene que ver con la calidad de los restos de muralla que se conservan en la actualidad en los que predomina sobre todo la mampostería.

${ }^{248}$ AGS, RGS, 149905, fol. 173. 
un aspecto poco atractivo y se insiste en la necesidad de su reparación, pues esta cayda y aportillada por algunas partes ${ }^{249}$.

De manera habitual el concejo o los vecinos informaron a los monarcas de que había partes que estaban derribadas pues la çerca es de tapia vieja y buena parte de sus muros estaban fechos de tierra muerta, que se deteriora por las grandes aguas que ha hecho este ynvierno ${ }^{250}$. La escasa diligencia que mostraron las autoridades locales para poner solución a esta situación obligó a los monarcas a recordarles con frecuencia que la mitad de las penas impuestas en la villa debían ser destinadas al reparo de los muros ${ }^{251}$. Aún así, en ocasiones fue necesario recurrir a medidas extraordinarias como la concesión de varias licencias para echar sisas sobre los mantenimientos, como la que se hizo efectiva en 1499 por un montante de 50.000 maravedíes $^{252}$.

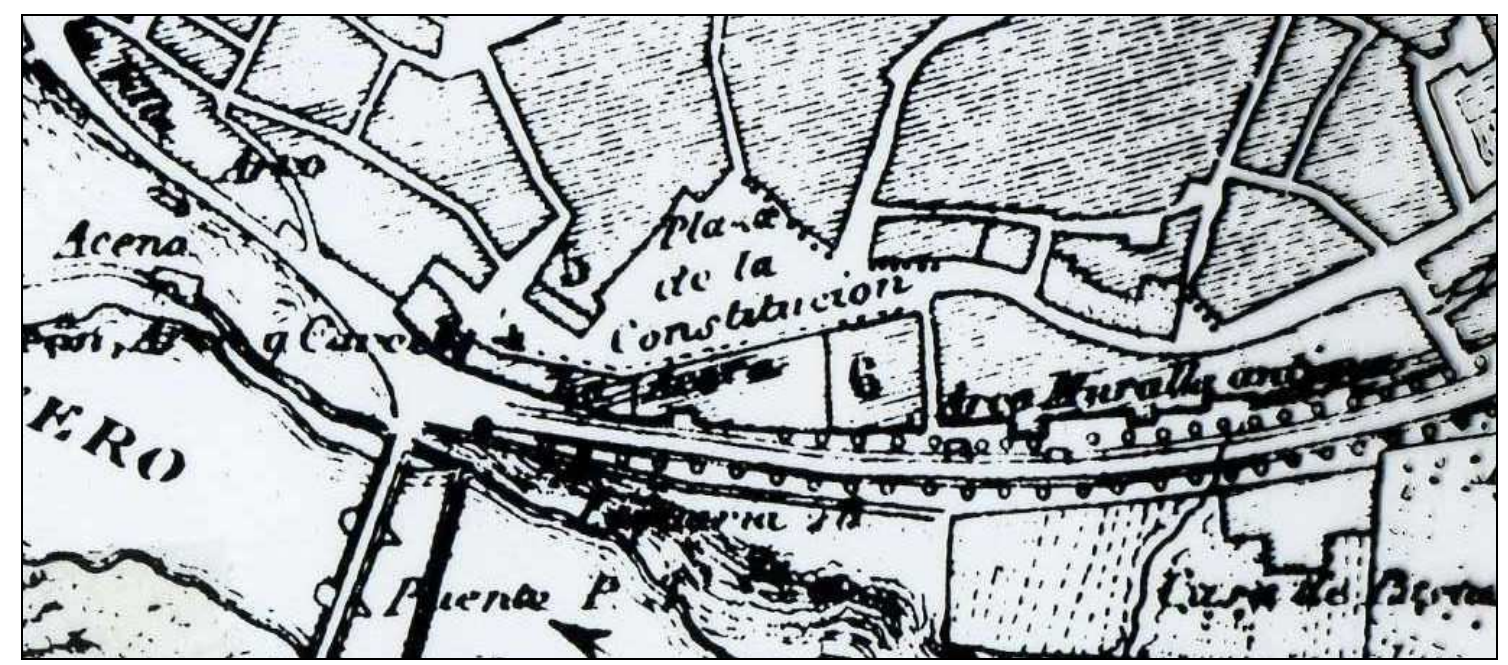

Imagen 7: Detalle de los lienzos de la muralla que aparecen en el plano de Coello de 1868.

${ }^{249}$ AGS, RGS, 149512, fol. 31. En 1503 los vecinos denunciaban que la cerca estaba mal reparada y aportillada (AGS, CC PUEBLOS, leg. 2, doc. 92). En 1510 el concejo solicitaba permiso a la reina para poder echar una sisa para el reparo de los muros (leg. 13, fol. 7). En 1515 algunos vecinos denunciaban que el concejo quería gastarse cierto dinero en el proyecto de traer el agua del Aranzuelo a la villa mientras tenía derrumbados ciertos tramos de la cerca (CR, leg. 40, doc. 40).

${ }^{250}$ AGS, CC MEMORIALES, leg. 152, doc. 116; y RGS, 149901, fol. 188.

251 AMA, leg. 42, doc. 3, transcrito por HURTADO QUERO, Documentos Reales..., doc. 26, pp.50-52; y AGS, RGS, 149802, fol. 40.

${ }^{252}$ AGS, RGS, 149905, fol. 146. Otra solución era el establecimiento de derramas entre los vecinos como la que se documenta en 1514 en la cercana localidad de Caleruega cuando se recogieron 2.700 maravedíes de los vecinos para reparar las puertas de la villa y construir la picota (AGS, CC PUEBLOS, leg. 5, doc. 67). 
La precariedad de la cerca continuó a lo largo del siglo XVI pues a finales de los años treinta el regidor Antonio Miranda se encargó de reconstruir algunos tramos de la muralla cerca de la calle del Toledano y en 1564 se reparó de nuevo buena parte de la cerca con el fin de evitar que entrara la peste ${ }^{253}$. Algunos tramos más de la muralla pervivieron al menos hasta el siglo XIX como podemos apreciar en el plano de Coello de 1868 donde se perciben lienzos y cubos en la calle Postas y en el Espolón.

Por otra parte, el segundo problema tenía que ver con la evacuación de las aguas residuales. En la villa apenas existían en este periodo más medios de evacuación de residuales que la filtración y la gravedad ${ }^{254}$. No es de extrañar por lo tanto que las calles de Aranda se definieran por una mezcla de basura, excrementos y lodos, aspecto del todo habitual en las calles de las ciudades castellanas. Sin embargo, había dos espacios que presentaban especiales problemas en este sentido debido a la interacción entre la configuración topográfica del terreno y el emplazamiento de la cerca. Se trataba de la Plaza Nueva y la calle del Hocino. En el primer espacio vertían las aguas tanto de la calle Hesilla y sus adyacentes por el Norte como de la Ronda por el Este. La principal vía de evacuación fue la puerta de Santa Cruz por lo que no se produjeron problemas significativos en este periodo, aunque poco después se construyeron las alcantarillas de la cárcel y carnicerías, espacios que se encontraban adosados a la cerca ${ }^{255}$. En el segundo de los espacios, la calle del Hocino, desaguaba la calle de San Juan por el Norte y el espacio urbano de la ermita de San Llorente por el Sur, pero, sobre todo, se evacuaban las fétidas aguas que provenían de la pescadería junto a los residuos de la actividad mercantil desarrollada en la Plaza Pública. No es de extrañar que cuando la comunidad judía fue trasladada allí en 1480 solicitara la apertura de un portillo en la cerca al final de esta calle, argumentando que ...por el dicho postigo podiesen manar e salir todas las dichas aguas e lluvias quando acaesçiesen o viniesen $^{256}$. Tras la expulsión de los judíos el portillo fue clausurado pero los nuevos vecinos

${ }^{253}$ VELASCO PÉREZ, Aranda. Memorias..., pp. 176 y 254-55.

${ }^{254}$ En el proyecto de canalización del Aranzuelo se propuso la construcción de varios caños para aprovechar el agua y guiandole por la villa ... sera cosa de mucha limpieza para las calles (AGS, CR, leg. 40, doc. 8).

${ }^{255}$ MADOZ señala que a mediados del siglo XIX había dos alcantarillas: la de la cárcel y la de las carnicerías. Ambas vertían al Duero en un recorrido bastante corto de aproximadamente 20 metros (Diccionario Geográfico..., vol. II, p. 50).

${ }^{256}$ AGS, RGS, 148608, fol. 71. 
volvieron a solicitar la reapertura del postigo alegando idénticos argumentos ${ }^{257}$. Incluso años después, cuando la calle se pobló de ilustres vecinos como don Juan de Acuña que construyó un magnífico palacio en el que se albergó el mismo monarca don Fernando, la calle todavía recibía la denominación de albollon ${ }^{258}$.

Junto a la muralla, y sirviendo de complemento defensivo a ésta, se encontraban los fosos o "cavas". La disposición de Aranda en la confluencia del Bañuelos con el Duero posibilitó el aprovechamiento del desnivel natural en los sectores junto a los ríos como verdadero foso defensivo por sus flancos Norte, Oeste y Sur. Sin embargo, el sector Este de la villa se encontraba desprotegido por lo que a la muralla se le añadió un foso. Estas cavas han sido constatadas arqueológicamente en la intervención realizada en el solar $n^{\circ} 43$ de la calle Postas y también se ha apreciado indirectamente en el solar $n^{\circ} 6$ de la calle Santa Lucia y en el no 38 de la calle Puerta Nueva. Seguramente el sistema constructivo de la muralla arandina ya implicaba el rebaje del espacio extramuros respecto al intramuros como se pone de manifiesto en la intervención arqueológica de Santa Lucia con un desnivel de casi dos metros y en Puerta Nueva con dos metros y medio. Esta medida conseguía potenciar la imagen vertical de la muralla vista desde el exterior.

La documentación escrita también hace referencia a la existencia de este foso que se extendía desde la depresión del Bañuelos hasta la puerta de Santa Cruz. El carácter defensivo de este elemento se mantenía todavía a principios del XVI como lo pone de manifiesto un vecino que propuso que se trajera el agua del Aranzuelo de tal manera que ...vendria derechamente hasta la çerca e cabas de la dicha villa que sera cosa de mucho provecho para la fortalesçer en tiempo de movimientos e guerras ${ }^{259}$. La documentación también nos informa de que este foso llevaba agua que tomaba de la fuente que diçen en las cavas de la puerta de Hesilla, aunque seguramente se trataba de un caudal modesto. Ocasionalmente el foso se llenaba de agua produciendo daños como ocurrió hacia 1480 cuando estaban ...las cabas de esta villa llenas de agua e que ha

${ }^{257}$ AGS, RGS, 149206, fol. 217.

${ }^{258}$ ARChV, RRE, Caja 259, doc. 5. Albollón es definido por la RAE como desaguadero de estanques, corrales, patios... También es sinónimo de albañal que es un canal o conducto que da salida a aguas inmundas (voces albañal y albañal en el Diccionario de la lengua española de la Real Academia Española, 22a ed.).

$$
{ }^{259} \text { AGS, CR, leg. 40, doc. } 8 .
$$


visto que algunas bodegas que estan çerca dellas se remanavan..., por lo que fue necesario ...sacar la dicha agua de las bodegas $^{260}$.

Imagen 8: La Puerta de Duero.

El último de los elementos del sistema defensivo arandino al que haremos mención son las puertas. Durante la Baja Edad Media el recinto contaba con cinco puertas, a las que se añadieron dos postigos, uno a finales de los años

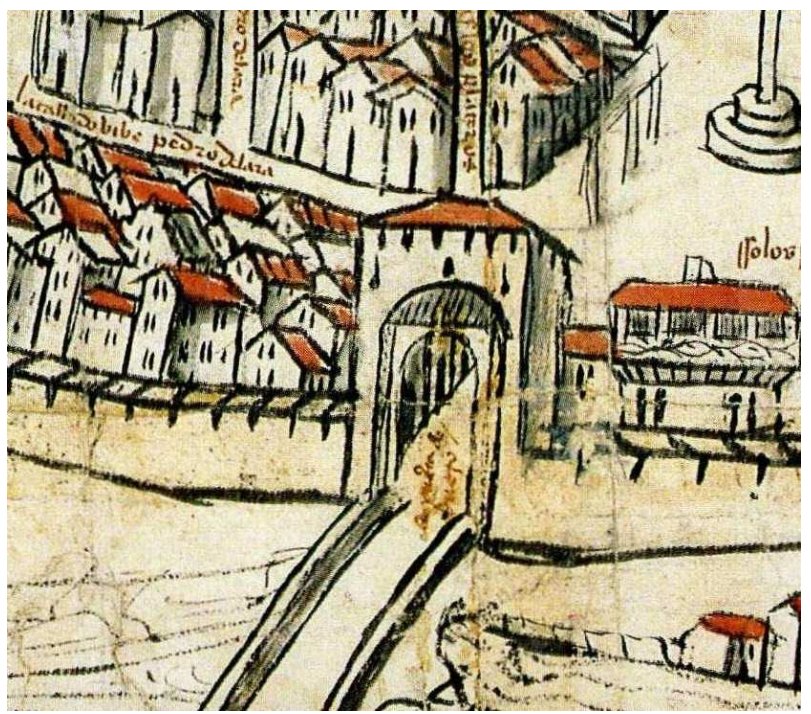
ochenta del siglo XV y otro a finales del periodo que tratamos. De todas ellas conservamos referencias documentales pe-

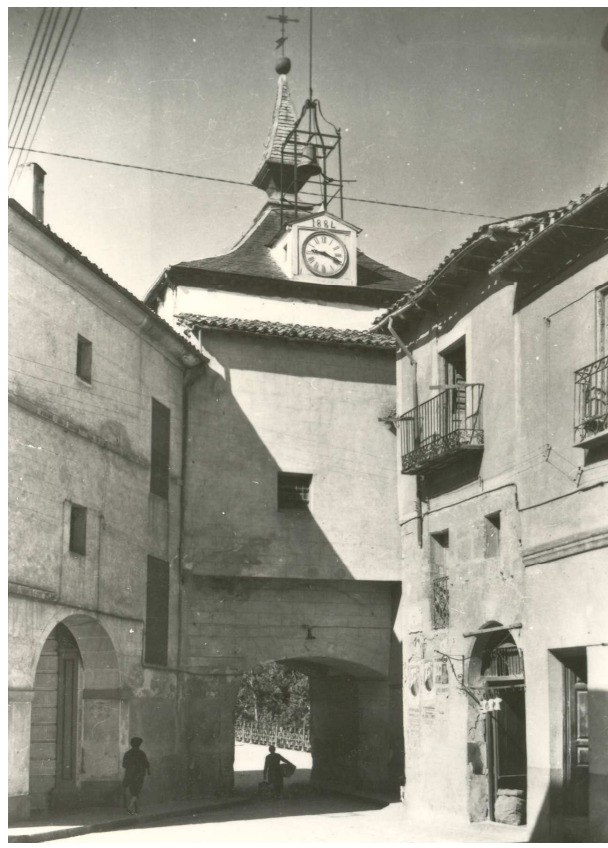
ro, salvo una parte del portillo de Puerta Nueva, en la actualidad han desaparecido.

\section{Imagen 9: La Puerta de Duero a mediados del siglo XX (CBMAD).}

La Puerta de Duero o Endeduero es sin lugar a dudas la más importante de todas ellas ${ }^{261}$. Sanz Abad señala que, debido a su carácter defensivo y el control que ejercía sobre el paso del Duero, esta puerta sería el castellum del que habla la documentación del siglo $\mathrm{XI}^{262}$. Este singular edificio albergaba en su parte superior una sala en la que en ocasiones se reunía el con-

${ }^{260}$ Las referencias a la fuente de Hisilla como a este testimonio de las bodegas se encuentran en AGS, CR, leg. 40, doc. 8 .

261 ...junto con la çerca de la dicha villa diz que ay una hazera de casas desde la puerta que diz Ende Duero fasta la de Santa Cruz (AGS, RGS, 149905, fol. 173).

${ }^{262}$ SANZ ABAD, Historia de Aranda..., p. 100. 
cejo $^{263}$. Además de estas funciones comentadas también pudo usarse como cadalso a tenor de las declaraciones de algunos vecinos de la tierra de Montejo que aseguraban que los alcaldes de la villa les amenazaron con que los ponia a cada uno de ellos en un palo y que al alcaide de Montejo lo colgarían de una puerta ${ }^{264}$. En el plano de 1503 se aprecia perfectamente este segundo cuerpo que contaba con varias aspilleras. El conjunto estaba rematado por una terraza almenada y cubierta con un tejado a cuatro vertientes $^{265}$. Asimismo parece intuirse en el dibujo la existencia de un rastrillo, previo a la puerta propiamente dicha.

En el siglo XIX todavía se conservaba con su configuración más o menos original y permaneció embutida dentro de las sucesivas remodelaciones hasta que en 1971 salió a la luz en la rehabilitación del Ayuntamiento y fue desmontada como se aprecia a través de la documentación fotográfica.
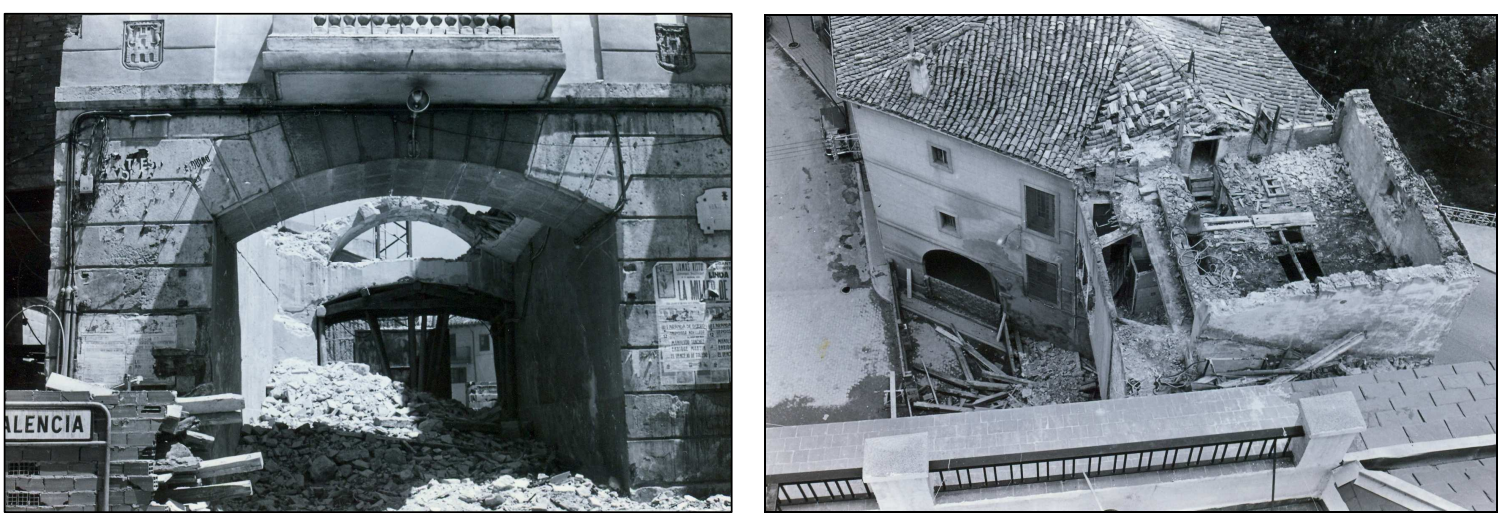

Imagen 10: Remodelación del Arco en 1971 (CBMAD).

La Puerta de Santa Cruz recibía su nombre de la cercana ermita de Santa Cruz $^{266}$. Se encontraba al final de la Plaza Nueva y presentaba una morfología muy simple con un único cuerpo rematado por una terraza almenada. Todavía en el plano de Coello de 1868 se señala con la denominación de arco.

${ }^{263}$ En muchas ocasiones se mencionan las casas del Concejo sin que sepamos en concreto si se refiere a la sala que estaba encima de la torre o al edifico colindante.

${ }^{264}$ AGS, CR, leg. 22, doc. 1. Estas declaraciones se deben tomar con cierta cautela pues son realizadas por los vasallos del conde de Miranda en el contexto del enfrentamiento entre la villa de Aranda y el conde por la jurisdicción del lugar de Milagros.

${ }^{265}$ CADIÑANOS BARDECI, I., Arquitectura fortificada en la provincia de Burgos. Madrid, 1987 , pp. 338-339.

${ }^{266}$...una de las puertas que se dize de Santa Cruz (AGS, CR, leg. 40, doc. 8). 
La Puerta de Hesilla se localizaba en el extremo Este de la villa y recibía el nombre de la calle al final de la cual se asentaba ${ }^{267}$. En el siglo XVIII todavía se conservaba según las informaciones del Catastro de la Ensenada, pero en el plano de Coello no aparece $^{268}$.

La Puerta de Cascajar o de Bañuelos estaba situada en el extremo Norte de la población y era la salida natural del Camino Real de Burgos ${ }^{269}$. Este acceso también era conocido como el Arco Pajarito porque, según la tradición popular, sobre ella había una hornacina con la imagen de la Virgen María y el Niño con un pájaro en las manos. La puerta desapareció en 1660 cuando se derrumbó tras el paso de una procesión ${ }^{270}$.

Hasta la década de los ochenta del Cuatrocientos la Puerta de San Juan era la única entrada a la villa desde el Oeste, por la que desde el camino de Palencia se accedía al espacio intramuros. Según se observa en el plano de 1503 esta puesta también contaba con dos cuerpos pues en la parte superior se aprecian cuatro saeteras. A pesar de estar mutilado el dibujo en esta parte del plano, se puede deducir que contaba con terraza almenada aunque no sabemos si estaba cubierta como la de Duero. De ella no sabemos nada a pesar de haberse hecho un seguimiento arqueológico en la zona donde presumiblemente debió situarse ${ }^{271}$.

El postigo de Santa Ana o del Hoçino se realizó entre 1480 y 1486 al final de la calle Hocino. Se trataba de una pequeña apertura en la cerca por la que podía pasar una bestia con carga de leña o aguaderas e un honbre cavalgando en una mula, permitiendo además la evacuación de las aguas residuales ${ }^{272}$. En 1486 este postigo fue cerrado temporalmente ante las quejas de los vecinos de la calle San Juan que vieron mermados sus negocios considerablemente al pasar la mayor parte de los viajeros por el nuevo vano en vez de subir por la empinada cuesta de San Juan. Tras su reapertura se mantuvo

267 ... a la puerta de la villa que dizen Dehesilla (AGS, CCP, leg. 2, doc. 65).

${ }^{268}$ ZAPARAÍN YÁÑEZ, Desarrollo artístico..., Vol. I, p. 131.

269 ... calle que va a la puerta de Vañuelos (AGS, CCP, leg. 2, doc. 107).

${ }^{270}$ DE LA CRUZ, Historia de la milagrosa..., pp. 163-64.

${ }^{271}$ CRISTÓBAL VILLANUEVA, E., Informe técnico del seguimiento arqueológico realizado en la Plaza de San Juan de Aranda de Duero (Burgos). Febrero, 1994. Depositado en el Servicio Territorial de Cultura de Burgos. $42-43$.

${ }^{272}$ AGS, RGS, 148607, fol. 71, transcrito por CADIÑANOS BARDECI, “Judíos y moros..., pp. 
abierto hasta 1492 con sus dimensiones originales. Pero en 1492, por iniciativa de los vecinos de la colación de San Juan, se desmontó el arco tras la expulsión de los judíos. Sin embargo, los nuevos vecinos, ya cristianos, consiguieron de los monarcas que se volviera a abrir a condición de que ...fagan arco de piedra en el dicho postigo para que el muro non resçiba dapno e bien asy pongan una puerta o postigo de madera reçia por que se pueda empotrar dar e cerrar en tiempo que sea nesçesario ${ }^{273}$. Este portillo posiblemente fuera el que se arruinó en el transcurso de la inundación que asoló la villa en año $1788^{274}$.

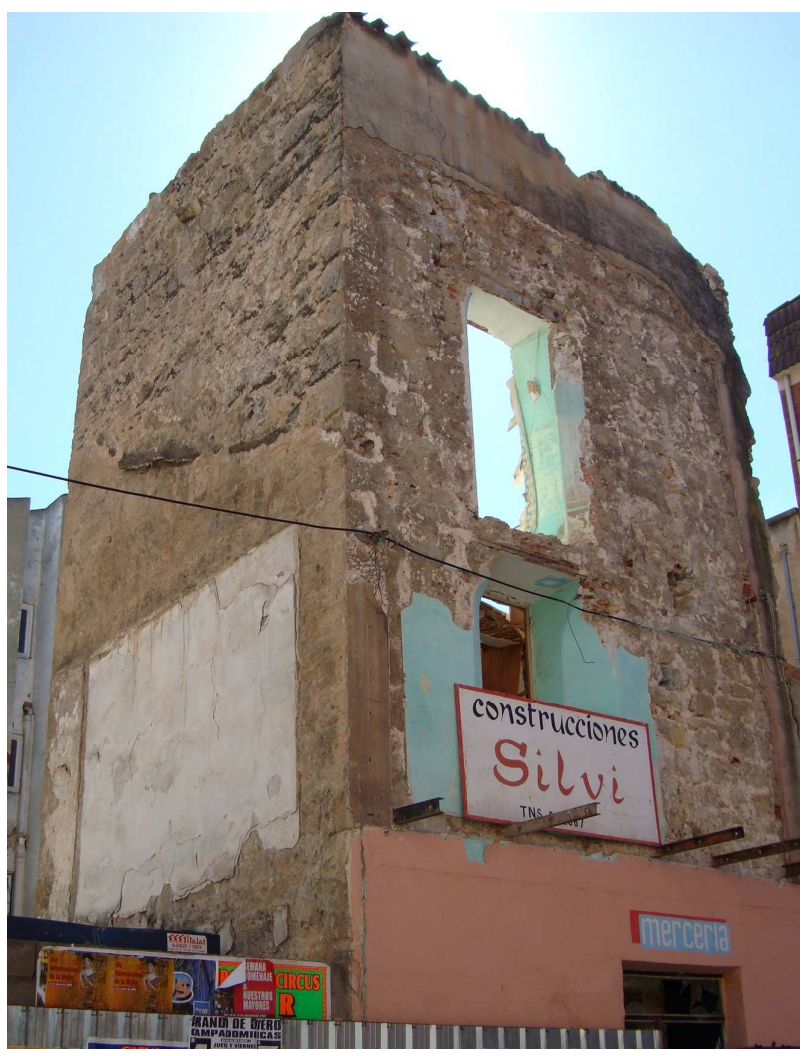

\section{Imagen 11: Restos del cubo meridional} de la Puerta Nueva (CBMAD).

La Puerta Nueva fue la última de las aperturas de la cerca arandina. En el famoso plano de 1503 no aparece e incluso los vecinos de la calle de Barrionuevo afirmaban en la solicitud de apertura de la calle del Pozo que no pretendían que se abriera ninguna puerta $^{275}$. Sin embargo, a lo largo de la década siguiente estos mismos vecinos $\mathrm{y}$, sobre todo, la emergente comunidad franciscana presionaron para que se permitiera construir esta puerta que diera paso directo desde el monasterio hasta el centro de la

${ }^{273}$ AGS, CC PUEBLOS, leg. 2, docs. 69 y 70.

${ }^{274}$ CADIÑANOS BARDECI, Arquitectura fortificada..., p. 339. Este autor no identifica el portillo que se arruinó pero suponemos que fue el de Santa Ana pues el otro susceptible de serlo sería la puerta de Santa Cruz que, como hemos dicho anteriormente, todavía se mantenía en pie a mediados del siglo XIX.

${ }^{275}$ AGS, CR, leg. 39, doc. 3: E sy la calle de Sant Juan de esta dicha villa oviese veydo perjuisio de la dicha calle de Señora Santana seria e fue por aver abierto puerta e postigo por la dicha calle en la çerca e muro de esta dicha villa e aun aquello fue utilidad e nobleçimiento de esta dicha villa e no se puede traer a este caso pues por nuestra parte no se pide ni suplica que se abra puerta ni postigo en la çerca de esta dicha villa. 
villa. Con anterioridad a 1517 el guardián y frailes del convento, junto con los vecinos de Barrionuevo, solicitaron a los reyes la apertura de un portillo que tuviera las mismas características que el realizado en Santa Ana. El argumento era que a través de este vano los fieles podrían acudir a los oficios y sermones del convento sin necesidad de dar mucho rodeo $^{276}$. Pese a la oposición de los vecinos de la calle Hesilla, Cascajar y del arrabal de Carrequemada, finalmente el portillo se abrió aunque no sabemos en qué momento concreto. Suponemos que no tardó mucho pues los monarcas dejaron el asunto en manos de los regidores, algunos de ellos muy próximos a la vecindad de Barrionuevo y a la comunidad franciscana ${ }^{277}$.

De todas las puertas con las que contaba la villa a finales de la Edad Media tan solo permanece hoy en pie uno de los lienzos exteriores del cubo Sur de la Puerta Nueva. Se trata de un muro de mampuesto al exterior y tapial al interior de aproximadamente 9 metros de altura por 5 de anchura y un grosor aproximado de dos metros en la base que va decreciendo en altura ${ }^{278}$. Recientemente se han derribado las casas que se apoyaban en este lienzo y su estado de conservación actual es deplorable.

Un memorial enviado por el corregidor de Aranda a mediados del siglo XVI respondiendo a una demanda de información sobre ciertos oficios de la villa y sus rentas muestra claramente la configuración de la cerca y sus puertas al final del periodo que estudiamos: ...dize que ay siete puertas y encima de una dellas una torre vieja, y que delas otras puertas no ay Alcayde ni llaves ni tiene nayde privilegio ni derecho dello y que assi este oficio es de poco valor ${ }^{279}$.

${ }^{276}$ AGS, CC MEMORIALES, leg. 121, doc. 132; leg. 124, doc. 141; y leg. 152, fol. 116. También recogido por ABAD LICERAS, J. M., "El ocaso de la presencia franciscana en Aranda de Duero a través de la documentación jurídica: los conventos de San Francisco y San Antonio en los siglos XVIII y XIX”, en Biblioteca 11. Estudio e Investigación. 1996, pp. 207-256, en concreto p. 210.

${ }^{277}$ Recordemos que al menos tres de los regidores vivían en esa calle (Quemada, Durango y Valladolid) y ya habían conseguido abrir su calle con el derribo de las casas del Pozo. Asimismo el regidor Santa Cruz fue uno de los promotores de la construcción del monasterio. Por su parte el convento de San Francisco logró poco antes que se creara una plaza frente a la fachada Oeste de su iglesia. Los vecinos de Hesilla señalaban en su negativa que esta solicitud se había tramitado por algunos regidores y un procurador, vecinos de Barrionuevo (AGS, CC MEMORIALES, leg. 121, doc. 132; y leg. 124, doc. 141).

${ }^{278}$ Las características de este lienzo de muralla distan bastante de las fortificaciones preparadas para soportar a la artillería que ya se estaban construyendo en Europa. Más información sobre este aspecto en VALDÉS SÁNCHEZ, A. (Coord.), Artillería y fortificaciones en la Corona de Castilla durante el reinado de Isabel la Católica. 1474-1504. Madrid, 2004.

${ }^{279}$ AGS, CC DIVERSOS, leg. 47, doc. 9. Este documento no aparece fechado pero por el tipo de letra parece de la segunda mitad del siglo XVI. 
No era del todo extraño que los arrabales medievales contaran con muralla, aunque bien es cierto que cuando se producía esta circunstancia se identificaba con una ampliación del núcleo urbano ${ }^{280}$. No tenemos noticias de la existencia de muralla en los arrabales arandinos hasta el final del periodo estudiado cuando las autoridades comuneras cerraron los arrabales ... lo cercaron todo y pusieron puertas ${ }^{281}$. Por el momento no podemos asegurar si esta cerca se configuró en el periodo comunero o si bien existía con anterioridad y, por lo tanto, se remontaría por lo menos a los años sesenta o setenta de la decimoquinta centuria. Por el momento esta es la única referencia que tenemos sobre esta cerca por lo que nos inclinamos por la primera hipótesis.

\subsubsection{Morfología urbana.}

En este apartado abordaremos los principales elementos que configuran la estructura interna de un núcleo urbano medieval como el arandino. En primer lugar, nos detendremos en analizar el entramado de las calles y plazas, así como su disposición y jerarquización. En un segundo momento intentaremos identificar las divisiones internas que presentaba la villa y que se concretaba en cuadrillas, collaciones y barrios. Finalmente, nos detendremos en la definición de los elementos urbanos que se encontraban extramuros pero que participan casi plenamente de las características propias de la ciudad.

\section{a. El trazado urbano.}

La calle es el principal elemento articulador del espacio urbano. A través de las diferentes fuentes con las que contamos trataremos de reconstruir el entramado viario de la villa de Aranda a finales de la Edad Media y a partir de ahí intentaremos comprender la dinámica de la sociedad que se desarrolló sobre este espacio estructurado y jerarquizado.

A través de la imagen idealizada que transmite el plano de 1503 se observa una tipología típica de núcleo urbano radial con centro en la Plaza Pública o de Santa María desde la que se configuran cuatro calles principales en el sentido de los puntos cardinales, distribuyéndose hacia las puertas de la ciudad). Lo cierto es que esta centralidad

${ }^{280}$ BENITO MARTÍN concluye tras el estudio del parcelario de Mayorga que el arrabal de Santa María de Arbás ya contaba con una cerca elíptica posiblemente desde el siglo XII (La formación de la ciudad..., pp. 172 y 216-218).

${ }^{281}$ AGS, CC MEMORIALES, leg. 141, doc. 98; y CR, leg. 450, doc. 8. 
también era percibida por los contemporáneos como los manifiestan ciertos vecinos en 1503: ...que en esta villa aya dos calles prinçipales e muy honrradas, la una que es la calle de Dehesylla e atraviesa por la plaza hasta la puerta de Sant Juan, e otra desde la puerta de Duero hasta la puerta de Cascajar; que es un cruzero donde toda la gente de Castilla, o la mayor parte que camina, atraviesa por ellas donde está loado el dicho cruzero e paso por el mijor de Castilla; e la villa por ello muy noblesçida e honrrada por ser como es tan señalado ${ }^{282}$. Sin embargo, la reconstrucción del entramado urbano sobre el parcelario real y otras informaciones documentales trasmiten una imagen menos idílica en la que predominan calles y callejuelas de carácter heterogéneo y bastante anárquico, junto a espacios todavía desestructurados.

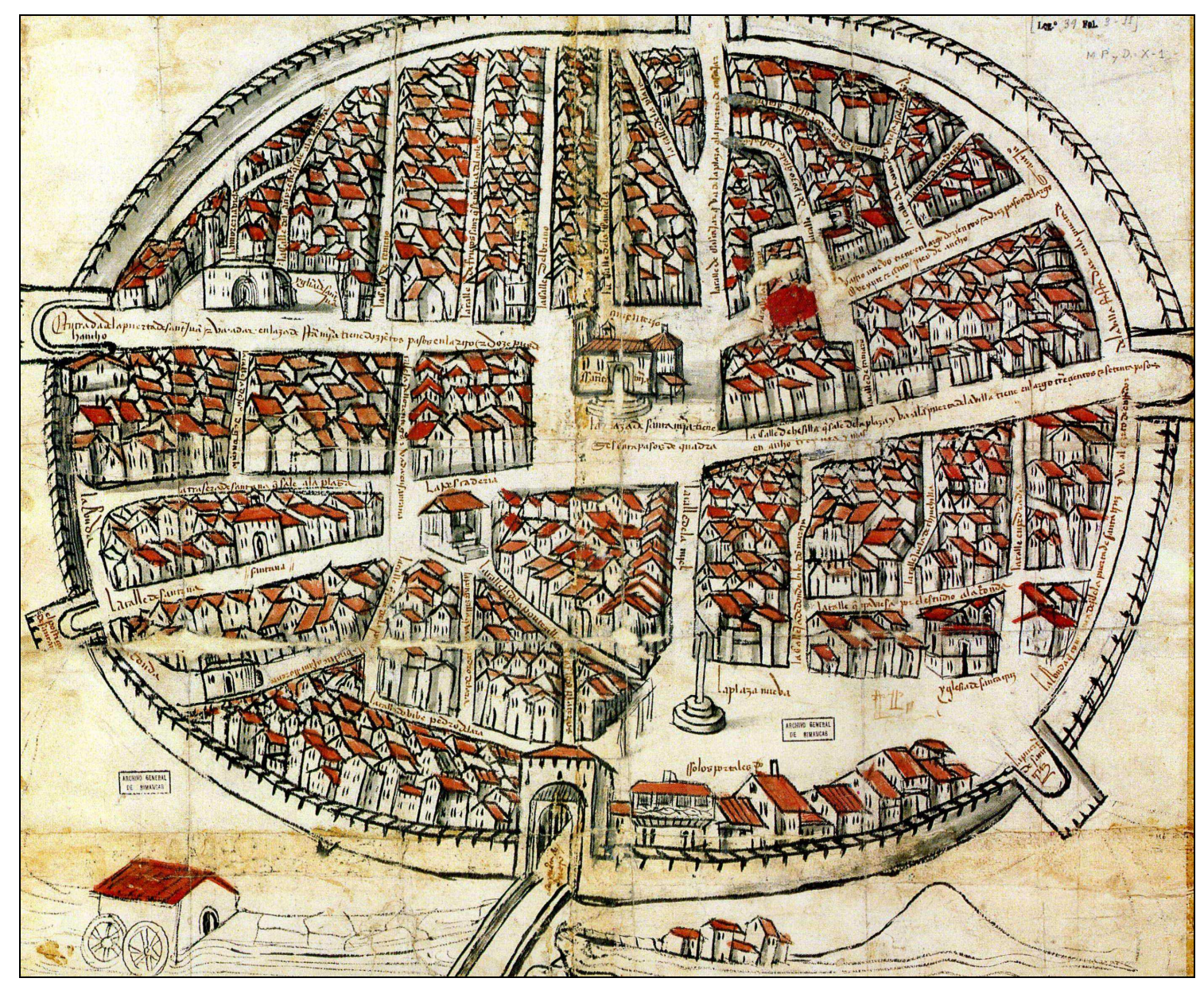

Imagen 12: Plano de 1503 (AGS, MPD, X, 1).

${ }^{282}$ AGS, CR, leg. 39, doc. 3. Extracto del interrogatorio presentado por los propietarios de las casas de la calle del Pozo. Todos los testigos interrogados confirman esta información (PERIBÁÑEZ OTERO y ABAD ÁlVAREZ, Aranda de Duero..., p. 178). 
A tenor de la información disponible, podemos concluir que existió una evidente jerarquización en el entramado urbano. Por una parte, los ejes principales del núcleo estarían conformados por las calles Cascajar y la Miel en su eje N-S y San Juan y Dehesilla en el eje O-E. Estos dos ejes compartían una serie de elementos comunes. En primer lugar ambos confluían en un punto central, la Plaza Pública; las cuatro calles culminaban en un punto final, las cuatro puertas más importantes de la villa; a través de ellas tenían una proyección extramuros a través de los cuatro arrabales de la villa; la gran mayoría de las calles eran subsidiarias de las cuatro principales; y en estos ejes se integraban las otras plazas de la villa, la Plaza del Trigo y la Plaza Nueva. Para los coetáneos el carácter preeminente de las calles también se manifestaba en la longitud y anchura y así lo confirma con precisión el artífice del plano de 1503: ...la calle de Hesilla, que sale de la plaza y va a la puerta de la villa, tiene en largo treçientos e setenta pasos; en ancho treynta (pies) y mas (515 metros de longitud por algo más de 8 metros de anchura); la calle de San Juan estimaban que tenía desde la puerta hasta la Plaza de María dozientos pasos en largo e doze pies de hancho (278 metros de longitud por tres metros y medio de anchura) $)^{283}$. Bien es cierto que no señalan ni la longitud ni la anchura de las otras dos calles que conformaban estos ejes porque sería contraproducente para sus intereses al ser calles bastante estrechas.

El resto del entramado urbano se componía de calles bastante tortuosas, estrechas e intrincadas, en las que predominaban los recodos como pueden ejemplificar la calle del Pozo, la callejuela de Chinchilla, la calle de la Comadre Vieja, o la calle del Cuerno $^{284}$. Sin olvidar la proliferación de corrales en las traseras de las casas, pero también corrales de vecindad como el de Caravo y el del Ozejudo o Orejudo, a los que se accedía por una calleja desde una calle principal y al que daban las fachadas de varias casas. Corrales como éste hubo en la manzana que se encontraba entre las calles Hesilla y Barrionuevo como se puede observar tanto en el plano de 1503 como en el de Co-

${ }^{283}$ Estos datos aparecen rotulados en el plano de 1503 (PERIBÁÑEZ OTERO y ABAD ÁLVAREZ, Aranda de Duero..., pp. 44-45).

${ }^{284}$ Todas ellas aparecen referidas en el plano de 1503 menos la del Cuerno que sí que aparece representada pero sin nombre. Era una bocacalle de la calle Empedrada y todo apunta a que su nombre proviene de su característica forma de L (PERIBÁÑEZ OTERO y ABAD ÁLVAREZ, Aranda de Duero..., pp. 44-45). 
ello $^{285}$. En la actualidad todavía se conserva uno de estos corrales fosilizados en la Plaza de Romualdillo, entre las calles de Barrionuevo y Cascajar $^{286}$.

Sin embargo, esta estructura jerarquizada heredera del planteamiento urbano que configuró la sociedad arandina a lo largo del siglo XV sufrió en los últimos decenios de este siglo una ligera transformación, fruto de los cambios propios de una sociedad dinámica. Esta transformación se concretó sobre todo en la calle Barrionuevo. El primer paso se dio en los primeros años de la década de los ochenta con la expulsión de un buen número de familias judías que habitaban en la confluencia de la calle Barrionuevo con el Pozo y su confinamiento en la calle del Hocino ${ }^{287}$. Estas haciendas y el resto de la calle fueron habitadas posteriormente por christianos honrados, que consiguieron que la dicha calle hubiera aumentado e noblesçido e honrado ${ }^{288}$. Pero esta evidente revalorización social de este espacio no terminó ahí. En 1503 los vecinos dieron un paso más e iniciaron un largo y costoso proceso para conseguir abrir su calle directamente hacia la Plaza de Santa María mediante el derribo de unas casas situadas en la calle del Pozo. Esta iniciativa provocó el rechazo de los propietarios de las casas y bodegas que se pretendían derribar y dio lugar al conocido pleito que nos ha proporcionado la fuente gráfica que anteriormente comentábamos. La puesta en práctica de esta iniciativa, tras contar con el visto bueno del corregidor y los monarcas, supuso la integración de la calle de Barrionuevo dentro del selecto grupo de las calles prinçipales de la villa con las connotaciones sociales y económicas que de ello se derivaron. Precisamente en el plano de 1503 ya se quería dotar a esta calle de las mismas características que poseían las grandes calles de la villa, especificándose que Varrio Nuevo tiene en largo dozientos e diez pasos de largo e veyte e çinco pies de ancho (casi trescientos metros de longitud y siete metros de anchura). De esta manera la jerarquización del espacio urbano arandino se vio

${ }^{285}$ AGS, CMC, leg. 355. Por el momento no hemos identificado el lugar concreto en el que se encontraban ni el corral de Caravo ni el corral del Ozejudo. Éste último no debía ser un lugar muy atractivo pues los informadores señalaban en 1522 que ...estan en parte donde no quiere morar nadie en ellas. En este corral tenían sendas casas los comuneros Pedro Sánchez de Mendoza y Miguel de la Gallega, aunque no residían en ellas. El también comunero Juan Esteban Mercader poseía una casa con su jaraíz en el corral de Caravo.

${ }^{286}$ A esta placita en la actualidad se accede a través de una estrecha travesía desde la calle Comadres y por una bocacalle desde Cascajar. Su origen puede estar vinculado a la desaparición hace unas décadas del antiguo callejón de las Quintanas que desde Barrionuevo comunicaba con Cascajar.

${ }^{287}$ Aspecto que trataremos con más profundidad en el apartado dedicado a la judería arandina.

${ }^{288}$ AGS, CR, leg. 39, doc. 3. (PERIBÁÑEZ OTERO y ABAD ÁLVAREZ, Aranda de Duero..., pp. 144 y ss). 
alterada debido a la iniciativa de los influyentes vecinos de esta calle, entre los que se encontraban destacados miembros de la oligarquía local. El proceso de puesta en valor de este nuevo espacio no concluyó hasta algunos años después con la apertura de la Puerta Nueva que puso en comunicación esta calle con el área extramuros y el influyente convento de San Francisco, como ya hemos abordado en el apartado dedicado a esta puerta. A partir de entonces la calle de Barrionuevo participó de todas las características señaladas anteriormente para los principales ejes viarios arandinos: confluía en la Plaza de Santa María; finalizaba en la Puerta Nueva; e incluso el antiguo arrabal de Hesilla pasará a denominarse de San Francisco. Tan solo faltaría contar con una plaza integrada en el recorrido de la calle, detalle que se consiguió con el tiempo cuando la noble familia de los Durango-Tamayo se hizo construir un palacio en esta calle y configuró una pequeña plaza frente a su fachada a finales del siglo XVI o principios del XVII ${ }^{289}$. Claro reflejo de la importancia que adquirió el vecindario de esta calle es que la reunión de la cuadrilla de Cascajar pasó a celebrarse junto al convento de San Francisco desde principios del siglo $\mathrm{XVI}^{290}$.

Sin tener la consideración de calle principal, pero sí jugando un papel importante dentro de la organización interna de la ciudad medieval, destaca la Ronda que circundaba todo el núcleo intramuros, salvo el pequeño tramo Sur de la Plaza Nueva. Esta circunstancia muestra claramente el carácter medieval de este núcleo urbano que se resistía a perder la función defensiva de su muralla y articuló unas rígidas condiciones para garantizar que no se impidiera cumplir con la función militar de la muralla en el espacio en el que se permitió la construcción de edificios adosados a la cerca ${ }^{291}$. También llama la atención el amplio espacio que se reservó para esta ronda. Aunque hoy estas calles no sobrepasan los cuatro metros, en su momento debieron contar con entre seis y ocho metros pues a las di-

289 ZAPARAÍN YAÑEZ, Desarrollo artístico..., Vol. I, pp. 131 y 151. Esta plaza aparece nombrada en el Catastro del Marqués de la Ensenada como Plaza de Tamayo, en relación con la familia propietaria del palacio. En la actualidad este espacio es denominado como la Plaza del Rollo por albergar desde hace algunos años un rollo que se encontraba anteriormente en la eras de Santo Domingo, junto al camino de Valladolid (CEBAS HERNANDO, J. A., Callejero comentado de Aranda de Duero. Aranda de Duero, 2000, p. 107).

\footnotetext{
${ }^{290}$ AGS, CONSEJO Y JUNTAS DE HACIENDA, leg. 4, doc. 2.

${ }^{291}$ VELASCO PÉREZ, Aranda. Memorias..., p. 87.
} 
mensiones actuales se debe añadir el espacio que fue usurpado por los nuevos edificios que se adosaron a las murallas ${ }^{292}$.

Además de las calles principales, otro elemento de primer orden en la morfología de la ciudad medieval es la plaza. Antes de analizar estos espacios en el contexto urbano arandino creemos conveniente reproducir algunas consideraciones a propósito de su significado conceptual siguiendo los planteamientos del profesor Sáinz Guerra ${ }^{293}$.

Desde el origen de las ciudades, la plaza se conformó como el espacio de reunión de la comunidad. Por este motivo la plaza se situaba generalmente en las inmediaciones de la iglesia principal o era un simple ensanchamiento de una calle principal. A su función de reunión vecinal se le añadió la de centro económico, sobre todo ligado al comercio. En esta primera fase este espacio se vinculó generalmente a la Iglesia, no sólo por cuestiones de proximidad, sino también por motivos económicos. Posiblemente en este primer momento se situaría la configuración de la Plaza de Santa María de Aranda. Sin embargo, en la Baja Edad Media la plaza experimentó cierto cambio respecto a la anterior situación en una doble vertiente: económica y social.

Respecto a la primera, y más importante, el crecimiento económico general de este periodo tuvo su principal exponente en los núcleos urbanos. La ampliación de las expectativas económicas planteó la necesidad de agrandar el espacio destinado a las operaciones comerciales -la plaza-. Esto supuso que, ante la incapacidad de ampliación en la zona intramuros, el centro comercial se trasladara a una zona extramuros. Con el fin de estar bien comunicada con el interior de la ciudad, se elegían emplazamientos junto a las puertas de acceso. En un principio se trataba de un espacio vacío, pero enseguida se construyeron edificios -ligados a diversas actividades artesanales y comerciales- en su entorno, dando a este espacio la morfología de una plaza. En muchas ocasiones esta nueva plaza fue absorbida por la ciudad mediante la ampliación del recinto amurallado. Esta dinámica se puede observar en el caso de la Plaza Mayor de Valladolid, los Mercados Menor y Mayor de Burgos y también en el caso de la Plaza Nueva de Aranda de Duero.

${ }^{292}$ En el caso del cubo localizado en la calle Puerta Nueva $\mathrm{n}^{\mathrm{o}} 38$ apenas se han tomado dos metros de la ronda pues el cubo ocupa casi cinco. Suponemos que en los tramos sin cubo la ronda alcanzaría los ocho metros de anchura (CRISTÓBAL VILLANUEVA, E., Informe técnico del seguimiento arqueológico realizado durante el derribo y vaciado del inmueble $n^{\circ} 38$ de la calle Puerta Nueva, de Aranda de Duero (Burgos). Febrero 1994. Depositado en el Servicio Territorial de Cultura de Burgos).

${ }^{293}$ Las ideas que se exponen a continuación han sido tomadas de SÁINZ GUERRA, La Génesis de la plaza..., pp. 45 y ss. 
En lo que se refiere a la vertiente social, se aprecia a finales del XV un nuevo concepto urbano que impulsó la creación de nuevas plazas o plazuelas en el interior del núcleo amurallado. Muchas de estas plazas respondieron a la iniciativa de los grupos sociales más poderosos que creaban una plazuela frente a su mansión o palacio como forma de reafirmar su importancia y prestigio social. Otras veces era el propio Concejo, la Iglesia o la Corona quien acometía esta tarea, pero la finalidad era la misma. Ejemplos de esta nueva mentalidad se aprecian en la Plaza de Pilatos en Sevilla, y también en Segovia, Burgos o Valladolid. En Aranda no encontramos ningún ejemplo del periodo estudiado. Sin embargo, como ya hemos apuntado anteriormente, la configuración de la actual plaza del Rollo estuvo relacionada con esta dinámica apuntada por el profesor Sáinz Guerra, aunque con un relativo retraso.

Asimismo a finales del XV las plazas mayores evolucionaron a una función lúdica celebrándose en ellas teatros y espectáculos, torneos, etc. En este sentido la plaza también se convirtió en espacio religioso que albergaba algunas manifestaciones de fe como podían ser las procesiones del Corpus, pero también los Autos de Fe. Tampoco podemos olvidar la función judicial, sirviendo de escenario de ejecuciones públicas. Este carácter jurídico se plasma materialmente en los famosos rollos o picotas. Como veremos más adelante, las plazas arandinas participaron de algunas de estas características que enumera el profesor Sáinz Guerra.

La plaza que tiene un mayor significado a finales de la Edad Media en Aranda es la Plaza Pública o de Santa María. El origen de este espacio pudo estar relacionado con la primitiva puerta SE del primer recinto de la villa donde se emplazó una ermita bajo la advocación de Santa María. Este espacio, relacionado bien con la puerta o con la iglesia, o puede ser que con las dos a la vez, se configuró a finales del siglo XIII como el centro comercial de la villa donde tenía lugar el mercado semanal y en el que se subastaban tanto las rentas de la villa como los bienes de los condenados ${ }^{294}$. Tras la ampliación del siglo XV este espacio se confirmó como el centro neurálgico de la villa. Como ya hemos adelantado, en la Plaza de Santa María confluían las principales calles o, lo que es lo mismo, era considerado por los vecinos como el cruzero de los principales caminos de Castilla $^{295}$.

${ }^{294}$ AGS, EXPEDIENTES DE HACIENDA -EH-, leg. 4; y CARRETE PARRONDO, C., Fontes Iudaeorum Regni Castellae II. El tribunal de la Inquisición en el Obispado de Soria (1486-1502). Salamanca, 1985, doc. 308, pp. 130-31.

${ }^{295}$ AGS, CR, leg. 39, doc. 3, transcrito por PERIBÁÑEZ OTERO y ABAD ÁLVAREZ, Aranda de Duero..., pp. 144 y ss. 
Además de las funciones religiosa y económica de este espacio, también adquirió una función política como lo prueba el hecho de que el concejo se reuniera en las gradas de la Iglesia de Santa María que estan en la plaza de la dicha villa y fuera el primer lugar en el que se pregonaban los acuerdos municipales o las órdenes reales ${ }^{296}$. Una prueba más de su incuestionable vitalidad es que este espacio también fue el escenario de las disputas entre vecinos que, en ocasiones, solventaban sus diferencias recurriendo a la agresión física o al homicidio ${ }^{297}$.

Muy próximo a la Plaza Pública y vinculado a la iglesia de Santa María se encontraba el cementerio. Éste se localizaba junto al muro Norte de la iglesia. En el periodo bajomedieval este lugar estaba íntimamente unido al mundo de los vivos, siendo considerado como un espacio público más. Prueba de esta afirmación son los numerosos documentos castellanos que hacen referencia al Campo Santo como lugar de reunión, de juego o, incluso, como lugar apropiado para las citas amorosas. El cementerio arandino participó de estas características y comprobamos cómo en 1426 los regidores se reunieron junto a los procuradores de las aldeas de la villa en el cementerio como lo tienen de uso e costunbre para tratar un asunto relativo a la compra de la granja de Revilla de Olleros ${ }^{298}$. Pero también en el cementerio se desarrollaron situaciones violentas como la sucedida en 1486 cuando un vecino allí escondido pegó una cuchillada a otro ${ }^{299}$. Por último sabemos que hacia 1530 el párroco Diego Martínez de Oviedo compró unas casas situadas detrás de Santa María que fueron derribadas para ampliar el cementerio y permitir asimismo que los carros que traían las tercias circulasen por allí mejor ${ }^{300}$.

A lo largo de la Baja Edad Media la Plaza Pública perdió espacio debido a la ampliación de la iglesia de Santa María por lo que ciertas actividades que en el pasado se desarrollaron intramuros, como las ferias o los toros, buscaron un espacio más amplio, que

${ }^{296}$ AMA, leg. 43, doc. 5; AGS, CR, leg. 40, doc. 8; y CC PUEBLOS, leg. 2, docs. 82 y 97.

${ }^{297}$ AGS, RGS, 148809, fol. 82. Precisamente en la Plaza de Santa María se produjo la agresión que terminó con la vida del comunero Sebastián de Ventosilla días antes del desenlace final de Villalar (ARChV, RRE, Caja 361, doc. 8).

\footnotetext{
${ }^{298}$ AMA, leg. 43, doc. 4.

${ }^{299}$ AGS, RGS, 148603, fol. 56.

${ }^{300}$ VELASCO PÉREZ, Aranda. Memorias..., pp. 164-66.
} 
con el tiempo fue adsorbido por la nueva ampliación de la muralla. A este espacio se le designó con el apelativo de Plaza Nueva.

El profesor Sáinz Guerra ya planteó en su momento una interesante hipótesis sobre el origen mercantil de esta plaza y su configuración triangular en el espacio extramuros que fue absorbido por la ampliación urbana bajomedieval ${ }^{301}$. El hecho de que en 1432 el concejo subastara los solares del lado Sur de la plaza puede hacernos pensar que la ocupación de la villa fue muy lenta pues todavía por esas fechas no se había completado la urbanización de esta Plaza ${ }^{302}$. Sin embargo, nos inclinamos a pensar todo lo contrario. La premisa de la que partimos es que tanto en el primitivo recinto como en la reciente ampliación se respetó el espacio destinado a dar servicio a la muralla, la ronda. Sin embargo, la presión de los vecinos por ocupar un espacio bastante atractivo desde el punto de vista económico provocó que las autoridades locales permitieran construir edificios adosados a la muralla a cambio de cumplir con unas determinadas condiciones de construcción y seguridad, además de comprometerse a pagar un censo anual para los propios de la villa. Esta hipótesis parece confirmarse por el hecho de que a finales de siglo los vecinos de estos edificios decidieron solicitar al concejo la ampliación de sus viviendas. Las autoridades municipales dieron licencia para la ampliación hacia el Duero, por lo que tuvieron que desmontar la cerca y construirla de nuevo ${ }^{303}$. Es curioso que en este mismo documento de 1499 ya se nombrara a este espacio como la hacera, apelativo que se mantendrá en la memoria colectiva hasta periodos muy recientes de la historia arandina y que fue recogido como escenario de sus obras por literatos de la talla de Pío Baroja o Camilo José Cela ${ }^{304}$.

Tan solo queremos añadir que a su evidente carácter comercial debemos sumar su función administrativa, jurídica y lúdica. Así constatamos que los soportales de esta plaza se convirtieron en ocasiones en lugar de audiencia por parte del corregidor ${ }^{305}$. Por otra

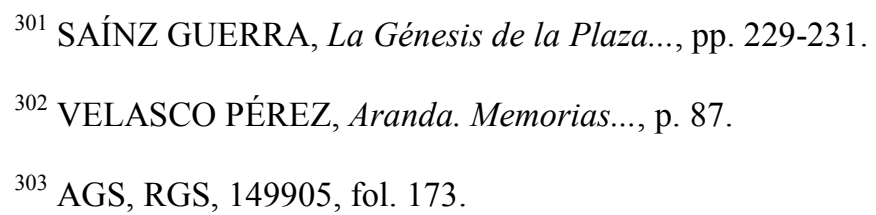
Ende Duero fasta la de Santa Cruz (AGS, RGS, 149905, fol. 173). BAROJA describe la Acera como lugar de paseo de los arandinos del Trienio Liberal en la narración de la vida de Eugenio de Aviraneta (Con la Pluma y con el sable. Cuarto volumen de Memorias de un hombre de acción. 1915). Por su parte CELA narra: El vagabundo, en la Acera, el paseo de las señoritas, bajo los soportales de la plaza, una plaza que tiene la forma de ataúd, se sienta a ver pasar las chicas... (Judios, Moros y Cristianos. 1956).

${ }^{305}$ AGS, CASAS Y SITIOS REALES, leg. 2, doc. 482. 
parte en el plano de 1503 se aprecia un esbelto rollo, emblema por excelencia de la jurisdicción de la villa. No con tanta nitidez también se vislumbra junto al rollo dos postes con un remate en su parte superior que algunos autores han identificado como horcas, elemento que guardaría una estrecha relación con esta función jurisdiccional ${ }^{306}$.

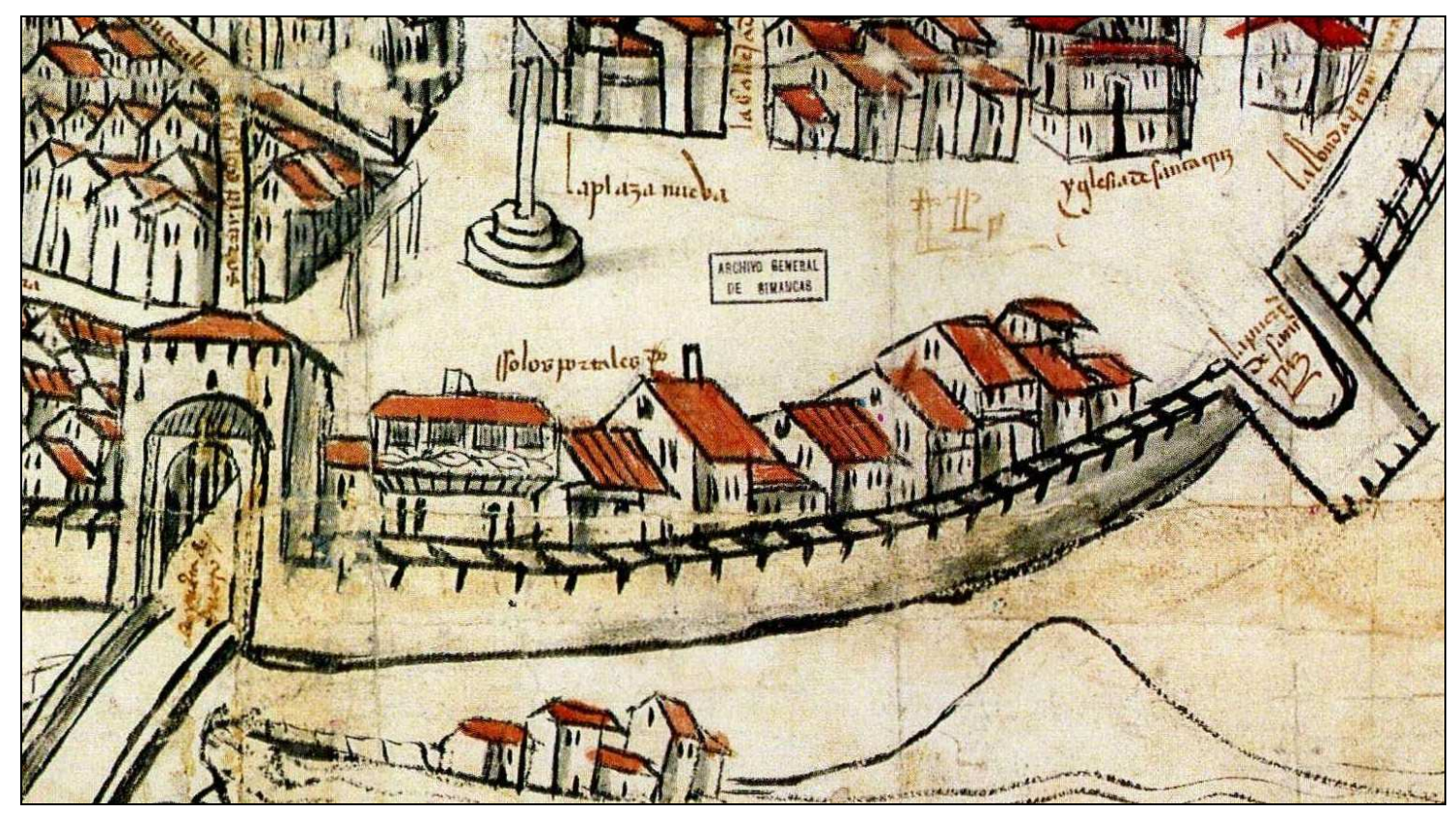

Imagen 13: Detalle de la Plaza Nueva.

Asimismo esta plaza fue escenario de eventos de carácter religioso como las procesiones del Corpus y en ella bien pudo celebrarse en 1490 el Auto de Fe en el que se quemaron a Diego de Roa y Alonso Sánchez Traspaso, vecinos de Aranda, y a maestre Juan, cirujano y vecino de Coruña del Conde, condenados por herejía ${ }^{307}$.

Además también este espacio servía para la diversión como lo indica la celebración de la toma de Túnez en 1535 ...que para regocijara el pueblo, se corran toros el dia de Nuestra Señora de Setiembre, y se jueguen cañas, y echen el arena en la plaza a costa de la villa, y que el mayordomo vaya luego por los toros, y que traya dos dellos para que se

306 SÁNCHEZ RIVERA, J. I., "Ermitas, rollos y humilladeros en la comarca ribereña”, en $B i$ blioteca 18. Estudio e Investigación. 2003, pp. 143-176. No sabemos a ciencia cierta dónde se ejecutaba a los condenados pero bien es cierto que cuando en 1510 el alguacil fue a ejecutar a un condenado unos estudiantes le atacaron para liberar al preso y el alguacil se refugió en la iglesia de Santa Cruz que estaba en las proximidades de la Plaza Nueva (AGS, CC PUEBLOS, leg. 2, doc. 100).

${ }^{307}$ No sabemos a ciencia cierta si el cadalso se instaló en la Plaza Nueva, en la Plaza de Santa María o extramuros (CARRETE PARRONDO, Fontes Iudaeorum..., pp. 97 y ss.; en concreto las declaraciones no 203, 204, 218 y 317). 


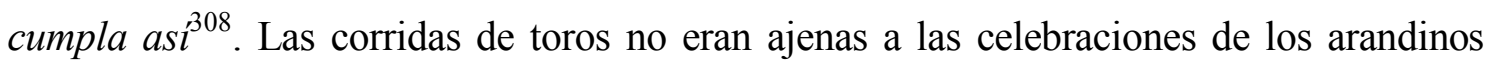
pues se celebraban regularmente en la villa como en 1531 recuerdan las autoridades municipales al monarca: ...de tiempo inmemorial se acostumbra correr toros tres veces al año por el dia de San Juan, Santa María de agosto y San Martín ${ }^{309}$. La primera evidencia documental sobre la celebración de una corrida en la villa se remonta a 1486 cuando dos toros corridos e agarrochados fueron pesados en la carnicería para después ponerse a la venta $^{310}$.

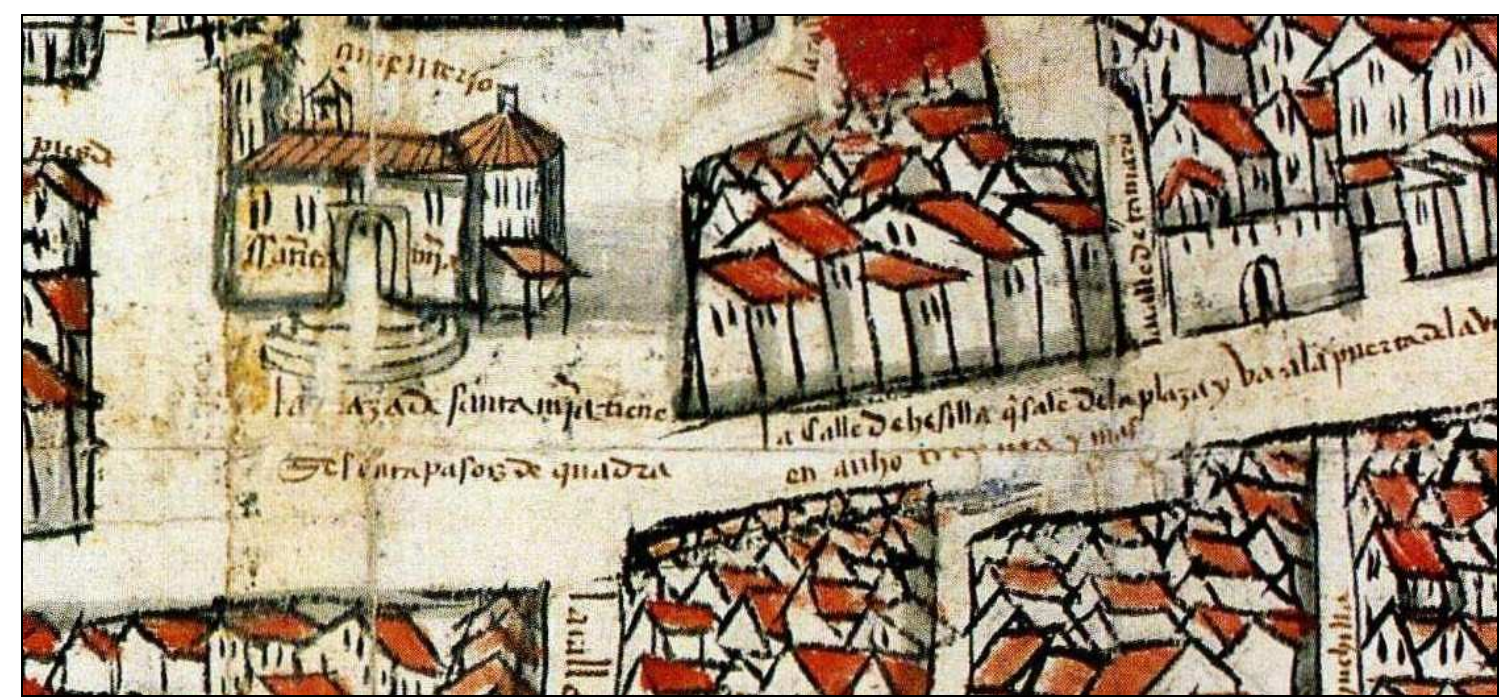

Imagen 14: Detalle de la Plaza Pública o de Santa María y de la Plaza del Trigo.

La Plaza del Trigo surgió como un espacio comercial extramuros junto a la puerta Este de la primitiva cerca ${ }^{311}$. Tras ser absorbida por la ampliación bajomedieval del recinto su actividad comercial se mantuvo y perduró su nombre, aunque en ocasiones también es

\footnotetext{
${ }^{308}$ VELASCO PÉREZ, Aranda, Memorias..., pp. 174-75.

${ }^{309}$ AMA, leg. 43, doc. 19.

${ }^{310}$ AGS, CC MEMORIALES, leg. 149, doc. 230.
}

${ }^{311}$ En realidad no tenemos constancia documental de que en este espacio se llevase a cabo la compraventa de cereal. Todos los autores, y nosotros también, pensamos que es obvio que este nombre implicaba esta actividad comercial. Para corroborar esta interpretación debemos acudir a la cercana localidad de Cuéllar donde también cuentan con una Plaza del Pan. Se trata de una zona, próxima a la Plaza Mayor, especializada en la venta de cereal los días de mercado. Esta actividad y su espacio estaban regulados por una serie de ordenanzas (OLMOS HERGUEDAS, E., La Comunidad de Villa y Tierra de Cuéllar a partir de las ordenanzas de 1546. Valladolid, 1997 (2 Ed.), pp. 92-102; y "Urbanística medieval en una villa de la cuenca del Duero. Cuéllar durante la Baja Edad Media" en La ciudad medieval. Aspectos de la vida urbana en la Castilla bajomedieval. Valladolid, 1996, pp. 53-81). El caso arandino bien pudiera ser similar al cuellarano, aunque no tenemos la suerte de conservar las ordenanzas. 
denominada como Plaza del $\operatorname{Pan}^{312}$. No es de extrañar la existencia de este espacio singular destinado a la compraventa de cereal pues no podemos olvidar que la economía ribereña de finales del medievo era netamente agraria y, aunque el vino jugó un importantísimo papel, tanto la producción como la compraventa de cereal fueron un elemento esencial para la población local. Prueba de ello lo encontramos en la proliferación de ingenios molinares que aprovechaban las abundantes aguas de los ríos próximos. Sólo en Aranda se documentan a principios del siglo XVI cinco aceñas en el Duero con dos ruedas cada una de ellas; cuatro molinos en el Arandilla, con ocho ruedas en total; y un molino con dos ruedas en el Bañuelos. Existía además otro molino en la aldea de Quemada, y posiblemente otro en Fuentespina, sobre el arroyo de la Nava. Para desgracia de los propietarios y arrendadores de los molinos, en muchas ocasiones el concejo se vio obligado a prohibir la molturación de grano foráneo para garantizar que el de los vecinos no se echara a perder. Incluso se planteó la posibilidad de construir dos nuevos molinos en los fosos de la cerca de la vi$1 \mathrm{a}^{313}$. No obstante, la situación más habitual era que la villa tuviera mucha necesidad de pan foráneo, en ocasiones por las negativas coyunturas que se traducían en crisis de subsistencia incrementadas por los fenómenos especulativos, pero sobre todo por la endémica carencia de cereal en un territorio dominado por el monocultivo de la vid, como se puso de manifiesto al menos en 1497, 1502, 1503, 1507 y 1530. Esta circunstancia provocó que el concejo acudiera con asiduidad a otras partes del reino a comprarlo para garantizar el abastecimiento de pan en la villa ${ }^{314}$.

Para concluir este apartado dedicado a las plazas debemos señalar que a finales del medievo comenzó a configurarse una nueva plaza extramuros de la villa en lo que posteriormente se llamaría plaza de la resina, Plaza del Palacio y actualmente Jardines

312 ...la plaça que se dyse del pan (AGS, RGS, 149205, fol. 472). A finales de la Edad Media el trigo y la mayor parte de los cereales se identificaban con el producto final: el pan. Las propiedades sembradas de cereal se denominaban heredades de pan llevar y asimismo se prohibía a los ganados entrar en heredades de pan y vino. La venta de cereal en esta plaza se mantuvo hasta mediados del siglo XX.

${ }^{313}$ Todos estos datos han sido obtenidos de AGS, CR, leg. 40, doc. 8. Este documento ha sido estudiado en ABAD ÁLVAREZ y PERIBÁÑEZ OTERO, “El control social del agua..., pp. 113-56.

${ }^{314}$ Así lo confirma la innumerable sucesión de quejas de los vecinos por falta de pan o por precios abusivos y las numerosas provisiones reales encaminadas a asegurar el abastecimiento de pan en la tierra de Aranda en los últimos años del siglo XV y buena parte del XVI (AGS, CC PUEBLOS, leg, 2, docs. 56, 75, 98 y 104; AMA. leg. 1, docs. 33, 34, 37; y leg. 63, doc. 146). La especulación se generalizó sobre todo a partir de 1502 con la imposición de la Tasa del Trigo. 
de don Diego ${ }^{315}$. Sáinz Guerra señala que la configuración de esta plaza fue plenamente medieval aunque su formación fuera posterior ${ }^{316}$. Lo cierto es que a principios del siglo XVI en el margen meridional de este espacio estaba construida la ermita de San Roque, donde celebraba sus reuniones la cuadrilla de Hesilla ${ }^{317}$. También en este espacio extramuros había unas casas y harrenal a la puerta de Santa Cruz que hera juego de pelota que pertenecieron al comunero Miguel Daza ${ }^{318}$. Desgraciadamente no tenemos más referencias que nos aclaren las características de este espacio o de la actividad que en él se desarrollaba, auque Velasco señala que entre las puertas de Santa Cruz y Hesilla había a finales de la Edad Media unas eras que posteriormente se convirtieron en un mercado de maderas. Lo cierto es que en el XIX en este espacio se celebraba una feria de ganado y un mercado de carnes ciertos sábados del año ${ }^{319}$.

$\mathrm{Al}$ igual que ocurre en otras ciudades castellanas, el nombre con el que se conocía a finales de la Edad Media a las calles y plazas de Aranda hacía referencia a diversos aspectos de la realidad próxima a sus vecinos ${ }^{320}$. No es de extrañar por lo tanto que muchos de los nombres de las calles se identificaran con los edificios religiosos más próximos como era el caso de la calle de San Juan, Santa Ana, San Llorente, San Lázaro o la plaza de Santa María. De igual manera otras calles recibieron el nombre de alguna construcción significativa cercana como es el caso de la calle de la Pontecilla, la Canaleja, la Ronda o el Pozo; o un accidente geográfico como la calle Costanilla, el Hocino o la Dehesilla. Otras muchas hacían referencia a alguna actividad económica que se desarrollaba en ellas como las calles de la Plata, Plateros, Miel, Comadre, Sal o las plazas del Aceite y del Trigo. Y en los arrabales también encontramos calles que se nombran con los lugares hacia los que se dirigían

${ }^{315}$ Como Plaza de la Resina aparece en el XVIII en el Catastro del Marqués de la Ensenada (ADPB, Catastro del Marqués de la Ensenada, Memorial de Seglares, vol. I, fol. 149). Con la construcción del Palacio obispal a finales del XVIII pasó a denominarse Plaza del Obispo (VELASCO PÉREZ, Aranda. Memorias..., pp. 388-391).

${ }^{316}$ SÁINZ GUERRA, La Génesis de la Plaza..., p. 231.

${ }^{317}$ AGS, CONSEJO Y JUNTAS DE HACIENDA, leg. 4, doc. 2.

${ }^{318}$ AGS, CMC, leg. 355.

${ }^{319}$ VELASCO PÉREZ; Aranda. Memorias..., p. 88; y MADOZ, Diccionario Geográfico..., Vol. II, p. 49.

${ }^{320}$ Sobre los nombres que aparecen en el plano de 1503 ya hemos hecho una primera aproximación en PERIBÁÑEZ OTERO y ABAD ÁLVAREZ, Aranda de Duero..., pp. 58-69. 
los caminos que en ellas nacían, bien fueran aldeas o ciudades, como eran las calles $\mathrm{Ca}$ rraquemada o Soria ${ }^{321}$, o bien pagos o molinos, como la calle del Pizarro ${ }^{322}$.

También percibimos entre los nombres de calles aquellos que hacen referencia a vecinos de las mismas, circunstancia que parece confirmar la relevancia social que para el resto de los habitantes de la villa tenían estos conciudadanos, seguramente por su poder e influencia, aunque no se puede descartar otras posibilidades. Esta circunstancia se confirma por el rótulo con el que se nombra en el plano de 1503 a la actual calle Béjar: La calleja de donde bibe don Martin ${ }^{323}$. Este don Martín fue don Martín Vázquez de Acuña, señor de Hoyales y Fuentelisendo, casado con doña Constanza de Avellaneda y padre de alguno de los protagonistas de la historia de la villa en la primera mitad del siglo $\mathrm{XVI}^{324}$. De igual manera una de las calles de la collación de San Juan recibía el nombre de La calle del Arcipreste, que hoy se conoce como la calle Palillos. Posiblemente hace referencia a Martín Fernández de Espinosa, arcipreste de la villa durante el último tercio del siglo XV, muy implicado en la vida política y económica de la villa ${ }^{325}$. En relación con cargos públicos también se encuentran la calleja de Llorente Gonzalez, que alude a uno de los primeros regidores de la Comunidad con los que contó la villa ${ }^{326}$; la calle do vibe Pedro de Lara, que fue procurador de la Comunidad ${ }^{327}$; la calle de Lope Sanchez de Hisilla, alcalde en 1487 y uno de los comisionados por la villa para comprar el lugar de Milagros al abad del

\footnotetext{
${ }^{321}$ AGS, CR, leg. 40, doc. 8.
}

${ }^{322}$ AGS, CMC, leg. 355.

${ }^{323}$ Esta misma denominación todavía se utilizaba tras la muerte de don Martín pues en un inventario de los bienes del arrendador Francisco de Berlanga fechado en 1507 se señalaba que poseía unas casas en la calle de don Martin (AGS, ESCRIBANÍA MAYOR DE RENTAS, -EMR-, leg. 567).

324 Aunque VELASCO PÉREZ señala que tenía sus casas en la calle de Santa Ana, no parece muy lógico que cuando don Martín se avecindó en la villa a finales de los años sesenta se instalara en el Hocino, espacio deshabitado y marginal que se eligió poco después para confinar a la comunidad judía (Aranda. Memorias..., p. 130).

${ }^{325}$ Entre 1487 y 1490 participó en el arrendamiento de la renta del vino y fue uno de los promotores del cierre del postigo de la judería tras la expulsión de los judíos (AGS, CC PUEBLOS, leg. 2, docs. 70 y 77$)$.

${ }^{326}$ AGS, CC MEMORIALES, leg. 149, doc. 230. Actualmente es la calle Costanilla.

${ }^{327}$ AGS, CC PUEBLOS, leg. 2, doc. 92. Después de la transformación que sufrió este espacio tras la demolición de la ermita del San Llorente esta calle recibió el nombre de Santo Cristo. 
monasterio de San Pedro de Gumiel ${ }^{328}$; o la calle de Centeno que se refiere a Pedro Sánchez Centeno, alcalde de la villa en $1490^{329}$. Pero además de estos destacados miembros de la comunidad hay otras muchas referencias a calles identificadas con el nombre de determinados vecinos que no desempeñaron ningún papel relevante en la vida arandina del momento ${ }^{330}$ : la calle de Frutos Sanz que se nombra del Toledano, actual calle Aguilera; la calle del Bravo, que hace referencia a Juan Sánchez Bravo y que corresponde con la actual calle Centeno; la calle de Rozador, hoy denominada Plaza Romualdillo; la calle de Tamarón, que mantiene su denominación; la calle de Chinchilla, que conservó su denominación hasta el siglo XVIII aunque en la actualidad se la conoce como calle las Montas ${ }^{331}$; la calleja de Juan de Gonzalo, que hoy tan solo es una pequeña travesía entre San Juan y Santa Ana; la calle que dizen de Pedro Sanchez de Santa Cruz que estaba en la collación de San Juan pero que no hemos podido identificar; lo mismo ocurre con la calle de Pedro Martinez de Gomiel, esta vez en las proximidades de Barrionuevo ${ }^{332}$; y la calle de Gomez Herrera, que desconocemos por completo su ubicación ${ }^{333}$. Esta situación nos induce a pensar que las calles de la villa, aparte de aquellas que se situaban junto a un elemento singular, eran conocidas sobre todo por el nombre de sus vecinos más significativos, lo que propiciaba que algunas de estas calles recibieran más de un nombre, como ocurre con la calle de San Llorente que en el plano de 1503 es nombrada como la calle do vibe Pedro de $\operatorname{Lara}^{334}$.

${ }^{328}$ AGS, CR, leg. 39, doc. 3; RGS, 148708, fol. 247; y CC PUEBLOS, leg. 13, doc. 3. Esta calle comunicaba Barrionuevo con Cascajar y desapareció en la segunda mitad del siglo XX absorbida por las fincas vecinas.

${ }^{329}$ AGS, CC PUEBLOS, leg. 1, doc. 231; y CR, leg. 39, doc. 3. La calle actualmente se conoce como calle Barcelona pero hasta el siglo XVIII mantuvo la denominación de Centeno (ZAPARAÍN YÁÑEZ, Desarrollo artístico..., p. 134). No sabemos en qué momento ni por qué este nombre se trasladó a la calle paralela cercana.

${ }^{330}$ Casi todas las denominaciones que señalamos a continuación aparecen en el plano de 1503 y la presencia de estos personajes en la villa a principios del siglo XVI ya fue analizada en PERIBÁÑEZ OTERO y ABAD ÁLVAREZ, Aranda de Duero..., pp. 65-69.

${ }^{331}$ ARCHIVO DE LA DIPUTACIÓN PROVINCIAL DE BURGOS -ADPB-, Catastro del Marqués de la Ensenada, Memoriales de Seglares, vol. I, fol. 4.

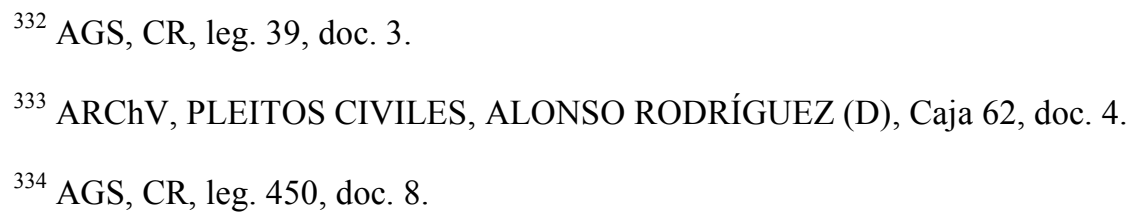




\section{b. Las divisiones internas de la villa: cuadrillas, collaciones y barrios.}

La ciudad castellana del XIV y XV presentaba una organización interna propia basada en las collaciones, parroquias u otras circunscripciones de carácter local. Las collaciones eran demarcaciones territoriales dentro de los núcleos urbanos que englobaban varias calles y que solían tener como referente una parroquia o edificio religioso. Desempeñaban asimismo funciones de carácter fiscal, militar y representativo.

El núcleo arandino contó con esta organización interna y así constatamos la existencia de alguna collaçion e vesindad como la de Sant Juan que en 1492, tras la expulsión de los judíos, solicitó que se cerrara el postigo de Santa Ana argumentando que les causaba grandes perjuicios económicos. Por su parte los vecinos de la colaçion de Santa Ana rogaban que se mantuviera abierto ${ }^{335}$. Intuimos que existieron otras en la villa, pero no tenemos constancia documental de ello.

En el caso concreto de la collación de San Juan se aprecia perfectamente cómo la parroquia del mismo nombre es el centro y referente de la demarcación como lo ponen de manifiesto los vecinos cuando nombran a sus representantes ...en el nuestro nombre e en nombre de todos los moradores e vesinos en la dicha collaçion e vesindad de la dicha iglesia ${ }^{336}$. En este caso se aprecia con bastante claridad la superposición de la organización vecinal sobre la parroquial, o viceversa, lo que supone un claro ejemplo de la imbricación de la vida civil con la espiritual en el mundo medieval.

Contemporáneas a las collaciones, pero con un rango superior, se observa la agrupación de vecinos en cuadrillas. La primera referencia documental que tenemos sobre esta organización vecinal se remonta a 1491 y se cita a los quadrilleros de las quadrillas desta dicha villa por sy e en nombre de toda la republica de la dicha villa ${ }^{337}$. Estas cuadrillas estaban formadas por todos los vecinos que habitaban una determinada demarcación territorial dentro del espacio intramuros. Prácticamente participan de las mismas funciones que detentaban las collaciones pues claramente se aprecia la función representativa que se concretaba en reuniones asamblearias presididas por las autoridades municipales en las que se

${ }^{335}$ AGS, CC PUEBLOS, leg. 2, doc. 69.

${ }^{336}$ AGS, CC PUEBLOS, leg. 2, doc. 70.

${ }^{337}$ AGS, CC PUEBLOS, leg. 2, doc. 88. El documento que mejor recoge la organización de las cuadrillas se remonta a 1517 y en él se relata el proceso mediante el cual el corregidor y los regidores convocaron a las cuadrillas para saber su opinión sobre la concesión del oficio de alguacil de la villa a Juan de Zúñiga, hermano del conde de Miranda (CONSEJO Y JUNTAS DE HACIENDA, leg. 4, doc. 20). 
discutían problemas y se elegían a diputados con capacidad para representar a la cuadrilla ante los órganos de gobierno municipales. Las cuadrillas también tenían cierta autonomía fiscal que se materializaba en la posibilidad de solicitar al monarca licencia para efectuar repartimientos entre los vecinos y la capacidad de actuar como agente recaudador de los mismos. Así se puso de manifiesto en 1517 cuando los diputados de las cuadrillas comisionaron a un procurador que debía acudir a Bruselas y solicitar al monarca licencia para este fin y así hacer frente a los gastos derivados del pleito por el alguacilazgo de la villa ${ }^{338}$. En 1518 las cuadrillas comenzaron a recaudar este repartimiento pero las autoridades municipales se lo impidieron alegando que no habían obtenido todavía la licencia real para ello ${ }^{339}$.

El espacio intramuros de la villa de Aranda a principios del siglo XVI estaba organizado en cuatro cuadrillas, aunque no conocemos por el momento a ciencia cierta las collaciones, barrios o calles que correspondían con cada una de ellas.

En la cuadrilla del Duero se encuadraba el sector SE de la villa, integrándose las calles aledañas a la ermita de San Llorente y la zona próxima a la Puerta de Duero. Seguramente collación y cuadrilla coincidirían en espacio y funciones pues el centro neurálgico de este espacio y el lugar de reunión de la cuadrilla fue la ermita de San Llorente.

La cuadrilla de Hesilla fue la más amplia de todas, pues incluía además de la calle que le daba nombre toda la expansión de la villa hacia el Sur, incluyendo la Plaza Nueva. Hemos documentado dos lugares de reunión de esta cuadrilla: en 1517 tenía su sede en la ermita de San Roque ${ }^{340}$, extramuros de la villa, junto a las eras de Santa Cruz. Pero en años posteriores también celebró sus asambleas en la ermita de Santa Cruz, situada en el espacio intramuros, en las proximidades de la Plaza Nueva ${ }^{341}$.

La Cuadrilla de Cascajar incluía la calle del mismo nombre y la emergente calle de Barrionuevo. No sabemos dónde se reunía con anterioridad al comienzo del Quinien-

\footnotetext{
${ }^{338}$ AGS, CC MEMORIALES, leg. 121, doc. 236.

${ }^{339}$ AGS, CC MEMORIALES, leg. 129, doc. 70.

${ }^{340}$ AGS, CONSEJO Y JUNTAS DE HACIENDA, leg. 4, doc. 20; VELASCO PÉREZ, Aranda.
} Memorias..., p. 388-91; y SANZ ABAD, Historia de Aranda..., p. 305.

${ }^{341}$ VELASCO PÉREZ recoge la reunión de esta cuadrilla en el año 1536 en la ermita de Santa Lucía, nombre con el que era también conocida la ermita de Santa Cruz (Aranda. Memorias,... pp. 17576). 
tos pero en buena lógica cabe sospechar que fuera en la iglesia de Santa María. Tras la construcción del convento de San Francisco a principios del siglo XVI y la pujante ascensión del vecindario de Barrionuevo, las sesiones pasaron a celebrarse cabo el monesterio del señor San Francisco, estramuros de la dicha villa de Aranda ${ }^{342}$.

La Cuadrilla de San Juan integraba a la collación del mismo nombre y se extendía por el espacio que correspondía al primitivo emplazamiento de la villa. Con toda probabilidad desde 1492 se añadió a esta cuadrilla el nuevo espacio constituido por la collación de Santa Ana. Celebraba sus reuniones vecinales cabo la iglesia del señor San Juan.

Aparte de collaciones y cuadrillas, también hemos identificado en la villa arandina algunas referencias a barrios. Por barrios en la ciudad medieval entendemos un espacio reducido dentro de ella, que a veces se presenta como una sola calle, delimitada por las características socioeconómicas de los grupos humanos que habitan en él.

En este sentido, en Aranda tan solo encontramos referencias a barrios en algunos casos muy concretos: el varrio e calle de Sant Juan; varrio de Cascajar y Barrio Nuevo, incluyéndose en todos los casos las calles principales que les dan nombre más las secundarias que a ellas abocan ${ }^{343}$. Y esta misma acepción fue utilizada también para hacer referencia a zonas concretas dentro de los arrabales como el barrio de San Andrés, en el arrabal de las Tenerías ${ }^{344}$.

\section{c. Los arrabales.}

En el periodo que nos ocupa el empuje demográfico y el crecimiento económico de las ciudades provocaron que la población tendiera a sobrepasar la cerca y asentarse extramuros. El arrabal medieval en general se caracterizaba por ser un ámbito intermedio entre el entorno urbano definido por la cerca y el espacio rural que circunda a la ciudad. Estos espacios extramuros tendieron a una especialización de las actividades económicas. Esta especialización se produjo bien por una cuestión de seguridad, como ocurrió a finales del

\footnotetext{
${ }^{342}$ AGS, CONSEJO Y JUNTAS DE HACIENDA, leg. 4, doc. 20; Y ABAD LICERAS, J. M., "El ocaso de la presencia franciscana..., pp. 207-56.

${ }^{343}$ AGS, RGS, 148906, fol. 167; 149205, fol. 510; y CR, leg. 39, doc. 3 (PERIBÁÑEZ OTERO y ABAD ÁlVAREZ, Aranda de Duero..., p. 148).

${ }^{344}$ AGS, CMC, leg. 355. Se hace referencia en concreto a un par de casas en el varrio de San Andres, propiedad del comunero Bernardino de Arauzo.
} 
siglo XV con el desplazamiento de las herrerías desde el interior a los arrabales ${ }^{345}$; bien por salubridad, como apunta el hecho de que la actividad relacionada con el cuero se concentrara en el arrabal occidental ${ }^{346}$; o bien porque su situación estratégica como cruce de caminos posibilitó una intensa actividad comercial ${ }^{347}$. Aunque tradicionalmente se le ha otorgado al arrabal cierta autonomía respecto al núcleo urbano propiamente dicho, observamos en el espacio arandino que la proyección de la ciudad sobre su arrabal es total y así las normas que regulan la actividad interior se impusieron asimismo en el arrabal. Lo mismo sucedió con ciertos privilegios, como la exención de moneda forera concedida en 1467 por Enrique IV, que se hizo extensiva a los vecinos de los arrabales, aunque no así a los de la Tierra arandina ${ }^{348}$. Para terminar con esta breve definición del arrabal debemos señalar que su planteamiento urbano fue bastante más flexible al no existir obstáculos físicos cursos de ríos o laderas pronunciadas-, o antrópicos - cerca- que impidieran su crecimiento a medida que la presión demográfica lo demandaba.

La división cuatripartita del espacio intramuros que hemos apreciado a la hora de estudiar las cuadrillas se reprodujo extramuros de la villa como una proyección exterior de cada una de estas demarcaciones. Así se observa que traspasando la puerta de San Juan se desarrollaba el arrabal de San Andrés al otro lado del Bañuelos. Lo mismo ocurría tras la puerta de Cascajar donde se encontraba el arrabal de Cascajar, más frecuentemente nombrado como Fuenteminaya. Al otro lado de la Puerta de Hesilla surgió hacia el Este un arrabal lleno de huertas que recibió el nombre de Carraquemada, pero que con la construcción del convento franciscano pasó a denominarse de San Francisco. Por último, pero precisamente el más dinámico junto al anterior, al otro lado de la Puerta de Duero tras cruzar el puente, se desarrolló ampliamente un arrabal comercial denominado Allende Duero.

Estos cuatro arrabales con los que contaba la villa de Aranda a finales de la Edad Media estaban perfectamente definidos y participaban de una serie de características que ya definieron los propios vecinos en su momento: ...cada uno de los dichos arrabales, para mas noblesçimiento de la poblaçion, (tenía) su puente e su fuente e su hermita

${ }^{345}$ VELASCO PÉREZ, Aranda. Memorias,... p. 88.

${ }^{346}$ No en vano este arrabal occidental recibe el nombre de Tenerías, participando de las mismas características que el homónimo de Valladolid (AGS, CMC, leg. 355; y EMR, leg. 567).

${ }^{347}$ Esta circunstancia fue la que se produjo en los arrabales de Allendeduero y Hesilla.

${ }^{348}$ AMA, leg. 43, doc. 18. 
de mucha deboçion e su monte a las salidas enderezadas e muy honrradas ${ }^{349}$. A continuación trataremos de definir brevemente cada uno de estos arrabales.

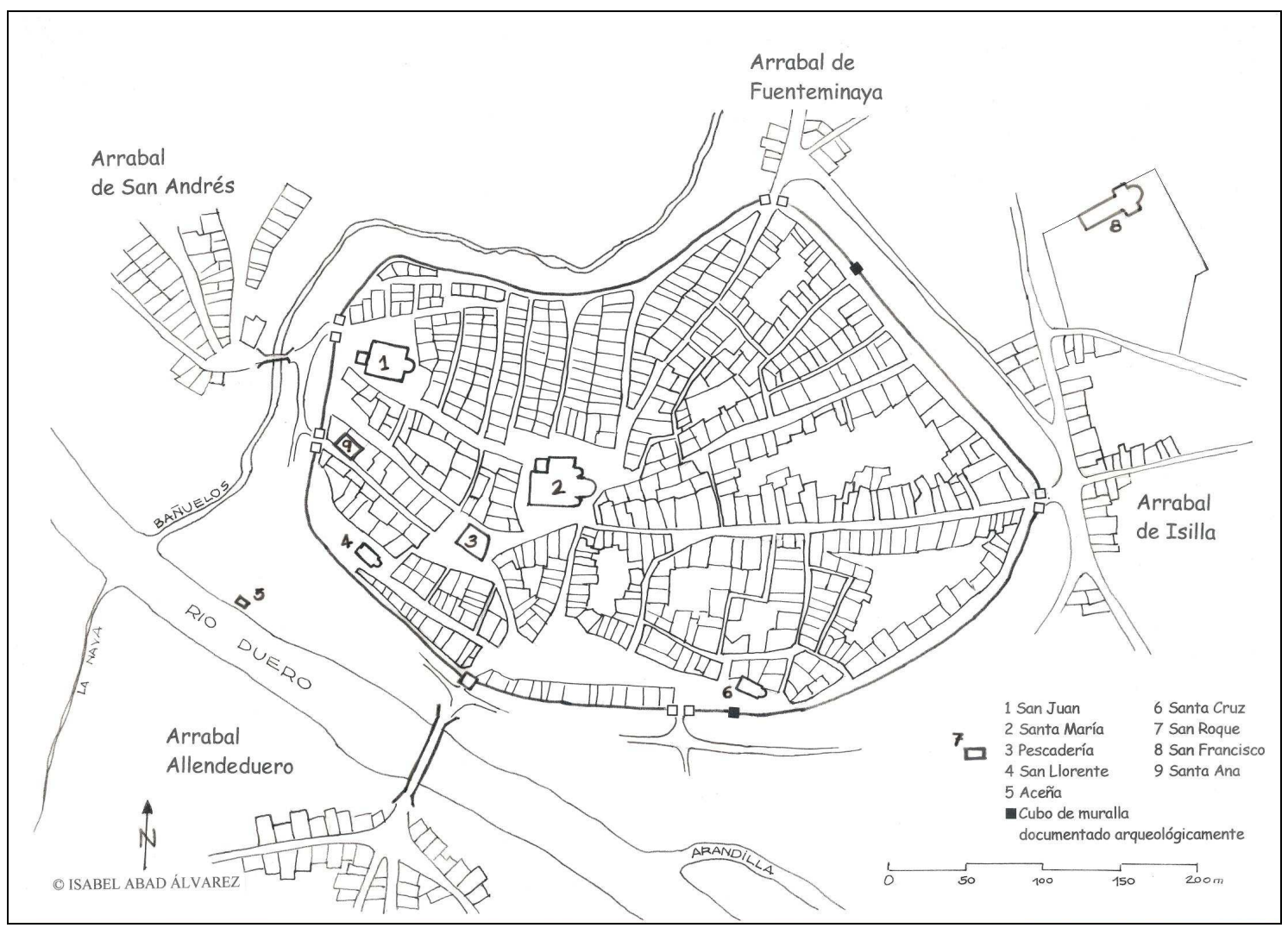

Plano 6: Aranda y sus arrabales a principios del siglo XVI.

El arrabal de Dehesilla, Carrequemada o San Francisco estaba situado junto a la puerta de Hesilla en el extremo Este de la villa, ocupando un basto territorio que iba desde el cauce del Bañuelos por el Norte, hasta el del Duero por el Sur. Estaba bastante desarrollado a finales del siglo XV y se articulaba en torno a dos calles, Carrequemada y Soria, el camino de San Esteban de Gormaz y un espacio abierto en el Sur que hacía las veces de eras y espacio comercial. A este arrabal llegaban los caminantes que procedían del Este: en él confluían los caminos que venían de Peñaranda y de la zona serrana de Huerta del Rey y Salas de los Infantes, más los provenientes de San Esteban de Gormaz, El Burgo de Osma y tierras de Soria, a través del puente Conchuela sobre el río Arandilla. También tenían acceso a él los caminantes que procedían del camino real de Burgos a través de un camino paralelo a las cavas y los del camino real toledano por las traseras de la Plaza Nueva. En definitiva, este arrabal se caracterizaba por una intensa actividad relacionada con el tránsito

${ }^{349}$ AGS, CR, leg. 39, doc. 3 . 
de personas y mercancías como nos trasmiten los testimonios de sus vecinos que certifican que ...suele venir por alli mucha carreteria de la Syerra e otra mucha gente e que pasa abaxo a Valladolid e a Medina ${ }^{350}$. Asociado a esta actividad se observa la proliferación de varios establecimientos hosteleros y postas instalados entre las puertas de Santa Cruz y Hesilla, que han dejado su impronta sobre el callejero arandino como se aprecia a través del nombre de dos calles: Postas y Ricaposada ${ }^{351}$. La existencia de estos establecimientos asociados al camino no implicó necesariamente su definición como arrabal comercial pues la mayor parte de los habitantes del mismo eran labradores y en él predominaban las viviendas asociadas a pequeñas huertas.

A comienzos del Quinientos el arrabal experimentó una serie de cambios, entre los que destaca el importante estímulo que recibió con la construcción del convento y hospital de San Francisco. El asentamiento de esta institución permitió el desarrollo de nuevas actividades y a la vez dotó al arrabal de una nueva articulación con la creación de nuevos espacios públicos asociados al monasterio. Asimismo en esta época se creó un espacio comercial extramuros de forma triangular al Sur de la Puerta de Hesilla y al Este de la de Santa Cruz que posiblemente albergara el mercado de ganado y madera ${ }^{352}$.

Este arrabal contaba con varias ermitas entre las que destacaban las de San Gregorio o Virgencilla, junto a la puerta de Hesilla; San Roque, equidistante de las puertas de Hesilla y Santa Cruz; Santiago, un poco más alejada junto a la calle Carraquemada; y en las inmediaciones de esa misma calle, pero integrada dentro del medio rural, la ermita de Santa Catalina. Junto a la puerta de Hesilla, en las cavas, se localizaba la fuente de este arrabal.

Para culminar con los elementos del arrabal es necesario señalar que a una cierta distancia al final de este arrabal se emplazaban los montes públicos de La Calabaza y Mataranda (Ver Mapa 5). El hecho de que los contemporáneos citaran el monte como

${ }^{350}$ AGS, CR, leg. 40, doc. 8; CC PUEBLOS, leg. 2, doc. 102; y CARRETE PARRONDO, Fontes Iudaeorum..., doc. 307, pp. 130.

${ }^{351}$ CEBAS HERNANDO asegura que Aranda fue estafeta y parada obligatoria de la ruta de correos entre Toledo y Burgos que estableció Fernando el Católico en 1483 (Callejero comentado..., p. 97). PÉREZ también señala la existencia de un servicio permanente de correos entre Bruselas y Toledo en el corto reinado de Felipe I que unía ambas ciudades en 15 días (Isabel y Fernando: los Reyes Católicos. Hondarribia, 1988, p. 143).

${ }^{352}$ SÁINZ GUERRA, La Génesis de la Plaza..., p. 231; y como Plaza de la Resina se la conoce en el siglo XVIII según el Catastro del Marqués de la Ensenada (ADPB, Catastro del Marqués de la Ensenada, Memorial de Seglares, vol. I, fol. 149). 
uno de los elementos definitorios del arrabal muestra la importancia que para ellos tenía el bosque y los recursos que de él extraían: alimentos diversos, leña para calentarse, madera para construcción y elaboración de herramientas,...

El arrabal de Cascajar, Bañuelos o Fuenteminaya se encontraba al Norte de la villa, junto a la puerta de Cascajar, y se desarrollaba a lo largo del camino real de Burgos. Se extendía sobre los dos lados del Bañuelos que se unían mediante un puente. Junto a él se situaba la fuente que daba nombre al arrabal. Este arrabal no tuvo un gran desarrollo a tenor de las escasas referencias que aparecen en la documentación ${ }^{353}$. A la salida del arrabal se encontraba la ermita de San Sebastián y el humilladero, junto al camino real de Burgos. Un poco más lejos se localizaba la ermita de la Virgen de las Viñas, aunque se encuentra a una considerable distancia en la ladera Sur del monte de Costaján. Precisamente en las inmediaciones de esta ermita comenzaba la masa forestal asociada a este arrabal: el Montehermoso.

El arrabal de San Andrés, de San Juan o de las Tenerías se desarrolló frente a la puerta de San Juan, al otro lado del Bañuelos, junto a una ermita que le daba nombre. Este barrio se articuló en torno al camino de Palencia y el puente que salvaba el Bañuelos. Este arrabal no fue muy mencionado en la documentación bajomedieval. Como todos los arrabales de la villa, estaba constituido por viviendas que tenían asociadas huertas y el predominio de la actividad agrícola lo confirma la existencia de unas eras. Sin embargo, ya desde este periodo se observa una cierta especialización en actividades relacionadas con el tratamiento de pieles y elaboración de cuero, productos indisolublemente unidos al comercio del vino ${ }^{354}$. Además del trabajo de preparación de cueros también se documenta en este arrabal la presencia de actividades relacionadas con los tintes $^{355}$. Al igual que ocurre en otras ciudades de Castilla, la localización de este arrabal aguas abajo de los dos ríos próximos, Duero y Bañuelos, lo configuran como el espacio más apropiado para establecer este tipo de actividades que precisaban gran cantidad de agua y cuyos vertidos eran incompatibles con el consumo humano. Esta actividad se mantuvo en el tiempo, constatándose un gran desarrollo en el siglo XVIII, cuando se

${ }^{353}$ AGS, CC PUEBLOS, leg. 2, doc. 107; y CR, leg. 40, doc. 8.

${ }^{354}$ Francisco de Berlanga era propietario de media tenería con sus calderas localizadas en este arrabal junto a la ribera del Duero (AGS, EMR, leg. 567). Más noticias sobre esta actividad en CR, leg. 40 , doc. 8 .

${ }^{355}$ Existen más noticias sobre tintes y cueros, aunque no se hace referencia en la documentación a su ubicación exacta (RGS, 148711, fol. 36; y CMC, leg. 355). 
consolidó el nombre de las Tenerías para este arrabal ${ }^{356}$. Este es el único arrabal del que no conocemos la ubicación de su fuente, si es que existió. El monte asociado a este espacio se encontraba a una considerable distancia en las proximidades de los pagos de Santiago y en torno al vallejo del Narejo.

El arrabal de Allendeduero o Endeduero se encontraba al otro lado del Duero y era el espacio extramuros que mayor grado de desarrollo alcanzaba a finales del siglo XV. Prueba de su vitalidad es que fue allí, y no en la villa, fue donde la princesa Isabel confirmó los privilegios de la villa en $1473^{357}$. Este notable desarrollo se debió en gran parte a su posición privilegiada como cruce de caminos al confluir en este espacio el camino real toledano, el de Valladolid y el de Soria, pero sobre todo por ser el paso obligado del Duero a través de su puente. Gracias al tránsito de viajeros y ganados, en este arrabal se desarrollaron innumerables actividades y el barrio se llenó de tiendas de cosas de comer y de aver tiendas de barberos y sastres y zapateros ${ }^{358}$. Fueron varios los mesones establecidos en él, entre los que se encontraba el Mesón del Rey ${ }^{359}$. Otro tipo de servicios personales tenía también su lugar en este activo arrabal pues en él estan las mugeres publicas ${ }^{360}$. La marginalidad del barrio también se advertía en el confinamiento al que fue sometida la comunidad mudéjar que fue recluida allí tras el apartamiento de $1480^{361}$.

En este sentido, el tránsito de personas también propició el establecimiento de órdenes religiosas que cuidaban de los caminantes. La primera referencia que tenemos sobre este aspecto se remonta a mediados del siglo XV cuando se instaló en el arrabal de Allendeduero la orden del Santo Espíritu de Sassia (Roma) y comenzó a construir una capilla y hospital. No parece que la obra se terminara pues el solar fue arrendado 24-26.

${ }^{356}$ APDB, Catastro del Marqués de la Ensenada, Memoriales de Seglares, vol. I, fol. 106-14.
${ }^{357}$ AMA, leg. 42, doc. 6, transcrito por HURTADO QUERO, Documentos Reales..., doc. 11, pp.

${ }^{358}$ AGS, RGS, 149002, fol. 176.

${ }^{359}$ AGS, RGS, 148910, fol. 129; 149701, fol. 19; CASAS Y SITIOS REALES, leg. 2, doc. 483.

${ }^{360}$ Uno de los argumentos que utilizó el concejo para rechazar la reedificación del hospital del Santo Espíritu fue ...que esta en la parte e çerca del lugar donde estan las mugeres publicas e se espera que sy la dicha casa se fiziere que en ella morarian e estarian echacuervos (alcahuete, embustero) e otras personas dyliçito e torpe bibir de que se seguirian muchos ruydos e escandalos e alborotos (AMA, leg. 42, doc. 2, transcrito por HURTADO QUERO, Documentos Reales..., doc. 36, pp. 64-66).

${ }^{361}$ AGS, CCP, leg. 2, doc. 61; y RGS, 148312, fol. 173. 
por el clérigo Bernardo de Aranda. A comienzos del siglo XVI la orden retomó el proyecto que tampoco se concretó por la oposición del concejo ${ }^{362}$. También con cierta polémica se intentó establecer la orden de San Lázaro en este arrabal apropiándose de una ermita que estaba bajo esta advocación. El concejo denunció esta usurpación pues la ermita era de patronazgo concejil y el problema se resolvió en 1502 con una sentencia arbitral que confirmó la propiedad municipal ${ }^{363}$. En buena medida el fracaso de estas iniciativas de establecer un hospital para atender a caminantes, enfermos y pobres en general se debió a que la villa ya contaba a finales del siglo XV con un hospital en este arrabal, como veremos más adelante. Precisamente junto a este hospital y muy cerca del puente de Duero se encontraba la fuente conocida como la del Torillo. En dirección Oeste se extendía una modesta superficie forestal que daba servicio al arrabal y que recibía el elocuente nombre de El Montecillo.

En definitiva, los arrabales de la villa, sobre todo los de Hesilla o San Francisco y el de Allendeduero, gozaban en el periodo estudiado de una intensa actividad que fomentó un gran desarrollo urbanístico que se confirmó en los años posteriores con la finalización del convento de San Francisco en el de Hesilla y el comienzo de la construcción de un convento dominico en el de Allendeduero.

\subsubsection{Elementos urbanos.}

El aumento de la complejidad de las funciones urbanas que se desarrollaron en las ciudades medievales se plasmó en la configuración de espacios y edificios específicos concebidos para desarrollar actividades cada vez más diversificadas. En este apartado trataremos de identificar estos espacios para tratar de contribuir al conocimiento de la dinámica interna de una sociedad en un contexto de notable crecimiento económico.

${ }^{362}$ En 1500 el comendador de la orden denunciaba ante los monarcas que algunos vecinos habían ... desfecho los cimientos de la dicha eglesia e ospital e han movido e quitado algunos de los limites de la dicha eglesia e ospital e de su suelo e entran e ocupan el dicho suelo (AGS, RGS, 150007, fol. 71). La protesta del concejo se ampara en que ...la dicha villa tyene constunbre ynmemorial que en ella nin en sus terminos non se puedan faser nin hedeficar yglesia nin monasterio nin ospetal syn su pedimiento e consentimiento (AMA, leg. 42, doc. 2, transcrito por HURTADO QUERO, Documentos Reales..., doc. 36, pp. 64-66).

\footnotetext{
${ }^{363}$ AMA, leg. 43, doc. 35.
} 


\section{a. Espacios religiosos.}

La historiografía local ha dedicado muchas páginas a los edificios con finalidad religiosa, sobre todo enfocadas a su estudio artístico. En las siguientes líneas intentaremos aproximarnos a estas construcciones desde un punto de vista urbanístico e histórico con el fin de analizar las repercusiones que sobre la sociedad arandina tuvieron ${ }^{364}$.

En el periodo final de la Edad Media la villa de Aranda contaba con tan solo dos parroquias a pesar de su tamaño y población, sobre todo si lo comparamos con otros núcleos de similar o menor envergadura y que, sin embargo, contaban con varias parroquias, como ocurría en Paredes de Nava o Roa de Duero ${ }^{365}$. Esta escasez de parroquias se compensaba con la gran cantidad de pequeñas ermitas que proliferaban tanto por los arrabales como por el espacio rural próximo. Por su parte, las aldeas de la Tierra arandina contaban cada una de ellas con su iglesia de referencia, aunque no sabemos a ciencia cierta si tuvieron en esa época la consideración de parroquias.

La iglesia de San Juan era la parroquia más veterana de la villa y seguramente también sea la construcción religiosa más antigua de Aranda. Es indudable su importante papel en la articulación y jerarquización del espacio intramuros pues era el centro neurálgico de la collación y cuadrilla del mismo nombre y en ella, o junto a ella, celebraban sus asambleas. Sin embargo, se observa en este periodo que esta iglesia había perdido el papel preponderante que sin duda jugó en momentos históricos anteriores y que se había desplazado a lo largo del siglo XV a la iglesia de Santa María. Esta pérdida de importancia se tradujo también al plano urbano pues la Plaza Pública o de Santa María se convirtió en el centro neurálgico de la villa.

En cuanto a sus características constructivas cabe destacar que la imagen de la iglesia que aparece en el plano de 1503 muestra la misma configuración que tiene en la actualidad salvo en el ábside. La cabecera que se representa parece ser la primitiva románica de planta semicircular y con cubierta abovedada. También se aprecian unos estribos o contrafuertes apoyados sobre los muros del ábside. Asimismo se observa que tanto el cuerpo de la iglesia como el ábside carecen de tejado, circunstancia que ha llevado a Sáinz Guerra a

${ }^{364}$ Una visión de conjunto la presenta la obra de ABAD ZAPATERO y ARRANZ ARRANZ, Las Iglesias de Aranda... Además existen múltiples trabajos específicos sobre estas iglesias como manifestaciones artísticas recogidos en varias publicaciones entre las que destacan Biblioteca. Estudio e Investigación. En el desarrollo de nuestro trabajo mencionaremos alguna de ellas.

${ }^{365}$ Paredes de Nava contaba en el siglo XV con cuatro parroquias (MARTÍN CEA, El mundo rural..., p. 240); Roa posiblemente llegó a tener cinco parroquias (ZAMORA LUCAS, F., La villa de Roa. Madrid, 1965, pp. 341-342). 
plantear la posibilidad de que en el momento de ser realizado el dibujo se estuviera acometiendo una reforma ${ }^{366}$. En el dibujo también destaca la verticalidad y estilización de la torre, que en absoluto se corresponde con la sobriedad y robustez del torreón de San Juan, por lo que este aspecto puede ser interpretado más bien como una licencia del dibujante

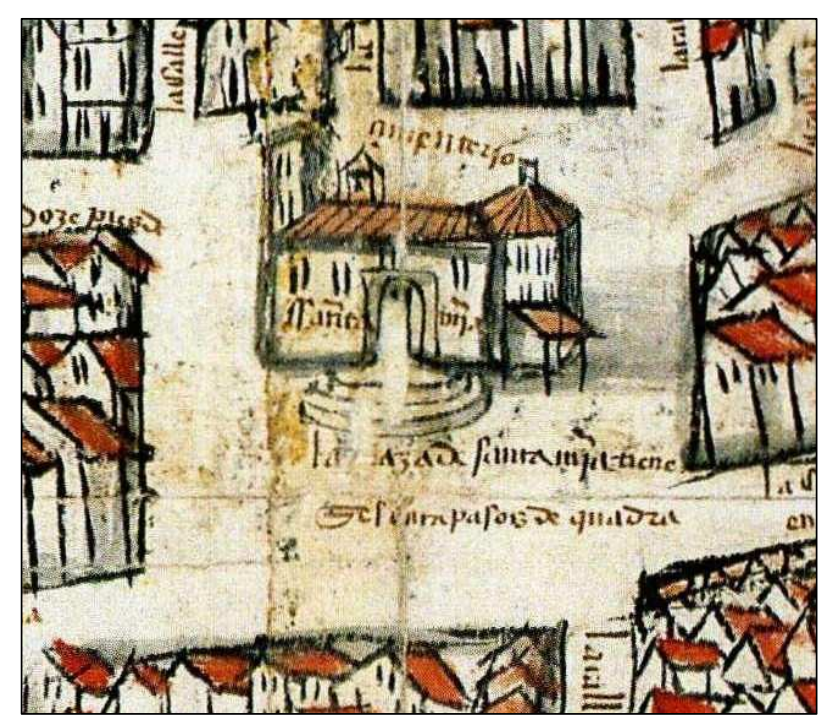
acorde con la moda de representar las ciudades en la época ${ }^{367}$.

Imagen 15: Plaza Pública, cementerio e iglesia de Santa María.

La iglesia de Santa María era sin lugar a dudas el principal edificio y punto de referencia del entramado urbano arandino, tanto en el plano real como en el imaginario colectivo. El hecho de que en su plaza se celebrara el mercado semanal y en sus gradas se pregonaran noticias, decretos y se realizaran subastas nos da una idea de la importancia de este ámbito, pues el origen y razón de ser del espacio público que albergaba estas actividades civiles era la iglesia que lo presidía. En este sentido tampoco debemos olvidar que la vida cotidiana estaba regida por el sonido de las campanas que albergaba la iglesia y los acontecimientos más importantes de la vida de los vecinos estaban marcados por el calendario litúrgico ${ }^{368}$.

Como ya hemos mencionado anteriormente, la iglesia de Santa María y su entorno adquirieron en este periodo el papel preponderante que anteriormente tuvo el templo de San Juan. La causa evidente fue la dinámica expansiva del núcleo urbano hacia el Este que provocó el consiguiente cambio en el punto de gravedad. Su posición destacada en la vida

${ }^{366}$ SÁINZ GUERRA, “Desarrollo urbanístico..., p. 46. Esta hipótesis se reafirma con la ausencia de espadaña, que sí aparece en el resto de las edificaciones religiosas.

${ }^{367}$ ARIZAGA BOLUMBURU, B., "La recuperación del paisaje urbano medieval: propuesta metodológica", en La ciudad medieval: aspectos de la vida urbana en la Castilla bajomedieval. Valladolid..., pp. 13-33, en concreto p. 26.

${ }^{368}$ La decisión que tomaron las autoridades en 1505 de prohibir estercolar las viñas se hizo pública mediante el habitual pregón en las gradas de Santa María, en la Plaza Nueva y en la calle de Hesilla. Este pregón se hizo, como tenían por costumbre, a la salida de las vísperas mayores y en presencia del teniente de corregidor, un regidor y los escribanos del concejo (AGS, CC PUEBLOS, leg. 2, doc. 107). 
de la villa se evidenciaba también en su polivalente función pues asumía un matiz político al albergar en ocasiones solemnes las reuniones del Concejo en su interior. En este sentido, parece muy elocuente la reunión plenaria de todos los oficiales del concejo en 1495 para acordar la compra del lugar de Milagros al abad y monasterio de San Pedro de Gumiel ${ }^{369}$. De igual manera, es bastante significativo que el arca del concejo, en el que se guardaban los privilegios que los diferentes monarcas habían otorgado a la villa, se encontraba depositada en una de las capillas de esta iglesia ${ }^{370}$.

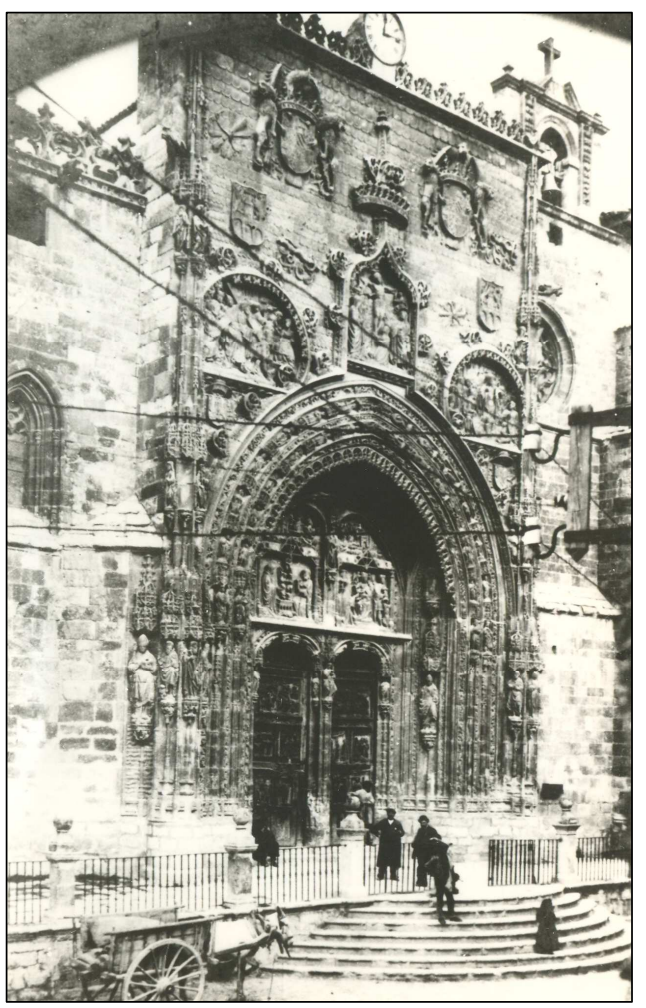

Imagen 16: Las gradas de Santa María a principios del siglo $X X$.

Por lo que respecta a la representación de este templo en el plano de 1503, lo primero que llama la atención es que no aparece la fachada retablo que hoy la caracteri$\mathrm{za}^{371}$. Es evidente que la fábrica estaba por terminar e incluso se puede apuntar, como ya han señalado algunos autores, que la pequeña construcción auxiliar adosada a la cabecera pudiera ser el área de trabajo de los artesanos que estaban ejecutando las obras $^{372}$. Asimismo se aprecia en el dibujo la escalinata semicircular que se representa en el acceso Sur de la iglesia y que es identificada en la documentación como las gradas de Santa María ${ }^{373}$.

${ }^{369}$ AGS, CC PUEBLOS, leg. 13, doc. 3.

${ }^{370}$ AGS, CC MEMORIALES, leg. 129, doc. 55. Esta misma circunstancia se reproduce en la cercana localidad de Roa donde el arca del concejo se guardaba en el interior de la iglesia mayor o colegiata (RGS, 149305, fol. 222).

${ }^{371}$ Según DOMÍNGUEZ CASAS la fachada se ejecutó entre 1500 y 1511 ("Heráldica en el arte del Renacimiento: Burgos y el Sur Provincial", en Biblioteca 18. Estudio e Investigación. 2003, pp. 219261).

${ }^{372}$ SÁINZ GUERRA, "Desarrollo urbanístico..., p. 47.

${ }^{373}$ AMA, leg. 43, doc. 5. 


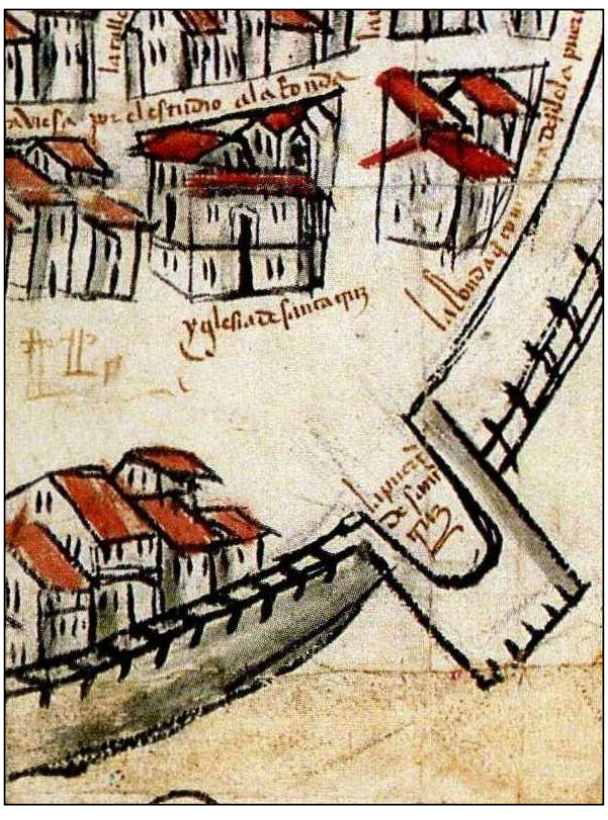

Imagen 17: Puerta y ermita de Santa Cruz.

La iglesia de Santa Cruz se localizaba en el extremo Este de la Plaza Nueva y suponemos que era una primitiva ermita extramuros que con la ampliación bajomedieval quedó integrada en el interior. Quizá su proximidad a las casas del concejo o un posible patronazgo concejil explican que fuera el lugar preferido por el ayuntamiento para celebrar sus sesiones $a$ campana repicada durante buena parte del Cuatro$\operatorname{cientos}^{374}$. En el plano de 1503 esta iglesia aparece representada con dos alturas y un vano de entrada que se extiende al segundo cuerpo. Parece apreciarse un pequeño ábside en el lado Este y el conjunto está rematado por una espadaña con campana. Posiblemente a comienzos del siglo XVII la ermita cambió su advocación de la Santa Cruz en el contexto de la unificación que se produjo entre las cofradías de la Santa Cruz de Mayo, también conocida como Santa Elena, y la de Santa Lucía ${ }^{375}$. No sabemos en qué momento fue derribada, pero lo cierto es que en el XVIII la ermita no existía y la calle en la que se localizaba ya recibía el nombre de Santa Lucia $^{376}$. Este edificio debió asentarse en el solar que en la actualidad se encuentra entre las calles Santa Lucía, Empedrada y travesía de Prado Marina.

${ }^{374}$ En 1429 ya se reunía el concejo en esta iglesia y así continuó haciéndolo habitualmente durante todo el siglo XV (AMA, leg. 43, doc. 4).

${ }^{375}$ Un documento de 1568 cita las cofradías arandinas y entre ellas están la de Santa Lucía y la de Santa Cruz (VELASCO PÉREZ, Aranda. Memorias..., p. 243-44). En 1609 se produjo la absorción de la cofradía de la Santa Cruz por parte de la de Santa Lucía ...para que en entrambas cofradias sean una y tenga voz y nombre de Señora Santa Lucia y sea todo un cabildo y hermandad permanente. El hecho de que se estableciera ...que el retablo de la dicha cofradia y hermandad de Señora Santa Elena este en el sitio y lugar que al presente esta, que es en medio de los dos altares de Santa Lucia y San Blas... parece confirmar la inicial advocación de la ermita asociada al culto a la Santa Cruz (ARCHIVO HISTÓRICO PROVINCIAL DE BURGOS -AHPB-, PROTOCOLOS NOTARIALES, JUAN DE PARDO, protocolo 4647/1). Seguramente la cofradía de Santa Lucía se instaló en ella con posterioridad pero con el tiempo tuvo más proyección que la titular y terminó por absorberla. Agradecemos la información transmitida sobre este aspecto a don Antolín Cebrecos Soto que además nos ha proporcionado amablemente la transcripción de este documento.

${ }^{376}$ ZAPARAÍN YÁÑEZ, Desarrollo artístico..., Vol. I, p. 134. 


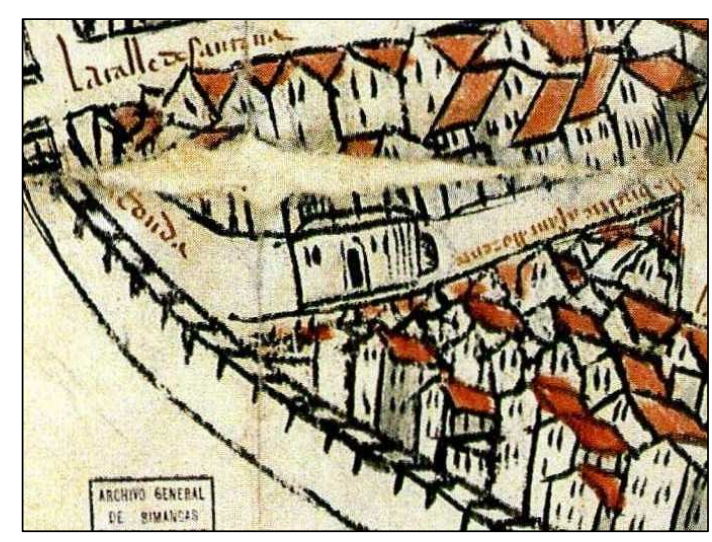

También en ella tenía su sede la cofradía del santo titular, que con el tiempo evolucionó a la advocación de San Lorenzo ${ }^{378}$. En el dibujo de 1503 se representa una modesta iglesia de aspecto románico por el pequeño ábside semicircular y unas columnillas adosadas en la zona del presbiterio. Son muy pocos los datos que tenemos sobre esta iglesia y tampoco sabemos cuándo cambió su denominación por la más conocida de Santo Cristo. Posiblemente esta circunstancia tuvo relación con la creación en 1658 por el obispo Juan de Palafox de la Humilde Escuela de Cristo en esta ermita ${ }^{379}$. En el siglo XVIII ya era identificada como ermita del Santo Cristo ${ }^{380}$. En 1958 la ermita se derrumbó al ceder una bodega que se encontraba bajo el edificio. Lo único que pervive en la actualidad de este edificio es la talla del Santo Cristo de San Llorente o San Lorenzo que está depositada en una capilla lateral del santuario de la Virgen de las Viñas y una reja renacentista que está colocada en el paseo que lleva a dicha ermita ${ }^{381}$.

${ }^{377}$ AGS, CONSEJO Y JUNTAS DE HACIENDA, leg. 4, doc. 20.

${ }^{378}$ CRIADO MAMBRILLA, R., Historia de la imagen, cofradía y ermita de Nuestra Señora de las Viñas. Aranda de Duero, 2006, pp. 41-42.

${ }^{379}$ VELASCO PÉREZ, Aranda. Memorias..., pp. 321-23. El autor señala que un año antes se sacó de la ermita la imagen del Santo Cristo de San Lorenzo por temor a que una inundación derribara el templo.

${ }^{380}$ ZAPARAÍN YÁÑEZ, Desarrollo artístico..., Vol. I, p. 134; y MADOZ, Diccionario Geográfico.., Tomo II, p. 50.

${ }^{381}$ CRIADO MAMBRILLA, Historia de la imagen..., , p. 42; y CEBAS HERNANDO, Callejero comentado..., p. 126. 


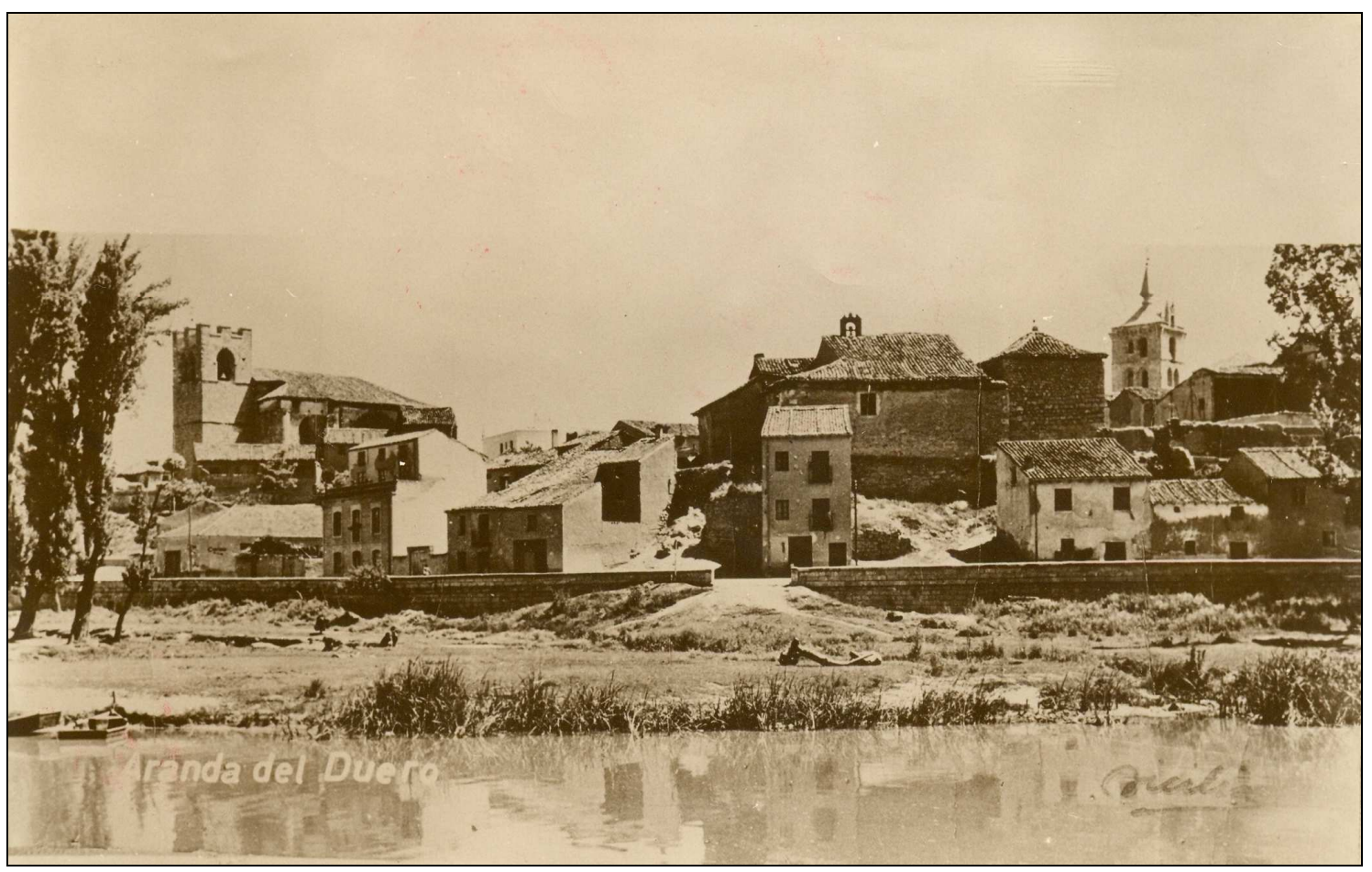

Imagen 19: Ermita de San Lorenzo poco antes de su derrumbe (CBMAD).

La ermita de Santa Ana estaba edificada en la calle del Hoçino, que después pasó a llamarse con el mismo nombre que la ermita y en la actualidad, inexplicablemente, recibe el nombre de Pedraja. Para don Aniceto de la Cruz esta ermita fue una fundación del rey Ramiro a mediados del siglo X para celebrar una victoria sobre el infiel ${ }^{382}$. En realidad la ermita de Santa Ana fue creada en 1492 como consecuencia de la sacralización de la antigua sinagoga abandonada por la aljama judía en el momento de su expulsión. Sin embargo, el proceso fue bastante complicado pues parte de la sinagoga fue vendida en un primer momento por la aljama al comendador Íñigo de Barahona, regidor de la villa, quien pagó una señal de los 25.000 maravedíes en que se fijó la compraventa. Paralelamente, ciertos vecinos de Aranda, inducidos por el provisor de Osma, tomaron violentamente la sinagoga y la sacralizaron bajo la advocación de Santa Ana. Barahona se quejó ante los reyes y consiguió que se la devolvieran. Pero los cofrades de Santa Ana apelaron la decisión argumentando que Barahona sólo había acordado la compra de una parte de la antigua sinagoga y no la había pagado, por lo que no le pertenecía. Barahona mantuvo que al menos una parte del edificio era suyo, pero finalmente los reyes dieron la razón a

${ }^{382}$ DE LA CRUZ, Historia de la Milagrosa..., pp. 112-14. Esta misma leyenda ha sido retomada por VELASCO PÉREZ y SANZ ABAD. 
los cofrades que recuperaron el edificio. En 1494 la antigua sinagoga pasó a ser defini-

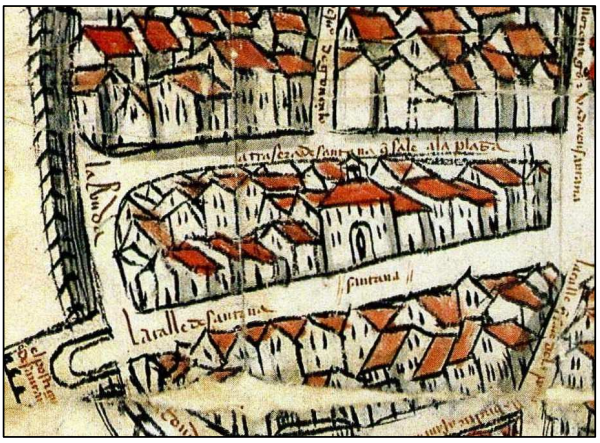
tivamente ermita dependiente de la parroquia de San Juan ${ }^{383}$.

Imagen 20: Postigo y ermita de Santa Ana.

El dibujo del plano de 1503 muestra una construcción bastante modesta y sencilla de dos plantas con ventanas en el piso superior. El edificio se cierra con una cubierta a cuatro aguas y está rematada por una espadaña central con campana. En el plano obtenido del Catastro del Marqués de la Ensenada de 1752 que presenta María José Zaparaín se observa que la ermita de Santa Ana estaba localizada al final de la calle Santa Ana, casi junto al lugar donde estaría el postigo ${ }^{384}$. Sin embargo, informaciones orales transmiten la existencia de una pequeña capilla en una casa particular situada entre el actual $n^{\circ} 8$ de la calle Pedraja y las escalinatas que suben a la actual calle Santa $\mathrm{Ana}^{385}$. En el plano de Coello de 1868 no aparece esta ermita ni se la cita en la relación de $\mathrm{Madoz}^{386}$. Desconocemos por el momento cuándo se arruinó o fue desacralizada.

Además de las iglesias y ermitas intramuros existieron en los arrabales y las proximidades de la villa un convento franciscano y numerosas ermitas, algunas de las cuales hemos logrado identificar.

La única institución conventual con la que contó la capital de la Ribera a finales de la Edad Media fue el convento de San Francisco. Este cenobio comenzó a construirse en 1499 bajo el patronato de don Martín Vázquez de Acuña. El convento enseguida se ganó las simpatías de los arandinos, pero también las enemistades de los clérigos y párrocos de

${ }^{383}$ AGS, RGS, 149205, fol. 451; 149303, fol. 357; y 149403, fol. 370. El primero y el último están publicados por CADIÑANOS BARDECI, “Judíos y moros..., pp. 43-45.

${ }^{384}$ ZAPARAÍN YÁÑEZ, Desarrollo artístico..., Vol. I, p. 134.

${ }^{385}$ Información transmitida por don Alberto Villahoz García que asegura haber visto la pequeña capilla en esta casa en la que vivían sus suegros. Desgraciadamente este edificio está hoy abandonado y arruinado y no hemos podido comprobar los datos aportados. Lo cierto es que este emplazamiento cuadra mejor con la representación del plano de 1503 que la aportada por ZAPARAÍN YÁÑEZ.

${ }^{386}$ MADOZ, Diccionario Geográfico..., Tomo II, p. 50. 
las iglesias locales que vieron cómo los feligreses y sus donativos preferían acudir al nuevo centro de culto ${ }^{387}$.

En principio, el monasterio se planteó con una iglesia que contaba con una capilla mayor y dos laterales. El maestro cantero, un tal Juan Daras ${ }^{388}$, proyectó una capilla mayor con su altar y gradas y por ello cobró 6.000 maravedíes y 50 cántaras de vino. Junto a esta iglesia también se ideó la creación de un hospital. La capilla mayor, la del Evangelio y el hospital fueron costeados por la familia Acuña; mientras que la de la Epístola fue patrocinada por Pedro de Santa $\mathrm{Cruz}^{389}$. La capilla mayor contaba con dos arcosolios en los que se hicieron enterrar los hijos de los patronos, dejando sus inscripciones y el escudo de su linaje ${ }^{390}$. Seguramente primó en su construcción el gótico final, florido asegura Velasco Pérez, acomodándose a los gustos de la época. Sin embargo, el conjunto sufrió en la década de los cuarenta del Quinientos un importante derrumbe que distorsionó considerablemente su aspecto originario ${ }^{391}$. La configuración del conjunto debía ser muy similar a la que muestra el plano de Coello de 1868 en el que aparece una planta de cruz latina con una única nave, capilla mayor semicircular y un transepto muy poco desarrollado que coincide con las dos capillas laterales referidas.

De este convento hoy queda tan solo parte del lienzo de la capilla del Evangelio que evidencia su carácter tardogótico. En este muro todavía se puede apreciar un escudo que simula estar colgado de la diestra por una cadena pendiente de una argolla. En él aparecen representados los emblemas del linaje de los Acuña, Portugal, Valencia y Ca-

${ }^{387}$ Esta situación provocó un conflicto entre párrocos y frailes que analizaremos más adelante (AGS, CC PUEBLOS, leg. 2, doc. 107, fols. 18, 19 y 20).

${ }^{388}$ Posiblemente se trate del maestro cántabro Juan de Aras que desarrolla una importante actividad en tierras palentinas y vallisoletanas a mediados del siglo XVI. No obstante, son muchos los canteros originarios de este valle cántabro y de momento resulta muy difícil identificarlo con alguno concreto (GONZÁlEZ ECHEGARAY, M. C. et álii, Artistas cántabros de la Edad Moderna: su aportación al arte hispánico. Diccionario biográfico-artístico. Santander, 1991, p. 46; y ALONSO RUIZ, B., "Un modelo funerario del tardogótico castellano: las capillas treboladas", en Archivo español de Arte, 311, 2005, pp. 277-295).

${ }^{389}$ ARChV, RRE Caja 315, doc. 20. Esta capilla la construyó Santa Cruz por una obligación que contrajo en Roma tras ganarse una dispensa papal relacionada con su condición de converso. Martín de Tamayo, vecino de Pinilla Trasmonte, declaraba que ...dixo Pedro de Santacrus que el avia ydo a Roma y avia traydo dispensaçion del Padre Sancto y que le mandaron façer un retablo (CARRETE PARRONDO, Fontes Iudaeorum..., doc. 415, p. 172).

${ }^{390}$ LOPERRAEZ CORVALÁN, Descripción histórica..., Vol. II, pp. 178-180. Más adelante analizaremos el significado de este linaje dentro del contexto de la nobleza local arandina.

${ }^{391}$ VELASCO PÉREZ, Aranda. Memorias..., p. 177. 
beza de Vaca (Ver Imagen 49), por lo que se identifica con el emblema de don Martín Vázquez de Acuña, patrono fundador del convento ${ }^{392}$.

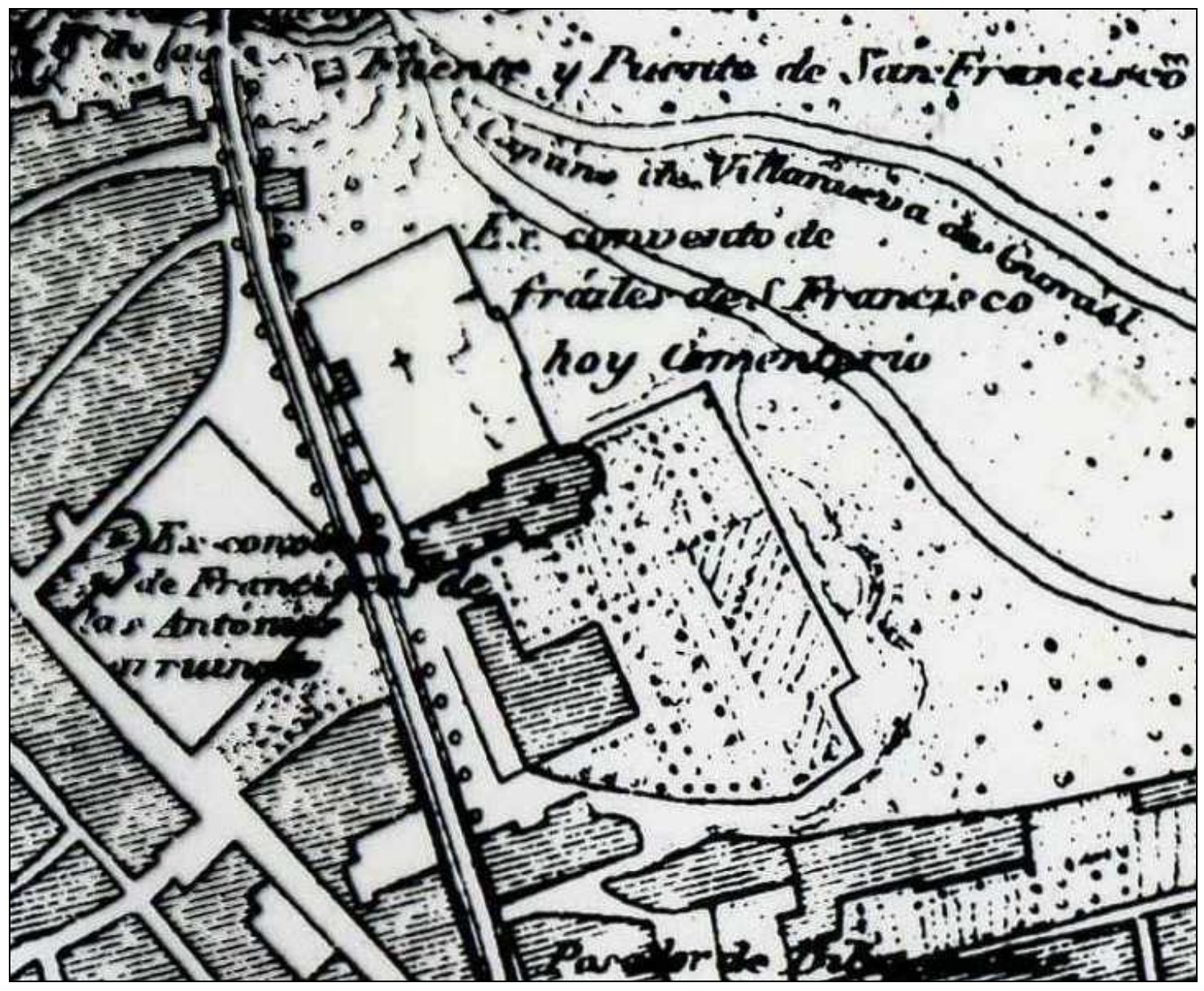

Imagen 21: Detalle del convento de San Francisco según el plano de Coello de 1868.

Sin lugar a dudas, esta nueva construcción condicionó el desarrollo urbano del arrabal oriental pues, como ya hemos visto, sirvió de acicate para el gran desarrollo del mismo durante este periodo. Asimismo la comunidad franciscana ejerció una gran influencia sobre la articulación del espacio próximo. La influencia del cenobio sobre las autoridades de la villa se materializó en 1515 con la creación de ...una calle publica e ancha, frontera de la puerta de la dicha iglesia..., que se realizó para ...hornato e ponpa e noblescimiento de la villa, pero sobre todo del monasterio ${ }^{393}$.

${ }^{392}$ DOMÍNGUEZ CASAS, "Heráldica en el arte..., pp. 232-233. Don Martín era hijo de don Enrique de Acuña y doña Isabel de Valencia.

${ }^{393}$ AGS, CC PUEBLOS, leg. 2, doc. 107. 
El paso más significativo en el contexto de la revalorización urbanística del entorno próximo del monasterio se forjó pocos años después con la apertura de una nueva puerta en la muralla, comunicando el centro de la villa con el monasterio directamente a través de la calle Barrionuevo. Como ya hemos mencionado anteriormente, en 1517 los vecinos de Barrionuevo y los frailes de San Francisco solicitaron que ...manden hacer un portillo de la cerca de la villa frontero del dicho monesterio, el qual va a dar a la calle de Barrionuevo, no mayor que pueda caber una persona encima de una mula..., sin temor de que tal decisión moleste a nadie, pues ...no ay camino ninguno que vaya a dar al dicho portillo, salvo para yr o venir al dicho monesterio ${ }^{394}$. A pesar de la oposición de los vecinos de la calle Hesilla, finalmente la muralla se horadó. Con estas dos actuaciones se infiere una evidente revalorización del espacio urbano extramuros entorno al monasterio de San Francisco que actuó como polo de atracción, pero también como promotor de esta nueva realidad espacial.

También intentó la comunidad franciscana actuar sobre el entorno rural próximo a través de un ambicioso proyecto hidráulico que pretendía desviar el curso del río Aranzuelo para mejorar el abastecimiento de agua del convento de San Francisco y de la villa de Aranda, además de potenciar la explotación agrícola de regadío en una amplia zona al NE de la villa. Pero a pesar de haber recibido las autorizaciones correspondientes, contar con un presupuesto y haber iniciado las obras, el proyecto quedó relegado para una mejor ocasión que no llegará hasta cuatro siglos después ${ }^{395}$.

Aparte del monasterio, el término de Aranda contaba a finales de la Edad Media con un importante número de ermitas localizadas en los arrabales y en el entorno rural circundante.

La más importante de todas las ermitas extramuros, no por su proyección espacial sino por su significado en el contexto de la religiosidad popular, fue la ermita de la Virgen de las Viñas ${ }^{396}$. Buena prueba de ello era que en las mandas testamentarias era habitual que se dejaran cinco maravedíes para el mantenimiento de la ermita de la patrona, mientras que

${ }^{394}$ AGS, CC MEMORIALES, leg. 124, doc. 141 y leg. 152, doc. 116.

${ }^{395}$ El proyecto aparece recogido en AGS, CR, leg. 40, doc. 8 y ha sido estudiado por ABAD ÁLVAREZ y PERIBÁÑEZ OTERO, “El control social del agua..., pp. 113-156. Tras este primer fracaso, la comunidad franciscana intentó de nuevo promover su proyecto a mediados del siglo XVI pero también fracasó (VELASCO PÉREZ. Aranda. Memorias..., pp. 186-190).

${ }^{396}$ Esta ermita ha sido recientemente estudiada por CRIADO MAMBRILLA, aunque son escasos los datos históricos que se tienen sobre su desarrollo medieval (Historia de la imagen..., pp. 17-31). 
al resto de las ermitas extramuros tan solo se las dejaba un maravedí ${ }^{397}$. A falta de estudios más profundos, podemos asegurar que nada queda de la ermita que a finales de la Edad Media cobijó a la patrona de Aranda pues su santuario fue remodelado completamente a mediados del siglo XVI y en el siglo XVIII. La tradición afirma que hasta mediados del Quinientos esta ermita estaba asistida por un grupo de beatas que vivía en comunidad en los edificios anexos a la propia ermita ${ }^{398}$. Sin poner en duda lo anterior, hemos constatado documentalmente que estas beatas disponían de unas casas situadas frente al convento de San Francisco que el regidor Pedro de Santa Cruz les había cedido ${ }^{399}$. Al menos desde 1506 esta comunidad de mujeres recibía de la Corona un juro por valor de 1.500 maravedíes anuales situados sobre la alcabala del vino de Aranda ${ }^{400}$. Estas beatas también recibieron donativos de particulares que, como ya hemos visto, les supusieron algún que otro conflicto.

Entre la iglesia de la patrona y el arrabal de Fuenteminaya se encontraba la ermita de San Sebastián ${ }^{401}$. En ella se albergaba a la cofradía del mismo nombre y su festividad se celebraba con una procesión alrededor de la villa que comenzaba y terminaba en la ermita. La construcción de esta primera ermita debió ser bastante deficiente pues a finales del siglo XVII se derrumbó y fue reedificada. A comienzos del siglo XIX fue habilitada para dar cristiana sepultura a las numerosas víctimas del brote de peste que asoló la villa en 1804 . El edificio también sufrió las consecuencias de la presencia francesa durante la Guerra de la Independencia y tuvo que ser rehabilitado tras el fin de la contienda. Ya por entonces la ermita estaba asociada a la advocación de San Antón ${ }^{402}$.

${ }^{397}$ AGS, CASA Y SITIOS REALES, leg. 2, doc. 484.

${ }^{398}$ La presencia de esta comunidad de beatas está documentada desde al menos 1463. Ese año mantienen un conflicto con la comunidad dominica de Caleruega por la posesión de unas heredades en Aranda (MARTÍNEZ LIÉBANA, Colección diplomática..., doc. CCCIX, pp. 396-397).

${ }^{399}$ De esta situación tenemos noticias a través de un documento fechado en 1515 en el que Pedro de Santa Cruz dice tener ...una casa que tiene junto con el dicho solar, que la tiene para beatas (AGS, CC PUEBLOS, leg. 2, doc. 107). Según VELASCO PÉREZ estas beatas fueron obligadas en 1584 a acogerse al recién construido convento de franciscas que, bajo la advocación de Santa Isabel y más tarde San Antonio, se fundó en 1560 junto al convento de San Francisco (Aranda. Memorias..., p. 272).

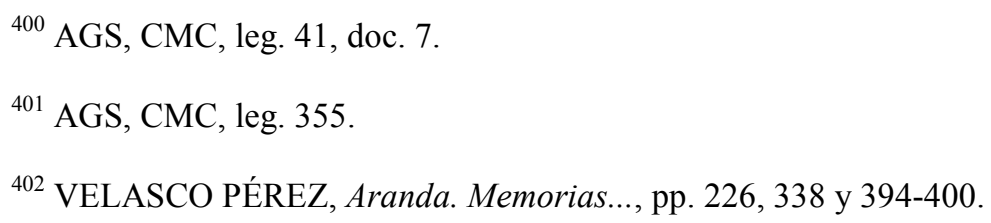




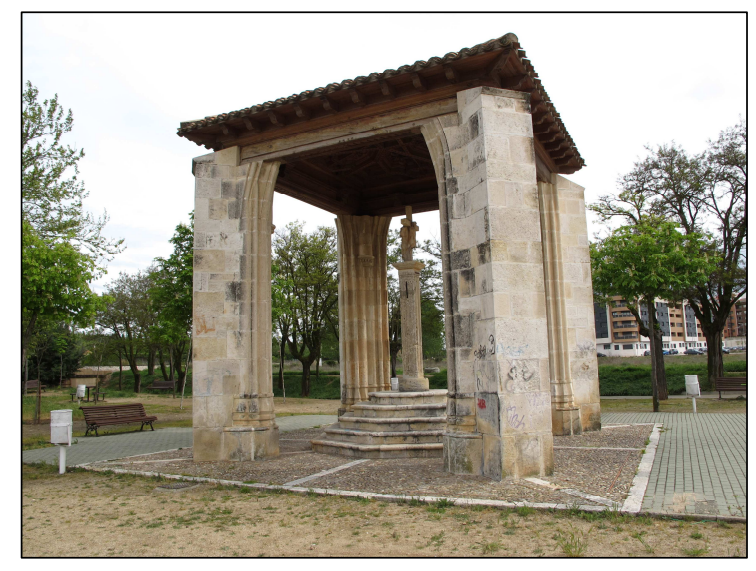

Imagen 22: Humilladero (CBMAD).

Junto a esta ermita y al lado del camino real de Burgos se situaba el Humilladero. Los cruceros o humilladeros son elementos religiosos situados en las entradas y salidas de los pueblos, generalmente junto a los cruces de los

caminos, que invitan al caminante a humillarse ante la cruz que remata una columna o pilar y a solicitar la protección ante el camino que se emprende o agradecer un tránsito sin incidencias. A finales de la Edad Media es posible que el humilladero arandino estuviera cubierto por una estructura arquitectónica compuesta de cuatro pilares esquineros apuntalados por contrafuertes unidos por arcos de medio punto y cubierta por una bóveda vaída sostenida con un entramado de nervios de crucería ${ }^{403}$. No tenemos noticia de que existieran otros cruceros en la villa, aunque sí que hubo una serie de rollos jurisdiccionales emplazados junto a los principales caminos a la entrada del término de Aranda. Tan solo conocemos la pervivencia de uno de ellos que estaba junto al camino de Valladolid y que seguramente marcaba el límite con la jurisdicción de la Comunidad de Villa y Tierra de Haza, territorio perteneciente al Conde de Miranda ${ }^{404}$.

La ermita de San Lázaro se encontraba extramuros de la villa en el arrabal de Allendeduero y también tenía la advocación de San Benito. Estaba bajo el patronazgo del concejo y así se mantuvo a pesar de las pretensiones de la orden de San Lázaro que a finales del siglo XV intentó enajenarla ${ }^{405}$. La ermita dio nombre a la calle en la que estaba, aunque se trataba de un sector semiurbano pues a su alrededor había muchas huertas ${ }^{406}$. Todavía en el siglo XVIII existía como tal, pero con la gran mortandad de 1804 se utilizó

${ }^{403}$ SÁNCHEZ RIVERA, “Ermitas, rollos,..., pp. 150-153.

${ }^{404}$ Este rollo se mantuvo junto al camino hasta mediados del siglo XX cuando se decidió trasladarlo a su actual emplazamiento en la plaza situada junto al palacio de los Berdugo. Con el tiempo esta plaza fue renombrada como Plaza del Rollo (CEBAS HERNANDO, Callejero comentado..., p. 107).

${ }^{405}$ Sabemos de su existencia desde finales del siglo XV pero seguramente fuera bastante anterior (AMA, leg. 43, docs. 26 y 35 ).

${ }^{406}$ AGS, CR, leg. 450, doc. 8. 
como cementerio $^{407}$. En la actualidad no se conoce el emplazamiento de esta ermita, aunque pervive la calle donde estuvo.

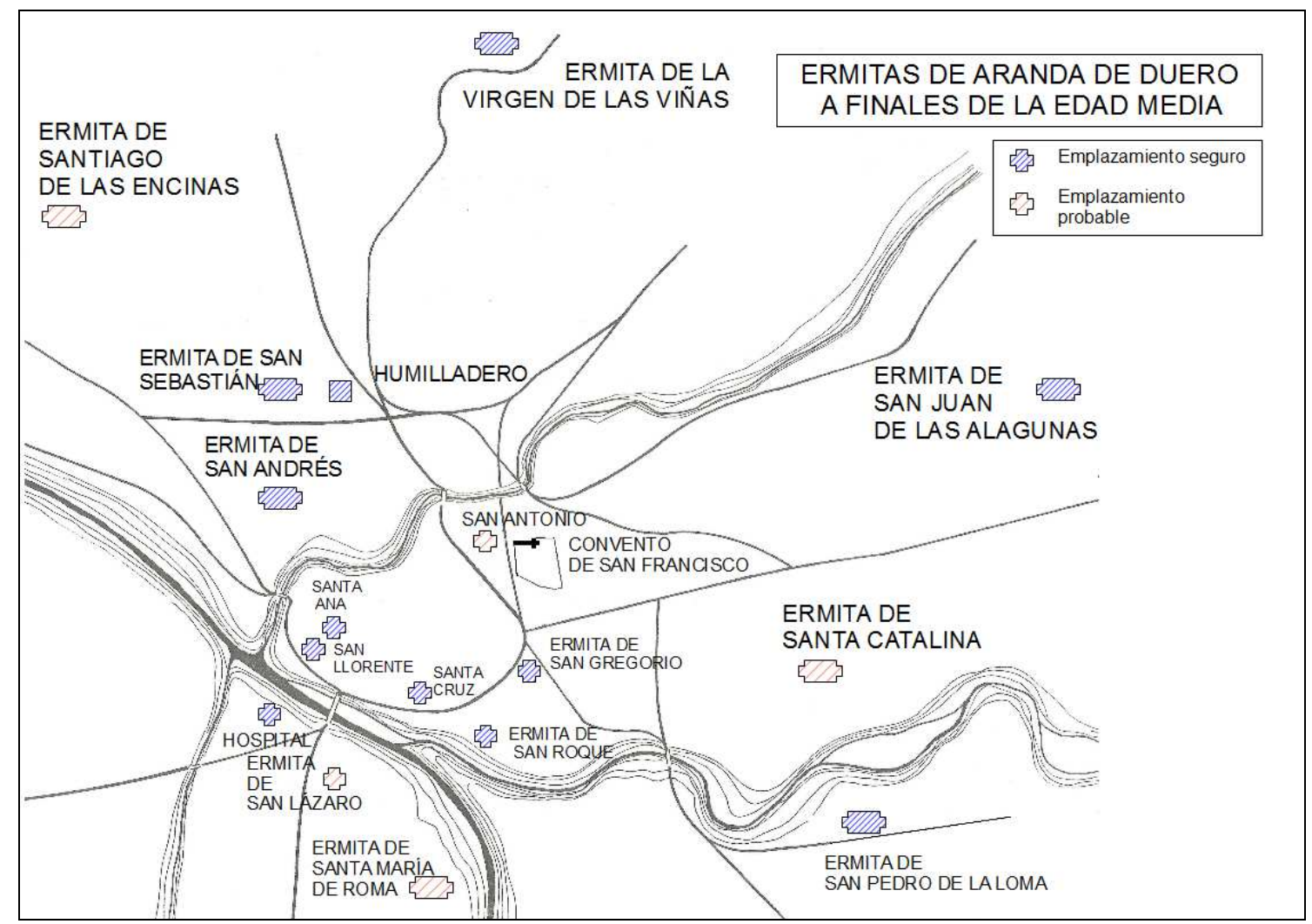

Mapa 8: Las ermitas de Aranda.

También en las proximidades de este arrabal, en el cercano espacio rural y rodeada de huertas y heredades, se encontraba la ermita de Nuestra Señora de Roma, en el pago denominado Chelva ${ }^{408}$. Esta iglesia también debió estar bajo el patronazgo del concejo aunque son muy pocos los datos que tenemos sobre ella. Todavía estaba en píe a finales del siglo XVII cuando se desplazó a esta ermita el itinerario de la procesión de la Santísima Trinidad que sustituyó al tradicional destino de la ermita de Casasola con motivo de la emancipación de la aldea de Fuentespina ${ }^{409}$.

La ermita de San Roque estaba localizada en el lado Sur de las eras de Santa Cruz, en el arrabal de Hesilla. Desconocemos el momento de su fundación y tan solo sabemos

407 ADPB, Catastro del Marqués de la Ensenada, Memoriales de Seglares, vol. I, fol. 2; y VELASCO PÉREZ, Aranda. Memorias..., pp. 395-97.

${ }^{408}$ Gaspar de Santa Cruz era propietario de una viña y huerta ... a Santa María de Roma en la ribera del rio Duero (AGS, EH, leg. 878, doc. 14).

${ }^{409}$ VELASCO PÉREZ, Aranda. Memorias..., pp. 65, 126 y 341-342. 
que acogía las reuniones de la cuadrilla de Hesilla. A finales del siglo XVIII fue comprada por el obispo de Osma para construir sobre ella un palacio para sus estancias en la villa ${ }^{410}$.

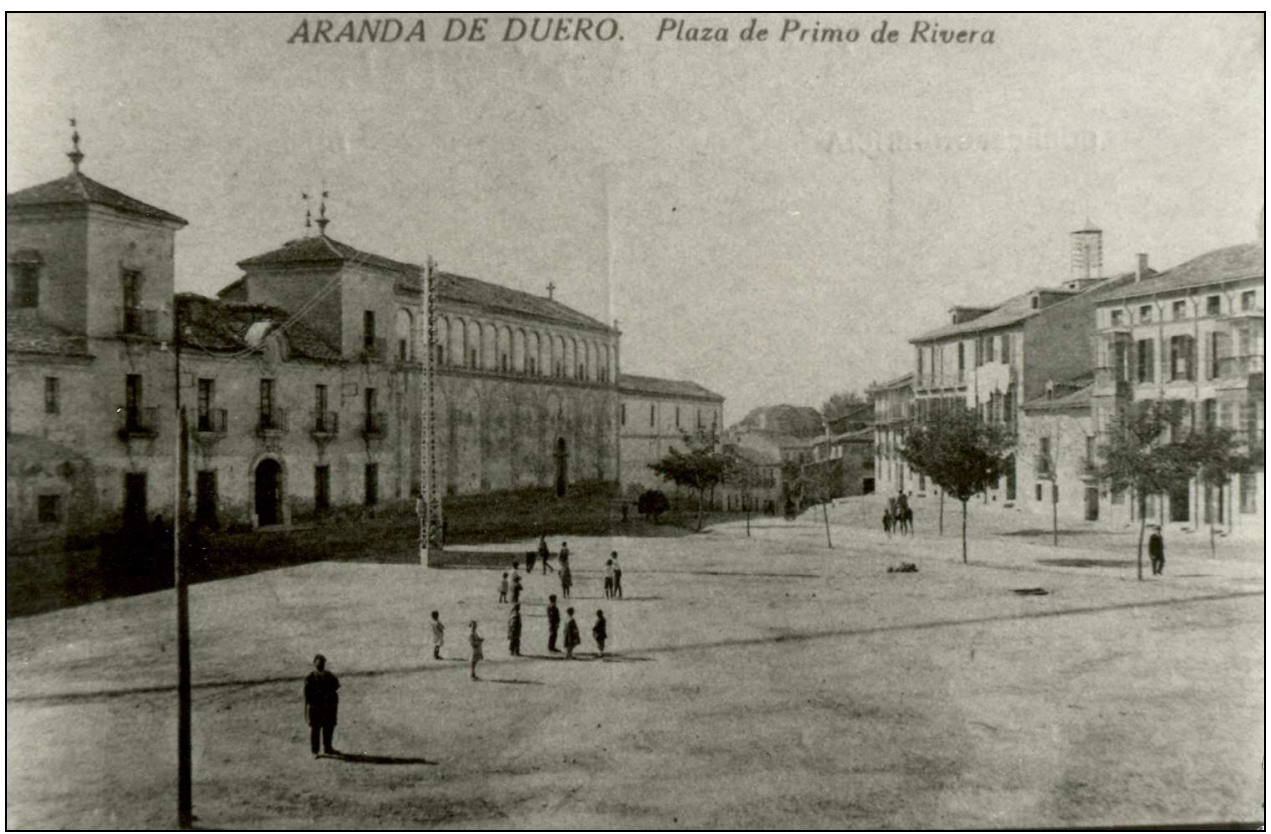

Imagen 23: La Plaza del Obispo o de la Resina a principios del siglo XX (CBMAD).

También en el arrabal de Hesilla se encontraba la ermita de San Gregorio, que a partir del siglo XVII fue conocida con el popular nombre de Virgencilla. Esta ermita fue destruida por las tropas francesas tras su retirada en 1813 y poco después reconstruida. se mantuvo en pie hasta mediados del siglo XX. No contamos por el momento con ninguna referencia documental medieval a esta ermita, salvo las aportadas por Velasco Pérez ${ }^{411}$. Sin embargo, tenemos constancia de que su culto estaba muy extendido en la villa de Aranda y la comarca. Así se pone de manifiesto en el retablo de Santa Ana del lugar de Sinovas en el que en la predela aparece representada la misa de San Gregorio ${ }^{412}$.

${ }^{410}$ AGS, CONSEJO Y JUNTAS DE HACIENDA, leg. 4, fol. 20. La desaparición de esta ermita se produjo en 1779 cuando la cofradía del mismo nombre se la vendió al Obispo de Osma que construyó el Palacio que posteriormente pasó a la congregación de los Misioneros del Corazón de María, popularmente conocidos como claretianos (VELASCO PÉREZ, Aranda. Memorias..., p. 388-91 y SANZ ABAD, Historia de Aranda..., p. 305).

${ }^{411}$ El popular nombre de Virgencilla le vino dado tras la instalación en 1683 de una pequeña imagen de Nuestra Señora del Buen Suceso (VELASCO PÉREZ, Aranda. Memorias..., pp. 65, 86, 334, 407 y 408; CEBAS HERNANDO, Callejero comentado..., p. 143).

412 Este retablo fue finalizado en 1503 y en la actualidad se encuentra en el Museo Larrea de Buenos Aires (HERNANDO GALLARDO, J. L., "Pintura gótica en la Ribera del Duero: el arte de contar historias", en Biblioteca 17. Arte e Investigación., 2002, pp. 145-187). Este mismo motivo aparece en el retablo renacentista de Cabañes de Esgueva ("Notas sobre la pintura del siglo XVI en la Ribera del Duero: párvulos hallazgos y otras apostillas”, en Biblioteca 18. Arte e Investigación. 2003, pp. 315-355.). 
Algo más alejada del núcleo urbano, pero también próxima al camino de Quemada, estaba la ermita de Santa Catalina. Desconocemos el emplazamiento concreto de esta iglesia pero la documentación bajomedieval ofrece varias referencias al término que la albergaba $^{413}$. En 1673 en la ermita de Santa Catalina, extramuros de la dicha villa se juntaron a cavildo los hermanos cofrades de Señora Santa Catalina para solicitar al provisor de Osma que se les permitiera renovar sus ordenanzas ...por cuanto las reglas y ordenanzas de la dicha cofradía son muy antiguas y estan rotas y maltratadas y que no se pueden usar de ellas ${ }^{414}$. A finales del siglo XVIII se aprovechó una fuente situada en sus proximidades para abastecer el recientemente construido palacio obispal construyendo sobre ella una arca y una canalización. Todavía en el siglo XIX se mantenía en pie, pues durante el brote de peste de 1804 se habilitó como cementerio para dar cabida a los numerosos cadáveres que habían saturado las iglesias y ermitas de la localidad ${ }^{415}$.

A unos dos kilómetros al Este de la villa se emplazaba la ermita de San Juan Evangelista que, por estar cerca de una pequeña laguna, era conocida popularmente como San Juan de la Laguna o Alagunas ${ }^{416}$. Su emplazamiento se situaba sobre un pequeño promontorio al Norte de la laguna y tenemos constancia de que a mediados del siglo XVI se celebraba su festividad el 6 de mayo con una procesión. Desconocemos hasta cuándo estuvo en pie, pero en la actualidad tan solo se observan en el lugar restos de aparejo y teja que dela$\tan$ su ubicación ${ }^{417}$.

Bastante más alejada de la villa, después de pasar el puente Conchuela sobre el Arandilla y junto al camino que conducía a San Esteban, se encontraba la pequeña ermita de San Pedro de la Loma ${ }^{418}$. Como veremos más adelante, en Aranda existió una cofradía de San Pedro con gran proyección entre los arandinos. Suponemos que en ella celebrarían

${ }^{413}$ AGS, CR, leg. 40, doc. 8; EMR, leg. 560; y CMC, leg. 355.

${ }^{414}$ ABAD ZAPATERO, J. G., Apuntes para una Historia de Aranda. Aranda de Duero, 19841988, pp. 44-47.

${ }^{415}$ VELASCO PÉREZ, Aranda. Memorias..., pp. 390 y 395-96.

${ }^{416}$ AGS, CR, leg. 40, doc. 8; y CMC, leg. 355.

${ }^{417}$ PALOMINO LÁZARO, A. L., Informe del Inventario Arqueológico del Término Municipal de Aranda de Duero. 1993. Depositado en el Servicio Territorial de Cultura de Burgos.

${ }^{418}$ ARChV, RRE, Caja 176, doc. 18; y AGS, EMR, leg. 571. También existe el topónimo San Pedro y Carrasampedro que se designa al camino que pasa junto a la ermita (AGS, CC PUEBLOS, leg. 2, doc. 94 y 107; y CMC, leg. 355). 
los actos propios de su festividad pero, dada su lejanía, la sede de esta cofradía seguramente estuvo en la capilla de San Pedro de la iglesia de Santa María ${ }^{419}$. Actualmente es de las pocas ermitas que sobreviven y en ella se celebra todavía su festividad y romería el 29 de junio de cada año.

La ermita de San Andrés estaba en lo que hoy conocemos como barrio de las Tenerías. A finales de la Edad Media daba nombre a este arrabal situado frente a San Juan, al otro lado del Bañuelos ${ }^{420}$. A esta ermita se acudía en procesión el lunes previo a la Asunción. La ermita parece que se derrumbó en el siglo XVIII y su culto y rogativa se trasladaron a la cercana ermita de $\mathrm{San} \mathrm{Gil}^{421}$.

A ciencia cierta no sabemos dónde estaba emplazada la ermita de Santiago de las Encinas, aunque es muy probable que se encontrara junto al pago del mismo nombre que se encuentra al Oeste del arrabal de San Andrés, en las cercanías del camino de La Aguilera. En esta ermita terminaba la procesión que se celebraba el martes anterior a la festividad de la Asunción y suponemos que en ella se asentaba la cofradía del mismo nombre ${ }^{422}$.

A todas estas ermitas se deben añadir las iglesias de cada una de las aldeas de la tierra arandina. Sinovas contaba con una iglesia bajo la advocación de San Nicolás de Bari; a la Asunción de Santa María estaba dedicada la de Quemada; la iglesia de Fuentespina tenía por patrón al arcángel San Miguel; advocación que compartía con el lugar de Villalba; la aldea de Casasola contaba con una ermita dedicada a la Santísima Trinidad; y en la aldea de Prado había otra ermita bajo la advocación de Santa María. Todas estas construcciones religiosas se conservan en la actualidad, aunque bien es cierto que bastante modificadas

${ }^{419}$ ARCHIVO DE LA DIÓCESIS DE BURGOS (ADB), LIBRO DE FÁBRICA DE SANTA MARÍA, vol. I, s.f. 24.

${ }^{420}$ AGS, CR, leg. 40, doc. 8; EMR, leg. 560; CMC, leg. 355; y ARChV, RRE, Caja 366, doc.

${ }^{421}$ VELASCO PÉREZ, Aranda. Memorias..., pp. 226-228. Aunque este autor señala que la ermita de San Gil es de origen medieval (p. 65) no hemos localizado ninguna referencia a esta ermita ni tampoco al topónimo. Además sabemos que el espacio que posteriormente ocupó esta ermita estaba ocupado a finales de la Edad Media por unas eras (AGS, CMC, leg. 355).

${ }^{422}$ AGS, CC DIVERSOS, leg. 25, doc. 1. Esta procesión está documentada por VELASCO PÉREZ a mediados del siglo XVI (Aranda. Memorias..., p. 226). En la documentación medieval se menciona el pago pero no la ermita (AGS, EH, leg. 878, doc. 14; y EMR, leg. 560). 
por reformas y reconstrucciones posteriores ${ }^{423}$. De todas ellas, tan solo la de San Nicolás de Sinovas mantiene más o menos intacta la nave de origen medieval a la que se le sumaron otros elementos durante el siglo XVI. Esta nave también alberga el monumental artesonado mudéjar al que ya nos hemos referido con anterioridad ${ }^{424}$.

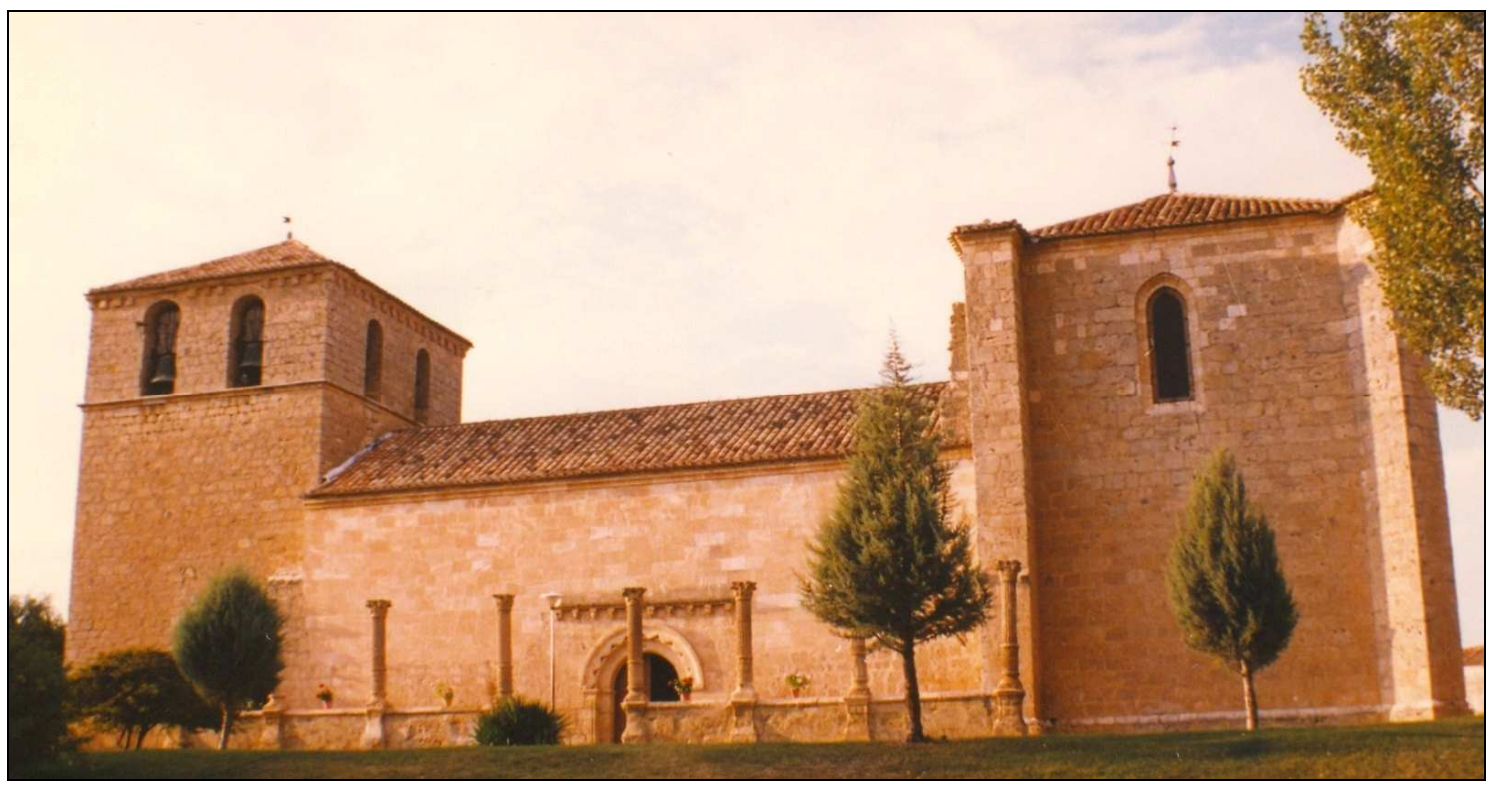

Imagen 24: Iglesia parroquial de San Nicolás de Bari de Sinovas (CBMAD).

Podemos concluir que el espacio urbano arandino y su entorno próximo se encontraban a finales de la Edad Media jalonados de numerosos hitos sagrados, ya fueran parroquias, santuarios, monasterios, conventos o ermitas. En definitiva, parece evidente que en este momento final de la Edad Media se había consolidando la sacralización del espacio que ya se había estado configurando desde siglos anteriores. De esta manera se impuso también sobre el territorio una religiosidad resultado de la materialización sobre el espacio de la ideología imperante que regulaba la vida cotidiana de los seres humanos durante este periodo histórico.

${ }^{423}$ Incluso los templos de los despoblados de Prado y Casasola han pervivido a pesar de haber perdido su población, integrándose como ermitas de Villalba y Fuentespina respectivamente. En la actualidad su fisonomía medieval se ha perdido por completo tras las reformas barrocas.

424 ABAD ZAPATERO y ARRANZ ARRANZ, Las Iglesias..., pp. 128-134; y GÓMEZ GÓMEZ, "La techumbre mudéjar..., pp. 71-90. 


\section{b. Espacios económicos.}

La ciudad fue a lo largo de la Edad Media el espacio comercial por excelencia y jugó un papel imprescindible dentro de la economía agraria feudal, posibilitando el intercambio a una escala comarcal o regional ${ }^{425}$. La imperiosa necesidad de abastecerse de una sociedad que contaba con una importante cantidad de jornaleros que no disponían de otros medios más que su salario para acceder a los productos necesarios para la subsistencia y la creciente especialización comarcal en el cultivo de la vid que proporcionó importantes ingresos monetarios de la venta del vino, hicieron posible un gran desarrollo de la actividad comercial. Esta realidad socioeconómica tuvo su plasmación en el espacio urbano con la consolidación de la función comercial en determinados espacios centrales y la extensión de esta actividad por el entorno próximo. De esta manera las plazas y calles de la capital de la Ribera albergaron las más diversas y variadas actividades artesanales y comerciales. La organización gremial predominante marcó los ritmos del desarrollo de la producción manufacturera y también ordenó su distribución espacial tendiendo a la concentración de los pequeños talleres-tienda en determinados viales a los que la mentalidad colectiva terminó por identificar con sus correspondientes actividades.

El espacio comercial por excelencia en la villa de Aranda en este periodo fue la Plaza Pública o de Santa María. En ella tenían lugar, primero todos los sábados y después los lunes, un mercado semanal que abastecía de todo tipo de productos a los vecinos de la villa y sus arrabales pero también a los de su tierra y la comarca ${ }^{426}$. Este mercado se imbricaba perfectamente con los de la comarca y así, por ejemplo, en Roa se celebraba los martes y en Gumiel del Mercado los jueves ${ }^{427}$. Para hacernos una idea del ambiente que se vivía en esta plaza debemos recurrir a la descripción que hizo de ella el párroco de Santa María a finales del siglo XVI: ... avia en la villa una plaza nueba que era grande, muy desente, con muchos soportales donde podian estar todas las cosas de bastimentos que se bendieran en la plaza frontero de la iglesia mayor de Santa María desta villa sin que envaraçase como los embaraçava el paso de las yglesias e paso de curas e benefiçiados y los demas clérigos y gentes prinçipales que yban a misa; ademas de la gran suçiedad e

${ }^{425}$ OLIVA HERRER, H. R., La Tierra de Campos a fines de la Edad Media. Economía, sociedad y acción política campesina. Valladolid, 2002, pp. 394 y ss.

${ }^{426}$ En Aranda se celebraba los sábados pero se cambió en 1326 a los lunes para que pudiera participar en él la comunidad hebrea (VELACO PÉREZ, Aranda. Memorias..., pp. 61-62).

${ }^{427}$ NUÑO GONZÁLEZ, "Pautas de ocupación territorial..., p. 95. 
hediendez que alli se facia y boces e ruidos de los que compravan e vendian y de los ganapanes e otras gentes baxas que llegavan a asar pescados e carnes y a lo comer ${ }^{428}$.

La variedad de los productos que se vendían en este mercado semanal abarcaba desde los alimentos necesarios para el consumo diario como el pescado fresco e fruta e ortaliza e otras cosas menudas ${ }^{429}$, hasta todo tipo de tejidos, zapatos o herramientas de diversa consideración. Pero también otros productos más específicos como las especias o el azafrán ${ }^{430}$.

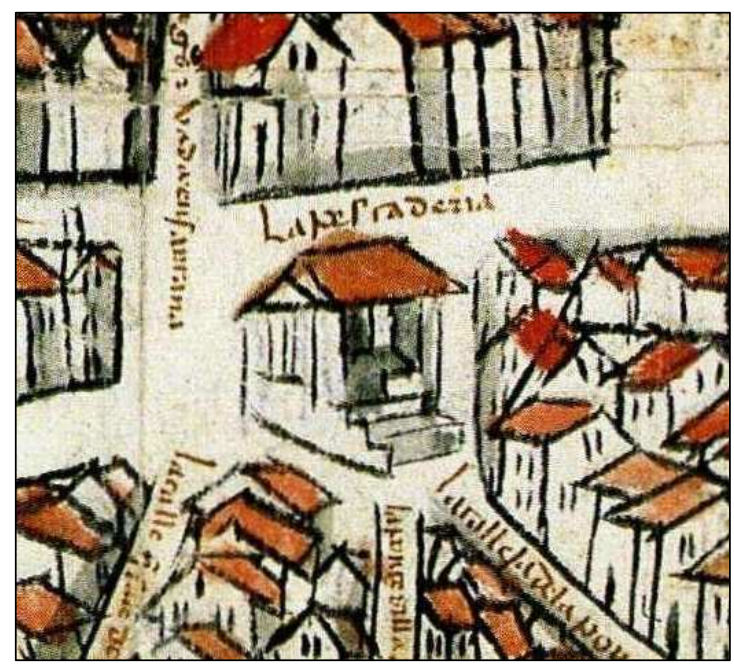

\section{Imagen 25: Pescadería.}

En el extremo Oeste de la Plaza Nueva se encontraba la Pescadería. El plano de 1503 muestra el alzado de un edificio que presenta muchas similitudes en cuanto a su estructura con los "halles" del SO francés o con un mercado de abastos. Era una construcción exenta de grandes dimensiones, asentada sobre una plataforma a la que se accedía por una escalinata orientada hacia el SE. Contaba con grandes vanos y estaba cubierta con un tejado a dos aguas sustentado en grandes pilares. En el interior disponía de mostradores o tablas con los diferentes productos: pescado fresco fluvial, pescado cecial o seco, pescado en salazón y, en algunas ocasiones, pescado fresco del Cantábrico ${ }^{431}$. El edificio no contaba con ningún sistema de alcantarillado para eliminar las aguas y residuos del pescado por lo que se vertía todo hacia el vallejo del Hocino, lo que motivó las quejas de la comunidad judía que allí residía. Cuando a principios del siglo XVI se proyectó la canalización del Aranzuelo hacia la ciudad, se planteó entre otras cosas que se ...podria tomar por

${ }^{428}$ ARChV, RRE, Caja 1699, doc. 4. El documento en cuestión acompañaba a la solicitud que hizo el párroco de Santa María para que se trasladara el mercado a la Plaza Nueva.

${ }^{429}$ AGS, RGS, 149705, fol. 76.

${ }^{430}$ CARRETERO ZAMORA, La averiguación de la Corona de Castilla..., Vol. I, pp. 225-226.

${ }^{431}$ En la pescadería arandina se vendían pescados marinos como sardinas y besugos. (AGS, CC MEMORIALES, leg. 149, doc. 230). 
tres puertas de la villa por cada una un caño de agua, especialmente por la puerta de Dehesilla que hira a dar a la Plaza Nueva e otro por la calle de Barrio Nuevo e por la Plaza de Santa María hasta dar a la pescadería por donde se podria probeer que el agua corra por donde se remoja el pescado ${ }^{432}$.

El edificio era propiedad del concejo que lo arrendaba en subasta pública a cambio de una renta anual para los propios de la villa ${ }^{433}$. Una de las condiciones de este contrato de arrendamiento hacía especial hincapié en la obligación que adquirían los arrendatarios de garantizar el abastecimiento de pescado a los vecinos, aspecto importante si tenemos en cuenta el papel fundamental que jugaba este alimento en los ritos alimenticios del calendario cristiano.

Las autoridades municipales también intervenían en las transacciones comerciales con la creación de oficiales municipales, fieles, que fijaban los precios y velaban por el control de los pesos, la calidad de los productos y las condiciones higiénicas en el proceso de venta del pescado. A finales del siglo XV esta función fue usurpada por los regidores que fijaban los precios a su antojo e imponían multas que cobraban para sí. De igual manera, estos oficiales impusieron un nuevo impuesto sobre la venta del pescado, la postura, que mermaba considerablemente el beneficio de los tratantes de pescado ${ }^{434}$.

Parece que en el siglo XVIII la venta del pescado seguía desarrollándose en este espacio que continuaba bajo titularidad municipal. Sin embargo, en el siglo XIX el edificio ya no aparece en el plano de Coello y tampoco se nombra en la relación de los bienes de propios que señala Madoz por lo que suponemos que fue desamortizado poco antes como bien comunal que era. Seguramente el edificio fue demolido y su nuevo propietario construyó sobre él, configurando el espacio privado que hoy ocupa el solar de la antigua pescadería ${ }^{435}$.

En la actualidad el pequeño ensanchamiento que se localizaba junto a la pescadería como prolongación de la Plaza de Santa María recibe el nombre de Plaza del Aceite. Esta

${ }^{432}$ AGS, CR, leg. 40, doc. 8.

${ }^{433}$ AGS, CC PUEBLOS, leg. 2, doc. 104; y EH, leg. 4.

${ }^{434}$ AGS, CC PUEBLOS, leg. 2, doc. 88; y RGS, 148311, fol. 140.

435 ZAPARAÍN YÁÑEZ, Desarrollo artístico..., p. 134; y MADOZ, Diccionario Geográfico..., Vol. II, pp. 49-50. 
actividad tiene su origen en el mundo medieval pues en la pescadería, además de venderse pescado, tanto fresco como salado o seco, se vendía aceite y velas ${ }^{436}$.

Justo en la dirección contraria a la de la Pescadería, en el extremo Este de la Plaza Pública se abría una calle que conectaba con la Plaza del Trigo y que la tradición ha bautizado con el ilustrativo nombre de calle de las Boticas. Independientemente de que el término botica sirviera en la época para designar a cualquier tienda fuera cual fuese el producto que vendiera ${ }^{437}$, lo cierto es que la iglesia de Santa María tuvo en propiedad varias boticas en las proximidades de la plaza que arrendaba a particulares ${ }^{438}$. Entre éstos pudo encontrarse Francisco de Garay, boticario de medicinas, que ejerció como tal desde finales del siglo XV y al menos hasta $1522^{439}$. A este boticario le sucedió en el oficio su hijo Fernando de Garay ${ }^{440}$.

Hacia el Sur se extendía la Calle de la Miel que comunicaba la Plaza Pública con la Plaza Nueva. En este privilegiado emplazamiento sitúa la tradición popular el emplazamiento del activo gremio de los zapateros ${ }^{441}$. Aunque no tenemos referencias expresas sobre esta asociación en época medieval, sí que hemos documentado la existencia de un taller textil que Diego de Guadalajara tenía en esta calle y que se complementaba con la tienda que regentaba su mujer, la de Guadalajara la tendera ${ }^{442}$. Prueba de la valoración de esta calle es que dos conocidos arrendadores arandinos adquirieron varias propiedades en esta calle en la última década del siglo XV con la intención de alquilarlas ...porque estan

${ }^{436}$ AGS, EH. leg. 4, y RGS, 148311, fol. 140.

${ }^{437}$ En la documentación suele denominarse a cualquier tienda botica, o en concreto botica de mercadurias (AGS, CC MEMORIALES, leg. 151, doc. 113). Incluso se hace referencia a la botica en la que se cobraba la alcabala del vino (AGS, CMC, leg. 41, doc. 7).

${ }^{438}$ ADB, LIBRO DE FÁBRICA DE SANTA MARÍA, Tomo I, s. f.; y CEBAS HERNANDO, Callejero comentado..., pp. 26-27.

439 AGS, CC PUEBLOS, leg. 2, doc. 95; y CMC, leg. 355.

${ }^{440}$ En 1548 el teniente de corregidor envió a la Corte un informe sobre las enfermedades que había en la villa pues tenían intención de venir a ella la Infanta Juana y el Príncipe Carlos. En este informe se recogen los testimonios de los dos médicos y los tres boticarios que había en la villa (AGS, GUERRA ANTIGUA, leg. 34, doc. 54).

${ }^{441}$ Una coplilla popular recita: Zapateros son todos en la calle de la Miel/ zapateros son todos/ menos Recobret.

${ }^{442}$ Este taller tuvo asalariados como el judío Taytaça que durante tres años trabajó para Guadalajara (CARRETE PARRONDO, Fontes Iudaeorum..., doc. 378, p. 158); y AGS, EMR, leg. 571. 
en lo bueno de la villa y cabe de la Plaza ${ }^{443}$. También el hacendado comunero Alonso de Moradillo poseía tres pares de casas en esta calle que estaban tasadas en 80.000 maravedíes. El lote se subastó tras la revuelta y el bachiller Borja las compró por $35.000^{444}$. Sobre la miel apenas tenemos referencias documentales que nos permitan sugerir el peso de este producto en la economía de la capital de la Ribera, aunque sí que se constata su producción en algunas zonas de la comarca como el valle del Esgueva, Moradillo o Haza ${ }^{445}$. Es de suponer que esta calle recibió este nombre en un determinado momento de la Edad Media, posiblemente por la instalación en ella de puestos de venta de este producto. Su representación en el plano de 1503 está bastante idealizada pues se dibuja con una amplitud que no se correspondía con la realidad. A pesar de las declaraciones emitidas al respecto por los testigos del proceso, lo cierto es que esta calle se denominaba habitualmente en la documentación como la calleja de la Miel, ajustándose así a la realidad de una calle bastante estrecha $^{446}$.

También en las proximidades de la Plaza de Santa María se encontraba el callejón del Pozo. Esta calle era bastante despreciada por los vecinos por su recorrido intrincado y estrecho que llevó a algunos a comentar que...a sido e hes calle muy suçia e que se an echado e echan basura e estiercol e otras suziedades e cosas muertas. A pesar de todo esto, esta calleja contaba con uno de los principales puntos de venta de vino: el portal del Arco de Calicanto. En este vendedero confluían tres bodegas que contaban en conjunto con 43 suelos y sumaban entre todas más de 8.000 cántaras de vino ${ }^{447}$.

${ }^{443}$ En concreto Francisco de Mena compró dos pares de casas a Alonso de Burgos por 40.000 maravedíes y Diego de Almagro se las compró a un cuñado suyo por 42.000 maravedíes (AGS, EMR, leg. 571).

${ }^{444}$ Como ya veremos más adelante fue una práctica habitual entre los vencedores aprovecharse de su posición de poder tras la victoria realista para aumentar sus haciendas. La Corona interpuso pleito para que se pagara el precio tasado o se devolvieran estos bienes (AGS, CMC, leg. 385).

445 Tan solo tenemos noticias de que el conde de Castro cobraba parte de sus rentas sobre sus lugares del Valle del Esgueva en especie, en concreto cada lugar debía aportar una cántara de miel, salvo Villovela que aportaba dos (AGS, CMC, leg. 2, doc. 2). También la miel fue utilizada por el concejo de Moradillo para pagar la deuda que contrajeron con el judío don Simuel (AGS, RGS, 149402, fol. 311, transcrito por CADIÑANOS BARDECI, "Judíos y moros..., doc. 1, p. 42 ). En las Averiguaciones realizadas a comienzos del siglo XVI se especifica que: cojen los vezinos mucho açafran, espeçialmente en la dicha villa de Aça e su tierra, e ansymismo tienen ganados e colmenas en mediana cantidad (CARRETERO ZAMORA, La Averiguación de la Corona de Castilla..., Vol. I, pp. 225-226).

${ }^{446}$ AGS, RGS, 149506, fol. 43.

${ }^{447}$ AGS, CR, 39, doc. 3, transcrito por PERIBÁÑEZ OTERO y ABAD ÁLVAREZ, Aranda de Duero..., pp. 143 y ss. 
En la Aranda bajomedieval tuvo cierta importancia el negocio de la plata pues entre sus calles encontramos dos que hacen referencia expresa a esta actividad: una calle recibía el nombre del metal (Calle de la Plata), mientras que la otra se nombraba por el oficio que trabajaba este metal (Calle de los Plateros). Tradicionalmente se ha señalado que la Calle de la Plata albergaba a los plateros, pero el plano de 1503 complica esta afirmación, pues la calle que comunicaba la Pescadería con la Puerta del Duero aparece rotulada como la calleja de la Pontecilla tras los plateros. Se concentren los artesanos de este metal en una u otra calle, lo cierto es que la villa arandina conoció un importante desarrollo de la actividad como lo demuestran los abundantes trabajos de investigación existentes sobre la platería arandina y ribereña de este periodo ${ }^{448}$. Por otra parte, también nos parece ilustrativo del peso que tuvieron estos artesanos en la comunidad el hecho de que alguno de ellos se significara como arrendador de rentas o estuviera presente como testigo en algunos de los acontecimientos más notables del momento. Esta circunstancia nos ha permitido elaborar una abultada lista de plateros que desarrollaron su actividad a finales del siglo XV y principios del XVI en la villa: Sancho de Sepúlveda, estuvo activo en 1477; Alonso Rodríguez, arrendó la renta del pan en 1481 y en 1482 la de las aves y frutas además de las Tercias; Rodrigo Platero desarrolló su actividad entre 1482 y 1513; y Juan Platero y Francisco Fresnillo trabajaron en $1521^{449}$. Con toda seguridad todos estos artesanos formaban parte de talleres familiares en los que se iba transmitiendo la maestría de generación en generación ${ }^{450}$.

Como ya hemos comentado, la calle de la Pontecilla se encontraba en las inmediaciones de la pescadería y comunicaba la zona de Santa María con la puerta de Duero. También hemos hecho referencia al origen que pudo tener este pequeño puente que salvaría el desnivel del Hocino y comunicaría los dos hipotéticos núcleos primigenios. En la

${ }^{448}$ BARRÓN GARCÍA, A., "La platería arandina en el siglo XVI", en Biblioteca 10. Estudio e Investigación. 1995, pp. 39-65; "Platería y artes decorativas medievales en la Ribera del Duero", en Biblioteca 17. Estudio e Investigación. 2002, pp. 233-67; "Platería y artes decorativas en el Renacimiento del Duero", en Biblioteca 18. Estudio e Investigación. 2003, pp. 177-215. Prueba de la continuidad de esta actividad en la villa es el trabajo de IGLESIAS, L. S. y ZAPARAÍN YÁÑEZ, M. J., La Platería de Aranda de Duero. Siglos XVII y XVIII. Burgos, 1992.

${ }^{449}$ AGS, EH, leg. 4, para Alonso Rodríguez y Sancho de Sepúlveda; Rodrigo Platero era testigo en CR, leg. 40, doc. 8; en esta misma condición actuaron Juan Platero y Francisco Fresnillo en AGS, CR, leg. 450 , doc. 8 .

${ }^{450}$ También con el nombre de Alonso Rodríguez aparece un platero que trabajó en Aranda y la Ribera entre 1584 y 1620 (BARRÓN GARCÍA, "La platería arandina..., pp. 58-59). Esto mismo lo podemos apreciar en el caso de Francisco Fresnillo que posiblemente fuera el padre de Cristóbal Fresnillo que trabajó desde 1535 hasta 1588 en un taller en Aranda junto a sus hijos (pp. 50-52). 
actualidad este tramo viario se denomina calle de la Sal. Este nombre parece que tiene su origen en un establecimiento de venta de sal que estuvo allí en el XIX. Posiblemente esta sea una de las calles que ha experimentado un mayor número de denominaciones: al ya referido nombre medieval de la Pontecilla, le sucedió la denominación de la Puente; en el XVIII aparece en el Catastro del Marques de la Ensenada como Calle de los Bodegones, por la abundancia que en ella había de estos establecimientos hosteleros; y, aunque popularmente se la conoció así durante largo tiempo, después de la última Guerra Civil pasó a denominarse Rodríguez de Valcárcel ${ }^{451}$.

Otra calle con un pasado comercial es la actual calle Béjar que al final de la Edad Media era conocida como la calleja donde vive don Martín como aparece en el plano de 1503. Velasco Pérez señala que ya desde mediados del siglo XV esta calle albergaba la venta de la aloja ${ }^{452}$, una bebida muy popular elaborada a partir de agua, miel y especias, con lo que ya recibía entonces el nombre de Alojería ${ }^{453}$. Este autor también informa de la existencia de una alcantarilla a comienzos del siglo XV que facilitaba el desagüe de la calle Isilla hacia la calle de la Miel a través de unas casas del Arcediano de Aza. Ciertos problemas de evacuación obligaron a mediados del siglo XV a eliminarla y habilitar el desagüe directamente a través de la calle Béjar hacia la Plaza Nueva ${ }^{454}$.

También entre los espacios comerciales se encontraban el matadero y las carnicerías. Tenemos muchas referencias sobre la actividad de los carniceros en la villa pero muy pocas evidencias sobre la situación de estos establecimientos. Todo parece indicar que ambos espacios estaban juntos y se situaban en la Plaza Nueva, en las inmediaciones de la Puerta de Santa Cruz. Aunque Velasco Pérez afirma que el primitivo matadero

${ }^{451}$ ZAPARAIIN YÁÑEZ, Desarrollo artístico..., Vol. I, p. 134; y CEBAS HERNANDO, Callejero comentado..., pp. 109-110.

${ }^{452}$ Diccionario de la Lengua Española. Real Academia Española (22a Ed.), voz Aloja. Recordemos que esta bebida basada en la miel fue muy habitual en todo el Mediterráneo recibiendo diversos nombres. Ya Lucio Junio Moderato Columela en el siglo I de nuestra era daba en su tratado sobre la Agricultura una receta de esta bebida (Los doce libros de Agricultura. Libro XII, Cap. XII, Traducido por ÁLVAREZ DE SOTOMAYOR Y RUBIO, J. M., Madrid, 1824, vol. II, p. 173).

${ }^{453}$ VELASCO PÉREZ, Aranda. Memorias..., p. 87. No obstante, la primera mención en la documentación escrita de esta calle no la hemos encontrado hasta el siglo XVIII (ADPB, Catastro del Marqués de la Ensenada, Memoriales de Seglares, vol. I, fol. 14), aunque bien es cierto que nuestra investigación no ha sido sistemática con fechas posteriores a 1525 .

${ }^{454}$ VELASCO PÉREZ, Aranda. Memorias..., pp. 87-88. Posiblemente esta alcantarilla no fuera más que una pequeña canalización como la que existía a principios del siglo XX en esa misma calle y que se puede apreciar en algunas fotografías de la época. 
se encontraba en Cascajar y las carnicerías junto a la Puerta de Santa $\mathrm{Cruz}^{455}$, los diferentes testimonios sobre el proyecto de canalización del Aranzuelo nos llevan a concluir que ambos edificios se localizaban en el segundo de los emplazamientos señalados. Entre las ventajas que alegaban los patrocinadores de este proyecto se señalaba que ...el matadero de las carnecerias, que suele ser cosa de mucho hedor, se alimpiaria. Antonio de Mari Quemada concretaba más y situaba el matadero junto a las cavas cuando afirmaba que ...por quel dicho matadero sale a las cabas e estando limpia la caba esta el matadero limpio ${ }^{456}$. Las carnicerías eran propiedad del concejo que las arrendaba por un censo anual destinado a los propios que en 1520 alcanzaba la cifra de 1.500 maravedíes $^{457}$. A pesar de los problemas de olores y suciedades asociados al sacrificio de los animales, ambos edificios estaban integrados dentro del caserío pues hemos constatado la existencia de viviendas adosadas a estos espacios ${ }^{458}$.

Estas carnicerías tuvieron una intensa activad como lo muestra el contrato que firmaron en 1500 tres carniceros de la villa con el ganadero Pedro de Berlanga para que les abasteciera de 1.600 carneros a razón de 550 carneros çapatados a entregar antes del viernes de Pasión, y los otros 1.050 debían ser carneros merinos desquilados e castrados que debían ser entregados el día de San Juan de junio ${ }^{459}$. Como ocurre en otras carnicerías castellanas, al ovino deberíamos añadir otros tipos de ganado entre los que destacaría el vacuno, por lo que podemos asegurar que el consumo de carne en la villa de Aranda fue notable $e^{460}$.

${ }^{455}$ VELASCO PÉREZ, Aranda. Memorias..., p. 218.

${ }^{456}$ AGS, CR, leg. 40, doc. 8. Sobre la regulación de esta actividad en el reino de Castilla puede verse ORTEGA VALCÁRCEL, J, "El microcosmos humanizado: los núcleos urbanos y las comunicaciones", en Historia de la Ciencia y de la Técnica en la Corona de Castilla. Valladolid, 2002, Vol. I, pp. 277-443, en concreto p. 363

${ }^{457}$ AGS, CR, leg. 450, doc. 8 .

458 Juan de Oquillas, conocido arrendador próximo a Pedro de Santa Cruz, poseía unas casas en las carneçerias, donde vivía su suegra (AGS, EMR, leg. 567). Curiosamente Oquillas fue el arrendador de la renta de los tajones de las carnicerías durante algunos años a comienzos del siglo XVI (EH, leg. 4; y ARChV, RRE, Caja 298, doc. 5).

${ }^{459}$ Los carniceros eran García de Buitrago, Benito de Hontangas y Juan Daza. En el contrato se establece el peso de los carneros, las condiciones de entrega y pago, la exclusividad y otras condiciones (ARChV, RRE, Caja 157, doc. 19).

${ }^{460}$ A modo de ejemplo, las carnicerías de Burgos en las primeras décadas del siglo XVI tenían un mayor consumo y en lo que se refiere al ganado ovino también se consumían los carneros zapatados y merinos (HERNÁNDEZ ESTEVE, E., Noticias del abastecimiento de carne en la ciudad de Burgos (1536-1537): Libro Mayor del Obligado de las carnicerías. Madrid, 1992). 
Las carnicerías se mantuvieron junto a la Puerta de Santa Cruz como se aprecia en el plano de Coello de 1868. Seguramente el matadero se encontraba en el lado Oeste de la puerta como se aprecia en el parcelario obtenido del catastro de la Ensenada ${ }^{461}$ y en un momento indeterminado del comienzo del siglo XIX fue desplazado a la otra orilla del río Duero, donde todavía hoy se conserva su antiguo edificio.

En este periodo la villa contaba también con un edificio destinado a albergar el peso. Allí acudían los vecinos para pesar el grano que posteriormente llevaban a moler a los diferentes molinos de la zona, aunque también se utilizaba para pesar otras mercancías $^{462}$. Era también un edificio de titularidad municipal, aunque desconocemos dónde estuvo ubicado. Debió tener un primer emplazamiento pero a finales del siglo XV dejó de funcionar y hubo un periodo en que no estuvo activo por lo que los vecinos presentaron sus quejas ante las autoridades a causa de las malas prácticas de los molineros. Ya en 1494 los monarcas comisionaron al corregidor para que, junto a los regidores, buscaran una casa aparejada para establecer en ella el peso y así pesar el trigo que se llevaba a los molinos y la harina que se trajera. También ordenaban que se hicieran unas ordenanzas que regularan el proceso y se creara un fiel con su salario para que las hiciera cumplir $^{463}$. Pero a pesar de los continuos mandamientos ${ }^{464}$, no fue hasta los primeros años del siglo XVI cuando el peso comenzó a funcionar ${ }^{465}$. Nada sabemos sobre su ubicación, salvo que estaba lejos de las aceñas del Duero ${ }^{466}$. Posiblemente se situó junto a la carnicería como lo muestra el plano de 1868 y el informe de $\mathrm{Madoz}^{467}$.

${ }^{461}$ ZAPARAÍN YÁÑEZ, Desarrollo artístico..., Vol. I, p. 134; y MADOZ, Diccionario Geográfico..., Vol. II, pp. 49-50.

${ }^{462}$ AGS, CC PUEBLOS, leg 2, doc. 59. En 1504 los mercaderes de la villa se quejaban de que los regidores les obligaban a pesar sus mercancías en el peso municipal sin dejarles utilizar sus pesos particulares.

463 AGS, RGS, 149410, fol. 170; y AMA, leg. 43, fol. 16, transcrito por HURTADO QUERO, Documentos Reales..., doc. 25, pp. 49-50.

${ }^{464}$ AGS, RGS, 149601, fol. 75; 150012, fol. 324; 150001, fol. 6; y AMA, leg. 43, fol. 14, transcrito por HURTADO QUERO, Documentos Reales..., doc. 27, pp. 52-53.

${ }^{465}$ AGS, CC PUEBLOS, leg 2, doc. 59.

${ }^{466}$ AGS, RGS, 150012, fol. 324. El licenciado Illescas, propietario de las aceñas del Duero, se quejaba en 1500 de que el corregidor y los regidores querían hacer una casa del peso de la harina muy lejos de la puente y del lugar donde estaban las aceñas, causando gran daño a los vecinos y molineros pues para tres costales se pasarian todo el dia.

${ }^{467}$ MADOZ, Diccionario Geográfico..., pp. 49. 


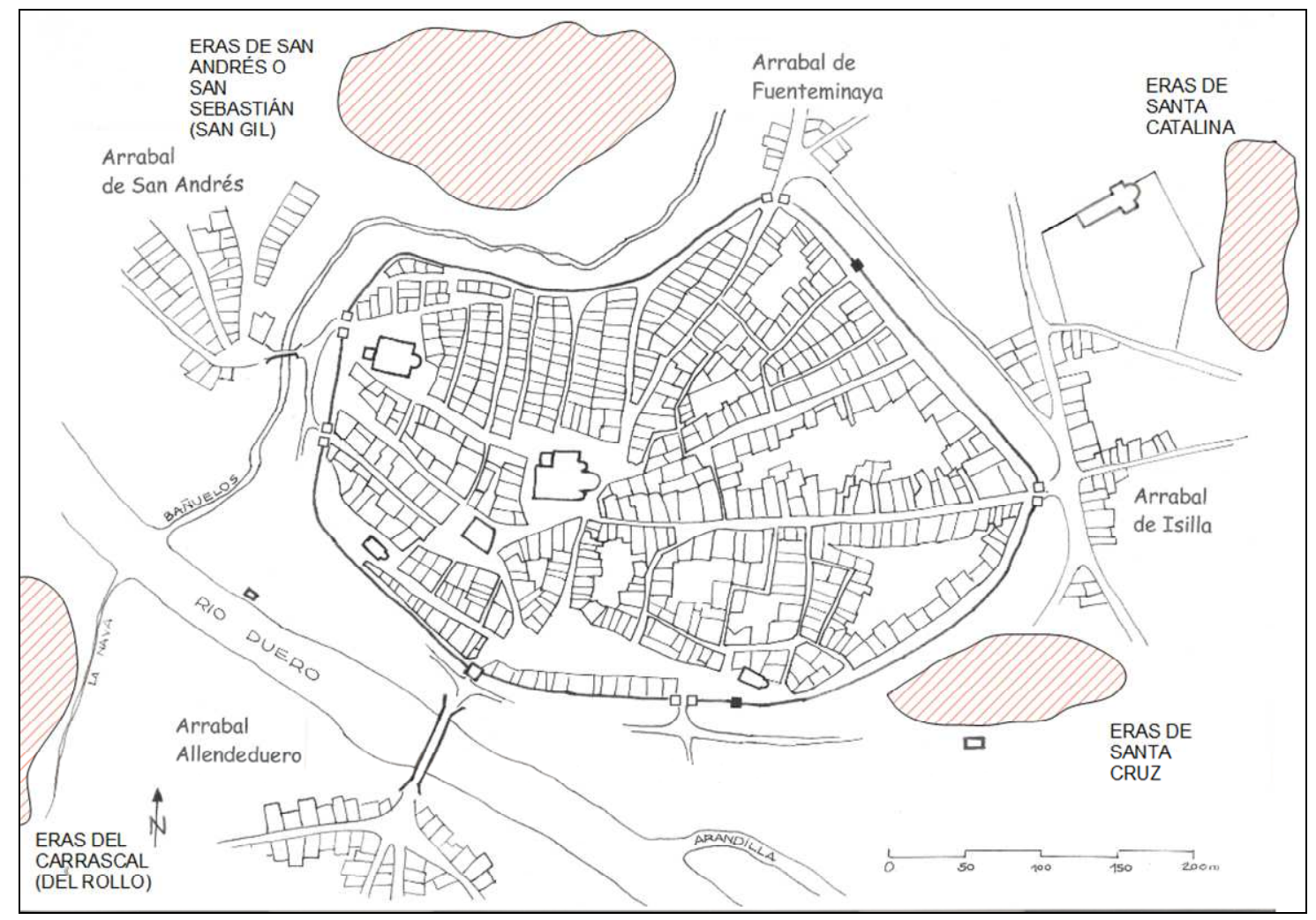

Plano 7: Localización de las eras arandinas.

En las pequeñas ciudades medievales donde la agricultura todavía constituía una actividad importante se desarrollaron espacios estrechamente vinculados al sector primario como fueron las eras ${ }^{468}$. Estos espacios especializados para la trilla del cereal se localizaban en las inmediaciones de los arrabales. Suponemos que ya en esta época presentaban un suelo empedrado tal y como hoy se puede observar en algunos tramos. Las referencias medievales a estas zonas se localizan en cuatro puntos concretos del espacio extramuros. El primero de ellos estaba situado en las inmediaciones de la puerta de Santa Cruz y con el tiempo se convirtió en el espacio comercial extramuros denominado Plaza de la Resina. El segundo se encontraba entre los arrabales de San Andrés y Fuenteminaya y recibía indistintamente el apelativo de eras de San Andrés o de San Sebastián, por encontrarse entre

${ }^{468}$ HERNÁNDEZ ÍNIIGO, P., “Aproximación al utillaje agrícola bajomedieval a través de los protocolos notariales: el caso de Córdoba”, en Vida cotidiana en la España medieval. Madrid, 1998, pp. 281-302. Además de la obvia función económica, las eras también se convirtieron en un espacio de recreo durante los periodos que no se utilizaban para la trilla. Curioso es el episodio en que el conde de Miranda y el regidor arandino Pedro de Mora pasearon durante tres horas por las eras de Peñaranda para discutir sobre el problema del curato de las Alcobas del que hablaremos más adelante (AGS, CC PUEBLOS, leg. 1, doc. 233). 
ambas ermitas $^{469}$. En la actualidad todavía se conserva parte de este segundo conjunto pero nada del primero. También se conserva en bastante buen estado el tercero de los conjuntos que hoy denominamos eras de Santa Catalina. Aunque este topónimo es plenamente medieval, no tenemos ninguna referencia concreta que lo identifique con eras, aunque el $p a-$ lomar en las eras y espaldas del monasterio, propiedad de Juan Esteban Mercader, se refiere en concreto a este espacio que hoy identificamos con las eras de Santa Catalina ${ }^{470}$. Por contra, no se conserva ningún resto del cuarto espacio, las eras del Carrascal, que estaban situadas en el arrabal de Allendeduero ${ }^{471}$. A pesar de la apariencia homogénea y abierta que presentaban las eras, se trataba de propiedades privadas perfectamente delimitadas por pequeños mojones o, en los casos en que estaban empedradas, las parcelas se delimitaban con guijarros de color blanco en contraposición a los cantos de río más oscu$\operatorname{ros}^{472}$. En los periodos que seguían a la siega estos espacios se llenaban de vida y muchos vecinos se instalaban provisionalmente en ellos para aprovechar los largos días de verano y proteger la cosecha ${ }^{473}$. Esta circunstancia generaba multitud de situaciones tensas que en ocasiones se materializaban en violencia. En este sentido es bastante llamativo que para el periodo de tiempo estudiado hemos identificado dos asesinatos en las eras de localidades cercanas a Aranda: en los años setenta Juan Román, vecino de Fresnillo, mató a un vecino de Fuentelcésped en las eras mientras estaba echado en una cama; tiempo después otro vecino de Fresnillo, Pedro Monje, también cometió un asesinato en las eras, aunque no sabemos de dónde ${ }^{474}$.

Para terminar esta exposición de los espacios con dedicación económica pasamos a abordar el más original de todos ellos que no es otro que el destinado al almacenamiento del vino. A diferencia de otros lugares de la comarca donde las bodegas se encontraban en

${ }^{469}$ AGS, CC PUEBLOS, leg. 2, doc. 107; y CMC, leg. 355.

${ }^{470}$ AGS, CMC, leg. 355.

${ }^{471}$ AGS, CMC, leg. 355.

${ }^{472}$ Hasta tal punto se considera que las eras son propiedad privada que cuando a principios de agosto de 1516 el corregidor tuvo que comunicar una disposición del Concejo Real a la mujer de Juan Alonso de Guma ordenó al alguacil que acudiera a su era para entregársela (AGS, CC PUEBLOS, leg. 2, doc. 107).

${ }^{473}$ Alonso de Moradillo poseía, entre otras muchas propiedades, una casilla en las eras de San Sebastián en la que a buen seguro pernoctaban sus criados. Bernaldino de Arauzo también tenía una casilla en las eras de San Andrés (AGS, CMC, leg. 355). Estas precarias instalaciones se habilitaban incluso con camas (AGS, CR, leg. 22, doc. 1).

${ }^{474}$ AGS, CR, leg. 22, doc. 1. 
las laderas de pequeñas lomas integradas dentro del mismo núcleo, como puede ser La Aguilera o Fuentespina, o en sus proximidades como ocurre con Vadocondes, las peculiaridades topográficas de Aranda obligaron a emplazar estos almacenes en el propio subsuelo del núcleo urbano ${ }^{475}$. Por lo tanto, el espacio dedicado al vino no se define en superficie como los mercados de las diferentes plazas y principales calles, sino que se desarrolla a una decena de metros por debajo del suelo en un intrincado laberinto de galerías, zarceras, sumideros y escaleras. La creación de esta red de bodegas subterránea fue posible gracias a la configuración geológica del suelo ya que presenta un primer horizonte o estrato de greda o arcilla compacta de aproximadamente seis metros de espesor bajo el cual se encuentra otro de arenisca en el que se han excavado las galerías aprovechando las facilidades de este tipo de roca ${ }^{476}$. El resultado final fue un conjunto de galerías con una temperatura estable todo el año y protegidas de la humedad, el ruido y las vibraciones donde se podía almacenar y madurar el vino en unas condiciones óptimas ${ }^{477}$. En este sentido, son bastante reveladoras las palabras de los propietarios de las bodegas del Pozo que señalaban que ...en esta villa tengan las bodegas en mucha guardia e custodia, asy de los soles como de los ayres, e ansy mismo de los ruydos de las carretas e de otros pasajes en manera que todas las bodegas e las mas dellas se juntan por las traseras por que estan mijor guardadas unas con otras, e por apartallas de las calles e ruydos e ynconvinientes ${ }^{478}$.

Las galerías estaban divididas en pequeños espacios o suelos donde se instalaban las cubas. Estas bodegas pertenecían en su mayor parte a la comunidad de propietarios de los suelos, aunque existía alguna de pequeño tamaño propiedad de un individuo o grupo

${ }^{475}$ Este elemento tan singular de la cultura popular arandina ha sido abordado con detalle por IGLESIAS BERZOSA y VILLAHOZ GARCÍA, Viñedo, vino y bodegas.... La mayor parte de las referencias que se hacen en nuestro trabajo han sido obtenidas de esta monografía. También contamos con una aproximación al cultivo del vino en época medieval en la cuenca del Duero en el trabajo de GARCÍA MANSO, E., "El vino en época medieval en la Ribera del Duero", en El vino en época tardoantigua y medieval. 2009, pp. 227-252.

${ }^{476}$ No obstante, la percepción o el interés de algunos de los vecinos contrarios a la canalización del río Aranzuelo por el interior de la villa les llevó a afirmar que la villa esta asentada sobre cascajo y por lo tanto el agua se filtraría mientras que los promotores afirmaban que la mayor parte de las bodegas de la villa eran altas o que las mas hondas son a quatro o cinco pasos (AGS, CR, leg. 40, doc. 8).

${ }^{477}$ El cumplimiento de estas condiciones era una de las principales preocupaciones de los propietarios. De nuevo a propósito del desvío del Aranzuelo, sus detractores argumentaban que agora se remana algunas bodegas y si se trajera más agua causaría más daño a las bodegas (AGS, CR, leg. 40, doc. 8).

${ }^{478}$ AGS, CR, leg. 39, doc. 3, transcrito por PERIBÁÑEZ OTERO y ABAD ÁLVAREZ, Aranda de Duero..., p. 146. 
familiar $^{479}$. Las bodegas eran identificadas generalmente por el nombre del vecino en cuya casa se situaba el portal de acceso a la bodega y que evidentemente cambiaba con el tiempo $^{480}$. Pero en otras ocasiones responden a nombres más descriptivos y que, por lo tanto, permanecieron durante más tiempo como fue la bodega Larga de la calle del Pozo, la del Beneficio, la del Caño o la de Abajo ${ }^{481}$.

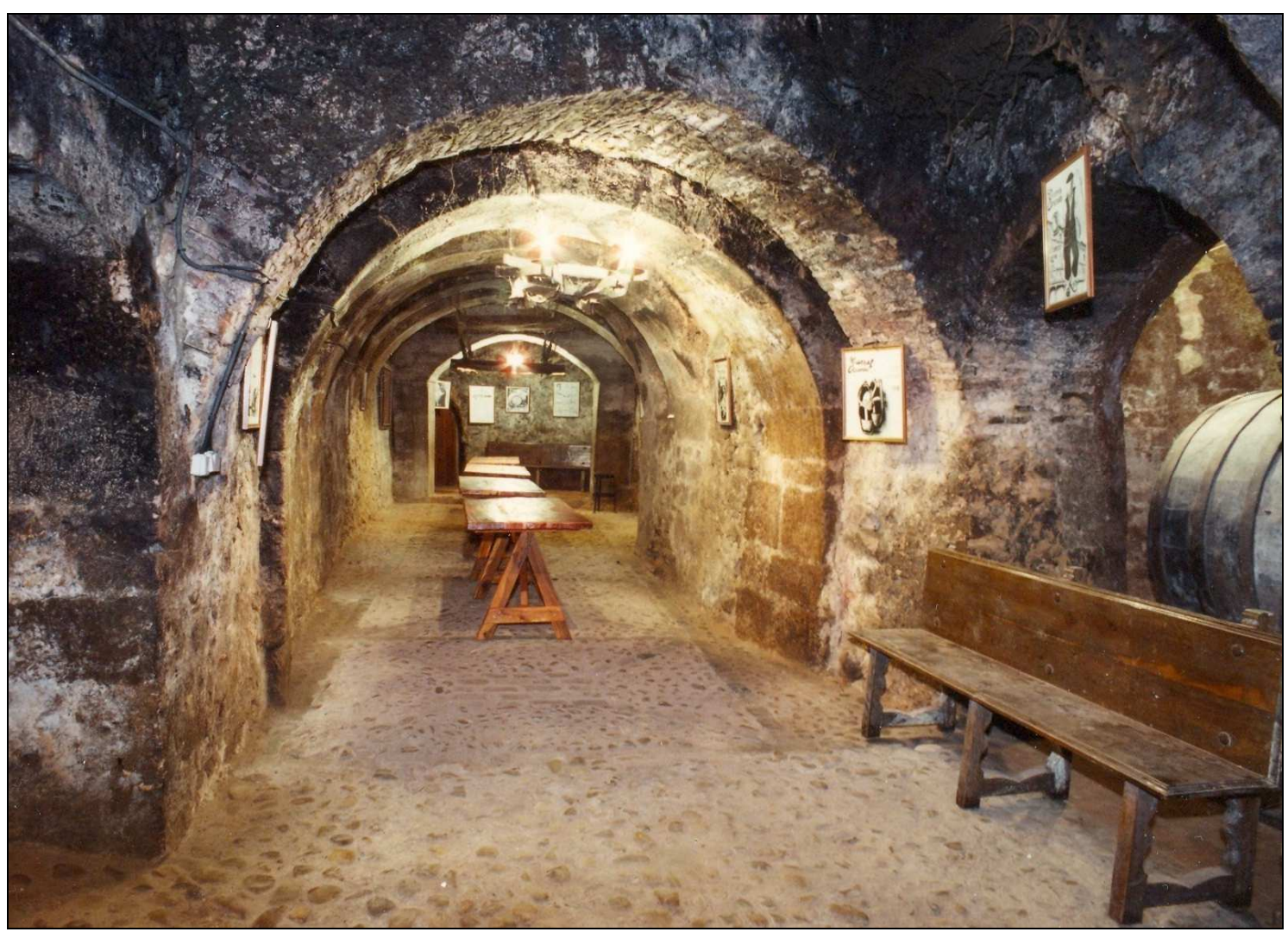

Imagen 26: Interior de la bodega Tierra Aranda o Requejo (CBMAD).

El conjunto se completaba con vendederos, portales o cabañones integrados en el caserío arandino donde se vendía el vino ${ }^{482}$.

${ }^{479}$ Este es el caso de algunos de los hacendados arandinos como Pedro de Santa Cruz, Francisco de Berlanga o Francisco de Mena que en los inventarios de sus bienes citan una o varias casas con sus bodegas (AGS, EMR, leg. 560 y 567). También entre los bienes de los comuneros exceptuados se recoge este término como es el caso de Alonso de Aranda o Alonso de Moradillo (AGS, CMC, leg. 355).

${ }^{480}$ Así, por ejemplo, conocemos las bodegas de Moradillo en la calle del Pozo (AGS, CR, leg. 39, doc. 3); la de Alonso González de Curiel (EMR, leg. 567); la de Arce o la de Gonzalo del Rincón (CMC, leg. 355).

${ }^{481}$ AGS, EMR, leg. 560; CMC, leg. 355; y ARChV, RRE, Caja 281, doc. 26.

${ }^{482}$ En ocasiones también se utiliza el término bodegón como sinónimo de portal o vendedero y sin la connotación de establecimiento donde se preparaban comidas (AGS, CMC, leg. 355). 
En este sentido el pleito sobre la apertura de la calle Barrionuevo en 1503 ofrece una somera descripción de una de estas bodegas, la del Poço o Portal del Arco de Calicanto, que se encontraba bajo las casas que se querían derribar para permitir el acceso desde Barrionuevo a Santa María ${ }^{483}$. Realmente se trataba de un conjunto de tres bodegas que sumaban entre todas ellas 43 suelos que albergaban cubas de entre cien y ciento cincuenta cántaras cada una. Las tres compartían el mismo portal o vendedero donde se cerraban los tratos entre propietarios y compradores.

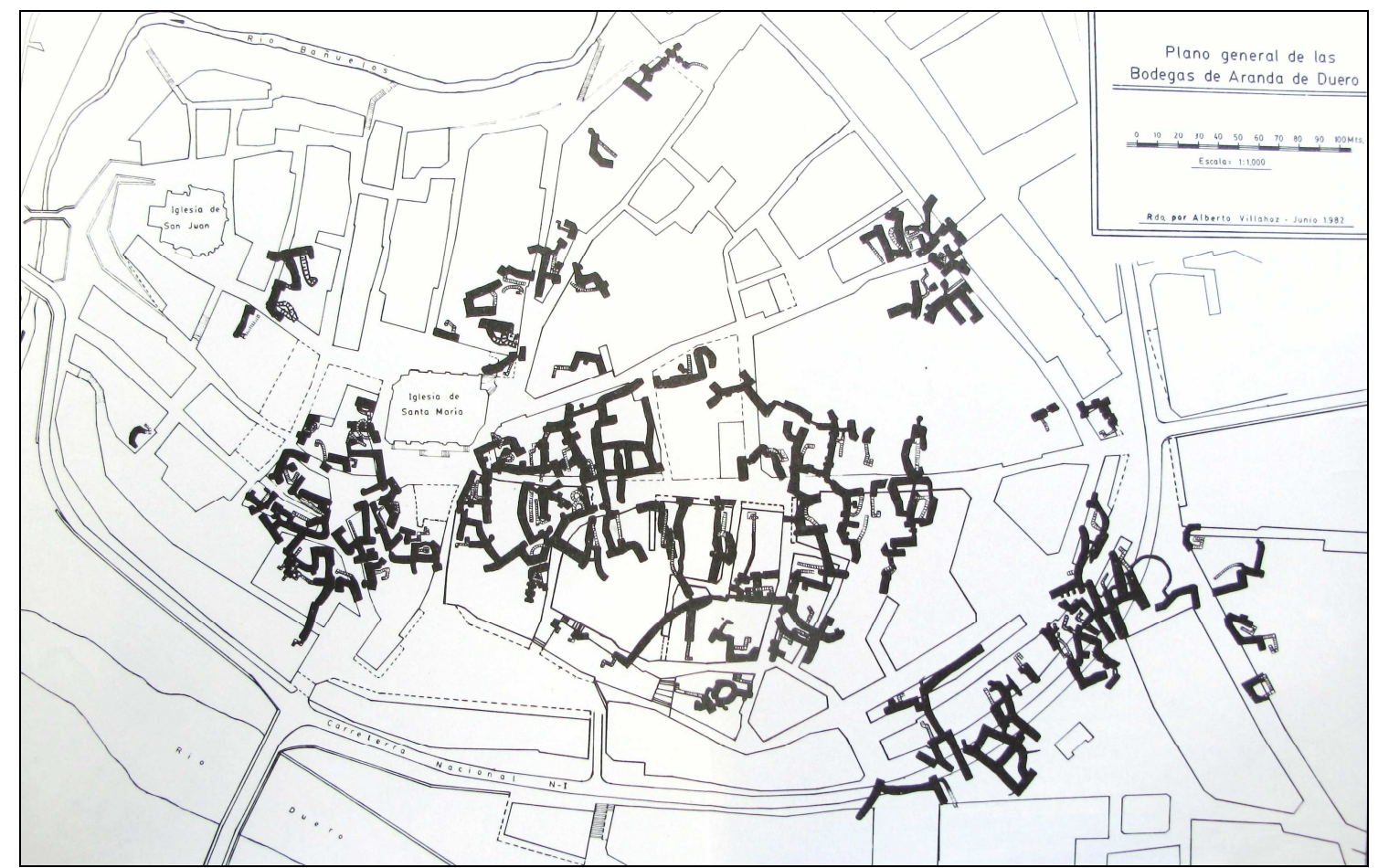

Plano 8: Plan de las bodegas subterráneas de Aranda según Iglesias y Villahoz.

Al igual que las bodegas estaban integradas dentro y bajo el caserío de la villa, también los lagares o jaraíces se emplazaban junto a alguno de los portales. Esta cercanía era fundamental para agilizar la transformación de la uva en zumo como paso previo a su fermentación y almacenamiento ${ }^{484}$. Sin negar la existencia de lagares colectivos asociados a las grandes bodegas con muchos propietarios, la documentación tan solo nos ha

${ }^{483}$ PERIBÁÑEZ OTERO y ABAD ÁLVAREZ, Aranda de Duero..., pp. 145 y ss.

${ }^{484}$ En la actualidad son muy pocos los lagares que se conservan en el espacio intramuros. Arqueológicamente se han documentado los restos de uno de ellos en un solar de la plaza de Santa María, posiblemente vinculado a la bodega de la Cofradía de las Ánimas (ABAD ÁLVAREZ, I. y PALOMINO LÁZARO, A. L., Informe técnico del sondeo arqueológico realizado en el solar $n^{\circ} 13-15$ de la Plaza de Santa María. Aranda de Duero (Burgos). Febrero 1997. pp. 10-14). 
transmitido la existencia de jaraíces particulares ${ }^{485}$. Seguramente estos lagares particulares, además de ser utilizados por su propietario, se alquilaban a aquellos labradores que no disponían de este necesario instrumento.

Poco se sabe a ciencia cierta sobre el origen de las bodegas arandinas aunque suponemos que la mayor parte de las que se encuentran en el espacio intramuros son de época medieval $^{486}$, si bien es cierto que sufrieron modificaciones y ampliaciones posteriores. Las bodegas no ocupaban de manera uniforme todo el subsuelo de la villa sino que se concentran en determinados espacios, confirmando la preferencia por ocupar espacios de caserío y evitar las zonas abiertas, aunque la mayor parte de los portales se situaban en las inmediaciones de la Plaza de Santa María y adyacentes, San Juan, calle y puerta de Cascajar, calle y puerta de Hesilla, Plaza del Trigo y Boticas; es decir, los principales focos de actividad comercial $^{487}$. El gran crecimiento que experimentó la actividad vitivinícola a lo largo de la primera mitad del siglo XVI derivó en la carencia de bodegas que se trató de atajar mediante la concesión de licencias por parte del concejo para construir nuevas galerías. Así en 1551 Carlos V permitió al concejo conceder licencias para que los vecinos hiziesen ciertas bodegas soterranas dentro en la dicha villa e fuera della dando cierto censo para propios della ${ }^{488}$. Seguramente a esta nueva fase constructiva pertenece el conjunto de bodegas de la Puerta Nueva y otras realizadas en el arrabal de Carrequemada. La crisis económica del siglo XVII se plasmó en la capital de la Ribera, entre otras muchas cosas, en el freno de la expansión bodeguera. No fue hasta el siglo XVIII cuando se habilitaron nuevas bodegas como las de Ricaposada o las del Palacio del Obispo ${ }^{489}$.

${ }^{485}$ El comunero Alonso de Aranda poseía un lagar de madera con su aparejo (AGS, CMC, leg. $355)$.

${ }^{486}$ A principios del siglo XVI ya se tiene constancia de la existencia de alguna bodega en los arrabales, suponemos que en el de Carrequemada, pues en 1525 el corregidor prohibió al cubero Gonzalo trabajar en el portal que estaba contiguo a la bodega de Alonso de Luis porque le echaba a perder su vino. Ambos vivían en uno de los arrabales, aunque no se especifica en cuál de ellos (ARChV, RRE, Caja 380, doc. 21).

${ }^{487}$ Para el periodo bajomedieval hemos identificado la existencia de bodegas en la calle del Pozo, Barrionuevo (AGS, CR, leg. 39, doc. 3), Béjar (EMR, leg. 567), Cascajar (EMR, leg. 560), Empedrada (CMC, leg. 355), Hesilla (EMR, leg. 560), Pontecilla (CMC, leg. 355), Pozo (CR, leg. 39, doc. 3) San Juan y San Llorente (CR, leg. 450, doc. 8), y Canaleja (ARChV, RRE, Caja 261, doc. 47).

${ }^{488}$ AMA, leg. 63, doc. 155, transcrito por BERZOSA ESTEBAN y VILLAHOZ GARCÍA, $V i$ ñedo, vino y bodegas..., pp. 75-76.

${ }^{489}$ BERZOSA ESTEBAN y VILLAHOZ GARCÍA, Viñedo, vino y bodegas..., p. 76. 
Respecto al vino que se almacenaba en estas bodegas podemos decir que habitualmente la documentación lo denomina con un genérico vino y tan solo en algunas ocasiones se especifica si se trata de vino tinto o blanco ${ }^{490}$. Nos parece significativo que en el inventario de los bienes confiscados a los comuneros exceptuados del perdón se hiciera mención la mayoría de las veces a cubas de vino, y tan solo en algunos casos concretaban si era vino tinto o blanco. En el registro de los bienes del hacendado Alonso de Aranda se especificaban las cubas de vino tinto y blanco pero hay otras que tan solo se citan como vino. No sabemos si esta circunstancia se debió al desconocimiento por parte del escribano o si por el contrario el genérico hiciera referencia al vino clarete o rosado, bastante extendido por la comarca hasta hace unas décadas ${ }^{491}$.

No quisiéramos concluir sin mencionar la pervivencia en la toponimia urbana de un término que evoca a uno de los procesos de elaboración del vino. Tradicionalmente se ha identificado el término Cascajar con una de las características del suelo sobre el que está asentada la villa: terrenos de aluvial con abundancia de arcillas, arenas y cantos rodados ${ }^{492}$. Pero el término cascajar tiene otra acepción que ha pasado desapercibida para la historiografía local: vertedero de la casca u hollejo de la uva fuera del lagar ${ }^{493}$. Este hollejo era el resultado directo del prensado de la uva o bien se extraía tras macerar con el vino en el proceso de obtención de vinos tintos. Tras ser retirado de los lagares suponemos que era reaprovechado como fertilizante o directamente vertido en un basurero o muladar.

Con la peculiaridad de la arquitectura subterránea y la actividad vitivinícola concluimos este apartado dedicado a los espacios económicos, que no es más que la constatación del evidente dinamismo que experimentó la sociedad arandina a finales de la Edad Media.

${ }^{490}$ AGS, CMC, leg. 355; y ARChV, RRE, Caja 121, doc. 24. En La Rioja las referencias al tipo de vino se ciñen exclusivamente a estas dos variedades: blanco, algo más apreciado a tenor de su mayor precio, y tinto (GOICOLEA JULIÁN, F. J., "El vino en el mundo urbano riojano a finales de la Edad Media”, En la España medieval, 30, 2007, págs. 217-244, en especial 238-241).

${ }^{491}$ Rosados y claretes, aunque se han utilizado como sinónimos, responden a una elaboración diferente. Mientras al rosado se le retiran los hollejos en una fase temprana de la fermentación, el clarete es una mezcla de mostos de uvas tintas y blancas.

${ }^{492}$ DE LAS HERAS MOLINOS, “El medio físico..., pp. 57-71; y CEBAS HERNANDO, Callejero comentado..., pp. 33-34.

${ }^{493}$ Diccionario de la Lengua Española. Real Academia de la Lengua (22a Ed.), voz cascajar. 


\section{c. Espacios residenciales: las viviendas.}

Entre otras muchas funciones, los núcleos urbanos medievales se caracterizaban por albergar edificios de carácter privado destinados a cobijar a los vecinos que en ella habitaban. Aunque evidentemente el espacio del caserío es el más importante cuantitativamente, los diferentes análisis de los historiadores se han encaminado tradicionalmente hacia el estudio de una mínima parte de estos elementos urbanos, aquellos más significativos por la calidad artística o técnica de su construcción o por la condición social de sus habitantes, dejando de lado el estudio de las construcciones más humildes o populares. Pero esta actitud ha cambiado significativamente desde hace unas décadas a medida que una nueva generación de historiadores ha comenzado a abordar el estudio del caserío o zonas residenciales populares con el objetivo de aproximarse a los grupos sociales que lo habitaron ${ }^{494}$. En este sentido, la profesora Arízaga ya ha puesto de manifiesto en numerosas ocasiones la necesidad de analizar y preservar lo que denomina el patrimonio menor, en el que se encuadrarían las viviendas, pero también los almacenes, tiendas, hornos y un largo etcétera. Este patrimonio sería la manifestación de lo ordinario, frente a los castillos, fortalezas, palacios y catedrales que serían el reflejo de lo extraordinario dentro de la sociedad feudal medieval ${ }^{495}$.

Por lo tanto, en el núcleo urbano que estamos estudiando diferenciamos dentro de las construcciones residenciales dos ámbitos claramente definidos. Por una parte, la mayoría de los edificios presentan un carácter homogéneo e impersonal; y por otra, existen un pequeño número de edificios singulares tanto por su aspecto como por su calidad y la de sus propietarios que se diferencia nítidamente del resto de las viviendas. Esta diferenciación ya era percibida por los propios vecinos como lo pone de manifiesto el plano de 1503 en el que las manzanas se rellenaron de casas simples en las que sólo se marcan las paredes, vanos y cubiertas. Esta monotonía tan solo era rota por la representación pormenorizada de algunas construcciones notables entre las que destacan los elementos religiosos o defensivos, pero también algunas residencias con elementos constructivos diferenciados. Nuestro objetivo en este apartado es intentar pergeñar los

\footnotetext{
${ }^{494}$ Son muchos los ejemplos de este nuevo enfoque, por lo que sólo citaremos algunos de los que tienen una mayor proximidad geográfica y temporal con nuestro ámbito de estudio: MARTÍN CEA, El mundo rural..., pp. 325-336; OLMOS HERGUEDAS, La Comunidad de..., pp. 59-61; y ÁLVAREZ ÁLVAREZ, C., La ciudad de León en la Baja Edad Media: el espacio urbano. Madrid. 1992, pp. 116 y ss.

495 ARÍZAGA BOLUMBURU, B., Urbanística medieval (Guipúzcoa). San Sebastián, 1990; y La imagen de la ciudad medieval. La recuperación del paisaje urbano. Santander, 2002, pp. 15-16.
} 
elementos más significativos tanto de los unos como de los otros con el absoluto convencimiento de que ambos son una evidencia material de la sociedad que los creó y, por lo tanto, nos ayudará a percibir ésta de una forma más completa.

\section{El caserío.}

La documentación se muestra parca en noticias que ayuden en el intento de reconstruir las características de la vivienda popular ${ }^{496}$. Esta circunstancia ha provocado que los historiadores se encaminen hacia otras fuentes como la arqueología o la etnografía $^{497}$. En el caso arandino contamos con escasos datos arqueológicos por lo que nos vemos obligados a recurrir sobre todo a la etnografía y a una fuente gráfica excepcional como es el ya mencionado plano de $1503^{498}$.

Las referencias documentales a las viviendas populares son muy habituales pero no pasan de la utilización del genérico casa, sobre todo en plural que habitualmente se concreta en pares de casas, como ocurre en otros lugares de Castilla ${ }^{499}$.

Los materiales utilizados en la construcción fueron muy variados destacando por su calidad la piedra, madera, teja, cal, arenas, cantos y yeso ${ }^{500}$. Pero en lo que se refiere a la edificación de las viviendas populares todo apunta a que fue la tierra el material más utilizado, empleando para ello la técnica de la acumulación, bien fuera mediante adobes o tapiales ${ }^{501}$. Además de las escasas evidencias arqueológicas a las que más tarde hare-

${ }^{496}$ SÁNCHEZ DEL BARRIO, A., "Las construcciones populares medievales: un ejemplo castellano de comienzos del XIV”, en Studia Historica. Historia Medieval. 7, 1989, pp. 127-153.

${ }^{497}$ GARCÍA GRINDA, J. L., "La arquitectura popular castellana en sus tipos básicos. El ejemplo burgalés como encrucijada de influencias", en Aproximación etnográfica a Castilla y León. Barcelona, 1988, pp. 333-376; y GARCÍA CAMINO, I., "La vivienda medieval: perspectivas de investigación desde la arqueología", en La vida cotidiana en la Edad Media. Logroño, 1998, pp. 77-110.

${ }^{498}$ Hay bastantes obras sobre la arquitectura popular en la comarca de la Ribera del Duero entre las que destacan las de LOBATO CEPEDA, B. et álii, "Arquitectura de adobe en la Ribera del Duero", Narria, 28, 1982, pp. 10-13; y la más completa de MARTÍN CRIADO, A., La ornamentación en la arquitectura tradicional de la Ribera del Duero. Ávila. 2008. Sobre el plano de 1503 ya hicimos junto a ABAD ÁLVAREZ una pequeña aproximación en Aranda de Duero..., pp. 85-87.

${ }^{499}$ MARTÍN CEA, El mundo rural..., p. 326.

${ }^{500}$ Así se desprende de los pagos recogidos en el Libro de Fábrica de Santa María para el año 1529. La tapia calicostrada o calicanto, como normalmente se denomina en la Ribera, era muy utilizada para las construcciones que debían ser más consistentes como las de carácter defensivo (AGS, CR, leg. 22, doc. 1; y CC MEMORIALES, leg. 163, doc. 57). También se constata su utilización para la construcción de los mojones de las demarcaciones territoriales (RGS, 149306, fol. 117).

${ }^{501}$ FONT ARELLANO, J., "Técnicas medievales de construcción con tierra", en Construir la ciudad en la Edad Media. Logroño, 2010, pp. 335-356. En otras localidades de la Ribera sí que se em- 
mos alusión, esta conclusión la sustentamos en la abundancia del material arcilloso en la comarca que ya fue utilizado en periodo históricos anteriores con bastante frecuencia, como ponen de manifiesto los abundantes estudios arqueológicos protohistóricos, así como el paralelismo con otros espacios próximos cronológicamente que sí cuentan con estas evidencias, y la continuidad en su utilización en la Ribera del Duero hasta tiempos recientes $^{502}$.

La arquitectura del barro en Aranda se caracterizaba por utilizar como base el adobe $^{503}$ o tapial que solía asentarse sobre unas pocas hiladas de mampuesto a hueso que actuaría a modo de zócalo o cimiento ${ }^{504}$. Generalmente en el alzado del primer piso se utilizaba exclusivamente tierra, aunque en algunas ocasiones se empleaban piedras calizas más o menos desbastadas en los ángulos y sobre todo en las jambas y dinteles de los vanos. En el cerramiento de las segundas y sucesivas plantas se utilizaba como material auxiliar la madera, bien de pino o de sabina ${ }^{505}$, que se configuraba como un entramado de formas geométricas que se rellenaba con adobes. Grandes vigas de madera también eran utilizadas como soportes de los diferentes pisos, así como pies derechos o escaleras $^{506}$. El conjunto se remataba con un tejado generalmente a doble vertiente que desaguaba hacia la calle y al espacio posterior, habitualmente un corral o dependencia

pleaba la piedra para las construcciones populares por su fácil acceso a la caliza paramera (MARTÍN CRIADO, La ornamentación..., pp. 15-20).

502 SÁNCHEZ DEL BARRIO, A., Arquitectura popular, Valladolid, 1987; ALONSO PONGA, J. L., La Arquitectura del Barro. Valladolid, 1994; y SACRISTÁN DE LAMA, J. D., LA Edad del Hierro...; VALDEÓN BARUQUE, J., "Un despoblado medieval castellano del siglo XIV: Fuenteungrillo", en En la España Medieval. 3, 1982, pp. 705-716.

${ }^{503}$ Tenemos constancia de la existencia entre los vecinos arandinos del oficio de adobero, como por ejemplo el comunero Pinto (AGS, PR, leg. 4, doc. 16). De igual manera conocemos ciertos pagos que hacen referencia a este oficio como son el Barroso o La Adobera. Por otra parte, al comunero Miguel Daza se le confiscó un barrero en la ribera del Arandilla (CMC, leg. 355).

${ }^{504}$ CRISTÓBAL VILLANUEVA, E., Informe técnico de los sondeos y seguimiento arqueológicos realizados en el solar $n^{\circ} 6$ de la Plaza de San Juan, en Aranda de Duero (Burgos). Junio 1994. Informe depositado en el Servicio Territorial de Patrimonio y Promoción Cultural de Burgos, pp. 11-14. En este seguimiento arqueológico se detectó una estructura de algo más de seis metros de longitud por 75 centímetros de anchura compuesta pos dos hiladas de mampuesto a hueso sobre la que se asentaba un pequeño nivel arcilloso compacto de aproximadamente 10 centímetros de altura que contenía una moneda de 2 maravedíes de los Reyes Católicos. La escasa entidad del nivel arcilloso no permitió identificar claramente si se trataba de adobe o tapial.

${ }^{505}$ El concejo daba licencias para que los vecinos pudieran abastecerse de madera de los montes comunales para emplearlos en la construcción (AGS, CC MEMORIALES, leg. 149, doc. 230). La madera de sabina, conocida popularmente en la Ribera como enebro, era muy apreciada (RGS, 149306, fol. 198).

${ }^{506}$ AGS, RGS, 149312, fol. 178. 
anexa. El espacio bajo la techumbre era utilizado como desván o sobrado y servía como secadero de diferentes alimentos. Estos tejados se cubrían con tejas curvas de barro cocido que se disponían en hiladas de canales sin cobijas $^{507}$. La escasa fijación de las tejas al entramado de vigas y tablas obligaba a trastejar de manera habitual para evitar las humedades $^{508}$. Finalmente las paredes se revocaban con una capa de barro para protegerlas y en ocasiones se encalaba ${ }^{509}$. El tapial se utilizaba sobre todo en los cercados de las construcciones auxiliares como eran los corrales, palomares y huertos ${ }^{510}$.

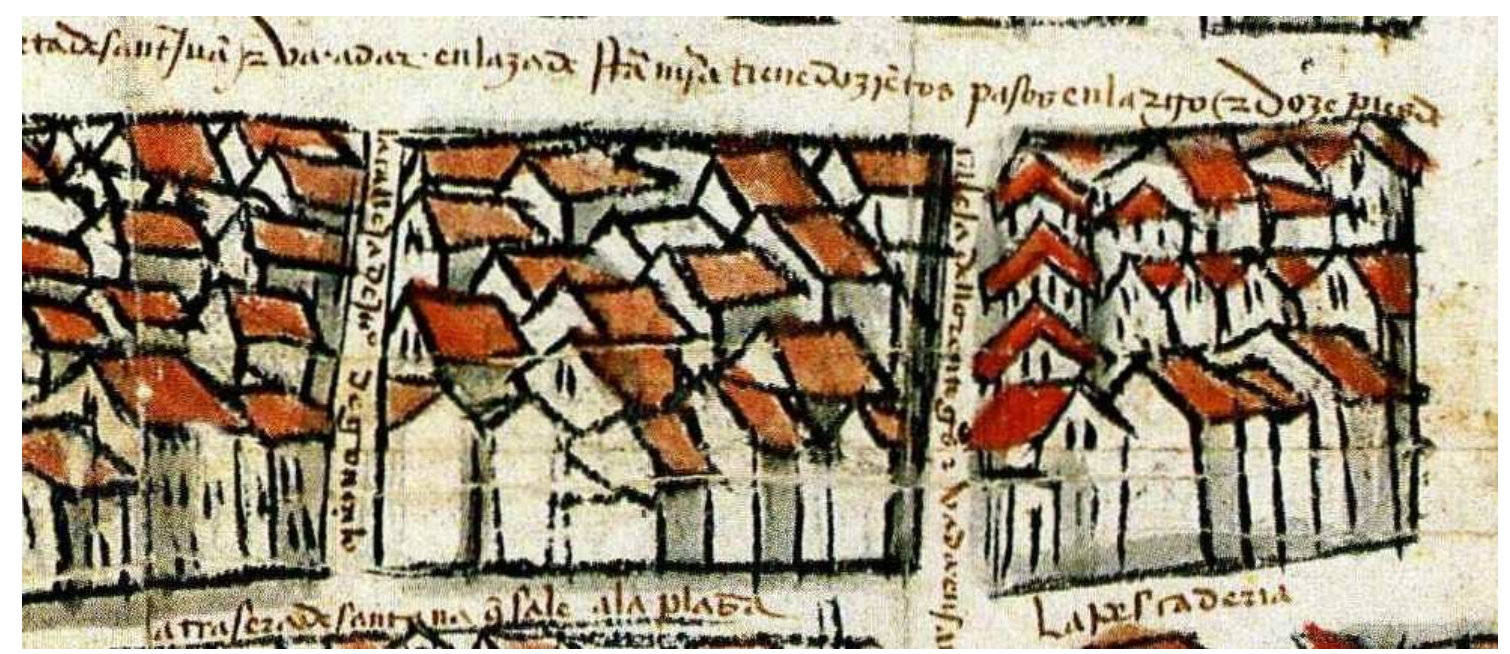

Imagen 27: Detalle del caserío en el plano de 1503.

Si nos atenemos a la imagen de la villa que nos proporciona el plano de 1503 podemos ver cómo las viviendas se disponían adosadas unas a otras en lotes perpendiculares a las vías de comunicación y con una planta característica estrecha y alargada. $\mathrm{Al}$ exterior el edificio presentaba un aspecto compacto y sobrio, con escasos y pequeños vanos. Predominaban las casas de dos alturas más el espacio de sobrado bajo el tejado, aunque también se perciben escasas viviendas de una sola planta y algunas más que

${ }^{507}$ GARCÍA GRINDA asegura que esta característica disposición respondía a causas económicas, ya que la ausencia de cobijas abarataba el coste, y estructurales, pues se aligeraba notablemente el peso de las cubiertas ("La arquitectura popular..., p 376). Esta típica disposición de las tejas en la comarca ribereña se puede apreciar en alguno de los tejados del plano de 1503.

${ }^{508}$ Llama bastante la atención que prácticamente la totalidad de los depositarios de los bienes confiscados a los comuneros decidieran retejar las casas de los condenados en el otoño-invierno de 1521 . Posiblemente esta fuera una de las tantas estrategias utilizadas por los depositarios para justificar gastos y así hacerse con una porción más elevada de las haciendas de los comuneros y evitar su entrega a la Corona (AGS, CMC, leg. 355).

${ }^{509}$ MARTÍN CRIADO, La ornamentación..., pp. 24 y 183-190.

${ }^{510}$ AGS, CR, leg. 40, doc. 8; y CMC, leg. 355. 
sobrepasan las dos alturas. Estas últimas tienden a concentrarse en el frontal Sur de la villa, tanto en las inmediaciones de San Llorente como en el flanco meridional de la Plaza Nueva. En este sentido, conviene recordar que ya en 1432 se obligaba a los vecinos de esta zona a preservar el espacio del adarve en las casas adosadas a la cerca. Esta circunstancia pudo condicionar el crecimiento en altura de estas edificaciones adosadas a la muralla para salvar esta dificultad y no perder superficie ${ }^{511}$.

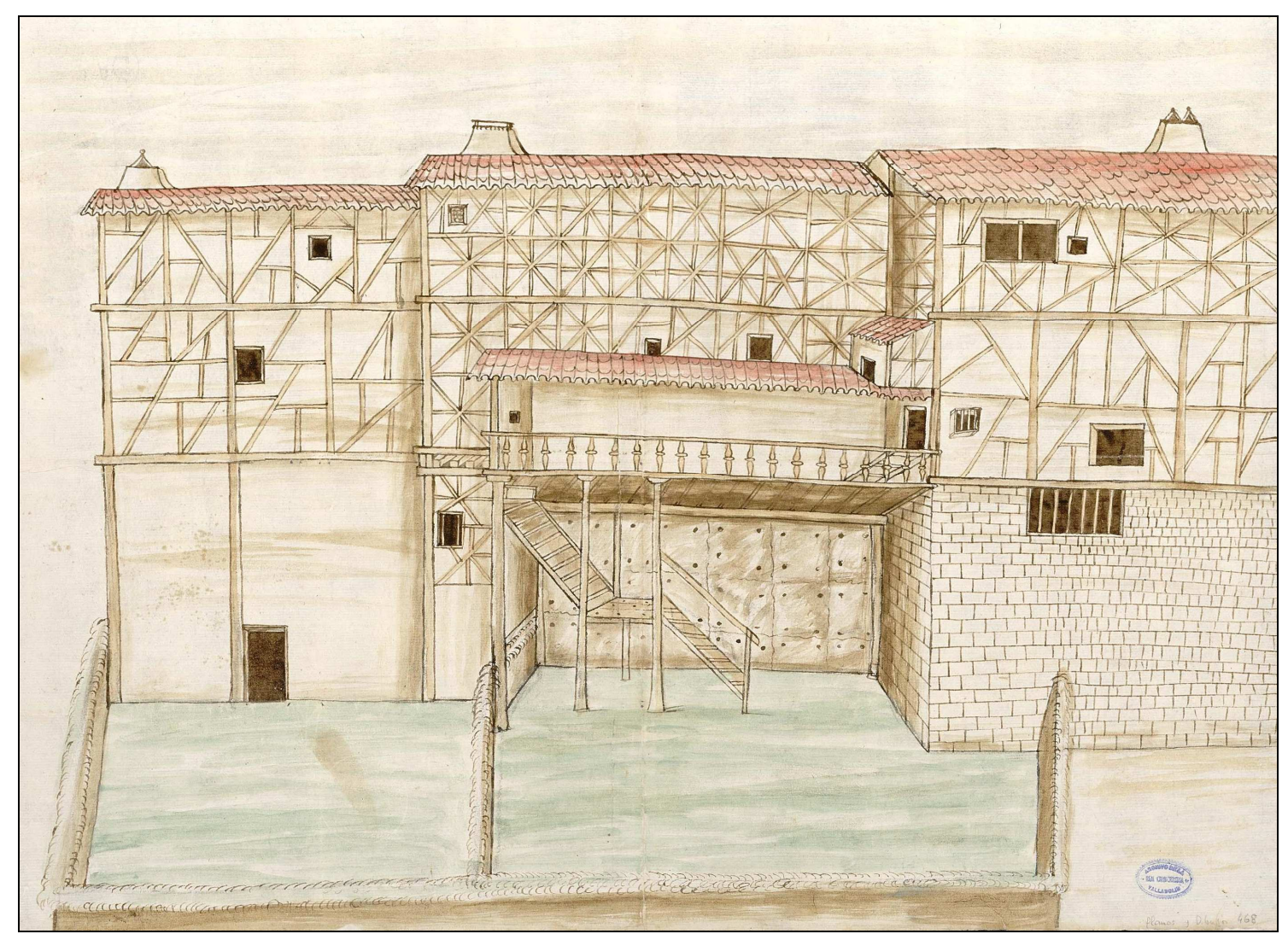

Imagen 28: Alzado de las traseras de unas casas del siglo XVIII en la calle Empedrada (ARChV, Planos y Dibujos, doc. 468).

A pesar de la prohibición expresa de las ordenanzas municipales de enajenar espacio público $^{512}$, la proliferación de soportales se convirtió en un hecho consumado a

${ }^{511}$ VELASCO PÉREZ, Aranda. Memorias..., p. 87.

${ }^{512}$ No han llegado hasta nosotros las ordenanzas municipales pero las hemos podido reconstruir parcialmente a través de algunos comentarios como: .. es costumbre en la villa buena y laudable que si algún vecino de fuera entrare y tomare o ocupare cosa concejil como exido, campo, termino o ribera sin licencia o merced de la villa que esto sea derrocado y el edificador pague a la villa el valor de aquello que entró y no goce de ello; y si otra vez torna asimismo pague lo que le tasaren y no se quede con ello sino que lo derribaren... esta costumbre es jurada por toda la villa de tiempos inmemoriales y hoy es obligado derrocar los edificios y pagar a los edificantes la tasa y costas que la villa ha gastado (AGS, CC MEMORIALES, leg. 161. doc. 122). 
finales de la Edad Media. El asoportalamiento fue la práctica más evidente y habitual en la villa arandina para privatizar el uso del espacio público como se deduce de su proliferación en la Plaza Nueva y también en alguna de las otras plazas ${ }^{513}$. En muchas ocasiones este soportal no sólo era la proyección aérea del espacio privado sobre el público, sino también el físico sobre la calle pues muchas de las actividades económicas traspa-

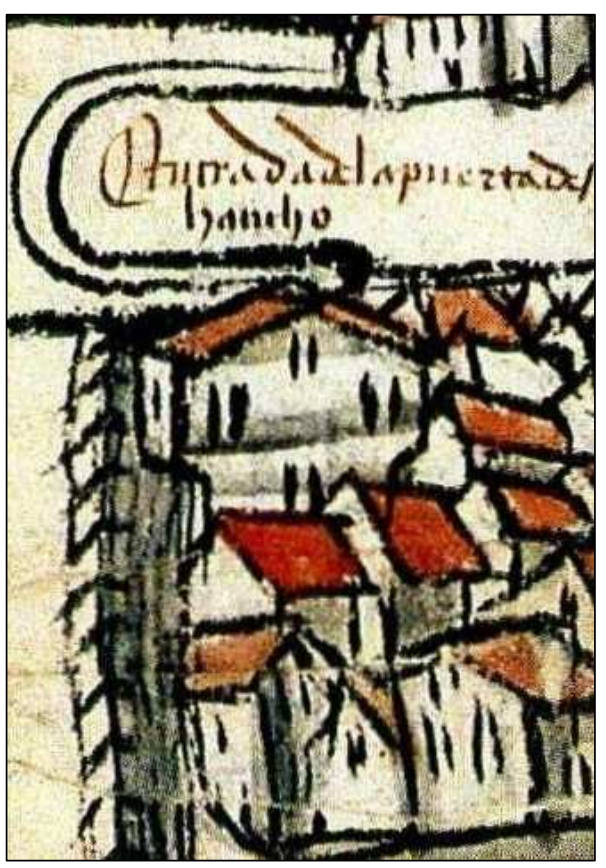
saban la tienda de la casa y se emplazaban en el soportal ${ }^{514}$.

Imagen 29: Detalle de voladizo en el mapa de 1503.

Pero como en otras ciudades castellanas ${ }^{515}$, una buena parte de las fachadas de las viviendas arandinas se proyectaron hacia el espacio público a través de voladizos que provocaban que las calles fueran suçias e oscu$\operatorname{ras}^{516}$. Algunos de estos volados se pueden apreciar en el plano de 1503. El más destacado de todos ellos es el que se encontraba en la Ronda cerca de la calle de San Juan con sendos voladizos en cada una de sus fachadas.

Otros ejemplos se localizaban en la calle de San Llorente, la Pontecilla, la calle do vive Pedro de Lara o la Costanilla. La generalización de los voladizos motivó una serie de quejas de las autoridades locales ante los monarcas. Éstos ordenaron a su corregidor que proveyera lo necesario ...para que en adelante no se labren ni edifiquen en las calles

${ }^{513}$ En el tantas veces mencionado plano de 1503 aparece el rótulo solosportales junto a la Acera de la Plaza Nueva. En 1504 el teniente de corregidor celebró una audiencia en los soportales de la Plaza Nueva (AGS, CASA Y SITIOS REALES, leg. 2, doc. 482). A finales del siglo XVI en el proceso para cambiar el emplazamiento del mercado uno de los promotores afirmaba que ... avia en la villa una plaza nueba que era grande muy desente con muchos soportales (ARChV, RRE, Caja 1699, doc. 4).

514 Gonzalo de Cubillo labraba cubas debaxo de un portal de unas casas en que mora Pedro de Castrillo (ARChV, RRE, Caja 380, doc. 21).

${ }^{515}$ TORRES BALBÁS, Resumen histórico..., pp. 141-143; y LADERO QUESADA, M. F., "La vivienda: espacio público y espacio privado en el paisaje urbano medieval", en La vida cotidiana en la Edad Media. Logroño, 1998, pp. 111-128, en concreto pp. 116-118.

${ }^{516}$ AGS, CR, leg. 39, doc. 3, transcrito por PERIBÁÑEZ OTERO y ABAD ÁLVAREZ, Aranda de Duero..., p. 150. 
públicas pasadizos, ni saledizos, ni corredores, ni balcones que sobresalgan de las fachadas, ni otros edificios que rompan el alineamiento de modo que queden las calles alegres, limpias y claras y se pueda transitar por ellas sin dificultad ${ }^{517}$. Pero estas disposiciones no fueron muy efectivas pues todavía en 1503 Sancho de la Peña describía una de las principales calles de la villa, Cascajar, como ...razonable calle aunque es algo oscura porque los texados estan muy juntos por lo alto ${ }^{518}$. Pocos años después era el regidor Pedro de la Plaza el que se quejaba de nuevo ante los monarcas argumentando que .... a causa de los salediços e algadicos que salen de las casas azia las calles publicas de la dicha villa muchas de las dichas calles estan muy oscuras y enfermas, por lo que solicita ...que se cortasen los cuellos salediços e colgadiços de las dichas casas que salen en las calles publicas ${ }^{519}$. La insistencia de las demandas confirma la generalización de esta práctica que se mantuvo en la villa hasta que la regeneración del casco histórico de la villa a finales del siglo XX hizo desaparecer buena parte de su patrimonio popular.

A pesar del aspecto atiborrado que nos ofrece el plano de 1503, tenemos la certeza de que en el recinto intramuros había espacios vacíos, carentes de edificaciones. Los más habituales eran los corrales adosados a las viviendas familiares. Estos patios o corrales ofrecían toda una serie de posibilidades en el contexto de la economía familiar pues albergaban tanto a animales domésticos como pequeñas estancias utilizadas a modo de almacén o incluso la letrina ${ }^{520}$.

También con el nombre de corrales era denominado el conjunto de viviendas que se organizaba entorno a un gran patio central y que se comunicaba con una calle a través de un gran portalón. Para el periodo que estudiamos hemos documentado al menos dos, el de Caravo y el del Orejudo ${ }^{521}$. Aunque no sabemos con certeza dónde se encontraban, nos parecen muy llamativas las tres entradas que se representan a lo largo de la

${ }^{517}$ AGS, RGS, 150105, fol. 306.

${ }^{518}$ AGS, CR, leg. 39, doc. 3, transcrito por PERIBÁÑEZ OTERO y ABAD ÁLVAREZ, Aranda de Duero..., pp. 175-176.

${ }^{519}$ AGS, CC MEMORIALES, leg. 133, doc. 91.

${ }^{520}$ ÁLVAREZ ÁLVAREZ, La ciudad de León..., p. 96; y SÁNCHEZ DEL BARRIO, A., Arquitectura popular. Construcciones secundarias, Valladolid, 1995.

${ }^{521}$ AGS, CMC, leg. 355. 
calle de Hesilla en el plano de 1503 y que se corresponden con los grandes vacíos que muestra el plano de 1868 .

Sobre la distribución interior de las viviendas populares poco podemos decir. Generalmente la planta baja, el portal, se destinaba al desarrollo de actividades económicas, bien fueran artesanales o comerciales, pero también agrícolas ${ }^{522}$. También este portal era un espacio de socialización donde fundamentalmente las mujeres realizaban sus tareas cotidianas relacionándose con sus convecinas ${ }^{523}$. Las pocas referencias que hemos encontrado sobre el espacio de la cocina la sitúan también en la planta baja ${ }^{524}$. Suponemos que estas cocinas contaban con un hogar sobre el suelo o sobre una pequeña plataforma. No parece que fuera muy habitual la instalación de chimeneas pues en el plano de 1503 tan solo tres de las casas cuentan con esta infraestructura ${ }^{525}$. La planta superior estaba destinada a habitaciones o cámaras que contaban con un escaso mobiliario que generalmente se limitaba a una cama o jergón y un arca en el que se guardaban las ropas ${ }^{526}$. Tan solo algunos de los vecinos más hacendados contaban con elementos decorativos en sus habitaciones entre los que apenas destacan algunas mantas de pared y algún que otro cuadro ${ }^{527}$. El conjunto se remataba con el sobrado o troxe bajo el tejado donde se guardaban algunos alimentos ${ }^{528}$. En ocasiones este sobrado contaba con una solana o balcón rehundido ${ }^{529}$.

${ }^{522}$ Un vecino describía en 1488 la casa del mercader Benito Ortiz: vio en el portal de su casa una botica con asaz paños mayores y menores y otras muchas joyas (AGS, CC MEMORIALES, leg. 151, doc. 113).

${ }^{523}$ Hacia 1498 María García junto a su madre y su hermana estavan en el portal de su casa cosiendo y labrando, cuando llegó el clérigo Diego de Mexías que hizo ciertos comentarios sobre el infierno y el paraíso que le valieron posteriormente una denuncia ante la Inquisición (CARRETE PARRONDO, Fontes Iudaeorum..., doc. 151, p. 79).

${ }^{524}$ Así ocurría con la cocina de la casa de Pedro de Santa Cruz (AGS, CR, leg. 39, doc. 3).

${ }^{525}$ SÁINZ GUERRA, "Desarrollo urbanístico..., p. 53. Dos de estas chimeneas se encontraban en el sector Sur de la Plaza Nueva y otra en una casa de la calle Santa Ana, esquina con Costanilla.

${ }^{526}$ AGS, CMC, leg. 355.

${ }^{527}$ Doña Constanza de Avellaneda empeñó en casa de Gaspar de Mansilla una manta de pared de arbolenda por 10.310 maravedíes (ARChV, RRE, Caja 229, doc. 60). En la casa del comunero Bernaldino de Arauzo se confiscó una manta vieja de figuras de Flandes tasado en 25 reales; de la misma manera en la casa de Alonso de Aranda se confiscó un paramento de arboleda viejo valorado en 170 maravedíes y otro paramento de figuras viejo tasado en 204 maravedíes; de la casa de Alonso de Moradillo se llevaron los depositarios una paño de figuras y una alfombra; en la casa de Gaspar de Mansilla se intervino un paño de figuras valorado en 900 maravedíes; de misma manera en la casa de Pedro Sánchez de Mendoza se llevaron dos paramentos de figuras viejos (AGS, CMC, leg. 355).

528 ...pan que estaba ensomo en unas troxes (AGS, CR, leg. 39, doc. 3). 


\section{Edificios singulares.}

En lo que se refiere a las construcciones más relevantes que había en el núcleo urbano arandino a finales de la Edad Media vamos a intentar sistematizar la información con la que contamos, siempre teniendo en cuenta que la principal fuente para la elaboración de este apartado ha sido el plano de 1503.

Lo primero que tenemos que advertir es que entre los edificios significativos encontramos ciertas características comunes que pueden ayudamos a definir estas construcciones.

En primer lugar, se observan casas de una sola planta con arco de medio punto en la puerta de acceso y que en algunos casos presenta también un remate almenado en vez de tejado. El plano de 1503 muestra varios ejemplos de este tipo de edificación que podemos denominar casa-fuerte. Se advierte una alta concentración en la collación de San Juan. En la calle del mismo nombre, al Oeste de la iglesia y junto a la puerta, se encontraba un edificio de estas características; en la calle del Bravo (hoy Centeno) se localizaba otra; y en la calle de la Plata apreciamos otra con una pequeña torre que sobresale del conjunto. El resto de las casas con estas características estaban dispersas por la villa, aunque el autor se tomó la molestia de representarlas con cierto detalle. Dos de ellas se encontraban en Barrionuevo, esquina con el Pozo y Las Quintanas; y la otra

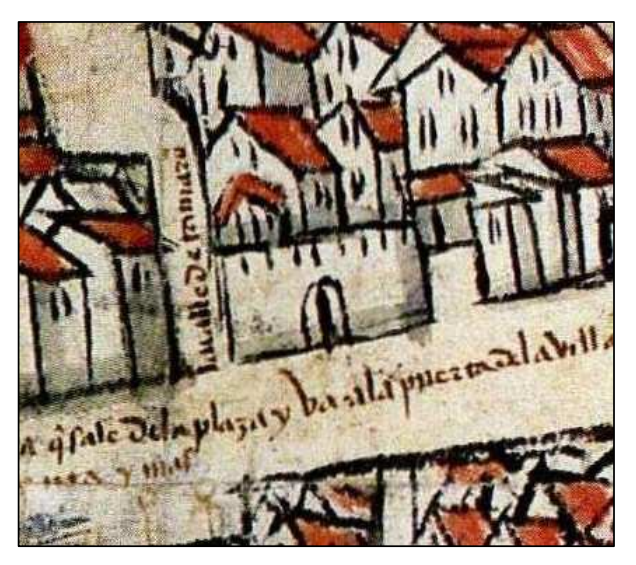
estaba en la esquina formada por la calle Hesilla y Tamarón.

Imagen 30: Detalle de las casas de Pedro de Santa Cruz.

Poco podemos decir de este tipo de casa, salvo su apariencia robusta y defensiva. Intuimos que sus propietarios eran personajes distinguidos de la sociedad arandina de finales de la Edad Media y que nos podría llevar a identificarlas con las residencias de la nobleza local. Al menos dos de esas casas han podido ser identificadas y hemos comprobado como esta correlación no es acertada pues

\footnotetext{
${ }^{529}$ GARCÍA GRINDA, “La arquitectura popular..., pp. 368-371.
} 
una de las de Barrionuevo fue la casa y prisión de la Inquisición y la otra, la de Hesilla, fue la residencia de Pedro de Santa Cruz que, aunque miembro de la oligarquía local, no tenía la condición de privilegiado ${ }^{530}$.

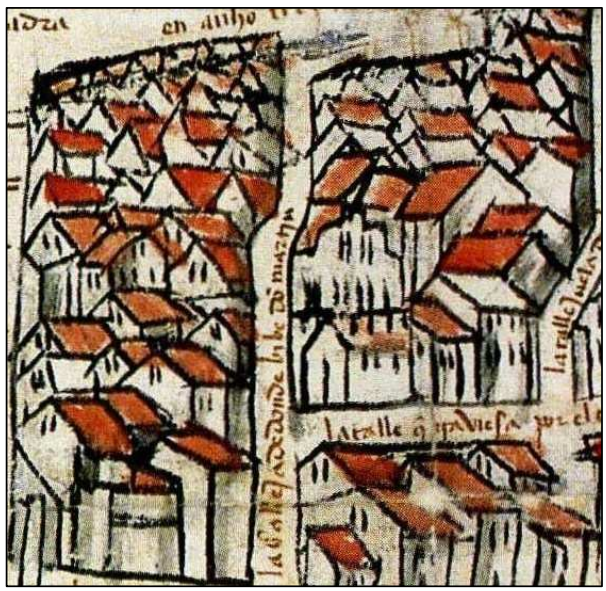

Imagen 31: Detalle de las casas de don Martín Vázquez de Acuña.

Otro grupo significativo de edificios es el que presenta hastiales escalonados en su fachada de clara influencia flamenca ${ }^{531}$. En el plano de 1503 se aprecian al menos cuatro de estas casas. En la calle de San Juan, esquina con la de Bravo, se observa un edificio de dos plantas rematado por una tercera planta con esta característica forma escalonada. Igualmente en el apiñado espacio entre la cerca y la calle de Pedro de Lara se advierten otras dos casas de este tipo. La última la encontramos en la actual calle Béjar, en la calleja de donde vive don Martín. Esta circunstancia nos hace pensar que ésta fuera la casa de don Martín Vázquez de Acuña. La documentación informa de que sus casas se encontraban en la parte alta de la calle, linderas con las que el regidor Pedro de Salazar tenía en la Plaza del Trigo. Sabemos que las casas de don Martín se construyeron a finales del siglo XV por un conflicto que mantuvo con su vecino. La disputa vecinal tuvo como punto de partida el derribo de las viejas casas. Ambos habían acordado previamente en una escritura demoler a la vez sus antiguas viviendas para posteriormente edificar las nuevas, estipulando que se debían cumplir unas normas ...en el resçibir de las aguas y en otras cosas. Sin embargo, cuando en 1492 don Martín decidió edificar comenzaron los problemas pues ...enbiaron a desir al dicho Pedro de Salazar derribase su casa e fisiese çiertos edifiçios en çierta forma con amenazas e comiciones y sy asy no lo fisiese que ellos mandarian derribar dicha casa. La ausencia de don Martín de la villa no impidió que su mujer tomara las riendas del asunto y cuando vio que Salazar comenzaba a construir, ...la dicha doña Costanza, aso-

${ }^{530}$ Son varios los testimonios que nos informan sobre esta casa a propósito del caño de agua sucia que salía de sus cocinas y que hacía intransitable la calleja de Tamarón (AGS, CR, leg, 39, doc. 3).

${ }^{531}$ YARWOOD, D., La Arquitectura en Europa. La Edad Media (650-1550). Madrid, 1996, vol. 2, p. 118. 
lutamente como sy fuera señora de la dicha villa, lo mando que deçendiese e sy no lo fasia que lo mandaria matar a palos; e que porque tan presto non cumplio su mandamiento dis que lo puso en obra e mando a su un hermano suyo que se llama Avellaneda e otros curados y escuderos suyos que lo matasen a palos y lo derribase de la viga. Los aparejos de Salazar fueron derribados y parece que se libró de la paliza gracias al recurso a sus familiares y clientes. Desgraciadamente no tenemos más noticias del conflicto ni tampoco del acuerdo previo al que llegaron para construir sus respectivas casas y que a buen seguro que podía haber puesto algo de luz sobre los procesos constructivos de la época $^{532}$.

A pesar de la relativa abundancia de edificios con hastiales escalonados en la villa, no hemos encontrado ninguna referencia a construcciones de estas características en Castilla que nos permita hablar de la llegada de este sistema constructivo a la Península y nuestro único argumento se limita a la información transmitida por el plano ${ }^{533}$.

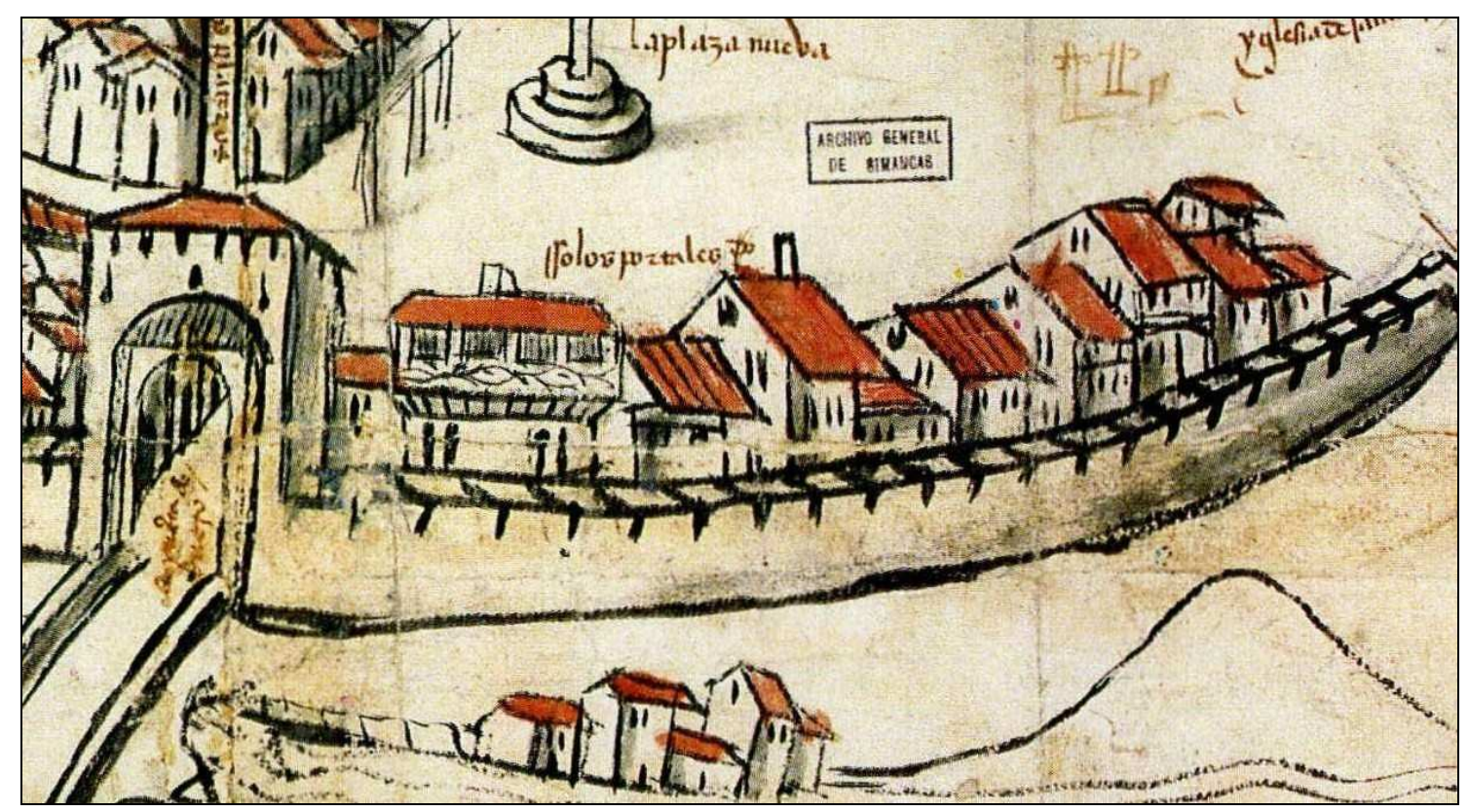

Imagen 32: Detalle de las casas del Ayuntamiento.

De nuevo retomando el plano de 1503, observamos en la fachada Sur de la villa, al Este de la Puerta de Duero, una amplia casa de tres alturas que presenta una balcona-

${ }^{532}$ AGS, RGS, 149205, fol. 472.

${ }^{533} \mathrm{Ni}$ siquiera hemos encontrado rastro de este tipo de construcciones en las impresionantes vistas realizadas por Van den Wyngaerde a mediados del siglo XVI (KAGAN, R. L., Ciudades del siglo de Oro: las vistas españolas de Anton Van den Wyngaerde. Madrid, 1986). 
da o solana muy desarrollada que sobresale por encima de la cerca. Este edificio cuanta además con una decoración vegetal en la balconada que recuerda el esgrafiado gótico segoviano o bien la decoración incisa tradicional ${ }^{534}$. Este edificio además presenta una de las pocas chimeneas que se ven en el plano y tiene una apariencia troncopiramidal que recuerda las de tipo serrano. El detalle con el que se representa este edificio y su situación nos hace pensar que se trata de las casas del ayuntamiento que se convirtió a partir de 1501 en lugar de reunión de las autoridades municipales, sustituyendo a otros emplazamientos tradicionales como era la ermita de Santa Cruz, en el lado opuesto de la Plaza Nueva ${ }^{535}$. La configuración estas nuevas dependencias municipales a partir del comienzo de siglo debe de estar en relación con la aplicación en la capital de la Ribera de la disposición de las Cortes de Toledo de 1480 que estipulaba la creación de una casa concejil para que ...se ayunten las justicias e regidores a entender en las cosas cumplideras a la republica de an de governar ${ }^{536}$.

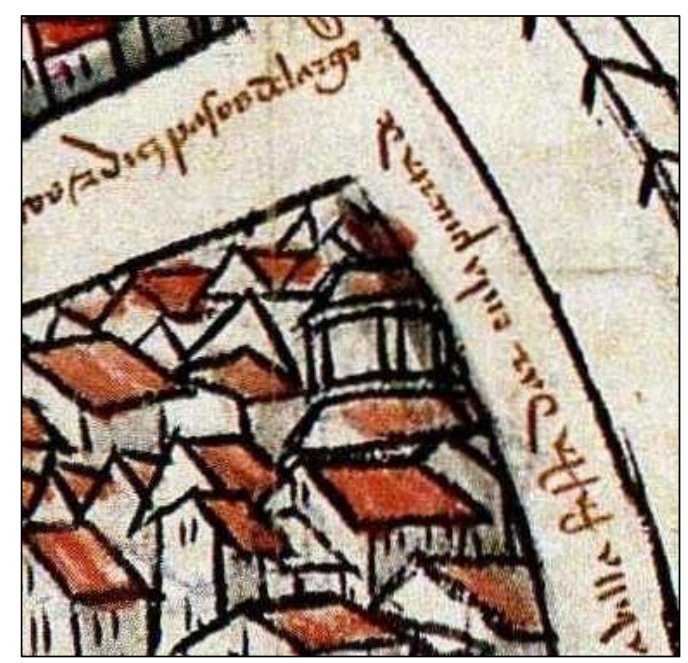

Imagen 33: Detalle de la cubierta en forma de cúpula.

Entre todas las construcciones peculiares destaca una casa situada en el extremo Este de la villa, en la calle Ronda o Traslacerca, que está rematada por una cúpula con su tambor. Desgraciadamente, salvo esta evidencia, nada más hemos podido averiguar sobre esta obra arquitectónica que llama la atención por sus características en una modesta villa castellana, ya que se encuentra marginada entre el caserío, en un lugar en el que no hay referencia a iglesias, ermitas o edificios públicos. Suponemos que tuvo su origen en la iniciativa privada, pero sobre sus promotores y funcionalidad nada sabemos por el momento.

${ }^{534}$ V.V.A.A., Historia de Segovia. Madrid, 1987, pp. 114-16. MARTÍN CRIADO enumera con profusión los múltiples ejemplos de ornamentación incisa y esgrafiado sobre los revestimientos de las fachadas ribereñas tradicionales (La ornamentación..., pp. 186-215). doc. 5 .

${ }^{535}$ AGS, EH, leg. 4; CC MEMORIALES, leg. 151, doc. 148; CR, leg. 450, doc. 8; y leg. 453,

${ }^{536}$ VAL VALDIVIESO, M. I., "La identidad urbana al final de la Edad Media", en Anales de historia medieval de la Europa atlántica. 1, 2006, pp. 5-28, en especial p. 18. 


\section{d. Espacios marginales.}

A lo largo de la historia de la humanidad se constata en los núcleos urbanos la existencia de espacios definidos fundamentalmente por su carácter marginal desde un punto de vista socioeconómico. El final de la Edad Media castellana añadió un elemento más dentro de la generación de marginalidades urbanas: el criterio religioso. Efectivamente desde 1480 se impuso la segregación espacial de ciertos grupos de población que se diferenciaban del resto del vecindario por su confesión religiosa, si bien es cierto que ya desde hacía algunas décadas se había perfilado una concentración de las minorías religiosas en determinados sectores urbanos. Como no podía ser de otra manera, la villa de Aranda participó de esta dinámica generalizada en toda Castilla.

Antes de analizar los espacios segregados en razón de la religión creemos conveniente matizar la diferencia existente entre los términos judería o morería y la realidad de las aljamas. La judería era el espacio físico en el que habitaba la población hebrea que, tras el decreto de 1480, se vio obligada a vivir en un espacio rígidamente delimitado. La aljama judía era el nombre que se utilizaba para denominar a la comunidad de una localidad y que como tal tenía una serie de obligaciones, sobre todo fiscales, pero también una serie de derechos, como el regirse internamente por sus propias leyes o disponer de sus propios oficiales que impartían justicia (dayyanim), velaban por la seguridad (bedin) o sus propios representantes ante instancias superiores. Esta misma apreciación era aplicable para la morería y la aljama mudéjar ${ }^{537}$.

\section{Judería.}

El confinamiento de la población judía en un determinado espacio fue una dinámica configurada en los siglos anteriores al periodo que nos ocupa. Los asaltos a las juderías castellanas en 1391 tuvieron mucho que ver con una cierta dispersión de la población hebrea por los diferentes sectores de los núcleos urbanos. Sin embargo, desde las primeras décadas del siglo XV se configuró una política de segregación espacial que comenzó con el Ordenamiento de Valladolid de 1412 y culminó con el apartamiento establecido por las Cortes de Toledo en 1480. Esta disposición establecía que las minorías religiosas debían ser recluidas en barrios apartados del resto de la vecindad. Se fijaba asimismo que este

${ }^{537}$ LADERO QUESADA, M. F., Las ciudades de la Corona de Castilla en la Baja Edad Media (siglos XIII-XV). Madrid, 1996, pp. 29-32. 
aislamiento debía quedar reflejado en unos elementos físicos, la cerca y las puertas, que preservarían y regularían el contacto con la mayoría cristiana. El argumento principal para justificar esta medida era evitar el proselitismo religioso que los hebreos pudieran ejercer sobre los recientemente convertidos. En ocasiones esta cerca también ofreció a las minorías una cierta protección en momentos de hostigamiento generalizado.

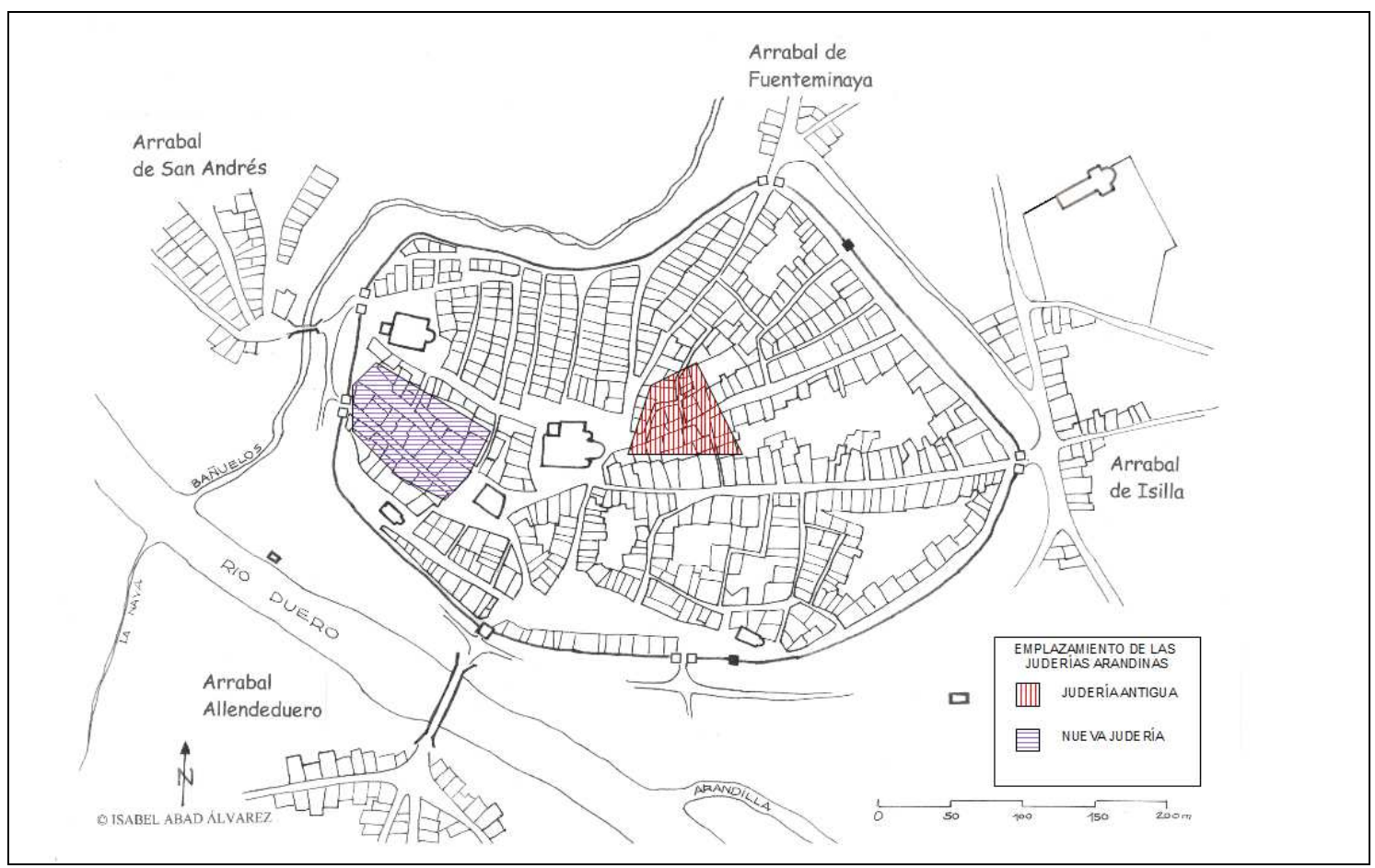

Plano 9: Emplazamiento de la antigua y nueva judería.

El gran crecimiento y prosperidad que experimentó la comunidad judía arandina en las últimas décadas del siglo XV fue un claro reflejo del gran desarrollo social, económico y urbano que tuvo la villa a lo largo de la segunda mitad de este siglo.

Hasta 1480 los judíos arandinos vivían derramados o dispersos por las diferentes calles de la villa, aunque se documenta una notable concentración en torno a su centro de culto, la sinagoga, hasta tal punto que los vecinos denominaron posteriormente a esta zona la judería vieja ${ }^{538}$. Ésta se encontraba en Barrionuevo, en las proximidades de la calle del $\mathrm{Pozo}^{539}$. Emplazamiento que se confirma en las declaraciones que ante la Inquisición hizo

${ }^{538}$ AGS, CC MEMORIALES, leg. 151. doc. 113.

${ }^{539}$ En el pleito sobre la apertura de la calle de Barrionuevo comenzado en 1503 los vecinos de la calle insistían en señalar que las casas que debían ser derribadas formaron parte de la judería antigua de la villa. Incluso Sancho de la Peña, sobrino de uno de los propietarios de las casas y primo de otro de los implicados, señala: ... en la calle Barrio Nuevo bivian muchos judios e otros en otras partes de esta villa 
en 1502 Fernando de Arandilla. En ellas declaró que hacía más o menos 25 años Constanza Díaz, madre del regidor Gonzalo García de Quemada que vivía en la calle Barrionuevo, junto a la calleja del Tamarón, reprendió a unos vecinos que al pasar por allí començaron a faser burla de los judios que estavan dentro, en la synoga, que hera çerca de la dicha ca$s a^{540}$. Según la declaración de Alonso Vela en 1503, tras el traslado de la población judía al Hocino, su antigua sinagoga esta hecha casa e buena ${ }^{541}$. Desconocemos también si esta primera judería estaba cercada como ocurrió en otras poblaciones castellanas, aunque la pervivencia hasta comienzos del siglo XVI del llamado arco de calicanto en la calle del Pozo puede inducir a pensar que pudiera ser el postigo que diera acceso a este espacio ${ }^{542}$.

A propósito del apartamiento establecido en las Cortes de Toledo de 1480, los monarcas comisionaron al visitador Juan Ortega de Carrión para que estableciera un espacio apropiado para confinar a las almajas hebrea y mudéjar ${ }^{543}$. La aljama judía fue obligada a trasladarse a un espacio marginal, el Hoçino, donde fueron confinados todos los judíos de la villa ${ }^{544}$. A principios de los ochenta este espacio era una zona prácticamente despoblada intramuros de la villa, el qual dicho lugar es ynabitable e donde nunca fue poblado nin se espero poblar ${ }^{545}$. Paralelamente al traslado de las residencias de estos vecinos, también se habilitaron en la nueva judería espacios para el desarrollo de sus actividades, tanto las económicas como las vinculadas a su religión y costumbres. En ella se construyó una nueva sinagoga, que también contaba con una escuela talmúdica, las carnicerías y otras de-

(AGS, CR, leg. 39, doc. 3; transcrito por PERIBÁÑEZ OTERO y ABAD ÁLVAREZ, Aranda de Duero..., pp. 174-176).

${ }^{540}$ CARRETE PARRONDO, Fontes Iudaeorum..., doc. 371, p. 154.

${ }^{541}$ AGS, CR, leg. 39, doc. 3; transcrito por PERIBÁÑEZ OTERO y ABAD ÁLVAREZ, Aranda de Duero..., p. 152.

${ }^{542}$ Esta información sobre el primer y el segundo emplazamiento de la primera judería de la localidad la transmite el expediente que acompaña al plano de 1503 a través de las declaraciones de los diferentes testigos (AGS, CR, leg. 39, doc. 3).

${ }^{543}$ AGS, CC PUEBLOS, leg. 2, doc. 61.

${ }^{544}$ Diego de Córdoba declaraba en 1503 que ...trabajo en echallos de la dicha calle de Barrio Nuevo e los llevaron a la calle de Santana (AGS, CR, leg. 39, doc. 3; transcrito por PERIBÁÑEZ OTERO y ABAD ÁLVAREZ, Aranda de Duero..., pp. 160-161).

545 Este confinamiento en espacios degradados también se documenta en otras ciudades castellanas. En Segovia, la judería fue instalada junto al lienzo de muralla que bordea el río Clamores, en las inmediaciones de uno de los vertederos utilizados por la población urbana (ASENJO GONZÁLEZ, M., Segovia. La ciudad y su Tierra a fines del medievo. Segovia, 1986). 
pendencias. A pesar del confinamiento, algunos judíos mantuvieron importantes propiedades inmuebles fuera de la judería ${ }^{546}$.

Pero este traslado no fue tan solo el resultado de una decisión de carácter político sino que tuvo una trascendencia significativa en el desarrollo urbano de la villa. Si atendemos a la dinámica urbana medieval de Aranda, se puede comprobar que el núcleo primitivo de la villa se expandió en el siglo XIV hacia el Este, configurando una serie de arrabales periféricos que durante el siglo XV fueron absorbidos plenamente por una ampliación de la muralla (Plaza Nueva, Plaza del Trigo-Isilla y Barrionuevo) ${ }^{547}$. En este contexto, la primitiva zona de concentración de la población judía y su sinagoga se localizaban en un espacio intermedio y desestructurado, la calle del Pozo y el primer tramo de la de Barrionuevo ${ }^{548}$, que se encontraba entre el nuevo centro del núcleo ampliado en el siglo XV (la plaza e iglesia de Santa María) y la zona de expansión oriental. La decisión de desplazar a un grupo de población marginal, los judíos, de esta zona con una gran proyección social y económica, confinándolo en un sector urbano degradado, con escaso índice de ocupación debido a su configuración física y a sus evidentes problemas de evacuación de aguas residuales, pone de manifiesto un claro fenómeno de revaloralización urbana paralelo a un proceso de especulación inmobiliaria. Este aspecto se confirma en las declaraciones de algunos de los testigos del pleito de 1503 en las que se señala que la calle de Barrionuevo, tras la marcha de los judíos a la calle del Hocino, se ...ha valorizado y ennobleçido ${ }^{549}$. Esta gran proyección de Barrionuevo continuó pocos años después del traslado judío con la apertura de esta calle a la Plaza de Santa María tras derribar unas casas de la calle del Pozo. La revalorización de este sector aumentó con la creación en 1515 de una nueva calle que comunicaba el convento de San Francis-

${ }^{546}$ El mejor ejemplo lo encontramos en el matrimonio formado por Yuçe de Soto y doña Bienvenida que conservaron gran cantidad de propiedades fuera de la judería hasta el momento de la expulsión (AGS, RGS, 148906, fol. 167; y 149205, fol. 510).

${ }^{547}$ SÁINZ GUERRA, La Génesis de la Plaza..., pp. 118-119. Este planteamiento ha sido seguido también por BENITO MARTÍN, La formación..., p. 258; y PERIBÁÑEZ OTERO y ABAD ÁLVAREZ, Aranda de Duero..., pp. 35-40.

${ }^{548}$ En 1503 la calle del Pozo ...no es derecha e tiene bueltas y ...por ser lugar escondido se an cometido muchos delitos e que es lugar dispuesto par los cometer. De la calle de las Quintanas se decía ...es angosta como las de Granada (AGS, CR, leg. 39, doc. 3).

${ }^{549}$ No obstante, la calle del Pozo no experimentó esta misma revalorización y se fosilizó en un callejón en forma de U al perder su condición de paso entre Barrionuevo y Santa María. En 1503 el párroco Martín Sánchez Quijada señalaba que ...la calle del Poço es la mas suçia que ay en Castilla" (AGS, CR, leg. 39, doc. 3). 
co con la cerca a la altura de Barrionuevo y culminó definitivamente con la apertura de un nuevo portillo en la cerca, Puerta Nueva, que permitía una comunicación directa entre Barrionuevo y el afamado convento de nueva creación ${ }^{550}$.

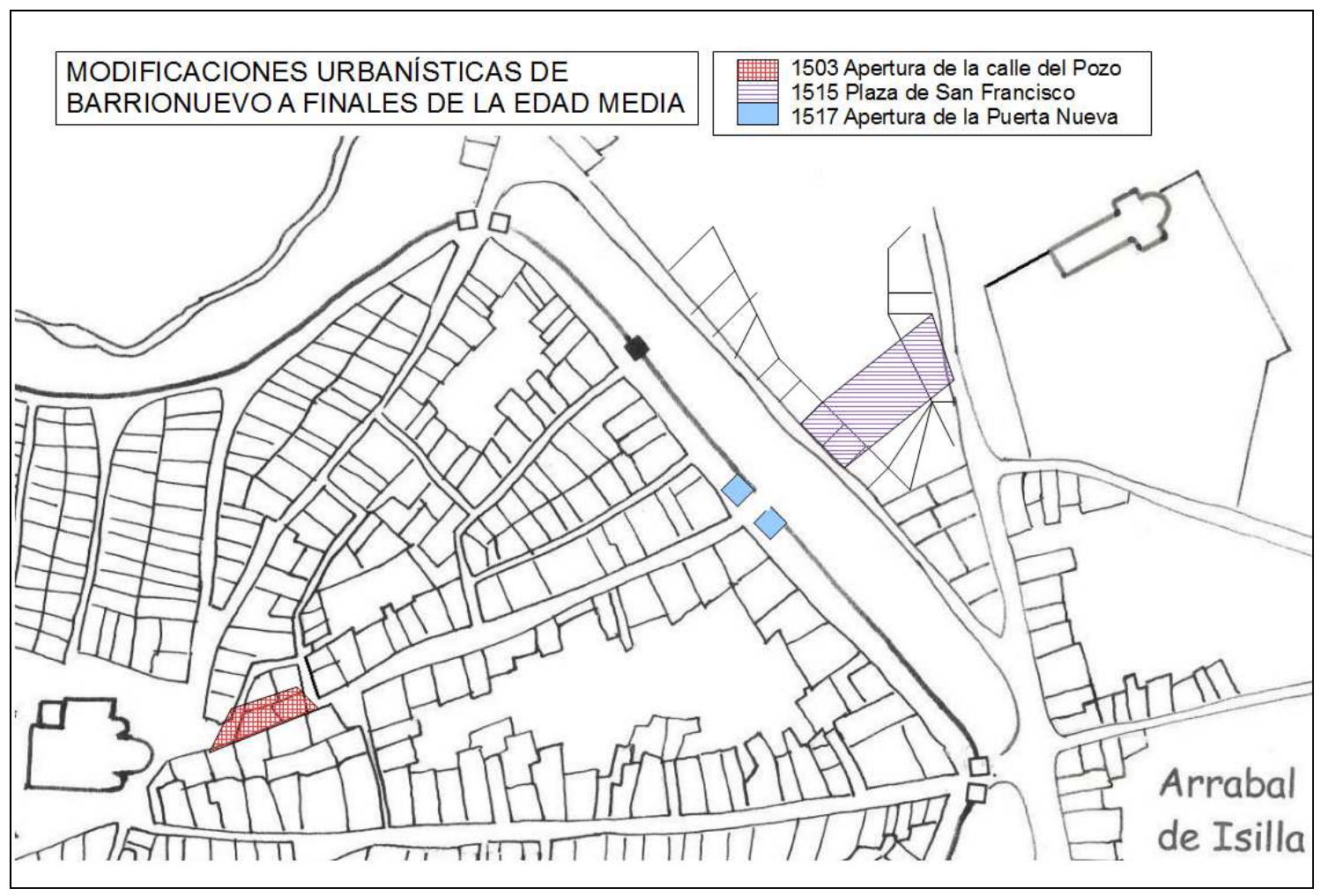

Plano 10: Modificaciones urbanísticas en Barrionuevo a finales de la Edad Media.

La instalación de la comunidad judía en el Hocino también supuso una serie de transformaciones urbanas significativas. Nada más acomodarse en este vallejo entre la colina de San Juan y la de San Llorente, los nuevos vecinos advirtieron que en su nueva calle se acumulaban ...todas las alimañas que se morían e porque en el tiempo de las aguas todas las dichas aguas yban a dar al dicho Hoçino, situación que se agravaba porque la cerca impedía que esta basura se evacuara hacia el río Bañuelos. A causa de estas condiciones insalubres, la aljama solicitó ...abrir un postigo en la çerca de la dicha villa e apartamiento, asy para servidumbre de la dicha judería como para que por el dicho postigo podiesen manar e salir todas las dichas aguas e lluvias quando acaesçiesen o viniesen. Tras las oportunas licencias, y a pesar de la oposición de los vecinos

${ }^{550}$ Como ya hemos referido anteriormente al abordar el desarrollo del arrabal de San Francisco, la nueva calle se solicitó en 1512 y finalmente se trazó sobre el espacio que ocupaban dos pares de casas propiedad del Concejo (AGS, CC PUEBLOS, leg. 2, doc. 107). El proceso de apertura de la Puerta Nueva se comenzó en 1517 (AGS, CC, MEMORIALES, leg. 121, doc. 132; leg. 123, doc. 141; leg. 124, doc. 141 ; y leg. 152, doc. 116). 
de la cercana calle de San Juan, el portillo se abrió en $1486^{551}$. A pesar de los argumentos de peso que hacían alusión a la salud pública, detrás de esta iniciativa y decisión se perciben los intereses económicos de un gran número de miembros de esta comunidad que tenían importantes negocios y se vieron afectados por el traslado de un espacio central, Barrionuevo, a una zona totalmente marginal. La posibilidad de establecer una vía de comunicación con el exterior permitiría reactivar sus maltrechas haciendas. Por lo tanto, lo que en principio parecía un simple problema de evacuación de aguas residuales era, a nuestro entender, una maniobra para revalorizar un espacio marginal que acababa de ser ocupado por una minoría marginada, pero cuyo poder económico y capacidad de influir sobre las autoridades permitió la puesta en valor de este espacio.

Por lo tanto, podemos concluir que tanto el episodio de la expulsión de Barrionuevo como la revalorización del Hocino con la apertura del postigo son una clara evidencia de la de jerarquización social del espacio arandino a finales de la Edad Media. Parece claro en este caso que el factor religioso condicionó, pero en absoluto de manera exclusiva, este capítulo que se enmarca dentro de la dinámica propia de los intereses sociales y económicos que configuraron los distintos elementos espaciales de un núcleo urbano en pleno desarrollo.

Ya hemos comentado en el apartado dedicado a la ermita de Santa Ana que su origen estuvo en la sacralización de la segunda judería inmediatamente después de la expulsión de los judíos, no sin cierta polémica. En los meses previos a la salida, una parte de la sinagoga fue vendida por la aljama al comendador Íñigo de Barahona por 25.000 maravedíes pero, posiblemente fruto de la exaltación antijudía del momento, se produjo una revuelta popular encabezada por ciertos clérigos que terminó con la toma de posesión violenta del edificio. Éste fue inmediatamente sacralizado y convertido en ermita bajo la advocación de Santa Ana, a cuya cofradía pasó a pertenecer el inmueble ${ }^{552}$. A pesar de las reclamaciones del comendador ante el provisor de Osma y una primera re-

551 AGS, RGS, 148607, fol. 71. Recordemos que en 1492, tras la expulsión de los judíos, los procuradores de los veçinos de la calle del Hoçino volvieron a retomar el argumento de la evacuación de aguas residuales para denunciar el perjuicio que recibirían si se cerrase el postigo de la cerca (AGS, RGS, 149206, fol. 217).

${ }^{552}$ AGS, RGS, 149205, fol. 451. El comendador denunciaba que ...unos vezinos de la dicha villa con intençion e proposito de lo danificar mas, que non con zelo de servicio de Dios... diz que fizieron alboroto e escandalo syn consentymiento de la justicia desa villa e antes contra su voluntad; (...) diz que vinieron con una crus a la dicha synoga e que por fuerça e contra su voluntad se entro en la dicha synoga, e le despojaron della, e la fizieron iglesia... (Publicado por CADIÑANOS BARDECI, "Judíos y moros..., doc. 3, pp. 43-44). 
solución a su favor, finalmente todo el edificio fue confirmado como propiedad de la Cofradía de Santa Ana en marzo de $1494^{553}$.

El edificio de la sinagoga tenía una única puerta de acceso pero internamente se organizaba en dos salas separadas por un pequeño murete, una para varones y otra para mujeres. Alguno de los implicados en el pleito entre el comendador Barahona y la cofradía de Santa Ana la describen de la siguiente manera: ...sinoga que hera donde dis que entravan las judias como quier que era toda una casa e un cuerpo porque ay una pequeña pared dentro en la dicha iglesia donde los dichos judios estavan ${ }^{554}$.

Tras la salida de la población judía de Castilla, este barrio pasó a denominarse de Santa Ana en honor al nuevo espacio sacralizado y se integró perfectamente en el entramado físico y social de la villa pues los anteriores hogares judíos fueron comprados y habitados sobre todo por cristianos viejos que se preocuparon de reabrir el postigo de Santa Ana a las pocas semanas de salir los hebreos ${ }^{55}$. Llama bastante la atención la rápida revalorización de este espacio que, recordemos, tan solo hacía una docena de años era una zona despoblada y abandonada. Puesta en valor que se amplifica por el hecho de que algunas de las familias más destacadas del siglo XVI tuvieron su solar en esta calle de Santa Ana como ocurrió con la de los Vázquez de Acuña, la de Ortiz de Zárate, los porteros de cámara Francisco Tomillo y Sancho de Castro ${ }^{556}$. Una evidencia más de esta revalorización de Santa Ana es que cuando en 1515 el rey Fernando llegó a esta villa se alojó en las casas que don Juan de Acuña poseía en esta calle ${ }^{557}$.

\section{Morería.}

La población mudéjar que habitaba en el reino de Castilla a finales de la Edad Media también tenía sus particularidades jurídicas y fiscales ${ }^{558}$. Además de mantener sus prácticas religiosas y sus señas de identidad cultural, las comunidades mudéjares también deja-

\footnotetext{
${ }^{553}$ AGS, RGS, 149403, fol. 370.

${ }^{554}$ AGS, RGS, 149303, fol. 357.

${ }^{555}$ AGS, CC PUEBLOS, leg. 2, docs. 69 y 70; y AGS, RGS, 149206, fol. 217.

${ }^{556}$ VELASCO PÉREZ, Aranda. Memorias..., pp. 130 y 177; y AGS, CCP, leg. 2, doc. 70.

${ }^{557}$ SANZ ABAD, Historia de Aranda..., pp. 137 y 143.

${ }^{558}$ LADERO QUESADA, M. A., Los mudéjares de Castilla en tiempo de Isabel I. Valladolid, 1969.
} 
ron en el espacio algunas marcas propias de su cultura como eran las mezquitas, baños, etc. $^{559}$.

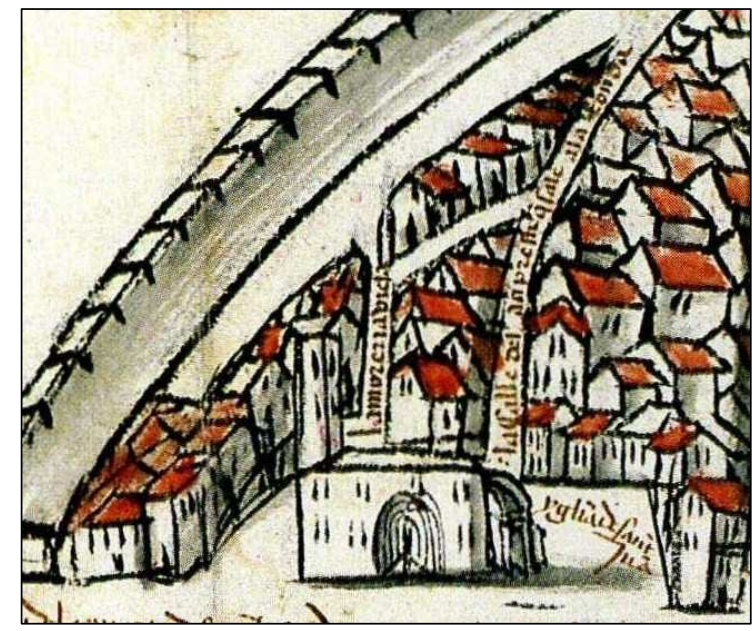

Imagen 34: Detalle de la calle de la Morería Vieja.

Poco sabemos sobre el origen de la comunidad islámica en Aranda ya que tan solo contamos con referencias documentales desde finales del siglo $\mathrm{XV}$. Con anterioridad al apartamiento de 1480 los mudéjares arandinos ya vivían concentrados en un espacio o morería que se situaba en las traseras de la iglesia de San Juan. Este sector urbano todavía era identificado muchos años después del apartamiento como la Morería Vieja y así fue plasmado en el plano de $1503^{560}$.

Como ocurrió con el caso de la judería, el Consejo Real también encomendó a Juan Ortega de Carrión buscar un emplazamiento para esta comunidad tras la disposición de las Cortes de Toledo de 1480. El lugar escogido fue el arrabal de Allendeduero por lo que la comunidad mudéjar fue obligada a desplazarse a este espacio extramuros donde establecieron sus nuevas residencias ${ }^{561}$. La información de la que disponemos nos hace pensar que la configuración de la morería arandina fue bastante sencilla, ubicando su caserío a ambos lados de una de las calles del arrabal, muy próxima al río Duero. Aunque desde un primer momento esta morería contaba con una cerca que los mantenía aislados del resto de la vecindad, no se habían dispuesto puertas por tratarse de una calle pública con mucho tránsito. Sin embargo, pocos años después las quejas de los vecinos cristianos del arrabal, ...porque los moros hacen más trato que ellos al estar la morería en una calle por donde pasan

${ }^{559}$ LADERO QUESADA, Las ciudades de la Corona de Castilla..., pp. 33-34.

${ }^{560}$ En AGS, CR, leg. 39, doc. 3 se hacen varias menciones a este antiguo emplazamiento de la morería.

561 ...al tiempo que nos mandamos faser los apartamientos de los judios e moros de estos nuestros reinos fue a la dicha villa por visitador e para faser los dichos apartamientos Iohan Ortega de Carrion; el qual dis que los señalo lugar para el dicho apartamiento fuera de la dicha villa en el araval de Duero; el qual con sus gastos e fatigas dis que han fecho sus casas; e que la calle que les fue señalada para el dicho apartamiento es calle publica por donde pueden entrar e salir a la dicha villa los viandantes (AGS, CC PUEBLOS, leg. 2, fol. 61). 
todos los caminantes..., provocaron que las autoridades ordenaran que se cerrara esta calle con dos puertas y que no se pudieran abrir salvo para introducir mercancías para el mantenimiento de la morería ${ }^{562}$. No obstante, algunos de sus miembros mantuvieron sus negocios fuera de la morería, sobre todo aquellos relacionados con las herrerías ${ }^{563}$.

Además de las residencias de los mudéjares, en este nuevo espacio también se creó una meschita donde celebraban los ritos propios de su religión ${ }^{564}$. De la misma manera debieron trasladar allí sus carnicerías donde sacrificaban los animales siguiendo su propio ritual $^{565}$.

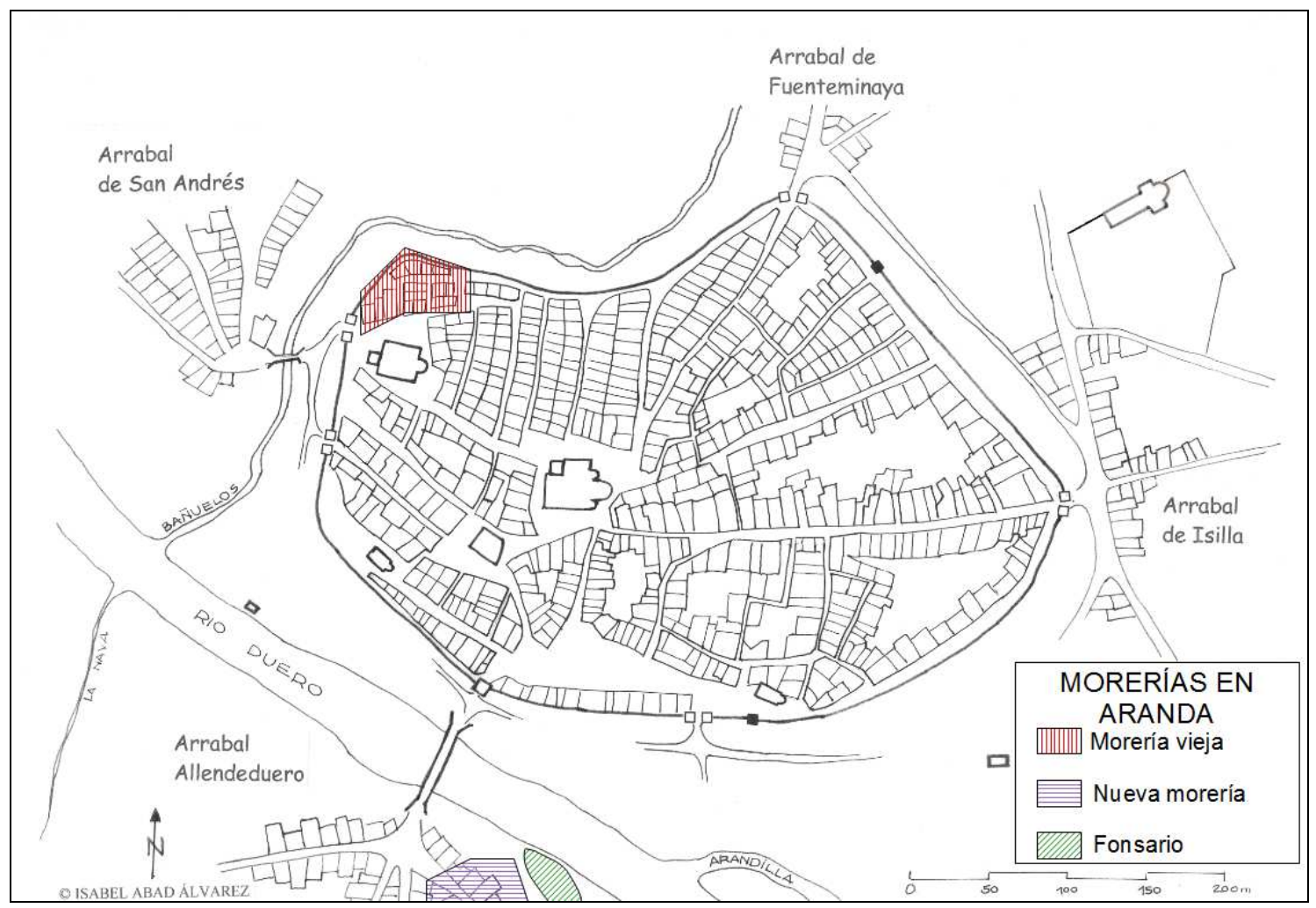

Plano 11: Hipotético emplazamiento de las morerías vieja y nueva y el fonsario.

Por otra parte, junto a este nuevo emplazamiento se habilitó una zona en el reducido espacio que existía entre la morería y el río Duero para instalar allí su fonsario o maq-

\footnotetext{
${ }^{562}$ AGS, CC MEMORIALES, leg. 163, doc. 57.

${ }^{563}$ AGS, RGS, 148312, fol. 173.

${ }^{564}$ AGS, RGS, 150002, fol. 52.

${ }^{565}$ AGS, RGS, 150008, fol. 54.
} 
bara $^{566}$. Desgraciadamente no contamos con datos documentales o arqueológicos que permitan conocer la localización y entidad de la necrópolis anterior al apartamiento ${ }^{567}$.

Tras la masiva conversión de la población mudéjar al cristianismo en 1502, el espacio de la morería se reintegró fácilmente en la estructura urbana del arrabal tras la eliminación de las acotaciones físicas introducidas en los años anteriores.

\section{Mancebía.}

En una sociedad como la medieval cristiana el ejercicio de la prostitución fue considerado éticamente reprobable y, aunque estaba socialmente admitido, quienes ejercían este oficio se encontraban en una clara situación de marginalidad y, por lo tanto, apartados del resto de la sociedad. Las autoridades tanto reales como municipales tomaron una serie de iniciativas encaminadas a controlar a quienes ejercían esta actividad, pero también a todo el submundo de alcahuetas y rufianes que vivían al cobijo de la prostitución generando desórdenes y alborotos que alteraban la convivencia urbana. Por otra parte, a diferencia de los marginados por motivos religiosos, este colectivo presentaba unas fuertes connotaciones económicas que lo hicieron partícipe de la misma dinámica que afectaba al resto de actividades productivas, por lo que también fueron objeto de regulación en este sentido. Las peculiaridades de esta actividad se plasmaron también en el espacio urbano y así desde finales del siglo XV aparecen definidos en las ciudades castellanas determinados establecimientos y sectores urbanos donde se desarrollaba esta actividad perfectamente regulada por las autoridades: la mancebía ${ }^{568}$.

${ }^{566} \mathrm{ARChV}$, RRE, Caja 12, doc. 44. El término fonsario se utilizó como sinónimo de cementerio o necrópolis de judíos o mudéjares en otras ciudades castellanas como Ciudad Real o Cuenca. En Valladolid se conocía como el osario de los moros (MORATINOS GARCÍA, M. y VILLANUEVA ZUBIZARRETA, O., "Consecuencias del decreto de conversión al cristianismo de 1502 en la aljama mora de Valladolid”, en Sharq al-Andalus. 16-17, 1999-20002, pp. 117-139.

${ }^{567}$ La reducida demografía de la comunidad mudéjar arandina hace pensar que ambas necrópolis tuvieron un reducido tamaño. Por lo que respecta al fonsario de la segunda morería es posible que cualquier evidencia física haya desaparecido debido a las grandes transformaciones que ha sufrido la ribera del río en el tramo en el que posiblemente estuvo emplazada la necrópolis pues en el siglo XIX se instaló en ese espacio una industria resinera y en la segunda mitad del XX este sector ha sido completamente reurbanizado.

568 VÁZQUEZ GARCÍA, F. y MORENO MENGÍBAR, A., Poder y prostitución en Sevilla. Tomo I (Edad Moderna). Salamanca, 1995, pp. 61 y ss; y CASTRILLO DE LA FUENTE, J. M., "Conflictividad social alrededor de la prostritucion ilegal en la Castilla bajomedieval", en Conflictos y sociedades en la historia de Castilla y León: aportaciones de jóvenes historiadores. Valladolid, 2010, pp. $317-$ 326. 
Evidentemente, esta actividad y el espacio destinado a ella no alcanzó en Aranda el desarrollo que en otras grandes urbes vecinas como Segovia, Valladolid o Palencia, pero sí que observamos una dinámica similar a menor escala ${ }^{569}$.

Aunque tenemos noticias del ejercicio de la prostitución de forma aislada intramu$\operatorname{ros}^{570}$, a finales del siglo XV ya se había configurado un espacio específico para el desarrollo de esta actividad en el arrabal de Allendeduero. En este espacio extramuros se encontraba el lugar donde estan las mugeres publicas, seguramente como consecuencia de la concentración de varios mesones y del gran número de viajeros que transitaba por él ${ }^{571}$.

Evidencia de la existencia de mesones en el arrabal de Allendeduero hay muchas pero ninguna nos asegura su identificación como un establecimiento donde se ejerciera la prostitución. No obstante, tenemos noticias de un mesonero, Juan de Ortega, que poseía un mesón en este arrabal y que fue acusado en 1489 de mantener una relación carnal con una moza que trabajaba en su establecimiento, situación que quizá encubriera un negocio sexual $^{572}$.

Para el resto de los vecinos la mancebía se identificaba con marginalidad. Esta situación de marginación no se vinculaba tanto a la actividad propiamente dicha, sino más bien se asociaba con al estilo de vida nada edificante de aquellas personas que frecuenta-

${ }^{569}$ ESTEBAN RECIO, M. A. Palencia a fines de la Edad Media: una ciudad de señorío episcopal. Valladolid, 1989, pp. 89 y ss. Ver también ESTEBAN RECIO, M. A. e IZQUIERDO GRACÍA, M. J., "Pecado y marginación. Mujeres públicas en Valladolid y Palencia durante los siglos XV y XVI", en La ciudad medieval: aspectos de la vida urbana en la Castilla bajomedieval. Valladolid, 1996, pp. 13168 .

${ }^{570}$ Varios testimonios de 1503 sobre la calle del Pozo certifican el ejercicio de la prostitución en la calle del Pozo: ...en la dicha calle del Poço se acometen suçiedades con mugeres por ser calle escondida y oscura y lugar dispuesto para ello; ...este testigo pasando por ella de noche ha visto onbres y mugeres rebueltos; ... que ha oydo desyr que algunas vezes mugeres se an echado con honbres en la dicha calle del Poço (AGS, CR, leg. 39, doc. 3). 64-66.

${ }^{571}$ AMA, leg. 42, doc. 2, transcrito por HURTADO QUERO, Documentos Reales..., doc. 36, pp.

${ }^{572}$ AGS, RGS, 148303, fol. 84; 148708, fol. 110 y 124; y 148910, fol. 60. En Sevilla o Lorca las mancebías son denominadas mesones (MORENO MENGÍBAR, A. y VÁZQUEZ GARCÍA, F., "Poder y prostitución en España (siglos XIV-XVII). El caso de Sevilla", en Criticón. 69, 1997, pp. 33-49; MOLINA MOLINA, A. L., "La mancebía lorquina en la primera mitad del siglo XVI", en Murgentana. 103, 2000, pp. 43-55; y CASTRILLO DE LA FUENTE, J. M., "Medidas contra la violencia que rodea a la prostitución clandestina en las ciudades medievales", en La convivencia en las ciudades medievales. Logroño, 2008, pp. 503-514). 
ban estos lugares como ...echacuervos e otras personas dyliçito e torpe bibir, de los que sólo se podía esperar que ...se seguirian muchos ruydos e escandalos e alborotos ${ }^{573}$.

En definitiva, en la villa de Aranda, como en otras muchas ciudades castellanas, existieron espacios marginales que albergaron grupos de vecinos marginados, bien por su creencia religiosa, o por su actividad profesional. El reconocimiento físico de estos espacios marginales permitiría reconstruir con mayor grado de certeza la realidad social a ellos asociados. No obstante, la carencia de datos arqueológicos y de pervivencias físicas de estos recintos limita en gran medida las conclusiones que podemos obtener de su reconstrucción basada casi exclusivamente en evidencias documentales, que tampoco son muy abundantes.

\section{e. Dotaciones e infraestructuras urbanas.}

Para terminar con el epígrafe de la estructura urbana vamos a detener nuestra atención en una serie de aspectos bastante significativos para el desarrollo de la vida urbana, que atendían necesidades propias de sus habitantes como podían ser la asistencia de pobres y enfermos, la educación de los menores, las infraestructuras de comunicación o todos aquellos aspectos relacionados con el abastecimiento de agua y su evacuación tras ser utilizada bien para el consumo humano o para el desarrollo de determinadas actividades industriales o comerciales.

\section{Dotaciones sanitarias y educativas.}

El hecho de que Aranda contara a finales de la Edad Media con un millar de vecinos, muchos de los cuales eran jornaleros con escasos recursos, y la gran cantidad de viajeros que transitaban por la villa son argumentos suficientes para justificar la existencia de un hospital situado en el arrabal de Allendeduero. En concreto estaba instalado en las proximidades del puente del Duero en un espacio comprendido entre el camino real de Valladolid y la ribera del Duero, en el pago conocido como la Madelena ${ }^{574}$.

El hospital de pobres de Aranda era una fundación concejil. El ayuntamiento se encargaba de su mantenimiento y nombraba a un mayordomo para que se ocupara de su

${ }^{573}$ AMA, leg. 42, doc. 2, transcrito por HURTADO QUERO, Documentos Reales..., doc. 36, pp. 64-66. Sobre la asociación entre prostitución y violencia ver CASTRILLO DE LA FUENTE, "Medidas contra la violencia..., p. 507.

${ }^{574}$ VELASCO PÉREZ, Aranda. Memorias..., pp. 162-163 y 238-239. 
gestión. Sus arcas además se nutrían de los donativos que recibía de los arandinos que, en los momentos previos a la muerte, establecían mandas testamentarias con pequeñas cantidades para el mantenimiento del hospital ${ }^{575}$. Pero también hubo quien aportó casas o propiedades diversas que después la administración del hospital arrendaba con el objetivo de obtener unos ingresos con los que poder hacer frente a sus continuos gastos ${ }^{576}$.

En esta época también se proyectaron otros tres hospitales vinculados a otras tantas órdenes religiosas. Por una parte, la orden del Santo Espíritu de Sassia intentó construir una capilla y un hospital también en el arrabal de Allendeduero a mediados del siglo XV, iniciativa que como ya hemos visto fracasó ${ }^{577}$. Lo mismo ocurrió con la orden de San Lázaro que pretendió enajenar la ermita del mismo nombre para crear un establecimiento asistencial a finales de ese mismo siglo pero el concejo, ejerciendo en calidad de patrono de la ermita, se lo impidió ${ }^{578}$. Por último, también la comunidad franciscana intentó levantar un hospital en su convento pero los problemas con los herederos de don Martín Vázquez de Acuña impidieron su ejecución ${ }^{579}$.

Vinculado también con el sector sanitario se encontraba el oficio de comadrona o partera. Esta mujer, cuya función consistía en ayudar a las parturientas en el trance de traer al mundo un nuevo ser, recibía en Aranda el nombre de comadre. Esta figura aparece en la documentación medieval como un oficio reconocido y valorado dentro de la sociedad urbana y adquirió tanta importancia que en algunos lugares la actividad se regulaba en las ordenanzas municipales ${ }^{580}$. Es lógico pensar que todos los arandinos conocieron con exac-

${ }^{575}$ En el testamento del antiguo regidor Juan Fernández Mejía redactado en 1500 se reflejaba una donación de 5 maravedíes al hospital de la villa. Suponemos que ésta era una práctica habitual entre los arandinos (AGS, CASA Y SITIOS REALES, leg. 2, doc. 484).

${ }^{576}$ El comunero Gaspar de Mansilla tenía en censo unas casas propiedad del hospital por las que pagaba a su mayordomo una renta anual de 1.100 maravedíes (AGS, CMC, leg. 355). En 1527 el clérigo Sebastián Martínez ordenó en su testamento que los 400 maravedíes que había dejado en censo al cabildo de San Nicolás pasaran al hospital si la cofradía se disolviera (VELASCO PÉREZ, Aranda. Memorias..., pp. 162-163).

${ }^{577}$ AMA, leg. 42, doc. 2; y AGS, RGS, 150007, fol. 71.

${ }^{578}$ AMA, leg. 43, doc. 35.

${ }^{579}$ ARChV, RRE, Caja 315, doc. 20.

580 Ordenanzas Municipales de Portugalete de 1459, Capítulo 38: De la oficial de las mujeres (comadrona): ... que la mujer que pariere que le de a la oficiala veinte maravedis por su trabajo e de comer fasta que sea parida;... que la dicha oficial sea tenida de ir a donde quiera que llamasen dentro de la dicha villa asi de noche como de dia, asi como sea llamada luego sin dilacion alguna; ...e asi mismo que la dicha oficial non sea osada de ir fuera de la dicha villa a ninguna mujer que este para parir en las comarcas so la dicha pena porque de lo tal podria venir peligro a las mujeres de la dicha villa 
titud el lugar al que acudir a solicitar los servicios de esta mujer. Una de las calles que aparecen en el plano de 1503 se rotula como la calle de la Comadre Vieja, que en la actualidad mantiene el nombre de Comadres. El hecho de que aparezca el calificativo viejo indica que debía existir otra nueva, de la que sabemos por la documentación relacionada con este plano que vivía al otro extremo de la villa, en la collación de San Juan: la calle que dizen de la Comadre e... que acuden todas a la calle prinçipal de Sant Juan ${ }^{581}$. Lo que no sabemos es si la comadre vieja y la nueva ejercieron juntas su oficio o si la calle de la Comadre

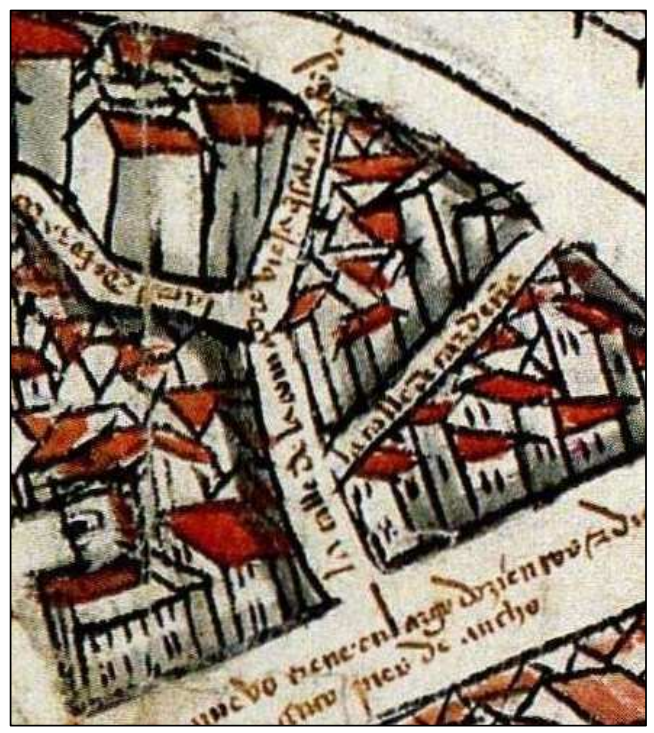

Vieja define el lugar donde habitó una antigua comadrona.

Imagen 35: Detalle de la calle de la Comadre Vieja.

En lo que se refiere a la dotación educativa sabemos que la villa de Aranda contaba a finales del Cuatrocientos con una Escuela y un Estudio de Gramática como se deduce de las mandas testamentarias que el antiguo regidor Juan Fernández Mejías dejó en su testamento en las que establecía la asignación de 4.000 maravedíes para que su hijo Juan ...aprenda en el escuela leer e escribir e en el estudio $^{582}$. De la escuela apenas tenemos más información, pero sí del Estudio y, sobre todo, de sus estudiantes ${ }^{583}$. Sabemos que el Estudio se encontraba en la actual calle Prado Marina pues en el plano de 1503 se define a este vial como la calle que traviesa por el Estudio a la Ronda, aunque nada sabemos sobre sus características físicas. Más pródigas

(CIRIQUIAIN-GAIZTARRO, M., Monografía Histórica de la noble villa y puerto de Portugalete. Bilbao, 1942, p. 234).

${ }^{581}$ AGS, CR, leg. 39, doc. 3, transcrito por PERIBÁÑEZ OTERO y ABAD ÁLVAREZ, Aranda de Duero..., p. 148.

${ }^{582}$ El testamento está redactado el 24 de abril de 1500 (AGS, CASA Y SITIOS REALES, leg. 2, doc. 484).

${ }^{583}$ GUIJARRO GONZÁLEZ ha estudiado las escuelas de gramática de los ámbitos catedralicios castellanos ("Los centros de cultura urbana en el siglo XV: las escuelas de gramática castellanoleonesas", en 1490, en el umbral de la modernidad: el Mediterráneo europeo y las ciudades en el tránsito de los siglos $X V$-XVI. Valencia, 1994, vol. 2, pp. 243-256). También se han documentado estudios de gramática en núcleos urbanos ajenos a los centros diocesanos y de titularidad concejil como ocurre en Cuéllar (OLMOS HERGUEDAS, La comunidad de..., p. 65). 
en detalles son las fuentes sobre sus usuarios, que más que destacar por su vinculación al mundo del conocimiento, mantenían en la villa una intensa actividad lúdico-festiva. Así, en marzo del año 1500 las autoridades se quejaban de que los estudiantes del Estudio de Gramática, clérigos en su mayor parte, se aprovechaban de su inmunidad eclesiástica para llevar armas por la villa y protagonizar broncas por las noches. También fueron recriminados en 1510 por asaltar al alguacil cuando iba a ejecutar a un condenado en la Plaza Nue$\mathrm{va}^{584}$. Por lo tanto podemos concluir que nuestra villa se encontraba relativamente bien servida de centros educativos, una escuela y un estudio, por lo que pudo convertirse en centro receptor de estudiantes del entorno, como pone de manifiesto el converso soriano Francisco de Cuéllar que se encontraba preso en Aranda junto a otros reconciliados ...en la carcel perpetua en esta villa donde estudiesen ${ }^{585}$.

\section{Puentes.}

La localización de la villa en la confluencia de varios ríos (Duero, Arandilla, Bañuelos y la Nava) obligó a sus habitantes a habilitar ciertas infraestructuras para franquearlos y garantizar tanto la comunicación como el transporte de mercancías ${ }^{586}$.

Tradicionalmente se ha identificado el origen del emplazamiento de Aranda con la existencia de un vado natural que permitía el paso del Duero, pero desgraciadamente este planteamiento no pasa de ser más que una hipótesis de improbable y difícil comprobación ${ }^{587}$.

Sin lugar a dudas, el puente más importante de la villa en época medieval fue el que se construyó para salvar el Duero. La identificación del puente con el núcleo urbano fue tal que incluso se incorporó en el símbolo que representaba a la villa pues su escudo tenía a finales de la Edad Media un castillo flanqueado de leones sobre un puente de tres ojos.

584 ...estan e residen muchos estudiantes e clerigos en el estudio de gramatica los quales dis que han andado e andan de noche con armas fasiendo desvarios e travesuras (AGS, RGS, 150003, fol. 469; y CC PUEBLOS, leg. 2, doc. 100).

${ }^{585}$ CARRETE PARRONDO, Fontes Iudaeorum..., doc. 131, p. 69.

${ }^{586}$ Sobre el significado de los ríos, puentes y vías de comunicación en la villa arandina véase el artículo de VAL VALDIVIESO, M. I., "Río y vida urbana en la Castilla del siglo XV", en Biblioteca 24. Estudio e Investigación. 2010, pp. 47-62.

${ }^{587}$ CADIÑANOS BARDECI, I., "Los puentes del Sur de la provincia de Burgos durante la Edad Moderna”, en Biblioteca 11. Estudio e Investigación. 1996, pp. 7-44. 
Con certeza sabemos de su existencia a finales del siglo XIII pues en 1306 durante el sitio de la villa que realizó el rey Fernando IV se ordenó que se derribara el pilar más meridional para que los que habían salido de la villa al arrabal no pudieran retirarse tras los muros de la muralla ${ }^{588}$. Sin embargo, el profesor Sánchez Ribera estima que la representación que aparece en el plano de 1503 permite establecer el origen de este puente en el siglo XII, antes de que se generalizara el uso del arco apuntado ${ }^{589}$.

Más problemático se presenta el asunto del número de arcos que tenía el puente en época medieval. Las referencias documentales para este periodo hablan de los arcos de la puente pero en ningún caso se especifica el número. Si bien es cierto que el escudo de la villa más antiguo del que tenemos noticia presenta un castillo con tres torres sobre un puente de cuatro ojos (Ver Imagen 42$)^{590}$, los referentes de finales del siglo XV y principios del XVI presentan un puente con sólo tres ojos. De la misma manera, el puente que se dibuja en el plano de 1503 también cuenta tan solo con tres $\operatorname{arcos}^{591}$. Sin embargo, la reparación que ejecutó Juan de Naveda en 1572 deja claramente sentenciado el problema pues el maestro cantero descubrió cuando lo reparaba que uno de sus pilares amenazaba ruina por lo que determinó suprimirlo y hazer de dos arcos $u n o^{592}$. Por lo tanto, parece evidente que hasta finales del siglo XVI el puente sobre el Duero contaba con cuatro arcos de medio punto, sin que podamos dar una explicación por el momento de la causa por la que se prefirió representar un puente con tres ojos en el escudo de la villa.

El plano de 1503 también permite apreciar el pretil de piedra que discurría continuo hasta la puerta de la muralla y los tajamares triangulares, rematados en vierteguías ${ }^{593}$.

${ }^{588}$ NUÑO GONZÁLEZ, “La Ribera del Duero..., p. 18.

${ }^{589}$ SÁNCHEZ RIVERA, J. I., Los puentes de la Ribera burgalesa. Vitoria, 2010, p. 167.

${ }^{590}$ Se encuentra en una de las claves de las bóvedas de la iglesia de San Juan Bautista (HARO ÁLVAREZ, M. L. e IGLESIAS AGÜERA, P., "Restauración de la iglesia de San Juan Bautista por el módulo de piedra-mármol de la Escuela-Taller", en Restauración Iglesia de San Juan Bautista. Aranda de Duero. Aranda de Duero, 1990, pp. 15-19.

${ }^{591}$ SÁNCHEZ RIVERA atribuye esta circunstancia a que el dibujo está recortado, por lo que no aparece el arco más meridional (Los puentes..., p. 167).

592 ARAMBURU-ZABALA HIGUERA, M. A., Las obras públicas de Castilla entre 1575 y 1650: los puentes. Madrid, 1990, T. II, p. 524; del mismo autor, La arquitectura de puentes en Castilla y León, 1575-1650. Valladolid, 1991, pp. 118-119; y LOSADA VAREA, C., La arquitectura en el otoño del Renacimiento: Juan de Naveda, 1590-1638. Santander, 2007, p. 106.

593 SÁNCHEZ RIVERA, Los puentes..., p. 168. Un pretil de estas características también se aprecia en el grabado de Saleneuve y en algunas fotos antiguas. 
El mantenimiento del puente corría a cargo de las autoridades municipales que debían recurrir a los propios de la villa para hacer frente a las habituales reparaciones. En este sentido, el mantenimiento de este puente se convirtió, junto al de la cerca, en uno de los principales gastos corrientes a los que se debieron enfrentar las maltrechas arcas concejiles por lo que eran frecuentes las súplicas a los monarcas para que proporcionaran recursos extraordinarios. Así ocurrió en 1503 cuando las autoridades locales solicitaron licencia para echar sisa sobre los mantenimientos ...para reparar la puente que esta un arco della por hundirse e caherse; e que si no se fecha la dicha sysa en los dichos mantenimientos que no tiene la dicha villa propios de que se puede reparar ${ }^{594}$. Ante esta precariedad los monarcas decidieron en 1504 aprovechar la reforma de las escribanías del número para que ...sobre los escribanos que asi eligiereis cargueis de pension para el reparo de la puente de la dicha villa sobre cada uno 2.000 maravedies ${ }^{595}$.

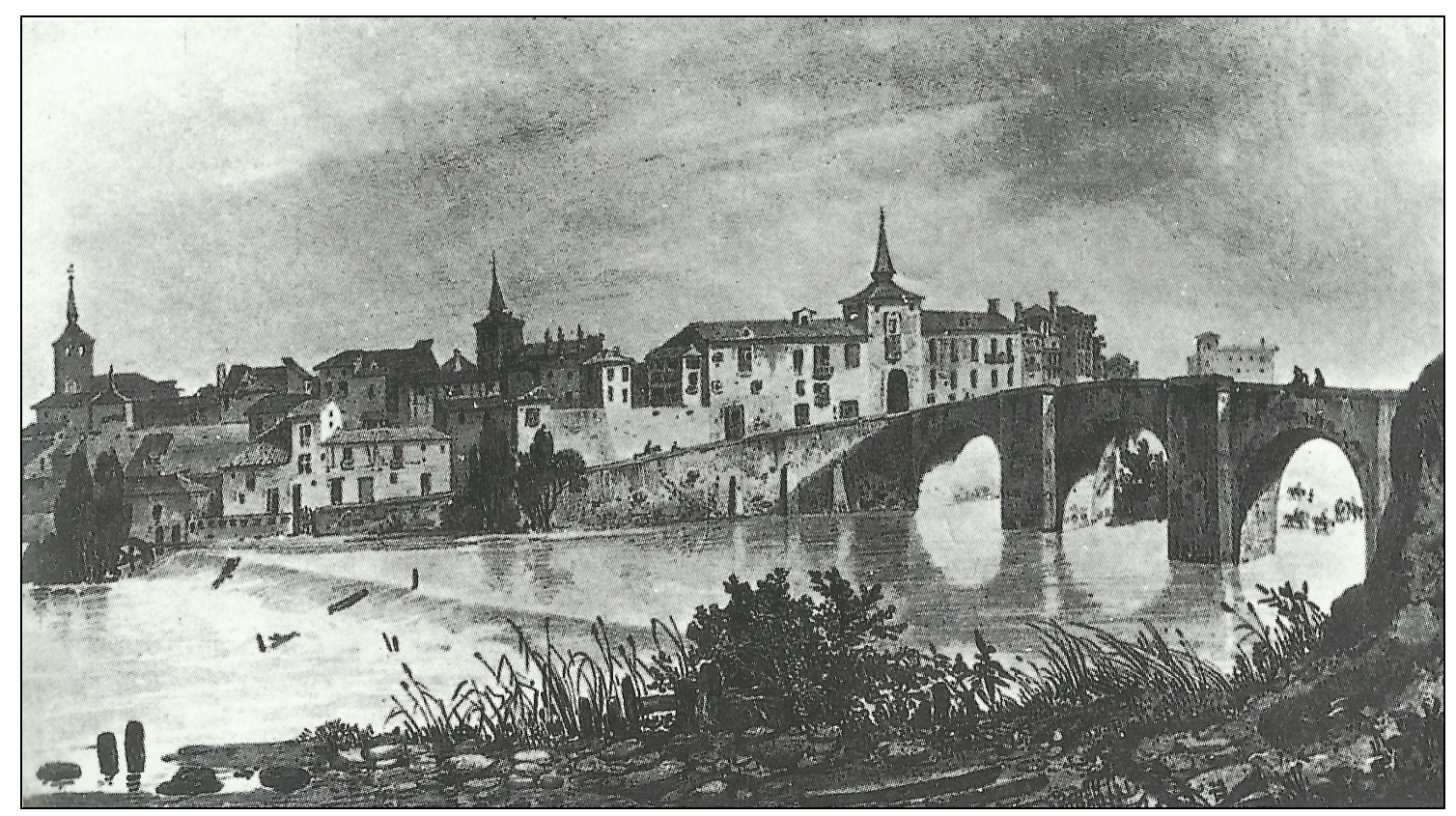

Imagen 36: Grabado de Salneuve, s. XVIII.

A pesar de que una buena parte de la información que tenemos sobre el puente del Duero se refiere sobre todo a los problemas de su mantenimiento y los cuantiosos recursos que consumía de las arcas municipales y de los vecinos, no se puede olvidar que este puente generó una inmensa cantidad de riqueza pues canalizaba hacia la villa arandina los viaje-

\footnotetext{
${ }^{594}$ AGS, CC PUEBLOS, leg. 2, doc. 92.

${ }^{595}$ AGS, CR, leg. 453, doc. 5.
} 
ros y las mercancías que se movilizaban por la comarca y buena parte de la región. No en vano este puente era uno de los que utilizaba la gran cabaña ganadera del Concejo de la Mesta al menos desde el siglo $\mathrm{XIV}^{596}$. Precisamente el paso de este ganado por el puente generó una importante fuente de ingresos para una de las principales familias arandina, los Quemada, que recibió en 1477 el privilegio del pontazgo sobre los ganados que cruzaran el puente sobre el Duero en Aranda ${ }^{597}$.

Además del puente sobre el Duero, en la villa existieron a finales de la Edad Media otros tres puentes situados en las proximidades del núcleo urbano e íntimamente

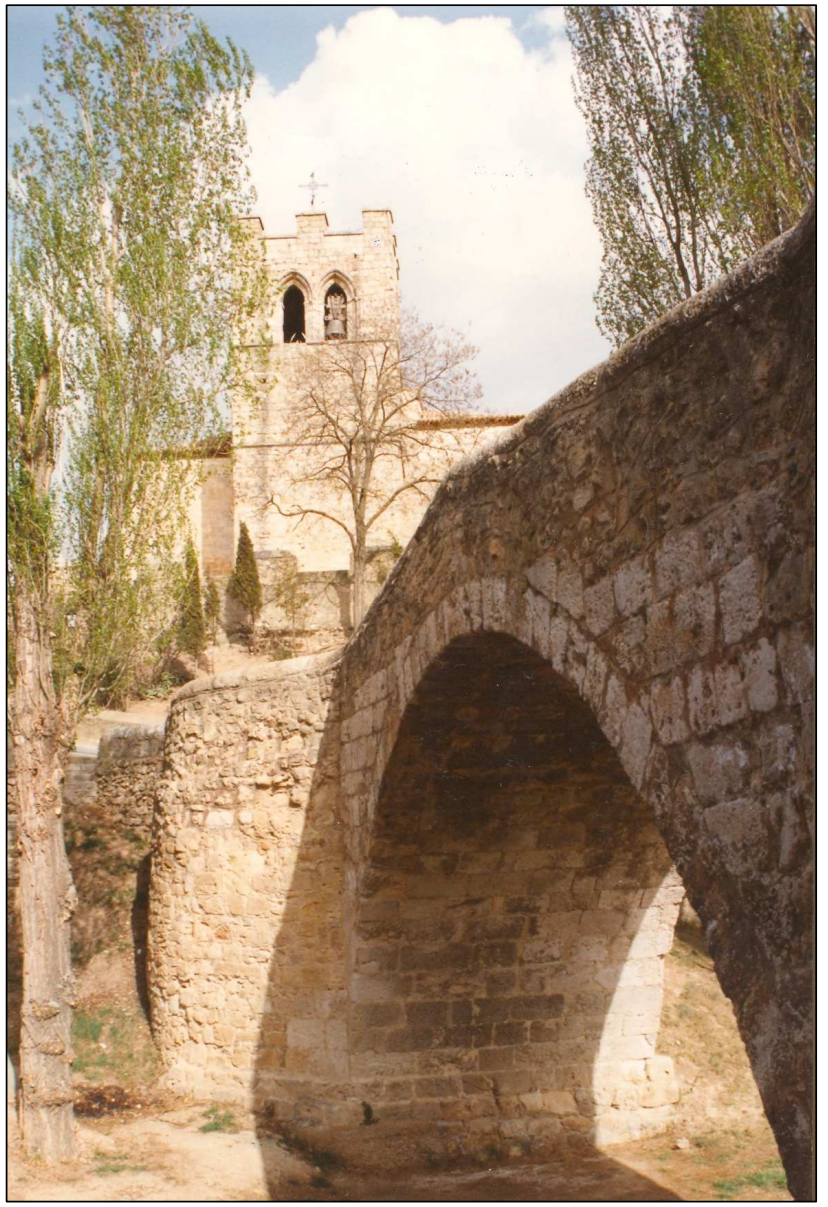

relacionados con las principales vías de comunicación.

Imagen 37: Puente e iglesia de San Juan.

El que tiene la fama de ser el más antiguo, que no la certeza, es el puente de San Juan. Aunque comúnmente es conocido como puente romano, no existe ninguna evidencia ni documental ni técnica que pueda confirmar esta hipótesis $^{598}$. A través de este puente se ponía en comunicación el espacio extramuros a través de la puerta de San Juan con el arrabal de San Andrés o Tenerías. Asimismo

${ }^{596}$ A finales del siglo XIV se dirimió un pleito entre la Mesta y la villa por la existencia de una cañada en la tierra de Aranda. Finalmente se falló que no existía tal cañada y que los ganados debían ir por el camino real toledano. Los jueces ordenaron ...que pasen por la puente de Aranda de suso segund que pasaron en los tiempos pasados (AMA, leg. 43, doc. 3).

${ }^{597}$ El privilegio fue concedido a Gonzalo García de Quemada. Durante unos años tuvo un valor variable pero con el tiempo se fijó en 5.000 maravedíes anuales (AGS, EH, leg. 4).

${ }^{598}$ SÁNCHEZ RIVERA, Los puentes..., p. 62. Aunque conserva un perfil de lomo de asno típicamente medieval su fábrica es completamente moderna, fruto de las continuas reparaciones que ha sufrido. 
estaba estrechamente vinculado con el camino que se dirigía por el margen derecho del Duero hacia el Oeste, comunicando Aranda con Roa, Valdesgueva y Palencia.

En el extremo Norte de la villa se levantaba la puente de Vañuelos, en el interior del arrabal de Fuenteminaya. Este puente permitía salvar el curso encajado de este río y dar continuidad al camino real que, bien desde la villa o desde el próximo arrabal de Carrequemada, se dirigía a Burgos. Cadiñanos señala que hasta el siglo XVI fue de madera pero no contamos con ninguna referencia documental que nos permita confirmar o desmentir tal afirmación $^{599}$.

Lo cierto es que en este periodo ya existían dos puentes en esta zona, el de Bañuelos o Minaya, y la puente del Molinillo o del molino de la Peñuela. Desde la óptica de los vecinos el más importante era el de Minaya como especifican claramente cuando describen el itinerario de las procesiones que desde la villa se dirigen a una devota yglesia que dizen de Nuestra Señora de las Viñas ... que se faze cada año por el camino que va orilla de las casas del dicho solar a la puente de Vañuelos; e que no puede yr por otra parte salvo a la fuente Minaya que dizen que si por la dicha puente. Pero algunos vecinos, como Martín Sebastián, insistián en que ...todas las mas procesiones que la villa haze ansy quando handa alrededor de la villa como quando van a Nuestra Señora de la Viñas; van por alli orilla de la caba de la cerca e orilla del dicho solar pero advierte ... que si la puente del molinillo estuviese adovada que puede yr también como por esta otra parte $e^{600}$. Por lo tanto, concluimos que a finales de la Edad Media ya existían los dos puentes que se mantienen en la actualidad sobre el Bañuelos al Norte de la villa. Aunque no tenemos certeza sobre el material con el que estaban aparejados, todo parece apuntar a que el de Minaya ya debía ser de piedra a tenor del gran tránsito que soportaba ...por que suele venir por alli mucha carreteria de la Syerra e otra mucha gente e que pasa abaxo a Valladolid e a Medi$n a^{601}$. Algo más inestable debía ser el segundo, más tarde conocido como el puente de San Francisco, pues como ya hemos visto no era utilizado para el paso de las procesiones por no estar su estructura adobada.

El puente Conchuela se encontraba al final del arrabal de Hesilla y permitía el franqueo del río Arandilla. Este puente se articulaba dentro del camino aragonés que conectaba

\footnotetext{
${ }^{599}$ CADIÑANOS BARDECI, “Los puentes del Sur..., p. 17.

${ }^{600}$ AGS, CC PUEBLOS, leg. 2, doc. 107.

${ }^{601}$ AGS, CC PUEBLOS, leg. 2, doc. 107.
} 
con las tierras de San Esteban de Gormaz y Osma a través de Vadocondes ${ }^{602}$. No en vano, la calle de Soria que se documenta a finales de la Edad Media en el arrabal de Hesilla o Carrequemada comunicaba el camino de Burgos desde la puerta de Cascajar hasta este puente $^{603}$. Esta construcción cuenta con un solo arco de medio punto y posiblemente en la Edad Media presentara un perfil de lomo de asno que ha desaparecido con las posteriores modificaciones. Sánchez Rivera, recurriendo a un método comparativo, plantea la posibilidad de que el término Conchuela estuviera en relación con un posible camino empedra$\mathrm{do}^{604}$. Por el momento no contamos con ninguna referencia documental sobre este puente para el periodo bajomedieval.

Pero el panorama de los puentes relacionados con la villa de Aranda no se limitaba a estos ejemplares situados todos ellos extramuros. Como ya hemos señalado anteriormente, en el interior del núcleo urbano existió un pequeño puente, la Pontecilla, que salvaba el desnivel del Hocino, entre los barrios de San Juan y la puerta del Duero ${ }^{605}$. No obstante, durante el periodo estudiado tan solo tenemos referencias al nombre pero ninguna a la construcción por lo que suponemos que ya no existía.

\section{Abastecimiento y evacuación de aguas.}

Uno de los principales problemas a los que debieron enfrentarse las comunidades urbanas medievales fue el abastecimiento y posterior evacuación de las aguas. Por regla general este aspecto estaba regulado y controlado por las autoridades municipales que debían encargarse de habilitar el acceso regular del vecindario a este recurso así como garantizar una mínima calidad ${ }^{606}$.

${ }^{602}$ El camino que comunicaba la puerta de Santa Cruz con este puente ya se perfila en el plano de 1503. Todavía en el siglo XIX Madoz señala que este puente da paso al camino de Vadocondes y el Burgo de Osma (Diccionario Geográfico..., Vol. 2, p. 51).

${ }^{603}$ AGS. CR, leg. 40, doc. 8.

${ }^{604}$ SÁNCHEZ RIVERA, Los puentes..., pp. 65-67. Este autor identifica el término concha con una serie de calzadas empedradas en tierras cántabras (Pie de Concha, Mediaconcha y Somaconcha).

${ }^{605}$ BONACHÍA HERNANDO "El desarrollo urbano..., p. 24. En el plano de 1503 en esta calle aparece el siguiente rótulo: la calleja de la Pontecilla tras los plateros. (AGS, MPD, leg. X, doc. 1).

${ }^{606}$ Este aspecto ha sido abordado en profundidad durante los últimos años desde un punto de vista pluridisciplinar. Baste como ejemplo la obra de VAL VALDIVIESO, M. I., Agua y poder en la Castilla bajomedieval. Valladolid, 2003; así como las obras colectivas coordinadas por esta misma autora El agua en las ciudades castellanas durante la Edad Media. Valladolid, 1998; Usos sociales del agua en las ciudades hispánicas de la Edad Media. Valladolid, 2002; Vivir del agua en las ciudades medievales. Salamanca, 2006; y Musulmanes y cristianos frente al Agua en las Ciudades Medievales. Santander, 2008. Dentro de este contexto, ya nos hemos aproximado anteriormente a esta problemática en ABAD 
El hecho de que el núcleo urbano arandino estuviera emplazado en las inmediaciones de un río de considerable envergadura como el Duero y encajado entre otros tres cursos fluviales de menor consistencia, el Arandilla, Bañuelos y la Nava, debió ser motivo suficiente para garantizar la satisfacción de las necesidades hídricas básicas que la población tuvo a finales de la Edad Media.

Sin embargo, las fuentes documentales nos muestran ciertas carencias que tenían que ver con la calidad de este recurso y los perjuicios que en ocasiones provocaban estos cursos fluviales.

Hasta la década de los treinta del siglo XX buena parte del abastecimiento de agua se extraía del Duero lo cual indica una relativa buena calidad de las aguas de este río $^{607}$. A través de diferentes testimonios de los vecinos de la villa se deduce que a finales de la Edad Media se equiparaban las calidades de las aguas del Duero y Arandilla, pues eran definidas como buenas para el consumo humano. Sin embargo, no consideraban las del Bañuelos de la misma manera pues algunos vecinos señalan ...que es un agua pestifera e no es natural e los que lo beben se ynchan de abozuelos en verano... e es gusaniento e fetido ${ }^{608}$.

De forma complementaria al agua de los ríos, los arandinos utilizaron otros recursos. Para la Aranda bajomedieval tenemos constancia de la existencia de varias fuentes, caños o manantiales que participaban de dos características. En primer lugar, todas ellas se localizaban en el espacio extramuros de la villa, o lo que es lo mismo, el núcleo urbano intramuros carecía de fuentes.

Tampoco existía en el interior de la villa ningún punto de abastecimiento público de agua como caños o pilones, lo que era considerado por los vecinos como un problema grave, no tanto por la incomodidad para obtener agua para el uso doméstico sino, sobre todo, porque an aconteçido grandes fuegos en esta villa e a causa de estar el agua lexos se an fecho mucho mas daño ${ }^{609}$. Para tratar de solucionar esta ausencia de

ÁLVAREZ y PERIBÁÑEZ OTERO, "El control social del agua..., pp. 113-156; y Aranda de Duero...., pp. 99-103.

${ }^{607}$ Las obras de traída de aguas y alcantarillado se llevaron a cabo en 1935, tras el fracaso de numerosos proyectos previos (SANZ ABAD, Historia de Aranda..., p. 340). 40 , doc. 8

${ }^{608}$ La mayor parte de la documentación utilizada para este apartado procede de AGS, CR, leg. ${ }^{609}$ AGS, CR, leg. 40, doc. 8; y CC PUEBLOS, leg. 2, doc. 101. 
agua intramuros se emprendió en los primeros años del siglo XVI el ambicioso proyecto de encauzamiento del río Aranzuelo desde Quemada hasta el núcleo urbano de Aranda. En este proyecto se contemplaba la posibilidad de tomar por tres puertas de la dicha villa por cada una un caño de agua, especialmente por la puerta de Hesilla que yria a dar a la Plaça Nueva e otro por la calle de Barrionuevo e por la Plaza de Santa Maria hasta dar en la pescaderia por donde se podian proveer que el agua corra por donde se remoja el pescado yten se pueden probeer para beber. Incluso algunos vecinos señalaban cómo debía realizarse ese caño: Alonso Sánchez Tejero propuso que el agua fuera encañado por losas y Juan de Peñafiel Manjano, vecino de Peñaranda y maestro de obras del Conde de Miranda, aseguraba que seran de mucho provecho (los caños) si se hazen algunas arcas de piedra ${ }^{610}$.

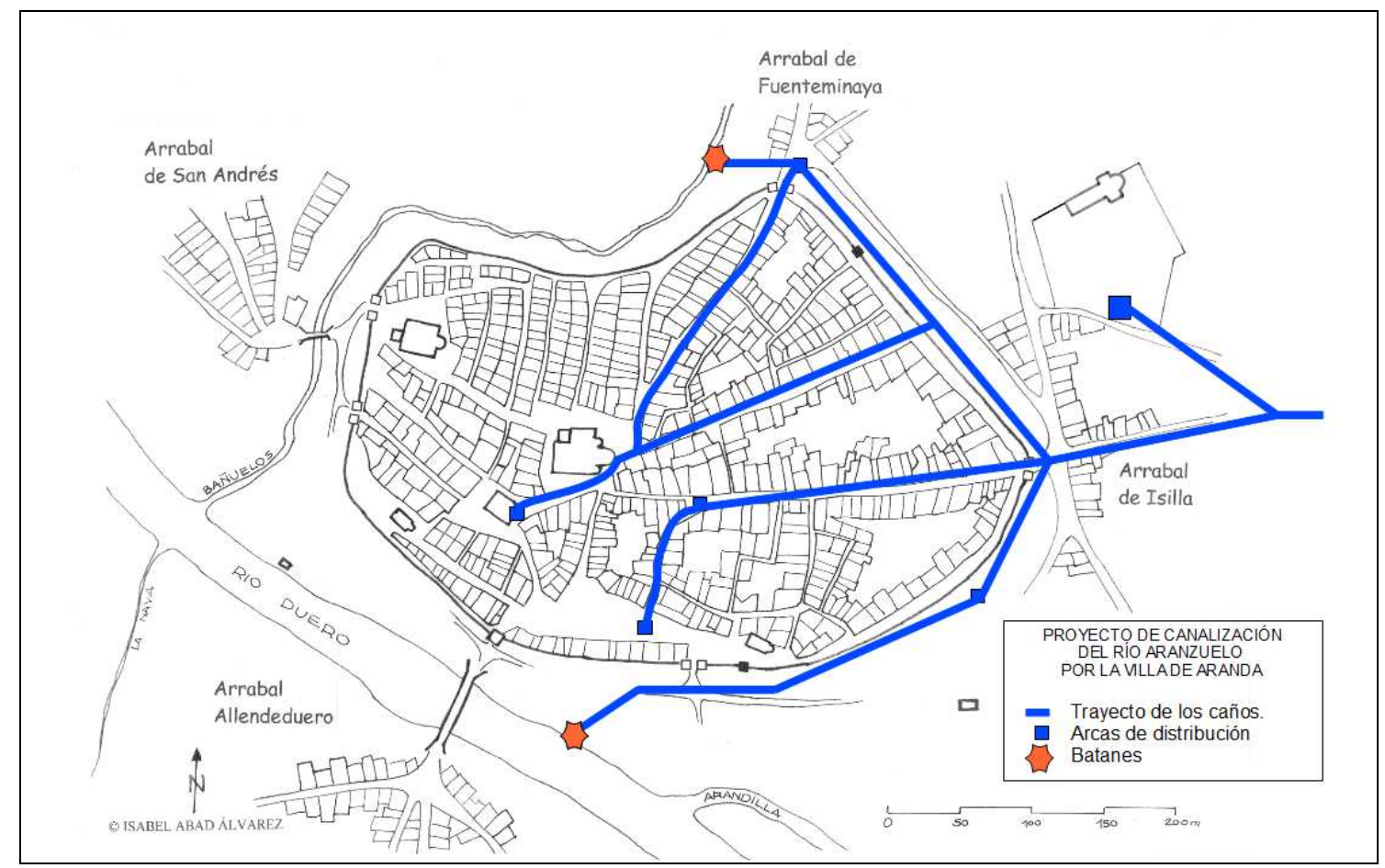

Plano 12: Trazado del proyecto de canalización del río Aranzuelo en la villa de Aranda.

La segunda característica es que todas las fuentes estaban localizadas en las inmediaciones de alguna de las puertas de entrada de la villa o en significativos lugares de tránsito. Así, junto a la puerta septentrional de Cascajar y el puente sobre el Bañuelos se

${ }^{610}$ ABAD ÁLVAREZ y PERIBÁÑEZ OTERO, “El control social del agua..., pp. 148-152. 
encontraba la fuente que daba nombre al arrabal: Fuenteminaya ${ }^{611}$. Muy cerca de allí también se localizaban otros pequeños manantiales que estaban próximos al puente del molino de las Peñuelas; una de ellas era conocida como la Fuente del Lagunillas, por

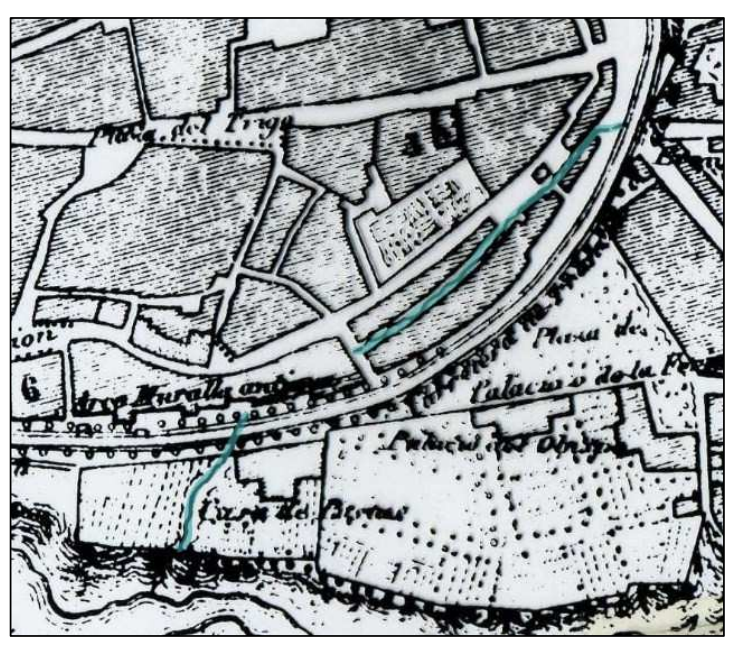
encontrarse junto a las tapias de la huerta de Pedro González Laguni$11 \mathrm{ss}^{612}$.

Imagen 38: Detalle de la fuente de Hesilla y su recorrido en el plano de Coello de 1868.

En el arrabal de Carrequemada se localizaba la fuente que diçen en las cavas de la puerta de Hesilla. En el plano de 1868 realizado por Coello se observa un regato de agua que nacía en la confluencia de las actuales calles Pedrote y San Gregorio, frente al Arco Isilla, y que discurría en dirección NE-SO por el espacio donde estuvieron las antiguas cavas, muriendo poco después en el Arandilla ${ }^{613}$. Por último, al otro lado del puente del Duero, en el arrabal de Allendeduero junto al Camino Real de Valladolid y próximo al hospital local se localizaba la Fuente del Torillo ${ }^{614}$. Con el paso del tiempo esta fuente paso a denominarse de Santo Domingo, por la proximidad al convento que bajo la misma advocación se instaló en la villa arandina a mediados del siglo XVI. Esta fuente fue reformada en el periodo moderno y se conserva todavía hoy junto al Hospital de los Santos Reyes.

${ }^{611}$ Esta fuente sufrió un accidente a mediados del siglo XVI y el concejo decidió ... que se derribe la fuente e se dexe alli una arca con su agua y se encañe e faga un pilon... e se lleven canteros que den traza dello. Finalmente fue reparada por el corregidor en 1554 que colocó una placa sobre el arca con una inscripción conmemorativa que todavía hoy se encuentra allí emplazada (VELASCO PÉREZ, Aranda. Memorias..., pp. 219-220).

${ }^{612}$ AGS, CR, leg. 40, doc. 8. Esta fuente pasó a denominarse después de San Francisco por la proximidad al convento del mismo nombre. En la actualidad se conserva aunque muy modificada.

${ }^{613}$ Hace años todavía se podía ver una pequeña arqueta por la que presumiblemente se canalizó el agua de esta fuente y que está en relación con el albañal documentado por CRISTÓBAL VILLANUEVA, E., Informe técnico sobre el seguimiento arqueológico llevado a cabo en el solar $n^{\circ} 43$ de la calle Postas de Aranda de Duero (Burgos). Julio 1998. Informe depositado en el Servicio Territorial de Cultura de Burgos.

${ }^{614}$ AGS, CR, leg. 40, doc. 8. 


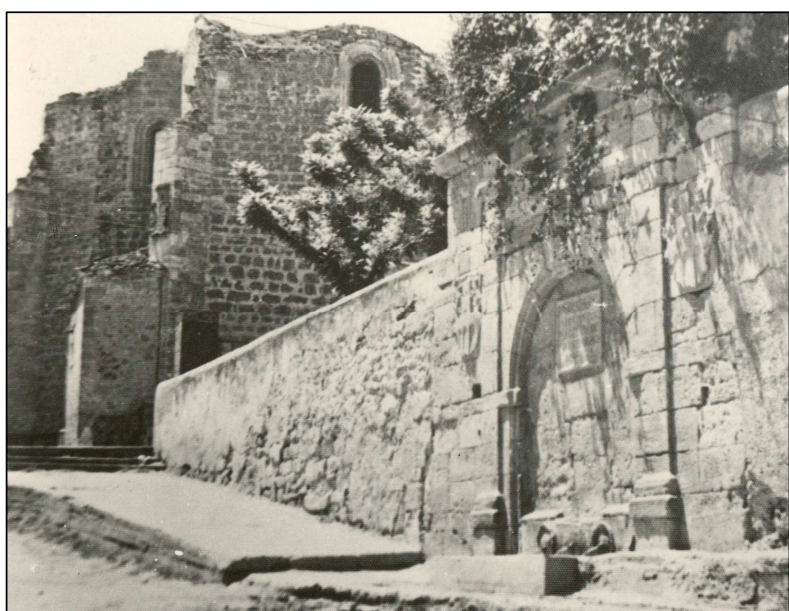

el riego sistemático ${ }^{615}$.

\section{Imagen 39: Fuente de Santo Domingo o del Torillo (CBMAD).}

A todas estas fuentes de carácter netamente urbano debemos añadir una serie de fuentes y manantiales localizados en el entorno próximo de la villa cuyo aprovechamiento fue básicamente pecuario, siendo anecdótico su uso para

Junto a los ríos y fuentes otros elementos de abastecimiento de carácter antrópico fueron los pozos, albercas o aljibes. Sobre éstos dos últimos tan solo hemos encontrado la mención a una alberca localizada en el huerto del convento de San Francisco que recogía el agua que la noria sacaba de un pozo ${ }^{616}$. Sin embargo, sí que son numerosas las referencias a pozos. La existencia de un nivel freático a escasa profundidad posibilitaba la proliferación de pequeños pozos como dejan de manifiesto las declaraciones del alguacil que afirmaba que en la dicha villa ay poços espeçialmente en la calle de Hesylla. Asimismo es significativo que una de las calles reciba el nombre de calle del Poço $^{617}$. Este tipo de pozos todavía hoy se puede apreciar en algunas de las bodegas del subsuelo arandino ${ }^{618}$ o en el patio del palacio de los Berdugo. Uno de estos pozos ha sido localizado debajo de uno de los cubos de la cerca situado en el lienzo Este, en un

${ }^{615}$ Posteriormente algunos de estos manantiales fueron empleados para el abastecimiento de la villa. Así, por ejemplo, finales del siglo XVIII se aprovechó una fuente situada en las proximidades de la ermita de Santa Catalina para abastecer al recientemente construido palacio obispal. Para ello se construyó sobre ella un arca y una canalización (VELASCO PÉREZ, Aranda. Memorias..., p. 390). Una breve descripción del estado de las fuentes arandinas a finales del siglo XX la encontramos en el artículo de LÓPEZ SANZ, M. "Las fuentes públicas en Aranda de Duero", en Siglo XXI. Sept. de 1998, pp. 18 y 19.

${ }^{616}$ AGS, CR, leg. 40, doc. 8.

${ }^{617}$ AGS, CR, leg. 40, doc. 8. La escasa profundidad se verifica cuando se describen los pozos del monasterio y se asegura que tienen agua muy somera a menos hondo de media lia (soga de esparto machacado).

${ }^{618}$ IGLESIAS ESTEBAN y VILLAHOZ GARCÍA, Viñedo, vino y bodegas..., pp. 94 y 135. 
solar de la actual calle de Puerta Nueva ${ }^{619}$. Sin embargo, las referencias más frecuentes aluden a pozos situados en los arrabales y particularmente en el de Carrequemada, al Este de la villa, como señalaba en su declaración de Bernaldino de Arauzo: ...que sabe que ay muchos pozos en la calle de Carrequemada e en la calle de Soria que riegan por mano e con çigoñales ${ }^{620}$. De igual manera los arrabales de Allendeduero y San Andrés estaban rodeados de numerosos huertos que nos permiten concluir la existencia de una notable franja hortícola en estas zonas concretas regada por una multitud de pozos privados, posibles gracias a la existencia del acuífero subterráneo anteriormente citado ${ }^{621}$. Posiblemente esta relativa facilidad de acceso al nivel freático promovió la sobreexplotación del acuífero, provocando que en periodos de prolongada sequía estos pozos se secasen. Esta situación la ponen de manifiesto numerosos testimonios de vecinos por el año 1515 , y aún en la actualidad este problema se reproduce con cierta frecuencia ${ }^{622}$.

Teniendo en cuenta lo hasta aquí visto, podemos concluir que la villa de Aranda participaba de esa sensación de humedad ${ }^{623}$ que rodeaba a un buen número de ciudades de la Castilla Bajomedieval, como ponen de manifiesto numerosos trabajos de las últimas décadas ${ }^{624}$.

No obstante, esta sensación real de humedad trajo consigo una serie de inconvenientes para los vecinos de la villa ribereña, sobre todo a la hora de construir. Diversas intervenciones en el subsuelo arandino en los últimos años han constatado la utilización de haces de enebro en los cimientos de los edificios para, en cierto sentido, drenar y dar

${ }^{619}$ CRISTOBAL VILLANUEVA, E., Informe técnico del seguimiento arqueológico realizado durante el derribo y vaciado del inmueble $n^{\circ} 38$ de la calle Puerta Nueva, de Aranda de Duero (Burgos). Febrero 1994. Depositado en el Servicio Territorial de Cultura de Burgos.

${ }^{620}$ AGS, CR, leg. 40, doc. 8; y EMR, leg. 571.

${ }^{621}$ ARChV, RRE, Caja 366, doc. 24; y AGS, EH, leg. 878, doc. 14.

${ }^{622}$ DE LAS HERAS, "El medio físico...”, pp. 60-61. Varios testigos del proceso de la canalización del Aranzuelo aseguraban que los pozos del monasterio y otros cercanos se secaban durante el verano (AGS, CR, leg. 40, doc. 8).

${ }^{623}$ BONACHÍA HERNANDO, J. A., "El agua en la documentación municipal: los Libros de Actas", en El Agua en las ciudades castellanas durante la Edad Media. Valladolid, 1998, pp. 41-70, en especial p. 49. Esta idea es reafirmada por varios testigos que indican que la villa de Aranda es lugar humedo (AGS, CR, leg. 40, doc. 8).

${ }^{624}$ Referencias sobre este aspecto encontramos en ÁLVAREZ ÁLVAREZ, La ciudad de León...; y VAL VALDIVIESO, M ${ }^{\mathrm{a}}$. I. "El abastecimiento de agua a Segovia en el contexto bajomedieval castellano”. Estudios Segovianos. 94, 1996, pp. 731-52. 
solidez a la construcción ${ }^{625}$. Esta misma humedad afectó, y afecta, a buena parte de las bodegas de la capital de la Ribera ${ }^{626}$. De igual manera, la excesiva humedad era considerada por los contemporáneos como una fuente de enfermedad, como declara Pedro Sánchez de Lagunillas en 1515: ...que sabe que en el arrabal de Carrequemada... que quando ay muchas aguas e humidades... que a visto enfermar antes en el dicho arrabal las personas que no en otras partes ${ }^{627}$.

Pese a todo, parece evidente que las necesidades básicas de la villa en cuanto al abastecimiento de agua a finales de la Edad Media estaban garantizadas por este rico patrimonio hídrico.

Reafirmándonos en lo anterior, no es menos obvio que las características naturales propias de estos ríos fueron también el origen de problemas y perjuicios para los vecinos.

Característica propia de las corrientes fluviales vinculadas al clima mediterráneo es su carácter variable que alterna periodos de fuertes estiajes en los veranos con crecidas e inundaciones en las estaciones equinocciales. Los vecinos de finales de la Edad Media padecían más si cabe esta circunstancia como manifiestan numerosos testimonios que lamentaban la falta de agua tanto para el riego como para mover los ingenios molinares. Lamentos que se alternaban con las constantes quejas por las periódicas avenidas que destruían las presas y hasta traer las ruedas ${ }^{628}$. En este sentido, las riadas más espectaculares fueron las del Duero que en varias ocasiones, como en 1503, estuvo a punto de llevarse el puente ${ }^{629}$. Más frecuentes eran los perjuicios sobre la industria harinera

${ }^{625}$ Desgraciadamente, ninguna de estas intervenciones ha sido de carácter arqueológico por lo que no ha sido posible registrarlas convenientemente. Tan solo contamos con diversas informaciones orales que aseguran haber sacado gavillas de sarmientos de los cimientos de casas antiguas y la información recogida por LÓPEZ SANZ que habla de la utilización de haces de enebro en las proximidades de la actual parroquia de Santo Domingo, espacio ocupado en su momento por el convento del Sancti Spiritus ("La fuentes públicas..., p. 19).

${ }^{626}$ Francisco de Hoyales, vecino de la villa, comentaba ...que esta villa esta asentada en cascajo e a visto algunas bodegas de suyo ser humidas. Otro de los testigo señala que hacia 1480 estaban ...las cabas de esta villa llenas de agua e que ha visto que algunas bodegas que estan çerca dellas se remanavan... (y el testigo)...fue en sacar la dicha agua de las bodegas (AGS, CR, leg. 40, doc. 8).

${ }^{627}$ De igual manera Alonso de Pan y Agua señalaba ...que por ser humida e aver en ella muchos poços es calle muy enferma (AGS, CR, leg. 40, doc. 8).

${ }^{628}$ AGS, CR, leg. 40, doc. 8.

${ }^{629}$ Ese año el concejo solicitó licencia para echar sisa sobre los mantenimientos para reparos de la villa, especialmente para reparar la puente que esta una arco della por hundirse e caherse (AGS, CC PUEBLOS, leg. 2, fol. 92 y 93). A partir de la segunda mitad del XVI las referencias son más abundantes 
que veía paralizada su actividad como consecuencia de las grandes avenidas como lo recuerda uno de los vecinos: ...que a visto que con grandes avenidas no muelen las açeñas (del Duero)... una bez abra quinze años ... por espaçio de mas de dos meses... e otras vezes estan quinze e veynte dias que no muelen ${ }^{630}$. Aunque los fenómenos más espectaculares se producirían cuando se inundaba el núcleo urbano ${ }^{631}$.

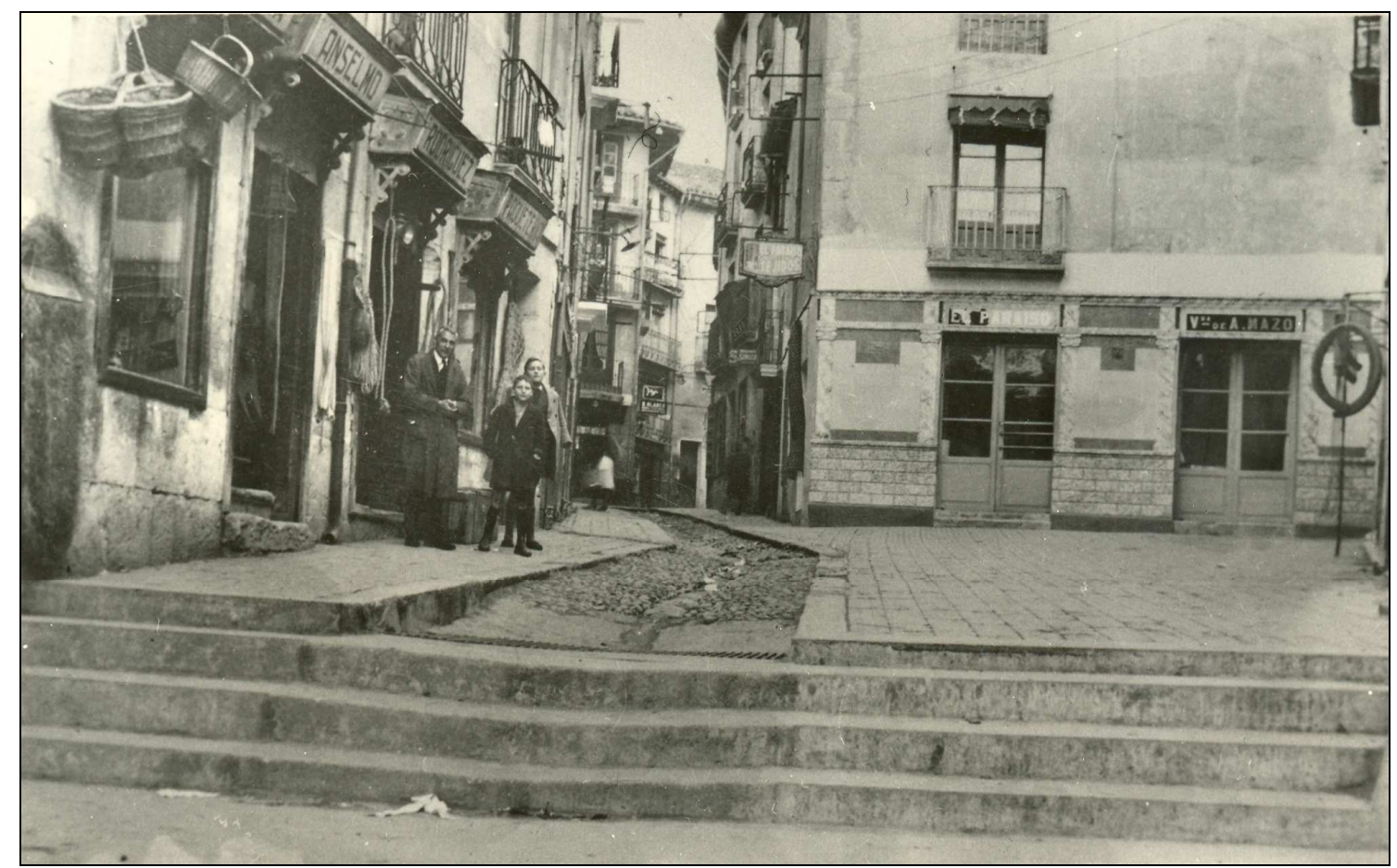

Imagen 40: La calle Béjar o Alojería a comienzos del siglo XX (CBMAD).

Paralelamente al problema del abastecimiento del agua se situaba el de su evacuación tras su utilización. Una de las primeras noticias documentales con la que contamos hace referencia de forma indirecta a un problema con el desagüe de las aguas que

como recogen ARAMBURU-ZABALA, La Arquitectura... pp. 118-19; y CADIÑANOS BARDECI, "Los Puentes del Sur..., pp. 15-17.

${ }^{630}$ AGS, CR, leg. 40, doc. 8.

${ }^{631}$ No disponemos de noticias sobre grandes inundaciones en Aranda de cronología bajomedieval pero creemos que la narración en primera persona de la baronesa d'Aulnoy sobre un acontecimiento de estas características a finales del siglo XVII puede ser en gran medida extrapolable al periodo referido (YEVES, "Aranda de Duero en los libros de viajes..., pp. 104-105). Lo mismo podemos decir de las noticias de la gran avenida que se produjo entre el 13 y el 17 de mayo de 1658 provocando efectos devastadores: ...llegando el agua hasta la plaza, (...) subiendo hasta el altar de la ermita de Santa Ana, rebasando por medio estadio la puentecilla de Bañuelos, hundiendo las tenerías y llevándose (...) un gran trozo de paredón del puente del Duero y derribando por completo los de Vadocondes y La Vid. La Nava parecía río, y el agua que traía el camino de Carrequemada parecía Duero. Inundose todo el barrio de San Lázaro (Allendeduero) y el convento de Santo Domingo... (VELASCO PÉREZ, Aranda. Memorias..., p. 323). 
desde la calle Isilla bajaban por las casas del arcediano de Haza hasta la calle de la Miel, provocando algunos problemas en las propiedades del clérigo. Finalmente se optó por encauzar este desagüe por la calle de la Alojería para que tuviera salida directa a la Plaza Nueva, siguiendo una disposición que se ha mantenido hasta hace pocas décadas ${ }^{632}$.

De todas formas y salvo este caso particular, creemos que la Aranda bajomedieval careció de cualquier tipo de red de saneamiento -alcantarillas, cloacas, etc.- que no fuera la inclinación natural de sus calles ${ }^{633}$. Esta circunstancia derivó en que ciertos sectores urbanos de la villa sufrieron serios problemas a causa de la evacuación de aguas. Entre estos destacaba sobre todo el ya mencionado caso del Hocino. Este nombre ya es bastante ilustrativo de sus características geográficas, pues este término se define como una angostura del terreno por el que pasa un río o arroyo entre dos montañas ${ }^{634}$. En el caso que nos atañe, esta angostura era un pequeño vallejo entre dos colinas: al Norte la de San Juan y al Sur la de San Llorente. Aunque no tenemos constancia de la existencia de arroyo, pero sí de puente, este vallejo se convirtió en el aliviadero de ambas colinas cuando llovía como ponen de manifiesto las declaraciones de alguno de sus vecinos en 1486: ...en el tiempo de las aguas todas las dichas aguas yban a dar al dicho Hoçino ${ }^{635}$. Como ya hemos visto, parte del problema se solventó con la apertura de un postigo en la cerca para que las aguas residuales no se estancaran en esta zona y pudieran desaguar en el Bañuelos. Pero esta zona no era la única que tenía problemas de este tipo por lo que podemos suponer que la mayor parte de las calles arandinas a finales del medievo se definían por una tortuosa mezcla de basura, excrementos y lodo ${ }^{636}$. No obstante, las autoridades municipales emprendieron desde finales del Cuatrocientos una serie de medidas, entre las que se encontraba el empedrado de las principales vías y la prohibición de

${ }^{632}$ VELASCO PÉREZ, Aranda. Memorias..., pp. 87-88.

${ }^{633}$ MADOZ informa de que a mediados del XIX en la villa arandina no había más que dos alcantarillas: la de la cárcel y la de las carnicerías. Ambas vertían al Duero y su recorrido era bastante corto pues ambos edificios se encontraban a escasos 20 metros de la ribera del Duero (Diccionario Geográfico..., Vol. 2, p. 50). Creemos que ambas canalizaciones son posteriores a la cronología que abarcamos en nuestro estudio. La alcantarilla de las carnicerías puede tener su origen en la reforma que se realizó en éstas a mediados del siglo XVI (VELASCO PÉREZ, Aranda. Memorias..., p. 221). Sobre la de la cárcel no contamos con ninguna referencia sobre su origen.

${ }^{634}$ Diccionario de la Lengua Española. Real Academia de la Lengua (22a Ed.), voz hocino. 2, pp. 42-43.

${ }^{635}$ AGS, RGS, 148607, fol. 71, transcrito por CADIÑANOS BARDECI, “Judíos y moros..., doc.

${ }^{636}$ Son numerosos los vecinos que señalan que el encauzamiento del Aranzuelo ...guiandole por la villa... sera cosa de mucha limpieza para las calles (AGS, CR. leg. 40, doc. 8). 
que los animales estuvieran por las calles ${ }^{637}$, todo ello con el objetivo de hacer más transitables las calles de esta localidad.

En este sentido, llama la atención la existencia a finales de la Edad Media de una calle en la villa que recibía el nombre de calle Empedrada, calificativo con el que aparece identificada en el plano de 1503 y que ha mantenido hasta la actualidad. Parece un poco aventurado señalar que quizá esta calle fuera la primera en ser pavimentada y que por ello mantuvo este significativo nombre, máxime cuando tenemos la constancia de que a finales del siglo XV buena parte de las calles del espacio intramuros estaban empedradas ${ }^{638}$. Ahora bien, la calidad de esta pavimentación no debía ser muy buena pues los mismos vecinos que afirmaban que las calles del Pozo, Comadres, Tamarón y Traslacerca estaban empedradas señalaban a continuación que era frecuente que se encontraran llenas de barro y lodo. No es de extrañar que el concejo acometiera una nueva pavimentación de las calles de la villa durante la primera mitad del siglo $\mathrm{XVI}^{639}$.

\subsubsection{El espacio periurbano: la Tierra de Aranda.}

Además del espacio urbano propiamente dicho, la realidad jurídica de Aranda estaba conformada a finales de la Edad Media por un modesto espacio rural circundante que constituía su Tierra. En ella estaban integradas una serie de pequeñas aldeas: Villalba y Prado por el Oeste; Fuentespina y Casasola al Sur; Quemada y Vega Duero por el Este; y Sinovas por el Noreste.

Algunos autores señalan que algunas de estas aldeas ya formaron parte de la jurisdicción de la villa de Aranda en el momento de su creación ${ }^{640}$, aunque desde nuestro punto de vista ésta no se produjera hasta el siglo XIII. Estos lugares serían todos los señalados anteriormente menos Quemada.

Salvo Vega Duero, todos los demás están perfectamente identificados. Villalba, Fuentespina y Sinovas son todavía hoy poblaciones habitadas que, bien se independizaron de la villa en época moderna y hoy persisten como municipios (Villalba y Fuentespina), o bien están integradas en el término municipal de Aranda como pedanía (Sino-

${ }^{637}$ VELASCO PÉREZ, Aranda. Memorias..., p. 184.

${ }^{638}$ AGS, CR, leg. 39, doc. 3, transcrito por PERIBÁÑEZ OTERO y ABAD ÁLVAREZ, Aranda de Duero..., p. 147.

\footnotetext{
${ }^{639}$ VELASCO PÉREZ, Aranda. Memorias..., p. 184.

${ }^{640}$ VELASCO PÉREZ, Aranda. Memorias..., pp. 46-47.
} 
vas). Los términos de Casasola y Prado ya contaban a finales de la Edad Media con una escasa población sin que podamos especificar más. Hoy todavía se conservan las iglesias vinculadas a estos núcleos aunque fueron profundamente remodeladas en el siglo XVIII tras convertirse en ermitas de las cercanas poblaciones de Fuentespina y Villalba, respectivamente. El lugar de Vega Duero no hemos conseguido localizarlo por el momento a pesar de contar con algunas referencias sobre su existencia tanto en época medieval como moderna ${ }^{641}$. Por el significado del topónimo y los datos que tenemos, suponemos que se encontraba en la zona Este de la villa, posiblemente en el interfluvio entre el Duero y el Arandilla, al Sur del monte de la Calabaza en las proximidades de lo que hoy conocemos como Colonia de la Enebrada ${ }^{642}$. Esta localización se confirma por la información transmitida por el mapa del monte de la Calabaza del siglo XVIII que se conserva en el Archivo de la Real Chancillería de Valladolid. En este mapa el término Vega Duero aparece junto a la ribera del río al Sur del monte de la Calabaza (Ver Mapa $5)^{643}$.

No fue hasta avanzado el siglo XIV, en el contexto de la recuperación de la crisis de la Baja Edad Media, cuando el concejo arandino comenzó una política de ampliación de su territorio ${ }^{644}$. El primer episodio se produjo en 1396 con la adquisición de Quemada a la abadesa de Fuencaliente. Según Pérez Embid este lugar pertenecía en 1179 al monasterio de San Pedro de Gumiel ${ }^{645}$. No obstante, a principios del siglo XIII estaba en manos de don Pedro Núñez de Guzmán y doña Urraca García que se lo vendieron al monasterio de San Pedro de Gumiel, aunque lo recuperaron en $1248^{646}$. En

${ }^{641}$ Uno de los testigos a los que el obispo de Osma tomó declaración en 1429 para confirmar la venta de Revilla de Olleros era vecino de Vegaduero (AMA, leg. 43, doc. 4). También aparece enumerado entre los lugares de la Tierra arandina exceptuados del privilegio de la moneda forera concedido por Enrique IV en 1467 (leg. 43, doc. 18).

${ }^{642}$ En el deslinde que se produjo entre el termino de Aranda y Quemada en 1640 tras la enajenación de la segunda, el monte de la Calabaza y Vegaduero pasaron a Quemada, aunque después de algunos pleitos se recuperaron para el concejo arandino (VELASCO PÉREZ. Aranda. Memorias..., pp. 315-316 y 369-371).

${ }^{643}$ ARChV, PLANOS Y DIBUJOS, ÓLEOS, doc. 90.

${ }^{644}$ Dinámica que guarda paralelismos con otros espacios de la geografía castellana como La Rioja (GOICOLEA JULIÁN, "Expansión territorial..., pp. 293-331.

${ }^{645}$ PÉREZ EMBID, El Císter..., p. 280.

${ }^{646}$ VELASCO PÉREZ, Aranda. Memorias..., p. 91; y ÁlVAREZ PALENZUELA, V.A., Monasterios cistercienses en Castilla (siglos XII-XIII). Valladolid, 1978, p. 227. 
1319 fue cedido por doña María de Molina a la mujer de Alvar Díaz de Haro, después de habérsela comprado a Ruy Pérez de Sasamón ${ }^{647}$. Algunos años después la propiedad del lugar pasó a Juan Martínez de Leyva que se la dejó en herencia a su hija, Isabel Sánchez de Leyva, abadesa del monasterio de Fuencaliente. Finalmente la abadesa y el cenobio vendieron el lugar al concejo arandino en 1366, aunque la venta no se pudo hacer efectiva hasta 1396 a causa de no contar con la confirmación del Reformador de la Orden Cisterciense ${ }^{648}$.

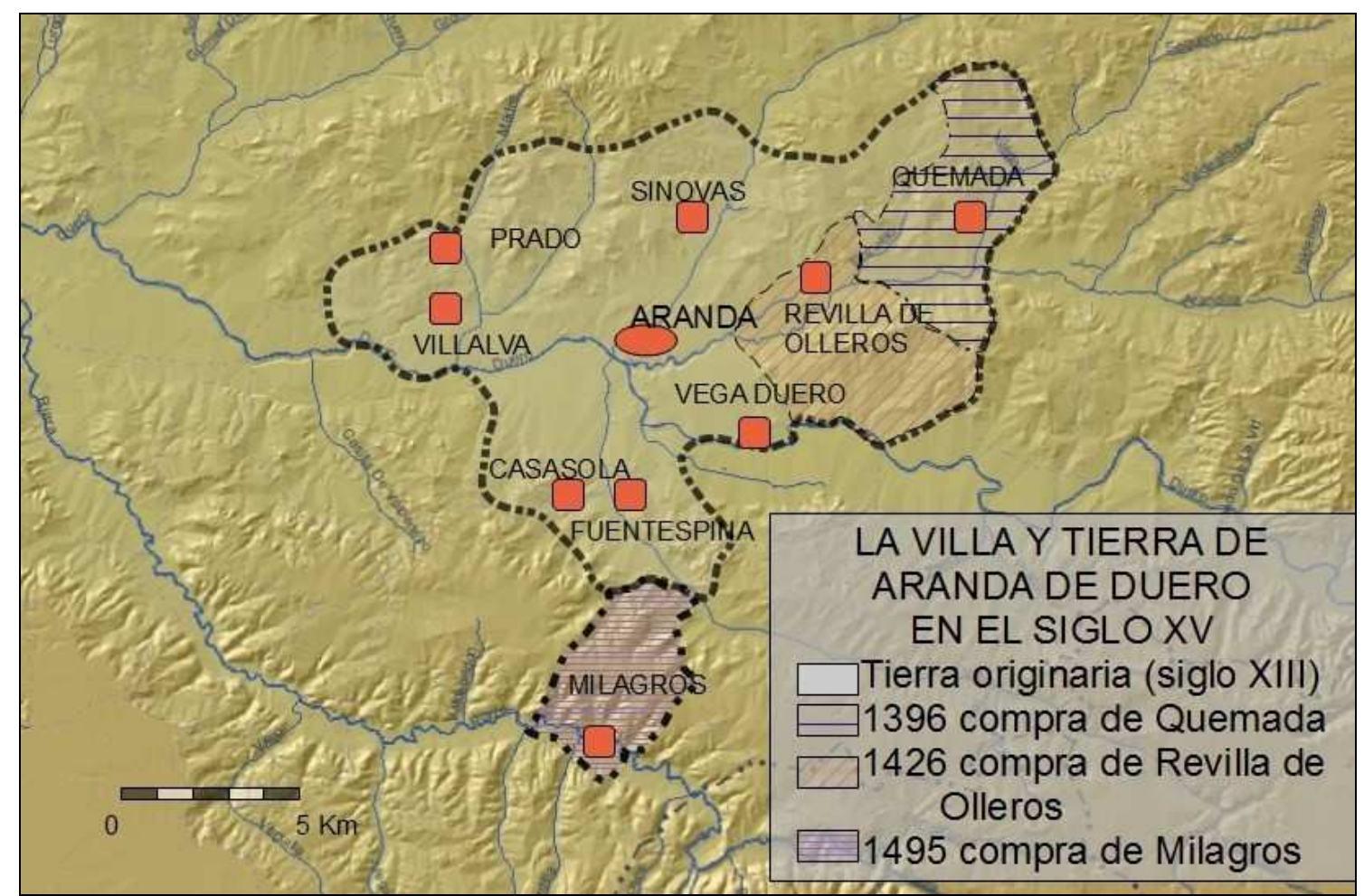

Mapa 9: Los lugares de la Tierra arandina.

Poco tiempo después, en 1426, el concejo de Aranda acordó con la vecina comunidad premostratense de La Vid la compra de los términos linderos de Revilla de Olleros, Las Palizas y Páramo por un censo de 65 florines anuales ${ }^{649}$. Estos terrenos próximos a Aranda pertenecían al monasterio desde que en 1150 le fueron donados según constaba en los archivos del cenobio, y en sus manos se mantuvieron hasta comienzos del siglo XIV a tenor de las sucesivas confirmaciones y apeos de estas propieda-

\footnotetext{
${ }^{647}$ VELASCO PÉREZ, Aranda. Memorias..., p. 57.

${ }^{648}$ VELASCO PÉREZ, Aranda. Memorias..., pp. 91-92.

${ }^{649}$ VELASCO PÉREZ, Aranda. Memorias..., pp. 89-91; y AMA, leg. 43, doc. 4.
} 
$\operatorname{des}^{650}$. Aunque el acuerdo se firmó en febrero de 1426, la venta no se hizo efectiva hasta marzo de 1430 tras la ratificación del obispo de Osma que había sido comisionado por el Papa Martín $\mathrm{V}^{651}$. Tras estas iniciativas la expansión territorial de Aranda se paralizó durante varias décadas.

A finales de la Edad Media la Tierra arandina tenía unas dimensiones bastante modestas, sobre todo si se comparaba con los amplios términos de las Comunidades de Villa y Tierra que la rodeaban como Roa, Haza o Montejo, y sobre todo con los grandes estados señoriales que se estaban consolidando a su alrededor. El concejo arandino, consciente de la desventaja que suponía esta situación para los intereses de la villa, trató por todos los medios de ampliar el término jurisdiccional. A pesar de los continuos intentos por conseguir de los reyes la adhesión de algunos lugares comarcanos como La Ventosilla, Hontoria de Valdearados, Fresnillo de las Dueñas o Fuentelcésped, no se produjo ninguna ampliación hasta 1495 cuando se adquirió al monasterio de San Pedro de Gumiel el lugar de Milagros, como veremos más adelante con mayor profundidad.

Todos los lugares de la Tierra arandina presentaban un carácter netamente rural con una población mayoritariamente campesina que se dedicaba a las labores del campo al igual que lo hacía una buena parte de los labradores arandinos. Las dos principales características que definían la relación de la villa con sus aldeas fueron la dependencia y la marginación.

El hecho de que tanto la población de las aldeas como la distancia entre estas y la villa fueran muy reducidas ${ }^{652}$ permitió a las autoridades de la villa proyectar directamente su autoridad sobre los vecinos de las aldeas. De la misma manera, el mercado de la villa canalizaba la producción de las partidas rurales de tal forma que el intercambio en las aldeas era muy limitado. En este mismo sentido, hemos podido constatar cómo los intereses económicos de algunos de los miembros de la oligarquía local así como de

${ }^{650}$ MARÍN DE SAN MARTÍN, El monasterio de Santa María de la Vid. 850 años. Madrid, 2004, doc. 2, p. 124. En 1239 el rey Fernando III confirmaba una concordia entre el monasterio y unos nobles locales en la que se garantizaba la propiedad vitense de Revilla de Olleros (GONZÁLEZ, J., Reinado y Diplomas de Fernando III. Córdoba, 1980, Vol. III, doc. 646). Más tarde, en 1264, se produjo un conflicto sobre los límites entre este término y la villa de Aranda que concluyó con la elaboración de un apeo (ARCHIVO HISTÓRICO NACIONAL -AHN-, CLERO, Carpeta 380, doc. 17).

${ }^{651}$ AMA, leg. 43, doc. 4.

${ }^{652}$ No conocemos a ciencia cierta el número de vecinos de las aldeas de la Tierra arandina para este periodo. No obstante, las averiguaciones realizadas a mediados del siglo XVI arrojan una cifra de 1318 vecinos para toda la Villa y Tierra (CARRETERO ZAMORA, La averiguación de la Corona..., Vol. III, p. 967). 
los ricos labradores se extendieron hacia la Tierra, pues muchos de ellos tenían importantes haciendas tanto de pan como de viñedo en estos lugares. Baste como ejemplo el caso de algunos personajes singulares de la villa como el regidor Fernando de Covarrubias que se instaló en sus propiedades de Quemada durante el verano de 1486 para huir del brote de peste que se había desatado en Aranda ${ }^{653}$; asimismo la rica familia Santa Cruz poseía una importante hacienda en Villalba y Sinovas ${ }^{654}$; de igual manera, el regidor y arrendador Mena poseía un molino en Quemada ${ }^{655}$; y también algunos de los hacendados comuneros tenían importantes propiedades en Sinovas y Quemada ${ }^{656}$.

También parece evidente la situación de marginalidad en que se encontraba la población de las aldeas. Estos lugares contaban desde tiempo inmemorial con sus representantes en el concejo arandino, los procuradores de la Tierra, que se encargaban de canalizar las inquietudes de los vecinos de las aldeas y exponerlas ante las autoridades locales. Sin embargo, esta representatividad fue reduciéndose hasta que al amparo de la reforma del regimiento a principio de la década de los ochenta del Cuatrocientos se les impidió la entrada en los ayuntamientos ${ }^{657}$. Desde entonces su presencia se limitaba tan solo a las ocasiones más solemnes, reduciendo su asistencia a aquellos acontecimientos de notable importancia como fueron la toma de posesión del lugar de Milagros en 1495 y las posteriores disputas sobre su jurisdicción ${ }^{658}$ o el procedimiento para recuperar el alguacilazgo comenzado en $1517^{659}$. De igual manera, la marginación también se proyectaba sobre los privilegios como el de la moneda forera concedido por Enrique IV en el que se negaba explícitamente la exención de este impuesto a los habitantes de la Tierra a pesar de ser beneficiarios los moradores del arrabal y las minorías religiosas ${ }^{660}$.

${ }^{653}$ CARRETE PARRONDO, Fontes Iudaeorum ... doc. 159, p. 82.

${ }^{654}$ AGS, EH, leg. 878, doc. 14. Esta importante hacienda en origen fue de don Juan Álvarez Delgadillo que en 1510 empeñó en manos de Pedro de Santa Cruz a cambio de cien ducados de oro.

${ }^{655}$ AGS, EMC, leg. 560.

${ }^{656}$ AGS, CMC, leg. 355.

${ }^{657}$ AGS, RGS, 149106, fol. 107; y 149111, fol. 210.

${ }^{658}$ AGS, CC PUEBLOS, leg. 13, docs. 3 y 4.

${ }^{659}$ AGS, CC DIVERSOS, leg. 41, doc. 35; y CONSEJO Y JUNTA DE HACIENDA, leg. 4, doc. 20.

${ }^{660}$ E otro si que non gozen ni puedan gozar de la dicha mi merced e franqueça en la dicha mi carta contenida los dichos vezinos e moradores de los lugares e tierra de la dicha villa de Aranda (AMA, leg. 43, doc. 18). 
Con lo visto en este epígrafe concluimos el apartado dedicado a la configuración de la villa de Aranda como un centro urbano y las características que la definían a finales de la Edad Media y que la consolidaron como el principal núcleo urbano de la comarca ribereña.

\subsection{La integración en el sistema urbano de la Castilla Septentrional.}

La villa de Aranda formó parte de esa extensa red de "ciudades pequeñas" definidas por Hilton y que el maestro Valdeón interpretó en el espacio castellano como centros de intercambio comercial de ámbito comarcal y que, a pesar de haber nacido al amparo de la iniciativa regia, fueron cayendo bajo la órbita de la nobleza terrateniente a lo largo de la Edad Media ${ }^{661}$.

Según el análisis planteado por el profesor Benito Martín la configuración de la red de poblamiento en la Castilla septentrional se conformó en tres etapas. El primer paso se produjo en el periodo altomedieval pero no se articuló una verdadera red hasta un segundo momento plenomedieval en el que las aldeas representaban un modelo acabado de ocupación del territorio rural y en el que además surgieron las villas amuralladas como organismos protourbanos. En la tercera etapa sólo algunas de estas villas evolucionaron hacia verdaderas ciudades que se convirtieron en los puntos centrales de la red urbana bajomedie$\mathrm{val}^{662}$.

\subsubsection{Factores que explican el desarrollo urbano de Aranda.}

Dentro de la jerarquía de la red urbana bajomedieval de la vieja Castilla encontramos un grupo destacado de núcleos urbanos plenamente desarrollados entre los que se impone sin lugar a dudas la centralidad de Valladolid, seguida de otras ciudades y villas como Burgos, Segovia, Salamanca, Medina del Campo, Palencia, Zamora, Segovia o Ávila. En un tercer nivel se encontraba un importante grupo de núcleos medianos entre los que se encontraba la villa de Aranda junto a Benavente, Soria, Miranda de Ebro, Cuéllar, Pare-

661 HILTON, R., Conflicto de clases y crisis del feudalismo. Barcelona, 1988, p. 112; y VALDEÓN BARUQUE, J., "Revueltas en la Edad Media castellana", en Revueltas y revoluciones en la historia. Salamanca, 1990, pp. 9-20.

${ }^{662}$ BENITO MARTÍN, La formación de la ciudad..., pp. 272-274. 
des de Nava o Ciudad Rodrigo, entre otros. A tenor de los datos que hemos consignado en la primera parte de este capítulo, podemos afirmar que la condición de entidad mediana dentro de la jerarquía urbana castellana se configuró a lo largo de la segunda mitad del Cuatrocientos y se consolidó en el primer cuarto del siglo XVI para mantenerse así durante buena parte de la Modernidad ${ }^{663}$.

Desde nuestro punto de vista tal situación fue posible por la confluencia de una serie de factores de distinto tipo. En primer lugar, sin que ello signifique que fuera el más importante, está el factor geográfico. En este sentido, el emplazamiento del núcleo urbano de Aranda en terreno llano, en el corazón de una amplia vega junto a un caudaloso río, posibilitó el desarrollo de una importante actividad agrícola que se especializó, gracias a las cualidades edafológicas y climáticas, en el cultivo de la vid.

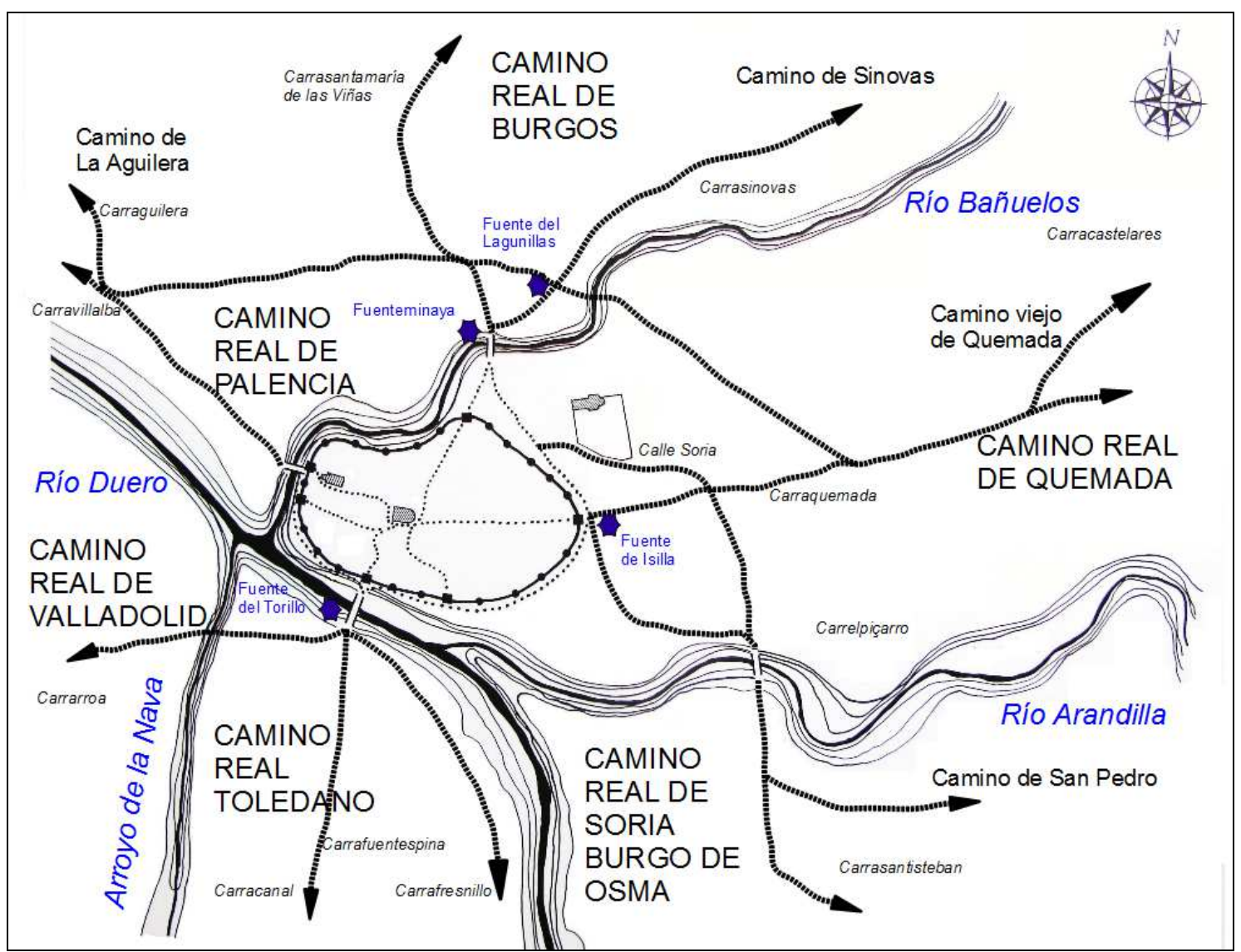

Mapa 10: La red de caminos de la villa de Aranda a finales de la Edad Media.

${ }^{663}$ Afirmación que para la segunda mitad del Quinientos se confirma con el exhaustivo estudio cuantitativo de VELA SANTAMARÍA, F. J.,'El sistema urbano del Norte de Castilla en la segunda mitad del siglo XVI", en Ciudad y mundo urbano en la Época Moderna. Madrid, 1997, pp. 15-43. 
Otro factor a tener en cuenta es el estratégico al configurarse a lo largo de la Baja Edad Media como un significativo cruce de caminos ${ }^{664}$. Por una parte, la villa de Aranda y su puente se convirtieron en paso obligado de los movimientos de personas, mercancías y ganados que desde las Extremaduras se dirigían hacia la ciudad de Burgos y los puertos del Norte siguiendo el Camino Real Toledano. Por otra parte, su emplazamiento en el corredor del Duero la situaba en una de las vías tradicionales de comunicación con el vecino reino de Aragón. Si este camino de los aragoneses ya gozaba de una notable significación en el pasado, los acontecimientos políticos que se desarrollaron en Castilla durante buena parte del Cuatrocientos incrementaron el valor estratégico de Aranda como se puso de manifiesto en el interés del rey de Navarra a mediados del XV por controlar la villa y su utilización como base de operaciones por parte de su hijo y la princesa Isabel a lo largo del conflicto sucesorio $^{665}$.

A pesar de la existencia de vías de comunicación consolidadas anteriormente, se observa en este periodo que todos ellos se subordinaron a estos dos grandes ejes N-S y E-O que articulaban de forma patente todas las comunicaciones de la comarca. Y esta situación se produjo, no tanto por la pérdida de tránsito de las ya existentes, como por el gran crecimiento de estos dos grandes ejes. Buen ejemplo de esta situación son las dos vías que discurrían paralelas a los cauces del Esgueva y el Riaza ${ }^{666}$. La configuración de una infraestructura viaria muy desarrollada se atestigua recurriendo a la cartografía histórica como se ha realizado en otros ámbitos castellanos ${ }^{667} \mathrm{o}$ a algunos elementos que han pervivido hasta nuestros días como son los puentes.

Estas infraestructuras fueron bastante más abundantes de lo que pudiéramos imaginar y así se pone de manifiesto en el elevado número de puentes que existían sobre el pequeño río del Gromejón en el tramo que compartía La Aguilera con sus vecinos de Quinta-

${ }^{664}$ En 1503 un vecino testificaba que ...la calle de Varrio Nuevo (...) sy estovyese abierta por que todos quantos pasan de las montañas allende el puerto la berian e agora non la been por que está cerra$d a "$ (AGS, CR, leg. 39, doc. 3). Un vecino señalaba en 1515 que por el arrabal de Carrequemada ...suele venir por alli mucha carreteria de la Syerra e otra mucha gente e que pasa abaxo a Valladolid e a Medina (CC PUEBLOS, leg. 2, doc. 107).

${ }^{665}$ Como veremos más adelante, tras la adhesión al bando de la princesa en 1472 la villa fue el escenario de un Concilio en el que, además de cuestiones teológicas, el arzobispo Carrillo trató de ganar aliados para la causa isabelina. También fue el escenario de varias estancias de los príncipes en los momentos previos a su reconciliación con el monarca en la Navidad de 1473.

${ }^{666}$ ZAMORA LUCAS, La villa de Roa..., p.186; SÁNCHEZ RIVERA, Los puentes..., p. 14.

${ }^{667}$ Por ejemplo en el caso de la comarca cuellarana (OLMOS HERGUEDAS, Agua, paisaje,..., pp. 261-281). 
na del Pidio, Gumiel del Mercado y La Ventosilla. Así constatamos que en el límite con Quintana había un vado y al menos dos puentes ${ }^{668}$. El Gromejón ejerció de límite entre La Aguilera y Gumiel de Mercado y en su recorrido contaba con al menos cuatro puentes y un pontón. El más importante era el que comunicaba directamente las dos localidades y era denominado la puente nueva porque recientemente los vecinos de Gumiel habían construido un arco e puente e calçada. Las otras construcciones eran la puente nueva del molino de Pedrazo, la puente de la casa de Lara, la puente de la aceña al Mosellar y, por último, el pontón que debían reparar y mantener los vecinos de La Aguilera. El conjunto se cerraba con la puente de Aldea Duero y la puente de la cuesta de Calcarrascosa en el límite con La Ventosilla ${ }^{669}$. La diferenciación que se hace entre puentes y pontones parece indicar la calidad del material empleado en su construcción, piedra para la construcción del arco $e$ puente e calçada, mientras que el pontón sería de madera. No obstante, en la vecina comunidad de Haza se regulaba por aquellos años las condiciones de uso los montes comunales de su Tierra, estableciendo en uno de sus puntos las licencias para cortar postes e madera para labranza o para haser algunas puentes ${ }^{670}$.

Volviendo de nuevo al tema de la villa arandina, podemos concluir que las características físicas y estratégicas condicionaron en gran medida el desarrollo urbano de Aranda, pero estos mismos condicionantes eran compartidos por otros muchos asentamientos que nacieron y se desarrollaron con anterioridad al núcleo arandino y que incluso adquirieron una configuración protourbana ya en el siglo XII, como la villa de Roa, Haza o los Gumieles ${ }^{671}$. Por lo tanto, debieron existir otros factores que condicionaron la evolución del núcleo arandino hacia la realidad urbana que presentaba a finales del siglo XV.

A nuestro entender fueron dos los factores complementarios de los anteriores, pero determinantes en la resolución urbana final: la iniciativa política y el dinamismo económico. En primer lugar, el hecho de que la fundación o reactivación de Aranda en el siglo XIII fuera promovida por los monarcas castellanos dio un notable impulso a esta evolución.

${ }^{668}$ AMA, leg. 1101, doc. 5. En el documento sólo se cita el vado y la primera puente, por lo que suponemos que al menos existía un segundo puente.

${ }^{669}$ AMA, leg. 1198, doc. 3; y leg. 1199, doc. 19.

${ }^{670}$ AGS, CC PUEBLOS, leg. 9, doc. 124. No obstante, no debemos descartar la posibilidad de que esta madera se utilizara para la elaboración de las cimbras necesarias para la construcción de los arcos de los puentes. ción..., p. 273).

${ }^{671}$ BENITO MARTÍN lo ejemplifica con las villas de Amaya, Muño, Lara y Carazo (La forma- 
Como veremos más adelante, esta promoción real se vio seriamente comprometida a lo largo del Trescientos para después reactivarse por iniciativa de Juan II y Enrique IV. Pero el impulso definitivo se produjo en el último tercio del siglo XV de la mano de los Reyes Católicos que convirtieron a la villa en el referente del poder real en una comarca notablemente señorializada ${ }^{672}$.

No menos importante fue el factor económico. Evidentemente la comercialización del vino supuso la integración de la villa en un tejido comercial que tenía su proyección más allá del espacio comarcal como ya era evidente en 1440: ...desides que la mas prinçipal provysion que los vesinos de esa dicha villa e su tierra tenedes de que vos aprovechades e mantenedes es la labrança del vino e la saca que della e de su tierra de cada año salle, asi por las çibdades de Burgos e Soria, como por otras partes ${ }^{673}$. Pero más significativo parece el hecho de que un grupo de mercaderes arandinos tejieron una importante red de relaciones comerciales que controlaban desde Aranda y que incluían productos tan variados como vino, lana, tejidos, pero sobre todo dinero, bien fuera a través de préstamos o de arrendamientos de rentas reales o eclesiásticas ${ }^{674}$.

En definitiva, estos factores consolidaron a la villa de Aranda como un centro urbano de mediana entidad encuadrado dentro de la jerarquizada red de poblamiento de la Castilla septentrional.

${ }^{672}$ PERIBÁÑEZ OTERO, J. G., "El control del territorio en la Ribera del Duero en la Baja Edad Media”, en Biblioteca 25. Estudio e Investigación. 2011, pp. 39-65.

${ }^{673}$ AMA, leg. 43, doc. 7, transcrito por HURTADO QUERO, Documentos Reales..., doc. 5, pp. 13-14. En este documento Juan II de Navarra, como señor de la villa, ordenaba a las autoridades locales y a su recaudador que se anulara una anterior disposición que ordenaba imponer el estanque del vino. Otros estudios han puesto de relieve estas transacciones a partir de la segunda mitad del siglo XVI (IGLESIAS BERZOSA, J., "Importancia del vino en el desarrollo económico de la villa y tierra de Aranda (s. XVI). Estudio de las bodegas", en Biblioteca 18. Estudio e Investigación. 2003, pp. 75-116; y HUETZ DE LEMPS, A., Vinos y viñedos de Castilla y León. Segovia, 2004, pp. 256 y ss.). Esta creciente integración en circuitos comerciales interregionales también ha sido documentada por OLIVA HERRER en la Tierra de Campos ("El mundo rural en tiempos de Isabel I", en Sociedad y economía en tiempos de Isabel La Católica. Valladolid, 2002, pp. 41-75).

${ }^{674}$ CASADO ALONSO, H., "Crecimiento económico y redes de comercio interior en la Castilla Septentrional (siglos XV y XVI)", en Imágenes de la diversidad. El mundo urbano en la Corona de Castilla (s. XVI-XVIII), Santander, 1997, pp. 283-322; y "El Duero oriental a finales de la Edad Media y principios del siglo XVI: crecimiento económico y transformaciones", en Biblioteca 25. Estudio e Investigación. 2011, pp. 25-37. 


\subsubsection{Indicadores del dinamismo urbano.}

Este centro urbano se caracterizaba por un acusado dinamismo a finales de la Edad Media como se pone de manifiesto a través de algunos indicadores que creemos significativos.

En primer lugar, se advierte durante el último tercio del siglo XV un constante flujo de nuevos vecinos y moradores que se asentaron en la villa atraídos por un amplio abanico de oportunidades para fraguarse un futuro prometedor, bien en el campo de los negocios o en el del ejercicio del poder municipal ${ }^{675}$. Este aspecto lo hemos podido constatar perfectamente entre los miembros de la oligarquía local. Baste como ejemplo los casos de las familias Acuña y Salazar que se instalaron en la villa durante los últimos años del reinado de Enrique IV y se hicieron con una importante fortuna además de controlar los resortes del poder concejil ${ }^{676}$. Una década después se instaló en la villa la familia Santa Cruz que fraguó una de las fortunas más importantes de Castilla, además de ocupar varios de los regimientos arandinos ${ }^{677}$. Creemos que de esta dinámica participó un gran número de vecinos que desde las aldeas cercanas fueron atraídos por las posibilidades de la ciudad. Esta afirmación se basa en la abundancia de apellidos que hacen alusión a estas localidades (Peñaranda, Fuentelcésped, Haza, Gumiel, Oquillas,...), pero también a los conflictos que se generaron con algunos de los nobles comarcanos por la salida de vecinos de sus dominios hacia Aranda ${ }^{678}$. La atracción de población también se proyectó a espacios extracomarcales como puede ser Burgos, Calahorra o Valladolid, e incluso quizá de origen extranjero como deja entrever el apellido Londres ${ }^{679}$. En definitiva, la suma de la dinámica natu-

${ }^{675}$ Sobre el significado del factor demográfico véase ASENJO GONZÁLEZ, M., "Demografía. El factor humano en las ciudades castellanas y portuguesas a fines de la Edad Media", en Las sociedades urbanas en al España Medieval. Pamplona, 2003, pp. 97-150.

${ }^{676}$ Don Martín Vázquez de Acuña fue el patrono fundador del monasterio de San Francisco de Aranda y uno de sus hijos, don Juan de Acuña, fue regidor de la villa. Por su parte, Pedro de Salazar fue regidor y su hermano García alcalde. El origen y evolución de ambas familias serán abordados detenidamente más adelante.

${ }^{677}$ Como veremos más adelante, Pedro de Santa Cruz se instaló en Aranda en la década de los ochenta. Además de arrendador y prestamista consiguió en 1494 un regimiento perpetuo que heredó su nieto Cristóbal de Salazar. Gaspar de Santa Cruz, hijo de Pedro, y otro de sus nietos, Pedro de Avellaneda, también fueron regidores a comienzos del siglo XVI.

${ }^{678}$ A modo de ejemplo sirva el caso de Pedro Martínez Seco y su familia que solicitaron una carta de seguro a los monarcas ante el temor de que el marqués de Denia tomara represalias contra ellos por haber abandonado Gumiel de Mercado para instalarse en Aranda (AGS, RGS, 149304, fol. 167).

${ }^{679}$ Cristóbal y Gonzalo de Londres estaban vinculados a la clientela de Pedro de Santa Cruz (AGS, CC MEMORIALES, leg. 187, doc. 19; y ARChV, RRE, Caja 382, doc. 53). 
ral de la población arandina más los numerosos aportes migratorios referidos anteriormente posibilitaron que en los primeros años del siglo XVI, según Moral García, la villa de Aranda contara con aproximadamente mil vecinos, lo que se traduce según el índice que utilicemos en una población total que superaría los 5.000 habitantes ${ }^{680}$. Esta aproximación demográfica se confirma con los datos aportados para dos décadas después por la Averiguación de la Corona de Castilla que señala que ay en la dicha villa y sus aldeas mill e trezientos e deziocho vezinos pecheros con bibdas e menores. A este número debemos sumar todos los privilegiados avecindados en la villa (hidalgos y clérigos), sin olvidar los ...mas de setenta pobres que no los enpadrona la villa porque dizen que son muy pobres $^{681}$.

En segundo lugar, la villa de Aranda se consolidó como el principal mercado de ámbito comarcal en el que se vendía todo tipo de productos que abarcaba los alimentos como aceite, fruta o cebollas e ajos e de nabos e todas hortalizas que se traen de la tierra de Haza porque en esta villa no hay mucha hortaliza salvo lechugas e rabanos e berzas que se cultivan en las huertas de los arrabales ${ }^{682}$. El mercado se abastecía de truchas, barbos y anguilas de los ríos y lagunas locales, aunque también ofertaba pescado cecial, congrios, sardinas y besugos que se traían de los puertos del Cantábrico ${ }^{683}$. Asimismo las tiendas o boticas de la villa contaban entre sus productos con objetos de lujo como las telas flamencas o inglesas, pero también con los productos más cotidianos como los borzeguis, servillas, alcorques, pantuflos, chapines o çuecos ${ }^{684}$. Y cómo no, la villa también contaba con un mercado de dinero al que recurría buena parte de los vecinos y campesinos de la comarca para solicitar pequeños préstamos con los que subsistir ${ }^{685}$, aunque en ocasiones también eran los concejos los que solicitaban préstamos para hacer frente a alguna situa-

${ }^{680}$ MORAL GARCÍA, J., "Evolución de la población de Aranda de Duero en los primeros tiempos de la Edad Moderna”, en Biblioteca 6. Estudio e Investigación. 1991, pp. 159-190.

${ }^{681}$ CARRETERO ZAMORA, La Averiguación de la Corona..., Vol. III, p. 967.

${ }^{682}$ AGS, CR, leg. 40, doc. 8.

${ }^{683}$ AGS, RGS, 148311, leg. 140; 149705, fol. 76; y CC MEMORIALES, leg. 149, doc. 230.

${ }^{684}$ ARChV, PLEITOS CIVILES, PÉREZ ALONSO (F), Caja 676, doc. 6.

${ }^{685}$ En este sentido llama la atención la gran cantidad de préstamos que el comunero Gaspar de Mansilla hizo en la comarca arandina, pero también en tierras de Cuéllar y Madrigal, bajo la forma de uno o dos cerdos y que no superaban los 500 maravedíes (AGS, CMC, leg. 355). 
ción especial como era la compra de pan en periodos de carestía ${ }^{686}$. Al mercado permanente además se ha de sumar la feria que desde 1298 se celebraba durante los quince días siguientes al día de Santa María de febrero ${ }^{687}$.

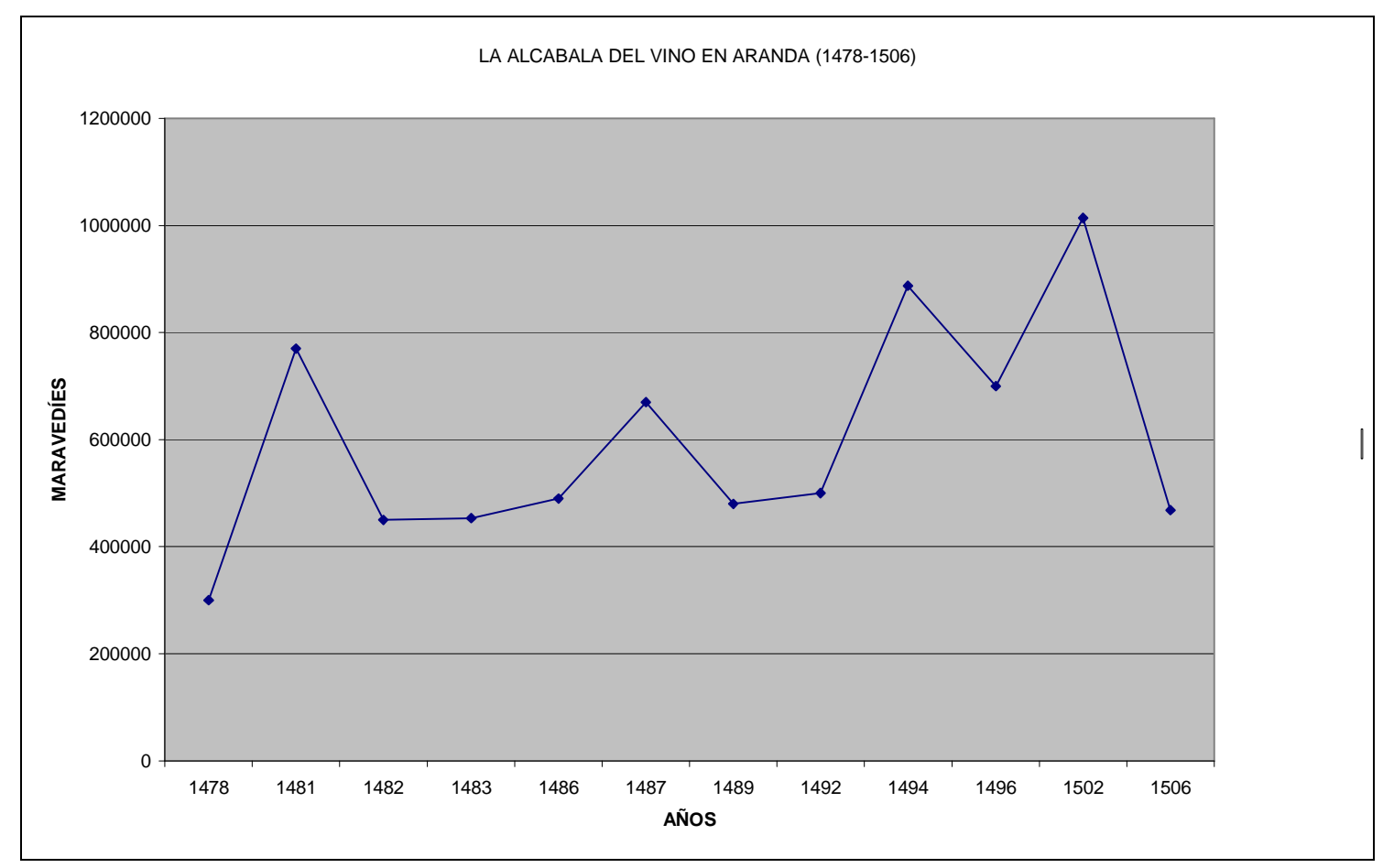

Cuadro 2: Evolución de la alcabala del vino en Aranda (1478-1506).

Como ya hemos comentado anteriormente, el negocio del vino era la principal transacción comercial que se desarrollaba en la villa como se puede apreciar en el montante de las alcabalas del vino. Además debemos tener en consideración que esta actividad ejercía como dinamizador de otros oficios auxiliares como eran la tonelería, el trabajo del cuero y el transporte.

En tercer y último lugar, se observa que la villa arandina también ganó peso dentro del contexto político de la Castilla bajomedieval como se puede colegir de la creciente

${ }^{686}$ Sirvan como ejemplo el préstamo que los lugares de Moradillo y Sotillo solicitaron a un judío para reconstruir los pueblos tras su destrucción durante la guerra con Portugal (AGS, RGS, 149402, fol. 311, transcrito por CADIÑANOS BARDECI, "Los judíos y moros..., doc. 1, pp. 40-41) y el préstamo de 26.000 maravedíes que hizo Pedro de Santa Cruz al concejo arandino en 1513 para abastecer al mercado local de pan (AGS, CC PUEBLOS, leg. 2, doc. 104).

${ }^{687}$ VELASCO PÉREZ, Aranda. Memorias..., pp. 56 y 108. Entre la documentación bajomedieval consultada no hemos encontrado ninguna referencia a la feria de Aranda lo que parece indicar que ésta posiblemente dejó de celebrarse. Tampoco hemos encontrado ninguna referencia a esta feria en la monografía de LADERO QUESADA, M. A., Las ferias de Castilla: siglos XII al XV. Madrid, 1994. No obstante, sí que existen noticias sobre la participación de arandinos en las ferias de Medina del Campo, Villalón o San Esteban de Gormaz. 
actividad del corregidor arandino que amplió su radio de acción hasta lugares tan alejados de la comarca ribereña como las tierras de Lerma, Lara, Huerta del Rey, San Esteban de Gormaz o Caracena.

En este sentido, también es reveladora de este peso político la relativa frecuencia con la que los diferentes monarcas que reinaron en este periodo instalaron su corte de manera intermitente en la villa. La presencia de Juan II no llama mucho la atención pero sí la de Enrique IV que dejó en varias ocasiones a su segunda esposa en la villa para que descansara, acompañada en alguna ocasión de la entonces infanta Isabel ${ }^{688}$. Más espaciadas en el tiempo fueron las visitas de los Reyes Católicos, aunque sí que estuvo doña Isabel en la villa durante algunos meses al final del año 1473. Don Fernando fue un asiduo de las tierras ribereñas pues durante el conflicto sucesorio tuvo la villa como escala habitual en sus numerosos desplazamientos entre ambos reinos. Pero fue sobre todo al final de sus días cuando se incrementaron estas visitas para disfrutar de la caza en La Ventosilla ${ }^{689}$. La presencia de los hijos de doña Juana y don Felipe fue bastante más pródiga pues el Infante Fernando asentó durante una buena temporada su corte en la capital de la Ribera acompañando al regente Cisneros. No en vano fue en Aranda donde don Carlos despachó a su hermano hacia Alemania ${ }^{690}$.

Para concluir este capítulo no podemos resistir la tentación de recurrir a una información accesoria pero que entendemos que es bastante reveladora de la vinculación de la Corte con Aranda y el concepto propiamente urbano que los contemporáneos daban a esta villa en la primera mitad del siglo XVI. La anécdota la protagonizó el secretario Juan de Zuazola que envió a la Corte castellana un informe desde Rastisbona cuando acompañaba al Emperador. En él trata de definir las distancias entre las ciudades del Danubio y para ello recurre a un símil con el Duero, no sin antes prevenir que ...no se puede poner comparación con cosas de esos reinos. En definitiva, el secretario explicaba: ...paréceme que se puede figurar que Zamora sea Belgrado y que Aranda sea Viena, y Almazán esta ciudad de Ratisbona... y que el Duero sea el Danubio ${ }^{691}$.

${ }^{688}$ AZCONA, Isabel la Católica., p. 41.

${ }^{689}$ VAL VALDIVIESO, M. I., "El reinado de los Reyes Católicos y su repercusión en la comarca de Aranda de Duero”, en Biblioteca 25. Estudio e Investigación. 2011, pp. 9-24.

${ }^{690}$ SANZ ABAD, Historia de Aranda..., pp. 151-156.

${ }^{691}$ CARANDE, R., Carlos Vy sus banqueros. Barcelona, 2004, p. 415. 
En definitiva, podemos concluir que la villa de Aranda se consolidó al final de la Edad Media como un centro urbano de segundo orden capaz de articular el territorio de su comarca natural pero que fue capaz de proyectar su zona de influencia más allá gracias a su dinamismo y vitalidad tanto desde un punto de vista social como económico. 


\section{LOS ACTORES POLÍTICOS EN LA RIBERA DEL DUERO A FINALES DE LA EDAD MEDIA}

Defensores son uno de los tres estados por que Dios quiso que se mantuviese el mundo; ca bien asi como los que ruegan á Dios por el pueblo son dichos oradores; et otrosi los que labran la tierra et facen en ella aquellas cosas por que los homes han de vevir et de mantenerse son dichos labradores...

Las siete partidas del rey don Alfonso el Sabio. Partida Segunda, Título XXI. 
En palabras del maestro Valdeón “...en la segunda mitad del siglo XV... de Norte a Sur y de Este a Oeste una tupida red de señoríos impregnaba el solar de la Corona de Castilla". Estos señoríos englobaban realidades diversas según se tratara de aquellos que estaban en manos del rey, de señores laicos, instituciones eclesiásticas o concejos urba$\operatorname{nos}^{692}$. El territorio de la Ribera del Duero burgalesa participaba de esta realidad y así encontramos en la comarca una serie de actores que pugnaban por el control del territorio, sus gentes y sus recursos.

Una vez que hemos estudiado el escenario físico, en este capítulo trataremos de analizar a los diferentes grupos sociales que sobre él desarrollaron sus actividades y proyectaron sus inquietudes. Los verdaderos protagonistas de este capítulo son sin lugar a dudas los hombres y mujeres que poblaron la Ribera en la Baja Edad Media. Aún manteniendo como principio fundamental lo anterior, somos conscientes de que en este periodo que abordamos ya se había configurado un conjunto de actores principales que detentaban la capacidad de ejercer su control sobre este territorio y el resto de seres humanos que lo ocupaban. Las mismas bases ideológicas en las que se basaba la organización social feudal fueron las que fundamentaron este ejercicio del poder ${ }^{693}$. Por lo tanto, la Monarquía, la nobleza, las instituciones religiosas y los concejos no fueron más que la plasmación política de la concepción ideológica del mundo feudal. La interacción de estos actores sobre un mismo territorio y sus recursos provocó una serie de roces y conflictos que configuraron su posición de poder en la estructura sociopolítica feudal. No obstante, la rígida organización política amparada en unos principios legitimadores creados y consolidados por la clase dominante no era estática sino que evolucionaba y se adaptaba a las nuevas realidades generadas por una sociedad dinámica. En consecuencia, cuando la estructura política no fue capaz de asimilar los cambios internos de la sociedad se generó una contradicción que precisaba un reajuste traumático, que bien rompiera la estructura de poder previa y diera paso a una nueva relación de fuerzas, o

${ }^{692}$ VALDEÓN BARUQUE, J. "Señoríos y nobleza en la Baja Edad Media (El ejemplo de la Corona de Castilla)", en Les Senyories medievals. Una visió de les formes del poder feudal. Revista d'Història Medieval, 8. Valencia, 1997, pp. 15-24.

${ }^{693}$ ALVARADO PLANAS, J., De la ideología trifuncional a la separación de poderes. Madrid, 1993. 
bien se eliminaba o reconducía el elemento social distorsionador y, por lo tanto, daba paso a una fase evolucionada de la anterior realidad.

Para abordar la identificación y definición de los protagonistas de los conflictos, intentaremos averiguar cuáles fueron los orígenes y evolución para después analizar sus principales líneas de actuación e intereses en el periodo bajomedieval.

El desarrollo de este bloque lo iniciaremos con el estudio de la presencia y significado de la Corona en la comarca y la proyección que tuvieron sobre este territorio las políticas de consolidación de la autoridad real. El punto de partida fue la débil presencia de la monarquía a través del realengo y, en menor medida, las behetrías. Con el paso del tiempo y la consolidación de su poder su papel fue clave en la relación de fuerzas de los distintos actores comarcanos pues actuó como "juez", pero sobre todo como "parte" con el objetivo de conseguir imponer la autoridad regia por encima de cualquier otra.

Lejos del modelo que representaba la ciudad de Burgos, en la Ribera encontramos también el intento de configurar un señorío urbano en el caso de la villa de Aranda de Duero que, a través de una dinámica claramente expansionista, siguió un proceso de consolidación de su poder paralelo y contrapuesto al del sector nobiliario. No obstante, en el seno de la sociedad arandina convivían dos realidades políticas con notables diferencias, oligarquía y Comunidad, que trataremos de identificar y analizar.

En este territorio identificamos asimismo algunas de las principales familias emergentes de lo que se ha venido denominando "nueva nobleza" que trató de consolidarse como una fuerza de primer orden en el tramo final del periodo medieval, utilizando para ello una variada serie de estrategias.

Mucho más modesta fue la incidencia de las behetrías sobre la organización territorial de la comarca. A lo largo del periodo estudiado se observa un incremento de la presión a la que se vieron sometidas sobre todo por la poderosa nobleza comarcana que las convirtieron en uno de sus objetivos preferidos en su dinámica de incremento de su patrimonio territorial.

Por último, las instituciones eclesiásticas de la comarca presentaban una situación diametralmente opuesta. Tras un pasado más o menos glorioso, la Baja Edad Media supuso para el poder de la Iglesia una merma considerable de su patrimonio territorial, aunque siguió vigente su indudable capacidad de control social. 


\section{LA AUTORIDAD REAL.}

Durante toda la Edad Media los diferentes monarcas utilizaron diversas herramientas para gestionar con mayor eficacia e imponer su autoridad sobre aquellas ciudades que estaban bajo su señorío ${ }^{694}$. El hecho mismo de la concesión o renovación de un Fuero, y no tanto su contenido, es una evidencia de esta autoridad superior que tenía la potestad de renovar o revocar el estatuto jurídico que regía la vida de las ciudades y que, por lo tanto, hacía necesario que cada nuevo monarca lo confirmara como poseedor personal de esta potestad ${ }^{695}$. Dentro de este contexto, las autoridades municipales efectuaban el reconocimiento de este poder acudiendo una y otra vez ante los sucesivos reyes para solicitar la confirmación de los privillegios e cartas e merçedes e ofiçios e libertades. Los lugares de realengo, como la villa de Aranda de Duero, se encargaban de salvaguardar estos documentos, no sólo como garantes de sus prerrogativas particulares, sino también como legitimadores de su encuadramiento dentro del señorío real en el contexto más amplio de la realidad feudal. Hasta tal punto los ciudadanos apreciaban este reconocimiento del poder real que los documentos de confirmación de privilegio se depositaban en un arca que se guardaba en el edificio más sólido de la villa, que en los casos arandino y raudense no fueron las dependencias municipales sino sus respectivas iglesias mayores. Evidencia material que en definitiva muestra la estrecha interrelación entre los grupos que monopolizaban el dominio social y político del mundo urbano medieval: Corona, concejo e Iglesia.

\section{1. Los instrumentos de gobierno.}

Con el asentamiento de la dinástica Trastamara en Castilla se dio un nuevo impulso al reconocimiento de la autoridad real, pero fue sobre todo desde el reinado de Juan II cuando la monarquía castellana sentó las bases de su reafirmación frente a los grupos de poder de la sociedad feudal. Dinámica que se plasmó de una manera decidida

${ }^{694}$ Proceso que según MONSALVO ANTÓN ya comenzó entre los siglos XI y XIII con la conversión del realengo directo en realengo concejil o transferido con la intención de conseguir una mayor eficacia al implicar en la gestión a las propias comunidades locales ("Centralización monárquica castellana..., pp. 176-178).

${ }^{695}$ LADERO QUESADA, M. A., "Monarquía y ciudades de realengo en Castilla siglos XII a XV”, en Anuario de Estudios Medievales. 24, 1994, pp. 718-773, en concreto pp. 725-726. 
en una política de consolidación del poder real con el ascenso al trono de doña Isabel. Para fortalecer la autoridad de la monarquía, la reina, con la estrecha colaboración de don Fernando, se sirvió de una serie de instrumentos: unos ya existentes a los que dota de nuevas facultades; y otros creados ex novo para esta finalidad. De todos los instrumentos ideados y desarrollados por los monarcas para consolidar su poder tan solo analizaremos a continuación aquellos que tuvieron un papel primordial en la configuración de la realidad bajomedieval de la comarca ribereña ${ }^{696}$.

\subsubsection{El orden y la justicia: la Santa Hermandad y el Corregimiento.}

La resolución de los problemas de seguridad que asolaban Castilla en los años 70 fue un objetivo prioritario en la mente de Isabel I y para ello se sirvió de dos experiencias anteriores que reconfiguró a la medida de sus necesidades. Gracias a éstas y a la consolidación de las instituciones de justicia real, la reina consiguió imponer en gran medida el orden y la justicia en toda Castilla.

\section{a. La Santa Hermandad.}

Son varias las monografías que han tratado este tema con detenimiento por lo que en este apartado tan solo analizaremos la incidencia que este instrumento de orden público tuvo en el espacio ribereño ${ }^{697}$.

La primera noticia sobre la actuación de la Santa Hermandad en la Ribera se remonta a los años cuarenta de la decimoquinta centuria. En 1503, en el contexto del pleito entre la villa de Aranda y el conde de Miranda, Juan García de Tobladillo recordaba que ...hace más de sesenta años que la Hermandad Vieja que en aquel tiempo había, que era la cabeza de esta tierra la villa de Sepúlveda, venía tras un fraile ladrón y juntaron los alcaldes de Montejo y de la comarca y a voz de Hermandad vio que

${ }^{696}$ Por lo tanto quedan al margen instituciones tan significativas como el Consejo Real o la Real Chancillería que, sin lugar a dudas, condicionaron el desarrollo histórico de la comarca como el de toda Castilla, máxime cuando buena parte de la información de la disponemos en la actualidad proceden de estas dos instituciones.

${ }^{697}$ Destaquemos las monografías de PUYOL Y ALONSO, J., Las hermandades de Castilla y León: estudio histórico seguido de las ordenanzas de Castronuño. Madrid, 1913; ÁLVAREZ MORALES, A, Las Hermandades: expresión del movimiento comunitario en España. Madrid, 1974; UROSA SÁNCHEZ, J., Política, seguridad y orden público en la Castilla de los Reyes Católicos. Madrid, 1998; y la más reciente de LADERO QUESADA, M. A., La Hermandad de Castilla: cuentas y memoriales, 1480-1498. Madrid, 2005. Asimismo debemos sumar los numerosos estudios de SÁNCHEZ BENITO, J. M., entre los que destaca "Notas sobre la Junta General de la Hermandad en tiempos de los Reyes Católicos", en Anales de la Universidad de Alicante. 8. Alicante, 1991, pp. 147-168. 
mandaron poner una horca çerca del lugar de Miraglos, a ojo del camino Toledano, en la qual ahorcaron al dicho frayle. Además se constata por las mismas fechas la existencia de un alcalde de la Hermandad en la villa de Montejo ${ }^{698}$.

En 1456 por iniciativa regia ya se experimentó la constitución de una entidad que agrupaba a Segovia, Burgos, Valladolid, Palencia, Ávila, Arévalo, Roa y Aranda. Se configuró siguiendo el modelo de la Hermandad Vieja, aportando cada núcleo dos cuadrilleros por cada cuarenta vecinos. Los resultados en principio fueron positivos alcanzando una notable reputación, pero el enfrentamiento político de la época provocó que las Hermandades se convirtieran en instrumentos que se implicaban en las luchas políticas del momento y dejaban de lado la finalidad inicial de luchar contra la delincuencia y el bandolerismo ${ }^{699}$.

El periodo de inestabilidad que vivió Castilla durante los primeros años 70 incrementó la inseguridad por lo que Enrique IV se planteó la idea de retomar este viejo instrumento, aunque no se materializó hasta que en las Cortes de Madrigal de 1476 la reina Isabel configuró la Santa Hermandad. La primera Junta General celebrada ese mismo año en Dueñas definió una ágil organización y un holgado presupuesto que facilitaron la eficacia de las cuadrillas locales. El resultado final fue el restablecimiento más o menos general del orden y la seguridad en los caminos de Castilla ${ }^{700}$.

La presencia de la Hermandad General en la Ribera se constata en el año 1477 cuando los monarcas encomendaron a los alcaldes y diputados de la villa de Aranda que garantizaran el cobro de unos impuestos relativos a esta institución ${ }^{701}$. Suponemos que la mayor parte del territorio que estudiamos, con la villa de Aranda a la cabeza, se encuadraría en la provincia de Burgos ${ }^{702}$.

${ }^{698}$ AGS, CR, leg. 22, doc. 1. El ladrón en cuestión se llamaba Pedro de Sevilla y fue acusado de ir disfrazado de fraile y robar una mula. Finalmente fue ahorcado después de permanecer apresado en un cepo de Milagros.

${ }^{699}$ PUYOL ALONSO, Las hermandades..., pp. 50-61; ÁLVAREZ MORALES, Las Hermandades..., pp. 120-123; y UROSA SÁNCHEZ, Politica, seguridad.... p. 104.

${ }^{700}$ SUÁREZ FERNÁNDEZ, L. Los Reyes Católicos. La conquista del Trono. Madrid, 1989, pp. 238 y ss.; y UROSA SÁNCHEZ, Política, seguridad..., pp. 159 y ss. pp. 26-27.

${ }^{701}$ AMA, leg. 43, doc. 30; transcrito por HURTADO QUERO, Documentos Reales..., doc. 12,

${ }^{702}$ La recaudación de la contribución de la Hermandad en la villa de Aranda en el año 1489 fue realizada por Juan Velázquez, ejecutor de la Hermandad de la provincia de Burgos (AMA, leg. 1222, doc. 21; transcrito por HURTADO QUERO, Documentos Reales..., doc. 22, pp. 43-45). 
Las noticias que transmite la documentación sobre la actuación de la Hermandad en territorio ribereño se centran casi exclusivamente en el mantenimiento del orden y, sobre todo, en los problemas derivados del pago de la contribución.

En este sentido, cabe destacar el problema surgido en 1487 cuando uno de los alcaldes de la Hermandad de Aranda, Pedro de Aranda, y alguno de sus cuadrilleros fueron agredidos por los vecinos de Castrillo que además les quebraron las varas de la justicia. La petición de auxilio del alcalde a los vecinos de Aranda se materializó en el asalto del lugar de Castrillo por varias decenas de arandinos. No obstante, como veremos más adelante, este episodio debe encuadrarse dentro de la dinámica de enfrentamiento entre la villa de Aranda y el conde de Miranda, de quien era ese lugar ${ }^{703}$.

Ese mismo año de 1487 Francisco Triguero, alcalde general de la Hermandad, recibió la misión de embargar todos los bienes de Juan Álvarez Delgadillo, señor de Castrillo, que había sido acusado de maltratar a una de sus hermanas, provocando su muerte, además de haberse apropiado de la herencia de otra de ellas ${ }^{704}$.

En 1489 el Consejo de la Hermandad colaboró con el rey Fernando en su intento de cerrar las heridas del conflicto que enfrentó al marqués de Denia y al conde de Urueña en su disputa por el lugar de Gumiel de Izán. En concreto el Consejo de la Hermandad se encargó de establecer el reparto de los 750.000 que debió abonar el marqués de Denia, condenado por el robo de bienes a algunos vecinos de Gumiel de Izán. Además este organismo se comprometió a velar por el cumplimiento de la pena de destierro que se impuso como condena a algunos hombres del conde de Urueña que asaltaron la villa de Gumiel del Mercado, jurisdicción del marqués ${ }^{705}$.

Hasta finales de los noventa no encontramos una nueva intervención de la Hermandad en la comarca. En 1498 los alcaldes de la Hermandad en el lugar de Hontoria de Valdearados nada pudieron hacer para impedir el asalto de este lugar por parte de las huestes del conde de Miranda, dirigidas por el alcaide de Peñaranda ${ }^{706}$.

\footnotetext{
${ }^{703}$ AGS, CC MEMORIALES, leg. 149, doc. 230; y leg. 161, doc. 122.

${ }^{704}$ AGS, RGS, 148710, fols. 135 y 180.

${ }^{705}$ SECCIÓN NOBLEZA ARCHIVO HISTÓRICO NACIONAL -SNAHN-, OSUNA, Caja 79, doc. 80 .

${ }^{706}$ Más adelante veremos este episodio encuadrado dentro del expansionismo de la casa de Miranda sobre las behetrías (AGS, RGS, 149806, fol. 5; y 149809, fol. 74).
} 
Un año después los monarcas limitaron la capacidad de impartir justicia de los alcaldes de la Hermandad de Aranda y Hoyales ante el robo de una mula a un vecino de Hoyales por el alcaide de $\mathrm{Haza}^{707}$.

Pero sin lugar a dudas, los problemas de financiación de este instrumento de seguridad es el asunto que más información ha transmitido. En la villa de Aranda el recurso más utilizado para hacer frente a la contribución de la Hermandad fue la imposición de una sisa sobre las carnicerías y el peso ${ }^{708}$, aunque esta situación generó las protestas de los arrendadores que veían excesiva esta iniciativa ${ }^{709}$. No obstante, no parece que esta medida extraordinaria fuera suficiente pues en algunas ocasiones el concejo tuvo que recurrir a la venta de leña para hacer frente al pago de esta contribución $^{710}$. Aranda no fue la única en tener problemas financieros, Caleruega tuvo que recurrir al préstamo para cumplir con sus obligaciones en los gastos de la Hermandad $^{711}$.

En este ámbito de la financiación de la Hermandad, pero vinculado al arrendamiento de rentas de las Guardias Reales, es destacable que el arandino Pedro de Santa Cruz fue uno de los miembros de la compañía de Alonso Gutiérrez de Madrid, actuando como fiador en el asiento realizado en $1496^{712}$.

Por último, sólo resta consignar en este apartado dedicado a la Santa Hermandad la celebración en enero de 1488 de una Junta General en Aranda ${ }^{713}$. Los principales asuntos tratados en esta reunión fueron, entre otros, el acuerdo alcanzado por la Hermandad alavesa y el reino de Navarra para perseguir a los delincuentes, así como los desacuerdos entre la Hermandad de Talavera y la Orden de Calatrava. Asimismo se

${ }^{707}$ AGS, RGS, 149912, fol. 163.

${ }^{708}$ En 1485 los reyes concedieron su licencia para que el concejo pudiera imponer sisa para hacer frente a los gastos de la Hermandad y las levas de Alhama, a condición de que no fuera sobre las mercaderías que vinieran de fuera (AGS, RGS, 148509, fol. 51).

${ }^{709}$ En 1492 los recaudadores consiguieron que los monarcas limitaran la sisa a las carnicerías alegando que con lo obtenido de ésta bastaba para sufragar la contribución (AMA, leg. 1222, doc. 19; transcrito por HURTADO QUERO, Documentos Reales..., doc. 23, pp. 45-47).

${ }^{710}$ AGS, CC PUEBLOS, leg. 2, doc. 68.

${ }^{711}$ AGS, CC PUEBLOS, leg. 5, doc. 67.

${ }^{712}$ LADERO QUESADA, La Hermandad de Castilla..., pp. 91-93. Junto a Santa Cruz fueron también fiadores Gonzalo de Pisa y Juan Gutiérrez de Toledo (AGS, RGS, 149809, fol. 179).

${ }^{713}$ AGS, RGS, 148801, fol. 230 
establecieron repartimientos extraordinarios por valor de 24.125.000 maravedíes con los que pagar 10.000 peones para la guerra de Granada ${ }^{714}$. También en la reunión de Aranda se constató el cada vez mayor control que la Corona ejerció sobre la Hermandad a través de sus hombres de confianza ${ }^{715}$.

\section{b. El Corregimiento de Aranda de Duero.}

La generalización de la figura del Corregidor en las principales ciudades castellanas fue un hecho tras la reglamentación definitiva de su oficio en las Cortes de Toledo de 1480. Este representante real tenía amplias competencias en el ámbito judicial, militar, fiscal, etc., de manera que nada se hacía en el municipio sin su aprobación. Este modelo de gobierno municipal significó el reconocimiento de la supremacía de la Corona en el ámbito urbano y también cierto grado de estabilidad y seguridad que permitió un elevado desarrollo socioeconómico de las ciudades castellanas en los últimos decenios del Cuatrocientos ${ }^{716}$.

\section{b. 1. Antecedentes.}

A lo largo del siglo XV el gobierno de la villa estuvo en manos del concejo y bajo la tutela real, aunque también sufrió las injerencias propias de importantes personajes de la Castilla de mediados de esta centuria. En concreto, entre 1436 y 1444 la villa pasó a situarse bajo el dominio del rey de Navarra que tomó la iniciativa de implantar el corregimiento al menos desde agosto de $1439^{717}$. Sin embargo, la toma de la villa por el

${ }^{714}$ LADERO QUESADA, La Hermandad de Castilla..., p. 68; y UROSA SÁNCHEZ, Política, seguridad... pp. 217-219 y 240.

${ }^{715}$ SÁNCHEZ BENITO, “Notas sobre la Junta General..., p. 160.

${ }^{716}$ LUNENFIELD, M., Los corregidores de Isabel la Católica. Barcelona, 1989; GONZÁLEZ ALONSO, B., "La reforma del gobierno de los concejos en el reinado de Isabel", en Isabel la Católica y la politica. Valladolid, 2001, pp. 293-312. Existen numerosos estudios sobre la implantación del regimiento en las urbes castellanas entre los que destacan los realizados GUERRERO NAVARRETE, Y., "La política de nombramiento de corregidores en el siglo XV: entre la estrategia regia y la oposición ciudadana", en Anales de la Universidad de Alicante. 10, 1994-1995, pp. 99-124; y "Orden público y corregidor en Burgos (siglo XV)", Anales de la Universidad de Alicante. 13, 2000-2002, pp. 59-102.

${ }^{717}$ En el desaparecido Becerro del Archivo Municipal de Aranda había un censo fechado el 23 de agosto de 1439 en el que aparecía un tal Mosén Pedro de Quijana como corregidor de la villa en nombre del rey de Navarra (VELASCO PÉREZ, Aranda. Memorias..., p. 85). En 1443 ese cargo parece desempeñarlo el bachiller Álvaro Martínez de Roa, aunque en la documentación aparece citado como alcalde por el rey de Navarra. Tenía bajo su mando un lugarteniente (MARTÍNEZ LIÉBANA, Colección Diplomática..., doc. XCIX, pp. 119-120). 
príncipe Enrique puso fin a este episodio de jurisdicción señorial, aunque la figura del corregidor se mantuvo pues en 1454 se cita al ...honrrado cavallero Pedro de Torres, corregidor de la dicha villa por nuestro señor el príncipe..., oficio que también se mantuvo bajo el señorío de la reina Juana ${ }^{718}$.

Al comienzo de la década de los 70, en el contexto del enfrentamiento sucesorio que asoló Castilla, el concejo de Aranda se inclinó por el partido de la princesa Isabel. A cambio de su apoyo la villa obtuvo el reconocimiento de sus fueros antiguos que, en lo que a este apartado se refiere, se centraba en el respeto de la tradición a la hora de nombrar a los oficiales del concejo y en el compromiso de no enviar corregidor si no era reclamado por los vecinos ${ }^{719}$.

Efectivamente, durante la primera década del reinado de los nuevos monarcas esta promesa se mantuvo firme. Sin embargo, con el paso del tiempo se observó una progresiva intervención de la Corona en la política local a través de la presencia cada vez más frecuente de alcaldes reales y pesquisidores que fueron comisionados a la villa durante periodos cortos de tiempo, cuarenta días por regla general, para solucionar algún problema concreto $\mathrm{y}$, sobre todo, aquellos que implicaban al regimiento.

El primer caso del que tenemos noticias tuvo lugar durante los primeros años del reinado de los Reyes Católicos cuando se comisionó a un pesquisidor para averiguar lo ocurrido cuando, en el contexto del conflicto sucesorio, los partidarios de Juana, capitaneados por don Pedro de Zúñiga, intentaron tomar la villa. Desgraciadamente desconocemos el contenido de esta pesquisa, pero no así su coste que se estimó en más de 20.000 maravedíes que debieron sufragar a partes iguales denunciantes (la Comunidad) y denunciados (la clientela arandina del Conde de Miranda) ${ }^{720}$. En los años 80 el principal motivo por el que se requería la presencia de pesquisidores en la villa fue el enfrentamiento abierto entre los regidores de los linajes y la Comunidad: así en 1480, pocos meses antes de enviar los Reyes Católicos el primer corregidor, se comisionó a Antonio Martínez de Aguilera para que pusiera paz entre ambas partes. Exactamente por los mismos motivos acudió a la villa el licenciado Diego de Burgos en 1483. Especialmente

${ }^{718}$ AHN, Clero, leg. 1066, no 1.

${ }^{719}$ AMA, leg. 43, fol. 32. Más adelante trataremos con profundidad lo referente al nombramiento de los oficiales municipales.

${ }^{720}$ En 1478 la Comunidad seguía demandando que se le devolvieran los 10.000 maravedíes que había tenido que aportar para pagar la mitad del salario del pesquisidor y su escribano (AMA, leg. 43, doc. 25). 
activa fue la misión desarrollada por Diego de Encinas en 1487, enviado para realizar una investigación sobre las malas prácticas realizadas por los regidores de los linajes y los alcaldes ${ }^{721}$. Pero también acudieron pesquisidores durante este periodo por otros motivos: en 1486 Juan Alonso del Toro acudió a la villa para averiguar lo sucedido en el monasterio de San Pedro de Gumiel cuando fue tomado por unos criados de don Martín Vázquez de Acuña y, de paso, se le requirió para que pusiera orden en el espacio de la morería arandina ${ }^{722}$. En 1488 el corregidor de Palencia, Francisco de Vargas, fue comisionado para realizar una pesquisa sobre el aprovechamiento del monte que se disputaban el concejo arandino y el conde de Miranda. Paralelamente intentó poner solución al conflicto planteado entre los hidalgos de la villa y el concejo a propósito de la exención fiscal sobre la tasa de la martiniega ${ }^{723}$.

Con la implantación definitiva del corregimiento no concluyó la presencia de los pesquisidores en la villa. En cualquier enfrentamiento entre vecinos era una práctica habitual que la parte condenada por la justicia ordinaria del corregidor adujera parcialidad del oficial real en su perjuicio y solicitara de los monarcas la intervención de un pesquisidor, aunque no parece que fuera muy frecuente la aceptación de la solicitud para dirimir problemas entre particulares ${ }^{724}$. No obstante, la figura del pesquisidor la encontramos con cierta frecuencia actuando en la comarca cuando se trataba de problemas de jurisdicción, sobre todo eclesiástica. Así fue habitual que se enviara un pesquisidor para investigar todos aquellos asuntos en los que chocaba la justicia real con los privilegios jurídicos de la Iglesia ${ }^{725}$.

${ }^{721}$ AGS, RGS, 148002, fol. 256; AMA, leg. 43, doc. 15; AGS, CC PUEBLOS, leg. 2, docs. 85 y 86; y CC MEMORIALES, leg. 161, doc. 122, respectivamente. leg. 2, doc. 61 .

${ }^{722}$ AGS, RGS, 148605, fols. 38 y 202; CC MEMORIALES, leg 163, fol. 57; y CC PUEBLOS,

${ }^{723}$ AMA, leg. 42, doc. 4; y leg, 41, doc. 5, transcritos por HURTADO QUERO, Documentos Reales..., doc. 21 y 24 , pp. $41-43$ y $47-48$.

${ }^{724}$ Es el caso del conocido pleito de la apertura de la calle de Barrionuevo de 1503. La parte de los propietarios de las casas requirió el envío de un pesquisidor tras haber emitido el corregidor un informe favorable a los intereses de los vecinos de Barrionuevo que solicitaban derribar sus casas (AGS, CR, leg. 39, doc. 3).

${ }^{725}$ Es 1510 se nombró como pesquisidor al licenciado Francisco Velázquez para que investigara ciertos altercados entre la justicia ordinaria de Aranda y unos estudiantes y clérigos vinculados al convento de San Francisco (AGS, CC PUEBLOS, leg. 2, doc. 100). 


\section{b. 2. La implantación del Corregimiento en Aranda.}

La promesa que hiciera la entonces princesa Isabel en 1473 al concejo arandino se mantuvo firme apenas siete años. El instrumento más utilizado por los monarcas para garantizar su control sobre las ciudades de realengo, el corregidor, fue impuesto en la villa en 1480 cuando Pedro del Castillo fue nombrado para ocupar este oficio por un año $^{726}$. Posteriormente se nombraron otros corregidores pero de manera intermitente y no fue hasta 1492 cuando se sucedieron los corregidores ininterrumpidamente con un mandato que se extendía entre uno y tres años ${ }^{727}$. En definitiva, en la capital de la Ribera se reprodujo el mismo fenómeno que en otros núcleos urbanos castellanos, el nombramiento extraordinario de oficiales reales para solucionar problemas concretos se convirtió en la configuración de un cargo municipal ordinario que se justificaba y asentaba su legitimidad en la aplicación del orden y la justicia ${ }^{728}$.

Evidentemente la imposición del corregidor como máxima autoridad coartaba las libertades y privilegios que en su momento juró la reina Isabel. Sin embargo, es reseñable que fueron los propios procuradores del Común los que en febrero de 1480 demandaron el envío de un oficial de la Corona para tratar de poner freno a los desmanes de los regidores de los caballeros ${ }^{729}$. La oligarquía, por su parte, escudándose en la defensa de los privilegios locales, rechazó la solicitud en una actitud claramente de salvaguarda de su estatus particular y de la autonomía en el ejercicio del poder. Los argumentos de procurar el bien común y el respeto de los fueros se convirtieron en la fachada que encubría la defensa a ultranza de su posición de élite del poder frente a la injerencia

${ }^{726}$ Es probable que Castillo no fuera el primer corregidor nombrado por los monarcas pues al establecer su sueldo, 200 maravedíes diarios, se señala que para obtenerlos ...fased repartimiento segud e por la via e forma que fasta aqui lo fesistes e acostumbraste faser para los otros corregidores que han seydo de la dicha villa (AGS, RGS, 148006, fol. 23). No obstante, estos corregidores a los que se refiere pudieran ser los que ya hemos citado anteriormente vinculados al rey de Navarra, el rey Enrique o la reina Juana.

${ }^{727}$ La relación y condición social de los corregidores arandinos han sido expuestas por DIAGO HERNANDO, M., "Cambios políticos e institucionales en Aranda de Duero desde el acceso al trono de los Reyes Católicos hasta la Revuelta Comunera", en Edad Media. Revista de Historia. 9, 2008, pp. 299342, en concreto pp. 302-308.

${ }^{728}$ GUERRERO NAVARRETE, “La política de nombramiento..., p. 105.

${ }^{729}$ La Comunidad pidió a los monarcas que enviaran un alcalde para impartir justicia pues la villa llevaba más de tres años en una situación insostenible porque los alcaldes ordinarios no cumplían con sus obligaciones. Los regidores de los linajes por su parte argumentaban que no era necesario el corregidor, pues sería suficiente con un pesquisidor. Los monarcas comisionaron en principio al bachiller Aguilera por cuarenta días para tratar de resolver los problemas (AGS, RGS, 148002, fol. 256). No obstante, recordemos que en junio de 1480 fue nombrado Pedro del Castillo como corregidor (148006, fol. 23). 
de la Corona $^{730}$. Por otro lado, la solicitud de justicia por parte de la Comunidad posiblemente no fuera más que la manifestación de su deseo de participar en el ejercicio del poder municipal.

Cuadro 3: Relación de los corregidores de Aranda entre 1480 y 1524.

\begin{tabular}{|l|l|l|}
\hline \multicolumn{1}{|c|}{ AÑO NOMBRE } & \multicolumn{1}{c|}{ OFICIO } \\
\hline 1480 & Pedro del Castillo & Corregidor \\
\hline 1483 & Nuño Orejón & Corregidor \\
\cline { 2 - 3 } $12 / 1483$ & Diego de Burgos & Juez de Residencia \\
\hline 1484 & Gonzalo Fernández de las Risas & Corregidor \\
\hline 1492 & Pedro Núñez de Peñalver & Corregidor \\
\hline \multirow{2}{*}{$1492-1494$} & Licenciado Francisco del Fresno & Corregidor \\
\cline { 2 - 3 } & Francisco Sánchez de Tapia & Juez de Residencia \\
\hline $1495-1497$ & Licenciado Pedro de Tórtolas & Corregidor \\
\hline $3 / 1498-08 / 1500$ & Licenciado Francisco de Herrera & Corregidor \\
\cline { 2 - 3 } & Gonzalo Lisón & Juez de Residencia \\
\hline $1500-1502$ & Gonzalo Lisón & Corregidor \\
\hline $1502-1504$ & Hernando de Gamarra & Corregidor \\
\hline 1505 & Francisco de Mercado & Corregidor \\
\hline 1506 & Sancho Pérez de Machuca & Corregidor \\
\hline $1506-1509$ & Francisco de Mercado & Corregidor \\
\hline $1509-1513$ & Diego de Soto & Corregidor \\
\cline { 2 - 3 } & Tristán de León & Juez de Residencia \\
\hline $1513-1517$ & Álvaro de Aldana & Corregidor \\
\hline 1518 & Juan Fernández Calvete & Corregidor \\
\hline $1520-1522$ & Juan Manrique de Luna & Corregidor \\
\cline { 2 - 3 } & Juan de Robles & Juez de Residencia \\
\hline 1524 & Rodrigo de Torres & Corregidor \\
\hline
\end{tabular}

Hasta el último decenio del siglo XV las noticias que tenemos de los corregidores son escasas: tan solo la toma de residencia al corregidor Nuño Orejón por parte de Diego de Burgos en diciembre de $1483^{731}$. Aunque Orejón ya había sido corregidor de Sepúlveda

${ }^{730}$ Oposición que también se aprecia en otros espacios urbanos castellanos como en las Cuatro Villas donde el rechazo del corregidor se materializa de forma más radical (SOLÓRZANO TELECHEA, J. A., "Elites urbanas y construcción del poder concejil en las Cuatro Villas de la Costa de la Mar (siglos XIII-XV)", en Ciudades y villas portuarias del Atlántico en la Edad Media. 2005, pp. 187-230). Sin embargo, BERMÚDEZ AZNAR señala que a un nivel más general la oposición al corregidor en las ciudades fue bastante discreta y que finalmente este oficial real se convirtió en el garante del mantenimiento del estatus de poder de las élites del gobierno local ("Los concejos y la administración del reino", en Concejos y ciudades en la Edad Media hispánica. Madrid, 1990, pp. 569-600).

731 AGS, RGS, 148312, fol. 82. Poco después, en marzo y julio de 1484, volvemos a tener noticias de este corregidor realizando una serie de investigaciones en Granada y Trujillo por orden de la Corona. 
no podemos afirmar que ya en los años ochenta el corregimiento arandino estuviera asociado al de Sepúlveda como ocurrirá a partir de $1492^{732}$.

Pero a partir de 1492 el panorama cambió radicalmente y la intervención del corregidor en los asuntos municipales se hizo patente. Así, por ejemplo, el bachiller Francisco González del Fresno, corregidor de Sepúlveda y Aranda, actuó en numerosos problemas, sobre todo jurídicos, que afectaban a la comunidad desde finales del año 1492 hasta febrero de $1494^{733}$. Los campos de actuación de este corregidor fueron muy amplios: desde los conflictos generados entre los vecinos de la villa y el Concejo de la Mesta por el tránsito de ganado; pasando por cuestiones relacionadas con la expulsión de los judíos; o problemas con los pueblos vecinos ${ }^{734}$.

Este individuo puede ser tomado como ejemplo para explicar las características de los oficiales que ejercieron como corregidores en esta villa a finales del siglo XV. Su procedencia fue siempre ajena al solar arandino, asegurándose de que no tenía ningún tipo de lazo familiar-afectivo en esta zona; gozaba de una condición social elevada y generalmente contaba con una titulación, ya fuera bachiller o licenciado ${ }^{735}$.

Tras la estancia del bachiller del Fresno, Francisco Sánchez de la Tapia actuó en Aranda como juez de residencia ${ }^{736}$. Entre 1495 y la primavera de 1497 ejerció como

${ }^{732}$ Tenemos noticias de la figura Sancho del Campo actuando de corregidor de Sepúlveda en 1479 (AGS, RGS, 147908, fol. 97). Después de Orejón fue nombrado corregidor de esta localidad segoviana Gonzalo Fernández de Risas y Pedro Núñez de Peñalver (148402, fol. 233; y 149007, fol. 70). No obstante, no tenemos ninguna noticia que asocie a estos personajes con el corregimiento arandino o con cualquier actividad en la Ribera.

${ }^{733}$ Sobre este personaje tenemos numerosas referencias. Sabemos que antes de ser nombrado corregidor de Sepúlveda y Aranda estuvo hasta agosto del 92 en Écija actuando de juez de términos. El ejercicio de su cargo lo realizó hasta febrero de 1494, momento en el cual Francisco Sánchez de la Tapia le tomó residencia (AGS, RGS, 149402, fol. 90). Fresno fue nombrado en noviembre de ese mismo año corregidor de Ávila.

734 AGS; RGS, 149312, fol. 41; 149303, fol. 157 y 149311, fol. 117; y 149304, fol. 166 y 149311, fol. 120

${ }^{735}$ Las características señaladas tienen evidentes paralelismos en otras villas del reino como, por ejemplo, Paredes de Nava, según lo refleja Martín Cea en El mundo rural castellano..., pp. 181-84.

${ }^{736}$ AGS, RGS, 149503, fol. 141. Este documento es un requerimiento para que el licenciado de la Tapia se presentara ante el Consejo Real por un supuesto abuso sobre un vecino arandino. 
corregidor el licenciado Pedro de Tórtoles ${ }^{737}$, a quien le tomó residencia el licenciado Francisco Francés ${ }^{738}$.

El licenciado Francisco de Herrera ocupó el corregimiento arandino entre marzo de 1498 y agosto del año 1500. Además de una importante relación de actividades desarrolladas en la villa, este corregidor tuvo un serio encontronazo con una de las poderosas familias de la oligarquía local pues acusó a Martín de Durango y sus familiares de injuriarle y proferir amenazas de muerte. Este incidente desencadenó un escandaloso proceso judicial que veremos más adelante ${ }^{739}$.

Gonzalo de Lisón actuó como juez de residencia a mediados del año 1500 y seguidamente fue designado como corregidor, ejerciendo el cargo entre los años 1501 y $1502^{740}$. Entre las instrucciones que recibió este corregidor destacó la de controlar que el regimiento cumpliera con sus obligaciones y deberes en un momento en el que los regidores estaban sumidos en cierta dejadez respecto a sus obligaciones municipales ${ }^{741}$.

En 1502 comenzó el activo mandato de Hernando de Gamarra que se alargó hasta 1504 y que ha dejado el impresionante testimonio del plano de la villa de todos conocido $^{742}$.

La muerte de la reina Isabel tuvo aparejada en la villa un cambio de corregidor y así desde 1505 hasta 1509 se desarrolló la actividad del medinense Francisco del Mercado. El momento de inestabilidad asociado al cambio dinástico llevó al concejo arandino a solicitar el reconocimiento de sus viejos privilegios y, por lo tanto, la destitución de Mercado como corregidor. Como respuesta a esta solicitud, el concejo recibió la confirmación de Mercado en su oficio ${ }^{743}$, si bien es cierto que el rey Felipe impuso durante su corto reinado a Sancho Pérez de Machuca en el cargo ${ }^{744}$. El hecho de que Mercado

737 AGS, CC PUEBLOS, leg. 2, doc. 3. En RGS, 149509, fol. 182, aparece citado como licenciado Torres pero parece tratarse de un error.

${ }^{738}$ AGS, RGS, 149705, fol. 166. El siguiente destino del licenciado Tórtoles fue ocupar el corregimiento de Santo Domingo de la Calzada.

${ }^{739}$ AGS, RGS, 149808, fol. 54.

${ }^{740}$ AMA, leg. 43, doc, 14.

${ }^{741}$ AMA, leg. 43, doc. 33.

${ }^{742}$ AGS, EMR, leg. 683; CR, leg, 39, doc. 3; y MPD, leg. X, doc. 1.

${ }^{743}$ AMA, leg. 43, doc. 17; y AGS, CC CÉDULAS, libro 7, leg. 130, exp. 2.

${ }^{744}$ AGS, CC PUEBLOS, leg. 2, docs. 97 y 107. 
fuera sustituido por un hombre del rey Felipe y restituido en su cargo tras la muerte del monarca nos hace pensar que seguramente el medinense se encontraba entre el personal de confianza del rey Fernando ${ }^{745}$.

Entre 1509 y 1513 se desarrolló el corregimiento más largo de este periodo que corresponde a Diego de Soto. Su primera actuación en la villa fue realizar el juicio de residencia de Mercado. La relación entre vecinos y corregidor no fue muy cálida pues el corregidor puso todo tipo de impedimentos para que se realizara el proyecto de mayor envergadura en la capital de la Ribera por aquel tiempo y que consistía en canalizar el río Aranzuelo hasta la villa y crear una serie de caños y molinos. Además fue denunciado por la Comunidad de la villa que le acusaba de cometer abusos sobre los vecinos y haber tomado 40.000 maravedíes a la villa $^{746}$.

Tras el juicio de residencia instruido por Tristán de León, fue nombrado como corregidor el caballero Álvaro de Aldana que permaneció en este cargo hasta $1517^{747}$. A diferencia de Soto, la impresión que dejó entre los vecinos la actuación de Aldana fue muy positiva y así el concejo solicitó a los monarcas en diciembre de 1517 que se le prorrogara el mandato ${ }^{748}$. Quizá en esto tuvo que ver su decidida apuesta por seguir los trámites para que la villa pudiera manifestar su queja ante el nuevo monarca por el nombramiento de don Juan de Zúñiga como alguacil de la villa ${ }^{749}$. Pero Aldana no fue renovado pues a partir de 1518 fue sustituido por Juan Fernández Calvete ${ }^{750}$.

En 1520 ocupaba el cargo de corregidor Juan Manrique de Luna, vecino de Burgos, que fue depuesto de su oficio por el gobierno comunero en septiembre de 1520 y no lo recuperó hasta mayo de 1521, llevando a cabo la represión sobre los arandinos

${ }^{745}$ Esta circunstancia reafirma la posibilidad de identificar a este Francisco de Mercado con el contino que pertenecía a la casa del Infante don Fernando. Además actuó como corregidor en Ciudad Rodrigo y finalmente se alineó en el bando comunero en 1520 (PÉREZ, J., La revolución de las comunidades de Castilla (1520-1521). Madrid, 1978, pp. 89, 475 y 486).

${ }^{746}$ AGS, CC PUEBLOS, leg. 2, docs. 103 y 104.

${ }^{747}$ AGS, CC PUEBLOS, leg. 2, doc. 67; y CC DIVERSOS, leg. 41, doc. 35.

${ }^{748}$ AGS, CONSEJO Y JUNTAS DE HACIENDA, leg. 4, doc 9.

${ }^{749}$ AGS, CONSEJO Y JUNTAS DE HACIENDA, leg. 4, doc 20. Prueba de ello es que hoy conocemos esta información gracias a que remitió traslado de todo el proceso al Consejo de Hacienda junto a la solicitud para realizar un repartimiento de 40.000 maravedíes para costear el viaje de los representantes del concejo a Flandes.

${ }^{750}$ AGS, CR, leg. 453, doc. 5. 
sublevados $^{751}$. Finalmente, Juan de Robles realizó el juicio de residencia a Luna en 1522 y Rodrigo de Torres actuó como corregidor en $1524^{752}$.

Así pues, se observa una clara continuidad en el nombramiento de corregidores por parte de la Corona desde 1492, si bien es cierto que el mayor volumen de las funciones vinculadas a este oficio fue desempeñado por un teniente de corregidor que estaba asentado permanentemente en la villa y que solía ser también experto en leyes. Entre estos delegados del corregidor destacaron las figuras de Juan del Valle, Alfonso de la Cadena, Juan de la Torre, Francisco de Ladero, Antonio Ruiz o Diego de Guadalajara ${ }^{753}$.

\section{b. 3. La proyección del corregidor sobre la comarca ribereña.}

Existen ya varias monografias que fijan claramente los cometidos de los corregidores en el gobierno del municipio, el mantenimiento del orden público y la administración de justicia de las ciudades y villas que tienen encomendadas ${ }^{754}$. El corregidor arandino participó muy activamente de todos los procedimientos y procesos relativos a estas funciones. Así, el corregidor o su teniente estaban continuamente presentes en todos aquellos actos que tenían un matiz administrativo o político como podían ser la elaboración de ordenanzas, el nombramiento de procuradores, las convocatorias de reuniones del ayuntamiento o de las cuadrillas, los reclutamientos de gentes de armas, la realización de repartimientos, la inspección de los espacios públicos como eran la cercas, puertas, peso, cárcel, mojones, pastos, montes, etc. Asimismo la documentación da cuenta de su intensa actividad como juez de primera instancia en la villa de Aranda y su comarca ${ }^{755}$.

Otra importante función del corregidor era la fiscal, actuando como garante del buen desarrollo de los procesos de arrendamientos o encabezamientos de rentas. Estos oficiales se encontraban presentes en cuantos remates se celebraban en la villa y con

${ }^{751}$ Tras su paso por Aranda su carrera experimentó una importante promoción al ser nombrado corregidor de Salamanca primero y después de Cuenca en la década de los 30.

${ }^{752}$ AGS, CR, leg. 450, leg. 8; y EH, leg. 878, doc. 14.

${ }^{753}$ Casi todos ellos eran licenciados o bachilleres.

${ }^{754}$ Las funciones judiciales, administrativas y políticas del corregidor han sido ampliamente estudiadas por BERMÚDEZ AZNAR, A., El Corregidor de Castilla durante la Baja Edad Media (13481474). Murcia, 1974, pp. 161 y ss. diencia Real.

${ }^{755}$ Información que nos ha llegado gracias a las numerosas apelaciones de litigantes ante la Au- 
bastante frecuencia se encargaban de perseguir a aquellos individuos que no cumplían con sus obligaciones contractuales, que culminaban habitualmente con la ejecución de sus bienes. El corregidor arandino también era el encargado de controlar el buen desarrollo de la actividad fiscal en los pueblos de la comarca. Hay muchas evidencias de esta actividad. A modo de ejemplo destacamos la gira que en 1501 realizó el corregidor Gonzalo de Lisón por buena parte de los pueblos de la Ribera para comunicar a los respectivos concejos la merced concedida por los monarcas de prorrogarles los encabezamientos de las alcabalas por otros cuatro años. El problema surgió cuando algunos de ellos rechazaron la prorroga y el corregidor se vio obligado a iniciar una pesquisa con la correspondiente declaración de testigos ${ }^{756}$.

Pero sobre todo el corregidor ejerció como agente político de los monarcas, tanto en la villa como en la comarca, aunque a finales de la centuria sobrepasó frecuentemente estos límites geográficos, ampliando significativamente su tradicional radio de acción.

Por una parte, en algunas ocasiones el corregidor fue el intermediario directo entre los intereses de los vecinos y los monarcas, delegando casi siempre estos últimos en el corregidor para que atendiera a las demandas de los vecinos según su criterio. Así se observa, por ejemplo en la apertura de la calle Barrionuevo en 1503 pues la decisión final de la reina se sustentó en el informe favorable emitido por Hernando de Gamarra ${ }^{757}$. En 1514 la reina Juana fue más explicita en el proyecto de canalización del río Aranzuelo presentado por el concejo y la comunidad franciscana ya que ordenó a su corregidor que ...luego veais lo susodicho e lo proveais e remedieis como vos vieredes que mas convenga al bien desa dicha villa e vesinos della que para ello vos doy poder complido, aunque bien es cierto que el oficial se demoró bastante en el cumplimiento de esta orden ${ }^{758}$. Un año después esta situación se repitió ante la posibilidad de habilitar una plaza frente a la fachada del monasterio de San Francisco a costa de unas casas de propiedad municipal ${ }^{759}$.

${ }^{756}$ Entre los pueblos que no aceptaron el encabezamiento se encontraban Arauzo de Salce, Quintana del Pidio y Ventosilla (AGS, EH, leg. 11).

${ }^{757}$ PERIBÁÑEZ OTERO y ABAD ÁLVAREZ, Aranda de Duero..., pp. 196-198.

${ }^{758}$ AGS, CC PUEBLOS, leg. 2, doc. 101 y 102.

${ }^{759}$ AGS, CC PUEBLOS, leg. 2, doc. 107. El Consejo Real ordenó que ...mande lo al corregidor o su lugarteniente que vea esto y sy viese que cumple al servicio y ornato del monasterio les de la calle que pide conforme a su parecer aunque la villa pierda el censo. 
Si en un primer momento se observa que sus competencias jurisdiccionales se limitaban a los territorios de realengo y behetrías de la comarca, desde los últimos años del siglo XV se aprecia que el espacio sobre el que ejercía sus funciones era cada vez más amplio. Así observamos que en los años finales del Cuatrocientos el corregidor recibió la misión de intervenir en lugares relativamente alejados como las tierras de Lerma y Lara, Huerta del Rey, Caracena, Fuencaliente, Ucero, o San Esteban. En buena parte de estas comisiones actuó tanto sobre dominios de señorío como de abadengo y su principal cometido fue ejecutar y garantizar la justicia real.

El carácter excepcional de estas intervenciones del corregidor arandino en un territorio ajeno a su jurisdicción lo manifestaba el propio oficial cuando, por ejemplo, en 1516 la priora del convento de Caleruega solicitó de los reyes que el corregidor de Aranda acudiera a Caleruega para impartir justicia pues se sentía amenazada por los vecinos de la villa. El corregidor se negó alegando que no era territorio de su jurisdicción y no estaba incluido en su salario. Una carta de la reina Juana ordenó que acudiera cuando la priora le requiriera ...mandando vos dar salario saliendo fuera de vuestra juredicion, estableciendo que ...llevedes de salario para vuestra costa e mantenimiento cada un dia de los que en lo susodicho entendieredes saliendo fuera de vuestra juredicion ciento e cinquenta maravedís los que ayades e cobredes e vos sean dados e pagados por las personas e bienes de los que en lo susodicho fallaredes culpados repartidos por cada uno dellos por rata según la culpa que toviere ${ }^{760}$.

Quizá esta circunstancia se debía a la mínima presencia de realengo en el amplio espacio comprendido entre el Pisuerga por el Oeste (Valladolid, Dueñas, Palencia), la Tierra Burgos por el Norte y Soria por el Este ${ }^{761}$. El corregidor arandino se convirtió por lo tanto en la prolongación del brazo real sobre un territorio fuertemente señorializado que se había mantenido al margen de la autoridad real durante buena parte de la Edad Media ${ }^{762}$.

${ }^{760}$ MARTÍNEZ LIÉBANA, Colección Diplomática..., doc. CL, pp. 187-190. Cuando el procurador del convento solicitó en 1570 que el corregidor acudiera a Caleruega esgrimía esta carta para establecer su salario en 150 maravedíes. El corregidor respondió que ese salario estaba desfasado pues ...entonces los alimentos y todas las demas cosas valian en muy bajos preçios... pero después aca todas las cosas se an subido en escesibos precios e por esto... mandandole su magestad dar salario competente esta presto de yr.

${ }^{761}$ LUNENFIELD, Los Corregidores..., pp. XII y XIII.

${ }^{762}$ Recordemos en este sentido la gran presencia de los señores de Lara o Haro en la Ribera burgalesa en la Plena Edad Media o la más reciente de los infantes de Aragón a lo largo de la primera mitad del siglo XV. 
En conclusión, se observa cómo la implantación del corregimiento en la villa de Aranda en los años finales de esta centuria supuso no sólo una cortapisa al poder político de los oficiales municipales, pues poco a poco los corregidores monopolizaron las funciones ejercidas hasta entonces por regidores y alcaldes, sino que también estrecharon el control de la Corona sobre la oligarquía urbana y, por lo tanto, sobre el funcionamiento político de la villa. Pero además se aprecia que la figura del corregidor adquirió en este periodo importantes cuotas de poder tanto en el gobierno de la villa como es obvio, como también a escala comarcal, extendiendo su radio de acción por aquellos espacios limítrofes ajenos al realengo ${ }^{763}$.

\subsubsection{La Hacienda Real.}

No menos importante fue el papel que jugó la Hacienda Real que se encargaba de buscar recursos para las múltiples actividades regias. Nada más comenzar el reinado de Isabel, las Cortes de Toledo de 1480 suprimieron la mitad de los juros y reintegraron a la Corona la mayor parte de las rentas y tierras enajenadas en favor de la nobleza desde 1464. Pero además se produjo un proceso de restauración y renovación del sistema fiscal que dio liquidez a la Corona para llevar a buen fin las múltiples empresas en las que se embarcó ${ }^{764}$.

La inmensa mayoría de las poblaciones que forman la comarca de la Ribera del Duero burgalesa estaba encuadrada en el partido fiscal de la Merindad de Santo Domingo de Silos. Excepcionalmente la villa de Aranda y su tierra constituía una demarcación fiscal propia ${ }^{765}$.

${ }^{763}$ Aspecto identificado también en otros espacios castellanos (DIAGO HERNANDO, M., "El papel de los corregidores en los conflictos políticos en las ciudades castellanas a comienzos del siglo XVI”, en En la España Medieval. 27, 2004, pp. 195-223, en concreto p. 198).

${ }^{764}$ Son numerosos los trabajos que durante los últimos años han abordado la problemática de la Hacienda Real. En su mayoría tienen como punto de partida la obra de LADERO QUESADA, M. A., La Hacienda Real en Castilla en el siglo XV. La Laguna, 1973. Otros estudios importantes son: del mismo autor "Estado y Hacienda en Castilla durante la Baja Edad Media"; y MACKAY, A., "Hacienda y Sociedad en la Castilla Bajomedieval", en Estado, Hacienda y Sociedad en la Historia de España. Valladolid, 1989, pp. 13-43 y 47-78, respectivamente; o los diferentes trabajos coordinados por MENJOT, D. y SÁNCHEZ MARTÍNEZ, M., en Fiscalidad de Estado y fiscalidad municipal en los reinos hispánicos medievales. Madrid, 2006. Para el estudio de la fiscalidad en los primeros años del siglo XVI en los partidos de la Ribera destaca la tesis de ALONSO GARCÍA, D., Fisco, poder y monarquía en los albores de la modernidad: Castilla 1504-1525. Universidad Complutense de Madrid, 2004 http://eprints.ucm.es/tesis/ghi/ucm-t27728.pdf (consultada el 24/09/2011).

${ }^{765}$ Entiéndase el partido fiscal como una entidad geográfica adscrita a un tributo, en este caso las alcabalas y tercias. 
Como en el resto de Castilla, en la Ribera se recurrió a dos mecanismos fiscales de recaudación. Por una parte, el arrendamiento de las rentas fue el procedimiento más habitual durante los primeros años del reinado de los Reyes Católicos. Consistía en una subasta pública en la que un particular adquiría el compromiso de recaudar unas determinadas rentas de un partido fiscal a cambio de un prometido más las posibles ganancias resultantes. En el partido fiscal de Aranda este fue el método que se utilizó hasta el año 1500 , para después retomarse entre los años 1503 y $1511^{766}$. En este sentido, son varios los vecinos de la comarca que se dedicaron al negocio del arrendamiento de rentas. En 1462 el judío vecino de Coruña del Conde, Santo Abarhí, pujó en Medina del Campo por las alcabalas de la Merindad de Santo Domingo aunque finalmente fueron los arandinos Álvaro de Ávila y Lope Sánchez de Durango los que se hicieron con ellas $^{767}$. Pero sobre todo fue el arandino Pedro de Santa Cruz quien más destacó en la gestión de estos arrendamientos, bien como arrendador mayor, o bien asociado a personajes de gran peso en la Hacienda Real como Salomón Seneor ${ }^{768}$. Lejos de circunscribirse al espacio próximo, Santa Cruz formó una importante compañía que pujó por diversas rentas tanto reales como diocesanas ${ }^{769}$. En esta empresa se embarcó junto a sus convecinos Francisco de Mena y Pedro de Berlanga. En ocasiones también actuaron como fiadores miembros de la nobleza local como don Juan de Acuña, don Francisco Hurtado de Mendoza o don Bernardino de Avellaneda ${ }^{770}$.

El otro procedimiento incorporado a la Hacienda Real desde mediados de los años noventa fue el encabezamiento por el que las entidades locales se encargaban del cobro de las alcabalas y tercias comprometiéndose a entregar una cantidad global a la

\footnotetext{
${ }^{766}$ AGS, EH, leg. 4; y ALONSO GARCÍA, Fisco, poder..., vol. I, pp. 647-648.

${ }^{767}$ AGS, EMR, leg. 11, docs. 11 y 12.

${ }^{768}$ DIAGO HERNANDO, M. “Arrendadores arandinos al servicio de los Reyes Católicos”, en
} Historia, Instituciones, Documentos. 18, 1991, pp. 71-76; y PERIBÁÑEZ OTERO, J. G., "Violencia y espacio urbano. La percepción espacial de las relaciones sociales entre judíos, mudéjares y cristianos en la Ribera del Duero burgalesa", en Castilla y el mundo feudal. Valladolid, 2009, Vol. II, pp. 25-42, en especial p. 29.

${ }^{769}$ Entre estas rentas se encontraban los diezmos y aduanas de los obispados de Calahorra, Osma y Sigüenza; las alcabalas y tercias de Calahorra y la merindad de Logroño; las rentas de la merindad de Cerrato; las herrerías de Vizcaya; el impuesto de Canarias; las alcabalas y el salín de San Vicente de la Barquera; y el almojarifazgo de Sevilla (CASADO ALONSO, "El Duero oriental..., p. 35).

${ }^{770}$ AGS, EMR, leg. 121, doc. 1; y DIAGO HERNANDO, M. “Arrendadores arandinos..., . 
Corona $^{771}$. Este segundo método permitía que los concejos participaran de los beneficios de la recaudación $y$, por extensión, también las oligarquías locales que gestionaban el proceso. Un primer intento se produjo en 1501 cuando la villa de Aranda y buena parte de los pueblos de la Merindad de Santo Domingo recibieron la merced de encabezar las tercias y alcabalas. Sin embargo, no tuvo mucho éxito pues, aunque los monarcas decidieron prorrogar la merced para el año 1502, varias localidades renunciaron a este derecho por considerar el precio fijado muy gravoso para los concejos $^{772}$. En Aranda se mantuvo el año 1502 pero de nuevo en 1503 se optó por el arrendamiento $^{773}$. De nuevo en 1511 se retomó el encabezamiento y ya no se abandonó durante todo el primer cuarto del siglo $\mathrm{XVI}^{774}$. Algunos de los pueblos de la Ribera también optaron por este procedimiento desde 1505 enviando a sus procuradores a la Corte para obtener de los monarcas la licencia para el encabezamiento de las alcabalas y $\operatorname{tercias}^{775}$.

En ambos procedimientos bien el arrendador mayor o el concejo subarrendaban las diferentes rentas que formaban el conjunto de las tercias y alcabalas. Este proceso se hacía mediante subasta pública, que en el caso de Aranda se celebraba ...en el auditorio de la plaza de Santa Maria de la dicha villa donde se suelen faser las rentas de las alcabalas $^{776}$, ante el Escribano Mayor de Rentas, el arandino Pedro García de Aranda $^{777}$. En esta subasta participaba buena parte de los vecinos más pudientes de la villa.

771 Para LADERO QUESADA este procedimiento se habilitó por parte de los monarcas como consecuencia, por una parte, del debilitamiento de las compañías de recaudadores derivado del proceso de expulsión de los judíos y, por otra, de la necesidad de pacificar los ánimos en las ciudades, alejando a los conversos de la actividad fiscal ("Corona y ciudades en la Castilla del siglo XV", en En la España Medieval. 8, 1986, pp. 551-574, en especial p. 570).

${ }^{772}$ AGS, EH, leg. 11.

${ }^{773}$ AGS, EH, leg. 4.

${ }^{774}$ ALONSO GARCÍA, Fisco, poder y monarquía..., vol. I, pp. 647-648.

${ }^{775}$ Los poderes de los concejos se encuentran en AGS, EMR, leg. 687. Entre los solicitantes se encuentran las localidades de Alcoba de la Torre, Aldeanueva de la Serrezuela, Arauzo de Salce y Torre, Baños de Valdearados, Fresnillo, Fuentelcésped, Hontoria, Moradillo, Vadocondes,...

${ }^{776}$ AGS, EMR, leg. 4.

${ }^{777}$ El primer escribano mayor de rentas del que tenemos noticias fue Pedro García de Aranda en la segunda mitad de la década de los setenta. Tras su muerte le sucedió su hijo Pedro de Mora que ocupó este cargo hasta 1505 (AGS, EMR, leg. 4). Posteriormente el secretario Pedro Ximénez recibió la escri- 


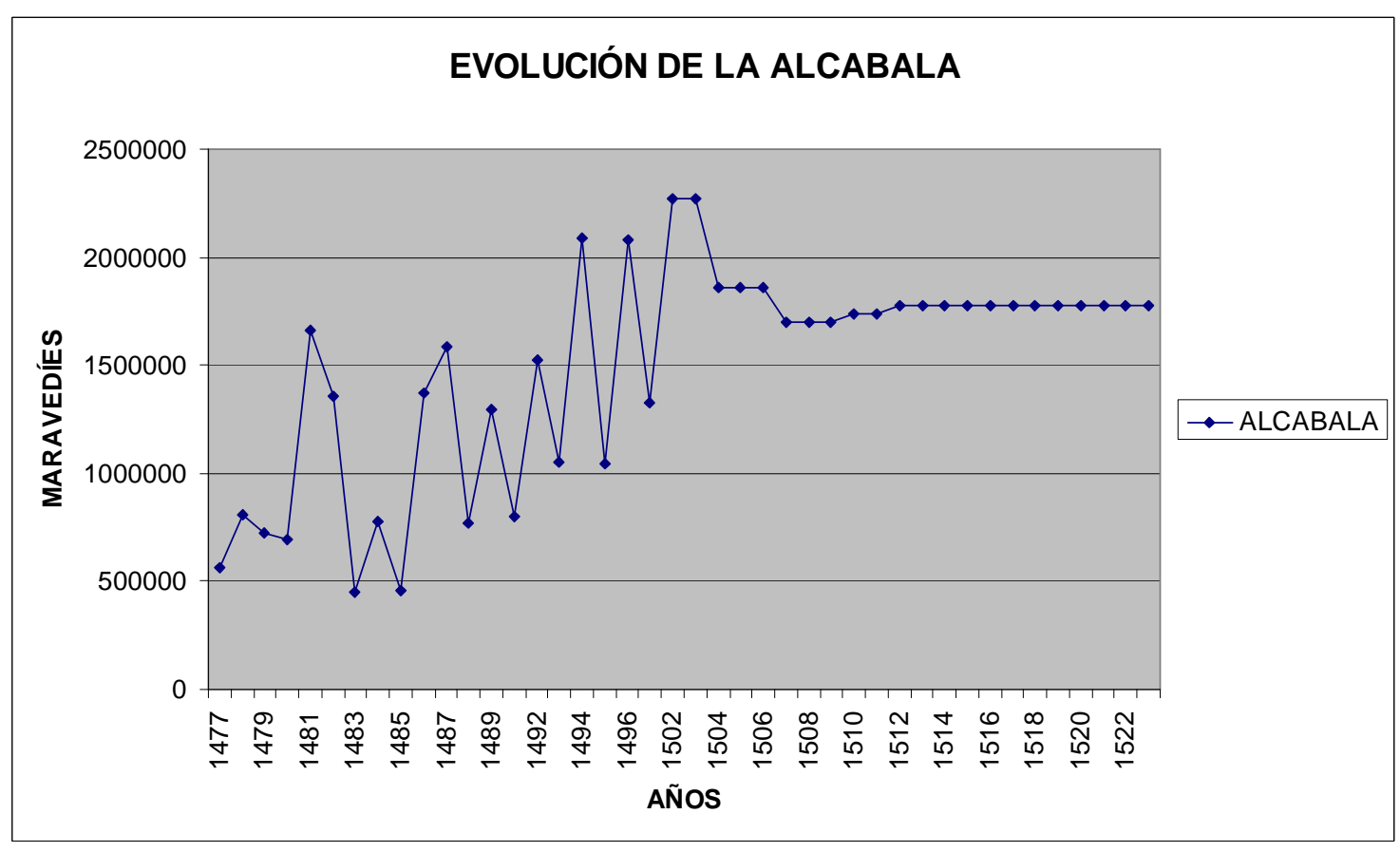

Cuadro 4: Evolución de las alcabalas en la villa de Aranda (1477-1523).

En cuanto a la suma de las rentas reales en el territorio de la Ribera burgalesa los datos que conocemos en la actualidad nos dejan aproximarnos a su significado, sobre todo en el caso de la Villa de Aranda gracias a su configuración como partido fiscal. Sin ánimo de entrar en un estudio pormenorizado, los datos fiscales de Aranda en los últimos años del siglo XV y el primer cuarto del siglo XVI muestran una serie de características bastante significativas.

En primer lugar, se aprecia desde los años setenta del Cuatrocientos un crecimiento sostenido hasta 1503 . No obstante, estos datos deben ser observados con cierta cautela y aplicar los necesarios ajustes monetarios. A nuestro entender este crecimiento es otro de los síntomas que confirma la fase expansiva de la economía local en este periodo. A partir de 1504 la cuantía mermó considerablemente debido sin duda a la crisis generalizada que sacudió Castilla por aquellos años. A partir de 1511 el recurso sistemático al encabezamiento y la política real de garantizar unos ingresos más fiables hicieron que el monto de las rentas reales se estancara no permitiéndonos apreciar las variaciones de la actividad económica arandina.

banía del rey Felipe I. En noviembre de 1507 el rey Fernando hizo merced de este oficio al arandino Pedro de Ormaza (ALONSO GARCÍA, Fisco, poder y monarquía..., Vol. I, pp. 345-346). 
Como no podía ser de otra manera, la alcabala del vino fue el principal recurso fiscal que generó la villa. Sin embargo, el arrendamiento de esta alcabala chocaba en bastantes ocasiones con varios inconvenientes. Por una parte, su elevada cuantía no estaba al alcance de los arrendadores locales habituales y frecuentemente quedaba en manos de los arrendadores mayores que recurrían al mecanismo de la fieldad. Pero además se trataba de una renta un tanto compleja a la hora de recaudarla pues existían numerosos corredores y contadores, situación que fomentaba el fraude fiscal ${ }^{778}$.

Por último, el gran peso específico de la alcabala del vino en las rentas reales, además de confirmar el tópico de una economía en extremo dependiente del cultivo de la vid, la elaboración del vino y su comercialización, también permite reconstruir vagamente la microeconomía ribereña gracias a las acusadas fluctuaciones de esta renta, que tenían que ver tanto con fenómenos naturales, como las heladas o el solano que mermaban las $\operatorname{cosechas}^{779}$, o las vicisitudes del mercado que obligaba a malvender o tirar el vino que no había podido ser vendido ${ }^{780}$.

Parece claro que la consolidación de la Hacienda Real jugó un importante papel dentro de la política general de los monarcas castellanos a finales de la Edad Media a través de la uniformización de los tributos y la organización de su recaudación. Pero también observamos que en la Ribera la actividad recaudatoria se convirtió en un campo más para el desarrollo de los negocios de algunos individuos que se especializaron en el arrendamiento de rentas. Asimismo estas rentas deben ser consideradas como una importante fuente de información que permite comprender mejor la realidad socioeconómica de este territorio.

${ }^{778}$ Los representantes de las cuadrillas denunciaban en 1491 los abusos en el cobro de la renta del vino y señalaban que ...en la qual dicha renta se han fecho e fazen muchos fraudes e engaños (AGS, CC PUEBLOS, leg. 2, doc. 88).

${ }^{779}$ AGS, CMC, leg. 355; y RGS, 148909, fol. 106. En buena lógica, la variabilidad de las cosechas tuvo su repercusión sobre la percepción de la correspondiente alcabala y, por lo tanto, en el monto final. No obstante, también han de tenerse en cuenta los importantes problemas que tuvieron los arrendadores y recaudadores de la alcabala del vino a la hora de subastarla y cobrarla. A falta de un análisis más preciso, el estudio de los alcances de este periodo deja entrever que en alguna ocasión el monto final derivado de la venta del vino pudo ser parcial debido a problemas de recaudación o de otro tipo.

${ }^{780}$ En 1440 el señor de Aranda, a la sazón don Juan de Navarra, impuso el estanco del vino. Los vecinos rápidamente presentaron sus quejas pues ...si el tal estanque se diese lugar que çesaria la saca e los que alli suelen venir por el dicho vino avrian de yr a otras partes por ello e aun que çesarian e se mermaria el meneo de los mercados de esa dicha villa e vendrian muy grandes daños e otros enconvinientes dello a las rentas de las alcavalas desa dicha villa e su tierra (AMA, leg. 43, doc. 7, transcrito por HURTADO QUERO, Documentos Reales..., doc. 5, pp. 13-14). 


\subsubsection{La uniformidad religiosa: el Tribunal de la Inquisición en la Ribera.}

Un último punto en lo que se refiere al ejercicio de la autoridad real es el de la política de unificación religiosa y la actividad del Santo Oficio en la persecución de las prácticas al margen de la ortodoxia católica. Abundantes y variados han sido los estudios que durante las últimas décadas se han centrado en este asunto, como asimismo han sido múltiples las interpretaciones. Este no es el lugar para hacer una revisión sobre estos trabajos, pero sí que creemos oportuno destacar el hecho de que la complejidad del aparato represor de la Inquisición ha llevado a buena parte de los especialista en la materia a afirmar que se trataría de un instrumento de unificación política en el ámbito de la consolidación del Estado Moderno, especializado en eliminar todo tipo de disidencia utilizando para ello la salvaguarda de la ortodoxia de la fe católica ${ }^{781}$. Buena prueba de esta afirmación es la rápida actuación del Tribunal en la comarca ribereña que contaba con una importante y activa comunidad conversa, tanto en los momentos previos como en los posteriores a la expulsión de los judíos. La idea del Santo Ofício como un instrumento para velar por el orden público, independientemente de su componente religioso, se aprecia también en el imaginario colectivo como lo muestran las injurias que Juan Rodríguez recibió de su primo Juan de la Torre en la plaza pública de la villa ante los alcaldes y regidores calificándole de ...ruin onbre e traydor rebolvedor de pueblos e y por eso devia ser quemado ${ }^{782}$.

La creación de la Inquisición en el Obispado de Osma tuvo lugar en enero de $1489^{783}$, aunque bien es cierto que se conocen testificaciones de vecinos arandinos

${ }^{781}$ PÉREZ, J., “Los Reyes Católicos 1476-1516”, en Tuñón de Lara (Dir.) Historia de España. Vol. V. Barcelona, 1989, pp. 139-75, en especial p. 158; GARCÍA CÁRCEL, R., "Orígenes y naturaleza de la Inquisición", en 1490, en el umbral de la modernidad: el Mediterráneo europeo y las ciudades en el tránsito de los siglos XV-XVI. Valencia, 1994, vol. 1, pp. 425-436; y ALCALÁ, A., "La política religiosa de los Reyes Católicos. La Inquisición. La expulsión de los judíos" Isabel la Católica y la política. Valladolid, 2001, pp. 117-156. En esta misma línea interpretativa destaca la obra del profesor NETANYAHU, B., Los marranos españoles desde finales del siglo XIV a principios del XVI según las fuentes hebreas, Valladolid, 1994; Los orígenes de la Inquisición en la España del siglo XV, Barcelona, 1999; y "Causas y fines de la Inquisición española”, en Isabel la Católica y la política. Valladolid, 2001, pp. 315-331. Una visión de conjunto se puede ver en NARBONA VIZCAÍNO, R., "La introducción de la Inquisición en las ciudades de Castilla y de la Corona de Aragón”, en Tolerancia y fundamentalismo en la Historia. Salamanca, 2007, pp. 53-98.

${ }^{782}$ AGS, RGS, 149012, fol. 330.

${ }^{783}$ CONTRERAS, J. y DEDIEU, J. P., "Estructuras geográficas del Santo Oficio en España”, en Historia de la Inquisición en España y América. Madrid, 1993. Vol. II, pp. 3-47, en concreto p. 31. 
previas realizadas ante los tribunales de Segovia o Valladolid ${ }^{784}$. Lo cierto es que la actividad inquisitorial en la comarca se desarrolló con cierta celeridad pues se constata la presencia del Tribunal durante los dos últimos meses de ese mismo año y en $1490^{785}$. A este último año corresponde la celebración de un Auto de Fe en la villa de Aranda en el que se produjo la ejecución en la hoguera de dos vecinos, Diego Sánchez de Roa y Alonso Sánchez Traspaso ${ }^{786}$, junto a maestre Juan, cirujano y vecino de Coruña del

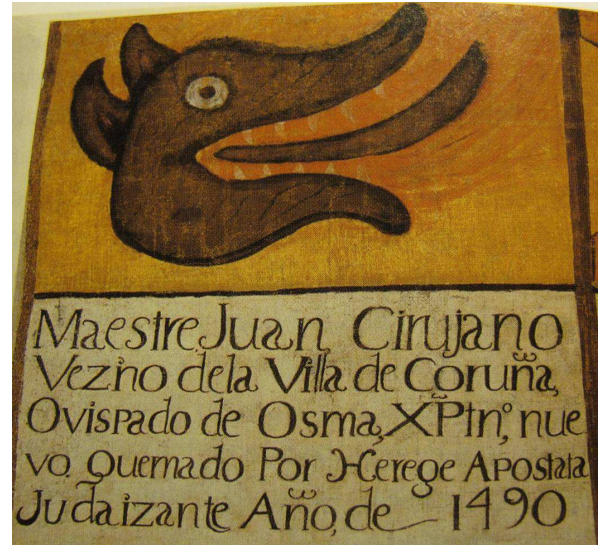

Conde, como nos recuerda una inscripción conservada en la iglesia coruñesa $^{787}$.

Imagen 41: Sambenito de maestre Juan. Maestre Juan Cirujano vezino de la Villa de Coruña, Ovispado de Osma, Cristiano nue vo Quemado Por Herege Apostata Judaizante Año de 1490.

${ }^{784}$ La primera noticia documental del Tribunal de la Inquisición de Segovia fue la declaración de Pedro García de Henares, vecino de Aranda, el 27 de enero de 1486 (AGS, PATRONATO REAL -PR-, caja 28, doc. 73, fol. 417r; y CONTRERAS y DEDIEU, "Estructuras geográficas..., p. 38). También a este tribunal pertenecen dos declaraciones fechadas el 22 de diciembre de 1488. A la Inquisición de Valladolid y Palencia corresponde la declaración fechada el 2 de abril de 1489. Los testimonios recogidos entre el 15 de noviembre y el 4 de diciembre de 1488 en Roa y Aranda parecen ser un error del copista al fechar hojas sueltas que pueden pertenecer bien al año 1489 o a 1501 (AGS, PR, leg. 28, doc. 73, fol. 389).

${ }^{785}$ Contamos con varios testimonios de la presencia de la Inquisición en la villa arandina, bien imponiendo penas (AGS, CONSEJO Y JUNTA DE HACIENDA, leg. 1, doc. 61) o reclamando rentas (CC PUEBLOS, leg. 2, doc. 68).

${ }^{786}$ En el Libro de declaraciones... son muy numerosas las referencias de los testigos sobre estas ejecuciones aunque nunca señalan una fecha concreta. En lo que sí coinciden muchos de ellos es en que la mayoría de los testigos que los inculparon eran falsos. De Diego Sánchez de Roa sabemos que fue alcalde de la villa en 1480 (AGS, EH, leg. 4) y que ya había tenido anteriormente encontronazos con la justicia y había sido acusado de alborotador ...hasiendo ligas e monipodios e consideraciones e rebolviendo los unos con los otros (RGS, 148711, fol. 72) y de defender a los conversos (CC MEMORIALES, leg. 149, doc. 173). De Traspaso no sabemos nada.

${ }^{787}$ Esta inscripción aparece junto a otras cinco y ha sido publicada, junto a la de Alonso de Soria, por ABAD ZAPATERO, J. G. Caminos de Silos. Valladolid, 1982, p. 110. CADIÑANOS BARDECI publicó también las otras tres con las fotografías de todas ellas. Junto a la inscripción de maestre Juan aparece el dibujo de un dragón que lanza una gran llama por la boca. Las otras inscripciones van acompañadas de los correspondientes sambenitos con forma de cruz de San Andrés roja sobre fondo amarillo. Una de ellas corresponde también al año 1490 y pertenece a María la Navarra, vecina de Coruña y cristiana nueva, reconciliada por hereje, judaizante y apóstata. Este autor informa de la declaración de un testigo en 1641 que aseguraba que en la iglesia de Santa María de Aranda se guardaban sambenitos de los años 1489, 1490 y 1492, correspondientes a Alonso González, platero, y otros relajados entre los que estaba el cura de Villalba. También indica que existía la tradición de que en la villa se había celebrado el Auto de Fe más antiguo de Castilla la Vieja ("Judíos y moros en el Duero arandino", en Biblioteca 18. Estudio e Investigación. 2003, pp. 57-74, en concreto pp. 70-72). 
Tras este primer momento de gran intensidad, la actividad del Santo Oficio se centró en la identificación de prácticas contrarias a la ortodoxia y en la persecución de conversos. Las referencias sobre la presencia del Tribunal en esta zona a finales del siglo XV son bastante esporádicas e indirectas.

El principal periodo de actividad de la Inquisición en la comarca ribereña se desarrolló en los meses finales de los años 1500 y 1501. Pero sobre todo destaca la continua presencia de los oficiales inquisitoriales durante el año 1502. Esta persistencia provocó una notable psicosis colectiva que se materializó en el aumento considerable de las declaraciones ante el tribunal pero, sobre todo, en la generalización de un estado de miedo y desconfianza absoluto como lo ponen de manifiesto los testimonios de algunos vecinos. Baste el ejemplo de cinco vecinas de Quintana del Pidio. Un sábado de diciembre de 1501 estaban cociendo pan y comentando la llegada de la Inquisición a la villa. Una de ellas comentó: Por mi vida que he miedo. Tras un intercambio de opiniones, una tal Juana sentenció: Maldito el miedo, que agora lo tengo, que todo es sacadinero. Apenas unos días después las otras cuatro se presentaron en Aranda para denunciar a la dicha Juana ${ }^{788}$. La presencia de los reverendos padres inquisidores se proyectó amenazante por todos los rincones de la Ribera del Duero, como veremos más adelante.

Pero la violencia, persecución y exclusión social de los conversos no fue un monopolio de la Inquisición. Los grupos de cristianoviejos ribereños también crearon y utilizaron mecanismos que, con el argumento de la pureza -evidentemente racial-, apartaban del camino de la integración social a los nuevos cristianos. Este es el caso de las autoridades de la Cofradía de San Pedro de la villa de Aranda que expulsaron de su seno a unos cofrades acusados de tener sangre judía, provocando con esta decisión enfrentamientos y gastos $^{789}$.

${ }^{788}$ CARRETE PARRONDO, Fontes Iudaeorum..., docs. 293-296, pp. 126-127.

${ }^{789}$ El concejo denunciaba ante los reyes en 1503 que ... ay una cofadria de la adbocacion de San Pedro que en ella no pueden reçebir a ninguna persona que benga de sangre de judios; de que a cabsa dello se han recreçido muchas enemistades y aun oy dia las ay; que aunque sea un onbre ydalgo de padre e habuelos sy en alguna manera toca en qualquier parte de confeso non lo reçiben; e sy por caso lo han reçebido y despues lo saben lo hechan fuera; y sobre semejante caso se an gastado muchas cuantias de maravedies y hizose con mala yntencion para robarlos y fueron a la chançelleria y los quisieron punir y castigar y queman las ordenanças (AGS, CC PUEBLOS, leg. 2, doc. 94 y ARChV, RRE, caja 150, doc. 50). 
En conclusión, los instrumentos configurados por los monarcas para conseguir la consolidación de una Corona fuerte y pergeñar el desarrollo de un Estado Moderno tuvieron su repercusión sobre la comarca de la Ribera del Duero de una manera muy notable pues se transformaron significativamente las estructuras del poder político local y, en consecuencia, también la realidad socioeconómica de este territorio.

\section{2. Relaciones con los distintos poderes del reino.}

Además de los mecanismos que hemos comentado en el apartado anterior, los soberanos también establecieron los principios rectores de las relaciones entre la monarquía y los diferentes poderes del reino: nobleza, clero y concejos ${ }^{790}$. A continuación trataremos de perfilar brevemente la relación de la monarquía con estos poderes como paso previo para identificar a los actores concretos del panorama de poder en el territorio ribereño.

Las relaciones de los Reyes Católicos con el clero se basaron desde un principio en intentar controlar a los individuos que ocupaban las altas dignidades eclesiásticas por cuanto comportaban una importante participación en la riqueza económica del reino, además de tener una gran influencia política y social. Por ello la reina Isabel solicitó a la Santa Sede la concesión de la capacidad de nombrar a los altos cargos en sus territorios (Derecho de Patronato y Presentación). En un primer momento no lo consiguió y tuvo que conformarse con el derecho de "súplica" que supuso en la práctica los mismos efectos que el de presentación. El tira y afloja entre los reyes y el Papado fue continuo hasta que en 1523 Carlos I obtuvo estos derechos, aunque previamente se había conseguido el derecho de patronato para Granada en 1486 y poco después para Canarias y los territorios americanos ${ }^{791}$.

\footnotetext{
${ }^{790}$ En la elaboración de este apartado sobre la política regia en el reinado de los Reyes Católicos hemos utilizado fundamentalmente la información y estructura de VAL VALDIVIESO, M. I. "Las líneas maestras de la obra política isabelina en Castilla", en Sociedad y Economía en tiempos de Isabel la Católica. Valladolid, 2002, pp. 265-283; y PÉREZ, “Los Reyes Católicos..., pp. 139-75.

${ }^{791}$ La relación diplomática de los Reyes Católicos con los diferentes Papas, y en concreto con Alejandro VI, ha sido abordada por FERNÁNDEZ DE CÓRDOVA MIRALLES, A., Alejandro VI y los Reyes Católicos. Relaciones político-eclesiásticas. Roma, 2005.
} 
La pretensión de doña Isabel en este sentido fue doble. Por un lado, mantuvo una constante lucha contra la injerencia extranjera que suponía tener a eclesiásticos italianos ocupando obispados castellanos. Ejemplo de esta situación fue el nombramiento en 1482 del sobrino del Papa Sixto IV, Rafael Sansoni Riario, como obispo de Osma ${ }^{792}$. Pero además la reina pretendía controlar el poder de la Iglesia colocando a hombres de su confianza en las principales sedes castellanas, en la medida de lo posible, no vinculados con las grandes familias aristocráticas. Buena prueba de esta dinámica fue el respaldo que hombres como Cisneros, Talavera o Deza dieron a su proyecto político ${ }^{793}$.

En la relación de la monarquía con el poder de la Iglesia encontramos otros dos objetivos de carácter secundario. El primero de ellos fue el intento de reformar el clero adaptando su vida a la práctica evangélica y primando su formación intelectual ${ }^{794}$. El segundo se encaminó a luchar por conseguir el sometimiento del clero a la jurisdicción real en los asuntos no espirituales. De ambos objetivos encontramos ejemplos en la Ribera como ponen de manifiesto las disposiciones del Concilio de Aranda de 1473 para el primero y los constantes conflictos que a lo largo del reinado se produjeron respecto al segundo ${ }^{795}$. Ambos aspectos serán abordados más adelante con profundidad.

Tradicionalmente se ha presentado a la reina Isabel como la gran vencedora frente a los intereses de la aristocracia. Sin embargo, la reina fue consciente de que para consolidar la fortaleza de la Corona era necesario tener una nobleza fuerte. La hipótesis del enfrentamiento reyes-nobleza se disipa ante la evidencia del fortalecimiento social y económico de la aristocracia castellana que culminó con la generalización del mayorazgo a partir de $1505^{796}$. Y es que la relación de la monarquía con la nobleza no

\footnotetext{
${ }^{792}$ PORTILlO CAPILlA, T., Instituciones del Obispado de Osma. Soria, 1985, pp. 58-59.

${ }^{793}$ VAL VALDIVIESO, “Las líneas maestras..., pp. 271-76.

${ }^{794}$ GARCÍA ORO, J., Cisneros y la reforma del clero en España en tiempos de los Reyes Católi-
} cos. Madrid. 1971; y BONACHÍA HERNANDO, J. A., "La Iglesia en Castilla, la reforma del clero y el Concilio de Aranda de 1473”, en Biblioteca 25. Estudio e Investigación. 2011, pp. 269-298.

795 PÉREZ, J., "Los Reyes Católicos..., pp. 153-5; SÁNCHEZ HERRERO, J., "El clero en tiempos de Isabel I de Castilla", en Sociedad y Economía en tiempos de Isabel la Católica. Valladolid, 2002, pp. 151-181; RUBIAL GARCÍA, A., "Isabel de Castilla y los movimientos religiosos en España durante su reinado. Su impacto en América”, en Isabel la Católica y la política. Valladolid, 2001, pp. 351-362.

${ }^{796}$ ATIENZA HERNÁNDEZ, I., "La aristocracia en tiempos de Isabel I de Castilla: una aproximación cuantitativa y cualitativa”, en Sociedad y Economía en tiempos de Isabel la Católica. Valladolid, 2002, pp. 133-49. 
se basaba en el enfrentamiento sino en la iniciativa de contrarrestar y reconducir el inmenso poder nobiliar; dinámica que posibilitó, por ejemplo, el acceso de doña Isabel al trono. Con este fin los reyes llevaron a cabo una serie de medidas que comenzaron por la recuperación del patrimonio real enajenado por los nobles en los últimos años del reinado de Enrique IV; pasaron por el nombramiento de Fernando como Maestre de las Órdenes Militares; y culminaron con la relativa marginación de la alta nobleza de los órganos decisorios del gobierno real ${ }^{797}$. En definitiva, doña Isabel controló a la nobleza, lo cual no fue impedimento para que durante su reinado esta nobleza se consolidara como la principal fuerza socioeconómica del reino y, como veremos más tarde, de la Ribera del Duero ${ }^{798}$.

La presencia de la aristocracia en las tierras ribereñas fue muy limitada al comienzo del periodo que estudiamos pues estas tierras fueron controladas por linajes de segunda fila, encuadrados dentro de lo que la historiografía tradicional ha denominado la "nobleza nueva", aunque bien es cierto que emparentados o vinculados con la aristocracia ${ }^{799}$. Se trata de los Avellaneda, Zúñiga, Sandoval, Girón, de la Cueva o Mendoza. Sin embargo, el cambio dinástico en la Castilla de comienzos del XVI supuso una clara evolución en el seno de esta nobleza que se identificó paulatinamente con los intereses de los nuevos monarcas, labrándose una carrera política que les permitió escalar a los más elevados órganos decisorios del nuevo Estado.

El otro gran pilar sobre el que se asentaba el reinado de los Reyes Católicos fue el de las ciudades. En su relación con las instituciones de gobierno municipal, los concejos, los monarcas aplicaron un alto grado de intervención a la vez que afirmaron los mecanismos que consolidaron el monopolio que la oligarquía urbana ejercía sobre la administración local.

Las ciudades castellanas a lo largo de todo el siglo XV sufrieron en su seno grandes dosis de violencia e inestabilidad con el enfrentamiento de los linajes-bandos por el control del poder municipal. Tras una primera iniciativa encaminada a conseguir la pacificación en el seno de la sociedad urbana, la política de los Reyes Católicos no

${ }^{797}$ PÉREZ, J., “Los Reyes Católicos..., pp. 152-153.

${ }^{798}$ VAL VALDIVIESO, “Las líneas maestras..., pp. 282-83.

${ }^{799}$ MOXÓ, S., "De la nobleza vieja a la nobleza nueva. La transformación nobiliaria castellana en la Baja Edad Media", en Cuadernos de Historia. Anexos de la revista Hispania. 3, 1969, pp. 1-210. 
fue otra que la de consolidar a los miembros de la oligarquía urbana en sus oficios dentro del concejo con medidas tales como el nombramiento de regidores perpetuos y la aceptación tácita del carácter hereditario de los oficios concejiles ${ }^{800}$. Todo ello llevó a la consolidación de una oligarquía urbana que extendió su control sobre la vida social y reguló, sistemáticamente y en su provecho, las relaciones productivas ${ }^{801}$. Pero el precio a pagar fue la desaparición de su relativa autonomía política y la supeditación a las directrices de la Corona como veremos más adelante en el caso de la villa de Aranda de Duero.

\section{LA VILLA DE ARANDA DE DUERO.}

El principal núcleo urbano de la Ribera del Duero es el objeto de análisis de este segundo apartado. Su condición de realengo y su propia dinámica socioeconómica convirtieron a esta villa en uno de los principales actores políticos del periodo estudiado.

A continuación analizaremos la inestabilidad que caracterizó la pertenencia de la villa al realengo durante la Baja Edad Media. Seguidamente nos centraremos en la organización del poder político en la villa, prestando especial atención a las transformaciones que experimentó en este periodo. Finalmente analizaremos la realidad social que sustentaba el ejercicio del poder con el análisis de los grupos antagónicos que se definían en su seno, sin olvidar aquellos sectores sociales marginales.

${ }^{800}$ VALDEÓN BARUQUE, J., “Las oligarquías urbanas”, en Concejos y Ciudades en la Edad Media Hispánica. Madrid, 1990, pp. 509-535; TOMÁS Y VALIENTE, F., “Origen bajomedieval de la patrimonialización y la enajenación de oficios públicos en Castilla", en Actas del I Symposium de Historia de la Administración. Madrid, 1970, pp. 132-54; PÉREZ, J., "Los Reyes Católicos..., pp. 148-49; VAL VALDIVIESO, M. I., "Dinámica social en las ciudades castellanas en torno a 1494", en El Tratado de Tordesillas y su época. Salamanca, 1993, vol. I, pp. 113-130; de la misma autora "Las líneas maestras..., pp. 283-84; y ASENJO GONZÁLEZ, M., "La aportación del sistema urbano a la gobernabilidad del Reino de Castilla durante la época de los reyes católicos (1474-1504)", en Anuario de estudios medievales. 39/1, 2009, pp. 307-328, en especial p. 327.

${ }^{801}$ OLIVA HERRER, H. R., "El mundo rural y la política en tiempos de los Reyes Católicos”, en Isabel La Católica y su época. Valladolid, 2007, vol. 1, pp. 299-318. 


\section{1. Realengo y enajenaciones.}

Ciertamente no tenemos datos concluyentes sobre la adscripción de esta localidad al realengo, aunque para Sanz Abad la donación realizada en 1236 por Fernando III de unas aceñas y tierras en Aranda al Monasterio de San Pedro de Gumiel de Izán ya apuntaba al carácter realengo de la villa ${ }^{802}$. Esta condición se afirmaría con Alfonso X a través de lo señalado en la confirmación de privilegios de Sancho IV en $1291^{803}$. El dominio real se interrumpió con la toma violenta de la localidad por parte de don Diego López de Haro en 1295, que posiblemente mantuvo la villa hasta la mayoría de edad de Fernando IV. El reinado de Alfonso XI supuso cierta estabilidad para Aranda, pues parece que estuvo bajo su dominio directo por lo menos hasta 1346, momento en que cedió el señorío de la villa a uno de sus hijos naturales, don Tello, fruto de la unión extramatrimonial con doña Leonor de Guzmán y, por lo tanto, hermano de don Enrique de Trastamara $^{804}$.

Con esta cesión se inauguró un periodo de más de cien años en el que la villa fue de mano en mano, pasando a ser señorío de algunos de los más influyentes señores de la corte, muchos de ellos familiares de la Casa Real. Durante este largo periodo la situación jurídica de la villa fue bastante confusa pues aunque no se pueda identificar como señorío en sentido estricto, tampoco puede ser considerada de realengo pues su señor no fue el rey sino uno de sus familiares. De hecho estos señores actuaban sobre la villa durante los cortos pero continuos periodos en los que fue enajenada como el resto de los señores nobiliarios de la comarca.

Como ya hemos anticipado, el señor de Aranda desde 1346 fue don Tello. La inestable relación con su hermanastro el rey Pedro hizo que abandonara la villa en 1352 como relata el cronista: Quando el Rey Don Pedro... se venia para Castilla, Don Tello su hermano, fijo del Rey Don Alfonso e de Doña Leonor de Guzmán, estaba en la villa de Aranda de Duero, que era suya: é quando sopo que el rey venia, ovo grand miedo dél... é partieron de Aranda, é robaron la recua que venia de Burgos, é iva para la feria

\footnotetext{
${ }^{802}$ SANZ ABAD, Historia de Aranda..., p. 51.

803 Todos los privilegios y confirmación de privilegios están publicados por HURTADO QUERO, Documentos Reales.., docs. 2 y 3, pp. 4-12.

${ }^{804}$ VELASCO PÉREZ, Aranda. Memorias..., pp. 50-61.
} 
de Alcalá de Henares, en la qual tomaron grande aver ${ }^{805}$. Poco después Pedro I revirtió el señorío de la localidad a la Corona como pone de manifiesto la confirmación de los privilegios de la villa fechada en León el 13 de julio $1352^{806}$. Poco duró esta situación pues en 1356 aparecía citado como señor de Aranda el infante don Fernando, señor de Tortosa $^{807}$. Pedro I cedió el señorío de la villa a don Fernando en agradecimiento a su fidelidad y al apoyo prestado en la guerra que mantenía contra Pedro IV de Aragón. En la Crónica del rey Don Pedro se hace referencia a los acuerdos a los que llegaron el Rey Pedro de Castilla con Doña Leonor y Don Fernando en 1354: ...É alli fue tratado que el Rey diese á la Reyna de Aragon Doña Leonor su tía la villa de Roa; é al infante Don Ferrando de Aragon su primo la villa de Madrigal, é el Real de Manzanares, é Aranda é aún otros lugares en el Andalucia. Pero este acuerdo cambió sustancialmente cuando poco después el señor de Tortosa se pasó al bando del Trastamara ${ }^{808}$. En el transcurso del enfrentamiento fratricida castellano la capital de la Ribera revirtió de nuevo a don Tello. A pesar de las disposiciones del señor de Vizcaya, a su muerte en 1370 la villa retornó a la Corona ${ }^{809}$.

Otros señores y lugares comarcanos también fueron actores de la contienda civil. Roa estuvo en el partido del rey Pedro y cuando su señora, Doña Leonor de Aragón, se inclinó por el pretendiente fue apresada y ejecutada, permaneciendo la villa bajo control del rey junto a la vecina $\mathrm{Haza}^{810}$. Por su parte los Gumieles apostaron por el Trastamara.

805 LÓPEZ DE AYALA, P., Crónica del rey Don Pedro. Año 1352, cap. V. (En Crónicas de los Reyes de Castilla. Tomo Primero, p. 426). El mismo acontecimiento es narrado en la obra de ROMANO DE THUESEN, E. A. Transcripción y edición del Catálogo Real de Castilla, autógrafo inédito de Gonzalo Fernández de Oviedo y Valdés. Edición digital a partir del texto original de la tesis doctoral. P. 576 (Sexta Edad, fol. 118v y 119r), en http://www.cervantesvirtual.com, consultada 01/09//2011.

${ }^{806}$ HURTADO QUERO, Documentos Reales.., doc. 3, pp. 4-12.

${ }^{807}$ AMA, leg. 43, fol. 3. Se trata de una copia realizada en 1398 de una carta de sentencia fechada el 18 de julio de 1356 en la que se menciona al alcalde y alguacil mayor de la villa nombrado ...por nuestro señor el infante don Fernando. Se trata de Don Fernando, marqués de Tortosa, hijo de Doña Leonor, infanta de Castilla, y Alfonso IV de Aragón. Era, por lo tanto, medio-hermano de Pedro IV de Aragón y primo carnal de Pedro I de Castilla.

${ }^{808}$ LÓPEZ DE AYALA, Crónica del rey..., Tomo Primero, p. 459. El Infante murió en 1363 por orden de su hermanastro Pedro IV, contando para ello con la colaboración del Conde de Trastamara (pp. 528-529).

${ }^{809}$ Para VELASCO PÉREZ don Tello recuperó la villa tras la proclamación de Enrique como rey en 1366 (Aranda. Memorias..., p. 71), aunque las posteriores desavenencias entre los hermanos tuvieron como consecuencia que don Tello perdiera intermitentemente su señorío (p. 72). Finalmente la villa revirtió a la Corona el 29 de noviembre de 1370 (pp. 73-74).

${ }^{810}$ ZAMORA LUCAS, La villa de Roa., p. 150. 
Cuadro 5: Los señores de la villa de Aranda de Duero (s. XIII-XV).

\begin{tabular}{|l|l|}
\hline \multicolumn{1}{|c|}{ SEÑORES } & \multicolumn{1}{|c|}{ CRONOLOGÍA } \\
\hline Don DIEGO LÓPEZ DE HARO & $\begin{array}{l}\text { Desde 1296 hasta principios } \\
\text { del siglo XIV }\end{array}$ \\
\hline Don TELLO, hijo natural de Alfonso XI & $\begin{array}{l}\text { Intermitentemente entre } \\
1346 \text { y } 1370\end{array}$ \\
\hline $\begin{array}{l}\text { Infante Don FERNANDO, hijo de Alfonso IV de Aragón y } \\
\text { señor de Tortosa }\end{array}$ & $1356-1360$ \\
\hline $\begin{array}{l}\text { Infante Don ENRIQUE, hijo natural de Enrique II y duque de } \\
\text { Medinasidonia }\end{array}$ & $1390-1404$ \\
\hline Infante Don JUAN, rey de Navarra y Aragón & $1436-1444(1454)$ \\
\hline Don ENRIQUE, Príncipe de Asturias & $1444-1454$ \\
\hline $\begin{array}{l}\text { Doña JUANA DE PORTUGAL, reina de Castilla y segunda } \\
\text { mujer de Enrique IV }\end{array}$ & $1461-1469$ \\
\hline $\begin{array}{l}\text { Doña ELVIRA DE QUIÑONES, condesa de Tendilla. } \\
\text { Actuaba como tenente don Pedro de Zúñiga }\end{array}$ & $1469-1472$ \\
\hline $\begin{array}{l}\text { Doña ISABEL, Princesa de Asturias. } \\
\text { Ejercía como tenente don Diego de Rojas }\end{array}$ & $1472-1474$ \\
\hline
\end{tabular}

La inestabilidad y la pugna por el control del territorio en la comarca ribereña y en la villa arandina continuaron tras la contienda. A pesar de la confirmación de sus privilegios realizada por Enrique II en $1377^{811}$, Aranda fue concedida, posiblemente por Juan I, al Infante don Enrique Enríquez, su hermanastro y primer Duque de Medina Sidonia, que la mantuvo hasta su muerte en $1404^{812}$.

En los primeros años del Cuatrocientos el señorío de Aranda se mantuvo en manos de la Corona, incluso a pesar de la utilización de la villa en 1415 como garantía de la dote que la Infanta María de Castilla llevó en su matrimonio con su primo el Infante

${ }^{811}$ HURTADO QUERO, Documentos Reales..., doc. 4, pp. 12 y 13.

${ }^{812}$ Hasta ahora hemos localizado dos documentos en los que don Enrique aparece como señor de Aranda. El primero es la confirmación del Fuero de Ledigos el 20 de febrero de 1392 en el que figura como testigo: Don Enrique, tio del Rey, sennor de Alcalá, y de Aranda, y de Cabra, y de Portillo (BURRIEL, A. M., Memorias para la vida del santo rey Don Fernando III. Madrid, 1800, pp. 263-268. Versión digital en http://www.cervantesvirtual.com, consultada el 12/05/2011). El otro es un documento fechado en Aranda el 30 de agosto de 1398 que recoge una copia solicitada ante Johan Alfonso de Narbaes, alcalde en la dicha villa por nuestro señor el duque de Medina Sydonia de las tres sentencias arbitrales de 1356, 1374 y 1376 a las que hemos hecho referencia anteriormente (AMA, leg. 43, fol. 3). VELASCO PÉREZ hace referencia a otro documento depositado en el Archivo y fechado en 1392. Se trata de una carta de pago de 17.000 maravedíes que el Infante tenía sobre las rentas de la villa. En este documento, dice Velasco, se hace mención al aparato burocrático del Duque en la villa, así como a una interesante red clientelar (Aranda. Memorias..., pp. 79-80). Este documento es uno más de los consultados por Velasco que se perdieron posiblemente en los trabajos de reforma de las dependencias municipales a principios de los años setenta del siglo XX. 
Alfonso de Aragón. Las garantías fueron entregadas al rey de Aragón, pero pronto retornaron a la Corona castellana como se certificó con una nueva confirmación de privilegios otorgada por Juan II en $1420^{813}$.

Poco después la capital de la Ribera se convirtió de nuevo en moneda de cambio en las complicadas relaciones entre Castilla y Aragón. En la concordia de 1436 se acordó, entre otras cosas, el matrimonio del Príncipe de Asturias, el futuro Enrique IV, y Blanca de Navarra, hija del rey de Navarra y sobrina de Alfonso V de Aragón. Entre las cláusulas se establecía ...que por el dicho Señor Rey de Castilla sean é hayan de ser dados... al dicho Señor Rey de Navarra para dotar en dote é con la dicha Señora Infanta, las villas de Medina del Campo é Aranda de Duero, Roa y Olmedo é Coca y el Marquesado de Villena. Dada la edad de los contrayentes, 11 y 12 años, se permitió a Juan II administrar estos territorios en los siguientes cuatro años y se estableció que, si el matrimonio no tuviera hijos, todas las villas tornarían a Castilla. Esta nueva situación permitió la vuelta del Infante de Aragón a los asuntos castellanos ${ }^{814}$. En el ámbito comarcal Juan II de Navarra actuó efectivamente como señor de Aranda como lo pone de relieve la documentación en la que se dirige a las autoridades ...de la nuestra villa de Aranda e su tierra ${ }^{815}$.

No parece que Juan de Navarra cumpliera con la entrega de la dote a su hija. Además sus múltiples intrigas en Castilla hicieron que se enfrentara de nuevo a su primo, Juan II, y a su yerno, el príncipe Enrique. Por lo que toca al señorío de la villa arandina, el momento decisivo fue 1444. En el contexto del conflicto entre el monarca castellano y los Infantes de Aragón, primero Roa, y después Aranda, se rebelaron contra el Navarro y tomaron las armas por el rey, aunque fue el Príncipe el que recuperó ambas

813 PÉREZ DE GUZMÁN, Crónica del serenísimo..., Tomo Segundo, p. 363; VELASCO PÉREZ, Aranda. Memorias..., p. 83; y SANZ ABAD, Historia de Aranda..., p. 69. La escritura otorgada (4 de junio de 1415) por la Infanta María renunciando al marquesado de Villena y las villas de Aranda y Portillo se encuentra en AGS, CC, DIVERSOS, leg. 11, doc. 1. Tampoco ha llegado hasta nosotros esta confirmación de Juan II y tan solo tenemos noticia de ella a través de las referencias de Velasco y Sanz Abad.

814 PÉREZ DE GUZMÁN, Crónica del serenísimo..., Tomo Segundo, pp. 529 y 535-546; y SUÁREZ FERNÁNDEZ, L., Enrique IV. Barcelona, 2001, p. 16.

${ }^{815}$ HURTADO QUERO, Documentos Reales..., docs. 5 y 6, pp. 13-16. Se trata de dos documentos redactados el 13 de junio y el 3 de agosto de 1440, poco antes de los desposorios de don Enrique y doña Blanca. A estos documentos hay que añadir una referencia de VELASCO PÉREZ que indica la existencia de un documento fechado el 23 de agosto de 1439 en el que figura como corregidor de la villa un tal Mosén Pedro de Quijada en nombre de nuestro señor el Rey de Navarra (Aranda. Memorias..., p. 85). Aunque Velasco señala incluso el número de folio, 142, hoy este documento también está extraviado. 
localidades ${ }^{816}$. Sin embargo, no fue hasta el 8 de octubre de 1454 cuando Juan de Navarra renunció oficialmente a las plazas que fueron como garantía de dote de su hija. De hecho, el señorío de Aranda estaba ya en las manos del Príncipe de Asturias, que no de la Corona, bastante tiempo antes como lo confirma un documento del archivo municipal fechado el 2 de febrero de $1448^{817}$.

Con el ascenso al trono de Enrique en 1454, la capital de la Ribera retornó a la Corona $^{818}$. Pero fue por poco tiempo pues en la primavera de 1461 el rey concedió el señorío de la villa a su segunda mujer, doña Juana de Portugal: ...por gratificar su preñez, que tanto avia sido deseada, hizole merced de aquella villa de Aranda é su tierra, donde luego fue jurada é obedecida por Señora ${ }^{819}$. Tres aspectos son reseñables en el periodo en que doña Juana fue señora de la villa. Por una parte, gracias a su intercesión, el rey concedió el privilegio de la exención del pago de la moneda forera y los pedidos para la localidad el 29 de julio de 1467. Este privilegio fue concedido en agradecimiento por los servicios prestados por los arandinos en la guarda de la villa y el reparo de sus murallas en los momentos de inestabilidad ${ }^{820}$.

También sabemos que doña Juana otorgó a la villa las primeras ordenanzas de las que tenemos noticia y de las que tan solo conocemos algunos de sus artículos. Éstos

${ }^{816}$ Mientras se ejecutaba el sitio de Peñafiel en 1444 ...algunos vecinos de Roa tovieron trato con el Príncipe que fuese allá é que le darian entrada por una puerta; al Príncipe le plugo y acebtó el trato é partió del Real con hasta doscientos hombres darmas... Y estando allí, supo como los de Aranda se habían alzado por él é tomado su apellido, é fue el Príncipe allá é tomó la posesión de la villa (PÉREZ DE GUZMÁN, Crónica del Serenísimo..., Tomo Segundo, p. 624).

${ }^{817}$ VELASCO PÉREZ señala que la renuncia de Juan de Navarra al señorío de la villa, junto a los de las otras villas, se produjo en 1455 y se confirmó tres años más tarde (Aranda. Memorias..., pp. 104-105). SANZ ABAD señala el tratado de Ágreda de 8 de octubre de 1454 (Historia de Aranda..., pp. 73-74). El documento del archivo arandino Enrique lo dirige a las autoridades ...de la mi villa de Aranda (HURTADO QUERO, Documentos Reales..., doc. 7, pp. 16-17).

${ }^{818}$ No contamos hasta el momento con ninguna confirmación de privilegios de Enrique IV pero sí que se conservan algunos documentos reales de este monarca en el archivo municipal. El más relevante (16 de agosto de 1456) hace mención a la prohibición al Conde de Miranda de edificar un castillo en las cercanías de la villa (HURTADO QUERO, Documentos Reales..., doc. 9, pp. 19-21).

${ }^{819}$ VALERA, Memorial de diversas.., Tomo Tercero, p. 118.

${ }^{820}$ AMA, leg. 43, doc. 18. De este documento hace reseña VELASCO PÉREZ en Aranda. Memorias..., p. 108, pero no señala que se trata de una copia del siglo XVI. También afirma que Enrique IV concedió a la villa que tuviese dos ferias cada año. Esta afirmación debemos tomarla con cautela pues este autor manifiesta que ya en su momento el documento había desaparecido y concluye que el privilegio debía ser semejante al de Roa de 1465 "si se tiene presente que el Rey no había de ser menos espléndido con la Reina, que con D. Beltrán de la Cueva”. Por su parte, SANZ ABAD (Historia de Aranda..., p. 77) también hace mención a estos documentos, aunque cree que están perdidos. 
tenían que ver con el funcionamiento interno del concejo, los linajes y los repartimien$\operatorname{tos}^{821}$

Y por último, la Reina, a la vez que favorecía los intereses de los habitantes de la villa como ya hemos visto, contentaba a los nobles siguiendo la política de donaciones emprendida por su marido. Salazar y Castro recoge la cesión que hizo del señorío de la villa el 31 de diciembre de 1469 a la condesa de Tendilla, doña Elvira de Quiñones, aunque no sabemos hasta qué punto fue efectiva ${ }^{822}$. Asimismo también tenemos noticias, a través de las crónicas y de la documentación, de que la villa pasó a ser tenencia de don Pedro de Zúñiga, permitiendo la reina que señoreara por la villa provocando alborotos que las autoridades no pudieron controlar. Ante esta situación, algunos vecinos solicitaron la protección del partido de la Princesa Isabel, quien encomendó a don Diego de Rojas tomar posesión de la villa para su partido. Este episodio fue un ejemplo más de la resistencia de las ciudades a la pérdida de la condición de realengo y la imposición del dominio señorial que vivió un momento álgido en Castilla al final del reinado de Enrique IV, aunque en este caso el dominio no lo ejerciera la señora de la villa, sino uno de los nobles comarcanos más fuertes ${ }^{823}$. No obstante, no debemos perder la perspectiva del momento singular en el que se produjo este episodio que no fue otro que el de la pugna por el control del reino.

A pesar de la pérdida de la condición de realengo y de la inestabilidad generalizada, el periodo final del reinado de Juan II y durante todo el de Enrique IV supuso para la villa de Aranda un momento de gran desarrollo que preludiaba la gran expansión que experimentó a lo largo del último cuarto del siglo XV y los primeros años del Quinientos. Esta afirmación la hacemos, a falta de datos más relevantes, al amparo de las múltiples noticias que nos aportan los cronistas; las numerosas y prolongadas estancias de los reyes y su corte en la localidad; la utilización de la villa como punto de partida para varias de las expediciones militares que tenían como escenario el Norte Peninsular; y el

\footnotetext{
${ }^{821}$ AGS, RGS, 148002, fol. 256.

${ }^{822}$ VAL VALDIVIESO, M. I., Isabel la Católica, princesa (1468-1474), Valladolid, 1974, p. 251.

${ }^{823}$ VAL VALDIVIESO, Ma. I., "Resistencia al dominio señorial durante los últimos años del reinado de Enrique IV”, en Hispania. Revista Española de Historia. 34, 1974, pp. 53-104, especialmente p. 72 .
} 
gran interés que tuvieron los distintos bandos que se enfrentaron a lo largo del tercer cuarto del siglo XV por dominar la villa ${ }^{824}$.

Con la entronización de doña Isabel como reina de Castilla en 1474 la villa pasó al realengo y en él se mantuvo durante un largo periodo que sólo se vio interrumpido por la transitoria cesión de la villa a la Emperatriz Isabel ${ }^{825}$.

\section{2. El concejo: el regimiento y los oficiales concejiles.}

La organización política de la villa de Aranda durante la Baja Edad Media se fundamentó en la institución del regimiento, si bien es cierto que su implantación en la villa se produjo con un relativo retraso respecto a otros espacios urbanos castellanos ${ }^{826}$. En este apartado intentaremos identificar el proceso de implantación de este sistema de gobierno municipal así como su evolución a lo largo del periodo estudiado. Asimismo describiremos sus principales mecanismos internos así como las características más significativas de su funcionamiento ${ }^{827}$.

\section{2. 1. Antecedentes.}

Si bien es cierto que la principal institución del gobierno municipal arandino durante la Baja Edad Media fue el regimiento, no sabemos a ciencia cierta cuándo se instauró este sistema en la villa. Parece que la reforma municipal introducida por Alfonso XI no llegó a tierras ribereñas a tenor de la primera referencia que tenemos sobre la or-

${ }^{824}$ Es sintomático, o cuanto menos oportunista, que en los diferentes conflictos que jalonaron la segunda mitad del siglo, la villa de Aranda siempre se posicionó al lado de los vencedores en los momentos previos a su victoria. Así, por ejemplo, en 1444 abandonó a Juan de Navarra y tomó el partido del rey Juan II y del Príncipe Enrique antes de la decisiva victoria de Olmedo en 1445.

${ }^{825}$ VELASCO PÉREZ, Aranda. Memorias..., p. 172.

${ }^{826}$ El Ordenamiento de Alcalá de 1348 fue el punto de partida de la instauración del regimiento en los núcleos urbanos castellanos. No obstante, esta implantación se dilató en el tiempo pues, por ejemplo, la imposición del regimiento se produjo en Logroño en la época de Juan II y en Toledo en 1411 (JARA FUENTE, J. A.,’'Estructuras formales de poder y de organización de las clases dominantes urbanas en Castilla. El regimiento: una crisis del siglo XIV en el siglo XV", en Edad Media. Revista de Historia. 8, 2007, pp. 225-241).

${ }^{827}$ Algunos aspectos de la organización política del concejo arandino han sido ya abordados por DIAGO HERNANDO en "Cambios políticos..., pp. 309 y ss.; e "Hidalgos y pecheros en la lucha por el ejercicio del poder en Aranda de Duero durante el periodo bajomedieval", en Biblioteca 25. Estudio e Investigación. 2011, pp. 109-126. Por nuestra parte, también hemos realizado una aproximación a este aspecto en PERIBÁÑ̃Z OTERO, “La pugna por el poder..., pp. 131-161. 
ganización política de la villa fechada en 1329. Se trata del traslado de un privilegio real de Sancho IV en el que se hace expresa mención al alcalde de la villa por el rey, Johanes Peres de Carrion, y a dos vesinos e fieles, de los que hablaremos más adelante ${ }^{828}$. Las escasas referencias documentales tan solo nos permiten señalar la hipótesis de la inexistencia del regimiento como órgano de gobierno municipal en la capital de la Ribera hasta comienzos del siglo XV. De hecho las confirmaciones de privilegios de los diferentes monarcas anteriores a ese momento se dirigen al conçeio e homes buenos de la mi villa de Aranda, sin que en ningún momento se refleje el oficio de regidor ${ }^{829}$. La escasez de información al respecto nos permite tan solo plantear la hipótesis de que hasta el siglo XIV el gobierno municipal estaría compuesto por un alcalde, nombrado por el rey o el señor correspondiente, y unos fieles con atribuciones inciertas que a menudo se identificaban también como procuradores de la villa y que parecen ser nombrados por ella, aunque desconocemos el mecanismo ${ }^{830}$.

El panorama cambió significativamente en los primeros años del siglo XV pues los documentos los produce o se dirigen al conçejo, justiçias, regidores, cavalleros, escuderos e omes buenos de la mi villa de Aranda $^{831}$. Esta incorporación tardía del regimiento en la villa a buen seguro que tuvo que ver con el centenar de años en los que su señorío estuvo enajenado del patrimonio real de forma intermitente ${ }^{832}$. Es bastante probable que el retorno de la villa en 1404 a la Corona tuviera como consecuencia la

${ }^{828}$ AMA, leg. 3038 , doc. 10.

${ }^{829}$ Confirmaciones de privilegios de Sancho IV en 1291, Alfonso XI en 1329 y Pedro I en 1352 (AMA, leg, 3038, fol. 10, transcrito por HURTADO QUERO, Documentos Reales..., doc. 3, pp. 4-12). La fórmula se repite en la confirmación de Enrique II en 1377 (AMA, leg. 42, fol. 1; Ídem, doc. 4, pp. 1213).

${ }^{830}$ AMA, leg. 40, doc. 2; y leg. 43, doc. 3. En 1376 aparece citado Juan Pérez como alcalde de la villa en la copia de un privilegio de Alfonso XI al convento de Santo Domingo de Caleruega hecha por el escribano Pedro Fernández. Fueron testigos Juan Fernández de Vigana, Alfonso, hijo de Martín Díaz, y Martín Fernández, carnicero (MARTÍNEZ LIÉBANA, Colección Diplomática ..., doc. LXXXIX, pp. 108110).

${ }^{831}$ La referencia al regimiento más antigua que hemos documentado se remonta a 1413 . Se trata de una carta de procuración del concejo que en ese momento estaba integrado por dos alcaldes, tres regidores, dos fieles procuradores y un alguacil (AMA, leg. 42, fol. 7). Lo mismo se aprecia en una carta de compromiso entre las villas de Aranda y Gumiel de Izán fechada en 1425 (VELASCO PÉREZ, Aranda. Memorias..., pp. 95-96) y en las cartas que Juan de Navarra envió al concejo arandino en 1440 (AMA, 44, doc. 2; transcrito por HURTADO QUERO, Documentos Reales..., doc. 6, pp. 14-16).

${ }^{832}$ PERIBÁÑEZ OTERO, “El control del territorio..., pp. 46-50. 
implantación del sistema político imperante en los principales núcleos urbanos de realengo ${ }^{833}$.

\section{2. 2. La implantación del regimiento en Aranda y la tradición foral.}

A principios del Cuatrocientos ya estaba asentada en el concejo arandino una fórmula de gobierno municipal ampliamente extendida en Castilla: el Regimiento. Con bastante retraso respecto a otros núcleos urbanos, el concejo arandino se vio inmerso en la política centralizadora de la Monarquía, que fue asumiendo cada vez mayores atribuciones normativas y judiciales. Paralelamente, la implantación de este nuevo sistema supuso para la oligarquía local que controlaba el concejo su consolidación como grupo dominante urbano. Constituía pues la ratificación y plasmación jurídica de un estatus preexistente que ya identificó el profesor Estepa en la ciudad de León en las postrimerías del reinado de Alfonso XI y que otros muchos investigadores han identificado en otros ámbitos urbanos ${ }^{834}$.

El nuevo sistema de gobierno arandino que se configuró en ese momento estaba anclado en una tradición foral que presentaba una serie de características que vamos a intentar analizar a continuación.

El concejo de este periodo inicial estaba formado por dos alcaldes, cuatro regidores, un alguacil y un escribano. Habitualmente también concurrían a las reuniones dos fieles procuradores. Esta composición se mantuvo estable desde su origen hasta el reinado de los Reyes Católicos. El hecho de que fueran cuatro los regidores posiblemente tuviera su origen en los privilegios forales que establecían el nombramiento de un iudex

${ }^{833}$ Este retraso también se produjo en otros núcleos urbanos como los ya comentados de Logroño y Toledo. También en los primeros años del siglo XV se produce la imposición del sistema regimental en las villas cántabras de Santander, Laredo, San Vicente de la Barquera y Castro Urdiales (SOLÓRZANO TELECHEA, “Elites urbanas y construcción..., pp. 202-203).

${ }^{834}$ ESTEPA DÍEZ, C., Estructura social de la ciudad de León (s. XI-XIII). León, 1977, p. 486. Son muchos los ejemplos por lo que nos referiremos tan solo a algunos generales o representativos de diferentes entornos geográficos: MONSALVO ANTÓN, El Sistema político concejil..., pp. 150-151; MARTÍN CEA, J. C. y BONACHÍA HERNANDO, J. A., "Oligarquías y poderes concejiles en la Castilla Bajomedieval: balance y perspectivas", en Oligarquías políticas y elites económicas en las ciudades bajomedievales (siglos XIV-XVI). Revista d'Història Medieval, 9, Valencia, 1998, pp. 17-40; SOLÓRZANO TELECHEA, J. A., "De "Todos los más del pueblo" a la "Republica e comunidad": el desarrollo y la consolidación de la identidad del común de Laredo en los siglos XIV y XV", en Anales de historia medieval de la Europa atlántica. 1, 2006, pp. 61-106, en especial pp. 72-73; y JARA FUENTE, "Estructuras formales..., p. 227. 
por cada collación ${ }^{835}$. En este sentido, es significativo que a finales del siglo XIV o principios del XV se configuraron las cuatro collaciones o cuadrillas en que se organizaba el espacio urbano arandino durante el final de la Edad Media: las cuadrillas de Duero, San Juan, Cascajar y la de Isilla, que agrupaba la reciente expansión urbana hacia el Este.

Desde el establecimiento del regimiento en la villa se certifica el carácter electivo de los diferentes oficiales. Si bien hemos apreciado a lo largo del siglo XIV cómo los alcaldes que aparecen en la documentación casi siempre habían sido nombrados por el señor de la villa, fuera el rey o cualquiera de los nobles que la enajenaron ${ }^{836}$, a partir de la imposición del regimiento se percibe que tanto los oficios de alcaldes como los de regidores y otros oficiales menores fueron renovados por elección con una periodicidad anual. Lamentablemente no conocemos con detalle los criterios para ser elegibles, ni el segmento de electores, ni tampoco los mecanismos que lo regulaban ${ }^{837}$. Testimonios posteriores confirman este carácter electivo anual de los oficiales concejiles cimentado en la tradición foral, aspecto que la princesa Isabel se comprometió a respetar en $1472^{838}$. El sistema de renovación anual se mantuvo hasta los primeros años de la década de los ochenta, como veremos más adelante ${ }^{839}$.

${ }^{835}$ Et iudex sit [annalis] et per collationes (CALLEJAS, F., El Fuero de Sepúlveda. Madrid, 1837, p. 11; y LLORENTE, J. A., Noticias históricas de las tres provincias vascongadas: Álava, Guipúzcoa y Vizcaya. Madrid, 1807, Vol. III, p. 427. Se reproduce la interpretación de Llorente entre paréntesis). La elección anual y por distritos era algo habitual en el derecho foral castellano (GARCÍA MARÍN, J. M., El oficio público en Castilla durante la baja Edad Media. Madrid, 1987, pp. 157 y ss.).

${ }^{836}$ Entre los alcaldes conocidos del siglo XIV tan solo uno fue nombrado por el concejo, aunque para tratar específicamente un pleito con el Concejo de la Mesta en 1375, periodo que coincide con el retorno de la villa a manos de Enrique II (AMA, leg. 43, doc. 3).

${ }^{837}$ Así se desprende de los datos que aporta la documentación. Baste como ejemplo la movilidad de los cargos municipales en la década de los años 20: en 1425 los alcaldes fueron el bachiller Juan Rodríguez y Juan Maté; en 1426 ocuparon ese cargo Juan Romero y Pedro García; y en 1429 Juan Sánchez y Gonzalo Martínez. Lo mismo podemos apreciar en el oficio de regidor, aunque un Pedro Sánchez repitió oficio los tres años (AMA, leg. 43, doc. 3 y VELASCO PÉREZ, Aranda. Memorias... pp. 95-96).

${ }^{838}$ La confirmación dice textualmente ...guardaré e fare guardar... en el poner de los alcalldes, como de los regidores e procuradores de la dicha villa de Aranda e su tierra, como en el nombrar e ellegir e poner los ofiçiales en cada un año como syempre se acostrubraron poner en el dia de año nuevo en el poner de los electores (AMA, leg. 43, fol. 32; transcrito por HURTADO QUERO, Documentos Reales..., doc. 10, pp. 21-24). Probablemente este privilegio procede de la concesión por parte de Sancho IV de la extensión de los fueros e franquisas e libertades que an las otras nuestras çibdades e villas de la Extremadura e fuera de la Meryntat de Santo Domingo de Silos (Ídem, doc. 3, pp. 4-12).

${ }^{839}$ La pervivencia de esta prerrogativa prerregimental de la elección anual se mantuvo a lo largo del siglo XV también en las villas de la cornisa cantábrica (RUIZ DE LA PEÑA, J. I., Las 'polas' asturianas en la Edad Media: estudio y diplomatario. Oviedo, 1981; GARCÍA FERNÁNDEZ, E., Gobernar 
La elección de los oficiales concejiles se realizaba el día de Año Nuevo. Tanto para ser elegido como para formar parte de los electores era condición indispensable pertenecer a alguno de los dos linajes de la villa ${ }^{840}$. Los puestos de regidor se repartían equitativamente entre los dos linajes y de la misma manera cada linaje nombraba a un individuo para ejercer el oficio de alcalde ${ }^{841}$. El resto de oficiales menores, como el mayordomo, los fieles del peso, del vino, etc., también eran designados por los regidores entre los miembros de sus respectivos linajes o clientelas ${ }^{842}$.

Por otra parte, el resto de los vecinos elegía a sus representantes: los fieles e procuradores. Al menos desde el siglo XIV fueron dos los procuradores que representaban al vecindario ${ }^{843}$. Estas primeras evidencias de representatividad no pueden vincularse completamente con el concepto de Comunidad pues estos procuradores actuaban como delegados de la villa. No fue hasta el siglo XV cuando los procuradores se identificaron completamente como representantes de la Comunidad ${ }^{844}$. Suponemos que al principio su elección se realizaba por la asamblea de vecinos, aunque más adelante se habilitó un mecanismo mediante el cual la vecindad de cada cuadrilla elegía a uno o dos diputados. Estos representantes de las cuadrillas se reunían posteriormente y acordaban el día de

la ciudad en la Edad Media. Oligarquías y elites urbanas en el País Vasco. Vitoria, 2004; y SOLÓRZANO TELECHEA, "Elites urbanas y construcción..., p. 206).

${ }^{840}$ Como veremos más adelante, en la villa había dos linajes: el de don Romero y el de don Pedro García de la Puente.

${ }^{841}$ Ante los problemas que había con el nombramiento de los oficiales del concejo todos los años porque se elegían personas que no eran idóneas para el cargo, en 1478 los representantes de la Comunidad suplicaron a los monarcas que se permitiera entrar en los linajes a las personas que estuvieran capacitadas para desempeñar estos oficios (AGS, RGS, 147803, fol. 37).

${ }^{842}$ Esta situación se reproduce igualmente en buena parte de los concejos castellanos. Además en el caso arandino observamos cómo estos nombramientos presentaban un carácter personalista pues era uno de los regidores, como miembro de su linaje pero a título personal, el que elegía a la persona que iba a desempeñar el oficio: en 1485 el regidor Pedro de Salazar ...nombro e elegio por alcallde de su linage este presente año al dicho Garçia de Salaçar, su hermano... (AMA, leg. 43, fol. 2; transcrito por HURTADO QUERO, Documentos Reales..., doc. 19, pp. 38-39). Asimismo los procuradores de la Comunidad denunciaron que el regidor Pedro de Santa Cruz había nombrado como fiel a un vecino poco capacitado para asumir sus funciones (AGS, RGS, 149802, fol. 197).

${ }^{843}$ El primer documento en el que aparece citado el término fieles e vesinos con la atribución de representantes de la villa está fechado en 1329 (AMA, leg. 3038, doc. 10). En 1398 el representante de la villa era denominado con el término de fiel e procurador del conçeio de la dicha villa (leg. 43, doc. 3 ).

${ }^{844}$ La denominación fieles e procuradores que se utilizaba en el siglo XIV para nombrar a los representantes de la villa se simplificó en el siglo XV pasando a denominarse este oficio representativo tan sólo con el apelativo procurador. Desde ese momento, como en el resto de los núcleos urbanos castellanos, el término fiel se empleó exclusivamente para designar el oficio vinculado al control comercial que veremos más adelante. 
Año Nuevo qué dos vecinos ejercerían el oficio de procurador de la Comunidad durante ese año. Estas reuniones de las cuadrillas se celebraban por separado en los lugares que tenían por costumbre: la de Duero en San Llorente, la de Isilla en San Roque, la del Cascajar junto a su puerta y la de San Juan junto a la iglesia de su mismo nombre ${ }^{845}$. Los procuradores tenían derecho a acudir a los ayuntamientos, aunque no tenían voto. Sus competencias estaban vagamente perfiladas aunque parece que se centraban en la función representativa de los intereses de la Comunidad ante instancias superiores ya fueran locales o reales. Con frecuencia esta competencia se veía frenada por las dificultades que les ponían los otros miembros del concejo que bien no les permitían la entrada a las sesiones o no les daban traslado de lo acordado en el ayuntamiento ${ }^{846}$. También tenían ciertas atribuciones fiscales pues entre sus competencias se establecía que ...estavan al hazer de los repartimientos y miravan en que se gastava e destribuia e asy mismo en las contribuciones e gastos de la guerra y de la Hermandad ${ }^{847}$. Ocasionalmente también solicitaban y ejecutaban derramas entre los vecinos para los gastos de procuración, aunque estos representantes vecinales no veían compensado su trabajo con un sueldo ${ }^{848}$.

En ocasiones muy solemnes o importantes para el devenir de la villa también se convocaba a las reuniones del concejo a los representantes de otros colectivos. Es el caso de los procuradores de los lugares que configuraban la Tierra de la villa, es decir, los representantes de las aldeas de Sinovas, Quemada, Villalba, Prado, Vegaduero, Fuentespina y Casasola. De igual manera a comienzos del siglo XV en algunos casos

${ }^{845}$ AGS, CONSEJO Y JUNTAS DE HACIENDA, leg. 4, doc. 20. Este procedimiento es el que se seguía a principios del siglo XVI. Con todas las precauciones que plantea la diferencia temporal, podemos suponer que éste fuera el mecanismo utilizado durante el siglo XV para la elección de los Procuradores de la Comunidad.

${ }^{846}$ AGS, RGS, 149802, fol. 41; y 151204, s.f.

${ }^{847}$ AGS, RGS, 148002, fol. 256; y 149106, fol. 107. Estas atribuciones fiscales y los diferentes mecanismos de representación de la comunidad en diversas ciudades castellanas han sido estudiados por VAL VALDIVIESO en “Aspiraciones y actitudes..., pp. 230 y ss.

${ }^{848}$ En uno de los pocos capítulos que se han conservado de las ordenanzas que la reina Juana, mujer de Enrique IV, concedió a la villa se establecía ...que la dicha comunidad e omes buenos no puedan faser derrama ni repartimiento de mas de tres mil maravedis sin licencia real (AGS, RGS, 148002, fol. 256). Esta autonomía financiera fue limitada a finales de siglo mediante la asignación de 2.000 maravedíes de los propios destinados a los gastos de procuración de la Comunidad (AGS, CC PUEBLOS, leg. 2, doc. 95). En 1512 los procuradores seguían sin sueldo y solicitaron a los monarcas que se les asignara una retribución de 1.000 maravedíes anuales (AGS, RGS, 151204, s. f.). 
puntuales se citaba asimismo a los representantes de los dos estamentos privilegiados: el de los clérigos y el de los hidalgos ${ }^{849}$.

La institución concejil de estos primeros momentos también contaba con un escribano, un mayordomo, un alguacil y otros oficiales menores de los que hablaremos más adelante.

En conclusión, podemos afirmar que la implantación del regimiento en la capital de la Ribera se produjo con carácter tardío por iniciativa real siguiendo los mismos modelos que en otras ciudades y villas castellanas. De igual manera, este nuevo sistema de gobierno mantuvo unas características ancladas en la tradición foral como era el carácter electivo y anual de los oficios concejiles ${ }^{850}$. Sin lugar a dudas, el Regimiento implicó una serie de cambios en la gobernanza del municipio que condicionaron la evolución de la villa durante el final de la Edad Media.

\subsubsection{La reforma del Regimiento durante el reinado de los Reyes Católicos.}

Al comienzo de la década de los 70 , en el contexto del enfrentamiento sucesorio que asolaba Castilla, el concejo de Aranda se inclinó por el partido de la princesa Isabel. A cambio de su apoyo la villa obtuvo el reconocimiento de sus fueros antiguos que, en lo que se refiere a este punto que ahora tratamos, se centraba en la autonomía a la hora de nombrar a los oficiales del concejo y el compromiso de no enviar corregidor sino era reclamado por los vecinos ${ }^{851}$. A pesar del juramento, en los años posteriores la Corona fue dejando sin efecto ambas promesas, comenzando con la imposición de la figura del corregidor desde 1480 .

De igual manera, la política de los monarcas se centró en la reforma del Regimiento. En consecuencia, a lo largo de los primeros años 80 se instó a la modificación

${ }^{849}$ Entre uno y tres clérigos eran los representantes del estamento eclesiástico y dos los del estado de los hidalgos (AMA, leg. 43, doc. 3 y VELASCO PÉREZ, Aranda. Memorias... pp. 95-96). El hecho de que los clérigos fueran apartados del gobierno municipal no es novedoso pues ocurre lo mismo en Alba de Tormes, por ejemplo (MONSALVO ANTÓN, El Sistema político..., p. 154). Lo mismo ocurre en el caso de los hidalgos. La convocatoria extraordinaria de estos dos estamentos de privilegiados puede ser interpretada como muestra del peso que tenía el estamento clerical y la oligarquía local de caballeros e hidalgos en la sociedad arandina de comienzos del Cuatrocientos.

${ }^{850}$ La pervivencia de la tradición foral en el gobierno municipal también se ha documentado en otros núcleos urbanos como Paredes de Nava o Cuenca (MARTÍN CEA y BONACHÍA HERNANDO, “Oligarquías y poderes..., p. 28).

${ }^{851}$ AMA, leg. 43, fol. 32. 
de las principales características del modelo tradicional que había estado funcionando durante todo el siglo XV.

Los monarcas regularon el oficio de regidor de tal forma que perdió su tradicional forma electiva y anual pasando a ser designado por el monarca y además con carácter vitalicio. Y todo ello ...porque asy cumplia a nuestro serviçio e al bien e pro comun de la dicha villa e buen regimiento e governaçion della. La medida se tomó ... a cabsa de las diferençias que en esa dicha villa ha avido sobre rason de los ofiçios de alcalldias e regimientos e otros ofiçios della e sobre la eleçion dellos. En esta nueva regulación se establecía que los reyes nombrarían a aquellas personas más capacitadas para el cumplimiento del oficio y establecían la condición de que debía ser vecino de la villa o estar avecindado en ella al menos con seis meses de antelación a la fecha en la que vacara el oficio que le iba a ser asignado ${ }^{852}$.

Por lo tanto se trató de una reforma en toda regla en la que es evidente la imposición de la Corona que no solo reguló el funcionamiento del gobierno municipal, sino que también proyectó su control sobre los vecinos que iban a ejercer el poder local. Supuso además un claro refuerzo a la posición privilegiada en el seno de la sociedad urbana de una oligarquía que se consolidaba a perpetuidad en el gobierno municipal y daba el primer paso para la patrimonialización del ejercicio del poder, pues el procedimiento de la renuncia se convirtió en el mecanismo más frecuente para transmitir el oficio de regidor $^{853}$.

La reforma profundizó aún más en la configuración de la estructura de poder local. Además de la eliminación de la tradición foral vinculada al carácter electivo y anual de los oficiales, se impuso un nuevo reparto de fuerzas dentro del seno del regimiento. En primer lugar, el número de regidores se incrementó de cuatro a nueve: de éstos, tres correspondían al linaje de Don Romero, otros tres al linaje de Don Pedro García y los tres restantes fueron ocupados por los representantes del Común que pasaban a designarse Regidores de la Comunidad ${ }^{854}$. De esta decisión se puede colegir que la Corona

${ }^{852}$ AGS, RGS, 150105, fol. 301; y DIAGO HERNANDO, “Hidalgos y pecheros..., p. 114.

${ }^{853}$ Desde los primeros años del siglo XVI los regidores proponían a su sucesor en el cargo a través de la renuncia siguiendo una fórmula como la que utilizó Pedro de Santa Cruz ...regidor de por vida, e agora que es viejo e enfermo por no poder servir tan bien su ofiçio renunciaba en su nieto Cristóbal de Salazar (AGS, CC MEMORIALES, leg. 187, doc. 19).

${ }^{854}$ AMA, leg. 43, fol. 1; transcrito por HURTADO QUERO, Documentos Reales..., doc. 20, pp. 40-41. Esta división en tercios se constata también en la ciudad de Segovia donde los dos linajes se reser- 
también respondía con esta reforma a las pretensiones del Común que continuamente fiscalizaba las actuaciones de los regidores sin tener capacidad de intervenir en el gobierno de la villa. Con esta medida la Comunidad se vio representada en el gobierno municipal, aunque fuera en una posición minoritaria, en ocasiones marginal, respecto a los regidores de los linajes ${ }^{855}$.

En este mismo sentido, también se incrementó el número de alcaldes que pasó de dos a tres. Los dos primeros siguieron siendo nombrados por los linajes y la Comunidad era quien nombraba al de nueva creación ${ }^{856}$.

Además de los nombramientos de los regidores vitalicios, los monarcas también designaron a los escribanos del Concejo y proveyeron ...commo avian de ser elegidos $e$ nonbrados los alcalldes e otros ofiçiales de la dicha villa. La escribanía del concejo fue objeto de reforma, estableciéndose un oficio dúplice en el que se fijaba un escribano de los Caballeros y otro de los Hombres Buenos, propuestos por los regidores de los linajes y de la Comunidad, respectivamente, pero confirmados y nombrados por el monarca ${ }^{857}$. Sin embargo, se observa cierto grado de patrimonialización en este oficio pues en 1488 ya se detecta el mecanismo de la renunciación en el traspaso de la escribanía de manos de Sancho de Castro a Pedro García Quijadas ${ }^{858}$. Tras recibir el nombramiento real debían prestar juramento ante la asamblea del ayuntamiento. En su labor cotidiana era requisito indispensable que los documentos contaran con la firma de ambos escribanos para que las disposiciones municipales cumplieran con la legalidad ${ }^{859}$.

Además de los cambios anteriores, los monarcas también otorgaron a la villa unas ordenanzas que regulaban la elección de los alcaldes y oficiales menores; la asistencia y la validez de las decisiones; la obligatoriedad de residir en la villa un determi-

vaban cinco regidores cada uno y la Comunidad otros cinco, aunque bien es cierto que dos correspondían a los pecheros de la villa y tres a los de la Tierra (ASENJO GONZÁLEZ, Segovia. La ciudad..., p. 289).

${ }^{855}$ El primer Regidor de la Comunidad del que tenemos noticia fue Juan Sánchez del Prado que falleció en 1486 y fue sustituido por Juan Fernández Mexía (AGS, RGS, 148612, fol. 55).

${ }^{856}$ AGS, CC PUEBLOS, leg. 2, doc. 82; y CC MEMORIALES, leg. 149, doc. 230.

${ }^{857}$ AGS, RGS, 148509, fol. 85.

${ }^{858}$ Este mecanismo podía encubrir una venta o bien una relación familiar que desconocemos (AGS, RGS, 148803, fol. 16).

${ }^{859}$ AGS, RGS, 148509, fol. 85 
nado periodo de tiempo; las funciones y competencias de los distintos oficiales; así como otros asuntos.

Ahora bien, nos preguntamos en este momento si la reforma del regimiento arandino respondió a una causa coyuntural, en este caso el caos en que estaba sumido el gobierno municipal y los conflictos que se reproducían cada día de Año Nuevo con la elección de los oficiales, como denunciaban insistentemente los procuradores del Común. Si así fuera, esta reforma no sería más que la respuesta concreta para solucionar un problema y no debería tener mayor repercusión. Sin embargo, la combinación de la imposición del corregidor y la reforma del regimiento parecen responder a una dinámica de creciente intervención de la autoridad real en las ciudades de realengo, entre las cuales la arandina destacaba por el evidente retraso en adoptar las medidas que en otras ya eran habituales bastante tiempo antes.

Pero además de este retraso, también advertimos un relativo interés de la Corona por favorecer de alguna manera la participación del Común en los órganos de gobierno municipal. No sabemos si, como afirma González Alonso ${ }^{860}$, se intentaba equilibrar la influencia de caballeros y pecheros en los concejos; o si bien esta iniciativa respondía a la política de contentar a todos pero dejando las cosas como estaban, pues es evidente que la reforma sancionaba precisamente el desequilibrio. Fuera una u otra la intención, lo cierto es que la Corona impuso su reforma con lo que afianzó su posición de control sobre la vida política arandina. Si bien es cierto que esta modificación permitió la confirmación de la Comunidad como actor político y la dotó de instrumentos de representatividad dentro del gobierno municipal, lo cierto es que a medio plazo este cambio consolidó a la oligarquía tradicional en su posición de dominio en el ámbito urbano.

La situación se complicó más si cabe cuando a mediados de la última década del siglo XV los paladines de la defensa de los intereses de la Comunidad desde su posición de regidores de la Comunidad, Martín Sánchez de Casasola y Juan Fernández Mejías, optaron por retirarse de la política activa de una manera poco digna pero bastante renta-

${ }^{860}$ GONZÁLEZ ALONSO, B., "Sociedad urbana y gobierno municipal en Castilla (14501600)", en Sobre el Estado y la administración de la Corona de Castilla en el Antiguo Régimen. Madrid, 1981, pp. 57-84. El autor hace una relación de municipios en los que se promovió la participación de los gobernados en el gobierno local y retoma la idea de GIBERT de la existencia de una ley no incluida en el Ordenamiento de las Cortes de Toledo que versara sobre esta participación (p. 78). Por su parte, DIAGO HERNANDO plantea que el caso arandino es una excepción pues lo que predominaba en las villas castellanas gobernadas por los linajes era que no tuvieran que compartir el poder con los pecheros ("El papel de los linajes en las estructuras del gobierno urbano en Castilla y en el Imperio alemán durante los siglos bajomedievales", en En la España Medieval. 20, 1997, pp. 143-177, en especial p. 172). 
ble. En 1494 Casasola vendió su oficio al poderoso Pedro de Santa Cruz y poco después Antonio de Contreras se lo compró a Mejías ${ }^{861}$. Evidentemente, tras este paso la representatividad e identificación de este oficio con los intereses de la Comunidad desaparecieron por completo, como lo pone de manifiesto claramente el hecho que desde ese momento en ninguna ocasión aparezca el apelativo Comunidad en la designación de Pedro de Santa Cruz o de Antonio de Contreras como regidores. También es significativo de esta nueva realidad que en los últimos años del siglo XV de nuevo se recuperara la figura del procurador de la Comunidad como representante de este colectivo ${ }^{862}$.

Diago Hernando afirma que la imposición del regimiento vitalicio no fue aceptada de buen grado por amplios sectores de la sociedad política arandina que presionaron a los monarcas para restablecer el anterior sistema de gobierno municipal ${ }^{863}$. Entre los descontentos se encontrarían algunos miembros de la oligarquía, que vieron reducida su participación efectiva en los órganos de gobierno local, y una buena parte de la Comunidad que, como hemos visto, desde finales del siglo XV había perdido la posibilidad de verse representada a través de los regidores de la Comunidad ${ }^{864}$.

En conclusión, la situación de desequilibrio entre caballeros y Comunidad se vio confirmada durante los últimos años del Cuatrocientos al desaparecer cualquier mención expresa a los regidores de la Comunidad e incluso los propios monarcas sancionaron esta realidad al conceder la merced de los regimientos de este sector a individuos encuadrados dentro de la clientela de los linajes ${ }^{865}$. A comienzos del siglo XVI era eviden-

${ }^{861}$ AGS, RGS, 149908, fol. 129; y 150007, fol. 128.

${ }^{862}$ La figura del procurador no desapareció durante los años ochenta y primeros noventa pero no aparece el apelativo comunidad junto a él y, por el contexto, se interpreta como representante de la villa en su conjunto. En 1497 Juan Muñoz, vesino desa dicha villa en nombre de la comunidad della, presentó una serie de quejas contra la exención fiscal de algunos de los miembros de los linajes (AGS, RGS, 149705, fol. 137).

${ }^{863}$ DIAGO HERNANDO, “Hidalgos y pecheros..., pp. 1120-121.

${ }^{864}$ Los documentos en los que se basa el argumento de Diago Hernando son precisamente de 1504 y 1505, momentos en los que la Comunidad tan solo contaba con la figura del menospreciado Procurador de la Comunidad como representante de sus intereses en el seno del ayuntamiento (AGS, RGS, 150404, s.f.; y AMA, leg. 43, doc. 17, transcrito por HURTADO QUERO, M., y PERIBÁÑEZ OTERO, J. G., Los Reyes Católicos en el Archivo de Aranda de Duero. Aranda de Duero, 2004, pp. 145-147).

${ }^{865}$ El ejemplo más claro es, de nuevo, el de Pedro de Santa Cruz, emparentado con destacados miembros del linaje de don Romero - los Salazar-, que en 1494 recibió de los monarcas el regimiento perpetuo por renuncia de Martín Sánchez de Casasola, regidor de la Comunidad (AGS, RGS, 149406, fol. 74). 
te la desaparición de cualquier representatividad del común en el seno del regimiento ${ }^{866}$, convirtiéndose el oficio de regidor en un instrumento más de gratificación que utilizaron los monarcas para premiar a ciertos individuos distinguidos por sus servicios a la Coro$\mathrm{na}^{867}$.

Un paso más dentro del creciente intervencionismo de la Corona se produjo hacia 1504 con la imposición del nombramiento vitalicio también para las escribanías del número. Hasta ese momento este oficio se arrendaba anualmente lo que provocaba que ...en la villa hay mucho desorden y mal recaudo en los escribanos y en las escrituras de los vecinos y moradores. Ya en el año 1500 se intentó corregir esta situación y se encomendó al corregidor que cumpliera con lo estipulado en las Cortes de Toledo y se reuniera con los regidores para fijar el número de escribanos del número que necesitaba la villa ${ }^{868}$. En esta instrucción se establecían las modificaciones más importantes que se concretaron en 1504, amparándose en el consabido bien común ${ }^{869}$. La nueva medida estipulaba que el nombramiento era vitalicio y que el candidato debía ser vecino de la villa y ...personas de buena fama, aviles e sufiçientes, que tengan título de nos para poder ser escribano. Además ...sobre los escribanos que asi eligiereis cargueis de pension para el reparo de la puente de la dicha villa sobre cada uno 2.000 maravedies. También se establecía que cuando vacase una escribanía correspondía a la justicia, entiéndase corregidor, y regidores elegir al nuevo escribano que luego debía ser sancionado por el monarca ${ }^{870}$. La reforma no contó con el beneplácito del regimiento municipal, pues aunque seguían siendo los regidores los que nombraban al oficial, el paso de anual a perpetuo suponía una clara limitación al sistema de gratificaciones del sistema clientelar que los sustentaba y esta medida limitaba claramente uno de los recursos más lucra-

\footnotetext{
${ }^{866}$ DIAGO HERNANDO llega también a la misma conclusión después de analizar los casos de venta de regimientos a finales del siglo XV ("Hidalgos y pecheros..., p. 115).

${ }^{867}$ Como veremos más adelante, fue el caso de algunos miembros de las familias Acuña, Avellaneda y Zúñiga. La generalización de concesiones de regimientos provocó que a mediados del siglo XVI el número de regidores aumentara considerablemente, oscilando entre los 13 y los 18 (AGS, CC PUEBLOS, leg. 2, doc. 55).

${ }^{868}$ AGS, RGS, 150012, fol. 210.

${ }^{869}$ Este aspecto ha sido abordado con todo lujo de detalles por DIAGO HERNANDO, "Cambios políticos..., pp. 318-320.

${ }^{870}$ Pragmática hecha en Medina del Campo el 30 de marzo de 1504 (AGS, CR, leg. 453, doc. 5). Los reyes manifestaban que esta orden se limitaba a aplicar lo establecido en el Ordenamiento de Toledo de 1480 .
} 
tivos. Esta circunstancia la advertimos perfectamente en 1518 cuando vacó por defunción la escribanía de Juan Martínez de Quemada. Fue entonces cuando su hermano, Francisco de Quemada, presentó ante el Concejo la renuncia de su hermano en su favor. Los oficiales no la aceptaron porque ...no vibio el término de los veinte dias que establecía la ley. Junto a Quemada se presentaron otros tres candidatos: García Pilón ${ }^{871}$ que contaba con una carta de recomendación del rey y el apoyo del corregidor; Alonso de Pardilla al que respaldaban dos regidores; y Antonio de Ríos que sumaba el apoyo de cuatro regidores. En la sesión del concejo que debía determinar el sucesor de Quemada al frente de la escribanía asistieron seis regidores y el corregidor. El escrutinio de la votación secreta fue el reflejo de los apoyos con los que contaba cada aspirante. A pesar del resultado de la votación el corregidor decidió enviar el proceso de elección al Consejo Real para que allí se determinara a quién le correspondía la vacante. Por lo tanto advertimos claramente que esta reforma mermó considerablemente la capacidad de decisión de la oligarquía arandina pues estaba totalmente supeditada a la autoridad del corregidor o de las instituciones de la Corona ${ }^{872}$. No es de extrañar que una de las primeras medidas tomadas por el gobierno comunero fuera la de destituir a los escribanos del número, no sólo por retomar un antiguo privilegio, sino porque entre los escribanos se encontraban bien asentados los linajes de los caballeros o los servidores más fieles del monarca.

En definitiva, todas estas reformas supusieron un aumento significativo del control que la Corona ejercía sobre el gobierno municipal, a la vez que encumbró y consolidó en su posición de poder a una oligarquía cada vez más fuerte, pero también más dependiente de la Corona.

${ }^{871}$ García Pilón ya había conseguido en 1510 una notaría real (AGS, CC CÉDULAS, libro 7, leg. 229 , doc. 10).

${ }^{872}$ MONSALVO ANTÓN señala que con medidas de este tipo se fomentaba la patrimonialización de los oficios, que en este caso se puede extrapolar a las escribanías del número, a la vez que limitaban su control sobre los nombramientos de oficiales menores y las rentas, en este caso las generadas por la "subasta" anual de las escribanías, elementos sobre los que se asentaban las expectativas de sus clientelas ("La sociedad política en los concejos castellanos de la Meseta durante la época del regimiento medieval. La distribución social del poder", en Concejos y ciudades en la Edad Media hispánica. 1990. pp. 359-413). 


\subsubsection{Funcionamiento y características del concejo.}

Tras analizar la implantación de sistema del regimiento en el concejo arandino, vamos a detenernos a continuación en describir su funcionamiento interno y el papel que los diferentes oficiales del concejo desempeñaban en la vida política municipal. Finalmente analizaremos dos factores que nos parecen determinantes en este sistema político monopolizado por la oligarquía local que, por una parte, padeció en cierta medida la amenazada de la presencia de un Común cada vez más reivindicativo; y por otro lado, se vio sometida a la creciente influencia de las redes clientelares de una pujante nobleza comarcana encabezada por las casas de Miranda y Denia.

\section{a. Funcionamiento del concejo.}

A partir de los primeros años de la década de los 80 el concejo arandino estaba compuesto por los seis regidores de los linajes más los tres de la Comunidad.

No han llegado hasta nosotros las ordenanzas ni los libros de actas del ayuntamiento que hubieran permitido conocer con mayor detalle la organización interna del concejo $^{873}$. No obstante, a través de las fragmentarias informaciones que nos han transmitido otras fuentes hemos logrado reconstruir parcialmente la normativa que regulaba el funcionamiento del ayuntamiento arandino ${ }^{874}$.

Las sesiones del concejo se celebraban bajo la presidencia del corregidor o su teniente y reunían a los regidores más los alcaldes y escribanos. Para que la sesión tuviera validez era necesaria la presencia de al menos un regidor por cada uno de los tres estados; de alguno de los alcaldes; y de los dos escribanos, que debían actuar de forma colegiada $^{875}$. A estas reuniones también acudía regularmente el mayordomo y otros oficiales. Tras la desaparición de los regidores de la Comunidad también se incorporaron a

${ }^{873}$ Según diversos testimonios orales, durante las obras de reforma del edificio del Ayuntamiento arandino realizadas en 1971 se vacío el Archivo municipal y parte de los libros de actas, según algunos, se vendieron a un trapero o, según otros, se quemaron directamente. A día de hoy es posible que alguno de estos registros se encuentre en manos particulares por lo que no perdemos la esperanza de que algún día el contenido histórico de esta documentación vuelva a ser patrimonio de todos los arandinos.

${ }^{874}$ En buena medida el funcionamiento del regimiento arandino no debió diferir mucho del que tuvo lugar en el resto de las ciudades castellanas por lo que creemos apropiado recurrir a la obra de POLO MARTÍN, R., El régimen municipal de la Corona de Castilla durante el reinado de los Reyes Católicos (Organización, funcionamiento y ámbito de actuación). Madrid, 1999. A nivel local nos parece muy interesante el apartado dedicado al concejo en la obra de SOLÓRZANO TELECHEA sobre la villa de Santander (Santander en la Edad Media. Patrimonio, parentesco y poder. Santander, 2002, pp. 288 y ss.). tivamente.

${ }^{875}$ AMA, leg. 43, doc. 1; AGS, CC PUEBLOS, leg. 2, doc. 88; y RGS, 148509, fol. 85, respec- 
estas reuniones los Procuradores de la Comunidad ${ }^{876}$. Las reuniones se celebraban de manera ordinaria dos veces a la semana, siendo obligatoria la asistencia para todos los que estuvieran en la villa. El espacio elegido para la reunión varió bastante con el tiempo. Lo más habitual durante el siglo XV fue que el escenario de estas reuniones fuera la ermita de Santa $\mathrm{Cruz}^{877}$, mientras que con el cambio de siglo se optó por celebrar las sesiones en las casas del concejo que estaban situadas sobre y junto a la puerta más importante de la villa, la de Duero. No obstante, también se documentan reuniones en lugares tan dispares como las gradas ${ }^{878}$ o el cementerio de Santa María ${ }^{879}$.

Además de estas citas semanales, también se contemplaba la posibilidad de convocatorias extraordinarias para abordar temas importantes o urgentes ${ }^{880}$. En estas ocasiones el portero del concejo y un escribano debían notificar la convocatoria y el motivo de la asamblea extraordinaria casa por casa. En el caso de que alguno de los regidores no fuera avisado personalmente se le otorgaba el derecho de contradeçir lo resuelto por el resto de los regidores. Las decisiones se tomaban en principio por mayoría, aunque en ocasiones el corregidor hacía valer su calidad o incluso derivar ciertas decisiones importantes hacia el Consejo Real, independientemente de lo acordado en el ayuntamiento ${ }^{881}$.

Los regidores, como el resto de los oficiales del concejo, cobraban un salario que no conocemos y que recibían cada cuatro meses. También estaban sujetos a multas por

${ }^{876}$ AGS, RGS, 151204, s. f.

877 ... dentro en la yglesia de Santa Crus desa dicha villa de Aranda donde se suele e acostumbra faser regimiento e ayuntamiento... (AGS, CC PUEBLOS, leg. 2, doc. 69). Al menos desde 1413 las reuniones del concejo se realizan en esta iglesia (AMA, leg. 42, doc. 7).

${ }^{878}$ Sepan quantos este publico instrumento vieren como en la villa de Aranda de Duero, en las gradas de la Iglesia de Santa María, que estan en la plaza de la dicha villa a la hora de tercia del viernes... 28 de agosto de 1439, ...año noveno del pontificado de Eugenio IV, reunido el concejo de Aranda (AMA, leg. 43, doc. 5).

${ }^{879}$ El jueves 31 de enero de 1426 se reunió el concejo de Aranda con los procurares de sus aldeas en el cementerio de Santa María ...segun lo tienen de uso e costumbre (AMA, leg. 43, doc. 4). La utilización del cementerio como lugar de reunión era bastante habitual en las ciudades castellanas y también en la comarca ribereña: en 1433 el concejo de Peñaranda redactaba una carta de poder ...estando ayuntados en nuestro concejo a cerca de la entrada de la puerta del cementerio de la iglesia de San Miguel...(AHN, CLERO, leg. 1066, doc. 6); en 1510 el concejo de Fuentearmegil se reunía a campana tañida en el cementerio de la iglesia de San Andrés (AGS, EMR, leg. 687).

${ }^{880}$ Así se hizo en diciembre de 1518 cuando fueron convocados los regidores para elegir un nuevo escribano del número (AGS, CR, leg. 453, doc. 5).

${ }^{881}$ De nuevo en el proceso de elección de un escribano del número en 1518 se observa cómo tras la votación uno de los pretendientes tenía más votos que el propuesto por el corregidor. Finalmente fue el Consejo Real el que decidió sobre el asunto tras recibir la documentación del proceso de manos del corregidor (AGS, CR, leg. 453, doc. 5). 
no asistir a las reuniones del concejo sin justificación. Estas penas eran descontadas por el mayordomo del montante total del salario ${ }^{882}$. Pero además los regidores tenían ingresos extras, entre los que destacan los tres yantares anuales y otras prebendas ${ }^{883}$.

Los procuradores de la Comunidad disponían de 2.000 maravedíes adicionales ...para que aviendo nescesidad el procurador de la dicha comunidad pueda tomar de ellos los que fueren menester para nos faser saber el estado de la dicha comunidad e lo que en ella es nescesario proveer $^{884}$. Esta merced se consiguió en 1499 y puede parecer una iniciativa de apoyo de la Corona a la Comunidad. Sin embargo, más bien se trató de un instrumento para limitar la autonomía de la Comunidad, pues con esta medida se eliminaba el anterior privilegio que permitía la realización de repartimientos sin licencia real siempre que no se superasen los 3.000 maravedíes y se destinaran para gastos de procuración $^{885}$. Estos representantes de los pecheros no tenían sueldo, circunstancia que explica por qué este oficio fue sistemáticamente desempeñado por destacados y hacendados miembros de la Comunidad. En 1512 los dos procuradores presentaron al Consejo Real una petición para que se estableciera un sueldo para su oficio pues ...se les sigue mucho daño y perdida de sus haciendas porque han de entrar dos dias por semana en el ayuntamiento. Por todo ello solicitaron el establecimiento de un salario de 1.000 maravedíes anuales a cuenta de los bienes de propios del concejo ${ }^{886}$.

En cuanto a las funciones desempeñadas por los oficiales del concejo, la principal atribución del Regimiento arandino fue la de gobernar la ciudad en el sentido amplio del término. La escasa documentación con la que contamos muestra sobretodo dos campos en los que se centraba la acción de gobierno municipal. Por una parte, los oficiales se encargaban de regular la vida cotidiana de los vecinos en todos sus campos atendiendo al bien común: administraban justicia, garantizaban los abastecimientos, velaban por el cumplimiento de los pesos y mediadas así como de los precios, procuraban la seguripp. 53-55.

${ }^{882}$ AMA, leg. 1222, doc. 18, transcrito por HURTADO QUERO, Documentos Reales..., $\mathrm{n}^{\circ} 28$,

883 ...los dichos regidores puedan comer e coman tres yantares en cada año y no mas, el uno el dia que se fesieren las cuentas de los propios del concejo, e el otro de amasados las carneçerias, e el otro de la pescaderia (AGS, CC PUEBLOS, leg. 2, doc. 88). Estas comidas debían ser espectaculares pues llegaban a gastarse en cada una de ellas hasta 2.000 maravedíes (RGS, 150403, s. f.; y 150702, s.f.).

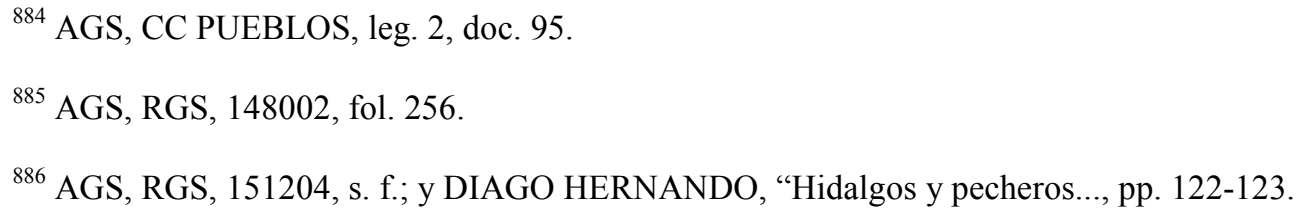


dad e higiene del espacio urbano, se encargaban del mantenimiento de las infraestructuras, promovían la salud de los cuerpos y de las almas, visitaban las cárceles y sus presos, regulaban planes urbanísticos e, incluso, fomentaban la especulación inmobiliaria $^{887}$

El segundo campo de actuación fue el control del territorio ${ }^{888}$. La mayor parte de la información con la que contamos de la primera mitad del siglo XV se centra en la defensa de los límites territoriales de la Tierra arandina que, como claro síntoma de expansión roturadora y ganadera, entró en conflicto con todos sus vecinos ${ }^{889}$. En este contexto, las autoridades encaminaron casi todos sus recursos humanos y económicos a incrementar el término de la villa con la adquisición de heredades que pertenecían a los maltrechos monasterios vecinos. Todo ello con la intención de garantizar la incipiente prosperidad económica, así como fortalecer el prestigio del floreciente núcleo urbano ${ }^{890}$.

Los oficiales encargados de impartir justicia eran los alcaldes. La primera mención que conocemos de los dos alcaldes se fecha en 1411 cuando Pedro García y Alfonso Fernández dieron fe de un traslado realizado por el notario Juan Fernández de un privilegio que Alfonso X concedió al convento de Santo Domingo de Caleruega ${ }^{891}$.

A pesar de la reforma de principios de los años 80 , se mantuvo el carácter electivo anual de este oficio que se renovaba también el día de Año Nuevo junto al resto de los oficiales menores del concejo. Al igual que los regidores, el oficio de alcalde estaba muy vinculado a los linajes pues eran los regidores de cada linaje los que elegían de entre los miembros de su clientela a la persona destinada a ocuparse de la justicia ${ }^{892}$.

${ }^{887}$ VELASCO PÉREZ, Aranda. Memorias..., pp. 87-88; AMA, leg. 43, doc. 20, transcrito por HURTADO QUERO, Documentos Reales..., no 17, pp. 34-36; y PERIBÁÑEZ OTERO, J. G. y ABAD ÁLVAREZ, I., "El agua como fuente para el estudio del poblamiento", en El agua en las ciudades castellanas durante la Edad Media. Valladolid, 1998, pp. 257-282.

${ }^{888}$ La defensa y el control del territorio era un elemento primordial dentro de la política de los concejos de realengo (ASENJO GONZÁLEZ, "La aportación del sistema urbano..., p. 318).

${ }^{889}$ En 1416 con La Aguilera (AMA, leg. 1101, fol. 4); en 1423 y 1426 con Gumiel de Izán; y con Haza en 1432 (VELASCO PÉREZ, Aranda. Memorias..., pp. 93-97). Fue tal la presión roturadora y los conflictos originados que en los años 30 se realizaron unas ordenanzas para regular las roturaciones (AMA, leg. 43, fol. 27).

${ }^{890}$ La aldea de Quemada fue comprada en 1396 a la abadesa del monasterio de Fuencaliente y el lugar de Revilla de Olleros al monasterio de La Vid en 1426 (VELASCO PÉREZ, Aranda. Memorias..., pp. 91-92 y AMA, leg. 43, doc. 4).

${ }^{891}$ MARTÍNEZ LIÉBANA, Colección Diplomática..., doc. XVI, pp. 20-21.

${ }^{892}$ AMA, leg. 43, doc. 2. 
Esto es lo que ocurrió en 1485 cuando el regidor Pedro de Salazar, del linaje de don Romero, nombró como alcalde a su hermano García. Con cierta frecuencia, como veremos más adelante, esta situación se tradujo en constantes protestas por parte de algunos arandinos que acusaban de parcialidad a los alcaldes en sus actuaciones y reclamaban a los monarcas la intervención de pesquisidores o corregidores para tratar de hacer justicia en la villa ${ }^{893}$. Con la reforma se incrementó la nómina de estos oficiales con un tercer alcalde y su elección se asignó al cuento de la Comunidad, como se hizo efectivo en la elección 1487 de Pedro Ortuño como alcalde por designación del regidor de la Comunidad Martín Sánchez de Casasola ${ }^{894}$.

Además de la función judicial, los alcaldes también formaban parte del ayuntamiento en el cual debían estar presentes y emitían su voto ${ }^{895}$. Para su actividad cotidiana estos oficiales contaban con la asistencia de un número indeterminado de sayones que se encargaban de comunicar las citaciones, ejecutar penas y embargos e incluso aplicar tormento sobre los presos para obtener confesiones ${ }^{896}$.

Otro de los principales oficios era el de escribano del concejo pues su firma sancionaba los asuntos y acuerdos de las autoridades municipales ${ }^{897}$.

La primera referencia a un escribano de la villa se remonta a los años finales del siglo XIII cuando este oficial actuó como árbitro en una sentencia entre el monasterio de Santa María de la Vid y el concejo de Vadocondes. La función institucional del escribano arandino se ve confirmada por la cláusula que especificaba la necesidad de incluir el sello del concejo arandino para refrendar el acuerdo ${ }^{898}$. No obstante, a lo largo del siglo XIV son muy reducidas las referencias a este oficio pues tan solo hemos localizado la

${ }^{893}$ AGS, RGS, 148002, fol. 256.
${ }^{894}$ AGS, CC MEMORIALES, leg. 149, doc. 230.
895 ...en los dichos ayuntamientos se han de estar presentes alcaldes e regidores e syn los unos e syn los otros non puede ser nin llamarse ayuntamiento e que se declaraba e declaro que sin voto de los dichos alcaldes o de alguno dellos non se pudiese nin puedan haser determinaçion alguna en los dichos regimientos e ayuntamientos y todo lo que de otra manera se fesiere que non vala nin sea complido e que se guarde e cumpla en esto lo que las leyes del reyno e el privilejio desta villa manda e dispone (AGS, CC PUEBLOS, leg. 2, doc. 88).

${ }^{896}$ AGS, RGS, 148705, fol. 36; y 148707, fol. 59.

${ }^{897}$ Sobre el importante papel que jugaba el escribano en el seno del concejo y las características de su oficio ver CUÑAT CISCAR, V. M.,"La memoria del poder concejil: el documento escrito", en $L a$ gobernanza de la ciudad europea en la Edad Media. Logroño, 2011, pp. 517-547.

${ }^{898}$ AHN, CLERO, carpeta 381, doc. 4. 
actividad del escribano Pedro Fernández que en 1376 parece actuar como tal cuando realizó una copia de un privilegio del convento de Santo Domingo de Caleruega con autoridad de Juan Perez, alcalde de Aranda ${ }^{899}$. Sin embargo, en varias intervenciones de este individuo desde 1326 tan sólo hemos conseguido identificarle como escrivano publico de Aranda ${ }^{900}$. Fuera escribano del concejo o no, llama la atención que este mismo nombre aparezca asociado a esta actividad durante medio siglo, lo que nos hace pensar que, a pesar de lo común del nombre, bien pudiera tratarse del mismo individuo -algo difícil tras cincuenta años- o más bien que fuera su hijo, por lo que estaríamos hablando de una incipiente patrimonialización del oficio ${ }^{901}$.

A lo largo del siglo XV actuaron diversos individuos como escribanos del concejo sin que podamos apreciar continuidad en el cargo. Todo ello nos lleva a deducir que se trataba de un oficio de elección anual como el resto. Por el momento no conocemos los mecanismos de elección, ni tampoco la vinculación con los linajes para este periodo inicial $^{902}$.

La documentación sobre los primeros años de funcionamiento del regimiento es muy parca en detalles pero parece intuirse la existencia de un solo escribano. Es posible que con el paso del tiempo este oficio se duplicara, pero no tenemos constancia evidente de esta duplicidad hasta la reforma de la institución a comienzos de los años ochenta ${ }^{903}$.

La presencia de los escribanos era imprescindible para que se pudiera desarrollar la sesión del concejo y solo sus firmas colegiadas daban validez a los acuerdos tomados en las sesiones del ayuntamiento. Para este fin el escribano contaba con un registro en el que tomaba nota de todo lo sucedido durante las sesiones del ayuntamiento ${ }^{904}$. Suponemos que este libro de registro se depositaría en el archivo del concejo que no era otra

${ }^{899}$ MARTÍNEZ LIÉBANA, Colección Diplomática..., docs. LXXXIX y XCII, pp. 108-110 y 112.

${ }^{900}$ Por este escribano pasaron numerosas ventas, donaciones y cartas de compromiso entre 1326 y 1376 (MARTÍNEZ LIÉBANA, Colección Diplomática..., docs. CCLXXV, CCLXXVI, CCLXXVIII, CCLXXIX, CCLXXXI, CCLXXXIV, CCLXXXV, pp. 363-376). En 1347 aparece Alfonso Sánchez como escribano de Aranda y Pedro Fernández, escribano, figuraba como testigo.

${ }^{901}$ Este mismo fenómeno lo ha detectado MARTín CEA en la villa de Paredes en la primera mitad del siglo XV (El mundo rural..., p. 197).

${ }^{902}$ La irreparable pérdida de los libros de actas del concejo no permite elaborar una relación cronológica detallada y tan solo contamos con escasas y fragmentarias informaciones.

${ }^{903}$ AGS, RGS, 148509, fol. 85.

${ }^{904}$ AGS, CC MEMORIALES, leg. 161. doc. 122. 
cosa que una gran arca de madera donde se guardaban los privilegios reales y documentos importantes para la villa y que se depositaba en una de las capillas de la iglesia de Santa María ${ }^{905}$.

El escribano del concejo en el momento de jurar su cargo se comprometía a trasladar fielmente las decisiones establecidas en el seno del ayuntamiento. En este sentido, se contemplaba la posibilidad de la destitución definitiva o la suspensión temporal del ejercicio de su oficio en caso de no cumplir escrupulosamente con su misión. Esta última sanción fue aplicada en el año 1500 al escribano Pedro García Quijadas. Fue acusado por parte del regidor Francisco de Mena de haber falsificado un documento. En su defensa el escribano alegaba que la equivocación fue inocente. Finalmente fue condenado a la suspensión temporal de su oficio y al pago de una multa de 2.000 maravedíes, a pesar de las quejas del regidor que exigía la destitución ${ }^{906}$.

La figura del escribano fue fundamental para la consolidación de un grupo de poder pues en la sociedad feudal el documento escrito se impuso como el principal instrumento de legitimación. Por lo tanto, el control del gestor y emisor de documentos escritos se convirtió en un preciado objetivo de todos aquellos que pretendían ejercer el poder.

El mayordomo era el oficial que se encargaba de velar por la hacienda municipal y gestionar los escasos propios de la villa. Se trataba de un cargo unipersonal que era elegido anualmente por los regidores. Su principal cometido era de índole contable y fiscal $^{907}$, aunque también debía establecer los precios de los mantenimientos junto a los fieles y velar por el buen funcionamiento del mercado ${ }^{908}$. Asimismo se encargaba de entregar los salarios de los oficiales del concejo y, en ciertas ocasiones, imponer multas y descontarlas de los sueldos ${ }^{909}$. El mayordomo consignaba en el libro del conçejo tanto

\footnotetext{
${ }^{905}$ AGS, CC MEMORIALES, leg. 129, docs. 43 y 55.

${ }^{906}$ AGS, RGS, 150008, fol. 312.
}

${ }^{907}$ Sus competencias estaban reguladas por un privilegio real al que se hace referencia en ocasiones pero que no ha llegado hasta nosotros. En 1491 los alcaldes ordenaron al mayordomo Alonso de Aranda que abonara cierta cantidad ...quellos se los arian reçebir en quenta e dar libramiento dellos; e el dicho Alonso de Aranda dixo que non los dara syn que le diese libramiento segund el previllegio lo mandava (AGS, CC PUEBLOS, leg. 2. doc. 88).

${ }^{908}$ AGS, RGS, 149705, fol. 76.

${ }^{909}$ En 1501 la reina impuso una multa de un real por cada una de las sesiones del ayuntamiento a las que los regidores no acudieran. El escribano del concejo debía tomar nota de los asistentes en todas las sesiones y pasarle el listado al mayordomo cada cuatro meses, coincidiendo con el pago de su salario. El 
los ingresos como los gastos y además gestionaba un registro de los bienes inmuebles propiedad municipal, el libro de los ençensos que tiene la villa, donde debía fijar las condiciones de los arrendamientos ${ }^{910}$. Este mismo cargo con idénticas atribuciones fiscales existía en otras villas de las mismas características que Aranda ${ }^{911}$.

Con la reforma de principios de los ochenta se creó una nueva figura, los alcaldes de cuentas, ligados a la comunidad y encargados de controlar las cuentas del concejo. No obstante, la escasez de noticias sobre este oficio nos hace pensar que este oficio tuvo poca continuidad y desarrollo ${ }^{912}$.

Importante también era el oficio de alguacil que se encargaba de hacer cumplir las decisiones tomadas por las autoridades, así como de ejecutar las penas e imponer las sanciones dictadas por la justicia ordinaria. De todos los oficiales mayores este fue el único que no tenía carácter electivo pues estuvo detentado desde los años setenta de la decimoquinta centuria hasta los primeros años del siglo XVI por el madrileño Juan de Cuero. Parece ser que este oficio lo obtuvo tras recibirlo como merced de manos de la reina Isabel ${ }^{913}$. Cuero fue absentista en el desarrollo de su oficio pues estuvo actuando por toda Castilla como delegado de los monarcas en numerosas misiones. En consecuencia, el alguacil nombró a un lugarteniente que realizaba sus funciones en la tierra $\operatorname{arandina}^{914}$. A partir de 1510 la villa retomó unilateralmente su capacidad de nombrar alguacil pero en 1516 este cargo fue a parar a don Juan de Zúñiga, hermano del conde

mayordomo debía comprobar la lista y restar el montante de las posibles multas antes de entregar el salario. En caso contrario, el mayordomo tendría que hacer frente a las multas con su propio salario (AMA, leg. 1222, doc. 18, transcrito por HURTADO QUERO, Documentos Reales..., nº 28, pp. 53-55).

${ }^{910}$ AGS, CC PUEBLOS, leg. 2, doc. 107; y CR, leg. 450, doc. 8.

${ }^{911}$ Así, por ejemplo, lo identifica OLMOS HERGUEDAS en la villa de Cuéllar (La Comunidad de Villa y Tierra..., p. 174); y MARTÍN CEA en la villa de Paredes de Nava, aunque allí también asumen el nombre y las competencias de los procuradores (El mundo rural..., pp. 194-196).

${ }^{912}$ En una queja presentada por los cuadrilleros en 1491 se señalaba que ...algunos de los dichos regidores dizen que los libramientos en que entendieren e consyntieren regidores de los tres estados que estos han de pasar syn ser vistos nin estimados por los alcaldes de cuentas que sus altesas costituyeron e fundaron en esta villa (AGS, CC PUEBLOS, leg. 2, doc. 88).

${ }^{913}$ El concejo arandino reclamó su derecho a nombrar al nuevo alguacil tras la muerte de Cuero argumentando que había sido una cesión del privilegio de la villa a la reina (AGS, CC PUEBLOS, leg. 2, doc 53).

${ }^{914}$ En 1478 ejercía como teniente de alguacil Alfonso Ordóñez y en 1480 Alonso de Tordomar. Hasta 1487 lo desempeñó Aparicio de Gormaz a quien sucedió Pedro Pérez de Espinosa durante varios años (AMA, leg. 1222, doc 20; AGS, RGS, 148012, fol. 275; 148502, fol. 182; CC PUEBLOS, leg. 2 doc. 60 y 96). Desde 1498 ocupó este oficio Luis de Vallejo y se mantuvo en él durante más de catorce años, incluso después de la muerte de Cuero (AGS, CR, leg. 450, doc. 8). 
de Miranda, por merced del rey Carlos $^{915}$. Esta circunstancia originó un nuevo conflicto entre la villa y la casa de Miranda del que trataremos más adelante.

Con carácter excepcional también se creaban oficios para abordar situaciones específicas o solucionar problemas concretos. Este fue el caso de los jueces de rompimientos, oficio que creó el obispo de Osma en su calidad de juez árbitro para solucionar las constantes disputas que sobre nuevas roturaciones se producían en la villa en 1433. El prelado estableció que estos dos jueces fueran dos vecinos, uno de ellos ...escogido por parte de los alcaldes regidores e los omes buenos de los linajes de la dicha villa; e el otro por los procuradores del comun de la dicha villa ${ }^{916}$.

Aunque no se trata de un oficial del concejo propiamente dicho, hemos constatado que el concejo contrataba generalmente los servicios de un letrado que asesoraba al regimiento en temas jurídicos ${ }^{917}$. Ya en 1486 los alcaldes ordinarios eran asesorados por este letrado antes de iniciar cualquier procedimiento ${ }^{918}$. Ese mismo año los regidores de la Comunidad decidieron unilateralmente contratar a un letrado aragonés para desempeñar esta función, aunque su capacidad fue puesta en entredicho por los regidores de los linajes y algunos vecinos ${ }^{919}$.

Entre las funciones del letrado destacaba la de asesorar a los regidores sobre la legalidad de algunas de las decisiones que tomaban en el concejo. Así lo comprobamos en 1517 cuando el regidor Martín de Durango solicitó que el letrado de la villa hiciera un informe sobre la base legal sobre la que se tenía que sustentar la oposición del concejo al nombramiento de don Juan de Zúñiga como alguacil de la villa ${ }^{920}$. En 1520 la asesoría jurídica la desempeñaba el bachiller Borja que fue depuesto por el gobierno comunero. Ocupó su lugar el bachiller Ventosilla que además ejercía de escribano del conce-

${ }^{915}$ AGS, RGS, 151611, s. f.

${ }^{916}$ AMA, leg. 43, doc. 27.

${ }^{917}$ En las ordenanzas de Peñaranda se recoge la figura del letrado de pobres que cumplía las funciones de lo que hoy denominamos un abogado de oficio. Este letrado estaba pagado por el ayuntamiento o, en su defecto, por el señor de la villa, el conde de Miranda (AMA, leg. 1172, doc. 5). En la villa de Aranda no hemos documentado la existencia de esta figura.

${ }^{918}$ AGS, CC MEMORIALES, leg. 161. doc. 122.

${ }^{919}$ Evidentemente las dudas sobre su profesionalidad estaban motivadas por las disputas entre unos y otros regidores. Los apelativos que utilizaron para calificar la profesionalidad del letrado fueron de lo más variopinto: echacuervo..., no sabia cosa ninguna..., no pareçia letrado... (AGS, CC MEMORIALES, leg. 149, doc. 230).

${ }^{920}$ AGS, CC DIVERSOS, leg. 41, doc. 35. 
jo $^{921}$. Tras la restitución de los regidores perpetuos, Borja volvió a ejercer como letrado de la villa ${ }^{922}$. El salario del letrado del concejo arandino rondaba a finales del siglo XV los 3.000 maravedíes anuales, aunque en ocasiones podía ascender a 100 reales $^{923}$.

En el seno del concejo, también existían otros cargos de menor importancia. Entre éstos se encontraban los pregoneros que cumplían una misión fundamental en una sociedad mayoritariamente iletrada, trasladando al lenguaje verbal todas aquellas comunicaciones que las autoridades querían transmitir a la mayoría de los vecinos. Habitualmente eran elegidos dos individuos para realizar este oficio y suponemos que era de carácter electivo anual. No obstante, se observa que algunos de ellos ejercieron el cargo durante varios años, circunstancia que seguramente estuviera relacionada más con las características físicas que precisaba el cargo que con una posible parcialidad ${ }^{924}$. Habitualmente los pregones se realizaban en los espacios públicos más representativos de la villa como la Plaza de Santa María, la Plaza Nueva o Plaza del Trigo. Pero también tenemos noticias de pregones emitidos desde la torre, que no sabemos si se refiere a la de Santa María o más bien a la parte superior de la puerta del Duero, que en ocasiones también albergaba las reuniones del concejo ${ }^{925}$.

Además de su evidente función, también eran requeridos sus servicios en las subastas de las rentas que se ejecutaban en la Plaza Pública de la villa, por lo que recibían una nada despreciable retribución ${ }^{926}$. Algo sorprendente es la actividad que Pedro de Hierro desarrolló dentro de sus competencias como pregonero en 1487. Los alcaldes le encomendaron que intimidara y diera tormento a un judío preso para que confesara ${ }^{927}$.

${ }^{921}$ En el listado con los principales comuneros arandinos enviado por un informante anónimo se señala: el bachiller Ventosilla letrado destos gran traydor (AGS, PR, leg. 4, doc. 16).

${ }^{922}$ AGS, CR, leg. 450, doc. 8; y CMC, leg. 355.

${ }^{923}$ AGS, CC MEMORIALES, leg. 149, doc. 230.

${ }^{924}$ En los años ochenta y noventa actuó varios años como pregonero Pedro del Hierro (AGS, CC PUEBLOS, leg. 2, docs. 82 y 88). Andrés de la Puerta fue pregonero al menos desde 1505 hasta 1514 (docs. 97 y 107). Entre 1515 y 1521 ejerció Juan Rojo (CR, leg. 40, doc. 8). Juan de Aranda también desarrolló este oficio entre 1514 y 1529 (EH, leg. 878, doc. 14).

${ }^{925}$ AGS, CC PUEBLOS, leg. 1, doc. 233.

${ }^{926}$ En 1506 el pregonero Andrés de la Puerta cobró 1.650 maravedíes por pregonar las alcabalas y tercias de la villa de Aranda (AGS, CMC, leg. 41).

${ }^{927}$ En la información recogida para denunciar los desmanes de los alcaldes un testigo declaraba que vio a Pedro Fierro, pregonero, traer debajo de la capa un vérdago y dijo que lo llevaba para dar con él a un judío que estaba preso en la cárcel porque no quería contestar lo que los alcaldes le preguntaban. El pregonero en su defensa afirmaba que no le mandaron dar tormento al judío sino a una mujer de Quemada 
Esta información no dejaría de transmitir la curiosa y tétrica forma de conseguir unos ingresos extras a título personal del susodicho Pedro si no fuera por una serie de expresiones que identifican el oficio de pregonero con el de verdugo. Así los diversos testigos que denunciaron los atropellos de la justicia afirmaban que ...llevaron pregoneros a la carçel para atormentalo...; o en otro caso que un regidor ayudó a una vecina y ...la defendio del pregonero.

Otro oficio menor era el de portero del Concejo. Suponemos que su función estaba asociada a la guarda y custodia de las casas del ayuntamiento pero también asumía la de acudir a las residencias de los regidores acompañado de un escribano para comunicarles las convocatorias extraordinarias de las sesiones del regimiento ${ }^{928}$.

En el grupo de los oficiales menores también se incluían los fieles. Si en un principio el término fiel era equiparable al de procurador de la villa ${ }^{929}$, con el tiempo el fiel se redujo a un oficio subalterno de claro perfil fiscal y económico. Los dos fieles del concejo eran elegidos anualmente por los regidores que además fiscalizaban su trabajo como sobrefieles. Su principal cometido era fijar el precio de los mantenimientos y velar por el buen funcionamiento del mercado de la villa, vigilando que los comerciantes no sobrepasasen los precios e imponiendo las multas y denuncias correspondientes. Muy a menudo recibían las críticas de sus convecinos que les acusaban de pasividad, falta de destreza o, simplemente, prevaricación. En 1497 la Comunidad se quejaba ante los monarcas de que los fieles no hacían su trabajo y permitían que fueran los regidores los que fijaran los precios y cobraran las multas para sí, generando múltiples conflictos que repercutía en su economía ${ }^{930}$. Los monarcas fueron claros en sus instrucciones y establecieron que los fieles pusieran el precio a la carne, el pescado çeçial, vino y candelas con el acuerdo del ayuntamiento y ...que en las otras cosas que cada dia entran e vienen a la dicha ciudad a se vender ansy como pescado fresco e fruta e ortaliza e otras cosas menudas que los dichos fieles puedan entender en ello e que los dos regidores nombrados como sobrefieles tengan cargo de desagraviar e desfacer qualquier agravio

con fama de ladrona, ...porque este testigo es el pregonero, aunque finalmente no lo hizo porque estaba preñada (AGS, CC MEMORIALES, leg. 161, doc. 122). pp. 53-55.

${ }^{928}$ AMA, leg. 1222, doc. 18, transcrito por HURTADO QUERO, Documentos Reales..., $\mathrm{n}^{\mathrm{o}} 28$,

${ }^{929}$ AMA, leg. 43, docs. 3, 4 y 27; y leg. 3038, doc. 10.

${ }^{930}$ AGS, RGS, 149705, fol. 76. 
que los dichos fieles oviesen fecho. Además establecieron que cuando vieran que los fieles eran negligentes en su oficio, los regidores debían prenderlos y juzgarlos junto a las justicias de la villa y el resto del regimiento. Por último, ordenaron que los regidores no cobrasen para sí las penas sino ...que sean para los lugares e personas que las hordenanças desa dicha villa lo disponen. Poco efecto tuvo la instrucción real pues apenas un año después la Comunidad volvió a quejarse de los fieles, en este caso porque Pedro de Santa Cruz había nombrado a uno de sus clientes, Rodrigo de Torre, como fiel a pesar de su manifiesta parcialidad para realizar el trabajo relacionado con el oficio ${ }^{931}$.

En este contexto de regulación de la actividad económica de la villa, a principios del siglo XVI se creó el nuevo oficio de fiel del peso que se encargaba de dar servicio a los vecinos que se habían quejado ante los monarcas de ser engañados por los molineros cuando llevaban su grano a moler y retornaban mermados en su harina ${ }^{932}$.

Sin embargo, la mayoría de los fieles que aparecen citados en la documentación poco tienen que ver con el oficio anteriormente descrito pues se encargaban de percibir las rentas, generalmente alcabalas que no se habían arrendado, a cambio de un salario o una cantidad establecida (prometido) ${ }^{933}$. El fielato más importante en Aranda era el del vino $^{934}$ y estaba perfectamente reglamentado, nombrándose a dos fieles cada año ...para que escrivan las cubas e otras vasijas que se venden del vino, como para las medir e

931 En concreto le acusaban de que siendo zapatero no se aplicaría a sí mismo las penas ...ni quemar suelas, ni pieças si las toviese falsas o quemadas como algunas vezes suele acaesçer, ni tampoco impondría penas sobre sus parientes y amigos. Además denunciaban que Torre tenía negocios de compraventa de cueros y pellejos por lo que sus principales vendedores eran los carniceros y ponían en cuestión que les impusiera las penas que les correspondieran (AGS, RGS, 149802, fol. 197).

${ }^{932}$ Los monarcas, ante las quejas de los vecinos, ordenaron en 1494 al corregidor y regidores que buscaran un edificio para instalar un peso regentado por un fiel al que se le debía proveer de un salario. La orden no fue muy efectiva pues en 1501 los reyes volvieron a solicitar lo mismo, aunque en este caso se establecía además el precio del servicio, dos cornados, que debían ser empleados para pagar al fiel y el resto para los propios de la villa (AMA, leg. 43, doc. 16 y 14; transcrito por HURTADO QUERO, Documentos Reales..., docs. 25 y 27 , pp. 49-50 y 52-53).

${ }^{933}$ En 1492 el arrendador Salomón Seneor acordó con el mayordomo Martín Sánchez Campesino que actuara como fiel de la renta del pan por un prometido de 6.000 maravedíes. De hecho, este contrato no es más que un arrendamiento pero con la figura del fiel por medio (AGS, EH, leg. 4).

${ }^{934}$ Frecuentemente la alcabala del vino no se conseguía arrendar por lo que se tomaba en fieldad por dos fieles que se encargaban de cobrar el impuesto por la venta del vino y entregárselo al arrendador mayor. A modo de ejemplo, los fieles en 1489 fueron Alonso Sánchez de Martín Esteban y don Lezar que entregaron al arrendador mayor 480.000 maravedíes por la renta del vino. Al año siguiente repitieron los mismos fieles y la renta sumó 587.183 maravedíes (AGS, CMC, leg. 41). Esta figura del fiel del vino se documenta también en otras regiones castellanas donde el negocio del vino tuvo una importancia notable como es el caso de La Rioja (GOICOLEA JULIÁN, "El vino en el mundo urbano..., p. 227). 
cobrar el alcavala dello; ...e fasen su libro en cada año ${ }^{935}$. Al final del ejercicio el escribano mayor de rentas del partido fiscal de Aranda tomaba declaración a los fieles del valor de la renta y se hacía el remate ${ }^{936}$. Otras rentas como el yantar y la martiniega también contaban con fieles de manera habitual ${ }^{937}$ y algunas como el pan, las varas, zapatería y carnicería sólo ocasionalmente cuando no se conseguían arrendar ${ }^{938}$.

Con esta descripción de los distintos oficiales del concejo nos podemos hacer una idea bastante precisa del funcionamiento del ayuntamiento arandino a finales de la Edad Media.

\section{b. La participación del Común en el ejercicio del poder.}

Con anterioridad a la reforma del regimiento emprendida por los Reyes Católicos a principios de la década de los ochenta el Común trató de intervenir en la política municipal a través de la figura del procurador del Común. La legitimidad de este representante se asentaba en un instrumento organizativo y territorial que agrupaba a todos los vecinos: las cuadrillas ${ }^{939}$. A lo largo de la Baja Edad Media la Comunidad mantuvo una relativa autonomía pues podía convocar sus reuniones a través de llamamientos con su propia campana y autofinanciándose a través de repartimientos con los que hacer frente a los gastos de representación que posibilitaban la presentación de peticiones ante los reyes o su Consejo. Sin embargo, estas iniciativas no fueron bien vistas por los linajes arandinos que trataron en todo momento de eliminar, o cuanto menos minimizar esta

${ }^{935}$ AMA, leg. 1222, doc. 20, transcrito por HURTADO QUERO, Documentos Reales..., doc. 14, pp. 29-31. IGLESIAS BERZOSA ha constatado también esta reglamentación en los últimos años del siglo XVI ("Importancia del vino..., p. 100).

${ }^{936}$ En junio de 1503 el escribano mayor de rentas, Pedro de Mora, solicitó ante el teniente de corregidor que se tomara declaración a los fieles sobre la renta del vino del año 1502. El primero de ellos, Francisco Collazos, dijo haber medido todas las cubas de vino de la villa y su tierra y haber registrado en el libro de su oficio 1.014.009 maravedíes y medio. Por su parte el segundo fiel, Gonzalo Mejía, señaló que había registrado 1.050.000 maravedíes (AGS, EH, leg. 4). En 1506 Collazos recibió de salario por actuar como fiel de la renta del vino 10.000 maravedíes (CMC, leg. 41).

${ }^{937}$ El escribano Juan de Aguilar fue en 1478 mayordomo y fiel de la renta del yantar y martiniega que se estableció en 4.900 maravedíes (AGS, EH, leg. 4).

${ }^{938}$ En 1485 junto al vino también quedaron sin arrendar las varas y corambre, zapatería, carnicería y cuatropea (AGS, EH, leg. 4).

${ }^{939}$ VAL VALDIVIESO, M. I., "La perturbación de la paz urbana en la Castilla del siglo XV", en La convivencia en las ciudades medievales. Logroño, 2008, pp. 23-52. 
autonomía con constantes denuncias ante las instancias superiores por considerar estas prácticas irregulares $^{940}$.

A partir de principios de los ochenta la representación pasó a la nueva figura del Regidor de la Comunidad que desempeñó un activo papel durante más de una década. Si bien es cierto que este nuevo oficial garantizaba la representatividad del Común en el Ayuntamiento, se ha de reconocer que esta medida supuso una importante pérdida de autonomía ya que, tras recibir la merced del monarca, el cargo se ostentaba con carácter vitalicio $^{941}$. No obstante, las cuadrillas siguieron nombrado procuradores que las representaban en conflictos puntuales.

Contrariamente a lo que tradicionalmente se mantiene, la estructura del linaje fue bastante permeable en los últimos decenios del Cuatrocientos. Como en otras ciudades de Castilla - como Burgos, Cuenca, Valladolid o Medina del Campo-, buena parte del grupo más destacado del Común, enriquecido notablemente con negocios relacionados con el arrendamiento de rentas o el comercio, consiguió introducirse en las clientelas linajudas de una forma bastante rápida y eficaz ${ }^{942}$. Y para este propósito estos ricos hombres emprendieron una serie de estrategias complementarias.

Además de estos oficiales representantes de la Comunidad, la principal estrategia de participación en el poder por parte de algunos notables miembros de la Comunidad fue su integración dentro de los sistemas linajudos arandinos. El primer paso sin lugar a dudas fue el de ser reconocido como un miembro más de los linajes y para ello los aspirantes utilizaron diversos instrumentos. En este sentido, Pedro de Santa Cruz es el ejemplo paradigmático del ascenso social en la villa de Aranda. De origen foráneo y converso se introdujo en uno de los linajes arandino, el de Don Romero, a través del enlace matrimonial de una de sus hijas, Isabel, con un caballero perteneciente a este linaje, Sancho de Salazar, hermano del regidor Pedro de Salazar. Una vez dentro de este grupo clientelar, el segundo instrumento fue ir escalando posiciones dentro de su jerarquía interna: el camino comenzaba siendo elegido oficial menor para más tarde ocupar una alcaldía y posteriormente optar al regimiento, si hubiera vacantes. Pero este

\footnotetext{
${ }^{940}$ AGS, RGS, 148002, fol. 256.

${ }^{941}$ AMA, leg. 43, doc. 15, transcrito por HURTADO QUERO, Documentos Reales..., doc. 15, pp. 31-33.

${ }^{942}$ Baste como ejemplo el estudio comparado presentado por GUERRERO NAVARRETE sobre Burgos y Cuenca (“Élites urbanas en el siglo XV: Burgos y Cuenca", Revista d'Historia Medieval. 9, 1998, pp. 81-104).
} 
peculiar cursus honorum fue percibido por Santa Cruz como un instrumento muy lento para sus aspiraciones, a pesar de conseguir ser nombrado alcalde en 1489 , poco tiempo después de instalarse en la villa. Por ello recurrió a una nueva vía de ascenso que hasta el momento no habíamos identificado en Aranda: la compra de un regimiento. Efectivamente, en 1494, sin tener miramiento sobre la prohibición de pasarse de los linajes a la Comunidad ${ }^{943}$, compró el oficio de Regidor a Martín Sánchez de Casasola, antaño activo regidor de la Comunidad y azote de los abusos de los regidores de los linajes. A pesar de las denuncias del fiscal, Santa Cruz recibió el beneplácito de la Corona que lo premió por sus apreciados servicios financieros ${ }^{944}$.

Santa Cruz no fue el único que hizo uso de este método para conseguir acceder al regimiento. Poco después Francisco de Mena compró el regimiento al comendador Íñigo de Barahona, y Antonio de Contreras pagó 34.000 maravedíes a Juan Fernández Mejías para que renunciara a su oficio de regidor en su beneficio ${ }^{945}$. Estos casos los conocemos por las denuncias interpuestas por el fiscal, aunque tan sólo en el caso de Contreras hubo una sentencia condenatoria ${ }^{946}$.

Santa Cruz no se conformó con llegar al concejo, su estrategia para consolidar su posición le llevó a establecer nuevas alianzas matrimoniales mediante las que emparentó con algunas de las familias de la oligarquía arandina. Tenemos noticias de tres de sus hijos $^{947}$. Gaspar era el varón y se hizo cargo de los negocios de su padre. Su padre negoció su matrimonio con la hija de un miembro de la pequeña nobleza leonesa que fructificó en 1518 con su enlace con doña Isabel Cabeza de Vaca ${ }^{948}$. Una de sus hijas, Francisca, se casó con don Francisco de Mendoza, gentilhombre del rey. Fruto de este matrimonio nacieron Juan y Pedro de Avellaneda. Este último fue regidor a mediados del

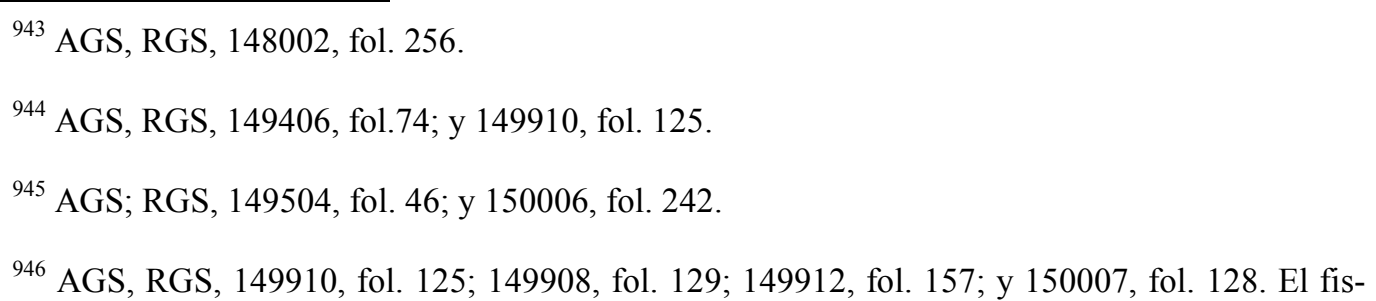

${ }^{946}$ AGS, RGS, 149910, fol. 125; 149908, fol. 129; 149912, fol. 157; y 150007, fol. 128. El fiscal, Diego de Romaní, fue recompensado en enero de 1501 con la concesión del regimiento que se retiró a Contreras (AGS, CONSEJO CÁMARA DE CASTILLA, libro. 5, leg. 22, doc. 1) aunque suponemos que no se hizo efectivo pues no tenemos noticias de que ejerciera como tal y, sin embargo, Contreras volvió a figurar en 1503 como regidor (AGS, CC PUEBLOS, leg. 2, doc. 93).

${ }^{947} \mathrm{La}$ mayor parte de la información que relatamos a continuación está extraída de ARChV, RRE, Caja 374, doc. 18 y AGS, CR, leg. 3, doc. 3.

${ }^{948}$ AGS, EH, leg. 878, doc. 14. 
siglo XVI y miembro junto a su padre de la Cofradía de la Misericordia ${ }^{949}$. Como ya hemos señalado anteriormente, Isabel se casó con Sancho de Salazar, hijo de Rodrigo de Salazar y hermano del regidor Pedro y el alcalde García de Salazar ${ }^{950}$. De la unión entre Sancho e Isabel nacieron Cristóbal, Rodrigo y Francisca que, al morir sus padres, estuvieron bajo la tutela de Pedro de Salazar primero y de su abuelo Santa Cruz después.

La familia Santa Cruz ejemplifica notablemente la patrimonialización de los oficios municipales pues al cargo de regidor del patriarca se sumaron el de su hijo Gaspar, concedido en julio de 1521 por renuncia del aposentador Pedro de la Plaza, y el de su nieto Cristóbal, que lo recibió de por renuncia del propio Santa Cruz en 1527. Así, en 1535 Gaspar de Santa Cruz, Cristóbal de Salazar y Pedro de Avellaneda, nieto también de Pedro de Santa Cruz, coincidieron como regidores de la villa según consta en una de las actas del Ayuntamiento ${ }^{951}$.

Apenas una década después de la creación de los Regidores de la Comunidad, su carácter representativo de los intereses del Común se desvirtuó completamente. Ya hemos visto cómo Martín Sánchez de Casasola cedió su puesto a Pedro de Santa Cruz a cambio de una interesante cantidad de dinero ${ }^{952}$. Desde ese momento el nuevo regidor no volvió a aparecer reflejado en la documentación con el atributo de la Comunidad. Es más, todo hace pensar que el regimiento se integró en todos los sentidos dentro del linaje al que pertenecía, el de don Romero. Siguiendo esta misma dinámica, ya hemos visto como poco después fue Juan Fernández Mejías el que vendió su oficio de regidor de la Comunidad a Antonio Contreras. No es menos significativo que el tercer regidor de la Comunidad también perdió el elemento identificador de la representatividad de su oficio.

A partir de ese momento, los procuradores del Común volvieron a retomar su protagonismo en las denuncias de los desmanes de los regidores de los linajes, aunque la situación de marginalidad se mantuvo como en el periodo anterior a la reforma. Los

\footnotetext{
${ }^{949}$ VELASCO PÉREZ, S., Aranda. Memorias..., p. 169.

${ }^{950}$ AMA, Leg. 1, n 21, transcrito por HURTADO QUERO, Documentos Reales..., doc. 19, pp.
} 38-39.

951 DIAGO HERNANDO, “Cambios políticos..., p. 312 (no hay referencia a documento); AGS, CC MEMORIALES, leg. 187, fol. 19; y VELASCO PÉREZ, Aranda. Memorias..., pp. 171-172. Otras familias también patrimonializaron los cargos municipales como Martín de Durango que heredó en 1508 el regimiento de su padre, también llamado Martín (AGS, RGS, 150801, s. f.).

${ }^{952}$ AGS, RGS, 149406, fol. 74; y 149910, fol. 125. 
cargos de procuradores fueron copados por esa elite del común o medianos a los que se refieren la profesora del Val y el profesor Ladero Quesada. Estos representantes de la Comunidad intentaron, con poco éxito, presentar una postura política alternativa ante la arbitrariedad e ineficacia en la gestión del día a día del gobierno de la oligarquía y la marginación a la que era sometida la mayoría de la vecindad ${ }^{953}$. Como veremos más adelante, el punto culminante de esta dinámica sociopolítica fue la Revolución Comunera.

\section{c. Injerencia nobiliaria.}

El siglo XIV y buena parte del XV se caracterizaron por el sistemático acoso al que la aristocracia nobiliaria sometió a muchas de las ciudades y villas de realengo. Para la nobleza los núcleos urbanos suponían, además del incremento de sus señoríos y control estratégico del territorio, una atractiva fuente de recursos derivados tanto de la actividad mercantil que en ellas se realizaba como de la enajenación de las rentas reales que generaban ${ }^{954}$. Como ya hemos visto anteriormente, la villa de Aranda se vio sometida al dominio señorial intermitente durante buena parte del Trescientos. La situación se reprodujo en los años centrales del siglo XV con el señorío efectivo que ejerció Juan de Navarra durante casi un decenio, convirtiendo la villa, junto a la cercana Peñafiel, en centro de operaciones de sus pretensiones sobre Castilla, así como una importante fuente de recursos. Esto último se aprecia perfectamente en su intervencionismo en la principal actividad económica de Aranda, la venta del vino, y en la apropiación de las rentas de su primo el rey castellano ${ }^{955}$.

Poco tiempo después, en el contexto del conflicto sucesorio, Aranda pasó a ser tenencia de don Pedro de Zúñiga, que tuvo su principal consecuencia en el incremento de alborotos y conflictos en el seno de la villa. Esta situación empujó al concejo a solicitar la ayuda de la princesa Isabel. Como ya hemos comentado, este acontecimiento pue-

${ }^{953}$ LADERO QUESADA, "Monarquía y ciudades de realengo..., p. 761; del mismo autor "Castilla a comienzos del siglo XVI: sociedad y poder", en Entorno a las comunidades de Castilla. Cuenca, 2002, pp. 27-44, en concreto p. 41; y VAL VALDIVIESO, M. I., "Oligarquía versus Común. Consecuencias sociopolíticas del triunfo del regimiento en las ciudades castellanas”, en Medievalismo: Boletín de la Sociedad Española de Estudios Medievales. 4, 1994, pp. 41-58.

${ }^{954}$ LADERO QUESADA, “Monarquía y ciudades de realengo..., pp. 754-758.

955 AMA, leg. 43, doc. 7; y leg. 44, doc. 2; ambos transcritos por HURTADO QUERO, Documentos Reales..., docs. 5 y 6, pp. 13-16. 
de encuadrarse dentro del fenómeno de resistencia antiseñorial como respuesta al temor de perder la condición de realengo y, en consecuencia, la imposición del dominio señorial, circunstancia bastante habitual en la Castilla del final del reinado de Enrique IV $^{956}$. Ladero Quesada afirma que la oligarquía local, con su posición de dominio amenazada por la injerencia nobiliaria, organizó al resto de la población para enfrentarse al poder señorial impuesto y buscó la alianza con la pretendiente con la certeza de que sólo una monarquía fuerte podría garantizar sus propios intereses políticos ${ }^{957}$. En este contexto tampoco podemos olvidar que cuando la villa se pasó al bando de la Princesa fue ocupada militarmente por los hombres de don Diego de Rojas y su madre la Condesa de Castro, convirtiéndose el primero en tenente de la plaza ${ }^{958}$.

A pesar del triunfo de doña Isabel y las garantías de permanencia en el realengo, las presiones de los principales linajes de la nobleza comarcana no dejaron de proyectarse en la capital de la Ribera durante todo su reinado. Los instrumentos utilizados por los señores para extender su influencia por el realengo fueron variados. Entre ellos destaca la usurpación de oficios concejiles, como veremos más adelante, y, sobre todo, la extensión de los lazos del clientelismo nobiliario sobre la oligarquía arandina.

La consolidación del realengo tras la guerra civil no supuso por lo tanto el final de la presencia de los intereses nobiliarios en la villa. A principios de los años 80, para evitar esta situación, los monarcas especificaron claramente en las ordenanzas que regulaban el ejercicio del poder municipal ...que los regidores e alcalldes e ofiçiales que ha de aver en la dicha villa sean vesinos della e que non vivan nin lleven acostamiento de personas algunas salvo de nos e que de otra manera non puedan aver los dichos ofiçios, epígrafe que, sin lugar a dudas, confirma el carácter habitual de esta mala práctica. Contrariamente a la flexibilidad con que se aplicó esta norma en otras ciudades, en Aranda su cumplimiento fue más riguroso, evitando la concesión de licencias para simultanear el servicio a nobles con el desempeño de los oficios concejiles. En este contexto se situó la destitución en 1485 de García de Salazar, nombrado alcalde por su

\footnotetext{
${ }^{956}$ VAL VALDIVIESO, “Resistencia al dominio señorial..., p. 19.

${ }^{957}$ LADERO QUESADA, “Monarquía y ciudades de realengo..., p. 758.

${ }^{958}$ AMA, leg. 42, doc. 6.
} 
hermano y regidor de linaje, Pedro de Salazar. La causa de esta medida fue que García estaba al servicio del duque de Alburquerque ${ }^{959}$.

Sin embargo, la norma se relajó considerablemente tras la muerte de la reina Isabel pues, a pesar de la insistencia de la reina Juana reclamando su cumplimiento ${ }^{960}$, se observa que varios regidores perpetuos estaban al servicio de los principales nobles comarcanos. Así, por ejemplo, sin ningún tipo de pudor el regidor Rodrigo de Durango se identificaba como alcaide de Gumiel del Mercado y justificaba su absentismo en las reuniones del Regimiento por estar en Tordesillas con el marqués de Denia ${ }^{961}$.

Sin lugar a dudas, la red clientelar más extendida en la villa era la del conde de Miranda. El regidor Fernando de Covarrubias fue mayordomo del conde y su suegro, Juan López de Haza, su contador; Martín de Durango padre e hijo fueron criado y Contador de los Zúñiga, respectivamente; y Hernando de Sepúlveda es identificado por Diago Hernando como cliente del conde. Pero no sólo los regidores estaban bajo la influencia de la familia Zúñiga, también otros oficiales como el alguacil Vallejo que en mayo de 1515 se convirtió en el brazo ejecutor de los intereses de la familia Zúñiga en el asalto del monasterio de Santa María de la $\mathrm{Vid}^{962}$. No obstante, el dato más revelador de esta extensa red clientelar lo ofrecen las propias apreciaciones de los vecinos arandinos. Sebastián de Ventosilla, procurador de la villa de Aranda en el pleito por el alguacilazgo, exigió en 1518 al corregidor que se le pagara su salario y que le proporcionara traslado de una cedula del rey Fernando guardada en el arca del Concejo, sugiriéndole que sacara el traslado sin presencia de ningún regidor porque todos ...biben con el conde de Miranda y buscan le servir ${ }^{963}$.

\footnotetext{
${ }^{959}$ AMA, leg. 43, doc. 2; transcrito por HURTADO QUERO, Documentos Reales..., doc. 19, pp. 38-39). DIAGO HERNANDO, "Cambios políticos..., p. 327.

${ }^{960}$ Las quejas de la Comunidad en este sentido fueron muy frecuentes en los primeros años del siglo XVI. Ante éstas, la reina Juana envió una provisión para que se cumpliera la ordenanza en 1507 (AMA, leg. 43, doc. 38) y nuevamente en 1515 en la que dejaba sin validez cualquier licencia o cédula que don Fernando hubiera otorgado con anterioridad (leg. 43, doc. 41; transcrito por HURTADO QUERO, Documentos Reales..., doc. 39, pp. 70-71).

${ }^{961}$ AGS, CR, leg. 453, doc. 5.

${ }^{962}$ CARRETE PARRONDO, Fontes Iudaeorum..., doc. 148, p. 78; VELASCO, Aranda. Memorias..., p. 169; DIAGO HERNANDO, "Cambios políticos..., p. 325; y AGS, CC PUEBLOS, leg. 17, docs. 462 y 463.

${ }^{963}$ AGS, CC, MEMORIALES, leg. 129, docs. 43 y 55.
} 


\subsection{Oligarquía y Comunidad.}

Tras abordar la realidad política de la villa de Aranda, creemos conveniente en este momento prestar atención a la realidad social de los actores que tuvieron un destacado protagonismo en el ejercicio del poder político en la villa, ya fuera monopolizándolo o luchando por conseguir acceder a la gestión de este poder.

El esquema social de la sociedad arandina es bastante básico en superficie y extremadamente complejo en los detalles. Evidentemente la realidad sociopolítica arandina presentaba una clara dicotomía entre la oligarquía que controlaba férreamente los resortes del poder político y la Comunidad, sujeto pasivo de unas decisiones sobre las que apenas podía interferir. Cada uno de estos grupos presentaba unas características que lo definen en su singularidad y que intentaremos identificar en este punto. En cada uno de estos dos grandes grupos hemos tratado de rastrear las distintas redes clientelares que tuvieron como base la familia amplia y la dinámica en la que se vieron inmersos en este periodo de tránsito a la Modernidad ${ }^{964}$.

Como ya hemos anticipado, la propia dinámica socioeconómica de la sociedad arandina posibilitó que la oligarquía no se mantuviera hermética y asimilara poco a poco la posibilidad del ascenso social. Por otra parte, entre la gran masa de la Comunidad se consolidó un activo grupo que destacó entre el resto por su dinamismo tanto económico como ideológico y que fue capaz de movilizar a todo el grupo para conseguir ganar una mayor cuota de poder.

El final de este apartado está dedicado a aquellos grupos de población que no estaban incluidos en ninguno de los dos grandes sectores sociales comentados anteriormente. Y es que efectivamente, los grupos marginados en razón de su religión se encontraban fuera de la sociedad cristiana, tanto física como, sobre todo, ideológicamente. Sin embargo, estaban y además condicionaron de manera notable la vida de sus vecinos cristianos. Por todo ello creemos necesario perfilar en este punto su realidad socioeconómica.

${ }^{964}$ En este sentido coincidimos con NARBONA VIZCAÍNO y JARA FUENTE en la necesidad de apostar por aproximaciones metodológicas de naturaleza prosopográfica para aportar más luz en el estudio de los grupos oligárquicos y comunidades de pecheros de las ciudades medievales (respectivamente "El método prosopográfico y el estudio de las élites de poder bajomedievales", en El Estado en la Baja Edad Media: nuevas perspectivas metodológicas. Zaragoza, 1999, pp. 31-49; y "Posiciones de clase y sistemas de poder: vinculación y contradicciones en la construcción del 'común de pecheros' en la baja Edad Media”, en Los espacios de poder en la España medieval. Logroño, 2002. pp. 511-532, en especial p. 531). 


\subsubsection{Oligarquía y linajes.}

La definición de oligarquía no presenta muchas dificultades pues este término define a un reducido número de personas que monopoliza los órganos de gobierno de una sociedad. En buena parte de la Europa medieval estos individuos se agruparon en torno a las clientelas familiares o, más concretamente, linajes ${ }^{965}$.

En la villa de Aranda, como en otras ciudades castellanas, sólo existieron dos linajes: el de don Romero y el de don Pedro García de la Puente ${ }^{966}$. El origen de los linajes arandinos a día de hoy no está claro, pero sí es evidente que sobre la tradición foral del sistema político arandino del que hemos hablado anteriormente se superpuso a lo largo del Cuatrocientos la realidad de los linajes que se repartieron la designación de los regimientos y demás oficios concejiles. A continuación veremos cómo en este periodo se consolidó un verdadero monopolio del ejercicio del poder municipal por parte de un grupo oligárquico que anclaba su legitimidad en un pasado mítico asociado a la caballería villana.

\section{a. El origen de los linajes en Aranda de Duero.}

A ciencia cierta no sabemos cuándo se organizaron en la villa de Aranda los linajes pues, por el momento, la primera referencia documental con la que contamos está datada en 1433 aunque parece lógico pensar que su origen se remonte algunos años atrás $^{967}$.

A continuación vamos a plantear una hipótesis de trabajo sobre el origen y fundamento de la existencia de linajes que explicaría en gran medida la legitimación de la

965 Entendemos como linaje una agrupación de ciudadanos unidos por lazos de parentesco o clientelismo que tienen reconocidas unas atribuciones políticas que les permiten repartirse los oficios relacionados con el gobierno municipal. Véase MONSALVO ANTÓN, J. M., "Parentesco y sistema concejil. Observaciones sobre la funcionalidad política de los linajes urbanos en Castilla y León (siglos XIII-XV)", en Hispania. Revista Española de Historia. 1993, 185, pp. 937-969; DIAGO HERNANDO, "El papel de los linajes..., pp. 143-177; y SOLÓRZANO TELECHEA, J. A., "Linaje, comunidad y poder: desarrollo y consolidación de identidades urbanas contrapuestas en la Castilla bajomedieval", en Familia y sociedad en la Edad Media (siglos XII-XV), Zaragoza, 2007, pp. 71-94.

${ }^{966}$ AGS, CC PUEBLOS, leg. 2, doc. 78. Esta dualidad también se observa en Segovia, Salamanca, Ciudad Rodrigo, Cuéllar o Valladolid.

${ }^{967}$ AMA, leg. 43, doc. 27. 
posición privilegiada de la oligarquía urbana que se configuró a lo largo del Cuatrocientos en la capital de la Ribera ${ }^{968}$.

En alguna de las ciudades castellanas donde existieron los linajes como Ciudad Rodrigo, Segovia, Soria o Valladolid, se ha constatado que su consolidación se produjo con la implantación de los regimientos a partir del siglo XIV, evidenciando la confluencia de intereses entre la Corona, que desarrollaba una política netamente intervencionista sobre las ciudades, y las oligarquías urbanas, deseosas de mantener su posición de poder en el ámbito urbano ${ }^{969}$. Posiblemente en la villa de Aranda ocurriera algo similar pero con un pequeño matiz: como ya hemos visto con anterioridad, la implantación del regimiento se produjo a principios del siglo $\mathrm{XV}$, bastante tiempo después del comienzo de la reforma emprendida por Alfonso XI.

Ya sabemos cuándo, pero ¿qué justificaba el privilegio de configurar un linaje? La respuesta es simple: un antepasado mítico que se ganó ese derecho ${ }^{970}$. En el caso arandino conocemos el nombre de los cabeza de linaje, Don Romero y Don Pedro García de la Puente. En este punto no cabe más que preguntarse si estos personajes fueron el fruto de una leyenda o si realmente hay un trasfondo histórico en ellos. Rastreando la documentación encontramos numerosos Pedro García, sin el don delante, y varias menciones a don Romero ${ }^{971}$. Pero el hallazgo más significativo es la mención a los dos personajes, don Pedro Garçia e don Romero, en el traslado de un privilegio real fechado en

${ }^{968}$ La ausencia de datos sobre la realidad social arandina anteriores al siglo XIV nos impiden reconstruir la evolución de la oligarquía local previa a este momento por lo que no podemos poner en relación el caso arandino con otros espacios arandinos en los que la caballería villana tuvo un papel fundamental en la configuración de las oligarquías bajomedievales. Sobre estos aspectos ver MÍNGUEZ FERNÁNDEZ, J. M., "Feudalismo y concejos. Aproximación metodológica al análisis de las relaciones sociales de los concejos medievales castellano-leoneses”, en En la España medieval. 3, 1982 pp. 109-122; MONSALVO ANTÓN, J. M., "Concejos castellano-leoneses y feudalismo (Siglos XI-XIII). Reflexiones para un estado de la cuestión”, en Studia Historica. Historia Medieval. 10, 1992, 203-243; y DIAGO HERNANDO, M., "Caballeros e hidalgos en la Extremadura castellana medieval (siglos XII-XV)", en En la España Medieval. 15, 1992, pp. 31-62.

969 DIAGO HERNANDO, “El papel de los linajes..., p. 165; y JARA FUENTE, "Estructuras formales de poder..., pp. $237 \mathrm{y}$ ss.

${ }^{970}$ Baste el ejemplo de Segovia donde se dice que los capitanes de las milicias urbanas segovianas Fernán García de la Torre y Día Sanz de Quesada obtuvieron el honor de encabezar los linajes de la ciudad tras conquistar la villa de Madrid en tiempos de Alfonso VI.

${ }^{971}$ Don Romero, hijo de Pedro Pérez, procurador de la villa en 1357, y un regidor, yerno de Don Romero, en 1425 (VELASCO PÉREZ, Aranda. Memorias..., pp. 94-95). 
1329 en el que ambos aparecen como vesinos e fieles de la villa ${ }^{972}$. Ante el carácter fragmentario de la documentación y la ausencia de referencias a los linajes hasta comienzos del siglo XV se nos presenta una nueva disyuntiva. Una posibilidad es que los linajes arandinos arrancaran de estos dos individuos histórico. Por otra parte, también es posible que estos nombres fueran retomados con posterioridad, a la par que se implantaba el regimiento en la villa y se consolidaban los linajes como agentes que monopolizaban el ejercicio del poder municipal. De esta manera, la elección de estos antiguos nombres reafirmaría el origen de tiempos inmemoriales de las clientelas linajudas bajomedievales. Esta última opción aúna dos ventajas importantes: por una parte, la legitimidad se asienta sobre la primera referencia documental que se conserva en la que se nombran oficios o cargos municipales; y por otra, los personajes a los que se alude ostentaban la representatividad de la villa.

Es curioso que estos dos míticos personajes, don Romero sin lugar a dudas y don Pedro García transformado en don Nuño, fueron utilizados a cientos de kilómetros de Aranda, en la jienense localidad de Alcalá la Real, con la misma función legitimado$\mathrm{ra}^{973}$. Se trata en concreto del linaje de los Aranda, descendientes de un tal don Romero, caballero hidalgo que vivió en las cercanías de Aranda, posteriormente se avecindó en ella y recibió de la villa para ellos y para sus desçendientes los ofizios de alcaydias, alguazilazgo y rejimientos, y los otros menores ${ }^{974}$. En esta genealogía también aparece

${ }^{972}$ AMA, leg, 3038, doc. 10. Se trata de un traslado fechado en 1329 de un privilegio de Sancho IV datado en 1291 que fue confirmado ese mismo año por el monarca Alfonso XI. Transcrito por HURTADO QUERO, Documentos Reales..., doc. 3, pp. 4-12.

973 TORO CEBALLOS, F., El discurso genealógico de Sancho de Aranda. Alcalá la Real, 1993. Esta obra recoge la transcripción de la obra que Sancho de Aranda, miembro del linaje de los Aranda, escribió en 1548. La misma narración fue utilizada por varios genealogistas durante el siglo XVI para legitimar el origen de diversas familias Aranda repartidas por la geografía castellana como refiere en el siglo XVIII Sebastián del Castillo Ruíz de Molina cuando confeccionó su Noticias genealogicas de la antigua familia de Aranda de la que justifica su descendencia don Joachin de Aranda y Amezaga, publicada en Madrid en 1741. Este y otros aspectos relacionados con la legitimación del poder han sido estudiados para la Castilla meridional por JIMÉNEZ ALCAZAR, J. F., Un concejo de Castilla en la frontera de Granada. Lorca 1460-1521. Granada, 1997; y "Con el qual deseo murieron todos los nuestros antepasados: propaganda, legitimidad y pasado como factores de gobierno en los concejos castellanos (siglos XIII-XVI), en La gobernanza de la ciudad europea en la Edad Media. Logroño, 2011, pp. 487-515.

${ }^{974}$ En las cercanias de la villa de Aranda de Duero vivian dos cavalleros hijosdalgo en unas aldeas suyas. Al uno dezian don Romero y al otro don Nuño. Los quales, como tuviesen muchas vezes diferencias y questiones con los de la villa de Aranda sobre los terminos, vinieron a las manos y recrezerse muchas muertes y hambres. Despues de esto vinieron en conzierto con ellos, que se viniesen a vivir a ella y que en enmienda, de un servizio, que los que en ella vivian, les avian de pagar lo que llamavan Martiniega. Del qual, segun fuero y costumbre de la dicha villa, que en ella viviese de cavallero hijodalgo que fuese, se podia excusar. Que la villa les daria para ellos y para sus desçendientes los ofizios de alcaydias, alguazilazgos y rejimientos, y los otros menores, assi del campo como del pueblo. El Concejo les 
un descendiente de don Romero llamado don Pedro Garzia de la Puente cuyo sobrenombre tiene su origen en la iniciativa emprendida por este vecino de construir el primero de los arcos del puente sobre el río Duero ${ }^{975}$. Finalmente un tal Domingo Romero se vio envuelto en las banderías de la decimocuarta centuria y, acusado de homicidio, abandonó la villa de Aranda para establecerse en Martos. Allí tuvo un hijo, Pedro Fernández, que cambió el apellido Romero por el del lugar de origen del padre. Según el erudito alcalaino Sancho de Aranda este fue el nacimiento del linaje de los Aranda de Alcalá la Real que posteriormente se extendió por otras localidades andaluzas ${ }^{976}$.

También observamos otro posible instrumento de legitimación de la oligarquía arandina en la configuración del escudo de armas de Aranda ${ }^{977}$. Según el cronista más antiguo de la villa, D. Aniceto de la Cruz, el escudo primitivo tenía por armas siete castillos, pero en un momento indeterminado el rey concedió su licencia para cambiarlo por el actual ${ }^{978}$. El autor afirma que las siete torres correspondían a las siete puertas que configuraban el recinto amurallado de Aranda, aspecto insostenible pues en el plano de 1503 sólo se aprecian seis puertas de las cuales la de Santa Ana fue abierta después de 1480 y la séptima puerta, la Puerta Nueva, fue habilitada con posterioridad a 1517.

proveyese con las quales condiziones, estos cavalleros se fueron a morar a la dicha villa con sus deudos y parientes y asta oy dia los dichos ofizios se proveen por mitad en los descendientes del uno y del otro (TORO CEBALLOS, El discurso genealógico..., libro I, p. 68).

975 Que como en aquella sazon la dicha villa aun no tuviese puente sobre Duero, y siendo rio tan caudaloso que pasa junto a la par de ella, este cavallero, movido de caridad por muchos peligros de personas que ofrezian, determinó de hazerla y edificarla a su costa, y hizo el arco primero y prinzipal de ella, que es el que esta azia la villa. La muerte le atajó que no acavase su proposito. La villa, viendo quan provechosa y nezesaria era, de los propios que tenia, edifico el segundo de en medio. Y el terzero, para zerrar la dicha puente, que era el menor, hizo y labro a su costa el maestro de la misma obra... (Ídem., libro II, p. 79).

${ }^{976}$ Sobre el recurso generalizado a la recreación de unos orígenes heroicos que dieran legitimidad a los linajes o bandos véase la obra de SEGURA, S., La idea de ciudad en la cultura hispana de la Edad Moderna. Barcelona, 1992.

${ }^{977}$ Hasta mediados del siglo XIV en muchas de las villas y ciudades castellanas los emblemas del concejo eran la enseña, utilizada como referencia para las milicias locales, y el sello, marca que refrendaba los documentos concejiles. Según MENÉNDEZ PIDAL DE NAVASCUÉS a partir de los años centrales del Trescientos hubo un cambio conceptual en la consideración de los concejos, de entidades colectivas a singulares, que posibilitó que los concejos asimilaran los símbolos representativos de los señores: los emblemas heráldicos. En palabras de este autor los concejos "tendrán por supuesto escudo de armas y hasta se les inventarán halagadoras genealogías míticas, como a los grandes hombres, atribuyendo su fundación a héroes más o menos fabulosos" "“Símbolos de identidad de los protagonistas de la acción política: reyes, señores, concejos”, en Los espacios de poder en la España medieval. Nájera, 2002, pp. 371-407, en especial 401-406).

${ }^{978}$ DE LA CRUZ, Historia de la Milagrosa..., pp. 128-129. 


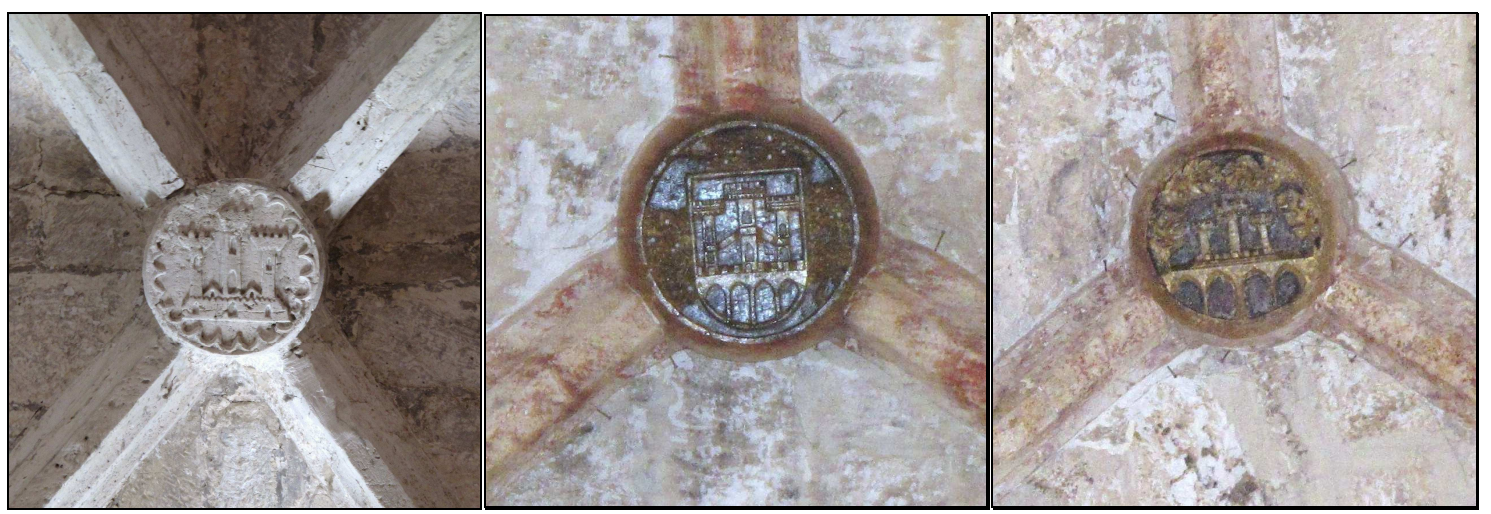

Imagen 42: Claves de la iglesia de San Juan Bautista con el primitivo escudo de Aranda.

Por el momento los escudos de la villa más antiguos que conocemos se encuentran en las claves de las bóvedas de la iglesia de San Juan Bautista y presentan un castillo con tres torres sobre un puente con cuatro ojos ${ }^{979}$. Si tenemos en cuenta que la iglesia se comenzó a construir en el siglo XIV y siguió durante parte del $\mathrm{XV}^{980}$ no es descabellado pensar que este fue el escudo de la villa por lo menos hasta los primeros años del siglo XV.

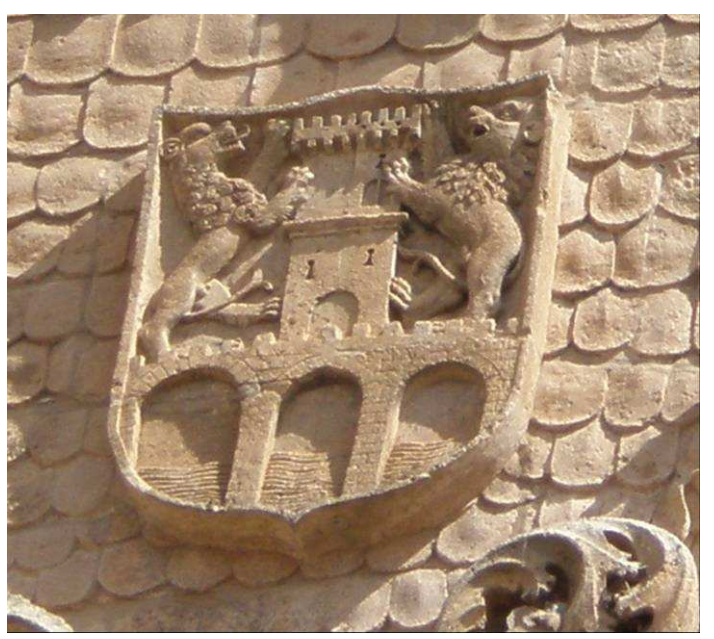

Imagen 43: Escudo de la villa de Aranda de la fachada de Santa María.

En un momento indeterminado del siglo XV el antiguo escudo fue sustituido por uno nuevo en el que se aprecian significativas modificaciones: por una parte, se mantiene el río pero sobre

${ }^{979}$ HARO ÁlVAREZ e IGLESIAS AGÜERA, "Restauración de la iglesia de San Juan..., pp. 16,20 y 22. Tenemos noticias de una referencia más antigua al sello del concejo arandino a finales del siglo XIII. En una avenencia entre el monasterio de La Vid y Vadocondes fechada en 1297 se especifica la inclusión del sello de cera del concejo de Aranda como consecuencia de la actuación del escribano de la villa como árbitro. No obstante, aunque el documento se conserva en buen estado, hemos podido comprobar que ya no existe ningún sello asociado a él (AHN, CLERO, carpeta 381, doc. 4).

${ }^{980}$ Aún a riesgo de ser algo temerarios, la iconografía del castillo que se representa en la clave arandina guarda similitud con los castillos que aparecen en los cornados de Enrique II o en las blancas de Enrique III y Juan II, pero también en el maravedí que acuñó Enrique IV a comienzos de los años sesenta (DE FRANCISCO OLMOS, J. M., "La moneda de la Castilla bajo medieval. Medio de propaganda e instrumento económico", en II Jornadas Cientificas sobre Documentación de la Corona de Castilla (siglos XIII-XV). Madrid, 2003, pp. 278-348, ver p. 330). 
él se levanta un puente con solo tres ojos; en segundo lugar, las tres torres del castillo se han reducido a una sola; y por último, pero quizá más significativo, el castillo aparece flanqueado por dos leones rampantes. Según De la Cruz este escudo representaba el episodio legendario de la defensa que dos nobles arandinos, Don Romero y Don Julián, hicieron de la villa ante la amenaza de los $\operatorname{moros}^{981}$. Dejando al margen mitos y leyendas, lo cierto es que en este nuevo escudo aparecen todos los elementos identificativos de la villa, pero no los de la Alta Edad Media, sino los de la Aranda del Cuatrocientos: el río, que configura su identificación; el puente sobre el Duero; el castillo, que representa a la ciudad amurallada y sede del Ayuntamiento; y los leones, símbolos de los dos linajes que "defienden" los intereses de la villa y controlan el concejo. Poniendo esto en relación con lo indicado por De la Cruz, no parece difícil la adscripción de este mítico don Romero con el linaje del mismo nombre, aunque la identificación de Don Julián con el otro linaje es menos evidente. Sin embargo, el carácter tan común del nombre de Don Pedro García pudo llevar a la tradición o al cronista ilustrado a buscar una alternativa más aristocrática. Lo que queda claro a través de la documentación es que el nombre del segundo linaje adquirió su epíteto ya avanzado el siglo XV con la intención de distinguirlo del resto. El hecho de que se optara por de la Puente, lo hace todavía más fácilmente identificable con el segundo león que defiende la torre sobre la puente. Por lo tanto, podemos concluir que los dos leones fueron el emblema de los dos linajes que a lo largo del siglo XV se fueron haciendo con el control de los resortes del poder municipal arandino y que no dudaron en modificar la iconografía del escudo local para emplazar junto a la torre y el puente a los dos fieros leones.

Lejos de la idea de clientelas cerradas, los linajes arandinos evidencian en el último cuarto del siglo XV cierta permeabilidad a la incorporación de nuevos miembros que debilitaron la identificación de los lazos de sangre como elemento de conexión. La relajación del carácter sólido y cerrado de los linajes se advierte también en el trasvase de efectivos entre linajes o incluso, inimaginable en otras ciudades castellanas, la mi-

${ }^{981}$ DE LA CRUZ, en su descripción del escudo de la villa, señala: ...dos Leones levantados en campo azul, que estan defendiendo con sus garras la entrada de un Castillo, sito sobre una Puente de tres ojos, por donde pasa el Duero, en memoria de la célebre victoria que consiguieron de los Moros los dos hermanos Arandinos Don Julian y Don Romero. El propio autor pone en relación a los hermanos arandinos con los míticos ancestros de los linajes segovianos cuando afirma que actuaron como ...gloriosos competidores de los valientes Segovianos Don Dia Sanz y Don García, defendiendo à su patria de la entrada que quisieron hacer por la Puente mayor y puerta principal (Historia de la Milagrosa..., pp. 128-129). 
gración hacia la Comunidad ${ }^{982}$. Circunstancia ésta que manifiesta la quiebra de una configuración social muy jerarquizada y que da paso poco a poco a unas nuevas formas propias de las sociedades de transición.

Aunque pueda parecer contradictorio respecto a lo señalado anteriormente, a finales de la Edad Media se configuró un nuevo instrumento de cohesión asociado a los linajes que se concretó en la creación de dos cofradías que consolidaron el carácter clientelar y solidario de la oligarquía arandina.

La primera de ellas estaba en sintonía con una tendencia que se desarrolló en Castilla durante la Baja Edad Media y que la historiografía lo identifica como las cofradías de caballeros ${ }^{983}$. Las primeras evidencias de la existencia de una agrupación de hidalgos en la villa de Aranda se remontan a 1425 cuando Gómez Hernández de Sedano e Íñigo López de Gamarra estuvieron presentes por si e en nombre de los fijosdalgo de la dicha villa en la redacción de una carta de poder que el concejo formalizó para realizar un apeo con la vecina villa de Gumiel de Izán ${ }^{984}$. La materialización de esta agrupación de hidalgos en una cofradía bajo la advocación de Santiago no se sabe con certeza cuándo ocurrió aunque suponemos que fue durante el siglo XV. Las noticias que de ella tenemos relativas al siglo XVI son bastante explícitas en cuanto a la calidad de sus miembros pues a la cofradia del señor Santiago... pertenecen de ordinario los caballe-

${ }^{982}$ Ya en los años 60 la reina Juana, señora de la villa, se vio obligada a dictar unas ordenanzas prohibiendo ...que ningún vecino o morador de la villa que fuese de los linajes que dise de don Pedro García e de Don Romero e permanesciese en el linaje e una vez oviese entrado e entrase que no se mudase al otro ni entrase en el cuento de la comunidad so ciertas penas... (AGS, RGS, 148002, fol. 256; DIAGO HERNANDO, "El papel de los linajes..., p. 172).

${ }^{983}$ ROMERO MARTÍNEZ, A., "El asociacionismo del poder: las cofradías de hidalgos y caballeros", en En la España Medieval. 18, 1995, pp. 135-162; DIAGO HERNANDO, M., "Las corporaciones de caballeros hidalgos en las ciudades castellanas a fines de la edad media. Su participación en el ejercicio del poder local", en Anuario de Estudios Medievales. 36/2, 2006, pp. 803-838. Este tipo de agrupaciones han sido perfectamente documentadas y analizadas en ciudades de máximo nivel como Burgos (BONACHÍA HERNANDO, J. A., El concejo de Burgos en la Baja Edad Media ((1345-1426). Valladolid, 1978) y también en otros núcleos urbanos más modestos como las villas riojanas (GOICOLEA JULIÁN, F. J., "Los más nobles y honrados: caballeros e hidalgos en las ciudades y villas riojanas (s. XV - inicios s. XVI)”, Brocar: Cuadernos de investigación histórica, 31, 2007, pp. 411-440, en especial p. 420).

${ }^{984}$ VELASCO PÉREZ, Aranda. Memorias..., p. 95. La presencia de representantes de colectivos en las sesiones del concejo parece ser bastante habitual hasta la imposición del concejo cerrado en sentido pleno por parte de los Reyes Católicos (DIAGO HERNANDO, "Las corporaciones de caballeros..., p. 812). 
ros e hijosdalgo y otros escuderos vecinos de la villa y su tierra ${ }^{985}$. Posiblemente su sede estuviera en la iglesia de Santa María aunque no hay que descartar que algunos de sus oficios se realizaran en la cercana ermita de Santiago de la Encina, situada en el arrabal de Hesilla. Entre sus celebraciones destacaba una especie de alarde que celebraban ...la vispera y al otro día (de la festividad de Santiago) se juntan los más principales vecinos de esta villa a caballo e como mejor cada uno puede yr, reforzando su carácter caballeresco y nobiliario frente a las procesiones vinculadas a la religiosidad de la cofradías devocionales.

Por otra parte estaba el Cabildo y Cofradía de San Nicolás que tuvo un carácter más religioso. En un principio se constituyó como una asociación exclusivamente de clérigos, pero con el tiempo fue abriendo sus puertas a los laicos, no sin ciertas reticencias, a través de la creación de fundaciones de memorias y aniversarios ${ }^{986}$. De esta manera varios de los miembros de las principales familias arandinas como los Durango, Salazar, Quemada, Miranda o Acuña fueron integrándose dentro de este cabildo, a la vez que engrosaban con sus memorias las arcas de la cofradía. Esta corporación tuvo su sede en la iglesia de Santa María y celebraba oficios en esta parroquia, pero también en otras ermitas de la villa. La principal función de esta cofradía era la de procurar el bienestar espiritual de los cofrades difuntos a través de la celebración de misas y vísperas cantadas por sus clérigos. Pero también había cabida para tareas asistenciales como la memoria dejada en 1527 por el clérigo Sebastián Martínez ordenando que uno de los censos que aportó a su fundación se destinara para los pobres del espital desta dicha villa que es a la Madalena ${ }^{987}$.

En conclusión, tanto linajes como cofradías ayudaron a consolidar los lazos de unión que mantuvo a un grupo más o menos endogámico ligado por lazos de parentela, clientelismo y solidaridad. Este grupo más o menos cohesionado y claramente permeable a nuevas incorporaciones de cierta calidad se consolidó como una verdadera oligarquía que controlaba los resortes del poder político municipal y, por extensión, la vida socioeconómica arandina.

${ }^{985}$ Las noticias sobre su composición y ceremonial son bastantes tardías pues se recogen en una información requerida por Felipe II en 1572 sobre las hermandades y cofradías de hidalgos del reino (AGS, CC DIVERSOS, leg. 25, doc. 1).

\footnotetext{
${ }^{986}$ VELASCO PÉREZ, Aranda. Memorias..., pp. 160-164.

${ }^{987}$ VELASCO PÉREZ, Aranda. Memorias..., pp. 162-163.
} 


\section{b. Las principales familias de la oligarquía arandina.}

La oligarquía arandina de finales de la Edad Media estaba configurada por tres grupos fundamentalmente. El más numeroso era el de las familias hidalgas, en su mayoría foráneas, que fueron acaparando poco a poco los principales oficios del gobierno municipal y relegando al resto de los grupos a una posición minoritaria. El segundo grupo correspondía a las familias más antiguas de la villa y estaba configurado por los ricos labradores de la localidad. El tercer y último sector era el de los conversos también de origen foráneo y estrechamente vinculados al mundo de las finanzas. Su acceso a la oligarquía fue bastante tardío y a través de algunos de los mecanismos a los que ya hemos hecho mención.

\section{b.1. Las familias hidalgas.}

El primero y más relevante de los grupos que conformaban la oligarquía arandina era el de los hidalgos. Resulta muy difícil rastrear el origen y la composición de estas familias pero se advierten una serie de rasgos generales de los que participaron en gran medida todas ellas.

En primer lugar, el número de hidalgos avecindados en la villa de Aranda era bastante reducido $^{988}$, limitándose a varias familias que englobaban una numerosa parentela sobre la que en pocas ocasiones se extendía la condición privilegiada ${ }^{989}$. Así se confirma en el llamamiento que hicieron los Reyes Católicos en el año 1494 a los caballe-

${ }^{988}$ Fueron muchos los nobles que poseían propiedades en Aranda. La documentación informa de que don Juan de Navarra y el condestable don Álvaro de Luna tuvieron casa en la villa. Ocurrió lo mismo con los condes de Miranda, los Marqueses de Denia y los señores de Castrillo, pero ninguno de ellos fue vecino de la villa (AGS, RGS, 148811, fol. 176; y ARChV, RRE, Caja 259, doc. 5). En este sentido, llama la atención el contraste con otros espacios castellanos donde el porcentaje de hidalgos que habitaban los núcleos urbanos supera el 30\% del total (GOICOLEA JULIÁN, "Los más nobles y honrados: caballeros..., pp. 411-412).

${ }^{989}$ En 1488 Pedro de Salazar, García de Salazar, Juan de Revenga, por sí y en nombre de Diego Fernández de Valladolid, Pedro de Mora, Íñigo de Barahona y Martín de Acuña se negaron a pagar la martiniega aludiendo a su condición de hidalgos. Los regidores de la Comunidad los denunciaron por incumplimiento de la costumbre inmemorial que obligaba a todos sus vecinos a pagar este impuesto para el mantenimiento de la villa, argumentando que... los susodichos que por se fallar emparentados e favorecidos e nuevos regidores quieren quebrantar la posesión y constumbre antigua... (AGS, RGS, 148811, fol. 176). El 3 de febrero de 1489 un numeroso grupo de vecinos se presentó en las residencias de don Martín de Acuña, el comendador Íñigo de Barahona, Pedro de Salazar y García de Salazar y los expulsaron de la villa por negarse a pagar la martiniega (AGS, RGS, 148902, fol. 132). Estos datos no son determinantes para conocer el número de familias hidalgas, pues nada dice de aquellas que pagaban, aunque sí nos puede dar una idea aproximada de la situación. 
ros hidalgos al que respondieron tan solo una docena de vecinos arandinos ${ }^{990}$. Esta situación minoritaria se acentuó con la negativa del concejo a permitir el avecindamiento de ciertos nobles en este periodo ${ }^{991}$. Entre estas familias hidalgas podemos identificar a los Durango, Salazar, Barahona, Mora y Avellaneda.

La presencia en tierras ribereñas de estas familias de hidalgos fue un fenómeno bastante tardío, remontándose como mucho a mediados del siglo XV. Asimismo se ha constatado un origen norteño, bien de las montañas burgalesas o de los territorios vascos. Si bien es cierto que no hemos logrado identificar la procedencia de alguna de estas familias hidalgas, el origen foráneo de la gran mayoría deja sin argumentos a la pretendida vinculación de la condición de privilegiados de este grupo social con la caballería villana de siglos precedentes, uno de los pilares fundamentales sobre los que se asentaba la legitimación de los linajes. Pero esta incoherencia o contradicción no fue óbice para que estas familias hidalgas foráneas se integraran plenamente en la estructura linajuda arandina. Así se observa en los años ochenta cuando los Salazar se encontraban integrados en el linaje de don Romero, mientras que los Mora y Barahona se encuadraban en el de don Pedro García de la Puente

Otra de las características comunes es el progresivo control que ejercieron estas familias sobre los resortes del poder local, evolucionando hacia un monopolio y patrimonialización de las instituciones políticas del concejo. Asimismo se observa el establecimiento de alianzas con los ricos pecheros locales que se materializó en una serie de enlaces matrimoniales que respondían al interés mutuo por adquirir la condición privilegiada y sustentar un título sobre unas bases patrimoniales cada vez más amplias. Por último, y no menos importante, estos hidalgos se encuadraban de forma clara y evidente en las redes clientelares de la aristocracia castellana con intereses en la comarca, sobre todo bajo el amparo de los Zúñiga y Sandoval. Esta situación reforzaba la posición de

${ }^{990}$ Acudieron al llamamiento don Martín de Acuña, Martín de Durango, Gonzalo de Quemada, García de Salazar, Pedro de Salazar, Pedro de Santa Cruz, Francisco de Mena, Juan de Aranda, el bachiller Torres, el licenciado Peñafiel, Avellaneda, hijo de Juan de Avellaneda, y Gonzalo de Salazar, hijo de Rodrigo de Salazar. Aunque en el encabezamiento se hace referencia a la condición de hidalgos, algunos de los incluidos en la relación eran pecheros como Quemada, Santa Cruz y Mena, por lo que suponemos que se trata de aporte de soldados, más que de un censo de hidalgos locales (OSUNA Y RUS, M. Memorias Sagradas. Sevilla, 1678, vol. 2, pp. 341-371; y Anales de la Real Academia Matritense de Heráldica y Genealogía. Tomo I, Madrid, 1991, pp. 275-298).

991 A Lope Ochoa de Avellaneda se le impidió en 1485 avecindarse en Aranda a causa de ciertas enemistades con los alcaldes de la villa (AGS, RGS, 148504, fol. 93). 
poder de esta baja nobleza en el ámbito local y, a la vez, prolongaba los intereses de los grandes linajes en el medio urbano, en este caso sobre una villa de realengo.

A continuación procedemos a describir cada una de estas poderosas familias hidalgas que estaban asentadas en la villa a finales de la Edad Media.

\section{La familia Durango.}

Los escasos trabajos sobre esta familia hacen descender a los Durango arandinos de don Martín de Durango, quien fue nombrado caballero de la banda por el rey Juan II en $1445^{992}$.

No obstante, la primera referencia documental a un miembro de esta familia arandina la localizamos en 1457 cuando Lope Sánchez de Durango, vecino de Aranda, arrendó al monasterio de Bujedo las posesiones que éste tenía en Báscones del Agua con sus granjas de Valdesalce, Valdetardaja y San Román más un molino de tres ruedas. Estos bienes los mantuvo arrendados la familia hasta principios del siglo $\mathrm{XVI}^{993}$. Este mismo personaje actuó en 1463 como fiador de Álvaro de Ávila, también arandino, en el arrendamiento de las rentas de la alcabala de la Merindad de Santo Domingo de Silos entre los años 1463 y $1465^{994}$.

Durante el conflicto civil que sacudió Castilla en los años 70 los Durango se posicionaron del lado del partido portugués pues sus posesiones en Báscones del Agua, muy próximas a Lerma, y unas heredades de Villafruela fueron tomadas por don Diego de Rojas y ocupadas durante siete años ${ }^{995}$.

Hijo de Lope Sánchez fue Pedro de Durango que trató de recuperar los bienes de su padre en Báscones del Agua. Tras una larga negociación finalmente se le reconoció en 1495 su señorío sobre el lugar ${ }^{996}$. Después de una temporada avecindado en Aranda,

992 VILAR Y PASCUAL, L., y VILAR PSAYLA, J. J., Diccionario histórico, genealógico y heráldico de las familias ilustres de la monarquía española. Madrid, 1886, vol. VIII, p. 171; DE LA CRUZ, V., La abadía cisterciense de Bujedo de Juarros. S. XII-XIX. Burgos, 1990, p. 166.

${ }^{993}$ DE LA CRUZ, La abadía..., pp. 166-167 y 174. Por el censo entregó 100 doblas de oro y se comprometió a pagar una renta anual de cien fanegas de cereal por el día de San Miguel de septiembre (AHN, CLERO, carpeta 173, $\left.\mathrm{n}^{\circ} 13\right)$. vedíes.

${ }^{994}$ AGS, EMR, leg. 11, doc. 12. El montante total del arrendamiento ascendió a 220.000 mara-

${ }^{995}$ En 1485 el hijo de Diego López de Durango seguía reclamando justicia y se quejaba de las dilaciones del alcalde de Burgos que se encargaba del asunto (AGS, RGS, 148503, fol. 196).

${ }^{996}$ AGS, RGS, 149508, fol. 108; y 149608, fol. 24. 
donde tuvo alguna disputa con otros vecinos por cuestiones de deudas, se trasladó a Burgos. En esta ciudad hizo fortuna creando una compañía con otros mercaderes burgaleses que se dedicaba a la compra paños en Londres y su posterior importación a Casti$1 a^{997}$. En este periodo Pedro de Durango tuvo que hacer frente a las reclamaciones de sus hermanos Alonso, Lope, Bernaldino e Isabel de Contreras a propósito de la herencia de sus padres. Así, en 1497 su hermana Isabel, mujer de Diego de Mendoza y vecina de Santa Cruz de la Salceda, reclamó a su hermano el pago de 160.000 maravedíes que se le habían prometido como dote, así como el disfrute por unos años del lugar de Báscones del Agua ${ }^{998}$. La ofensiva de los hermanos continuó ese mismo año con la iniciativa de Alonso de Durango que, en nombre de sus hermanos, tomó posesión de forma violenta de Báscones y sus granjas. Esta situación se mantuvo poco tiempo pues la justicia dio la razón a Pedro y los hermanos se vieron obligados a devolver su posesión y todos los bienes requisados ${ }^{999}$. No obstante, las disputas continuaron y así, un año después, Bernaldino consiguió de la justicia real el reconocimiento de una deuda de 27.000 maravedíes más treinta coronas de oro que le debía su hermano ${ }^{1000}$.

Otro miembro de esta familia, aunque no conocemos la relación de parentesco concreta con los anteriores, fue Juan de Durango. En 1486, junto a otros vecinos, denunció ciertas violencias cometidas en la villa por los criados de don Martín Vázquez de Acuña. Los reyes enviaron un pesquisidor que halló culpables a los denunciantes por lo que tuvieron que hacerse cargo del coste de la pesquisa ${ }^{1001}$. Un año después Juan de Durango constituyó una sociedad que se dedicaba al negocio del arrendamiento de rentas. En el desarrollo de su actividad los reyes le ordenaron en 1487 que no procediera a ejecutar los bienes de los vecinos de ciertos lugares de Fuentepinilla acusados falsamen-

${ }^{997}$ En 1487 tuvo problemas con un vecino de Aranda, Juan Sánchez Bravo, por el embargo de una mula (AGS, RGS, 148708, fol. 247; y 148710, fol. 67). Desde 1991 ya se encontraba en Burgos (149111, fol. 111).

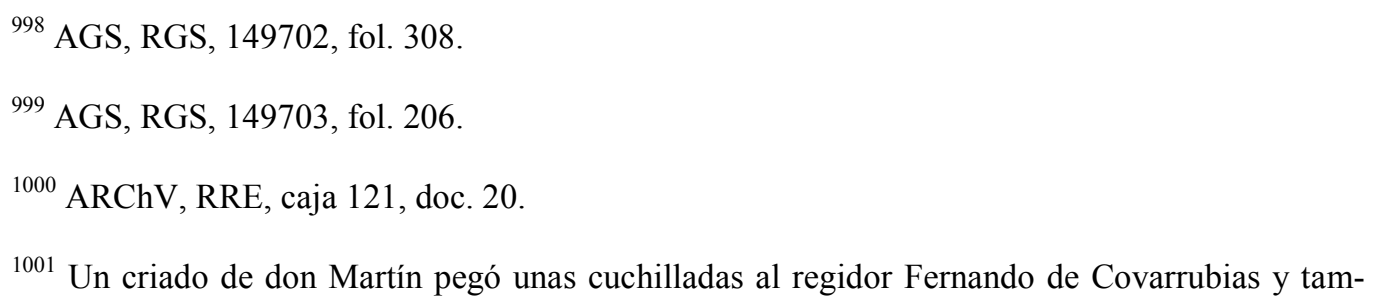

${ }^{1001}$ Un criado de don Martín pegó unas cuchilladas al regidor Fernando de Covarrubias y también participó en el asalto del monasterio de San Pedro de Gumiel de Izán. Ante la demanda de los vecinos, los monarcas enviaron un pesquisidor que consideró culpable al agredido y a los vecinos que lo denunciaron (AGS, RGS, 148605, fols. 38 y 178). Posteriormente Durango también se vio implicado en un delito de falsificación pues los hermanos Calero le denunciaron por añadir falsamente sus firmas en la petición de pesquisidor (148606, fol. 143). 
te de no haber abonado las alcabalas al arrendador, don Mayor de Soria ${ }^{1002}$. A partir de este episodio no volvemos a tener noticias suyas.

A partir de los 90 comenzamos a tener noticias de otro grupo de la familia Durango que no hemos podido relacionar directamente con los descendientes de Lope Sánchez aunque la coincidencia en el tiempo, e incluso en los nombres, nos lleva a concluir cierta proximidad sanguínea, aunque no podemos descartar un origen foráneo. Se trata de los hermanos Hernando, Martín, Lope, Bernaldino y Flores. Todos ellos utilizaron el apellido Durango salvo el primero que empleaba el de Torquemada. A partir de los años 90 las noticias sobre esta rama familiar de los Durango fueron muy frecuentes, convirtiéndose en uno de los principales linajes de la oligarquía arandina que se mantuvo muy activo durante toda la modernidad.

Hernando de Torquemada era el mayor de los hermanos. Según su testamento fue morador de la villa de Aranda y habitante de La Coruña con la que tenía una gran relación pues dispuso ser enterrado en el convento de San Francisco de esa ciudad. ${ }^{1003}$. Su presencia en la villa fue muy discreta y tan solo lo hemos identificado como alcalde en $1492^{1004}$. Fue hombre de armas y prestó sus servicios a la Corona en la conquista de Canarias, aunque no sabemos por el momento cuál fue su papel en esta empresa ${ }^{1005}$. Por esta misión los monarcas le premiaron con varias mercedes entre las que se encontraban unas casas y cierta cantidad de dinero ${ }^{1006}$. Durante su vida reunió un importante patrimonio entre el que se contaban varios bienes inmuebles, un batán en la ribera del Aran-

${ }^{1002}$ AGS, RGS, 148707, fol. 54.

${ }^{1003}$ AGS, CASA Y SITIOS REALES, leg. 4, doc. 148. El testamento estaba redactado en La Coruña en abril de 1496 y dejaba como sus testamentarios a su hermano Martín y a su primo García de Sedano. Esta vinculación con las tierras gallegas también se aprecia en la posesión de unas heredades en Cangas de Morrazo.

${ }^{1004}$ AGS, CC PUEBLOS, leg. 2, fol. 69.

${ }^{1005}$ Esta condición de marino y militar explica su residencia en La Coruña. A principio de los 90 obtuvo 18.000 maravedíes sobre las alcabalas de Aranda por el acostamiento de tres jinetes. En su testamento legó sus caballos, mulas y armas a su hermano Martín (AGS, CMC, leg. 41).

${ }^{1006}$ Por su actividad en la conquista de Canarias se le asignó un sueldo de 50.000 maravedíes. En 1504 todavía faltaban por pagar más de 28.000 maravedíes. Le fueron entregados ese mismo año 10.000 a su hermano Martín, en nombre de su viuda e hijos (AGS, CASA Y SITIOS REALES, leg. 4, doc. 147). En 1524 su hijo Martín de Torquemada consiguió cobrar los 18.000 restantes (leg. 7, docs. 437-440). Tras la expulsión de los judíos los reyes le hicieron merced de unas casas que habían sido de Yuça de Huete, aunque no sabemos dónde estaban. Tras la conversión del judío, de cristiano Pedro Álvarez de la Peña, se planteó un problema pues demandaba la devolución de los bienes confiscados. El corregidor de Salamanca fue comisionado para solucionar el asunto por lo que suponemos que las casas estaban emplazadas en esa ciudad o sus proximidades (AGS, RGS, 149807, fol. 113). 
dilla y algunas heredades en la vega de la tierra arandina ${ }^{1007}$. Hernando y su mujer María Ortega o Romera tuvieron dos hijos que todavía eran menores a la muerte del progenitor: Martín de Torquemada y María de Durango. El varón tuvo una participación destacada durante la revolución comunera, encuadrado entre las huestes realistas en la batalla del Villalar, en el transcurso de la cual fue herido ${ }^{1008}$.

El hermano con mayor relevancia en Aranda fue Martín de Durango que en 1490 ya era citado como regidor perpetuo de la villa, seguramente encuadrado en el linaje de Don Romero. Por entonces se vio inmerso en las disputas entre los bandos que controlaban el Concejo arandino, y así intervino activamente al lado de los Quemada en la disputa que mantuvo con Mora por el beneficio de Alcoba ${ }^{1009}$.

Ya desde estos primeros momentos de la vida pública de Martín de Durango se asociaba a la casa del conde de Miranda. En 1490 es nombrado en la documentación como criado del Conde de Miranda y acompañó a éste en alguno de los conflictos en los que intervino ${ }^{1010}$. Esta vinculación con la familia Zúñiga se mantuvo en el tiempo pues tanto su hijo como su nieto ejercieron como contadores del conde a lo largo de la primera mitad del siglo XVI ${ }^{1011}$.

$\mathrm{Su}$ actividad como regidor de la villa de Aranda se desarrolló desde al menos 1490 hasta 1508, participando muy activamente en casi todos los asuntos que marcaron la vida política de la capital de la Ribera. Tuvo un significativo papel tanto en los diferentes conflictos que se generaron entre los linajes, como entre éstos y los procuradores de la comunidad. Incluso en 1498 los hermanos Durango, con Martín a la cabeza, se enfrentaron con el corregidor de la villa, el licenciado Herrera, y su alcalde. No sabemos la causa del debate pero la consecuencia fue que el corregidor denunció a los Durango

${ }^{1007}$ Además de las mencionadas anteriormente, debió poseer unas casas en las inmediaciones de la calle el Pozo pues su viuda aparece como una de las afectadas por la apertura de la calle de Barrionuevo en 1503 (AGS, CR, leg. 39, doc. 3; PERIBÁÑEZ OTERO y ABAD ÁLVAREZ, Aranda de Duero..., p. 123). También se vio afectado el batán de Torquemada, propiedad de los herederos de Hernando, por el proyecto de desvío del río Aranzuelo en 1515. Ese año se estimaba que el batán rendía 3.000 maravedíes al año (CR, leg. 40, doc. 8; ABAD ÁLVAREZ y PERIBÁÑEZ OTERO, "El control social..., p. 138). En 1529 la iglesia de Santa María tenía un censo de 90 maravedíes anuales sobre una heredad de la viuda de Torquemada en la vega de Sinovas (ADB, LIBRO DE FÁBRICA, tomo I, s. f. ).

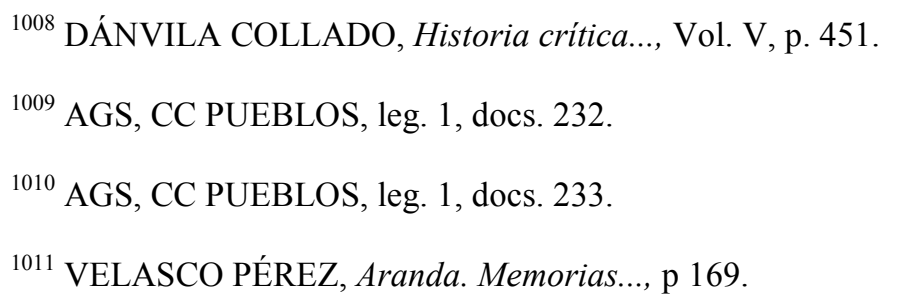


de causar ciertos alborotos y amenazarle de muerte. Durante el otoño de ese año se inició una investigación en la que participaron como testigos varios vecinos de Aranda y la comarca. Durante el proceso los bienes de Martín, Lope y Bernaldino fueron confiscados y ellos conducidos a Valladolid donde estuvieron encarcelados una temporada ${ }^{1012}$. Desconocemos también la resolución final del problema pero en diciembre de ese mismo año el Consejo Real ordenó que se les liberara y les devolvieran sus bienes ${ }^{1013}$.

Suponemos que el patrimonio de este Durango era importante, aunque lo cierto es que tan solo tenemos información sobre pequeñas cantidades libradas sobre la renta de la alcabala de Aranda y alguna referencia a heredades en la tierra arandina ${ }^{1014}$.

Martín de Durango murió en 1508 renunciando previamente a su oficio de regidor perpetuo en favor de su hijo primogénito, también llamado Martín ${ }^{1015}$.

Bernardino de Durango, hermano del primer Martín, fue vecino de Aranda, en concreto tenía sus casas en la Calle de Durango ${ }^{1016}$, en la cuadrilla de San Juan. Desarrolló en ella una importante actividad económica destacando en el negocio de la venta de vino ${ }^{1017}$, y acumuló un importante patrimonio que incluía viñas, heredades, casas y bienes valorados en cerca de 2.000 ducados en el momento de su muerte en 1519. Su participación en la vida política de la villa se limitó a su elección en 1517 como procurador de la cuadrilla de San Juan para tratar el asunto del alguacilazgo de la villa ${ }^{1018}$. Estuvo casado con Magdalena de Lerma y tuvo cinco hijos. Uno de ellos, Gerónimo se

${ }^{1012}$ AGS, RGS, 149808, fol. 54 y 310; 149809, fol. 255 y 273; y 149810, fol. 328.

${ }^{1013}$ AGS, RGS, 149812, fol. 106.

${ }^{1014}$ AGS, CMC, leg. 41. En 1506 se le abonaron 15.000 maravedíes de un libramiento de la reina concedido en mayo de 1503. La misma cantidad se asignó en 1511 a los herederos de Martín de Durango. En 1509 se ordenó a los contadores mayores que abonaran a los herederos de Martín los maravedíes que tenían como merced (AGS, CC CÉDULAS, libro 7, leg. 172, doc. 3).

1015 AGS, RGS, 150801, s.f. El 18 de enero se concedió el regimiento a Martín de Durango hijo por lo que suponemos que la muerte del padre tuvo lugar a principios de ese mismo año.

${ }^{1016}$ Era bastante habitual nombrar las calles por alguno de sus vecinos ilustres como se puede apreciar en el plano de 1503. No obstante, no sabemos por el momento a qué calle corresponde ésta donde vivía Bernardino.

${ }^{1017}$ AGS, CC PUEBLOS, leg. 2, doc. 107. Se trata de una carta de espera de un vecino de Aranda que le debía a Bernardino 2.250 maravedíes de media cuba de vino. En el interrogatorio se afirmaba que Durango era persona rica y que la espera no le ocasionaría ningún daño. Lo mismo se recoge en AGS, RGS, 149810, fol. 141.

1018 AGS, CC MEMORIALES, leg. 121, doc. 236; y CONSEJO Y JUNTAS DE HACIENDA, leg. 4, doc. 20 . 
casó con Elena de Quemada pero murió joven y sin descendencia ${ }^{1019}$. Del resto no hemos logrado obtener ninguna información.

De Lope poco sabemos salvo el altercado con el corregidor citado anteriormente. Posiblemente se trasladó a Cervera pues un Lope de Durango, vecino de Cervera, tuvo cierto pleito con García de Sedano, vecino de Aranda, que le había engañado en la venta de un esclavo canario ${ }^{1020}$. Menos información tenemos sobre el hermano menor, Flores, pues tan solo sabemos que a finales de siglo estaba casado con una tal María y que tuvo al menos una hija, Beatriz de Durango ${ }^{1021}$.

Martín de Durango, hijo del primer Martín, siguió el mismo patrón que su padre pues también se caracterizó por una notable actividad política como regidor perpetuo. Asimismo estuvo al servicio de los condes de Miranda actuando como su contador. A través de su matrimonio se produjo la consolidación de la alianza entre los Durango y una de las más destacadas familias de ricos labradores arandinos: los Quemada. Como ya hemos visto anteriormente, ya el primer Martín apoyó los intereses de la familia Quemada en su disputa con Pedro de Mora a comienzos de los 90. El matrimonio entre el segundo Martín con Juana de Quemada, hija de Gonzalo García de Quemada, no hizo más que sancionar una alianza de intereses. Como ya hemos visto en otras ocasiones, los Durango aportaban la hidalguía y los Quemada un notable patrimonio que se materializó, entre otros bienes, en la aportación como dote del privilegio que la reina Isabel concedió a Gonzalo García de Quemada del portazgo sobre los ganados que pasaban por el puente de Aranda ${ }^{1022}$. Fruto de esta relación nació Cristóbal de Durango que heredó de su padre tanto el cargo de regidor del concejo arandino como el oficio de contador del conde de Miranda ${ }^{1023}$.

1019 ARChV, RRE, Caja 389, doc. 40.

1020 AGS, RGS, 149407, fol. 277. No sabemos a ciencia cierta si este Lope de Durango era el hermano de Martín, en cuyo caso Sedano sería su primo, o si bien era el hijo de Lope Sánchez de Durango del que hemos hablado anteriormente.

${ }^{1021}$ AGS, CASA Y SITIOS REALES, leg. 4, doc. 148.

${ }^{1022}$ VILAR Y PASCUAL y VILAR PSAYLA, Diccionario histórico... Vol. VIII, p. 175. Posiblemente entre los bienes heredados por Juana de Quemada se encontraba el solar del palacio actual de los Berdugo pues en el pleito de 1503 no se citaba a ningún Durango entre los vecinos de Barrionuevo y sí varios de los Quemada.

${ }^{1023}$ VELASCO PÉREZ, Aranda. Memorias..., p. 231. 
En los primeros años del Quinientos entró en escena un nuevo Durango, Rodrigo. No sabemos a ciencia cierta su filiación pero es evidente que pertenecía a este linaje. Recibió el oficio de regidor perpetuo de la villa de Aranda en agosto de $1512^{1024}$. Al menos desde 1514 simultaneó este oficio con el de alcaide de la villa de Gumiel de Mercado al servicio del marqués de Denia sin que mediara ningún tipo de incompatibilidad o inhabilitación ${ }^{1025}$. Lo cierto es que el oficio de alcaide concentró la mayor parte de su tiempo y energías pues tuvo que gestionar los intereses del marqués en sus territorios ribereños a causa de sus continuas estancias en Tordesillas al cuidado de la reina madre. Incluso en ocasiones el alcaide acompañaba a su señor en esta tarea ${ }^{1026}$.

El linaje de los Durango se mantuvo fiel al monarca durante el conflicto de las Comunidades como parece mostrar la activa participación de Martín de Torquemada en Villalar y las importantes compensaciones que después recibió del monarca ${ }^{1027}$. Por su parte, Rodrigo actuó muy severamente durante la posterior represión. Podemos afirmar que incluso con exceso de celo y en beneficio propio pues en la subasta de los bienes de uno de los exceptuados, Bernaldino de Arauzo, adquirió su hacienda por 35.000 maravedíes, siendo el montante de la tasación de 60.000 maravedíes $^{1028}$. Durante varios años la Corona, el damnificado y su viuda pleitearon para que se les hiciera justicia, pero no nos consta que consiguieran algo positivo ${ }^{1029}$.

También tenemos noticias de otras ramas colaterales de esta familia que jugaron un papel bastante más modesto en el desarrollo de la villa de Aranda. Entre éstas desta-

1024 AGS, RGS, 151208, s. f., dato obtenido de DIAGO HERNANDO, “Arrendadores arandinos..., p. 90. El oficio lo obtuvo tras la vacante dejada por el fallecimiento de Francisco de Mena.

${ }^{1025}$ El 8 de octubre de 1514 el rey Fernando ordenó a Rodrigo que ...la monteria e caza del monte de Ventosilla se guarde para mi recreacion... e impidiera que nadie más pudiera cazar en dicho monte (AGS, CC PUEBLOS, leg. 22, doc. 82).

${ }^{1026}$ AGS, CR, leg. 453, doc. 5. En el proceso de elección de un nuevo escribano en diciembre de 1518 el escribano del concejo acudió a la casa de Durango y allí le dijeron que el regidor se encontraba ausente por estar con el marqués en Tordesillas y, aunque le habían hecho llamar, no sabían cuándo regresaría. No obstante, en la reunión que tuvo lugar dos días después sí que se encontraba presente en las casas del ayuntamiento.

${ }^{1027}$ Recordemos que Torquemada fue herido en Villalar (DÁNVILA COLLADO, Historia crítica..., Vol. V, p. 451). Asimismo fue uno de los beneficiados por la merced de 500 ducados de oro que concedió el monarca en 1523 a una serie de destacados arandinos realistas (AGS, CMC, leg. 355).

${ }^{1028}$ AGS, CMC, leg. 355.

${ }^{1029}$ AGS, CR, leg. 75, doc. 16; y ARChV, RRE, Caja 378, doc. 15. 
có la figura de García de Sedano, primo de los hermanos Durango ${ }^{1030}$. Su vida se orientó en varios frentes pues la documentación lo muestra tanto arrendando rentas de la villa o lugares comarcanos como vendiendo esclavos ${ }^{1031}$. A pesar de su reconocido parentesco con los Durango, solicitó el ingreso en la Comunidad y fue aceptado en 1492. En este proceso tuvo ciertos problemas con el escribano del concejo que debía dar testimonio del procedimiento, así como con ciertos miembros de la Comunidad que se negaban a que disfrutase de sus privilegios, seguramente por su vinculación con uno de los linajes de los caballeros ${ }^{1032}$. Además se destacó como procurador de su suegro, García Sánchez de Calahorra, en el pleito que mantuvo contra el Consejo de la Santa Inquisición. Debió fallecer en los inicios del nuevo siglo pues su familia política se disputaba en 1503 su herencia con sus hijos legítimos ${ }^{1033}$.

Hijos de Sedano fueron Juan de Durango y Luis de Sedano. El primero de ellos permaneció en la villa amasando un modesto patrimonio a principios del siglo XVI, mientras que su hermano debió emigrar aunque no sabemos dónde ${ }^{1034}$.

A mediados del siglo XVI la familia Durango enlazó con el linaje de origen burgalés de los Tamayo. Una de las hijas de Cristóbal de Durango, María, contrajo matrimonio con Pedro de Tamayo. Tras varios pleitos con sus hermanos, María, con el apoyo de su marido, se hizo con la mayor parte de la herencia paterna y consolidó su posición frente al resto de los herederos ${ }^{1035}$. A finales del XVIII se produjo la unión de los Ta-

${ }^{1030}$ AGS, CASA Y SITIOS REALES, leg. 4, doc. 148.

${ }^{1031}$ En 1489 participó del arrendamiento de las tercias de Guzmán (AGS, RGS, 149204, fol. 310) y en 1493 formaba parte del grupo que arrendó las tercias de Aranda (EH, leg. 4). Su primo Lope de Durango le denunció en 1494 por venderle un esclavo canario a sabiendas de que era libre por ser cristiano (RGS, 149407, fol. 277). Debió contar con una importante fortuna pues fueron varios los litigios que tuvo abiertos a la vez por diferentes causas lo que suponía necesariamente un cierto nivel de riqueza. También es significativo que en 1497 pagara a un vecino de Gumiel de Izán para que fuera a servir de azadonero al Rosellón con el ejército real (CC PUEBLOS, leg. 2, doc 71).

${ }^{1032}$ AGS, RGS, 149204, fol. 310.

${ }^{1033}$ Sedano se casó en segundas nupcias con Francisca de los Ríos, hija de Calahorra y viuda de un vecino de Peñafiel. Mantuvo un pleito con la familia del primer marido para recuperar la dote de su nueva esposa (AGS, CONSEJO Y JUNTAS DE HACIENDA, leg. 1, doc. 61). A la muerte de García, la hermana de Francisca, Leonor de los Ríos, reclamó los bienes que su hermana aportó al matrimonio (ARChV, RRE, Caja 176, doc. 20). doc. 61 .

${ }^{1034}$ ARChV, RRE, Caja 176, doc. 20; y AGS, CONSEJO Y JUNTAS DE HACIENDA, leg. 1,

${ }^{1035}$ Del matrimonio entre Cristóbal y Francisca del Barrio nacieron al menos dos varones, Gonzalo y Pedro, y dos mujeres, María y Gerónima. Son muchos los pleitos entablados por María contra sus hermanos que la acusaban de haber ocultado los bienes de su padre cuando este murió e impedir la divi- 
mayo-Durango con la familia, también foránea, de los Berdugo que hoy da nombre al palacio originario del linaje de los Durango ${ }^{1036}$.

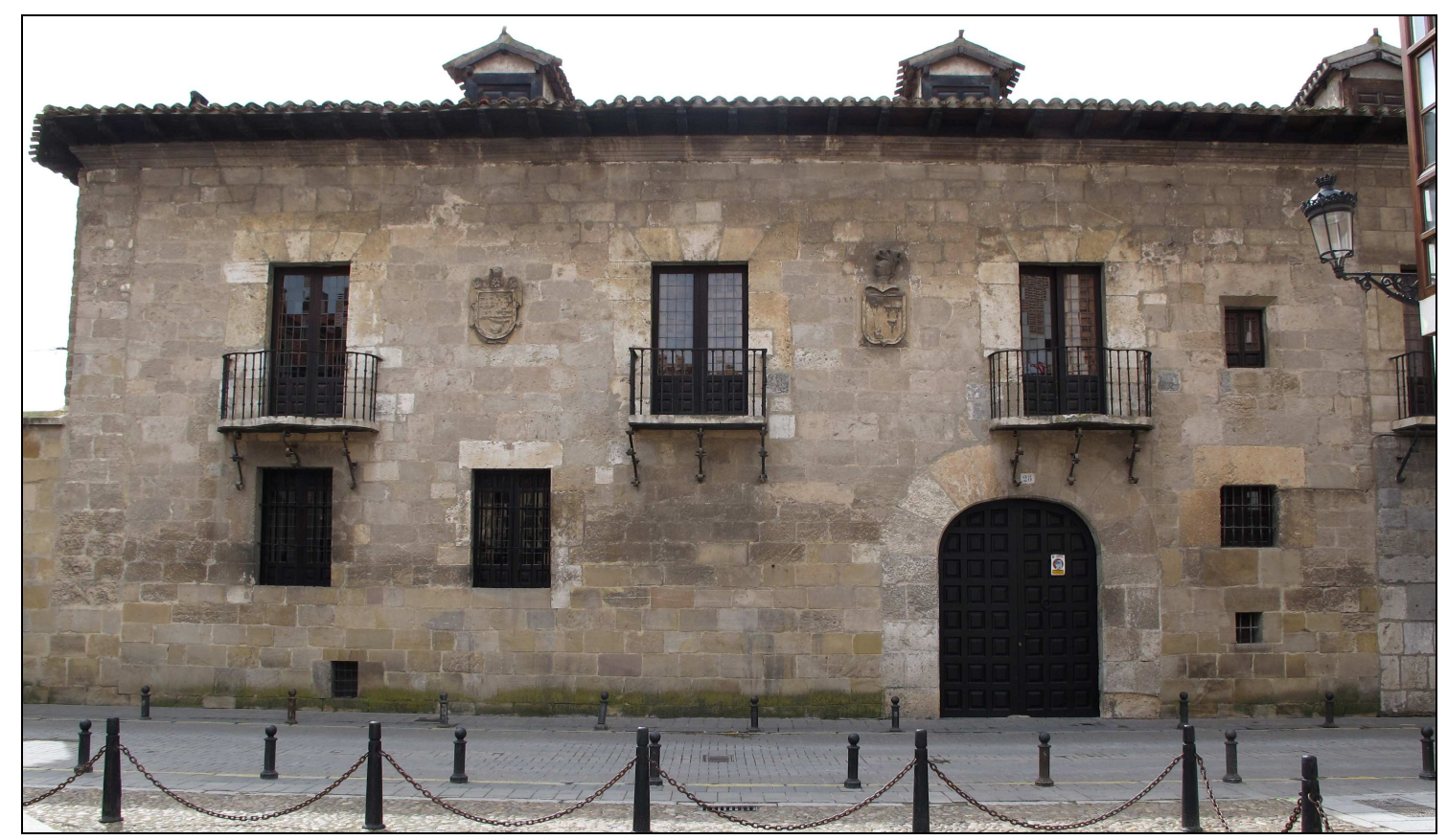

Imagen 44: Palacio de los Berdugo en la actualidad.

\section{La familia Salazar.}

La presencia de los Salazar en Aranda es perceptible a principios de los años setenta cuando Rodrigo de Salazar apareció junto a los oficiales de un concejo presidido por el corregidor Juan de Avellaneda. No parece ostentar ningún oficio pero su implicación en algunos incidentes junto a los alcaldes permite identificarlo como alguacil de la villa $^{1037}$. Sin embargo, el aspecto más destacado de su presencia en la villa en estos primeros momentos fue su participación junto a su parentela en la toma de Aranda para la princesa Isabel. El destrozo causado por las gentes de Salazar sobre los partidarios del rey Enrique fue tan grande que la princesa se vio obligada a compensar con 250.000 maravedíes a los damnificados en el asalto. Esta compensación fue el preludio para el

sión entre los herederos legítimos (ARChV, RRE, Caja 1275, doc. 65). El matrimonio Durango-Tamayo también recibió la herencia de don Íñigo de Zúñiga, casado con Gerónima Durango, que murió sin herederos (Caja 1213, doc. 15).

${ }^{1036}$ VILAR Y PASCUAL y VILAR PSAYLA, Diccionario histórico... Vol. VIII, p. 195; y ARChV, RRE, Caja 3778, doc. 31 .

${ }^{1037}$ En torno a 1470 acompañaba a los alcaldes de la villa en la persecución de un vecino de Aranda que había robado el vino a unos comerciantes y se había refugiado en Vadocondes (AGS, RGS, 148504, fol. 128). 
acto de conciliación entre Salazar y Pedro García de Aranda y sus respectivas clientelas que tuvo lugar en Segovia en el verano de $1474^{1038}$. Salazar también obtuvo su premio por el servicio prestado a doña Isabel pues recibió como merced la mitad de las tercias de los lugares de Fresnillo, Vadocondes y Pinilla Trasmonte que ascendían a 10.000 maravedíes ${ }^{1039}$. Posiblemente como consecuencia de la presencia de Rodrigo en la villa $\mathrm{y}$ esta intervención varios miembros de la familia Salazar se asentaron en la villa ${ }^{1040}$.

Rodrigo de Salazar estableció su residencia en Aranda pero su presencia en la vi1la fue intermitente pues su activo servicio a la Corona le llevó a desplazarse por todo el reino para ejecutar diferentes misiones. Todavía en el contexto de la guerra con Portugal recibió el encargo de reclutar gentes para dotar a la armada que se estaba organizando en Bilbao y para ello se le confirió el poder de otorgar el perdón real a todos los delincuentes que se comprometieran a servir por un año en las naves de Andrés de León ${ }^{1041}$. La persecución de malhechores fue su siguiente destino en el Principado de Asturias donde actuó como juez pesquisidor durante $1480^{1042}$. Tras ese año perdemos su pista y tan solo tenemos noticias de su posible fallecimiento a finales de la década de los ochenta $^{1043}$. Además de su posición privilegiada, Rodrigo logró consolidar una importante fortuna basada en los juros ya comentados y en la propiedad de importantes bienes inmuebles entre los que destacan los molinos de los Salazar y Revilla más un batán, todos ellos en la ribera del río Arandilla ${ }^{1044}$.

${ }^{1038}$ La merced se firmó en Segovia el 24 de julio de 1474 (AGS, CASA Y SITIOS REALES, leg. 3, doc. 123). Pedro García de Aranda fue uno de los honrados omes que acudieron a recibir a la Princesa al arrabal de Allendeduero el 6 de octubre de 1473 para hacerle entrega de la villa (HURTADO QUERO, Documentos Reales..., doc. 11, pp. 24-26).

${ }^{1039}$ AGS, CMC, leg. 41. La merced situada sobre las tercias de Pinilla montaba 4.500 maravedíes. Curiosamente la otra mitad de las tercias de este lugar eran propiedad del conde de Miranda, su principal enemigo en el asalto de la villa de Aranda. Posteriormente los herederos de Rodrigo tuvieron problemas con el conde por el reparto de las tercias (AGS, RGS, 149908, fol. 40).

${ }^{1040}$ En la probanza de hidalguía presentada en 1511 por Pedro de Salazar se afirmaba que su padre, García de Salazar, se había trasladado a vivir a Aranda hacía 35 años (ARChV, RRE, Caja 261, doc. 25).

${ }^{1041}$ AGS, RGS, 147907, fol. 29.

1042 AGS, RGS, 148011, fol. 38; y 148012, fol. 56 y 248.

${ }^{1043}$ En 1489 se le libraron 12.000 maravedíes de las rentas de Aranda por el acostamiento de cuatro lanzas que se entregaron a su mujer por que él había fallecido (AGS, CMC, leg. 41). Lo mismo ocurrió en 1490.

${ }^{1044}$ A su muerte estos molinos fueron heredados por sus hijos y nietos. En 1515 el molino de los Salazar contaba con dos ruedas y era propiedad de Pedro, Ana y los hijos de Sancho. La familia lo tenía 
Hemos documentado al menos cuatro hijos de Rodrigo de Salazar avecindados en la villa desde los años ochenta. Pedro de Salazar fue el que más destacó de todos ellos pues ocupó el cargo de regidor perpetuo al menos desde 1485, encuadrado en el linaje de don Romero. Gracias a su influencia, su hermano García fue nombrado alcalde, aunque la estrecha relación que tenía García de Salazar con el duque de Alburquerque provocó su destitución en aplicación de una disposición real ${ }^{1045}$. En torno a 1495 Pedro de Salazar dejó de ser regidor sin que tengamos constancia del motivo, aunque bien es cierto que se vio inmerso en varias polémicas como muestran las numerosas acusaciones de corrupción y amenazas interpuestas por parte de los regidores de la Comunidad. Estas denuncias le ocasionaron el destierro en alguna ocasión ${ }^{1046}$. También se vio implicado en 1490 en las disputas entre los regidores Pedro de Mora y Gonzalo García de Quemada, tomando partido por el primero y acudiendo junto a las tropas del marqués de Denia a auxiliarle $\mathrm{e}^{1047}$.

El tercer hermano, Sancho de Salazar, ostentó el cargo de alcaide de la villa y fortaleza de Coruña del Conde a finales de los ochenta, al servicio de los Suárez de Figueroa. Como ya hemos visto, Sancho se casó con Isabel de Berlanga, hija del acaudalado Pedro de Santa Cruz ${ }^{1048}$. Por último, la única hija de Rodrigo de Salazar que conocemos, doña Ana de Salazar, contrajo matrimonio con don Hernando de Arce ${ }^{1049}$.

Poco a poco esta familia fue consolidándose en la villa y configurando su posición social así como un importante patrimonio. La defensa de su condición privilegiada

arrendado y generaba anualmente 140 fanegas de trigo más un puerco. Por esos años la familia se vio inmersa en un largo pleito por el intento del concejo y el convento de San Francisco de desviar el curso del río Aranzuelo. Sin embargo, a pesar de contar el proyecto con el visto bueno de los monarcas y de la justicia, no se finalizó por lo que su patrimonio molturador no se vio afectado (AGS, CR, leg. 40, doc. 8; CC MEMORIALES, leg. 133, doc. 236; y ABAD ÁLVAREZ y PERIBÁÑEZ OTERO, "El control social..., pp. 116-119). pp. 38-39.

1045 AMA, leg. 43, doc. 2, transcrito por HURTADO QUERO, Documentos Reales..., doc. 19,

${ }^{1046}$ AGS, CC MEMORIALES, leg. 161, doc. 122.

1047 AGS, CC PUEBLOS, leg. 1, doc. 233

${ }^{1048}$ AGS, RGS, 148803, fol. 46; y 149003, fol. 423.

${ }^{1049}$ Hernando de Arce fue vecino de la cuadrilla de Duero y fue elegido diputado de la misma en 1517 (AGS, CONSEJO Y JUNTAS DE HACIENDA, leg. 4, doc. 20). Otro destacado miembro de la familia Arce, posiblemente descendiente del anterior, fue Martín de Arce que ocupó uno de los regimientos en la segunda década del siglo XVI (AGS, CC PUEBLOS, leg. 2, doc. 107; CR, leg. 40, doc. 8; y leg. 453, doc. 5). 
provocó un tenso enfrentamiento con el concejo arandino. Los hermanos Salazar, junto a don Martín de Acuña, encabezaron la resistencia de los hidalgos locales a pagar la martiniega que les exigía el concejo. Por ello les fueron tomadas prendas e incluso fueron expulsados de la villa, aunque finalmente la justicia les dio la razón y se mantuvieron exentos de tributar ${ }^{1050}$.

La pujanza de esta familia en la villa se vio incrementada mediante la alianza con uno de los individuos más poderosos de la comunidad: Pedro de Santa Cruz. Esta alianza se materializó en la concertación del matrimonio entre Sancho de Salazar e Isabel de Berlanga ${ }^{1051}$. Además de importantes bienes inmuebles, la mujer aportó al matrimonio un juro de 28.500 maravedíes. De esta unión nacieron tres hijos. La temprana muerte de su padre les obligó a depender primero de la tutela de su tío Pedro de Salazar para después pasar a la de su abuelo Santa Cruz. Ya desde jóvenes se vieron envueltos en disputas con otros vecinos y así los dos hermanos fueron denunciados por un escribano de la villa en 1519 que los acusaba de haberle dado unas cuchilladas. Ambos eludieron la acción de la justicia alegando su condición de clérigos ${ }^{1052}$.

El abuelo Santa Cruz se encargó de formarlos y procurar su promoción social dentro de la oligarquía arandina. Esto último lo consiguió al final de su vida protagonizando un episodio más de patrimonialización de los oficios municipales pues Santa Cruz cedió en 1527 su regimiento perpetuo a su nieto Cristóbal de Salazar, que se unió a su tío Gaspar de Santa Cruz que lo era desde 1521. Con anterioridad a 1535 también se les sumó otro de los nietos de Santa Cruz, Pedro Martínez de Avellaneda ${ }^{1053}$. Por otra parte, también tenemos noticias de un Rodrigo de Salazar, vecino de Aranda e hijo de Sancho de Salazar, que en 1534 partió hacia el Perú después de un fracasado intento de fletar un barco junto a otros aventureros arandinos en el puerto de Sevilla ${ }^{1054}$.

${ }^{1050}$ AGS, RGS, 148902, fol. 132; y ARChV, RRE, Caja 106, doc. 6.

${ }^{1051}$ AGS, CR, leg. 3, doc. 3.

${ }^{1052}$ AGS, CR, leg. 518, doc. 2; y leg. 544, doc. 10.

${ }^{1053}$ AGS, CC MEMORIALES, leg. 187, fol. 19; DIAGO HERNANDO, “Cambios políticos..., p. 312; y PERIBÁÑEZ OTERO, “La pugna por el poder..., pp. 148-149.

${ }^{1054}$ En la empresa americana le acompañó el comendador Gregorio Meléndez, también vecino de Aranda e hijo de Juan de Gumiel. Ambos llevaban más de los 50.000 maravedíes requeridos, situación que denota una posición bastante acomodada. En el proceso denunciaron al maestre Ginés de Carrión por incumplimiento de la carta de flete. (ARCHIVO GENERAL DE INDIAS -AGI-, CATÁLOGO DE PASAJEROS, Libro 1, exp. 4893; y JUSTICIA leg. 715, N 6; CONTRATACIÓN, 5536, Libro 3, fol. 4). 


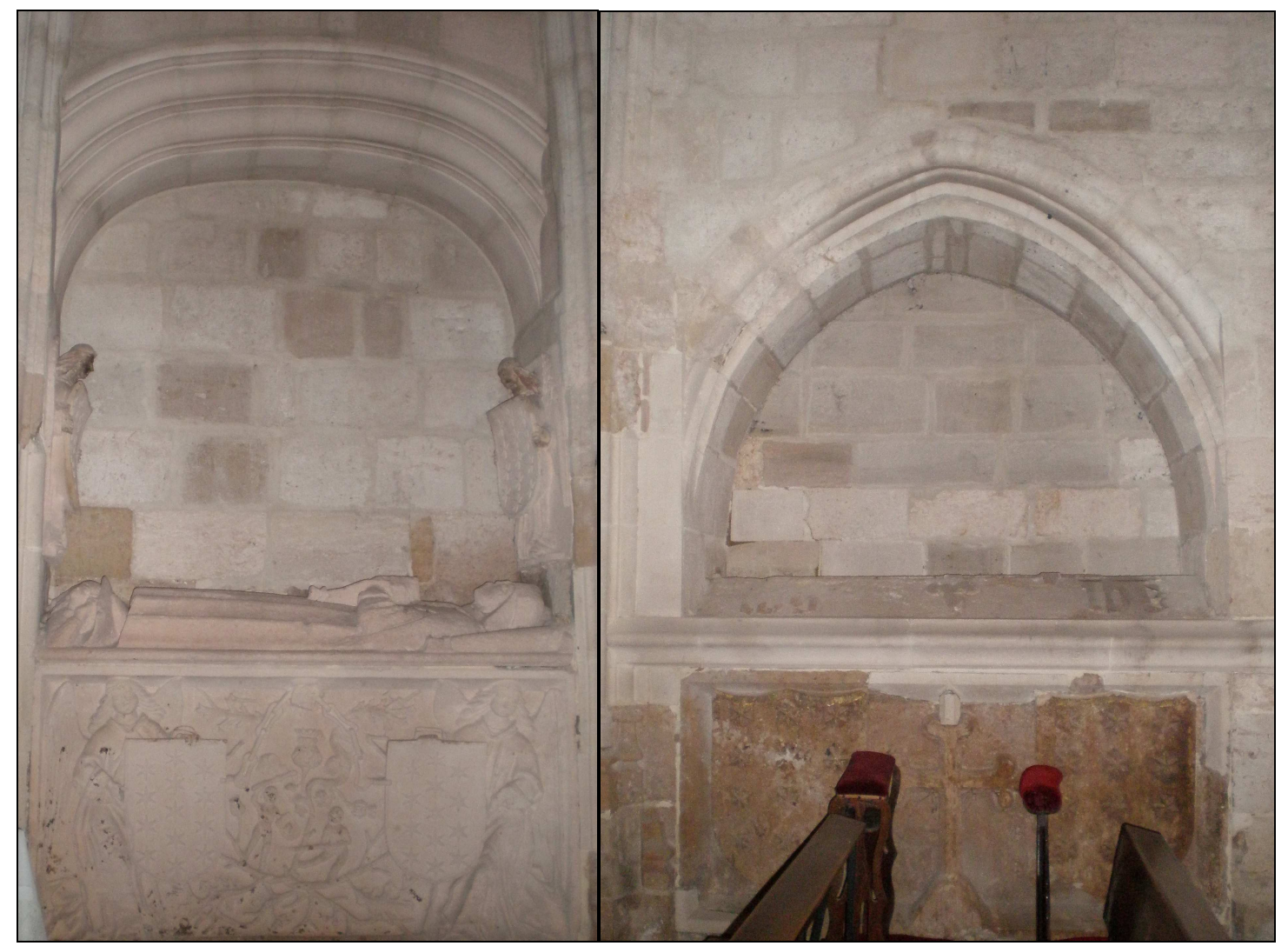

Imagen 45: Sepulcro de Pedro de Salazar (izq.) y de sus padres (der.) en la capilla de los Salazares de la iglesia de Santa María.

Otro destacado miembro de esta familia del que desconocemos su relación con Rodrigo, sus hijos y sus nietos fue García de Salazar. Oriundo de La Bureba se instaló en la capital de la Ribera a principio de los años 70 y desarrolló en ella su vida sin que tengamos una idea clara de su actividad ni patrimonio ${ }^{1055}$. Estaba casado con Isabel de Salazar con la que tuvo a principios de los ochenta un hijo, Pedro. En 1511 Pedro de Salazar vio reconocida su hidalguía por la Audiencia Real en el pleito que mantuvo con el concejo arandino. Este Salazar fue el fundador de la capilla funeraria de los Salazares que todavía hoy se conserva en la nave de la epístola de la iglesia de Santa María de la capital de la Ribera. En ella reposan los restos de sus padres en un sencillo sepulcro y

${ }^{1055}$ García de Salazar era hijo de Gutierre de Salazar y nieto de otro García de Salazar. Procedía de Tamayo, cerca de Oña, y tenía intereses también en el cercano lugar de Terminón. No obstante, el abuelo tenía su casa solariega en La Rioja y Gutierre vivió también en Rodezno (La Rioja) pero después estuvo en Arévalo y recaló en Tamayo (ARChV, RRE, Caja 261, doc. 25). La falta de información sobre la actividad de García de Salazar en Aranda está en gran medida provocado por la coincidencia en el nombre con uno de los hijos de Rodrigo de Salazar que nos impide identificar de qué García se trata, a no ser que aparezca la referencia expresa de parentesco. 
los suyos en otro profusamente decorado con su emblema heráldico en el que se representan trece estrellas de oro sobre campo de gules ${ }^{1056}$.

\section{La familia Barahona.}

Las primeras noticias de la familia Barahona en la Ribera se remontan a 1480 cuando Íñigo de Barahona actuó como receptor del pleito homenaje que realizaron Pedro de Sandoval y su sobrino don Diego de Rojas en Lerma. En esta ocasión se le nombraba como caballero fyjodalgo en el encabezamiento y como testigo entre los cavalleros y cryados del dicho señor conde de Castro ${ }^{1057}$. Parece evidente, por lo tanto, que este primer Barahona se encuadraba dentro de la clientela del futuro marqués de Denia y que bien pudo instalarse en Aranda tras la toma de la villa para la princesa por parte de las tropas de don Diego.

También pudo tener mucho que ver en este asunto el matrimonio que concertó con doña María de Ceballos o Çaballos, hija de Alonso de Villanueva ${ }^{1058}$. La familia Villanueva poseía un importante patrimonio basado en unas cuantiosas rentas y algunos bienes inmuebles como la mitad de la aceña de la Sinovilla en el Duero. Precisamente en concepto de dote el comendador recibió esta aceña y un juro de heredad de 4.263 maravedíes $^{1059}$.

En la documentación Barahona casi siempre aparece nombrado como comendador $^{1060}$, además de como vecino y regidor de la villa de Aranda. Todo parece apuntar a que Barahona fue uno de los primeros regidores perpetuos nombrados por los reyes y

1056 VELASCO PÉREZ, Aranda. Memorias..., p. 163; GÓMEZ BÁRCENA, M. J., "Escultura gótica funeraria en Burgos. La Ribera del Duero", Biblioteca 17. Estudio e Investigación. 2002, pp. 269292; y DOMÍNGUEZ CASAS, “Heráldica en el arte del Renacimiento..., pp. 235-236.

1057 SNAHN, OSUNA, Caja 79, docs. 49-50.

${ }^{1058}$ Desconocemos el origen de la presencia de la familia Villanueva en Aranda. Alonso de Villanueva estaba casado con Constanza Muñoz y tuvieron dos hijos además de María. El primogénito fue Bernaldino de Çaballos y profesó como fraile. El segundo, Beltrán de Villanueva, heredó los bienes de su hermano cuando todavía era menor, aunque tuvo que recurrir a la justicia real para que Pedro de Santa Cruz le abonara unos juros heredados (AGS, RGS, 149706, fol. 185). Estos juros procedían de una compra al oidor García López de Madrid quien los había obtenido de Enrique IV (AGS, CONTADURÍA DE MERCEDES, leg. 165, doc. 23; y CONTADURÍA MAYOR DE HACIENDA, leg. 22, doc. 41).

${ }^{1059}$ ARChV, RRE, Caja 12, doc. 44; y AGS, CMC, leg. 41.

${ }^{1060}$ Suponemos que se trata de una encomienda de la Orden de Santiago pues su hija Isabel de Mendoza estableció en 1569 que se pusiera la cruz de Santiago en la capilla funeraria en la que se encontraban enterrados sus padres en el monasterio de San Francisco de Aranda (AGS, CONTADURÍA DE MERCEDES, leg. 165, doc. 23). 
que se encuadraba dentro del linaje de don Pedro García de la Puente ${ }^{1061}$. Su actividad en el seno del concejo fue muy intensa participando de forma activa en la política municipal. Esta situación propició constantes enfrentamientos con otros miembros del concejo. Fue denunciado por los regidores de la Comunidad por corrupción, abusos y amenazas $^{1062}$. Las fricciones en el seno del concejo también le llevaron a enfrentarse con Gonzalo García de Quemada, regidor del linaje de don Romero, tanto por cuestiones políticas como personales ${ }^{1063}$.

Su actividad política se extendió hasta abril de 1495, momento en el que decidió renunciar a su cargo de regidor a favor de Francisco de Mena, acaudalado arrendador converso. En 1499 el procurador fiscal Romaní le acusó de haber vendido el oficio siendo por ello condenado ${ }^{1064}$.

Paralelamente a sus quehaceres políticos don Íñigo también se mantuvo al servicio de la Corona como se aprecia en varias misiones que se le encomendaron durante los primeros años noventa. Así, en enero de 1491 fue comisionado por los reyes para que acudiera a la villa de Mandayona, en tierras de Guadalajara, para realizar una pesquisa sobre los daños realizados por ciertos vecinos de Atienza ${ }^{1065}$. Al final de ese mismo año se le envió junto al bachiller Alonso de Torres, también vecino de Aranda, a Tejada para que indagasen sobre la posible violación de una menor ${ }^{1066}$. Por último, en febrero de 1493 también recibió el encargo de acudir a La Aguilera para investigar un asunto en el que estaba implicado el alcaide de Gumiel del Mercado, Juan de Hontoria $^{1067}$.

${ }^{1061}$ AGS, CC PUEBLOS, leg. 2, doc. 78.

${ }^{1062}$ Los regidores de la Comunidad denunciaron en 1487 que Barahona había tomado 4.000 maravedíes del mayordomo del concejo para su disfrute personal y que había asignado 50 reales a su hijo para su mantenimiento. Asimismo se le acusaba de amenazar a estos representantes de la Comunidad (AGS, CC PUEBLOS, leg. 2, doc. 83; y CC MEMORIALES, leg. 161, doc. 122).

${ }^{1063}$ En 1490 el comendador acompañó a los hombres de armas del marqués de Denia que acudieron a Alcubilla para defender a Pedro de Mora en su disputa con Gonzalo García de Quemada por el beneficio curado de dicho lugar (AGS, CC PUEBLOS, leg. 1, doc. 233). Posteriormente Barahona y Quemada dirimirán sus diferencias ante la justicia (AGS, RGS, 149206, fol. 282).

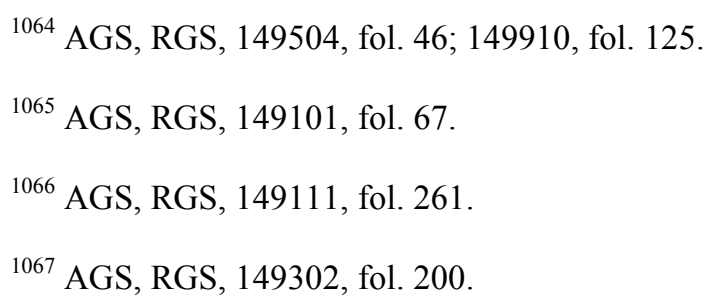


La política municipal y el servicio a los monarcas dejaron sitio al desarrollo de negocios que tuvieron como escenario la vida económica arandina. Sus actividades se desarrollaron en diferentes ámbitos entre los que destacan el arrendamiento de la importante alcabala del vino entre los años 1487 y 1490; el negocio heredado de la molienda; y la compraventa inmobiliaria que tuvo su máximo exponente en la compra de la sinagoga a la comunidad judía en 1492, momentos antes de la expulsión ${ }^{1068}$. No obstante, no parece que culminara con éxito estos negocios pues la sinagoga la perdió a manos de la cofradía de Santa Ana y en 1495 se vio obligado a hipotecar la media aceña de la Sinovilla que pasó a manos del regidor Juan de Aranda ${ }^{1069}$. Estas pérdidas, junto a la venta del oficio de regidor, parecen evidenciar graves apuros económicos para los Barahona al final del siglo XV.

No sabemos la fecha de su muerte pero sí que se hizo enterrar en una capilla funeraria que la familia patrocinó en el recientemente construido monasterio de San Francisco, extramuros de la villa de Aranda ${ }^{1070}$.

Hijos del matrimonio entre Barahona y María de Ceballos fueron doña Ana de Barahona, don Íñigo de Barahona y Mendoza y doña Isabel de Mendoza ${ }^{1071}$. Don Íñigo parece que se trasladó a Lerma, posiblemente al servicio del marqués de Denia ${ }^{1072}$, y de doña Ana no sabemos nada. Doña Isabel de Mendoza se casó con Antonio de Salazar y continuó en Aranda, fundando el patronato de la capilla funeraria en la que reposaron sus padres ${ }^{1073}$.

\section{La familia Mora-Aranda.}

El licenciado Pedro García de Aranda o Valdecuendes es el primer miembro de esta familia del que tenemos noticias. Se trata de un personaje clave en el periodo con-

${ }^{1068}$ AGS, CC PUEBLOS, leg. 2, doc. 77; RGS, 149205, fol. 451; y 149303, fol. 357.

${ }^{1069}$ ARChV, RRE, Caja 81, doc. 34.

${ }^{1070}$ AGS, AGS, CONTADURÍA DE MERCEDES, leg. 165, doc. 23.

${ }^{1071}$ No sabemos por el momento de dónde procede el apellido Mendoza que toman los hijos pero todo hace suponer que lo heredan del padre. Cuando doña Isabel de Mendoza estableció el escudo que debía figurar en la capilla funeraria de sus padres determinó que éste portara las armas de los Barahona y Mendoza.

${ }^{1072}$ ARChV, SALA DE HIJOSDALGO, Caja 517, doc. 3.

1073 AGS, CONTADURÍA DE MERCEDES, leg. 165, doc. 23. Doña Isabel también era cofrade del Cabildo de San Nicolás (VELASCO PÉREZ, Aranda. Memorias..., p. 241). 
vulso del conflicto sucesorio en Aranda. Según los datos de los que disponemos, Pedro García encabezó el bando que se mantuvo fiel a Enrique IV y su hija Juana en la vi$1 a^{1074}$. En el contexto de la toma violenta de la villa para el partido de la princesa Isabel por parte de las tropas de don Diego de Rojas, su posición y hacienda sufrieron un considerable daño ${ }^{1075}$. No obstante, la promoción de la estabilidad y conciliación por parte de doña Isabel derivaron en que el licenciado García de Aranda encabezara al grupo de los honrados omes buenos de la dicha villa que, junto a las autoridades municipales, recogieron en el arrabal de Allendeduero el juramento de la princesa por el que se comprometía a respetar los privilegios de la villa. Asimismo el licenciado participó en la concordia de Segovia que puso paz entre ambos bandos y que se selló con una compensación económica para aquellos que habían sufrido pérdidas durante el proceso ${ }^{1076}$. No obstante, García de Aranda también recibió en el ámbito personal una cuantiosa gratificación por su papel en la reconciliación pues se le concedió la merced de 15.000 maravedíes anuales de por vida situados en las alcabalas de las carnicerías de la villa de Aranda ${ }^{1077}$. Además recibió el oficio de Escribano Mayor de Rentas del partido fiscal de Aranda, aunque no conocemos la fecha de tal concesión ${ }^{1078}$.

Poco más sabemos de Pedro García salvo que debió fallecer a finales de la década de los setenta y que tuvo al menos cuatro hijos: Pedro de Mora, Juan de Aranda, Alonso de Mora y Catalina Martínez. De los dos últimos poco sabemos, tan solo conocemos sus nombres y el matrimonio de Catalina con Bartolomé de Torres con el que

${ }^{1074}$ Este bando aparece denominado en la documentación como ...la parte e parçialidad del licenciado Vadocondes e sus parientes e valedores (AGS, RGS, 148803, fol. 35).

${ }^{1075}$ AGS, CASA Y SITIOS REALES, leg. 3, doc. 124.

${ }^{1076}$ La concordia se realizó en el verano de 1474 y se estableció además una compensación de 250.000 maravedíes por los daños sufridos por la parentela de los Mora. Se establecieron dos plazos para el pago de esta cantidad que, ante los recelos de los beneficiados, se fijó sobre las rentas reales de Aranda para los años 1475 y 1476. Esta desconfianza era premonitoria pues hasta 1503 no se abonaron los últimos 150.000 maravedíes que se dejaron en depósito en el monasterio franciscano de La Aguilera (AGS, CASA Y SITIOS REALES, leg. 3, doc. 123). La indemnización también se extendió a la familia Mejías que recibió 50.000 maravedíes por los daños causados por las tropas de don Diego de Rojas y García Cotes (leg. 2, doc. 480).

1077 AGS, CMC, leg. 41.

${ }^{1078}$ AGS, EH, leg. 4. Actuó como tal en los arrendamientos de los últimos años setenta. 
tuvo dos hijos. Catalina murió al poco de nacer sus hijos y éstos apenas sobrevivieron a su madre ${ }^{1079}$.

Pedro de Mora debió ser el primogénito y desarrolló su vida profesional y política en la villa de Aranda. Heredó de su padre el oficio de Escribano Mayor de Rentas del partido de Aranda, oficio que desempeñó durante casi treinta años ${ }^{1080}$. En este sentido, hemos constatado que buena parte de su patrimonio provenía de las alcabalas de la villa pues además de lo que le rentaba su oficio, cerca de 20.000 maravedíes anuales, se sumaban a su patrimonio los 15.000 de juro sobre las carnicerías que heredó de su padre y una media de 9.000 maravedíes anuales por acostamientos, lo que suponía en total una renta anual de 44.000 maravedíes $^{1081}$. Por otra parte, también participó en ciertas compañías de arrendamiento de rentas eclesiásticas junto con otros vecinos arandinos ${ }^{1082}$.

Con la reforma del regimiento arandino a mediados de la década de los ochenta, Pedro de Mora fue honrado con la concesión de un regimiento perpetuo dentro del linaje de don Pedro García de la Puente y desde entonces participó muy activamente en la vida política de la villa. Mora se vio directamente implicado en la lucha de bandos en la que estuvo inmerso el concejo arandino encabezando uno de ellos. El episodio más significativo de este enfrentamiento, del que hablaremos más adelante con detenimiento, tuvo como protagonista a Mora y como antagonista a Gonzalo García de Quemada. Ambos disputaron por preservar los derechos de sus respectivos hermanos sobre el curato de Alcoba y Alcubilla. En este conflicto, en principio particular, se proyectó la tensión existente en el seno del concejo ribereño y, por extensión, se vio involucrada la sociedad arandina, así como los poderes nobiliarios comarcanos ${ }^{1083}$. A diferencia de lo que ocurrió con su padre, en este momento la vinculación de Mora con el linaje de los Sandoval

1079 ARChV, RRE, Caja 241, doc. 63. La muerte de Catalina y sus hijos se produjo en 1509 y provocó que Catalina de Mora, sobrina de la difunta, reclamase la herencia de su tía. La sobrina afirmaba asimismo que era concesionaria de su tío Alonso por lo que suponemos que no se encontraba en la villa por entonces.

${ }^{1080}$ AGS, EH, leg. 4.

${ }^{1081}$ En 1501 Mora recibió de las tercias y alcabalas de Aranda 17.730 maravedíes de su oficio de escribano mayor, más los 15.000 del juro sobre las carnicerías y 8.860 por acostamientos. En 1502 y 1503 los 10 maravedíes al millar ascendieron a 22.255 (AGS, CMC, leg. 41).

${ }^{1082}$ Al final de su vida se integró dentro de un grupo de vecinos que arrendó al obispado de Osma los pontificales de la villa de Aranda (ARChV, RRE, leg. 241, doc. 63).

1083 AGS, CC PUEBLOS, leg. 1, docs. 229-232. 
se hizo evidente pues el marqués de Denia envió a varios de sus hombres de armas para que defendieran a Mora del ataque de los Quemada ${ }^{1084}$.

Mora también mantuvo un enconado enfrentamiento con el concejo, junto a don Martín de Acuña, los Salazares y Barahona, a propósito del reconocimiento de su condición de privilegiados y su negativa a pagar la martiniega ${ }^{1085}$.

Pedro de Mora debió morir en $1505^{1086}$ y tan solo dejó una hija, Catalina de Mora, que contrajo matrimonio con Pedro Vaca ${ }^{1087}$. Catalina murió en abril de 1510 sin descendencia por lo que con ella terminó la línea principal del linaje de los Mora en la villa de Aranda ${ }^{1088}$.

Otro de los hijos de Pedro García de Aranda fue Juan de Aranda que se encaminó hacia la vida eclesiástica. En 1484 se encontraba en Salamanca como estudiante de cánones donde sufrió el acoso de unos prestamistas judíos a los que había solicitado un préstamo $^{1089}$. Tras terminar sus estudios de bachiller se trasladó a Roma donde consiguió del cardenal de San Jorge y obispo de Osma la concesión del beneficio curado de Alcoba de la Torre y Alcubilla de Avellaneda en el verano de 1490. La tarea de tomar posesión de su parroquia se la trasfirió a su hermano Pedro que, a pesar de contar con la ayuda del arcipreste de San Esteban, se vio incapacitado para llevarla a cabo pues unas semanas antes el beneficio había sido otorgado al deán de Logroño, Francisco de Que-

${ }^{1084}$ AGS, CC PUEBLOS, leg. 1, doc. 233. Bien es cierto que esta vinculación pudo ser interesada por ambas partes pues tal vez la reacción de los Sandoval fue la respuesta al apoyo expreso que hizo el conde de Miranda a la otra parte implicada.

${ }^{1085}$ ARChV, RRE, Caja 106, doc. 6.

${ }^{1086}$ Lo suponemos por la ausencia de información sobre Mora a partir de este año y porque en 1506 Felipe I hizo merced del oficio de Escribano Mayor de las Rentas de Aranda a Pedro Ximénez. En 1507 fue sustituido por el arandino Pedro de Ormaza (ALONSO GARCÍA, Fisco, poder y monarquía..., vol. I, pp. 347-348).

${ }^{1087}$ Pedro Vaca actuó en 1504 como procurador de Diego de Aranda, clérigo residente en Roma, que había recibido el beneficio de Santa María de Aranda y estaba en disputa con Juan Daza (AGS, CC PUEBLOS, leg. 2, doc. 98). Desconocemos si este Diego de Aranda también pertenecía a la familia Mora.

${ }^{1088}$ El juro de los 15.000 maravedíes sobre la alcabala de las carnicerías se transfirió a Catalina tras la muerte de su padre. En el situado de las rentas de 1510 se señalaba que Catalina de Mora murió a finales de abril de 1510 por lo que sólo se abonaban 5.000 maravedíes y los 10.000 restantes se entregaban al contador real. En el situado del año 1511 los 15.000 maravedíes fueron asignados directamente al contador (AGS, CMC, leg. 41).

1089 AGS, RGS, 148410, fol. 61. 
$\operatorname{mada}^{1090}$. Este episodio violento debe encuadrarse dentro del contexto del conflicto que en el seno de la diócesis oxomense enfrentó al obispo Rafael Sansoni Riario, sobrino del Papa Sixto IV, y a su provisor el arcediano de Haza con el cabildo catedralicio ${ }^{1091}$.

Posiblemente como compensación a este beneficio frustrado, un año después Juan de Aranda consiguió una canonjía en Santo Domingo de la Calzada. Pero de nuevo se vio inmerso en disputas por este beneficio, en este caso con el capellán real Sancho Gómez de Santa Gadea que le acusaba de usurpador y de no tener la capacitación como licenciado para ocupar el puesto. Esta situación le acarreó a Juan de Aranda su encarcelamiento en Aranda entre finales de agosto y principios de septiembre de 1491. Finalmente el capellán consiguió el auxilio del brazo secular para desalojar a Juan de Aranda del beneficio de Santo Domingo de la Calzada ${ }^{1092}$. Tras estas disputas perdemos la pista de este miembro de la familia Mora. La ausencia de referencias a este personaje en el pleito que mantuvo su sobrina por la herencia de Catalina Martínez hace pensar que pudo fallecer a finales del siglo XV.

La falta de datos concretos no nos permite identificar a otros personajes con el apellido Aranda como miembros de esta familia hidalga pero sospechamos que, por ejemplo, el regidor Juan de Aranda o el arcipreste Diego de Aranda, muy activos en sus oficios durante los primeros años del Quinientos, formaron parte de este linaje $\mathrm{e}^{1093}$.

\section{Otras familias hidalgas.}

La amplia fragmentación de la familia Avellaneda en ramas laterales provoca que encontremos con frecuencia este apellido instalado por la Ribera y, ocasionalmente, en la villa de Aranda sin que podamos establecer ni parentescos ni condición hidalga. Este es el caso de un Lope Ochoa de Avellaneda al que el concejo arandino puso trabas a mediados de la década de los 80 para avecindarse en la villa de Aranda. Sabemos que procedía de Peñafiel, figuraba entre la clientela del marqués de Denia y además era cu-

${ }^{1090}$ AGS, CC PUEBLOS, leg. 1, docs. 226 y 228.

${ }^{1091}$ DIAGO HERNANDO, M., Estructuras de poder en Soria a fines de la Edad Media. Valladolid, 1993, pp. 297-299.

${ }^{1092}$ AGS, RGS, 149108, fols. 302 y 312; y 149207, fol. 69

${ }^{1093}$ ARChV, RRE, Caja 81, doc. 34; y AGS, CC PUEBLOS, leg. 2, doc. 98. El arcipreste Diego de Aranda fue párroco de Castrillo y beneficiado de la iglesia de Santa María. Su sepultura todavía se podía identificar en esta última iglesia a principios del siglo XX (VELASCO PÉREZ, Aranda. Memorias..., p. 210). 
ñado del licenciado Yllescas, vecino de Valladolid, miembro del Consejo Real y propietario de uno de los molinos de la villa ${ }^{1094}$.

Esta misma fragmentación e indefinición la encontramos con el apellido Zúñiga que se repite con frecuencia en la documentación. Destaca en este sentido la figura de don Íñigo de Zúñiga que ya en los años 80 reclamaba su condición de hidalgo ${ }^{1095}$. Bien el mismo o su hijo, fue nombrado regidor perpetuo por los monarcas en 1511 y aparece citado como comendador, aunque no sabemos a que orden militar pertenecía ${ }^{1096}$. También destacó como oficial real, ocupando el corregimiento de Soria entre 1518 y 1520 y actuando como juez de residencia en Zamora en $1521^{1097}$. Participó muy activamente al servicio de Carlos I en el contexto de la revuelta comunera interviniendo en la batalla de Villalar y aplicando la represión posteriormente sobre los comuneros arandinos ${ }^{1098}$.

Esta rama de los Zúñiga emparentó con el linaje de los Durango en el segundo cuarto del siglo XVI a través del matrimonio del tercero de los Íñigo de Zúñiga con Gerónima, una de las hijas de Cristóbal de Durango ${ }^{1099}$.

Diego de Valladolid fue aposentador real y regidor perpetuo del linaje de don Pedro García de la Puente en los años ochenta. Durante algún tiempo prestó sus servicios a la Corona y percibió importantes sumas de las rentas reales de la villa. En 1488 formó parte del grupo de hidalgos que se negó a pagar la martiniega ${ }^{1100}$.

Otra familia destacada fue la de los Valle. Las referencias a la presencia de esta familia son bastante tardías. El primero de sus miembros que tuvo presencia en la villa fue Diego Hernández del Valle quien ejerció como regidor perpetuo hasta $1502^{1101}$. Este

${ }^{1094}$ AGS, CC MEMORIALES, leg. 151, doc. 148; RGS, 148504, fol. 93; y SNAHN, OSUNA Caja 79, doc. 80 y Caja 49 doc. 50. Sobre el licenciado Yllescas ver HURTADO QUERO, Documentos Reales..., doc. 31, pp. 56-57.

${ }^{1095}$ ARChV, RRE, Caja 106, doc. 6.

${ }^{1096}$ AGS, RGS, 151105, s. f.; y CC DIVERSOS, leg. 41, doc. 35.

${ }^{1097}$ AGS, CR, leg. 304, doc. 10; leg. 453, doc. 5; y leg. 730, doc. 13.

1098 AGS, PR, leg. 4, doc. 64; y CMC, leg. 355.

${ }^{1099}$ ARChV, RRE, Caja 1213, doc. 15. Tras el fallecimiento sin herederos de don Íñigo y doña Gerónima la herencia familiar pasó a su hermana María de Durango que, como ya hemos visto, se había casado con un miembro de la burgalesa familia de los Tamayo.

${ }^{1100}$ AGS, CC PUEBLOS, leg. 2, doc. 78; RGS, 148402, fol. 77; CMC, leg. 41, doc. 2; y RGS, 148811, fol. 176 .

${ }^{1101}$ Este primer Valle tenía además el oficio de despensero de la reina (AGS, CC PUEBLOS, leg. 2, docs. 91 y 93). 
regimiento se patrimonializó en esta familia pues a Diego le sucedió Francisco del Valle que lo disfrutó hasta 1508, sin que podamos establecer la relación de parentesco entre ellos $^{1102}$. Hijo del anterior suponemos que fue Bernardino del Valle. Conocemos su actividad como regidor perpetuo desde 1508 hasta $1522^{1103}$. Asimismo ostentó la condición de aposentador real por la que recibía una renta de 30.000 maravedíes anuales, situados generalmente sobre las alcabalas de Aranda ${ }^{1104}$. Durante el conflicto comunero destacó significativamente en el bando realista y aparece reflejado en las fuentes con el rango de capitán ${ }^{1105}$. En mayo de 1521 capitaneó los cien peones que desde Aranda se mandaron al frente de Navarra ${ }^{1106}$. Contrajo matrimonio con Catalina Daza y tuvo al menos un hijo, Juan del Valle. Bernaldino debió morir entorno a 1522, siendo su hijo todavía menor $^{1107}$. Juan del Valle sucedió en el oficio de regidor a su padre, así como en el de aposentador ${ }^{1108}$. Esta familia ejerció su patronazgo sobre la capilla de San Antonio del cercano convento de Domus Dei de La Aguilera. Al menos desde don Diego, todos los miembros de esta familia se enterraron en esta capilla hasta finales del siglo XVI ${ }^{1109}$.

Juan de Revenga ocupó una de las alcaldías de la villa en la segunda mitad de los años 80 a nombramiento de uno de los linajes. También actuó como procurador de los regidores de los linajes ante las denuncias de los regidores de la Comunidad ${ }^{1110}$.

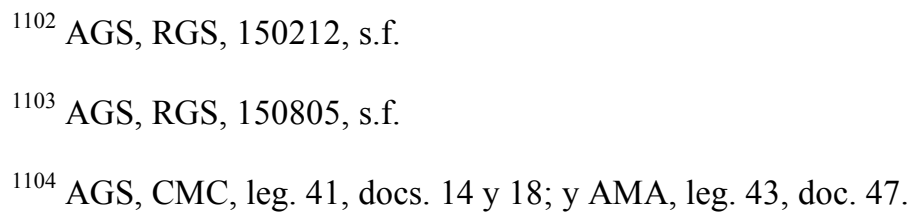

${ }^{1105}$ En enero de 1521 recibió unas ordenes del Condestable en su condición de capitán, aunque desconocemos su contenido (AGS, RGS, 152101, s. f.). En el transcurso del enfrentamiento la familia del Valle fue expulsada de la villa por el comunero Ramón Cestero que posteriormente fue acusado por ...echar la mujer e hijos del Capitán del Valle porque hacía la gente para el rey (DÁNVILA COLLADO, M., Historia crítica y documentada de las Comunidades de Castilla, Madrid, 1897-1900, vol. II, p. 398).

${ }^{1106}$ AMA, leg. 43, doc. 42.

${ }^{1107}$ AGS, CMC, leg. 41, doc. 18; y AMA, leg. 43, doc. 47. En el situado de las rentas de los años 1522 y 1523 se especificaba la entrega de 38.416 maravedíes anuales a Catalina Daza por el asiento de Bernaldino hasta que su hijo tenga edad de servir. 386, doc. 22)

${ }^{1108}$ Y así lo ejerció por lo menos hasta 1563 (AGS, CC DIVERSOS, leg. 47, doc. 30; y CR, leg.

${ }^{1109}$ AGS, EMR, leg. 683; CMC, leg. 41, doc. 18; y CC DIVERSOS, leg. 47, doc. 30.

${ }^{1110}$ Revenga fue alcalde al menos en 1487 (AGS, CC MEMORIALES, leg. 161, doc. 122) y es procurador de los regidores de los linajes en 1488 (CCP, leg. 2, doc. 85). Ese mismo año se niega a pagar la martiniega (AGS, RGS, 148811, fol. 176). 
Por su parte, Diego Martínez de Roa fue un controvertido personaje vinculado a los linajes durante un tiempo como muestra el hecho de que fuera nombrado por uno de ellos para ejercer el oficio de alcalde de la villa en 1480. Sin embargo, ciertas desavenencias con los linajes le llevaron poco después a aliarse con los representantes de la Comunidad y enfrentarse a los regidores de los caballeros. Éstos le denunciaron ante los monarcas por cometer parcialidades, parentelas, lios y monipodios, además de defender a los conversos. Finalmente el Consejo Real le consideró culpable y le condenó a una multa $^{1111}$. Posiblemente este personaje terminó sus días en 1491 en la hoguera condenado por la Inquisición ${ }^{112}$. Aunque no conocemos su expediente, todo apunta a que fue acusado de judaizante y que en la decisión final tuvo un gran peso sus constantes enfrentamientos con las autoridades ${ }^{1113}$.

Más problemas plantea la condición hidalga de la familia Curiel. Lo cierto es que los miembros de este clan estuvieron dentro de la órbita de los linajes como lo demuestra el hecho de que Alonso González de Curiel fuera alcalde del concejo en el año $1492^{1114}$. De igual manera Antonio de Curiel fue alcalde en 1500 y desarrolló una importante actividad en la villa, primero como bachiller y después como licenciado. Además fue elegido procurador de la cuadrilla de Duero y su nombre aparece con bastante frecuencia como letrado de rentas, escribano o testigo en diferentes acontecimientos ${ }^{1115}$.

Diego de Curiel, padre, tenía sus casas en la céntrica calle Hesilla y disfrutó de una destacada posición en el espacio económico arandino. Sus hijos Diego y Alonso continuaron la trayectoria del padre como arrendadores de rentas y activos hombres de

${ }^{1111}$ AGS, EH, leg. 4; CC MEMORIALES, leg. 149, doc. 173; y RGS, 148803, fol. 108.

1112 Son muchas las referencias documentales asociadas a este nombre por lo que suponemos que existieron varios vecinos llamados así. La documentación muestra a Diego de Roa como propietario de una posada en Aranda y examinador de las personas que usan el ofiçio de curar cosas quebradas e desconçertadas (AGS, RGS, 149703, fol. 139; y 149704, fol. 176). Estas referencias son posteriores al auto de fe en el que fue ejecutado Diego de Roa en 1491.

${ }^{1113}$ En 1502 el sobrino de Diego de Roa declaraba: ...que a Diego de Roa, su tio, e a Alonso Traspaso no los quemaron por herejes, que no tenian herejia ninguna, syno por otros males que fasian. Este mismo comentario era compartido por varios vecinos (CARRETE PARRONDO, Fontes Iudaeorum..., doc. 204, p. 98).

\author{
${ }^{1114}$ AGS, CC PUEBLOS, leg. 2, doc. 69. \\ 1115 AGS, RGS, 150005, fol. 398; CMC, leg. 41; y CONSEJO Y JUNTAS DE HACIENDA, leg.
} 4, doc. 20. También actuó como juez árbitro a petición de Juan Vázquez de Acuña en la resolución del pleito con la comunidad franciscana arandina (ARChV, RRE, Caja 315, doc. 20). 
negocios ${ }^{1116}$. Ambos hermanos actuaron como síndicos representantes del monasterio de San Francisco y la villa de Aranda en el pleito que mantuvieron con los propietarios de los molinos del Arandilla a propósito de proyecto de canalización del Aranzuelo ${ }^{1117}$. En 1520 Diego de Curiel ostentaba el cargo de mayordomo del concejo y fue destituido por la rebelión comunera. Este oficio lo compatibilizaba con el de receptor de las rentas de la villa. Tras la restitución de la legalidad recuperó su oficio y mantuvo su actividad como receptor $^{1118}$.

A pesar del gran número de noticias que tenemos sobre esta familia, ninguna de ellas nos permite deducir su condición hidalga. En consecuencia, no sabemos qué relación guardan los Diego de Curiel, padre e hijo, con el Diego de Curiel, el viejo, que aparece como regidor de Burgos integrado dentro de la cofradía de Santiago y al que se le atribuye un origen arandino ${ }^{119}$. En el estudio de Menéndez Pidal de Navacués que acompaña a la edición facsímil de la Cofradía de Santiago se habla de dos cofrades llamados Diego de Curiel, padre e hijo, que desempeñaron el oficio de regidor en el concejo burgalés. Ambos se encuentran en la relación de cofrades que comenzó a realizarse en el año 1531 y a la que se fueron incorporando nombres progresivamente. Se afirma que Diego de Curiel, suponemos que el padre, era natural de Aranda de Duero y se avecindó en la Cabeza de Castilla a mediados del siglo XVI. También se señala que uno de ellos fue sepultado en la capilla de Santiago del convento de San Francisco de Burgos en 1588. La coincidencia de nombre, parentesco, procedencia y la relación con la comunidad franciscana nos permite plantear la posibilidad de que los Curiel arandinos y los regidores burgaleses fueran las mismas personas. En la actualidad el escudo de armas que identifica a los Curiel en el Libro de Caballeros de la Cofradía de Santiago lo podemos apreciar incrustado en el palacio de los Berdugo, en teoría casa solariega ori-

${ }^{1116}$ AGS, CMC, leg. 41 y 355; y CASA Y SITIOS REALES, leg. 9, doc. 1117. Diego de Curiel desarrolló bastantes negocios con el clan familiar de Santa Cruz, entre los que destaca el arrendamiento de una importante parte de su gran hacienda rústica (EH, leg. 878, doc. 14).

${ }^{1117}$ AGS, CC PUEBLOS, leg. 2, doc. 102. Alonso también intervino en otros asuntos como síndico del monasterio (CASA Y SITIOS REALES, leg. 7, doc. 222).

${ }^{1118}$ AGS, CMC, leg. 355.

${ }^{1119}$ MENÉNDEZ PIDAL DE NAVASCÚES, F. (Edit.), El Libro de la Cofradía de Santiago de Burgos. Bilbao, 1977, pp. 38 y 70. Esta relación de los Curiel con Aranda ha sido reflejada por SANZ ABAD, Historia de Aranda..., p. 197; y NUÑO GONZÁLEZ, J. "Aranda y sus tierras en el siglo XVI: ambiente histórico en un tiempo de grandes empresas", en Biblioteca 18. Estudio e Investigación. 2003, pp. 9-37. 
ginaria de los Durango en Aranda. En este escudo aparece en uno de sus cuarteles una banda y en el otro tres martillos.

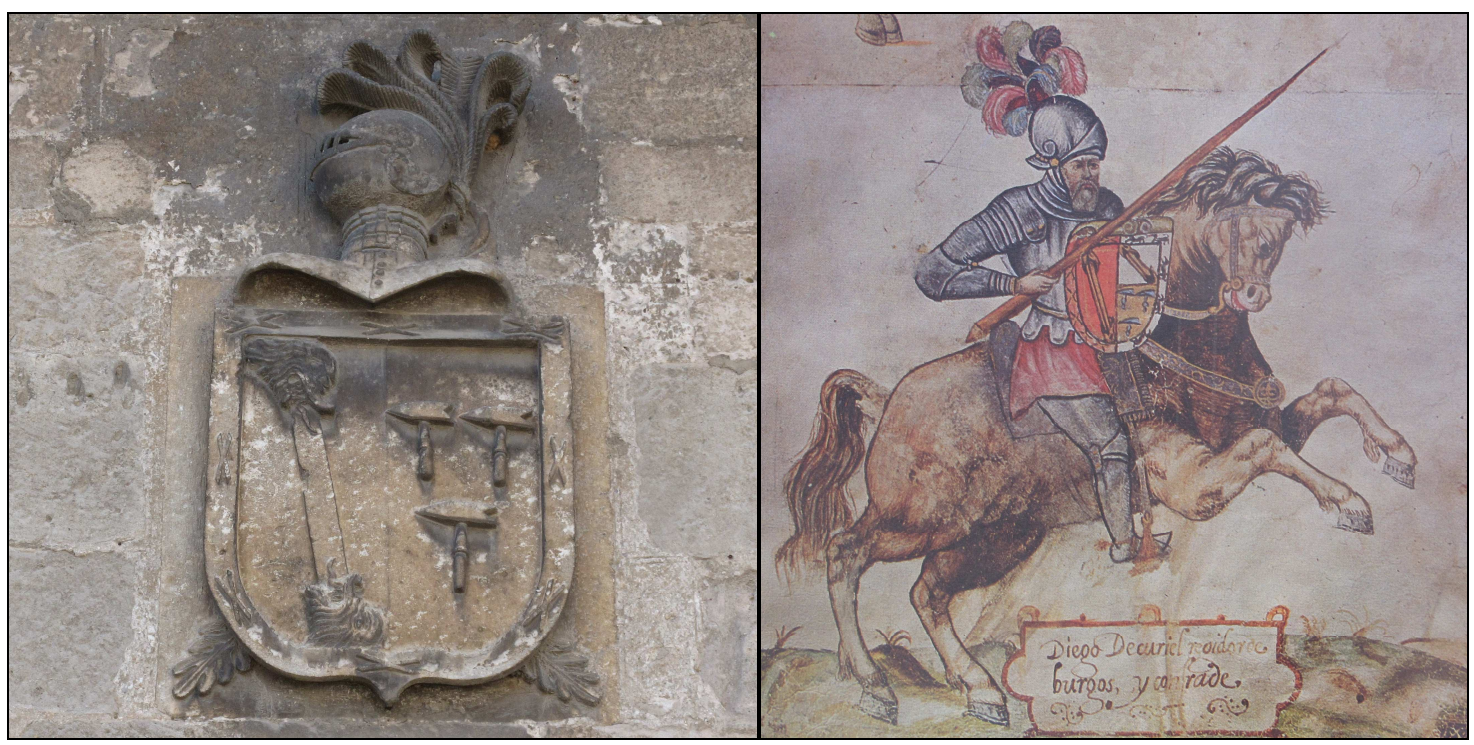

Imagen 46: Escudo localizado en el palacio de los Berdugo e imagen de Diego de Curiel en el Libro de los caballeros de la Cofradía de Santiago de Burgos.

La nómina de los hidalgos arandinos seguramente fue más extensa pero no disponemos de más información precisa que nos permita identificar más que someramente a otros miembros de la oligarquía local con esta condición privilegiada. Entre éstos se encontrarían las familias Arce, Borja, Plaza, etc.

\section{b.2. Los ricos labradores.}

El segundo grupo que formaba parte de la oligarquía local era el de los hacendados labradores. A diferencia de los anteriores, este grupo estaba compuesto por pecheros y el origen de su presencia en la villa se remonta a siglos pasados, herederos en teoría de los omes buenos del siglo XIII ${ }^{1120}$. Si al principio del periodo que nos ocupa todos los oficios concejiles estaban en sus manos, con el paso del tiempo fueron perdiendo peso

${ }^{1120}$ Son muy escasos los datos que tenemos sobre estos omes buenos pero es posible establecer un paralelismo con otras situaciones que sí que se han documentado en otros espacios castellanos. Por ejemplo, en Laredo los omes buenos se definen en el siglo XIV como un grupo destacado entre los pecheros por su poder económico y prestigio social que controlan el poder municipal y su representatividad. Esta situación se mantuvo hasta que a principios del siglo XV se impuso el regimiento y los omes buenos fueron relegados a una posición secundaria en beneficio de los linajes (SOLÓRZANO TELECHEA, "De 'Todos los más del pueblo'..., pp. 64-73). Por su parte, ASENJO GONZÁLEZ señala que los linajes surgieron como contraposición a las estructuras de parentela de los boni homines ("Acerca de los linajes urbanos y su conflictividad en las ciudades castellanas a fines de la Edad Media", en Clio y Crimen: Revista del Centro de Historia del Crimen de Durango. 6, 2009, pp. 52-84, en especial p. 66). 
paulatinamente en favor del grupo de hidalgos. Así se puede apreciar en 1473 pues los cuatro regidores y sus dos alcaldes pertenecían a este grupo de pecheros ${ }^{1121}$. Sin embargo, tras la instauración del regimiento perpetuo en la villa su presencia se hizo cada vez menor y, así, en 1487 de los seis regidores de los linajes, cuatro eran hidalgos, así como uno de los alcaldes ${ }^{122}$. En los años previos a la revuelta comunera al menos seis de los nueve regidores eran hidalgos y esa misma proporción se mantuvo después, aunque bien es cierto que los regidores pecheros estaban estrechamente emparentados con los hidal$\operatorname{gos}^{1123}$.

Si bien es cierto que dentro de este grupo podríamos identificar a ciertas familias como los De la Puente, Calahorra, Hesilla o Prado, destacó entre todos los demás la familia Quemada.

No sabemos nada sobre el origen de este clan familiar pero suponemos por el apellido y por la situación de sus solares en la calle de Barrionuevo que su asentamiento en la villa no fue muy antiguo. Las primeras noticias que tenemos de la presencia de esta familia en la villa se remontan a comienzos del siglo XV cuando Pedro García de Quemada fue nombrado procurador de la villa para negociar con el abad y monasterio de Santa María de la Vid la compra del censo de la granja de Revilla de Olleros en $1426^{1124}$. Pedro García de Quemada, el Viejo, tenía sus casas en la calle Barrionuevo, en concreto en la esquina con la calle Tamarón ${ }^{1125}$. Hijos de este Quemada fueron otro Pedro y Gonzalo García de Quemada.

Éste último contrajo matrimonio con Constanza Díaz, hija de Pedro García de la Puente, y tuvo al menos seis hijos de los que hablaremos más adelante ${ }^{1126}$. Gonzalo consolidó a lo largo de su vida una hacienda y fortuna considerables: heredó el amplio

${ }^{1121}$ AMA, leg. 42, doc. 6, transcrito por HURTADO QUERO, Documentos Reales..., doc. 11, pp. 24-26.

${ }^{1122}$ AGS, CC PUEBLOS, leg. 2, doc. 78; y CC MEMORIALES, leg. 149, doc. 230. Eran Pedro de Salazar, Íñigo de Barahona, Diego de Valladolid, Pedro de Mora y el alcalde Juan de Revenga.

${ }^{1123}$ En 1518 eran regidores de condición hidalga Martín de Arce, Martín y Rodrigo de Durango, Íñigo de Zúñiga, Antonio de Miranda y Bernardino del Valle (AGS, CR, leg. 453, doc. 5). En 1535 era regidor Gaspar de Santa Cruz que, aunque no tenía condición noble, era tío de otros dos regidores hidalgos, Cristóbal de Salazar y Pedro de Avellaneda (VELASCO PÉREZ, Aranda. Memorias..., p. 171).

${ }^{1124}$ AMA, leg. 43, doc. 4.

${ }^{1125}$ AGS, CR, leg. 39, doc. 3, transcrito por PERIBÁÑEZ OTERO y ABAD ÁLVAREZ, Aranda de Duero..., p. 147.

${ }^{1126}$ AGS, RGS, 148710, fol. 117. 
solar familiar en la calle Barrionuevo; era propietario de una bodega y contador donde vendía vino; poseía el molino de Pizarro en la ribera del Arandilla; también obtenía notables ingresos de censos situados sobre algunas casas; y poseía una importante cantidad de heredades entre las que destacaban más de 50 hectáreas de viñedo valoradas en cerca de 150.000 maravedíes. Gonzalo y Constanza debieron morir entorno a 1481 dejando un importante patrimonio a sus hijos ${ }^{1127}$.

Las escasas referencias que tenemos sobre el concejo arandino anteriores a la reforma informan de una intensa participación de los Quemada en el regimiento de la vi1la. Hacia 1470 Juan Martínez de Quemada ostentaba el oficio de regidor ${ }^{128}$. Otro destacado miembro de este clan fue Alonso Martínez de Quemada que en 1473 recibía a la princesa Isabel en el arrabal de Allendeduero en calidad de regidor. En este acto le acompañaba Gonzalo de Quemada ...en nombre de otros muchos honrados omes buenos de la dicha villa e su tyerra que presentes estavan e en boz e nonbre de todos los otros vecinos e moradores de la dicha villa de Aranda e su tierra. Por el momento no sabemos con seguridad si este Gonzalo era el que hemos descrito anteriormente o su hijo primogénito, aunque nos inclinamos por esta segunda opción. Además en este solemne acto figuraba como testigo el escribano Pedro Martínez de Quemada ${ }^{1129}$.

Nada sabemos de la intervención de esta familia en el conflicto sucesorio, pero a tenor de la destacada presencia que tuvo en la entrega de la villa a la princesa intuimos que tuvo que ser notable. En este sentido, Gonzalo García de Quemada actuó durante los primeros años del reinado de los Reyes Católicos como uno de sus hombres de confianza en la villa ${ }^{1130}$. Esta estrecha relación con los monarcas se confirmó con la conce-

${ }^{1127}$ Esta hacienda figura en diversos documentos: AGS, EH, leg. 878, doc. 14; RGS, 149508, fol. 152; CR, leg. 40, doc. 8; y ARChV, RRE, Caja 176, doc. 18. En un apeo realizado en 1448 ya era citado como propietario de viñas.

${ }^{1128}$ AGS, RGS, 148504, fol. 128.

${ }^{1129}$ AMA, leg. 42, doc. 6, transcrito por HURTADO QUERO, Documentos Reales..., doc. 11, pp. 24-26.

${ }^{1130}$ En 1477 fue comisionado como juez ejecutor en un asunto de recaudación de rentas reales. Frecuentemente fue requerido ante la Corte por ...algunas cosas cumplideras a nuestro serviçio de que queremos ser ynformados (AMA, leg. 43, docs. 13 y 30, transcritos por HURTADO QUERO, Documentos Reales..., docs. 12 y 16, pp. 26-27 y 33-34.). 
sión en 1477 del privilegio del pontazgo sobre los ganados que cruzaban el puente sobre el Duero en Aranda ${ }^{1131}$.

A partir de los años ochenta entró en escena Gonzalo García de Quemada, primogénito de Gonzalo y Constanza. Tras la reforma del concejo recibió la merced de un regimiento perpetuo, circunstancia que certificaba la posición de poder que ocupaba esta familia entre la oligarquía local ${ }^{1132}$. Este aspecto viene a confirmar la confluencia de intereses entre la Corona, que intensificó su intervención sobre la villa, y las élites locales que vieron asegurada y consolidada su posición de poder previa.

Su intervención en la vida pública arandina fue muy intensa formando parte del regimiento durante casi veinte años e interviniendo en todos los episodios importantes de la vida local como veremos más adelante. A diferencia del resto de sus compañeros en el concejo, su fortuna se asentaba sobre todo en bienes raíces pues poseía un considerable patrimonio basado en heredades, casas y rentas de la villa y su tierra ${ }^{1133}$, circunstancia que le permitió permanecer de manera continua en la villa o sus alrededores. Ocasionalmente los monarcas le comisionaron para entender en algún asunto menor en la comarca como en 1489 cuando fue enviado a Arauzo de Miel para determinar los agravios que denunciaron recibir los vecinos por parte de los alcaldes de Santo Domingo de Silos ${ }^{1134}$.

Otra notable diferencia respecto al resto de sus compañeros de regimiento era su condición de pechero. A principios del año 1489 se produjeron ciertos altercados entre los hidalgos y los vecinos que terminaron con la expulsión de los hidalgos que se negaban a contribuir en la martiniega de la villa. Tras recibir la queja de los hidalgos, los monarcas solicitaron a Quemada que acudiera a la Corte para dar información sobre estos incidentes. Quemada relató lo sucedido, justificando la actuación popular en que

${ }^{1131}$ El privilegio fue concedido a Gonzalo García de Quemada pero no sabemos con certeza si al padre o al hijo. Durante unos años tuvo un valor variable, pero con el tiempo se fijó en 5.000 maravedíes anuales (AGS, EH, leg. 4). No obstante, en 1493 el Concejo de la Mesta se quejó de que Quemada le llevaba media oveja por cada rebaño que pasaba por el puente (RGS, 149312, fol. 41).

${ }^{1132}$ AGS, RGS, 148412, fol. 88.

${ }^{1133}$ A la amplia herencia recibida de sus padres se ha de añadir que Gonzalo actuó durante casi toda su vida como administrador de los bienes de alguno de sus hermanos, sobre todo del Deán y la hermana monja, disfrutando de sus rentas y frutos sin participar de ellos a sus hermanos (ARChV, RRE, Caja 176, doc. 18).

${ }^{1134}$ AGS, RGS, 148908, fols. 191 y 384. Fue un encargo frustrado pues se le envió la carta de comisión el 11 de agosto y el 26 ya se le ordenaba que no interviniera en el asunto. 
...los susodichos syendo vecinos de la dicha villa e algunos dellos regidores obligados de guardar los usos e costumbres e fueros de la dicha villa se eximian de contribuyr con los otros vecinos de la dicha villa en sus repartimientos y derramas. Finalmente ...suplico que mandasemos que el dicho destierro fuese guardado fasta que los susodichos se allanasen a bevir como los otros vesinos de la dicha villa ${ }^{1135}$. Esta actitud de Quemada deja en evidencia la habitual asociación entre oligarquía y privilegiados que, aunque fuera una tendencia que se fue imponiendo cada vez con mayor rigor, no era todavía una realidad en la capital de la Ribera a finales de la Edad Media.

Ciertamente Gonzalo García de Quemada no tuvo muy buenas relaciones con alguno de los hidalgos de la oligarquía arandina. En 1490 se enfrentó directamente a sus compañeros del ayuntamiento Pedro de Mora, Íñigo de Barahona y Pedro de Salazar cuando trató de defender los intereses de su hermano Francisco sobre el beneficio curado de las Alcobas ${ }^{1136}$. De nuevo con Barahona tuvo un altercado que le supuso al comendador el destierro, aunque la justicia tenía sus sospechas sobre una provocación previa de Quemada ${ }^{1137}$. No tuvo tanta suerte en el enfrentamiento con Martín Vázquez de Acuña. En 1484 Gonzalo salió en defensa de su hermano García que previamente había enviado a uno de sus allegados a herir a unos criados de Acuña. Finalmente la justicia le condenó a pagar una multa ${ }^{1138}$. Sus disputas con el hidalgo Sancho de Salcedo comenzaron en 1487 por asuntos de herencias ${ }^{1139}$. El conflicto culminó en 1495 con la condena a uno de los hijos de Quemada por haber agredido a Salcedo ${ }^{1140}$.

Por contra, los Quemada mantuvieron muy buenas relaciones con los condes de Miranda como lo demuestra la ayuda recibida en el momento de disputar con Pedro de Mora el beneficio curado de las Alcobas. Precisamente esta vinculación con los Zúñiga

${ }^{1135}$ AGS, RGS, 148902, fol. 132.

${ }^{1136}$ AGS, CC PUEBLOS, leg. 1, doc. 231-233. En el apartado dedicado a los conflictos dedicaremos un amplio capítulo a este incidente.

${ }^{1137}$ AGS, RGS, 149206, fol. 282.

${ }^{1138}$ AGS, RGS, 148412, fol. 88; y 148605, fol. 38

${ }^{1139}$ AGS, RGS, 148710, fol. 117 y 120. La disputa parece que comenzó por la administración de unos bienes tras la muerte de uno de sus tíos. Según Quemada, Salcedo se había apropiado de unos suelos de bodega que pertenecían a Pedro García de la Puente, su abuelo. Salcedo era un hidalgo originario de Miranda de Ebro y que se avecindó durante una temporada en Aranda junto a su hermano Juan (ARChV, RRE, Caja 14, doc. 17).

${ }^{1140}$ AGS, RGS, 149505, fol. 364. 
tuvo que ver con la alianza entre los Quemada y la familia hidalga de los Durango que se consolidó a través de varios enlaces matrimoniales. El más significativo de todos ellos fue el que acordaron Gonzalo y Martín de Durango para unir sus familias a través del enlace de Juana de Quemada y el primogénito de los Durango que compartía nombre con su padre. Juana aportó una buena dote que incluía la renta del pontazgo concedido por la reina Isabel a su familia en 1477 y un importante patrimonio. Los Durango por su parte hicieron partícipes a los Quemada de la condición de privilegiados. Otros miembros de la familia Quemada confirmaron esta alianza y así un primo de Martín, Gerónimo de Durango, se casó con Elena de Quemada pero murió joven y sin descendencia $^{1141}$.

Gonzalo García de Quemada murió a principios de 1500, no sin antes haber renunciando a su oficio de regidor perpetuo en favor de su hijo Antonio ${ }^{1142}$. Fue tal el peso específico de Gonzalo García de Quemada en el concejo arandino que un año después de su defunción y sustitución el escribano del concejo todavía lo incluyó, suponemos que por error inconsciente, entre los regidores que se comprometieron a cumplir una carta real por la que se ordenaba instalar un peso en la villa ${ }^{1143}$.

Tenemos muy pocas noticias de la actividad de Antonio de Quemada. Su presencia en el concejo arandino no fue más allá de 1503 y las escasas noticias sobre su vida son también anteriores a esta fecha ${ }^{1144}$. Tan solo tenemos referencias a un altercado violento con un viejo enemigo de su padre al que dio unas cuchilladas en $1495^{1145}$. La ausencia de noticias documentales sobre Antonio nos hace sospechar que posiblemente muriera por esas fechas.

El segundo hijo del primer Gonzalo de Quemada fue Francisco de Quemada que encaminó su vida a una carrera eclesiástica con bastante éxito. En 1479 ya era provisor de Lerma.

${ }^{1141}$ ARChV, RRE, Caja 389, doc. 40. Gerónimo era hijo de Bernardino de Durango y Magdalena

1142 AGS, RGS, 150004, fol. 61. En la confirmación del oficio se justificaba el nombramiento por los servicios prestados a los monarcas y en sustitución de su padre fallecido.

${ }^{1143}$ AMA, leg. 43, doc. 14. La carta está datada el 15 de enero de 1501 y el escribano Alonso de Huete recogía el compromiso de los regidores el 15 de marzo de ese mismo año.

${ }^{1144}$ Precisamente la última referencia documental sobre la presencia de Antonio de Quemada en el concejo arandino se produjo el 13 de marzo de 1503 en el contexto del pleito por la apertura de la calle de Barrionuevo (AGS, CR, leg. 39, doc. 3, transcrito por PERIBÁÑEZ OTERO y ABAD ÁLVAREZ, Aranda de Duero..., pp. 189).

${ }^{1145}$ AGS, RGS, 149505, fol. 364. 
del obispado de Calahorra y poco después fue designado deán de San Martín de Albelda y Santa María la Redonda de Logroño ${ }^{1146}$. Esta dignidad no estuvo exenta de polémica pues en 1484 Diego Sánchez de Yanguas acusó a Quemada de haber ...caydo e incurrido en çiertos crimenes, incrementando su delito por continuar celebrando los oficios después. El Papa Sixto IV envió unos jueces para investigar el asunto ${ }^{1147}$. En un primer momento dieron sentencia contra Quemada y le privaron de su canonjía y deanato que fueron entregados a Yanguas. Quemada reaccionó rápidamente y ...mano armada dis que se entro en la dicha yglesia de Santa María la Redonda e se apodero con çierta gente. A finales de 1485 la situación se invirtió y fue Yanguas el que utilizó la violencia, pero Quemada se ganó el apoyo real para la restitución de su deanato. Todavía en 1489 seguía la disputa entre ambos y Quemada solicitó y consiguió el amparo real. No tenemos más noticias sobre este conflicto, pero todo parece indicar que Quemada se mantuvo en la posesión del deanato pues así aparece en la documentación de $1496^{1148}$.

La estrecha vinculación de Francisco de Quemada con el controvertido obispo Pedro de Aranda llevó al historiador Groizard a plantear la hipótesis de que Francisco fue nombrado obispo auxiliar de Calahorra por Aranda en 1478 y que cambió su nombre por el de Juan ${ }^{1149}$. Este obispo auxiliar se hizo cargo de la sede calagurritana hasta 1492, momento en el que Pedro de Aranda tomó posesión de su diócesis. No es nuestra intención someter a crítica el erudito y elaborado trabajo de Groizard pero lo cierto es que la documentación presenta a Francisco durante los años que supuestamente está ocupando el obispado con su nombre e inmerso en serios problemas como acabamos de ver. No obstante, bien es cierto que en una iguala que presentó Alonso García de Quemada aparecía como árbitro el obispo Juan de Quemada, su hermano, junto a Fernando de Covarrubias y el licenciado Diego de la Villa. Este parentesco debe ser tomado con mucha cautela pues la iguala ya generó serias dudas en 1495 cuando se presentó ante el

\footnotetext{
1146 Sobre el importante peso del deán en el cabildo secular de Calahorra puede consultarse GRANADO HIJELMO, I., "El régimen jurídico del Cabildo catedralicio calagurritano hasta la codificación canónica de 1917”, en Kalakorikos. N 15, 2010, pp. 37-96.

${ }^{1147}$ AGS, RGS, 147909, fol. 99.

${ }^{1148}$ AGS, RGS, 148410, fol. 70; 148512, fol. $199 ; 148905$, fol. 146; 148906, fol. 140; y ARChV, RRE, Caja 96, doc, 4.

1149 GROIZARD Y CORONADO, C., Ensayo de investigación histórica. La Diócesis de Calahorra en el siglo XV. Don Juan de Quemada, obispo auxiliar (1478-1492). Madrid, 1913; y GARCÍA Y GARCÍA, A., Synodicon Hispanum. VIII: Calahorra-La Calzada y Pamplona. BAC, Madrid, 2007.
} 
teniente de corregidor ${ }^{1150}$. Además, Fernando de Covarrubias también tenía un hermano obispo de Calahorra por aquellos años, por lo que el calificativo de hermano pudo referirse a este personaje que le acompaña en la iguala. Por lo tanto, no podemos negar categóricamente por el momento la identidad de Francisco y Juan de Quemada pero parece más coherente, a tenor de la información aportada por la documentación expuesta, que eran dos personas diferentes. De lo que no cabe duda es de la estrecha relación que mantuvieron el deán y el obispo Pedro de Aranda que permitió que el primero se convertirse en el hombre de confianza del prelado ${ }^{1151}$.

A pesar de que Francisco de Quemada desarrolló toda su carrera en tierras de Logroño no perdió la vinculación con la villa de Aranda. Ya en 1480 el rey Fernando le recriminaba las maniobras hechas a favor de su paisano Juan de Aranda para procurarle una canonjía que el Papa había concedido a Ruy Sánchez de Zuazo, capellán real ${ }^{1152}$. Es cuanto menos llamativo que diez años después Quemada y Juan de Aranda se enfrentaron por el beneficio de las Alcobas, que incluía las ribereñas parroquias de Alcubilla de Avellaneda y Alcoba de la Torre, arrastrando a sus familiares arandinos como ya hemos comentado $^{1153}$.

También mantuvo la relación con sus hermanos, sobre todo con Gonzalo, ya fuera ésta de colaboración o de enfrentamiento. En 1490 Gonzalo fue el que defendió los intereses de Francisco en el conflicto por el beneficio de las Alcobas aunque poco después le denunció por no repartir equitativamente la herencia de su padre entre todos sus hermanos ${ }^{1154}$. En un primer momento estas diferencias trataron de solventarse recurriendo a una iguala redactada por el obispo de Calahorra Juan de Quemada, el regidor Fernando de Covarrubias y el licenciado Diego de Villa. La negativa de Gonzalo provocó que sus hermanos recurrieran al corregidor que determinó que fueran tres vecinos los

${ }^{1150}$ Cuando el teniente de corregidor recibió la iguala señaló que ...estraña por que es symple e no esta sygnada ni firmada de escribano ni paresçe el dia ni el mes ni año en que se dio e el escribano ante quien paso que dice que es Pedro Martínez de Quemada no halla el compromiso ni registro de la dicha sentencia que lo ha perdido e se hallo en su poder la dicha escritura e el confiesa que se dio e pronuncio la dicha yguala e sentencia según que en la dicha escritura se contiene (ARChV, RRE, Caja 176, doc. 18).

\footnotetext{
${ }^{1151}$ GROIZARD Y CORONADO, C., Ensayo de investigación histórica. La Diócesis..., p. 45. 
que tasaran y repartieran los bienes. A esta solución se opuso Francisco que alegaba haber comprado los bienes de su hermana Isabel, monja en Calabazanos, y recurrió a la Audiencia Real que confirmó la sentencia del corregidor ${ }^{1155}$. Después de este incidente con sus hermanos perdemos la pista del deán de Calahorra.

Alonso García de Quemada era el tercero de los hermanos. A diferencia de los anteriores las noticias que tenemos de él están relacionadas casi exclusivamente con una más que notable actividad económica que se centraba en el negocio del vino. A la importante hacienda que heredó de su padre, que incluía más de una docena de hectáreas de viñedo, sumó más propiedades que le convirtieron en uno de los principales vendedores de vino en la villa ${ }^{1156}$. También heredó de su padre una cuarta parte del molino de Pizarro en la ribera del Arandilla. Precisamente para defender su negocio molturador se vio inmerso al final de su vida en una disputa con el concejo arandino y la comunidad franciscana cuando éstos trataron de sacar adelante el proyecto de desviar el curso del río Aranzuelo, arroyo subsidiario del Arandilla ${ }^{157}$. También contaba con una importante cantidad de cabezas de ganado distribuidas por la tierra de Aranda ${ }^{1158}$. Sabemos que estuvo casado con Justa García de Quemada pero no hemos conseguido identificar a sus descendientes.

El cuarto de los hermanos fue García de Quemada. Además de las actividades agraria ligada al vino y la molturadora heredadas de su padre, también destacó en la actividad mercantil aunque se especializó sobre todo en el negocio de los paños y el préstamo $^{1159}$. Se casó con Leonor de los Ríos, hija de Gonzalo de Calahorra, y tan solo

${ }^{1155}$ ARChV, RRE, Caja 176, doc. 18.

${ }^{1156}$ Cuando en 1490 los corredores del vino fueron condenados a devolver los maravedíes tomados de más por la venta del vino, Alonso fue de los vecinos que más dinero recibió, rondando los 1.000 maravedíes (AGS, CC PUEBLOS, leg. 2, doc. 77).

${ }^{1157}$ AGS, CR, leg. 40, doc. 8.

${ }^{1158}$ No conocemos su tipo ni su número pero eran más de cincuenta cabezas pues se vio obligado a pagar una nueva renta que creó el concejo para aquellos rebaños que superaran esta cifra (AGS, RGS, 149705, fol. 133).

${ }^{1159}$ Ambas actividades se mezclaban pues García prestaba dinero a un importante vendedor de paños arandino, el converso Benito Ortiz, en lo que podríamos calificar de una compañía al uso. En esta compañía también participaba Pedro de Santa Cruz (AGS, RGS, 148707, fol. 61; y CC MEMORIALES, leg. 151, doc. 113). 
conocemos a una heredera, Constanza de Quemada ${ }^{1160}$. Ésta contrajo matrimonio con Francisco de Sarmiento, regidor de Burgos, y la dote que recibió es un buen indicador del nivel de riqueza que alcanzó Quemada pues ascendía a 420.000 maravedíes, más de la mitad en dinero y el resto en propiedades y ajuar ${ }^{1161}$.

Tampoco se vio ajeno a los conflictos vecinales y participó de la enemistad que su hermano tenía con Martín Vázquez de Acuña, hasta el punto de que uno de sus criados acudió a la plaza de Santa María y acuchilló a un criado de Acuña en el momento en el que acompañaba a misa a doña Constanza de Avellaneda. A pesar de la intervención de su hermano regidor, García no se libró de ser condenado a destierro por tres meses más una multa de 4.000 maravedíes, además de la obligación de hacerse cargo de las costas del proceso que ascendían a 13.000 maravedíes $^{1162}$.

Las noticias sobre las dos hermanas Quemada son muy discretas. Se limitan a señalar que María se casó con Pedro de Luna y que ya era viuda en 1496. Isabel por su parte ingresó en el monasterio de Calabazanos y vendió la hacienda heredada de su padre a sus hermanos por 15.000 maravedíes ${ }^{1163}$.

De la magnitud de la clientela familiar de los Quemada tenemos constancia a través de las numerosas referencias a sus miembros, si bien es cierto que el locativo Quemada es muy frecuente y en ocasiones no conllevaba un lazo familiar ni tampoco clientelar $^{1164}$. A pesar de ello, la estructura familiar amplia de los Quemada era percibida claramente por el resto de vecinos, con las connotaciones simbólicas y de poder que

${ }^{1160} \mathrm{ARChV}$, RRE, Caja 3, doc. 34; y caja 176, doc. 20. Leonor de los Ríos contrajo matrimonio en primeras nupcias con Francisco Sánchez de Calahorra. Tras la muerte de éste se casó con García de Quemada.

${ }^{1161}$ ARChV, RRE, Caja 420, doc. 3.

${ }^{1162}$ AGS, RGS, 148412, fol. 88; y 148605, fol. 38.

${ }^{1163}$ ARChV, Caja 176, doc. 18. Ciertamente la cifra entregada al monasterio de Calabazanos era bastante ridícula pues en un primer reparto se estableció que a cada uno de los hijos le correspondían 25.000 maravedíes tan solo del viñedo que poseía su padre. Esta cantidad fue abonada por Francisco y Alonso, por lo que solicitaron que en el reparto final se les asignara solamente a ellos la parte correspondiente a su hermana Isabel.

${ }^{1164}$ En 1490 otro Gonzalo de Quemada, el cevadero, formó parte de la clientela que apoyó a Pedro de Mora en su disputa con Gonzalo García de Quemada (AGS, CC PUEBLOS, leg. 1, doc. 233). En 1515 Pedro Hernández de Quemada fue presentado como testigo por los promotores del canal del Aranzuelo y declaró que era pariente de la mayoría de los dueños de los molinos en tercer o cuarto grado. Mostraba su apoyo al desvío del cauce y señalaba que todos en la villa se olgaban de ello e yban a ayudar escepto algunos grados e amigos de los dueños de los molinos, afirmación que desmonta la identidad entre parentela y clientela (AGS, CR, leg. 40, doc. 8). 
eso representaba. En 1478 un vecino de Aranda que mantenía un pleito con Alfonso Martínez de Quemada recelaba del daño que el clan de los Quemada le pudiera causar por lo que solicitó carta de seguro a los monarcas para él, su mujer e hijos y así asegurarlo de su oponente e de sus hermanos e parientes e amigos ${ }^{1165}$.

Otro buen ejemplo de esta red clientelar lo encontramos en la rapidez con la que Gonzalo García de Quemada reunió a sus deudos en 1490. En apenas unas horas consiguió movilizar a varias decenas de hombres que le acompañaron a Alcubilla para hacer frente a las huestes reunidas por Pedro de Mora en el enfrentamiento por el beneficio curado de las Alcobas ${ }^{1166}$.

El prestigio social que alcanzó el linaje de los Quemada también se manifestó en el emblemático espacio de la iglesia de Santa María donde esta familia era una de las pocas que poseía un panteón funerario ${ }^{1167}$.

Muchos de estos miembros de la familia Quemada se significaron en la vida socioeconómica de la villa ocupando oficios concejiles de segundo orden, escribanías o desempeñando lucrativas actividades económicas. Es bastante significativo que con el paso del tiempo el clan de los Quemada perdió el antiguo esplendor que los había mantenido durante más de cien años en posiciones destacadas dentro del concejo arandino. Tras la desaparición de Antonio de Quemada, la familia dejó de estar representada en el concejo, aunque bien es cierto que a través de interesados enlaces matrimoniales se había logrado emparentar con reconocidos linajes hidalgos como los Durango arandinos o los Sarmiento burgaleses. En definitiva, este clan familiar de la oligarquía arandina con el tiempo pasó a integrarse en el grupo de los privilegiados, participando de la dinámica de aristocratización que experimentó el concejo arandino desde el último tercio del siglo XV.

\section{b.3. Los conversos.}

El tercer grupo que conformaba la oligarquía local era el de los acaudalados conversos agrupados entorno a la figura de Pedro de Santa Cruz, que accedieron al re-

${ }^{1165}$ AGS, RGS, 147806, fol. 26.

${ }^{1166}$ AGS, CC PUEBLOS, leg. 1, doc. 231-233.

${ }^{1167}$ VELASCO PÉREZ, Aranda. Memorias..., p. 210. Todavía hoy se conservan varias capillas con arcosolios funerarios en la iglesia de Santa María pero las diferentes reformas que ha sufrido el templo impide por el momento identificar la situación del panteón familiar de los Quemada. 
gimiento en la mayor parte de los casos a través de la compra del oficio. Comparten con el grupo anterior su condición de pecheros y también una clara pretensión de emparentar con la nobleza como veremos más adelante ${ }^{1168}$.

El primero de los conversos que formó parte de la oligarquía local fue Fernando de Covarrubias. Era un acaudalado hombre de negocios de origen burgalés que posiblemente se instaló en la villa a finales de los años setenta ${ }^{1169}$. No sabemos la vinculación que tuvo con la influyente familia de los Covarrubias burgaleses, pero es significativo que el Fernando de Covarrubias escribano mayor de Burgos interviniera como árbitro en las disputas por la herencia de un hermano del Fernando de Covarrubias regidor $\operatorname{arandino}^{1170}$.

Sabemos que Covarrubias contaba con seis hermanos de los que tan solo conocemos a dos de ellos. Micer Sancho suponemos que era letrado y vivía en Burgos, donde amasó una considerable fortuna que ascendía en el momento de su muerte a cuatro cuentos de maravedíes ${ }^{1171}$. El otro hermano era el obispo de Calahorra ${ }^{1172}$, aunque no sabemos con certeza cuál de ellos, pues por esta época lo fueron Juan Díaz de Coca o Covarrubias (1470-1477), de familia burgalesa conversa; y Pedro de Aranda (14771494), asimismo de origen converso y que se vio inmerso en un proceso inquisitorial que terminó con su destitución ${ }^{1173}$. También en esta época las fuentes citan a Juan de

${ }^{1168}$ La presencia de los conversos entre la oligarquía que controlaba el poder político municipal ha sido constatada en varias villas y ciudades castellanas. Sirvan como ejemplo los casos de Burgos y Cuenca documentados por la profesora GUERRERO NAVARRETE (“Élites urbanas..., pp. 81-104).

${ }^{1169} \mathrm{Al}$ menos es vecino de la villa desde 1477 según declara ante la Inquisición el franciscano fray Francisco de Aranda (AGS, PR, leg. 28, doc. 73, transcrito por CARRETE PARRONDO, Fontes Iudaeorum..., doc. 308, pp. 131).

1170 Sobre la familia Covarrubias de Burgos se puede ver la obra de GUERRERO NAVARRETE, Y., Organización y gobierno en Burgos durante el reinado de Enrique IV de Castilla (1453-1476). Madrid, 1986, pp. 166-168.

1171 AGS, RGS, 148605, fol. 115. El regidor arandino informó de que su hermano micer Sancho había muerto hacía tres meses sin dejar testamento válido. Por el contexto se deduce que sus sobrinos, hijos de Juan de Puentedura y su mujer - posiblemente hermana de Covarrubias y Sancho-, se apropiaron de toda la hacienda de su hermano. Reclamaba la sexta parte de la herencia y solicitaba la intervención del escribano Covarrubias y del alcalde de Burgos, Juan de la Mota, pues los agresores tenían muy buena posición y parientes en la Cabeza de Castilla.

1172 Maestre Antonio, cirujano arandino, afirmaba ante la Inquisición en 1502, haciendo referencia a hechos ocurridos en 1486, que Fernando de Covarrubias era hermano del obispo de Calahorra (AGS, PR, leg. 28, doc. 73, transcrito por CARRETE PARRONDO, Fontes Iudaeorum..., doc. 159, pp. 82).

${ }^{1173}$ El proceso inquisitorial contra Pedro de Aranda lo recoge LLORENTE, J. A., Historia Crítica de la Inquisición Española. Barcelona, edic. 1870, Vol. I, pp. 157-158; y AZCONA, T., La elección y reforma del episcopado español en tiempo de los Reyes Católicos. Madrid, 1960, pp. 223-224.. Pedro de 
Quemada como obispo auxiliar de Calahorra nombrado por el obispo Aranda mientras residía en Roma ${ }^{1174}$. Este Juan de Quemada, como ya hemos visto, actuó de árbitro en una disputa familiar entre los Quemada, acompañado también de Fernando de Covarrubias. El obispo aparece identificado como su hermano en lo que parece una alusión a Alonso García de Quemada pero es significativo que el arbitraje se hizo entre los hermanos Quemada y nunca se cita a ningún Juan. Además el nombre que sucede al del obispo en la iguala es precisamente Fernando de Covarrubias ${ }^{1175}$.

Durante los primeros ochenta Covarrubias desarrolló una actividad económica bastante diversificada pues actuó como prestamista, invirtió en la compra de un molino en la ribera del Arandilla, el Molino Nuevo, y participó en alguna compañía pañera lo$\mathrm{cal}^{1176}$.

Su nombramiento como regidor perpetuo tras la reforma del regimiento nos hace suponer que su participación en el conflicto sucesorio debió ser importante aunque no tenemos ningún dato que lo corrobore. Covarrubias fue nombrado por el linaje de don Romero junto a Quemada y Salazar. Tuvo una vida política muy activa siendo asidua su participación en los ayuntamientos y se destacó en la defensa de los intereses de los linajes. Asimismo, al igual que los Quemada, estuvo estrechamente vinculado con la casa de los condes de Miranda pues ejerció como su mayordomo ${ }^{1177}$.

Quizá esta filiación con la familia Zúñiga estuviera en el origen del intenso enfrentamiento personal que mantuvo con don Martín Vázquez de Acuña. El conflicto llegó a su punto álgido el martes 22 de febrero de 1486 cuando Covarrubias fue objeto de una agresión por parte de uno de los criados de don Martín junto al cementerio de Santa María. El agresor le pegó una cuchillada en la cabeza y el regidor salvó la vida

Aranda era hijo del converso Gonzalo Alonso de Burgos y hermano del arzobispo de Montreal en Sicilia, Alonso de Burgos.

${ }^{1174}$ GROIZARD Y CORONADO, Ensayo de investigación histórica...; y GARCÍA Y GARCÍA, Synodicon Hispanum...

1175 ARChV, RRE, Caja 176, doc. 18.

${ }^{1176}$ En 1480 el converso Fernando de Ayllón le acusaba de haberle aplicado usura en un préstamo (AGS, RGS, 148003, fol. 15); en 1484 compró un molino y una huerta al bachiller Luis Arias de Salamanca (148510, fol. 32); y en 1485 actuó como inversor en el negocio de paños de la familia Calahorra (148606, fol. 127).

1177 AGS, PR, leg. 28, doc. 73, transcrito por CARRETE PARRONDO, Fontes Iudaeorum..., doc. 148, pp. 78 . 
gracias a refugiarse en la iglesia ${ }^{1178}$. El pesquisidor enviado por los monarcas para aclarar el incidente redactó un informe que no conocemos pero sí la sanción de 100 reales de plata que se le impuso al agredido. El pleito se prolongó en el tiempo pero no tenemos más datos por el momento ${ }^{1179}$.

Covarrubias se casó con la hija del contador del Conde de Miranda, el converso Juan López de Haza ${ }^{180}$ y tuvo al menos dos descendientes. El varón era conocido como el licenciado Covarrubias pero no heredó el regimiento de su padre y, dadas las escasas noticias que de él tenemos, suponemos que falleció o emigró ${ }^{1181}$. La hija, Isabel de Covarrubias o de Cuevas, se casó con un destacado vecino arandino, el doctor Torres ${ }^{1182}$. Isabel heredó el Molino Nuevo y se vio inmersa en un dilatado pleito con el concejo arandino por su oposición a la realización del encauzamiento del río Aranzuelo, que continuó su hijo Pedro de la Torre ${ }^{1183}$.

Los últimos años de Fernando de Covarrubias se vieron ensombrecidos por la enfermedad que su médico, el cirujano converso maestre Antonio, definía como mania, pues ...tenia pensamiento que todos le davan yervas. Asimismo se vio acosado por la Inquisición que había recibido denuncias de prácticas judaizantes ${ }^{1184}$. Finalmente Covarrubias falleció en 1497 y con él terminó la presencia de esta familia entre la oligarquía que controlaba el poder político de la villa.

${ }^{1178}$ AGS, RGS, 148603, fol. 56.

${ }^{1179}$ AGS, RGS, 148605, fol. 38; y 148606, fol. 48.

${ }^{1180}$ Juan López de Haza fue acusado de judaizante ante la Inquisición y detenido (AGS, PR, leg. 28, doc. 73, transcrito por CARRETE PARRONDO, Fontes Iudaeorum..., doc. 148, pp. 78).

${ }^{1181}$ En el oficio de regidor Covarrubias fue sustituido por Juan Daza, copero de la infanta Catalina (AGS, RGS, 149703, fol. 8).

${ }^{1182}$ Alonso de la Torre o Torres ejerció como delegado de los monarcas en varios asuntos entre los que destacan los problemas que surgieron con la expulsión de los judíos en la comarca ribereña (AGS, RGS, 149111, fol. 261; 149205, fols. 331, 510, 524, 526 y 531; 149206, fol. 182; y 149208, fol. 89). En la documentación de los años 90 aparece mencionado como bachiller pero en la de la primera década del Quinientos ostenta el título de doctor (CR, leg. 40, doc. 8).

${ }^{1183}$ AGS, CR, leg. 40, doc. 8.

${ }^{1184}$ En 1486 Covarrubias se refugió con su familia en Quemada durante un episodio de pestilencia. El cirujano Rabí Salomón acudió allí para atender a la mujer de Covarrubias que tenía la peste y recibió el encargo del regidor de que rogase a Dios este testigo e su madre, que era judia, que le revelase quien le dava aquellas yervas, agradeciéndoselo con dos reales. Este carácter paranoico ya estaba presente en Covarrubias con anterioridad pues en 1477 recelaba de Alonso de Curiel por sospecha que del tenia que se echava con su muger (AGS, PR, leg. 28, doc. 73, transcrito por CARRETE PARRONDO, Fontes Iudaeorum..., doc. 159 , pp. 82 y doc. 308 , p. 131). 
El principal exponente de este grupo fue sin lugar a dudas Pedro de Santa Cruz $^{1185}$. Sus orígenes son todavía hoy desconocidos para los investigadores que lo han estudiado. A nuestro entender era oriundo de Salas de los Infantes y se debió instalar en la villa de Aranda durante la segunda mitad de la década de los ochenta ${ }^{186}$. Las múltiples referencias a su relación profesional con judíos y la amplia clientela de origen converso que encabezaba no dejan lugar a dudas sobre su condición de converso. Esta afirmación se confirma con los numerosos testimonios que sobre él se recogen en el Libro de Declaraciones, aunque no sabemos si fueron sus padres o él mismo quien optó por las aguas del bautismo ${ }^{1187}$.

Sabemos que contrajo matrimonio en dos ocasiones. Su primera mujer fue Isabel Rodríguez de Berlanga, que posiblemente fuera originaria de Salas de los Infantes y estuviera emparentada con los Berlanga de esa localidad ${ }^{188}$. De este matrimonio nacieron al menos tres hijos de los que hablaremos más adelante: Gaspar de Santa Cruz, Isabel de Berlanga y Francisca de Mendoza ${ }^{189}$. Su primera mujer debió fallecer con el cambio de siglo pues en los primeros años del siglo XVI se casó de nuevo con Ana de

${ }^{1185}$ La documentación es copiosa, como veremos a continuación, en cuanto a detalles de la existencia de este individuo. Son varios los estudios que han profundizado sobre la figura de este personaje. Entre ellos destaca la biografía realizada por DIAGO HERNANDO que se centra en su actividad profesional en general y en el campo de los arrendamientos de rentas reales en particular, aunque también presenta un breve perfil político ("Arrendadores arandinos..., pp. 71-99). También el trabajo de ALONSO GARCÍA se ha centrado en la actividad arrendadora de Santa Cruz y su parentela (El erario del reino. Fiscalidad en Castilla a principios de la Edad Moderna.1504-1525. Valladolid, 2007, pp. 115-121). Más centrado en su condición de converso y actividad política era el estudio que realizamos en PERIBÁÑEZ OTERO, "Violencia y espacio..., pp. 29-31. Recientemente el profesor CASADO ALONSO ha hecho una puesta al día de la importancia de este arandino en el mundo de las finanzas castellanas ("El Duero Oriental..., pp. 34-37).

${ }^{1186}$ En un documento fechado en 1485 aparece como vecino de Salas y en la relación de su hacienda inmueble de 1507 que recoge DIAGO HERNANDO se indica que, además de las numerosas propiedades que tenía en Aranda o sus inmediaciones, poseía unas casas y heredad en Salas de Barbadillo por lo que suponemos que se trata del solar familiar (“Arrendadores arandinos..., pp. 86-87). No conocemos ningún pueblo con esta denominación aunque bien pudiera tratarse de Salas de los Infantes, en cuyas proximidades se encuentran varias localidades con el término Barbadillo (de Herreros, del Mercado, del Pez).

${ }^{1187}$ AGS, PR, leg. 28, doc. 73.

${ }^{1188}$ Pedro de Berlanga fue socio en diversas ocasiones de Santa Cruz. Era natural de Salas y se avecindó en Aranda a finales del siglo XV. Francisco de Berlanga también desarrolló una intensa y conflictiva relación mercantil con Santa Cruz (DIAGO HERNANDO, "Arrendadores arandinos..., p. 80).

${ }^{1189}$ ARChV, RRE, Caja 374. doc. 18. 
las Cuevas, hacendada viuda de Pedro de Berlanga. De este matrimonio no hay constancia de ningún descendiente ${ }^{1190}$.

No contamos con ninguna noticia suya hasta que en 1484 aparece como arrendador y recaudador de la Merindad de Santo Domingo de Silos en calidad de socio del judío don Bueno ${ }^{1191}$. Su carrera profesional como arrendador fue intensísima. Hasta 1494 desarrolló una notable actividad con el arrendamiento de las alcabalas y tercias de la Merindad de Santo Domingo, el diezmo y medio diezmo de moriscos del obispado de Cartagena y las rentas del partido de Aranda. A mediados de la década de los noventa sus negocios aumentaron considerablemente haciéndose con los diezmos y aduanas de los obispados de Osma, Calahorra y Sigüenza; las alcabalas y tercias de Calahorra y de la Merindad de Logroño; las rentas de la Merindad de Cerrato; las herrerías de Vizcaya; el impuesto de Canarias; las alcabalas y el salín de San Vicente de la Barquera; las rentas de Aranda y su Tierra; de Soria y su Tierra; de Sepúlveda, etc. ${ }^{1192}$. Esta prosperidad alcanzó su cénit con la creación de una compañía con otros arandinos para el arrendamiento del almojarifazgo de Sevilla ${ }^{1193}$. Prueba de su significado en el contexto general de las finanzas castellanas es que entre 1495 y 1497 fue el fiador de Alonso Gutiérrez de Madrid en el arrendamiento de todas las rentas del reino y que actuó como socio de Francisco Fernández Coronel en la subasta que se celebró en Barcelona en $1519^{1194}$. A los beneficios del negocio financiero debemos añadir las ganancias derivadas del comercio, sobre todo de paños, y los ingresos percibidos por el arrendamiento de bienes inmuebles ${ }^{1195}$. Evidentemente era un hombre con una gran fortuna que, a decir de los

${ }^{1190}$ Berlanga y Cuevas no tuvieron descendencia por lo que la viuda heredó la fortuna de su primer marido que debía ser notable (ARChV, RRE, Caja 339, doc. 40). Ana aportó al matrimonio más de 125.000 maravedíes de dote y su marido, además de los negocios de arrendamientos de rentas que hizo en compañía de Santa Cruz, también se dedicaba a la venta de ganado. En 1500 vendió a los carniceros arandinos 1.600 carneros (Caja 157, doc. 19). Por las declaraciones de diferentes testigos se concluye que Pedro de Berlanga poseía numerosas cabezas de ganado de carácter trashumante que trasladaba desde la Vera de Plasencia a la Sierra de Urbión (DIAGO HERNANDO, “Arrendadores arandinos..., pp. 89-90).

${ }^{1191}$ AGS, RGS, 148408, fol. 19.

${ }^{1192}$ CASADO ALONSO, “El Duero Oriental..., p. 35.

1193 AGS, EMR, leg. 121, doc. 1. En diciembre de 1510 Santa Cruz promovió la formación de una compañía que agrupaba a Francisco de Mena y Juan de Gumiel para pujar por las rentas del almojarifazgo de Sevilla, las del partido de Aranda y las del obispado de Osma para el periodo comprendido entre 1512 y 1517. Posteriormente se sumó a esta compañía Francisco de Berlanga.

${ }^{1194}$ ALONSO GARCÍA, Fisco, poder y monarquía..., p. 492; y CASADO ALONSO, "El Duero Oriental..., p. 35.

${ }^{1195}$ ARChV, PLEITOS CIVILES, Fernando Alonso, Caja 1449, doc. 4 y Caja 286, doc. 51. 
que le conocían, había logrado con su trabajo, sin que hubiera recibido herencias o dote reseñables.

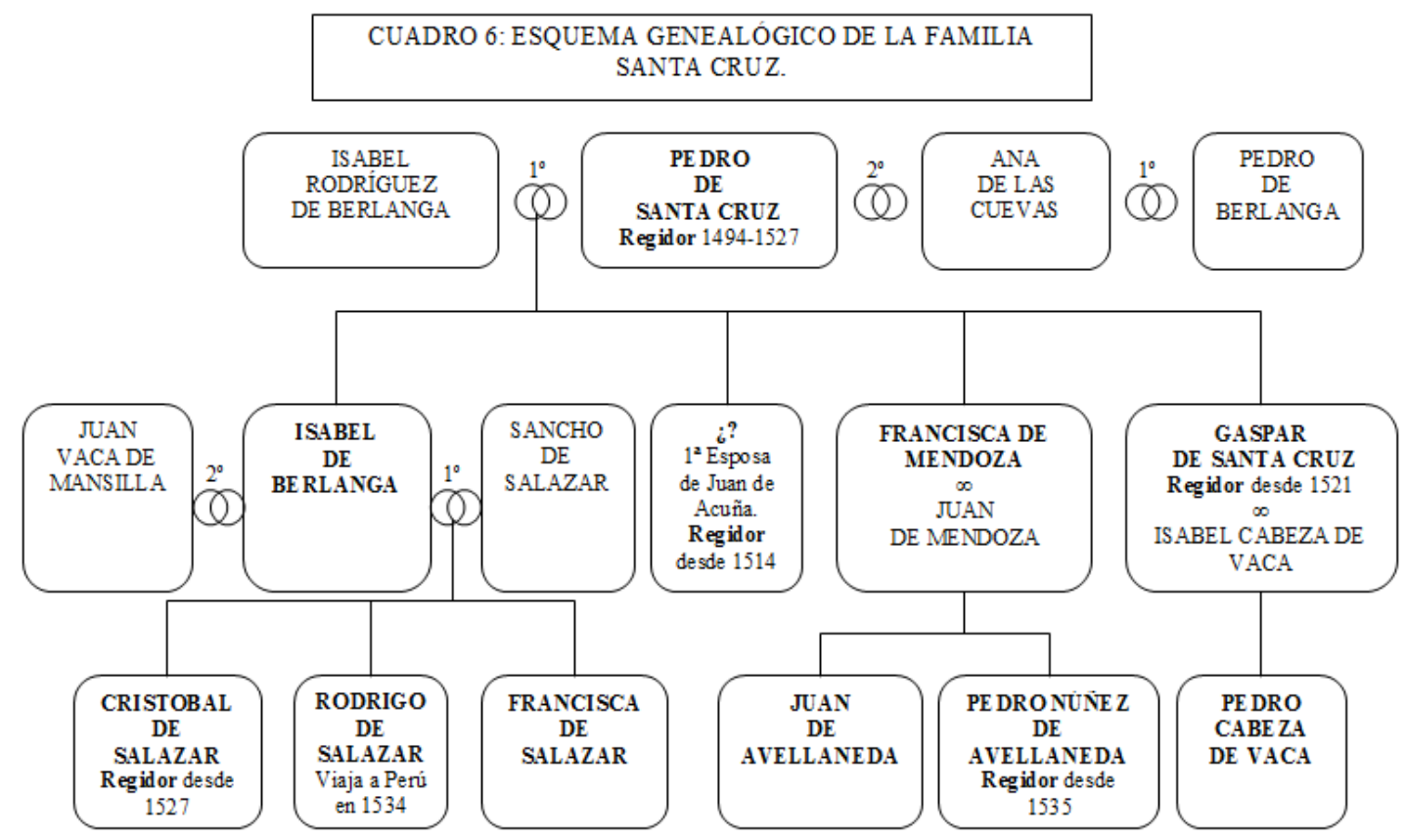

Pero además de riqueza, Santa Cruz buscó reconocimiento social y participación en los órganos de gobierno municipales. Para ello siguió el mismo camino que ya antes otros habían recorrido ${ }^{1196}$. No sabemos si primero emparentó con alguna de las familias de la oligarquía arandina y después se hizo un hueco entre los oficiales del concejo; o si primero compró sus cargos concejiles y después emparentó. Sea como fuere, lo cierto es que en 1489 ya aparece en la documentación como alcalde y el dos de junio de 1494 los reyes le otorgaron un regimiento vitalicio. Este nombramiento se produjo después de comprárselo a Martín Sánchez de Casasola, aunque no pudo probarse judicialmente ${ }^{1197}$. Llama la atención la intensa presencia de Santa Cruz en la vida política arandina que compatibilizaba perfectamente con el manejo de sus negocios a pesar de sus frecuentes y lejanos viajes a la Corte, Sevilla o incluso Flandes o Roma ${ }^{198}$.

${ }^{1196}$ MÁRQUEZ VILLANUEVA, F., "Conversos y cargos concejiles en el siglo XV”, en Revista de Archivos, Bibliotecas y Museos. Tomo LXIII, 2, 1957, pp. 503-540.

${ }^{1197}$ AGS, RGS, 149406, fol. 74 y 149910, fol. 125.

1198 DIAGO HERNANDO señala que acudió ante el mismo Emperador en 1517 en Flandes para reclamar el encabezamiento de la renta del almojarifazgo (“Arrendadores arandinos..., pp. 76-77). Por 
En cuanto a las alianzas matrimoniales con la oligarquía arandina sabemos que emparentó con algunas de las familias más influyentes de la villa. Para llevar a cabo su estrategia de promoción social utilizó a sus tres hijos ${ }^{1199}$.

Posiblemente la hija mayor fuera Isabel de Berlanga. Como ya hemos avanzado, Isabel se casó con Sancho de Salazar lo que supuso emparentar con una de las familias más influyentes de la villa. Éste era hijo de Rodrigo de Salazar, quien jugó un activo papel en la toma de la villa para el partido de la Princesa Isabel ${ }^{1200}$. Sancho fue durante algún tiempo alcaide del castillo de Coruña al servicio de los Suárez de Figueroa $^{1201}$. Hermanos de Sancho fueron Pedro y García de Salazar, regidor el primero y alcalde el segundo. De la unión entre Sancho e Isabel nacieron Cristóbal, Rodrigo y Francisca, que al morir su padre estuvieron bajo la tutela de Pedro de Salazar primero y de su abuelo Santa Cruz después ${ }^{1202}$. En 1527, poco antes de morir, Santa Cruz hizo renuncia de su oficio de regidor perpetuo en su nieto Cristóbal en un ejemplo más de patrimonialización del poder político local ${ }^{1203}$. El hecho de que la tutela de los hijos de este matrimonio pasara primero al tío y después al abuelo nos incita a pensar que Isabel debía haber fallecido, pero en ninguno de los documentos en los que se la cita aparece como difunta en contraposición a las referencias a su marido. No obstante, es bastante revelador que por aquellos años una Isabel de Berlanga contrajo matrimonio en segundas nupcias con el alcaide don Juan Vaca de Mansilla, señor de Valdespino, Vaca y Villamoratiel de las Matas, noble leonés de segunda fila, y que poco después éste se convirtió en el suegro de Gaspar de Santa Cruz. Estas circunstancias permiten plantearse la posibili-

otro lado, uno de los denunciantes de Santa Cruz ante la Inquisición afirmaba que éste había ido a Roma a pedir una dispensa papal (CARRETE PARRONDO, Fontes Iudaeorum..., doc. 415, p. 172).

${ }^{1199}$ La mayor parte de la información que relatamos a continuación está extraída de ARChV, RRE, Caja 374, doc. 18 y AGS, CR, leg. 3, doc. 3.

${ }^{1200}$ AGS, CASA Y SITIOS REALES, leg. 3, fol. 123.

${ }^{1201}$ AGS, RGS, 149003, fol. 423.

${ }^{1202}$ AGS, CR, leg. 3, doc. 3.

${ }^{1203}$ AGS, CC MEMORIALES, leg. 187, doc. 19; y DIAGO HERNANDO, "Arrendadores arandinos..., p. 90. 
dad de que se tratara de una doble alianza entre los Vaca y Santa Cruz, aunque no podemos confirmarlo rotundamente a falta de información más concreta ${ }^{1204}$.

La otra hija, Francisca de Berlanga, se casó con don Francisco de Mendoza, gentilhombre del rey ${ }^{1205}$. Mendoza intervino en alguno de los negocios de la familia Santa Cruz como socio y fiador ${ }^{1206}$. Fruto de este matrimonio nacieron Juan y Pedro de Avellaneda. Este último disfrutó del oficio de regidor a mediados del siglo XVI y fue miembro junto a su padre de la Cofradía de la Misericordia ${ }^{1207}$.

Gaspar era el único varón y el último de sus hijos. Sabemos que se hizo cargo de los negocios de su padre, sobre todo de aquellos relacionados con Sevilla y el espacio americano $^{1208}$. Fue vecino de la villa pero sus ocupaciones le obligaron a desplazarse con asiduidad a Sevilla ${ }^{1209}$. Gaspar contrajo matrimonio en 1518 con doña Isabel Cabeza de Vaca, hija de don Juan Vaca de Mansilla, del que ya hemos hablado con anteriori$\operatorname{dad}^{1210}$. De esta unión al menos nació un hijo, Pedro Vaca ${ }^{1211}$.

Casado Alonso afirma que don Juan de Acuña era yerno de Santa Cruz y que participó en varias de sus empresas financieras ${ }^{1212}$. Por lo tanto debemos suponer que Santa Cruz tuvo una tercera hija que se casó con Acuña con lo que se conformaría una

${ }^{1204}$ ARChV, RRE, Caja 362, doc. 16; y PLEITOS CIVILES, PÉREZ ALONSO (F), Caja 969, doc. 2. Mansilla tuvo varios hijos de un primer matrimonio con Isabel de Gros. Tras la muerte del alcaide, los herederos e Isabel de Berlanga se enzarzaron en varios pleitos por la herencia.

${ }^{1205}$ AGS, CONSEJO Y JUNTAS DE HACIENDA, leg. 5.

1206 CASADO ALONSO, “El Duero Oriental..., p. 35. Mendoza y su hijo Pedro Martínez de Avellaneda actuaron como testigos en la entrega de la carta de arras de Gaspar de Santa Cruz a Isabel de Vaca en febrero de 1518 y también ambos estuvieron presentes en la apertura de un proceso contra su concuñada y tía Isabel Vaca en 1529 (AGS, EH, leg. 878, doc. 14).

${ }^{1207}$ VELASCO PÉREZ, Aranda. Memorias..., p. 169.

${ }^{1208}$ Gaspar gestionó el negocio familiar desde la segunda década del Quinientos. Se hizo cargo del almojarifazgo de Sevilla y pujó por el de Cuba (AGI, INDIFERENTE, leg. 419, doc. 6, fols. 623-625 y 635-636). Continuó como socio de Fernández Coronel en los arrendamientos de distintas rentas del reino. También se encontraba en Zaragoza cuando el monarca llamó a los financieros castellanos en enero de 1519 (ALONSO GARCÍA, Fisco, poder y monarquía..., p. 494).

${ }^{1209}$ AGS, CR, leg. 660, doc. 5.

${ }^{1210}$ Tras la muerte del alcaide, Gaspar se vio involucrado en las disputas por su herencia junto a Isabel de Berlanga (ARChV, PLEITOS CIVILES, PÉREZ ALONSO (F), Caja 473, doc. 1; y Caja 474, doc. 1).

${ }^{1211}$ AGS, EH, leg. 878, doc. 14.

${ }^{1212}$ CASADO ALONSO, "El Duero Oriental..., p. 35. 
nueva alianza con una de las principales familias nobiliarias arandinas. Sin embargo, la ausencia de nuevos datos sobre esta supuesta hija y la referencia a otros matrimonios de don Juan nos hacen suponer que esta hija de Santa Cruz debió morir joven y sin descendencia $^{1213}$.

Por lo visto hasta ahora parece evidente que Pedro de Santa Cruz logró consolidar una importante posición dentro de la oligarquía local mediante un intenso sistema de alianzas matrimoniales. Por lo tanto Santa Cruz participó al final de su vida de todas las características que definían a la oligarquía castellana ${ }^{1214}$ : ostentaba un cargo político de primer orden en el gobierno municipal; poseía una inmensa fortuna ${ }^{1215}$; se hizo construir una suntuosa mansión en la arteria más importante de la villa, la calle Isilla (ver imagen $30)^{1216}$; y sus principales fuentes de ingresos eran el arrendamiento de las rentas reales y el comercio.

En este sentido cabe destacar que también imitó las pautas del comportamiento nobiliario, sobre todo en lo que al gusto por lo suntuario y el deseo de perpetuar su nombre en la memoria colectiva. Esta característica se plasmó en la financiación de la construcción de una de las capillas principales en el convento de San Francisco de la villa, promoción que estaba en relación con la obligación que contrajo en Roma tras ganarse una dispensa papal ${ }^{1217}$. Esta capilla era gemela de la que posteriormente construyó la familia Acuña, patrona del monasterio. Por otra parte, Santa Cruz también cedió

${ }^{1213}$ En la cartela funeraria de don Juan de Acuña en el monasterio de San Francisco figuraba como marido de Catalina de la Mota (LOPERRÁEZ CORVALÁN, Descripción histórica..., Vol. II, pp. 179-180).

${ }^{1214}$ MARTÍN CEA y BONACHÍA HERNANDO, “Oligarquías y poderes concejiles..., p. 23.

${ }^{1215}$ En 1507 los bienes que presentó como fianza para realizar el arrendamiento de unas rentas estaban valorados en más de seis millones de maravedíes (AGS, EMR, leg. 567; y CASADO ALONSO, "El Duero oriental..., p. 36).

${ }^{1216}$ Esta casa aparece representada como una casa fuerte rematada con almenas en el famoso plano de 1503 (AGS, MPD, leg. X, doc. 1). Además poseía otras muchas propiedades inmobiliarias en la villa, incluso varias casas en la Plaza de Santa María, corazón de la villa. Seguramente optó por instalarse en Isilla por las escasas posibilidades de suntuosidad que presentaban los solares de la Plaza.

${ }^{1217}$ En 1502 Martín de Tamayo, vecino de Pinilla Trasmonte, declara: ...dixo... Pedro de Santacrus que el avia ydo a Roma y avia traydo dispensaçion del Padre Sancto y que le mandaron façer un retablo. (CARRETE PARRONDO, Fontes Iudaeorum..., doc. 415, p. 172). Esta promesa parece estar cumplida en 1516 pues en el convenio entre el monasterio de San Francisco y Juan Vázquez de Acuña, este último se comprometió a construir una capilla igual que la que hizo Pedro de Santa Cruz (ARChV, RRE, Caja 315, doc. 20). 
unas casas para que se asentara en ellas una comunidad de beatas que fue el germen del futuro convento de clarisas de San Antonio ${ }^{1218}$.

Pero ni su riqueza, ni su participación en los órganos de decisión municipales, ni tampoco sus exquisitos e influyentes vínculos familiares le libraron de enfrentarse a la temida Inquisición y pagar con la incautación de parte de sus bienes e incluso la cár$\operatorname{cel}^{1219}$. Parece evidente que el dinero, el poder y las influencias no limpiaron su sangre.

A pesar de tantos éxitos en el mundo financiero, sus últimos años se caracterizaron por la franca decadencia de sus negocios. Debido a la quiebra crediticia que vivió Castilla en la década de los años veinte varias compañías encabezadas por los otrora pujantes financieros castellanos como los Fernández Coronel, Cuenca o Álvarez de Madrid quebraron ${ }^{1220}$. En el caso de la familia Santa Cruz la debacle se produjo cuando en 1523 tuvieron que abandonar los arrendamientos de Córdoba por lo que en 1525 Pedro de Santa Cruz fue encarcelado y sus bienes confiscados. La caída no fue definitiva pues Gaspar de Santa Cruz logró remontar la empresa familiar y continuar con algunos de los negocios familiares ${ }^{1221}$, lo que no fue impedimento para que él mismo se viera envuelto en una nueva quiebra poco más tarde ${ }^{1222}$.

Pedro de Santa Cruz debió morir poco después de ceder el regimiento a su nieto en 1527 pues sabemos que en 1528 se pagó a la iglesia de Santa María 4.000 maravedíes de depósito por la sepultura de Santa Cruz, más 9.000 al año siguiente. Sin embargo, no sabemos si se enterró allí pues el depósito expiró ${ }^{1223}$. También es posible que su

${ }^{1218}$ AGS, CC PUEBLOS, leg. 2, doc. 107. El convento femenino de San Antonio se situaba frente al convento de San Francisco. Más adelante abordaremos el origen y situación de esta comunidad a finales de la Edad Media.

${ }^{1219}$ En un documento de mayo de 1503 se indica que no se le han pagado las rentas para la paga de las guardas por haber estado preso en la cárcel de la Inquisición (AGS, CONSEJO DE LA CÁMARA DE CASTILLA, leg. 6, doc. 106-2). La confiscación de bienes la deduce CARRETE PARRONDO de la denuncia de Rodrigo de Prado (Fontes Iudaeorum..., doc. 147, pp. 77-78).

${ }^{1220}$ ALONSO GARCÍA, D., "El sistema fiscal castellano (1503-1536). Elementos de análisis, palabras de discusión", en Entre Clio y Casandra. Poder y sociedad en la Monarquía Hispánica durante la Edad Moderna. Murcia, 2005, pp. 233-255; del mismo autor Fisco, poder..., pp. 517 y ss.; y CASADO ALONSO, "El Duero Oriental..., p. 37.

${ }^{1221}$ ALONSO GARCÍA, "El sistema fiscal..., pp. 238-243.

1222 En 1529 el fiscal comenzó un proceso contra Gaspar de Santa Cruz por una deuda de 700.000 maravedíes de la recaudación de rentas reales (AGS, EH, leg. 878, doc 14).

${ }^{1223}$ ADB, LIBRO DE FÁBRICA DE SANTA MARÍA, Libro I, Inventario del año 1529, s. f. 
cuerpo reposase definitivamente en el monasterio de San Francisco de Aranda en consideración a su importante aportación para la construcción de este nuevo convento.

Francisco de Mena era sobrino de Pedro de Santa Cruz y desarrolló asimismo una intensa actividad financiera y política en la villa de Aranda ${ }^{1224}$. Desde al menos finales de los años ochenta estuvo inmerso en los arrendamientos de las rentas de la Merindad de Logroño en compañía de Mose Abaçaque ${ }^{1225}$ y desde los noventa participaba con su tío en las rentas del obispado de Osma, Merindad de Santo Domingo de Silos y el partido de Aranda de Duero. En los primeros años del siglo XVI traspasó el ámbito más cercano con su participación en la compañía encabezada por Santa Cruz para arrendar el almojarifazgo sevillano entre 1512 y $1517^{1226}$. También formó sus propias compañías al margen de su tío y apostó por el arrendamiento tanto de rentas privadas, como en los noventa cuando arrendó las rentas del conde de Coruña, como reales con la puja sobre las de Molina a principios del nuevo siglo ${ }^{1227}$.

Tuvo una actividad económica muy diversificada pues al tradicional negocio del vino se le sumaron otros como la compraventa de lana o los arrendamientos de inmuebles tanto en Aranda como en Peñafiel ${ }^{1228}$. A finales de la primera década del siglo XVI su fortuna se estimaba en cerca de un millón de maravedíes y entre sus propiedades destacaban unas casas principales en la calle Cascajar con su bodega, una docena de pares de casas distribuidas intramuros y en los arrabales que estaban arrendadas, unas tenerías, medio molino en Quemada y varias hectáreas de viñedo y cereal repartidas entre la tierra de Aranda y La Ventosilla. A este inmenso patrimonio se sumaba una esclava con su hijo más un caballo, dos mulas de silla y una acémila ${ }^{1229}$.

${ }^{1224}$ ALONSO GARCÍA, Fisco, poder..., p. 159, obtiene el dato de EMR, leg. 124.

1225 AGS, RGS, 149601, fol. 151.

${ }^{1226}$ AGS, CMC, leg. 41, doc. 4; CASA Y SITIOS REALES, leg. 9, docs. 1018, 1019 y 1024; y EMR, leg. 121, doc. 1. DIAGO HERNANDO asegura que Mena actuó en algunos de estos arrendamientos como "hombre pantalla" de Santa Cruz que ocupaba el oficio de escribano de rentas en la Merindad de Santo Domingo de Silos (“Arrendadores arandinos..., pp. 74 y 79).

${ }^{1227}$ AGS, RGS, 149606, fol. 201 y 149703, fol. 54; y EMR, leg. 571.

${ }^{1228}$ AGS, EMR, leg. 571; ARChV, RRE, Caja 209, doc 36; y DIAGO HERNANDO, M., "El comercio de la lana en Soria en época de los Reyes Católicos”, en Celtiberia. 77-78, 1989, pp. 25-75.

${ }^{1229}$ Todas estas propiedades fueron adquiridas por Mena. El medio molino corresponde a la dote que recibió de Rodrigo de Prado cuando se casó con su hija Ana. Como herencia de su padre recibió unas casas en Peñafiel que incrementó con la compra de la parte de su hermana (AGS, EMR, leg. 560 y 571; y ARChV, RRE, Caja 374, doc. 18). 
Su actividad política comenzó en 1495 cuando los monarcas le otorgaron el oficio de regidor perpetuo de la villa en sustitución del comendador Íñigo de Barahona que había renunciado en favor de Mena previamente, por lo que se integró en el linaje de don Pedro García de la Puente ${ }^{1230}$. No obstante, el procurador fiscal Romaní le acusó de haber comprado la renuncia de Barahona e inició un proceso que no parece que llegara a culminar pues Mena conservó el oficio hasta su muerte ${ }^{1231}$. A pesar de los negocios de arrendamiento, la presencia de Mena en la villa fue bastante regular y participó de casi todos los principales acontecimientos que se desarrollaron en Aranda. Así, por ejemplo, nada más ser nombrado regidor formó parte del séquito municipal que tomó posesión del lugar de Milagros en 1495. Esta continuidad le convirtió en idóneo para ser nombrado sobrefiel en el conflicto que enfrentó al gremio de los zapateros contra el concejo en $1501^{1232}$. Paradójicamente, Mena se convirtió en defensor de los intereses de los vecinos frente a las pretensiones de sus colegas, los arrendadores de la renta de la leña, de cobrar la alcabala por la madera que los vecinos cortaban con licencia del concejo de los montes de la villa los días antes de Navidad para celebrar esas fiestas ${ }^{1233}$.

Mena era hijo de Pedro de Mena y Catalina Díaz. Contrajo matrimonio con María de Prado, hija de Rodrigo de Prado, que además fue su socio en alguno de los arrendamientos que contrató ${ }^{1234}$. Prado actuó también como arrendador junto a Pedro de Santa Cruz con el que mantuvo algunas diferencias que le llevaron a denunciarle ante la Inquisición por maltratar a su mujer. Él es asimismo objeto de denuncias ante el Santo Oficio acusado de poner en tela de juicio la actividad del tribunal. Esta relación con Santa Cruz y las denuncias ante la Inquisición han hecho sospechar a algunos investigadores su posible condición conversa ${ }^{1235}$.

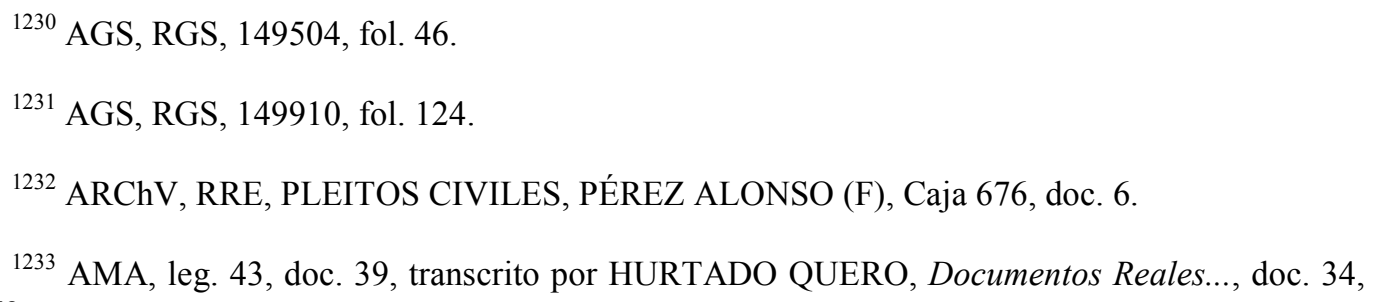
pp. 62-63.

${ }^{1234}$ ARChV, RRE, Caja 375, doc. 8; Caja 413, doc. 49; y AGS, EMR, leg. 571.

1235 CARRETE PARRONDO Fontes Iudaeorum..., doc. 147, pp. 77-78 y doc. 412, p. 170; y DIAGO HERNANDO, “Arrendadores arandinos..., p. 79. Este último autor afirma que la hija de Prado se llamaba Inés. 
A mediados del año 1512 Mena murió sin descendencia ${ }^{1236}$. Tras su muerte sus parientes emprendieron una intensa pugna por la herencia que enfrentó primero a la madre de Mena con Pedro y Gaspar de Santa Cruz, y posteriormente a la suegra de Mena con los anteriores. Todavía en 1525 se mantenían las disputas ${ }^{1237}$.

Originarios también de Salas de los Infantes y familiares de Santa Cruz fueron Francisco y Pedro de Berlanga. Ambos participaron junto a él en numerosas compañías de arrendamiento de rentas aunque con una posición notablemente más modesta ${ }^{1238}$. El final de la relación con ambos fue ciertamente escabroso pues, como ya hemos visto, tras la muerte de Pedro de Berlanga, Santa Cruz se casó con su viuda. Por otra parte, mantuvo varios pleitos con Francisco a propósito de unas deudas relacionadas con $\operatorname{arrendamientos}^{1239}$. No obstante, Francisco de Berlanga prosperó de manera inversamente proporcional a Santa Cruz extendiendo el negocio más allá de las fronteras castellanas y alcanzado cierto nivel en el seno de la oligarquía arandina que permitió que su hijo, Antonio de Berlanga, alcanzara el oficio de regidor de la villa a mediados del siglo $\mathrm{XVI}^{1240}$.

Junto a estos familiares directos, Santa Cruz contaba con una densa red de criados que actuaban como sus factores en las sucursales que tenía por Castilla ${ }^{1241}$. Así por ejemplo, en Soria tenía como factor al judío Abraén Alvo que se convirtió posteriormente al cristianismo tomando el nombre de Antonio de Morales. A principios del siglo XVI se instaló en Aranda y siguió trabajando para Santa $\mathrm{Cruz}^{1242}$. Otros vecinos estrechamente vinculados con Santa Cruz fueron Lope de Segura, Francisco de Peñafiel o

${ }^{1236}$ Tuvo que ser en el verano de 1512 pues los monarcas dispusieron de su oficio de regidor en agosto para concedérselo a Rodrigo de Durango (AGS, RGS, 151208, s. f.).

${ }^{1237}$ ARChV, RRE, Caja 374, doc. 18; y caja 375, doc. 8.

${ }^{1238}$ Francisco era socio minoritario en la compañía que creó Santa Cruz para arrendar el almojarifazgo de Sevilla en 1512 (AGS, EMR, leg. 121, doc. 1; y DIAGO HERNANDO, "Arrendadores arandinos..., p. 80). Pedro encabezó el grupo de arandinos que arrendaron las alcabalas del partido de Aranda los años 1502 y 1503 (EMR, leg. 683).

${ }^{1239}$ ARChV, RRE, Caja 331, doc. 33; y Caja 353, doc. 50.

${ }^{1240}$ En 1506 su fortuna se estimaba en medio cuento de maravedíes (DIAGO HERNANDO, “Arrendadores arandinos..., pp. 88-89). También tuvo tratos con el genovés Juan Lomelín (ARChV, PLEITOS CIVILES, FERNANDO ALONSO (F), Caja 1276, doc. 5).

1241 DIAGO HERNANDO ya hizo en su momento una aproximación a estos colaboradores de Santa Cruz en su trabajo “Arrendadores arandinos..., pp. 91-93.

1242 CARRETE PARRONDO Fontes Iudaeorum..., doc. 6, pp. 19-20, y doc. 427, p. 175. 
Diego de Almagro. Pero entre todos ellos destacaron los Diego de Reyna, padre e hijo. Del padre sabemos poco, tan solo atestiguamos su presencia en el remate de las rentas del año 1478. Todo lo contrario ocurre con su mujer, Catalina González de Reyna, que mantuvo una intensa actividad económica durante los ochenta como mercadera de paños, con un establecimiento abierto en la Plaza Nueva, y también como arrendadora de diferentes rentas ${ }^{1243}$. De su condición de conversa dan fe las denuncias presentadas ante el Santo Oficio, la confiscación de sus bienes, el encarcelamiento de Catalina a mediados de los noventa en la cárcel secreta que la Inquisición tenía en Soria y su posterior reconciliación ${ }^{1244}$.

Diego de Reyna, hijo, nació en los primeros años setenta y desarrolló una intensa actividad pública $^{1245}$. Desconocemos dónde estudió pero a finales de siglo consiguió el título de bachiller y ejerció como escribano en la villa. Tras la reforma de las escribanías del número llevada a cabo por los monarcas, Reyna fue uno de los primeros en obtener el nombramiento como escribano vitalicio en $1504^{1246}$. Actuó como procurador de la villa en numerosas ocasiones como en el pleito por el privilegio de la moneda forera o la disputa con la encomienda del Santo Espíritu por el patronazgo de la ermita de San Lázaro $^{1247}$. Su posición en el seno del concejo se vio reforzada tras la contienda comunera con su nombramiento como alcalde de cuentas en el proceso de fiscalización de la actividad de ayuntamiento comunero ${ }^{1248}$. Asimismo representó a la comunidad franciscana EH, leg. 4.

1243 AGS, CC MEMORIALES, leg. 151, doc. 113; RGS, 148504, fol. 108; 148907, fol. 79; y

${ }^{1244}$ Sus casas de la Plaza fueron confiscadas y entregadas a Gonzalo de Salcedo, repostero del rey. Las dudas que hubo sobre esta confiscación obligaron a los monarcas a trocar estas propiedades por otras (AGS, RGS, 149302, fol. 232). El cura de Valdanzo acudió a Soria para pedir explicaciones al inquisidor Amusco por el encarcelamiento de Catalina. El inquisidor le respondió: Calla, ay, loco. Que tan judias y villanas son como pueden ser. E luego llamo al escrivano de la Ynquisición y le dixo: muestra aqui al cura lo de aquellas mugeres, y gelo mostro. Después el cura de Valdanzo intercedió por Catalina y a cabsa de hablar con ella se avia salvado. La mujer se lo agradeció enviándole un manto (CARRETE PARRONDO, Fontes Iudaeorum..., doc. 196, pp. 94-95).

${ }^{1245}$ En 1502 aparecía como testigo en la declaración de bienes de Francisco de Mena y afirmaba tener 30 años (AGS, EMR, leg. 560).

${ }^{1246}$ AGS, CC PUEBLOS, leg. 2, doc. 91; RGS, 150407, s.f.; y CR, leg. 453, doc. 5.

${ }^{1247}$ AMA, leg. 43, docs. 18 y 35; y ARChV, PLEITOS CIVILES, FERNANDO ALONSO, Caja 962 , doc. 2 .

${ }^{1248}$ AGS, CR, leg. 450, doc. 8. 
arandina en el pleito que mantuvo con los dueños de los molinos del Arandilla que se oponían a la canalización del río Aranzuelo ${ }^{1249}$.

Esta intensa vida pública como escribano y procurador de la villa no le impidió desempeñar su actividad como representante de la familia Santa Cruz. Así en 1516 fue el procurador de Pedro de Santa Cruz en la solicitud de éste ante el corregidor para hacerse con la tutela de sus nietos Cristóbal, Rodrigo y Francisca de Salazar ${ }^{1250}$. Poco después, en 1517, ejerció como factor de Gaspar de Santa Cruz presentando la segunda postura sobre el almojarifazgo de la isla Fernandina ${ }^{1251}$.

Suponemos que Diego de Reyna murió en 1524 pues por entonces renunció a su oficio de escribano del número en favor de Diego de $A_{r a u z o}{ }^{1252}$. Sabemos que Reyna contrajo matrimonio aunque por el momento no hemos identificado con quién. No obstante, podemos intuir que su mujer debía tener una posición bastante acomodada pues en 1522 cedió a su marido 45.000 maravedíes que tenía situados sobre las alcabalas de Aranda $^{1253}$.

Además de los anteriormente referidos, entre la extensa nómina de empleados de Santa Cruz figuraban Juan Jimeno, Juan de Villarreal, Diego de Collazos, Gonzalo de Herrera y Juan del Rincón. Asimismo colaboraba con un destacado grupo de hombres de negocios entre los que se encontraban los miembros de la familia Mejías y Berlanga, Juan de Barrionuevo, Juan de Gumiel, García Sánchez de Aranda, el platero Rodrigo Sánchez de la Plaza, el cirujano real Francisco de Aranda, etc ${ }^{1254}$. Además de las funciones propias a su condición de empleados o socios, en ocasiones estos individuos eran utilizados por Santa Cruz como testaferros en los arrendamientos en los que él no podía acceder a la subasta, bien por gozar de un cargo incompatible, como el de Escribano Mayor de Rentas de la Merindad de Santo Domingo de Silos, o bien por decoro como sucedió con frecuencia en el arrendamiento de las rentas de la villa de

\footnotetext{
${ }^{1249}$ AGS, CC PUEBLOS, leg. 2, doc. 107. 
$\operatorname{Aranda}^{1255}$. Estas irregularidades ocasionaron a Santa Cruz una denuncia por parte del fiscal en 1499 que le acusaba de fraude en la recaudación de las rentas del reino durante los últimos quince años ${ }^{1256}$. No obstante, estas anomalías no le impidieron establecer una serie de negocios con algunos destacados miembros de la oligarquía local como los Acuña, Avellaneda, Salazar o Mendoza, e incluso con el conde de Miranda ${ }^{1257}$.

Así pues se observa que el clan de los conversos, y más concretamente la familia Santa Cruz, alcanzaron una notable posición de poder en el seno de la sociedad arandina de este momento de transición que estamos estudiando. Su incuestionable pujanza económica, ligada al arrendamiento de rentas y otras actividades económicas, les permitieron acceder a los órganos de gobierno municipal y a establecer significativos vínculos con las principales familias de la oligarquía arandina, haciéndose un hueco bastante confortable en su seno. Sin embargo, la sombra del pasado judío todavía se perfilaba en el horizonte e imprimió la marca del converso sobre este clan familiar que se vio presionado por la acción del Santo Oficio en la Ribera durante la última década del Cuatrocientos y los primeros años del siglo XVI.

\subsubsection{La Comunidad.}

Frente al grupo de los linajes o caballeros se configuró un grupo antagónico denominado común o comunidad que, en principio, incluía a todos los habitantes de la villa no pertenecientes a la clase dominante. Conformaba por tanto un grupo bastante heterogéneo en el que se integraban labradores, jornaleros, así como artesanos y comerciantes locales de todo tipo. Todos ellos compartían su condición de pecheros y la carencia de privilegios ${ }^{1258}$.

A continuación trataremos de matizar esta idea clásica del concepto Comunidad en el ámbito concreto de la villa de Aranda para pasar después a analizar la gran diversidad social que se englobaba bajo este término. Prestaremos especial atención a la configuración de un grupo destacado en el seno de la Comunidad que pergeñó una serie de

${ }^{1255}$ AGS, RGS, 149907, fol. 244; 149909, fol. 478; y CC PUEBLOS, leg. 2, doc. 91.

${ }^{1256}$ DIAGO HERNANDO, “Arrendadores arandinos..., p. 74.

${ }^{1257}$ FRANCO SILVA, A., La fortuna y el poder. Cádiz, 1996, p. 487.

${ }^{1258}$ VAL VALDIVIESO, "Elites urbanas en la Castilla del siglo XV (Oligarquía y Común), en Elites e redes clientelares na Idade Media. Lisboa, 2001, pp. 71-89, en concreto p. 78. 
aspiraciones sociopolíticas y trató de dinamizar la sociedad feudal en el periodo de transición que estamos analizando.

\section{a. El concepto de Comunidad.}

La definición del término Comunidad parece bastante compleja a tenor de los numerosos estudios que han intentado dar respuesta a este interrogante. Nos encontramos por lo tanto con definiciones del concepto que, como la apuntada por nosotros en la introducción, se generan por exclusión frente al otro grupo social urbano; otras identifican simplemente Comunidad con vecindad; también se plantea la utilización del término Comunidad para denominar a los vecinos enfrentados con el concejo frente a común como el conjunto de los vecinos; o define una "universitas" con personalidad jurídica propia; y otras definiciones, condicionadas en gran medida por el conflicto comunero, dotan al concepto Comunidad de unas connotaciones defensivas o como una propuesta alternativa al orden político imperante ${ }^{1259}$.

Los escasos datos con los que contamos para el caso concreto de la villa de Aranda no nos permiten establecer una definición completa del significado que tenía este concepto, aunque sí que podemos aproximarnos mínimamente.

En principio podemos confirmar que no existe una identificación completa entre Comunidad y pechero, pues como hemos visto en las páginas precedentes, algunos de los miembros de los linajes, como los de la familia Quemada, no solo eran pecheros sino que además hacían gala de ello a la vez que estaban perfectamente integrados e identificados en su linaje oligárquico ${ }^{1260}$. La situación se complica todavía más debido

1259 ASENJO GONZÁLEZ, M., "Las ciudades", en Orígenes de la Monarquía Hispánica: propaganda y legitimación (ca. 1400-1520). Madrid, 1999, pp. 105-140, en concreto p. 116; VAL VALDIVIESO, "Aspiraciones y actitudes..., pp. 218-219; de la misma autora "La Revolución comunera", en Scripta, 1998, pp. 617-633, en especial pp. 619 y 623; RUCQUOI, A, "Del concejo a la comunidad", en Valladolid en la Edad Media. La villa del Esgueva. Valladolid, 1993, pp. 75-101; MONSALVO ALONSO, J. M., "La participación política de los pecheros en los municipios castellanos de la Baja Edad Media. Aspectos organizativos", en Studia Historica. Historia Medieval. 7, 1989, pp. 37-94; GUTIÉRREZ NIETO, J. "La semántica del término comunidad antes de 1520. Las asociaciones juramentadas de defensa”, en Hispania. 136, 1977, pp. 316-379; SÁNCHEZ LEÓN, P., "La constitución histórica del sujeto comunero: orden absolutista y lucha por la incorporación estamental en las ciudades de Castilla (1350-1520)", en En torno a las comunidades de Castilla. Cuenca, 2002, pp. 159-208; y SOLÓRZANO TELECHEA, “De 'Todos los más del pueblo’..., pp. 61-106, en especial pp. 77-84.

${ }^{1260}$ Recordemos que Gonzalo García de Quemada abogó ante los monarcas para que sus compañeros regidores hidalgos pagaran la martiniega y ...se allanasen a bevir como los otros vesinos de la dicha villa (AGS, RGS, 148902, fol. 132). Este rechazo al privilegio puntual de los hidalgos no fue óbice para que Quemada aspirase a alcanzar la condición privilegiada como lo puso de manifiesto el matrimonio de su hija con el hidalgo Martín de Durango. 
al contradictorio y excepcional comportamiento de algunos de los vecinos, refrendado por los monarcas, de abandonar los linajes para pasarse al cuento de la Comunidad ${ }^{1261}$. Evidentemente este incipiente transfuguismo tenía unos costes como lo ejemplifica el caso de Diego de Roa. Éste fue un destacado miembro de los linajes que decidió pasarse a la Comunidad a mediados de los ochenta. Esta mudanza se tradujo en varias denuncias, no solo ante los monarcas, sino también ante la Inquisición ${ }^{1262}$.

Tampoco parece que en la villa de Aranda se mantuviera la máxima de identificar Comunidad con vecindad pues en las ordenanzas que la reina Juana otorgó a la villa en los años sesenta se incluía el siguiente capítulo: que ningunas ni algunas personas vecinos e moradores de la dicha villa que fuese de los dichos linajes que disen de don Pedro García e de Don Romero e permanesciese en el linaje; e una vez oviesen entrado e entrasen que no se mudasen al otro ni entrasen en el cuento de la comunidad so çiertas penas e destierros e prendimiento de bienes ${ }^{1263}$. Por lo contenido en este capítulo no parece que la condición de vecino fuera imprescindible para entrar en los linajes o la comunidad y todo indica que se dejaba la puerta abierta también a los moradores ${ }^{1264}$.

Como ocurre en otras ciudades castellanas, sí que parece claro que para entrar en la Comunidad era necesario contar con la aprobación de los procuradores y diputados de la misma. Al menos eso se deduce de la condición que impusieron los Reyes Católicos para que los miembros de los linajes pudieran pasarse a la Comunidad ...que sea contento de procuradores e diputados de la dicha comunydad ${ }^{1265}$. Además de contar con esta conformidad, los nuevos miembros debían ser recibidos en la Comunidad formalizando una serie de solemnidades que culminaban con un juramento ante el procurador o regi-

${ }^{1261}$ Esta práctica se produjo ya durante el reinado de Enrique IV y la reina Juana lo prohibió por los debates y alborotos que provocaba. Sin embargo, en 1478 la reina Isabel concedió su licencia y facultad para que ...sy algunos de los linajes quesieren entrar como dicho es que sea contento de procuradores e diputados de la dicha comunydad e los tengades en vuestra guarda e prosensyon segund que entre vosotros e ellos esta asentada aunque los tales sean de los linajes de la dicha villa (AGS, RGS, 147803, fol. 37; y 148002, fol. 256). Tampoco podemos descartar que esta dinámica no respondiera a la táctica de alguno de los miembros de los linajes que, tras verse relegado en su ámbito linajudo o por cualquier otro motivo que se nos escapa, pretendía volver a la Comunidad para así medrar u obtener algún beneficio.

${ }^{1262}$ AGS, CC MEMORIALES, leg. 149, doc. 173.

${ }^{1263}$ AGS, RGS, 148002, fol. 256.

${ }^{1264}$ La diferencia entre vecino y morador, así como el proceso que regulaba las condiciones y proceso para alcanzar el estatus de vecino han sido documentado para el caso de Toledo por IZQUIERDO BENITO, R., Un espacio desordenado. Toledo a fines de la Edad Media. Toledo, 1996, pp. 144-146.

1265 AGS, RGS, 147803, fol. 37. 
dor de la Comunidad y el escribano del concejo. Tras este formalismo el nuevo miembro recibía un auto firmado por el escribano que le permitía disfrutar de los privilegios de la Comunidad ${ }^{1266}$. Desgraciadamente no conocemos la calidad de estos privilegios a los que hace referencia la documentación.

Respecto a los matices semánticos que diferencian entre "común" y "comunidad", podemos señalar que la primera referencia que conocemos sobre la figura institucional que representaba al común es bastante tardía y se remonta a 1434 cuando Álvaro García de Castro actuó como procurador del comun en una iguala sobre roturaciones ${ }^{1267}$. No obstante, durante el último cuarto del siglo XV se empleaba casi siempre el término comunidad o estado de la comunidad, utilizándose el vocablo "común" como sinónimo de "comunidad", incluso en el mismo documento ${ }^{1268}$. Esta duplicidad se mantuvo durante los primeros años del siglo XVI. En el contexto del gobierno comunero el bando realista utilizó con profusión el término comunidad mientras que las autoridades comuneras se identificaban indistintamente como la Vniversydad o la honrada comunidad desta noble y leal villa de Aranda ${ }^{1269}$. En este sentido, no deja de ser significativo que tras el episodio comunero los representantes de la comunidad que asistían a las reuniones del ayuntamiento cambiaron su apelativo por procuradores generales de la villa, omitiendo el término comunidad ${ }^{1270}$.

${ }^{1266}$ Este proceso fue seguido por García de Sedano cuando en 1491 se integró en la Comunidad. El problema surgió cuando el escribano Pedro García de Quijadas no le entregó el auto que certificaba la recepción (AGS, RGS, 149204, fol. 310).

${ }^{1267}$ En la iguala se acordaba que para solucionar los problemas derivados de nuevas roturaciones se nombraran dos fieles, uno ...escogido por parte de los alcaldes regidores e los omes buenos de los linajes de la dicha villa; e el otro por los procuradores del comun de la dicha villa (AMA, leg. 43, doc. 27).

${ }^{1268}$ Una provisión de la reina Isabel fechada en marzo de 1478 hace referencia a una información enviada por los procuradores e diputados e omes buenos de la comunidad desa dicha villa e su tierra, y termina ordenando que se devuelva cierta cantidad a los dichos diputados e omes buenos del comun della (AMA, leg. 43, doc. 25, transcrito por HURTADO QUERO, Documentos Reales..., doc. 13, pp. 27-28). Asimismo en una carta real fechada en enero de 1499 se hace mención a la información presentada ante los monarcas en nombre de la comunidad de la villa sobre las reticencias de los regidores a entregar cierta cantidad de dinero al procurador del comun para enviar mensajeros a la corte (AGS, CC PUEBLOS, leg. 2, doc. 95).

1269 AGS, PR, leg. 1, doc. 22; y CC MEMORIALES, leg. 140, doc. 68, transcrito por PERIBÁÑEZ OTERO, J. G., "La Revolución Comunera en Aranda de Duero", en Biblioteca 26. Estudio e Investigación. 2012, pp. 55-78.

${ }^{1270}$ Esta situación se produjo inmediatamente después de que el corregidor recuperase el control municipal. En julio de 1521 el concejo se reunió para tomar las cuentas de los propios de la villa y entre sus miembros, además de los regidores, se encontraban los dos procuradores generales de la villa, por entonces Jimeno de Barrio y Gonzalo de Quemada (AGS, CR, leg. 450, doc. 8). Esta figura se mantuvo 
Se utilice un término u otro, lo significativo es que la Universidad o Comunidad de la villa se consolidó a lo largo del periodo que estudiamos como una fuerza política y una instancia de poder reconocida que, como veremos más adelante con mayor detalle, trató de acceder al poder de manera violenta en el contexto de la Revolución Comunera pero que, tras una corta experiencia, fracasó en el intento de consolidarse como tal y participar del poder político ${ }^{1271}$.

\section{b. La gran diversidad de la Comunidad.}

A parte de los rasgos imprecisos que hemos intentado definir anteriormente, el común se caracterizaba sobre todo por su gran heterogeneidad. Esta circunstancia y las evidentes carencias que presenta la documentación nos impiden realizar una sistematización que permita tener una visión cuanto menos general de esta gran masa social.

Tan solo hemos podido reconstruir las principales características del grupo más destacado dentro del común gracias a su capacidad de generar documentación, bien por sus actividades económicas, o bien por su implicación en la configuración de la Comunidad como alternativa política. Asimismo hemos identificado ciertos elementos de corporativismo y solidaridad a través de las escasas noticias que hemos obtenido sobre el funcionamiento de las organizaciones gremiales y cofradías.

El rasgo distintivo del común arandino era su vinculación a la tierra. En el año 1500 el procurador de la aljama mudéjar de Aranda, Braime de Córdoba, definía perfectamente la realidad social de la villa al afirmar que estaba ...prinçipalmente poblada de labradores e gente comun ${ }^{1272}$. Esta misma visión era compartida por la mayor parte de los ribereños ${ }^{1273}$.

En el periodo estudiado la villa de Aranda presentaba un abundante grupo de labradores propietarios de medianas, los menos, o pequeñas haciendas, los más, que subsistían gracias a su trabajo personal. Este paisaje de pequeños propietarios se puede apreciar en el proceso emprendido por los representantes de las cuadrillas contra los

en el tiempo como lo muestra una sesión celebrada en 1535 (VELASCO PÉREZ, Aranda. Memorias..., pp. 171-172).

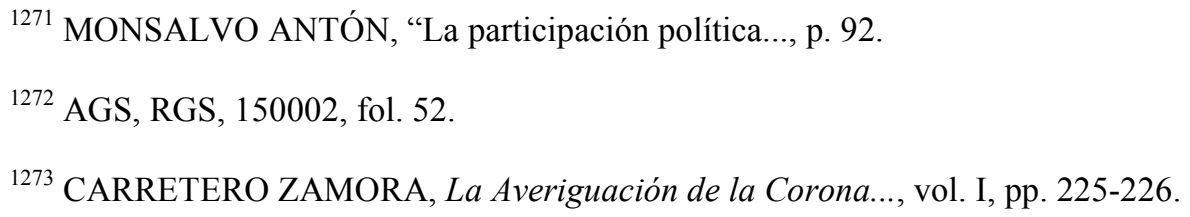


corredores del vino en $1491^{1274}$. Entre los años 1487 y 1490 los arrendadores de la alcabala del vino habían cobrado de más a los vendedores por lo que los vecinos presentaron una queja ante los monarcas. La autoridad real respondió con una orden por la que se obligaba a los recaudadores a devolver lo tomado indebidamente. En 1491 se procedió a la devolución de más de 45.000 maravedíes entre los vecinos. Este documento presenta un listado de más de 225 vecinos arandinos a los que se les devolvieron sumas que oscilaban entre los 34 maravedíes (un real) de los más modestos hasta el millar de los más hacendados. Pero lo más significativo es que el grueso de los vecinos recibió entre los 5 y los 10 reales (170-340 maravedíes), circunstancia que confirma este predominio de los pequeños y medianos propietarios ${ }^{1275}$.

Otra buena muestra de esta característica y la gran fragmentación de la propiedad en la tierra arandina la encontramos en el pleito que mantuvieron los propietarios de las heredades situadas en el pago de Revilla de Olleros con micer Bernardino, abad de Medina, por el abono del diezmo en $1514^{1276}$. Por estas fechas eran algo más de cincuenta los vecinos que se avinieron a pagar el diezmo con el abad, aunque no conocemos los que se negaron. El pago de Revilla contaba con algo menos de cien hectáreas de terreno que incluía heredades de pan, viñas, vega y monte bajo. Aunque en la documentación no se hace referencia al tamaño de las propiedades ni a la cuantía del diezmo que abonó cada uno, las dimensiones del término y la cantidad de propietarios permiten reafirmar la idea de heredades de pequeño tamaño que conformaban una propiedad muy fragmentada.

Son pocos los labradores que poseían la suficiente hacienda como para garantizar la subsistencia familiar, por lo que era muy habitual que estos labriegos con pequeñas propiedades vendieran su fuerza de trabajo coincidiendo con las fases de mayor actividad agraria. Como parece lógico en un espacio especializado en la producción vitivinícola, la mayor parte de las noticias documentales con las que contamos referidas a jornaleros se refieren a actividades relacionadas con la vid, sobre todo la vendimia, pero también la poda o la eliminación de malas hierbas que se engloban bajo el genérico

${ }^{1274}$ AGS, CC PUEBLOS, leg. 2, docs. 77, 88 y 89.

1275 Sobre el importante papel que jugó la explotación del viñedo en la subsistencia de los pequños y medianos campesinos véase la obra de BORRERO FERNÁNDEZ, M., "El papel social de la vid en un mundo dominado por la gran propiedad", en Historia, Instituciones, Documentos. 36, 2009, pp. 1126.

${ }^{1276}$ AGS, CC PUEBLOS, leg. 2, doc. 107. 
labrar las viñas ${ }^{1277}$. Un escalón inferior estaría ocupado por lo que las fuentes denominan pobres; hacia 1530 se estimaba que en Aranda había ...setenta pobres que no los enpadrona la villa porque dizen que son muy pobres ${ }^{1278}$.

En el polo opuesto e integrada dentro de esta gran masa social de los labradores podemos identificar claramente un grupo que se erigió en representante del común, canalizando sus quejas tanto ante las autoridades municipales como ante los monarcas y monopolizando el ejercicio de los oficios propios de la Comunidad.

En 1487 un arandino declaraba que vio juntar çiertos hombres, los mas prinçipales de la comunidad, para solicitar la firma de otros vecinos en una petición dirigida a los monarcas para que enviaran un pesquisidor que pusiera freno a las injusticias de los alcaldes y a los desmanes de los regidores de los linajes ${ }^{1279}$. A pesar de las reticencias de algunos convecinos que consideraban innecesaria la propuesta e incluso solicitaron a los promotores que la justificaran, finalmente se impuso el criterio de los mas prinçipales y se tramitó la solicitud de pesquisidor.

Resulta bastante difícil identificar a estos destacados miembros de la Comunidad que encabezaban las iniciativas de este amplio y heterogéneo grupo. A continuación trataremos de esbozar algunas características de estos individuos que asumieron la representatividad de la Comunidad a través de la definición de aquellos que ejercieron los oficios de procuradores y regidores de la comunidad.

Los primeros de los que tenemos noticias en el periodo que nos ocupa fueron Pedro Negro y Juan de Ortuño que estuvieron presentes como procuradores de la Comunidad en el recibimiento que las autoridades arandinas hicieron a la princesa Isabel en el arrabal del Allendeduero en $1473^{1280}$. Pocas son las noticias que tenemos de estos personajes. Conocemos la activa participación de Juan de Ortuño en la toma de la villa para la princesa al lado de las tropas de don Diego de Rojas, momento que aprovechó para incrementar su patrimonio confiscando algunos bienes de los partidarios del otro

${ }^{1277}$ Por ejemplo, don Martín Vázquez de Acuña contrató a varios labradores para labrar e vendimiar sus viñedos. En el genérico labrar se incluían todas las actividades relacionadas con el cultivo de la vid (AGS, EMR, leg. 689).

1278 Este dato incluye también a los pobres de la Tierra arandina (CARRETERO ZAMORA, La Averiguación de la Corona..., Vol. III, p. 967).

1279 AGS, CC MEMORIALES, leg. 149, doc. 230.

${ }^{1280}$ AMA, leg. 42, doc. 6, transcrito por HURTADO QUERO, Documentos Reales..., doc. 11, pp. 24-27. 
bando. Todavía en 1480 alguno de los vecinos perjudicados reclamaba a los herederos de Ortega la devolución de unas cubas y un par de viñas ${ }^{1281}$.

Lo único que sabemos por el momento de Pedro Negro es que arrendó la correduría de la venta del vino de Aranda en 1491 por un total de 63.000 maravedíes y 3.000 de prometido $^{1282}$.

Tras la reforma del regimiento en los primeros años de la década de los ochenta fueron nombrados como regidores de la comunidad Juan Sánchez del Prado, Martín Sánchez Casasola y Llorente González ${ }^{1283}$. A parte de su actividad como regidores son pocos los datos que transmite la documentación. De Prado sabemos que era labrador propietario y que en 1481 arrendó junto a su hermano Fernando la renta de las varas y corambre por un monto total de 78.000 maravedíes y un prometido de $1.500^{1284}$. Prado murió en 1486 seguramente como consecuencia de la pestilencia que se instaló aquel año en la villa, siendo sustituido en el cargo por Juan Fernández Mejías ${ }^{1285}$.

Las noticias sobre Llorente González son todavía más escuetas, tanto en su actividad política como en su trayectoria socioprofesional. Ocupó el oficio de regidor de la comunidad desde la reforma de principios de los ochenta hasta 1487 , cuando fue sustituido por Juan de Aranda ${ }^{1286}$. Poseía una importante hacienda que incluía viñas, heredades de secano y también de regadío, pues entre sus bienes se encontraba un canal que compartía con otro vecino. Como era habitual en la villa, también participaba del negocio de la venta del vino y además era propietario de un buey entre otros ganados ${ }^{1287}$.

Muy diferente fue la actividad política que desarrolló Martín Sánchez de Casasola que destacó de manera sobresaliente en sus enfrentamientos con los regidores de los linajes y los alcaldes de la villa. Sin embargo, apenas sabemos nada de otros aspec-

${ }^{1281}$ AGS, RGS, 148003, fol. 104.

${ }^{1282}$ AGS, CC MEMORIALES, leg. 150, doc. 45.

${ }^{1283}$ AGS, CC MEMORIALES, leg. 149, doc. 230.

${ }^{1284}$ No conocemos su hacienda y tan solo tenemos noticias de la venta de una viña a García de Quemada (ARChV, RRE, Caja 176, doc. 18; y AGS, EH, leg. 4).

${ }^{1285}$ AGS, RGS, 148612, fol. 55.

${ }^{1286}$ AGS, CC PUELOS, leg. 2, doc. 60.

${ }^{1287}$ Los arrendadores de la renta del vino le devolvieron 12 reales que le habían tomado de más al vender el vino (AGS, CC PUEBLOS, leg. 2, docs. 60 y 77, EMR, leg. 567; y RGS, 149103, fol. 520). 
tos de su vida salvo su estrecha relación con Pedro de Santa Cruz que alcanzó su punto álgido con la venta del regimiento que le hizo en $1494^{1288}$.

Juan Fernández Mejías sustituyó, como ya hemos dicho más arriba, a Juan Sánchez de Prado en el oficio de regidor de la comunidad en diciembre de 1486. Su actividad política ya se manifestó en los primeros años setenta cuando se significó en el bando de los partidarios de la pretendiente Juana. Esta posición le supuso unas severas pérdidas en su hacienda durante la toma de la villa por parte de don Diego de Rojas pues sus tropas le requisaron pan, vino, oro, plata y joyas por un valor superior a los 50.000 maravedíes. La compensación prometida por estas pérdidas en el perdón de Segovia no llegó hasta treinta años después ${ }^{1289}$. Sin lugar a dudas, su nombramiento como regidor de la Comunidad tuvo que ver con la política de reconciliación de la que ya dio notables muestras la reina Isabel al nombrar a varios de los partidarios de Juana como regidores perpetuos de los linajes. La carrera de Mejía en el consistorio se desarrolló paralelamente a la de Casasola, enfrentándose incluso personalmente con alguno de los regidores de los linajes como veremos más adelante.

Mejías se casó en dos ocasiones. En primeras nupcias con María García, hija de García de Roa, de quien tuvo cuatro hijos: Diego, Isabel, Catalina y Juan, el mayor. Tras la muerte de su primera esposa se casó con Juana Díaz, también viuda, que aportó como dote la modesta suma de 25.000 maravedíes en joyas, casas y yeguas. De esta segunda esposa tuvo seis hijos: Francisco, Leonor, Alonso, Juan, el menor, Rodrigo y Lucas. Cuando en 1500 redactó su testamento los cuatro últimos todavía eran menores de 14 años y tras su muerte quedaron bajo la tutela de su primogénito y otros parientes ${ }^{1290}$. Para sus tres hijas logró concertar matrimonio con individuos que gozaban de una reconocida posición en la villa arandina: Isabel se casó con el escribano Nuño González Pilón, Catalina con Fernando Martínez de la Tahona, y Leonor con Francisco de Solís ${ }^{1291}$.

En lo que se refiere a su condición social, Mejías estuvo muy bien relacionado sobre todo con el grupo de los poderosos conversos. La relación con Pedro de Santa

${ }^{1288}$ AGS, RGS, 149406, fol. 74 y 149910, fol. 125.

${ }^{1289}$ AGS, CASA Y SITIOS REALES, leg. 2, doc. 480. Evidentemente la compensación la recibieron sus herederos, en concreto su hijo Francisco firmó el recibo en enero de 1504.

${ }^{1290}$ AGS, CASA Y SITIOS REALES, leg. 2, docs. 481-485.

${ }^{1291}$ AGS, CASA Y SITIOS REALES, leg. 2, doc. 482. 
Cruz comenzó en los primeros años de presencia del arrendador en la villa cuando Mejía le vendió una serie de propiedades y la mitad del batán que su familia poseía en el Duero por la nada despreciable cifra de 200.000 maravedíes. Posteriores problemas legales con la reconstrucción del batán echaron por tierra la transacción como consecuencia de la sentencia definitiva de la justicia que ordenó derribar el batán ${ }^{1292}$. No obstante, la relación se estrechó con el paso del tiempo de tal manera que Diego de Reina, hombre de confianza de Santa Cruz, se convirtió en el tutor del menor Alonso, e incluso Francisco acudía asiduamente a casa de Santa Cruz para jugar a las tablas ${ }^{1293}$.

La posición económica de Mejías parece que se mantuvo a pesar de todos los sinsabores que sufrió como lo demuestra el hecho de que dos de sus hijos mantuvieron tras la muerte de su padre importantes negocios como mercaderes ${ }^{1294}$.

Siguiendo los pasos de Casasola, también Mejías vendió su oficio de regidor. En esta ocasión el comprador fue Antonio de Contreras, que pagó la modesta cantidad de 34.000 maravedíes para que Mejías renunciara en su favor ${ }^{1295}$. El fiscal Diego de Romaní persiguió a ambos y consiguió que Contreras fuera depuesto, que Mejías fuera condenado a devolver la cantidad recibida y que ambos se hicieran cargo de las costas procesales. La ejecución en los bienes de Mejía llegaron en el momento en el que éste se encontraba agonizando y redactando su testamento en favor de sus hijos ${ }^{1296}$. En 1501 los monarcas gratificaron a Romaní con la concesión del regimiento cuestionado ${ }^{1297}$. Suponemos que las quejas que envió el concejo a los monarcas alegando que esta decisión iba en contra del privilegio de la villa hizo revocar el nombramiento pues no tenemos más noticias de Romaní como regidor en Aranda ${ }^{1298}$.

${ }^{1292}$ AGS, RGS, 148711, fol. 53; y ARChV, RRE, Caja 12, doc. 44.

1293 AGS, CASA Y SITIOS REALES, leg. 2, doc. 486. Francisco relata en julio de 1502 ante los inquisidores lo siguiente: un día estava este testigo jugando a las tablas con Pero de Santa Crus ... en su casa .... y este testigo gano a Pero de Santa Crus obra de tres reales, y tenia mucho enojo... (CARRETE PARRONDO, Fontes Iudaeorum..., doc. 161, pp. 82-83).

1294 Tanto Diego, el primogénito, como Francisco, el primero de los hijos de su segunda esposa, aparecen identificados en la documentación como mercaderes. Francisco en concreto especializado en la venta de paños (AGS, CASA Y SITIOS REALES, leg. 2, doc. 483; y RGS, 149810, fol. 293).

1295 AGS, RGS, 149908, fol. 129; 149912, fol. 157; y 150006, fol. 242.

1296 AGS, RGS, 150007, fol. 128; y CASA Y SITIOS REALES, leg. 2, doc. 484. Mejías redactó su último testamento el 25 de abril de 1500 ...enfermo de dolençia natural.

${ }^{1297}$ AGS, CC CÉDULAS, libro 5, leg. 22, doc. 1.

1298 AGS, RGS, 150105, fol. 301; y DIAGO HERNANDO, "Hidalgos y pecheros..., p. 114. 
Evidentemente, tras la venta de sus oficios realizada por estos regidores de la comunidad, la representatividad e identificación de este oficio con los intereses de la comunidad desaparecieron por completo, como lo pone de manifiesto claramente el hecho de que desde ese momento en ninguna ocasión aparezca el apelativo Comunidad en la designación de Pedro de Santa Cruz o de Antonio de Contreras como regidores. También es significativo de esta nueva realidad que después de las ventas de los regimientos volvió a cobrar especial protagonismo la figura del procurador que reaparecía en los últimos años del siglo XV. En un primer momento estos representantes se identificaban como procuradores de la villa, aunque por el contexto es evidente que defendían los intereses de la Comunidad, y no fue hasta la segunda década del XVI cuando al término procurador le acompañó el apelativo Comunidad que se mantuvo hasta el comienzo de la revolución comunera ${ }^{1299}$.

Casi todos los vecinos que ocuparon este renovado oficio de procurador de la comunidad en los primeros años de la decimosexta centuria se vieron implicados con mayor o menor protagonismo en el conflicto comunero. Alonso Daza, Miguel Sánchez de la Torre y Sebastián de Ventosilla tuvieron cargos de notable responsabilidad, como veremos más adelante, en el gobierno comunero. A pesar de conocer bastante bien su actividad política, pocos son los datos que nos ofrecen las fuentes sobre la vida y las actividades socioeconómicas de los dos últimos.

Bastante diferente es el caso de Alonso Jiménez Daza, en su momento nombrado regidor en el contexto de la Revolución Comunera. La documentación ofrece bastante información sobre su vida y un largo historial de actuaciones como procurador. Ya en 1492 desempeñó la procuración de la cuadrilla de San Juan cuando reclamaron a los monarcas el cierre del portillo de Santa Ana ${ }^{1300}$. En 1498 actúo como procurador de la villa denunciando las irregularidades cometidas por los regidores en el nombramiento de los fieles, la manipulación del precio de los mantenimientos y la apropiación indebi-

${ }^{1299}$ Bartolomé Sánchez de la Torre y Juan Bonilla fueron procuradores de la villa en 1504 cuando reclamaron al mayordomo que cumpliera con la disposición real que en 1499 ordenaba ...que deys en cada un año al procurador del comun de la dicha villa de los propios e rentas della dos mill maravedies para que esten en deposyto en poder de una buena persona para que aviendo nescesidad el procurador de la dicha comunidad pueda tomar de ellos los que fueren menester para nos faser saber el estado de la dicha comunidad (AGS, CC PUEBLOS, leg. 2, doc. 95).

${ }^{1300}$ AGS, CC PUEBLOS, leg. 2, doc. 70; y CR, leg. 39, doc. 3. El mismo Daza declaraba en 1503 que fue a lo pleytear ante sus altezas a Çaragoça (PERIBÁÑEZ OTERO y ABAD ÁLVAREZ, Aranda de Duero..., pp. 173 y 174). 
da de los propios ${ }^{1301}$. Además Daza se encontraba presente como testigo en varios de los asuntos importantes que afectaron a la villa como fue el conflicto mantenido entre los regidores de los linajes y de la Comunidad en 1487. Pero también tuvo esta condición de testigo en los pleitos que se desarrollaron entre el monasterio de San Pedro de Gumiel y el conde de Miranda por el lugar de Milagros ${ }^{1302}$ o las disputas entre Juan Vázquez de Acuña y la comunidad franciscana de Aranda tras la muerte del padre del primero, patrón del nuevo monasterio ${ }^{1303}$. Tras un largo paréntesis, Daza volvió a representar los intereses de la villa en 1515 promoviendo el proyecto de la canalización del río Aranzuelo hasta el centro de la villa arandina, previo paso por el monasterio y huerta de San Francisco ${ }^{1304}$.

$\mathrm{Su}$ vida personal se nos presenta con serios interrogantes pues no conseguimos identificarlo definitivamente con la poderosa familia Daza. Los Daza estuvieron presentes en la villa al menos desde principios del siglo XV con Alfonso Jiménez Daza como patriarca de la familia ${ }^{1305}$. Su hijo, Pedro Jiménez Daza, desarrolló una importante actividad económica en la villa y se casó con Beatriz González de León, hija del palentino Álvaro González de León ${ }^{1306}$. De este matrimonio fueron fruto Álvaro Daza, escribano de los caballeros del concejo, y Catalina de León, mujer de Francisco Tomillo, portero de sus altezas ${ }^{1307}$. El hecho de que Alonso Jiménez Daza comparta los apellidos de esta familia nos hace pensar que quizá fuera hijo de Pedro, posibilidad que se incrementa al ostentar Alonso el oficio de despensero de la reina de Portugal. No es de extrañar por lo tanto que esta relación familiar, más los contactos relacionados con su oficio cortesano, consiguieran que su nombre desapareciera de la lista de oficiales y simpatizantes del

${ }^{1301}$ AGS, RGS, 149802, fol. 197 y 283.

${ }^{1302}$ En 1501 Daza fue presentado como testigo por parte del monasterio de San Pedro para confirmar la jurisdicción del cenobio sobre Milagros (AGS, CR, leg. 22, doc. 1). doc. 20)

${ }^{1303}$ Daza fue testigo del acuerdo suscrito entre ambas partes en 1516 (ARChV, RRE, Caja 315,

${ }^{1304}$ AGS, CR. leg. 40, doc. 8.

${ }^{1305}$ AHN, CLERO, LEGAJOS, leg. 1066, doc. 1.

${ }^{1306}$ AGS, RGS, 149011, fol. 81.

1307 AGS, RGS, 148509, fol. 85; y CC PUEBLOS, leg. 2, doc. 66. Francisco de Tomillo acusó a su mujer de adulterio al tener un hijo mientras él estaba ausente de la villa al servicio de los monarcas. 
movimiento comunero que un anónimo informador envió al Condestable ${ }^{1308}$ y que no se encontrara entre los exceptuados del perdón general en 1522 ni tampoco en el listado de los desterrados ${ }^{1309}$. No obstante, no se libró de pagar por su participación en el gobierno comunero pues tras la victoria realista una parte de sus bienes fue confiscada ${ }^{1310}$.

Lo que no deja lugar a dudas es que Daza disfrutó de una desahogada situación económica pues a lo que le podía rentar su oficio de despensero se le sumaba una considerable hacienda que contaba con una participación en la propiedad de una de las aceñas de la villa, más ciertas heredades de pan y varias viñas. Asimismo poseía una bodega en la que almacenaba el vino que posteriormente vendía ${ }^{1311}$. Además de la presumible relación con la familia Daza también estaba emparentado con algunos destacados vecinos pues era yerno de Bartolomé de Torres, primo segundo de Alonso de Moradillo, y una de sus sobrinas era la esposa de Pedro de Ormaza, camarero del marqués de Denia ${ }^{1312}$.

Otros de los procuradores de este periodo fue Juan Bonilla. Además de su faceta política, Bonilla destacó por una intensa actividad económica bastante diversificada pues sabemos que previamente a la salida de los judíos compró varias de sus propiedades que posteriormente arrendó ${ }^{1313}$. También se dedicó a negocios financieros de la mano de su tío mosén Alonso de Bonilla, del que recibió una suculenta herencia ${ }^{1314}$. Para no faltar a la tradición arandina, también se dedicaba a la agricultura pues contaba con unas casas deshabitadas en la calle del Pozo con una bodega donde guardaba y vendía

${ }^{1308}$ En este memorial se enumeraban pormenorizadamente los vecinos que participaron en la Comunidad. En el apartado dedicado a los regidores aparece en cuarto lugar Alonso Jiménez Daza, pero alguien tachó deliberadamente ese nombre (AGS, PR, leg. 4, doc. 16).

${ }^{1309}$ AGS, PR, leg. 3, doc. 141.

${ }^{1310}$ AGS, CR, leg. 450, doc. 8 .

${ }^{1311}$ ARChV, RRE, Caja 270, doc. 45.

1312 ARChV, RRE, Caja 281, doc. 26; y AGS, CR, leg. 39, doc. 3 (PERIBÁÑEZ OTERO y ABAD ÁlVAREZ, Aranda de Duero..., pp. 173-174).

${ }^{1313}$ AGS, RGS, 149211, fol. 178; y ARChV, RRE, Caja 106, doc. 16.

${ }^{1314}$ Su tío falleció en 1487 y le dejó como único heredero. Cuando estaba enterrando a su tío en el monasterio de La Aguilera, el alcaide de Gumiel del Mercado le tomó preso por ciertas deudas de su tío con el marqués de Denia que ascendían a un cuento de maravedíes. Esta amenaza llevó a Bonilla a solicitar un seguro real que le fue concedido (AGS, RGS, 148705, fol. 37 y 51). 
su vino. La parte superior estaba destinada a almacén de cereal ${ }^{1315}$. Las últimas noticias que tenemos sobre este personaje son del primer decenio del siglo XVI por lo que suponemos que bien pudo fallecer por esa época o bien abandonó la villa.

Pero no todos los procuradores tenían un perfil tan nítido dentro de la Comunidad. Bartolomé de Torres fue compañero de Bonilla como procurador en 1504. Era vecino de la cuadrilla de San Juan y fue uno de los promotores en 1492 de la solicitud a los monarcas para que cerraran el portillo de la calle Santa Ana por el daño que le viene a sus casas, y a buen seguro su negocio pues tenemos constancia de que era propietario de heredades y viñas y se dedicaba a la venta de vino ${ }^{1316}$. Torres contrajo matrimonio en segundas nupcias con Catalina Martínez, hija del licenciado Pedro García de Vadocondes, y por tanto hermana del regidor de linaje Pedro de Mora ${ }^{1317}$. Esta circunstancia le situaba entre la clientela del linaje de don Pedro García de la Puente. Este matrimonio tuvo como fruto dos hijos que sobrevivieron a la madre pero que murieron siendo niños. Tras la muerte de sus hijos y de Pedro de Mora, la hija de éste, Catalina de Mora, emprendió un pleito para recuperar los bienes de su tía, circunstancia que a buen seguro distanció a Torres de su familia política. Posteriormente contrajo nuevas nupcias que le procuraron un nuevo hijo que se sumó a los seis que le dio su primera esposa ${ }^{1318}$. Por otra parte, Torres mantenía también una estrecha relación con algunos destacados miembros de la Comunidad como es el caso de Alonso de Moradillo, del que hablaremos más adelante, Juan Bonilla, Alonso Daza, del que era suegro, además de ser primo de Juan de Hesilla, procurador de Moradillo. Esta vinculación se puso sobre todo de manifiesto cuando Torres fue presentado por Moradillo como uno de sus testigos en el pleito por la apertura de la calle Barrionuevo ${ }^{1319}$. Torres murió hacia 1512 con cerca de

${ }^{1315}$ AGS, CR, leg. 39, doc. 3. Bonilla era uno de los propietarios de las casas de la calle del Pozo que se derribaron para ampliar la calle Barrionuevo (PERIBÁÑEZ OTERO y ABAD ÁLVAREZ, Aranda de Duero..., pp. 177 y ss).

${ }^{1316}$ AGS, CC PUEBLOS, leg. 2, docs. 70 y 77; RGS, 149311, fol. 117; y ARChV, REE, Caja 281 , doc. 26. No se trataba de un gran vendedor pero poseía dos bodegas que albergaban al menos 9 cubas.

${ }^{1317}$ ARChV, RRE, Caja 241, doc. 63.

${ }^{1318}$ ARChV, REE, Caja 281, doc. 26.

1319 AGS, CR, leg. 39, doc. 3, transcrito por PERIBÁÑEZ OTERO y ABAD ÁLVAREZ, Aranda de Duero..., pp. 170-172. Como veremos más adelante, Moradillo utilizó como testigos a varios parientes y miembros de su clientela que le acompañaron también en la aventura comunera. 
55 años dejando mujer, varios hijos y algún nieto. Los herederos se enfrentaron durante algún tiempo por el reparto de la herencia ${ }^{1320}$.

Jimeno del Barrio, al igual que Torres, fue presentado como testigo por Moradillo en el mismo pleito que el anterior. Si bien es cierto que declaró no tener ningún parentesco con los propietarios de las casas del Pozo, en su declaración se aprecia claramente cierta inclinación por su posición ${ }^{1321}$. En 1517 fue el procurador de la villa y tuvo una activa participación en el rechazo a la imposición de don Juan de Zúñiga como alguacil por parte de Carlos $\mathrm{I}^{1322}$. Desde esta última fecha no tenemos más noticias suyas hasta que en mayo de 1521 la documentación lo muestra como procurador general al lado de los recientemente repuestos regidores. Su papel en ese momento se centró en la fiscalización de la actuación del gobierno comunero, participando por lo tanto de la represión posterior $^{1323}$. Paradójica pues la actuación de Barrio que pocos años antes se enfrentó a Juan de Acuña cuando acudió al ayuntamiento para tomar posesión de la vara del alguacilazgo y que tras Villalar se encuadró junto a los caballeros participando de la represión que se llevó a cabo sobre sus antiguos compañeros de la Comunidad. Curiosamente en 1521 ostentaba el mismo oficio que en 1517 pero transformando el peligroso apelativo de Comunidad por el más neutro de general.

Además de estos representantes de la Comunidad que acabamos de analizar existió otro nutrido grupo que, sin ejercer ningún cargo institucional dentro del concejo, estuvieron presentes en todos los grandes y pequeños conflictos que se desarrollaron en los primeros años del siglo XVI. A pesar de este papel secundario en la representatividad de la Comunidad en estos años, con el estallido de la revolución comunera muchos de ellos se convirtieron en los principales agentes del gobierno comunero que se hizo con el control de la villa entre septiembre de 1520 y abril de 1521. En este sentido, destacan las figuras de Alonso de Moradillo, Alonso de Aranda, García Ximeno, Gaspar de Mansilla, García Tomillo y un largo etcétera que, como veremos más adelante, también

\footnotetext{
${ }^{1320}$ ARChV, REE, Caja 281, doc. 26.

${ }^{1321}$ AGS, CR, leg. 39, doc. 3, transcrito por PERIBÁÑEZ OTERO y ABAD ÁLVAREZ, Aranda de Duero..., pp. 167-169.

${ }^{1322}$ AGS, CONSEJO Y JUNTAS DE HACIENDA, leg. 4, doc. 20; y CC DIVERSOS, leg. 41, doc. 35 .

${ }^{1323}$ AGS, CR, leg. 450, doc. 8 .
} 
participaban de las mismas características socioeconómicas de los representantes de la Comunidad expuestos en este apartado.

En conclusión, los individuos que se erigieron con la responsabilidad de representar los intereses de la Comunidad a comienzos de la decimosexta centuria compartían una serie de rasgos comunes, entre los que destaca el disfrute de una posición económica solvente, aspecto imprescindible pues se ha de recordar que los procuradores de la Comunidad no tenían asignado sueldo ${ }^{1324}$. Esta circunstancia les permitió dejar de lado ciertos lazos de dependencia con los más poderosos y asumir la tarea de fiscalizar la labor de la oligarquía que trataba de controlar los procesos productivos y mercantiles a través de una reglamentación no exenta de parcialidades. Evidentemente esta determinación no era inocente y respondía al interés de este grupo por adquirir una cuota de poder en la toma de decisiones que condicionaban en gran medida la consolidación de su posición en el seno de la sociedad urbana del momento. No obstante, toda generalización es peligrosa y no debemos dejar de señalar que, aunque sí se aprecia que estos individuos tienen conciencia de la diferencia que los separa del los miembros de la oligarquía e incluso se constituyen como una alternativa política más o menos institucionalizada, parece todavía pronto para hablar de una conciencia de clase, máxime cuando cada individuo, como acabamos de ver, respondía a unos intereses muy particulares.

\section{c. Corporativismo y solidaridad: gremios y cofradías.}

Las agrupaciones gremiales no fueron asociaciones vinculadas exclusivamente a la Comunidad, si bien es cierto que en el contexto de un pequeño núcleo urbano como Aranda a finales de la Edad Media este fenómeno estaba relacionado sobre todo con el trabajo de los pecheros. De la misma manera, al carácter religioso de las cofradías se sumó ya desde el momento de su fundación una proyección laboral y asistencial. Ya hemos visto en el apartado dedicado a la hidalguía cómo también la oligarquía local participó de este fenómeno de las cofradías encuadrándose en las de Santiago y San Nicolás ${ }^{1325}$.

A buen seguro que en la villa de Aranda existieron varias agrupaciones de artesanos que cumplían con las características propias de los gremios: contaban con autori-

\footnotetext{
${ }^{1324}$ AGS, RGS, 151204, s. f.

${ }^{1325}$ VELASCO PÉREZ, Aranda. Memorias..., pp. 160-164.
} 
dades propias y una reglamentación para el ejercicio de un determinado oficio ${ }^{1326}$. Desgraciadamente no contamos con datos concretos más allá de algunas de estas asociaciones, por más que intuyamos que el resto de actividades profesionales se regían por este mismo mecanismo.

El que mejor conocemos es el gremio de los zapateros y borceguileros ${ }^{1327}$. Su organización interna era similar a la de cualquier otro de Castilla. Sabemos que esta agrupación estaba dirigida por un alcalde y que contaba asimismo con un mayordomo que gestionaba los recursos de la asociación. También formaban parte de la junta directiva algunos diputados o comisionados que trataban asuntos específicos. Por su parte los fieles veedores se encargaban de comprobar el cumplimiento de las ordenanzas, así como de acompañar a otros dos maestros zapateros que se encargaban de examinar a cualquier aspirante a abrir una tienda en la villa.

El gremio de zapateros de Aranda desarrolló su actividad con cierta autonomía durante todo el periodo bajomedieval, pero en 1501 las autoridades concejiles impusieron unas nuevas ordenanzas que regulaban el negocio, centrándose sobre todo en los aspectos relativos a la compra de la materia prima, el establecimiento de unos precios máximos, la definición de las calidades de las piezas y la prohibición de elaborar zapatos con pieles de equinos. Asimismo se obligaba a los oficiales a dar ciertas informaciones sobre las calidades del producto al consumidor ${ }^{1328}$. Ante la imposición, el gremio manifestó su oposición sobre todo a las cuestiones relativas a la compra de cueros y la fijación de precios máximos. Si bien en principio se rechazó el hecho mismo de la redacción de normas por parte del regimiento argumentando que esta prerrogativa sólo la tenían los reyes, posteriormente el colectivo aceptó la mayor parte de los preceptos. Pero rechazó de plano el establecimiento de precios máximos precisando que ni siquiera la ciudad de Burgos, caveça de la probinçia donde esta sytuada la dicha villa de Aran$d a$, ni otras villas y lugares comarcanos tenían esta tasación. Esta medida tuvo como

${ }^{1326}$ COLLANTES DE TERÁN SÁNCHEZ, A., "Solidaridades laborales en Castilla", en Cofradías, gremios y solidaridades en la Europa medieval. Pamplona, 1993, pp. 113-126; y MONSALVO ANTÓN, J. M., "Solidaridades de oficio y estructuras de poder en las ciudades castellanas de la Meseta durante los siglos XIII y XV (aproximación al estudio del papel político del corporativismo artesanal)", en El trabajo en la Historia. Salamanca, 1996, pp. 39-90.

${ }^{1327}$ La mayor parte de la información sobre este gremio ha sido obtenida de ARChV, PLEITOS CIVILES, PÉREZ ALONSO (F), Caja 676, doc. 6.

${ }^{1328}$ La ordenanza 22 establecía que el zapatero debía solicitar al cliente el tipo de piel que quería para su zapato, carnero o cordobán, e informarle del coste antes de realizar la pieza. 
resultado la merma de la autonomía de la corporación en cuanto a su control de la producción y comercialización, además de ser una clara evidencia de la escasa proyección del gremio sobre la política económica del concejo y su nula capacidad de participar del poder político de la ciudad ${ }^{1329}$.

Como ya hemos comentado anteriormente, la documentación se muestra muy esquiva a la hora de identificar estas agrupaciones gremiales. Suponemos que los cambistas de la villa también conformaban un gremio pues son múltiples las referencias que tenemos a este oficio y existe la constancia de una mínima organización corporativa que les llevó en 1491 a denunciar la abusiva imposición de una tasa por parte del regimiento ${ }^{1330}$. Algo similar podemos afirmar de los mercaderes de paños cuando presentaron una queja en 1498 contra la decisión del concejo de prohibirles vender paños berníes ${ }^{1331}$. Pero lo cierto es que nada más podemos decir por el momento sobre los diferentes gremios arandinos.

Muy relacionadas con las organizaciones de oficios estaban las cofradías. Si bien es cierto que en otros espacios peninsulares se ha logrado identificar la estrecha vinculación de los gremios con las cofradías, en el caso arandino tan sólo podemos plantear hipótesis basadas en sólidos argumentos ${ }^{1332}$.

En 1503 la villa envió a los monarcas un memorial en el que, entre otras cosas, informaba de que ...en esta villa ay veinte cofradias e que en las mas prinçipales dellas ay onbres que estan en diez o doze cofadrias; y acaeze que quando alguno muere que esta toda la mas de la villa ocupada en las onrras e osequias mas de la mitad del dia; y algunas a cabsa de las caridades que se dan estan todo el dia; y asy dice que biene de daño a la villa mas de diez mill maravedies ${ }^{1333}$.

${ }^{1329}$ Aspectos que según MONSALVO ANTÓN definen el corporativismo integral que sería la máxima expresión del gremio pero que no parece que existieran en la Castilla de finales de la Edad Media ("Solidaridades de oficio..., pp. 45 y ss.).

${ }^{1330}$ AGS, RGS, 149108, fol. 314.

${ }^{1331}$ AGS, RGS, 149810, fol. 293.

${ }^{1332}$ La imbricación entre lo laboral y lo religioso se aprecia perfectamente en las tierras vascas (GARCÍA FERNÁNDEZ, E., "Las cofradías de oficios medievales del País Vasco (1350-1550)", en Studia Historica, Historia Medieval. 15, 1997, pp. 11-40). En Murcia y Valencia se ha constatado la configuración de los gremios como una agrupación de marcada función laboral que más tarde tuvo su vertiente asistencial a través de la creación de las cofradías de oficio (GONZÁLEZ ARCE, J. D., Gremios, producción artesanal y mercado: Murcia, siglos XIV y XV. Murcia, 2000, pp. 48 y ss.).

${ }^{1333}$ AGS, CC PUEBLOS, leg. 2, doc. 94. 
De esta veintena de cofradías que existían en Aranda a finales del siglo XV estamos seguros de que la mayor parte eran de carácter religioso o devocional, a tenor de la posibilidad de que un mismo individuo fuera cofrade a la vez de más de una decena de cofradías. En cualquier caso, tenemos referencias documentales para las cofradías de San Pedro Mártir, Santa Ana y Corpus Christi.

La que mejor conocemos es la de San Pedro Mártir que, según sus cofrades de finales del siglo XV, estaba creada en la dicha villa de Aranda de tiempo inmemorial e confirmada e aprobada por el obispo de Osma ${ }^{1334}$. A buen seguro que casi todas las cofradías arandinas contemporáneas se regían y organizaban de manera muy similar a ésta. Su organigrama estaba definido en unos estatutos o regla jurada e guardada de tiempos inmemoriales u ordenanza que regía los procesos de admisión, las distintas actividades y celebraciones, así como las posibles sanciones ante el incumplimiento de las normas. La cofradía era dirigida por los alcaldes, acompañados de los mayordomos, más varios diputados. La reunión de los gestores de la cofradía constituía lo que en la documentación se denomina el cabildo. Tanto la terminología empleada para los oficios como sus funciones recuerdan las propias de organizaciones laicas como podían ser los concejos primitivos o las agrupaciones gremiales, aunque revestidos de un evidente trasfondo religioso, una muestra más de la indisoluble relación entre lo laico y lo religioso en la sociedad feudal del momento.

Además del acompañamiento a los cofrades difuntos ${ }^{1335}$, la actividad de las cofradías estaba marcada por una serie de rituales y ceremonias. Su cenit se producía en la festividad del santo patrón con la celebración de los correspondientes actos religiosos durante las vísperas que culminaban el día del patrón con una asamblea general. En esta reunión suponemos que se renovaban los cargos y se tomaban decisiones importantes para la cofradía. La fiesta continuaba con una comida de hermandad, bien ese mismo día o al siguiente, que generalmente se remataba con actividades lúdicas como las corridas de toros. Durante el resto del año también se hacían otras comidas e colaciones e las misas e caridades e procesiones e limosnas ${ }^{1336}$.

${ }^{1334}$ ARChV, RRE, Caja 150, doc. 50.

${ }^{1335}$ Uno de los capítulos de las ordenanzas de San Pedro establece claramente la principal función de la cofradía que se define por ...ser fecha en servicio de Dios nuestro Señor e para enterrar los muertos (ARChV, RRE, Caja 150, doc. 50).

${ }^{1336}$ AMA, leg. 43, doc. 49. 
Dentro de las ordenanzas de estas cofradías también había cabida para lo que algunos autores consideran un mecanismo de autodefensa de la sociedad cristiano-vieja contra la irrupción de los conversos, más conocido como estatuto de sangre ${ }^{1337}$. En la cofradía de San Pedro uno de sus capítulos establecía que ...non podian reçebir en ella por cofrade a persona alguna que veniese o deçendiese en qualquier manera o por qualquier linaje que fuese de judios. Esta disposición causó, como veremos más adelante, serios conflictos entre la cofradía y alguno de sus miembros, incluso hidalgos, que vieron rechazada su solicitud por la supuesta contaminación de sus ancestros ${ }^{1338}$.

También relacionada con el fervor popular y el rechazo a los judíos se presenta la información sobre la existencia de la cofradía de Santa Ana. En 1492 cuando los hebreos fueron obligados a abandonar el reino, el arcipreste de Aranda encabezó a los miembros de esta cofradía que ocuparon la sinagoga que abandonaron los judíos en la calle del Hocino. Tras la ocupación, el edificio fue sacralizado y convertido en ermita bajo la advocación de su patrona, configurándose como nueva sede de esta cofradía ${ }^{1339}$. Poco más sabemos de esta cofradía salvo que a ella pertenecían muchas mujeres como aseguraba un vecino en 1493: ... a la cual las señoras de esta villa han tenido devoción ${ }^{1340}$. Es posible que esta cofradía estuviera en relación con la notable fuerza que adquirió por estos años el culto a la Inmaculada Concepción impulsado sobre todo por la orden franciscana ${ }^{1341}$. Prueba de este fervor es que en el retablo de Santa Ana de Sinovas que compró la parroquia en 1503 se puede apreciar perfectamente el argumentario de la doctrina inmaculista a través de las diferentes tablas que componen esta obra $^{1342}$.

${ }^{1337}$ EGIDO, T., "El problema histórico de los judeo-conversos españoles", en Las tres culturas en la Corona de Castilla y los sefardíes. Salamanca, 1990, pp. 165-178.

${ }^{1338}$ AGS, CC PUEBLOS, leg. 2, doc. 94; y ARChV, RRE, Caja 150, doc. 50.

1339 AGS, RGS, 149205, fol. 451; y 149403, fol. 370. Ambos documentos transcritos por CADIÑANOS BARDECI, "Judíos y moros..., docs. 3 y 4, pp. 43-45.

${ }^{1340}$ AGS, RGS, 149303, fol. 357. Esta referencia apunta a la relación de la cofradía con las mujeres embarazadas de las que Santa Ana era patrona.

${ }^{1341}$ La fundación franciscana de Aranda se creó bajo la advocación la Conçebçion de Nuestra Señora (ARChV, RRE, Caja 315, doc. 20). Para más información sobre la relación entre la orden franciscana y el culto a la Inmaculada Concepción se puede consultar RAMBLA, P., "Historia del dogma de la Inmaculada Concepción", en Archivo Franciscano Digital. http://franciscanos.org. Consulta realizada el $01 / 07 / 2012$

${ }^{1342}$ HERNANDO GALLARDO, "Pintura gótica..., p. 186. Este magnífico retablo se encuentra en la actualidad en el Museo Larrea de Buenos Aires, Argentina. Recientemente el investigador J. M. 
También en esta época estaban activas las cofradías de San Llorente, San Andrés, San Roque y San Lázaro, esta última bajo el patronato del concejo. No tenemos noticias sobre su actividad pero sí sobre las ermitas en las que se ubicaban. La de San Llorente se encontraba intramuros y se la identifica perfectamente en el mapa de 1503 como una pequeña construcción románica exenta al Oeste de la Plaza Nueva y al Sur de la iglesia de San Juan ${ }^{1343}$. En el arrabal de las Tenerías, se encontraba la ermita de San Andrés ${ }^{1344}$. También extramuros se situaba la ermita de San Roque, junto a la puerta Este de la villa. Su recinto albergó frecuentemente las reuniones de la cuadrilla de Hesi$1 l a^{1345}$. Por último, la de San Lázaro se encontraba en el arrabal de Allendeduero junto al camino real de Toledo ${ }^{1346}$. Posiblemente la cofradía de la Santa Cruz tuviera también su sede en la ermita del mismo nombre que se encontraba en las inmediaciones de la Plaza Nueva, aunque parece ser que esta cofradía se fundo en $1532^{1347}$.

Posiblemente de esta época fueran otras cofradías como las de Santa Lucía, San Juan Evangelista, San Sebastián, Corpus Christi y la Misericordia, pero no contamos con ninguna referencia documental que lo avale ${ }^{1348}$.

LÓPEZ VILABOA ha realizado un estudio pormenorizado sobre su peculiar traslado a Argentina y su vinculación con la religiosidad popular a principios del siglo XVI. Lamentablemente todavía no se ha publicado.

${ }^{1343}$ AGS, MPD, leg. X, doc. 1.

${ }^{1344}$ En ocasiones este arrabal también era denominado como de San Andrés (AGS, CR, leg. 40, doc. 8; EMC, leg. 460; y ARChV, Caja 366, doc. 24).

${ }^{1345}$ La ermita se encontraba situada en la confluencia de los caminos que desde esta puerta se dirigían hacia Burgos, el Burgo de Osma a través del puente Conchuela, y hacia el Sur por el Puente Duero (AGS, CONSEJO Y JUNTAS DE HACIENDA, leg. 4, doc. 20).

${ }^{1346}$ Esta ermita estaba bajo la advocación de San Lázaro y San Benito y el concejo tenía la prerrogativa de nombrar sus mayordomos, luminarios y caseros (AMA, leg. 43, doc. 45; y AGS, CR, leg. 450, doc. 8).

${ }^{1347}$ VELASCO PÉREZ señala que sus ordenanzas fueron elaboradas en 1532 pero que "por el contexto de ellas se da a entender la mayor antigüedad de la institución", lo que le lleva a inclinarse por atribuirle un origen alto medieval (Aranda. Memorias..., pp. 99-100). El culto a San Sebastián en Aranda estaba muy extendido pues además de la ermita que hemos citada también aparece su imagen en la predela del retablo de Santa Ana de Sinovas junto a otros santos de gran devoción en la villa como Santa Catalina y San Gregorio (HERNANDO GALLARDO, "Pintura gótica..., p. 186).

${ }^{1348}$ De nuevo VELASCO PÉREZ asegura que todas ellas existían ya en 1568 cuando el provisor del Obispado de Osma ordenó que enviaran sus reglas y ordenanzas ante el obispo para recibir su aprobación y confirmación (Aranda. Memorias..., pp. 243-244). 
Además de estas cofradías devocionales, recordemos que existían en la villa dos de ellas que encuadraban a los miembros de la oligarquía arandina y tenían un claro matiz privilegiado: eran la cofradía de Santiago y el Cabildo de San Nicolás.

Hemos identificado por tanto tan solo once de la veintena de cofradías que había en la Aranda de finales del siglo XV. Una serie de indicios nos llevan a pensar que algunas de esas cofradías no identificadas estaban directamente relacionadas con agrupaciones de artesanos y destinadas a ofrecer una serie de servicios asistenciales a los trabajadores y sus familias. La ausencia de referencias documentales nos obligan a acudir a otro tipo de fuentes como las iconográficas y qué mejor recurso que la fachada de Santa María la Real ${ }^{1349}$.

Como es habitual en las iglesias castellanas contemporáneas, en esta portada encontramos un nutrido grupo de santo intercesores adosados a las pilastras, jambas, arquivoltas y puertas. Como es también frecuente en el repertorio iconográfico en la fachada de Santa María se introdujeron los denominados santos universales como son los evangelistas, apóstoles, padres de la Iglesia, vírgenes ecuménicas, o los santos sanadores medievales como San Cosme y San Damián, San Blas, San Antón, etc. Pero también era habitual que entre estos santos intercesores se incluyeran algunos de devoción más inmediata y prueba de ello es que aparecen las imágenes de San Pedro, San Andrés, San Nicolás, Santiago, San Roque, San Lázaro, San Sebastián o Santa Lucía. Es factible que entre los santos que aparecen en esta fachada también se encuentre el patrono de las cofradías que nos faltan por identificar ${ }^{1350}$.

A modo de hipótesis, no parece descabellado afirmar que tal vez en la villa existiera una cofradía bajo la advocación de San Bartolomé que era el patrón de los curtidores. Son muchas las referencias a estos profesionales entre los vecinos arandinos que desarrollaron una importante actividad en la villa como consecuencia de la gran deman-

${ }^{1349}$ Esta iglesia y fachada han sido estudiadas desde el punto de vista artístico por varios autores entre los que destacamos: ABAD ZAPATERO, J. G. y ARRANZ ARRANZ, J., Las Iglesias de Aranda., pp. 61-87; MARTÍNEZ MARTÍNEZ, M. J., "Aproximación iconográfica de la fachada de Santa María la Real de Aranda de Duero", en Biblioteca 10. Estudio e Investigación. 1995, pp. 23-37; ANDRÉS ORDAX, S., "Escultura monumental castellana en el tránsito del siglo XV al XVI: la portada de Santa María de Aranda de Duero", en Biblioteca 17. Estudio e Investigación. 2002, pp. 315-347; y de nuevo MARTÍNEZ MARTÍNEZ, M. J., "Orgullo, miedos y esperanzas del pueblo de Aranda a finales de la Edad Media: la fachada de Santa María la Real”, Biblioteca 25. Estudio e Investigación. 2011, pp. 153186.

${ }^{1350}$ ANDRÉS ORDAX ha documentado esta misma dinámica en San Nicolás de Bari, el claustro de San Salvador de Oña y en el sepulcro de Alonso de Cartagena en la catedral de Burgos ("Escultura monumental..., pp. 329-331). 
da que de sus productos ejercía el negocio de la venta y transporte del vino. En la fachada de Santa María encontramos la imagen de este santo en una posición destacada, en el primer cuerpo del pilar izquierdo, representado con un demonio encadenado a sus pies $^{1351}$. Igualmente la presencia de San Cristóbal en la portada puede indicar la existencia de una cofradía de carreteros, algo por otra parte bastante probable en una villa donde el tránsito de mercancías era una de sus principales actividades.

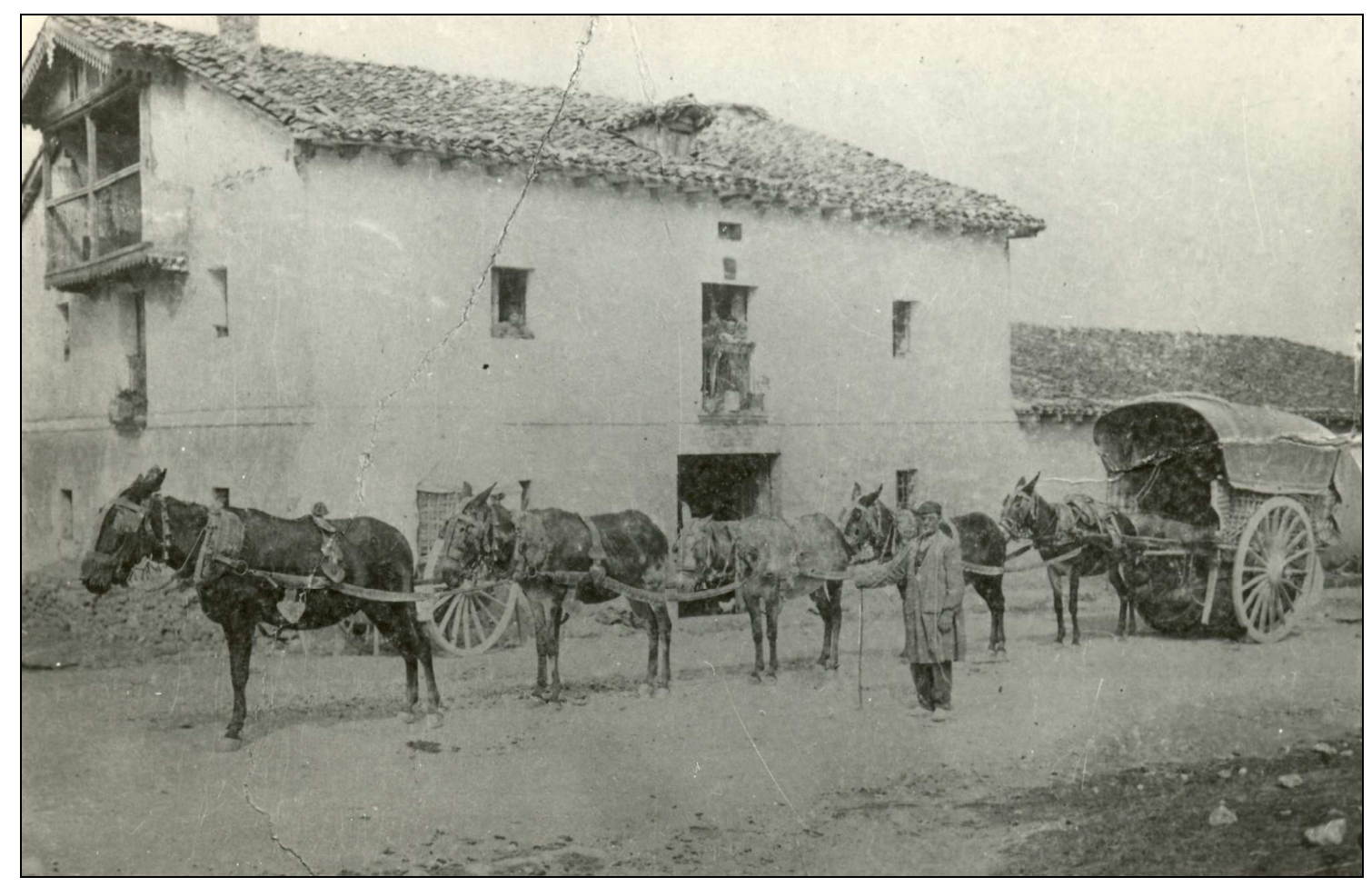

Imagen 47: Carretero a principios del siglo XX (CBMAD).

Asimismo no sería descabellado pensar que el santo obispo que aparece junto a Santa Inés fuera San Eloy patrón de los plateros que contaban en la villa con importantes negocios en una sus calles a espaldas de esta misma iglesia y que recibía el significativo nombre de calle de la Plata ${ }^{1352}$. De igual manera, la representación de Santa Catalina de Alejandría estaría vinculada con la devoción popular a esta santa que tenía una pequeña ermita al Este de la villa, junto al camino de Quemada, y que daba nombre al

${ }^{1351}$ MARTÍNEZ MARTÍNEZ, “Aproximación iconográfica..., p. 29; y “Orgullo, miedos..., p. 170.

${ }^{1352}$ AGS, MPD, leg. X, doc. 1. 
pago inmediato ${ }^{1353}$. Lo mismo ocurría con San Juan Evangelista que tenía una ermita sobre una pequeña colina al NE de la villa, muy próxima a la laguna del mismo nombre $^{1354}$.

Sean éstas o no las veinte cofradías con las que contaba la villa de Aranda a finales de la Edad Media, lo que sí que es evidente es la importancia que desempeñaba la religiosidad y la solidaridad en la vida de todos los arandinos, impregnando el ciclo vital del ser humano, sus relaciones sociales y sus estrategias de subsistencia de un ceremonial y sentido formal trascendente que, bien es cierto, a fuerza de ser tan cotidiano se iba difuminando y desacralizando ${ }^{1355}$.

En conclusión, la Comunidad se configuró a finales del siglo XV y durante los primeros años del siglo XVI como una realidad política emergente que aglutinó los intereses de un pequeño grupo de vecinos con un destacado poder adquisitivo derivado de la pujante actividad económica que se desarrolló en este periodo pero que no consiguió acceder a los resortes del poder político local por los métodos tradicionales. Estos vecinos canalizaron las inquietudes del resto de vecinos a través de los escasos instrumentos de representatividad que permitía el sistema. Instrumentos y representatividad vecinal que en muchas ocasiones se pusieron al servicio de los intereses de estos destacados personajes, tanto en el ámbito individual como colectivo. Si bien es cierto que en otros espacios urbanos las agrupaciones gremiales y las cofradías participaron de esta misma dinámica $^{1356}$, en el caso arandino no hemos percibido ningún tipo de iniciativa de este tipo. Por lo tanto, fueron las clientelas y parentelas de todos los sectores implicados las que intervinieron de manera decisiva en las pugnas que entre oligarquía y Comunidad se

${ }^{1353}$ AGS, CR, leg. 40, doc. 8; y EMC, leg. 560. También existía un pago con el nombre de Santa Margarita pero no conocemos ninguna ermita relacionada con esta santa.

${ }^{1354}$ La proximidad provocó que la ermita recibiera el nombre de San Juan de Alagunas y que la laguna se conociera como la de San Juan (AGS, CR, leg. 40, doc. 8).

1355 ASENJO GONZÁLEZ, M., "El ritmo de la comunidad. Vivir en la ciudad, las artes y los oficios en la Corona de Castilla", en La vida cotidiana en la Edad Media. Logroño, 1998, pp. 169-200.

${ }^{1356}$ En este sentido destacan las cofradías cantábricas que se convirtieron en instrumentos políticos que canalizaron los intereses de sus miembros (GARCÍA FERNÁNDEZ, "Las cofradías de oficios..., p. 18). Destaquemos sobre todo el caso de Laredo estudiado por SOLÓRZANO TELECHEA donde la cofradía de pescadores se convierte a partir de 1440 en sinónimo de Comunidad y canaliza todas las reivindicaciones sociales y políticas de este colectivo (“De 'Todos los más del pueblo'..., pp. 76 y ss.). 
desarrollaron a finales de la Edad Media, sin que hayamos identificado por el momento la intervención o proyección sobre gremios y cofradías.

\subsubsection{Los marginados.}

Para finalizar el análisis de la realidad arandina abordaremos brevemente la situación de la población marginada por motivos religiosos o jurídicos en una sociedad mayoritariamente cristiana. Las comunidades judía y mudéjar, que aunque minoritarias en número, no dejaron de tener un significativo peso en la realidad socioeconómica de este centro urbano y, por extensión, sobre toda la comarca. Aspecto que se incrementa con el importante significado que tuvo en este periodo la notable y poderosa comunidad judía de la cercana localidad de Coruña del Conde.

La dinámica homogeneizadora de los monarcas castellanos provocó, por una parte, la salida del reino de un importante contingente de población hebrea que tuvo unas significativas repercusiones desde el punto de vista cualitativo. Pero por otra parte, también derivó en una severa adaptación a la realidad cristiana imperante de los individuos que formaban estas comunidades y que optaron por el bautismo. Esta opción, lejos de solucionar un problema, generó serios conflictos asociados a un nuevo grupo, no ya marginado por su religión, sino por su sangre: los conversos.

\section{a. Judíos.}

A pesar de lo mucho que se ha escrito sobre la población hebrea ribereña, y en particular sobre la arandina, conocemos muy poco sobre el origen de su presencia en estas tierras $^{1357}$. Sabemos que en la Distribución de los tributos que pagaban las aljamas judías

${ }^{1357}$ CADIÑANOS BARDECI, I. "Judíos y moros en Aranda de Duero y sus contornos" en Sefarad. 50/1 y 2. 1990. El mismo artículo aparece en Biblioteca 7. Estudio e Investigación. 1992, pp. 23-51. Estos datos se amplían en "Judíos y moros en el Duero arandino", en Biblioteca 18. Estudio e Investigación. Aranda de Duero, 2003, pp. 57-74; CANTERA MONTENEGRO, E., "Pleitos de usura..., pp. 597622; "Relaciones judeocristianas en la diócesis de Osma en el último tercio del siglo XV", en Encuentros en Sefarad. Actas del Congreso Internacional sobre los Judios en la Historia de España. Ciudad Real, 1987, pp. 103-136; "El apartamiento de judíos y mudéjares en las diócesis de Osma y Sigüenza a fines del siglo XV", en Anuario de Estudios Medievales. 17, 1987, pp. 501-510; "Las comunidades mudéjares de las diócesis de Osma y Sigüenza a fines de la Edad Media", en Espacio, tiempo y forma, 4, 1989, pp. 137173; "Una familia prestamista y arrendadores judíos en tiempos de la expulsión: los Soto de Aranda de Duero", en Espacio, tiempo y forma. Historia Medieval, 12, 1999, pp. 11-46; y "Notas acerca de la expulsión de los judíos de la diócesis de Osma (Soria)", en Espacio, tiempo y forma. Historia Medieval. 13, 2000, pp. 57-84; "Las comunidades judía y mudéjar de Aranda de Duero a finales del siglo XV", Biblioteca 25. Estudio e Investigación. 2011, pp. 127-152; CARRETE PARRONDO, C., Fontes Iudaeorum Regni Castellae II. El Tribunal de la Inquisición en el Obispado de Soria (1486-1502). Salamanca, 1985; LADERO QUESADA, M. A., "Deudas y bienes de judíos del obispado de Burgos en 1492", en Aragón en la Edad Media. 19, 2006, pp. 285-300; LÓPEZ MARTÍNEZ, N., Judaizantes e Inquisición en la Ribe- 
en Castilla en el año 1291 no aparecen mencionadas ni Aranda ni Coruña del Conde que, como ya hemos anticipado, fueron las principales comunidades bajomedievales ${ }^{1358}$. Sin embargo, las vecinas localidades de Roa y Haza sí que se mencionan en el documento. Posiblemente los judíos vecinos de los dos primeros núcleos, si es que los había, se encuadraban fiscalmente en las aljamas de estos dos pueblos vecinos.

El panorama del poblamiento judío en la comarca cambió sustancialmente desde los primeros años del siglo XIV. En el caso concreto de Aranda lo observamos en la primera referencia documental directa a la población judía de esta villa datada el 6 de mayo de 1326. Se trata de un privilegio de Alfonso XI que permitía el traslado del día de mercado del sábado al lunes, argumentando que al ser el primero día festivo para los judíos, éstos no podían participar, circunstancia que iba en detrimento del óptimo desarrollo del mismo ${ }^{1359}$. Además del evidente interés económico de la medida, esta concesión debemos encuadrarla dentro de la iniciativa regia de reorganización del poblamiento mediante la cual se pretendía potenciar la posición de las villas de realengo frente al creciente poder señorial en la comarca ${ }^{1360}$. Por otra parte, este privilegio es un incentivo más dentro de la política pro-judía llevada a cabo en los primeros años del reinado de Alfonso XI, quien tomó una serie de medidas en favor de los judíos para salvar el daño -se entiende sobre todo económico- causado por la masiva marcha de los hebreos desde los lugares de realengo a los de señorío ${ }^{1361}$.

Nada sabemos de la situación de la población judía en la Ribera en los conflictivos años finales del siglo XIV. Sin embargo, el gran desarrollo y dinamismo de la comarca a lo largo de toda la decimoquinta centuria se vio acompasado con el de la comunidad hebrea como lo muestra la abundante documentación que hace referencia a este grupo ${ }^{1362}$.

ra del Alto Duero (1486-1502), Burgos, 2005; MONSALVO ANTÓN, J. M., "Herejía conversa y contestación religiosa a fines de la Edad Media. Las denuncias a la Inquisición en el Obispado de Osma", en Studia Historica. Historia Medieval. 2, 1984, pp. 109-138; y PERIBÁÑEZ OTERO, "Violencia y espacio urbano..., pp. 25-42.

1358 AMADOR DE LOS RÍOS, J., Historia social, política y religiosa de los judíos de España y Portugal. Madrid, 1875-76 (reed. 1973), pp. 916-931.

${ }^{1359}$ VELASCO PÉREZ, Aranda. Memorias..., pp. 61-62. Tan solo conocemos la reseña aportada por este autor pues el documento original ha desaparecido del Archivo Municipal.

${ }^{1360}$ PERIBÁÑEZ OTERO y ABAD ÁLVAREZ, Aranda de Duero..., pp. 27-36.

1361 SUÁREZ FERNÁNDEZ, L., Judios españoles en la Edad Media. Madrid, 1980, pp. 171172.

${ }^{1362}$ La mayor parte de la documentación ha sido sistemáticamente recogida por CADIÑANOS 
Baste como ejemplo la información que trasmite el Repartimiento hecho a los judíos en el año 1474 por Rabí Jacob Aben-Núñez, Juez Mayor de los judíos y físico de Enrique IV. En este documento se recoge que los de Coruña pagaron 4.000 maravedíes, los de Aranda abonaron 3.000, los de Peñaranda 1.700, los de Roa 1.000 y los Gumieles en su conjunto $750^{1363}$. Es significativo que la suma de la aportación de la comunidad judía ribereña tan sólo fue superada por las aportaciones de Ávila y Segovia. Además se aprecia que la mayor cantidad de población se concentraba en la villa de Coruña, relegando a un segundo lugar a la capital ribereña.

Según el profesor Cantera Montenegro, la población judía en la villa de Aranda hacia 1486 estaría entorno a los 220 individuos a tenor de los 37 pechos que contribuyeron en el servicio del castellano de oro. Estaríamos hablando por lo tanto de un 5\% de la población total de la villa ${ }^{1364}$.

Como ya hemos mencionado anteriormente, hasta 1480 la mayor parte de los judíos arandinos vivían agrupados en una de las zonas de expansión del siglo XV, la calle Barrionuevo, más concretamente en entorno a su sinagoga, en las proximidades de la calle del Pozo ${ }^{1365}$. Con el apartamiento decretado en 1480 los monarcas comisionaron al visitador Juan Ortega de Carrión para que estableciera un espacio apropiado para confinar a las poblaciones hebrea y mudéjar ${ }^{1366}$. La comunidad judía al completo fue obligada a trasladarse a un espacio marginal, el Hoçino ${ }^{1367}$. Allí mismo trasladaron también la sinagoga, escuela, carnicería y sus negocios. No obstante, el confinamiento no impidió que algunos judíos siguieran manteniendo importantes propiedades inmuebles fuera de la

BARDECI y CANTERA MONTENEGRO en los artículos relacionados anteriormente.

${ }^{1363}$ AMADOR DE LOS RÍOS, Historia social..., pp. 996-1003. Este documento se complementa con otro parcial de 1472 en que se establecía el pago de la aljama de Aranda en 2.100 maravedíes, la de Roa en 1.000, la de Peñaranda en 1.700 y los Gumieles en 600 (AGS, CC DIVERSOS, leg. 8, doc. 125).

${ }^{1364}$ CANTERA MONTENEGRO, “Las comunidades..., p. 130.

${ }^{1365}$ En el pleito sobre la apertura de la calle de Barrionuevo comenzado en 1503 los vecinos de la calle insistían en señalar que las casas que debían ser derribadas formaron parte de la judería antigua de la villa. Incluso Sancho de la Peña, sobrino de uno de los propietarios de las casas y primo de uno de los implicados, señalaba: ... en la calle Barrio Nuevo bivian muchos judios e otros en otras partes de esta villa (AGS, CR, leg. 39, doc. 3; transcrito por PERIBÁÑEZ OTERO Y ABAD ÁLVAREZ, Aranda de Duero..., pp. 174-176).

${ }^{1366}$ AGS, CC PUEBLOS, leg. 2, doc. 61.

${ }^{1367}$ Diego de Córdoba declaraba en 1503 que ...trabajo en echallos de la dicha calle de Barrio Nuevo e los llevaron a la calle de Santana (AGS, CR, leg. 39, doc. 3; transcrito por PERIBÁÑEZ OTERO y ABAD ÁLVAREZ, Aranda de Duero..., pp. 160-161). 
judería como fue el caso de doña Bienvenida que conservó un par de casas en San Juan o Yuçe de Soto que mantuvo la propiedad de unas casas en Cascajar hasta su partida en $1492^{1368}$

La población judía de Aranda estaba constituida como una aljama y como tal se relacionaba con la Corona en aquellos asuntos que incluía al conjunto de los judíos arandinos. Así, por ejemplo, se constata en la petición que se formuló en 1486 para que se permitiera al carnicero de la comunidad mantener 120 cabezas de ganado anuales en los pastos comunales y que se abriera un portillo en la cerca que permitiera evacuar las aguas residuales que se retenían entre la judería y el lienzo de la muralla ${ }^{1369}$. Esta aljama judía seguramente disfrutó en principio de instituciones propias, pero con el paso del tiempo fueron perdiendo esta autonomía, y así en 1476 fueron los alcaldes del concejo los que intervinieron en la resolución de un conflicto familiar por la herencia de la familia Soto $^{1370}$.

A buen seguro que la comunidad judía de Aranda, de la que dependían el resto de las comunidades vecinas, contó entre sus miembros con algún rabino que ostentaba la máxima autoridad, cuando menos en el plano religioso. Prueba de ello es que tenemos constancia de que en la villa debió existir una escuela talmúdica a tenor de la presencia de al menos un estudiante judío a finales de los años setenta ${ }^{1371}$.

Mucho se ha escrito sobre la vinculación de los judíos con los negocios del dinero, sobre todo aquellos relacionados con el arrendamiento de rentas o el oficio de prestamista. Una ligera aproximación a la documentación permite deducir que tanto los arrendamientos como los préstamos que realizaban los judíos ribereños se localizaban en el entorno próximo. Por ejemplo, Yuçe de Soto se dedicó al arrendamiento de algunas de las rentas de la villa de Aranda como las tercias o los pontificales; por su parte la familia Bienveniste tuvo participación en las rentas concejiles ${ }^{1372}$. En lo que se refiere a los préstamos es

${ }^{1368}$ AGS, RGS, 148906, fol. 167; y 149205, fol. 510. Doña Bienvenida era la mujer de Yuçe de Soto.

1369 AGS, RGS, 148607, fols. 71 y 72; el primero de ellos transcrito por CADIÑANOS BARDECI, “Judíos y moros..., doc. 2, pp. 42-43.

${ }^{1370}$ AGS, RGS, 147607, fol. 515.

${ }^{1371}$ Abraham Taytaça sugirió a la mujer de su patrón cristiano que pagara a un judío para que ayunara por ella y así sanar de unas llagas que tenía en las piernas. El elegido fue un judio estudiante pero el testigo no recuerda su nombre salvo como era judio estudiante e estaba alli, en Aranda (CARRETE PARRONDO, Fontes Iudaeorum..., doc. 378, pp. 158). fol. 222

1372 CANTERA MONTENEGRO, “Una familia de prestamistas..., p. 15; y AGS, RGS, 148502, 
significativo que buena parte de ellos se contrataron con cristianos de los pueblos de la comarca por cantidades reducidas, lo que hace pensar que se trataba del recurso de los pequeños campesinos ante las consecuencias de una mala cosecha ${ }^{1373}$. En este sentido destaca el estudio del profesor Cantera Montenegro sobre la familia Soto y la aproximación del profesor Ladero Quesada a los bienes y deudas de los judíos arandinos en los momentos previos a la expulsión ${ }^{1374}$. No es nuestra intención insistir en este asunto que ha quedado de sobra explicado en los trabajos anteriormente citados, pero sí que creemos necesario recalcar la vinculación de estas familias con el comercio del vino. Para hacernos una idea del peso que tenía Yuçe de Soto en el mercado del vino en Aranda baste señalar que cuando fue detenido a mediados de los ochenta por un problema con el arrendador Juan de Figueroa le fueron requisadas 7.000 cántaras que se encontraban almacenadas en su bodega. Aprovechando la coyuntura, uno de los socios de Soto que tenía en depósito en sus bodegas 1.500 cántaras se las apropió y vendió sin rendirle cuentas a Soto $^{1375}$.

Pero además de los Soto también participaron del negocio financiero y comercial otras familias e individuos. Fue el caso de la familia Bienveniste, originaria de la vecina localidad de Coruña del Conde. Una rama de esta familia encabezada por don Symuel se asentó en la capital de la Ribera a comienzos de los años ochenta. Su radio de acción no sobrepasó el ámbito comarcal y sus hijos Jacob e Isaac continuaron el negocio paterno ${ }^{1376}$. Este clan familiar centró su actividad tanto en el arrendamiento de rentas como en la gestión de préstamos a particulares, en especial a notables comerciantes arandinos, pero también a comunidades aldeanas. Este segundo caso puede ejemplificarse en sendos préstamos que don Symuel hizo al lugar de Moradillo para proceder a su reconstrucción tras haber quedado el pueblo arrasado después de la guerra con Portugal ${ }^{1377}$. De igual

${ }^{1373}$ CANTERA MONTENEGRO, "Pleitos de usura..., pp. 597-622.

1374 CANTERA MONTENEGRO, "Una familia de prestamistas...; y LADERO QUESADA, "Deudas y bienes...

1375 AGS, RGS, 148709, fol. 111. Si a esto sumamos los casi 140.000 maravedíes que tenía depositados en préstamos personales en la comarca antes de su exilio nos podemos hacer una idea del potencial económico de este individuo y su familia (LADERO QUESADA, "Deudas y bienes..., p. 289).

${ }^{1376}$ AGS, RGS, 148410, fol, 109; y 148502, fol. 222.

1377 AGS, RGS, 149402, fol. 311. Los vecinos de Moradillo solicitaron muchos años después, cuando don Symuel había abandonado el reino, que los fiadores del judío les devolvieran la usura cobrada por Bienveniste. 
manera, aunque disfrazada de compraventa de cereal, a principios 1477 don Symuel prestó dinero al lugar de Monterrubios de la Demanda con la condición de que se lo devolviera en mayo $^{1378}$. Evidentemente, estos datos los conocemos por el incumplimiento de alguna de las partes que, o bien el prestatario no abonó la devolución en el plazo marcado, o bien el prestamista sobrepasó el límite de la usura.

De igual manera que los Soto diversificaron sus actividades financieras invirtiendo en el negocio de la compraventa del vino, Rabí Ça también se dedicó a este negocio, así como al arrendamiento de rentas y el préstamo, aunque a una escala mucho más $\operatorname{modesta}^{1379}$.

Por su parte Tristán de Arcilla, nombre que adquirió tras su conversión, siguió la misma política diversificadora de los anteriores. A sus actividades financieras de préstamos y depósito de dinero se sumó el negocio de la venta de paños, bajo el genérico término de trapero ${ }^{1380}$.

Pero además del negocio del dinero o el gran mercado del vino, hay otras actividades que también eran desarrolladas por judíos en la villa arandina. El oficio de médico, físico o cirujano está tradicionalmente asociado a la comunidad hebrea y en Aranda se confirma este tópico pues buena parte de los médicos y cirujanos que conocemos eran judíos o recientemente se habían convertido. El primer testimonio que conocemos al respecto nos lo otorgan las actas concejiles de la ciudad de Burgos donde aparece mencionado un judío arandino con el oficio de cirujano ${ }^{1381}$. Más tarde también ejercieron como médicos mosén Lope de Uzedo y maestre Antonio, llamado Rabí Salomón antes de su conversión ${ }^{1382}$. A este colectivo sanitario pertenecían asimismo

1378 AGS, RGS, 148011, fol. 71.

${ }^{1379}$ AGS, CONSEJO Y JUNTAS DE HACIENDA, leg. 1, doc 61.

${ }^{1380}$ AGS, CC PERSONAS, leg. 2, doc. 200.

${ }^{1381}$ CADIÑANOS BARDECI, “Judíos y moros..., p. 56; y CANTERA MONTENEGRO, “Las comunidades..., p. 140.

1382 AGS, CC PUEBLOS, leg. 2, doc. 100; y CARRETE PARRONDO, Fontes Iudaeorum..., docs. 59 y 194, pp. 82 y 94. De la misma manera, maestre Juan y maestre Diego fueron cirujanos y físicos de Coruña del Conde (doc. 183, p. 90), y maestre Carlos, antes llamado Yuçe Lavan, ejerció como médico en Roa (CANTERA MONTENEGRO, "Notas para la expulsión..., p. 62). 
algunas ancianas judías que gozaban de fama de sanadoras y ofrecían sus servicios a todos los vecinos ${ }^{1383}$.

Los judíos arandinos también se dedicaron a los más variados y comunes trabajos artesanales como podía ser el de zapateros, sastres, tejedores, etc.; pero también otros menos comunes como el de ballestero o vidriero ${ }^{1384}$.

Cierto es que varios de los judíos arandinos, sobre todo los más pudientes, fueron propietarios de tierras, pero no hemos documentado ninguna referencia al trabajo del campo por parte de ningún miembro de la aljama hebrea de esta localidad ${ }^{1385}$.

El profesor Cantera Montenegro ha estudiado en varias ocasiones el proceso de expulsión de los judíos oxomenses y en concreto de los arandinos ofreciendo una visión de conjunto de notable calidad $^{1386}$. Un importante sector de la comunidad hebrea optó por la conversión pero la mayor parte se mantuvo fiel al judaísmo y se decantó por exiliarse en tierras portuguesas. Al trauma de la expulsión se sumaron los serios problemas que tuvieron para poder vender sus propiedades y cobrar sus deudas, convirtiéndose sus títulos de propiedad y contratos de préstamo en el codiciado objeto del deseo de numerosos especuladores. Las numerosas intervenciones de la Corona para garantizar la venta de sus bienes y su seguridad resultaron en buena medida infructuosas, generando multitud de conflictos que se dilataron durante bastantes años ${ }^{1387}$. Hasta tal punto llegó la situación que los mo-

${ }^{1383}$ Era el caso de doña Lunbre que desarrolló su actividad en los años ochenta en la villa de Aranda. Entre sus clientes se encontraban tanto judíos como cristianos. La madre de maestre Antonio además tenía fama de adivina (CARRETE PARRONDO, Fontes Iudaeorum..., doc. 230, p. 106; y doc. 59, p. 82).

${ }^{1384}$ Las declaraciones de los acusadores ante la Inquisición son muy ricas en informaciones sobre los oficios que desempeñaban los judíos y, sobre todo, los conversos. Entre todos ellos nos ha llamado la atención Pedro de Madrid, de oficio vallestero, que primero se convirtió, después fue acusado ante el Santo Oficio y finalmente reconciliado por el tribunal inquisitorial. Creemos que bajo esta denominación se encontraba el artesano dedicado a la fabricación de este arma y no tanto el oficio militar, sobre todo porque quien le denunció fue Pedro Espadero (CARRETE PARRONDO, Fontes Iudaeorum..., doc. 298, p. 128). Por su parte, el judío Leví se dedicaba al trabajo del vidrio (AGS, RGS, 149111, fol. 114).

1385 CADIÑANOS BARDECI pone en contraposición esta circunstancia con la de las juderías del Norte de la provincia donde sí que se documenta a judíos trabajando como agricultores ("Judíos y moros en el Duero..., p. 65).

${ }^{1386}$ En especial en "Notas sobre la expulsión..., y en detalle para el caso arandino en "La comunidad..., pp. 146-152.

${ }^{1387}$ La confiscación general de los bienes y deudas de los judíos decretada por los Reyes Católicos tras la expulsión de los judíos dio paso a pesquisas particulares como la que realizó entre 1494 y 1496 Alonso del Castillo sobre los bienes y deudas de los judíos en los territorios de Aranda, Coruña del Conde y Peñafiel. El pesquisidor resolvió que el cargo total de lo confiscado en la comarca ascendía a la nada despreciables cifra de 569. 310 maravedíes (LADERO QUESADA, “Deudas y bienes..., pp. 289). 
narcas comisionaron al bachiller Alonso de Torres para que velase por los intereses de los judíos ribereños, en especial de la familia Soto, e incluso los acompañara hasta la frontera portuguesa para garantizar su seguridad ${ }^{1388}$. Además de la familia Soto, otros arandinos también emprendieron el camino del exilio hacia Portugal como don Jacob Aben Simón, modesto prestamista que desarrolló su actividad en la comarca ribereña ${ }^{1389}$, o Jaco Abaro $^{1390}$

Algunos de los que marcharon resolvieron retornar poco tiempo después. El caso más conocido de los tornadizos es el del coruñés Yuçe de Valladolid que, tras bautizarse en Zamora y recibir el nombre de Pedro Núñez de Santa Fe, volvió a su tierra y se enfrentó con todos aquellos clientes que daban la deuda por saldada ${ }^{1391}$. Entre los que volvieron también se encontraban Francisco Calderón y otro Francisco que, tras pasar una temporada como aprendices de un zapatero arandino, emigraron a Coruña del Conde y Pinilla Trasmonte respectivamente ${ }^{1392}$. Asimismo Tristán de Arcilla parece ser un tornadizo que, tras recomponer su hacienda, emprendió la aventura de contratar una embarcación para ir en busca de otros tornadizos al puerto de Larache ${ }^{1393}$. Entre los tornadizos también se encontraban los ribereños Juan de Coimbra, tabernero de Fuentenebro; Fernando, vecino de Coruña y hermano de Moisés Hen; y Fernando García, vecino de Roa y comerciante de lino ${ }^{1394}$.

Después de la conversión la vida no fue más fácil para estos antiguos judíos. A la anterior discriminación y marginación de carácter religioso, se sumó un sistemático rechazo, esta vez asentado en la acusación de falsa conversión. En este contexto, la situación de los conversos se precarizó aun más con el recurso cotidiano y sin ningún tipo de pudor al componente racial que se manifestaba en insultos y amenazas espontáneas,

${ }^{1388}$ AGS, RGS, 149205, fol. 526.

${ }^{1389}$ Previamente se trasladó a Torregalindo. El alcaide de esta villa trató de cobrar a sus deudores tras la salida del judío a pesar de que algunos de ellos ya habían hecho efectivo el pago (AGS, RGS, 149209, fol. 263).

${ }^{1390}$ Así se deduce de las obligaciones de préstamo que cedió a maestre Tomás, vecino de El Burgo de Osma (LADERO QUESADA, “Deudas y bienes..., pp. 285-286).

${ }^{1391}$ AGS, RGS, 149208, fol. 89.

${ }^{1392}$ CARRETE PARRONDO, Fontes Iudaeorum..., doc. 176, p. 88.

${ }^{1393}$ AGS, RGS, 149509, fol. 205.

${ }^{1394}$ CARRETE PARRONDO, Fontes Iudaeorum..., doc. 149, p. 78; doc. 319, p. 134. 
pero también en la generalización de normas más complejas como fueron los estatutos de limpieza de sangre ${ }^{1395}$. Este aspecto de los conversos y la conflictividad social que generó será abordado con detenimiento más adelante.

\section{b. Mudéjares.}

No sabemos nada sobre el origen de la comunidad islámica en la Ribera. Tan solo la tenemos documentada desde finales del siglo XV y casi exclusivamente en las villas de Aranda, Peñaranda y Coruña. El profesor Ladero Quesada estima que en 1495 la población mudéjar arandina rondaría los 145 individuos, mientras que en Peñaranda no pasarían de medio centenar. Sin embargo, el profesor Cantera Montenegro aumenta en el caso arandino su número hasta los 200 mudéjares $^{1396}$. El volumen documental que hace referencia a esta comunidad es infinitamente menor al aportado por la hebrea, aspecto que ha condicionado notablemente todos los estudios que se han realizado. Esta escasa información, así como el reducido espacio físico de la primera morería arandina, justo detrás del cementerio de San Juan y constreñida por la proximidad de la cerca, nos hace pensar que no debía ser muy numerosa en el periodo anterior a $1480^{1397}$.

La disposición que ordenaba el confinamiento de los mudéjares que se tomó en las Cortes de Toledo de 1480 fue ejecutada poco después por el provisor Juan Ortega de Carrión ${ }^{1398}$. El delegado real eligió para el nuevo asentamiento de la morería un espacio extramuros en el arrabal de Allendeduero y allí fue trasladada toda la comunidad ${ }^{1399}$. Seguramente allí mismo se instalaron las carnicerías propias de la aljama ${ }^{1400}$. Con el paso

${ }^{1395}$ Ya en 1493 el Consejo Real envió una misiva a los corregidores y justicias del obispado de Osma conminando a castigar a todos los que insultaran a los conversos que habían vuelto del exilio portugués (AGS, RGS, 149310, fol. 146).

${ }^{1396}$ LADERO QUESADA, M. A. "Los mudéjares en Castilla", en Historia. Instituciones. Documentos. 5, 1978, pp. 257-304. CANTERA MONTENEGRO, "Las comunidades..., pp. 136-152. También hemos documentado alguna pequeña comunidad mudéjar en la Tierra de Montejo, posiblemente en Valdeherreros, a través de las declaraciones de un vecino de Fuentenebro que dice ...yendo del dicho lugar de Valdeherreros en compañía de unos moros a la dicha villa de Aranda, aunque bien pudieran ser arandinos que se encontraran por la zona prestando sus servicios (AGS, CR, leg. 22, exp. 1). leg. $\mathrm{X}$, doc. 1).

${ }^{1397}$ En el plano de 1503 todavía se identificaba este espacio como la moreria vieja (AGS, MPD,

1398 VILLANUEVA ZUBIZARRETA, O., "Regulación de la convivencia con los mudéjares en las ciudades de la cuenca del Duero", en La convivencia en las ciudades medievales. Logroño, 2008, pp. 351-367.

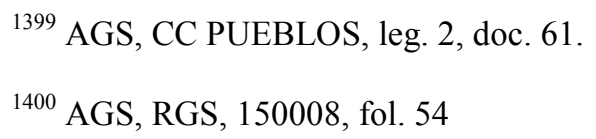


del tiempo este espacio fue rodeado de una cerca provista de dos puertas que se cerraban por las noches ${ }^{1401}$. En el reducido espacio que existía entre la morería y el río Duero se instaló su fonsario o maqbara ${ }^{1402}$. Sin embargo, algunos de sus negocios mantuvieron su anterior ubicación pues se trataba sobre todo de talleres relacionados con la metalurgia y el trabajo del metal.

La aljama mora de Aranda, como las del resto de Castilla, tenía su propio alcalde que se encargaba de impartir justicia entre la población musulmana ${ }^{1403}$. Este oficio está bastante bien documentado desde 1486 cuando fue nombrado para ocupar el oficio maestre Hamete de Torres, herrero de profesión, que lo ejerció hasta $1494^{1404}$. Tras la muerte de Torres, ocupó el cargo maestre Yuça ${ }^{1405}$. Las disputas internas dentro de la comunidad mudéjar llevaron a alguno de sus miembros a enfrentarse directamente con el alcalde y preferir la justicia ordinaria ante la severidad o parcialidad del alcalde mudéjar ${ }^{1406}$. En el fondo lo que se aprecia es una progresiva injerencia de las autoridades concejiles en la autonomía jurídica de la aljama como lo pone de manifiesto que el alcalde de moros tuviera que impartir justicia acompañado de un alcalde de la villa primero y después del corregidor $^{1407}$. Por lo que se refiere al alfaquí de esta comunidad sabemos que a mediados de la década de los ochenta ejercía como tal maestre Abdalla de Muño, aunque alguno de sus correligionarios le acusaba de que no sabe bien los secretos de su ley. En septiembre de

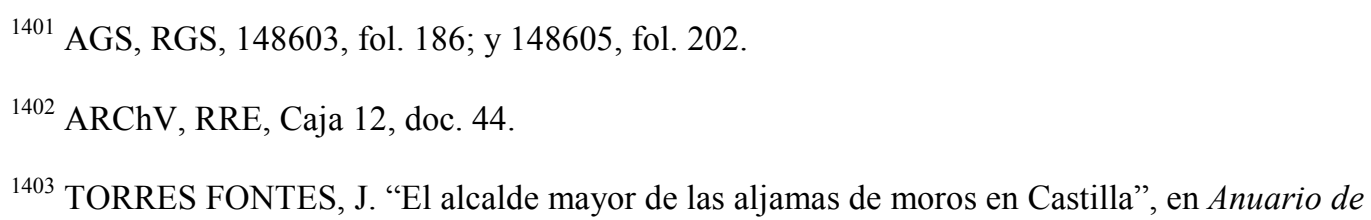
Historia del Derecho Español. XXXII, 1962, pp. 131-182. En el caso arandino las competencias de este oficio se confunden con las del alfaquí, que aunque su función era la de especialista en la ley islámica, también se ocupaba de los asuntos jurídicos de fuero interno a la comunidad (CANTERA MONTENEGRO, "La comunidad..., pp. 136-139).

${ }^{1404}$ AGS, RGS, 148606, fol. 148.

1405 AGS, RGS, 149402, fol. 21, transcrito por CADIÑANOS BARDECI, “Judíos y moros..., doc. 6, p. 46.

${ }^{1406}$ El enfrentamiento se mantuvo durante varios años a pesar de las sucesivas sustituciones del alcalde (AGS, RGS, 148801, fol. 217; 149008, fol. 61 y 149509, fol. 130).

${ }^{1407}$ AGS, RGS, 149007, fol. 249; 149205, fol. 302; 149607, fol. 196. Estos conflictos han sido analizados con profundidad por CANTERA MONTENEGRO, “La comunidad..., pp. 136-139. 
1485 los monarcas delegaron en las justicias arandinas para que solucionaran el problema como creyeran oportuno ${ }^{1408}$.

En cuanto a las ocupaciones profesionales de los mudéjares arandinos, los estudios realizados recurren a los tópicos para tratar de subsanar las escasas aportaciones de la documentación existente. De la profesión de alarife tan solo tenemos una referencia señalada por Cadiñanos Bardeci que cita a un tal Mohamed de Aranda al que el concejo burgalés abonó ciertas cantidades por la construcción de unas casas ${ }^{1409}$. La otra actividad tradicionalmente asociada a la comunidad mudéjar es la alfarería y la arandina participa de esta característica al menos con la ocupación de Ahudalla, alcaller ${ }^{1410}$. Además hemos constatado la existencia de barreros de los que se obtenía la arcilla, aunque estaban en manos de cristianos ${ }^{1411}$.

También tenemos constancia de actividad textil entre los mudéjares arandinos. Maestre Abdalá tenía el oficio de sastre ${ }^{1412}$ y además tenemos el testimonio de un vecino que afirmaba que alguna tejedora cristiana avia ydo a jornal a la moreria... a ganar jornal en fiestas e domingos ${ }^{1413}$.

La actividad en la que se especializaron los mudéjares arandinos fue la relacionada con la metalurgia, en concreto la herrería y la calderería. De la importancia de la producción arandina nos da cuenta Braen de Arévalo, herrero de San Esteban de Gormaz, que declaraba ...como en Aranda hay botica publica e cursada e contratación de dicho oficio y le es necesario ir a la dicha villa a comprar en la dicha botica las cosas necesarias para su oficio ${ }^{1414}$. Algunos de estos profesionales poseían sus fraguas y acicates fuera del área específica de la morería, situación que provocó la protesta de los herreros

${ }^{1408}$ AGS, RGS, 148509, fol. 130; y CANTERA MONTENEGRO, “La comunidad..., p. 138.

${ }^{1409}$ CADIÑANOS BARDECI, “Judíos y moros..., p. 31. No obstante, es necesario remarcar la posibilidad de que este Aranda tenga que ver más con Aranda del Moncayo donde efectivamente existió una gran tradición de alarifes mudéjares itinerantes (GARCÍA MARCO, F. J., Las comunidades mudéjares de la Comarca de Calatayud en el siglo XV. Zaragoza, 1993).

${ }^{1410}$ CARRETE PARRONDO, Fontes Iudaeorum..., doc. 375, p. 157.

${ }^{1411}$ AGS, CMC, leg. 355.

1412 ARChV, RRE, Caja 12, doc. 44.

${ }^{1413}$ CARRETE PARRONDO, Fontes Iudaeorum..., doc. 311, p. 132. Juana era aprendiz de tejedora en el taller de Alonso Sebastián. La mujer de Sebastián la enviaba a la morería y después recibía el jornal de la muchacha.

${ }^{1414}$ AGS, RGS, 149004, fol. 130. 
que tenían su negocio en la morería pues los que se desplazaban fuera aprovechaban para vivir en ellas y, según los denunciantes, obtenían mayor beneficio. Finalmente las autoridades dieron permiso para tener el negocio fuera de la morería pero con la condición de que durmieran en la morería ${ }^{1415}$. Resulta cuanto menos curioso que fuera el propio alfaquí el que incumpliera la norma y las autoridades le recordaron de nuevo en 1490 la prohibición de vivir en la fragua y su obligación de dormir en la morería ${ }^{1416}$.

La situación de la morería en el arrabal de Allendeduero, en un punto estratégico donde se cruzaban los caminos que llevaban a Valladolid, El Burgo de Osma, Segovia y Burgos, propició el desarrollo entre algunos miembros de la comunidad mudéjar de una importante actividad comercial. Pero su rápida y próspera expansión chocó con los intereses de los comerciantes cristianos que tenían sus establecimientos en este arrabal y que no tardaron en solicitar a las autoridades municipales que pusieran fin a esta competencia como efectivamente hicieron ${ }^{1417}$. A título individual otros mudéjares arandinos también se dedicaron al comercio a una escala mayor como fue el caso de Ibraim Zulema cuyo negocio se centraba en la venta de ganado en lugares tan alejados como Soria ${ }^{1418}$.

Frente a la visión tradicional que presenta a los mudéjares con una posición económica modesta, constatamos la existencia en la aljama arandina de ciertos individuos con una posición económica destacada. Fue el caso de maestre Mohamad que se prodigó en actividades financieras como se aprecia en un contrato de préstamo por valor de 20.000 maravedíes que firmó con una familia cristiana de comerciantes de paños en $1485^{1419}$. Otro ejemplo es el maestre Abdalla que en los momentos previos a la conversión vendió cuatro pares de casas con su corral, más un palomar y un huerto con su noria localizados en el arrabal de Allendeduero a Francisco de Mena por 40.000 maravedíes $^{1420}$. Esta situación de

1415 AGS, RGS, 148312, fol. 173, documento transcrito por CADIÑANOS BARDECI, “Judíos y moros..., doc. 7, p. 47.

${ }^{1416}$ AGS, RGS, 149004, fol. 169.

${ }^{1417}$ AGS, CC MEMORIALES, leg. 163, doc. 57.

${ }^{1418}$ Zulema denunció que el alcalde de las sacas del obispado de Osma en Soria le había requisado indebidamente siete vacas (ARChV, RRE, Caja 134, doc. 26). Otro moro arandino no identificado se dedicaba a la venta de equinos (AGS, CC CÉDULAS, libro 2-1, leg. 33, doc. 4).

${ }^{1419}$ En concreto con los hermanos García de Calahorra (AGS, RGS, 148506, fol. 127).

${ }^{1420}$ AGS, EMR, leg. 560. 
desigualdad en el seno de la comunidad mudéjar era perfectamente percibida por los propios mudéjares que por medio de maestre Mahomed informaron a los monarcas de que la mayoría de los moros de Aranda eran pobres y tan solo tenían lo que ganaban con sus manos, mientras que los más ricos contaban con el favor de algunos notables de la villa, agraviando a los más pobres queriéndoles hacer pagar lo mismo que ellos, tanto en lo referente al servicio de los mantenimientos de los moros, como en el servicio y medio servicio y en los otros pechos. Los monarcas ordenaron investigar la denuncia pero no sabemos cuál fue el resultado ${ }^{1421}$.

Tradicionalmente se ha supuesto que en 1502 la conversión de los mudéjares fue masiva. En el caso ribereño tenemos escasas noticias sobre los mudéjares convertidos al cristianismo o moriscos. Tan solo conocemos dos casos: maestre Lope de Maderuelo que aparece como nuevo cristiano, antes moro, en el arrendamiento de la renta de los aires de 1492; y maestre Abdalla que en 1502 se convirtió y adquirió el nombre de Juan Carrillo. En 1517 se le denominaba como Carrillo, herrero, morisco, veçino de Aranda ${ }^{1422}$. Otros testimonios indirectos muestran la permanencia de población morisca en los primeros años del siglo XVI. Así, por ejemplo, el provisor de Osma mostraba su interés en 1531 para que se llevara el control de los asistentes a los oficios así como su participación en la comunión y la confesión, haciendo especial hincapié en la vigilancia sobre los moriscos ${ }^{1423}$. De finales de siglo tenemos noticias de la existencia de varias familias moriscas en la villa que se reducen a catorce en el censo realizado previamente a la expulsión de 1609. En la relación de los moriscos expulsados a Francia se cita tres casas y doce individuos de Aranda, y en una relación elaborada ese mismo año se afirma que: En este corregimiento (Aranda y Sepúlveda) y en la villa de Ayllón ay siete casas que todas se an quedado, por aver dado ynformaçiones de buenos cristianos ${ }^{1424}$.

\footnotetext{
${ }^{1421}$ AGS, RGS, 150008, fol. 116.

${ }^{1422}$ AGS, EMR, leg. 571; EH, leg. 4; y CARRETE PARRONDO, Fontes Iudaeorum..., doc. 444, p. 182.

${ }^{1423}$ ADB, LIBRO DE FÁBRICA DE SANTA MARÍA, Libro I, s.f.

${ }^{1424}$ CADIÑANOS BARDECI hace referencia a un proceso inquisitorial contra una docena de moriscos arandinos en 1594 ("Judíos y moros..., p. 32); y CANTERA MONTENEGRO aporta el dato del censo de 1609 y las relaciones de 1610 ("Las comunidades..., p. 152).
} 


\section{c. Esclavos.}

Para terminar este apartado dedicado a los marginados no quisiéramos dejar de mencionar al escueto número de esclavos que había en la villa arandina durante este periodo. Al igual que ocurre en buena parte de la Castilla peninsular, los esclavos eran considerados más bien un objeto de lujo asociado al prestigio social y, por lo tanto, sin la connotación productiva que tuvo en otros momentos históricos. Por lo tanto, la existencia de esclavos debe ser entendida como una evidencia más del destacado poder económico que sus propietarios tuvieron en este periodo. El hecho de que fueran un reflejo del prestigio social de sus amos no mengua su condición de seres marginales. Prueba de su situación de marginalidad, cuando no de total y absoluta desconsideración hacia el género humano, es que en el inventario de los bienes que el regidor Francisco de Mena puso como fianza para la puja sobre las rentas de Molina, la esclava blanca y su hijo de ocho años fueron enumerados junto al resto de animales de su cuadra, las dos mulas de silla, un caballo y un acémila, otorgando al conjunto un valor de 180.000 maravedíes ${ }^{1425}$.

Evidentemente la consideración de objeto se perdía cuando se reconocía que el esclavo tenía alma y esto fue lo que le ocurrió a Lope de Durango que en 1492 compró un esclavo canario bautizado, llamado Alonso de la Gomera, a su pariente García de Sedano por 10.000 maravedíes. En 1494 la autoridad real le requisó el esclavo porque era cristiano y se había ordenado que todos los canarios que fueron cautivos en la isla de la Gomera fueran liberados. Durango, indignado, acudió a la justicia para reclamar que se le devolviera lo que pagó. La justicia real admitió la demanda y tras el juicio ordenó que le fuera devuelta la cuantía pagada, estimando que nunca debió ser vendido como esclavo al ser libre como el resto de los canarios de esa isla ${ }^{1426}$.

Este mismo sentimiento de estafa fue el que Catalina Daza, viuda del capitán y regidor Bernardino del Valle, sintió cuando comprobó que la esclava india que había comprado por 7.000 maravedíes a Juan de Gumiel en 1525 ...estava enferma en sy hinchada e avia estado e estava al tiempo que se la vendio e otras muchas enfermedades que tenia en la persona de la dicha esclava e mançillas en el cuerpo de donde proçedian las dichas enfermedades. Tras la denuncia interpuesta por la compradora, el corregidor sentenció que Gumiel debía recibir a la esclava y devolver el montante de la compraventa

\footnotetext{
${ }^{1425}$ AGS, EMR, leg. 571.

${ }^{1426}$ AGS, RGS, 149407, fol. 277.
} 
a Daza ${ }^{1427}$. Suponemos que por algo similar fue el pleito que mantuvieron por esas mismas fechas el bachiller Ventosilla y Marina de Quemada, su mujer, con Juan de la Cueva a causa de la propiedad de un esclavo ${ }^{1428}$. Resulta cuanto menos curioso que Valle y Ventosilla coincidieran pleiteando por una posesión de lujo, como eran por entonces los esclavos, cuando pocos años atrás se habían enfrentado enconadamente en el contexto del conflicto comunero. También el comunero Francisco de Torquemada era propietario de un esclavo granadino llamado Domingo que fue requisado junto a todos sus bienes. El tal Domingo pudo demostrar que era libre (horro) y fue puesto en libertad por los administradores de los bienes confiscados ${ }^{1429}$. De igual manera Gaspar de Mansilla, otro destacado activista comunero, poseía una esclava que fue valorada en 12.000 maravedíes por los factores que secuestraron sus bienes en $1521^{1430}$. Tenemos otros testimonios que confirman la existencia de más esclavos en Aranda, aunque no son más que menciones sin ningún tipo de información complementaria como el que pertenecía al converso Fernando de Ayllón ${ }^{1431}$.

Para terminar con este capítulo dedicado a los esclavos nos vamos a centrar en una huida que tuvo como protagonista el territorio de la Ribera y a un avispado vecino arandino. En el año 1500 un esclavo loro (mulato) llamado Francisco, propiedad del mercader vallisoletano Pedro de Alcoz, se escapó de la villa de Medina de Rioseco y hurtó a su propietario parte de su hacienda con la que se compró un caballo y varios pertrechos. En su huida llegó Aranda y allí adquirió otro caballo más algunos pertrechos para marcharse del reino. Un alcalde de Aranda tuvo noticias de la huida y mandó prenderlo, pero el fugitivo ya había comenzado la marcha. Ante esta situación, la autoridad comisionó a un vecino para que fuera en su búsqueda. Pasadas cuatro o cinco leguas, el vecino dio alcance al esclavo y lo detuvo, pero cuando estaban durmiendo el detenido aprovechó para fugarse de nuevo. El alcalde, receloso, sospechó que el susodicho vecino había dejado libre al esclavo a propósito tras quedarse con el dinero robado que portaba el ladrón y procedió

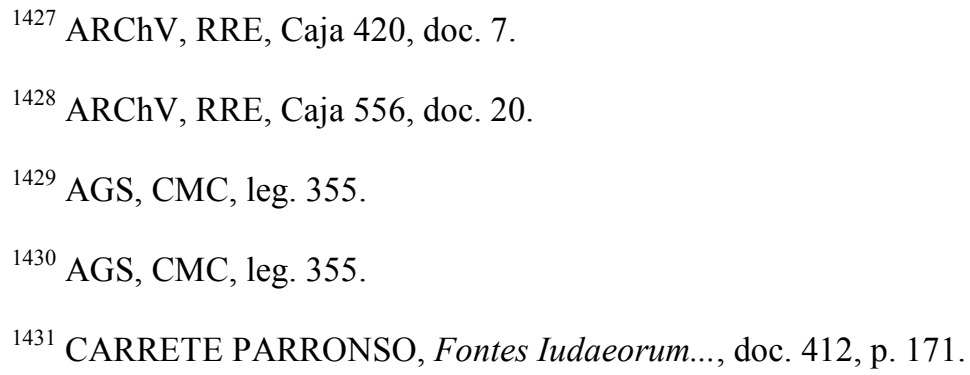


a encarcelar al desventurado vecino. Por su parte el mercader reclamaba que se llevara a Valladolid al preso para que se le restituyera lo robado y pagara por el esclavo huido ${ }^{1432}$.

Con esta curiosa desventura terminamos con el apartado dedicado a la realidad sociopolítica de Aranda. A lo largo de este punto hemos intentado esbozar la proyección política de la villa en el contexto general del reino y en el particular de la comarca de la Ribera del Duero burgalesa. Asimismo hemos analizados los elementos que configuran la realidad política del concejo, atendiendo sobre todo a los distintos actores que definen la sociedad arandina y sus estrategias de acceso al control de los resortes del poder municipal, prestando atención a los diferentes sectores sociales y a los más destacados de sus integrantes.

\section{LA NOBLEZA.}

En este capítulo trataremos de analizar la configuración de los principales estados señoriales que se desarrollaron en la Ribera del Duero burgalesa cuyo conocimiento es imprescindible para comprender, en su contexto, la historia de esta comarca en el periodo escogido. El punto de partida es la situación señorial heredada de la guerra civil que aupó a la dinastía Trastamara al trono y, como consecuencia de esta premisa, el asentamiento en la comarca del linaje de los Avellaneda gracias a las numerosas mercedes conseguidas de Enrique II. Como resultado de las alianzas matrimoniales que desarrolló este linaje durante la primera mitad del Cuatrocientos se desplegaron por la Ribera los intereses de alguno de los linajes emergentes bajomedievales como los Zúñiga y Sandoval. Éstos y otras importantes familias son el objeto de nuestro estudio pormenorizado.

En el análisis de cada una de las familias nobiliarias comenzaremos por identificar las bases territoriales de su poder, para seguir con la definición de sus dinámicas expansivas a lo largo del último cuarto del siglo XV y el primero del XVI.

${ }^{1432}$ AGS, RGS, 150005, fol. 414. 


\section{1. Consolidación territorial de los grandes señores.}

El panorama nobiliario en la Ribera se caracterizaba a comienzos del siglo XIV por la destacada actividad de una nobleza de segunda fila, aunque integrada dentro de la clientela de las grandes familias de la aristocracia castellana como eran los Haro, Guzmán, Lara, etc. La nobleza local contaba con territorios poco significativos y caracterizados por su discontinuidad, tanto en el espacio como en el tiempo, pero en evidente proceso de expansión. Los agentes pasivos que sufrieron las consecuencias de esta política expansiva fueron las instituciones eclesiásticas, las behetrías e, incluso, la autoridad real.

Una de las manifestaciones más significativas de esta relación de fuerzas la encontramos, por una parte, en la violencia que podríamos denominar como un verdadero "bandolerismo nobiliario"1433 y que contaba en la comarca con numerosos ejemplos. La mayoría de éstos se concretaban en la usurpación por parte de esta nobleza de algunas aldeas y granjas propiedad de los dominios monásticos que, en ocasiones, se disfrazaba bajo la figura de las encomiendas. Sirvan como ejemplo los problemas del monasterio de La Vid con su posesión de Fuentelcésped pretendida por los nobles Diego Ordóñez o Ramir Flórez; por su parte el monasterio de San Pedro de Gumiel tuvo que defenderse de las agresiones de Pedro Núñez de Guzmán en Vadocondes y de Ramir Flórez en Milagros; así como en el caso del monasterio de Silos que debió ceder en encomienda Quintana del Pidio a Gonzalo González de Acitores y Huerta del Rey a Pedro Fernández de Velasco ${ }^{1434}$.

Cabe destacar que durante la segunda mitad del siglo XIV se observa una aceleración de la tendencia a la concentración del poder en manos de los sectores más elevados de la nobleza, generalizándose a partir del cambio de dinastía un notable aumento

${ }^{1433}$ MORETA VELAYOS, S., Malhechores feudales: violencia, antagonismos y alianzas en clases en Castilla siglos XIII-XIV. Madrid, 1978. Los malhechores feudales son definidos como "todos aquellos individuos que pertenecientes a la clase feudal dominante en la formación económico social de Castilla en los siglos XIII y XIV emplearon la fuerza y la violencia en sus múltiples expresiones -desde el asesinato a las simples amenazas, la violación, el robo, las correrías de expolio y rapiña, etc.- en contra de las demás clases e instituciones sociales, incluidos los miembros de la propia clase, como práctica habitual para realizar determinados intereses individuales o globales de clase..." (pp. 20 y 21). Sobre este aspecto También puede consultarse VACA LORENZO, "Recesión económica..., pp. 33-56.

${ }^{1434}$ NUÑO GONZÁLEZ, “La Ribera del Duero..., pp. 9-41; y ÁLVAREZ BORGE, Poder y relaciones..., p. 238. 
del poder de los señores que se plasmó en la creación de verdaderos estados señoriales ${ }^{1435}$. En la Ribera no podemos hablar de la presencia significativa de la aristocracia castellana pero sí que nos encontramos con la creación de un pequeño estado señorial que se conformó como la base del poder territorial de la nobleza comarcana del siglo XV. Se trata de la familia de los Avellaneda.

Salazar y Castro ya situaba a los ancestros de esta familia afincados en la comarca de la Ribera desde al menos principios del Trescientos gracias a enlaces matrimoniales con miembros de la nobleza local. La vinculación del linaje de los Avellaneda con la Ribera se estableció a principios del siglo XIV con el matrimonio de Lope Díaz de Avellaneda, IV señor de esta casa, con Aldonza Díaz de Fuente Almexir, VII señora de este señorío situado en las tierras sorianas al Este de la comarca ribereña. El hijo de ambos, Diego López de Avellaneda, aumentó los territorios en la Ribera mediante su matrimonio con María Ochoa, señora de Peñaranda. Por lo tanto, su primogénito, Ochoa de Avellaneda ya era señor de Fuentearmengil y Peñaranda cuando contrajo matrimonio con María de Haza $^{1436}$. El VI señor de Avellaneda tuvo al menos dos descendientes que jugaron un notable protagonismo en la consolidación de este linaje en la comarca ribereña. El primogénito fue don Juan González y el segundón don Lope Ochoa. Sabemos por las Crónicas que en principio fueron de los pocos fieles que acompañaron a Pedro I cuando huía hacia el Sur en 1366, aunque ya en 1367 el primero de ellos aparecía entre las huestes del pretendiente Enrique en la derrota de Nájera ${ }^{1437}$. Tras la victoria final Trastamara "el de las Mercedes" concedió a ambos hermanos una serie de villas y lugares en la comarca por ...los altos e buenos e leales servizios. En concreto a don Juan le otorgó las villas de Haza, Peñaranda y Valdemontejo, con todos sus lugares; y a don Lope Gumiel del Mercado, Valdesgueva, Villovela, Ciruelos y Arauzo de $\mathrm{Miel}^{1438}$. Estos dominios fueron

1435 ÁlVAREZ BORGE, Poder y Relaciones... pp. 296-320. Este aspecto es ilustrado por este autor a través de la evolución de las behetrías, pero no debemos olvidar el importante papel que jugó en este aspecto la generalización de la institución del mayorazgo.

${ }^{1436}$ SALAZAR Y CASTRO, L. Historia Genealógica de la Casa de Lara. Madrid, 1694-1697 (Reed. 2009), Vol. III, pp. 350 y 404-405. La casa de Haza fue heredada por el primogénito de la casa, Fernán Rodríguez Daza, que la perderá en favor de su sobrino Juan González de Avellaneda (p. 351).

${ }^{1437}$ LÓPEZ DE AYALA, P., Crónica del rey Don Pedro. En ROSELL, C., Crónica de los Reyes de Castilla. Madrid, 1953, Tomo I, p. 539 y 552. Don Lope murió en el cerco de Lisboa en 1380 (SANZ ABAD, Historia de Aranda..., p. 67).

${ }^{1438}$ CADIÑANOS BARDECI, Arquitectura fortificada..., pp. 221, 238 y 240. De la donación de Valdemontejo a don Juan González de Avellaneda el 20 de septiembre de 1371 se conserva un traslado en AGS, CR, leg. 22, doc. 1. También don Juan González recibió el señorío de Íscar en las Cortes de Toro 
incrementados ligeramente a lo largo de la primera mitad del siglo XV por parte de sus descendientes $^{1439}$.

La actividad de los primeros Avellaneda en la Ribera fue bastante significativa pues encontramos a los dos hermanos aumentando temporalmente sus territorios a costa de los monasterios cercanos recurriendo para ello con cierta frecuencia a la encomienda. Así, don Lope se hizo con el lugar de Cilleruelo, patrimonio del monasterio de Santo Domingo de Silos; y don Juan González hizo lo propio con Fuentelcésped, aldea del cenobio de Santa María de La Vid ${ }^{1440}$.

La vinculación con la Ribera fue tan estrecha que don Lope junto a su mujer decidieron ser enterrados en la capilla de Santo Domingo de la iglesia del convento del mismo nombre en Caleruega ${ }^{1441}$.

En 1396 Alvar Díez de la Peña, alcayde del castiello de Gomiel de Mercado e merino por Diego Gonzalez de Abellaneda, ejerció como juez árbitro en un deslinde de términos entre Caleruega y Valdeande. Parece ser elegido por el segundo lugar, por lo que podemos deducir que la behetría se encontraba en ese momento bajo la encomienda de este Avellaneda $^{1442}$.

Evidentemente los Avellaneda configuraron en la Ribera un pequeño señorío territorial de cierta relevancia, pero lo más significativo de esta presencia es que con el paso del tiempo el patrimonio de este linaje se convirtió en la base territorial de las dos familias nobiliarias más importantes de la comarca a finales de la Edad Media: los Zúñiga y los Sandoval.

celebradas el 20 de septiembre de 1371 (SOLER NAVARRO, A. M., El Ducado de Peñaranda. Su origen y desarrollo hasta la desaparición del linaje de los Zúñiga. Tesis doctoral Universidad Complutense de Madrid, 2009, doc. 1, pp. 340-343), que fue confirmado por Juan I en 1379 (PÍA SENENT, M., "Los privilegios rodados del Archivo General de la Administración Central de Alcalá de Henares", en Espacio, Tiempo y Forma. Serie III, Historia Medieval. Tomo V, 1992, pp. 317-336).

${ }^{1439}$ La Aguilera, propiedad desde 1242 del obispado de Burgos, fue vendida en 1423 a los Avellaneda (CADIÑANOS BARDECI, Arquitectura fortificada..., pp. 238 y 243).

${ }^{1440}$ NUÑO GONZÁLEZ, “La Ribera del Duero burgalesa... p. 29.

${ }^{1441}$ Conocemos este dato por la disputa entre el convento y doña Catalina Martínez, viuda de don Nuño González de Torrecilla. Estos nobles habían establecido enterrarse en la capilla de Santo Domingo pero la priora cedió ese lugar a don Lope Ochoa de Avellaneda (MARTÍNEZ LIÉBANA, Colección Diplomática..., doc. CCXCIV, pp. 383-385).

${ }^{1442}$ MARTÍNEZ LIÉBANA, Colección Diplomática..., doc. CCXCVII, pp. 386-387. 


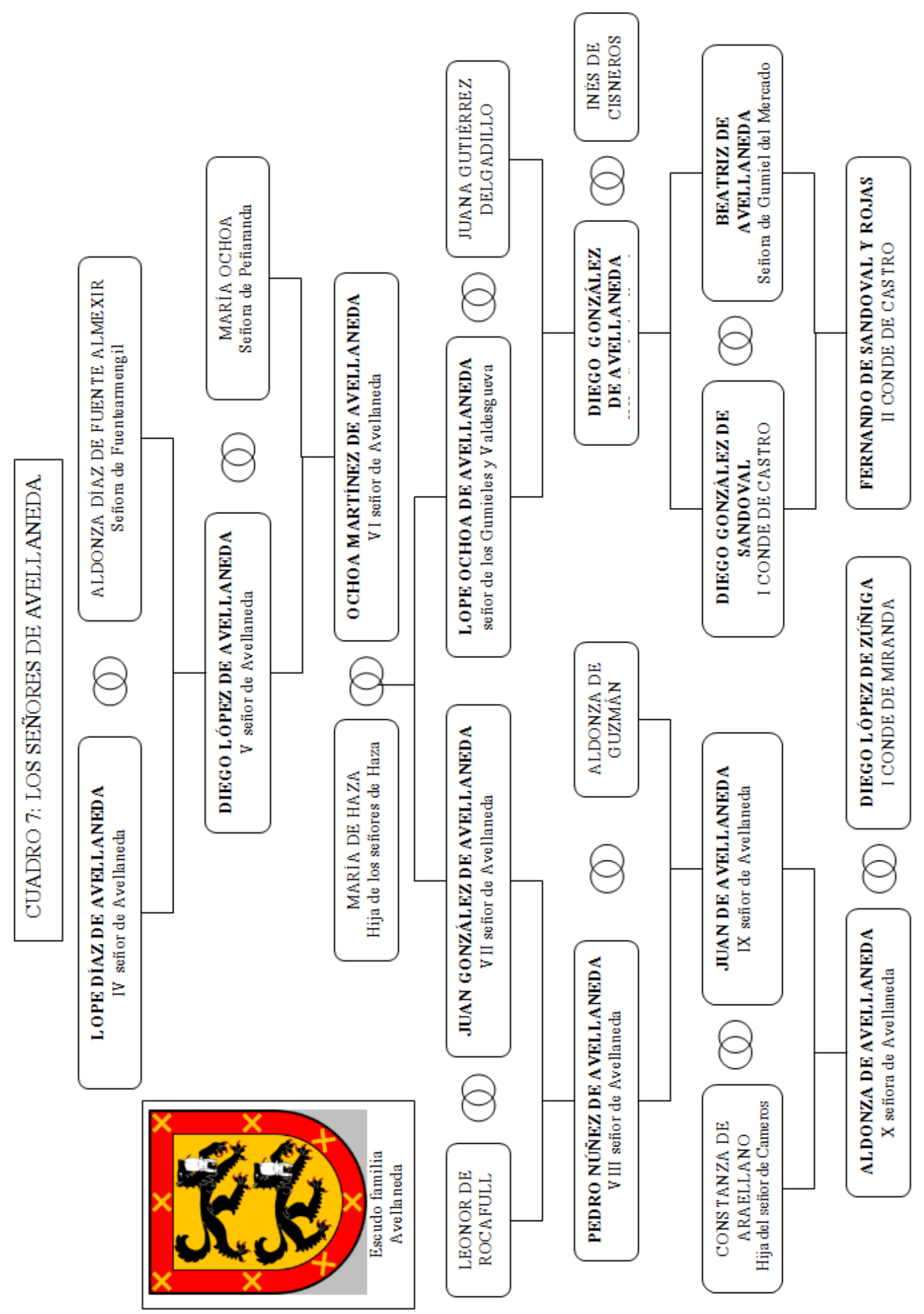


Por una parte, la herencia de los sucesores de don Juan González de Avellaneda pasó a la casa de los condes de Miranda por el enlace matrimonial entre doña Aldonza, heredera del último señor de Avellaneda, y don Diego López de Zúñiga, segundo hijo del señor de Béjar y poco después primer conde de Miranda del Castañar ${ }^{1443}$. De esta manera las villas de Haza, Peñaranda, Motejo y sus lugares se convirtieron en la base territorial de los condes de Miranda en esta comarca ${ }^{1444}$.

Por otro lado, la presencia de los Sandoval en la Ribera tuvo su origen en el matrimonio entre doña Beatriz de Avellaneda, nieta de don Lope, con don Diego Gómez de Sandoval, primer conde de Castro. La villa de Gumiel del Mercado y Valdesgueva engrosaron el patrimonio de los futuros marqueses de Denia. A éste se sumaron también la villa de Gumiel de Izán comprada en $1421^{1445}$.

\section{2. Las grandes familias nobiliarias de la comarca.}

La base ideológica que sustentaba el orden feudal era la teoría de la trifuncionalidad. Este principio justificaba un orden social que conseguía el equilibrio mediante el reparto de unas funciones claramente definidas: oratores, bellatores y laboratores debían desempeñar el papel que la estructura ideológica había asignado a cada uno ${ }^{1446}$. La propia evolución del feudalismo hizo necesario que la nobleza bajomedieval tuviera que adaptarse a una nueva realidad en la que la guerra dejaba de ser el principal instrumento para legitimar su condición de privilegiado. Quintanilla Raso identifica el cambio de la concepción de "defensores" a la de "servidores", dirigido a dos objetivos fundamentales: la vinculación directa con la monarquía, por cuanto el acceso a la condición nobiliar

${ }^{1443}$ El matrimonio se realizó entorno a 1447 y la concesión del título de Conde de Miranda lo otorgó Juan II en 1457.

1444 CADIÑANOS BARDECI, I., "Peñaranda de Duero: notas de historia y arte", en Biblioteca 8. Estudio e Investigación. 1993, pp. 111-131.

1445 Junto a Gumiel de Izán se incluyeron sus lugares de Bahabón, Oquillas y Cilleruelo de Arriba (CADIÑANOS BARDECI, Arquitectura fortificada..., pp. 266-267). En 1452, después del secuestro de los bienes del Conde de Castro por Juan II, la villa fue donada al Marqués de Santillana y en 1459 Enrique IV se la cedió a Pedro Girón, señor de Urueña. 1993.

${ }^{1446}$ ALVARADO PLANAS, J., De la ideología trifuncional a la separación de poderes. Madrid, 
se legitimaba por la voluntad regia, y la identificación con los intereses del reino ${ }^{1447}$. Evidentemente el comportamiento de la nobleza asentada en las tierras ribereñas no puede ser extrapolado al resto del reino pero sí que trataremos de identificar la evolución de estos linajes que evolucionaron desde unos orígenes muy modestos, sobre todo vinculados como segundones a algunas de las casas de la aristocracia castellana, y que fueron configurando una base territorial sobre la que asentaron su posición de poder. Poco a poco, y siempre unido al servicio a los diferentes monarcas de este periodo, estos linajes nobiliarios evolucionaron hacia una posición mucho más preponderante que alcanzó su cénit al final del periodo estudiado y en las décadas siguientes.

En este amplio apartado prestaremos atención a la evolución de las grandes familias nobiliarias que influyeron sobre el territorio ribereño a finales de la Edad Media. El estudio de cada linaje comienza por la identificación del origen familiar; continúa con el análisis de la formación de sus estados territoriales como elemento base de su posición de poder; y culmina con la descripción de sus relaciones a través de las alianzas matrimoniales y el estudio de su participación en la vida política del momento.

\section{2. 1. Linaje Zúñiga y Avellaneda: Condes de Miranda.}

A pesar de la importante presencia de esta familia y la trascendencia de su legado en la Ribera del Duero, son muy pocos los trabajos de investigación que se han centrado sobre los orígenes y evolución de los primeros Condes de Miranda. Casi todo lo que se ha escrito de ellos está relacionado bien con su genealogía o bien con su innumerable legado artístico desarrollado sobre todo en la villa de Peñaranda. Sin embargo, la actividad de los primeros condes y la creación de su señorío en la comarca han pasado desapercibidas para la historiografía local que nos aporta datos muy fragmentarios ${ }^{1448}$.

${ }^{1447}$ QUINTANILLA RASO, “La Nobleza”, en Orígenes de la Monarquía Hispánica. Propaganda y Legitimación (ca. 1400-1520). Madrid, 2004, pp. 63-104, en especial pp. 77 y ss.

${ }^{1448}$ Entre los estudios genealógicos destaca la obra de PELLICER DE TOVAR, Justificacion de la grandeça y cobertura de primera clase en la casa y persona de Don Fernando de Zúniga, noveno Conde de Miranda. Madrid, 1668. La mayor parte de los trabajos historiográficos dedicados a este linaje se centran en la rama mayor -duques de Béjar- y su señorío. No obstante, es bastante evidente la gran dependencia de la Casa de Miranda respecto a los Zúñigas mayores en los grandes asuntos del reino. Una visión general del ascenso social del linaje de los Zúñiga o Stúñiga la podemos encontrar en SUÁREZ FERNÁNDEZ, L. Nobleza y monarquía. Entendimiento y realidad. El proceso de construcción de la Corona española. Madrid, 2003, pp. 47, 144-145, 285 y 372-373. Una visión de la situación de este linaje en el contexto de la aristocracia castellana la realizó QUINTANILLA RASO, M. C., "El engrandecimiento nobiliario en la Corona de Castilla. Las claves del proceso a finales de la Edad Media", en Títulos, Grandes del Reino y Grandeza en la sociedad política. Fundamentos en la Castilla medieval. Madrid. 2006, pp. 17-100). 
Esta tendencia se ha invertido recientemente con la publicación de la tesis de Navarro Soler titulada El Ducado de Peñaranda. Su origen y desarrollo hasta la desaparición del linaje de los Zúñiga. Como indica su título, este trabajo abarca desde el periodo inicial de formación de este linaje hasta la desaparición del mismo, pero se centra sobre todo en el periodo ducal y, por lo tanto, fuera de nuestro ámbito de estudio ${ }^{1449}$.

Ya desde finales del siglo XIV detectamos la presencia del linaje de los Zúñiga en la Ribera. En 1396 Ochoa Martínez de Gauna, vecino de San Martín de Rubiales y merino por Diego López de Astuñiga, justicia mayor del rey, ejerció como juez árbitro en un deslinde de términos entre Caleruega y Valdeande, en representación de Calerue$\mathrm{ga}^{1450}$. Este Diego López de Stúñiga era el abuelo del primer conde de Miranda y ocupó una posición destacada en las cortes de los monarcas Juan I y Enrique III. Este primer Zúñiga fue el artífice de la integración y consolidación de este linaje entre la alta nobleza castellana en el periodo de los primeros Trastamara ${ }^{1451}$. Buena prueba de la posición que ocupó don Diego en la corte de Enrique III es la cláusula del testamento del monarca en el que se le encomendaba, junto al Mayordomo y al obispo de Cartagena, ...la crianza y enseñamiento del dicho Principe, tengan cargo de guardar y de regir e governar su persona del dicho Principe mi hijo, hasta que él haya edad de quatorce años; e otrosi de regir su casa ${ }^{1452}$. Sin embargo, las disposiciones testamentarias no se cumplieron por la negativa de los regentes y finalmente se solucionó el conflicto con un

1449 SOLER NAVARRO, A. M., El Ducado de Peñaranda. Su origen y desarrollo hasta la desaparición del linaje de los Zúñiga. Tesis doctoral leída el 21 de mayo de 2009 en la Universidad Complutense de Madrid. Publicación digital disponible en http://eprints.ucm.es/9818/.

${ }^{1450}$ MARTÍNEZ LIÉBANA, Colección Diplomática..., doc. CCXCVII, pp. 386-387.

${ }^{1451}$ El origen de la familia Zúñiga, Astúñiga o Stúñiga está en el reino de Navarra y parece ser que se asentaron en Castilla a lo largo del siglo XIII (VILLALOBOS Y MARTÍNEZ-PONTREMULI, M. L., "Los Estúñiga. La penetración en Castilla de un linaje de la nobleza nueva", en Cuadernos de Historia. Anexos de la Revista Hispania. 6, 1975, pp. 327-357). Diego López, camarero de Juan I y justicia mayor de Enrique III, era hijo de Íñigo Ortiz de Estúñiga y Juana de Orozco. Buena parte de su patrimonio estaba asentado en tierras riojanas aunque pronto recibió del monarca otros más significativos en toda Castilla entre los que destacaban los señoríos extremeños (DIAGO HERNANDO, M., "Linajes navarros en la vida política de la Rioja bajomedieval. El ejemplo de los Estúñiga", en Príncipe de Viana. 197, 1992, pp. 563-582). SOLER NAVARRO muestra un pormenorizado listado del patrimonio territorial que Diego López de Zúñiga consiguió reunir gracias a las mercedes de los diferentes monarcas, a los trueques y las compras. Entre estas adquisiciones tan sólo destaca en el ámbito ribereño la merced que consiguió del Infante don Fernando del lugar de Pesquera en 1395 (El Ducado de Peñaranda..., pp. 64 y $65)$.

${ }^{1452}$ Crónica del rey don Enrique, Tercero de Castilla é de Leon. En ROSELL, C. (Ed.), Crónica de los Reyes de Castilla. Madrid, 1953, Tomo II, Cap. XIX, p. 266. 
acuerdo económico entre las partes ${ }^{1453}$. No conocemos más intervenciones del primer señor de Béjar en la comarca aunque sí que constatamos que recibió en 1395 del Infante don Fernando la fortaleza de Curiel más el cercano lugar de Pesquera de Duero que convirtió en una importante base de operaciones y que posteriormente fue confirmada por el monarca Enrique III ${ }^{1454}$.

A la muerte de don Diego en 1417 le sucedió en sus estados y en el oficio de Justicia Mayor su hijo primogénito don Pedro de Estúñiga, primer conde de Plasencia y padre del conde de Miranda. También se mantuvo al servicio de los monarcas y ya destacó al lado del Infante don Fernando cuando actuaba como regente de su sobrino Juan II en las campañas emprendidas contra los $\operatorname{moros}^{1455}$. Consiguió incrementar considerablemente sus estados gracias a las mercedes reales y a su matrimonio con doña Isabel de Guzmán, hija del señor de Gibraleón. Entre las primeras destaca la concesión de Candeleda y Valdeverdeja en 1423 que, aunque no eran de gran entidad, se convirtieron con el tiempo en la base del patrimonio territorial sobre el que se constituyó el mayorazgo creado para el segundo de sus hijos ${ }^{1456}$. En lo que toca a las tierras ribereñas se ha de destacar que en 1425 se produjo la adquisición de la mitad de la villa de Guzmán ${ }^{1457}$. En los años centrales del siglo se involucró muy activamente en las distintas pugnas que sacudieron al reino de Castilla: se vio inmerso en la pugna de Juan II contra el rey de Navarra, se posicionó claramente contra el Condestable don Álvaro de Luna y se alió con el príncipe Enrique cuando se rebeló contra su padre ${ }^{1458}$. A su muerte le sucedió en sus estados su hijo primogénito Álvaro de Zúñiga, futuro duque de Béjar, que encabezaba el linaje de los Zúñiga mayores ${ }^{1459}$. Pero en su testamento realizado en 1450 daba

${ }^{1453}$ SOLER NAVARRO, El Ducado de Peñaranda..., pp. 67 y 68.

${ }^{1454}$ SNAHN, OSUNA, CP 42, doc. 3 y Caja 375, doc. 1.

${ }^{1455}$ En octubre de 1407 don Pedro tomó el lugar de Ayamonte por orden del regente (PÉREZ DE GUZMÁN, Crónica del Serenísimo..., Tomo II, Cap. XLII, p. 295).

${ }^{1456}$ Esta donación incluía las villas de Puebla de Enaciados, Candeleda, Alije, Valdeverdeja y El Gordo, más los lugares de Navia y Talavera la Vieja (SOLER NAVARRO, El Ducado de Peñaranda..., p. 69). La licencia real para crear un segundo mayorazgo la concedió Juan II a don Pedro en 1423.

${ }^{1457}$ CADIÑANOS BARDECI señala que la mitad de esta villa era de señorío y la otra mitad de behetría. Alfonso de Guzmán, señor de Valhenoso, la vendió por 35.000 maravedíes. En 1456 don Álvaro de Zúñiga consiguió la otra mitad (Arquitectura fortificada..., pp. 269-270).

${ }^{1458}$ SOLER NAVARRO, El Ducado de Peñaranda..., pp. 72 y ss..

${ }^{1459}$ CÁTEDRA GARCÍA afirma que la defunción del primer conde de Plasencia se produjo en el mes de julio de 1453 en Valladolid (La "Historia de la Casa de Zúñiga": otrora atribuida a Mosén 
forma al mayorazgo de su segundo hijo estableciendo: Otrosí mando al dicho don Diego, mi hijo, que haya para si por iuro de heredad mis villas de la Puebla e de Candeleda con sus terminos e señorios e iurisdiccion e mero e mixto imperio e con todos sus pechos e derechos. Otrosi que haya a mas los mis lugares de Canillas e Guzmán, según que yo agora he e tengo ${ }^{1460}$.

No fue hasta mediados del siglo XV cuando una de las ramas del linaje de los Stuñiga se instaló de forma definitiva en las tierras ribereñas. Esta circunstancia se produjo en el marco de la enmarañada estrategia del conde de Plasencia por dotar de contenido al mayorazgo que pensaba crear para su segundo hijo. Para abordar con detalle la llegada de los Zúñiga a la Ribera debemos retroceder en el tiempo y situarnos en 1426 cuando murió el IX señor de Avellaneda, don Juan, sin descendencia legítima. Su joven viuda, doña Constanza de Arellano, hija del señor de los Cameros, estaba embarazada y dio a luz una niña, doña Aldonza. Ante esta situación, Zúñigas y Avellanedas valoraron la posibilidad de un futuro enlace matrimonial, seguramente motivados por los lazos familiares, pues las abuelas de los futuros contrayentes eran primas ${ }^{1461}$, y por el buen partido que suponía el patrimonio de la niña. El acuerdo se concretó mediante la negociación en 1429 de un ventajoso matrimonio para ambas partes: los Zúñiga adquirían un amplio territorio que comprendía las tierras de Haza, Peñaranda, Montejo, Fuentearmegil en tierras ribereñas más la tierra de Íscar; y los Avellaneda recibieron la protección de una de las familias más respetadas en Castilla ${ }^{1462}$. Diez años después, en agosto de

Diego de Valera. Salamanca, 2003, p. 97), dato que se confirma con las sucesivas tomas de posesión que realizó don Álvaro López de Zúñiga de los castillos y alcázares de su padre en agosto de ese año (SNAHN, Caja 317, doc. 7 y Caja 318, doc. 21).

${ }^{1460}$ SNAHN, OSUNA, Caja 215, docs. 16-18 y 42-79.

${ }^{1461}$ Doña Isabel de Guzmán, mujer de don Pedro López de Zúñiga, era hija de doña Elvira de Ayala y nieta del famoso escritor, el canciller don Pedro López de Ayala. Por su parte, la madre de don Juan de Avellaneda fue doña Aldonza de Guzmán, hija de don Pedro Suárez de Guzmán y de doña Elvira de Ayala, la hermana menor del canciller (DACOSTA MARTÍNEZ, A., El Libro del Linaje de los Señores de Ayala y otros textos genealógicos. Materiales para el estudio de la conciencia del linaje en la Baja Edad Media. Bilbao. 2007; y GARCÍA FERNÁNDEZ, E., El linaje de los Ayala, Vitoria, 2007).

${ }^{1462}$ Recordemos que en 1429 don Diego rondaba los 15 años y la niña Aldonza apenas contaba con 3 por lo que estamos hablando de un compromiso de futuro. Conocemos dos documentos que hacen referencia a este acuerdo. Por una parte, en Curiel, castillo perteneciente al señorío del conde de Plasencia, el 11 de diciembre de 1429 el conde y su esposa revocaron una oferta y donación realizada a favor de su hijo Diego de las villas de Gibraleón, la Puebla de Arañuelo, Villalba de Alcor, Navia y Candelera, en principio cedidas por su matrimonio con doña Aldonza (SHAHN, Caja 214, docs. 132-144). El hecho de que se revocase confirma que anteriormente ya se había establecido un acuerdo entre las partes. Tres días después, esta vez en la villa de Haza, jurisdicción del señorío de Avellaneda, don Pedro López de Zúñiga se desdijo de lo anterior y redactó una nueva escritura de juramento por la que se comprometía a donar las 
1439, se ratificó el compromiso con la escritura de arras. Finalmente a mediados de los años cuarenta se celebraron los esponsales ${ }^{1463}$. Mediante este enlace se configuró la base del patrimonio territorial de los Zúñiga en la Ribera que se vio alterado por algunos cambios, compras, ventas y cesiones. Entre los primeros es significativo el realizado en 1453 por el conde de Plasencia que mantuvo bajo su jurisdicción las villas de Canillas y Guzmán, cediendo a su segundo hijo la villa de Miranda del Castañar ${ }^{1464}$.

La licencia que en 1440 concedió el monarca Juan II a don Pedro de Zúñiga para formar mayorazgo a favor de otro de sus hijos se materializó en 1457 con la merced del condado de Miranda para don Diego de Zúñiga como muestra de agradecimiento a la familia Zúñiga por los servicios prestados ${ }^{1465}$. Nacía así el Condado de Miranda del Castañar que se materializó con los señoríos de la villa salmantina homónima más las villas y lugares de Valdeverdeja, Candeleda, La Puebla y otros en tierras extremeñas y andaluzas $^{1466}$. A este título y señorío se unieron las posesiones aportadas por doña Aldonza en la Ribera y en la tierra de Íscar.

Tres fueron los principales objetivos del primer conde de Miranda. Por una parte, desarrolló una serie de iniciativas encaminadas a consolidar sus dominios señoriales, seguido de una política muy agresiva de expansión. En segundo lugar, y una vez asentada su base territorial, se significó activamente en cuantos conflictos políticos tuvieron lugar en el periodo que le tocó vivir con el claro objetivo de buscar su lugar dentro de la aristocracia castellana. Como tercer objetivo, complementario de los dos anteriores, el primer conde de Miranda pergeñó una estrategia de alianzas con los principales linajes

anteriores villas a su hijo Diego a condición de que se casase con doña Aldonza (Ídem., Caja 380, docs. $19-21)$.

${ }^{1463} \mathrm{La}$ escritura de arras, juramento y ratificación del mismo se firmaron el 5 de agosto de 1439 en Valladolid (SNAHN, OSUNA, Caja 215, docs. 1 y 2). La documentación no informa sobre la fecha concreta del enlace y los diferentes autores consultados no coinciden en sus apreciaciones: SUÁREZ FERNÁNDEZ señala 1447 (Historia de España, Madrid, 1970, vol. XV, p. 233), SOLER NAVARRO apunta al 29 de septiembre de 1444 (El Ducado de Peñaranda..., p. 77) y MERINO GAYUBAS en 1442 (Genealogía del solar de Guzmán. Salamanca, 2001, vol. I, pp. 547-548).

1464 SOLER NAVARRO, El Ducado de Peñaranda..., pp. 78-79. En 1460 vendió al conde de Urueña las villas de Olivera y Ayamonte más unas propiedades en Carmona (SNAHN, OSUNA, Caja 93, docs. 1-3).

${ }^{1465}$ SOLER NAVARRO, El Ducado de Peñaranda..., pp. 69, 98 y 99. Esta autora también señala que este nombramiento pudo responder al intento del monarca de poner paz entre don Álvaro y don Diego que estaban distanciados al menos desde 1454 a causa del reparto de la herencia de su padre (SNAHN, OSUNA, Caja 277, docs. 45 y 58-66).

${ }^{1466}$ MOXÓ, S, Los antiguos señoríos de Toledo. Toledo, 1973, pp. 94-98. 
castellanos que le proporcionaron una posición sólida en los tumultuosos años de la segunda mitad del siglo XV. El principal instrumento utilizado para ello fue una meditada política matrimonial ${ }^{1467}$.

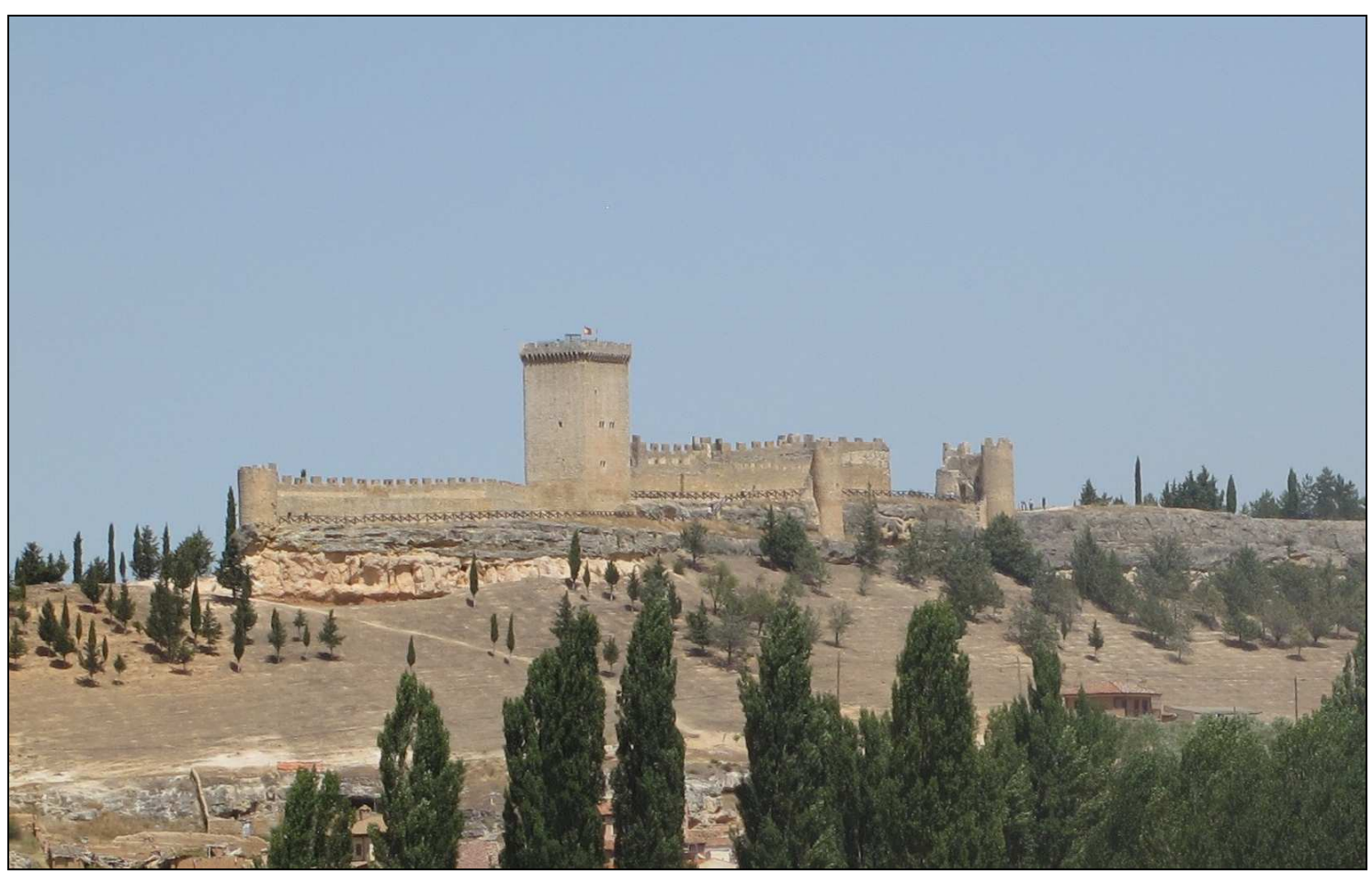

Imagen 48: Castillo de Peñaranda.

En lo que se refiere al primer objetivo, don Diego de Zúñiga quiso plasmar sobre el territorio su posición dominante de una manera clara y para ello invirtió una cuantiosa suma de dinero en remodelar el castillo y fortaleza de Haza, renovar completamente el castillo de Peñaranda y construir un nuevo bastión junto al camino de Valladolid justo enfrente de Aranda de Duero al que bautizarán con el revelador nombre de avnqueospe$s e^{1468}$. Para ello no dudó en enfrentarse en 1456 a la autoridad real al insistir en la cons-

${ }^{1467}$ Estrategia que ya ha sido analizada por QUINTANILLA RASO, M. C., "Sociabilidad nobiliaria y solidaridad jerárquica en la Castilla del siglo XV", Cuadernos de Historia de España. 76, 2000, pp. 155-184, especialmente p. 163.

${ }^{1468}$ En la construcción del castillo de Peñaranda invirtió ocho cuentos de maravedíes; en el Castillo del Monte otros tres y desconocemos lo que gastó en las reparaciones de Haza. Posiblemente estas cifras estén algo hinchadas debido a los comprensibles intereses de la informadora, doña Constanza de Arellano -tía del III conde-, que reclamaba su parte de la herencia de su padre, pero no deja de ser un dato bastante ilustrativo de la inversión del I conde de Miranda en sus territorios ribereños (ARChV, RRE, Caja 154, doc. 2). 
trucción de un castillo en las proximidades de la villa realenga ${ }^{1469}$. Pero este incidente no fue más que el comienzo de una tensa y conflictiva relación con la villa, como veremos más adelante.

Durante los años 50 y 60 el primer conde de Miranda siguió una política muy activa de consolidación de su poder en la comarca ribereña que se plasmó en dos iniciativas muy definidas. En primer lugar trató de ampliar sus estados jurisdiccionales haciéndose con una serie de lugares próximos a sus dominios ${ }^{1470}$. Así en las inmediaciones de Peñaranda compró Cuzcurrita, Zayas de Báscones y Bocigas ${ }^{1471}$. En la tierra de Montejo también adquirió hacia 1461 los lugares de Valdeherreros a Juan Delgadillo de Avellaneda y Pardilla a Juan de Guzmán ${ }^{1472}$ e hizo lo propio con Honrubia de la Cuesta y parte de Valdevacas. Por último, en la tierra de Haza compró cuarenta vasallos en Valdezate y Adrada. También por estas fechas adquirió el lugar de La Aguilera que, aunque no tiene conexión con ninguno de sus territorios, sí que se encontraba en un punto estratégico que abría una nueva brecha de expansión en el curso del Gromejón y que lindaba con los territorios de otros grandes señores comarcanos como eran el conde de Castro y el conde de Urueña, así como con la villa de Aranda ${ }^{1473}$. El recurso a la violencia fue otro medio del que se sirvió para incrementar sus estados y así en los años 50 se hizo por la fuerza con la behetría de Hontoria de Valdearados, usurpó el lugar de Fuentelcésped al

${ }^{1469}$ Existe una carta real y una copia notarial sobre este asunto. La primera ha sido transcrita por HURTADO QUERO, Documentos Reales..., doc. 9, pp. 19-21. La segunda se encuentra en AMA, leg. 43, fol. 31. Esta misma estrategia la desarrolló el conde algo más tarde en sus tierras extremeñas pues en 1478 las autoridades de la comarca de Vera de Plasencia solicitaron a los monarcas que prohibieran al conde de Miranda construir una fortaleza en la aldea de El Gordo (AGS, RGS, 147802, fol. 62).

${ }^{1470}$ A falta de localizar documentación más precisa, los datos que aportamos están obtenidos de la declaración de la condesa de Santa Marta, doña Constanza de Arellano, en el pleito que siguió contra su sobrino, el tercer conde de Miranda, para que se le entregara la parte de la herencia que le correspondía como heredera del primer conde de Miranda (ARChV, RRE, Caja 154, doc. 2).

${ }^{1471}$ Cuzcurrita fue comprada al señor de Valverde en 1470 (MERINO GAYUBAS, Genealogía del solar..., vol. II, p. 549).

${ }^{1472}$ Antes de esta compra el lugar de Pardilla pertenecía al arcediano de Calahorra que lo cedió a su hermano el Comendador de Griñón. Finalmente Juan de Guzmán, hijo del primero, vendió Pardilla al primer conde de Miranda (AGS, CR, leg. 22, doc. 1).

1473 También se compraron los lugares de Cogollos y Quintanilleja, al Sur de la ciudad de Burgos. En la declaración de la condesa de Santa Marta se afirmaba que se adquirió Torregalindo pero esta villa fue propiedad de Alonso de Sequera (AGS, RGS, 147812, fol. 27 y SNAHN, FERNANNUÑEZ, Caja 7, doc. 16) y posteriormente del Duque de Alburquerque que la cedió a uno de sus hijos para después revertir en el condado de Siruela (SNAHN, FERNANNÚÑEZ, Caja 89, doc. 22). No obstante, es posible que el conde comprara algunos vasallos de esta villa o durante un tiempo se hiciera con su jurisdicción pues por aquellos años la villa pasó por muchas manos, destacando los ya mencionados Muñoz de Castañeda o los condes de Gelves (SNAHN, OSUNA, Caja 35, docs. 69 y 70). 
monasterio de La Vid y asumió la encomienda de Milagros a pesar de la oposición del monasterio de San Pedro de Gumiel ${ }^{1474}$.

Estas adquisiciones jurisdiccionales se complementaron con numerosas compras de heredades por diversas localidades, así como unos molinos y aceñas en Haza, la compra de un molino de papel en Peñaranda o la adquisición de varias casas nobles en Peñafiel, Burgos y Valladolid. Tampoco podemos dejar de lado los importantes ingresos que para esta familia supuso el control de alguno de los pasos pecuarios entre ambas mesetas que poseía en tierras extremeñas ${ }^{1475}$.

A la par que don Diego consolidaba su posición territorial también se significó en las grandes cuestiones del reino que se desarrollaron en los años centrales del Cuatrocientos. Ciertamente la actividad de don Diego siempre estaba subordinada a las iniciativas emprendidas primero por su padre y después por su hermano don Álvaro, conde de Béjar y representante de la rama mayor de los Zúñiga. Así lo encontramos inmerso en las numerosas disputas que afectaban al reino y que tenían por protagonistas al monarca Juan II, a su hijo el Príncipe de Asturias, al valido don Álvaro de Luna o al eterno pretendiente don Juan de Navarra ${ }^{1476}$.

De mayor protagonismo gozó el conde de Miranda en las disputas que surgieron en los años 60 entre el monarca Enrique IV y una facción de la nobleza. Don Diego intervino activamente en la famosa deposición del monarca en Ávila en 1465 y la proclamación de don Alfonso ${ }^{1477}$. Asimismo le prestó su apoyo en 1467 en el enfrentamiento respectivamente.

1474 AGS, RGS, 148010, fol. 127; ARChV, RRE, Caja 76, doc. 6; y AGS, CR, leg. 22, doc. 1,

1475 MARTÍNEZ MORO, J. La renta feudal en la Castilla del siglo XV: Los Stúñiga. Valladolid, 1977. Tanto Candeleda como Berrocalejo fueron importantes puntos de la cañada que comunicaba ambas mesetas (KLEIN, J. La Mesta. Madrid, 1979, p. 38). De la importancia de estos ingresos dan testimonio los numerosos pleitos que mantuvieron los sucesivos condes de Miranda con el Concejo de la Mesta, que en ocasiones repercutían sobre las tierras de Haza y Peñaranda (ARChV, RRE, Caja 183, doc. 18; y AGS, RGS, 149609, fol. 174).

${ }^{1476}$ La participación de los dos primeros condes de Plasencia y del conde de Miranda en las intrigas políticas durante los reinados de Juan II y Enrique IV ya ha sido abordada en varios trabajos por lo que no creemos necesario insistir en ello, máxime cuando el protagonismo de don Diego fue bastante limitado (QUINTANILLA RASO, "El engrandecimiento nobiliario..., p. 92; y SOLER NAVARRO, El Ducado de Peñaranda..., pp. 84 y ss.).

${ }^{1477}$ Parece significativo que ENRÍQUEZ DEL CASTILLO cite en su crónica al conde de Miranda en último lugar de la relación de los participantes y no como tal, sino como hermano del Conde de Plasencia. No obstante, se le reservó un papel en la ficticia deposición: e así llegó Don Diego Lopez de Zúñiga, e derribo la estatua de la silla en que estaba, disciendo palabras furiosas e deshonestas. (Crónica del rey don Enrique IV. En ROSELL, C. (Ed.), Crónicas de los reyes de Castilla, Madrid, 1953, Tomo III, pp. 144-145). GALÍNDEZ DE CARVAJAL sigue esta misma versión cuando señala que Diego López 
que tuvo con el monarca en Olmedo ${ }^{1478}$, para poco después convertirse en acérrimo defensor del monarca y de su hija Juana frente a las aspiraciones de la princesa Isabel tras la repentina muerte del pretendiente Alfonso ${ }^{1479}$.

Instalado el linaje de los Zúñiga en el bando enriqueño, el conde de Miranda participó en buena parte de las intrigas y pactos que se desarrollaron en el contexto del conflicto sucesorio durante los primeros años 70. Tras la muerte del rey en 1474 la familia Zúñiga se decantó claramente por los intereses portugueses. Así en mayo de 1475 el conde de Miranda formaba parte del grupo de nobles que esperaba en Plasencia la llegada del Alfonso V de Portugal. Allí fue testigo de la proclamación del monarca portugués y doña Juana como reyes de Castilla el 25 de mayo ${ }^{1480}$. A partir de ese momento las huestes del conde participaron con mayor o menor protagonismo en la contienda que enfrentó a los Reyes Católicos con el rey de Portugal.

El final de la contienda supuso un duro contratiempo para los intereses de los Zúñiga que vieron resentida su posición dentro de la aristocracia castellana, aunque la política de reconciliación de la reina Isabel les permitió mantener buena parte de sus bases patrimoniales y, por lo tanto, de su capacidad de expansión ${ }^{1481}$.

de Stúñiga derrivó la estatua de la silla en que estava, diziendo que merescia perder el trono y asentimiento real, y todo ello diziendo palabras muy furiosas y deshonestras, con los pies lo derrivaron del cadalso en tierra con muy grande xemido y lloro de los que lo veían (Crónica de Enrique IV. En ROSELL, C. (Ed.), Crónicas de los reyes de Castilla, Madrid, 1953, Tomo III). Un estudio sobre las diferentes versiones que han ofrecido los cronistas lo encontramos en VAL VALDIVIESO, M. I., "La Farsa de Ávila en las crónicas de la época", en Espacios de poder y formas sociales en la Edad Media. Madrid, 2007, pp. 355-367.

${ }^{1478}$ VALERA señala que ... el conde de Miranda, don Diego de Estúñiga, que traxo fasta ochenta lanzas. El rey en su recorrido de Tudela a Olmedo intentó arrebatar al conde su fortaleza de Íscar pero no lo consiguió (Memorial de diversas hazañas..., p. 41). Posteriormente la plaza cayó en manos de don Enrique, situación que aprovechó en conde de Treviño para apresar a su madre, doña María de Sandoval (PALENCIA, A. Crónica de Enrique IV. Edición y traducción de PAZ Y MELIA, A., Madrid, 19041908, Tomo II, p. 92).

${ }^{1479}$ No es nuestro objetivo adentrarnos en los entresijos del conflicto sucesorio y la posterior guerra civil por lo que nos centraremos en aquellos hechos puntuales en los que intervinieron el conde de Miranda o su hijo don Pedro de Zúñiga. Para mayor información sobre este aspecto se puede consultar las obras de VAL VALDIVIESO, Isabel la Católica, princesa.... y SUÁREZ FERNÁNDEZ, Los Reyes Católicos. La conquista... Más adelante analizaremos con profundidad los acontecimientos que afectaron directamente a la comarca ribereña en este conflicto.

${ }^{1480}$ SUÁREZ FERNÁNDEZ, Los Reyes Católicos. La conquista..., p. 117.

${ }^{1481}$ VAL VALDIVIESO, “Las líneas maestras..., pp. 265-85. Seguramente la reconciliación con el conde de Miranda siguió un desarrollo similar a la de su hermano el duque de Plasencia que se materializó en unas capitulaciones (AGS, PR, leg. 11, doc. 13). 


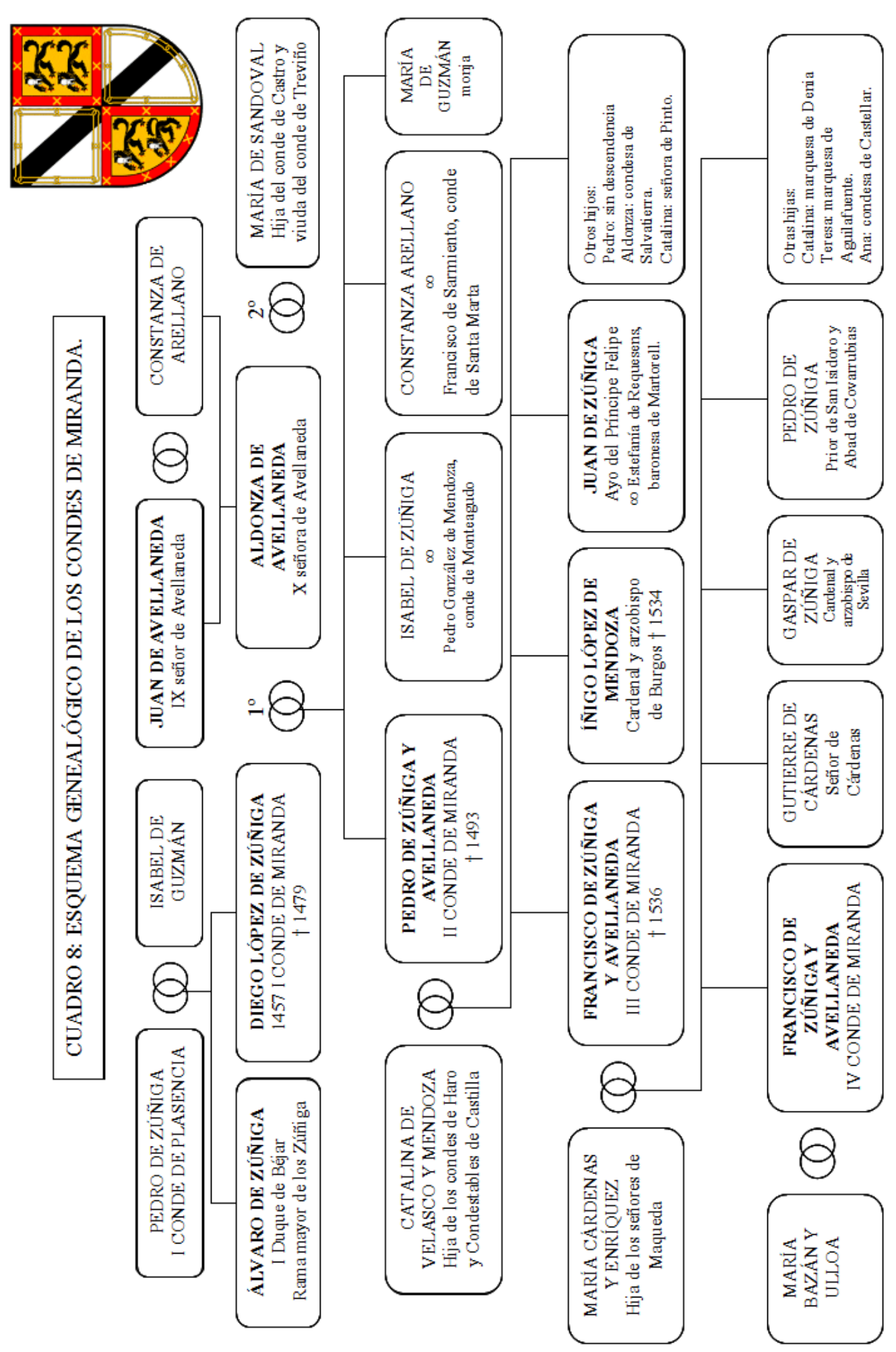


En lo que toca a la creación de alianzas con alguno de los linajes más significativos de Castilla se ha de destacar que don Diego utilizó a tres de sus cuatro hijos para tal fin. Del matrimonio entre don Diego y doña Aldonza de Avellaneda nacieron varios hijos: Pedro, Isabel, Constanza y María ${ }^{1482}$. Uno de sus principales triunfos fue conseguir emparentar con algunas de las familias más poderosas del momento. Para dos de sus tres hijas se concertaron matrimonios con destacadas familias: doña Isabel fue desposada con don Pedro González de Mendoza, I conde de Monteagudo y señor de Almazán; y doña Constanza se casó con don Francisco de Sarmiento, III conde de Santa Marta. Pero el punto álgido en esta política matrimonial se reservó para el varón, don Pedro, que entró en la órbita de una de las familias más poderosas de Castilla: los Fernández de Velasco, Condestables de Castilla ${ }^{1483}$. El primogénito del conde contrajo matrimonio con doña Catalina de Velasco y Mendoza, hija del conde de Haro y nieta del Marqués de Santillana. En esta misma operación los Zúñiga emparentaron indirectamente con otros grandes: el marqués de Villena, el conde de Urueña y, tras la muerte del primero, con el duque de Alburquerque.

Sin embargo, los éxitos de esta estrategia se vieron empañados desde finales de la década de los 60 cuando surgió la disensión entre el conde y su primogénito. El origen de la disputa entre padre e hijo parece estar en la decisión de don Diego de abandonar a la madre de don Pedro, doña Aldonza de Avellaneda, y convivir públicamente con doña María de Sandoval, condesa viuda de Treviño ${ }^{1484}$. El cronista Palencia habla claramente de concubinato ${ }^{1485}$ acusando a doña María de ser la instigadora de la ruptura

${ }^{1482}$ Las tres mujeres llevaron los diferentes apellidos de los abuelos: doña Isabel de Zúñiga, doña Constanza de Arellano y doña María de Guzmán (ARChV, RRE, Caja 154, doc. 2). La última no se casó y posiblemente ingresó en un convento. SOLER NAVARRO la nombra como doña Aldonza y señala que tomó el hábito de San Agustín en un convento fundado por la reina, sin especificar en cuál (El Ducado de Peñaranda..., p. 80).

1483 GONZÁLEZ CRESPO, E., Elevación de un linaje nobiliario castellano en la Baja Edad Media: los Velasco. Tesis leída en la Universidad Complutense de Madrid, 1981; y FRANCO SILVA, A., Entre los reinados de Enrique IV y Carlos V: los Condestables del linaje Velasco (1461-1559). Jaén, 2006.

${ }^{1484}$ La relación entre el conde de Miranda y doña María de Sandoval debió comenzar tras la muerte en el otoño de 1458 del conde de Treviño. Según relata SALAZAR Y CASTRO, los hermanos del difunto no vieron con buenos ojos la tutela de la condesa sobre su hijo el conde de Treviño por lo que el conde de Paredes decidió hacerse con su sobrino por la fuerza. El conde de Miranda, a petición de su hermano el conde de Plasencia, acudió a socorrer a la condesa (Historia genealógica de la casa de Lara, vol. II, pp. 67-70).

${ }^{1485}$ Como ya hemos visto con anterioridad, el conde de Treviño secuestró a su madre refugiada en Íscar. PALENCIA muestra su animadversión hacia esta señora con el siguiente comentario: El conde de Treviño, D. Pedro Manrique, llevó presa a su madre, no pudiendo sufrir que aquella dama, sobre 
matrimonial que finalmente concluyó a finales de los años 60 cuando el conde repudió a su esposa alegando parentesco y se casó en 1470 con la condesa de Treviño ${ }^{1486}$. Como narran los cronistas de la época, esta decisión no acarreó más que problemas pues los primogénitos de ambos contrayentes llevaron a cabo una serie de iniciativas hostiles contra sus progenitores ${ }^{1487}$. En concreto, a principios del año 1473 el hijo del conde de Miranda, non mirando a la obediencia e veneracion que le devia como a su padre, asesinó al alcaide de Haza y apresó al conde y la condesa para conducirlos a Roa donde presionó a su padre para que firmara una serie de contratos y facultades por los que le cedía buena parte de sus bienes y posesiones ${ }^{1488}$. La disputa continuaba en 1476 pues los monarcas comisionaron a la duquesa de Arévalo y a la condesa de Haro como juezas para que pusieran paz entre ambas partes, previo compromiso mutuo de acatar la sentencia arbitraria ${ }^{1489}$.

Aparte de los líos de alcoba y las rencillas familiares, lo que podemos concluir de este episodio es que estas desavenencias entre padre e hijo provocaron una evidente

otras muchas maldades cometidas contra un personaje de su valia, tuviese a sus años la desvergüenza de ser la concubina del conde de Miranda, y de emplear sus perversas artes para separar al licencioso magnate del lado de su mujer, joven y dotada con todas las ventajas del nacimiento, de la virtud y de la hermosura. (Crónica de Enrique IV. Tomo II, p. 92). En la Crónica Anónima de Enrique IV se relata: Y la condesa, no olvidando su costunbre, se dio enteramente al conde de Miranda, el qual a cabsa suya dexo a su muger doña Elvira (sic) de Avellaneda, que era una de las mas hermosas e mas nobles mugeres deste reyno; de que se siguieron grandes ynconvinientes en que la condesa gano poca honrra e al conde de Miranda se siguieron asaz daños... (p. 96). Alonso de Palencia o quien fuera el autor de las Coplas del Provincial tampoco tenía en gran estima a esta dama de la que decía: De Treviño fraile y conde, Manrique de Sandoval, la verdad nunca se esconde, bien la sabe el Provincial, que de hoy más, por el escote, podéis poner por reseña; no os podran poner por mote "hijo de la casta dueña". Tras la muerte del conde de Miranda, doña María fue apresada de nuevo por su hijo y encerrada en una torre de Nájera (SUÁREZ FERNÁNDEZ, L., Fundamentos de la monarquía. Madrid, 1989, p. 93). Doña María de Sandoval ingresó en 1491 en el monasterio de la Consolación de Calabazanos (VV. AA. "La Reina Católica y los Manriques. Nuevos datos", en Calabazanos a la vista. Palencia, 1959, pp. 350 y 359).

${ }^{1486}$ Biblioteca de la Real Academia de la Historia -BRAH-, Colección Salazar y Castro, M-1, fol. 103. Transcrito como doc. 4 por SOLER NAVARRO (El Ducado de Peñaranda..., Apéndice documental, pp. 11 y 12). El enlace se realizó en Cogeces de Íscar el 5 de septiembre de 1470 y entre los testigos se encontraba don Pedro de Zúñiga.

${ }^{1487}$ La amenaza sobre la herencia de los primogénitos era patente como lo muestra el hecho de que el conde de Miranda, para compensar las pérdidas de patrimonio de su esposa causadas por su hijo el conde de Treviño, hizo donación a doña María el 5 marzo de 1473 de las villas de Palos y Villalva del Alcor en Sevilla más Candeleda, Alija y La Puebla (SALAZAR Y CASTRO, Historia genealógica..., vol. II, p. 70).

${ }^{1488}$ No obstante, el 9 de marzo de ese mismo año, una vez a salvo en la cercana fortaleza de Curiel, propiedad de su hermano el conde de Plasencia, don Diego hizo una escritura de anulación de los anteriores contratos (BRAH, Colección Salazar y Castro, M-1, fol. 104; transcrito como doc. 5 por SOLER NAVARRO en El Ducado de Peñaranda..., Apéndice documental, pp. 13 y 15).

${ }^{1489}$ AGS, PR, leg. 11, doc. 13. 
división, no sólo en el seno del linaje, sino también en el plano territorial. Se intuye que el conde se mantuvo con sus dominios occidentales y meridionales mientras que el hijo tomó para sí los territorios más orientales, todos aquellos que su madre doña Aldonza aportó al matrimonio, menos las tierras de Íscar. Esta situación la podemos apreciar perfectamente en la intensa actividad que desarrolló don Pedro de Zúñiga en la comarca ribereña pues, aunque todavía no había heredado el título condal, actuaba como verdadero señor de estos territorios durante buena parte de los años 70. No es de extrañar por lo tanto que sus estados ribereños, con Peñaranda a la cabeza, se convirtieran en la base de su poder territorial.

Don Diego de Zúñiga murió en 1479. Un breve balance de su actividad nos define al I conde de Miranda como un noble de su tiempo, inmerso en las intrigas políticas de la época de la mano de su hermano el conde de Plasencia; obsesionado con expandir sus estados territoriales y por establecer lazos con familias poderosas que consolidaran su posición social. Al final de su vida estos logros se vieron empañados por su posición en el bando perdedor en la contienda civil y por el manifiesto enfrentamiento con su hijo. Ambas circunstancias le hicieron perder la posición y parte del patrimonio logrados a lo largo de los años anteriores.

La sucesión del I conde de Miranda no estuvo exenta de controversia. Si bien es cierto que de hecho don Pedro de Zúñiga y Avellaneda ya disfrutaba de algunos de los estados de su padre antes de su muerte, las relaciones con su madrastra, doña María de Sandoval, y con sus tíos y primos del linaje de los Zúñiga complicaron la situación. El cronista Palencia ya dio cuenta de ello al afirmar que ...la muerte de Diego de Estúñiga, conde de Miranda, fallecido entonces, ocasionando un pleito terrible entre los hijos y los parientes, pretendiendo por diversos medios, unos, que se le diera preferencia en derecho al primogénito, y los otros, el que habiendo sido rechazado por el padre, pasara a segundo lugar ${ }^{1490}$. En consecuencia, el II conde de Miranda tuvo que hacer frente a un pleito interpuesto por la condesa viuda que reclamaba como suyas las villas de Candeleda, Alija y la Puebla que le fueron entregadas por su difunto marido ${ }^{1491}$. Posible-

${ }^{1490}$ PALENCIA, A, Cuarta Década. LÓPEZ DE TORO, J. (Ed.), Madrid, 1974, pp. 134 y ss.

1491 SALAZAR Y CASTRO, Historia genealógica..., vol. II, p. 70. Hace mención a una donación ...por escritura que se otorgó en el camino que va de Aza a Roa en 5 de marzo de 1473 ... hizo donación entre vivos a la Condesa y a sus herederos y sucesores de sus villas de Palos, y Villalba del Alcor ... y también la dio en la misma forma las villa de Candeleda, Alija y la Puebla. 
mente en esta donación también se incluyera la villa de La Aguilera pues las fuentes muestran a doña María actuando como señora de La Aguilera y beneficiando a su hermano el conde de Castro, señor de la vecina villa de Gumiel del Mercado ${ }^{1492}$.

Por otra parte, don Fadrique de Toledo, primogénito de la Casa de Alba y casado con una de las hijas de los duques de Plasencia, reclamaba como arras y herencia de su mujer el condado de Miranda del Castañar ${ }^{1493}$. Ambas solicitudes tuvieron como consecuencia la pérdida de estos territorios temporalmente pues el duque de Alba tomó posesión de la villa de Miranda ${ }^{1494}$. Ésta no fue devuelta al linaje de los Zúñiga hasta 1487 gracias a la sentencia dictada por los monarcas en la que concedía a don Pedro la plena posesión del condado de Miranda ${ }^{1495}$. Por su parte, doña María actuó como verdadera señora de Candeleda, mantuvo el pleito con su hijastro por el disfrute de las ricas rentas de estos lugares e incluso cedió su señorío a su hijo en $1479^{1496}$. Las diferencias entre sus señores también se reprodujeron entre los vecinos de las villas de Alija y La Puebla que entraron en debates y peleas. El conflicto alcanzó tal magnitud que la reina se vio obligada a intervenir dando su seguro a los vecinos y poniendo en secuestro las ren$\operatorname{tas}^{1497}$. Finalmente rentas y jurisdicción volvieron al condado de Miranda hacia $1481^{1498}$.

${ }^{1492}$ AMA, leg. 1198, doc. 4. En el contexto de la disputa de los vecinos de La Aguilera y Gumiel del Mercado por el uso de las aguas del río Gromejón, los procuradores de La Aguilera argumentaban ...que en el tiempo del conde don Diego, cuya fue la dicha villa de Aguilera, como la condesa de Treviño hera hermana del marques de Denia e se fasia todo lo que ella queria e mandava en la casa e fasienda del conde; e que sabiamos que la dicha villa de Aguilera avia de venir al conde don Pedro; aquella que nos tratava muy mal porque consyntia aquellas causas e dava logar a ellas que los de Aguilera fuesen forçados e despojados de su uso (del agua del río).

${ }^{1493}$ SUÁREZ FERNÁNDEZ, Fundamentos de la monarquía..., pp. 102-103.

${ }^{1494}$ CALDERÓN ORTEGA, J. M., El Ducado de Alba: la evolución histórica, el gobierno y la hacienda de un estado señorial (siglos XIV-XVI). Madrid, 2005, pp. 110 y ss.

${ }^{1495}$ AGS, CC DIVERSOS, leg. 41, doc. 6. Un mes después, en marzo de 1487, la reina ordenaba a Sancho de Rojas que hiciera entrega de la fortaleza de Miranda a don Pedro de Zúñiga (AGS, RGS, 148703, fol. 41).

${ }^{1496}$ SUÁREZ FERNÁNDEZ, Fundamentos de la monarquia..., p. 93. En 1479 doña María de Sandoval trocó con su hijo el conde de Treviño estas villas a cambio de unas rentas en Navarrete (AGS, PR, leg. 59, doc. 39, 1).

${ }^{1497}$ AGS, RGS, 147907, fol. 127 y 134; 148002, fol. 237; 148003, fol. 320.

${ }^{1498}$ SUÁREZ FERNÁNDEZ, Los Reyes Católicos. La Conquista..., pp. 359 y 385. 
Estos conflictos desarrollados en el seno del linaje de los Zúñiga tuvieron como escenario sus estados occidentales mientras que en las tierras ribereñas el poder condal se encontraba consolidado en manos de don Pedro incluso antes de la muerte de su padre.

Siguiendo la política expansiva de la familia, el segundo conde de Miranda trató de incrementar su patrimonio utilizando para ello métodos casi exclusivamente violentos. Estos episodios de violencia se materializaron en el mantenimiento del control sobre la behetría de Hontoria de Valdearados o el abadengo de Fuentelcésped; o el intento de anexionar los lugares de Hoyales y Fuentelisendo tras la muerte de su titular, don Juan de Avellaneda ${ }^{1499}$. El culmen de este proceso tuvo lugar a principios de la década de los 70 cuando el futuro conde de Miranda, aliado por entonces de los intereses del rey Enrique y su hija doña Juana, pretendió tomar la villa de Aranda bajo su jurisdicción al amparo de la inestabilidad del conflicto sucesorio que vivía Castilla. El rechazo de buena parte de los vecinos de la villa provocó un enfrentamiento del que salió derrotado don Pedro y, en consecuencia, la adhesión definitiva de la villa al partido de la princesa Isabel. Ciertamente la violencia fue el denominador común de la actividad de don Pedro pues a sus iniciales enfrentamientos con su padre, al que despojó de sus estados ribereños, se sumó la intervención en el conflicto bélico que siguió a la proclamación de Isabel, circunstancia que aprovechó para aumentar su patrimonio gracias al asalto de mercaderes y caminantes ${ }^{1500}$. Años después, con la reactivación de la guerra de Granada, el conde pudo dar rienda suelta a sus inquietudes y hacer fortuna. Fue bastante destacada su actividad en la conquista de Alhama ${ }^{1501}$, aunque su contribución con hombres de armas fue más bien discreta ${ }^{1502}$.

Otros miembros de la gran familia de los Stúñiga tuvieron una presencia marginal en la periferia ribereña. Así, por ejemplo, la casa matriz, los señores de Béjar, eran los propietarios de la villa de Guzmán, en las proximidades del Cerrato palentino y muy

${ }^{1499}$ Más adelante, en el capítulo dedicado a la conflictividad, abordaremos con detenimiento todos estos episodios violentos.

${ }^{1500}$ AGS, RGS, 147503, fol. 338.

1501 PULGAR, H. Crónica de los Reyes Católicos. En ROSELL, C. (Ed.), Crónica de los reyes de Castilla. Madrid, 1953, Tomo III, cap. II, pp. 365 y ss.

${ }^{1502}$ Así se deduce del estudio de LADERO QUESADA, M. A., Castilla y la Conquista de Granada. Granada, 1993; y de los gráficos presentados por NAVARRO SOLER en Los Duques de Peñaranda..., pp. 117-120. 
próxima a su castillo de Curiel. Otra de las ramas desgajadas del tronco principal, los señores de Monterrey, tuvo también parte de sus estados en la Ribera, en concreto en Alcubilla de Nuño Pedro, en el oriente de la comarca. Este pequeño dominio conectaba con sus otras posesiones de Hacinas, ya en plena Demanda burgalesa. Más adelante haremos mención a algunos de los conflictos que protagonizaron pero lo cierto es que, a pesar de ser importantes linajes en el contexto de la aristocracia castellana, su proyección sobre el territorio que nos ocupa fue muy limitada.

La temprana muerte del segundo conde de Miranda en septiembre de 1493 supuso un periodo de inestabilidad en la casa Zúñiga Avellaneda pues el primogénito, don Francisco, tan solo contaba con doce años. Ante esta situación la condesa viuda, doña Catalina de Velasco y Mendoza, tuvo que asumir la tutela, no sin ciertas dificultades, y dirigir la política familiar ${ }^{1503}$. Aprovechando este momento de relativa debilidad, alguno de los concejos vecinos reclamó su autonomía frente a la imposición forzada de los anteriores condes, como ocurrió con Hontoria de Valdearados y Fuentelcésped. Esta situación también la aprovechó la villa de Aranda que inició una nueva fase de expansión sobre territorios tradicionalmente integrados en el área de influencia de los Zúñiga. En concreto, el concejo arandino presionó sobre los montes y pastos de la comunidad de villa y tierra de Haza y Montejo y compró en 1495 el lugar de Milagros al monasterio de San Pedro de Gumiel ${ }^{1504}$. Pero no fueron sólo los vecinos los aprovecharon la coyuntura, también el Honrado Concejo de la Mesta inició un largo proceso para reclamar una serie de derechos propios en las tierras de Haza y Peñaranda ${ }^{1505}$.

Del matrimonio entre don Pedro y doña Catalina nacieron al menos siete hijos: al primogénito don Francisco le siguieron don Pedro, don Íñigo, don Juan, doña Aldon-

1503 AGS, RGS, 149311, fol. 12. El dato de la edad del muchacho a la muerte de su padre lo aportan varios de los testigos del proceso por la jurisdicción de Milagros. Todos ellos coincidían en señalar el nacimiento de don Francisco entorno a 1481 (AGS, CR, leg. 22, doc. 1). SUÁREZ FERNÁNDEZ, Fundamentos de la monarquía..., p. 149, nota 237. la conflictividad.

${ }^{1504}$ Estos enfrentamientos se desarrollarán con detenimiento en el capítulo siguiente dedicado a

1505 AGS, RGS, 149507, fol. 162; 149609, fol. 70 y 174 y ARChV, RRE, caja 183, doc. 18. El pleito se extendió por lo menos hasta 1509 (AGS, CC CÉDULAS, libro 7, leg. 207, doc. 10). Esta dinámica no se limitó exclusivamente a los condes de Miranda pues durante los años noventa el Concejo de la Mesta reclamó sus derechos ante la Corona por considerar que la villa de Aranda, la condesa de Siruela o algunos particulares ribereños llevaban a cabo prácticas abusivas sobre el paso de sus ganados. 
za, doña María y doña Catalina ${ }^{1506}$. La temprana muerte del progenitor no le permitió organizar personalmente un complejo sistema de alianzas matrimoniales como el que había pergeñado su padre con él y sus hermanas. No obstante, la ausencia del padre y la delicada situación de la madre como tutora de unos hijos de corta edad ${ }^{1507}$ favoreció la proyección protectora del linaje de los poderosos Velasco sobre la joven camada de los Zúñiga Avellaneda. Los sucesivos Condestables tomaron bajo su amparo a sus sobrinos y, como veremos más adelante, promocionaron sus carreras como si se tratara de las de sus hijos. Uno de los primeros movimientos en este sentido se produjo en septiembre de 1495 cuando se establecieron las capitulaciones matrimoniales entre don Francisco y doña María de Cárdenas y Enríquez, hija de don Gutierre Cárdenas y doña Teresa Enríquez $^{1508}$. Con este enlace se consiguieron dos importantes objetivos: por una parte, se emparentaba con la realeza, pues doña Teresa Enríquez era prima del Rey Católico; y por otro lado, los Zúñiga reducían distancias respecto a la reina al emparentar con uno de los más estrechos colaboradores de doña Isabel, tanto en los años duros del conflicto sucesorio, como en los años de reinado, destacando en la toma de Granada o en la confección del Tratado de Tordesillas ${ }^{1509}$. Pero sobre todo este matrimonio suponía la rehabilitación absoluta del linaje Zúñiga Avellaneda al que se le redimía, evidentemente gracias a las maniobras de sus parientes los Velasco, de su pasada infidelidad por su destacado posicionamiento contra los intereses de la entonces princesa Isabel.

Don Juan, doña Aldonza y doña Catalina también participaron de la política matrimonial del linaje. Doña Aldonza fue enlazada con don Pedro López de Ayala, conde de Salvatierra ${ }^{1510}$; doña Catalina con don Alonso Carrillo de Acuña, señor de Pinto; y

${ }^{1506}$ NAVARRO SOLER añade una octava, doña Mencía, a la que sitúa como monja dominica en el convento de Santo Domingo de Caleruega (Los Duques de Peñaranda..., p. 112). Por el momento no hemos localizado ninguna noticia sobre este personaje.

${ }^{1507}$ Recordemos que don Francisco tenía doce años cuando falleció su padre por lo que podemos deducir que el resto de sus hermanos contarían con edades comprendidas entre los 10 años y unos pocos meses. No obstante, es más que probable que alguna de las hermanas fuera mayor que el heredero de la casa condal.

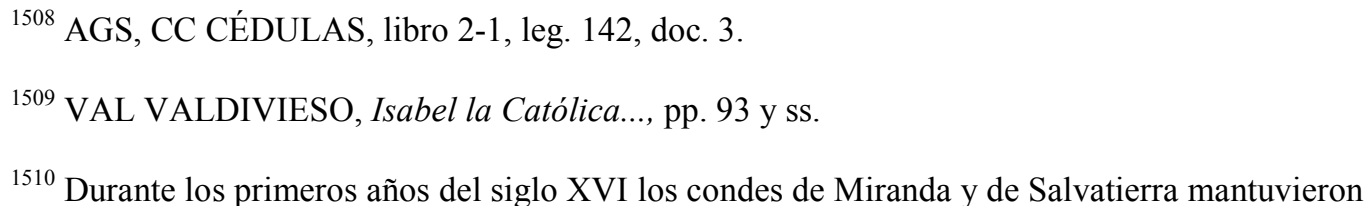
un pleito a propósito de los más de tres cuentos de maravedíes prometidos en dote a doña Aldonza y que el conde de Miranda no pagó. En 1503 la duquesa de Alburquerque dictó una sentencia arbitral que don Francisco no cumplió por lo que Ayala llevó ante la Chancillería el asunto que no concluyó hasta 1505 (AGS, CC CÉDULAS, libro 6, leg. 158, doc 3; ARChV, Pleitos Civiles, Caja 200, doc 10; y RRE, caja 200, doc 26). 
don Juan se unió en matrimonio con una noble catalana, doña Estefanía de Requesens, con lo que las alianzas matrimoniales se extendieron más allá de las fronteras castellanas. Del resto, don Íñigo, del que hablaremos más adelante, siguió la carrera eclesiástica y doña María profesó como monja dominica en Santo Domingo de Caleruega ${ }^{1511}$. De don Pedro nada sabemos.

Tras los años de tutela de doña Catalina, don Francisco tomó las riendas del condado y se hizo cargo de cuantos problemas arrastraba del periodo de inestabilidad que siguió a la muerte de su padre.

En el plano político se observa cómo el joven conde participó de los principales acontecimientos de la mano de sus familiares directos, bien los Condestables o bien los Cárdenas. Y así lo encontramos en 1502 en Fuenterrabía, junto a su suegro don Gutierre de Cárdenas, formando parte de la comitiva enviada por los Reyes Católicos para recibir a los príncipes Juana y Felipe ${ }^{1512}$. En la coyuntura de inestabilidad causada por los problemas sucesorios en Castilla se aprecia en términos generales cómo los grandes linajes nobiliarios se aproximaron a los herederos de la Corona con la intención de ver consolidada su posición política e influir sobre los futuros soberanos. De esta dinámica participó el conde de Miranda no dejando pasar la oportunidad de ganarse la confianza de los futuros monarcas desde la posición privilegiada que le confirió sus relaciones de parentesco $^{1513}$. Fue precisamente tras la muerte de la reina Isabel y el regreso de los príncipes herederos a Castilla cuando don Francisco se significó claramente en el bando felipista al acudir a Inglaterra sin el permiso del regente don Fernando. El conde se presentó ante los futuros monarcas junto a su hermano don Juan y otros caballeros para ofrecerles sus naves y reanudar su viaje hacia la Península ${ }^{1514}$. En definitiva, en el contexto de defini-

${ }^{1511}$ MERINO GAYUBAS, Genealogía del solar... vol. II, p. 731.

1512 PADILLA, L., Crónica de Felipe I, llamado el Hermoso. Colección de documentos inéditos para la Historia de España, Tomo VIII, Madrid 1846, p. 84.

${ }^{1513}$ QUINTANILLA RASO, M. C., "Élites de poder, redes nobiliarias y monarquía en la Castilla de fines de la Edad Media", en Anuario de Estudios Medievales, 37/2, 2007, pp. 957-981, en concreto pp. 970 y 977.

${ }^{1514}$ En su desplazamiento desde Flandes a Castilla, los príncipes tuvieron una incidencia que les obligó a recalar en un puerto ingles. Según PADILLA: Bastecida de nuevos bastimentos el armada, y reparados los navios, estando esperando tiempo en Falamua aportó una nao de España en la cual venian D. Francisco de Zúñiga, Conde de Miranda, y su hermano D. Joan de Zúñiga, y D. Joan de Castilla y otros muchos caballeros en busca del Rey, el cual les hizo muy buen rescibimiento y les agradesció mucho el trabajo y voluntad con que venian á le servir (Crónica de Felipe..., pp. 140-141). 
ción de dos bandos nobiliarios polarizados que tanto el regente como el futuro monarca llevaban tiempo promoviendo, don Francisco se decantó claramente por la opción felipista. Don Felipe por su parte, siguiendo el principio del compromiso de merced tras recibir muestras de servicio ${ }^{1515}$, gratificó rápidamente al conde con la concesión de las fortalezas de Hoyales y Ventosilla ${ }^{1516}$.

Pero la inesperada muerte del monarca en 1506 reavivó la lucha de bandos y esta vez se impuso el sector fernandino que promovió la regencia de don Fernando. Esta nueva situación debió suponer un duro golpe para las aspiraciones del conde de Miran$\mathrm{da}^{1517}$ que ni tan siquiera aparece entre los asistentes al juramento que en 1510 reconocía a don Fernando como Administrador y Gobernador de Castilla ${ }^{1518}$. No sabemos con certeza si en estos primeros años de la regencia del Rey Católico se produjo el exilio a la corte flamenca del conde de Miranda, pero de lo que sí tenemos constancia es de la presencia estable de su hermano don Juan en la Grand Chapelle de Gante y de las visitas intermitentes realizadas a la corte de Maximiliano por otro de sus hermanos, don Íñigo ${ }^{1519}$.

En 1512 el conde de Miranda entró por primera vez en contacto con Navarra participando con sus huestes en los ejércitos castellanos que anexionaron el reino tras la solicitud de ayuda del rey Fernando ${ }^{1520}$. Pocos años después volvió a Navarra pero en condición de Virrey.

A la muerte de don Fernando la situación política volvió a complicarse en el corto periodo de la regencia del Cardenal Cisneros y de nuevo la aristocracia castellana

${ }^{1515}$ QUINTANILLA RASO, “Élites de poder..., pp. 974.

1516 BRAH, SALAZAR Y CASTRO, M-59, fol. 63 (documento transcrito por SOLER NAVARRO, Los Duques de Peñaranda..., Ap. Doc, $\mathrm{n}^{\circ}$ 10, pp. 25-26). Aunque lo cierto es que se trataba de una venta disfrazada de merced (AGS, CMC, leg. 41, doc. 13).

${ }^{1517}$ Entre otras cosas el conde de Miranda perdió Hoyales y Ventosilla (AGS, CC CÉDULAS, libro 7, leg. 220, doc. 1), aunque se le devolvió al menos uno de los plazos abonados por su compra (AGS, CMC, leg. 41, fol. 13).

1518 LÓPEZ PITA. P. "Nobleza y monarquía en el Tránsito a la Edad Moderna. Títulos y Grandes en el movimiento comunero", en Títulos, grandes del reino y grandeza en la sociedad política: Fundamentos en la Castilla medieval. Madrid, 2006, pp. 163-213, en concreto pp. 169-174 y doc. VIII, pp. 325-333.

1519 DOMÍNGUEZ CASAS, R., Arte y etiqueta de los Reyes Católicos. Madrid, 1993, pp. 564574; y BRAH, SALAZAR Y CASTRO, A-12, fol. 206.

${ }^{1520}$ PADILLA, Crónica de Felipe..., pp. 201 y 232. 
movió sus fichas para colocarse en una posición de ventaja ante la inminente llegada del nuevo monarca. En este contexto tuvieron una importancia notable las alianzas entre los grandes linajes nobiliarios. Uno de los principales promotores de las confederaciones fue el Condestable de Castilla en cuyo círculo, como pariente y protegido que era, se movía el conde de Miranda. Precisamente este parentesco fue el que posibilitó que don Francisco actuara como intermediario en la alianza entre su tío materno el conde de Haro y su primo paterno el duque de Béjar ${ }^{1521}$.

Sin lugar a dudas, el gran salto cualitativo de la posición del III conde de Miranda se produjo tras la coronación de Carlos como rey de Castilla en 1517. A buen seguro que la proximidad al príncipe y la influencia de su hermano en la corte flamenca, más la destacada figura cortesana de su tío el Condestable condicionaron la posición privilegiada de don Francisco en la Corte del nuevo rey, convirtiéndose en uno de sus más eficaces servidores.

Un primer paso en su promoción dentro de la Corte de Carlos I se produjo en el contexto de la Revolución Comunera en la que jugó un significativo papel como hombre de armas al lado del Condestable. Su actividad durante todo el conflicto fue bastante notable destacando en varios asuntos relevantes: en el verano de 1520 consiguió la pacificación de la villa de Aranda ${ }^{1522}$; capitaneó la negociación para conseguir la adhesión a la causa realista del contingente de los Gelves ${ }^{1523}$; aseguró la ciudad de Burgos mientras su tío acudía al Norte para frenar al conde de Salvatierra ${ }^{1524}$; e intervino con sus tropas en las decisivas batallas de Rioseco, Tordesillas y Villalar ${ }^{1525}$. En este contexto bélico el Condestable trató de promover la carrera política de su sobrino y no dudó en solicitar insistentemente del monarca el reconocimiento de los servicios del conde como lo muestra una de sus cartas fechadas el 24 de mayo de 1521: El conde de Miranda asy

${ }^{1521}$ SHAHN, FRÍAS, Caja 22, doc. 89; y FRANCO SILVA, La fortuna y..., p. 487.

1522 FERNÁNDEZ CONTI, S., "Los consejeros de Carlos V. Francisco de Zúñiga y Avellaneda", en La Corte de Carlos V. (MARTÍNEZ MILLÁN coord.), Madrid, 2000, vol. 2, pp. 472-476.

${ }^{1523}$ En el apartado dedicado al conflicto comunero comentaremos con profundidad este episodio (PÉREZ, La revolución de las comunidades..., pp. 232-233).

${ }^{1524}$ El Condestable ordenó el 14 de noviembre de 1520 ...que el conde de Miranda se quede en Burgos para defender a la ciudad con 500 lanzas y gentes de a pie (AGS, PR, leg. 1, doc. 105, fol. 293).

${ }^{1525}$ AGS, PR, leg. 4, doc. 64. Su nombre aparece en el tercer lugar, después del Almirante de Castilla y el conde de Benavente, en el memorial realizado por el conde de Haro, Capitán General de las tropas realistas. 
como fue de los primeros que vinieron a servir a vuestra magestad, y siempre a estado en Tordesillas, asy a querido ser de los postreros. Vuestra magestad les es mucho cargo porque quien sirve tan contino mas merece que otros. E asi suplico a vuestra magestad le haga merced en todos sus negocios que a vuestro padre y a vos buenos lo tiene servi$d o^{1526}$. Por su parte, Carlos I envió varias cartas de agradecimiento a don Francisco que, sin embargo, no contenían ningún reconocimiento preciso y concreto como reclamaba el Gobernador $^{1527}$. Por su parte don Francisco también envió a su hermano don Íñigo a la corte imperial para exponer los numerosos servicios que el linaje prestaba a la monarquía $^{1528}$.

El posterior desarrollo de los acontecimientos y la inmediatez de la crisis navarra en la primavera de 1521 supusieron para don Francisco de Zúñiga su encumbramiento como magnate al servicio de la Corona. Este reconocimiento personal le llegó con la misión de pacificar Navarra y la elección del propio monarca para actuar como su representante en ese territorio. Ciertamente la coincidencia de la insurrección de una parte de la población navarra en los primeros días del mes de mayo con los últimos estertores del conflicto comunero supuso un contratiempo para Carlos I, más preocupado por entonces de sus negocios alemanes que de los asuntos domésticos castellanos. El problema se agravó con el apoyo francés a los insurrectos navarros, proyectándose el conflicto europeo entre Carlos y Francisco sobre el territorio peninsular. La ofensiva castellana no se hizo esperar y en el verano de 1521 el ejército imperial derrotó a las tropas franconavarras. En noviembre don Francisco de Zúñiga recibió el poder real para actuar en el terri-

${ }^{1526}$ AGS, PR, leg. 1, doc. 105, fol. 125. Más épicos son los comentarios del Gobernador durante la contienda. El 4 de octubre de 1520 señalaba: Aqui tengo al conde de Miranda que se dejará hacer pedazos por vuestro servicio también como por el de vuestro padre. Vuestra magestad le escriba teniendogelo en servicio y encargandoles lo por venir (fol. 206). Tan solo un día después envió otra misiva en la que comentaba: También ha estado aquí el conde de Miranda; esta muy bien en lo que debe al servicio de vuestra magestad. Yo le envie a su tierra para que travaje de sacar la gente que quedo de los Gelves e bolberse luego aquí. Vuestra magestad le escriba y enbie a mandar lo que haga (fol. 229). El 15 de noviembre de nuevo relataba: El conde de Miranda está aquí con migo, que vino a servir a vuestra magestad; trae 200 lanzas de su casa. Escribale vuestra magestad dandole las gracias que bien las merece (fol. 254).

${ }^{1527}$ Algunas de estas cartas han sido transcritas por SOLER NAVARRO (EL ducado de Peñaranda..., pp. $147 \mathrm{y} \mathrm{ss).} \mathrm{A} \mathrm{pesar} \mathrm{de} \mathrm{que} \mathrm{la} \mathrm{autora} \mathrm{quiere} \mathrm{ver} \mathrm{cierta} \mathrm{proximidad} \mathrm{y} \mathrm{confianza} \mathrm{en} \mathrm{el} \mathrm{tratamiento}$ específico de primo, estas cartas no parecen más que meros formularios que desde la Cancillería real se enviaban a todas las casas de la aristocracia castellana.

${ }^{1528}$ FERNÁNDEZ CONTI, “Los consejeros..., vol. 2, pp. 472. 
torio navarro como Virrey y Capitán General ${ }^{1529}$. A pesar del intenso trabajo del conde y las sucesivas campañas para recuperar los territorios perdidos, el conflicto no finalizó hasta 1524 con la rendición de Fuenterrabía. Efectivamente la carrera política del conde de Miranda se vio consolidada en el transcurso de esta contienda y su trabajo ampliamente gratificado por el monarca. En marzo de 1522 su posición se reafirmaba con su juramento solemne ante los tres estados del Reino de Navarra ${ }^{1530}$. El conde Miranda permaneció en este cargo hasta $1527^{1531}$.

A partir de entonces muchos fueron los reconocimientos del monarca hacia la labor de don Francisco. La confianza depositada por el monarca en el conde de Miranda se tradujo en su nombramiento como Mayordomo Mayor en 1528, justo antes de la marcha del rey hacia Italia, y en su incorporación al Consejo de Estado ${ }^{1532}$. Su principal misión en la Corte fue reorganizar la Casa de la Emperatriz, asistir a doña Isabel en su labor de regente, así como tratar los asuntos de Estado y Guerra ${ }^{1533}$. Todos estos cargos cortesanos estuvieron acompañados de mercedes más tangibles que se tradujeron en la concesión de rentas por parte del monarca ${ }^{1534}$ o la provisión de dignidades eclesiásticas de primer orden para sus familiares directos ${ }^{1535}$. El broche de oro a tan brillante carrera vino de la mano de su nombramiento como caballero del Toisón de Oro en el Capítulo

${ }^{1529}$ El primero de noviembre el rey Carlos confirmaba su nombramiento que ya había sido firmado por los gobernadores en agosto (AGS, PR, leg. 26, doc. 2). Don Francisco fue el elegido después de que el duque de Nájera abandonara el cargo y se descartaran otros candidatos mejor posicionados, como el hijo del duque de Alburquerque o el conde de Alba de Liste, vetados por el condestable de Navarra y el Almirante de Castilla, respectivamente (FERNÁNDEZ CONTI,“Los consejeros..., vol. 2, pp. 473).

${ }^{1530}$ AGS, PR, leg. 10, doc. 30 .

${ }^{1531}$ SOLA LANDA, T., El virreinato de Navarra en la etapa de los Austrias. Gobierno político y administración (siglos XVI-XVII). Tesis doctoral de la Universidad de Navarra, 1997, p. 634.

${ }^{1532}$ FERNÁNDEZ CONTI, “Los consejeros..., vol. 2, pp. 475.

1533 Todos estos aspectos se tratan con gran detalle en la obra coordinada por MARTÍNEZ MILLÁN (coord.) La corte de Carlos V. Madrid, 2000. Especialmente vol. 1, Tomo I, pp. 237 y ss. y Tomo II, pp. 43 y ss.

${ }^{1534}$ En 1531 se concedieron al conde 100.000 maravedíes de juro que se sumaban a los 7.538 recibidos en 1528 (AGS, CONTADURÍA MAYOR DE HACIENDA, leg. 49, docs. 26 y 30).

${ }^{1535}$ Además de las dignidades que consiguió su hermano don Íñigo, del que hablaremos más adelante, su hijo Gaspar fue designado sucesivamente para ocupar las dignidades del obispado de Segovia y los arzobispados de Santiago de Compostela y Sevilla. En 1570 fue nombrado cardenal por el Papa bajo el título de Santa Bárbara. Estos nombramientos se produjeron tras la muerte de don Francisco por lo que suponemos que en su consecución jugó un importante papel el IV conde de Miranda. 
celebrado en Tournai en $1531^{1536}$. Buena muestra de la posición destacada que ocupaba el conde de Miranda en la Corte de Carlos I fue precisamente esta ceremonia en la que don Francisco compartió honores con algunos de los personajes más destacados de la Europa del momento: el hijo del Emperador, el príncipe Felipe; don Juan III, rey de Portugal y cuñado del Emperador; don Fernando de Aragón, duque de Calabria y Virrey de Sicilia; don Pedro Fernández de Velasco, Condestable de Castilla y primo de don Francisco; y don Beltrán de la Cueva, duque de Alburquerque y futuro Virrey de Aragón y Navarra ${ }^{1537}$. Su influencia fue creciendo de tal manera que no se libró de verse inmerso en las habituales intrigas palaciegas que le llevaron a enfrentarse a la posición preponderante de Cobos y Tavera ${ }^{1538}$.

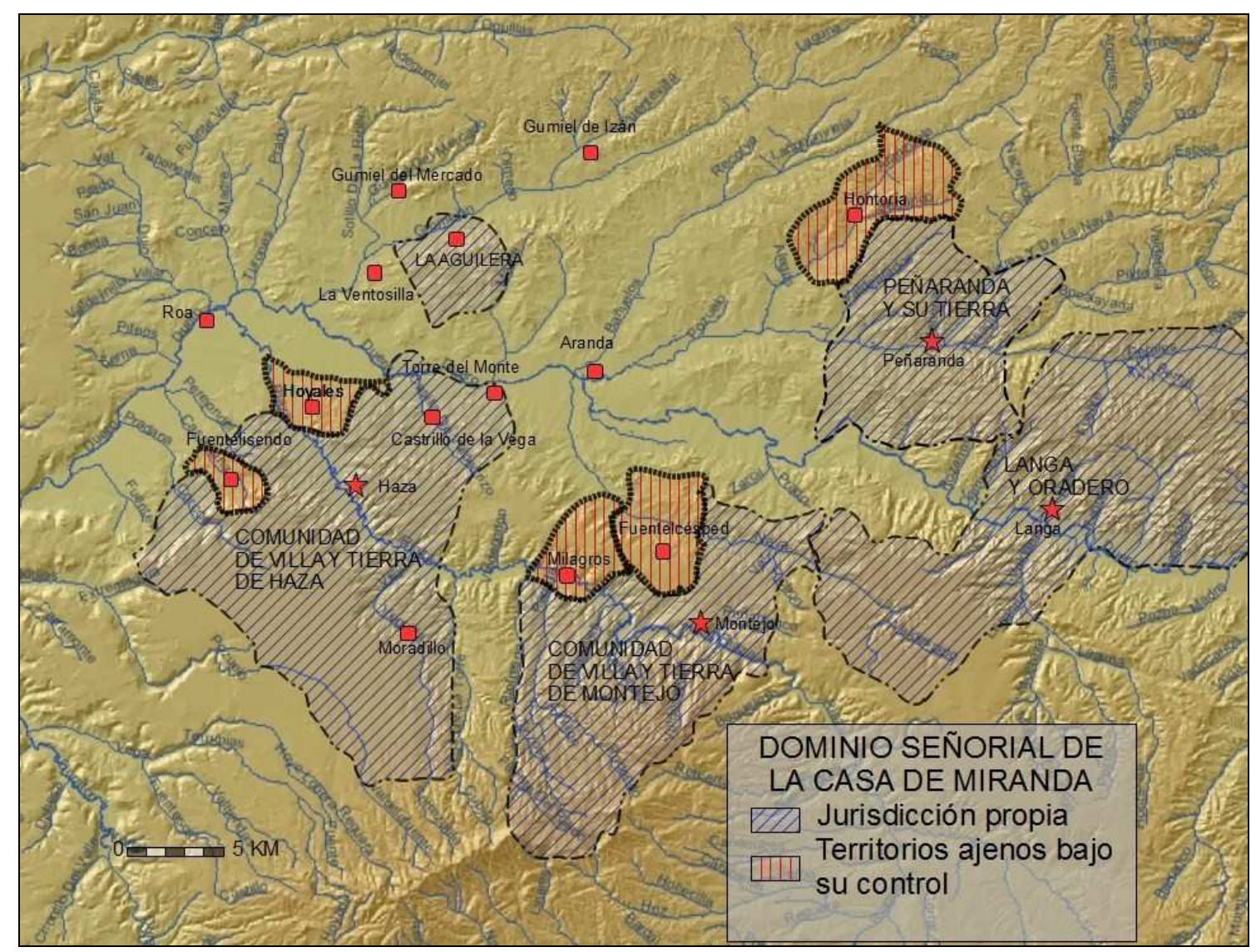

Mapa 11: Señorío territorial de los condes de Miranda en la comarca a fines de la Edad Media.

${ }^{1536}$ Las fechas y características de todas estas mercedes se pueden consultar en SOLER NAVARRO, EL ducado de Peñaranda..., pp. 153 y ss.

${ }^{1537}$ QUINTANILLA RASO, “El engrandecimiento nobiliario..., p. 117.

${ }^{1538}$ FERNÁNDEZ CONTI, “Los consejeros..., vol. 2, p. 476. 
En conclusión, observamos en la figura de don Francisco de Zúñiga el prototipo de la aristocracia moderna encumbrada en su posición dominante gracias a su identificación con una nueva configuración del Estado Moderno que asentaba sus bases sin lugar a dudas en la realidad política bajomedieval. El III conde de Miranda se instaló en el círculo más influyente de la Corte del Emperador gracias a los medios tradicionales: el linaje, la guerra, la oportunidad,... Pero su consolidación en esa posición sólo fue posible gracias a su labor de servicio a los intereses de la Corona. Esta disponibilidad absoluta hacia el monarca no fue un gesto tan solo individual: todo el linaje, cada miembro de la familia Zúñiga Avellaneda, se identificó con el servicio al Emperador, participando de este modo en una nueva relación entre la nobleza y el rey ${ }^{1539}$.

El III conde de Miranda falleció el 21 de junio de 1536. A su muerte la posición del linaje Zúñiga Avellaneda en la Corte estaba perfectamente consolidada gracias a la presencia de don Juan de Zúñiga, hermano del conde y ayo del príncipe Felipe. Por su parte su hijo primogénito, de nombre también Francisco, heredó no sólo el título condal sino su posición y vocación de servicio al monarca alcanzando cuotas de poder en los reinados de Carlos I y Felipe II incluso más elevadas que las de su padre. Además, resultado de la ancestral política expansiva a través de enlaces matrimoniales, el futuro heredero se unió en matrimonio a doña María de Bazán y Ulloa que aportó un considerable patrimonio territorial al linaje $\mathrm{e}^{1540}$. Los otros descendientes del conde también ocuparon puestos preeminentes tanto en el seno de la aristocracia como en las más altas esferas de la organización eclesiástica. Para el segundo hijo, don Gutierre de Cárdenas, se creó un nuevo mayorazgo con licencia del rey Carlos ${ }^{1541}$. Don Gaspar de Zúñiga desarrolló una importante carrera eclesiástica ocupando sucesivamente las importantes sedes de Segovia, Santiago de Compostela y Sevilla. Su carrera culminó con la consecución del capelo cardenalicio. Don Pedro de Zúñiga sucedió a su tío don Íñigo en el abadengo de Covarrubias y además fue prior de Aracena y San Isidoro de León. Doña Catalina de Zúñiga contrajo matrimonio con don Luis de Sandoval, IV marqués de Denia. Doña Teresa de Zúñiga se casó con su primo el marqués de Aguilafuente, don Pedro de

${ }^{1539}$ MARTÍNEZ MILLÁN, J. y DE CARLOS MORALES, C., Felipe II. La configuración de la monarquía hispánica. Valladolid, 1998, p. 26.

${ }^{1540}$ NAVARRO SOLER, El ducado de Peñaranda..., pp. 162 y ss.

${ }^{1541}$ SNAHN, FRÍAS, Caja 888, docs. 10-13. 
Zúñiga. Por último, doña Ana de Zúñiga se convirtió en la esposa del conde de Castellar, don Juan Arias de Saavedra ${ }^{1542}$. Parece ser que también tuvo otras hijas que profesaron como monjas bien en el monasterio de Santo Domingo de Caleruega o en el convento de franciscanas concepcionistas fundado por su madre en la villa de Peñaran$\mathrm{da}^{1543}$.

Don Íñigo fue el segundo hijo de los II condes de Miranda ${ }^{1544}$. Para don Íñigo se eligieron los apellidos maternos y se escogió el mismo nombre que su bisabuelo, el marqués de Santillana. A ninguno de los historiadores que han trabajado sobre la figura de este segundón se le escapa el firme propósito de la familia de encaminarle por la carrera eclesiástica y convertirle en un digno sucesor de su tio abuelo el Gran Cardenal, don Pedro González de Mendoza. Son escasos los datos que tenemos sobre sus primeros años pero nos consta que estuvo matriculado en la Universidad de Valladolid y continuó su formación en 1498 en el Colegio de San Bartolomé de Salamanca, donde obtuvo el grado de licenciado en Teología ${ }^{1545}$.

La promoción de don Íñigo fue paralela al acercamiento de don Francisco a la corte flamenca. En el contexto del intercambio de servicios por prebendas que se produjeron en el corto reinado de don Felipe, el linaje de los Zúñiga obtuvo el compromiso del monarca de conceder a don Íñigo un obispado. Sin embargo, esta promesa no se pudo materializar por la prematura muerte del monarca ${ }^{1546}$. Ante las nulas expectativas

${ }^{1542}$ LÓPEZ DE HARO, A., Nobiliario genealógico de los reyes de España. Madrid, 1622, Vol. I, pp 446-447.

${ }^{1543}$ NAVARRO SOLER, El ducado de Peñaranda..., p. 123; y MERINO GAYUBAS, Genealogía del solar de Guzmán..., vol. II, pp. 731-733.

${ }^{1544}$ Una relación de la bibliografía sobre el personaje y la descripción de su vida y obras se encuentran en RUIZ VÉLEZ, I. y PAMPLIEGA PAMPLIEGA, R., El Colegio de San Nicolás Instituto Cardenal López de Mendoza (1538-1967). Burgos, 2007, pp. 19-44. Sobre su actuación en las tierras de la Ribera cabe destacar la obra de ABAD ZAPATERO, Caminos de Silos., pp. 79-80.

${ }^{1545}$ En una Real Ejecutoria de 1500 se hacía referencia a la condición de clérigo de don Íñigo y su estancia en el Estudio de Valladolid. Esta fecha se refiere al momento en que se solicitó la ejecutoria después del desarrollo del pleito por lo que su estancia en Valladolid seguramente fue anterior a sus estudios en Salamanca (ARChV, RRE, Caja 154, doc. 2). El dato de Salamanca ha sido obtenido de MENDOZA, J. A., "El cardenal D. Íñigo López de Mendoza y el monasterio de La Vid", en Archivo Agustiniano, 44, 1950, pp. 67-84.

${ }^{1546}$ FERNÁNDEZ CONTI, “Los consejeros..., vol. 2, pp. 472. 
que se presentaban con la vuelta de don Fernando a Castilla, Mendoza optó en 1508 por trasladarse a la Corte del Emperador Maximiliano I ${ }^{1547}$.

Tras esta primera frustración, su carrera eclesiástica se dirigió a obtener algún beneficio en tierras ribereñas, no sin provocar ciertas controversias. Sabemos por testimonios indirectos que pretendió la abadía del monasterio cisterciense de San Pedro de Gumiel de Izán hacia 1508. Si bien no consiguió su objetivo, sí que obtuvo una cuantiosa renta por renunciar a sus pretensiones ${ }^{1548}$. Más adelante, en 1516, consiguió del Papa León X su nombramiento como abad comendatario del monasterio premostratense de Santa María de la Vid. Ni su toma de posesión ni su actividad reformadora en el cenobio estuvieron exentas de controversia como veremos más adelante.

Don Íñigo, y sobre todo su familia, aspiraban a objetivos más elevados. A partir del cambio dinástico la carrera del clérigo fue meteórica y pareja a la de su hermano el conde. En 1520 fue nombrado obispo de Coria, una diócesis con escasa proyección a tenor de las insistentes demandas de su tío el Condestable al monarca para que concediera a su sobrino la vacante de la más prestigiosa sede de Jaén ${ }^{1549}$. No obstante, tal solicitud no fue satisfecha y el prelado ribereño se mantuvo como titular de Coria hasta $1528^{1550}$.

${ }^{1547}$ BRAH, COLECCIÓN SALAZAR Y CASTRO, A-12, fol. 206.

${ }^{1548}$ En concreto consiguió una renta anual de 25.000 maravedíes. En el capítulo dedicado a los conflictos abordaremos con más detalle este asunto (AGS, CC PUEBLOS, leg. 13, doc. 6).

${ }^{1549}$ Buena muestra de la promoción que procuró el Condestable para su sobrino se observa a través de las insistentes peticiones que Íñigo Fernández de Velasco hizo al monarca Carlos en las numerosas misivas que se intercambiaron en el contexto de la Revolución Comunera. En una carta redactada el 14 de noviembre de 1520 el Condestable manifestaba: ...estando escribiendo esta carta supe como el obispo de Jaen es fallescido y, pues esto, se ha de proveer a persona natural destos vuestros reinos. Acuerdese vuestra magestad que teneys prometido a don Ýñigo de Mendoza, mi sobrino, el primer obispado que en estos vuestros reinos vacare. Suplico a vuestra magestad le haga merced de le proveer del dicho obispado porque, de mas de cumplir vuestra magestad con el lo que le tienen prometido, lo merescen los servicios del conde de Miranda su hermano y suyos. Insiste nuevamente el 24 de mayo de 1521 recordándole al rey: Lo del obispado de Jaen suplico a vuestra magestad mande proveer en don Ínigo de Mendoza a quien tengo por hijo (AGS, PR, leg. 1, doc. 105, fols. 125 y 291).

${ }^{1550}$ Parece ser que el infante Fernando manifestó sus reticencias a que Mendoza ocupara la vacante jienense. También es posible que se barajara la posibilidad de ocupar la sede leonesa pero tampoco fraguó. No obstante, el pretendiente debió recibir alguna compensación en forma de pensión sobre las rentas de ambos obispados a las que tuvo que renunciar en 1529 cuando fue nombrado arzobispo de Burgos (GOÑI, J, “López de Mendoza y Zúñiga, Íñigo”, en Historia Eclesiástica de España. Madrid, 1972, pp. 452-454; y RUÍZ VÉLEZ y PAMPLIEGA, El Colegio de San Nicolás..., pp. 24 y 35). 
A pesar de este relativo fracaso, la actividad de Mendoza al servicio de la Corona experimentó un cambio decisivo en este periodo ${ }^{1551}$. En 1526 fue comisionado por el rey como embajador ante la Corte inglesa. Su principal cometido era conseguir la ansiada paz universal entre los reinos cristianos. Sin embargo, las negociaciones no llegaron a buen fin por los intereses contrapuestos de las diferentes potencias europeas. Las relaciones entre Inglaterra y el emperador se tornaron más tensas por las pretensiones del monarca inglés de divorciarse de su esposa Catalina de Aragón, tía de don Carlos. Las gestiones del embajador imperial se centraron por lo tanto en mantener la alianza con el monarca inglés y evitar la pretendida ruptura matrimonial. Seguramente como agradecimiento a sus servicios, Mendoza fue propuesto por Carlos I para ocupar la sede de Burgos, circunstancia que se hizo efectiva en noviembre de 1528. A mediados de 1529 Mendoza fue sustituido como embajador y retornó a España para tomar posesión de su nuevo cargo como arzobispo de Burgos. En 1529 también fue nombrado abad de la Colegiata de Covarrubias, disfrutando de los beneficios ligados al Infantado ${ }^{1552}$.

Su estancia en Castilla fue muy corta pues en 1529 acompañó al monarca a Italia y participó activamente del ceremonial de coronación como emperador que se celebró en Bolonia en febrero de 1530. Posteriormente fue enviado al Sur de Italia donde tuvo que poner orden en la maltrecha administración y preparar la llegada del nuevo virrey de Nápoles, Pedro Álvarez de Toledo, en $1532^{1553}$. Durante su estancia en Italia y paralelamente a sus actividades de Estado, Mendoza fue nombrado por el Papa Clemente VII cardenal con el título de San Nicolás in carcere Tuliana el 9 de marzo de 1531.

Durante este largo periplo por los distintos centros de poder europeos, el obispo Mendoza entró en contacto con muchos de los ideólogos del humanismo renacentista entre los que destaca sobre todo Erasmo de Rótterdam. Durante su estancia en Londres

1551 Los datos consignados a continuación han sido obtenidos de la obra RUÍZ VÉLEZ y PAMPLIEGA, El Colegio de San Nicolás..., pp. 25 y ss., donde se narran con todo lujo de detalles las actividades de Mendoza en Londres e Italia.

1552 SERRANO, L., El Cartulario del Infantado de Covarrubias. Valladolid, 1907. Con don Íñigo comenzó un largo periodo en el que diferentes miembros de la casa de Miranda ocuparon esta institución eclesiástica. A la muerte de Mendoza le sucedió como abad su sobrino Pedro Núñez de Avellaneda (SOLER NAVARRO, El Ducado de Peñaranda..., p. 122).

${ }^{1553}$ La misión oficial de Mendoza era la de presidir la comisión que debía examinar los procesos abiertos contra los barones locales rebeldes que apoyaron en 1528 la invasión francesa de Lautrec. Durante su estancia criticó duramente la política seguida por el Cardenal Pompeo Colona, Lugarteniente del reino, a través de una serie de memoriales que envió al monarca recomendando el nombramiento de un nuevo virrey (HERNANDO SÁNCHEZ, C. J., Castilla y Nápoles en el siglo XVI. El Virrey Pedro de Toledo. Salamanca, 1994, p. 190) 
coincidió asimismo con el gran humanista Luis Vives que ejercía como docente en la Universidad de Oxford y que además recibió el encargo de la reina Catalina de tutelar la educación de su hija María Tudor. También se relacionó con otros humanistas españoles como Alfonso Valdés o Juan Maldonado. Todo ello nos hace pensar que el Cardenal se encontraba totalmente imbuido de esta nueva corriente de pensamiento y que debió aplicarlo en su actuación tanto política como pastoral ${ }^{1554}$.

En marzo de 1533 el Cardenal volvió a la Península y se estableció en Burgos para ejercer sus funciones pastorales. Apenas dos años después, en junio de 1535, el prelado murió tras una incierta enfermedad ${ }^{1555}$.

En conclusión, la vida del Cardenal Mendoza se caracterizó por seguir la estela de la política de promoción de la familia al amparo del servicio al Emperador, en este caso dentro de la carrera eclesiástica. Se puede apreciar perfectamente cómo su evolución tuvo dos fases bien diferenciadas. En la primera, tras el fracaso de la promoción junto a la nueva dinastía, el prelado intentó hacerse con una posición recurriendo a los medios tradicionales mediante los que consiguió su nombramiento como abad de La Vid o un incremento de su patrimonio tras su renuncia al abadiato de Gumiel. Estas maniobras no dejan de encuadrarse dentro de una dinámica tradicional y propia de los linajes más modestos y con una proyección exclusivamente local. Durante la segunda fase, encuadrado dentro del servicio a la monarquía y de la mano de su tío el Condestable de Castilla y su hermano el conde de Miranda, se afianzó como personal de confianza del Emperador, al igual que sus hermanos, y fraguó una posición tanto de poder como económica bastante destacada. Evidentemente esta nueva dinámica era más propia de las familias de la aristocracia castellana y tuvo una dimensión que sobrepasó el ámbito del reino.

Don Juan fue el menor de los hermanos Zúñiga Avellaneda y se convirtió en la pieza imprescindible en el afianzamiento de este linaje en el servicio al Emperador Car-

${ }^{1554}$ Buena prueba del apoyo que Mendoza prestó al desarrollo del humanismo en España es que Juan Maldonado le dedicó su obra Pastor bonus, y la correspondencia que mantenía con Juan Ginés de Sepúlveda (GARCÍA, H., "El reformismo del Pastor Bonus de Juan Maldonado", en Hispania Sacra. 71, 1983, pp. 193-218; BIETENHOLZ, P. y DEUTXCHER, Th., Contemporaries of Erasmus. A Biographical Register of the Renaissance and Reformation. Toronto, 1995, p. 346; y LOSADA, A., Epistolario de Juan Ginés de Sepúlveda. Madrid, 1979, pp. 49 y ss.).

${ }^{1555}$ VALLEJO PENEDO afirma que murió el 9 de junio de 1535 ("Monjes y libros: 850 años de Historia", en El monasterio de Santa María de la Vid. 850 años. Madrid, 2004, pp. 291-348, en concreto p. 329). 
los. Ya en 1506 acompañó a su hermano a Inglaterra para recibir a don Felipe y doña Juana. Tras la muerte de Felipe, su hermano le envió a la corte de Flandes para ponerse al servicio del Príncipe Carlos. Se integró por lo tanto en la camarilla de exiliados castellanos y ocupó el oficio de Chambelán desde julio de $1511^{1556}$. Tras la muerte del rey Fernando, don Juan recibió una serie de mercedes por sus servicios en la corte flamenca: la encomienda de Membrilla de la Orden de Santiago o un regimiento perpetuo en Valladolid dejaron en un segundo lugar la exigua renta del alguacilazgo de Aranda, de la que hablaremos más adelante. Sin embargo, esta merced supuso un importante paso en el sometimiento de la villa a los intereses de su hermano el conde ${ }^{1557}$.

A finales de 1517 don Juan volvió a la Península comisionado por Carlos para recoger cierta información. Cuando el monarca llegó por primera vez a Castilla, don Juan se integró en su Corte y le acompañó por sus reinos tanto peninsulares como europeos, detentando desde 1524 el oficio de capitán de la Guardia Española que acompañaba al monarca en todo momento. Este cargo le permitió mantener un estrecho contacto con el monarca que le premiará con nuevas mercedes como la encomienda mayor de Castilla de la Orden de Santiago en 1532. Pero la mayor distinción otorgada fue su nombramiento como ayo del príncipe Felipe en 1532 cuando se vio la necesidad de crear una Casa propia para el heredero ${ }^{1558}$. Además en 1536 entró a formar parte del Consejo de Estado de la regencia de la emperatriz. Tras la muerte de doña Isabel en 1539, don Juan se mantuvo al lado del príncipe Felipe y participó en las cuestiones de Estado que la regencia imponía.

Don Juan contrajo matrimonio con una noble catalana, doña Estefanía de Requesens, que aportó las baronías de Martorell y Molins del Rey. De este matrimonio nacieron dos hijos varones, don Luis y don Juan de Requesens, que jugaron un importante papel durante el reinado de Felipe II. Ambos fueron piezas clave de la gobernación de los territorios italianos.

${ }^{1556}$ FERNÁNDEZ CONTI, S., "Los consejeros de Carlos V. Don Juan de Zúñiga y Avellaneda”, en La Corte de Carlos V. (MARTÍNEZ MILLÁN coord.), Madrid, 2000, vol. 2, pp. 477-79. La mayor parte de los datos que se exponen a continuación han sido obtenidos de este trabajo.

${ }^{1557}$ AGS, CC DIVERSOS, leg. 41, doc. 35. La merced del alguacilazgo está fechada en Bruselas el 27 de noviembre de 1516. La encomienda se le concedió en enero de 1517 y el regimiento en mayo de ese año.

${ }^{1558}$ FERNÁNDEZ CONTI, S., "La organización de la Casa del príncipe Felipe (1535-1546), en La Corte de Carlos V. Madrid, 2000, vol. 1, Tomo II, pp. 97-120. 
Don Juan murió en Madrid el 27 de junio de $1546^{1559}$ habiendo servido fielmente al monarca y sobre todo a su hijo. Esta circunstancia se aprecia nítidamente en unas instrucciones del emperador dirigidas al príncipe Felipe: En lo de don Juan haura poco que dezir, porque le conoceys. Y aunque él se os figura algo aspero, no se lo debeys de tener a mal, antes debeys de tener muy a cierto que el amor que os tiene, deseo y cuydado de que seays tal qual es necesaryo, le haze apasionarse en ello y tener esta reziera, y por eso no deveys dexar de quererle mucho y honrarle y favorecerle y mostrar todo contentamiento dél ${ }^{1560}$.

En conclusión, la casa Zúñiga Avellaneda comenzó su andadura a mediados del siglo XV con la creación del condado de Miranda. Éste se dotó de una verdadera entidad territorial con la incorporación del amplio patrimonio territorial que los Avellaneda poseían en la Ribera del Duero. Unos comienzos duros y discretos, siempre de la mano de la rama mayor de los Zúñiga, en los que el I conde trató de expandir y consolidar unos estados que definieran su posición en el contexto de la aristocracia castellana. Este primer periodo culminó con una clara derrota en el conflicto sucesorio que sacudió a Castilla y la posterior guerra civil. A pesar de este fracaso, los frutos de una hábil estrategia matrimonial posibilitaron la reactivación del linaje, ahora al amparo de la familia de los Velasco, Condestables de Castilla. En este nuevo escenario la familia Zúñiga Avellaneda recondujo su estrategia hacia el servicio a la nueva dinastía austriaca. Las hábiles alianzas y la oportunidad política permitieron que el III conde de Miranda escalara posiciones al amparo de los nuevos monarcas, primero y brevemente con Felipe I, y después y definitivamente con Carlos I. Se consolidaba así el linaje Zúñiga Avellaneda como el prototipo de la nobleza de servicio identificada con el nuevo concepto de Estado planteado por la dinastía Habsburgo. Por lo tanto, su preeminente posición de poder estaba asentada en su función de servicio junto al monarca. Esta nueva realidad implicó el paso a un segundo plano de la configuración de un estado territorial fuerte que, aunque siguió siendo importante, ya no era fundamental.

${ }^{1559}$ El 16 abril de ese mismo año otorgó testamento en Madrid por el que declaraba heredero a su hijo Luis de Requesens (SNAHN, FERRER, CP. 344, doc. 17).

${ }^{1560}$ FERNÁNDEZ ÁlVAREZ, M., Corpus Documental de Carlos V. Salamanca, 1975, Vol. II, doc. CCLII, pp. 104-118. 


\section{2. 2. Linaje Sandoval y Rojas: Marqueses de Denia.}

Los estudios sobre los orígenes de la familia Sandoval son bastante numerosos y de muy buena calidad por lo que nuestro trabajo se limita casi exclusivamente a recopilar los datos referidos a la comarca ribereña aportados por otros investigadores ${ }^{1561}$.

Al igual que ocurrió con los Zúñiga, la presencia de los Sandoval en la Ribera tuvo su origen en un enlace matrimonial con el linaje de los Avellaneda, en este caso con doña Beatriz, una de las descendientes de don Lope Ochoa de Avellaneda. No sabemos en qué momento a caballo entre los siglos XIV y XV doña Beatriz contrajo matrimonio con don Diego Gómez de Sandoval, aportando al matrimonio como dote la villa de Gumiel de Mercado, que es en Diocesis de Osma, con los lugares de Valdesgueva, que son estos: Santivañez, Bahabon y Monzon, y Sotillo, y Pinillas, y Terradillos, e Villovela, e Villatuelda, y la Torre de Cabriada, ... y la villa de Villafrechos, que es en Diocesis de Leon ${ }^{1562}$.

Don Diego, de origen modesto, pronto se vinculó a la casa del infante Don Fernando de la mano de su tío don Sancho de Rojas ${ }^{1563}$. La carrera política de Sandoval estuvo estrechamente vinculada al gobierno como regente del futuro rey de Aragón y así le acompañó como su mariscal en las campañas por tierras granadinas, destacando en la toma de Antequera. Su destreza y el apoyo del regente le sirvieron para recibir de Juan II el título de Adelantado Mayor en $1411^{1564}$. Prueba de la confianza depositada en él fue su nombramiento como ayo del infante don Juan, futuro rey de Navarra y Aragón. Como muestra de agradecimiento en 1412 el de Antequera, ya como rey de Aragón, concedió a don Diego la villa y fortaleza de Lerma ${ }^{1565}$. Precisamente con esta donación

${ }^{1561}$ Destacamos dos estudios fundamentales: FRANCO SILVA, A., "El linaje Sandoval y el señorío de Lerma en el siglo XV", en El Pasado Histórico de Castilla y León. Edad Media. Salamanca, 1984. Vol. I, pp. 133-149; del mismo autor y con el mismo título en Anales de la Universidad de Cádiz, I, 1984, pp. 45-61; y FEROS, A., El Duque de Lerma. Realeza y privanza en la España de Felipe III. Madrid, 2002, pp. 77-85. La mayoría de los datos presentados a continuación proceden de estos estudios.

1562 SALAZAR Y CASTRO, Historia genealógica..., vol. III, pp. 508-509. Se trata de la transcripción de una carta fechada el 3 de marzo de 1426. También se hace referencia a que esta dote le fue entregada por Juan Delgadillo y Álvaro Díaz de la Peña, tutores de doña Beatriz.

${ }^{1563}$ Don Diego era hijo de don Hernán Gutiérrez de Sandoval y doña Inés de Rojas. Don Sancho de Rojas fue promovido primero a la sede episcopal de Palencia para culminar su carrera con el arzobispado de Toledo.

${ }^{1564}$ SÁEZ, C., "Diego Gómez de Sandoval y la escritura precortesana en Sicilia (1415-1416)", en Signo. Revista de Historia de la Cultura Escrita. 2, 1995, pp. 9-18. Este autor hace referencia a documentos del Archivo Ducal de Medinaceli que no hemos podido localizar.

1565 SNAHN, OSUNA, Caja 1946, docs, 1-3 y Caja 1963, doc. 1. 
tomó impulso la formación de un verdadero estado señorial en las tierras meridionales burgalesas pues hasta el momento tan solo contaba con la villa de Gumiel de Mercado y Valdesgueva, heredadas de los Avellaneda. Entre 1415 y 1416 don Diego se desplazó junto al infante don Juan a Sicilia donde actuó como consejero de Fernando I y Alfonso $\mathrm{V}^{1566}$.

De vuelta a Castilla, don Diego incrementó sus dominios con la compra de la villa de Cea en 1418 y consiguió de Juan II licencia para formar mayorazgo ${ }^{1567}$. Asimismo fue nombrado miembro del Consejo Real y se vio envuelto en las numerosas intrigas promovidas por los Infantes de Aragón. Sandoval siempre se mantuvo al lado del infante don Juan, fluctuando junto a él bien al servicio del monarca castellano o en el polo opuesto guerreando contra él. A mediados de los años 20 don Diego mantuvo una estrecha relación de servicio con el rey de Castilla como se refleja en el ambiente de armonía que propició que don Diego y doña Beatriz fueran los padrinos en el bautizo del príncipe don Enrique el 5 de enero de $1425^{1568}$. En agradecimiento a sus servicios el monarca también le concedió el título de conde de Castro en 1426, añadiendo a su patrimonio territorial las villas de Castrojeriz, Osorno, Saldaña, Portillo y otras nueve más ${ }^{1569}$. En lo que se refiere al ámbito ribereño es destacable que en 1421 don Diego adquirió la villa de Gumiel de Izán con lo que se incrementó su posición de poder en la comarca $^{1570}$.

A finales de la década de los veinte su situación cambió drásticamente a causa de su identificación con los intereses del infante don Juan y su oposición a don Álvaro de Luna. En 1429 don Diego se retiró a Peñafiel donde opuso resistencia al avance del Condestable que finalmente tomó el castillo y obligó a Sandoval a huir a Aragón. Este

${ }^{1566}$ SÁEZ, "Diego Gómez de Sandoval..., p. 9 y docs. 1-12. La documentación certifica la presencia de don Diego junto al infante don Juan en Catania entre agosto de 1415 y junio de 1416. Como premio a esta labor el rey Alfonso de Aragón concedió en 1417 a don Diego la jurisdicción de la tierra y castillo de Augusta en Sicilia (SNAHN, MONCADA, CP. 307, doc. 4).

${ }^{1567}$ Existe un documento de toma de posesión fechado en 1416 (SNAHN, OSUNA, Caja, 2086, doc, 8) y la carta de pago de la compra el 23 de agosto de 1418 (docs. 5 y 6). La merced para constituir mayorazgo fue concedida el 14 de septiembre de 1419 (doc. 7 ).

${ }^{1568}$ VAL VALDIVIESO, Isabel la Católica..., p. 33. Fueron también padrinos de don Enrique el almirante don Alonso Enríquez y el condestable don Álvaro de Luna junto a sus esposas.

${ }^{1569}$ Título concedido por Juan II en 1426. A este título el monarca agregó, a petición de don Diego, las villas de Lerma, Cea y Gumiel del Mercado (FRANCO SILVA, “El linaje..., pp. 51 y 52).

${ }^{1570}$ CADIÑANOS BARDECI, Arquitectura fortificada..., p. 267. 
apoyo a los Infantes en su pugna con don Álvaro de Luna primero y con el monarca castellano después le ocasionó la pérdida de su patrimonio en Castilla que fue embargado por la Corona ${ }^{1571}$. No obstante, Alfonso V recompensó su fidelidad al clan aragonés con la cesión de los señoríos valencianos de Denia, Ayora y Jávea ${ }^{1572}$. Se inició de esta manera el intento de arraigo en tierras valencianas que se confirmó con el concierto de un nuevo matrimonio, tras la defunción de doña Beatriz en 1436, con doña Isabel Ladrón de Pallars, heredera de los vizcondes de Vilanova y Chelva en $1438^{1573}$.

A propósito de la muerte de doña Beatriz, el cronista Carrillo de Huete informa que ésta se produjo de forma violenta por orden de su marido: ...el conde de Castro, don Diego Gómez de Sandoval, envió desde Aragón, donde estaba desterrado a don Diego de Sandoval, su sobrino, e a un bachiller suyo con fasta veynte roçines a Villafrechós, lugar suyo donde estaba la condesa su muger en un monasterio de monjas. E llamaron a la puerta deziendo que el conde venía allí, e entraron dentro en la cámara onde la condesa estava, de noche, e afogáronla. El motivo para tal decisión parece que estaba claro pues ...la raçon porque el conde mandó fazer esto fue porque estando él ausente usó mal de su persona ${ }^{1574}$.

A mediados de los años 40 don Diego volvió a tierras castellanas acompañando de nuevo al rey de Navarra. Participó activamente en la batalla de Olmedo y cayó prisionero del monarca castellano. Sin embargo, por el acuerdo de Astudillo de 1446 se le concedió el perdón y Juan II le permitió utilizar de nuevo su título de conde de Castro y recuperar parte de sus señoríos ${ }^{1575}$.

${ }^{1571}$ En lo que al territorio que estudiamos se refiere destaca la confiscación de la villa de Gumiel de Izán (SNAHN, OSUNA, Caja 79, docs. 35-38).

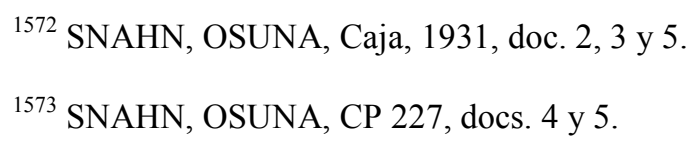

${ }^{1574}$ CARRILlO DE HUETE, P., Crónica del Halconero de Juan II. Madrid, 1946, p. 233. Tomado de CÓRDOBA DE LA LLAVE, R., "Adulterio, sexo y violencia en la Castilla medieval", en Espacio, Tiempo y Forma. Serie IV, $\mathrm{H}^{\mathrm{a}}$ Moderna. 7, 1994, pp. 153-184.

${ }^{1575}$ SNAHN, OSUNA, Caja 1946, doc. 5. La villa de Cea no fue recuperada hasta 1456 cuando el marqués de Villena se la devolvió al hijo de don Diego. Villafrechós fue cedida a los Velasco en 1445 (SNAHN, OSUNA, Caja 106, docs. 1-3). 


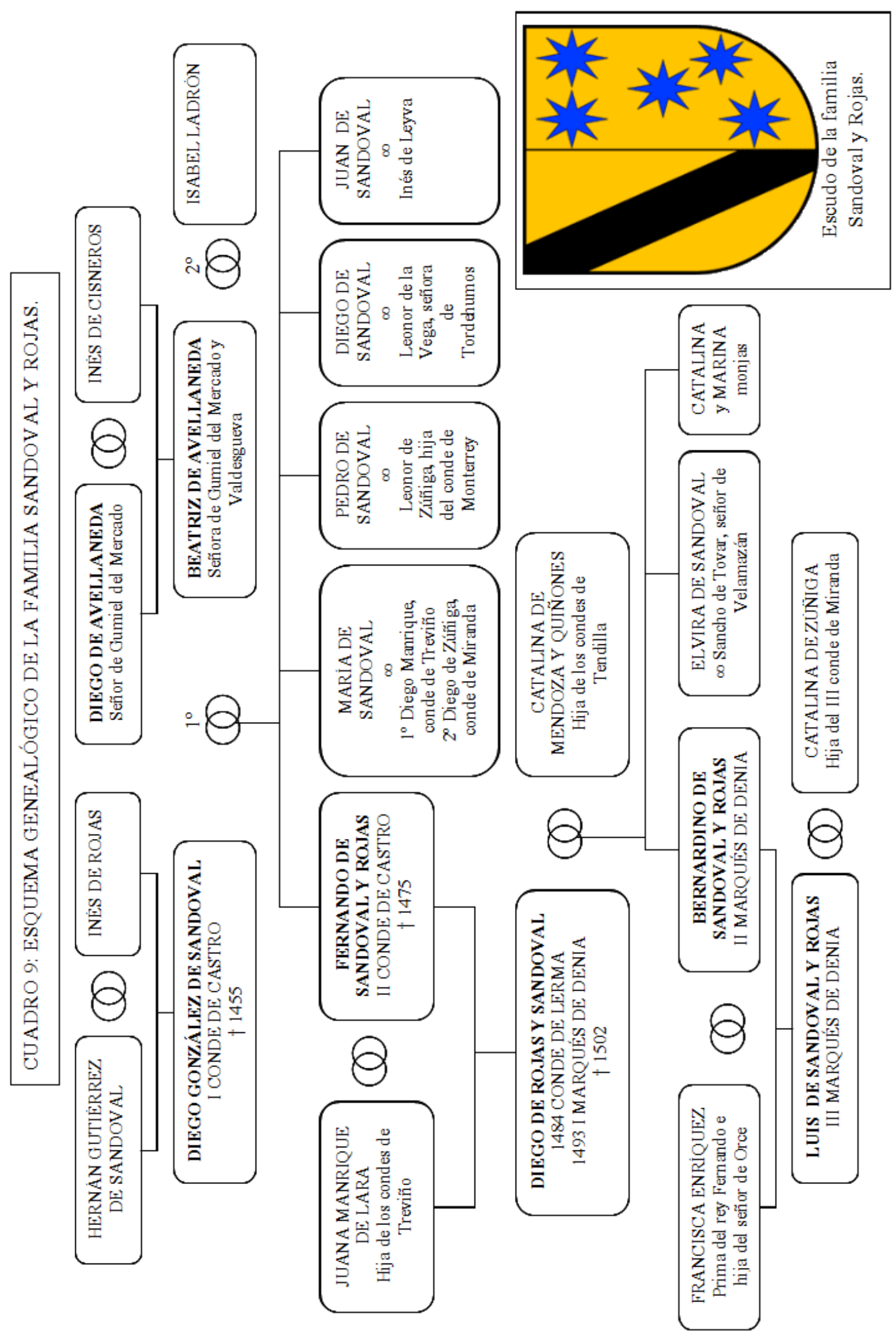


Don Diego también utilizó las alianzas matrimoniales para consolidar su posición política. Sus dos hijos mayores sellaron un potente vínculo con el linaje riojano de los Manrique de Lara, asimismo ferviente partidario del bando de los infantes de Aragón. El heredero de la casa Sandoval, don Fernando, se casó con doña Juana Manrique, mientras que la segunda hija de don Diego, doña María, contrajo matrimonio con el heredero de los señores de Treviño, don Diego Gómez Manrique de Lara. El resto de sus hijos también se emparentaron con otros miembros de la nobleza aunque de una posición más modesta: para don Pedro de Sandoval se concertó su matrimonio con doña Leonor de Zúñiga, hija del conde de Monterrey ${ }^{1576}$; don Diego de Sandoval se casó con doña Leonor de la Vega, señora de Tordehumos; y don Juan de Sandoval con doña Inés de Leyva ${ }^{1577}$.

Don Diego Gómez de Sandoval murió en 1455 tratando de recuperar el amplio patrimonio que había conseguido a lo largo de su intensa vida y que los avatares de la política castellana no le habían permitido mantener. Sin lugar a dudas, don Diego fue el verdadero fundador de este linaje que asentó sus bases territoriales en Castilla en torno a la villa de Lerma y que extendió sus ramificaciones de forma secundaria por las tierras ribereñas de Gumiel del Mercado y Valdesgueva.

$\mathrm{Su}$ sucesor, don Fernando Gómez de Sandoval, invirtió buena parte de sus esfuerzos y fortuna en recuperar el patrimonio territorial de su padre que, bien por confiscación de los monarcas o por herencias, se había fragmentado de manera considerable $^{1578}$. En primer lugar, intentó recuperar los territorios confiscados a su padre por los reyes de Castilla y así se hizo con la villa de Cea en $1457^{1579}$. Sin embargo, no ocurrió

${ }^{1576}$ SNAHN, OSUNA, Caja 79, doc. 1-4.

1577 SNAHN, OSUNA, Caja 1954, doc. 1; Caja 1781, doc. 5; OSUNA, Caja 1932, docs. 10-12; y SALAZAR Y CASTRO Historia genealógica..., vol. III, p. 510.

${ }^{1578}$ A pesar de la ya comentada licencia para establecer mayorazgo, el I conde de Castro repartió entre sus herederos todos los territorios. En los dominios valencianos se produjo la división de todas sus posesiones y así se observa como cada uno de los hermanos tenía su correspondiente participación en Denia, Javea o Ayora (ARCHIVO DEL DUCADO DE MEDINACELI -ADM-, DENIA-LERMA, leg. 14, doc. 25). Esta situación se complicó más si cabe con la negativa de los vasallos a reconocer como señores a los herederos (leg. 14, doc. 24 y leg. 110, doc. 11). SALAZAR Y CASTRO afirma que don Diego estableció con licencia real el 8 de julio de 1427 la creación de tres mayorazgos para don Fernando (Castrojeriz, Portillo, Saldaña, Cea, Lerma y Osorno), don Diego (Gumiel de Izán y del Mercado, Villa Rielda, Villovela, Terradillos, Pinillos, Cabañas, Bahabón, Oquillas y Alcocer) y Don Pedro (Villafrechós y Valdenebro). Pero, como veremos más adelante, la realidad fue un poco más complicada (Historia genealógica..., vol. III, p. 509).

${ }^{1579}$ En la concordia de Ágreda y Almazán de 1454 el monarca castellano permitió el retorno de los nobles castellanos refugiados en Aragón. En el caso concreto de los Sandoval fijó la devolución al 
lo mismo con los territorios vinculados al condado de Castro ni tampoco con la jurisdicción de la villa de Gumiel de Izán en tierras ribereñas. En esta política de recuperación de patrimonio también recurrió a la compra de la herencia de sus hermanos que le permitió integrar en su dominio los territorios valencianos a excepción de la villa de Ayo$\mathrm{ra}^{1580}$. Tuvo menos éxito con los territorios castellanos pues sus hermanos se mostraron reacios a devolvérselos o incluso se los vendieron a otros linajes que entraban en competencia directa con los intereses del propio conde. En este sentido, es bastante revelador el ejemplo de la villa de Gumiel de Izán que fue confiscada por la Corona por el apoyo del I conde de Castro a los infantes de Aragón. Posteriormente Enrique IV reconoció la posesión de la villa a los herederos pero éstos impidieron que fuera recuperada por su hermano mayor y optaron por vender sus participaciones a los condes de Urueña ${ }^{1581}$.

En el plano político el II conde de Castro se alineó con los opositores a Enrique IV siguiendo las preferencias paternas por el partido de los infantes de Aragón. Al igual que le había ocurrido a su padre, esta postura le acarreó la pérdida de parte de sus territorios castellanos durante algunos años ${ }^{1582}$. Tras la vuelta a la obediencia del monarca, el conde consiguió la promesa de la reintegración de su patrimonio ${ }^{1583}$ que, sin embar-

primogénito de los bienes secuestrados al conde de Castro (VICENS VIVES, J., Juan II de Aragón, 13981479. Barcelona, 1953, pp. 153 y ss.).

${ }^{1580}$ En 1457 compró sus respectivas partes a sus hermanas Inés y María por 15.000 florines a cada una y en 1460 por 10.000 a su hermano Pedro (SNAHN, OSUNA, Caja 2086, docs. 31-32 y FRANCO SILVA, El linaje..., p. 54).

${ }^{1581}$ SNAHN, OSUNA, Caja 79, docs. 31-38; y 46-48. Después de muchos enfrentamientos que veremos más adelante, el III conde de Castro consiguió en 1480 que su tío, don Pedro de Sandoval, firmara un contrato por el que se comprometía a cederle sus derechos sobre la villa de Gumiel de Izán a cambio de la villa de Villovela o su valor en dinero. Finalmente el acuerdo no se cumplió, bien fuera por muerte de don Pedro, aunque una de las cláusulas ya preveía su validez a pesar de este inconveniente, o bien por otros motivos. Finalmente, doña Leonor de Zúñiga, que se dice en el documento viuda de don Pedro, terminó por vender los derechos sobre Gumiel al conde de Urueña en 1481 (SNAHN, OSUNA, Caja 79, docs. 49-50 y 55-58). No obstante, este episodio resulta bastante confuso pues encontramos numerosas referencias en la documentación a don Pedro de Sandoval, hijo del I conde de Castro y hermano de don Diego, en fechas posteriores a esta venta (AGS, RGS, 148710, fol. 118).

1582 Entre 1466 y 1467 perdió de nuevo la villa de Cea que fue tomada por orden de Enrique IV. Lo mismo ocurrió con la villa de Lerma y el lugar de Yecla (SNAHN, FRÍAS, Caja 659, doc. 24; y FRANCO SILVA, El linaje..., p. 54). Además se le requisó la villa de Almansa con su castillo (SNAHN, FRÍAS, Caja 129, docs. 36 y 37).

${ }^{1583}$ En julio de 1465 Enrique IV ordenó la restitución de Gumiel de Izán al conde de Castro (SNAHN, OSUNA, leg. 4135, doc. 1). 
go, no se hizo efectiva por el apoyo del conde al pretendiente don Alfonso ${ }^{1584}$. De esta manera, en un nuevo intento por ampliar sus posesiones y siguiendo la tradición familiar de fidelidad al partido aragonés, pactó con los príncipes Isabel y Fernando su apoyo a la causa isabelina a cambio de la restitución de sus bienes ${ }^{1585}$. Promesa que de nuevo se vio incumplida pues buena parte de los bienes requisados estaba en manos de poderosos partidarios de los príncipes como era el caso de los Mendoza que poseían el señorío de Castrojeriz.

El II conde de Castro vio muy mermada su capacidad de maniobra para abordar alianzas a través de enlaces matrimoniales pues tan solo tuvo un descendiente ${ }^{1586}$. Aun con esta limitación, don Fernando promovió su vinculación con la poderosa familia de los Mendoza gracias al matrimonio de su primogénito con doña Catalina de Mendoza y Quiñones, hija del conde de Tendilla y, por lo tanto, nieta del marqués de Santillana.

De todos los miembros de este linaje, el III conde de Castro fue el que mayor relación tuvo con la Ribera del Duero. Don Diego Gómez de Sandoval y Rojas heredó todos los estados que su padre tenía en la comarca cuando éste murió en 1475, pero ya antes don Diego se había forjado una importante y meritoria carrera militar y política al lado de los príncipes Isabel y Fernando. Precisamente en el contexto del conflicto sucesorio y teniendo como escenario la comarca ribereña el heredero del conde de Castro se labró su futuro como servidor de los monarcas.

Al igual que hiciera su abuelo durante algunos momentos de su vida, don Diego alteró el orden de sus apellidos y antepuso el apellido Rojas al del linaje Sandoval ${ }^{1587}$. Posiblemente esta decisión estuvo motivada por la necesidad de marcar distancias con su tío don Diego Gómez de Sandoval ${ }^{1588}$ con el que todavía estuvo disputando para tra-

\footnotetext{
${ }^{1584}$ El infante-rey don Alfonso mandó que le fueran devueltas al conde las villas de Cea y Lerma (FRANCO SILVA, El linaje..., p. 54).

${ }^{1585}$ El 4 de diciembre de 1469 los príncipes prometieron a don Fernando la devolución de sus bienes, garantizándole además el cobro de sus rentas hasta que ésta se hiciera efectiva (FRANCO SILVA, El linaje..., p. 55).

${ }^{1586}$ No conocemos más descendientes de don Fernando y doña Juana.

${ }^{1587}$ El I conde de Castro así lo hizo mientras estuvo bajo la tutela de su tío el obispo Sancho de Rojas pero posteriormente dio preeminencia al apellido Sandoval (SNAHN, OSUNA, leg. 1946, docs. 1 y 4).

${ }^{1588}$ Don Diego Gómez de Sandoval se significó como defensor de su hermana doña María cuando ésta fue perseguida por su cuñado el conde de Paredes tras la muerte de su marido el conde de Treviño (Crónica anónima de Enrique IV. Edición de SÁNCHEZ-PARRA, M. P., Madrid, 1991, pp. 95 y ss.). Él y su hermano don Juan impidieron que don Fernando recuperara totalmente el patrimonio fragmentado
} 
tar de recuperar el patrimonio forjado por su abuelo ${ }^{1589}$. Precisamente como don Diego de Rojas se cita al heredero del conde de Castro en los numerosos documentos que hablan de su intervención en la Ribera al servicio de los pretendientes, destacando sobre todo la conquista de la villa de Aranda y su posterior entrega a la princesa Isabel en $1473^{1590}$.

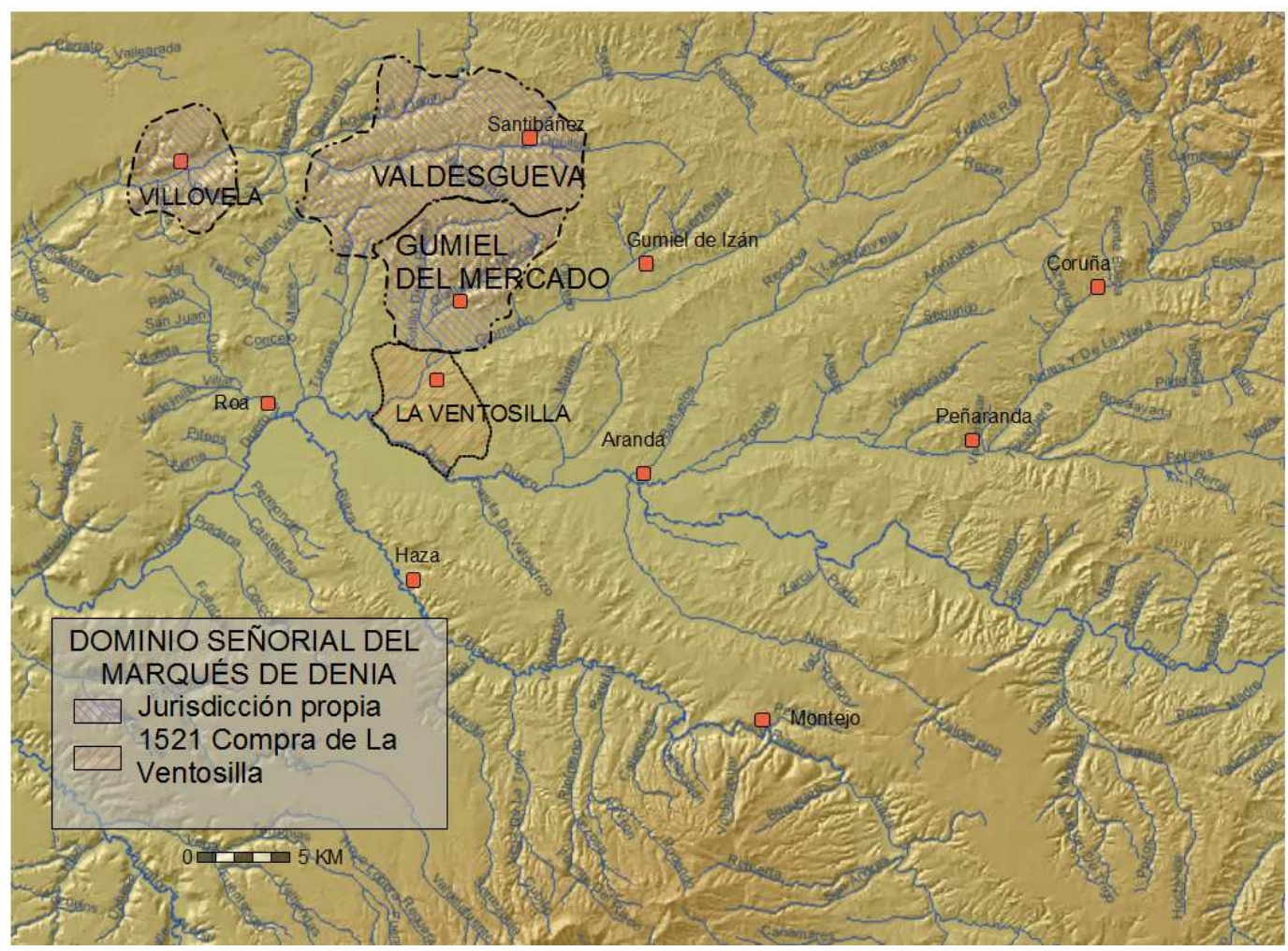

Mapa 12: El señorío territorial de los marqueses de Denia en la Ribera a fines de la Edad Media.

Cuando en 1475 heredó los estados de su padre también recibió la problemática del condado de Castro. No fue hasta 1484 cuando se puso punto final a este capítulo con

por la herencia de su padre, llegando incluso a vender en 1459 Villafrechós al conde de Urueña (SHAHN, OSUNA, leg. 106, docs. 7-10). Todo parece indicar que tío y sobrino también fueron enemigos en el conflicto sucesorio pues el tío recibió en 1467 de Enrique IV el Adelantamiento Mayor de Castilla que le fue retirado a Juan Padilla por haberse pasado al bando del Infante Alfonso. Por su parte, el sobrino se significó abiertamente por esas fechas por el partido del Infante (SHAHN, OSUNA, leg. 1959. doc. 1).

${ }^{1589}$ Don Diego había comprado las participaciones de sus hermanos Pedro y Juan por un montante total de 2.400 .000 maravedíes (ADM, DENIA-LERMA, leg. 14, doc. 28). Finalmente en 1481 tío y sobrino llegaron a un acuerdo para que el marqués recuperara toda la jurisdicción sobre Denia y Javea. Incluso se hizo un intercambio de esta participación por el lugar de Terradillos que pasaba al tío aunque el sobrino se guardaba el derecho de recompra (doc. 29). En Ayora y Villavega no hubo acuerdo y este patrimonio no volvió al señorío de los marqueses de Denia (doc. 21).

${ }^{1590}$ Más adelante abordaremos con mayor profundidad este episodio. 
la concesión por parte de los monarcas de todas las rentas reales de Lerma y Cea junto al título de conde de Lerma ${ }^{1591}$. Como contrapartida don Diego renunció definitivamente a la jurisdicción de Castrojeriz ${ }^{1592}$. Asimismo, en atención a sus servicios en la guerra de Portugal y la conquista de Málaga, en 1493 don Diego recibió la merced del título de marqués de Denia ${ }^{1593}$. No obstante, durante bastantes años los sucesivos marqueses volvieron a reclamar la restauración de sus bienes a través de interminables pleitos o de la intercesión de los monarcas ${ }^{1594}$.

A pesar de seguir manteniendo la villa de Lerma como capital de sus estados, el I marqués de Denia desarrolló una importante actividad en la Ribera que se plasmó en unas serie de conflictos con la nobleza comarcana entre los que destacaron los enfrentamientos con el conde de Urueña por recuperar la jurisdicción de Gumiel de Izán y con el conde de Miranda por el aprovechamiento del río Gromejón. Asimismo extendió su influencia sobre la cercana villa de Aranda donde, además de tener sus casas en la Plaza Nueva ${ }^{1595}$, también contaba con fieles servidores entre los miembros de la oligarquía local $^{1596}$.

Casó el marqués a sus hijos con destacados miembros de la nobleza castellana, aunque bien es cierto que no se contaban entre la aristocracia más poderosa. El primogénito, don Bernardino, contrajo matrimonio con doña Francisca Enríquez, prima del rey Fernando e hija de don Enrique Enríquez, señor de Orce. Doña Elvira se casó con don Sancho de Tovar, hijo de los señores de Velamazán, rama secundaria de los Tovar. Desconocemos los matrimonios del resto de los hijos, aunque sí que sabemos que dos de sus hijas, doña Catalina y doña Marina, ingresaron en el monasterio de San Pedro Mártir de Toledo ${ }^{1597}$.

\footnotetext{
${ }^{1591}$ FRANCO SILVA, El linaje..., p. 55.

${ }^{1592}$ AHN, DIVERSOS-COLECCIONES, leg. 18, doc. 1602.

${ }^{1593}$ FRANCO SILVA, El linaje..., p. 55.

${ }^{1594}$ FRANCO SILVA, El linaje..., p. 56; y FEROS, El Duque de Lerma..., pp. 78-79.

${ }^{1595}$ VELASCO PÉREZ, Aranda. Memorias..., p. 177.

${ }^{1596}$ El regidor Íñigo de Barahona ya aparece como criado del conde de Castro en 1480; Pedro de Ormaza, uno de los principales promotores de la apertura de la calle Barrionuevo, era Camarero del marqués; Rodrigo de Durango, regidor de la villa, fue su alcaide en la fortaleza de Gumiel de Mercado a principios del siglo XVI.

${ }^{1597}$ SNAHN, OSUNA, Caja 1847, doc. 1.
} 
Al final del siglo XV el patrimonio territorial de los marqueses de Denia en la Ribera se extendía por la zona Noroeste de la comarca. Desde su principal posesión en la zona, la villa de Gumiel de Mercado, sus estados se asentaban en el curso medio del Esgueva contando con los lugares de Monzón, Sotillo, Villatuelda, Pinillos, Terradillos, Santibáñez, Cabañes de Valdesgueva, entre otros ${ }^{1598}$.

En 1502 murió don Diego y le sucedió don Bernardino. Pronto siguió los pasos de sus antepasados al servicio de los monarcas aragoneses, destacando en los asuntos de Nápoles. A la muerte de la reina Isabel se vio envuelto en la pugna por el poder entre don Fernando y su yerno, siempre apoyando incondicionalmente al rey Católico. Gracias a esta estrecha vinculación afianzó su posición durante la regencia posterior. La llegada de Carlos I supuso una contradictoria situación: por una parte, su labor de servicio con don Fernando se vio reconocida con su nombramiento como Mayordomo Mayor y Gobernador de la Casa de la reina Juana; pero por otra, esta misión supuso su aislamiento definitivo y el alejamiento de los grandes asuntos del reino. Su activa participación en el conflicto de las Comunidades tan solo supuso un pequeño paréntesis en el anodino desempeño de sus responsabilidades en Tordesillas y las veladas acusaciones que tachaban su actuación de negligente en la defensa de la plaza o incluso de falta de delicadeza en el trato de la Reina ${ }^{1599}$.

Evidentemente la estancia continua del marqués en la corte de la reina Juana le mantuvo muy alejado de sus estados territoriales y más aún de sus posesiones en la comarca ribereña. No obstante, la vinculación con la comarca todavía era perceptible en el verano de 1518 cuando el marqués planteó al rey Carlos la posibilidad de trasladar la Casa de la reina a la capital de la Ribera ante el peligro de propagación de la peste desde Valladolid $^{1600}:$...con este correo escrivo al corregidor de Aranda que enbie la relacion

${ }^{1598}$ AGS, CMC, leg. 2, doc. 1. En el balance de las rentas de la Merindad de Santo Domingo de 1483 figuran estas aldeas como propias de don Diego de Rojas. No obstante, sabemos que, por ejemplo, la localidad de Santibáñez estaba siendo disputada con el conde de Urueña que siguió comprando los derechos que los herederos del I conde de Castro y otros personajes tenían sobre ella.

${ }^{1599}$ FEROS, El Duque de Lerma..., pp. 79 y ss. Sobre el papel del marqués de Denia en la Corte de la reina Juana pueden consultarse las obras de ARAM, B., La reina Juana: gobierno, piedad y dinastía. Madrid, 2001, pp. 195 y ss; y ZALAMA, M. A., Juana I. Arte poder y cultura en torno a una reina que no gobernó, Madrid, 2010.

${ }^{1600}$ AGS, ESTADO, leg. 5, doc 308, transcrito por BERGENROTH, Calendar of Letters..., Suplemento de los volúmenes I y II, doc. 36, pp. 171-174; y ZALAMA, M. A., Vida cotidiana y arte en el palacio de la reina Juana I en Tordesillas. Valladolid, 2000, p. 258. Si los informes de Aranda no eran favorables el marqués planteaba un posible traslado a Zamora. 
de la salud que ay en aquella villa a Vuestra Alteza y sy esta sana pareceme que aquel seria el lugar donde Su Alteza podria estar mejor, asi porque no es grand lugar, como porque no ay en el personas que puedan poner enbaraço en nada...

En conclusión podemos señalar que el linaje de los Sandoval tuvo una notable presencia en la Ribera del Duero pero que tan solo se significó durante el periodo del III conde de Castro. En ese momento el protagonismo de esta casa fue notable pues intervino de manera decisiva en el devenir del conflicto sucesorio y actuó como el resto de los nobles comarcanos siguiendo una política de expansión territorial. No obstante, la cercanía de la capital de sus estados en el valle del Arlanza y la posterior vinculación del linaje a la casa de la reina Juana limitaron el interés de esta familia por sus posesiones ribereñas.

\section{2. 3. Linaje de la Cueva: duques de Alburquerque y condes de Siruela.}

El origen de la casa ducal de Alburquerque y la meteórica carrera política de don Beltrán de la Cueva han sido objeto de profundos estudios por lo que tan solo nos limitaremos a señalar aquellos aspectos que tienen que ver con su desarrollo en tierras ribereñas $^{1601}$.

A pesar de su incontestable influencia sobre Enrique IV y por lo tanto sobre la política castellana en general, la presencia de don Beltrán en la Ribera del Duero burgalesa se produjo con carácter tardío, a partir de 1464. Este contacto con la comarca se produjo como consecuencia de su renuncia al maestrazgo de Santiago concedido por el propio monarca poco tiempo antes. En compensación don Beltrán recibió las villas de Roa, Aranda y Torregalindo, entre otras, más una suma de dinero considerable sobre las

${ }^{1601}$ Son numerosos los trabajos en los que la doctora CARCELLER CERVIÑO ha abordado la figura política de don Beltrán de la Cueva y la formación del ducado de Alburquerque. Entre ellos destaca su tesis doctoral Realidad y representación de la nobleza castellana del siglo XV: el linaje de la Cueva y la casa ducal de Alburquerque. Tesis de la Universidad Complutense de Madrid, 2006. Disponible en formato digital en http://eprints.ucm.es/tesis/ghi/ucm-t29153.pdf. Consulta realizada el 31/01/2012. Otros trabajos de la misma autora sobre don Beltrán son: "Los bandos nobiliarios y la carrera política: ascenso y privanza de Beltrán de la Cueva", en Anuario de Estudios Medievales. 36, 2006, pp. 783-801; "Nobleza cortesana, caballería y cultura: la casa ducal de Alburquerque", en Títulos, grandes del reino y grandeza en la sociedad política: sus fundamentos en la Castilla medieval. Madrid, 2006, pp. 215-263; y "El privado como eje vertebrador del partido regio durante la época de Enrique IV: Beltrán de la Cueva", en El contrato político en la Corona de Castilla: cultura y sociedad política entre los siglos X y XVI. Madrid, 2008, pp. 355-390. 
tercias y alcabalas de Roa ${ }^{1602}$. A pesar del importante atractivo económico y estratégico de la villa raudense, el duque tan sólo residió en ella ocasionalmente, debido sobre todo a la cercanía de su villa de Cuéllar en la que había establecido la capitalidad de sus estados.

Aunque la villa de Aranda no formó parte de sus señoríos, a pesar de su inclusión en la consabida compensación por el Maestrazgo de Santiago, sí que jugó un importante papel en la vida del I duque de Alburquerque pues fue en ella donde se dieron los primeros pasos para la configuración de su supuesta relación con la reina doña Juana, argumento que fue utilizado en el conflicto sucesorio de Castilla de los años posteriores. Efectivamente en 1461 el rey dejó a la reina en Aranda mientras él se encargaba de varios asuntos en el Norte. El cronista Palencia, parte interesada en el conflicto, aseveraba que la ausencia del monarca facilitó la relación entre la reina y don Beltrán que dio como resultado a la infanta Juana ${ }^{1603}$.

Es bastante conocida la destacada posición de don Beltrán durante todo el reinado de Enrique IV y la animadversión que esta situación creó entre la aristocracia castellana y, sobre todo, en el anterior privado del rey, don Juan Pacheco, marqués de Villena. Precisamente este personaje fomentó la consolidación de una confederación de nobles que mostró su oposición al monarca en la famosa Farsa de Ávila de 1465 que supuso la confirmación de la polarización de la nobleza castellana ${ }^{1604}$. Don Beltrán se mantuvo fiel a don Enrique hasta tal punto que amparó al monarca en sus territorios y le ofreció su protección ${ }^{1605}$. Las posteriores negociaciones entre el monarca y los insurrectos llevaron a un segundo plano a don Beltrán que se retiró a sus posesiones de Cuéllar y Roa. En estos momentos de inestabilidad tuvo lugar el intento de asedio de la villa de Roa por parte de la nobleza partidaria de don Alfonso. No obstante, la rápida interven-

${ }^{1602}$ CARCELLER CERVIÑO, M. P., Realidad y representación..., pp. 172-175 y 252-253. Desde entonces la villa de Roa estuvo en manos de la familia de la Cueva. La villa de Aranda no llegó a estar bajo la jurisdicción del duque en ningún momento pues se mantuvo bajo el señorío de la reina Juana.

${ }^{1603}$ El cronista, después de un duro alegato contra la reina y la condición femenina en general, afirmaba: ...diré que la Reina permaneció en Aranda, mientras el rey marchó a Logroño; que desde aquí, como desde Navarra, D. Beltrán iba a visitarla con gran familiaridad y que sus visitas eran esperadas (PALENCIA, Crónica de Enrique IV..., Cap. V, p. 354).

${ }^{1604}$ Don Beltrán estaba emparentado con el linaje de los Mendoza por su matrimonio con doña Mencía de Mendoza, hija del II marqués de Santillana. Fue nombrado conde de Ledesma por Enrique IV en 1462 .

${ }^{1605}$ CARCELLER CERVIÑO, Realidad y representación..., pp. 200-201. 
ción de don Beltrán logró sofocar el alzamiento de la villa de Roa y mantener la plaza bajo su control ${ }^{1606}$. En 1467 el monarca siguió apoyándose en don Beltrán y reunió a sus partidarios en la fortaleza del Cuéllar desde donde se dirigieron a Olmedo para enfrentarse a las tropas del infante-rey don Alfonso. El incierto resultado de la contienda dio paso a nuevas negociaciones entre ambos bandos.

La incertidumbre se acrecentó cuando en 1468 murió don Alfonso y la infanta Isabel se convirtió en pretendiente al trono. Don Beltrán se mostró temeroso ante la insistencia de doña Isabel por recuperar la villa de Cuéllar por lo que se apresuró a realizar diversos pactos que aseguraran la defensa de la villa ${ }^{1607}$.

Durante los últimos años del reinado de Enrique IV el duque de Alburquerque mantuvo una fluctuante posición respecto al monarca. A finales de 1468 se retiró de la Corte junto al grueso de los miembros del linaje de los Mendoza por la aceptación por parte del rey de doña Isabel como Princesa de Asturias ${ }^{1608}$. Más adelante estableció nuevas alianzas con el marqués de Villena, de nuevo defensor del monarca y de su hija Juana $^{1609}$. Aunque por otra parte, acordó el compromiso matrimonial de don Francisco, su heredero, con una de las hijas del conde de Alba ${ }^{1610}$. No obstante, el peso político del duque en la corte se vio notablemente debilitado por el renovado protagonismo de $\mathrm{Pa}-$ checo, por la pérdida de apoyos del duque y por la necesidad de solucionar cuestiones domésticas importantes ${ }^{1611}$. A pesar de todo, en este periodo de inestabilidad los duques de Alburquerque consiguieron consolidar el inmenso patrimonio que don Beltrán había

${ }^{1606}$ Crónica anónima de Enrique IV, Tomo I, cap. LXXXIV, p. 203.

${ }^{1607}$ CARCELLER CERVIÑO, Realidad y representación..., pp. 232-233. Cuéllar había sido entregada a la entonces infanta doña Isabel por su padre Juan II (AGS, PR, leg. 32, doc. 4).

${ }^{1608}$ Circunstancia que se produjo en septiembre con la firma de la Concordia de los Toros de Guisando (VAL VALDIVIESO, Isabel la Católica..., pp. 109 y ss.).

${ }^{1609}$ En marzo de 1469 el monarca encabezó una confederación que unía a Pacheco, los linajes de los Zúñiga, Mendoza y Velasco para conseguir el doble matrimonio de doña Isabel con el rey de Portugal y de doña Juana con su heredero. Fruto de esta alianza fue el apoyo del rey al duque de Alburquerque en su enfrentamiento con el duque de Medina Sidonia en marzo de 1470 (VAL VALDIVIESO, Isabel la Católica..., pp. 251-252).

${ }^{1610}$ CARCELLER CERVIÑO, Realidad y representación..., pp. 667 y ss. En las capitulaciones se establecía que don Francisco recibiría de su padre el título de conde de Ledesma.

${ }^{1611}$ En 1469 murió don Gutierre de la Cueva, hermano del duque y obispo de Palencia. En 1470 comenzó la rebelión de Alfonso de Torres, alcaide de Alburquerque, que no fue controlada hasta 1472 (CARCELLER CERVIÑO, Realidad y representación..., pp. 296 y ss.). 
ido configurando gracias a la licencia que el rey les concedió en 1472 para formar mayorazgo $^{1612}$.

En el último periodo del reinado de Enrique IV, don Beltrán mantuvo una actitud expectante, cuando no contradictoria. Por una parte, seguía ligado a los Mendoza que ya se habían inclinado por el partido de los príncipes; y por otra, establecía alianzas con don Juan Pacheco, tras el conato de reconciliación del monarca con su hermana en Segovia en los últimos días del año de $1473^{1613}$.

Tras la muerte de Enrique IV, el duque de Alburquerque, después de un breve periodo de indecisión, se decantó por el partido de doña Isabel, actuando el marqués de Santillana como garante. Como contrapartida, los nuevos monarcas garantizaron en enero de 1475 la seguridad e integridad de los bienes de don Beltrán ${ }^{1614}$. En este sentido, cabe destacar que después de la muerte del monarca muchos de sus fieles servidores se pasaron al bando de Isabel a quien consideraban como la legítima heredera del trono castellano $^{1615}$. A partir de este momento, y a pesar de su pasado proenriqueño y la supuesta paternidad sobre doña Juana, el duque de Alburquerque se mantuvo fiel a la reina Isabel en la guerra contra Portugal, no sin ciertas reticencias por la ausencia del duque en la decisiva batalla de Toro ${ }^{1616}$.

1612 CARCELLER CERVIÑO, Realidad y representación..., pp. 324-325. En 1466 don Beltrán ya había conseguido la licencia real para formar mayorazgo (p. 847), pero no se creó hasta 1472 (p. 864).

${ }^{1613}$ Un primer acuerdo se produjo en los primeros meses del año (VAL VALDIVIESO, Isabel la Católica..., p. 327) y en junio de 1474 se confirmó con una confederación en la que don Beltrán prometía al Marqués de Villena ayudarle en la defensa de los intereses de la Infanta Juana y se comprometió a no aliarse con los Reyes de Sicilia (SNAHN, FRÍAS, Caja 16, doc. 28).

1614 CARCELLER CERVIÑO, Realidad y representación..., pp. 352 y ss. En la confederación firmada el 27 de diciembre de 1474 en Segovia los grandes de Castilla se comprometían a defender a doña Isabel. En ella se dejaba la puerta abierta para que se sumaran el marqués de Santillana y el duque de Alburquerque (VAL VALDIVIESO, Isabel la Católica..., p. 360).

1615 VAL VALDIVIESO, M. I. "Los bandos nobiliarios durante el reinado de Enrique IV”, en Hispania. Revista Española de Historia. Vol. 35, nº 130, 1975, pp. 249-294.

${ }^{1616}$ La sospecha de infidelidad de los recién incorporados al bando isabelino, en concreto el conde de Benavente y don Beltrán, ya se apreciaba tras el fallido intento de don Fernando de tomar Toro el 21 de julio de 1474. Esta sospecha se incrementó por la ausencia del duque de Alburquerque en la batalla de Toro el primero de marzo de 1476 (SÚAREZ FERNÁNDEZ, Los Reyes Católicos. La Conquista..., pp. 134 y ss.). 


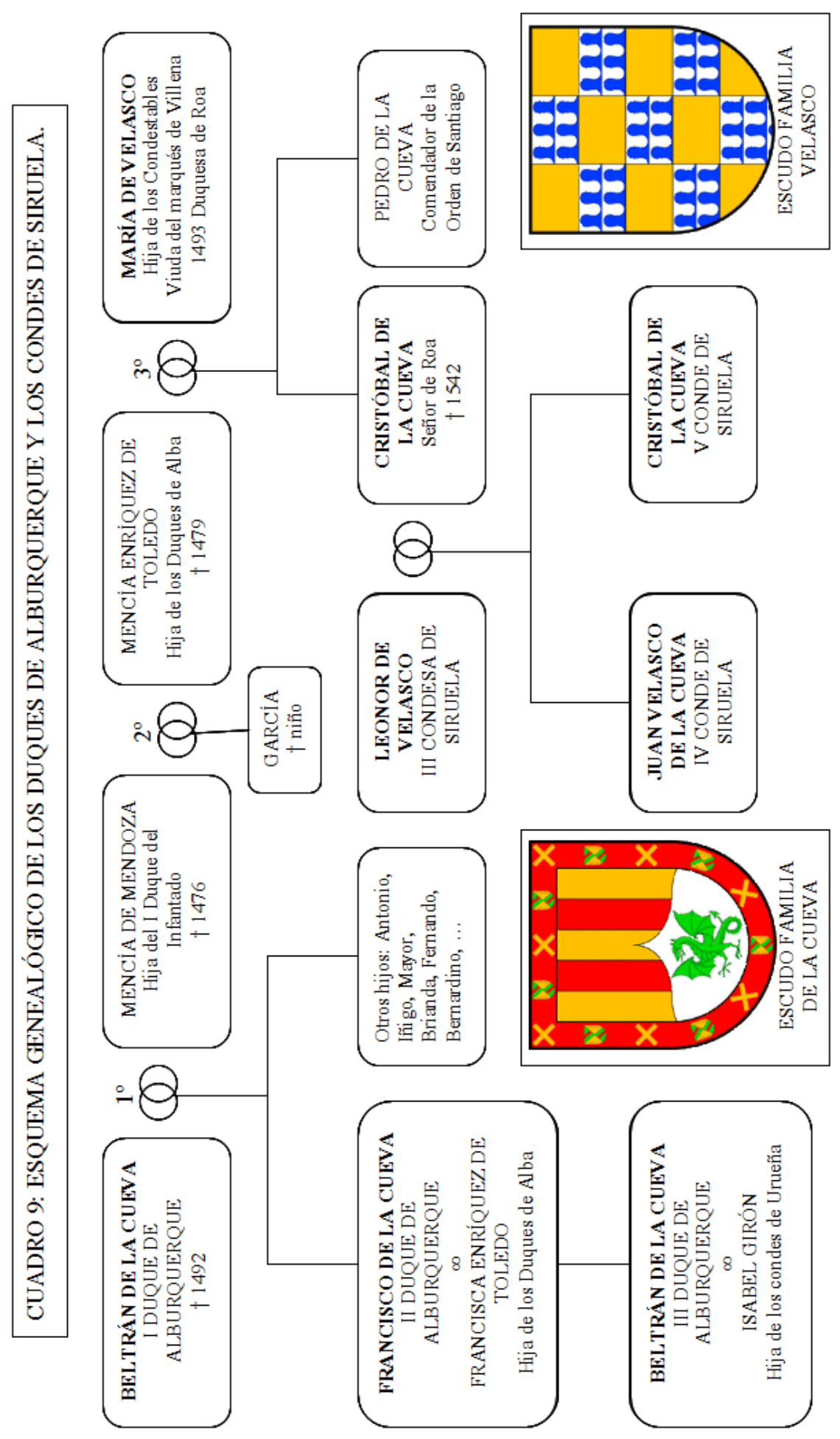


Cuando en 1476 murió su primera mujer, doña Mencía de Mendoza, don Beltrán preparó un nuevo matrimonio. En esta ocasión consolidó las relaciones ya establecidas en los años de inestabilidad con el linaje de los Álvarez de Toledo. La elegida fue la hija mayor de los duques de Alba, doña Mencía Enríquez de Toledo, hermana a su vez de la esposa de su hijo, doña Francisca. Con la finalidad de garantizar la herencia a los herederos de este nuevo matrimonio, los monarcas concedieron licencia para establecer mayorazgo sobre la villa de Mombeltrán ${ }^{1617}$.

Pero doña Mencía Enríquez falleció en 1479 y don Beltrán retomó su política de alianzas matrimoniales. En esta ocasión contrajo matrimonio con doña María de Velasco, hija del Condestable de Castilla y viuda de don Juan Pacheco, marqués de Villena. Esta nueva situación provocó un choque de intereses entre la nueva esposa y el primogénito del primer matrimonio, don Francisco de la Cueva. La tensión entre padre e hijo se aprecia perfectamente en la redacción de las capitulaciones matrimoniales firmadas por los contrayentes que son bastante reveladoras del significado de la política matrimonial de la nobleza castellana ${ }^{1618}$.

Durante los años ochenta el duque de Alburquerque ocupó una posición en la Corte bastante menos relevante de la que disfrutó en tiempos de Enrique IV. Seguía siendo miembro del Consejo Real pero sin peso político significativo. Participó como todos los miembros de la aristocracia castellana en las diferentes campañas de la guerra de Granada. En concreto, intervino en la toma de Alhama enviando a su hijo don Francisco para que ocupara su lugar al mando de las huestes ducales ${ }^{1619}$.

En lo que se refiere a la política matrimonial, ya hemos visto cómo el propio duque utilizó sus tres matrimonios para fraguar alianzas con tres de las más poderosas familias castellanas: los Mendoza, los Álvarez de Toledo y, por último, los Velasco. También hemos visto cómo su hijo primogénito se enlazó con los duques de Alba. Sin embargo, con el resto de sus hijos concertó vínculos bastante más modestos. Don Antonio, señor de La Adrada, se casó con doña Elvira de Ayala. Don Íñigo contrajo matri-

${ }^{1617}$ CARCELLER CERVIÑO, Realidad y representación..., p. 375.

${ }^{1618}$ Este asunto ha sido abordado ampliamente por CARCELLER CERVIÑO, Realidad y representación..., pp. 653 y ss.

${ }^{1619}$ CARCELLER CERVIÑO, Realidad y representación..., pp. 402 y ss. 
monio con doña Ana de la Cueva y Mendoza ${ }^{1620}$. Las hijas del primer matrimonio, doña Mayor y doña Brianda, concertaron matrimonio con el mariscal don Pedro de Navarra y con don Fernando Gómez de Ávila, señor de Villatoro y Navalmorcuende, respectivamente ${ }^{1621}$. En lo que toca a los hijos del tercer enlace, la muerte del titular provocó que fuera doña María de Velasco la que se encargara de buscar un matrimonio conveniente para su hijo primogénito como veremos más adelante.

El patrimonio territorial del duque de Alburquerque era bastante extenso como lo muestran los diferentes estudios citados. Si nos centramos en las tierras de la Ribera del Duero se observa que al núcleo central de Roa ${ }^{1622}$ que estaba en sus manos desde 1465 se fueron añadiendo otros lugares cercanos como Torregalindo ${ }^{1623}$ comprado en 1471. En 1480 también adquirió el lugar de Portillejo con su fortaleza, en tierra de Roa, a Gonzalo Muñoz de Castañeda ${ }^{1624}$.

Don Beltrán murió en su villa de Cuéllar el primero de noviembre de 1492 después de una vida en la que se labró un inmenso patrimonio y en la que jugó un importante papel político como privado de Enrique IV.

Después de la muerte del I duque de Alburquerque sus herederos emprendieron una fraticida lucha por la herencia que tuvo dos grandes protagonistas: por una parte, el primogénito don Francisco de la Cueva; y por la otra, doña María de Velasco que defendía los intereses de los dos hijos habidos en su matrimonio con don Beltrán.

${ }^{1620}$ SOLER SALCEDO, J. M., Nobleza española: nobleza inmemorial, 1520. Madrid, 2008, p 73.

${ }^{1621}$ CARCELLER CERVIÑO, Realidad y representación..., pp. 669 y ss.

1622 Una de las múltiples copias de la merced de Roa se encuentra en SNAHN, FERNÁN NÚÑEZ, Caja 2, docs. 32 y 33. El 4 de enero de 1465 el alcaide de Roa, Diego Cabeza de Vaca, por orden del rey hizo entrega de la villa y su fortaleza a Alfonso de Torres, quien la recibió en nombre de don Beltrán de la Cueva (doc. 30).

${ }^{1623}$ La villa había sido asignada ya al duque en la compensación por la renuncia al maestrazgo de Santiago en 1464 pero, al igual que pasó con Aranda, dicha asignación no se hizo efectiva. Finalmente, el duque de Alburquerque compró Torregalindo en 1471 a don Alfonso de Sequera (SNAHN, FERNÁN NÚÑEZ, Caja 309, doc. 5; Caja 1538, doc. 16 y Caja 2056, doc. 19). Durante los años de la guerra contra Portugal la villa todavía estuvo en manos de don Alfonso de Sequera, partidario del rey de Portugal. Por tal motivo los reyes requisaron la villa y se la entregaron a su contador mayor, Rodrigo de Ulloa (AGS, RGS, 147812, fol. 27). Al menos desde 1482 la villa volvió a estar en manos de don Beltrán (CARCELLER CERVIÑO, Realidad y representación..., p. 389).

${ }^{1624}$ AGS, CC DIVERSOS, leg. 41, doc. 26. La fortaleza había sido concedida por don Fernando a doña Mencía Enríquez en 1477 pero tras el perdón general debió restituirse a su dueño original don Gonzalo Muñoz de Castañeda que se la vendió al duque (CARCELLER, Realidad y representación..., p. 411). 
Cuando en 1472 se creó el mayorazgo para don Francisco se incluyeron en él todos los territorios que hasta el momento poseía su padre entre los que se encontraban Roa y Anguix en la Ribera del Duero ${ }^{1625}$. Con el nuevo matrimonio con doña Mencía Enríquez se configuró un nuevo mayorazgo para el hijo de ambos, don García, que no alteró el contenido que se había asignado para el de don Francisco. La temprana muerte de don García no hizo más que incrementar la herencia del primogénito por lo que no hubo ningún tipo de oposición por parte de éste.

El nuevo matrimonio de don Beltrán con doña María de Velasco supuso la aceptación de unas cláusulas en las que se establecía la creación de mayorazgo para los descendientes del enlace. Además de las anteriores posesiones asignadas para el mayorazgo de don García se sumaba también la villa y fortaleza de Torregalindo ${ }^{1626}$. Una nueva modificación en el reparto de la herencia se produjo en 1492 después del último testamento del duque de Alburquerque ${ }^{1627}$. En él se establecía la asignación para doña María y sus dos hijos, don Cristóbal y don Pedro: la villa de Cuéllar y sus rentas se fijaban para doña María; Mombeltrán más el gredero y las arenas de Roa a don Cristóbal; y para don Pedro Torregalindo y Portillejo. Evidentemente don Francisco recurrió a la justicia real para salvaguardar su mayorazgo dando lugar a un largo pleito que tardó varios años en resolverse. En 1493 se alcanzó un primer acuerdo por el que la duquesa viuda entregaba a don Francisco las villas de Cuéllar y Mombeltrán a cambio de la de Roa más una compensación económica ${ }^{1628}$. Asimismo, en virtud de esta solución, los monarcas concedieron a doña María el título de duquesa de Roa ${ }^{1629}$. No obstante, el acuerdo tardó algún tiempo en materializarse a causa de las reticencias mantenidas por ambas partes y no fue hasta 1503 cuando doña María dio por zanjado el asunto ${ }^{1630}$.

\footnotetext{
${ }^{1625}$ SNAHN, OSUNA, leg. 2275, doc. 82-97.

${ }^{1626}$ SNAHN, FERNÁN NÚÑEZ, leg. 101, doc. 12.

${ }^{1627}$ AGS, CC DIVERSOS, leg. 37, doc. 26; y CARCELLER CERVIÑO, Realidad y representación..., pp. 455 y ss.

${ }^{1628}$ AGS, RGS, 149305, fol. 9.

${ }^{1629}$ CARCELLER CERVIÑO, Realidad y representación..., p. 459.

${ }^{1630}$ SNAHN, FERNÁN NÚÑEZ, leg. 2079, doc. 13. Todavía en 1497 ambas partes se otorgaron cartas de pago y finiquito. El problema realmente no concluyó pues posteriormente se inició un nuevo pleito (CARCELLER CERVIÑO, Realidad y representación..., pp. 461-468 y 681 y ss).
} 
Este periodo de inestabilidad en la casa ducal también se plasmó en Roa que, si bien había enviado en un primer momento una carta al nuevo duque perdonando las deudas que con la villa tenía don Beltrán ${ }^{1631}$, acto seguido protagonizó un episodio de levantamiento antiseñorial. En la primavera de 1493 los vecinos de Roa se sublevaron contra la autoridad de don Francisco y solicitaron la vuelta a la jurisdicción real. Los monarcas respondieron enérgicamente y ordenaron la disolución de la rebelión y la vuelta de la villa a la jurisdicción del duque. La villa obedeció aunque solicitó una carta de seguro para defenderse de los duques y su alcaide ${ }^{1632}$. Esta situación de sometimiento al duque no se mantuvo durante mucho tiempo pues a finales de mayo la duquesa viuda y el II duque de Alburquerque acordaron que la villa de Roa pasase a doña María y a su hijo Cristóbal ${ }^{1633}$.

En definitiva, tras la revuelta antiseñorial de 1493 y los acuerdos suscritos entre el duque de Alburquerque y la duquesa viuda, la villa de Roa y Torregalindo pasaron finalmente a los hijos de doña María de Velasco. Durante los últimos años del Quinientos el señorío de Roa estuvo regido por doña María de Velasco pues su hijo Cristóbal todavía era un muchacho cuando su padre murió. Y así observamos cómo era a ella a quien se dirigían los monarcas para solucionar cuantos problemas se generaban en este territorio, sobre todo los relacionados con el paso de los ganados del Concejo de la Mesta $^{1634}$. Del gran peso que tuvo doña María en la configuración del señorío de Roa habla también el hecho de que, a pesar de las disposiciones testamentarias del duque de Alburquerque que establecía que sus hijos debían tomar sus apellidos, don Cristóbal antepuso el linaje materno, Velasco, al paterno ${ }^{1635}$.

También fue doña María, junto a su familia, la que se encargó de concertar el matrimonio de don Cristóbal buscando para ello a una heredera de título nobiliario. La elegida fue doña Leonor de Velasco, hija única de don Francisco de Velasco y doña

${ }^{1631}$ CARCELLER CERVIÑO, Realidad y representación..., pp. 497-498. Por su parte el duque había perdonado a los vecinos de Roa cierta cantidad de trigo que debían abonarle (SNAHN, FERNÁN NÚÑEZ, leg. 658, doc. 29.

1632 AGS, RGS, 149305, fols. 23 y 158

${ }^{1633}$ CADIÑANOS BARDECI, Arquitectura fortificada ..., pp. 315-320.

${ }^{1634}$ AGS, RGS, 149506, fol. 18 y 149708, fol. 146.

${ }^{1635}$ Incluso el escudo de armas presentaba el emblema de los Velasco en el lado izquierdo como se puede apreciar en sendos escudos del convento del Corpus Christi de Viarce que hoy están en el hastial de la iglesia de Santa María de Redondo, La Pernía (Palencia). 
Francisca Carrillo, condes de Siruela ${ }^{1636}$. Las capitulaciones se firmaron en 1502, pero no fue hasta 1519 cuando se incorporó el título condal al señorío de Roa ${ }^{1637}$.

Con este enlace el patrimonio territorial de don Cristóbal creció considerablemente pues se añadieron los estados de Siruela, Cervera y Pernía. Pero la base territorial del nuevo conde de Siruela siguió manteniéndose en la Ribera del Duero con la villa de Roa como cabecera de sus estados. En este sentido cabe destacar que la villa de Torregalindo y su tierra parece que estuvo desde un primer momento bajo el control de don Cristóbal a pesar del testamento de su padre en el que establecía claramente que debía ser para su hermano don Pedro. Esta situación fue confirmada por las posteriores capitulaciones entre doña María y el II duque de Alburquerque. Evidentemente esta circunstancia provocó la disputa entre los dos hermanos que se tradujo en una demanda presentada por don Pedro en 1511 para solicitar el reconocimiento de su señorío sobre la villa de Torregalindo. Desconocemos el desarrollo del pleito pero todo parece indicar que don Pedro vendió la villa a su hermano en $1512^{1638}$. Años después don Pedro testó en su sobrino don Juan, IV conde de Siruela, poco antes de morir sin descendencia ${ }^{1639}$.

Son muy escasas las noticias que tenemos del conde de Siruela durante el primer cuarto del siglo XVI y se limitan a conflictos con nobles vecinos, sobre todo de sus dominios extrarribereños. Asimismo mantuvo algún litigio familiar a cuenta de la herencia de su padre, pues todavía en 1514 don Cristóbal sostenía un pleito con un hijo natural de don Beltrán, Bernardino de la Cueva, que reclamaba el pago de sus alimentos ${ }^{1640}$. De nuevo tuvo que pleitear en 1517 con su hermanastro don Antonio de la Cueva y con su sobrino don Pedro de Navarra por la posesión de Torregalindo. Y hasta 1521 no consi-

${ }^{1636}$ Este señorío tuvo su origen en una rama de los Fernández de Velasco. El primer conde de Siruela fue don Juan de Velasco, sobrino del primer conde de Haro, que recibió el título en 1470. La evidente relación familiar entre doña Leonor y don Cristóbal requirió de una dispensa matrimonial de consanguinidad.

${ }^{1637}$ SNAHN, FERNÁN NÚÑEZ, Caja 101, doc. 14. En 1505 el II conde de Siruela ya había establecido como su única heredera a doña Leonor y a su muerte el título pasó a ésta (Caja 96, doc. 17). No obstante, hubo algunos problemas con la sucesión pues cuando murió doña Leonor en 1519, la condesa viuda de Siruela, doña Francisca Carrillo, renunció a todos sus derechos sobre el título en favor de su hija para ingresar en un convento (Caja 101, doc. 1).

${ }^{1638}$ SNAHN, FERNÁN NÚÑEZ, Caja 89, doc. 22 y Caja 127, doc 13.

${ }^{1639}$ SNAHN, FERNÁN NÚÑEZ, Caja 96, doc. 2. Don Pedro recibió el título de Caballero de la Orden de Santiago y ejerció como comendador (AHN, CONSEJO DE ÓRDENES, SANTIAGO, exp. 2292).

${ }^{1640}$ ARChV, RRE, Caja 296, doc. 23. 
guió que el duque de Alburquerque le devolviera la fortaleza de Portillejo que el conde de Siruela reintegró en la villa de Roa ${ }^{1641}$.

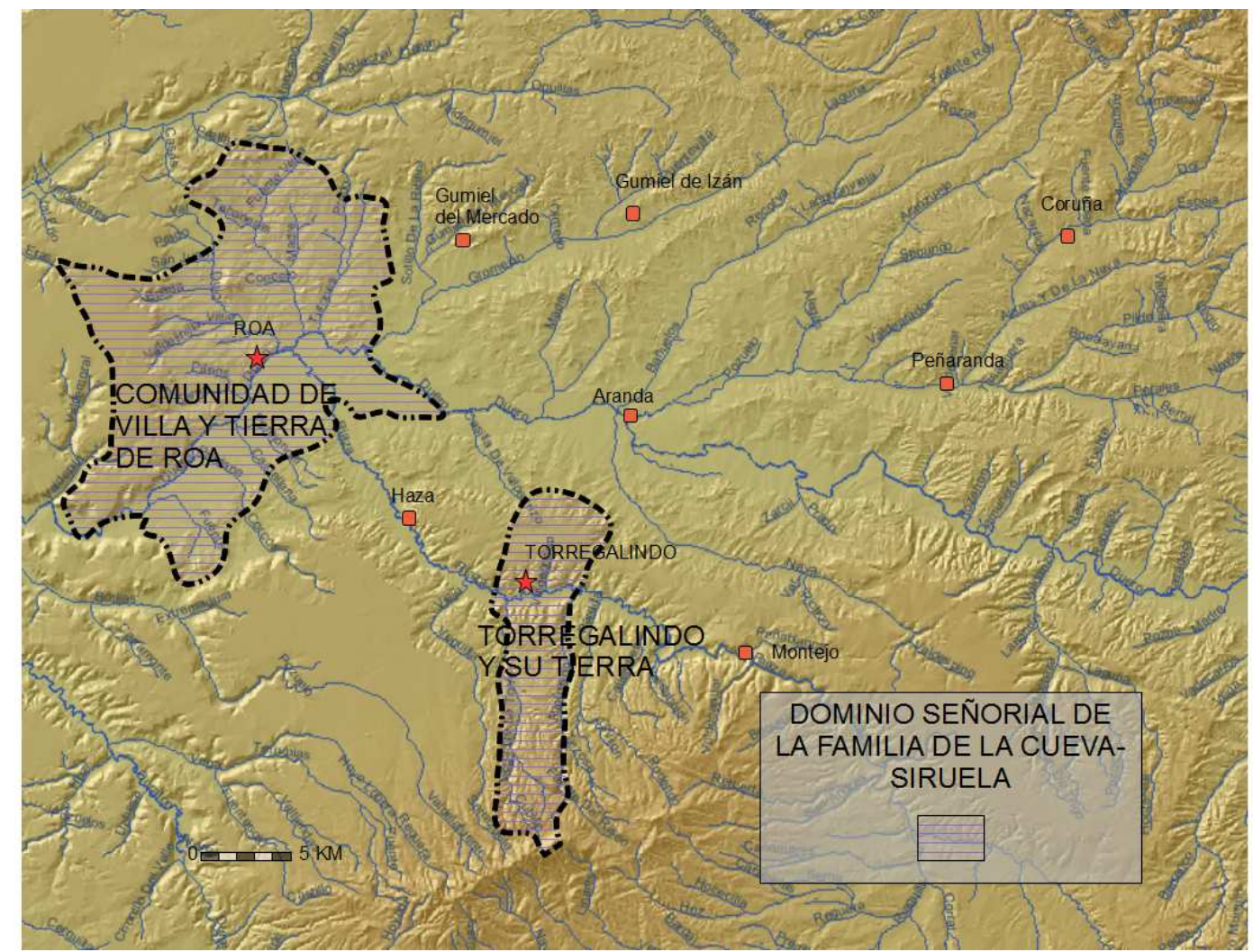

Mapa 13: El señorío territorial de los De la Cueva-Siruela en la Ribera a fines de la Edad Media.

Desconocemos completamente su participación en las intrigas políticas relacionadas con la sucesión dinástica pero suponemos que estuvo cerca del parecer de sus familiares los Fernández de Velasco. Tan solo tenemos constancia del juramento que prestó en 1511 al príncipe don Carlos desde su villa de Roa ${ }^{1642}$.

$\mathrm{Su}$ participación en el conflicto comunero fue bastante modesta limitándose a cumplir las órdenes que le transmitió el Condestable. La consigna fue permanecer en su señorío de Roa para tener este paso e tierra aparejado para el servicio de vuestra alte$z a^{1643}$. Esta situación llevó al conde a enviar una misiva a Carlos I justificando su au-

${ }^{1641}$ CARCELLER CERVIÑO, Realidad y representación..., pp. 467, 489 y 511.

${ }^{1642}$ AGS, PR, leg. 7, doc. 181.

${ }^{1643}$ En una carta fechada el 24 de mayo de 1521 el Condestable informaba al monarca de estas órdenes: ...la villa de Roa es cosa muy importante para el tiempo en que estamos y porque aquella estuviese cierta para el servicio de vuestra magestad yo no he consentido que el conde de Syruela saliese della... (AGS, PR, leg. 1, doc. 105). 
sencia en el enfrentamiento de Tordesillas y mostrando su total adhesión a la causa realista $^{1644}$. La necesidad de recursos militares tras Villalar, esta vez para hacer frente a la situación de Navarra, obligó al Condestable a solicitar la ayuda de don Cristóbal que aportó cincuenta lanzas al ejército imperial ${ }^{1645}$.

No quisiéramos dejar de mencionar la relación que los condes de Siruela mantuvieron con alguna de las familias arandinas más poderosas. Por una parte, García de Salazar, alcalde de la villa arandina y hermano de regidor Pedro de Salazar, estuvo al servicio del duque lo que le costó la pérdida de su oficio concejil ${ }^{1646}$. Por otra parte, la vinculación con la poderosa familia Santa Cruz también fue muy estrecha. En 1529 doña Isabel de Vaca, esposa de Gaspar de Santa Cruz, encontró refugio en el palacio de los condes de Siruela en Roa en el contexto del proceso abierto contra su marido por incumplimiento de los pagos de los arrendamientos reales. Desconocemos si esta vinculación era por parte de Santa Cruz o por doña Isabel pues varios miembros de la familia Cabeza de Vaca desarrollaron su actividad en la villa raudense en este periodo ${ }^{1647}$.

En conclusión, la presencia del linaje de la Cueva-Siruela en la Ribera del Duero asentó su poder en los territorios vinculados a la villa de Roa y Torregalindo. La actividad política del I duque de Alburquerque en el tercer cuarto del siglo XV fue muy relevante pero apenas tuvo proyección sobre sus territorios ribereños. En contraposición a su padre, el conde de Siruela centró su actividad en las tierras raudenses pero el hijo de don Beltrán apenas tuvo participación en la compleja actividad política de los primeros años del Quinientos.

\section{2. 4. Linaje Téllez-Girón: Condes de Urueña.}

El origen de la familia Téllez-Girón se remonta a don Martín Vázquez de Acuña, noble de origen portugués del que surgieron varios de los linajes que alcanzaron mayor poder en la Castilla de la segunda mitad del siglo XV. Su proyección en la Ribera del

${ }^{1644}$ AGS, PR, leg. 3, doc. 47.

1645 ...hasta agora que vino con cincuenta lanzas muy bien adereçadas a servir a vuestra magestad que, como los mas de los grandes que se hallaron a Villalar se volvieron a sus casas desde Valladolid, ha sido nescesario proveernos de otras gentes (AGS, PR, leg. 1, doc. 105). pp. 38-39.

${ }^{1646}$ AMA, leg. 43, doc. 2, transcrito por HURTADO QUERO, Documentos Reales..., doc. 19,

${ }^{1647}$ Diego de Vaca fue alcaide de la fortaleza de Roa en los años sesenta (SNAHN, FERNÁN NÚÑEZ, Caja 2, doc. 30). 
Duero burgalesa fue doble pues del primer conde de Valencia de don Juan descendían tanto los condes de Urueña como la familia arandina de los Acuña, de la que hablaremos más adelante ${ }^{1648}$.

Don Martín se casó en primeras nupcias con doña Teresa Téllez Girón y fruto de esta unión nació don Alfonso Téllez Girón, que contrajo matrimonio con doña María Pacheco, señora de Belmonte. De esta unión nacieron don Juan Pacheco y don Pedro Girón. Ambos entraron siendo jóvenes al servicio del príncipe don Enrique y ya en 1440 don Juan Pacheco se convirtió en el hombre de confianza del príncipe de Asturias que le premió con el marquesado de Villena entre otros títulos ${ }^{1649}$. Por su parte don Pedro se hizo con el maestrazgo de Calatrava en $1445^{1650}$. A partir de ese momento ambos hermanos junto al príncipe encabezaron el partido contrario a don Álvaro de Luna, privado del rey Juan $\mathrm{II}^{1651}$. Don Enrique agradeció su servicio con la concesión de innumerables mercedes que afianzaron su posición de poder en Castilla ${ }^{1652}$ y que culminó con la confirmación por Juan II de la elección de don Pedro Girón como maestre de la Orden de Calatrava $^{1653}$. El primer paso de la presencia de la familia Girón en la Ribera del Duero se produjo en 1448 cuando el príncipe de Asturias concedió a don Pedro Girón la villa de Peñafiel, recientemente recuperada del rey de Navarra ${ }^{1654}$. En este contexto se ha de

${ }^{1648}$ ROMERO PORTILLA, P., "Exiliados en Castilla en la segunda mitad del siglo XIV: origen del partido portugués", en Poder y sociedad en la Baja Edad Media hispánica: homenaje al profesor Luís Vicente Díaz Marín. Valladolid, 2002, Vol. 1, pp. 519-540; y de la misma autora "El peso de la familia Acuña en el nacimiento del partido portugués", en Homenaje al profesor Eloy Benito Ruano. Murcia, 2010. Vol. 2, pp. 683-692.

${ }^{1649}$ FRANCO SILVA, A., "Juan Pachecho. De doncel del príncipe de Asturias a marqués de Villena (1440-1445)", en Anuario de Estudios Medievales. 39/2, 2009, pp. 723-775.

${ }^{1650}$ VIÑA BRITO, A. C., "Don Pedro Girón y los orígenes del señorío de Osuna”, en Historia, instituciones, documentos. 17, 1990, pp. 267-285. Esta autora presenta un completísimo estudio sobre la actividad política de don Pedro Girón y la formación de su patrimonio territorial y económico.

${ }^{1651}$ Los datos referidos en este apartado han sido obtenidos de AGUADO GONZÁLEZ, F. J., El ascenso de un linaje castellano en la segunda mitad del siglo XV: los Téllez-Girón, condes de Urueña. Tesis Doctoral de la Universidad Complutense de Madrid, 1990; y LINDE, L. M., Don Pedro Girón, duque de Osuna. La Hegemonía española en Europa a comienzos del siglo XVII. Madrid, 2005, pp. 2634.

${ }^{1652}$ En 1444 concedió a don Pedro los oficios de alcalde, alguacil y escribano público de Medina del Campo; en 1445 la alcaldía mayor de lo morisco de Jaén, Baeza, Úbeda y Andújar; ese mismo año recibió las villas de Tiedra y Urueña más las tercias de Arévalo (SNAHN, OSUNA, Caja 36, doc. 1-22; caja 35, doc. 103; caja 108, docs. 3-5; CP 21, doc. 3 y 5).

${ }^{1653}$ SNAHN, OSUNA, Caja 98, doc. 7 y caja 41, docs. 2-4.

${ }^{1654}$ SNAHN, OSUNA, CP 66, doc. 7. En la donación se incluían todos los derechos que el príncipe tenía sobre la villa y su tierra, incluidas las alcabalas y tercias. La ceremonia de toma de posesión se 
destacar el pacto realizado el 26 de julio de 1449 en la villa ribereña de Coruña entre el clan de los Pacheco, Velasco y Mendoza que dio origen a una liga contra el Condestable que sirvió asimismo para garantizar las mercedes que habían recibido el marqués y su hermano ${ }^{1655}$. Todas estas maniobras contribuyeron al desenlace final que provocó la destitución y ejecución del Condestable.

Con la coronación de Enrique IV los dos hermanos se convirtieron en los personajes más poderosos de Castilla, si bien don Juan destacó en los asuntos políticos y don Pedro se decantó más por las cuestiones militares. En este sentido, destacó en varias incursiones en el reino granadino y en la toma de la villa de Archidona, que pasó por merced real al primogénito del maestre, don Alfonso. También como rey, don Enrique siguió premiando con nuevas mercedes a don Pedro. Entre éstas destacó la concesión en 1457 del lugar de Santibáñez de Esgueva ${ }^{1656}$. En 1459 recibió asimismo la villa de Gumiel de Izán en compensación por no haber conseguido la villa de Fregenal de la Sierra el año anterior ${ }^{1657}$. No obstante, en ambos casos tal merced parece la sanción regia de una compra pues el dominio efectivo sobre lugar y villa no fue posible hasta el abono de una cuantiosa suma a diferentes personajes que hicieron valer ante la justicia sus derechos sobre estas poblaciones ${ }^{1658}$.

realizó los días 15 y 16 de agosto de 1448 (Caja 96, docs.12-15). La villa había sido devuelta a don Enrique por su suegro el rey de Navarra en virtud de las capitulaciones de paz firmadas entre ellos y tras la renuncia de don Juan de Aragón (docs. 21-25).

${ }^{1655}$ SUÁREZ FERNÁNDEZ, Enrique IV..., pp. 18-20.

${ }^{1656}$ SNAHN, OSUNA, Caja 36, docs. 87-89. No obstante, esta donación debe ser matizada pues el I y el II conde de Urueña tuvieron que comprar los derechos que sobre esta villa tenían los herederos del licenciado Muñoz (caja 36, docs. 92-99 y 102)

1657 SNAHN, OSUNA, Caja 79, docs. 17-21 y FRÍAS, caja 307, docs. 41-42. Fechada en Madrid, el 7 de octubre. El día 8 el rey ordenó a su alcaide en la villa, Fernando de Silva, que se la entregara al maestre (docs. 22-24). Éste envió a Diego de San Pedro que tomó posesión de la villa el 21 y 22 de noviembre (docs. 25-28). VIÑA BRITO, A. C., "Gumiel de Izán, una villa en litigio entre el conde de Urueña y el de Castro", en Historia, instituciones, documentos. 21, 1994, pp. 501-513. Las continuas confirmaciones reales y tomas de posesión hacen pensar a esta autora que el disfrute de la villa no fue efectivo hasta su incorporación al señorío de Osuna en 1481 (pp. 503-504).

${ }^{1658}$ Los sucesivos condes de Urueña tuvieron que pagar a los hijos y nietos del I conde de Castro más de un cuento de maravedíes por la renuncia a sus derechos sobre la villa (VIÑA BRITO, "Gumiel de Izán..., p. 508). Más adelante veremos cómo la posesión de la villa de Gumiel de Izán ocasionó un serio enfrentamiento con el marqués de Denia. 


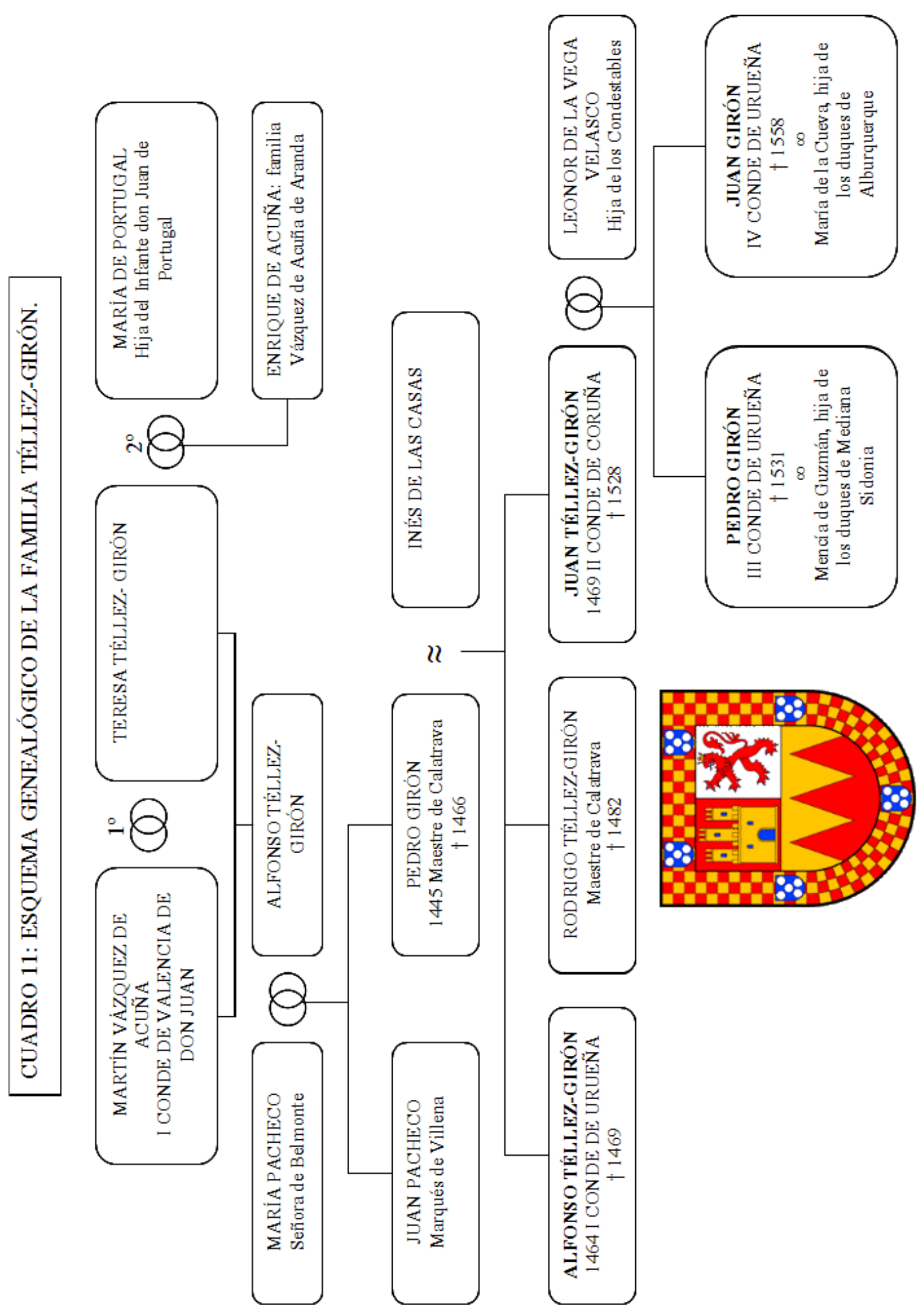


Evidentemente don Pedro se mantuvo al lado de su hermano el marqués de Villena prestándole su apoyo militar en las intrigas políticas que tuvieron lugar durante el reinado de Enrique IV. Como ya hemos visto, el ascenso de don Beltrán de la Cueva como favorito del monarca ocasionó la oposición frontal de don Juan Pacheco que aglutinó entorno a su persona a todos los detractores del privado. Pacheco, con la ayuda de su hermano, formó una liga que, en principio, se comprometía a liberar y defender a los infantes don Alfonso y doña Isabel ${ }^{1659}$ y que evolucionó en una alternativa política que proponía la entronización de don Alfonso ${ }^{1660}$. En este contexto, don Pedro adquirió un gran protagonismo pues en 1466 don Enrique pactó con Pacheco el apoyo de la facción nobiliaria que encabezaba. Entre los compromisos adquiridos en la conferencia de Coca del mes de abril se establecía que don Pedro se casara con la infanta Isabel y a cambio aportaría 3.000 lanzas y 70.000 doblas en favor de la causa de Enrique IV. El pacto concluía con el compromiso de que el marqués de Villena volviera al servicio del monarca acompañado del infante don Alfonso. Don Pedro para ello renunciaba en su hijo don Rodrigo al cargo de Maestre de Calatrava además de contar con la correspondiente dispensa papal. Sin embargo, estos planes se vieron frustrados cuando Girón se encaminaba con sus huestes hacia Madrid para formalizar el compromiso. En Villarrubia sufrió una indisposición que acabó con su vida el dos de mayo ${ }^{1661}$. Tras la muerte del patriarca, sus sucesores continuaron apoyando a su tío en el conflicto sucesorio, si bien es cierto que sin el protagonismo de su padre.

A lo largo de su vida don Pedro conformó un inmenso patrimonio territorial, en ocasiones a costa de los dominios de su propia orden ${ }^{1662}$, que legó a sus hijos gracias a la licencia concedida por Enrique IV en 1457 para fundar mayorazgo ${ }^{1663}$. Don Pedro

${ }^{1659}$ El 16 de mayo de 1464 se firmaba la liga entre el arzobispo de Toledo, don Alonso Carrillo, y los hermanos Pacheco-Girón (SNAHN, FRÍAS, caja 696, doc.11). Esta confederación se amplió una semana después al Almirante de Castilla y a los condes de Alba y Paredes (Caja 12, doc. 2).

${ }^{1660}$ SNAHN, OSUNA, Caja 1635, doc. 30. Como agradecimiento al apoyo de don Pedro, el infante-rey Alfonso concedió al maestre y a su hijo carta de finiquito de cualquier cantidad de alcabalas, tercias o pechos que pertenecieran a la Corona (caja 105, doc. 24).

${ }^{1661}$ VAL VALDIVIESO, Isabel la Católica..., pp. 123-125. Isabel contaba en ese momento con 15 años mientras que el pretendiente tenía 43.

1662 Don Pedro consiguió del Papa Pío II una bula que le concedía la potestad de testar (SNAHN, OSUNA, Caja 1, docs. 48-51) y que fue proclamada por el obispo de Burgos, don Luis de Acuña. Esta licencia permitía testar incluso los bienes del maestrazgo que no tuvieran designación especial (docs. 5960).

${ }^{1663}$ SNAHN, OSUNA, Caja 1, docs. 44-47. Licencia que fue confirmada en 1460 (docs. 65-68). 
tuvo varios hijos naturales de doña Inés de las Casas que vieron reconocida su legitimidad tanto por la Santa Sede como por los monarcas castellanos ${ }^{1664}$. El primogénito fue don Alfonso y su padre consiguió para él un título nobiliario que él nunca había detentado. En 1464 Enrique IV le concedió el título de conde de Urueña y don Pedro fundó un mayorazgo para él que incluía las villas de Peñafiel y Gumiel de Izán así como el lugar de Santibáñez entre otros ${ }^{1665}$. Su padre pactó su matrimonio con doña Blanca de Herrera Niño, señora de Pedraza, que se celebró el 14 de agosto de $1464^{1666}$.

La actividad del joven conde fue muy discreta debido sobre todo a su edad y a la gran personalidad de su progenitor. Incluso varios intercambios y compras que se realizaron en beneficio del condado fueron ejecutados en su nombre por su padre o sus tíos y tutores, don Juan Pacheco y don Enrique de Figueredo ${ }^{1667}$. Sus movimientos en tierras ribereñas se limitaron a la adquisición de algunos lugares en el entorno de su villa de Peñafiel ${ }^{1668}$, la compra de los derechos de alguno de los herederos del conde de Castro sobre la villa de Gumiel de Izán ${ }^{1669}$, así como los de los herederos del licenciado Alonso Muñoz en el lugar de Santibáñez de Valdesgueva ${ }^{1670}$.

${ }^{1664}$ En 1452 el Papa Nicolás V concedió al maestre una bula que le facultaba para poder testar y disponer de sus bienes en sus hijos tenidos fuera del matrimonio (SNAHN, OSUNA, Caja 1, docs. 36-37 y CP 60, doc. 2). Su hijo primogénito, don Alfonso, fue legitimado por el Papa Calixto III en 1456 (Caja 1, docs. 38-39) y se convirtió en su heredero. Lo mismo ocurrió con don Rodrigo que heredó el título de maestre de su padre. Don Juan fue reconocido como legítimo por Enrique IV en 1459 (SNAHN, OSUNA, Caja 1, doc. 54-55 y FRÍAS, Caja 1513, doc. 12).

${ }^{1665}$ Coincidiendo con la merced del título condal el maestre de Calatrava donó a su hijo un importante patrimonio territorial. El 5 de octubre de 1464 don Alfonso y su tutor, don Enrique de Figueredo, tomaron posesión de la villa de Peñafiel (SNAHN, OSUNA, Caja 79, docs. 29-30). El 4 de octubre de ese mismo año el concejo y vecinos de Santibáñez de Esgueva reconocían a don Alfonso como su señor (SNAHN, caja 36, docs. 90-91).

1666 SNAHN, OSUNA, Caja 476, doc. 60. Las capitulaciones matrimoniales se firmaron el 20 de junio de 1464 (FRÍAS, caja 445, doc. 56-57).

1667 Así, por ejemplo, ocurrió con la toma de posesión de la villa de Olvera que había sido comprada al I conde de Miranda (SNAHN, OSUNA, Caja 93, docs. 13-15) o en la ya mencionada de Peñafiel.

${ }^{1668}$ En febrero de 1465 compró a su tío el marqués de Villena los lugares de Padilla de Duero, Fuenpedraza, Canalejas y otros (SNAHN, OSUNA, Caja 97, docs. 1-5).

${ }^{1669}$ En 1469 doña Inés de Sandoval, hija de don Diego Gómez de Sandoval, otorgaba carta de pago a don Enrique de Figueredo en razón del pago de la parte de los derechos que tenía sobre la villa de Gumiel de Izán (SNAHN, OSUNA, Caja 79, docs. 33-34).

${ }^{1670}$ El documento es una confirmación de 1480 de una venta realizada en tiempo del I conde de Urueña (SNAHN, OSUNA, Caja 36, docs. 92-93). Todavía en 1505 y 1508 se estaba negociando con los herederos del licenciado Muñoz el pago de esta compraventa (docs 94-99 y 102). 
La temprana muerte del I conde de Urueña en 1469 no impidió que el patrimonio familiar se consolidara en la figura de su hermano don Juan que heredó el título condal al ostentar su hermano gemelo, don Rodrigo, el cargo de maestre de Calatrava desde mayo de $1466^{1671}$. El rey don Enrique confirmó el privilegio de mayorazgo para don Juan y sus sucesores ese mismo año de 1469 y además le hizo merced de numerosos donaciones sobre las rentas reales de varias localidades andaluzas ${ }^{1672}$, así como de ciertas localidades próximas a sus feudos como Quintanilla de Arriba y de Abajo, en las proximidades de Peñafiel ${ }^{1673}$.

Durante el conflicto sucesorio castellano el joven conde siguió los pasos de su tío el marqués de Villena que volvió a recuperar su posición de privado de Enrique IV tras la desaparición del Infante don Alfonso y las pretensiones de doña Isabel. Así le encontramos en 1470 en Segovia haciéndose cargo de la reina y la infanta Juana mientras el rey acudía a Medina del Campo ${ }^{1674}$. De la misma manera en los primeros compases de la guerra con Portugal los Téllez Girón se alinearon junto al monarca portugués en la defensa de los intereses de doña Juana.

En este contexto, los Reyes Católicos redactaron una provisión real fechada en mayo de 1475 por la que ordenaban a todos los vasallos del conde de Urueña, de su hermano el maestre de Calatrava y de otros adeptos al rey de Portugal que no obedecieran a sus señores. La medida se justificaba por el crimen de lesa majestad que los anteriores habían cometido al haber conspirado contra la reina ${ }^{1675}$. Esta medida se concretó

${ }^{1671}$ CIUDAD RUÍZ, M., "El maestrazgo de Don Rodrigo Téllez Girón”, en En la España Medieval. 23, 2000, pp. 321-365. Circunstancia contraria a las disposiciones testamentarias de don Pedro que establecían que el mayorazgo debería pasar a don Rodrigo en caso de fallecimiento de don Alfonso sin descendencia (SNAHN, OSUNA, Caja 2, docs. 32-33).

1672 SNAHN, OSUNA, Caja 1, doc. 29 y Caja 3, doc. 19-21. El 20 de diciembre de 1469 Enrique IV envió una provisión al concejo de Gumiel de Izán para que recibiera como su señor a don Juan Téllez Girón por estar dicha villa incluida en el mayorazgo que fundó don Pedro Girón (SNAHN, OSUNA, Caja 79, docs. 39-40). Los juros se situaron sobre las rentas reales de sus villas de Archidona, Olvera y Ortejicar, pero también sobre las alcabalas y tercias de Sevilla, Córdoba y Jerez (Caja 93, docs. 24-25 y Caja 61, docs. 22-28). También le concedió la notaría mayor de Castilla y el oficio de camarero mayor de la Cámara de Paños (Caja 3, docs. 6-8 y 16-18).

${ }^{1673}$ Merced otorgada el 25 de octubre de 1470 (SNAHN, OSUNA, Caja 96, docs. 62-64). En 1480 el conde compró al obispo de Segovia, don Juan Arias de Ávila, estas dos localidades con sus vasallos y rentas (Caja 97, docs. 12-23).

${ }^{1674}$ VAL VALDIVIESO, Isabel la Católica..., p. 258. Don Juan también fue objeto de nuevas mercedes del monarca precisamente sobre la villa de Medina que mermaron los derechos de la infanta Isabel sobre la misma.

${ }^{1675}$ SNAHN, OSUNA, Caja 279, doc. 14. 
en julio con la confiscación de sus villas de Gumiel de Izán y Villafrechós que fueron devueltas a la familia Sandoval ${ }^{1676}$.

Pero poco a poco la política de reconciliación emprendida por los monarcas y la intercesión del Condestable de Castilla, suegro del conde de Urueña ${ }^{1677}$, permitieron que don Juan consiguiera el perdón en mayo 1476. Como consecuencia de este perdón los reyes le confirmaron las donaciones de todas las mercedes, villas y lugares que había hecho Enrique IV a su padre el maestre de Calatrava ${ }^{1678}$. En las negociaciones para recuperar su patrimonio uno de los puntos conflictivos fue el retorno de la villa de Gumiel de Izán. Recordemos que los monarcas habían ordenado la restitución de Gumiel al linaje Sandoval en julio de 1475 pero la fortaleza debió quedar en manos del Condestable, suegro del conde de Urueña ${ }^{1679}$. Lejos de llevarse a cabo lo estipulado en las capitulaciones de mayo en las que se establecía la devolución de la villa a don Juan en el plazo de tres meses ${ }^{1680}$, el propio monarca tomó partido por don Diego de Rojas, hijo del II conde de Castro, y participó en la toma de la plaza a mediados de octubre de ese mismo

${ }^{1676}$ AGS, RGS, 147507, fol. 528.

1677 Desconocemos en qué momento contrajo matrimonio el conde con doña Leonor de la Vega Velasco, hija de don Pedro Fernández de Velasco y doña María de Mendoza, pero seguramente tuvo que ver con el matrimonio de su tío don Juan Pacheco con otra de las hijas del Condestable, doña María. Recordemos que el patriarca de los Velasco había conseguido emparentar, además de con los Mendoza a través de su propio matrimonio, con la realeza y con buena parte de la aristocracia castellana: Tovar, Manrique, Zúñiga, Guzmán, y, tras la muerte del marqués de Villena, con los duques de Alburquerque.

${ }^{1678}$ SNAHN, OSUNA, Caja 3, doc. 11-15. La concordia se firmó el 21 de mayo de 1476 en Valladolid. El conde prestó obediencia y servicios a los monarcas y recibía de éstos la confirmación de las mercedes hechas a sus antecesores. Llama la atención que entre estas mercedes se mantuviera la exención del pago de alcabalas y tercias a los vasallos del conde como se puso de manifiesto en algunas comunicaciones a los arrendadores. Evidentemente esta situación convirtió a las villas y lugares del señorío de Urueña en significativos puntos de atracción para la población en general y para los comerciantes en particular (caja 79, docs. 72-78).

${ }^{1679}$ En febrero de 1476 el Condestable dio garantías al conde de Castro de que el conde de Urueña o sus partidarios no entrarían en Gumiel durante los 70 días que la reina había fijado para ajustar los debates sobre la villa (ADM, ARCHIVO HISTÓRICO, leg. 197, 11, nº 1).

${ }^{1680}$ En el compromiso firmado en Valladolid el 21 de mayo de 1476 entre el Condestable, en nombre del conde de Urueña, y los monarcas se establecía que: en el caso de Gomiel de Yçan se aya de entregar y entregue al dicho conde de Urueña desde oy de la fecha desta escritura en tres meses primeros syguientes apoderandose en lo alto y baxo della... el conde haga seguridad por esta escritura que durant los dichos tres meses no tomara la dicha villa e fortaleza por trato o furxo ni en otra manera $y$ que durant este tiempo el rey e reina nuestros señores paguen la gente que estuviere en la guarda de la dicha villa y fortaleza y ponga el alcaide en ella ... e que a los vecinos de la dicha villa no les sea tomado el vino que tienen en la Villanueva ni otras cosas...(SNAHN, OSUNA, Caja 3, docs. 24-29). A tenor de lo pactado la plaza debería ser devuelta a finales de agosto. 
año ${ }^{1681}$. Finalmente, en febrero de 1477 Girón recuperó definitivamente su villa de Gumiel de Izán ${ }^{1682}$.

Tras la reconciliación, el II conde de Urueña se hizo con un lugar destacado en la corte de los Reyes Católicos ${ }^{1683}$. Esta circunstancia se debió sobre todo a su activa participación en las diferentes campañas de la guerra de Granada. La actividad bélica también le permitió engrandecer sus estados con las incorporaciones de las villas de Belefique y Senes, entre otras ${ }^{1684}$.

Una vez restituida su posición de poder en la corte castellana, el II conde de Urueña emprendió una clara política de engrandecimiento del patrimonio territorial de los Téllez Girón que se centró sobre todo en tierras andaluzas pero que también tuvo alguna manifestación en el espacio ribereño.

A lo largo de los años ochenta de la decimoquinta centuria don Juan hizo efectivas algunas compras en esta comarca. En los primeros años ochenta se hizo con los lugares de Bahabón, Oquillas y Cilleruelo que compró a don Pedro de Sandoval, hijo del I conde de Castro, pero que no se confirmó hasta $1488^{1685}$. En 1486 también adquirió de doña Constanza de Avellaneda la villa de Santa María de Mercadillo que limitaba con sus posesiones de Gumiel de Izán y Bahabón ${ }^{1686}$. A comienzos de los años 90 don Juan culminó la compra de los derechos que los hijos de don Diego Gómez de Sandoval tenían sobre la villa de Gumiel de Izán ${ }^{1687}$. Pero esto no impidió que se mantuviera el en-

${ }^{1681}$ PALENCIA, Crónica de Enrique IV. Libro XXVII, cap. X, Tomo II, p. 320.

1682 Martín de Acuña, alcaide nombrado por los monarcas, hizo entrega de la villa de Gumiel al conde el 17 de febrero y, a petición del conde, se mantuvo en ese puesto (SNAHN, OSUNA, Caja 79, doc. 44-45).

1683 Así lo afirma SUÁREZ FERNÁNDEZ, Fundamentos de la monarquía..., p. 99.

${ }^{1684}$ AGS, RGS, 149206, fol. 11. SUÁREZ FERNÁNDEZ, L. Los Reyes Católicos: El tiempo de la guerra de Granada. Madrid, 1989, p. 71. En el asedio de Loja en julio de 1482 murió el hermano gemelo del conde, don Rodrigo Téllez Girón, maestre de Calatrava.

${ }^{1685}$ SNAHN, OSUNA, Caja 36, doc. 42-44; Caja 80, docs. 7-9.

${ }^{1686}$ En principio Santa María del Mercadillo se declaraba ...behetría que somos de mar a mar para nos dar e ser e faser vasallos solariegos de quien quisyeremos, y decidía en 1485 aceptar como su señor al conde de Urueña pues ...el dicho lugar de Santa María del Mercadillo behetria heramos fatigados e reçebyamos muchos agravios e dapnos e synrasones asy de los lugares e señores comarcanos que nos entravan e entraron y tomaran e tomaron muchos de nuestros terminos e montes... (SNAHN, OSUNA, Caja 36, doc. 78-81). El 20 de enero de 1486 se materializó el contrato de compraventa por el que doña Constanza de Avellaneda y su marido don Martín de Acuña cedieron todos sus derechos sobre el lugar al conde de Urueña (docs. 72-75).

${ }^{1687}$ SNAHN, OSUNA, Caja 79, docs. 55-58. 
frentamiento, en ocasiones armado, con don Diego de Rojas que reivindicaba sus derechos sobre esta villa. La situación de inestabilidad obligó al rey Fernando a intervenir y proponer un arbitraje que se materializó en una compensación económica para don Diego y el reconocimiento para don Juan del señorío de Gumiel ${ }^{1688}$.

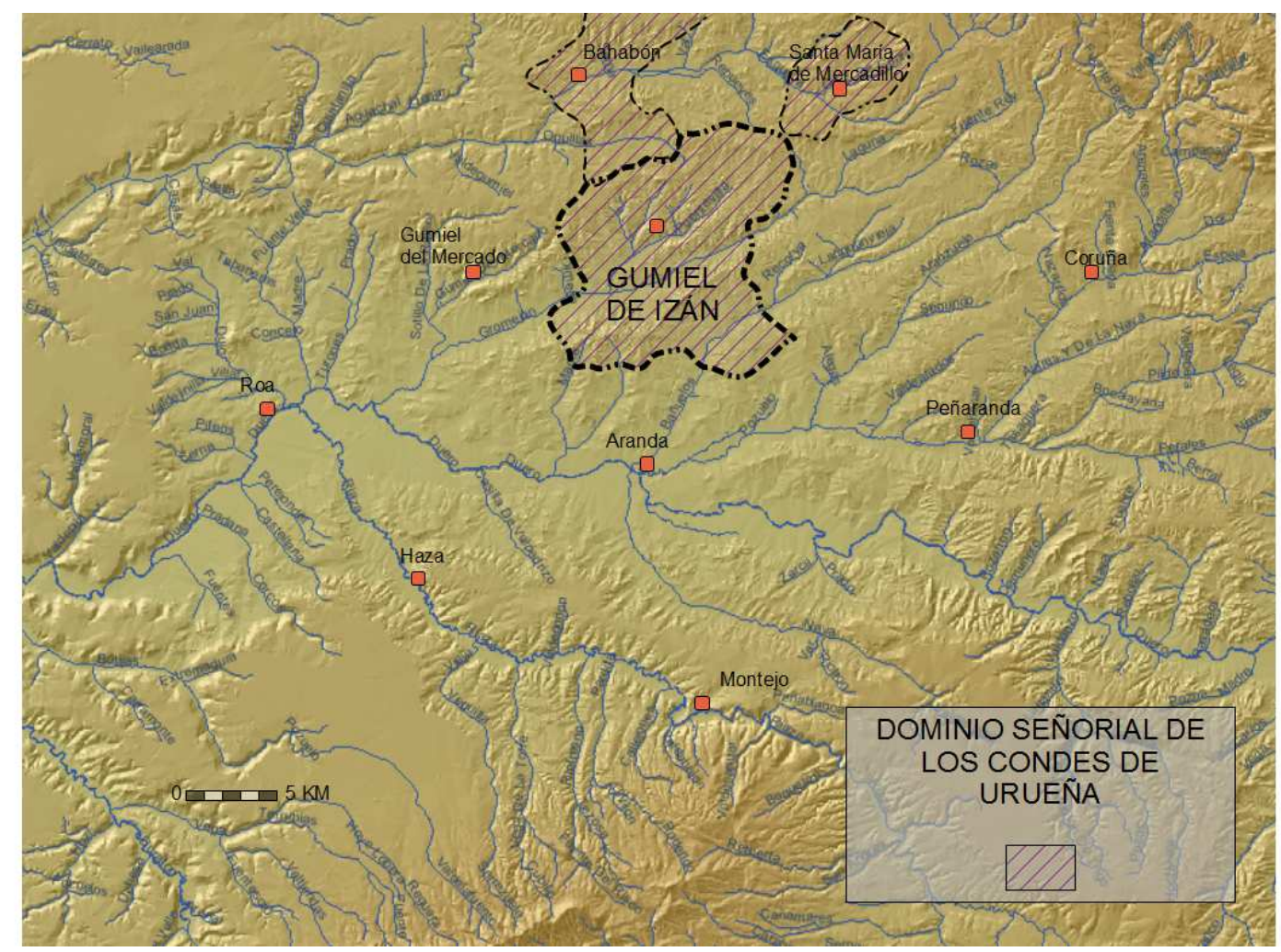

Mapa 14: Señorío territorial de los condes de Urueña en la Ribera a fines de la Edad Media.

El cabeza de linaje de los Girón también participó de las expectativas que se plantearon con la llegada de los nuevos monarcas tras la muerte de la reina Isabel. La perspectiva de aprovechar la inestabilidad de la sucesión castellana con unos monarcas débiles y necesitados de apoyos abrió de nuevo las esperanzas de engrandecer a la familia consiguiendo nuevas mercedes reales. Los intentos de aproximarse al nuevo monarca por parte de don Juan fueron bastante evidentes como se puso de manifiesto en la invitación que hizo a don Felipe para que tomara a uno de sus hijos para su corte. Ante tal sugerencia, el archiduque le contestó afirmativamente asegurándole ...le hacer mercedes

1688 SNAHN, OSUNA, Caja 79, docs. 79-80 y Caja 80, docs. 1-6. Este episodio lo desarrollaremos más ampliamente en el capítulo dedicado a los conflictos nobiliarios. 
por amor de vos ${ }^{1689}$. La muerte de don Felipe y la vuelta de don Fernando como Gobernador frustraron estas expectativas. Además don Fernando frenó de manera tajante las pretensiones del linaje Girón sobre algunos territorios andaluces, especialmente sobre el ducado de Medina Sidonia ${ }^{1690}$.

La posición del linaje de los Téllez Girón en tiempo de don Juan estaba firmemente asentada en las alianzas matrimoniales que en su momento se establecieron a través de su matrimonio con doña Leonor de la Vega Velasco, hija de don Pedro Fernández de Velasco. Además de convertirse en yerno primero y cuñado después de los tres primeros Condestables del linaje Velasco, también estableció lazos familiares con otros importantes linajes a través de doña Leonor. Recordemos que la esposa del conde de Urueña era hermana de doña Catalina, condesa de Miranda. También lo era de doña María, quien primero fue tía de don Juan, al desposarse en primeras nupcias con don Juan Pacheco, y después se convirtió tras un nuevo matrimonio en duquesa de Alburquerque. Por último, la esposa de don Juan era hermana de doña Isabel, duquesa de Medina Sidonia y su futura consuegra.

En esta misma línea, don Juan siguió una política de alianzas matrimoniales muy intensa encaminada a consolidar sus posiciones en Andalucía. Así, a principios de siglo concertó el matrimonio de su primogénito, don Pedro, con su prima doña Mencía de Guzmán, hija del duque de Medina Sidonia y de doña Isabel de Velasco, hermana de doña Leonor. Precisamente esta alianza marcó al heredero pues buena parte de sus esfuerzos hasta 1521 se encaminaron a hacerse con el control de este ducado ${ }^{1691}$. El fracaso de esta empresa es un factor que no debe obviarse a la hora de explicar su adhesión a la causa comunera.

${ }^{1689}$ QUINTANILLA RASO, M. C., "Fórmulas y prácticas de la cultura política nobiliaria: los Grandes en la crisis dinástica castellana (1498-1507)", en Gobernar en tiempos de crisis. Las quiebras dinásticas en el ámbito hispánico (1250-1808). Madrid, 2008, pp. 199-220.

${ }^{1690}$ AGUADO GONZÁLEZ, F. J., "La sucesión en el Ducado de Medina Sidonia a la muerte de don Juan de Guzmán y el linaje de los Téllez-Girón”, en Anuario de Estudios Medievales. 19, 1989, pp. 689-708

${ }^{1691}$ La temprana muerte de su suegro, don Juan Alonso de Guzmán, permitió a don Pedro ejercer de tutor de su joven cuñado don Enrique. Pero el rey Fernando se opuso a esta situación e intervino para frenar las intenciones de don Pedro sobre el ducado. La muerte de don Enrique complicó aún más las cosas pues le sucedió su hermanastro don Alfonso Pérez de Guzmán, en contra de la última voluntad de don Enrique que cedió sus derechos a su hermana doña Mencía, a buen seguro influido por las pretensiones de don Pedro (SNAHN, OSUNA, Caja 120, docs. 28-34). El apoyo de don Fernando al nuevo duque se confirmó con el matrimonio con su nieta, doña Ana de Aragón. 
También fortaleció los vínculos con la casa de Alburquerque al concertar en 1508 el matrimonio del primogénito del linaje de la Cueva, don Beltrán, con su hija, doña Isabel Girón ${ }^{1692}$. De igual manera en 1510 se firmaron las capitulaciones para establecer el enlace entre el hermano del Almirante de Castilla, don Hernando Enríquez, con otra de las hijas del conde, doña María Girón ${ }^{1693}$. Posteriormente se pactó el matrimonio entre doña Juana Girón con el duque de Arcos, don Rodrigo Ponce de León. Éste se casó de nuevo con una Girón pues, tras el fallecimiento de doña Juana, contrajo matrimonio con la joven viuda doña María, quien previamente había estado casada con don Enrique de Guzmán, duque de Medina Sidonia ${ }^{1694}$. En conclusión, bien con su propio matrimonio o con el de sus hijos, el II conde de Urueña fijó claramente su posición junto a los más destacados miembros de la aristocracia castellana. No obstante, este trabajo de fina estrategia se vio notablemente enturbiado por la actitud de su primogénito don Pedro ante los acontecimientos que sacudieron Castilla entre 1520 y 1521.

El periodo de inestabilidad generado por la muerte de don Fernando y la llegada del nuevo monarca fue aprovechado por los Girón para intentar incrementar su poder, de nuevo con el intento de controlar el ducado de Medina Sidonia. Sin embargo, la rápida actuación del regente Cisneros frustró otra vez más la empresa ${ }^{1695}$. Las posteriores reclamaciones ante la justicia no obtuvieron los resultados deseados por lo que don Pedro decidió acudir directamente ante don Carlos que pospuso su respuesta y, a pesar de sus promesas, abandonó el reino en 1520 sin resolver el conflicto.

Buena parte de la aristocracia castellana se encontraba frustrada por el fracaso de sus expectativas ante la llegada del nuevo monarca y los acontecimientos que se desarrollaron al final de la primavera, que en algunas ciudades se percibieron como un castigo a la insolencia flamenca pero también como la oportunidad para sacar partido de un monarca extranjero y necesitado de ayuda. Frente a la inicial pasividad ante la sublevación comunera de buena parte de los grandes linajes de la nobleza castellana, rayana

${ }^{1692}$ SNAHN, OSUNA, Caja 4, doc. 1-2.

${ }^{1693}$ SNAHN, OSUNA, Caja 4, doc. 3-5. Dos hijas de don Juan y doña Leonor recibieron el nombre de María.

${ }^{1694}$ SNAHN, OSUNA, Caja 4, doc. 33-34 y caja 121, docs. 4-17.

${ }^{1695}$ LÓPEZ PITA. P. "Nobleza y monarquía..., pp. 184 y ss. A la muerte del monarca don Pedro trató de tomar por la fuerza el ducado de Medina Sidonia pero las tropas enviadas por el Cardenal Cisneros se lo impidieron. Sus pretensiones sobre este señorío le llevaron incluso a autotitularse duque de Medina Sidonia en algunas ocasiones (SNAHN, OSUNA, Caja 59, docs. 23-24). 
incluso en la aceptación interesada, don Pedro Girón se inclinó de manera activa por la causa comunera. Este protagonismo se vio reforzado por su nombramiento como jefe de las tropas de las fuerzas comuneras en detrimento de Padilla. Esta decisión estuvo envuelta en una intensa polémica que se acrecentó tras la derrota de Tordesillas, haciéndose entonces evidentes las acusaciones de traición ${ }^{1696}$. Más adelante analizaremos la actividad de Girón centrada en sus movimientos por tierras ribereñas ${ }^{1697}$.

Tras la derrota comunera don Pedro quedó excluido del perdón general. Con la intención de alcanzarlo, Girón trató de hacer méritos al servicio de Carlos I en la guerra de Navarra y así se encaminó con sus mesnadas a Pamplona donde actuó de manera valerosa según relatan las crónicas.

Sin embargo, el monarca le tenía reservada una nueva penitencia para obtener su perdón. Así, le desterró a Orán durante una breve temporada para que defendiera la plaza de las incursiones turcas y berberisca ${ }^{1698}$. Finalmente, las solicitudes de su padre y familiares consiguieron que el 9 de enero de 1523 la reina Juana y el rey Carlos le concedieran su perdón ${ }^{1699}$.

Después de este paréntesis para los intereses de la casa Téllez Girón, en 1523 don Juan fundó el mayorazgo de Osuna para su hijo primogénito gracias a las licencias concedidas por los monarcas ${ }^{1700}$.

Tras casi 60 años de gobierno sobre sus estados, don Juan Téllez Girón murió el 21 de mayo de 1528 y don Pedro pudo por fin ostentar un título nobiliario, aunque disfrutó poco tiempo de él pues murió en su villa de Peñafiel el 25 de abril de 1531.

En conclusión, el linaje de los Téllez Girón se configuró con mucha fuerza durante el reinado de Enrique IV, consiguiendo los dos hermanos, don Juan Pacheco y don Pedro Girón, crear dos grandes estados señoriales y ejercer una gran influencia sobre los acontecimientos políticos que marcaron la historia de Castilla en los años 70. Su derrota en el conflicto sucesorio no impidió que el II conde de Urueña consolidara sus dominios

${ }^{1696}$ PÉREZ, La revolución..., pp. 219 y ss.

1697 Aspecto que aparece reflejado sobre todo en su correspondencia que se encuentra en AGS, PR, leg. 2, doc. 14 y leg. 3, doc. 104.

1698 SÁNCHEZ DONCEL, G., Presencia de España en Oran (1509-1792). Toledo, 1991, pp. 603-605.

\footnotetext{
${ }^{1699}$ SNAHN, FRÍAS, caja 1512, doc. 14.

${ }^{1700}$ SNAHN, OSUNA, Caja 4, docs. 35-38.
} 
territoriales y su posición de poder en la corte de los Reyes Católicos, aunque sin alcanzar la extraordinaria notoriedad de su padre. El periodo que nos ocupa concluyó con el protagonismo del heredero del condado, don Pedro Girón, que, tras el fallido intento de hacerse con el ducado de Medina Sidonia, se erigió en caudillo del movimiento comunero. Después del fracaso de la experiencia comunera trató de recuperar el favor real aunque su paso por la titularidad del condado fue efímero y poco productivo para los intereses del linaje.

\section{2. 5. Linaje Suárez Figueroa y Mendoza: Condes de Coruña.}

La poderosa familia de los Mendoza también tuvo una destacada presencia en las tierras ribereñas, aunque su aparición fue más bien tardía y su influencia real bastante escasa $^{1701}$.

El asentamiento de esta familia en la comarca ribereña se produjo en el contexto de las numerosas intrigas políticas que se desarrollaron durante el conflicto sucesorio al final del reinado de Enrique IV ${ }^{1702}$. En 1469 la villa de Coruña pertenecía a don Juan Pacheco, que poco tiempo atrás la había comprado a la familia Padilla. El marqués de Villena, en un intento de atraerse al servicio real a la poderosa familia de los Mendoza, pactó un acuerdo que contenía entre sus cláusulas la cesión de la villa de Coruña al monarca para que éste se la concediera al tercer hijo del marqués de Santillana ${ }^{1703}$. Así fue como el 28 de abril de 1469 el rey otorgaba a don Lorenzo Suárez de Figueroa ... la my villa de Coruña e su tierra con su castillo e fortaliesa y con la casa de Quintanarraya con sus heredamyentos e con los lugares de Espeja y Espejón y su tierra y con todos los vasallos y tierra... erigiendo a esta villa en sede condal ${ }^{1704}$. Junto a la villa que da nom-

${ }^{1701}$ El linaje de los Mendoza ha sido profusamente estudiado, aunque bien es cierto que la atención prestada a la rama de los condes de Coruña ha sido bastante escasa. Entre estos estudios, aunque se centra exclusivamente en su actividad y dominios en tierras de Guadalajara, destacamos la tesis de RIESCO DE ITURRI, M. B., Nobleza y Señoríos en la Castilla Centro-Oriental en la Baja Edad Media (Siglos XIV y XV). Tesis doctoral de la Universidad Complutense de Madrid, 2002. Disponible en formato digital en http://eprints.ucm.es/2453/1/H0030101.pdf. Consulta realizada el 30/08/2012.

${ }^{1702}$ Con anterioridad a recibir la merced condal don Lorenzo, junto al conjunto del linaje de los Mendoza, se había significado en el bando de Enrique IV en el enfrentamiento con su hermanastro don Alfonso (Crónica anónima de Enrique IV..., Cap. LXVIII, p. 164).

1703 SUÁREZ FERNÁNDEZ, Los Reyes Católicos. La conquista..., p. 30. Además de esta cesión, se pactó el matrimonio del heredero de don Juan Pacheco con doña Juana Luna, hija del marqués de Santillana.

${ }^{1704}$ LAYNA SERRANO, F., Historia de Guadalajara y sus Mendozas en los siglos XV y XVI. Madrid, 1942. Tomo II, pp. 145-146. 
bre al condado y los lugares citados se incluyeron también los cercanos de Arandilla, Brazacorta y Peñalba. A estos territorios ribereños, tras la muerte del II marqués de Santillana se sumaron al patrimonio condal la villa de Torija y otros lugares en Guadalaja$\mathrm{ra}^{1705}$.

La presencia del I conde de Coruña en el contexto del conflicto sucesorio fue escasamente relevante a título individual pero siempre vinculado a los decisorios movimientos de sus parientes los Mendoza. Dentro de esta dinámica se interpreta su participación en la ceremonia de Valdelozoya en noviembre de 1470 en la que se nombró a la infanta Juana sucesora de su padre Enrique $\mathrm{IV}^{1706}$. En 1472 don Lorenzo actuó como representante de su clan familiar en el acuerdo establecido con el conde de Haro para posicionarse junto al marqués de Villena en defensa del rey Enrique IV ${ }^{1707}$. Esta dinámica del linaje Mendoza cambió sustancialmente tras la muerte del rey y así el conde de Coruña siguió los pasos de su clan afiliándose al bando de la reina Isabel y apoyando a ésta en la guerra contra Portugal. No obstante, Figueroa siguió participando plenamente en las intrigas nobiliarias junto al resto de los Mendoza ${ }^{1708}$.

Don Lorenzo tomó su nombre y apellidos de su abuelo materno, añadiendo a las armas de los Mendoza y de la Vega las de los Figueroa ${ }^{1709}$. Además, siguiendo la tradición familiar santiaguista, fue nombrado comendador de la Orden de Santiago, disfrutando de la encomienda de Mohernando ${ }^{1710}$.

1705 RIESCO DE ITURRI, Nobleza y Señoríos..., Vol. IV, pp. 901 y ss. Más adelante también se integró la villa de Paredes que fue comprada por el conde a don Luis de la Cerda, conde de Medinaceli.

${ }^{1706}$ VAL VALDIVIESO, Isabel la Católica, Princesa..., p. 226.

${ }^{1707}$ PALENCIA, Crónica de Enrique IV, vol. II, pp. 58-59.

${ }^{1708}$ Según PALENCIA el conde de Coruña participó en la reunión de los principales nobles en Tordesillas en la primavera de 1472 en la que acordaron condicionar su apoyo militar a los monarcas para evitar una victoria rotunda sobre los portugueses y así mantener su dependencia de las fuerzas nobiliarias (Crónica de Enrique IV..., vol. II, pp. 206-207).

${ }^{1709}$ Don Lorenzo tomó un escudo de armas partido en palo que sumaba los dos blasones: por un lado el de los Mendoza con el Ave María de los De la Vega, y en el otro las cinco hojas de higuera sobre campo de oro de los Figueroa. El abuelo del que tomó el nombre fue Maestre de la Orden de Santiago entre 1387 y 1409. El II conde de Coruña dejó de lado el apellido Figueroa para resaltar el Mendoza.

${ }^{1710}$ RIESCO DE ITURRI, Nobleza y Señorios..., Vol. I, p. 108. 


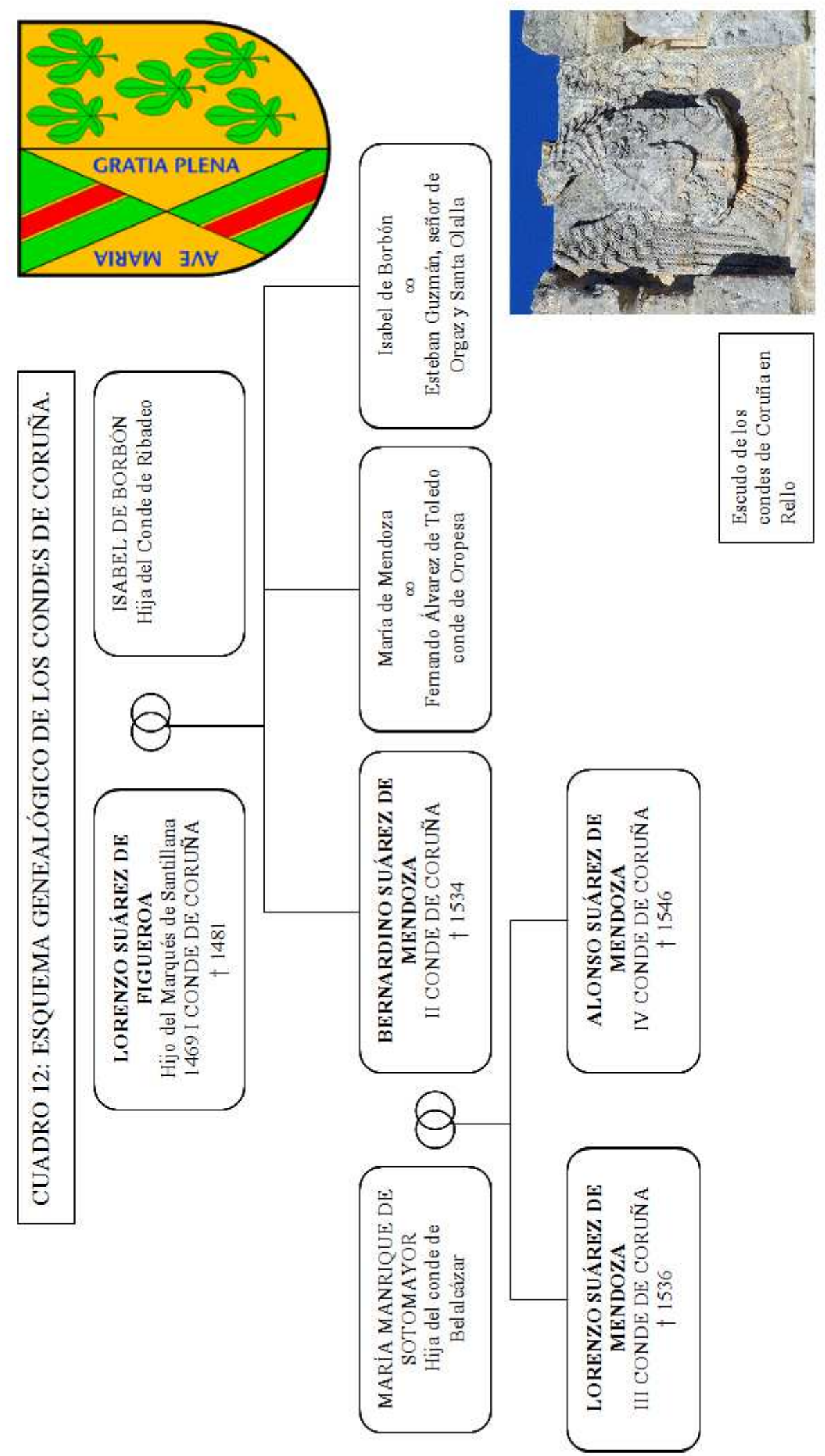


Dentro de la amplia política matrimonial de los Mendoza, el marqués de Santillana concertó el matrimonio de su hijo Lorenzo con doña Isabel de Borbón, hija del I conde de Ribadeo. El heredero fruto de esta unión fue don Bernardino Suárez de Mendoza que se casó con doña María Manrique de Sotomayor, hija del I conde de Belalcá$\operatorname{zar}^{1711}$. Las otras dos hijas también fueron enlazadas con importantes familias nobiliarias: doña María de Mendoza contrajo matrimonio con don Fernando Álvarez de Toledo, II conde de Oropesa y nieto de los duques de Béjar; y por su parte, doña Isabel de Borbón se casó con don Esteban Guzmán, señor de Orgaz y Santa Olalla.

En el espacio ribereño hemos localizado escasas referencias de la presencia del I conde de Coruña. Por una parte, sabemos que al poco tiempo de recibir el condado realizó importantes obras en la fortaleza de la villa titular del condado para acondicionar$\mathrm{la}^{1712}$. Asimismo conocemos que en los últimos años de la década de los 70 vendió su torre de Quintanarraya y ciertas heredades al concejo del lugar por cierta cantidad más un censo anual de 110 fanegas de pan $^{1713}$. Esta escasa presencia no debe extrañar pues tanto su residencia como sus intereses estaban profundamente asentados en Guadalajara, espacio estrechamente vinculado a la parentela de los Mendoza ${ }^{1714}$.

En 1480, poco antes de morir, el I conde de Coruña fundó mayorazgo a favor de su hijo mayor, don Bernardino, incluyendo en él todas las posesiones ribereñas ${ }^{1715}$. Finalmente Don Lorenzo murió en Guadalajara el 21 de mayo de 1481 y fue enterrado en el panteón familiar situado en el monasterio de San Jerónimo de Lupiana ${ }^{1716}$.

Don Bernardino Suárez de Mendoza sucedió a su padre como titular del condado. Varios testimonios presentan al II conde de Coruña preocupado por consolidar sus estados territoriales en las tierras del Duero, aunque su centro de gravedad siguió manteniéndose en sus estados de Guadalajara y Madrid.

${ }^{1711}$ Las capitulaciones matrimoniales se firmaron el 4 de octubre de 1477 entre el conde de Coruña y doña Elvira de Zúñiga, condesa de Belalcázar (SNAHN, OSUNA, caja 325, doc. 103; y SUÁREZ FERNÁNDEZ, Fundamentos de la monarquía..., pp. 114-115).

${ }^{1712}$ RIESCO DE ITURRI, Nobleza y Señorios..., Vol. I, p. 169.

${ }^{1713}$ AGS, RGS, 149612, fol. 232.

${ }^{1714}$ RIESCO DE ITURRI, Nobleza y Señorios..., Vol. IV, p. 900.

1715 La facultad para fundar el mayorazgo la concedió la reina en noviembre de 1480 (AGS, RGS, 148011, fol. 10) y se constituyó ese mismo año (SNAHN, OSUNA, Caja 516, doc. 34; y FERNÁN NÚÑEZ, Caja 430, doc. 8).

${ }^{1716}$ RIESCO DE ITURRI, Nobleza y Señorios..., Vol. I, p. 108. 
Durante los años 90 mantuvo varios pleitos para garantizar sus derechos jurisdiccionales sobre los lugares cercanos a la villa de Coruña. Así en 1496 consiguió varias sentencias favorables de la Chancillería que avalaban sus derechos sobre la villa de Espeja y el lugar de Espejón que se disputaba con el Monasterio de San Jerónimo de San Marcelino. No obstante, el monasterio vio reconocidos sus derechos fiscales al conseguir el amparo real para percibir de los vecinos de esas localidades el pago de ciertos servicios e igualas antiguas que éstos se negaban a pagar amparados por el conde de Coruña ${ }^{1717}$.

También observamos ciertos indicios de aumento de la presión señorial sobre los vasallos del conde. A finales del año 1496 el alcaide de Quintanarraya reclamaba a los vecinos del lugar que abonaran un maravedí anual por cada casa. Justificaba tal medida en el incumplimiento de las cláusulas de un antiguo censo sobre la torre y ciertas heredades vendidas 18 años atrás por el I conde de Coruña ${ }^{1718}$.

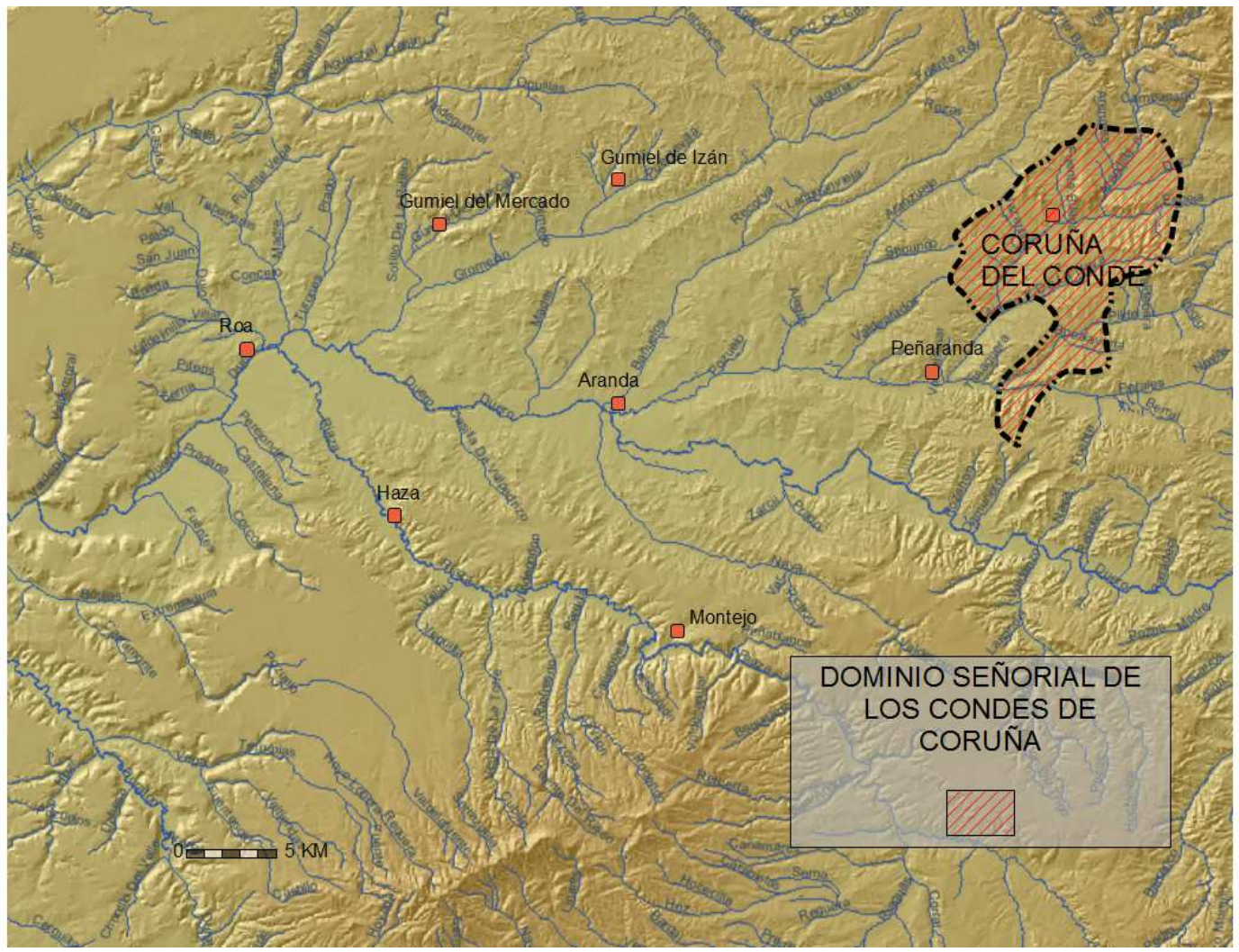

Mapa 15: Señorío territorial de los condes de Coruña en la Ribera a fines de la Edad Media.

${ }^{1717}$ ARChV, RRE, Caja 101, doc. 3. 30-6-1496; y AGS, RGS, 149609, fol. 169.

${ }^{1718}$ AGS, RGS, 149612, fol. 232. 
Por otra parte, también mantuvo ciertas discrepancias con la villa de Santo Domingo de Silos y el Condestable de Castilla por la jurisdicción de los lugares vecinos de Quintanarraya, Hinojar, Arauzo de Salce, Arauzo de Torre, Santa María del Mercadillo, Pinilla Trasmonte, Cilleruelo de Arriba, Pineda Trasmonte y Baños ${ }^{1719}$. Además de un enfrentamiento claramente intranobiliario, asimismo se aprecia en este conflicto la progresiva e imparable imposición señorial sobre las escasas behetrías que pervivían a finales del siglo $\mathrm{XV}$, pues varios de los lugares implicados ostentaban esta condición.

El papel que jugó el II conde de Coruña en las disputas sucesorias del comienzo del Quinientos fue poco significativo y suponemos que se mantuvo en la misma postura que los miembros más significativos del clan familiar de los Mendoza. Todavía disponemos de menos información sobre su participación directa en la revuelta comunera, aunque posiblemente se encontró al servicio de la Corona como sus parientes de Guadalajara. En el posterior proceso de represión sí que tenemos noticias de la protección que prestó en su villa de Torija al exceptuado licenciado Bernaldino, consejero jurídico de la Junta y de la Comunidad de Valladolid. No obstante, tal protección no debe entenderse como acto de simpatía con el movimiento comunero sino como un interesado favor personal a un valioso jurista del cual el conde ya había sido cliente y del que, con seguridad, esperaba obtener otros agradecidos servicios ${ }^{1720}$.

Durante los primeros años del reinado de Carlos I don Bernardino Suárez de Mendoza no figuraba entre los miembros de su Corte ni tampoco hemos localizado ninguna actividad política relevante. La documentación consultada tan solo aporta la facultad que en 1525 le concedió el monarca para poder aumentar los bienes de su mayorazgo $^{1721}$.

Finalmente, en 1534 el II conde de Coruña falleció y le sucedió su hijo don Alonso Suárez de Mendoza ${ }^{1722}$.

Por lo visto hasta el momento podemos concluir que durante el último cuarto del siglo XV la familia Mendoza configuró en la zona oriental de la comarca ribereña un notable patrimonio territorial que tuvo como capital la villa de Coruña y que se extendió

${ }^{1719}$ Las disputas debieron tener lugar durante los últimos años del siglo XV pues la ejecutoria de la Chancillería estaba fechada en noviembre de 1503 (ARChV, RRE, Caja 186, doc. 1).

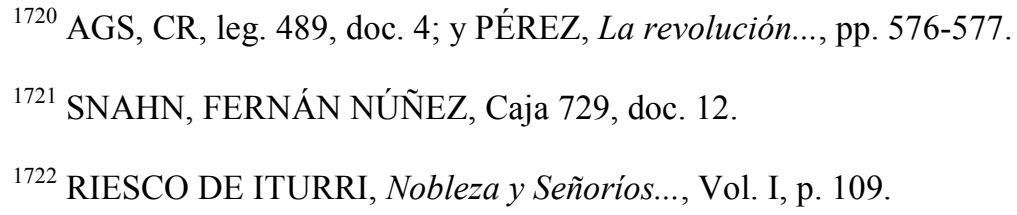


por los ambientes serranos septentrionales y sorianos. Sin embargo, la capacidad de este linaje de influir sobre la propia dinámica de la comarca fue bastante más modesta pues los sucesivos condes de Coruña vivieron volcados en los asuntos de sus dominios de Guadalajara, relegando a un segundo plano los estados originarios de su condición condal.

Parece evidente que los grandes linajes nobiliarios, sobre todo la casa de los Condes de Miranda y los titulares del Marquesado de Denia, configuraron unos notables dominios territoriales en la comarca de la Ribera del Duero durante la segunda mitad del siglo XV. Es bastante significativo que la irrupción de estas dos familias tuviera un origen común, la herencia de los Avellaneda asimilada a través de un enlace matrimonial. También se produjo una coincidencia en las estrategias seguidas por estas familias, y otras más que se sumaron a esta dinámica, para consolidar y aumentar su base territorial y su poder. Los Zúñiga, Sandoval, Cueva-Siruela y Téllez-Girón asentaron su poder en una estudiada política de alianzas matrimoniales que, además de aumentar significativamente sus estados territoriales, colocaron a estos linajes segundones en la órbita de la aristocracia castellana. Se estaba fraguando así el ascenso definitivo de estos linajes a las esferas más elevadas del poder político, social y económico. Con el cambio dinástico también se produjo una adaptación de estas familias a un renovado canal de promoción como era el servicio a la Corona que en esos momentos emergía como un poder fuerte que traspasaba las fronteras tradicionales tanto físicas como ideológicas con la configuración del estado autoritario con proyección europea. De nuevo los linajes de los Zúñiga y Sandoval ejemplifican nítidamente esta dinámica. Aunque su discurrir fue paralelo y contrapuesto en ocasiones, al final del periodo que nos ocupa ambos convergieron en intereses y alianzas, primero al lado del Emperador Carlos y después a la sombra de los siguientes Habsburgo hispánicos.

\section{3. El papel de la pequeña nobleza.}

A parte de los grandes linajes nobiliarios, en el espacio ribereño tuvo cabida un número significativo de familias nobles de segunda fila que se integraron de una manera u otra en la amplia red clientelar de la aristocracia castellana. En este apartado vamos a analizar alguna de estas familias, posiblemente las de mayor éxito a corto y medio pla- 
zo: la familia Acuña, la familia Delgadillo, señores de Castrillo, y la familia Avellaneda, señores de Valverde. Concluiremos este apartado con una breve referencia al numeroso grupo de hidalgos que habitaban el principal núcleo urbano de la comarca, la villa de Aranda, y que copaban las principales posiciones de la oligarquía urbana que controlaba el concejo arandino.

\section{3. 1. La familia Acuña.}

La presencia de la familia Acuña en el reino castellano desde los años finales del siglo XIV está muy bien documentada. Varios hermanos de esta familia de origen portugués emigraron a tierras castellanas tras prestar su apoyo a Enrique III en sus disputas con el reino vecino. El monarca agradeció su colaboración con varias mercedes y posesiones en Castilla. A uno de ellos, don Martín Vázquez de Acuña, le correspondió el condado de Valencia de don Juan. La presencia en tierras ribereñas de este linaje se remonta a la segunda mitad del siglo $\mathrm{XV}$, a través de dos de sus múltiples ramas: por una parte los Téllez-Girón, de los que ya hemos hablado con anterioridad, y por la otra, los Vázquez de Acuña de la nos ocuparemos a continuación.

En los años 60 del siglo XV hizo acto de presencia por esta comarca el primero de los Acuñas: don Martín Vázquez de Acuña, nieto del primer conde de Valencia de Don Juan, del mismo nombre. Don Martín era hijo de Enrique de Acuña y Portugal, primer señor de Valdegema, y de doña Inés de Valencia y Cabeza de Vaca. Aunque la documentación se refiere a su persona como señor de Villaester, lo cierto es que tan solo le correspondía una octava parte del señorío, pues lo compartía con sus siete herma$\operatorname{nos}^{1723}$. Por aquellos años contrajo matrimonio con doña Constanza de Avellaneda, hija de Juan González de Avellaneda ${ }^{1724}$, señor de Villalobón e hijo bastardo del noveno señor de Avellaneda que tenía el mismo nombre. Doña Constanza aportó al matrimonio un modesto dominio territorial que incluía el señorío de la villa de Hoyales y de Fuente-

${ }^{1723}$ De hecho mantuvo un complicado pleito con uno de sus hermanos, Fernando, sobre sus respectivos derechos en este señorío (AGS, RGS, 148901, fol. 365; 148911, fol. 166; 149008, fol. 303).

${ }^{1724}$ Don Juan de Avellaneda fue el fruto de la relación del IX señor de Avellaneda ...seyendo moço en una donçella moça. Fue reconocida su legitimidad por el rey Juan II (ARChV, RRE, Caja 166, doc. 2). Estaba avecindado en Aranda y participó muy activamente en la vida política de la villa durante el reinado de Enrique IV. Ocupó el cargo de corregidor por la reina doña Juana al menos desde 1464 (VELASCO PÉREZ, Aranda. Memorias..., p. 97) y seguía siéndolo durante el conflicto sucesorio (AGS, CC PERSONAS, leg. 2, doc. 200). Seguramente falleció entorno a 1473 pues de esa fecha conservamos el reconocimiento del señorío y vasallaje a doña Constanza y don Martín por parte de los vecinos de Santa María del Mercadillo (SNAHN, OSUNA, Caja 36, docs. 76 y 77). 
lisendo, más el señorío sobre la behetría de Santa María del Mercadillo. Posiblemente la cercanía de este territorio a la capital de la Ribera fue el motivo por el cual don Martín se asentó en Aranda en el último tercio de la decimoquinta centuria ${ }^{1725}$.

Realmente este patrimonio era bastante exiguo en comparación con el de las grandes familias que hemos analizado anteriormente. No obstante, la villa de Hoyales y Fuentelisendo les aportaba un nivel de rentas notable ${ }^{1726}$. Bajo su jurisdicción había 90 vasallos que rentaban en especie 36 fanegas y media de trigo más otro tanto en cebada y 92 gallinas ${ }^{1727}$. Además los señores de Hoyales poseían una serie de heredades que les generaban más ingresos: las tierras de la vega eran arrendadas a algún vecino por diez años y rentaban 140 fanegas, un tercio de trigo y el resto de cebada; la huerta del señor se dedicaba al cultivo de frutales y también se arrendaba pero su rentabilidad era muy variable según el mercado pues podía proporcionar entre los 9.000 y los 20.000 maravedíes anuales ${ }^{1728}$; los dos molinos sobre el Riaza rentaban cerca de 250 fanegas de cereal al año, aunque su valor también era variable en función de la cosecha ${ }^{1729}$; por último, los señores de Hoyales también eran propietarios de una viña que explotaban directamente, la mandaban labrar e vendimiar, y reportaba a sus arcas 200 cántaras de vino anuales. En definitiva, aunque su señorío era bastante modesto, los ingresos que les proporcionaban no eran nada desdeñables.

1725 SANZ ABAD, Historia de Aranda..., pp. 139-145; DOMÍNGUEZ CASAS, R., "Heráldica en el arte..., pp. 217-261; y DOMINGO ZAPATERO, E., La Comunidad de Villa y Tierra de Haza. Hoyales. Fuentelisendo. Madrid, 2002, p. 78.

${ }^{1726}$ AGS, EMR, leg. 689. Los datos que se citan hacen referencia a los años 1503 y 1504.

${ }^{1727}$ Cada vasallo estaba obligado a pagar en reconocimiento del señorío una cantidad de cereal y una gallina. El aporte parece ser que es proporcional pues, aunque la mayor parte de los vecinos pagan una yunta y una gallina, hay otros que contribuyen por media yunta o por dos gallinas. El valor de la gallina se estimaba aproximadamente en 25 maravedíes. LADERO QUESADA considera que la yunta y la yugada eran unidades de cuenta básica correspondiente a la tierra labrada por una familia campesina sobre las que se aplicaba una renta, que en el caso de Hoyales a finales de la Edad Media se pagaba todavía en especie, mitad trigo y mitad cebada ("El sistema impositivo en Castilla y León siglos X-XIII), en I Jornadas sobre Documentación jurídico-administrativa, económico financiera y judicial del reino castellano-leonés (siglos X-XIII). Madrid, 2002, pp. 283-302).

${ }^{1728}$ En concreto las autoridades de la villa señalan que en 1503 esta huerta sólo rentó 9.000 maravedíes ... porque vino mucha fruta en la comarca y obo poco pan para la poder llevar a ninguna parte.

${ }^{1729}$ También influía en la renta otros aspectos. Los informadores señalan que la renta bajó el año anterior porque el conde de Miranda había prohibido a sus vasallos acudir a moler a los molinos de Hoyales. 


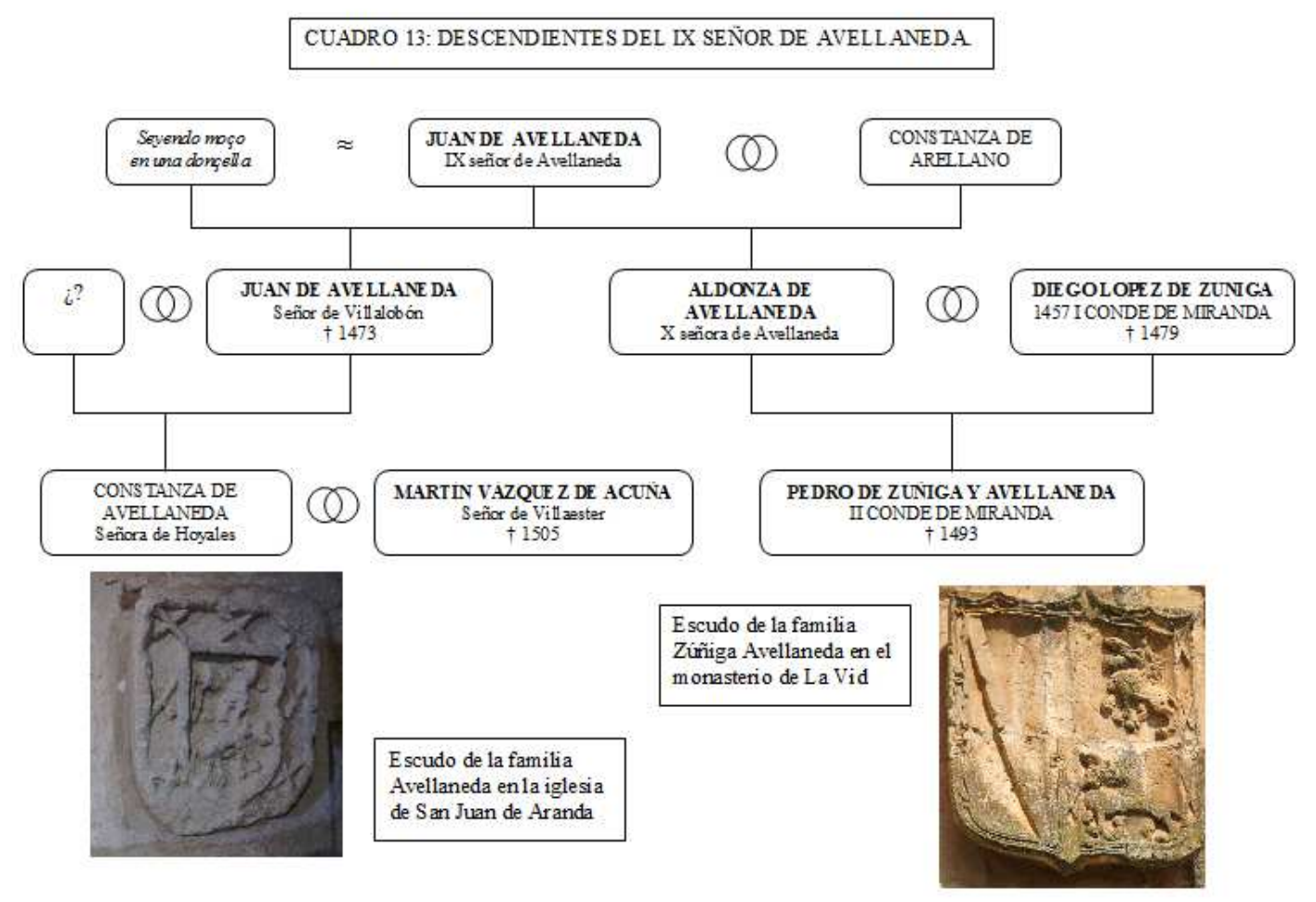

Son bastantes las noticias que tenemos sobre la vida pública del primero de los Acuñas en la Ribera del Duero, gracias sobre todo a su gran capacidad de generar problemas con otros vecinos o instituciones. Las primeras informaciones lo sitúan junto a Juan de Avellaneda, por entonces corregidor por la reina Juana en la villa, en el desarrollo del conflicto sucesorio que vivió Castilla a finales de los años $60 \mathrm{y}$ principios de los $70^{1730}$.

A pesar de esta vinculación con el bando perdedor, los Reyes Católicos le encomendaron varias tareas para su servicio. En 1477 le comisionan para que se hiciera cargo de la villa de Gumiel de Izán y le ordenaron, tras perdonar al conde de Urueña, que realizara la devolución del emplazamiento. Tras recibir la villa, Girón solicitó a Acuña que permaneciera en ella como alcaide ${ }^{1731}$. En 1492 también se le encomendó que acudiera al monasterio de Caleruega para tratar de mediar entre las distintas familias dominicas $^{1732}$.

\footnotetext{
${ }^{1730}$ AGS, CC PERSONAS, leg. 2, doc. 200.

${ }^{1731}$ SNAHN, OSUNA, Caja 79, docs. 44 y 45.

${ }^{1732}$ AGS, RGS, 149208, fol. 214.
} 


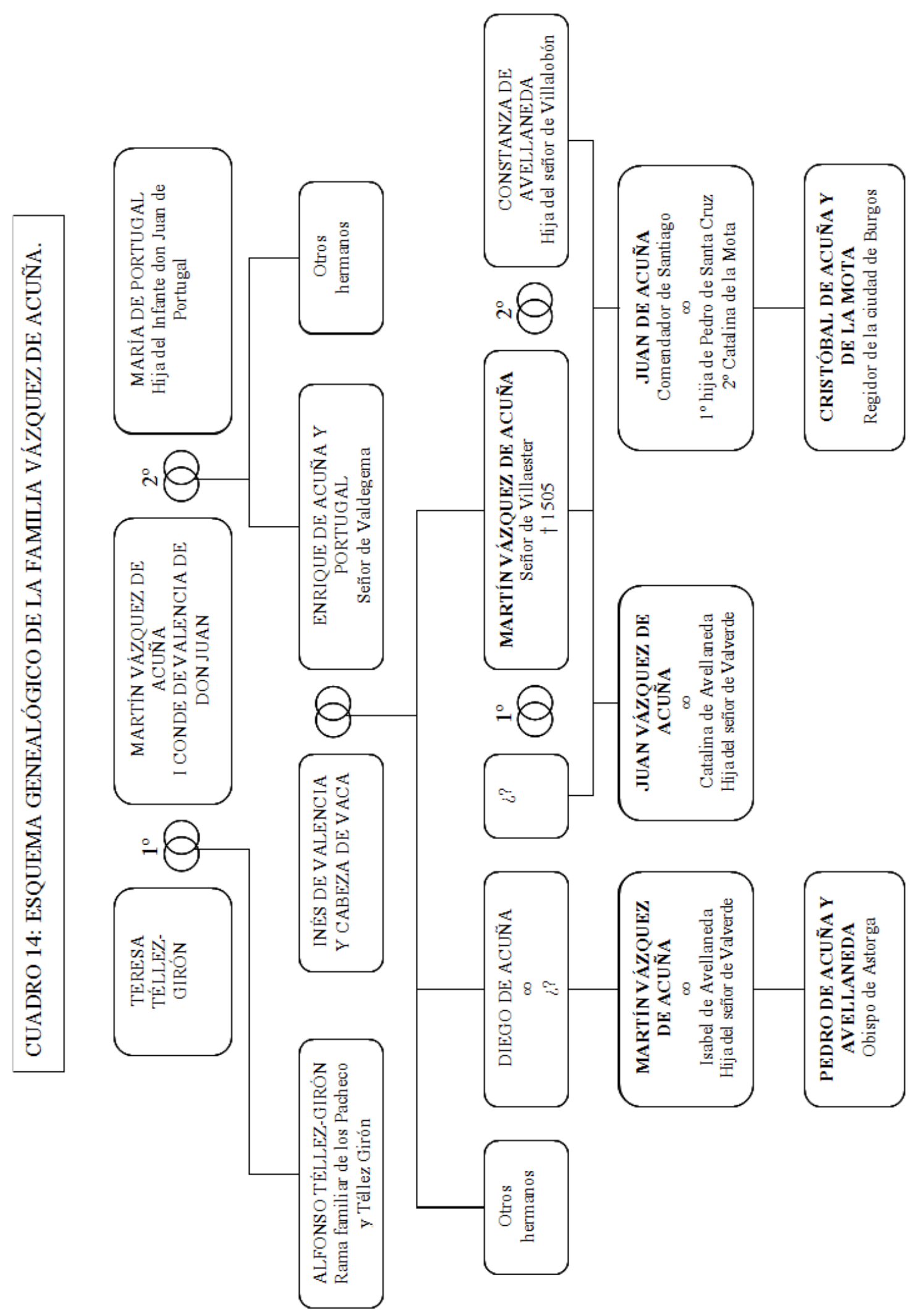


En ocasiones fue el propio don Martín el que tomó la iniciativa a la hora de mediar en conflictos. Así en 1486 decidió intervenir de la forma más contundente en las disputas internas que se desarrollaban en el seno de la congregación cisterciense de San Pedro de Gumiel de Izán. Acuña fue el promotor del asalto al monasterio a mediados del mes de febrero, cuando ciertos criados suyos y varios vecinos de Aranda armados despojaron de su cargo al abad fray Juan de Ocio. En el proceso derribaron varios muros, expulsaron a algunos monjes y finalmente encastillaron el monasterio ${ }^{1733}$. Los Reyes, informados del suceso, ordenaron a varios de sus alcaldes que acudieran a poner orden en el monasterio, lo desencastillaran y expulsaran a los asaltantes ${ }^{1734}$. Finalmente la Audiencia Real dictó sentencia a favor del abad despojado que fue restituido en su cargo en julio de $1486^{1735}$.

Por otra parte, tuvo varios enfrentamientos con las autoridades municipales tanto por problemas de orden público como por asuntos fiscales. Vázquez de Acuña fue acusado en 1486 de provocar disturbios y agredir, bien directamente o por encargo, a otros vecinos. En concreto se le acusaba de incitar a uno de sus criados, Ortuño, para que asesinara al regidor Fernando de Covarrubias. El agresor asestó una cuchillada en la cabeza de la víctima en la Plaza de Santa María. El agredido salvó la vida al acogerse a sagrado en la iglesia. En otra ocasión don Martín ordenó a varios hombres que dieran una paliza a un vecino en su casa ${ }^{1736}$. El recurso a la violencia más explicita también fue utilizado por doña Constanza que no dudó en amenazar al regidor Pedro de Salazar con una paliza si no accedía a sus demandas relacionadas con la construcción de unas casas ${ }^{1737}$.

Los problemas fiscales se debieron a la negativa de don Martín a pagar la martiniega, alegando que era hidalgo y que por lo tanto estaba excluido de este impuesto. El concejo respondió desterrando a don Martín y otros vecinos en la misma situación. En

${ }^{1733}$ La acción estuvo encabezada por los hermanos Lisas, criados de don Martín y vecinos de Aranda (AGS, RGS, 148603, fol. 56).

${ }^{1734}$ El monasterio debió estar varios meses en posesión de los asaltantes pues, a pesar de los requerimientos al alcalde Juan Alfonso de Toro en marzo y Juan Valera en abril, el monasterio no fue recuperado hasta mayo por don Pedro de Sandoval (AGS, CC PUEBLOS, leg. 17, doc. 172; RGS, 148604, fol. 41; y 148605, fol. 68).

${ }^{1735}$ AGS, CC PUEBLOS, leg. 17, doc. 170.

${ }^{1736}$ AGS, RGS, 148603, fol. 56 y 148606, fol. 48.

${ }^{1737}$ AGS, RGS, 149205, fols. 472 y 637 . Todos estos enfrentamientos los analizaremos con detenimiento en el capítulo dedicado a los conflictos en la villa de Aranda. 
1492 consiguió una confirmación de hidalguía por parte de la Chancillería de Valladolid y entabló sendos pleitos con el concejo en 1496 y 1498 por no reconocer su exención ${ }^{1738}$.

Como veremos en un capítulo posterior, el mayor volumen de la documentación generada por don Martín y su esposa, doña Constanza, está relacionado con los conflictos y pleitos que mantuvieron con los principales nobles comarcanos y que finalizaron con la desaparición de sus dominios territoriales. Por una parte, en 1486 decidieron vender sus derechos sobre la behetría de Santa María del Mercadillo al conde de Urueña, tras una negociación más o menos pacífica. Y por otra, mantuvieron un enconado enfrentamiento con el Conde de Miranda a propósito de la jurisdicción de Hoyales y Fuentelisendo que tras años de debates finalizó con la venta de estos lugares a la reina Isabel en $1504^{1739}$.

A pesar de los múltiples enfrentamientos y fracasos que experimentó a lo largo de su vida, al final de sus días don Martín recibió el reconocimiento de la Corona con su nombramiento como corregidor de la ciudad de Ávila en 1504. Precisamente en esta ciudad fue donde falleció poco tiempo des-

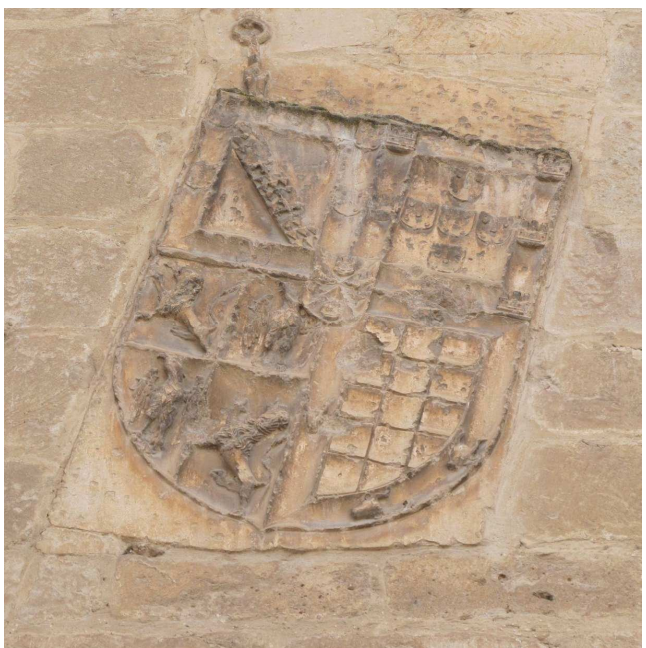
pués ${ }^{1740}$. Imagen 49: Escudo de don Martín Vázquez de
Acuña en San Francisco de Aranda.

El balance final es obvio. El patrimonio territorial que el matrimonio AcuñaAvellaneda heredó en los años setenta del siglo XV había desaparecido completamente a comienzos del Quinientos ${ }^{1741}$. Sin em-

${ }^{1738}$ AGS, RGS, 148902, fol. 132; SANZ ABAD, Historia de Aranda .., p. 139; y ARChV, RRE, Caja 106, doc. 6 y Caja 122, doc. 3.

${ }^{1739}$ Ambos episodios se incluyen dentro de los conflictos generados por la política expansiva de los grandes señores comarcanos que veremos más adelante.

${ }^{1740}$ El 25 de octubre de 1504 Martín Vázquez de Acuña fue nombrado corregidor de Ávila (AGS, CC CÉDULAS, libro 9, doc. 225, fol. 3).

${ }^{1741}$ Es posible que la participación territorial en la herencia del padre de don Martín Vázquez de Acuña fuese convertida también en dinero a través de la venta de sus derechos a uno de sus hermanos (AGS, RGS, 149403, fol. 415; 149405, fol. 122; y 149611, fol. 151). 
bargo, el hecho de haber vendido sus señoríos les había reportado una importante cuantía económica que les permitió plantearse la posibilidad de perpetuar su memoria a través de la fundación de un establecimiento religioso en la localidad donde se habían asentado, creado su riqueza y establecido sus lazos clientelares. Y es así como don Martín y doña Constanza decidieron al final de sus vidas fundar el convento franciscano de la Inmaculada Concepción en la capital ribereña. Diversos problemas retardaron la construcción del edificio por lo que Acuña dictó en su testamento el 15 de septiembre de 1505 ser enterrado en Santa Clara de Tordesillas hasta que pudiera descansar en San Francisco de Aranda, donde finalmente fueron trasladados sus restos ${ }^{1742}$. Posteriormente falleció su esposa aunque no sabemos la fecha concreta. Doña Constanza nombró como sus testamentarios a su hermano don Juan de Avellaneda y a su hijo don Juan de Acuña ${ }^{1743}$.

Don Martín y doña Constanza tuvieron descendencia. Sabemos que Acuña tuvo dos hijos, que por cierto compartían nombre. Si bien no es extraña la existencia de hermanos con el mismo nombre en las familias castellanas, esta situación solía ocurrir cuando se trataba de hijos de diferente madre ${ }^{1744}$. Aunque no tenemos ningún dato que corrobore una explicación al hecho de compartir los dos hermanos el mismo nombre, es posible que Juan Vázquez de Acuña fuera hijo de un primer matrimonio del que no tenemos ninguna noticia ${ }^{1745}$, mientras que don Juan de Acuña lo fuera del segundo matrimonio $^{1746}$. La duplicidad del nombre complica en gran medida la identificación de ambos, si bien es cierto que habitualmente el primogénito aparece identificado con el

${ }^{1742}$ BRAH, SALAZAR Y CASTRO, M-4, fol. 174-178; y SANZ ABAD, Historia de Aranda..., pp. 140-142.

1743 AGS, CMH, leg. 102, doc. 25; y ARChV, RRE, Caja 229, doc. 14.

${ }^{1744}$ Ya hemos visto esta situación en los descendientes del II conde de Urueña que tuvo dos hijas con el nombre de María. La mayor fue primero duquesa de Medina Sidonia y después de Arcos, mientras que la menor contrajo matrimonio con don Enrique Enríquez. De igual manera el regidor arandino Juan Fernández Mejías tuvo dos hijos a los que puso su mismo nombre: Juan el mayor, fue hijo de María García, y Juan el menor, era hijo de Juana Díaz.

${ }^{1745}$ Esta hipótesis se basa en el hecho de que Juan Vázquez de Acuña heredó el apellido completo de su padre, fue nombrado su testamentario y también heredó los problemas que su padre tuvo para que el concejo arandino le reconociera su hidalguía. Aspectos todos ellos que no compartió con su hermano don Juan de Acuña.

${ }^{1746}$ Además de lo señalado en la nota anterior, debemos añadir que don Juan fue nombrado testamentario por su madre junto a su tío y en ningún momento se cita al otro hermano. Además la repetición del nombre es fácilmente explicable por la tradición familiar entre los Avellaneda pues el bisabuelo, el abuelo y el tío compartían el mismo nombre. 
patronímico Vázquez y sin el don delante del nombre mientras que el segundo siempre aparece como don Juan de Acuña.

Hacia 1470 nació el primogénito ${ }^{1747}$, Juan Vázquez de Acuña, que continuó la obra de su padre como su albacea y se casó con Catalina de Avellaneda, hija del señor de Valverde ${ }^{1748}$. Siguió la estela de su padre pues también se enfrentó en un pleito con el concejo para que se reconociera su exención fiscal por su condición de hidalgo ${ }^{1749}$. De igual manera mantuvo la línea de enfrentamiento con el conde de Miranda, destacándose en la oposición al nombramiento de don Juan de Zúñiga como alguacil de la villa $^{1750}$. A pesar de las mandas testamentarias de su padre, se negó a continuar sufragando las obras de construcción del convento de San Francisco tras la muerte del progenitor. Después de un largo conflicto llegó a un acuerdo con la comunidad franciscana para hacerse cargo de la obra a cambio de sustituir a su padre en el patronazgo de la institución religiosa ${ }^{1751}$.

Participó activamente en la vida política arandina, aunque no consiguió acceder a ninguno de los oficios importantes del concejo y tuvo que conformarse con ser elegido en alguna ocasión procurador de la collación de Cascajar ${ }^{1752}$. Disfrutó de una vida acomodada gracias a la herencia familiar y a un importante capital inmobiliario ${ }^{1753}$.

El segundo hijo fue don Juan de Acuña, caballero de la Orden de Santiago, Contino de la Casa Real, Corregidor y Capitán de Guerra de Murcia, Lorca y Cartagena ${ }^{1754}$. Ya desde muy joven destacó en la villa por su vinculación a la Corona y llama la aten-

${ }^{1747}$ En 1515 dice tener 45 años en una probanza para abrir una calle frente a la fachada de San Francisco (AGS, CC PUEBLOS, leg. 2, fol. 107).

${ }^{1748}$ SANZ ABAD, Historia de Aranda..., pp. 144 y 145.

${ }^{1749}$ ARChV, RRE, Caja 259, doc. 5.

${ }^{1750}$ AGS, CONSEJO Y JUNTAS DE HACIENDA, leg. 4, doc. 20.

${ }^{1751}$ ARChV, RRE, Caja 315, doc. 20.

${ }^{1752}$ AGS, CC MEMORIALES, leg. 121, doc. 236.

${ }^{1753}$ ARChV, RRE, Caja 366, doc. 24.

${ }^{1754}$ Estos son los títulos que presentaba la inscripción del arcosolio del lado de la Epístola de la desaparecida capilla mayor del monasterio de San Francisco de Aranda. En ella también se señalaba que era hijo de los fundadores del monasterio, es decir, de don Martín Vázquez de Acuña y doña Constanza de Avellaneda (LOPERRÁEZ CORVALÁN, Descripción histórica..., vol. II, pp. 179-180). El cargo de contino de la Casa del Emperador lo ejerció al menos entre 1535 y 1539 (MARTÍNEZ MILLÁN, J. (Dir.), La Corte de Carlos V. Madrid, 2000, Vol. IV, p. 49). 
ción que en 1515 el rey Fernando se hospedara en las casas que don Juan había heredado de su padre en la calle de Santa $\mathrm{Ana}^{1755}$, a pesar de existir en la villa residencias de nobles de mayor alcurnia ${ }^{1756}$. También destacó como un reconocido miembro de la oligarquía local, siendo conocido entre los vecinos como el Comendador Acuña y manifestando su evergetismo a través de la fundación de la Capellanía del Regimiento con cuyos fondos se pagaba al profesor del Estudio de Gramática habilitado por la villa ${ }^{1757}$. También actuó como regidor de la villa, al menos desde 1521, aunque Diago Hernando ha documentado un primer nombramiento en 1514 y otro en $1518^{1758}$. Recibió en herencia una notable fortuna pues su madre le dejó al menos un cuento de maravedíes ${ }^{1759}$.

A tenor de la información transmitida por Casado Alonso es posible que su primera esposa fuera una hija del potentado local Pedro de Santa Cruz, aunque debió de fallecer tempranamente sin aportar descendencia ${ }^{1760}$. Tras este posible primer matrimonio don Juan de Acuña se casó con doña Catalina de la Mota con quien tuvo por heredero a don Cristóbal de Acuña, regidor de la ciudad de Burgos.

Como se puede deducir por los títulos que aparecían en su cartela funeraria, la vida de don Juan de Acuña fue un claro ejemplo de los miembros de familias nobiliarias de segundo orden que hicieron fortuna y méritos bajo la nueva monarquía. Al igual que su padre, su vida estuvo consagrada al servicio a la Corona, evidentemente con más éxito. Además de su activa intervención en la guerra de las Comunidades en el bando realista, dirigió una compañía de 800 hombres en la posterior defensa de Navarra ${ }^{1761}$. Por todo ello fue gratificado con su admisión como caballero de la Orden de Santiago. Además, en 1524 se le encomendó aparejar cien navíos de guerra para hacer frente a la escuadra francesa y entre 1535 y 1538 desarrolló su actividad como corregidor en la

\footnotetext{
${ }^{1755}$ ARChV, RRE, Caja 259, doc. 5.

${ }^{1756}$ SANZ ABAD, Historia de Aranda..., p. 143.

${ }^{1757}$ SANZ ABAD, Historia de Aranda..., p. 143 y 183. En el plano de 1503 se señala una de las calles como la calle que traviesa por el Estudio a la Ronda y que podemos identificar con la actual calle

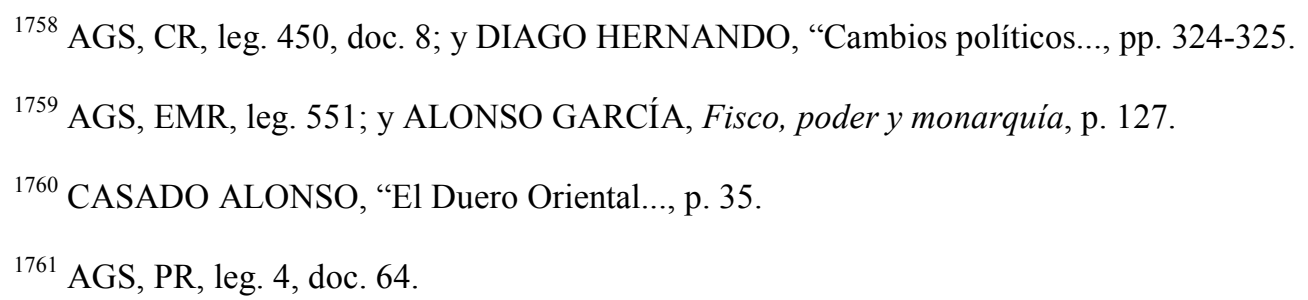
Prado Marina. 
región murciana ${ }^{1762}$. Al contrario que su progenitor y hermano, don Juan tuvo una vinculación bastante estrecha con la casa de Zúñiga pues en 1517 actuó como representante de don Juan de Zúñiga en todos los asuntos referentes a su nombramiento como alguacil de la villa de Aranda y sus acciones en la guerra de Navarra estuvieron tuteladas por el Conde de Miranda ${ }^{1763}$.

Tras esta intensa actividad al servicio real, parece que sus últimos años los pasó en Aranda actuando como regidor de la villa ${ }^{1764}$.

Por último, otro destacado miembro de la familia Acuña fue otro don Martín, sobrino del primero. Fue hijo de don Diego de Acuña, hermano de don Martín Vázquez de Acuña. Posiblemente se instaló en la villa a principios de la decimosexta centuria y por el mismo motivo que su tío: el matrimonio. Sabemos que en 1509 se unió también a la familia Avellaneda a través del enlace con doña Isabel de Avellaneda, hija del señor de Valverde, hermana a su vez de Catalina de Avellaneda, mujer de su primo Juan Vázquez de Acuña ${ }^{1765}$.

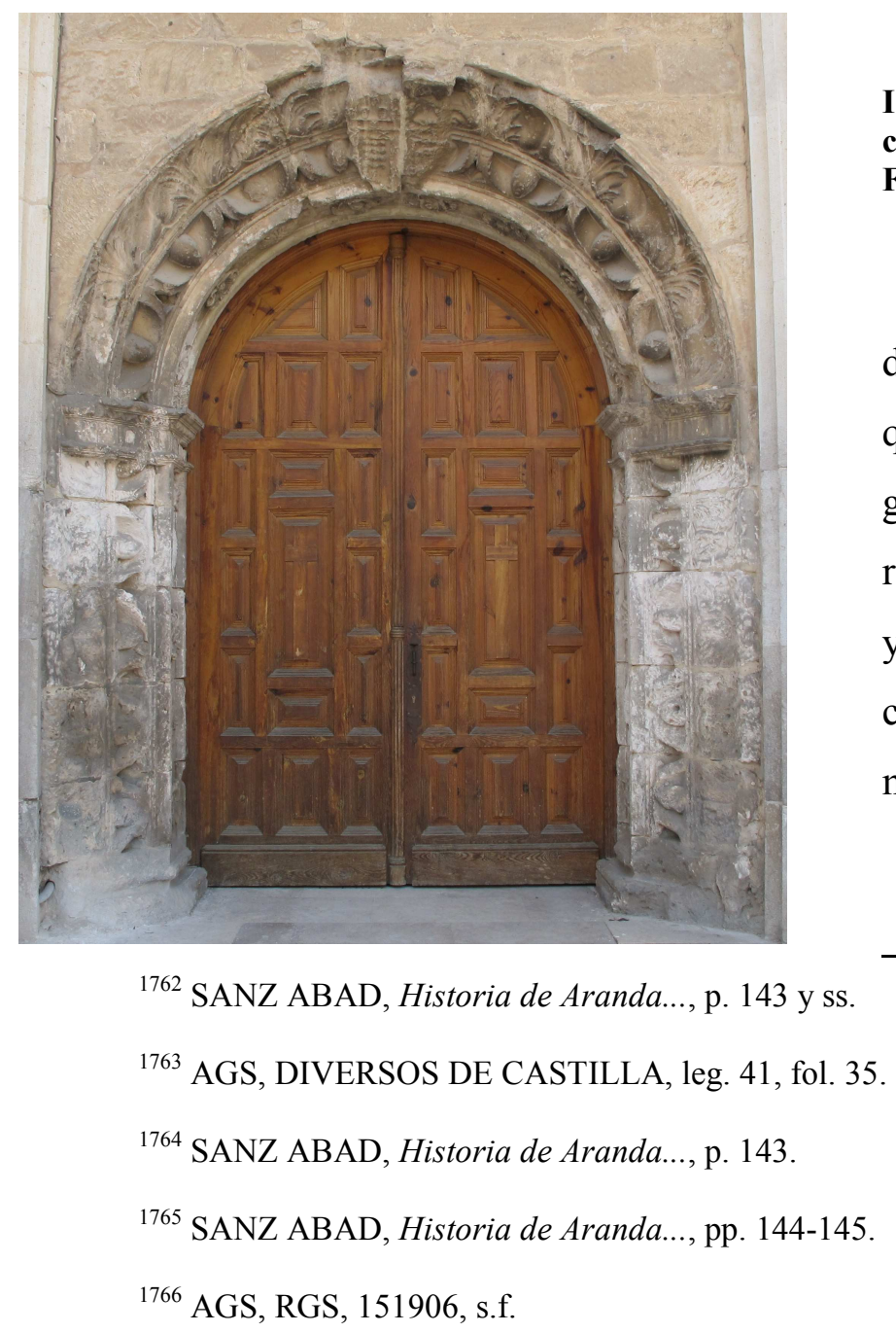

Imagen 50: Puerta renacentista de la capilla de los Acuña Avellaneda en San Francisco de Aranda.

Su implicación en la vida de la capital de la Ribera fue tal que ya en 1519 fue nombrado regidor de la villa ${ }^{1766}$. Fue un activo realista en la revolución comunera y estuvo al servicio del monarca como corregidor de Madrid en los momentos posteriores a la rebe- 
lión. ${ }^{1767}$ Lo más significativo en el contexto de la microhistoria local es que fue padre de don Pedro de Acuña y Avellaneda, obispo de Astorga ${ }^{1768}$. Los restos de padre e hijo reposan en sendos arcosolios de la fundación de su hijo: el Colegio de la Veracruz, actual parroquia de San Juan de la Veracruz. Los emblemas que coronan la fundación y los enterramientos muestran las armas de don Martín de Acuña y de don Pedro de Acuña y Avellaneda pero son obra del siglo XVII ${ }^{1769}$. En la puerta de acceso a la primitiva capilla adosada a la cabecera de la iglesia de San Francisco, todavía hoy se pueden apreciar los restos de un escudo en el intradós del arco renacentista en el que se vislumbran las armas de los Acuña y Avellaneda.

En conclusión, como ya hemos visto en otras ocasiones, a la raíz territorial de los Avellaneda se sumó un componente foráneo, en este caso los Acuña, que se asentó en la capital de la Ribera para hacer fortuna. Bien es cierto que esta familia nobiliaria no puede ser comparada con las que hemos visto anteriormente pero el comportamiento en una primera fase es similar a las mencionadas en el capítulo anterior. Tras luchar durante muchos años por consolidar un pequeño dominio territorial, con el cambio de siglo la familia Acuña modificó la estrategia y se decantó por abandonar sus bases territoriales y centrar sus aspiraciones en el ámbito urbano. Esta nueva fase estuvo ligada, al igual que la nobleza de primer orden, al servicio de la Corona. Tanto don Juan como don Martín de Acuña pueden ser considerados como dos claros ejemplos del prototipo de la nueva generación de miembros de la nobleza de segunda fila que hizo carrera y fortuna al servicio de la nueva dinastía y su nueva concepción de Estado. A esta característica debemos añadir la inquietud que esta familia tuvo por perpetuar su linaje en la memoria colectiva que se materializó en la promoción de la construcción del monasterio de San Francisco primero y del colegio de la Vera Cruz después.

\footnotetext{
${ }^{1767}$ AGS, PR, leg. 1, doc. 2.
}

1768 Tradicionalmente se ha identificado a don Pedro de Acuña como hijo de su tío. SANZ ABAD ya aclaró en su momento su filiación aunque el error se ha seguido reproduciendo (Historia de Aranda..., p. 143). Una completa visión del notable papel que jugó el obispo de Astorga durante el reinado de Carlos I lo podemos consultar en EZQUERRA REVILLA, I. J. y PIZARRO LLORENTE, H. P., "Los consejeros de Carlos V. Pedro de Acuña y Avellaneda" en La Corte de Carlos V, vol. 2, pp. 13-16. Su testamento lo hizo en Aranda el 14 de septiembre de 1555 y un extracto del mismo fue recogido por SALAZAR Y CASTRO (BRAH, Tomo XXVIII, M-4, fol. 182-183).

${ }^{1769}$ DOMÍNGUEZ CASAS, “Heráldica en el arte..., pp. 257-258. 


\section{3. 2. La familia Avellaneda, señores de Valverde.}

Los señores de Valverde también proceden del linaje de Avellaneda. Lope Ochoa de Avellaneda tuvo dos hijos de su matrimonio con Juana Delgadillo: Diego González de Avellaneda y Juan Álvarez Delgadillo. El primero heredó Gumiel del Mercado, Valdesgueva y Villovela mientras que el segundo dio lugar al linaje de los Delgadillo, que veremos posteriormente.

Don Diego heredó muy joven el patrimonio de su padre tras la muerte de éste en el sitio de Lisboa en 1384. Contrajo matrimonio con doña Inés de Cisneros, señora de Villafrechós. La sucesión genealógica se complica considerablemente en este punto. Según Salazar y Castro ${ }^{1770}$, así como para la mayor parte de los genealogistas, la heredera de don Diego fue su hija doña Beatriz que, como ya hemos visto, contrajo matrimonio con don Diego Gómez de Sandoval y dio paso a la presencia de esta familia en la Ribera.

Otros autores, encabezados por Merino Gayubas ${ }^{1771}$, afirman que don Diego se casó con doña Juana de Acitores y que su primogénito fue Ochoa de Avellaneda, señor de Alcubilla y Alcoba. Tras la muerte de su padre, Ochoa heredó de forma indirecta en 1436 el mayorazgo de Valverde de su tío segundo, don Ruy González de Avellane$\mathrm{da}^{1772}$, con su fortaleza y vasallos más sus casas de Aranda. La inexplicable preferencia de la mujer sobre el varón en aquel contexto nos lleva a pensar que el matrimonio con doña Juana se produjo en segundas nupcias lo que explicaría en cierta medida por qué Ochoa de Avellaneda recibió una herencia bastante menos significativa que doña Beatriz o, tal vez, se tratara de un hijo bastardo. Según estos mismos autores, Ochoa de Avellaneda tuvo tres hijos: don Juan, don Diego y doña Catalina. El primero heredó la casa de Valverde y el segundo fue el progenitor de don Diego de Avellaneda, futuro obispo de Tuy y regente del reino de Navarra bajo el reinado de Carlos $\mathrm{I}^{1773}$.

Desconocemos casi todo sobre la trayectoria vital de Ochoa de Avellaneda pero su hijo don Juan ya aparece en la documentación ejerciendo como señor de Valverde

\footnotetext{
${ }^{1770}$ SALAZAR Y CASTRO, Historia genealógica..., vol. III, p. 350.

${ }^{1771}$ MERINO GAYUBAS, Genealogía del solar de Guzmán..., Vol. I, pp. 548-553. Sin citarlo expresamente, parece que se basa en el estudio de Pellicer.

${ }^{1772}$ Este Ruy González de Avellaneda, según Merino, era hijo de don Juan González de Avellaneda, señor de Peñaranda, Montejo, Íscar y Haza.

${ }^{1773}$ FERNÁNDEZ CONTI, “Los consejeros..., vol. 2, p. 475.
} 
desde 1474 cuando solicitó a los lugares de Alcubilla, Pinilla, Alcoba la Yerma y Valverde que se le otorgaran los 5.000 maravedíes que tenía de juro de heredad sobre sus alcabalas y tercias $^{1774}$.

La mayor parte de la información con la que contamos sobre don Juan de Avellaneda se centra en los numerosos y persistentes enfrentamientos que mantuvo con sus vecinos. Al menos desde 1475 y durante buena parte de los años ochenta el señor de Valverde asaltó e incendió de manera repetida la villa de Quintanilla de Nuño Pedro, propiedad de los señores de Baides, por aquel entonces pretendientes del mayorazgo de Monterrey ${ }^{1775}$.

Por otra parte, don Juan también acosó a la comunidad cisterciense de Fuencaliente, disputando y usurpando con violencia su jurisdicción sobre la villa de Fuentearmegil y su valle ${ }^{1776}$. La tensión no finalizó hasta que en 1518 don Bernardino, heredero de don Juan, llegó a un acuerdo con la abadesa de Fuencaliente por el que cedía al monasterio los derechos que le pertenecían sobre Fuentearmegil a cambio del lugar de Ravanera más unos heredamientos en Arandilla e Hinojar ${ }^{1777}$.

Los señores de Valverde no solamente se dedicaron a señorear por sus tierras y las de sus vecinos. Don Juan también apostó por otros negocios bastante más lucrativos como fue la compra de deudas de terceros que después se encargaba de cobrar, suponemos que de forma expeditiva y con una gratificación extra ${ }^{1778}$. En este sentido, también la documentación muestra al Avellaneda litigando con el marqués de Denia en 1495 por el pago de una mula que vendió el primero al segundo ${ }^{1779}$.

Don Juan contrajo matrimonio con doña Teresa Pineda, hija de don Pedro Fernández de Pineda, caballero de Plasencia. Fruto de este matrimonio fue un único hijo

${ }^{1774}$ AGS, RGS, 147404, fol. 21.

1775 AGS, RGS, 147511, fol.743; 147911, fol. 60; 148411, fol. 50; 148501, fol. 88; 148503, fol. $90 ; 148605$, fol. 103 y 166. Más adelante abordaremos con más detalle estos conflictos.

${ }^{1776}$ AGS, RGS, 148902, fol. 298; 149303, fol. 262.

1777 SALAZAR Y CASTRO, Historia genealógica..., vol. III, p. 405.

${ }^{1778}$ Así se concluye del contenido del pleito mantenido con Juan de Vitoria, vecino de Aranda. Vitoria debía 40 enriques viejos a Ortuño de Salde quien se los traspasó al señor de Valverde. Don Juan pidió la ejecución de sus bienes a las justicias de Aranda aunque Vitoria recurrió (ARChV, RRE, Caja 3, doc. 5). 100 , doc. 1 .

1779 ARChV, PLEITOS CIVILES, FERNANDO ALONSO (F), Caja 1408, doc. 8; y RRE, Caja 
varón, don Bernardino, y varias mujeres. Al igual que hemos visto en el caso de los principales linajes de la nobleza comarcana, los hijos fueron el instrumento perfecto para que en el seno del señorío de Valverde se desarrollara una precisa política de alianzas matrimoniales que permitió emparentar con destacadas familias nobiliarias ${ }^{1780}$. En esta estrategia sobre todo primó la meditada apuesta por consolidar lazos con los linajes ribereños más destacados del momento, siempre dentro del contexto de la nobleza de segundo rango. El heredero, don Bernardino, firmó sus propias capitulaciones matrimoniales con don Gutierre Delgadillo, señor de Castrillo, para acordar el matrimonio con su hermana doña Isabel Delgadillo ${ }^{1781}$. Con este enlace se establecían los primeros pasos para la unión definitiva, 70 años después, de estos dos linajes en don Bernardino de Avellaneda y Delgadillo, I conde de Castrillo y nieto de los contrayentes.

Como ya hemos visto en el capítulo dedicado a la familia Acuña, a principios del siglo XVI Isabel y Constanza de Avellaneda, hijas de don Juan y hermanas de don Bernardino, contrajeron matrimonio con dos destacados miembros de esta familia de origen portugués. Según Sanz Abad el 24 de junio de 1509 se firmaron las capitulaciones matrimoniales para el enlace de doña Catalina con Juan Vázquez de Acuña y de doña Isabel con don Martín de Acuña, primo del anterior ${ }^{1782}$.

La imbricación del señor de Valverde en el seno de la oligarquía arandina fue total a principios del siglo XVI y su culminación llegó en octubre de 1519 cuando don Bernardino recibió el nombramiento de regidor perpetuo de la villa de Aranda ${ }^{1783}$. Al igual que otros destacados miembros de la oligarquía local se asoció al clan de los Santa Cruz en algunos de sus negocios financieros ${ }^{1784}$.

Durante la revolución Comunera fue destituido de su cargo como el resto de regidores vitalicios. En el conflicto tuvo una postura claramente decantada hacia el bando

${ }^{1780}$ MERINO GAYUBAS, Genealogía del solar de Guzmán..., vol. II, pp. 550-551. Doña María casó con el señor de Piña de Esgueva; doña Catalina con don Juan de Acuña y Sarmiento; doña Mencía con Luis Bañuelos, Veinticuatro de Sevilla; doña Teresa con el señor de Villagarcía; y doña Leonor fue dama de la reina doña Germana y se casó con un caballero napolitano.

${ }^{1781}$ BRAH, SALAZAR Y CASTRO, M-4, fol. 184. Al ser don Bernardino quien firmó las capitulaciones suponemos que don Juan ya había fallecido aunque MERINO GAYUBAS señala que su muerte se produjo al principio del reinado del emperador (Genealogía del solar de Guzmán..., vol. II, p. 550).

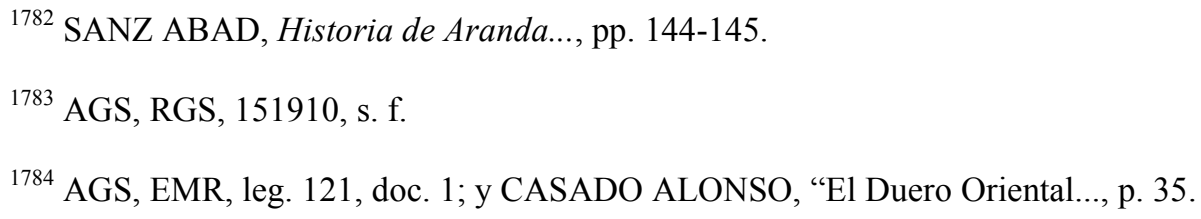


realista, aunque no de una manera tan destacada como sus cuñados. Tras la restitución de la legalidad en mayo de 1521 don Bernardino recuperó su condición de regidor y participó en las tareas de censura de la actuación del gobierno comunero y en la posterior represión $^{1785}$.

Al final del periodo que nos ocupa la familia de los señores de Valverde ya había establecido de forma estable su residencia en la villa de Aranda, completamente integrada en el seno de la oligarquía local. Desde esta posición central mantuvo los vínculos con su reducido patrimonio territorial en la zona oriental ribereña, limitado a Alcubilla de Avellaneda y Alcoba, que incluso experimentó una modesta expansión.

\section{3. 3. La familia Álvarez Delgadillo, señores de Castrillo.}

El origen de la presencia de esta familia en el territorio ribereño está imbricado también en el linaje de los Avellaneda. En el último cuarto del siglo XIV se efectuó el matrimonio entre don Lope Ochoa de Avellaneda, señor de Gumiel de Mercado, y doña Juana, hija de Gutierre Fernández Delgadillo y doña Juana de Formicedo ${ }^{1786}$.

Como ya hemos visto, de esta unión nacieron varios hijos. El primogénito fue don Diego González de Avellaneda que heredó Gumiel del Mercado más Valdesgueva, cuya descendencia se integró en el linaje de los Sandoval. El segundo varón, don Juan Álvarez Delgadillo, heredó el patrimonio de su madre con el señorío de Castrillo de Luis Díaz a la cabeza y en el que se incluían los lugares de Cevico Navero, también en la Merindad de Cerrato, más Ciruelos y Tejada, en la de Santo Domingo de Silos ${ }^{1787}$. A esta herencia don Juan añadió ciertas heredades en La Aguilera que compró en $1418^{1788}$.

Este primer Juan Álvarez Delgadillo se casó con doña Constanza Fajardo, sin que tengamos constancia por el momento de si esto supuso un aumento de su patrimo-

${ }^{1785}$ AGS, CR, leg. 450, doc. 8; y CMC, leg. 355. Avellaneda fue el depositario de los bienes confiscados del comunero Gaspar de Mansilla.

${ }^{1786}$ Este primer Delgadillo fue caballero al servicio del rey Pedro I y falleció en la batalla de Nájera en 1467 (MERINO GAYUBAS, Genealogía del solar de Guzmán..., vol. II, p. 548). El solar de esta familia debió estar en el valle de Valdivielso, en el Norte burgalés (LAVADO PARADINAS, P., "El palacio fortaleza de los Delgadillo en Castrillo de don Juan", en Publicaciones de la Institución Tello Téllez de Meneses. 41, 1979, pp. 217-231). No obstante, debemos tomar esta información con cierta cautela pues los datos aportados por este último trabajo sobre los miembros de esta familia contienen algunas imprecisiones.

\footnotetext{
${ }^{1787}$ MERINO GAYUBAS, Genealogía del solar de Guzmán..., vol. II, pp. 556 y ss.

1788 SNAHN, FERNÁN NÚÑEZ, Caja 2061, doc. 10.
} 
nio en tierras ribereñas. Una de las primeras noticias que tenemos de él se refiere a su actuación como tutor de su sobrina, doña Beatriz de Avellaneda, en el contrato de arras previo a su matrimonio con don Diego Gómez de Avellaneda ${ }^{1789}$.

Delgadillo estuvo al servicio de los monarcas castellanos y fue distinguido como Alférez Mayor del rey entre 1426 y 1432. Asimismo participó en alguna de las campañas contra los granadinos en una posición destacada entre las huestes reales. Todo parece indicar que el señor de Castrillo falleció en $1432^{1790}$.

Su sucesor fue su primogénito don Gutierre Delgadillo, primero de este nombre. Éste contrajo matrimonio con doña Inés Dávila y parece que se casó en segundas nupcias con doña María de Zúñiga, como aparece en su testamento redactado en $1473^{1791}$.

Don Gutierre aumentó notablemente el patrimonio del señorío con la anexión de la villa de Alcozar que hasta entonces había pertenecido a los obispos de Osma ${ }^{1792}$. Asimismo sabemos que tenía una importante hacienda que incluía 28 hectáreas de cereal más otras dos de viñedo repartidas por las inmediaciones de Aranda y en su tierra $^{1793}$. De igual manera la documentación informa de un notable patrimonio inmobiliario, además de poseer unas aceñas en las villas de Aranda y Roa ${ }^{1794}$. Al final de sus días don Gutierre había logrado configurar un modesto dominio territorial que incluía las villas de Castrillo y Cevico Navero más los lugares de San Pedro de Yedra, Zayas de la

${ }^{1789}$ SALAZAR Y CASTRO, Historia genealógica..., vol. III, p. 509.

${ }^{1790}$ El rey movió sus pendones tendidos, e haces, e batallas bien ordenadas. Levaba aquel día el pendón del Rey Juan Álvarez Delgadillo de Avellaneda, Alférez mayor del Rey... (Crónica de don Álvaro de Luna, condestable de los reynos de Castilla y de León. FLORES, J. M. (Ed.), Madrid, 1784, Título XXXVIII, pp. 119-120).

${ }^{1791}$ BRAH, SALAZAR Y CASTRO, M-4, fol. 184. Extracto del testamento de Gutierre Delgadillo otorgado en virtud de su poder por doña María de Zúñiga, su mujer, y por Juan Delgadillo, señor de Castrillo su hijo mayor.

1792 CALDERÓN ORTEGA, J. M., Álvaro de Luna: riqueza y poder en la Castilla del siglo XV. Madrid, 1998, p. 217. LOPERRÁEZ CORVALÁN afirma que don Juan Delgadillo usurpó Alcozar al obispado de Osma para luego cedérselo a don Álvaro de Luna. En 1459 todavía seguía la disputa entre don Gutierre y el obispo de Osma (Descripción histórica..., tomo I, pp. 360-361).

${ }^{1793}$ Esta información la transmite un traslado del apeo realizado en 1448 que se encuentra entre la documentación de un expediente de 1529 (AGS, EH, leg. 878, doc. 14). En concreto poseía más de 8 hectáreas en las proximidades de Santa María de las Viñas; otras cinco en la aldea de Villalba y más de 15 en la de Sinovas. Las viñas se encontraban en las inmediaciones de Aranda. También poseía otras viñas que se encontraban perdidas y que parece que las acababa de adquirir pues todavía se hace referencia en el apeo a su anterior propietario.

${ }^{1794}$ ARChV, RRE, Caja 259, doc. 5. En Aranda poseía unas casas en la calle Hisilla que heredó su hijo Juan (Caja 214, doc. 35). 
Torre, Ciruelos, Alcozar y Tejada. Posiblemente también poseyera el lugar de Valdeherreros, o al menos algunos derechos sobre él, en la tierra de Montejo ${ }^{1795}$. Además contaba con un significativo ingreso por rentas que se acercaba a los 500.000 maravedíes anuales más una importante cabaña de ganado ovino que rondaba las 7.000 cabezas $^{1796}$.

Desconocemos por el momento la participación de don Gutierre en las intrigas políticas de los años centrales del siglo XV, así como su posicionamiento en el conflicto sucesorio del final del reinado de Enrique IV. No obstante, suponemos su adhesión al monarca pues en 1466 Delgadillo fundó mayorazgo a favor de su primogénito y éste fue aprobado por Enrique IV en $1467^{1797}$. En este sentido, tan solo podemos presuponer cierta proximidad al partido de doña Juana y del rey portugués si atendemos al matrimonio concertado entre doña Isabel Delgadillo, hija de don Gutierre, con don Gonzalo Muñoz de Castañeda, señor de Hormaza y activo promotor de los intereses del rey de Portugal en tierras ribereñas ${ }^{1798}$. Esta indefinición se vio incrementada a causa del fallecimiento en 1474 de don Gutierre y de la situación familiar que, como veremos, se tornó un poco complicada.

Tras la muerte de don Gutierre le sucedió como señor de los estados de Castrillo su hijo primogénito, don Juan Álvarez Delgadillo. Su matrimonio parece que se concertó en un primer momento con doña Magdalena de Sandoval, hija del conde de Castro. Sin embargo, la temprana muerte de la novia llevó a un nuevo enlace con doña Isabel de Obregón $^{1799}$.

La trayectoria de don Juan Álvarez Delgadillo como señor de Castrillo se caracterizó por una gran conflictividad durante buena parte de los más de treinta años que

${ }^{1795}$ Esta noticia la conocemos de manera indirecta a través del pleito por la jurisdicción de Milagros. Uno de los testigos afirmaba que Valdeherreros, antes de ser propiedad del conde de Miranda, pertenecía a un tal Juan Delgadillo que se lo vendió a principios de los años 70. Suponemos, por lo tanto, que este lugar formó parte de la herencia que don Gutierre dejó a su hijo (AGS, CR, leg. 22, doc. 1).

${ }^{1796}$ Estos datos los aporta su hija doña Beatriz en 1487 y deben ser tomados con cautela pues responden al interés de la denunciante por recuperar la parte de su herencia por lo que seguramente estén algo hinchados (AGS, RGS, 148708, fol. 87).

${ }^{1797}$ SNAHN, OSUNA, Caja 3327, doc. 4; y BRAH, SALAZAR Y CASTRO, M-4, fol. 183.

${ }^{1798}$ El señor de Hormaza actuó en la Ribera desde su fortaleza de Portillejo y se encargó de recaudar dinero para el partido portugués. Entre los damnificados se encontraban varios vecinos de Fuentespina que fueron asaltados y robados por Castañeda (AGS, RGS, 147811, fol. 53; y 147812, fols. 98, 135 y 136). De todas formas debemos ser cautos pues la implicación del yerno no garantiza la postura del suegro.

${ }^{1799}$ MERINO GAYUBAS, Genealogía del solar de Guzmán..., vol. II, p. 558. 
estuvo al mando de su señorío. Los conflictos se manifestaron rápidamente en enfrentamientos con sus propios vasallos a los que pretendía usurpar sus heredades ${ }^{1800}$, o con sus vecinos, ya fueran éstos los concejos aledaños, como Canillas o Encinas de Esgue$\mathrm{va}^{1801}$, o las instituciones religiosas cercanas, en concreto San Pelayo de Cerrato y Santa María de Tórtoles, como veremos más adelante. También mantuvo varias disputas por la jurisdicción de Ciruelos tanto con el monasterio de Silos, que aducía ciertos derechos sobre el lugar, como con las autoridades de la Merindad de Santo Domingo de Silos que ostentaban el ejercicio de la justicia civil y criminal sobre el mismo lugar a pesar de las reticencias de los vecinos y de don Juan ${ }^{1802}$.

Este carácter polemista del señor de Castrillo volvió a manifestarse en 1498 cuando envió a su alcaide para que acudiera a Zayas de la Torre y despojara a Juan de Villafañe, clérigo de León y familiar del Santo Padre, del beneficio curado de este lugar. La agresión culminó con el encastillamiento de la iglesia parroquial ante la presencia de las autoridades eclesiásticas ${ }^{1803}$.

Paralelamente a estas disputas también emprendió varios pleitos con los recaudadores de alcabalas y tercias de la Merindad de Santo Domingo por ciertos juros de heredad situados sobre las rentas de Zayas de la Torre y Alcoba de la Torre ${ }^{1804}$.

El acontecimiento que marcó este periodo fue la relación de don Juan con sus hermanas solteras. En un cruel intento de mantener el rico patrimonio heredado de su padre, don Juan decidió en el verano de 1474 apresar a sus hermanas y encerrarlas durante nueve o diez años en una de las torres de la fortaleza de Castrillo. Allí doña Beatriz y doña María fueron sometidas a un trato denigrante, privándolas de comida, así como de atención médica y espiritual. En tan largo encierro doña María enfermó y quedó tullida para finalmente morir en prisión. Cuando doña Beatriz fue liberada por orden

${ }^{1800}$ En 1478 Catalina de Gaona, vecina de Castrillo, solicitó la protección del duque de Alburquerque pues don Juan pretendía usurparle unos sembrados (AGS, RGS, 147807, fol. 26).

${ }^{1801}$ AGS, RGS, 148411, fol. 27; 148509, fols. 69, 83 y 132; y 148511, fol. 79.

1802 ARChV, RRE, Caja 42, doc. 17; PLEITOS CIVILES, FERNANDO ALONSO (F), Caja 1437, doc. 2. En 1515 su hijo Gutierre continuó el pleito con el abad y monasterio de Silos que afirmaba poseer en el lugar ciertos vasallos (AGS, CC PUEBLOS, leg. 2, doc. 107, fol. 16).

${ }^{1803}$ Ante esta situación los reyes enviaron al corregidor de Aranda para que averiguara lo sucedido y, si procedía, auxiliara a las autoridades eclesiásticas (AGS, RGS, 149809, fols. 23 y 203 ).

${ }^{1804}$ AGS, RGS, 1148502, fol. 282; 148503, fol. 59; 148504, fols. 68 y 157. Un nuevo pleito se planteó más tarde con el obispado de Palencia por el cobro de los diezmos en sus villas y lugares (ARChV, RRE, Caja 48, doc. 11). 
de los monarcas denunció a su hermano y reclamó la devolución de su herencia así como la de su hermana, pues ésta se la había cedido antes de morir ${ }^{1805}$.

Delgadillo huyó a Palencia y se refugió en una supuesta condición clerical para evitar la acción de la justicia real. Los monarcas le condenaron a muerte en noviembre de 1487 y poco después ordenaron secuestrar sus bienes para acto seguido ceder a su hermana la parte que le correspondía ${ }^{1806}$. La ejecución de la sentencia no se llevó a cabo y todo apunta a que doña Beatriz recibió su parte de la herencia que invirtió en el Hospital de la Caridad de Valladolid ${ }^{1807}$.

Tras la devolución de la herencia a sus hermanas un nuevo varapalo económico sacudió al señor de Castrillo. En el año 1500 los monarcas impusieron a don Juan una multa de 380.000 maravedíes por haber cobrado durante diecinueve años un juro de heredad de 20.000 maravedíes anulado desde 1480. Tras una pesquisa llevada con el máximo secreto posible se dictó orden de encarcelar al señor de Castrillo en la fortaleza de Cabezón en agosto de $1505^{1808}$. Seguramente esta situación fue la que le obligó a empeñar la importante hacienda que poseía en la villa de Aranda en 1508 al rico arrendador Pedro de Santa Cruz por 100 ducados de oro ${ }^{1809}$.

Por lo tanto, don Juan Álvarez Delgadillo al final de sus días vio considerablemente mermado su patrimonio como consecuencia de los problemas familiares, las continuas disputas en las que se vio inmerso, la merma de sus ingresos al perder el favor real y sus altercados con la justicia. El considerable patrimonio heredado de su padre a buen seguro que no lo pudo transmitir a su hijo primogénito. Don Juan murió entorno a 1510 y le sucedió en sus estados el joven don Gutierre Delgadillo ${ }^{1810}$.

${ }^{1805}$ AGS, RGS, 148708, fol. 87.

${ }^{1806}$ AGS, RGS, 148710, fols. 179 y 180; y 148711, fol. 51.

1807 ANTOLÍNEZ DE BURGOS, J. y ORTEGA RUBIO, J., Historia de Valladolid. Valladolid, 1887 , p. 395.

1808 AGS, CC DIVERSOS, leg. 6, doc. 5; CÉDULAS, Libro 4, leg. 151, doc. 2; libro 7, leg. 84, doc. 2 ; y libro 8 , leg. 51 , doc. 1 .

${ }^{1809}$ AGS, EH, leg. 878, doc. 14. No conocemos la fecha con certeza. En 1524 se aseguraba que se habían empeñaron hacía 16 años y en 1527 se indicaba que habían pasado 19 años desde que se empeñaron los bienes.

${ }^{1810}$ Suponemos que era menor de edad porque en una compra realizada antes de 1517 aparecía el doctor Villovela como tutor y curador de don Gutierre Delgadillo (AGS, CMC, leg. 41, doc. 14). 
Son pocos los datos con los que contamos del señor de Castrillo anteriores a la revolución comunera y casi todos se centran en los intentos por recuperar el patrimonio que su padre había perdido. Esta empresa se vio refrendada por la Corona ya que en 1512 confirmó su mayorazgo ${ }^{1811}$.

Don Gutierre fue el encargado de firmar las capitulaciones matrimoniales con don Bernardino de Avellaneda, señor de Valverde, para el matrimonio de este noble comarcano con su hermana Isabel Delgadillo ${ }^{1812}$. Recordemos que este compromiso fue el primer paso para la unión de los destinos de ambas familias que cristalizó un siglo después en el condado de Castrillo.

En lo que se refiere a la defensa de su patrimonio, todavía mantuvo la vieja disputa con el monasterio de Silos por la jurisdicción de Ciruelos y para ello don Gutierre recurrió a la justicia del corregidor arandino que, sin embargo, tuvo que abandonar sus pesquisas ante la una orden real solicitada por el poderoso abad de Silos. La autoridad real conminó al oficial arandino a inhibirse a favor del corregidor de Burgos ${ }^{1813}$.

Asimismo trató de recuperar la hacienda que su padre empeño en Pedro de Santa Cruz. El proceso fue largo y costoso y desconocemos si llegó a buen fin a pesar de las numerosas sentencias favorables. En 1524 consiguió que el teniente de corregidor arandino admitiera que las tierras empeñadas correspondían al mayorazgo que su padre le dejó en herencia y, por lo tanto, ordenaba a Santa Cruz que se las devolviera. Esta sentencia no se cumplió pues en una nueva sentencia de marzo de 1527 el teniente de corregidor recordaba a Santa Cruz su obligación de reintegrar las heredades a Delgadillo en el plazo de nueve días más una cantidad por lo que rentaron durante los últimos 18 años. Sin embargo, en 1529 la hacienda estaba todavía en posesión de doña Isabel Vaca, esposa de Gaspar de Santa Cruz, quien la había recibido de su marido. Por esas mismas

${ }^{1811}$ BRAH, SALAZAR Y CASTRO, M-4, fol. 183. Esta concesión tuvo sus efectos prácticos en el proceso de reclamación que el señor de Castrillo hizo de la devolución de los bienes que su padre había empeñado a Santa Cruz. Los Delgadillo argumentaban que esas propiedades se encuadraban en el mayorazgo por lo que la transacción no fue una venta como argumentaban los Santa Cruz (AGS, EH, leg. 878, doc. 14).

${ }^{1812}$ BRAH, SALAZAR Y CASTRO, M-4, fol. 184. En el texto señala que se trataba de la hija de Gutierre pero la lógica nos permite concluir que era hermana de Gutierre e hija de Juan Álvarez Delgadillo (MERINO GAYUBAS, Genealogía del solar de Guzmán..., vol. II, p. 558).

1813 AGS, CC PUEBLOS, leg. 2, doc. 117. 
fechas el pleito continuaba pendiente en la Chancillería de Valladolid ${ }^{1814}$. Desconocemos cómo terminó el proceso.

Sin embargo, y a pesar de no recuperar su hacienda arandina, sabemos que todavía mantenía en Aranda sus casas y parte de sus intereses pues en torno a 1516 compró una parada de una aceña sobre el Duero ${ }^{1815}$.

Nada sabemos sobre la intervención del señor de Castrillo en el conflicto de las comunidades aunque algún autor lo sitúa al lado del Emperador ${ }^{1816}$. También aparece al servicio del príncipe Felipe como paje de su Casa entre 1543 y $1544^{1817}$.

Tras el conflicto civil siguió actuando por tierras ribereñas hasta su muerte en $1547^{1818}$. Le sucedió su hijo, don Juan Delgadillo de Avellaneda, que murió sin descendencia. Esta situación permitió que su sobrino Bernaldino González de Avellaneda, señor de Valverde, le sucediera y aunara los señoríos de Valverde y Castrillo. En 1610 obtuvo del monarca la merced condal que le convirtió en el I conde de Castrillo.

Como ya hemos visto anteriormente, además de estas familias nobiliarias con importantes intereses en la Ribera, se aprecia también la existencia de un grupo de hidalgos asentado principalmente en los núcleos urbanos como Aranda y Roa ${ }^{1819}$. Nuestro estudio de este colectivo se ha centrado sobre todo en las familias nobiliarias de la villa de Aranda de Duero, condicionado sobre todo por la información transmitida por

${ }^{1814}$ Toda esta información se encuentra incluida en el expediente abierto contra doña Isabel Vaca, como fiadora del arrendador Santa Cruz. Cuando los bienes de doña Isabel se iban a subastar en Aranda, el procurador de don Gutierre presentó toda la documentación para impedir que las heredades que consideraba suyas salieran en pública almoneda hasta que no hubiera una sentencia firme de la Audiencia (AGS, EH, leg. 878, doc. 14). Este expediente culminó con la anulación de las actuaciones del juez y la devolución de todos los bienes confiscados a doña Isabel, incluidos los pretendidos por don Gutierre.

1815 ARChV, RRE, Caja 259, doc. 5; y AGS, CMC, leg. 41, doc. 13.

${ }^{1816}$ MERINO GAYUBAS, Genealogía del solar de Guzmán..., Vol. II, p. 558.

${ }^{1817}$ FERNÁNDEZ CONTI, S. (Coord.), "Los servidores de las casas reales”, en La Corte de Carlos V. Madrid. 2000. Vol. 3, p. 101.

${ }^{1818}$ En 1524 estuvo disputando con el Concejo de la Mesta por ciertas exenciones de los ganados a su paso por Zayas de la Torre (ARChV, RRE, Caja 367, doc. 30); en 1543 el pleito lo mantuvo con el monasterio de Santa María de la Vid por ciertas posesiones del cenobio en Alcozar y Cubillas (PLEITOS CIVILES, FERNANDO ALONSO (F), Caja 271, doc. 4).

${ }^{1819}$ En algunos pueblos de la Ribera como Quintana del Pidio, Guzmán o Zayas de la Torre también se constata la existencia de hidalgos (ARChV, RRE, Caja 22, doc. 10; Caja 69, doc. 25; AGS, RGS, 149002, fol. 160). 
las fuentes. Por lo tanto, nos remitimos a lo ya señalado en el anterior bloque que en buena medida se puede hacer extensivo a los hidalgos raudenses.

En conclusión, podemos apreciar cómo la nobleza comarcana presentaba una pujante situación que la convertía en el principal poder de la zona. Su evidente heterogeneidad no fue inconveniente para que cada uno de los tres niveles -aristocracia comarcana, nobleza de segunda fila e hidalguía urbana- copasen los principales resortes de poder a los que tuvieron acceso, cada uno de ellos adaptándose a su propia escala.

Por una parte, los grandes linajes comarcanos -Zúñiga, Sandoval, Téllez-Girón, de la Cueva y Mendoza- configuraron importantes dominios territoriales sobre los que asentaron su poder como primer paso para extender su influencia sobre otros espacios y situaciones. La rápida adaptación a la nueva configuración del Estado que impusieron los Austrias les llevó a lo largo del Quinientos a escalar alguno de los más importantes puestos de confianza de los monarcas y, por lo tanto, a engrandecer su posición de poder e incrementar sus niveles de riqueza.

La nobleza de segunda fila apenas pudo mantener sus exiguos dominios territoriales por la feroz competencia de la nobleza dominante. Ante esta situación este grupo optó por una estrategia gracias a la cual se convirtió en el principal grupo de presión en los escasos núcleos urbanos de la comarca. Complementariamente este sector de la nobleza buscó la consecución de sus objetivos poniéndose al servicio de la Corona.

Por último, la hidalguía urbana copó casi por completo el ámbito de la oligarquía urbana, más concretamente la arandina, disponiendo a su antojo de los resortes del poder municipal.

Este panorama se completó con la integración de los dos últimos grupos dentro de las redes clientelares de las grandes familias nobiliarias con lo que su dominio sobre la comarca fue casi completo. 


\section{LAS BEHETRÍAS.}

La realidad de las behetrías en Castilla ha sido analizada con profusión en los últimos años y además recientemente estudiada por el profesor Estepa Díez en una exhaustiva monografía que aborda el origen y desarrollo de este elemento territorial y jurídico $^{1820}$.

En lo que atañe al espacio ribereño, este autor presenta las diferentes realidades que se vislumbran bajo el genérico nombre de behetría, observando diferentes tipos. Así identifica a la mayoría de las behetrías ribereñas como behetrías de naturales con derechos, aunque también señala la existencia de alguna behetría de linaje, como es el caso de Arauzo de Salce ${ }^{1821}$. También resulta interesante la identificación de los mecanismos por los cuales durante el periodo plenomedieval antiguas behetrías se convirtieron en abadengos, como Caleruega, o solariegos, entre las que se encontraban Quemada o Ventosilla $^{1822}$. En este sentido, nos llama la atención la villa de Gumiel de Izán que a finales del siglo XII tenía una situación jurídica particular pues la mitad de la villa era abadengo dependiente del cercano monasterio de San Pedro ${ }^{1823}$ y la otra mitad se mantenía como behetría ${ }^{1824}$. Con el paso del tiempo y sin que conozcamos muy bien el proceso esta villa se convirtió en solariego. Ya en el siglo XV algunos señores comarcanos trata-

${ }^{1820}$ ESTEPA DÍEZ define el señorío de behetría como "un señorío de laicos que actúan de manera conjunta sobre unos campesinos, existiendo dos niveles en el ejercicio del señorío, el propio del conjunto de los diviseros como un poder compartido y el propio y superior del señor singular" aunque matiza que esto no es más que un esquema general de aproximación pues muchas behetrías no coinciden con esta definición (Las Behetrías..., Vol. I, p. 86).

${ }^{1821}$ ESTEPA DÍEZ, Las Behetrías..., Vol. I, p. 120-122, 149 y ss. Las behetrías de naturales con derecho son aquellas en las que existe un conjunto de naturales, entre los que se encuentra su señor singular, que perciben la tasa divisera. Entre los naturales o diviseros estaba presente generalmente el linaje de los Lara y Haro, circunstancia bastante habitual entre las behetrías ribereñas. Estepa identifica este tipo con aquellas behetrías en las que su señor singular viene precedido del término agora. Es el caso de Arauzo de Miel y Torre, Quintanarraya y Hontoria.

${ }^{1822}$ ESTEPA DÍEZ, Las Behetrías..., vol. I, pp. 187-188 y 194-195.

${ }^{1823}$ En teoría los vasallos que poseía el monasterio en la villa de Gumiel los obtuvo por donación de Fernando III (AGS, PR, leg. 58, doc. 5). El documento en sí es un traslado realizado en Aranda en 1400 y da la impresión de que se trata de una falsificación pues el documento original del que se hace el traslado estaba fechado en era de 1235. Independientemente de la fiabilidad del documento, lo que sí que se aprecia es que hay un trasvase de divisas de la behetría desde la Corona al monasterio como también se aprecia en el caso de Caleruega.

${ }^{1824}$ AGS, CC DIVERSOS, leg. 41, doc. 3. Se trata de un traslado realizado en 1400 que recoge una sentencia arbitral fechada en 1199 sobre la disputa entre el concejo de Gumiel y el monasterio por el nombramiento de los oficiales del Concejo. 
ron de hacerse con los derechos sobre la villa que no culminaron hasta bien avanzado este siglo. Finalmente Gumiel de Izán se configuró como el baluarte señorial de los Girón en tierras ribereñas, previa compra de las participaciones que los hijos del I conde de Castro tenían sobre la villa. Algo similar ocurrió con Santa María del Mercadillo que en 1473 reconocía a doña Constanza de Avellaneda como su señora en virtud del privilegio de behetría de Juan de Avellaneda, su padre ${ }^{1825}$. Todavía en 1485 el concejo argumentaba ser behetría y elegir conforme a su privilegio al conde de Urueña como su señor $^{1826}$.

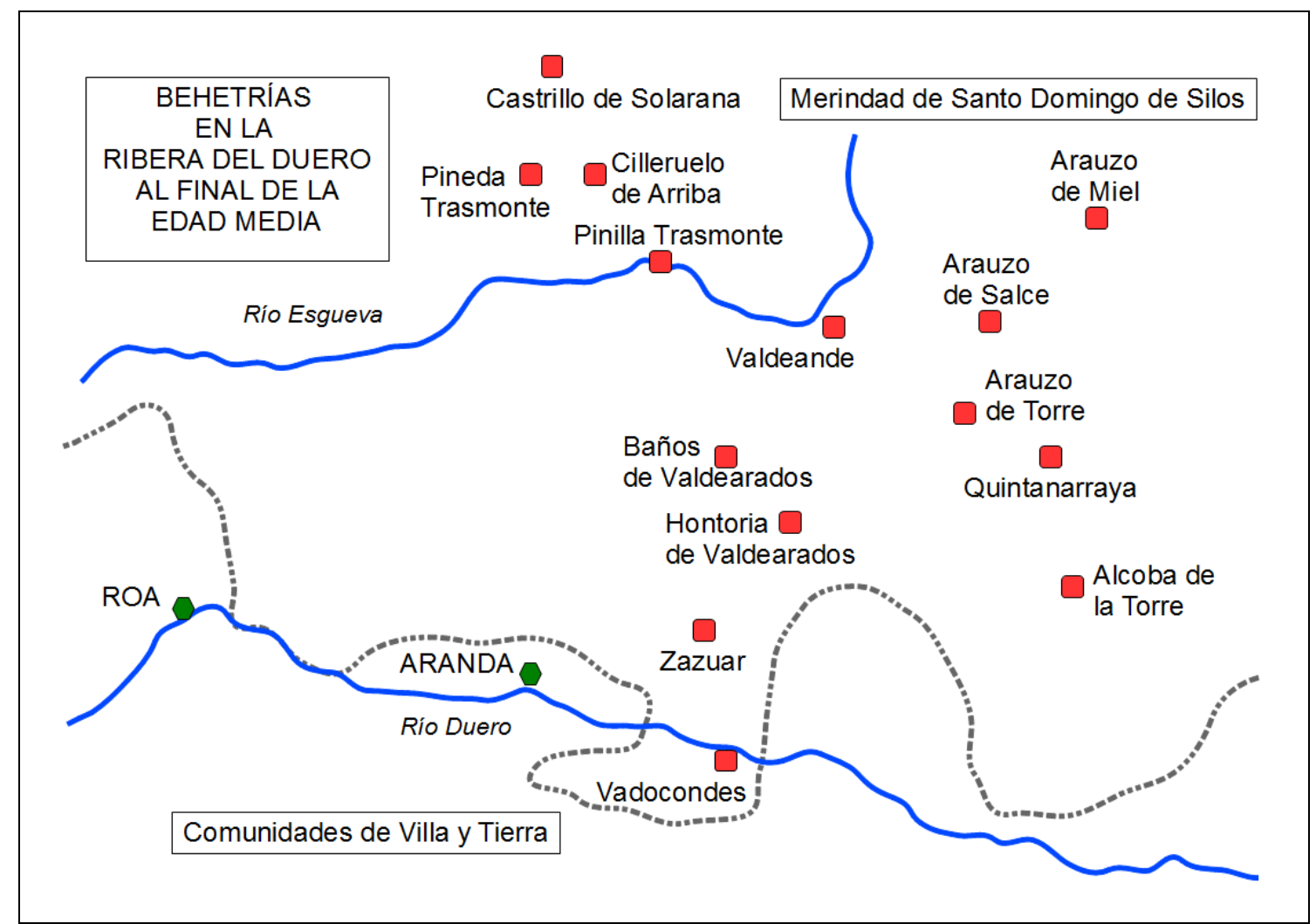

Mapa 16: Las behetrías en la Ribera del Duero burgalesa según Estepa Díaz.

El famoso Becerro de las Behetrías de 1352 describe una fase avanzada de la evolución de esta realidad que Nuño González ya ha descrito para el caso concreto de la Ribera y que muestra una visión general del panorama señorial a mediados del siglo

${ }^{1825}$ SNAHN, OSUNA, Caja 36, docs. 76-77. Conviene recordar que tanto Gumiel de Izán como Santa María del Mercadillo figuraban entre los 22 núcleos ausentes de la relación del Becerro de las Behetrías por lo que desconocemos su condición en la época.

${ }^{1826}$ SNAHN, OSUNA, Caja 36, docs. 78-81. 
$\mathrm{XIV}^{1827}$. En términos generales las behetrías castellanas se vieron inmersas en un proceso de concentración en manos de las familias más destacadas de la nobleza regional que incrementaron así su patrimonio territorial, produciéndose una disminución considerablemente de su número. Así las behetrías en la comarca ribereña a mediados del siglo XIV eran pocas pues tan solo encontramos catorce: Arauzo de Salce, Arauzo de Torre, Arauzo de Miel, Baños de Valdearados, Cilleruelo de Arriba, Guzmán, Alcoba de la Torre, Quintanarraya, Pinilla-Trasmonte, Pineda-Trasmonte, Valdeande, Vadocondes, Zazuar y Hontoria de Valdearados.

En 1370 se produjo un hecho que condicionó significativamente el devenir de las behetrías ribereñas. A la muerte de don Tello, hermano de Enrique II, los derechos que el linaje de los Lara tenía sobre las behetrías se transfirieron a la familia real. Los sucesivos monarcas hicieron merced de estos derechos en diferentes personajes relevantes. Fue el caso de la cesión que en 1390 hizo Juan I a favor de su hijo Fernando de Antequera del señorío de Lara junto a la villa de Peñafiel. Con esta cesión se traspasaron también los derechos de los Lara sobre las behetrías que, a su vez, fueron cedidos por el Infante a terceros afectos a su causa ${ }^{1828}$. De igual manera, desde finales del siglo XIV algunos nobles comarcanos se hicieron con el control de algunas de estas behetrías como fue el caso de Diego González de Avellaneda, señor de Gumiel del Mercado, que en 1396 hizo suyo el lugar de Valdeande ${ }^{1829}$.

Durante todo el siglo XV esta situación de subordinación de las localidades de behetría bajo las principales clientelas nobiliarias castellanas se reprodujo sistemáticamente, bien amparándose en la figura de la encomienda o en una política de hechos con-

${ }^{1827}$ NUÑO GONZÁLEZ, “La Ribera del Duero..., pp. 37-39. Una visión general de la situación del campesinado de behetría se puede consultar en MARTÍNEZ GARCÍA, L., "Los campesinos solariegos en las behetrías castellanas durante la Baja Edad Media", en Los señoríos de Behetría. 2001, pp. 187226.

${ }^{1828}$ ESTEPA DÍEZ, Las Behetrías..., Vol. I, pp. 278 y ss. En 1488 doña María de Castañeda consiguió de los reyes una carta dirigida a los concejos de Guzmán y otras behetrías del Cerrato en la que les ordenaban que abonaran cierta cantidad de una merced que Fernando de Antequera concedió a Pedro Muñoz de Guzmán sobre las martiniegas y yantares de esos lugares a los que tenía derecho la casa de Lara (AGS, RGS, 148808, fol. 41).

${ }^{1829}$ MARTÍNEZ LIÉBANA, Colección Diplomática ..., doc. CCXCVII, pp. 386-387. 
sumados que derivó en su conversión en solariegos ${ }^{1830}$. El mejor ejemplo lo podemos apreciar en el caso de la villa de Guzmán ${ }^{1831}$.

Guzmán era en 1352 un lugar de behetría de linaje: tenía por señor singular a don Ramir Flórez de Guzmán y entre sus diviseros se encontraban diferentes miembros de los linajes de los Haro, Lara y Guzmán. En 1425 se produjo la irrupción del linaje mayor de los Zúñiga mediante la compra que realizó el señor de Béjar a Alfonso de Guzmán de su participación sobre la behetría. En 1454 don Pedro de Zúñiga contaba con 25 vasallos en el lugar y además recibía como martiniega 700 maravedíes tanto de sus vasallos como del resto de los vecinos de behetría. El proceso culminó en 1456 cuando el conde de Plasencia recibió a los vecinos de la behetría bajo su señorío. El balance final es que en apenas tres décadas la antigua behetría pasó a encuadrarse dentro del señorío de los Zúñiga, perdiendo desde entonces cualquier relación con la situación jurídica anterior.

En sentido contrario, los monarcas trataron de preservar las behetrías de la presión nobiliaria. El principal exponente de esta protección se materializó en el privilegio general concedido a las behetrías por Juan II. En abril de 1454 el monarca estableció el impuesto de los galeotes sobre las behetrías y también prohibió a los nobles e hidalgos vivir y tener bienes en estos lugares. Este mecanismo de protección real supuso de hecho la progresiva identificación de la behetría con el realengo ${ }^{1832}$. En la Ribera esta protección se plasmó en la encomienda que hasta 1480 ejerció el duque de Villahermosa, hermano del rey, sobre las behetrías de Quintanarraya, los Arauzos, Castrillo de Solarana, Pineda Trasmonte, Vadocondes, Valdeande y Baños ${ }^{1833}$. Es significativo que en la relación de lugares bajo la encomienda del duque de Villahermosa se incluyeran también algunos de abadengo como Tubilla, Caleruega y Huerta del Rey. Esta circunstancia parece confirmar el papel protector de la Corona ante la presión señorial, tanto sobre las behetrías como sobre las entidades religiosas de la comarca. Este mecanismo de protec-

${ }^{1830}$ ÁLVAREZ BORGE, Poder y Relaciones sociales..., pp. 296 y ss.

${ }^{1831}$ La información que referimos a continuación ha sido obtenida de ESTEPA DÍEZ, Las behetrías..., vol. II, p. 284 y ss.; CADIÑANOS BARDECI, Arquitectura fortificada... pp. 269-270; y NUÑO GONZÁLEZ, "La Ribera del Duero..., p. 37.

${ }^{1832}$ ESTEPA DÍAZ, Las behetrías..., vol. II, pp. 313 y ss. Este autor manifiesta que el tributo de los galeotes fue incluso anterior al privilegio, por lo que el fundamento de esta medida fue básicamente la protección de las behetrías.

${ }^{1833}$ AGS, RGS, 148003, fol. 36. 
ción llegó a su máximo exponente cuando la princesa Isabel, reina de Portugal, tomó bajo su encomienda a la behetría de Castrillo de Solarana en 1498 después de haber sido reclamado el corregidor de Aranda para que acudiera al lugar y defendiera su jurisdicción frente a las ingerencias de la villa de Santo Domingo de Silos ${ }^{1834}$. Tras la muerte de la princesa la encomienda pasó a su hijo el infante don Miguel. Cuando éste falleció, el corregidor de Aranda fue comisionado para recibir la encomienda de dicho lugar ${ }^{1835}$. Asimismo la prohibición a los nobles de poseer propiedades en las behetrías se puso en práctica en el año 1500 cuando se ordenó al marqués de Denia que entregara al concejo de Pinilla Trasmonte una casa que compró en el lugar y que se le compensara con el montante del precio que pagó ${ }^{1836}$.

La identificación entre behetría y realengo se aprecia también en 1516 cuando los monarcas enviaron una cédula a las villas de Aranda y Sepúlveda, junto a las behetrías de la Merindad de Santo Domingo de Silos, permitiéndoles echar sisa sobre los mantenimientos para conseguir el dinero suficiente con el que proveer de armas a la infantería que tenían que poner a disposición de los reyes, en concreto del gobernador Adriano $^{1837}$.

No obstante, la nobleza de la Ribera no cesó en su empeño de anexionarse las behetrías como solariegos durante la segunda mitad del siglo XV. Como veremos más adelante, los condes de Miranda se apropiaron durante varios decenios de la behetría de Hontoria de Valdearados y el conflicto se prolongó durante bastantes años a pesar de la continua intervención de la Corona ${ }^{1838}$.

En 1492 se mantenían como behetrías al menos ocho localidades: Quintanarraya, los Arauzos, Valdeande, Zazuar, Baños de Valdearados y Vadocondes ${ }^{1839}$. No obstante, la realidad de cada una de ellas era bastante diversa pues Quitanarraya estaba de hecho

${ }^{1834}$ AGS, RGS, 149708, fol. 184; y 149808, fol. 1.

1835 AGS, RGS, 150008, fol. 263.

${ }^{1836}$ AGS, RGS, 150001, fol. 122.

${ }^{1837}$ AGS, CC PUEBLOS, leg. 3, doc. 191.

${ }^{1838}$ AGS, CR, leg. 6, doc. 5. Un resumen del conflicto también se puede ver en ESTEPA DÍAZ, Las behetrías..., vol. II, pp. 320-321.

${ }^{1839}$ Así se refiere en la relación de las rentas de alcabalas de la Merindad de Santo Domingo de Silos de los años 1492, 93 y 94. Curiosamente Hontoria de Valdearados aparece en esta relación pero no se señala su condición jurídica (AGS, EH, leg. 11). 
integrada en el señorío de los Suárez de Mendoza y en Arauzo ejercían su dominio los señores de Castrillo.

A comienzos del siglo XVI, a tenor de los datos ofrecidos en los repartimientos de galeotes de los años 1508 y 1531, sabemos que al menos diez lugares de la Ribera mantenían su condición de behetría: Baños de Valdearados, Pinilla Trasmonte, los Arauzos, Valdeande, Hontoria de Valdearados, Zazuar, Quintanarraya, Pineda Trasmonte y Cilleruelo de Arriba. A estos debemos añadir Vadocondes, que por lo menos lo era hasta 1492, y Castrillo de Solarana que, aún no incluyéndose en el ámbito territorial ribereño, estaba bajo la órbita del corregidor y del concejo arandino ${ }^{1840}$.

Durante el conflicto comunero buena parte de las behetrías del Cerrato, Campos y Carrión se alinearon con los insurgentes ${ }^{1841}$, pero en la Ribera no tenemos por el momento ninguna constancia de posicionamiento alguno ni a favor ni en contra. Tan solo la villa de Aranda se decantó claramente por la Comunidad.

Tras el conflicto, al igual que en el resto de Castilla, la situación jurídica de las behetrías se mantuvo. El profesor Estepa Díaz concluye que a partir de las Comunidades las behetrías deben ser consideradas como realengos ${ }^{1842}$.

En conclusión, la complejidad de las behetrías en la Ribera del Duero se dejó sentir durante la Baja Edad Media. Durante este periodo se asistió a la transformación de esta realidad que, por una parte, en su mayoría sufrió las acometidas de las pretensiones nobiliarias que las convirtieron finalmente en solariegos, contribuyendo así al proceso de señorialización. Por otra parte, las escasas behetrías que resistieron el acoso nobiliario vieron reforzada su posición por la protección de la Corona que las asimiló, de hecho, a la condición de realengo. Con esta solución se mantuvo la autonomía de estos lugares frente a la onda expansiva nobiliaria, a la vez que se incrementó la presencia del realengo en una comarca fuertemente señorializada. No obstante, el escaso número y entidad de las behetrías ribereñas atenuaron en gran medida esta segunda conclusión.

\footnotetext{
${ }^{1840}$ ESTEPA DÍAZ, Las Behetrías..., vol. II, pp. 360 y 368.

${ }^{1841}$ ESTEPA DÍAZ, Las Behetrías..., vol. II, pp. 335.

${ }^{1842}$ ESTEPA DÍAZ, Las Behetrías..., vol. II, pp. 338-339.
} 


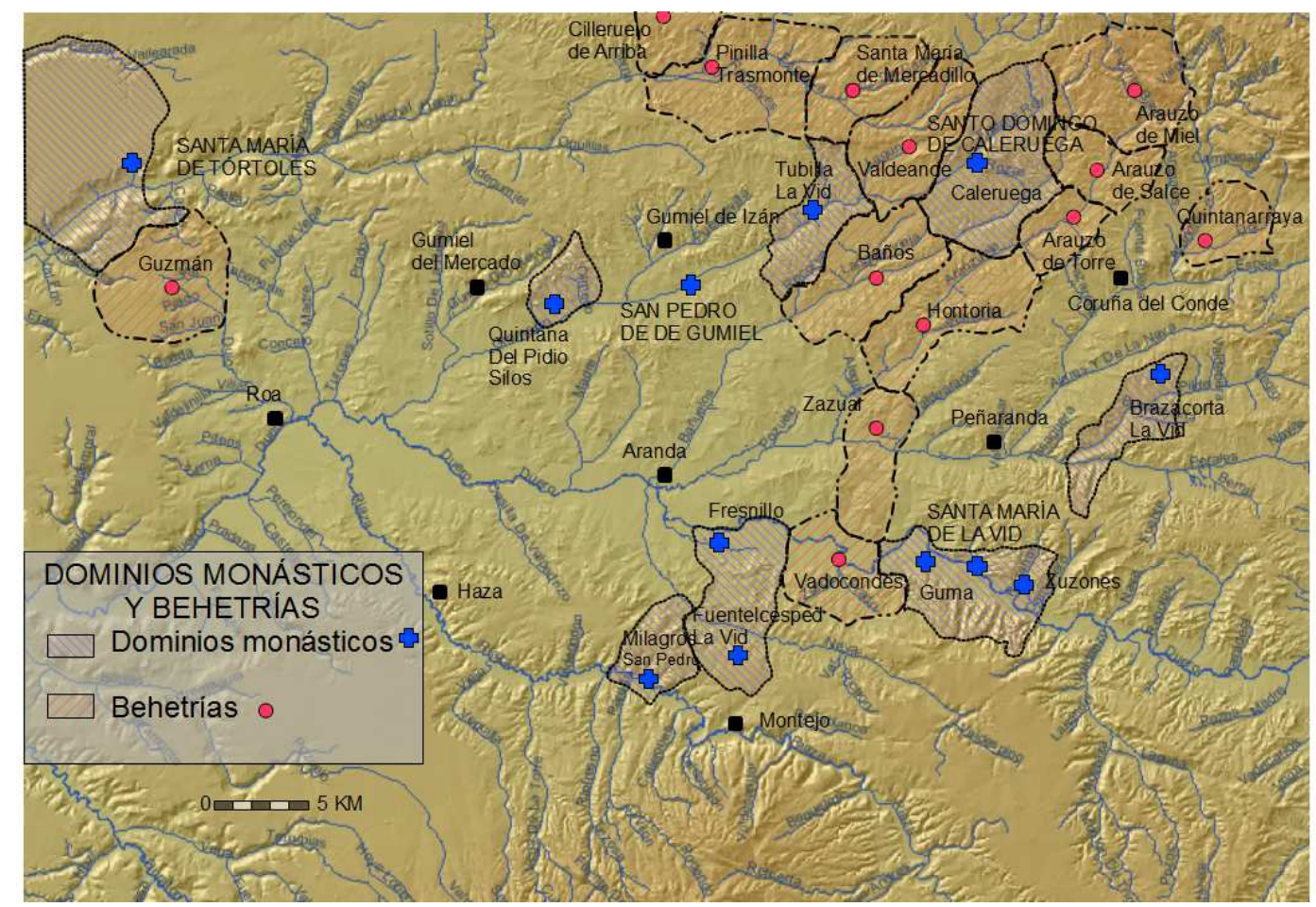

Mapa 17: Dominios monásticos y behetrías en la Ribera a finales de la Edad Media.

\section{LAS INSTITUCIONES RELIGIOSAS.}

El evidente protagonismo de las instituciones eclesiásticas en la comarca a lo largo de la Edad Media es incuestionable. Ya desde el periodo altomedieval algunos cenobios jugaron un papel fundamental en la articulación del territorio: baste recordar las posesiones del monasterio de San Pedro de Arlanza en Casuar, Boada o Valdeande; o del cenobio de Santo Domingo de Silos en Quintana del Pidio. Pero sin lugar a dudas los establecimientos más significativos fueron los que tuvieron su sede en la Ribera y fueron fundados a lo largo del siglo XII: el monasterio premostratense de La Vid primero y el cisterciense de San Pedro de Gumiel después. Tampoco debemos olvidar la presencia dominica en Caleruega, la franciscana en la Domus Dei de La Aguilera y en San Francisco de Aranda, e incluso los dominios asociados al clero secular como el de La Aguilera perteneciente al obispo de Burgos y la tupida red parroquial del obispado de $\mathrm{Osma}^{1843}$. A continuación presentaremos brevemente la realidad medieval de estas instituciones en la comarca.

${ }^{1843}$ SERRANO, Cartulario de San Pedro..., Doc. XI, pp. 34-36, Doc. XIV, pp. 40-43 y Doc. XXIX, pp. 63-66; GONZÁLEZ, El reino de Castilla..... Vol. II, doc. 560, pp. 961-963; MANSILLA REOLlO, D., Catálogo Documental del Archivo de la Catedral de Burgos (804-1416). Madrid- 


\section{1. El obispado de Osma: la configuración del sistema diocesano y la red parroquial.}

Antes de comenzar este punto es conveniente matizar que el territorio que pretendemos estudiar estaba encuadrado mayoritariamente en la Diócesis de Osma. No obstante, algunas localidades del Sur de la comarca, casi todas las pertenecientes a la tierra de Montejo, pertenecían a la Diócesis de Segovia. Y asimismo, algunas de las localidades más occidentales, como Guzmán, se situaban dentro de la Diócesis de Palencia. Por lo tanto, casi todas las apreciaciones que haremos en este apartado se refieren al espacio oxomense aunque, en la medida de nuestras posibilidades, introduciremos todos aquellos datos relevantes que se refieran a las otras diócesis.

El punto de partida para todo estudio de la Diócesis de Osma ha de ser sin lugar a dudas la monumental Descripción histórica del Obispado de Osma redactada por don Juan Loperráez Corvalán a finales del siglo XVIII ${ }^{1844}$. Además del estudio histórico basado en los estereotipos de la época este autor también recopiló un riquísimo y abundantísimo corpus documental. Posteriores estudios de gran calidad han enriquecido la perspectiva histórica de esta demarcación eclesiástica ${ }^{1845}$.

\section{1. 1. Los orígenes.}

La creación del Obispado de Osma se remonta a la Antigüedad Tardía, en el contexto del fenómeno de organización episcopal vinculado a la desintegración del poder político romano en la que los obispos se hicieron con una posición de liderazgo en

Barcelona, 1971, doc. 628. La Aguilera en 1400 todavía seguía siendo propiedad del obispo de Burgos (AMA, leg. 1199, doc. 19).

${ }^{1844}$ Se trata de una obra en tres volúmenes editados en Madrid en 1778. La edición consultada es el facsímil editado por Turner en 1978.

${ }^{1845}$ Entre estas obras destacamos las de PORTILLO CAPILLA, T., Instituciones del Obispado ...; VAL VALDIVIESO, M. I., "Introducción al estudio del Obispado de Osma en la Baja Edad Media", en Celtiberia. 70, 1985, pp. 211-252; y REGLERO DE LA FUENTE, C., "El obispado de Osma hasta mediados del siglo XIII: génesis y problemática", en Santo Domingo de Caleruega: contexto eclesial religioso. IV Jornadas de Estudios Medievales. Salamanca, 1996, pp. 183-224. Recientemente se ha publicado un trabajo de síntesis en el contexto de la obra colectiva sobre la Historia Diocesana española (BARTOLOMÉ HERRERO, B., "La Iglesia de Osma-Soria", en Historia de las diócesis españolas. Vol. 20, Madrid, 2004, pp. 321-492). 
el ámbito de las civitas $^{1846}$. La elección como sede episcopal de la Uxama Argaela romana frente a la capital del convento, Clunia Sulpicia, parece estar en relación con el fuerte proceso de despoblación que sufrió la segunda frente a la continuidad poblacional de la primera ${ }^{1847}$. No obstante, aunque hay evidencias de la existencia de sedes episcopales en los territorios vecinos desde mediados del siglo $\mathrm{V}$, no fue hasta finales del siglo VI cuando se constata la aparición de un obispo oxomense ${ }^{1848}$. Desde entonces se sucedieron los prelados que actuaron sobre el territorio diocesano como verdaderos agentes del poder político y fiscal de la monarquía visigoda. La desaparición de referencias documentales que aludan a los prelados de Osma a partir del siglo VIII ha llevado a algunos historiadores a proponer el traslado de la sede a Valpuesta o simplemente la huida del titular oxomense hacia las tierras del Norte tras la incursión musulmana. No obstante, otros autores mantienen que los escasos datos existentes no permiten descartar la continuidad del obispado de Osma en los territorios del Duero durante los siglos VIII y $\mathrm{IX}^{1849}$.

Desde el 912 el territorio del valle del Duero fue dominado de forma gradual y discontinua por los condes castellanos al servicio del monarca astur-leonés. Este primer intento de dominio cristiano soportó los embates del poder omeya, obligando a posponer en más de un siglo el control efectivo del territorio. Esta inestabilidad propició que

${ }^{1846}$ MARTÍN VISO, I., “Organización episcopal y poder entre la Antigüedad Tardía y el Medievo (siglos V-XI): las sedes de Calahorra, Oca y Osma”, en Iberia. 2, 1999, pp. 151-190; y CRESPO ORTIZ DE ZÁRATE, S., "Conflicto religioso entre paganismo y cristianismo en la Diócesis de Osma durante la Antigüedad Tardía Hispana”, en Hispania Antiqua, XXVIII, 2004, pp. 179-196.

${ }^{1847}$ GARCÍA MERINO, C., "Las raíces históricas de la sede episcopal oxomense: aproximación a la etapa tardoantigua de Uxama", en I Semana de Estudios históricos de la Diócesis de Osma-Soria. Soria, 2000. Vol. I, pp. 179-196; DÍAZ MARTÍNEZ, P. C., "La Diócesis de Osma en la Antigüedad”, en Arte e Historia de la Diócesis de Osma. El Burgo de Osma, 1998, pp. 205-230. Sin embargo, otros autores no creen que el factor demográfico sea suficiente para explicar esta elección, máxime cuando Clunia se mantuvo como centro político de primer orden en la región en el periodo Altomedieval (MARTÍN VISO, "Organización episcopal..., p. 159; y ESCALONA MONGE, J., "Comunidades, territorios y poder condal en la Castilla del Duero en el siglo X”, en Studia Histórica. Historia Medieval. 18-19, 2000-2001, pp. 85-120).

${ }^{1848}$ Esta situación ya fue puesta de manifiesto en su momento por LOPERRÁEZ CORVALÁN (Descripción histórica..., vol. I, pp. 36 y ss.) que además denunciaba los abusos de los eruditos que se empeñaron en buscar los orígenes de la Diócesis en los mismos Apóstoles.

${ }^{1849}$ La primera interpretación se basa en la presencia de Eterio, Hoxomae ...episcopus, junto a Beato en Liébana a mediados de la década de los 80 del siglo VIII en el contexto de la querella adopcionista con el metropolitano toledano y la presencia en el 882 de un obispo de Osma en la nómina de prelados que reconocieron el poder astur-leones (SERRANO, El obispado de Burgos..., vol. I, pp. 76 y 118 ; y PORTILLO CAPILLA, Instituciones..., p. 36). Por su parte PASTOR DÍAZ DE GARAYO argumenta la continuidad en Osma del titular oxomense (Castilla en el Tránsito..., pp. 132-136), hipótesis que es secundada por BARRIOS GARCÍA ("Notas sobre..., pp. 236-242) 
determinados miembros de la nobleza asumieran durante los siglos X y XI el poder local en detrimento de la posición de los obispos, convertidos en cierta medida en instrumentos del poder real/condal que mantenían cierto peso específico sobre un territorio poco definido ${ }^{1850}$. Parece por lo tanto que la proyección territorial de la diócesis de Osma posiblemente se limitó al reducido radio de la civitas en su sentido más literal, sin que se pueda hablar de otra cosa que no sea la catedral, el obispo y su cabildo, manteniéndose el amplio territorio rural que lo circundaba bajo la influencia de los monasterios e iglesias privadas próximas ${ }^{1851}$. Esta percepción casi inexistente de la administración diocesana en la Alta Edad Media se materializó, por ejemplo, en la proliferación por toda la Ribera de pequeños monasterios, algunos de ellos de carácter familiar, ajenos totalmente al control del obispo. Con el paso del tiempo, estos pequeños cenobios cayeron bajo la influencia de los grandes monasterios comarcales o regionales, incrementando en gran medida el desarrollo de la gran propiedad feudal que sustentaba el poder de estos grandes centros monásticos castellanos ${ }^{1852}$. Para este periodo se han documentado los de Santa María de Haza, dependiente del monasterio de Bujedo de Jua$\operatorname{rros}^{1853}$; y también los de San Pedro de Cubillas, San Llorente entre Torregalindo y Montejo, San Cucufate de Monzón y San Miguel de Quintana del Pidio pertenecientes al monasterio de Santo Domingo de Silos ${ }^{1854}$. En esta dinámica destaca sobre todo la proyección en la Ribera del monasterio de San Pedro de Arlanza que integró ya desde el siglo X Casuar y San Andrés de Boada e incrementó sus intereses en la comarca bajo el reinado de Fernando I con las donaciones de Santa María de Cela de Valdeande, San

${ }^{1850}$ MARTÍN VISO lo define como "tradición territorial” y señala que en el caso de la Diócesis de Osma su utilización como instrumento de ordenación del territorio estaría muy matizada por el carácter fronterizo de la zona (“Organización episcopal..., pp. 171 y 179).

${ }^{1851}$ SÁNCHEZ HERRERO y LÓPEZ BAHAMONDE, “La Geografía eclesiástica..., p. 300.

${ }^{1852}$ Esta situación debemos ponerla en relación con la política centralizadora que los monarcas castellanos intentaron imponer sobre el reino desde tiempos de Fernando I. Para ello utilizaron entre otros instrumentos el fomento de la implantación benedictina en sus territorios y la imposición de la reforma gregoriana. Para ÁLVAREZ BORGE estas iglesias y monasterios propios fueron un elemento más dentro del proceso de desintegración de las comunidades de aldea, convirtiéndose en un factor fundamental para la consolidación del sistema feudal y el reforzamiento de la autoridad real (Poder y relaciones sociales..., pp. 53-72).

${ }^{1853}$ GONZÁLEZ, El Reino de Castilla..... Vol. I, p. 299.

${ }^{1854}$ VIVANCOS GÓMEZ, Documentación del monasterio..., Docs. 17, 61, 74 y 78, pp. 19-21, 87-88, 105-106 y 113-115. (En el caso de San Llorente, en el texto se lee Sancti Florenti); y SERRANO, El Obispado de Burgos..., Vol. II, p. 262. 
Lorenzo y Santa Eugenia de Gumiel del Izán y Santa Cruz de Baños de Valdearados. La anexión en 1048 de Santa María de Retortillo supuso la integración de los monasterios de Santa María de Quintanarraya, Santa María de Zayas, San Isidoro de Hontoria y San Esteban de Baños in Clunia $^{1855}$. Incluso el propio obispado de Osma recibió en donación el monasterio de San Pedro de Haza, junto a la aldea de Valdezate y la serna de Salzedón ${ }^{1856}$. De otros tantos como San Isidoro de Clunia, San Juan de Peñaranda o San Mamés de Gumiel del Mercado poco sabemos por el momento ${ }^{1857}$.

De manera complementaria durante la segunda mitad del siglo XI se desarrolló una reestructuración de la organización diocesana que perduró durante toda la Edad Media $^{1858}$. Esta reorganización se caracterizaba por dos fenómenos complementarios: por una parte, la restauración de las diócesis provocó la desaparición de ciertos núcleos y la concentración y consolidación de los más fuertes; y por otra, la territorialización que determinó límites precisos en los cuales se reafirmó el poder episcopal frente a otras formas de organización religiosa como pudo ser la de las poderosas comunidades monacales $^{1859}$.

Dentro de la primera dinámica se encuadraría la creación de la nueva diócesis de Burgos entre 1068 y 1075 que aunaba las demarcaciones territoriales de las antiguas Sasamón, Oca y Valpuesta, en una evidente maniobra política emprendida por Alfonso VI que culminó con su confirmación como sede exenta ${ }^{1860}$. Así pues, a finales del siglo

1855 SERRANO, L., Cartulario de San Pedro..., docs, XI, XIV, XXIX, XXX, XLIX, LI y CXLIII, pp. 34-36, 40-43, 63-66, 75-76, 101-102, 103-107 y 257-261; ÁLVAREZ BORGE, Poder y relaciones sociales..., pp. 112-113; BLANCO LOZANO, P., Colección Diplomática de Fernando I. León, 1987. Doc. 36, pp. 114-117. La documentación relativa a estas primeras anexiones a los monasterios deben ser contempladas con cierta cautela pues la crítica diplomática ha puesto en evidencia que muchos de los documentos de periodo altomedieval que se encuentran en los cartularios monásticos son falsificaciones de siglos posteriores. Este podría ser el caso de la donación al monasterio de San Pedro de Arlanza del priorato de Casuar.

${ }^{1856}$ REGLERO DE LA FUENTE, “La Diócesis de Osma..., p. 207. El autor intuye que estos bienes fueron donados por Alfonso VII con posterioridad a 1136 pero no señala de dónde ha obtenido el dato.

${ }^{1857}$ NUÑO GONZÁLEZ, "Pautas de ocupación territorial..., pp. 96-97.

${ }^{1858}$ Este fenómeno está relacionado con la promoción de la reforma gregoriana que los monarcas castellanos fomentaron desde la llegada al poder de Fernando I (FACI, J., "La reforma gregoriana en Castilla y León”, en Historia de la Iglesia en España. Vol. II-1, pp. 262-275).

${ }^{1859}$ MARTÍN VISO, “Organización episcopal..., pp. 183 y ss.

${ }^{1860}$ MANSILLA REOYO, D., “Obispado y monasterios”, en Historia de Burgos. Burgos, 1986, vol. II, pp. 295-356, en concreto pp. 297 y ss; y ÁLVAREZ BORGE, Poder y relaciones sociales..., pp. 120-125. 
XI el extremo occidental del territorio "tradicional" de Osma se encuadraba dentro de la zona de influencia del obispado burgalés. Se completaba así una importante merma territorial que había comenzado en 1016 con la división política entre Castilla y Navarra que se tradujo en la inclusión bajo la tutela del obispado de Calahorra del extremo oriental de la antigua diócesis de Osma ${ }^{1861}$. En este contexto reaccionó el recién nombrado metropolitano toledano, Bernardo de Salvetat. El mismo tomó las riendas de Osma, promovió la restauración de la sede oxomense y reivindicó su integridad. Para ello recurrió a la "tradición episcopal", Hitación de Wamba incluida ${ }^{1862}$.

En el proceso de territorialización de la sede oxomense se generó un serio conflicto precisamente por las tierras de la Ribera del Duero con el vecino arzobispado de Burgos. En 1088 al amparo del Concilio de Husillos se intentó llegar a un acuerdo entre ambas partes que se materializó en una delimitación detallada de la frontera entre ambas diócesis: ...et sicut aqua ipsa currit et labitur in Arandam, aqua quae discurrit per Cluniam, et pertransit ipsam Cluniam, usque Penam de Aranda, donec labitur in fluvium Dorium, et omnes villae ex hac parte fluminis Arandae... ${ }^{1863}$. A pesar de ser sancionado el acuerdo con una Bula del Papa Pascual II en 1107, los enfrentamientos entre ambas diócesis por la adscripción de la comarca ribereña se reprodujeron hasta que en 1136 el legado pontificio puso fin a la disputa con una concordia. En ella se citaban las villas asignadas a la Diócesis de Osma: ...Aszam, Turrem de Galindo, Fresnelo, Vado de Condes, Baralanguas, Rivales, Rozam, et totum campum de Roza, Guzman, Villamuela,

${ }^{1861}$ REGLERO DE LA FUENTE, “La Diócesis de Osma..., p. 185.

${ }^{1862}$ Bernardo dirigió la sede oxomense hasta que en 1101 nombró a uno de sus discípulos, Pedro de Burgés, que continuó la obra de su maestro. Sobre la Hitación de Wamba y los intereses que promovieron su creación destaca la obra clásica de VÁZQUEZ DE PARGA, L., La división de Wamba. Contribución al estudio de la historia y geografía eclesiástica de la Edad Media española. Madrid, 1943. Este mismo documento fue utilizado también para definir la territorialidad de la vecina diócesis de Segovia (VILLAR GARCÍA, L. M., Documentación medieval de la Catedral de Segovia (1115-1300). Salamanca, 1990, docs. 8, 11 y 64, pp. 51-52, 54-56 y 111-112). La diócesis de Osma continuó siendo sufragánea de Toledo hasta que se aplicó la nueva distribución en archidiócesis establecida en el Concordato de 1851. A partir de entonces pasó a depender del arzobispado de Burgos (MARTÍNEZ DÍEZ, G., "Algunos aspectos de la Diócesis de Osma en la Edad Contemporánea", en Arte e Historia de la Diócesis de Osma. El Burgo de Osma, 1998, pp. 281-317). mo III, p. 7.

${ }^{1863}$ El fragmento ha sido tomado de LOPERRÁEZ CORVALÁN, Descripción Histórica... To- 
Villamualera, Aquilora, Castellum de Aranda, Cremada, Tovela, Valdefande, Pennela, Pennam de Aranda ${ }^{1864}$.

Por lo tanto, podemos afirmar que a partir de los primeros años del siglo XII, tras el arduo proceso de restauración de la sede oxomense, se definió la diócesis como un elemento de vertebración y jerarquización territorial a través del establecimiento de los arcedianatos, los arciprestazgos y una extensa red de parroquias dependientes que además se convirtieron en instrumento de detracción de los excedentes económicos a través del diezmo $^{1865}$. Poco a poco se implantó en la Ribera del Duero la autoridad episcopal que hizo prevalecer su organización y sus derechos decimales pero que no contaba en la comarca con un patrimonio señorial significativo. Éste se limitaba a las ya comentadas propiedades ligadas al monasterio de San Pedro de Haza, la efímera usurpación de Cela Quesón a los monjes de Arlanza en los años centrales del siglo XII, y las incorporaciones a finales de siglo de la aldea de Santa María del Páramo, donada por el concejo de Roa, y el villar de Valverdón, cerca de Coruña del Conde, que respondió a la iniciativa real ${ }^{1866}$.

En este sentido, encontramos evidencias de la reafirmación del poder episcopal frente a los monasterios vecinos, aunque algo tardías en relación con otros ámbitos peninsulares. Esta política generó a lo largo del siglo XII numerosos conflictos entre el titular oxomense y las comunidades monásticas que contaban con intereses en la comarca. Así, a lo largo de la segunda mitad del siglo XII se produjo el enfrentamiento entre los sucesivos obispos y el poderoso monasterio de San Pedro de Arlanza por la posesión de algún término o monasterio, pero sobre todo por el reconocimiento de los derechos

${ }^{1864}$ LOPERRÁEZ CORVALÁN, Descripción Histórica... Vol. III, pp. 16-18 y 555. Esta limitación territorial definida en 1136 se mantuvo estable hasta 1956 momento en el que se aplicó una de las cláusulas del Concordato suscrito en 1953 entre el Estado Español y la Santa Sede por el que se preveía la adaptación de los límites diocesanos a las fronteras provinciales. Las 94 parroquias situadas en los arciprestazgos de Roa, Aranda, Coruña del Conde y Haza pasaron a depender desde ese momento del arzobispado de Burgos y las parroquias de Aldeanueva de la Serrezuela y Aldehorno se cedieron a la diócesis de Segovia (MARTÍNEZ DÍEZ, “Algunos aspectos..., pp. 301-306).

1865 SÁNCHEZ HERRERO y LÓPEZ BAHAMONDE, "La geografía eclesiástica..., pp. 295313. Sobre las relaciones económicas entre la autoridad real y el episcopado ver NIETO SORIA, J. M., "Las relaciones Monarquía-Episcopado en Castilla, siglos XIII-XIV. Definición de sus caracteres e interpretación de conjunto”, en El Pasado Histórico de Castilla y León. Edad Media. Vol. I, pp. 285-294, especialmente p. 289.

${ }^{1866}$ REGLERO DE LA FUENTE ha identificado el dominio del señorío episcopal concentrado en cuatro áreas: las heredades cercanas a la iglesia de San Pedro en el alfoz de Soria; amplias propiedades en el alfoz de Osma; aldeas, castillos e iglesias en el de Gormaz; y un importante patrimonio en San Esteban de Gormaz ("EL Obispado de Osma..., pp. 205-209). 
episcopales y la pertenencia de varias iglesias ${ }^{1867}$. Características similares presentaba el conflicto del obispado con el monasterio de Santo Domingo de Silos pues desde finales del siglo XII se disputaban los diezmos de ciertos lugares de propiedad benedictina situados en la diócesis de Osma. Finalmente en 1235 se llegó a un acuerdo duradero que no estuvo exento de nuevos episodios de enfrentamiento en los siglos XIV y XV ${ }^{1868}$.

También comprobamos este enfrentamiento en la disputa entre la Diócesis y el monasterio de San Pedro de Gumiel que en 1179 hizo valer su derecho de presentación de clérigos en ciertas parroquias de la comarca ribereña ${ }^{1869}$. Un nuevo capítulo tuvo lugar a propósito de los diezmos que el monasterio debía pagar al obispo y que no terminó hasta que en 1335 el cenobio gomellense cedió el lugar de Fonciana al obispo de Osma como contraprestación de los diezmos adeudados ${ }^{1870}$. Aparte de los aspectos decimales, los conflictos con el monasterio de La Vid fueron más allá al argumentar en todo momento el prelado que el cenobio se asentaba sobre un solar de la catedral pues en 1150 el obispo Juan cedió a los eremitas de Montesacro el lugar de La Vid para que se edificara el monasterio. Como consecuencia de esta situación, a juicio del obispo se infería la sujeción de la comunidad vitense a la sede de Osma ${ }^{1871}$. El conflicto se mantuvo durante varios siglos hasta que en 1455 el obispo don Pedro de Montoya y el abad fray Sancho de Aranda firmaron una concordia en la que el monasterio reconocía ciertos derechos diocesanos, las pilas bautismales y las visitas, mientras que el prelado renunciaba a cualquier derecho de jurisdicción sobre el monasterio y sus dominios ${ }^{1872}$.

${ }^{1867}$ SERRANO, Cartulario de San Pedro..., docs. XXXII, CIII y CXXIX, pp. 44-45, 193-195 y 236-237. En 1147 el obispo de Osma requirió la propiedad de Cela Quesón pero finalmente tuvo que reconocer la titularidad del cenobio. A finales de siglo ambas instituciones disputaron por el diezmo en ciertos lugares entre los que se encontraba Boada de Roa. El conflicto concluyó con una avenencia entre las partes en 1195 .

1868 LOPERRAEZ CORVALÁN, Descripción histórica..., Tomo. III, doc. XXX, pp. 41.42; y ÁLVAREZ BORGE, Poder y relaciones sociales..., p. 181.

${ }^{1869}$ ONTORIA OQUILLAS, P., "El arcipreste de Gumiel, Don Gonzalo García de Aza, tutor de Santo Domingo de Guzmán”, en Santo Domingo de Caleruega. Jornadas de Estudios Medievales. Salamanca, 1994, pp. 277-297.

${ }^{1870}$ LOPERRAEZ CORVALÁN, Descripción histórica..., Tomo. III, doc. CIV, pp. 258-259.

${ }^{1871}$ RIAÑO RODRÍGUEZ, T. y GUTIÉRREZ, M. C., "Documentos de los siglos XII y XIII del archivo de la Catedral de Burgo de Osma”, en Archivo de Filología Aragonesa. XVIII y XIX, 1976, pp. 217-284.

${ }^{1872}$ LOPERRAEZ CORVALÁN, Descripción histórica..., Tomo III, doc. CXXIX, pp. 296-298. 
Las florecientes comunidades franciscanas y dominicas no se libraron de numerosos enfrentamientos con la autoridad diocesana durante los últimos años de la Baja Edad Media. Más adelante, en el capítulo dedicado a los conflictos religiosos, abordaremos con detenimientos estos episodios.

En conclusión, y a pesar de la ausencia de datos específicos para el espacio oxomense, podemos afirmar que desde mediados del siglo XIII el territorio de la Ribera del Duero estaba plenamente integrado dentro una la organización eclesiástica jerarquizada que garantizaba la actividad pastoral y el cuidado de las almas, sin olvidar el control del territorio y la percepción de las rentas eclesiásticas.

Para el espacio ribereño dependiente del obispo de Segovia no hay dudas sobre este aspecto, pues la jerarquización se aprecia desde el momento mismo de su restauración. Ya en los primeros años del siglo XII se citan algunas localidades, entre ellas Monteio, como items significativos del territorio diocesano que un siglo después aparecen confirmadas como cabezas de arciprestazgo (in archipresbiteratu de Monteio), dentro del Arcedianato de Sepúlveda y así se mantuvieron en el siglo $\mathrm{XV}^{1873}$. Por paralelismo con el caso segoviano, podemos intuir que el espacio oxomense bien se pudo organizar en Arcedianatos que a su vez estaban subdivididos en varios arciprestazgos ${ }^{1874}$. Suponemos que este Arcedianato era el de Haza que constatamos en época Bajomedieval, periodo en el que también identificamos cuatro arciprestazgos con cabecera en las villas de Haza, Roa, Coruña del Conde y Aranda de Duero ${ }^{1875}$.

1873 VILLAR GARCÍA, Documentación medieval..., docs. 8 y 141, pp. 51-52 y 216-234; y BARTOLOMÉ HERRERO, B., "Una visita pastoral a la diócesis de Segovia durante los años 1446 y 1447”, en En la España Medieval, 18, 1995, pp. 303-349. El Arcedianato de Sepúlveda integraba el arciprestazgo de esa misma localidad más los de Pedraza, Fresno, Maderuelo y Montejo. Éste último en la relación de 1587 aparece como Vicaría (GONZÁLEZ, T., Censo de Población de las provincias y partidos de la Corona de Castilla en el siglo XVI. Madrid, 1829, red. 2009, p. 332).

\footnotetext{
1874 ÁLVAREZ BORGE, Poder y relaciones sociales..., pp. 194-195.
}

1875 Así lo refleja la obra de LOPERRÁEZ CORVALÁN (Descripción Histórica... vol. II, pp. 148-156, 174-206, 209-211 y 214-216) y el estudio de PORTILLO CAPILLA (Instituciones del Obispa$d o \ldots$, pp. 260), aunque bien es cierto que ambos hacen referencia a la organización territorial del siglo XVIII. Reproducimos el mapa realizado por LOPERRÁEZ CORVALÁN en 1774 (Biblioteca Digital de la Real Academia de la Historia, consulta realizada el 01/10/2012, http://bibliotecadigital.rah.es/dgbrah/i18n/consulta/registro.cmd?id=12755). PORTILLO CAPILLA identifica en el mapa que acompaña a su estudio los arciprestazgos de Guzmán, Gumiel de Izán y del Mercado, Huerta del Rey y Peñaranda, además de los anteriormente referidos. No obstante no hemos conseguido encontrar en su análisis elementos que justifiquen esta realidad. BARTOLOMÉ HERRERO también se inclina por esta estructura organizativa al menos desde la segunda mitad del siglo XII ("La Iglesia de Osma..., pp. 358-360). 


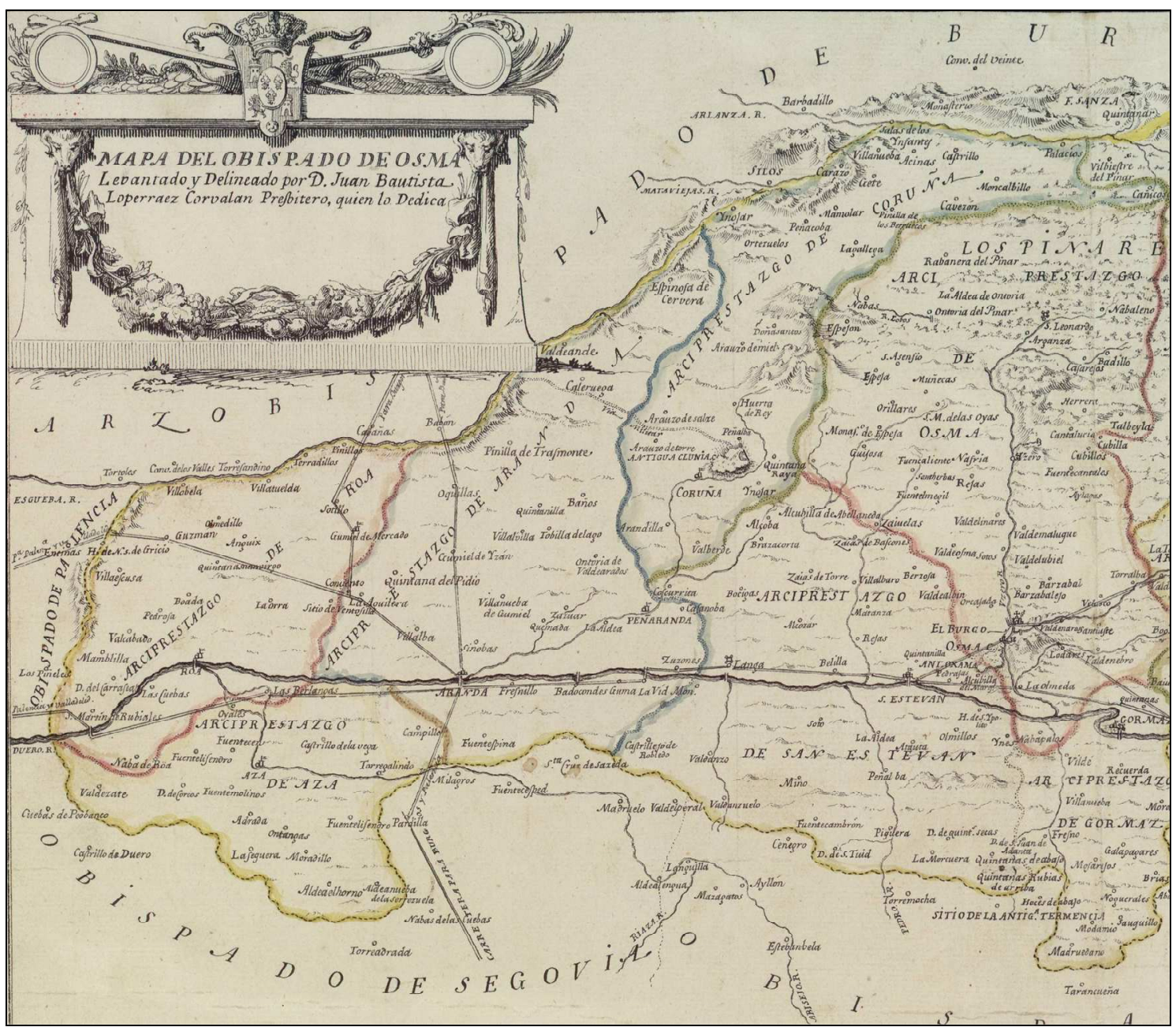

Mapa 18: Fragmento de la zona occidental del Obispado de Osma según Loperráez Corvalán.

Por lo tanto, al comienzo de la Baja Edad Media la Ribera del Duero estaba en su mayor parte perfectamente encuadrada dentro de la Diócesis de Osma mostrando una estructura administrativa sólidamente asentada en una tupida red de parroquias desde donde se ejercía el control social sobre la población, además de constituirse como un útil instrumento de exacción fiscal ${ }^{1876}$.

\section{1. 2. La organización de la Diócesis de Osma.}

A finales del siglo XIV la organización diocesana presentaba una estructura jerárquica bien definida pero que, sin embargo, manifestaba cierta ambigüedad en su plasmación espacial $^{1877}$. El Arcedianato de Haza parece corresponder a una demarca-

${ }^{1876}$ VAL VALDIVIESO, “Introducción al estudio..., pp. 248-250.

${ }^{1877}$ El Estatuto de 1444 establecía claramente esta jerarquía en la disposición física de los clérigos en las sesiones de los sínodos y en el turno de palabra: la cabeza del obispado era evidentemente el obispo, tras él estaba el Cabildo con su prior al frente, seguido del arcediano de Osma, al que le sucedía el 
ción territorial heredada de la organización del siglo XIII que agrupaba a los arciprestazgos occidentales de la Diócesis. Sin embargo, la figura del arcediano bajomedieval se transformó en una dignidad capitular de contenido honorífico-beneficial, pasando a un segundo plano, cuando no desapareciendo completamente, su papel como vicario del obispo en un ámbito territorial con entidad propia $^{1878}$.

Situación particular representaban en el obispado las Colegiatas que en el periodo medieval se limitaban a las de San Pedro de Soria y Santa María de Roa. Por lo que respecta a la situada en el territorio ribereño poco sabemos de ella. Loperráez Corvalán señala que su origen pudo estar en el traslado a la villa raudense de una comunidad de canónigos regulares que habitaba en San Esteban de Gormaz en los últimos años de la decimocuarta centuria aunque no identifica los motivos. El prior de Roa ocupaba una posición de preeminencia en la jerarquía diocesana, tras las dignidades del cabildo catedralicio y el prior de San Pedro de Soria. No conocemos la composición exacta del cabildo de la colegiata raudense bajomedieval pero suponemos que el prior era el clérigo que dirigía la comunidad. Asimismo parece que el arcipreste de Roa era una de las dos dignidades del cabildo. El conjunto se cerraba con una serie de canonjías de las que desconocemos su número. Ninguno de los trabajos consultados sobre Roa aporta datos sobre la relevancia del cabildo colegial ni sobre su capacidad de control social ni sobre la entidad de los bienes materiales a él asociados ${ }^{1879}$.

de Soria y el de Haza, todos ellos miembros del Cabildo. A continuación estaban los priores de las Colegiatas de Soria y Roa. En último lugar se encontraban los arciprestes respetando un orden establecido. Cabe destacar que el de Roa ocupaba el tercer lugar, el de Aranda el séptimo puesto, noveno el de Haza y undécimo el de Coruña de un total de catorce (LOPERRÁEZ CORVALÁN, Descripción histórica..., Vol. III, doc. 146, pp. 326-328).

1878 Conocemos esta figura a través de un documento fechado en 1426 en el que uno de los testigos era Antón Sánchez de Castillejo, Arcediano de Haza en la iglesia de Osma (AMA, leg. 43, fol. 4). Sobre la evolución de la dignidad del arcediano ver SÁNCHEZ HERRERO y LÓPEZ BAHAMONDE, "La geografía eclesiástica..., p. 310. A pesar de la pérdida real de la función representativa en el territorio, todavía en el estatuto del Cabildo realizado en 1488 se recordaban las obligaciones de los beneficiados y entre ellas que ...oviese Arcedianos, para que visitasen el Obispado (LOPERRÁEZ CORVALÁN, Descripción histórica..., Vol. III, doc. 146, pp. 326-328).

1879 LOPERRÁEZ CORVALÁN, Descripción histórica..., Vol. II, pp. 152-154; y ZAMORA LUCAS, La villa de Roa..., pp. 307 y ss. El documento más antiguo al que tuvo acceso Loperráez estaba fechado en 1400 y hablaba de una comunidad de canónigos regulares. Hace referencia también a otros documentos posteriores que trataban sobre donaciones por lo que intuimos que debía contar con un notable patrimonio aunque no conocemos su verdadera entidad. También señala que se mantenían recluidos en la Calongía y que ni siquiera salían al pueblo para recoger a los difuntos que iban a ser enterrados en la Colegiata. En 1455 el obispo don Pedro de Montoya concedió al cabildo colegial unas nuevas constituciones que desconocemos por el momento. 
Por su parte el arciprestazgo reunía bajo la dirección del arcipreste al conjunto de los clérigos de todas las parroquias que se incluían en su circunscripción. La función del arcipreste era en principio la de actuar como intermediario entre el arcediano y los párrocos pero con el paso del tiempo adquirió mayor relevancia al ir asumiendo las competencias primitivas del arcediano ${ }^{1880}$.

La unidad básica de la organización eclesiástica era la parroquia. Además de su evidente función religiosa, este espacio también se convirtió en una importante referencia de la identidad colectiva en el medio rural $^{1881}$. Al frente de la parroquia estaba el beneficiado cura o curero pues debía hacerse cargo del cuidado de las almas de sus parroquianos. Sólo había un cura por parroquia pero estaba asistido por tantos beneficiados como pudieran mantener las rentas de la parroquia. Los elementos definidores de la parroquia, además del beneficiado curado, eran la pila bautismal, un territorio claramente delimitado en esta época y los parroquianos. Todo vecino integrado en el territorio de una parroquia estaba ligado a ella debiendo acudir a los oficios divinos, cumplir con los preceptivos sacramentos y contribuir con los correspondientes impuestos eclesiásticos, así como depositar sus limosnas ${ }^{1882}$. Ante esta situación, los posibles traspasos de feligreses entre unas y otras parroquias o hacia las atractivas propuestas religiosas de los nuevos establecimientos mendicantes provocaron, como veremos más adelante, continuos enfrentamientos entre los propios párrocos de una misma villa o entre éstos y los frailes de las comunidades próximas.

En el territorio ribereño fueron escasas las parroquias que contaban con otros beneficiados que no fuera el cura párroco. Se limitaron casi exclusivamente a las cabeceras de arciprestazgo más algunas parroquias de ambos Gumieles. A parte del cabildo de la colegiata de Roa, tan solo en el caso arandino hemos podido localizar en la documentación a alguno de estos beneficiados: la iglesia de Santa María contaba en 1515 con su cura párroco y al menos con cinco beneficiados ${ }^{1883}$. Entre estos beneficiados ya

${ }^{1880}$ SÁNCHEZ HERRERO y LÓPEZ BAHAMONDE, “La geografía eclesiástica..., p. 312.

${ }^{1881}$ NUÑO GONZÁLEZ señala que ya en el periodo pleno medieval la parroquia debe ser considerada como una entidad jurídica que consiguió que los ritos religiosos estuvieran estrechamente vinculados a los procesos de integración social de los vecinos ("Las iglesias rurales..., pp. 151 y ss.).

${ }^{1882}$ GARCÍA DE CORTAZAR, La sociedad rural..., p. 90.

${ }^{1883}$ El cura párroco era Alonso Martínez de Buitrago y los beneficiados que le acompañaban eran el bachiller Francisco de Valverde, Pedro García Quixadas, Diego Martínez de Buitrago, Martín Sánchez Ibáñez y Martín Sánchez de Mendoza (AGS, CC PUEBLOS, leg. 2, docs. 107, 18 y 20). Seguramente a esta nómina debamos añadir otros beneficiados como Diego de Aranda que aparece en la documentación 
se contaba desde principios del siglo XV con el capellan librero que se encargaba de gestionar el archivo y la documentación de la iglesia ${ }^{1884}$.

Asimismo en las parroquias de cierta entidad existía la figura del mayordomo que se encargaba de gestionar las rentas y bienes de la parroquia. En el caso de la principal parroquia arandina, Santa María la Real, este oficio era dúplice y se renovaba anualmente ${ }^{1885}$. En las parroquias menos notables tan sólo existía un mayordomo como se aprecia en 1503 en San Nicolás de la aldea arandina de Sinovas ${ }^{1886}$. La ausencia de referencia a este oficio en las parroquias más modestas nos hace pensar que la gestión de sus recursos la realizaría el propio párroco o su capellán.

Por otra parte, en las parroquias rurales ribereñas era bastante habitual el absentismo del titular que delegaba sus funciones pastorales en un capellán al que gratificaba con una porción de las rentas generadas por la iglesia. Aunque no se trate del clero diocesano exactamente, la situación se ejemplifica claramente en el caso de la parroquia de Milagros. El monasterio de San Pedro de Gumiel ejercía su señorío sobre esta granja y estableció en ella un prior para servir espiritualmente a esa comunidad. Sin embargo, no sabemos muy bien por qué a principios del siglo XV no cubrió esta plaza por lo que el abad de San Pedro llegó a un acuerdo en 1403 con un clérigo del cercano lugar de Pardilla para que administrara los sacramentos los domingos y fiestas de guardar a cambio de una contraprestación económica fijada en 300 maravedíes $^{1887}$. Asimismo advertimos este carácter absentista en 1490 cuando el regidor arandino Pedro de Mora tomó posesión de la parroquia de Alcubilla de Avellaneda en nombre de su hermano Juan de Aranda, residente por entonces en la corte romana, y nombró como capellán al clérigo

como tal ya desde 1504 y en 1529 como arcipreste de la villa (Ídem. doc. 96 y ADB, LIBRO DE FÁBRICA DE SANTA MARÍA, Tomo I, s. f.).

${ }^{1884}$ AMA, leg. 43, doc. 5. En 1439 ocupaba este cargo Juan Sánchez. En el mismo documento aparecen el cura párroco de Santa María, Alfonso Fernández, más otro capellán, Juan González de Astudillo, y el sacristán Pedro Rodríguez.

${ }^{1885}$ ADB, LIBRO DE FÁBRICA DE SANTA MARÍA, Tomo I, s. f.

${ }^{1886}$ En la base de la predela del retablo de Santa Ana aparece la inscripción: Este retablo se hiso a honor y reverencia de Señora Santana acabose año de mill y quinientos $i$ tres siendo cura el honrado Alonso Gonsalez y maiordomo Rodrigo de Arandilla (HERNANDO GALLARDO, "Pintura gótica..., p. 168).

${ }^{1887}$ AHN, CLERO, leg. 1066, doc. 5, fol. 2. Se trata de una carta de pago del abad de San Pedro de Gumiel a Diego González fechada el dos de diciembre de 1404. En ella se hace referencia al acuerdo suscrito el día de la Virgen de Agosto del año anterior. 
Pascual González ${ }^{1888}$. Estos capellanes eran asistidos por un sacristán que se encargaba de las más diversas tareas y recibían un salario por su trabajo ${ }^{1889}$.

\section{1. 3. Actividad pastoral y religiosidad.}

A parte del control del territorio a través de la red de parroquias y de la obtención de recursos económicos gracias a la exacción decimal, el mayor exponente del poder relacionado con el clero fue su inmensa capacidad de control social sobre los individuos.

El necesario primer paso para garantizar este control social fue mantener una ortodoxia, no solo entre los fieles, sino también entre los ministros de la fe. Parece evidente que en un territorio tan extenso era bastante complicado hacer cumplir las disposiciones ordenadas por las autoridades eclesiásticas, así que para no perder la necesaria cohesión y mantener la práctica de la comunidad cristiana dentro de la ortodoxia católica se recurrió con carácter ordinario a dos instrumentos de gran valor: las reuniones sinodales y las visitas.

Los sínodos diocesanos se realizaban con cierta regularidad y en ellos el obispo daba a conocer normas o decisiones sobre diferentes aspectos de la administración diocesana, ya fueran de tipo organizativo, económico o pastoral. En un periodo en el que los prelados oxomenses se caracterizaban por un elevado nivel de absentismo, estas reuniones servían para poner en contacto directo al obispo con las dignidades capitulares, priores y arciprestes. Estos últimos actuaban como verdaderos delegados territoriales cuya función fue la de transmitir las decisiones que tomaba el obispo a todos los párrocos de su jurisdicción. En 1444 se otorgaron unos estatutos para regir estas reuniones. En ellos se establecía la convocatoria, los asistentes y su preeminencia, los asuntos a tratar y la obligación de presentar una serie de informes sobre el estado de las parroquias, sus rentas, el cumplimiento de las normas por parte de los fieles y la denuncia de

${ }^{1888}$ Este individuo ya estaba ejerciendo como tal por delegación del anterior cura párroco (AGS, CC PUEBLOS, leg. 1, doc. 229).

1889 Así, por ejemplo, lo encontramos en Pardilla. Capellán y sacristán actuaron como intermediarios para solucionar un problema que enfrentó a los vecinos de Aranda y Fuentespina contra los de Pardilla y Valdeherreros a propósito del lugar de Milagros (AGS, CR, leg. 22, doc. 1). Entre las tareas asignadas al sacristán se encontraban las relacionadas con el mantenimiento del edificio, el tañido de campanas o el servicio al sacerdote en los oficios. En ocasiones también realizaba tareas catequizadoras por las que cobraba su salario extra como se especifica en Aranda (ADB, LIBRO DE FÁBRICA DE SANTA MARÍA, Tomo I, s. f.). 
los comportamientos inadecuados de los Clerigos desolutos, iufadores... usureros o $\operatorname{periuros}^{1890}$.

Pero además de los sínodos diocesanos, se convocaron también reuniones de más amplio radio. En este contexto parece necesario hacer alusión al Concilio provincial que se celebró en la villa de Aranda en los meses de noviembre y diciembre de 1473. En el mes de octubre el arzobispo de Toledo, don Alonso Carrillo, convocó a todos los obispos sufragáneos de su provincia para tratar de atajar la corrupción eclesiástica extendida por todas las diócesis de la provincia ${ }^{1891}$. Es significativo que la mayoría de los cánones, 20 de 29, se referían a la reforma del clero. En primer lugar, se apelaba a la necesidad de incrementar el nivel cultural de los clérigos estableciendo que ninguno sea, en adelante, promovido a las sagradas órdenes sin saber hablar latín ${ }^{1892}$. Asimismo se prestaba especial atención a erradicar algunas actitudes poco coherentes con la misión pastoral del clero por lo que se aconsejaba recato en las vestiduras puesto que por el hábito exterior se manifiesta de qué naturaleza debe ser la compostura interior de los prelados ${ }^{1893}$. Más explícita era la condena del juego, en especial de los dados, $\mathrm{y}$ los servicios armados a los laicos ${ }^{1894}$. La reglamentación era tan ambiciosa que incluso prohibía a los obispos percibir contraprestaciones pecuniarias por conferir las órdenes $\operatorname{sagradas}^{1895}$.

Sin lugar a dudas, el mayor esfuerzo reformador de este Concilio se concentró en frenar el amancebamiento de los clérigos ${ }^{1896}$. El canon más extenso de toda la consti-

${ }^{1890}$ LOPERRÁEZ CORVALÁN, Descripción histórica..., Tomo. III, doc. CXXIV, pp. 285-290. Se establecía que los sínodos se celebrasen siempre en El Burgo de Osma y se convocaran con quince días de antelación para que los asistentes tuvieran tiempo de recabar toda la información pertinente.

1891 PÉREZ GONZÁleZ, C., El Concilio de Aranda (1473). Segovia, 2007, pp. 40 y ss. Ver también ONTORIA OQUILLAS, P., "El Concilio de Aranda. Aportaciones para su historia externa", en Boletín de la Institución Fernán González. 187, 1976, pp. 999-1046; del mismo autor "Aportaciones bibliográficas al Concilio de Aranda", en Biblioteca. Estudio e Investigación. 3 y 4, 1985-86, pp. 79-84 y 101-118, respectivamente; y BONACHÍA HERNANDO, "La Iglesia en Castilla..., pp. 269-298.

${ }^{1892}$ Citamos la traducción al castellano realizada por PÉREZ GONZÁLEZ, quien también aporta la transcripción original latina (El Concilio de Aranda..., Cánones III y X, pp. 147-148 y 156-157).

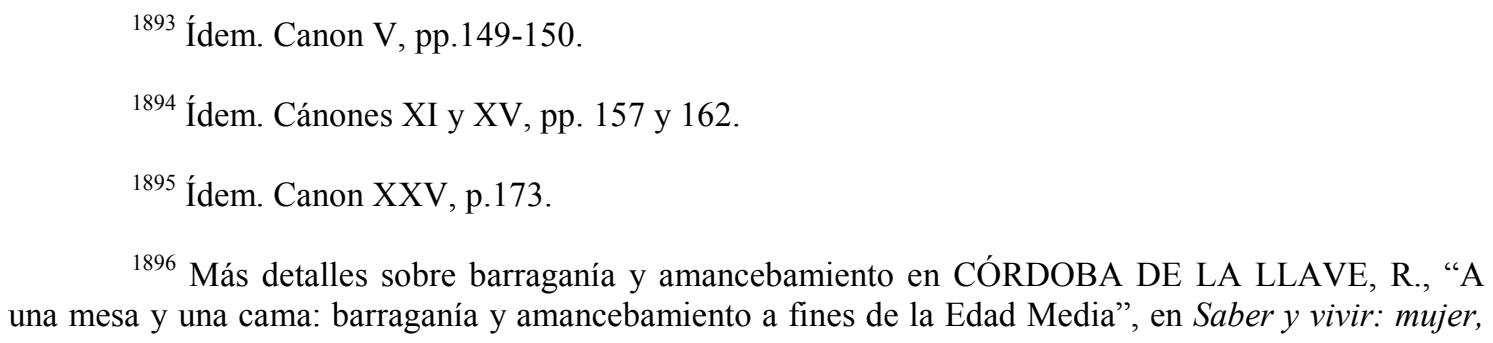

${ }^{1896}$ Más detalles sobre barraganía y amancebamiento en CÓRDOBA DE LA LLAVE, R., “A una mesa y una cama: barraganía y amancebamiento a fines de la Edad Media”, en Saber y vivir: mujer, 
tución se centraba concretamente en el proceso que se debe seguir contra los clérigos que públicamente tienen concubina ${ }^{1897}$. El capítulo comenzaba por reconocer el muy repugnante crimen de nuestra torpe condición, el cual hace a los clérigos despreciables ante los ojos del pueblo y atesora para si la ira de la venganza divina. El canon continuaba con el establecimiento de unos plazos para que los clérigos denunciados por amancebamiento se separaran de sus mujeres, bajo pena de perder progresivamente los frutos de sus beneficios. Si bien es cierto que las autoridades tanto eclesiásticas como laicas lucharon sistemáticamente por imponer un comportamiento honesto entre el clero con especial atención al cumplimiento del celibato, no es menos cierto que la práctica del amancebamiento de los clérigos era un comportamiento ampliamente extendido y aceptado socialmente durante toda la Edad Media ${ }^{1898}$. Paradójicamente los mismos monarcas que lucharon contra la relajación de costumbres favorecieron con sus privilegios esta práctica. Y así comprobamos cómo el rey Alfonso X despenalizó oficialmente este comportamiento al legitimar a los hijos de los clérigos de la Clerecía y arciprestazgo de Roa y permitir que pudieran heredar de sus padres, situación confirmada en 1300 por Fernando $\mathrm{IV}^{1899}$. Asimismo comprobamos que alguno de los prelados contemporáneos a la constitución del Concilio de Aranda fueron practicantes del concubinato y siguieron una política activa de promoción social de sus propios hijos, incluso dentro de la Iglesia. Paradigmático en este caso fue el propio arzobispo Carrillo que tuvo al menos dos hijos: Troilo Carrillo y Lope Vázquez ${ }^{1900}$. Otro buen ejemplo de esta situación fue el obispo oxomense don Pedro de Montoya quien, a la vez que establecía el estatuto que regulaba la vida del cabildo catedralicio, también procuró el matrimonio de su hija con un miembro del linaje de los Mendoza ${ }^{1901}$.

antigüedad y medievo. 1996, pp. 127-154; y SÁNCHEZ HERRERO, J., “Amantes, barraganas, compañeras, concubinas clericales", en Clio y Crimen. 5, 2008, pp. 106-137.

1897 Ídem. Canon IX, pp 153-156.

1898 AZCONA, T. "Reformas del Episcopado y del clero de España en tiempo de los Reyes Católicos y de Carlos V", en Historia de la Iglesia de España. Madrid, 1980. Vol. III-1, pp. 115-210, en especial pp. 172 y ss.

${ }^{1899}$ LOPERRÁEZ CORVALÁN, Descripción histórica..., Tomo. III, doc. LXXI, pp. 204-207.

1900 PÉREZ GONZÁLEZ, El Concilio de Aranda..., p. 59.

${ }^{1901}$ PORTILLO CAPILLA, T., “D. Pedro Montoya, obispo de Osma (1454-1474)”, en Celtiberia. 50, 1975, pp. 231-244; LOPERRÁEZ CORVALÁN, Descripción histórica..., Tomo. I, p. 368; y VAL VALDIVIESO, "Introducción al estudio..., p. 216. Recordemos que Montoya era el obispo de la 
A pesar de las disposiciones del Concilio y de la nueva reglamentación civil emanada de las Cortes de Toledo de $1480^{1902}$, la realidad del clero castellano, y en particular del ribereño, continuaba presentando los mismos comportamientos que en el pasado. Así se aprecia en la villa de Aranda donde en los años finales del siglo XV identificamos algunos procesos abiertos contra ciertas mujeres acusadas de amancebamiento con clérigos. Entre ellos cabe destacar el caso de Beatriz, manceba confesa del clérigo Francisco de Roa que, según su propia declaración, ...estaba por su manceba a pan e cuchillo e dormia con el continuamente en una cama y se conocian carnalmente. Aunque bien es cierto, según denuncian los regidores de la Comunidad, que dicha declaración se consiguió atemorizándola con tormento por que lo confiesen. Llama la atención en este caso que fue el propio provisor de Osma el que tomó la defensa del clérigo implicado y castigó con la excomunión a los alcaldes que habían impuesto las penas a la acusada $^{1903}$. Las denuncias ante la Inquisición también transmiten información a este respecto: en 1502 el cura de Bahabón y Alonso de la Reyna, clérigo de Aranda, fueron denunciados, no tanto por mancebía, como porque el primero dormia con su madre, mientras que Reyna compartía la manceba con su padre ${ }^{1904}$.

Además del contenido estrictamente doctrinal y reformista, los autores que han estudiado el Concilio arandino afirman que paralelamente se celebró una Asamblea del Clero convocada por el arzobispo para abordar temas concretos de marcado carácter

Diócesis de Osma en 1473 pero que no asistió al concilio arandino. Esta ausencia se explicaría por las posibles desavenencias políticas con su promotor, el arzobispo Carrillo.

1902 AZCONA, "Reformas del Episcopado..., pp.172 y ss. Se establecía una sanción económica, un marco de plata, como condena. En el caso de reincidencia se imponía además destierro por un año. En 1485 el alguacil de Aranda se quejaba ante los monarcas de que los alcaldes ordinarios de la villa recaudaban estas multas a pesar de que era un asunto de su competencia y, por lo tanto, se le estaba causando un perjuicio económico (AGS, RGS, 148503, fol. 84)

${ }^{1903}$ Las acusadas eran Juana Rodríguez y la citada Beatriz. En una petición que presentaron los regidores de la Comunidad denunciando los abusos cometidos por los alcaldes se alegaba que ambas confesaron por la amenaza de tortura y con la declaración falsa de los criados de los alcaldes. Beatriz fue condenada una primera vez a pagar el marco de plata y, tras reincidir, también fue desterrada de la villa durante un año. Las gestiones realizadas por Francisco de Roa y el provisor de Osma dieron sus frutos porque finalmente, en diciembre de 1487, la justicia real ordenó a los alcaldes que devolvieran las prendas tomadas a Beatriz. De Juana no sabemos nada. Conocemos un nuevo episodio de amancebamiento en 1524 (AGS, RGS, 148707, fol. 57 y 110; 148712, fol. 136; CCM, leg. 161, doc. 122; y ARChV, RRE, Caja 367, doc. 13).

${ }^{1904}$ La mujer que compartían padre e hijo se llamaba María de Torres y esta situación provocó la recriminación del padre hacia el hijo: ...mal onbre, no duermas con esta muger, que yo he dormido (CARRETE PARRONDO, Fontes Iudaeorum..., doc. 353, pp. 144-145). 
político y económico ${ }^{1905}$. En concreto, la intención política se centraba en intentar conseguir el apoyo a la causa de la princesa Isabel del mayor número de prelados posibles. Eso explicaría la presencia de obispos de otras provincias como el de Burgos y las ausencias de sufragáneos pero del partido contrario como los de Sigüenza, Osma o Cuen$\mathrm{ca}^{1906}$. En esta asamblea también se abordó, a instancias del legado pontificio ${ }^{1907}$, el tema del subsidio para la cruzada turca que pretendía la Santa Sede desde hacía algún tiempo. Sí que parece que se consiguió el apoyo de los prelados a la causa de la cruzada pues en 1475 ya se habían recaudado más de 77.000 ducados $^{1908}$.

El otro preciado instrumento de cohesión era la visita pastoral. En principio las visitas debían realizarlas los arcedianos pero ya hemos señalado que en la Baja Edad Media estas dignidades habían delegado esta función en los arciprestes. Sin embargo, de manera habitual el obispo encomendaba esta misión a delegados especiales: los visitadores. La función específica de tales visitas pastorales era vigilar el cumplimiento de las normas canónicas y conocer el estado de las iglesias, beneficios, clérigos y fieles, tratando de solucionar los problemas y conflictos detectados. En el sínodo de Segovia de 1216 ya se establecía que los arciprestes visitaran su jurisdicción al menos una vez al año y también se regulaba el pago de los servicios del visitador por parte de los beneficiados de las parroquias visitadas. La visita realizada en el arciprestazgo de Montejo en 1446 aporta escasa información pues en el cuaderno de la visita tan solo se hace constar el deplorable estado de la iglesia de Santa María de Pradales, la mitad dela eglesia se llovía e estava panda e destejada, la ausencia del cura de Pardilla y la acusación de amancebamiento al cura de Villalbilla que convivía con dos mujeres casadas ${ }^{1909}$.

1905 Tanto AZCONA como PÉREZ GONZÁLEZ confirman la existencia de una asamblea del clero en Aranda (Isabel la Católica..., pp. 481-482; y El Concilio de Aranda..., pp. 40-47).

${ }^{1906}$ PÉREZ GONZÁLEZ, El Concilio de Aranda..., pp. 58-64. La enemistad personal y política entre el cardenal González de Mendoza y Carrillo era pública y notoria. Algo similar ocurría con el obispo conquense, don Antonio Jacobo de Veneris. Por otra parte, don Luís de Acuña y Osorio, arzobispo de Burgos, era sobrino de Carrillo. Es posible que también acudieran a la Asamblea los prelados de León y Oviedo, aliados del arzobispo toledano.

${ }^{1907}$ Rodrigo de Borgia fue nombrado legado pontificio por Sixto IV para abordar ciertos asuntos en los reinos de Castilla y Aragón, entre los que destaca el apoyo a la pretendiente Isabel y la recaudación de la bula de Cruzada. Llegó a Valencia en la primavera de 1472 y regresó a Roma en octubre de 1473. A tenor de esta cronología PÉREZ GONZÁLEZ asegura que el legado no estuvo presente en el concilio arandino, aunque sí sus planteamientos sobre la bula de Cruzada (El Concilio de Aranda..., p. 64).

${ }^{1908}$ AZCONA, "Reformas del Episcopado..., pp. 190-191.

${ }^{1909}$ BARTOLOMÉ HERRERO, "Una visita pastoral..., pp. 304, y 332. También se hace mención de las parroquias de Fuentelcésped, buena con su adeganna; Honrubia, buen clérigo, entendido y 
Más explícita es la información que trasmite la primera visita de la que tenemos constancia en la villa de Aranda de Duero realizada por el doctor Piedra en noviembre de $1529^{1910}$. En la iglesia de Santa María se reunieron el delegado episcopal, su notario y todos los clérigos de la villa, tanto los beneficiados de Santa María como los de San Juan. Lo primero que hizo el visitador fue tomar las cuentas del Libro de Fábrica a los mayordomos de Santa María, enumerando una a una las entradas de rentas propias de la parroquia, así como las cantidades generadas por los enterramientos y las limosnas. Seguidamente, los mayordomos dieron cuenta de los gastos del mantenimiento del templo y establecieron el alcance del Libro de Cuentas ${ }^{1911}$. Para el año 1529 el monto total ascendió a 102.359 maravedíes. El segundo capítulo de la visita se centró en recoger los agravios de los fieles que, en ese año en concreto, se redujeron a las quejas de un feligrés al que se le había cobrado de más por la sepultura de su hija. Finalmente, el visitador dictó una serie de instrucciones concretas sobre el mantenimiento de la iglesia.

En último lugar el visitador estipuló la necesidad pastoral de impartir catequesis en la parroquia y la obligación de los padres de enviar a sus hijos: ...que el sacristan enseñe a los niños y niñas cada domingo despues de comer: signar y santiguar, Pater Noster, Ave María, Credo y Salve Regina, mandamientos y pecados mortales; todo esto en romance poco a poco. Para lo qual el sacristan tenga la campana una señal diferenciada para que los padres al punto ymbien sus niños desde seis años fasta diez o doze y las niñas de cinco años a diez. Y el cura amoneste cada domingo a la misa que los ymbien por el orden que el diere por casas o barrios, haziendo una matrícula o memoria de ellos para que el que lo supiere lo quiten de alli y ninguno se olvide de venir. Y el padre que no imbiare sus niños como dicho es, pague por cada vez que no los ymbiare çinco maravedis de pena para el sacristan, y el cura los mande pagar y siendo rebeldes a pagar la pena pida favor a la justicia seglar para que un alguacil executor de la dicha pena, y sea la mitad para el tal alguacil y la otra mitad para el sacristan. Y asi, si necesario es, lo manda el dicho visitador a la justicia lo prevea so pena de excomunión. $Y$ por el trabajo y diligencia que el sacristan pusiere en enseñar esto se le pague de la

bien usado; y Montejo, bene, del alcayde que rescibia algunos agravios. Creemos que falta una hoja en la que se haría referencia al resto de las parroquias de este arciprestazgo.

${ }^{1910}$ ADB, LIBRO DE FÁBRICA DE LA IGLESIA DE SANTA MARÍA, Tomo I, s.f.

${ }^{1911}$ Dentro de los gastos se incluían los 390 maravedíes que se pagaba al señor obispo de la costa de esta visitación (ADB, LIBRO DE FABRICA DE LA IGLESIA DE SANTA MARÍA, Tomo I, s.f.). 
fabrica como al cura le pareciere que pone diligencia, y el cura haga cumplir al sacristan este mandamiento so pena de 10 dineros para la cámara del obispo. Y el sacristan con juramento que le tome el cura de ejecutar este cargo fielmente y decir los que faltaren, asi lo paguen en efecto so pena de 5 dineros para la cámara del prelado. Este mandamiento es para ambas iglesias y aquellos que tuvieren excusa legítima la den al cura de su parroquia...

Pero además de estos instrumentos utilizados por la Iglesia para mantener la ortodoxia y establecer los principios básicos sobre los que se asentaba su control social sobre los fieles, también se han de destacar algunas de las herramientas cotidianas que se utilizaron para hacer llegar el mensaje pastoral y, sobre todo, imponer una forma de vida acorde con la moral cristiana establecida. Entre estas herramientas destacaron en la comarca ribereña dos fundamentales: por una parte los sermones o predicaciones y por otra el recurso al miedo, en este caso materializado en los entredichos. Ambos aspectos los abordaremos con detenimiento en el capítulo dedicado a los conflictos por las significativas repercusiones que tuvieron sobre la sociedad ribereña.

Lo comentado hasta ahora no es más que un ejemplo del férreo control que ejerció la Iglesia como institución sobre la mayor parte de los aspectos cotidianos de la vida de la sociedad medieval. La cotidianeidad de los hombres y mujeres de la Ribera del Duero estaba completamente imbricada y revestida de una apariencia religiosa. La llegada a este mundo estaba marcada por la administración del bautismo; la unión de los cónyuges se santificaba con otro sacramento que dispensaba el sacerdote-testigo ${ }^{1912}$; y en el paso a la otra vida el sacerdote proporcionaba la comunión y la extrema unción al moribundo ${ }^{1913}$. Asimismo el tiempo venía marcado por el tañer de las campanas que recordaban las rutinas diarias de una vida sacralizada ${ }^{1914}$. Asimismo la campana, con su

1912 Todavía debían ser frecuentes al final de la Edad Media los matrimonios al margen de la institución eclesiástica pues el mismo Concilio de Aranda de 1473 se inclinaba más por su legalización que por una condena taxativa: prohibimos totalmente en lo sucesivo tales desposorios clandestinos y ocultos, estableciendo que los que pensasen contraer tales esponsales clandestinos, a no ser que lo presencien al menos cinco testigos (que lo puedan probar cuando sea necesario), incurran ipso facto en sentencia de excomunión (PÉREZ GONZÁLEZ, El Concilio de Aranda..., Canon XVII, p. 164).

${ }^{1913}$ En el renombrado pleito sobre la apertura de la calle de Barrionuevo se pregunta expresamente si los testigos saben que por esas calles pasa el Corpus Christi quando es menester dar a los enfermos. Pedro Sánchez de la Riba, vicario de la iglesia de Santa María respondió que alguna vez había llevado el Corpus por una de estas calles pero que muchas veces las evitaba por la suciedad que en ellas había (AGS, CR, leg. 39, doc. 3).

${ }^{1914}$ LE GOFF, J., Tiempo, trabajo y cultura en el occidente medieval. Madrid, 1983, pp. En 1502 un vecino arandino presentó una denuncia ante el Tribunal de la Inquisición acusando a otro de judaizante 
peculiar código, era el habitual mensajero que comunica a la vecindad cualquier contingencia de la vida civil como eran las reuniones del concejo, los remates de las rentas, los incendios o la movilización de las milicias locales. Era práctica habitual en todos los pueblos de la Ribera la llamada al concejo ... a campana tañida segund que lo avemos de uso e de costunbre de nos ayuntar para los semejantes negocios. Posiblemente los campaniles que aparecen reflejados en las iglesias de Santa María y Santa Cruz de Aranda en el plano de 1503 tuvieron un carácter mixto, pues la tradicional función religiosa era complementada con usos fundamentalmente laicos ${ }^{1915}$. Así lo observamos en 1496 cuando mediante las campanas fueron convocados más de quinientos vecinos de Aranda para formar la milicia que se dirigió a Milagros con la intención de liberar a unos guardas de montes apresados por el alcaide de Montejo ${ }^{1916}$. Esta utilización polivalente de los campaniles también se realizaba en los pueblos de la comarca. En 1507 el corregidor de Aranda recibió el encargo de dar posada a una capitanía que estaba de paso por la Ribera, para ello encargó a un aposentador que fuera colocando a los soldados por los diversos pueblos de la comarca. Cuando éste llegó a Ciruelos acompañado de ocho hombres a caballos los vecinos los confundieron con ladrones y ... antes que llegasen al dicho lugar este testigo oyo replicar las campanas como arrebato e salieron mucha gente del dicho lugar dellos con vallestas armadas e dellos con lanzas e espadas e dellos con hondas ${ }^{1917}$.

La vida laboral se regía asimismo por el calendario cristiano, como dejaba de manifiesto uno de los cánones del concilio arandino: ...mandamos que los fieles descansen de todo trabajo manual los domingos y festivos y no esté permitido que nadie realice en ellos trabajos rústicos ni artesanales, ni que cultive los campos a no ser una necesidad urgente ... con licencia de sus sacerdotes ${ }^{1918}$. Incluso el pago de las rentas estaba

por ciertos comentarios que hizo ...estando este testigo... en la Plaça Nueva de la dicha villa, tañeron a la oraçion del Ave Maria e se fincaron todos de rodillas... (CARRETE PARRONDO, Fontes Iudaeorum..., doc. 199, p. 96). Cuando el visitador del obispo conminaba al párroco de Santa María a impartir catequesis le sugería ...para lo qual el sacristan tenga la campana una señal diferenciada para que los padres al punto ymbien sus niños (ADB, LIBRO DE FÁBRICA DE SANTA MARÍA, Tomo I, s. f.)

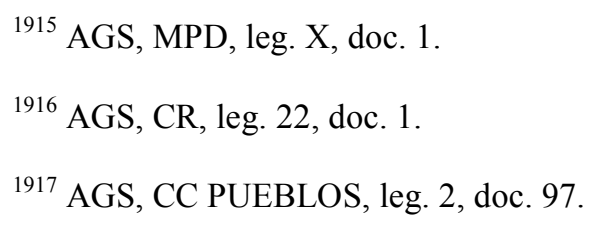

1918 PÉREZ GONZÁLEZ, El Concilio de Aranda..., Canon XVII, p. 164. De hecho, varias denuncias presentadas ante la Inquisición se referían a no respetar el descanso del domingo (CARRETE PARRONDO, Fontes Iudaeorum..., docs. 308 y 311, pp. 130-132). 
ligado al calendario cristiano como ejemplifica la contribución de la martiniega que debía ser satisfecha el 11 de noviembre, San Martín. De igual manera las transacciones comerciales establecían los días de pago en función del Santoral como vemos reflejado en el contrato realizado en 1502 entre el ganadero Fernando de Berlanga y los carniceros arandinos: una primera entrega de 550 carneros los carniceros se comprometían a pagarla en dos plazos, el primero el día de San Juan de junio y el segundo el día de Santa María de Agosto; para una segunda entrega de 1.050 carneros merinos también establecieron dos pagos, uno el día de San Miguel de septiembre y la otra el día de San Martín de noviembre ${ }^{1919}$.

La generalización de las cofradías también confirió al mundo del trabajo un revestimiento de religiosidad como se ejemplifica en la villa de Aranda donde, recordemos, en 1503 ay veynte cofradias ${ }^{1920}$.

Pero sobre todo, esta religiosidad aparecía en los momentos críticos en los que el ser humano veía peligrar su existencia. De esos episodios hubo muchos en la Baja Edad Media: epidemias, sequías, tormentas, guerras, etc. Precisamente en esos momentos era en los que más se recurría a la ayuda sobrenatural, eso sí, revestida de ortodoxia cristiana. Son varios los testimonios que hablan de ceremonias cuando menos curiosas para exorcizar los nublados agoreros del temido granizo y que han dejado huella en las torres de las iglesias con pequeños balconcitos o conjuraderos $^{1921}$; de procesiones para pedir agua; o los capítulos de histeria colectiva que solicitaba del santo de turno su intercesión para que el brote de peste pasase de largo ${ }^{1922}$. Pero la palma se la llevaba el momento

1919 ARChV, RRE, Caja 157, doc. 19. Asimismo las entregas de los carneros estaban fijadas según el calendario cristiano pues los primeros carneros se debían entregar en la víspera de Pascua Florida por lo que se intuye perfectamente cuál era el plato más demandado para celebrar el Domingo de Resurrección siguiendo claramente la tradición judía.

${ }^{1920}$ AGS, CC PUEBLOS, leg. 2, doc. 94. Sobre el carácter religioso asistencial de las cofradías y su vinculación con las actividades económicas ya hemos tratado en un apartado anterior.

${ }^{1921}$ En 1487 el Concejo pagó entre 4.000 y 5.000 maravedíes a un clérigo ...porque espantase los truenos y relampagos y nublos, con la promesa de concederle una capellanía de Santa María ...con tal que fuese seguro lo de los truenos (AGS, CC MOMERIALES, leg. 149, doc. 230). Todavía hoy se puede apreciar en la torre de la iglesia de Santa María de Gumiel de Izán un conjuradero que no es más que un pequeño vano desde el que un clérigo recitaban las correspondientes oraciones para conjurar a los nublados y pedriscos. Otro conjuradero parecido se puede observar en la iglesia de Guzmán (SÁNCHEZ RIVERA, J. I., "La torre de Gumiel de Izán y las iglesias encastilladas en la Ribera del Duero", en Biblioteca 25. Estudio e Investigación. 2011, pp. 67-88, en concreto p. 85).

${ }^{1922}$ En Aranda se realizaba anualmente una procesión solemne hasta la ermita de la Virgen de las Viñas: la comitiva salía de la villa y hacía un recorrido paralelo a las cavas hasta el puente del río Bañuelos; por allí se atravesaba el arrabal de Fuenteminaya y se encaminaba hacia la ermita (AGS, CC 
más inquietante para todo ser humano: la muerte. Testimonio de esta inquietud e incertidumbre, unida a la búsqueda de la paz de conciencia lo encontramos en los testamentos que fueron utilizados por los ribereños para ponerse en paz con Dios y con sus familiares y vecinos. Los formalismos propios del testamento establecían un orden predeterminado: comenzaban por los rituales relativos a su enterramiento, después mencionaban las limosnas para la cura del alma y, si había para más, el reparto de bienes entre los familiares y las reparaciones al resto de mortales ${ }^{1923}$.

Buena muestra de este esquema, pero también del carácter igualitario de la muerte así como del imaginario colectivo, es la relativa similitud de los testamentos de dos ribereños de condición social bien distinta. En el año 1500 el antiguo regidor de la Comunidad, Juan Fernández Mexía, realizó su testamento y, siguiendo los formularios testamentarios de la época, lo primero que reguló fue dónde (Santa María) y cómo (procesión, misas, etc.) debía ser enterrado. Posteriormente establecía las correspondientes limosnas que reflejaban las costumbres de la tierra, pero también ciertas vinculaciones y devociones personales: mandaba que dieran de comer a diez pobres, fijaba 10 maravedíes de limosna a la iglesia de Santa María, 5 a la de San Juan, otros 5 a la redención de cautivos, un maravedí a cada una de las ermitas foranas, otros 5 a Santa María de Osma, y lo mismo a Santa María de Guadalupe, a Santa María de las Viñas y al Hospital de la villa de Aranda. Por último, donaba medio real a Santa María de la Concepción que es el monasterio, es decir, a la comunidad franciscana que acababa de establecerse en Aranda. Finalizado el apartado de limosnas, y antes de nombrar sus herederos, introdujo una serie de cláusulas específicas entre las que destacaban los 4.000 maravedíes que dejaba a su hijo menor para que aprenda en el escuela leer e escribir e en el estudio; los 25.000 maravedíes de la dote de su segunda esposa; y la orden expresa de que se paguen todas las deudas que aparecieren de buena verdad. Por último, nombraba como su testamentario a su hijo Diego y declaraba herederos legítimos a sus nueve hijos ${ }^{1924}$.

PUEBLOS, leg. 2, doc. 107). En puntuales ocasiones se realizaba esta misma procesión para rogar a la patrona su intercesión ante un problema concreto que afectaba a la villa. No obstante, este carácter extraordinario terminó por convertirse en habitual y obligó al concejo en 1555 a regular la asistencia de los regidores a estos eventos (VELASCO PÉREZ, Aranda. Memorias..., pp. 225-228).

${ }^{1923}$ Sobre el significado, características y diferencias sociales que se aprecian en los testamentos en la época medieval consúltese MARTÍN CEA, J. C., "El modelo testamentario bajomedieval castellano y su reflejo en los diferentes grupos sociales", en Edad Media. Revista de Historia. 6, 2003-2004, pp. 103-156).

${ }^{1924}$ AGS, CASA Y SITIOS REALES, leg. 2, doc. 484. 
El mismo esquema, pero en otra dimensión, siguió el testamento del Cardenal don Íñigo López de Mendoza realizado en 1535. El prelado establecía como su lugar de sepultura la iglesia de Santa María de la Vid, pero como continuaba en obras mandaba que se le enterrara de forma provisional en la Domus Dei de La Aguilera. También establecía las correspondientes limosnas, mucho más prolijas que en el anterior ejemplo. Sin embargo, llama la atención la gran cantidad de incidentes en principio insignificantes que pesaban sobre la conciencia del cardenal en el lecho de muerte. Por ejemplo solicitaba que se reparase a los herederos de un labrador ...que murio cuando el alcayde de Aça tomo la posesión de San Pedro, se les den treynta ducados, sabrase en el lugar de Gomyel quienes son y faltando herederos pobres se lo den por el anyma del muerto a pobres vergonzantes. O también se aberiguare que en Coscorrita, logar cabe Peñaranda, ... aya muerto cierta mula de un labrador de alli, se le de a el o sus herederos lo que la mula valía ${ }^{1925}$.

En definitiva, todos estos ejemplos muestran hasta qué punto la vida de los hombres y mujeres de la Ribera estaba mediatizada por la rígida moral de la doctrina religiosa imperante que legitimaba la ideología feudal sobre la que se asentaba un determinado orden social. El clero en su conjunto, y el secular en particular, fue el grupo encargado de garantizar la ortodoxia del cumplimiento de esta doctrina, situación que le confería un significativo poder de control sobre el resto de la sociedad.

\section{2. Las órdenes regulares.}

Los monjes y frailes se definían en la Edad Media por su condición de privilegiados, el desarrollo de una vida en comunidad al amparo de una regla, su capacidad de gestionar importantes recursos económicos y el ejercicio de una importante influencia sobre los comportamientos sociales. La comarca de la Ribera del Duero fue el lugar elegido por un nutrido grupo de órdenes religiosas para establecer sus comunidades y participar en la configuración del espacio y la sociedad feudal que caracterizaba al periodo bajomedieval.

A la inicial y reducida presencia en tierras ribereñas de los benedictinos cluniacienses siguió poco tiempo después el asentamiento de premostratenses y cistercienses a 70 y ss.

1925 GARCÍA RÁMILA, I., El INEM Cardenal López de Mendoza. Burgos, 1958, reed. 1995, pp. 
lo largo del siglo XII. Posteriormente fueron los mendicantes los que buscaron acomodo en la comarca, aunque primero se asentaron en el medio rural, para después fijar alguno de sus establecimientos en el núcleo urbano más importante de la comarca ${ }^{1926}$.

En este capítulo analizaremos el proceso de consolidación de estas comunidades religiosas en la Ribera, prestando especial atención a las principales bases de su poder y su proyección sobre el territorio. Para ello estudiaremos cada una de las instituciones monásticas establecidas en la comarca.

\section{2. 1. Monasterio de Santa María de la Vid.}

La fundación del monasterio premostratense de Santa María de la Vid tuvo lugar a mediados del siglo XII, variando la fecha según los autores entre 1132, momento en que se estableció una pequeña comunidad de premostratense en el Monte Sacro, y 1152, fecha en la que se data el diploma de Alfonso VII por el que cedía el territorio en el que se asienta el actual monasterio ${ }^{1927}$. Aunque en origen este cenobio era dúplice, en 1164 se tomó la decisión de que los canónigos permanecieran en La Vid y que las mujeres se desplazaran a los monasterios de Brazacorta y Fresnillo. Las dos casas femeninas desarrollaron su actividad hasta la segunda mitad del siglo XIV, aunque bien es cierto que de manera bastante diferente. Mientras las canonesas de Fresnillo siempre se mantuvieron muy dinámicas, poniendo incluso en entredicho la autoridad del monasterio matriz, la comunidad de Brazacorta pasó por bastantes dificultades que se materializaron en constantes demandas de recursos que aliviaran su precaria situación ${ }^{1928}$.

A lo largo de los siglos XIII y XIV el monasterio fue creando y consolidando un importante señorío abacial que contaba con importantes posesiones en la Ribera y en otros espacios más distantes. El abad ejercía su jurisdicción civil sobre los colonos de las cercanas aldeas de Zuzones y Guma, era señor de Alcozar, Alcolea, Revilla de Olle-

${ }^{1926}$ Una visión de conjunto sobre la presencia monástica en el Sur de la provincia de Burgos se encuentra en REGLERO DE LA FUENTE, "Poder regio y dominios monásticos..., pp. 169-186; y PÉREZ CELADA, J. A., "El mundo monástico entre el Duero y el Arlanza a fines de la Edad Media", en Biblioteca 25. Estudio e Investigación. 2011, pp. 205-225.

${ }^{1927}$ LÓPEZ DE GUEREÑO SANZ, Monasterios medievales premostratenses..., Vol. I, pp. $227-$ 282; VAlLEJO PENEDO, J. J., “El Monasterio de Santa María de la Vid..., pp. 99-240. Una obra de referencia necesaria para abordar el estudio de este monasterio es el Índice de los documentos procedentes de los monasterios y conventos suprimidos que se conservan en el Archivo de la Real Academia de la Historia. Tomo I (Monasterios de Nuestra Señora de la Vid y San Millán de la Cogolla), Madrid, 1861.

317.

${ }^{1928}$ LÓPEZ DE GUEREÑO SANZ, Monasterios medievales premostratenses..., Vol. I, pp. 297 - 
ros, Fresnillo, Brazacorta, Tubilla del Lago y Fuentelcésped ${ }^{1929}$. Además era propietario de diversos bienes en Roa, Torregalindo, Fuentenebro, Vadocondes, Hontoria de Valdearados, Gumiel del Mercado, Gumiel de Izán, Aldea del Monte, Valdeande y Castillejo de Robledo, extendiéndose sus heredades por Medinaceli, Ayllón o San Esteban ${ }^{1930}$. A estas posesiones se añadieron privilegios como la exención de portazgo y la libertad de pastos concedida por Alfonso VIII en 1168; la exención en el impuesto de la sal de su pozo de Medinaceli, concedido por el mismo monarca en 1214; y diversas exenciones de pechos y derechos comprometidas por Sancho IV entre 1287 y $1293^{1931}$.

Por lo tanto, podemos afirmar que a finales del siglo XIII y durante buena parte del XIV el cenobio vitense gozó de un importante dominio territorial que le reportaba un más que notable nivel de riqueza y prestigio. Prueba de esta boyante situación es el desarrollo de un pleito con la casa matriz, el monasterio de Retuerta.

Es de suponer que durante los primeros siglos de existencia del cenobio la explotación de su extenso patrimonio se realizó de forma directa bien por yugueros ${ }^{1932}$, o bien gracias a las sernas u obrerizas de los vasallos del monasterio ${ }^{1933}$. Al igual que ocurre

${ }^{1929}$ Por lo que se refiere a las posesiones en la comarca ribereña sabemos que Revilla de Olleros junto a los términos de Paliza y Páramo fueron donados por Guter Pérez y doña Estefanía al primer abad Domingo de Campdespina en 1150 (VALLEJO PENEDO, "El Monasterio..., p. 112 y doc. 2, p. 139). Los lugares de Brazacorta y Fresnillo fueron donados por varios particulares en 1154 para la fundación de los cenobios femeninos bajo la jurisdicción del abad de La Vid (docs. 5 y 6, p.144). En 1159 varios donantes cedieron sus derechos sobre el lugar de Zuzones (p. 114 y docs. 7 y 8, pp. 144-146). La villa de Guma fue donada por Alfonso VII en 1168 (p. 113). En 1188 Alfonso VIII donó al abad la villa de Tubilla del Lago junto a Frolella, aunque más bien esta donación debe ser considerada una venta pues el rey recibió a cambio 1.000 maravedíes (p. 118 y doc. 38, p. 164). La villa de Fuentelcésped fue entregada por Fernando Gómez al abad de La Vid en 1217 (p. 127 y doc. 57, p. 176), aunque su posesión fue discutida por los herederos del donante (REGLERO DE LA FUENTE, "Poder regio y dominios monásticos..., pp. 178179).

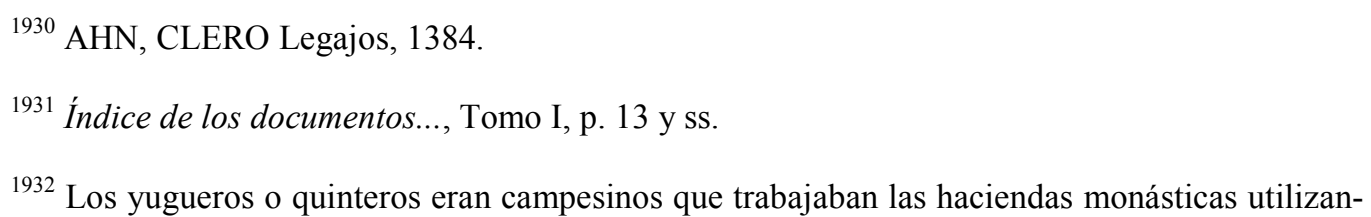
do los medios que les proporcionaban los monjes y recibía como contraprestación a este trabajo una parte de la cosecha. No obstante, la situación de este campesino es bastante variable pues también aparece en otros ámbitos como propietario de alguna de sus herramientas (MARTÍN CEA, J. C., "Una pequeña contribución al conocimiento del campesinado castellano: el yuguero", en El pasado histórico de Castilla y León. Burgos, 1983, Tomo I, pp. 101-112; y del mismo autor El campesinado castellano de la Cuenca del Duero. Aproximaciones a su estudio durante los siglos XIII al-XV). Zamora, 1986, p. 102. El monasterio de La Vid empleaba yugueros en la explotación de su finca de Quintanilla de Ricuerda (MARTÍNEZ DÍEZ, Libro Becerro..., vol. II, p. 635).

1933 También en el Libro Becerro se especifica que los vasallos de Fresnillo de las Dueñas dan a la priora del dicho monasterio de Frexnillo en reconoçimiento de señorio el que a par de bueyes cada año tres obrerizas (MARTÍNEZ DÍEZ, Libro Becerro..., vol. II, p. 632). 
en otras instituciones monásticas, desde finales del siglo XIV y durante buena parte del XV la tendencia a la explotación indirecta se generalizó ${ }^{1934}$. Sirva como ejemplo el caso del lugar de Cubillas que a partir de 1415 fue cedido por un censo anual de 1.600 maravedíes al concejo de Alcozar ${ }^{1935}$. La cesión de igual manera en 1426 de la granja de Revilla de Olleros al concejo arandino confirma esta dinámica ${ }^{1936}$.

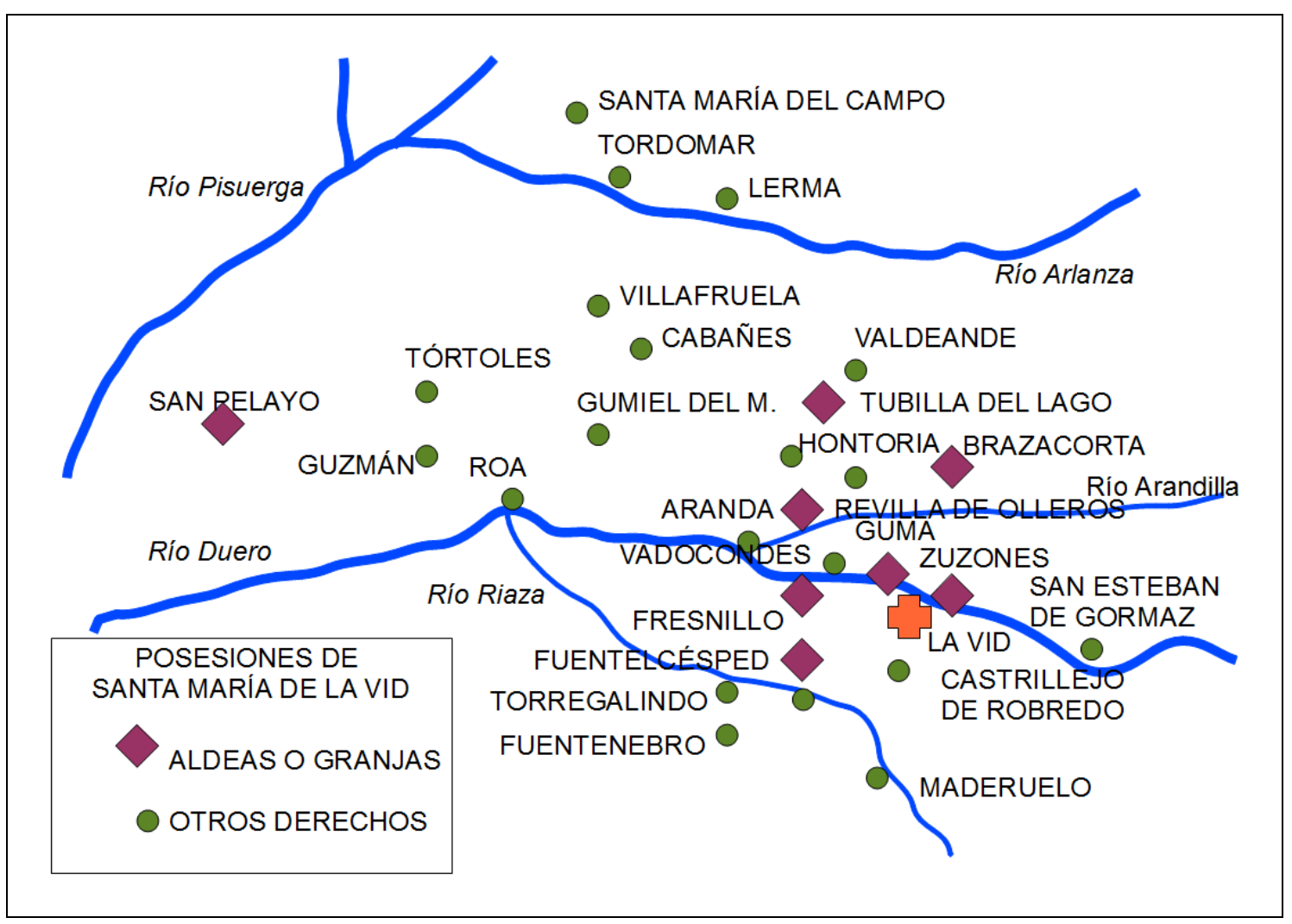

Mapa 19: Posesiones del monasterio de Santa María de La Vid en la Ribera del Duero.

Su emplazamiento en una zona fuertemente señorializada le reportó numerosos enfrentamientos con sus vecinos ya fueran nobles -los señores de Montejo-, concejos Aranda o Vadocondes-, o eclesiásticos - monasterio de San Pedro de Gumiel o el obispo de Osma- a lo largo de todo este periodo ${ }^{1937}$.

${ }^{1934}$ Esta dinámica ha sido documentada en los monasterios de Santo Domingo de Silos, San Pedro de Arlanza y San Pedro de Gumiel por PÉREZ CELADA, “El mundo monástico..., pp. 209-212.

1935 APARICIO DE ANDRÉS, D., "Donaciones al monasterio de La Vid en el término de Alcozar (1160-1190)", en Celtiberia. 91, 1997, pp. 135-144.

${ }^{1936}$ AMA, leg. 43, fol. 4.

1937 ÁLVAREZ BORGE, Poder y relaciones..., pp. 204-206; y REGLERO DE LA FUENTE, "Poder regio y dominios monásticos..., p. 180. 
Asimismo debemos añadir la vocación pecuaria de la institución que ya en 1165 recibía junto al lugar de Brazacorta 50 vacas y 300 ovejas. Apenas un siglo después, en 1292, la cabaña ganadera del monasterio contaba con al menos 4.000 ovejas y carneros, 100 yeguas y potros, 200 vacas y $200 \operatorname{cerdos}^{1938}$. Situación por cierto que contrasta con la extrema pobreza que por aquellos años afectaba a la comunidad femenina de Brazacorta que subsistió gracias a varios privilegios fiscales concedidos por diferentes monarcas, en atención a que ...las duennas de aquel logar eran muy pobres e muy mengua$\operatorname{das}^{1939}$.

Sin embargo, el final del siglo XIV supuso el comienzo de un claro deterioro del dominio monástico a causa de las sucesivas enajenaciones que mermaron la otrora boyante comunidad premostratense. Aunque los estudios sobre el monasterio no son muy precisos en este periodo, sí que se observan algunos indicios que reafirman esta dinámica negativa. La comunidad vitense no fue ajena al fenómeno de la encomienda y así la familia Avellaneda usurpó algunos de los dominios monásticos: en concreto Juan González de Avellaneda se hizo con el lugar de Fuentelcésped y su hermano Lope Ochoa hizo lo propio con Tubilla del Lago ${ }^{1940}$.

En la segunda mitad del siglo XIV desapareció la comunidad femenina de Fresnillo y el lugar pasó a estar regentado por un prior nombrado por el abad ${ }^{1941}$. Asimismo, a finales de siglo, bien en 1379 o 1390, el monasterio femenino de Brazacorta se abandonó y se convirtió en un priorato dependiente de La Vid. Finalmente el abad vitense procedió en 1469 a la venta de la jurisdicción de Brazacorta al conde de Coruña, Lorenzo Suárez de Figueroa ${ }^{1942}$. También podríamos incluir en este contexto negativo la venta que se hizo a la villa de Aranda de la granja de Revilla de Olleros, más los términos de

${ }^{1938}$ LÓPEZ DE GUEREÑO SANZ, Monasterios medievales premostratenses..., Vol. I, p. 297; VALLEJO PENEDO, “El Monasterio..., doc. 109, p. 206.

${ }^{1939}$ LÓPEZ DE GUEREÑO SANZ, Monasterios medievales premostratenses..., Vol. I, p. 298.

${ }^{1940}$ En 1380 Juan I ordenó a los dos hermanos que devolvieran las encomiendas de estos lugares a petición del abad fray Pedro (SUÁREZ FERNÁNDEZ, L., Historia del reinado de Juan I de Castilla. Madrid, 1982. Vol. II, pp. 330-331).

${ }^{1941}$ LÓPEZ DE GUEREÑO SANZ, Monasterios medievales premostratenses..., Vol. I, p. 315. La última noticia documental que se tiene por el momento de la presencia de la comunidad femenina en Fresnillo esta datada en 1348. En 1405 era prior de Fresnillo Gonzalo de Aguilar.

1942 LÓPEZ DE GUEREÑO SANZ, Monasterios medievales premostratenses..., Vol. I, p. 299. 
Palizas y Páramo en $1426^{1943}$. Hasta tal punto llegó la situación que en 1410 y 1462 el Papado tuvo que intervenir con sendas bulas que comisionaban a diversas autoridades eclesiásticas ...para que procure volver al derecho y propiedad del Monasterio de La Vid los bienes que, con grave perjuicio del mismo, habian sido enajenados ${ }^{1944}$. Pero el interés papal no tuvo el efecto pretendido pues durante la segunda mitad del siglo XV el cenobio estuvo inmerso en un proceso creciente de desintegración que se aprecia en una cascada de pérdidas territoriales: en 1469 el abad vendió la jurisdicción temporal de La $\mathrm{Vid}^{1945}$; en 1485 Juan Delgadillo, señor de Castrillo, enajenó San Pelayo de Cerrato ${ }^{1946}$; desde 1487 se desarrolló un conflicto con la Merindad de Santo Domingo por la jurisdicción de Tubilla del Lago ${ }^{1947}$; en la década de los noventa el Conde de Miranda se hizo con el lugar de Fuentelcésped, comenzando un largo pleito sobre su jurisdicción $^{1948}$; y en 1503 la villa de Aranda inició los trámites para comprar las aldeas de Fresnillo, Fuentelcésped y Tubilla del Lago ${ }^{1949}$.

La situación de decadencia no terminó hasta la aparición en escena de don Íñigo López de Mendoza ${ }^{1950}$ que fue nombrado abad comendatario en 1516, tras la muerte del abad Sancho de Aranda, la renuncia de Aloisi de Rosis y la destitución, como veremos más delante, de fray García de La Vid ${ }^{1951}$. La intensa actividad política del cardenal le impidió actuar in situ como abad. No obstante, se rodeó de valiosos colaboradores, co-

${ }^{1943}$ AMA, Leg. 43, fol. 4.

${ }^{1944}$ MENDOZA, “El Cardenal Don Íñigo..., pp. 67-88.

1945 VALLEJO PENEDO, J. J., “D. Íñigo López de Mendoza, abad comendatario del monasterio", en Cor Unum. 195-196, 1979, pp. 60-65.

${ }^{1946}$ AGS, RGS, 148505, fol. 63.

${ }^{1947}$ AGS, CC PUEBLOS, leg. 20, doc. 677 y RGS, 148704, fol. 103.

${ }^{1948}$ ARChV, RRE, Caja 76, doc. 6.

1949 AGS, CC PUEBLOS, leg. 2, doc. 94 y CC CÉDULAS, libro. 7, leg. 13, doc. 4.

${ }^{1950}$ Los abades comendatarios fueron clérigos que sin vinculación alguna con las comunidades monásticas conseguían su nombramiento como abades del Papa previo pago de una tasa. En teoría esta medida se tomaba para mantener la estabilidad de la vida monacal y la integridad de los recursos del establecimiento, pero más bien era un método encubierto de compraventa de beneficios (PÉREZ CELADA, "El mundo monástico..., pp. 214). Sobre la figura de don Íñigo véase el capítulo referente a la familia Zúñiga desarrollado anteriormente.

${ }^{1951}$ Aloisi de Rosis aparece nombrado en la documentación castellana Luiso Rojas Florentín. Entre la muerte de Sancho de Aranda y el nombramiento de don Íñigo se eligió un nuevo abad, fray Francisco de Moradillo, que ostentó el cargo unos meses hasta que posiblemente murió envenenado (AGS, CC PUEBLOS, leg. 17, doc. 467). 
mo el prior fray Clemente de Mendieta, que llevaron a cabo una importante reforma. Además promocionó la recuperación de los bienes anteriormente enajenados que convirtieron en 1525 a La Vid en el más rico de los centros premostratenses hispánicos ${ }^{1952}$. A este proceso de recuperación no fue ajeno su hermano el Conde de Miranda, don Francisco de Zúñiga y Avellaneda. No es de extrañar que tras el nombramiento de don Íñigo como abad, el conde, antaño uno de los principales extorsionadores del patrimonio monástico, se convirtiera en el protector de la comunidad premostratense. En este sentido, el conde no dejó de ocupar los lugares que anteriormente enajenó al monasterio ${ }^{1953}$ pero sí que consiguió acallar las voces que denunciaban esta situación. A pesar de todo, lo cierto es que los sucesivos condes de Miranda contribuyeron notablemente al gran desarrollo de cenobio. No en vano el abad y el conde patrocinaron la reforma de la iglesia monástica que terminó por convertirse en un majestuoso panteón familiar. El proceso de identificación del monasterio de La Vid con el linaje de los Zúñiga Avellaneda concluyó con la obtención del patronato del monasterio en $1549^{1954}$.

En conclusión, tras unos comienzos espectaculares se observa cómo el monasterio de Santa María de La Vid se encontraba a finales del siglo XV sumido en una situación de declive e inestabilidad, acosado y subordinado a los intereses de los poderes nobiliarios consolidados. Asimismo se convirtió en el codiciado objeto del deseo expansionista de la villa de Aranda. Esta dinámica cambió radicalmente a principios del Quinientos cuando la comunidad monástica cayó bajo el manto protector de la familia Zúñiga y Avellaneda de la mano del cardenal López de Mendoza que lo convirtió en una floreciente comunidad monástica pero también en el emblema del poder y la fortaleza de los condes de Miranda.

\section{2. 2. Monasterio de San Pedro de Gumiel de Izán.}

El origen del cenobio gomellano todavía no ha sido desvelado por la escasa bibliografía generada sobre este importante centro monástico. Por el momento, este origen incierto ha sido situado en la segunda mitad del siglo XI ligado siempre al ambiente

1952 LINAJE CONDE, A., “Memorias de La Vid”, en Cor Unum. 195-196, 1979, p. 48.

${ }^{1953}$ En la Averiguación de la Corona de Castilla el lugar de Fuentelcésped se refleja dentro del dominio señorial del conde de Miranda (CARRETERO ZAMORA, La Averiguación de la Corona..., vol. III, p. 1407).

1954 ZAPARAÍN YÁÑEZ, M. J., "El Monasterio de la Vid en el Arte de la Ribera”, El Monasterio de Santa María de la Vid 850 años. Madrid, 2004, pp. 33-97, en especial 51-58. 
benedictino, pero los diferentes autores no se ponen de acuerdo si dependiente o no del monasterio de Santo Domingo de Silos ${ }^{1955}$. Recientemente algunos autores apuntan a un origen cluniaciense del cenobio que fue refundado hacia 1180 por los monjes calatravos de san Raimundo. Finalmente en 1194 se produjo la afiliación de la abadía al Cister mediante la entrega realizada por el rey Alfonso VIII a la casa matriz de Morimond ${ }^{1956}$. Precisamente el Maestre calatravo don Diego de Velázquez eligió el recinto gomellense como su última morada, prueba fehaciente de la estrecha relación entre ambas instituciones $^{1957}$. Sin embargo, la pugna por el ejercicio del control sobre la orden generó un arduo conflicto entre el monasterio ribereño y la matriz francesa durante más de 40 años, con su punto álgido entre 1220 y 1237 . Este conflicto revistió interesantes matices de carácter político y provocó la intervención del monarca castellano e incluso del mismo Papa ${ }^{1958}$.

La documentación muestra que el cenobio en sus primeros años de vida se ganó el favor de la nobleza y de la monarquía. Gracias a sus donaciones el monasterio configuró un notable patrimonio que incluía varias heredades en 13 localidades de la comarca, 11 parroquias y la jurisdicción de tres villas entre las que se encontraban las ribereñas de Quemada y Tubilla del Lago, aunque el dominio de esta última provocó un largo

${ }^{1955}$ Son muy escasos los trabajos historiográficos que se han centrado en este monasterio a pesar de su significado histórico y la notable información que hoy conservamos. Sobre sus orígenes destacan las obras de PALACIOS MADRID, F., "Abaciologio del monasterio de San Pedro de Gumiel de Izán” en Boletín de la Institución Fernán González. 171, 1968, pp. 266-275 y 172, pp. 89-99; ÁLVAREZ PALENZUELA, V. A., Monasterios cistercienses en Castilla, siglos XII y XIII. Valladolid, 1978, pp. 97100 y 222-227; RODRÍGUEZ RODRÍGUEZ, M. C., "El Monasterio de San Pedro de Gumiel. Notas históricas (s. XII y XIII)", en Santo Domingo de Caleruega. Jornadas de Estudios Medievales. Salamanca 1994, pp. 299-324 y PÉREZ EMBID, J., El Císter en Castilla y León. Monacato y dominios rurales. Salamanca, 1986, p. 271. Mientras Pérez Embid indica que se trataba de un priorato de la abadía de Silos (p. 280), Rodríguez lo rechaza y declara su independencia aunque reconoce los orígenes benedictinos (p. 313).

1956 DE AYALA MARTÍNEZ, C., Las órdenes militares hispánicas en la Edad Media (siglos $X I I-X V)$. Madrid, 2007, pp. 152 y 251. El autor señala que es muy probable que esta cesión tuviera como condición el reconocimiento de la inmediata dependencia disciplinaria de la orden de Calatrava respecto al monasterio gomellano para así amortiguar el excesivo e incómodo intervencionismo de la abadía francesa sobre la joven milicia. En cierta mediada ÁLVAREZ PALENZUELA ya intuía un perfil más próximo a las directrices cistercienses varios lustros antes de la donación (Monasterios cistercienses..., pp. 9899).

${ }^{1957}$ PALACIOS MADRID, “Abaciologio del monasterio..., p. 270; y "El monasterio de Gumiel de Izán, panteón de los Guzmanes”, en Boletín de la Institución Fernán González. 119, 1952, pp. 179190.

${ }^{1958}$ DE AYALA MARTÍNEZ, Las órdenes militares..., pp. 250-252. El autor destaca los intereses políticos que se ocultaban tras este enfrentamiento entre Gumiel y Marimond, que tenían como protagonista a Fernando III. 
enfrentamiento con el cercano monasterio de La Vid que se saldó con su exclusión del patrimonio monástico ${ }^{1959}$.

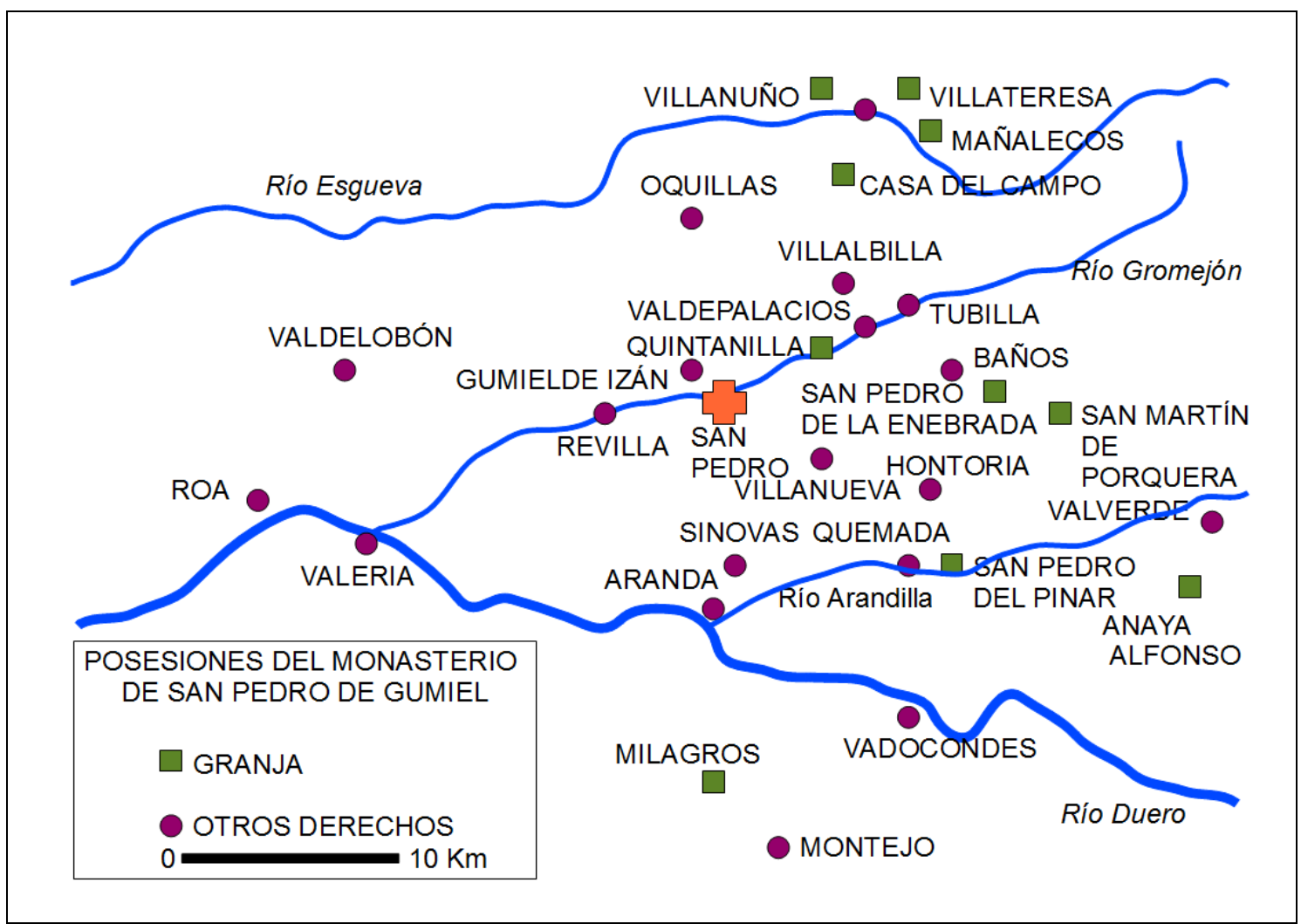

Mapa 20: Posesiones del monasterio de San Pedro de Gumiel en la Ribera del Duero.

El siglo XIII fue el de máxima prosperidad para el cenobio gomellense que vio ampliado enormemente su dominio sobre todo de la mano de su gran benefactor, el monarca Fernando III. Buena prueba de ello es la donación de varios solares, vasallos y heredades en la villa de Gumiel de Izán realizada en 1235. Un año después el monasterio recibió del mismo monarca unas aceñas y heredades en la villa de Aranda ${ }^{1960}$. El incremento más significativo de sus propiedades se realizó a través de compras y así

1959 RODRÍGUEZ RODRÍGUEZ señala que la Torrella de la documentación corresponde con el lugar de Tubilla del Lago ("El Monasterio de San Pedro..., p. 302). Este mismo lugar fue objeto de una donación real a la abadía premostratense de La Vid en 1188. Posiblemente esta situación originó conflictos entre los dos monasterios que se saldaron en 1223 con la firma de una sentencia arbitral por la que se reconocía la propiedad de La Vid sobre Tubilla a la vez que se hacía lo propio con la de San Pedro sobre Revilla y además se le cedía la serna de Anayalfonso (GONZÁLEZ, J., Reinado y diplomas de Fernando III. Córdoba, 1983, doc. 172).

${ }^{1960}$ AGS, PR, leg. 58, doc. 5; y AMA, leg. 41, doc. 4, transcrito por HURTADO QUERO, Documentos Reales..., doc. 1, pp. 3-4. LOPERRAEZ CORVALÁN recoge una confirmación de Fernando III que incluye la donación de propiedades en Linares, Aranda, Roa, Oquillas, Vadocondes, etc. (Descripción histórica..., Vol. II, p. 185). 
hacia 1270 el monasterio ya tenía configurado un importante dominio territorial que se extendía por buena parte de la Ribera, entre el Riaza y el Esgueva. El cenobio creó una importante red de granjas, entre ellas Milagros, San Pedro del Enebral, Anaya Alfonso, San Martín de Porquera, San Pedro del Pinar, Villa Teresa, Mañalecos, Villa Nuño y Casa de Campo. Esta gran cantidad de granjas en una comarca con un alto grado de señorialización supusieron para el cenobio grandes dificultades para asegurar su dominio efectivo sobre las nuevas adquisiciones que se tradujeron en un gran número de enfrentamientos ${ }^{1961}$. Las compras continuaron durante todo el periodo medieval aunque su significado fue mínimo en el conjunto del patrimonio monástico ${ }^{1962}$.

El régimen de explotación de estas granjas fue en su mayor parte la cesión bajo distintos regímenes de tenencias, entre los que se generalizó el préstamo vitalicio ${ }^{1963}$. En el siglo XIV continuó la dinámica de cesión de la explotación de la mayor parte de las granjas a los concejos vecinos aunque los arrendamientos se hicieron por periodos más cortos de tiempo ${ }^{1964}$. A comienzos del XV también se observa esta misma situación como se ejemplifica en el arrendamiento de la mitad de la granja de Alfonso Anaya por el concejo de Peñaranda en $1433^{1965}$, aunque también proliferaron arrendamientos a título

1961 ÁLVAREZ BORGE, Poder y relaciones..., pp. 211-212.

${ }^{1962}$ En 1412 el monasterio compró unas heredades y casas en Torriellas de las que era surquero el mismo cenobio. En 1426 se produjo otra compra de pequeña entidad (AHN, Clero, leg. 1066, no 5-3 y 5-4).

${ }^{1963}$ Era la dinámica de la que participaron la mayor parte de los monasterios cistercienses castellanos (PÉREZ EMBID, El Cister..., pp. 306-309). Ejemplo de este proceso fue la cesión por vida en 1231 a Ordoño Pérez de la granja de Anaya Alfonso con nueve yuntas de bueyes, detalle que indica que anteriormente a esta transacción se estaba explotando directamente la granja (ÁLVAREZ PALENZUELA, Monasterios cistercienses..., pp. 308-309; y PÉREZ CELADA, "El mundo monástico..., pp. 215-216). A principios del siglo XIV también se cedió en arriendo la granja de San Martín de Porquera a Fernando Sánchez de Velasco (AMA, leg. 41, doc. 2)

${ }^{1964}$ En 1336 se arrendó por seis años al concejo de Pineda el pasto de la Granja de Villa Teresa a cambio de seis carneros y seis carga de vino anuales (AHN, Clero, leg. 234, n 7); y en 1381 fue el concejo de Gumiel de Izán el que arrendó por otros seis años las granjas de Villanuño, Mañalecos, Villahoz y Casa del Campo ( $\left.n^{\circ} 15\right)$.

${ }^{1965}$ AHN, Clero, leg. 1066, no 6. 
individual $^{1966}$. Caso aparte constituyó el censo colectivo que realizaron los vecinos de Milagros en $1418^{1967}$.

Aunque otras comunidades cistercienses ya contaban con cabañas ganaderas que supusieron un notable aumento de sus ingresos, la comunidad gomellana no parece seguir los mismos pasos. Tenemos noticias de que en 1228 compró a un particular 150 ovejas y nueve vacas. Asimismo en 1232 Fernando III concedió al monasterio el privilegio de que sus ganados securen ambulent per totum regnum meum et pascant in omnibus locis ubi ganata mea debent pascare, aunque no se especificaba cantidad alguna de ganado como ocurrió con los privilegios concedidos a los monasterios vecinos ${ }^{1968}$. El lento proceso de conformación de la cabaña pecuaria del cenobio se confirma con la donación que en 1245 hizo un ganadero que se comprometía a entregar 40 ovejas en dos años para que el monasterio comience cabaña ${ }^{1969}$.

La Baja Edad Media supuso para el monasterio de San Pedro una merma significativa en cuanto a su poder y nivel de rentas. Son escasos los documentos que nos han llegado de este periodo pero parece que el cenobio gomellense siguió la misma dinámica que el resto de comunidades cistercienses. Ésta se caracterizó por una pérdida significativa de sus señoríos jurisdiccionales en beneficio de las grandes familias nobiliarias. Algo parecido ocurrió con los ingresos que provenían de las rentas eclesiásticas, aunque para aliviar este descenso se recurrió a la venta de indulgencias ${ }^{1970}$. En este sentido des-

${ }^{1966}$ En 1412 un vecino de Hontoria arrendó unas heredades de San Pedro del Enebral por 10 años estableciendo el pago de la renta fija en especie. En 1417 otro vecino arrendó otras heredades de la misma granja por 6 años con las mismas condiciones. En 1422 un nuevo vecino hizo lo propio por 5 años pero estableciendo que pagaría dos cuartas del pan que en ella cogiere (AHN, Clero, leg. 1066, $\mathrm{n}^{\circ}$ 6-1).

${ }^{1967}$ En 1418 fueron los 12 vecinos los que tomaron en censo los 12 quiñones de la granja de Milagros por 12 fanegas de pan mediano cada uno (total 144) a entregar por Santa María de Septiembre (PÉREZ EMBID, El Císter..., p. 505). En 1495 la villa de Aranda se hizo con la granja por un censo anual de 156 fanegas de pan, mitad trigo y mitad cebada, y dos pares de gallinas, más 35.000 maravedíes que debía abonar la villa en dos pagos (AGS, CC PUEBLOS, leg. 13, doc. 3). Pero en 1508 el monasterio de San Pedro y el conde de Miranda llegaron a un acuerdo por el que el lugar de Milagros pasó a manos del conde mediante una permuta. El conde adquirió la renta de Milagros más la "dudosa" jurisdicción del lugar a cambio de 11.000 maravedíes de juro sobre las alcabalas de Pinilla Trasmonte y Quintana del Pidio (AGS, CC PUEBLOS, leg. 13, doc. 6; y AHN, Clero, leg. 237, no 3, está última está fechada en 1509).

1968 Índice de los documentos..., Tomo I, p. 19. En los privilegios concedidos por diferentes monarcas a los cenobios de La Vid y Caleruega se incluía la cantidad de ganado.

1969 ÁLVAREZ PALENZUELA, Monasterios cistercienses..., pp. 224-225; y PÉREZ EMBID, El Císter..., p. 316.

${ }^{1970}$ PÉREZ EMBID, El Císter..., pp. 533-551. 
taca la bula otorgada en 1345 por el Papa Clemente VI que permitía conceder 40 días de indulgencia a quienes asistieran a los oficios y dieran limosna en los días festivos que se especificaban, intentando con esta medida la revalorización del santuario ${ }^{1971}$.

Pero la sensación de acoso sobre la jurisdicción y propiedades del monasterio se repitió continuamente a lo largo de todo el periodo bajomedieval. La institución de la encomienda también afectó al monasterio y así sabemos que en 1304 Gumiel dio a Pedro Núñez la granja de Mañalecos de por vida por haberlos defendido en las guerras pasadas. Situación similar se observa en la granja de Anaya Alfonso, tomada por Juan González de Avellaneda y que hasta 1395 no fue devuelta por su hijo, Pedro Núñez de Avellaneda, a pesar de las disposiciones testamentarias de su padre ${ }^{1972}$. Para intentar poner freno a estas prácticas el Papado trató de intervenir a través de unas constituciones que el cardenal don Pedro de Luna otorgó al monasterio. Entre ellas se encontraba una, De rebus ecclesie non alienandis, que específicamente afrontaba el asunto. Paralelamente, la Corona, a través de las diferentes iniciativas del monarca Juan I, intentó poner freno a las prácticas encomenderas aunque no conocemos por el momento ninguna intervención directa sobre el cenobio gomellense ${ }^{1973}$.

Asimismo las comunidades aldeanas aprovecharon la debilidad del monasterio para ampliar sus terrazgos o utilizar los recursos del cenobio gomellense. Así, por ejemplo, en 1301 los vecinos de Roa entraron en la granja gomellana de Villalobón para talar árboles ${ }^{1974}$. En este contexto de usurpación de propiedades, los monjes se vieron amparados en ocasiones por la Corona como ocurrió en la intervención real en 1307 para frenar las roturaciones de las propiedades del monasterio realizadas por los vecinos de Baños o Hontoria en sus granjas de San Pedro del Enebral. Algo similar ocurrió con la ocupación de la granja de San Martín de Porquera por los vecinos de Baños de Valdearados en $1404^{1975}$. No obstante, la efectividad de esta mediación real fue escasa a tenor de una nueva carta real que el procurador del monasterio entregó en 1333 a las autoridades de Zazuar para que realizaran una delimitación de las propiedades del cenobio

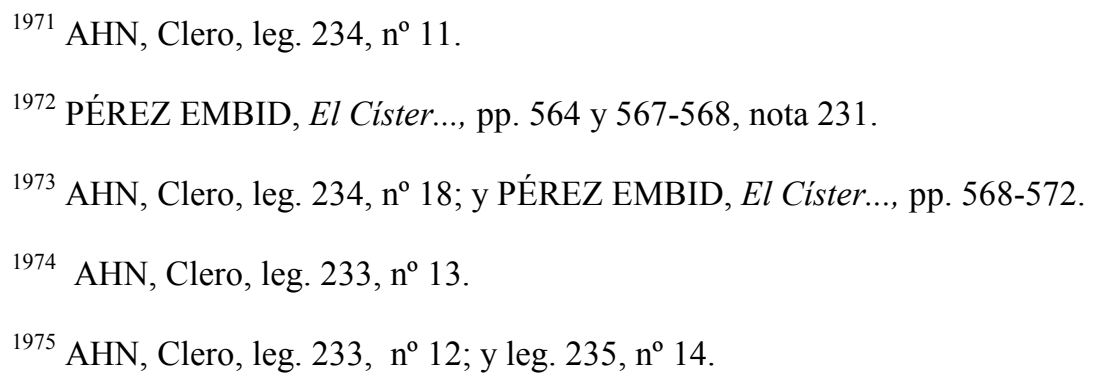


gomellense en la granja de San Pedro del Enebral ${ }^{1976}$. Todo ello llevó a que durante el siglo XV la comunidad de San Pedro se aviniera a negociar con las poblaciones limítrofes de sus granjas para tratar de conseguir cierta estabilidad. Esta iniciativa se materializó en los pactos alcanzados con Roa o los amojonamientos de San Pedro del Enebral en 1411, Villanuño, Mañalecos y Casa del Campo en $1420^{1977}$. Este tipo de pactos fue una práctica bastante habitual entre los cistercienses castellanos ${ }^{1978}$.

Además de las apropiaciones, también se reprodujeron en el periodo bajomedieval numerosos episodios de contestación al señorío abacial que se concretaron en la negativa al pago de los derechos o fueros sobre algunas de sus propiedades. Así ocurrió en 1443 cuando el concejo de Peñaranda se negó a pagar la renta del uso de una bodega del monasterio ${ }^{1979}$. En este contexto, destaca sobre todos los demás el conflicto que mantuvo el monasterio con los sucesivos condes de Miranda por la enajenación del señorío jurisdiccional y territorial del lugar de Milagros que abordaremos detenidamente más adelante ${ }^{1980}$.

El final de la Edad Media en el monasterio de San Pedro de Gumiel estuvo marcado por la disputa entre el Capítulo General del Císter y la Congregación de la Observancia. La reforma cisterciense comenzada en el primer cuarto de siglo por fray Martín de Vargas con la fundación en tierras toledanas de Montesión y la posterior expansión al cercano monasterio de Valbuena tuvo sus repercusiones en el cenobio gomellense varios años después, en la década de los $80^{1981}$. En este sentido, no debemos olvidar el importante apoyo de los Reyes Católicos al movimiento de renovación en el seno de la Iglesia hispánica motivado no sólo por su promoción de la reforma de la vida eclesiástica y religiosa, sino también con la intención de reafirmar su política de salvaguarda de

${ }^{1976}$ AMA, leg. 41, fol. 3.

1977 AHN, Clero, leg. 233, n 13; y AMA, leg. 41, fol. 3. En el caso de Roa se establecía que los vecinos raudenses podrían apacentar en la granja de Villalobón sus ganados pero respetando el prado, la huerta, el monte y la viña desde el primero de febrero hasta Santa María de Agosto y además tenían prohibido talar o cazar.

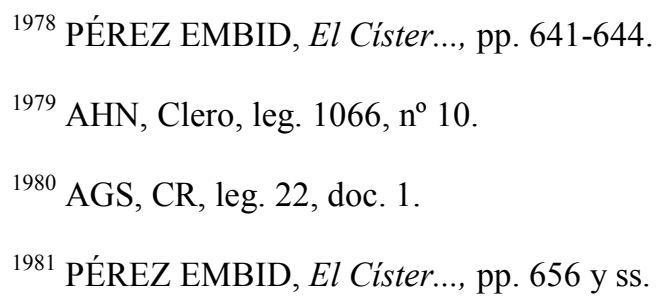


los recursos económicos del reino y de control político de los cargos eclesiásticos para evitar la injerencia extranjera ${ }^{1982}$.

En este contexto de la implantación de la Observancia en tierras castellanas debemos situar un acontecimiento que tangencialmente influyó en la comarca ribereña: la destitución en septiembre de 1479 del obispo de Osma, don Francisco de Santillán, como abad comendatario del monasterio cisterciense de Moreruela. Además de la destitución, el obispo fue prendido por el Papa, lo que generó cierta inestabilidad en el obispado degenerando en episodios de violencia ${ }^{1983}$.

En el año 1486 el monasterio se vio envuelto en varios episodios de violencia que Pérez Embid identifica con la disputa entre claustrales y observantes ${ }^{1984}$. A pesar de que este incidente tiene paralelismos con otros coetáneos en los que el recurso a la violencia era habitual entre las dos facciones cistercienses, creemos que este episodio violento en San Pedro de Gumiel no debe encuadrarse en la dinámica del enfrentamiento entre Observancia y Capítulo, sino más bien como una manifestación de las pugnas internas dentro de la familia cisterciense por hacerse con el control de una abadía, a la que no eran ajenos los intereses de la nobleza comarcana que trataba de ampliar sus influencias sobre las instituciones eclesiásticas. Esta afirmación se basa en el estudio detenido de los acontecimientos que desarrollaremos más adelante.

De lo que no hay ninguna duda es de la permanencia del monasterio gomellense en la posición de los claustrales en este periodo como se confirma en la facultad que en 1502 concedió el Capítulo General a los monasterios que permanecían fieles de poderse reunir en un Capítulo Provincial bajo la presidencia de los abades de Gumiel y Rioseco $^{1985}$.

${ }^{1982}$ VAL VALDIVIESO, M. I., “Las líneas maestras..., pp. 271-76; y PÉREZ EMBID, El Císter..., pp. 671 y ss.

${ }^{1983}$ PÉREZ EMBID, El Císter..., p. 674; RGS, 147909, fol. 138 y 148002, fol 215.

1984 PÉREZ EMBID, El Císter..., pp. 646-647 y 677-678; y PÉREZ CELADA, "El mundo monástico..., pp. 222-223). A pesar de utilizar la misma fuente (AGS, CC PUEBLOS, leg 17, docs. 169-173) nuestra lectura identifica los hechos a mediados del mes de febrero de 1486 mientras que Pérez Embid los sitúa en septiembre de 1485. La sentencia de la Audiencia está fechada en julio de 1486 sin especificar el día.

${ }^{1985}$ La incorporación definitiva de San Pedro de Gumiel a la Congregación de la Observancia parece que no se produjo hasta la segunda mitad del siglo XVI (PÉREZ EMBID, El Císter..., pp. 678 y 710). 
De nuevo durante los primeros años del Quinientos el monasterio se vio sometido a la presión de la nobleza comarcana, en este caso la injerencia vino de la mano del linaje de los Zúñiga Avellaneda. La vida monástica se vio alterada por un nuevo asalto del monasterio, esta vez de la mano de las gentes del conde de Miranda, que por medio de la fuerza pretendió situar a su hermano, don Íñigo López de Mendoza, como abad gomellano ${ }^{1986}$. Sin embargo, la intentona se frustró y se pasó a una segunda fase en el conflicto caracterizada por la negociación entre el conde de Miranda y el abad fray Roberto. El 1 de septiembre de 1508, después de que el abad hubo vendido el lugar de Milagros al conde, ambas partes acordaron finalizar el enfrentamiento mediante la firma de un asiento. Puesto que el abad Roberto e Íñigo de Mendoza tenían pendiente pleito en la Corte Romana sobre la posesión de la abadía de Gumiel ${ }^{1987}$ y esto les estaba costando mucho dinero, decidieron concertarse con licencia del Santo Padre. El acuerdo suponía la renuncia por parte de Mendoza a sus derechos sobre la abadía y recibía en compensación una pensión anual. El acuerdo fue ratificado por los diez monjes del monasterio reunidos en el capítulo celebrado el dos de octubre de $1510^{1988}$.

En conclusión, el monasterio de San Pedro de Gumiel de Izán se encontraba en los años finales de la Edad Media sumido en una situación crítica pues había perdido buena parte de su potencial económico como se evidencia en el creciente número de conflictos con los concejos vecinos que usurpaban sus otrora florecientes granjas. Pero sobre todo se vio afectado por un creciente proceso de injerencia por parte de la nobleza comarcana, protagonizado por la pujante casa de Miranda y otras poderosas familias comarcanas, que fue mermando tanto sus dominios territoriales como sus rentas. Asimismo, la comunidad gomellense se vio marginada dentro del movimiento reformista

1986 Apenas tenemos noticias de este asalto. Tan solo conocemos la información que refleja el propio Mendoza en su testamento cuando deja ordenado que se compense a la familia de un labrador de Villanueva ...que murio cuando el alcayde de Aça tomo la posesión de San Pedro (GARCÍA RÁMILA, El INEM Cardenal..., pp. 70 y ss.

${ }^{1987}$ Esta situación está vinculada con el fenómeno de los abades comandatarios nombrados desde Roma (PÉREZ EMBID, El Císter..., p. 589).

1988 AGS, CC PUEBLOS, leg. 13, docs. 6-4. Estos acuerdos económicos no eran ajenos a la familia cisterciense pues en muchas ocasiones las renuncias de derechos sobre ciertas abadías se compensaban con la creación de pensiones para los renunciantes. Fue el caso de Matallana donde el Papa impuso un abad comendatario y concedió unas pensiones a ciertos individuos para que cesasen en sus pretensiones sobre la abadía. También hicieron lo mismo los visitadores reformistas en Sandoval concediendo una pensión al antiguo abad para que renunciara a la perpetuidad (PÉREZ EMBID, El Císter..., pp. 590 y 677). 
que se extendía por toda la Corona de Castilla de la mano de la Congregación de la Observancia y se sumió en disputas internas que la debilitaron cada vez más.

\section{2. 3. Convento de Santo Domingo de Caleruega.}

En 1266 Alfonso X fundó un convento de dominicas en el solar en el que la tradición situaba el nacimiento del fundador de esta orden, Santo Domingo de Guzmán ${ }^{1989}$. Tras un proceso de adquisición de las divisas de la behetría de Caleruega, el monarca hizo entrega del señorío de la villa a la comunidad de canónigas del monasterio de Santa María de Castro en San Esteban de Gormaz y promovió el traslado de las monjas a Caleruega en $1270^{1990}$. Para Aguadé Nieto esta iniciativa real estaba profundamente imbricada en la política de Alfonso X encaminada a reforzar el poder de la monarquía, sirviéndose para ello de las órdenes mendicantes. Por una parte, se observa el reforzamiento del prestigio familiar con su matrimonio con doña Violante, familiar de la clarisa santa Isabel de Hungría; y por otra, y más importante para el tema que nos ocupa, apoyó la canonización del santo local, Domingo de Guzmán, dentro del contexto del proyecto nacionalista del rey Sabio ${ }^{1991}$.

El dominio del convento se incrementó considerablemente hasta mediados del siglo XIV gracias a las donaciones y, sobre todo, a los privilegios fiscales que le permitieron disfrutar de unos generosos recursos económicos con los que se adquirieron numerosas propiedades. Hacia 1360 la comunidad de religiosas contaba con heredades y derechos en una treintena de localidades situadas en el entorno de Caleruega o cerca del

${ }^{1989}$ Sobre el convento de Santo Domingo de Caleruega contamos con una abundantísima documentación publicada por MARTÍNEZ LIÉBANA, E., Colección Diplomática de Caleruega. Vergara, 1931 Además existe una prolija producción historiográfica entre la que destacamos la obra de GONZÁLEZ GONZÁLEZ, C., sobre todo con su monografía Real Monasterio de Santo Domingo de Caleruega. Salamanca, 1993. También son interesantes los numerosos artículos que han aparecido en las diferentes Jornadas de Estudios Medievales celebradas en el mismo convento a mediados de los años 90. En los últimos años ha visto la luz una tesis sobre el cenobio calerogano de la mano de la doctora RÍOS DE LA LLAVE que se ha traducido en una amplia monografía sobre el asentamiento de las órdenes femeninas en Castilla y los primeros siglos de vida del monasterio de Santo Domingo (Mujeres de clausura en la Castilla medieval: El Monasterio de Santo Domingo de Caleruega. Madrid, 2007).

1990 ÁLVAREZ BORGE, Poder y relaciones..., pp. 269-270. Este autor presenta la configuración inicial de Caleruega como villa de behetría. En su estudio reconstruye la comunidad de sus diviseros y el proceso de donación de las divisas a la comunidad religiosa que previamente había adquirido el monarca o que fueron cedidas directamente por algunos miembros destacados de la nobleza castellana.

1991 AGUADÉ NIETO, S. “Alfonso X y las órdenes mendicantes” en Könige, Landesherren und Bettelorden. Konflikt und Kooperation in West-und Mitterleuropa bis zur Frühen Neuzeit. Werl, 1998, pp. 288-292. Esta misma idea la presenta también en el prólogo de la obra de RÍOS DE LA LLAVE. 
espacio originario de San Esteban de Gormaz. Su riqueza también se manifestó en la rápida creación de una importante cabaña ganadera que ya en 1300 estaba constituida por 10.000 ovejas, 1.000 vacas, más de 1.000 puercos, 200 yeguas y 500 cabras y que gozaba de exención fiscal gracias a una serie de privilegios reales ${ }^{1992}$. No obstante, esta ganadería sufrió los rigores de la crisis y se vio considerablemente mermada a finales del siglo $\mathrm{XIV}^{1993}$. Los grandes beneficios que procuraba la ganadería a la comunidad dominica explican la política de protección de pastos que desarrollaron las sucesivas prioras durante toda la Edad Media, que se preocuparon constantemente por que sus vasallos ...non entrasen nin labrasen nin rompiesen los exidos. Todavía en 1510 se mantenía la dinámica de sancionar las roturaciones de términos concejiles y establecían que ...lo asi rompido, alçado el pan, quede por pasto comun ${ }^{1994}$.

A la promoción real y nobiliaria se sumó la iniciativa del papado que desde finales del siglo XIII concedió indulgencias a todos aquellos fieles que acudieran a la iglesia de Santo Domingo y entregaran sus limosnas ${ }^{1995}$.

Es significativo que el mayor avance en la creación y consolidación de este convento dominico se produjo precisamente en un periodo, la primera mitad del siglo XIV, que fue crítico para sus vecinos monásticos como hemos visto en los casos de Santa María de La Vid o San Pedro de Gumiel. Álvarez Borge cree que se debió sobre todo a la importancia de las rentas provenientes de la fiscalidad regia (portazgos, pechos, salinas, etc.) que permitieron afrontar con éxito su política de expansión a través de las compras $^{1996}$. No obstante, las características de estas rentas también generaron un im-

1992 Alfonso X concedió en 1277 un privilegio por el cual eximía de impuestos al ganado del monasterio y garantizaba su libre tránsito por todo el reino. Sancho IV lo confirmó en 1295, estableciendo un número máximo de cabezas. Los sucesivos monarcas confirmaron este privilegio (MARTÍNEZ LIÉBANA, Colección Diplomática..., docs. XX y LI, pp. 31-32 y 55; y LOPERRÁEZ CORVALÁN, Descripción histórica..., Vol. II, p. 207).

${ }^{1993}$ Eso parece deducirse del privilegio de Juan I otorgado en 1390 en el que se redujo el número de cabezas a 2.000 ovejas, 200 vacas, 500 cabras, 100 cerdos y 50 yeguas (MARTÍNEZ LIÉBANA, Colección Diplomática..., doc. CXII, p. 138). 179 y $370-375$.

1994 MARTÍNEZ LIÉBANA, Colección Diplomática..., docs. CXLIV y CCLXXXIV, pp. 174-

${ }^{1995}$ En 1297 el Patriarca de Constantinopla concedió 40 días de indulgencia a los fieles que visitaran el templo y dieran limosnas; en 1306 el Papa Clemente V otorgó 100 días si la visita se realizaba en la festividad de Santo Domingo o de San Pedro (MARTÍNEZ LIÉBANA, Colección Diplomática..., docs. CXCVIII y CXCIX, pp. 252-254).

1996 ÁLVAREZ BORGE, Poder y relaciones..., pp. 219-220. 
portante número de pleitos y molestias para la comunidad que en ocasiones no conseguía percibirlas y se veía obligada a litigar. Los casos más significativos fueron los de las rentas asentadas en las salinas de Añana, Poza y Rocío o en el portazgo de Medina del Campo ${ }^{1997}$.

En este sentido, tampoco era nada desdeñable el aporte económico que suponían las dotes y herencias de las monjas que ingresaban en el monasterio ${ }^{1998}$, muchas de ellas de importantes familias nobiliarias ${ }^{1999}$. Baste como ejemplo la herencia de doña Toda Martínez que se vendió en 1276 por 10.000 maravedíes que pasaron al patrimonio del convento. O las tres hermanas Martínez que hacia 1344 traspasaron al convento la herencia de su difunto padre ${ }^{2000}$. El convento también acogió a viudas nobles que entregaban todos sus bienes a cambio de que ...me mantengades en toda la mi vida de aquellas cosas que me cumplieren a mi onra ${ }^{2001}$. En este sentido cabe comentar el caso de doña María Díaz, viuda de don Juan González de Heredia, que solicitó entrar como monja junto a su hija Teresa, de la que era tutora, y ofreció todos sus bienes en Baños y Gumiel al convento. No obstante, introdujo una cláusula por la que si su hija no quisiere tomar este habito se le debía abonar 2.400 maravedíes, que era la parte que le correspondía de herencia, y se le permitiría abandonar el convento libremente ${ }^{2002}$.

Fue tal la capacidad de atracción del convento que las autoridades dominicas se vieron obligadas a establecer a los pocos años de la fundación un límite al número de

${ }^{1997}$ GONZÁLEZ GONZÁLEZ, Real Monasterio..., pp. 125-128; y RÍOS DE LA LLAVE, Mujeres de clausura..., pp. 391 y ss.

${ }^{1998}$ En 1287 Sancho IV concedió el privilegio de que las monjas ...ereden bien e complidamente e ninguno y non gelo enbargue, aunque ya anteriormente doña Toda Martínez, priora en 1274, había obtenido licencia para heredar de sus padres (MARTÍNEZ LIÉBANA, Colección Diplomática..., docs. XLI y CCL, pp. 47 y 335-336).

1999 En este sentido, resulta muy interesante el planteamiento realizado por RÍOS DE LA LLAVE sobre la condición social de las monjas y la irradiación e influencia social de la comunidad de Caleruega. La pervivencia de la situación social privilegiada a través del mantenimiento del tratamiento de doña parece un claro exponente de la realidad feudal que se impuso en una comunidad teóricamente fraternal. Lamentablemente la escasez de documentación no permite obtener unos resultados óptimos (Mujeres de clausura..., pp. 174-183 y 367-370).

${ }^{2000}$ MARTÍNEZ LIÉBANA, E. Colección Diplomática..., docs. CCLII y CCLXXXIII, pp. 339340 y $369-370$.

${ }^{2001}$ En 1326 Doña María, viuda de don Lope de Baños, entregó todos sus bienes en el lugar de Baños a cambio de que el convento la proveyera de todo lo necesario el resto de sus días (MARTÍNEZ LIÉBANA, Colección Diplomática..., doc. CCLXXV, p. 363).

${ }^{2002}$ MARTÍNEZ LIÉBANA, Colección Diplomática..., doc. CCLXXXVII, pp. 376-377. 
religiosas que podían formar parte de la comunidad: en 1288 el Maestro General de la Orden, fray Munio de Zamora, ordenó que no se admitieran en el convento más de cincuenta monjas y en 1331 uno de sus sucesores, fray Bernabé de Vercelis, fijó el número máximo en sesenta religiosas ${ }^{2003}$.

La suma de exenciones fiscales, cesión de fiscalidad regia, donaciones de particulares y las dotes de las monjas, permitieron configurar un importante patrimonio territorial que se extendía por toda la Ribera, con gran concentración en el entorno originario de San Esteban de Gormaz y Caleruega (Espinosa, Valdeande, Baños, Torrecilla, Bañuelos, Aranda, Arauzos, etc.), extendiéndose además a Peñafiel. Asimismo en Burgos gestionaba un importante capital rústico e inmobiliario ${ }^{2004}$.

Desde el nacimiento de la institución y hasta bien entrado el siglo XV tenemos constancia de que la hacienda próxima al convento se explotaba de forma directa a través de colonos, yugueros y las sernas de los vasallos de Caleruega ${ }^{2005}$. Sin embargo, nada sabemos sobre cómo se gestionaban las propiedades alejadas del cenobio, aunque podemos presuponer que se arrendaban como deja entrever la documentación existente a partir de principios del siglo $\mathrm{XV}^{2006}$. Durante este siglo este sistema indirecto de explotación se extendió también a las propiedades del monasterio en los pueblos cercanos donde los concejos (Baños de Valdearados, Arauzo de Salce y Caleruega), arrendaron las heredades a cambio de un censo generalmente fijado en una renta anual en espe-

${ }^{2003}$ En el documento de 1331 se deja entrever que el convento sufría presiones, en ocasiones acompañadas de violencias, para aceptar a las pretendientes (MARTÍNEZ LIÉBANA, Colección Diplomática..., docs. CCLXXII y CCLXXVII, pp. 352-354 y 364). Fue tal el éxito que cuando en 1344 el Infante don Juan Manuel quiso crear un convento en Cifuentes, acudió a Caleruega para reclutar monjas para su fundación. Algo similar debió pasar con Lequeitio y Quejana (GONZÁLEZ GONZÁLEZ, Real Monasterio..., pp. 132-134). También hacia 1468 la priora de Caleruega, doña Constanza Manuel, fue comisionada por el obispo de Burgos para ocupar el cargo de abadesa en el benedictino monasterio de Tórtoles de Esgueva (pp. 144-146).

${ }^{2004}$ La obra de RÍOS DE LA LLAVE incluye varios mapas que reflejan el dominio señorial del monasterio así como la ubicación de sus compras, donaciones o permutas (Mujeres de clausura..., pp. 231,283 y 298).

${ }^{2005}$ Es significativa la lista de trabajadores del monasterio que aparece en un documento de 1346 que están vinculados con diferentes actividades relacionadas con el trabajo de la tierra (ortolanos) y la ganadería (pastores e yeguerizos). También aparecen molineros e colmeneros y otros vecinos vinculados al monasterio (paniaguados). Una de las cláusulas del documento establecía que el conçejo que faga las sernas al dicho monasterio... cada año en labrar las viñas e la orden que les de la provisión de pan e vino e queso segund que es devida de constumbre (MARTÍNEZ LIÉBANA, Colección Diplomática..., doc. CCLXXXIV, pp. 370-375).

${ }^{2006}$ En 1403 los procuradores del convento dieron en censo perpetuo unas casas en Gamonal y en 1415 se encensaron las propiedades de Villavicencio (MARTÍNEZ LIÉBANA, Colección Diplomática..., docs. CCXCIX y CCCII, pp. 387 y 389-390). 
$\operatorname{cie}^{2007}$, aunque se mantuvo todavía la explotación directa en las propiedades de Caleruega $^{2008}$.

En conclusión, podemos afirmar que el convento de Santo Domingo contaba con un notable nivel de riqueza conformado por las propiedades a las que nos acabamos de referir más los beneficios que reportaba el importante rebaño disperso por todo el reino. Circunstancia que, sin lugar a dudas, convirtió al cenobio en un elemento muy atractivo para todos sus vecinos, sobre todo para la pujante nobleza comarcana.

Durante el siglo XIV la comunidad dominica de Caleruega se vio afectada por la inestabilidad que padeció Castilla y vio aumentar la presión de sus vecinos, nobiliarios y concejiles, sobre su patrimonio. En este sentido cabe interpretar la solicitud de ayuda realizada por la priora al Papa a principios de siglo. Desde Poitiers, Clemente V comisionó al obispo de Osma mediante una bula para que acogiera al monasterio bajo su protección $^{2009}$. Desconocemos en concreto las agresiones sufridas por las monjas ni sus protagonistas, pero parecen estar en consonancia con la dinámica de injerencia nobiliaria que ya hemos visto en Santa María de la Vid y San Pedro de Gumiel. Así, y a tenor de la información transmitida por la documentación, cabe destacar cómo durante esta época de inestabilidad fueron en ocasiones los propios representantes del rey, en este caso los merinos de la Merindad de Santo Domingo de Silos, los que actuaron contra los privilegios del monasterio. Durante el difícil periodo de las regencias de principios del siglo XIV el monasterio consiguió de Fernando IV el privilegio de eximirse de la justicia de los Merinos ${ }^{2010}$, pero a lo largo de todo su reinado y durante buena parte del de su

${ }^{2007}$ En 1430 el concejo de Baños arrendó la hacienda del monasterio en ese lugar y en 1498 hizo lo mismo con la finca de Torrecilla; en 1502 fue el concejo de Arauzo de Salce el que arrendó las propiedades que allí tenían las monjas; y en 1518 el propio concejo de Caleruega realizó una escritura de censo sobre el término de San Martín de Bañuelos (MARTÍNEZ LIÉBANA, Colección Diplomática..., docs. CCCV, CCCXV, CCCXVIII y CCCXX, pp. 391,399 y 401-405).

${ }^{2008}$ En 1435 todavía se mantenía al servicio directo del monasterio dos colonos y un hortelano a los que se eximía del pago de la moneda (MARTÍNEZ LIÉBANA, Colección Diplomática..., doc. CCCVII, , pp. 393-396).

${ }^{2009}$ Bula de Clemente V emitida el 3 de marzo de 1307. En ella el Papa solicita al obispo que utilice la fuerza de la censura eclesiástica contra robos, raptos e invasiones sin especificar más (MARTÍNEZ, E. Colección Diplomática..., doc. CC, pp. 254-255; y GONZÁLEZ GONZÁLEZ, Real Monasterio..., pp. 120-121).

${ }^{2010}$ MARTÍNEZ LIÉBANA, Colección Diplomática..., doc. LXII, pp. 64-66. 
hijo Alfonso XI estos oficiales reales no respetaron la jurisdicción de la priora y usurparon sus funciones judiciales ${ }^{2011}$.

Tampoco se mantuvo la comunidad dominica al margen del fenómeno de la encomienda. La primera de ellas fue la más llamativa pues en 1298 el convento de Santo Domingo cayó bajo la influencia del poderoso monasterio de las Huelgas de Burgos por iniciativa de su abadesa, la infanta Blanca de Portugal, que ofreció su protección a título personal $^{2012}$. Más adelante, en 1320 don Juan, hijo del Infante don Juan, tomó bajo su encomienda a la priora y las monjas del monasterio ...e a todos los vasallos, e a todas las sus cosas e a todos los sus ganados por doquier que los ayan e los $\operatorname{trayan}^{2013}$. Poco después, en 1326, hizo lo mismo don Fernando, hijo de don Diego López de Haro, junto a las propiedades y vasallos de Espinosa de Cervera ${ }^{2014}$. Más adelante, en 1395, Caleruega estuvo bajo la protección de don Diego López de Zúñiga, señor de Béjar ${ }^{2015}$. Parece evidente que ninguna de estas encomiendas se prolongó mucho en el tiempo y debemos ponerlas en relación con los movimientos propios de la inestabilidad del momento.

Algo más serio parece el problema del monasterio para hacer efectiva su jurisdicción sobre sus propios vasallos de la villa de Caleruega. Más adelante analizaremos el conflicto que la priora mantuvo con sus vasallos desde la década de los cuarenta del siglo XIV y que se mantuvo intermitentemente hasta las primeras décadas del Quinientos. En resumen, el aumento de la presión señorial de la priora y comunidad dominica sobre sus vasallos recibió la contestación del concejo calerogano. A pesar de las conti-

${ }^{2011}$ Esta situación se intuye en las notificaciones personales de Alfonso XI a los Merinos Mayores, Pedro González de Sandoval en 1314 y Garcilaso de la Vega en 1315. Circunstancia que se evidencia claramente en las ordenes dadas a Garcilaso de la Vega en 1326 y reiteradas en 1329 para que no entre ningún juez en Caleruega pues ...queredes entrar por fuerça en el dicho lugar de Caleruega a merynar, et por que vos lo non consienten e çierran las puertas del dicho lugar que prendades los sus vasallos do los fallares fuera de la villa (MARTÍNEZ LIÉBANA, Colección Diplomática..., docs. LXXI, LXXII, LXXXI Y LXXXV, pp. 81-83 y 102-195).

${ }^{2012}$ MARTÍNEZ LIÉBANA, Colección Diplomática..., doc. LIV, p. 57.

${ }^{2013}$ MARTÍNEZ LIÉBANA, Colección Diplomática..., doc. LXXVIII, pp. 87-88.

${ }^{2014}$ MARTÍNEZ LIÉBANA, Colección Diplomática..., doc. LXXXIV, pp. 103. Este mismo autor también incluye en su obra una referencia del archivo de Béjar que refleja una nueva encomienda en 1331 de don Diego López de Haro (Ídem, pp. 105-106).

${ }^{2015}$ No estamos seguros de si actúa como encomendero del monasterio o de la behetría de Caleruega, o de ambos. Lo cierto es que Ochoa Martínez de Gauna, merino por Diego López de Astuñiga justicia mayor del rey, aparece como juez árbitro nombrado por Caleruega en un apeo con el vecino lugar de Valdeande. (MARTÍNEZ LIÉBANA, Colección Diplomática..., doc. CCXCVII, pp. 386-387). 
nuas sentencias y disposiciones a favor de la comunidad dominica, el conflicto permaneció latente durante los siglos bajomedievales. Al final del periodo que nos ocupa la situación seguía siendo tensa entre señoras y vasallos, lo que provocó la intervención de la Corona en el conflicto a través de la figura del corregidor arandino, sin que ello supusiera la solución del problema ${ }^{2016}$.

Por otra parte, y como ocurrió con el resto de las instituciones eclesiásticas, las propiedades del monasterio también se vieron sometidas a presiones por parte de los concejos vecinos. El primer enfrentamiento del que tenemos noticia estaba relacionado con la expansión ganadera del convento pues en 1332 fue necesario llegar a un acuerdo para que sus rebaños pudieran pastar en el término de Baños de Valdearados, evidenciando una vez más la pujanza ganadera que adquirió la comunidad dominica en sus primeros años de existencia ${ }^{2017}$. Desde los últimos años del siglo XIV y durante todo el Cuatrocientos se reprodujeron incidentes de este tipo con los concejos vecinos: en 1396, 1496 y 1498 con Valdeande; en 1412 con Gumiel de Izán; 1434 en San Esteban de Gormaz; 1466 en Olmos; 1491 en Peñaranda; en 1498 y 1514 con en el propio concejo de Caleruega; y con Tubilla en $1501^{2018}$. Las diferencias también se produjeron con otras comunidades religiosas como en 1463 con las Beatas de Aranda de Duero ${ }^{2019}$. Todos estos conflictos son una manifestación más de la progresiva recuperación económica y el avance roturador de los siglos bajomedievales.

Otro de los problemas que acuciaron a la comunidad dominica a finales de la Edad Media fue la implantación de la reforma Observante. Tras los primeros pasos emprendidos por fray Álvaro de Córdoba en los años 20 del siglo XV, no fue sino una treintena de años después cuando el cardenal Juan de Torquemada convirtió al convento de San Pablo de Valladolid en foco irradiador de la reforma en el seno de la familia dominicana ${ }^{2020}$. A pesar de la oposición de la Provincia de España, la promoción y protec-

${ }^{2016}$ Este problema será analizado pormenorizadamente en el apartado dedicado a los conflictos relativos a la contestación antiseñorial.

${ }^{2017}$ MARTÍNEZ LIÉBANA, Colección Diplomática..., doc. CCLXXIX, pp. 366-367.

2018 MARTÍNEZ LIÉBANA, Colección Diplomática..., pp. 386-399; AGS, CR, leg. 22, doc. 1; CC PUEBLOS, leg. 5, doc. 67; y RGS, 149612, fol. 171.

${ }^{2019}$ MARTÍNEZ LIÉBANA, Colección Diplomática..., doc. CCCIX, pp. 396-397.

${ }^{2020}$ GARCÍA ORO, J., "Conventualismo y Observancia. La reforma de las órdenes religiosas en los siglos XV y XVI”, en Historia de Iglesia en España Madrid, 1980, vol. III-1º, pp. 211-349, en concre- 
ción de la reina Isabel al proyecto reformista hizo que ésta se extendiera ampliamente por Castilla durante los años 70 , aunque no sin ciertas resistencias como las mantenidas por el convento de San Esteban de Salamanca.

En este contexto, la implantación de la Observancia en el convento de Santo Domingo de Caleruega debió de realizarse en la segunda mitad de la década de los 70 . Por aquellas fechas los frailes de San Pablo de Valladolid, de la mano del vicario fray Alfonso de San Cebrián, impusieron la reforma y eliminaron del claustro dominico a aquellas monjas que no quisieron aceptarla ${ }^{2021}$. No sin ciertos recelos y contratiempos que analizaremos más adelante, la Observancia se estableció en Caleruega.

Por último, quisiéramos finalizar este apartado señalando cómo al final del periodo que nos ocupa el convento de Santo Domingo se vio inmerso en el intrincado tejido de control del territorio que fue desarrollando la casa condal de Miranda en la comarca ribereña. En 1522 se constata que la priora, doña Francisca de Mendoza, nombró como juez de residencia al licenciado Aguiar, que por la época era justicia mayor del Conde de Miranda ${ }^{2022}$. Parece evidente que la larga mano del conde se extendió también por el monasterio de Caleruega como ya hemos visto que sucedió en Santa María de la Vid y San Pedro de Gumiel y que también se reprodujo en la cercana Colegiata de Covarrubias $^{2023}$. Esta influencia del clan de los Zúñiga se vio incrementada con la presencia de varias de las hermanas e hijas de los condes entre las religiosas del convento a lo largo de todo el siglo XVI, no descartando que la propia doña Francisca de Mendoza perteneciera a esta familia ${ }^{2024}$.

to pp. 263-266; BELTRÁN DE HEREDIA, V., Historia de la Reforma de la Provincia de España (14501550). Roma, 1939, pp. 18-19; y RÍOS DE LA LLAVE, Mujeres de clausura..., pp. 217-219.

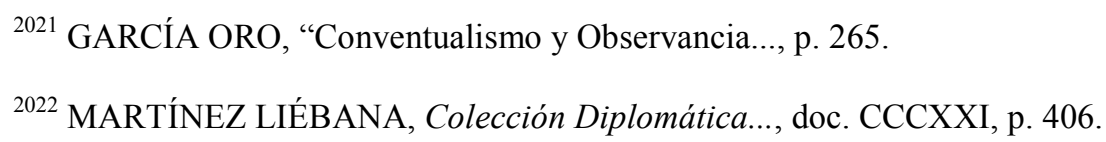

${ }^{2023}$ Recordemos que don Íñigo López de Mendoza consiguió por aquellos años la abadía de Santa María de La Vid y la colegiata de Covarruvias. Además el conde había llegado a un acuerdo en 1508 con el abad de Gumiel por el que renunciaba en nombre de su hermano a los derechos sobre la abadía a cambio de una importante compensación económica.

${ }^{2024}$ La documentación consultada indica que don Pedro de Zúñiga tuvo siete hijos de doña Catalina de Velasco y Mendoza: Francisco, Pedro, Íñigo, Juan, Aldonza, María y Catalina. Aldonza y Catalina se casaron. María, según MERINO GAYUBAS, fue monja de Caleruega, así como Mencía, otra hermana que no hemos logrado localizar documentalmente. Su sobrina Ana también fue religiosa de Santo Domingo en 1528 (Genealogía del solar de Guzmán..., vol. II, pp. 731-733). Recordemos que don Íñigo utilizó el apellido de su abuela materna doña Mencía de Mendoza, hermana del Cardenal Pedro González de Mendoza, para emprender su carrera religiosa. 
En conclusión, la comunidad dominica de Santo Domingo de Caleruega fue la institución eclesiástica ribereña que gozaba a finales de la Edad Media de una mejor situación económica y disfrutaba de mayor autonomía si la comparamos con sus vecinas. No obstante, el convento no se libró de los intentos de injerencia sobre todo por parte de la nobleza comarcana, ni de los conflictos propios de la época, con especial incidencia de los movimientos contestatarios a la autoridad señorial.

\section{2. 4. Convento Domus Dei de La Aguilera.}

Una de las instituciones religiosas que más peso tuvo en la vida religiosa ribereña en los años finales de la Edad Media fue el convento franciscano de La Aguilera. Llama la atención que este cenobio no haya sido objeto de estudio en los últimos años y que contemos con un escasísimo material historiográfico para acercarnos a la realidad de esta institución ribereña. Disponemos para ello casi exclusivamente de la interesante colección de artículos publicados por el padre Luis Carrión González en el Archivo Ibero-americano, que culminaron en 1930 con la edición de su monografía Historia documentada del convento de Domus Dei de La Aguilera ${ }^{2025}$. El infructuoso acceso a otro tipo de documentación nos ha obligado a plantear este apartado de nuestro trabajo en tres partes bien definidas. La primera se centra en todos los aspectos relativos a la creación del convento y su consolidación en el contexto de la lucha interna dentro de la familia franciscana entre conventuales y observantes. La segunda tratará de indagar las bases y estrategias económicas sobre las que se mantuvo la comunidad franciscana. Por último, intentaremos analizar el protagonismo de este convento que se convirtió en el escenario de acontecimientos muy relevantes en momentos muy críticos para la historia de Castilla en el tránsito hacia la Modernidad.

En el contexto del proceso reformador de la familia franciscana, uno de sus primeros protagonistas, fray Pedro de Villacreces, fundó hacia 1404 un eremitorio junto a una pobre ermita en el lugar de La Aguilera ${ }^{2026}$. En opinión de Carrión González, esta fundación se produjo en La Aguilera por la vinculación del reformador con el por en-

${ }^{2025}$ El autor se hace eco de los estudios anteriores e introduce los datos obtenidos de las fuentes documentales del propio monasterio, municipio y parroquia. En varios números del Archivo IberoAmericano publicó alguno de los documentos conservados por entonces en el Archivo Conventual.

${ }^{2026}$ La leyenda sobre la creación del santuario señala que los vecinos de La Aguilera observaron cómo en las cercanías había un lugar sobre el que descendían luces del cielo; el obispo, señor del lugar, decidió construir allí una ermita para celebrar el milagro. 
tonces obispo de Burgos, don Juan de Villacreces, señor del lugar y hermano de fray Pedro $^{2027}$. Ya desde los primeros años de su creación el eremitorio estuvo sumido en disputas fraticidas pues el cercano monasterio de San Francisco de Silos pretendía anexionar la nueva fundación. Esta amenaza fue eliminada por las gestiones realizadas por Villacreces en Constanza donde consiguió el reconocimiento formal del Papa que se materializó en las Constituciones Apostólicas ${ }^{2028}$.

Acompañando a Villacreces se instalaron en La Aguilera varios de sus discípulos entre los que destacaban fray Pedro de Santoyo y fray Lope de Salinas, quienes jugaron un importante papel en la posterior difusión de la reforma por toda Castilla. Entre todos los discípulos sobresalió la figura de fray Pedro Regalado que se hizo cargo de la nueva fundación y, gracias a su aura de santidad, consolidó al convento como uno de los centros de peregrinación más activos de la región ${ }^{2029}$.

Precisamente en su condición de Vicario de la Domus Dei, fray Pedro consagró la iglesia conventual el 4 de octubre de 1438, bajo la advocación de la Anunciación ${ }^{2030}$. Pero los años de gobierno de fray Pedro Regalado se caracterizaron sobre todo por la disputa entre Conventuales y Observantes. El mantenimiento de los principios de Villacreces, basados en la aplicación de la reforma pero manteniendo el reconocimiento de la autoridad de los ministros generales conventuales, hicieron que las comunidades de La Aguilera y El Abrojo navegaran entre dos aguas, convirtiéndose en objetivo de sometimiento por ambas partes, sobre todo de la Observancia que pretendía aglutinar a los reformistas bajo la autoridad de un Vicario General ${ }^{2031}$. En este ambiente de confrontación fraterna se desarrollaron los últimos años de Pedro Regalado al frente del convento ribereño hasta su fallecimiento el 30 de marzo de 1456. Tomó el relevo fray Alfonso de

2027 CARRIÓN GONZÁLEZ, L., Historia documentada del convento Domus Dei de La Aguilera. Madrid, 1930, pp. 86-87. La Aguilera estuvo vinculado al obispado de Burgos por lo menos desde mediados del siglo XIII cuando Leonor González de Lara donó al obispo la mitad de esta villa (SÁNCHEZ DE MORA, Los Lara..., doc. 223).

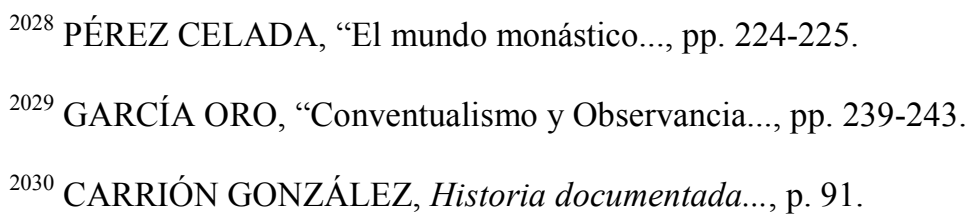

${ }^{2031}$ Situación que se refleja perfectamente en una carta de apelación realizada en 1453 por fray Pedro Regalado en la que señalaba que ...temia e teme que algunas personas, asi religiosas como seglares, han ganado e impetrado o ganaran adelante algunas bulas o breves del Santo Padre Apostolico las quales pueden ser o seran en detrimento o amenguamiento del serviçio de Dios e de las graçias e esençiones a estas dichas casas... (CARRIÓN GONZÁLEZ, Historia documentada..., p. 94). 
Valladolid. Con él se inició una larga lista de vicarios bianuales que controlaron los cenobios del Domus Dei y del Scala Coeli de El Abrojo. Estos vicarios mantuvieron su autonomía y, a pesar de las presiones de los reformistas santoyanos, tan solo tuvieron que rendir cuentas ante el General y Provincial de la Orden.

Esta postura reformista, pero sometida a los provinciales observantes, fue clave para que la Custodia de Domus Dei se hiciera cargo de la reforma del importante estudio de San Francisco de Toledo hacia $1462^{2032}$.

Los años centrales del Cuatrocientos supusieron para la Vicaría de La Aguilera su consolidación como institución religiosa en la comarca de la mano de la rápida expansión de la fama de santidad de su habitante más ilustre, fray Pedro Regalado. Gracias a su prodigalidad milagrera, junto con la concesión por parte del Papa de una serie de privilegios, licencias y exenciones, procuraron un nada despreciable incremento de las limosnas que mantenían a la comunidad ${ }^{2033}$. Asimismo se observa cómo la propuesta espiritual del Domus Dei se extendió por otros territorios más lejanos del reino de Castilla y así, a principios de los años 60, los conventos de Herrera de Pisuerga y Carrión de los Condes se incorporaron a la Vicaría de La Aguilera, provocando con ello la airada respuesta de los Conventuales de Palencia que reclamaron para sí el cenobio carrionense. Una década después la Vicaria contaba ya con seis casas extendidas por el corazón de Castilla con la anexión de Santa Marina de Manzaneda en tierras salmantinas ${ }^{2034}$.

La consolidación del convento de La Aguilera en el seno de la familia franciscana castellana se produjo en 1481 cuando adquirió la categoría de Custodia de Domus $D e i$ en virtud de un breve del Papa Sixto IV en $1481^{2035}$. Durante los años finales del siglo XV el radio de acción del cenobio ribereño se extendió con las incorporaciones de las comunidades de San Luis de Gormaz, San Francisco de Almazán y los homónimos de Soria, Atienza y San Esteban de Gormaz. En los primeros años del siglo XVI se ad-

${ }^{2032}$ GARCÍA ORO, “Conventualismo y Observancia... p. 259.

${ }^{2033}$ Los milagros atribuidos comenzaron poco después de morir el Santo Regalado. La primera semana de abril de 1456 una mujer tullida de Fuentelisendo fue sanada por su intercesión. El nuevo vicario decidió llamar a un escribano para que recogiese notarialmente los testimonios de los milagros y así lo hizo durante seis meses. Todos ellos se redactaron en el llamado Cuaderno de los milagros póstumos del Santo (CARRIÓN GONZÁLEZ, Historia documentada..., pp. 99-101 y 195 y ss).

2034 CARRIÓN GONZÁLEZ, Historia documentada..., pp. 100-102. No obstante, Manzaneda dejó de estar bajo el control de la Domus Dei en los últimos años del siglo XV pues su nombre no aparece reflejado en las congregaciones custodiales de esos años.

2035 CARRIÓN GONZÁLEZ, Historia documentada..., pp. 104 y ss. 
hirió el nuevo convento de San Francisco de Aranda y se recibió de la Provincia de Santoyo el de Silos en permuta por el de Carrión de los Condes ${ }^{2036}$. En 1503 también entró a formar parte de la familia del Domus Dei la casa de Nuestra Señora de Alveinte, en la serranía burgalesa.

Las tensiones entre los reformistas observantes y villacrecianos en el reino de Castilla se mantuvieron durante todo el reinado de los Reyes Católicos, apreciándose una clara apuesta de la Corona por el sector observante. En este sentido, destacan sobre todo las distintas iniciativas promovidas o amparadas por el franciscano y futuro cardenal Jiménez Cisneros. En su papel de Vicario provincial participó personalmente en la Congregación Custodial de 1494 y la Corona le reclamó constantemente su intervención para tratar de solucionar los debates internos entre la provincia de Santoyo y la Custodia de Domus Dei ${ }^{2037}$.

No obstante, el triunfo de la Observancia no se produjo definitivamente hasta la unificación de la Provincia de Santoyo y la Custodia de Domus Dei en la nueva Provincia de Santa María de la Concepción. Tal decisión se tomó en el Capítulo General de la Orden celebrado en Lyon en 1518 y se hizo efectiva en la reunión celebrada en Castrojeriz en septiembre de ese mismo año, no sin ciertas reticencias por parte de la Custo$\operatorname{dia}^{2038}$

Estas discrepancias se pusieron de manifiesto oficialmente en el Capítulo provincial de 1523 en Palencia. Para Carrión González la iniciativa del Comisario General, fray Francisco de los Ángeles, de fundar en la provincia de la Concepción la santa Recolección siguiendo el modelo de recogimiento, pobreza y soledad ya experimentado en Italia, no fue sino una maniobra para reconducir las quejas de los villacrecianos de la antigua Custodia de Domus Dei. Efectivamente en La Aguilera y El Abrojo, más otros tres cenobios de la antigua provincia de Santoyo, se impuso este nuevo modelo de vida recoleta, asignando al convento ribereño el papel de casa principal ${ }^{2039}$.

${ }^{2036}$ Solución que no hizo más que sancionar una realidad efectiva desde 1494 cuando el convento de Carrión fue despojado de la Custodia por la fuerza de las armas con el apoyo y consentimiento de la Corona (AMA, leg. 43, doc. 23; y AGS, RGS, 149303, fols. 259 y 367). Más adelante abordaremos la creación de la comunidad arandina y la disputa jurisdiccional con la Provincia de Santoyo.

${ }^{2037}$ AGS, CC, CÉDULAS, libro 4, leg. 223, doc. 1.

${ }^{2038}$ CARRIÓN GONZÁLEZ, Historia documentada..., pp. 154 y ss. El texto de la supresión lo transcribe en el Apéndice VIII, pp. 546-549; y GARCÍA ORO, "Conventualismo y Observancia..., pp. 286-288.

${ }^{2039}$ CARRIÓN GONZÁLEZ, Historia documentada..., pp. 160, 171 y ss. 
En conclusión, podemos apreciar en el desarrollo histórico del convento de La Aguilera su evidente vinculación con los movimientos reformistas en el seno de la familia franciscana, configurándose como una reforma vinculada a la vida de recogimiento y pobreza fiel a los principios de San Francisco. Su origen dentro de la iniciativa de fray Pedro de Villacreces se vio continuado por los posteriores vicarios, entre los que destacó fray Pedro Regalado. Durante este periodo se marcaron distancias con los conventuales pero también con los observantes, descendientes paradójicamente de la doctrina villacreciana. Finalmente, en los primeros años del siglo XVI, la Custodia de Domus Dei se vio adsorbida por la Observancia, aunque se mantuvo en cierta medida fiel al espíritu reformador de su fundador gracias a la nueva propuesta iniciada en aquellos años con la implantación de la vida recoleta en el cenobio ribereño.

Son escasos los datos que conocemos a día de hoy sobre las actividades económicas de la Custodia del Domus Dei. Las referencias documentales sobre aspectos económicos son muy escasas y llama la atención que en los archivos estatales no hemos encontrado ninguna referencia a esta institución, ni tan siquiera un pleito, donación o privilegio, lo cual tampoco es extraño habida cuenta del principio de pobreza que profesaba. El principal sustento de los franciscanos de La Aguilera fue la limosna que recogían por toda la comarca. Buena prueba de ello es el convenio que realizaron con la cercana comunidad franciscana de Aranda para disponer de posada independiente en el monasterio de la capital de la Ribera y así poder acceder directamente a la caridad de los $\operatorname{arandinos}^{2040}$. No obstante, un testimonio indirecto de 1468 confirma el incremento de su patrimonio a través de donaciones que incluían bienes muebles y raíces, pero por el momento no sabemos la verdadera entidad de las propiedades conventuales ${ }^{2041}$. En este sentido, destacaron las aportaciones económicas que realizó la Corona. Estas limosnas estuvieron relacionadas con las visitas personales que diferentes miembros de la Casa Real hicieron al convento: la más destacada por la tradición popular fue la que realizó la reina Isabel en 1492. Don Fernando también fue asiduo visitante del convento durante

\footnotetext{
${ }^{2040}$ ABAD LICERAS, "El ocaso de la presencia..., p. 209.

2041 Así se infiere de la queja presentada por el vicario de la casa que denunciaba que ...algunos
} hijos de la iniquidad habian ocultado los libros, instrumentos públicos, contratos, protocolos, escrituras públicas y privadas, cálices, cruces, ornamentos eclesiásticos, enseres de las casas, legados, testamentos, documentos, inventarios y otros bienes que el vicario y guardianes habian recibido de limosna para el sostenimiento de las casas y vida religiosa (CARRIÓN GONZÁLEZ, Historia documentada..., pp. 99101). 
sus estancias en el coto de La Ventosilla. Por su parte, don Carlos acudió al cenobio en 1518 y ...mandó darles vuena limosna para ayudarles a vivir y para que rogasen a Dios con él $l^{2042}$.

Asimismo hemos documentado cómo la comunidad franciscana actuó en ocasiones como mediadora en conflictos de diverso calado que tuvieron por protagonistas a vecinos ribereños. En la primavera de 1455 el eremitorio Domus Dey alojó a los delegados de las villas de Gumiel del Mercado y La Aguilera que tenían una disputa sobre aprovechamiento de términos. Ambas partes acordaron nombrar dos jueces árbitros para que realizaran un amojonamiento del límite entre ambas localidades. Para esta misión contaron con el asesoramiento de fray Juan de Castro, vicario de la casa, quien además actuó como receptor de los bienes confiscados por los vecinos implicados ${ }^{2043}$. Años más tarde el convento, en esta ocasión de la mano del guardián fray Francisco de Salazar, se convirtió en depositario de los 150.000 maravedíes que la reina Isabel ordenó pagar al regidor arandino Pedro de Mora por los daños sufridos durante la toma de la villa por los partidarios del bando isabelino treinta años atrás ${ }^{2044}$. También fue frecuente que el recinto del monasterio se convirtiera en refugio de los perseguidos por la justicia laica, aunque fue asimismo habitual que ésta no respetara la protección del espacio sagrado a pesar de los ruegos de los frailes ${ }^{2045}$.

El cenobio contaba con la protección de la nobleza comarcana. Así, por ejemplo, los duques de Alburquerque y la familia Sandoval fueron mencionados entre los bienhechores del convento en las reuniones de las Congregaciones Custodiales de 1492 y

2042 CARRIÓN GONZÁLEZ, Historia documentada..., pp. 551-553; y SANTA CRUZ, A., Crónica del Emperador Carlos V. Madrid, 1920, pp. 182-183. En 1504 la reina Isabel ordenó a Ochoa de Landa que entregara cierta cantidad en concepto de limosna al Custodio de Domus Dei para el mantenimiento de sus casas (AGS, CC, CÉDULAS, libro 9, leg. 31, doc. 1).

2043 AMA, leg. 1198, doc. 3.

${ }^{2044}$ AGS, CASA Y SITIOS REALES, leg. 3, docs. 123 y 124. En 1474 se estableció una compensación de 250.000 maravedíes, pero no fue hasta el 22 de abril 1503 cuando se terminó de abonar la cantidad total. Fray Francisco ya había sido guardián en el bienio 1494-1496 (CARRIÓN GONZÁLEZ, Historia documentada..., p. 321).

${ }^{2045}$ Fue el caso de Juan de Bonilla, vecino de Aranda, que, a pesar de acogerse a sagrado estando en el corral del monesterio, fue apresado por el alcaide Bocanegra y encarcelado en Gumiel del Mercado, a pesar de los requerimientos del guardián y frailes del convento (AGS, RGS, 148705, fol. 51). Bonilla fue procurador de la Comunidad en 1504 y uno de los propietarios de las bodegas de la calle Barrionuevo que motivaron el famoso plano de 1503 (PERIBÁÑEZ OTERO y ABAD ÁLVAREZ, Aranda de Duero..., p. 202). 
$1494^{2046}$. La relación de los Sandoval con el cenobio tuvo su origen bastantes años atrás pues doña Beatriz de Avellaneda, primera mujer del conde de Castro don Diego Gómez de Sandoval, eligió para su última morada una pequeña capilla dedicada a Santa María del Pópulo en el interior de la iglesia conventual. Precisamente su nieto, otro don Diego Gómez de Sandoval -joven de poca edad, gafo, tullido y contrahecho-, experimentó una curación milagrosa gracias a fray Pedro Regalado cuando en 1456, estando el santo en su lecho de muerte, pasándole la mano por sus deformidades le puso en perfecto uso de sus miembros. Aprovechando la coyuntura, el futuro marqués de Denia se hizo con el hábito del moribundo que convirtió en una reliquia transmitida entre la familia Sandoval de generación en generación. Leyenda o realidad, lo cierto es que destacados miembros de la familia Sandoval mantuvieron una estrecha vinculación con la comunidad franciscana que se prolongó en el tiempo ${ }^{2047}$.

Sin embargo, la familia que ostentó el patronazgo del convento de Domus Dei fue la de los Zúñiga y Avellaneda, condes de Miranda. No sabemos cuándo se convirtieron en patronos del eremitorio pero seguramente estuvo en relación con el traspaso del señorío de La Aguilera del obispado de Burgos a los señores de Avellaneda, circunstancia que se produjo entre 1420 y $1456^{2048}$. Varios testimonios confirman que el cenobio se convirtió en su panteón familiar pues en él se enterraron los primeros y segundos condes de Miranda ${ }^{2049}$. Más estrecha fue la vinculación del cardenal don Íñigo López de Mendoza con la Casa franciscana, pues además de establecer que su cuerpo reposara allí hasta que se terminara de construir la iglesia de Santa María de la Vid, futuro panteón familiar de los Zúñiga y Avellaneda, también patrocinó buena parte de las reformas constructivas del convento con la aportación de más de 400.000 maravedíes $^{2050}$.

Otras familias más modestas también ejercieron su patronazgo sobre alguna de las capillas del eremitorio. Fue el caso de la arandina familia Del Valle que era patrona

${ }^{2046}$ CARRIÓN GONZÁLEZ, Historia documentada..., pp. 106-110.

${ }^{2047}$ CARRIÓN GONZÁLEZ, Historia documentada..., pp. 288-290 y 373-375. Tiempo después el duque de Lerma se convirtió en uno de los principales benefactores del convento concediendo importantes dádivas.

2048 Doña Constanza de Arellano, hija del primer conde de Miranda, afirmaba que sus padres ...compraron Aguilera con su renta (ARChV, RRE, Caja 154, doc. 2).

${ }^{2049}$ CARRIÓN GONZÁLEZ, Historia documentada..., pp. 22-23 y 237-238.

${ }^{2050}$ CARRIÓN GONZÁLEZ, Historia documentada..., pp. 387-392. Su cuerpo se mantuvo en La Aguilera hasta que en 1579 fue trasladado a La Vid. 
desde 1503 de la capilla de San Antonio, situada a la entrada del cenobio. En esta capilla funeraria fue enterrado don Diego Hernández del Valle, despensero mayor de la reina Isabel y regidor perpetuo de la villa de Aranda. La capilla siguió vinculada a la familia del Valle hasta finales del siglo XVI, cuando, tras un incendio que la devastó y la negativa a la reconstrucción de los herederos de los Valle, se hizo con su patronato el conde de Miranda ${ }^{2051}$. Asimismo otros destacados vecinos de la comarca decidieron enterrarse en el convento franciscano ${ }^{2052}$.

A modo de conclusión, y asumiendo que desconocemos casi por completo el patrimonio del convento aguilereño, podemos inferir que la fama milagrera del Santo Regalado y la estrecha vinculación con los miembros más destacados de la nobleza comarcana garantizaron una más que segura estabilidad económica a esta comunidad franciscana que permitió su consolidación, además de adquirir un significativo peso en la vida religiosa de la comarca.

No menos relevante fue el hecho de que durante los primeros años del Quinientos la Casa de Domus Dei se convirtiera en un importante centro desde el que se tomaron relevantes decisiones que afectaron al devenir histórico de la Corona de Castilla. Independientemente de la tradición popular que vinculaba a la reina Isabel con fray Pedro Regalado desde $1492^{2053}$, lo cierto es que el rey Fernando también eligió la villa de Aranda y el lugar de Ventosilla para retirarse a descansar y disfrutar de la caza en la primavera y el verano de 1515. Dada la posición intermedia que ocupa el convento de Domus Dei podemos suponer que también lo utilizó como retiro espiritual ${ }^{2054}$.

Poco después, en 1517 el cenobio franciscano acogió entre sus muros a un moribundo Cardenal Jiménez de Cisneros que desde La Aguilera preparó la llegada de don

${ }^{2051}$ AGS, CC PUEBLOS, leg. 2, doc. 91 y EMR, leg. 683. La saga de los Del Valle formaron parte de la oligarquía arandina. Bernardino del Valle heredó los oficios de despensero y regidor perpetuo de su padre. Buena parte de su vida la dedicó al servicio de armas a la Corona y destacó como activo capitán realista durante la Revolución Comunera y en la posterior Guerra de Navarra (AGS, CC PUEBLOS, leg. 13, doc. 6-2; y CR, 450, doc. 8). Su hijo, Juan del Valle, también heredó el oficio de aposentador, el regimiento y fue asimismo enterrado en la capilla de San Antonio de la Domus Dei (AGS, CMC, leg. 41, doc. 18 y CC DIVERSOS, leg. 47, doc. 30). Magdalena del Valle Cepeda, hija de Juan y casada con el capitán de infantería Nicolás de Casanova, abandonó las obligaciones de reconstrucción de la capilla tras un incendio acaecido en 1589 por lo que se le retiró el patronazgo que fue otorgado por los frailes a don Juan de Zúñiga (CARRIÓN GONZÁLEZ, Historia documentada ..., pp. 367-369).

2052 En 1487 fue enterrado mosén Alonso de Bonilla, tío del arandino Juan de Bonilla (AGS, RGS, 148705, fol. 37 y 51).

${ }^{2053}$ CARRIÓN GONZÁLEZ, Historia documentada..., pp. 551-553.

${ }^{2054}$ VAL VALDIVIESO, “El reinado de los Reyes Católicos..., pp. 19-23. 
Carlos. Pero sobre todo tuvo que frenar las pretensiones de los distintos sectores de la nobleza castellana que vieron en estos momentos de inestabilidad la posibilidad de retomar sus viejas pretensiones de intervencionismo sobre la Corona. Al mismo tiempo, don Carlos encomendó al viejo Cardenal que controlara a su hermano, el Infante don Fernando, para que no se convirtiera en la bandera de un posible levantamiento contra su persona. El Regente ejecutó ambos cometidos desde una modesta celda del convento de La Aguilera pocos días antes de morir ${ }^{2055}$.

Algunos meses después, en la Semana Santa de 1518, fue el rey Carlos el que recaló en Aranda de Duero y decidió celebrar la Pasión de Cristo en el eremitorio ribereño. Así, él junto a sus más allegados se trasladaron el Jueves Santo 31 de marzo a La Aguilera y permanecieron allí hasta que el Lunes de Pascua retornaron a Aranda. Seguramente en su retiro espiritual meditó sobre la decisión de enviar a su hermano a Alemania y así alejarle de las pretensiones de una parte de la nobleza castellana ${ }^{2056}$.

Casualidad o no, lo cierto es que en un breve periodo de tiempo, entre $1515 \mathrm{y}$ 1518, las máximas autoridades del reino de Castilla acudieron al convento de La Aguilera y entraron en contacto con los frailes que allí residían. Llegados a este punto nos planteamos las causas que motivaron estas coincidencias y francamente no encontramos respuestas de peso que lo expliquen. Tan solo la situación estratégica de la comarca ribereña situada en un cruce de caminos que conectaba Castilla con Aragón y el Norte cantábrico con el Sur podría explicar esta reiteración en elegir Aranda como sede de la Corte $^{2057}$. Pero seguimos sin responder a la elección del cenobio aguilereño. Tal vez la respuesta la encontremos en la comunidad de franciscanos que allí residía o en alguno de sus miembros en concreto, aunque poco o nada sabemos sobre ellos y sobre su capacidad de influir sobre tan destacados personajes en el devenir histórico de Castilla. Sin

${ }^{2055}$ El prelado residió en el convento de La Aguilera entre el 12 de septiembre y el 17 de octubre (GARCÍA ORO, J. Cisneros: un cardenal reformista en el trono de España (1436-1517). Madrid, 2005, pp. 310 y ss.; y SANTA CRUZ, Crónica del Emperador..., Vol. I, pp. 154-155).

2056 ...porque en este tiempo era Semana Santa se fue a retraer al monasterio de Aguilera muy devoto, de los frailes Franciscanos. A su partida el rey ...mandó darles vuena limosna para ayudarles a vivir y para que rogasen a Dios con él. El infante Fernando fue enviado a Flandes desde Aranda el 4 de abril según Santa Cruz y el 20 según Vital (SANTA CRUZ, Crónica del Emperador..., vol I, pp. 182-183; y VITAL, Relación del primer viaje..., p. 29).

${ }^{2057}$ Parece evidente en el caso del rey Fernando que se instaló en Aranda por su proximidad a Burgos, donde tenía que celebrarse la reunión de Cortes, y camino de Monzón, a donde envió a doña Germana para que presidiera las de Aragón. También podría entenderse desde este punto de vista la decisión de don Carlos de recalar en Aranda, camino de Aragón, para desde aquí enviar a su hermano a Flandes por los puertos del Cantábrico. 
lugar a dudas se abre un interesante campo de investigación que por el momento sobrepasa los objetivos y posibilidades de nuestro estudio.

\section{2. 5. Convento de San Francisco de Aranda.}

A pesar de la evidente proyección urbana de la villa de Aranda a finales de Edad Media la presencia de las órdenes mendicantes fue bastante tardía y no se produjo hasta los años finales del siglo XV en el caso de los franciscanos y hasta mediados del XVI la de los dominicos $^{2058}$.

Como ya hemos visto anteriormente, la reforma de Villacreces en el seno de la familia franciscana tuvo su proyección en la Ribera con la fundación de una pequeña comunidad en la cercana población de La Aguilera en 1404. Posiblemente esta cercanía explique el tardío interés de estos mendicantes por instalarse en el núcleo urbano más significativo de la comarca ${ }^{2059}$.

La mayor parte de los estudios sobre el origen del convento de San Francisco coinciden en que las obras debieron comenzar el año 1499 bajo el amparo de la cercana comunidad de La Aguilera y gracias a la iniciativa de la familia Acuña que mediante su patronato financió su construcción ${ }^{2060}$. Esta nueva institución fue conocida entre los arandinos como el monesterio de la Conçebçion de Nuestra Señora de la orden de San Francisco $^{2061}$.

${ }^{2058}$ La Orden de Predicadores se instaló en el arrabal del Allendeduero donde construyó el convento del Sancti Spiritus. Comenzó a proyectarse en 1542 en las inmediaciones de la ermita de San Lázaro. El convento recibió el apoyo del obispo oxomense, don Pedro de Acosta, y se consagró su altar mayor el 8 de abril de 1562 (ABAD ZAPATERO y ARRANZ ARRANZ, Las Iglesias de Aranda, pp. 33-35).

${ }^{2059}$ Lo mismo podríamos afirmar para los dominicos, en este caso por la cercanía del convento de Santo Domingo de Caleruega, aunque en este caso era femenino.

${ }^{2060}$ LOPERRAEZ CORVALÁN, Descripción histórica..., Vol. II, pp. 178-180; VELASCO PÉREZ, Aranda. Memorias..., pp. 130-132; SANZ ABAD, Historia de Aranda..., pp. 39-142; el estudio más completo hasta el momento es el de ABAD LICERAS, J. M., "El ocaso de la presencia..., pp. 207256. Este autor presenta un apartado de antecedentes históricos en el que se hace eco de las noticias de los cronistas franciscanos, especialmente Francisco de Gonzaga y Alonso Mathias. También hace referencia a la fundación arandina CARRIÓN GONZÁLEZ, Historia documentada..., pp. 110-112.

${ }^{2061}$ ABAD LICERAS señala que el nombre oficial en este momento inicial era Convento de San Francisco ("El ocaso de la presencia..., p. 210). Por otro lado, SANZ ABAD identifica la fundación como Convento de la Purísima Concepción (Historia de Aranda..., pp. 139-140). Por nuestra parte hemos localizado bastantes documentos que identifican el cenobio con el culto a la Inmaculada Concepción (AGS, CR, leg. 40, doc. 8, CASA Y SITIOS REALES, leg. 2, doc 484; y ARChV, RRE, Caja 315, doc. 20). 
Por el momento desconocemos el documento concreto del asiento entre la comunidad franciscana y sus patrones, los Acuña, pero un pleito posterior entre los frailes y su heredero muestra algunos de los puntos más significativos:

- El convento cedía la capilla mayor para el enterramiento de don Martín Vázquez de Acuña y de los miembros de su familia.

- Don Martín se comprometía a donar 300.000 maravedíes, o más si hiciera falta, para cerrar la capilla de cal y canto bien labrada.

- Asimismo se obligaba a hacer efectivas ciertas mandas que su mujer Constanza de Avellaneda dejó en su testamento para cosas pías y que montaban a 4.000 ducados. Por facultad que le dio el Sumo Pontífice podía conmutarlas en obras y edificación del monasterio y para ello se traería bula del Santo Padre.

- También se comprometía a hacer un hospital junto al monasterio. Además Acuña había obtenido la facultad para construirlo y bula para que los que muriesen o quisieren morir en ese hospital fuesen absueltos de culpa. Ambas partes se concertaron en que la mitad de las limosnas que llegaran al hospital serían para la edificación del monasterio y hospital.

Aparte de este asiento, en las cláusulas testamentarias de don Martín se estableció que se debían dar otros 300.000 maravedíes ...viendo el dicho Martín que habian seydo por el muy engañados los dichos frailes por descargo de su conçiençia. Esta cantidad se complementó con ...paños ricos para la dicha capilla prinçipal ${ }^{2062}$.

En el año 1500 el convento ya debía tener alguna dependencia construida pues eran varios los frailes que lo habitaban y en él ya se celebraban algunos oficios y predicaciones $^{2063}$. Sin embargo, desde su nacimiento el convento se vio sumido en ciertas controversias jurisdiccionales y económicas que retrasaron la ejecución del proyecto.

Por una parte surgió un enfrentamiento entre la provincia franciscana de Castilla y la de Santoyo que provocó un significativo retraso en la configuración del nuevo convento. Por otra parte, la implantación de este nuevo establecimiento religioso en un núcleo urbano que hasta el momento contaba con tan solo dos parroquias provocó un re-

${ }^{2062}$ ARChV, RRE, Caja 315, doc. 20

${ }^{2063}$ Tenemos noticias de que a principios del año 1500 los mudéjares de la villa fueron apremiados a acudir a la iglesia de Santa María o al convento de San Francisco para escuchar los sermones de un fraile franciscano (AGS, RGS, 150002, fol.52). 
ajuste importante en los usos y costumbres del fervor popular. Esta nueva situación provocó un serio conflicto entre los frailes y el clero secular de la villa que derivó en episodios de tensión entre clérigos y frailes. Asimismo la cercanía con el Domus Dei de La Aguilera provocó roces entre ambas comunidades a pesar de su condición fraternal. Todos estos enfrentamientos los analizaremos con mayor detenimiento en el capítulo siguiente dedicado a los conflictos.

A pesar de los debates jurisdiccionales, en los primeros años del siglo XVI se reanudaron los trabajos de construcción del edificio pero surgió un nuevo problema, éste de índole económica. Como ya hemos señalado anteriormente, don Martín Vázquez de Acuña y su mujer, doña Constanza de Avellaneda, se comprometieron a ser los patronos y asumir el coste de la capilla mayor del convento. Sin embargo, la muerte en 1505 de don Martín puso freno a los aportes pecuniarios pues el albacea, su hijo Juan Vázquez de Acuña, no cumplió con el asiento de patronazgo ni con las mandas testamentarias de su progenitor. Esta situación provocó que la comunidad franciscana denunciara el incumplimiento del contrato y comenzara un tortuoso periplo judicial que culminó con una sentencia arbitral pronunciada el 19 de noviembre de $1516^{2064}$. Los principales puntos que se recogieron en este acuerdo fueron los siguientes:

- Por una parte, Juan Vázquez de Acuña se comprometía a construir en el plazo de un año la capilla del Evangelio ...de cara de la capilla que en la dicha iglesia hizo Pedro de Santa Cruz; ...que la capilla sea tal y tan buena e de tal alto e ancho como la dicha capilla que el dicho Pedro de Santa Cruz fizo. Aquella capilla sea rasa sin arcos de sepultura. En la capilla no podía poner sus armas, ni se reservaba ningún derecho para el benefactor, quedando para libre disposición del monasterio ${ }^{2065}$.

- En ese mismo plazo debía darse por acabada la capilla mayor con su altar y gradas tal como se contenía en el contrato por el que estaba obligado el maestro cantero Juan de Aras. Asimismo Acuña debía hacerse cargo de su salario (6.0000 maravedíes y 50 cántaras de vino).

- Acuña debía pagar a los frailes, antes del día de Navidad de $1516,100.000$ maravedíes. Para los años siguientes de 1517, 1518 y 1519 se establecía el

${ }^{2064}$ ARChV, RRE, Caja 315, doc. 20.

${ }^{2065}$ La capilla se construyó pero no se respetaron todas las cláusulas pues todavía hoy podemos ver en los restos de esta capilla el escudo de don Martín Vázquez de Acuña. 
pago de 16.666 maravedíes y cuatro cornados en cada una de las tres pagas anuales.

Este compromiso lo asumió Juan Vázquez de Acuña a cuenta de la obligación de 4.000 ducados, hacer el hospital, las limosnas, tres capellanías, 400.000 maravedíes y otras cosas que pedían los frailes.

En contraprestación, la comunidad franciscana se obligaba a entregar a la otra parte la bula original del Papa sobre el patronazgo de la capilla mayor, más las obligaciones y originales que firmaron los Acuña. Por lo tanto observamos cómo en los primeros años del Quinientos el monasterio de San Francisco ya estaba configurado en sus elementos más significativos gracias a los aportes económicos de dos de las familias locales más poderosas e influyentes: el linaje de los Acuña ${ }^{2066}$ y la familia Santa Cruz.

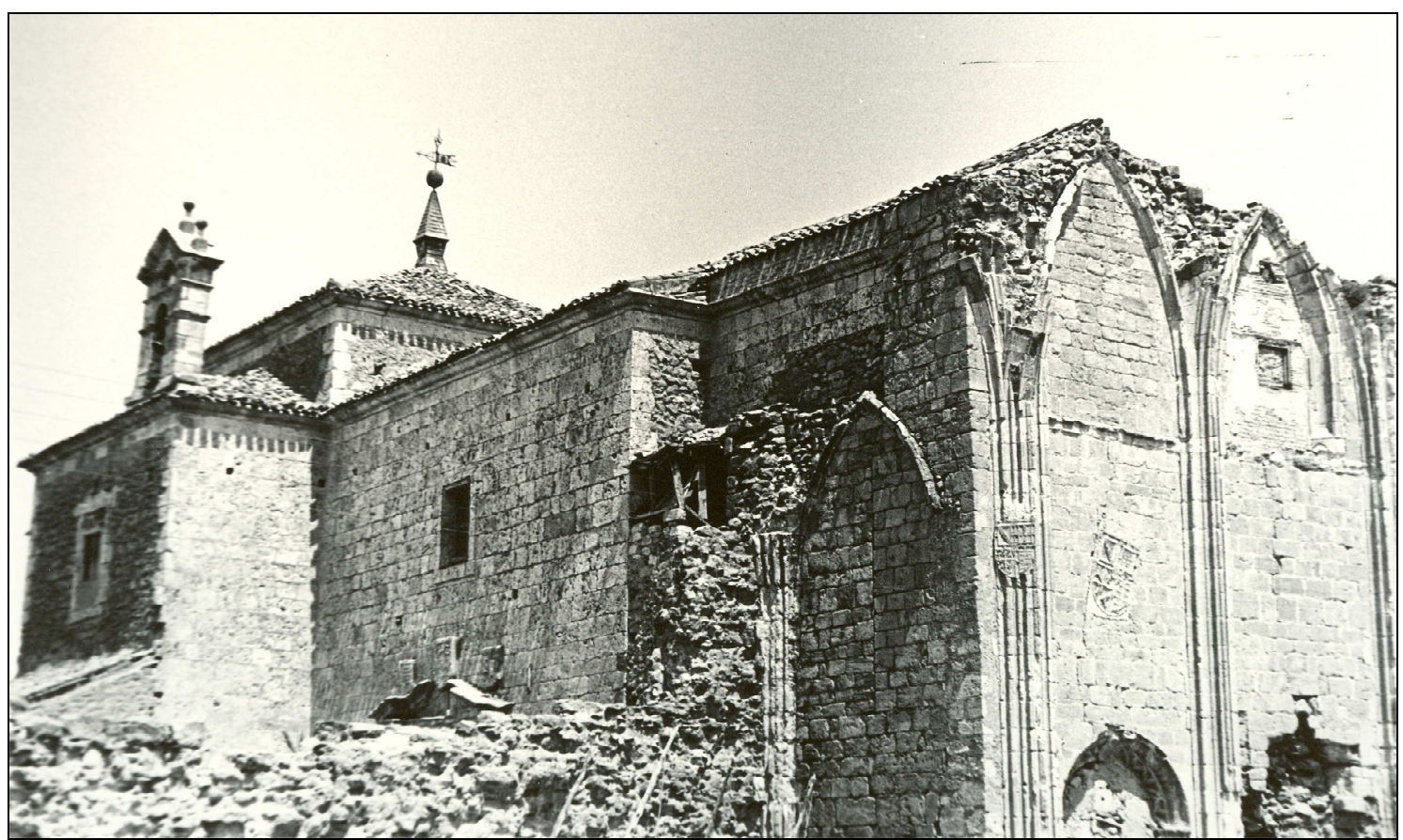

Imagen 51: Restos del antiguo convento de San Francisco de Aranda (CBMAD).

La envergadura de la empresa y la condición mendicante de la orden necesitó la intervención de otro importante donante, la Corona, aunque son escasos los testimonios que nos muestran las dádivas reales al monasterio. En 1514 se hizo efectiva una manda

${ }^{2066}$ Además del protagonismo de don Martín y Juan Vázquez de Acuña, también tuvieron cierta relevancia en la construcción del monasterio Juan de Avellaneda, hermano de doña Constanza de Avellaneda, que recibió sepultura antes de 1516 en la capilla mayor junto a su hermana. Asimismo, don Juan de Acuña, hijo de don Martín y con el mismo nombre que su hermano, fue un importante benefactor de San Francisco hasta el punto de que su enterramiento se situó en un arcosolio de la capilla mayor frente al de su hermano (ARChV, RRE, Caja 315, doc. 20). 
testamentaria de la difunta reina Isabel por la que concedía 38.000 maravedíes a San Francisco por los servicios prestados por fray Juan de Maldonado como tutor del príncipe Juan. Esta asignación se pagó con el dinero de las alcabalas de la villa de Aranda ${ }^{2067}$. En 1517 fue el propio guardián del convento el que suplicó limosna a los monarcas para sufragar las obras del monasterio, sin que tengamos noticias de su concesión ${ }^{2068}$. Sin embargo, los testimonios de alguna de las crónicas franciscanas insisten en la generosidad real, afirmando, por ejemplo, que: Intentó el P. Fr Matín de Astorga la del convento de Aranda de Duero, para nuestra Observancia: pero aviendose levantado contra su intento una montaña de dificultades, se allanó facilmente con el recurso a la piedad de estos Catholicos Monarcas; que, despues de desembarazar de las posiciones el passo, nos fabricaron el Convento a expensas de su Real Erario ${ }^{2069}$. En este mismo sentido se reafirmaba el guardián del cenobio cuando solicitó la ayuda de los monarcas para abrir un nuevo portillo alegando que ...el dicho monesterio es fundado del rey y reyna catolicos, e del rey don Felipe ${ }^{2070}$.

Tampoco podemos desdeñar en la empresa constructora la importante aportación de los fieles arandinos que enseguida mostraron su preferencia por la nueva institución para asistir a los oficios divinos, pero sobre todo para hacer del monasterio de San Francisco su última morada. Ejemplo de las aportaciones populares eran los 200 maravedíes que se debían abonar para que los frailes sacasen la cruz en los entierros, o los recelos de los párrocos que vieron a sus fieles acudir de forma masiva al convento para oír misa, con el consiguiente desplazamiento de sus limosnas ${ }^{2071}$. El cenobio incluso contó con las limosnas de ilustres personajes de la época como Fernando de Magallanes que en su testamento estableció una manda para ayuda de la claustra ${ }^{2072}$.

\footnotetext{
${ }^{2067}$ AGS, CASA Y SITIOS REALES, leg. 7, doc. 222 y leg. 9, doc. 1102.

${ }^{2068}$ AGS, CC MEMORIALES, leg. 123, doc. 141.

${ }^{2069}$ GONZÁLEZ DE TORRES, E., Chronica Seraphica. Octava parte. Madrid, 1737, p. 390.

${ }^{2070}$ AGS, CC MEMORIALES, leg. 152, doc. 116.

${ }^{2071}$ Las autoridades municipales se quejaban en 1503 ante los monarcas: Otrosy sy alguno falles-
} çe y se manda enterrar en San Francisco non quieren los clerigos yr con la cruz sy no da doçientos maravedies e acaeçe que alguno no los tiene para los poder pagar (AGS, CC PUEBLOS, leg. 2, fol. 94). Poco después la reina Isabel solicitó al obispo de Burgos ...que obligue a los clérigos de San Francisco de Aranda a que den sepultura a los cuerpos que se mandan enterrar en dicho monasterio sin exigir previamente el pago de doscientos maravedís (AGS, CC CÉDULAS, libro 7, leg. 14, doc. 1).

${ }^{2072}$ SANZ ABAD, Historia de Aranda..., p. 140. 
Aparte de los problemas jurisdiccionales y económicos de este nuevo centro religioso, su existencia supuso para la vida religiosa de la villa un nuevo estímulo, multiplicándose en los primeros años del nuevo siglo el seguimiento de los sermones predicados por los frailes franciscanos, quizá fruto de una más atractiva aproximación a la religiosidad de una sociedad cada vez más urbana. Aunque no podemos olvidar que también por aquellos años se hizo más intensa y persistente la presencia del Tribunal de la Inquisición por las tierras ribereñas, acicate nada desdeñable para el aumento del fervor religioso entre los fieles ${ }^{2073}$.

En ocasiones estos mismos frailes que predicaban una nueva relación con Dios y cuyo ejemplo de pobreza encandilaba a los arandinos se revelaron como instigadores de violencia hacia los infieles o hacia las autoridades civiles. Así se observa en 1500 cuando la comunidad mudéjar acudió a la justicia real y presentó una queja porque se sentía intimidada por los frailes que obligan a la población mudéjar a asistir a sus sermones en Santa María o San Francisco, amenazándoles con predicar en la misma morería si no obedecían $^{2074}$.

Más llamativa fue la promoción de la desobediencia y el enfrentamiento con la autoridad judicial que se produjo en 1510 cuando iba a ser ejecutado un zapatero condenado por homicidio y ...llevandose el alguasil de la dicha villa a esecutar en él (el reo) la dicha sentencia, recudieron contra él ciertos frailes de la horden de San Francisco que estavan puestos en acechanzas en una hermita que se dize de Santa Crus, con palos e cuchillos; e que, por fuerza y contra voluntad del dicho alguasil, tomaron al dicho Rodrigo de Salazar e le metieron en la dicha hermita donde dis que los dichos frailes e los clerigos e estudiantes de la dicha villa, que recudieron en su favor e con muchas armas, le defendieron; e que uno de los dichos frailes dio con un palo al dicho alguasil en la cabeza que le firio malamente. Tras este episodio se sucedió otro alboroto promovido por los defensores de los frailes. La situación se complicó cuando el guardián de San Francisco se negó a apresar a los frailes implicados como solicitaba el pesquisidor. Ante el proceso acometido por el pesquisidor, las autoridades eclesiásticas respondieron con la protección de los encausados y la apertura de un proceso al pesquisidor por haber

${ }^{2073}$ PERIBÁÑEZ OTERO, “Violencia y espacio urbano..., pp. 25-42.

${ }^{2074}$ AGS, RGS, 150002, fol.52. 
enjuiciado a un clérigo ${ }^{2075}$. No obstante, por el momento la documentación no permite aproximarnos al trasfondo del episodio más allá del habitual conflicto entre la jurisdicción civil y eclesiástica. Seguramente tras el asesinato que desencadenó los hechos y la intervención de frailes, clérigos y estudiantes se esconda algún tipo de vínculo clientelar u otro tipo de relación que por el momento se nos escapa.

Es evidente que el monasterio de San Francisco se integró rápidamente en la dinámica socioeconómica arandina. Tanto es así que a los pocos años de su fundación la comunidad franciscana, junto con el concejo de la villa, emprendió un ambicioso proyecto hidráulico para mejorar el abastecimiento de agua de la villa y del convento de San Francisco, además de potenciar la explotación agrícola de una amplia zona al NE de la villa $^{2076}$.

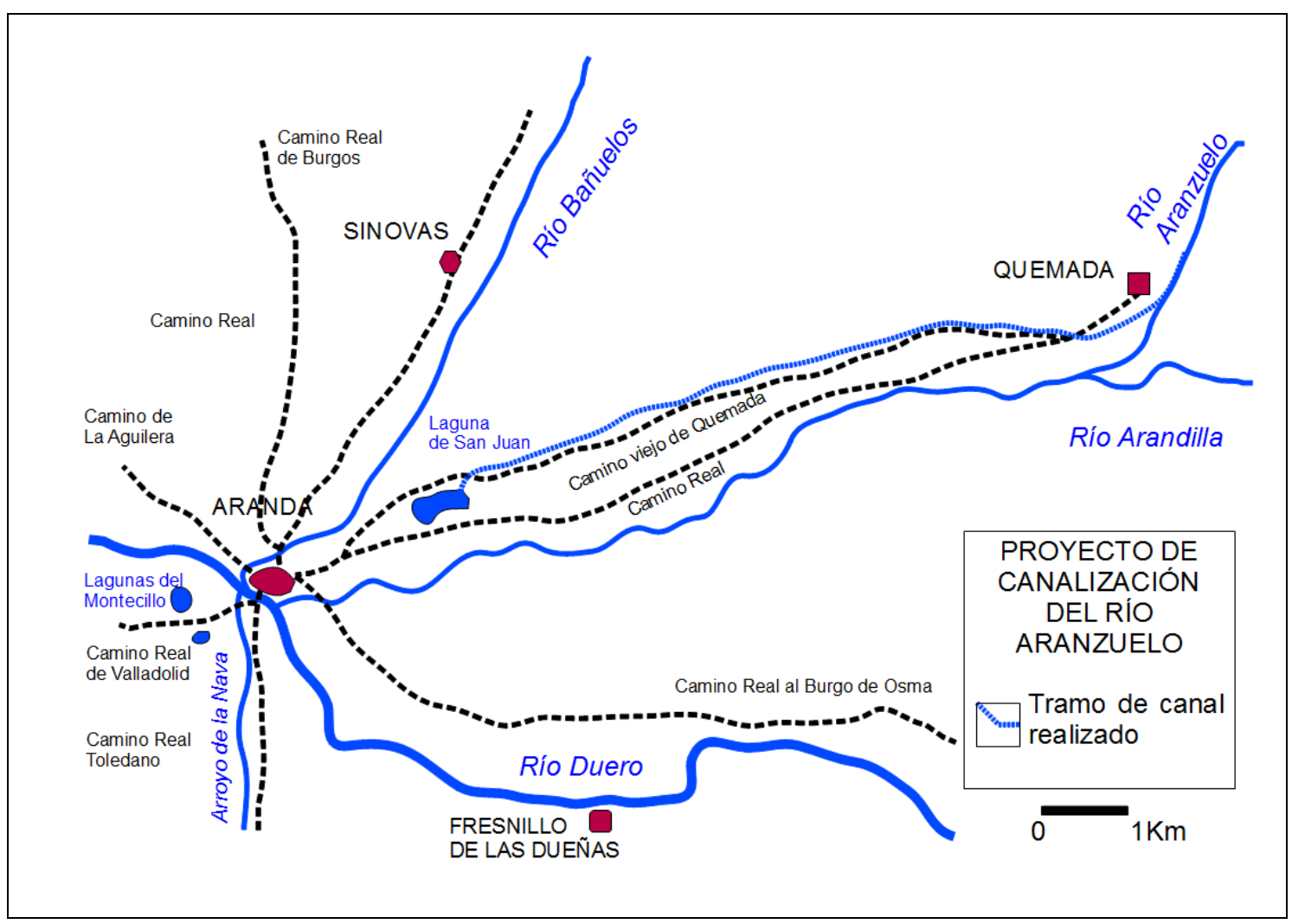

Mapa 21: Trazado del proyecto de canalización del río Aranzuelo.

${ }^{2075}$ AGS, CC PUEBLOS, leg. 2, docs. 100 y 107.

${ }^{2076}$ El proyecto aparece recogido en AGS, CR, leg. 40, fol. 8 y ha sido estudiado por ABAD ÁLVAREZ y PERIBÁÑEZ OTERO, “El control social del agua..., pp. 113-156. 
El plan consistía en desviar el cauce de un río, el Aranzuelo, y reconducirlo a lo largo de 10 kilómetros hasta el casco urbano de la villa de Aranda. Entre los años 1500 y 1503 se llevó a cabo un primer intento de desviar el curso del río como lo muestra una consulta del concejo arandino al presidente del Consejo Real realizada en mayo de 1503. En esta nota se indicaba ...que el rio Aranzuelo ... se traya a esta villa porque es cosa muy façil y ya se ha provado a traer y se ha traydo por medio de la villa ${ }^{2077}$. También se señalaban las reticencias de los dueños de los molinos del Arandilla, río en el que vierte sus aguas el Aranzuelo, aunque se aseguraba que el concejo estaba dispuesto a indemnizarlos. Las obras, tras superar algún que otro obstáculo, comenzaron en el verano de 1515. Sin embargo, la iniciativa de los dueños de los molinos obligó a paralizarlas cuando ya se había conducido el agua hasta la laguna de San Juan, en las inmediaciones de la huerta del monasterio.

Tras un farragoso proceso judicial, el Consejo Real dio la razón a los promotores de la iniciativa y dio permiso para la ejecución del proyecto, previa indemnización a la parte contraria. Inmediatamente el concejo consiguió licencia del rey Fernando para echar una sisa de 20.000 maravedíes sobre los mantenimientos de la villa con los que hacer frente a los gastos de la construcción de la canalización del río y pagar la indemnización a los dueños de los molinos. Pero ciertas necesidades que acuciaron a la villa en los años posteriores impidieron la puesta en práctica de la anterior sentencia y, por lo tanto, la conclusión del proyecto ${ }^{2078}$. Buena muestra del olvido en el que cayó esta idea es que en 1535 la comunidad franciscana volvió a solicitar la traída de las aguas del Aranzuelo a su convento $^{2079}$.

Si bien este proyecto hidráulico puede calificarse de un rotundo fracaso, los promovidos en el ámbito de la reordenación urbana sí que concluyeron exitosamente. Ya hemos comentado que la comunidad franciscana se instaló en el arrabal Este de la villa en un espacio ocupado anteriormente por huertas y equidistante de las puertas Norte o Cascajar y Este o Hesilla. Se trataba por lo tanto de un espacio secundario y con una

${ }^{2077}$ AGS, CC PUEBLOS, leg. 2, doc. 94.

${ }^{2078}$ En una carta de la emperatriz Isabel al corregidor de Aranda, fechada en febrero de 1530, se le ordenaba que los 20.000 maravedíes obtenidos de la sisa para desviar el Aranzuelo se utilizasen en la construcción de un depósito de pan que solventase los graves problemas de abastecimiento de la villa en esos momentos (AMA, leg. 63, doc. 146).

2079 VELASCO PÉREZ, Aranda. Memorias..., pp. 186-187. 
comunicación bastante deficiente con el centro neurálgico de la villa. Pero las cosas cambiaron notablemente con celeridad.

El primer episodio en el que estuvo directamente implicado el convento de San Francisco se desarrolló en 1515 cuando los frailes denunciaron ante la reina que frente a la puerta Oeste de su iglesia se estaban edificando casas en un campo público. Esta circunstancia causaba un gran perjuicio al convento por que se cerraba su acceso a la calle que discurría paralela a las cavas e impedía que se pudiera recibir a las diferentes procesiones que por ella discurrían. El convento solicitó que no se edificara o que al menos se dejara entre las edificaciones ...una calle publica e ancha frontera de la puerta de la dicha iglesia ... por hornato e ponpa e noblescimiento. La reina ordenó al corregidor que investigara y finalmente el Consejo Real autorizó la creación de esta nueva calle ${ }^{2080}$.

El paso más significativo en el contexto de la revalorización urbanística del entorno próximo del monasterio se forjó pocos años después con la apertura de una nueva puerta en la muralla, comunicando el centro de la villa con el monasterio directamente a través de la calle Barrionuevo. Ya en 1503 los vecinos de Barrionuevo, calle comercial por excelencia pero sin acceso directo a la Plaza Nueva, solicitaron a los monarcas el derribo de unas casas junto a la calle del Pozo para permitir una mejor comunicación con la zona de Santa María ${ }^{2081}$. Tras un largo proceso, los vecinos de Barrionuevo se salieron con la suya y se derribaron las casas que impedían el paso franco. Años después, en 1517, estos mismos vecinos junto con los frailes de San Francisco solicitaron que ...manden hacer un portillo de la cerca de la villa frontero del dicho monesterio, el qual va a dar a la calle de Barrionuevo; no mayor que pueda caber una persona encima de una mula, y argumentaban que no se causaba daño a ningún vecino pues ...no ay camino ninguno que vaya a dar al dicho portillo, salvo para yr o venir al dicho monesterio ${ }^{2082}$. A pesar de la oposición de los vecinos de la calle Hisilla, finalmente la muralla se horadó, aunque no conocemos la fecha precisa. Uno de los escasos restos de la primitiva muralla que se conservan en la actualidad pertenece al lienzo meridional de esta puerta que todavía hoy podemos contemplar en un solar entre las actuales calles de Barrionuevo y Puerta Nueva.

\footnotetext{
${ }^{2080}$ AGS, CC PUEBLOS, leg. 2, doc. 107.

${ }^{2081}$ AGS, CR, 39, 3. El pleito ha sido transcrito y estudiado por PERIBÁÑEZ OTERO y ABAD ÁLVAREZ, Aranda de Duero....

${ }^{2082}$ AGS, CC MEMORIALES, leg. 124, fol. 141 y leg. 152, fol. 116.
} 
De todas estas iniciativas se concluye una evidente revalorización del espacio urbano extramuros articulado entorno al monasterio de San Francisco. Por lo tanto, parece evidente que el convento franciscano actuó como polo de atracción que generó nuevos espacios urbanos. Asimismo el cenobio jugó un importante papel como agente dinamizador o promotor de una nueva realidad espacial.

En definitiva, el monasterio de San Francisco se configuró en los primeros años del siglo XVI como un elemento significativo en el creciente tejido urbano arandino y adquirió una posición preponderante tanto en el contexto de la religiosidad popular local como en la dinámica socioeconómica de la villa. Prueba de ello fue la progresiva identificación del arrabal próximo con el convento como lo muestra el hecho de que la cuadrilla de Cascajar trasladara su lugar de reunión junto al monasterio en los primeros años del Quinientos. De hecho con el tiempo la cuadrilla pasó a tomar la denominación de San Francisco ${ }^{2083}$.

\section{2. 6. Convento de Santa Isabel o de las Antonias.}

No quisiéramos terminar este apartado dedicado a la presencia franciscana en la capital de la Ribera sin hacer mención al convento de monjas clarisas, conocido en la villa con la popular denominación de Las Antonias. Estas religiosas contemplativas de la orden tercera estaban instaladas en el convento de San Antonio, denominado en sus orígenes de Santa Isabel, en el arrabal Este de la villa, muy próximo al emplazamiento del convento masculino de San Francisco.

Aunque tradicionalmente se fecha su fundación en 1560, una serie de indicios nos hacen pensar que esta comunidad femenina ya estaba asentada en la villa bastantes años atrás. Según algunos autores el origen de la presencia de las clarisas estaría en la facultad que concedió el Papa Pío II en 1463 a la reina Juana de Portugal para que fundara un colegio en el que las clarisas se encargaran de la educación de las jóvenes ${ }^{2084}$.

${ }^{2083}$ AGS, CONSEJO Y JUNTAS DE HACIENDA, leg. 4, fol. 20.

${ }^{2084}$ ABAD LICERAS (“El ocaso de la presencia..., pp. 210-211) recoge esta fundación moderna pero advierte que tanto Francisco de GONZAGA como OMAECHEVARRÍA (Las clarisas a través de los siglos. 1972, p. 102) discrepan con esta fecha tardía y apuntan 1460 o 1463. Suponemos que ambos autores recogen los datos de WADDING, L., Annales Minorum, Vol. XIII, reed. 1932, pp. 625-628. Lo mismo señala CASTRO Y CASTRO, M., "Monasterios Hispánicos de clarisas desde el siglo XIII al XVI" en www.franciscanos.org. La noticia también es recogida por NIETO SORIA, Iglesia y génesis..., pp. 246 y 396, citando a HÜNTEMANN, U., Bullarium franciscanum. Nova Series II, nº 1172. 
La documentación consultada no aclara nada sobre este colegio pero sí que hace referencia a unas beatas que habitaban en comunidad bajo el amparo de ermita de la Virgen de las Viñas. Los autores locales señalan que no vivían bajo el amparo de ninguna regla y que sus únicas labores consistían en seguir una vida contemplativa y atender las necesidades de la ermita y su patrona. Tras el Concilio de Trento las autoridades diocesanas ordenaron, siguiendo los preceptos trentinos, que todas las mujeres recogidas con el nombre de beatas que vivieran aisladas se retirasen a lugar poblado para garantizar su seguridad. Según estos mismos autores, fue así como en la segunda mitad del siglo XVI esta comunidad de beatas abandonó la ermita de la Virgen de las Viñas y, para unos, se asentaron en un convento extramuros bajo la advocación de San Antonio de Padua o, para otros, se integraron dentro de la comunidad de clarisas recientemente instaladas junto a San Francisco ${ }^{2085}$.

Fueran o no estas beatas el origen de la presencia franciscana femenina en Aranda, lo cierto es que la documentación atestigua su presencia ya en la segunda mitad del siglo XV. En concreto sabemos de su existencia a través de un conflicto que mantuvieron las beatas con el convento de monjas dominicas de Santo Domingo de Guzmán en 1463 a propósito de unas tierras en Aranda ${ }^{2086}$. También sabemos que al menos desde 1506 esta comunidad de mujeres recibía de la Corona un juro sobre la renta del vino de las alcabalas de la villa por un valor de 1.500 maravedíes anuales ${ }^{2087}$. Asimismo en 1515, en el contexto de la referida calle abierta frente a San Francisco, se hacía mención a que Pedro de Santa Cruz era propietario de parte de los solares afectados en los que dijo que tenía ... una huerta para una casa que tiene junto con el dicho solar que la tiene para beatas $^{2088}$. A falta de otras beatas, éstas serían las de la Virgen de las Viñas. Por lo tanto podemos afirmar que ya en estos primeros años del Quinientos tenía la comunidad de beatas un emplazamiento extramuros de la villa, cercano a una posible ermita de San

${ }^{2085}$ DE LA CRUZ, Historia de la milagrosa imagen..., pp. 68-71; y VELASCO PÉREZ, Aranda. Memorias..., pp. 261-263 y 272-273.

${ }^{2086}$ MARTÍNEZ LIÉBANA, Colección de documentos..., doc. CCCIX, pp. 396-397.

${ }^{2087}$ AGS, CMC, leg. 41, doc. 7.

${ }^{2088}$ AGS, CC PUEBLOS, leg. 2, doc. 107. 
Antonio $^{2089}$, y que coincidía con el espacio que posteriormente ocupó el convento de las clarisas.

En la periferia de la Ribera del Duero burgalesa también existían otros monasterios. En tierras sorianas estaba instalada la comunidad cisterciense femenina de Fuencaliente. El origen de este monasterio también está vinculado a la casa Avellaneda pues parece ser una fundación del siglo XII de doña Urraca de Avellaneda, viuda de don Martín López de Haro ${ }^{2090}$. Tanto Abad Zapatero como Álvarez Borge ya han estudiado el origen y formación de este monasterio por lo que nos remitimos a sus respectivos trabajos $^{2091}$.

En el extremo Oeste, lindando con la comarca del Cerrato se situaba el monasterio benedictino de Santa María de Tórtoles de Esgueva ${ }^{2092}$. Esta institución tuvo su origen a finales del siglo XII cuando la familia Armildez promovió la instalación de una comunidad femenina bajo la regla de San Benito, si bien es cierto que previamente se había intentado crear un cenobio bajo el amparo de los premostratenses de la $\mathrm{Vid}^{2093}$. A finales de la Edad Media la vinculación de estos establecimientos religiosos con el núcleo central de la comarca burgalesa fue bastante reducido y se limitó a ciertos enfrentamientos con algunos de los señores que abordaremos más ampliamente en el próximo capítulo. Sin embargo, con el paso del tiempo estas comunidades estrecharon su relación con la capital de la Ribera pues las dos comunidades femeninas terminaron por

${ }^{2089}$ VELASCO PÉREZ señala que "antes de 1560 se habla en los libros municipales del puente de San Antonio, refiriéndose sin duda al de Fuenteminaya, lo cual indica que alguna ermita o edificio dedicado al Santo prestaba su nombre al puente más vecino, así como el convento de S. Francisco dio también su nombre al puente que hoy llamamos el puente viejo” (Aranda. Memorias..., pp. 272-273). Nosotros no hemos tenido acceso a esos libros ni hemos encontrado por el momento ninguna referencia a la ermita de San Antonio en la documentación manejada.

${ }^{2090}$ SALAZAR Y CASTRO, Historia Genealógica..., vol. III, p. 405.

${ }^{2091}$ ABAD ZAPATERO, J. G., Apuntes para una Historia..., pp. 75-93; y ÁLVAREZ BORGE, Poder y relaciones..., p. 214.

2092 Algunas notas sobre el origen y evolución de este monasterio se pueden obtener de SERRANO, L., "Los Armíldez de Toledo y el monasterio de Tórtoles", en Boletín de la Real Academia de la Historia. 1933, pp. 60-140; y ESTEBAN VALLEJO, J. L., Historia documentada de Tórtoles de Esgueva. Burgos, 2011, pp. 169 y ss.

2093 ÁLVAREZ BORGE, Poder y relaciones..., p. 203. 
establecerse en Aranda: el monasterio cisterciense se trasladó a mediados del siglo XVI y el benedictino de Tórtoles ya en el siglo $\mathrm{XX}^{2094}$.

En el flanco Este de la comarca también se desarrolló la actividad de una comunidad de jerónimos que tuvo su sede en San Marcelino de Espeja y que a finales de la Edad Media tan solo mantenía vínculos con algunos señores ribereños como veremos más adelante. Sin embargo, la relación de la comarca con la orden jerónima tuvo un primer episodio frustrado con el intento de uno de los descendientes del linaje de los Avellaneda de establecer un monasterio jerónimo en Aranda o Langa. Finalmente esta iniciativa vio la luz en las inmediaciones de la villa de Valladolid dando origen al monasterio de Santa María del Prado ${ }^{2095}$.

En definitiva, la comarca de la Ribera del Duero burgalesa estuvo jalonada por una serie de importantes centros monásticos que se constituyeron a lo largo de los primeros siglos medievales en significativos centros de poder con un notable potencial económico. Sin embargo, el final de la Edad Media supuso para muchos de los cenobios tradicionales la confirmación de su pérdida de poder que ya había comenzado en época plenomedieval. A lo largo del Cuatrocientos tan solo dos nuevos establecimientos vieron la luz en tierras ribereñas y ambos asociados a la nueva religiosidad franciscana más adaptada a los cambios en la mentalidad de la sociedad urbana. A pesar de que todos estos monasterios y conventos se vieron sumidos en múltiples conflictos internos y sus bienes terrenales se convirtieron en los principales objetivos de la política expansiva de sus vecinos laicos, es incuestionable que todavía conservaron y ejercieron una importante influencia sobre el conjunto de la sociedad ribereña.

Tras identificar y analizar el papel que tuvieron cada uno de los actores que configuraron la realidad social, económica y política de la Ribera del Duero burgalesa al

${ }^{2094}$ En concreto la comunidad cisterciense de Fuencaliente se trasladó en 1585 por orden del obispo de Osma, configurando en el espacio intramuros de la villa el monasterio de Santa María del Valle (LOPERRÁEZ CORVALÁN, Descripción histórica..., Tomo II, p. 181). Este cenobio se trasladó de nuevo a mediados del siglo XX a un emplazamiento a las afueras de Aranda. (ABAD ZAPATERO, Apuntes para..., pp. 80-93). Finalmente las penurias vocacionales y económicas provocaron la clausura y demolición de este cenobio en los primeros años del siglo XXI. Por su parte, la comunidad benedictina de Tórtoles abandonó el viejo monasterio y se trasladó a Aranda en 1976.

${ }^{2095}$ El monasterio de Santa María del Prado fue fundado en 1441 por doña Isabel de Ávila, viuda de Ruy González de Avellaneda (RUCQUOI, A., Valladolid en la Edad Media. El mundo abreviado. Valladolid, 1997, Vol. II, p. 278). 
final de la Edad Media, podemos concluir que, además de otros factores que hemos definido, el control del territorio fue un elemento primordial en la creación y consolidación del poder sobre el que se sustentaba la posición de los protagonistas que hemos analizado. La proyección sobre el territorio de los intereses contrapuestos de estos actores políticos provocó necesariamente una tensión que derivó con frecuencia en conflictos. Desde nuestro punto de vista la comprensión de la dinámica de esta conflictividad es imprescindible para conseguir una visión completa de la evolución histórica de la sociedad en este ámbito geográfico. 
$Y$ del saco que dezis que abeys de benir a hazernos, vuestras mercedes serian digno del. Y hesos ocho mil ducados que nos pedys, enbyad vuestro reçeptor por ellos que aquí los tenemos puestos en el cambio para gelos dar, syno que son un poco escasos. Porque por esta os prometemos que os reçibamos con muy buena boluntad y estamos determinados de hazer lo que hazieron los de Jerusalem que es que quemaron sus byenes para que con mayor animo osasen morir en su defension.

Aranda de Duero, 30 de abril de 1521.

AGS, PR, CC MEMORIALES, leg. 140, doc. 68 
La coexistencia en el territorio ribereño a finales de la Edad Media de todos los actores que hemos analizado en el capítulo anterior provocó continuos conflictos por el control del poder, o lo que es lo mismo, la pugna entre estos protagonistas por conseguir un mayor dominio sobre el territorio y sus gentes. El objetivo de nuestro estudio es analizar el significado de estos conflictos e identificar la plasmación sobre el espacio de una dinámica violenta propia del feudalismo de la época.

Sin lugar a dudas, el conflicto es una situación inherente al ser humano. Todos los aspectos de la vida se encuentran salpicados de pequeños o grandes enfrentamientos $\mathrm{y}$ las relaciones sociales no se pueden entender sin este fundamental elemento que, lejos de constituir por sí mismo un factor negativo, se configura en muchas ocasiones como un elemento dinamizador clave en los procesos de creación, consolidación y crisis de las estructuras sobre las que se han asentado las distintas formas de organización social de los seres humanos a lo largo de la Historia ${ }^{2096}$. En consecuencia, el estudio de los diferentes conflictos permite al historiador reconstruir en gran medida las características propias de las diferentes sociedades y la organización del territorio sobre el que se desarrollaron $^{2097}$. En este sentido, es evidente que el conflicto juega un importante papel en la dinámica interna de la sociedad, bien sea como motor o como síntoma de una evolución propia y particular de cada grupo humano.

Somos conscientes de que el concepto de conflicto no lleva implícito la necesidad de manifestaciones violentas pero lo cierto es que en el periodo en el que nos situamos el recurso a la violencia formó parte de la cotidianeidad de la sociedad medieval ${ }^{2098}$

${ }^{2096}$ SCHELLING, Th., La estrategia del conflicto. Madrid, 1964, pp. 15 y ss. Este autor define las contrapuestas acepciones, visiones e interpretaciones que ha tenido el término conflicto a lo largo de la Historia. Evidentemente nuestra posición se ajusta a la definición que plantea el conflicto social como un mecanismo de innovación y cambio.

2097 Según la categorización de los conflictos nuestro análisis se centraría en los conflictos de recurso (CARBÓ, L., "Aproximación al conflicto bajomedieval castellano", en Cuestiones de Historia Medieval. Buenos Aires, 2011, Vol. II, pp. 373-403).

${ }^{2098}$ MARTÍN CEA señala que la violencia en el mundo feudal tuvo un carácter endémico y la caracteriza como un riesgo permanente ("La intervención política concejil en el mantenimiento de la convivencia. Castilla siglos XIV y XV", en La convivencia en las ciudades medievales. Logroño, 2008, pp. 393-425, en concreto p. 398). En palabras de SOLÓRZANO TELECHEA el conflicto y la violencia sustentaron el complejo edificio del sistema feudal y formaron parte del indisoluble lenguaje cotidiano de los individuos y los grupos sociales ("Violencia y conflictividad política en el siglo XV: el delito al servicio de la élite en las Cuatro Villas de la Costa de la Mar", en Anuario de estudios medievales, 35, 1, 2005, pp. 159-184, en concreto p. 160). La violencia como medio de vida ha sido estudiado por CABEZUELO PLIEGO, J. V., "Guerra y violencia en un espacio frontero”, en Canelobre. 52, 2007, pp. 42-57. 
y fue uno de los primeros y principales instrumentos utilizados para alcanzar los objetivos planteados por los diferentes protagonistas sociales ${ }^{2099}$. Nuestro trabajo se ha centrado en identificar y comprender las manifestaciones asociadas a las categorías de violencia estructural y cultural que definió en su momento Galtung, sin por ello dejar de lado los fenómenos de violencia directa que tuvieron lugar en la Ribera del Duero burgalesa a finales de la Edad Media ${ }^{2100}$. En este sentido, es necesario matizar que las manifestaciones violentas que hemos documentado en pocos casos pueden ser catalogadas como físicas pues en la mayoría de las ocasiones se recurre a la ostentación de fuerza, a la amenaza, el temor y el miedo, los castigos espirituales, o incluso la sangre y el honor, para conseguir la imposición de unos determinados planteamientos o intereses. En este sentido, nuestro objetivo en el desarrollo de este capítulo es analizar el papel e incidencia que la violencia tuvo, no tanto en sí misma, sino en el contexto de la conflictividad

Revelador de este carácter cotidiano de la violencia es la sistematización planteada por CÓRDOBA DE LA LLAVE a propósito de su tipología, escenarios y protagonistas ("Violencia cotidiana en Castilla a fines de la Edad Media", en Conflictos sociales, políticos e intelectuales en la España de los siglos XIV y $X V$. Logroño, 2004, pp. 393-444).

${ }^{2099}$ El profesor RUIZ ya señaló en su momento que "los actos de agresión individual y colectiva formaban parte de un lenguaje simbólico, una forma violenta de comunicar el poder" (Historia social de España, 1400-1600. Barcelona, 2002, p. 179). Sobre este aspecto nos parece muy interesante la reflexión de BARROS GUIMERANS que afirma que la violencia, además de instrumento, "es consecuencia -y síntoma- de desigualdades sociales, cuando no causa de conflictos, actuando asimismo como factor de regulación, como medio y rito restaurador de equilibrios rotos y superador de contradicciones extremas, lo cual paradójicamente vincula violencia, inseguridad y desorden con sus conceptos contrarios, paz, seguridad y orden, especialmente en el imaginario y el inconsciente colectivos" ("Violencia y muerte del señor en Galicia a finales de la Edad Media", en Studia Historica. Historia Medieval. 9, 1991, pp. 111158). La institucionalización de la violencia como instrumento de dominación ha sido abordada por VAL VALDIVIESO, M. I., "Cruelty in Medieval Castile. War, Towns and Monarchy in te XV Century", en On Cruelty. Sur la cruaté. Über Grausamkeit. Colonia. 2011, pp. 492-510.

${ }^{2100}$ Siguiendo los planteamientos de este autor, la violencia directa se manifiesta en agresiones físicas, verbales o psicológicas. La violencia estructural se define por la existencia de un conflicto entre dos o más grupos de una sociedad en el que el reparto, acceso o posibilidad de uso de los recursos es resuelto sistemáticamente a favor de alguna de las partes y en perjuicio de las demás debido a los mecanismos de estratificación social. Se trataría de una violencia intrínseca a los sistemas sociales, políticos y económicos. Por su parte, la violencia cultural incluiría aquellos aspectos de la cultura, en el ámbito de lo simbólico (religión e ideología, lengua y arte, ciencias empíricas y formales, símbolos), que pueden utilizarse para justificar o legitimar la violencia directa o estructural. También nos parece interesante el planteamiento de identidad entre violencia estructural y cultural cuando la primera es legitimada por la sociedad en la que se desarrolla. Evidentemente este esquema conceptual de la violencia ha sido planteado en el contexto de la resolución de conflictos en sociedades postindustriales pero creemos que algunos de los conceptos definidos por este autor son perfectamente aplicables al mundo feudal. A riesgo de ser simplistas, podemos identificar la violencia estructural con la dinámica general de los conflictos violentos y la violencia cultura con la ideología legitimadora de esa dinámica (GALTUNG, J., Tras la violencia, 3R: reconstrucción, reconciliación, resolución. Afrontando los efectos visibles e invisibles de la guerra y la violencia. Bilbao, 1998; y Violencia cultural. Guernica, 2003; una visión global sobre la obra de Galtung se puede consultar en CALDERÓN CONCHA, P., "Teoría de conflictos de Johan Galtung”, en Revista Paz y Conflictos. 2, 2009, pp. 60-81). 
que se desarrolló en el espacio ribereño bajomedieval siguiendo los pasos que desde hace algún tiempo ya marcaron otros investigadores en otros ámbitos geográficos ${ }^{2101}$.

Estrechamente relacionado con la conflictividad y la violencia, sobre todo cultural, se encuentra el instrumento de legitimación más manido del periodo bajomedieval: el bien e pro comun o la utilidad de la republica ${ }^{2102}$. Si bien es cierto que las relaciones sociopolíticas del mundo feudal se asentaban sobre la teoría trifuncional y la fuerza ${ }^{2103}$, durante la Baja Edad Media se desarrolló lo que algunos autores denominan un nuevo principio de acción política basado en la práctica del buen gobierno como instrumento para afianzar la legitimación de la clase dominante ${ }^{2104}$. Ciertamente este ha sido un aspecto sobre el que la historiografía medieval ha escrito muchas páginas entre las que podemos destacar las apreciaciones de Bonachía Hernando sobre el bienestar general y la defensa y promoción de la honra urbana, a las que se debe añadir la buena justicia de la que habla Monsalvo Antón ${ }^{2105}$. Mucho más ambiciosa es la propuesta de Jara Fuente al plantear que en los núcleos urbanos castellanos se desarrollaron mecanismos de reconstrucción de la percepción de la dominación, en los que tenía cabida la negociación y ciertas cesiones de la clase dominante, ligados a conseguir objetivos de bien común con lo que se obtenía un doble objetivo: por una parte, la legitimación de la dominación $\mathrm{y}$, por otra, la creación de espacios comunes en los que participaban los dominados,

${ }^{2101}$ Complementando las referencias citadas anteriormente y sin ánimo de ser exhaustivos, señalamos a continuación algunos trabajos sobre este aspecto: DINZELBACHER, P., "La violencia en la edad media. Reflexiones desde la perspectiva de la historia de las mentalidades", Temas medievales, 5, 1995, pp. 141-162; SOLÓRZANO TELECHEA, Santander en la Edad Media..., pp. 310 y ss; MARTÍN CEA, J. C., "Violencia y conflictividad social en Castilla, vista desde el prisma de la historia local (siglos XIV y XV), en Conflicto, violencia y criminalidad en Europa y América. Vitoria, 2004, pp. 105-144; MONSALVO ANTÓN, J. M., "Violence between Factions in Medieval Salamanca: some Problems of Interpretation", Imago temporis. Medium Aevum, 3, 2009, pp. 139-170; y BORRERO FERNÁNDEZ, M., "Violencia entre vecinos: las tensiones cotidianas en el ámbito rural medieval", en Homenaje al profesor Eloy Benito Ruano. 2010, vol. 1, pp. 145-158.

2102 AMA, leg. 43, doc. 15; y AGS, CC MEMORIALES, leg. 151, doc. 148.

${ }^{2103}$ BARROS GUIMERANS , "Violencia y muerte..., p. 115.

${ }^{2104}$ BLICKLE, P., "El principio del bien común como norma para la actividad política: La aportación de campesinos y burgueses al desarrollo del Estado Moderno temprano en Europa Central", en Edad Media: revista de historia. 1, 1998, pp. 29-46.

${ }^{2105}$ BONACHÍA HERNANDO, J. A., "Mas honrada que ciudad de mis reinos...: la nobleza y el honor en el imaginario urbano (Burgos en la Baja Edad Media)", en La ciudad medieval. Aspectos de la vida urbana en la Castilla bajomedieval. Valladolid, 1996, pp. 169-212; y MONSALVO ANTÓN, J. M., "Aspectos de las culturas políticas de los caballeros y los pecheros en Salamanca y Ciudad Rodrigo a mediados del siglo XV. Violencias rurales y debates sobre el poder en los concejos", en Lucha política. Condena y legitimación en la España medieval. 2004, pp. 237-297. 
todo ello en aras de reducir la conflictividad a unos niveles razonables ${ }^{2106}$. Hubiera o no espacio para la negociación entre la clase dominante y los dominados, lo cierto es que tanto los unos como los otros recurrieron al bien e pro comun desta villa. La oligarquía utilizó este recurso para legitimar su actividad de gobierno y además configuró sobre este concepto una identidad común a la que recurría cuando su posición predominante estaba amenazada por cualquiera de los actores políticos del momento, fuera la monarquía, la nobleza comarcana o la comunidad. Por su parte, los dominados, bien a través de la comunidad como alternativa política o del grupo de individuos que ostentaba la representatividad del común, apoyaban sus reivindicaciones sobre este mismo concepto ${ }^{2107}$. Esta situación provocó que en la práctica el mismo concepto fuera utilizado sin ningún pudor por dominados y dominantes para defender aspectos totalmente contrapuestos, clara evidencia de la confrontación que vivía la sociedad medieval ${ }^{2108}$. En definitiva, participamos del planteamiento señalado por Martín Cea que insiste en que no debe de perderse de vista la lectura social de todas las decisiones que se fundamentan en el bien común que no es otra que la legitimación de una determinada acción de gobierno y que la imagen de los gobernantes fuera mejor percibida por los ciudadanos. Por lo tanto, esta nueva cultura política no cuestionaba en absoluto el orden feudal sino que lo mantenía y reforzaba ${ }^{2109}$.

En el contexto de los numerosos enfrentamientos que tuvieron lugar en la comarca de la Ribera del Duero a finales de la Edad Media hemos centrado nuestro análisis en aquellos que consideramos más significativos para comprender la dinámica propia de esta sociedad feudal. En este sentido, nos inclinamos por dirigir nuestra atención al estudio de la pugna por el control del territorio, escenario sobre el que se plasma de

${ }^{2106}$ JARA FUENTE, J. A., "Negociando la dominación: las elites urbanas castellanas en el siglo XV (el ejemplo de Cuenca)", en La gobernanza de la ciudad europea en la Edad Media. Logroño, 2011, pp. 399- 425.

2107 VAL VALDIVIESO, “La identidad urbana..., p. 16; JARA FUENTE, J. A.,”Con mucha afección e buena voluntad por seruir a bien publico: la noción de 'bien común' en perspectiva urbana", en Studia historica. Historia Medieval. 28, 2010, pp. 55-82; y GUERRERO NAVARRETE, Y., "Poder patricio e identidad política en Burgos", en Anales de la Universidad de Alicante. 16, 2009-2010, pp. 6391.

${ }^{2108}$ En 1487 los regidores y alcaldes de la villa justificaban una serie de gastos del concejo argumentando que ...fasemoslo e entendemoslo faser por el bien e parte e comun de la dicha villa. Por su parte los representantes de la comunidad recurrieron al pro bien de la republica para justificar la denuncia a los regidores por la mala gestión de los recursos del concejo (AGS, CC PUEBLOS, leg. 2, doc. 78 y $88)$.

${ }^{2109}$ MARTÍN CEA, "La intervención política concejil..., p. 425. 
manera evidente la lucha por los recursos humanos y materiales a él vinculados ${ }^{2110}$. Asimismo analizaremos aquellos enfrentamientos que tuvieron su razón de ser en la lucha por el poder político y la dominación social, aspectos que también comportaron una proyección espacial.

A continuación presentaremos los principales enfrentamientos identificados en este periodo y su significado más allá de los acontecimientos propiamente dichos. El capítulo comienza con el análisis del papel de la autoridad real sobre la comarca en el contexto de la última guerra civil del siglo XV. A continuación abordaremos la problemática derivada de los conflictos de cariz religioso. Seguidamente nos centraremos en la dinámica expansiva de los principales linajes nobiliarios de la comarca. Posteriormente analizaremos la conflictividad propia de una sociedad urbana en expansión como lo era la arandina en este periodo. Finalmente, estudiaremos el conflicto que puso colofón a esta etapa y cuyas consecuencias condicionaron la posterior evolución de Castilla. Concluiremos por lo tanto con el análisis de la incidencia y consecuencias de la Revolución de las Comunidades en la Ribera del Duero burgalesa.

\section{LA RIBERA DEL DUERO BURGALESA COMO ESCENARIO DEL CONFLICTO CIVIL: EL RECONOCIMIENTO DE LA AUTORIDAD} REAL.

El último conflicto sucesorio del siglo XV y la consiguiente guerra con Portugal marcaron un significativo punto de inflexión en la historia de Castilla pero también en la microhistoria de la Ribera del Duero pues, como ya hemos visto, se configuraron cla-

2110 Nuestro planteamiento participa de las puntualizaciones señaladas en su momento por DAHRENDORF a propósito de la disociación entre el control y la propiedad de los medios de producción (Las clases sociales..., pp. 64-70; "Hacia una teoría..., pp. 97-107). El análisis de este autor se centra en la realidad industrial y ejemplifica su análisis con las sociedades de acciones. Aun a riesgo de ser temerarios podríamos identificar este mismo fenómeno en la sociedad feudal diferenciando la propiedad en su sentido pleno, los derechos jurisdiccionales que se poseen sobre vasallos y territorios y el control efectivo y real que se ejerce sobre una población y espacio. Tomemos dos ejemplos ribereños: el monasterio de San Pedro de Gumiel tenía unas propiedades y poseía los derechos jurisdiccionales sobre la granja de Milagros; de igual manera los señores de Hoyales eran propietarios de una importante hacienda y su jurisdicción se extendía sobre los 90 vasallos de la villa. Sin embargo, durante buena parte de la segunda mitad del siglo XV fueron los diferentes condes de Miranda los que ejercieron su control sobre ambos lugares y quienes se beneficiaron de los recursos económicos asociados a estos territorios y vasallos. 
ramente los principales actores que dinamizaron la vida política y social de la comarca durante al menos el siguiente medio siglo.

La crisis sucesoria de finales de los años sesenta y principios de los setenta sumió a la comarca ribereña en un periodo de gran inestabilidad. Como punto de partida tomemos el relato de la Crónica anónima de Enrique IV que describe un episodio acaecido en la capital de la Ribera en el transcurso del enfrentamiento sucesorio ${ }^{2111}$.

De cómo la villa de Aranda se dio a los prinçipes don Fernando e doña Ysabel, e de otras...

En tanto quel prinçipe don Fernando en Catalueña estava, los moradores de la villa de Aranda acordandose de la begninidad con que avian seydo tratados por el rey don Juan, su padre, en el tienpo que aquella villa era suya, determinaron de darse al prinçipe don Fernando, su fijo, e a la prinçesa doña Ysabel, su muger. Ayudo a esto aquella villa ser muy maltratada por malos onbres, a quien la reyna doña Juana avie dado el mando della, como el rey don Enrrique gela oviese dado; e cada dia las discordias e disensiones entre los moradores della se acreçentasen e siempre resçibiesen daño de los grandes que por vezinos tenian, espeçialmente de Pedro de Estúñiga, señor de Vaydes ${ }^{2112}$, de tal manera que como del asy los nobles como los populares eran maltratados, determinaron con algunos de cavallo yr pelear con el, teniendo muy mayor copia de gentes.

E como fallasen çerca de un aldea, los de Aranda tan valientemente pelearon, que Pedro de Estuñiga fue preso e su cavallo muerto, e muchos de los suyos muertos e feridos; y el rencor de que muchos dias estava se bengo. De lo

${ }^{2111}$ Crónica anónima de Enrique IV..., Capítulo LXXVII, pp. 425-426. Relato muy similar hace PALENCIA en Crónica de Enrique IV, tomo III, pp. 167-168. A este episodio también se hace referencia en un documento conservado en el Archivo Municipal de Aranda de Duero (AMA, leg. 43, fol. 25) que recoge las quejas de ciertos vecinos que reclamaban 10.000 maravedíes por las pérdidas sufridas al resistir la entrada de Pedro de Zúñiga. El documento ha sido transcrito por HURTADO QUERO, Documentos Reales... doc. 13, pp. 27-28.

${ }^{2112}$ Este Pedro de Zúñiga, señor de Baides, no era el hijo del conde de Miranda, sino su pariente el hijo del señor de Monterrey. No obstante, tan solo el anónimo cronista de esta crónica hace referencia a este título ya que Palencia, o bien sólo lo cita por el nombre, o bien lo identifica como conde de Miranda. Este aspecto también es incorrecto pues todavía en 1472 no había heredado el título de su padre (Crónica de Enrique IV, tomo III, pp. 167-168). Los diferentes autores que han estudiado este acontecimiento también identifican a este Pedro de Zúñiga con el heredero de la casa de Miranda (VELASCO PÉREZ, Aranda. Memorias..., p. 114; VAL VALDIVIESO, "Resistencia al dominio..., p. 19; y DIAGO HERNANDO, "Hidalgos y pecheros..., p. 117). 
qual grandes males se siguieron, en que la reyna ni sus comisarios ningun remedio dieron. E fue consejo tomado entre los de la villa de se dar a la prinçesa doña Ysabel, pues que el prinçipe estava en Catalueña, la qual los resçibio, y encomendo la guarda de aquella villa a don Diego de Rojas, cavallero muy noble, señor de la villa de Gumiel de Mercado.

Lo qual agramente sufrio la reyna Juana, cuya era aquella villa, por donaçion con trato de derecho a ella fecha por el rey don Enrrique; de lo qual no menos desplugo a don Diego de Estúñiga, conde de Miranda, como desamase mucho a los de aquella villa. E al maestre de Santiago fue tanto molesto como sy perdiera la villa de Belmonte, como le paresçiese los fechos de los prinçipes yr en otra manera de lo que el pensava, aviendoseles dado, pocos dias avie, la villa de Sepulveda e despues agora la villa de Aranda,...

Aunque no conocemos a ciencia cierta la fecha en la que tuvo lugar el levantamiento de la villa contra don Pedro de Zúñiga estimamos que se produjo en el otoño de 1472 , seguramente a finales de octubre ${ }^{2113}$. Tras este enfrentamiento las autoridades de la villa acudieron ante la princesa Isabel que se encontraba en Tordelaguna para ofrecerle la villa la víspera de la Navidad de ese mismo año ${ }^{2114}$. Al igual que ya había ocurrido con Sepúlveda poco tiempo antes, los arandinos consiguieron de la futura reina el compromiso de respetar los antiguos privilegios.

La disputa dinástica tuvo su proyección sobre la sociedad arandina como ponen de manifiesto la propia crónica y multitud de documentos posteriores. En ellos se hace referencia a una verdadera confrontación civil entre los vecinos como relataba años después la propia reina: ...que antes nos reynasemos en estos nuestro reinos, seyendo nues-

${ }^{2113}$ Este dato se deduce de varias informaciones complementarias. Por una parte, parece obvio que debió suceder antes de que doña Isabel confirmara los privilegios de la villa el 23 de diciembre, tras el juramento como princesa por parte de las autoridades arandinas (AMA, leg. 43, doc. 32; transcrito por HURTADO QUERO, Documentos Reales..., doc. 10, pp. 21-24). Por otra parte, Alonso de Palencia señala que el príncipe Fernando ...en los días en que la villa de Aranda, por espontáneo impulso, trocó la obediencia de la reina Doña Juana por la de la princesa Doña Isabel, salió de Valencia, donde había recibido con grande honra al obispo de Sigüenza (Crónica de Enrique IV. Tomo III, pp. 35-36). La 1legada del obispo Mendoza a Valencia se produjo el 20 de octubre y el 2 de noviembre se encaminó junto al legado Rodrigo de Borja hacia Madrid (AZCONA, Isabel..., pp.180-183). No obstante, tanto AZCONA como VICENS VIVES sitúan este hecho a principios de 1473 (Isabel la Católica, p. 188; y Fernando II de Aragón. Zaragoza, 1962, p. 326, respectivamente).

2114 AMA, leg. 43, doc. 32, transcrito por HURTADO QUERO, Documentos Reales..., doc. 10, pp. 24. No se conserva el documento original fechado el 23 de diciembre de 1472 y tan solo contamos con un traslado notarial de 1500 . 
tra la dicha villa de Aranda, entre los vesinos della dis que ovo parçialidades e deferençias en que se fesyeron de la una parte a la otra ynjustas e tomas de bienes ${ }^{215}$. Todo ello permite identificar en el contexto del conflicto sucesorio la existencia de dos bandos claramente definidos en el seno de la sociedad arandina: por una parte los partidarios de la reina Juana apoyados por la familia Zúñiga y, por la otra, los seguidores de la princesa Isabel con el soporte de don Diego de Sandoval. Entre los primeros destacaba la familia de los Mora con Pedro García de Aranda a la cabeza, y capitaneando a los segundos se encontraba Rodrigo de Salazar, patriarca del linaje de este nombre ${ }^{2116}$.

Uno de los momentos álgidos dentro de este enfrentamiento se produjo con motivo de la toma de la villa por parte de las huestes de don Diego de Rojas, auxiliado por García de $\operatorname{Cotes}^{2117}$. Este episodio violento es posible que tuviera lugar a finales del verano de $1473^{2118}$. Según Palencia, ante la situación de inestabilidad que vivía la villa, a los vecinos de Aranda ...fueles preciso aceptar la guarnición que les envió la Princesa al mando de Diego de Rojas, noble sujeto á quien varios de Aranda llamaron de la cercana villa de Gumiel de Mercado ${ }^{2119}$. El asalto de la villa debió ser cruento a tenor de los muchos destrozos que se ocasionaron. Así parece afirmarlo la compensación por valor de 250.000 maravedíes que fijó doña Isabel para la clientela del licenciado Pedro García de Vadocondes que había sufrido grandes pérdidas en sus haciendas a causa de la actuación de Rodrigo de Salazar, uno de los hombres de confianza de don Diego ${ }^{2120}$. Por idéntico motivo fueron compensados con 50.000 maravedíes la familia Mejías y con

2115 AGS, RGS, 148803, fol. 35. PALENCIA asegura que ...todo ello produjo luego escándalos para unos y otros funestos. (Crónica de Enrique IV, Tomo III, pp. 168).

2116 AGS, CASA y SITIOS REALES, leg. 3, docs. 123 y 124.

${ }^{2117}$ El escribano Martín Sánchez de Sepúlveda declaraba años después que al tiempo quando se entrego la villa de Aranda por mandado de la Reyna nuestra señora seyendo prinçesa e la entraron García de Cotes e el marques de Denia don Diego de Rojas (AGS, CC PERSONAS, leg. 2, doc. 200).

2118 Álvaro González se quejaba de que al tiempo que la villa se redujo al servicio real Martín Sánchez de Casasola, futuro regidor de la Comunidad, le vendimió una viña sin su permiso y se quedó con las 500 cántaras de vino que obtuvo (AGS, RGS, 149404, fol. 209). Teniendo en cuenta este dato es posible que la toma de la villa fuera a finales de septiembre, pocos días antes de la entrada de la princesa en la villa.

${ }^{2119}$ PALENCIA, Crónica de Enrique IV, Tomo III, pp. 168.

${ }^{2120}$ AGS, CASA Y SITIOS REALES, leg. 3, doc. 123. 
20.000 los Villarreal, a pesar de que aseguraban haber tenido unas perdidas de más de 250.000 maravedíes $^{2121}$.

Más ilustrativo de este clima de violencia nos parece el caso del robo que sufrió el prestamista Tristán de Arcilla en el transcurso de la toma de la villa. Según los diversos testimonios de sus vecinos: un viernes en la noche le robaron quantya de quatroçientos mil maravedies en oro e en plata; e que otro día de mañana por ser sabado no lo cato por que hera a la sazon judio; e que otro dia domingo fue abrir su tyenda e arca e que lo hallo menos e que començo a dar bozes que lo avian robado; e que el testigo por ser su vesino le echaron preso por sospecha e le pusyeron a questyon de tormento e que despues paresçio en poder de dos criados del conde e condesa de Castro ${ }^{2122}$. Efectivamente se probó que dos criados de la condesa de Castro, Lope y Bernal, robaron la cantidad de 800 castellanos y 800 reales de la casa de Arcilla. El fruto del robo fue recuperado por don Diego, y los criados encarcelados en Lerma. Sin embargo, en lugar de devolver el dinero a su legítimo dueño, la dicha condesa lo avia gastado en pagar la gente que avia venido a tomar la dicha villa por su altesa. Todo ello nos hace pensar que se trató más bien de una estratagema para obtener dinero de forma rápida y así contentar a los participantes en el despliegue bélico. Tras muchas reclamaciones, Arcilla consiguió una garantía de la princesa en la que se reconocía la deuda pero a pesar de tramitarla ante Abrahem Seneor no consiguió cobrarla ${ }^{2123}$.

No obstante, al amparo de este episodio violento también se produjeron una multitud de incidentes que poco tenían que ver con la disputa dinástica sino más bien con rencillas y venganzas que se estaban fraguando en el seno de la sociedad arandina. Así lo afirmaba Diego de Roa, partidario de la pretendiente Juana, poco tiempo después: ...en tiempo del señor don Enrique las partes contrarias con todos sus parientes amigos e valedores atentaron muchas veces con robar, ferir y matar a mis parientes y valedores e lo pusieron en obra y todavia lo fecieran e acabaran salvo por que plogo a Dios nuestro Señor de me dar fuerzas con mis parientes señores e amigos para me defender de todos ellos ${ }^{2124}$. De igual manera Fernando de Ayllón denunciaba que algunos vecinos

\footnotetext{
${ }^{2121}$ AGS, CASA Y SITIOS REALES, leg. 2, doc. 480; y leg. 4, docs. 143 y 146.

${ }^{2122}$ Declaración de Francisco de Aranda (AGS, CC PERSONAS, leg. 2, doc. 200).

${ }^{2123}$ AGS, RGS, 149412, fol. 197; y 149508, fol. 78.

${ }^{2124}$ AGS, CC MEMORIALES, leg. 149, doc. 173.
} 
aprovecharon el asalto de la villa para robarle ocho cubas, tres viñas, varias fanegas de trigo y algunas cántaras de vino ${ }^{2125}$. Algo similar le ocurrió a la familia Tintorero que fue despojada por la fuerza de su casa y tinte además de otros bienes, por odios y envi$\operatorname{dias}^{2126}$.

Tras este episodio violento la villa se sometió definitivamente a la obediencia de la princesa Isabel. El notable peso que tuvo en el contexto del conflicto sucesorio el paso de Aranda al bando de la pretendiente nos lo muestra el hecho de que poco tiempo después de la toma se presentó la princesa ante las puertas de la villa para recibir su posesión personalmente. Así el 6 de octubre de 1473 en el arrabal de allende Duero de la villa de Aranda... la muy magnifica esclareçida prinçesa e señora desta dicha villa, doña Ysabel por la graçia de Dios, veniendo su señoria de camino e antes que entrase en esta dicha villa..., y en presencia del arzobispo Carrillo y don Diego de Rojas, teniente de la dicha villa por la dicha señora prinçesa, fue recibida por las autoridades locales. Como paso previo a la entrega efectiva de la ciudad, los regidores solicitaron a doña Isabel la confirmación de sus privillejos, libertades e esecuçiones e usos e costunbres que esta dicha villa tenia e su tierra e todos los otros reyes anteçesores de su señoria le avian dado e confirmado e jurado. La princesa aceptó la solicitud y fiso juramento en forma devida de derecho en manos del dicho muy magnifico señor don Alfonso Carrillo, arzobispo de Toledo ${ }^{2127}$. Esta ceremonia estaba cargada de un gran valor simbólico. En primer lugar, la princesa fue recibida en el exterior de la villa y los portadores del poder municipal no le permitieron franquear las murallas hasta que no adquirió el firme compromiso de respetar y salvaguardar los privilegios y libertades de la villa. Por otra parte, el espacio elegido se encontraba al otro lado del río, convirtiéndose éste en una frontera o límite que había que salvar. El puente sobre el Duero era el vínculo de unión entre ambas orillas que simbolizaba el compromiso que permitía la unión entre doña Isabel y su villa ${ }^{2128}$.

La presencia de la princesa en Aranda se dilató durante algunos meses. Durante su estancia doña Isabel recogió la adhesión del señorío de Vizcaya y confirmó el 14 de

${ }^{2125}$ AGS; RGS, 148003, fol. 104.

${ }^{2126}$ AGS, RGS, 148711, fol. 36.

${ }^{2127}$ AMA, leg. 42, doc. 6, transcrito por HURTADO QUERO, Documentos Reales..., doc. 11, pp. $24-26$.

${ }^{2128}$ VAL VALDIVIESO, “El reinado de los Reyes Católicos..., pp. 13-14. 
octubre los privilegios de la villa de Bilbao ${ }^{2129}$. También desde la capital de la Ribera se llevó la gestión de las negociaciones que concluyeron con el encuentro con Enrique IV el 28 de diciembre de ese mismo año, que supusieron un paso muy importante en el reconocimiento de las aspiraciones sucesorias de doña Isabel ${ }^{2130}$. Tampoco fue casualidad que durante los meses finales de 1473 la iglesia de San Juan albergara las sesiones del Concilio que el arzobispo Carrillo convocó con la doble intención de poner las bases de la reforma del clero castellano y conseguir el apoyo político para la causa de Isabel de una parte de los magnates de su arzobispado.

Tras la estancia de la princesa en la villa durante la Navidad y su salida hacia Segovia, la villa se vio sumida de nuevo en la inestabilidad. Lejos de pacificarse la situación, las intrigas del conflicto sucesorio se proyectaron también en Aranda a través de las maquinaciones del marqués de Villena y las intenciones de algunos vecinos que pensaban traicionar a la princesa Isabel y entregar a sus enemigos a su hija la infanta Isabel, que residía en la villa desde el otoño de 1473. En febrero los príncipes, tras tener noticias de estas intrigas, decidieron trasladar a la infanta a un lugar más seguro, libre de las intrigas de Pacheco ${ }^{2131}$.

Aunque el enfrentamiento sucesorio finalizó como todos sabemos, las heridas que dejó en la villa arandina tardaron en cerrarse. Prueba de ello fue la necesaria intervención de doña Isabel en julio de 1474 con el objetivo de poner paz entre los vecinos. Uno de los participantes en el Juramento o Perdón de Segovia relataba las causas de esta intervención y el desarrollo del encuentro el 24 de julio:

Cuando la villa dio obediencia a la reina habia en ella muchas avenisas y parcialidades debido a los ruidos y muertes pasados; e estando vuestra alteza en la ciudad de Segovia mando llamar las personas principales de la villa e mando faser e fiso paz e amistad de todas las cosas pasadas en todos los vecino

2129 ENRIQUEZ FERNÁNDEZ, J., HIDALGO DE CISNEROS, C. y MARTÍNEZ LAHIDAlgA, A., Fuentes documentales del País Vasco. Colección documental del Archivo histórico de Bilbao (1473-1500. San Sebastián, 1999, doc. 102, pp. 413-415.

${ }^{2130}$ AZCONA, Isabel la Católica ..., pp. 194 y ss.; VAL VALDIVIESO, Isabel la Católica, princesa..., pp. 317 y ss.

${ }^{2131}$ PALENCIA asegura que el marqués de Villena ...fomentaría asimismo la discordia entre los de Aranda y tendería otros lazos emponzoñados con su maldad (Crónica de Enrique IV, Tomo III, p. 169). Los intentos de hacerse con la niña Isabel aparecen recogidos en las páginas 186 y 193. 
y perdonó a todos por todas las culpas y delitos pasados y todos hicimos juramento de guardar la dicha paz y amistad ${ }^{2132}$.

A la par que se puso paz entre ambos bandos también se establecieron unas compensaciones económicas a los damnificados en el asalto de don Diego de Rojas, a las que ya se ha hecho referencia para el caso de la clientela de Pedro García de Mora y a las familias Mejías y Villarreal ${ }^{2133}$.

No sólo Aranda se vio inmersa en el conflicto dinástico pues la vecina Roa también estuvo implicada desde los primeros embates del conflicto sucesorio cuando los partidarios de don Alfonso trataron de arrebatar la villa al duque de Alburquerque ${ }^{2134}$. Más adelante los vecinos de la villa y su tierra se levantaron a favor de la princesa Isabel durante tres días ${ }^{2135}$.

Tras la muerte de Enrique IV y la coronación de Isabel en la ciudad del acueducto, don Fernando atravesó las tierras ribereñas a finales del mes de diciembre en su camino desde Aragón a Segovia. El episodio que narra el cronista Palencia muestra una realidad de paz y estabilidad más deseada que real y, en un alarde de retórica propagandística, convierte al príncipe en el mensajero de la buena nueva que toda la vecindad esperaba:

...el Rey siguió hasta Aranda... En el dintel de la puerta, ya anochecido, presenció cómo subían por la muralla á hacer centinela hombres rústicos cubiertos con pellejas, y preguntando la causa, le respondieron que por temor á la tiranía de los Grandes, ansiosos del daño de los habitantes, por haber seguido el partido de los Príncipes. Entonces el Rey les dijo: "Desechad ya todo recelo y haced que esos labriegos se vuelvan á sus hogares. No pongáis guardias nocturnas, y que las puertas de la villa estén siempre abiertas para todos los vecinos, pues ya la violencia que temíais está subyugada, y mientras yo viva jamás

${ }^{2132}$ AGS, CC MEMORIALES, leg. 149, doc. 173.

${ }^{2133}$ En el caso de la familia Mora-Aranda se establecieron dos plazos para el pago de los 250.000 maravedíes que, ante los recelos de los beneficiados, se fijó sobre las rentas reales de Aranda para los años 1475 y 1476. Esta desconfianza era premonitoria pues hasta 1503 no se abonaron los últimos 150.000 maravedíes (AGS, CASA Y SITIOS REALES, leg. 3, doc. 123). La indemnización de los Mejías se encuentra reflejada en leg. 2, doc. 480; y la de los Villarreal en leg. 4, docs. 143 y 146.

2134 PALENCIA, Crónica de Enrique IV, Tomo I, pp. 45-46; y ZAMORA LUCAS, La villa de Roa.., pp. 243-244.

${ }^{2135}$ AGS, RGS, 149306, fol. 15. 
levantará la cabeza". Inmediatamente llamaron á los centinelas y, con gran aplauso de los circunstantes y gran alegría de todos, los mandó recogerse á sus casas... $^{2136}$.

Evidentemente los hechos se impusieron sobre los deseos y la posterior guerra civil también tuvo sus repercusiones en tierras ribereñas. En el otoño de 1476 las tropas de don Fernando y de don Diego de Rojas pusieron cerco a la villa de Gumiel de Izán ante la negativa de su alcaide de entregar la plaza. Aunque este incidente estuvo más relacionado con la disputa entre los Sandoval y Girón, inmersos desde años atrás en la disputa por esta villa, el incidente fue aprovechado por el cronista Palencia para poner de relieve la personalidad avasalladora de don Fernando y sus dotes de estratega militar:

Muy ajeno (el alcaide de Gumiel) de sospechar la presencia del Rey, oyó de pronto que unos hombres, previamente iniciados en la estratagema, exigían en alta voz á los guardias, ante las puertas del castillo, ser oídos por el Alcaide. Preguntoles desde el recinto qué querían, y le notificaron que el Rey les enviaba para que entregase el castillo á otros que oportunamente enviaría. Excusóse el Alcaide, y entonces el Rey, que se habia tapado el rostro, se descubrió de pronto, y en alta voz le dicho quién era y le mandó que, cumpliendo con su deber de vasallo, entregase la fortaleza á quien él ordenase. El Alcaide se negaba alegando los pactos, y entonces D. Fernando contestó: “A cuantos estáis al lado del Alcaide y habéis oído mi real mandato os ordeno que inmediatamente me abráis las puertas, aunque tengáis que romper pestillos y cerrojos, si es que preferís á las excusas la lealtad que se me debe". Al punto todos, sin cuidarse del Alcaide, rompieron con las hachas cerrojos y pasadores y abrieron la fortaleza a su Rey, ante las inútiles protestas del Alcaide ${ }^{2137}$.

Asimismo, diversos testimonios de la época informan sobre las consecuencias de la guerra en la Ribera: tenemos noticias del saqueo que sufrió el vecindario de Fuentespina a manos de Gonzalo Muñoz de Castañeda ${ }^{2138}$; la participación activa del señor de

${ }^{2136}$ PALENCIA, Crónica de Enrique IV, Tomo III, p. 326; y VAL VALDIVIESO, "El reinado de los Reyes Católicos..., p. 15.

${ }^{2137}$ PALENCIA, Crónica de Enrique IV, Tomo IV, pp. 304-305.

${ }^{2138}$ En 1478 varios vecinos de Fuentespina solicitaron que se les devolviera lo que Gonzalo Muñoz de Castañeda, conde de Hormaza, les robó para el rey de Portugal. Las cuantías variaban entre los 200.000 y los 40.000 maravedíes (AGS, RGS, 147811, fol. 53; y 147812, fols. 98, 135-137). 
Torregalindo al lado de Portugal ${ }^{2139}$; o la práctica total destrucción de los lugares de Sotillo de la Ribera y Moradillo ${ }^{2140}$.

Así pues el periodo de inestabilidad de los años 70 en Castilla, y en la Ribera en concreto, supuso un enfrentamiento a tres niveles. El primero y más reconocido fue motivado por la cuestión sucesoria entre los partidarios de doña Juana y los de doña Isabel que ha sido sobradamente estudiado. Paralelamente, y siguiendo la dinámica secular de injerencia de la alta nobleza en los asuntos del reino, se percibe en este periodo la disputa entre los distintos bandos nobiliarios que en nuestra comarca se ejemplifica a través de los ejemplos de don Pedro de Zúñiga y don Diego de Sandoval. Es reseñable que ambos no eran los titulares de sus señoríos en este momento pues todavía eran sus respectivos padres quienes ostentaban el título ${ }^{2141}$. Ambos aprovecharon las circunstancias para labrarse un prestigio y encontrar su lugar en un tiempo de grandes cambios. El último nivel de enfrentamiento se observa en la sociedad civil en la que, aprovechando la coyuntura y seguramente mediatizada por los contendientes, se desató una especial violencia que en ocasiones no era más que el afloramiento de viejas desavenencias que utilizaron el contexto bélico para ajustarse.

Paradójicamente, el paso del tiempo matizó de forma diferencial las heridas abiertas en el transcurso de la contienda sucesoria, pues el grado de pervivencia de los recelos causados por las disputas civiles fue indirectamente proporcional a los niveles anteriormente expuestos. Tras la guerra con Portugal, la autoridad de la Corona castellana se consolidó en la figura de los Reyes Católicos y la paz con Portugal se ratificó con una serie de alianzas matrimoniales entre ambos reinos. Por su parte, los bandos nobiliarios se ajustaron dentro del organigrama integrador marcado por la Corona que precisaba de una nobleza fuerte para consolidar su propio poder. A la postre, aunque no sin roces y tensiones como veremos más adelante, los bandos que posibilitaron el acceso al poder de doña Isabel confluyeron en intereses con los diferentes monarcas de este

${ }^{2139}$ A Alfonso de Sequera o Sequerra se le confiscó su villa de Torregalindo por participar en la guerra al lado del rey de Portugal (AGS, RGS, 147812, fol. 27).

${ }^{2140}$ AGS, RGS, 149402, fol. 311. El documento ha sido transcrito por CADIÑANOS BARDECI, "Judíos y moros..., doc. 1, p. 42.

${ }^{2141}$ Diego López de Zúñiga, primer conde de Miranda, murió en 1479. Recordemos que en los últimos años de su vida tuvo desavenencias con su hijo Pedro lo que provocó que éste heredase los señoríos de su madre cuando murió en 1476 (CADIÑANOS BARDECI, Arquitectura fortificada..., p. 238). La fecha de la muerte de Don Fernando de Sandoval no la conocemos, pero debió ser a finales de los 70 o principios de los 80 . 
periodo, consolidando a la aristocracia como la principal fuerza socioeconómica del reino $^{2142}$.

Pero entre los miembros de la sociedad ribereña, y en especial entre las élites urbanas, a lo largo de todo el reinado de los Reyes Católicos afloraron las viejas heridas que se reabrieron en el contexto del conflicto sucesorio y que nunca llegaron a cerrar. Esta conflictividad de baja intensidad, pero continua en el tiempo, se refleja con bastante asiduidad en la documentación de la época, como lo veremos a lo largo de este capítulo. A estos enfrentamientos se sumaron asimismo los propios de las relaciones entre los linajes y la Comunidad, que ya en los momentos anteriores a la disputa sucesoria se percibían en el seno de la sociedad urbana arandina.

Podemos afirmar, por lo tanto, que tras el conflicto sucesorio de los años 70 y el consiguiente enfrentamiento con Portugal se configuró en la comarca una dinámica del poder caracterizada por un peculiar equilibrio de fuerzas. Por una parte, un número muy limitado de clanes nobiliarios consolidó su control sobre un territorio cada vez mayor. Al igual que ocurre en otros espacios castellanos, este control no sólo se ejerció mediante la expansión de sus dominios territoriales sino, sobre todo, con la extensión de sus redes clientelares y sus lazos de influencia sobre otros territorios aledaños.

Si bien en 1474 los linajes Zúñiga y Sandoval estaban encuadrados en cada uno de los dos grandes bloques antagónicos en los que estaba escindida la alta nobleza castellana, con el desarrollo de la guerra y la política regia posterior ambos encontraron su sitio al amparo de los soberanos triunfantes. Por una parte, la postura del linaje de los Zúñiga al lado de doña Juana y Portugal en la guerra sucesoria supuso una clara desventaja al terminar la guerra ${ }^{2143}$. Sin embargo, la doble acción de la reina, consistente en sofocar con firmeza los últimos focos de resistencia y en aplicar posteriormente una política pacificadora y de perdón, permitió a este clan asegurarse su posición de élite de poder $^{2144}$. Por su parte, el linaje Sandoval partía con ventaja tras la guerra pues siempre

${ }^{2142}$ VAL VALDIVIESO, “Las líneas maestras..., pp. 265-285. Como veremos más adelante, la lucha de bandos rebrotó con las crisis sucesorias de 1504-1506 y 1516-1517. Tras el conflicto de las comunidades esta división bipartidista adquirió una nueva dimensión (MARTÍNEZ MILLÁN y DE CARLOS MORALES, Felipe II. La configuración..., p. 26).

${ }^{2143}$ SUÁREZ FERNÁNDEZ, L., Nobleza y monarquía. Puntos de vista sobre la historia politica castellana del siglo XV. Valladolid, 1975, pp. 368-373.

2144 QUINTANILlA RASO, M. C., "Los Grandes Nobles”, en Medievalismo. Boletín de la Sociedad Española de Estudios Medievales. 13-14, 2004, pp. 127-142; y "Élites de poder..., pp. 957-981; SÚAREZ FERNÁNDEZ, Nobleza y monarquía..., pp. 378-381. 
había mantenido una posición de fidelidad hacia los intereses de Fernando e Isabel. Su situación se vio reforzada con el nombramiento de su titular como Marqués de Denia en 1484, medida que en cierto sentido compensaba el incumplimiento del pacto firmado por su padre en 1469 por el que los entonces aspirantes se comprometían a la restitución de todos sus bienes en Castilla ${ }^{2145}$.

Por otra parte, la villa de Aranda vio claramente reforzada su posición en este momento. Su fidelidad a doña Isabel en una etapa crucial en el desarrollo de sus aspiraciones y su posición geoestratégica garantizaron el favor real ${ }^{2146}$. Así se apreció por el momento, durante los primeros años del reinado de los Reyes Católicos pues guardaron sus privilegios y la villa se mantuvo bajo el amparo real. De igual manera se fortalecieron los lazos entre los monarcas y la oligarquía local que fue convenientemente gratificada por el apoyo a la causa isabelina. Además los monarcas potenciaron su vitalidad y autonomía, convirtiéndola en un instrumento de su control del territorio en una comarca dominada casi exclusivamente por una nobleza emergente.

\section{CONFLICTOS DE CARÁCTER ECLESIÁSTICO Y RELIGIOSO.}

El evidente poder del estamento eclesiástico estaba fundamentado a finales de la Edad Media en su carácter privilegiado, su inmenso patrimonio económico ligado a los beneficios y, sobre todo, su gran capacidad de control social sobre el resto de la población $^{2147}$.

En este capítulo nos detendremos en analizar los frecuentes conflictos derivados de los enfrentamientos entre la justicia civil y eclesiástica. En segundo lugar, estudiaremos los enfrentamientos que se produjeron en el seno del estamento clerical, bien entre clérigos, o laicos por delegación de éstos, que luchaban por el control de las seguras

${ }^{2145}$ FRANCO SILVA, "El linaje..., p. 142.

${ }^{2146}$ VAL VALDIVIESO destaca la importancia de controlar esta villa pues se trataba de una estratégica encrucijada de caminos que facilitaba las relaciones con Aragón y además permitió a la princesa situarse cerca de Segovia, ciudad donde se encontraba el rey (Isabel la Católica..., p. 284).

${ }^{2147}$ Sobre la conflictividad del clero castellano se han realizado interesantes trabajos entre los que destacan la obra de NIETO SORIA, J. M., Iglesia y génesis del Estado Moderno en Castilla (13691480). Madrid, 1994; o alguno de los trabajos incluidos en la obra coordinada por ARANDA PÉREZ, F. J., Sociedad y élites eclesiásticas en la España Moderna. Cuenca, 2000. 
fuentes de riqueza que son los beneficios eclesiásticos; o bien los que discurrieron en el seno de las comunidades regulares al amparo de la reforma que las afectó en mayor o menor medida. Asimismo incluiremos un apartado destinado a los incidentes que se produjeron como consecuencia de la intensa política de control social que desarrollaron las diferentes instituciones eclesiásticas en la comarca. Además de los matices relacionados con aspectos jurídicos, económicos o de control de la religiosidad, también queremos abordar aquí los conflictos que surgieron por motivos religiosos y que tuvieron como protagonistas a los ribereños que no participaban de la religión mayoritaria y, en consecuencia, se encontraban en una situación de marginación: judíos y mudéjares.

\section{1. Enfrentamientos entre la jurisdicción regia y la eclesiástica.}

La conocida coexistencia de diferentes jurisdicciones en la Castilla bajomedieval provocó innumerables conflictos. Este apartado se centra en analizar aquellos generados por el privilegium fori del que disfrutaba el estamento eclesiástico y que tenía como consecuencia inmediata que cualquier clérigo sólo podía ser juzgado por un tribunal eclesiástico. En el ámbito ribereño este tribunal lo presidía el obispo de Osma que delegaba sistemáticamente en sus vicarios. La evidente expansión de la justicia real en este territorio y la ambigua delimitación de competencias entre ambas jurisdicciones provocó innumerables enfrentamientos entre los agentes reales y los delegados eclesiásticos. Seguramente a causa del origen de las fuentes, mayoritariamente de procedencia real o municipal, la mayor parte de los conflictos documentados se deben a la injerencia de las autoridades eclesiásticas en asuntos civiles, aunque también se observa la intervención de las autoridades laicas en competencias de carácter religioso.

Sin lugar a dudas, la intromisión de la justicia eclesiástica en asuntos civiles fue el conflicto que mayor repercusión tuvo sobre las instituciones municipales y la vida cotidiana de los vecinos. La continua intervención de los jueces eclesiásticos en prácticamente todos los ámbitos de la vida ribereña llevó al corregidor arandino, el bachiller Francisco González del Fresno, a denunciar a los vicarios de Osma ante los monarcas, argumentando que ...vos los dichos vicarios dis que en perturvaçion de nuestra juridiçion real ...usurpays quanto podedes la dicha nuestra juridiçion e ympedis que no se faga justicia ${ }^{2148}$.

${ }^{2148}$ AGS, RGS, 149311, fol. 117. 
Lo cierto es que el mantenimiento del orden público se hacía difícil cuando la condición de clérigo otorgaba patente de corso como lo demuestra la conducta de algunos estudiantes y clérigos arandinos ...los quales dis que han andado e andan de noche con armas fasiendo desvarios e travesuras; e que asymismo un moço vecino de esa villa, que se dize ser alguacil del obispo de Osma, que anda de noche con armas e que trahe vara fasiendo muchas liviandades. La intervención del alcalde y el alguacil del corregidor tomando las armas a los estudiantes fue sancionada por los vicarios emitiendo cartas de excomunión para el corregidor y sus oficiales y, por lo tanto, poniendo con ello en tela de juicio la jurisdicción real ${ }^{2149}$.

Más llamativa fue la promoción a la desobediencia y el enfrentamiento con la autoridad judicial que narraba en 1510 el pesquisidor real Francisco Velázquez: ...de pocos dias a esta parte un Rodrigo de Salazar, çapatero vecino de la villa de Aranda, mato a traicion a un Pedro de Mariocho vecino de la dicha villa de un golpe que le dio con un cuchillo; e dis que sobre ello el alcalde de la dicha villa le condeno a pena de muerte; e dis que llevandose el alguasil de la dicha villa a esecutar en el la dicha sentencia recudieron contra el ciertos frailes de la horden de San Francisco que estavan puestos en acechanzas en una hermita que se dize de Santa Crus con palos e cuchillos; e que por fuerza y contra voluntad del dicho alguasil tomaron al dicho Rodrigo de Salazar e le metieron en la dicha hermita donde dis que los dichos frailes e los clerigos e estudiantes de la dicha villa que recudieron en su favor con muchas armas le defendieron; e que uno de los dichos frailes dio con un palo al dicho alguasil en la cabeza que le firio malamente; a cabsa de lo qual dis que no se pudo esecutar en el dicho Rodrigo de Salasar la dicha sentencia; e por que lo susodicho es cosa fea e digna de mucha pugnacion e castigo por escarmiento $^{2150}$. Tras este episodio se sucedió otro alboroto promovido por los defensores de los frailes. En este nuevo enfrentamiento las autoridades reales identificaron a Martín López, cirujano y cristiano nuevo, como cabecilla de los alborotadores por lo que fue arrestado y castigado. Fue tal el escándalo e implicación de los vecinos en el asunto que el pesquisidor comunicó a los monarcas que no sabía qué hacer con todos los presos. La situación se complicó cuando el guardián de San Francisco se negó a apresar a los frailes implicados como le solicitaba el pesquisidor. Además el vicario de Aranda amenazó al

\footnotetext{
${ }^{2149}$ AGS, RGS, 150003, fol. 469.

${ }^{2150}$ AGS, CC PUEBLOS, leg. 2, docs. 100 y 107.
} 
oficial real con censuras si continuaba con su cometido. El asunto se calmó cuando intervino el obispo de Osma ordenando el arresto domiciliario de los clérigos implicados. Insistimos en que por el momento la documentación no permite aproximarnos al trasfondo del episodio más allá del habitual conflicto entre la jurisdicción civil y eclesiástica. Seguramente tras el asesinato que desencadenó los hechos y la intervención de frailes, clérigos y estudiantes se escondía algún tipo de vínculo clientelar u otro tipo de relación que por el momento se nos escapa.

Algo similar ocurrió cuando los alcaldes ordinarios de Aranda procesaron a Beatriz, mujer de Martín y manceba del clérigo Francisco de Roa, siguiendo el procedimiento establecido en las Cortes de Toledo. El clérigo consiguió una carta del provisor de Osma que amenazaba con la excomunión a los alcaldes por apresar a la manceba y tomarle prendas a cuenta del marco de plata que le habían impuesto de pena ${ }^{2151}$.

Más llamativo es el caso de unos vecinos de Aranda que fueron apresados en el otoño de 1483 por el alcaide de la fortaleza de Langa. El motivo no era otro que la represalia por la detención de unos vecinos de esta localidad llevada a cabo por el corregidor de Aranda en cumplimiento de una orden real. Los arandinos se vieron obligados a firmar un contrato por el que se comprometían a pagar ciertos maravedíes para ser puestos en libertad. Una vez liberados, se negaron a cumplirlo y fueron denunciados ante jueces eclesiásticos que, aunque la documentación no señala por qué, los condenaron a la excomunión ${ }^{2152}$.

La intromisión de las autoridades eclesiásticas también afectó al desarrollo de actividades económicas. Así se observa, por ejemplo, en el pleito que comenzaron en 1478 las comunidades de los Arauzos, Caleruega, Tubilla del Lago, Valdeande y Baños de Valdearados con algunos judíos de las aljamas ribereñas a los que acusaban de logros y usuras. Las quejas de los concejos llegaron al Consejo Real que enviaron un comisionado para que investigara. Mientras tanto los judíos implicados apelaron a la justicia eclesiástica que, a pesar de la normativa que penalizaba su intervención en pleitos de usura, emitieron las correspondientes excomuniones tanto para los implicados que no pagaran sus deudas como para los jueces enviados por el Consejo Real. Esta situación provocó la rápida respuesta del Consejo con la solicitud de inhibición a los jueces ecle-

\footnotetext{
2151 AGS, RGS, 148708, fol. 110.

${ }^{2152}$ AGS, RGS, 148310, fol. 58; y 148311, fols. 61 y 99.
} 
siásticos, pero el pleito jurídico y la inseguridad económica se prolongaron por lo menos hasta $1485^{2153}$.

También los monasterios participaron de esta injerencia en la justicia civil. En 1496 un vecino de Valdeande, jurisdicción de la Merindad de Santo Domingo de Silos, hizo una queja ante los alcaldes ordinarios de la Merindad acusando a unos vecinos de Caleruega de haberle tomado unos ganados cuando los llevaba a un termino comunero de ambas localidades. Los alcaldes hicieron justicia y condenaron a los agresores. Sin embargo, no pudieron hacer efectiva su sentencia porque el abad de San Pedro de Gumiel, como juez confirmador de las monjas de Caleruega, se lo impidió y además los excomulgó ${ }^{2154}$.

El recurso a la condición de clérigo fue el motivo más habitual que provocó roces entre las justicias civil y eclesiástica. La situación prototípica era la de un individuo que tras ser encausado por las autoridades civiles alegaba su condición de clérigo, generalmente coronado, para eludir el juicio y su castigo, amparándose en una siempre menos exigente justicia eclesiástica. Por lo general, esta condición privilegiada era de dudosa veracidad pero el objetivo de esquivar la condena civil se conseguía o, al menos, se dilataba la comparecencia ante la justicia ordinaria durante bastante tiempo. También era habitual que las autoridades civiles que intervenían en estos procesos recibieran como respuesta de las autoridades eclesiásticas la excomunión por la imposición de penas a los supuestos clérigos o, incluso, por la simple instrucción y apertura de la investigación, como veremos más adelante.

El caso de Julián Lagarto ejemplifica claramente este modelo. En 1492 las justicias de Vadocondes iniciaron una pesquisa acusándole de ser el causante de ...ciertos omes que avian muerto con yervas e beneno; e asymismo de çiertos corrompimientos de niñas virgenes ... que avia yntentado de corronper fasta quinse o dies e seys niñas, de fasta seys o syete años, llevandolas por engaños e por halagos; e por aver fecho dos juramentos falsos... El implicado alegaba su condición de coronado y los vicarios de Osma comenzaron un proceso contra los alcaldes de Vadocondes que fueron excomulgados. Ante las quejas de éstos, los monarcas ordenaron a los jueces eclesiásticos que se inhibieran. Sin embargo, los vicarios continuaron su proceso lo que provocó una nueva

${ }^{2153}$ Estos problemas con el préstamo han sido estudiados por CANTERA MONTENEGRO, "Pleitos de usura..., pp. 597-622; y "Las comunidades..., pp. 141-142.

${ }^{2154}$ AGS, RGS, 149609, fol. 73; y 149612, fol. 171. 
solicitud de los monarcas en la primavera de 1493 para que pusieran fin al proceso y dejaran actuar libremente a la justicia civil, por lo que suponemos que el acusado todavía no había sido castigado ${ }^{2155}$.

De igual manera los caballeros utilizaron esta solución para evitar la acción de la justicia. El señor de Castrillo, don Juan Álvarez Delgadillo, recurrió a su condición de tonsurado para eludir la condena por haber encerrado a sus hermanas en la fortaleza de Castrillo de Luis Díaz y haber provocado la muerte de una de ellas ${ }^{2156}$. Años después los hermanos Cristóbal y Rodrigo de Salazar también recurrieron a este ardid para eludir el castigo por haber agredido al escribano Juan Sánchez de Hesilla ${ }^{2157}$.

Otro aspecto que generaba conflictos era la violación de espacios sagrados por parte de la justicia civil. Frecuentemente las iglesias se convirtieron en espacios de refugio para algunos vecinos transgresores de la ley que optaban por acogerse a sagrado, fueran o no clérigos. Al final del verano de 1488 dos vecinos disputaron en las gradas de Santa María de Aranda a propósito del pago de unas alcabalas. La mediación de uno de los alcaldes, Juan Sánchez Gallego, evitó males mayores. Pocos días después uno de los contendientes acuchilló al otro y se refugió en la ermita de Santa Cruz al ser perseguido por el alcalde. El oficial declaró después que no había entrado a la ermita pero los jueces eclesiásticos le condenaron a pagar 80 florines por haber cometido sacrilegio y quebrantar la inmunidad eclesiástica ${ }^{2158}$. Idéntica consecuencia tuvo la intervención del licenciado Francisco de Herrera, corregidor de Aranda, y su alcalde, el bachiller Álvaro de Salzedo, cuando intervinieron en una disputa entre vecinos. Pedro González de Peñafiel discutió con Francisco Mejías y le dio dos bofetadas en la iglesia de Santa María. Previa licencia del vicario de la iglesia, el alcalde buscó a Peñafiel por la iglesia. Éste se había encastillado en la torre junto a varios vecinos armados de todas armas y allí se defendieron, injuriando a la autoridad. El corregidor procedió contra todos los implicados pero el obispo ordenó que se inhibiera, argumentando que el delito se había cometido en la iglesia y por lo tanto el castigo le correspondía imponerlo a él. El corregidor

${ }^{2155}$ AGS, RGS, 149211, fol. 165; y 149303, fol. 363. No sabemos cómo terminó el proceso pero en 1510 un vecino de Vadocondes con el mismo nombre aparecía firmando una carta de poder del concejo (AGS, EMR, leg. 699).

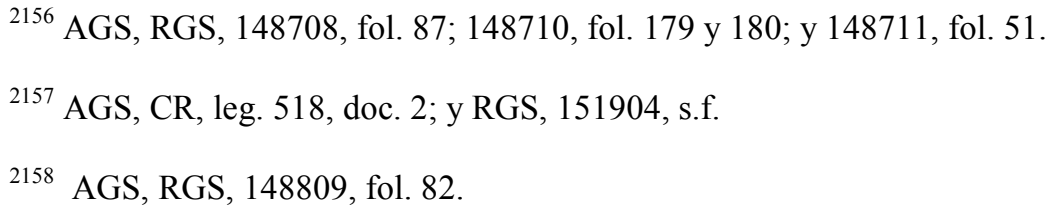


presentó su queja ante los monarcas y además denunció que también se le había excomulgado por dar sentencia contra un vecino que había hurtado ciertas piezas de oro y alegaba ser clérigo, sin probarlo ${ }^{2159}$.

La documentación también aporta información sobre conflictos derivados de la injerencia de las autoridades civiles en asuntos de competencia eclesiástica, aunque bien es cierto que en menor proporción. Aunque no se trataba en sentido estricto de un conflicto entre jurisdicciones, sí que es digno de mención la orden que a finales del año 1500 emitieron los monarcas para que los legos no se entrometieran en el conflicto que se mantenía en el seno de la comunidad franciscana entre la provincia de Santoyo y la custodia del Domus Dei de La Aguilera a propósito de la jurisdicción sobre la comunidad de San Francisco de Aranda ${ }^{2160}$.

En los últimos años del siglo XV se produjo un nuevo episodio de injerencia de la justicia civil en asuntos religiosos. Se trata de la intervención del corregidor arandino en la disputa que mantenían dos antiguos cofrades de San Pedro que habían sido expulsados de la cofradía acusados de tener sangre judía. El corregidor abrió un proceso judicial, a pesar de las quejas de los oficiales de la cofradía que argumentaban que nunca se había entrometido en sus asuntos la justicia ordinaria. El provisor de Osma respondió con unas cartas de censura que obligaron al delegado real a inhibirse. No obstante, años después fue la Audiencia la que se hizo cargo de la situación ${ }^{2161}$.

Asimismo hacia 1515 la reina Juana ordenó al corregidor de Aranda que no se entrometiera en el proceso entre el abad de Silos y don Gutierre Delgadillo a propósito de la jurisdicción de Ciruelos. Este caso muestra la clara indefinición de las competencias de las distintas jurisdicciones pues se aprecia sobre todo una disputa señorial puesto que ambos contendientes compartían el señorío sobre este lugar ${ }^{2162}$.

Parece claro por lo tanto, que la indefinición de competencias entre la justicia eclesiástica y la real, así como el abuso de la utilización del fuero eclesiástico por parte de laicos, generó considerables conflictos que alteraron notablemente la vida cotidiana de los habitantes de la Ribera del Duero.

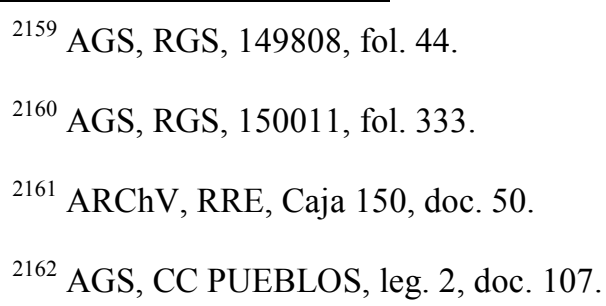




\section{2. Conflictividad en el seno de las instituciones religiosas.}

Además de los problemas ocasionados con la autoridad civil, el periodo bajomedieval se caracteriza por la proliferación de conflictos dentro del seno de las instituciones eclesiásticas. En este apartado nos centraremos en una serie de situaciones que se repitieron con bastante asiduidad en el territorio ribereño. Por una parte, los enfrentamientos entre clérigos por la posesión de beneficios eclesiásticos que, como veremos, tuvieron una importante repercusión sobre la sociedad civil a causa de su estrecha vinculación con las redes clientelares. Por otra parte, la irrupción en Castilla de las diferentes corrientes reformistas de algunas de las órdenes religiosas con representación en la comarca provocó algunos conflictos que trataremos de analizar en profundidad. Por último, prestaremos atención a la convivencia en determinados ámbitos del clero secular y el regular que provocó ciertos problemas de competencia.

\subsubsection{Pugna por los beneficios eclesiásticos.}

Este apartado está dedicado a los conflictos originados por el control de los bienes terrenales de las diferentes instituciones eclesiásticas, aunque sobre todo nos centraremos en el patrimonio diocesano y los beneficios colegiales o parroquiales. En un primer momento citaremos algunos de los numerosos episodios en los que diversos actores trataron de hacerse con parte del patrimonio de estas instituciones. Después analizaremos con mayor detenimiento las disputas que tuvieron como protagonistas a clérigos que pugnaban por controlar diferentes beneficios eclesiásticos.

En el nivel del contexto general diocesano, la lucha por preservar los derechos del obispado generó enfrentamientos contra los poderes laicos que trataban de menoscabar el patrimonio del obispo. Esta dinámica era una práctica habitual durante los siglos centrales de la Edad Media como lo ejemplifican, en los tumultuosos años finales del siglo XIII, las reclamaciones del obispo don Juan Álvarez al nuevo monarca Fernando IV para que fueran restituidos unos bienes usurpados por algunos nobles en los periodos en los que la sede quedó vacante. Finalmente el prelado consiguió el compro- 
miso del rey de proteger los bienes episcopales de las maniobras de algunos legados reales que se extralimitaban en sus competencias ${ }^{2163}$.

Esta misma dinámica se produjo en sentido contrario pues en otras ocasiones fueron los obispos los que usurparon los bienes de la Corona. Así se puso de manifiesto en la exhortación del Papa, a petición de Juan II, al obispo de Osma en 1450 para que devolviera todos los derechos reales que tenía enajenados ${ }^{2164}$.

La nobleza comarcana también trató de sacar provecho de momentos de inestabilidad para usurpar patrimonio de la Iglesia diocesana. Este fue el caso de don Juan Delgadillo que a principios del siglo XV se hizo con el lugar y castillo de Alcozar que pertenecía al obispo, contando para ello con el amparo del valido don Álvaro de Luna. Posteriormente el obispo Montoya insistió en recuperar su posesión y para ello obtuvo el apoyo del rey en 1459 que ordenó su devolución. Sin embargo, Alcozar siguió en manos de la familia Delgadillo durante todo el periodo que nos ocupa ${ }^{2165}$.

Pero no solo encontramos agresiones exteriores, la pugna por el control de los beneficios eclesiásticos se extendió por todos los estamentos de la estructura clerical: las intrigas y el recurso a la violencia fueron mecanismos habituales para conseguir cualquier dignidad o beneficio que llevara aparejada una importante fuente de ingresos.

Así encontramos a algunas de las grandes familias de la aristocracia castellana enzarzadas en la pugna por conseguir el nombramiento de alguno de sus miembros como obispo de Osma. Sirva como ejemplo las presiones que don Álvaro de Luna ejerció para que su hermanastro ocupara la sede oxomense durante el segundo cuarto del siglo $\mathrm{XV}$, o el puro recurso a la fuerza de la familia Mendoza para tratar de imponer a don Luis Hurtado de Mendoza como prelado de Osma ${ }^{2166}$.

\footnotetext{
2163 LOPERRÁEZ CORVALÁN, Descripción histórica..., Tomo I, p. 266; y VAL VALDIVIESO, “Introducción al estudio..., p. 219.

${ }^{2164}$ NIETO SORIA, Iglesia y génesis del estado..., p. 337.

${ }^{2165}$ LOPERRÁEZ CORVALÁN, Descripción histórica..., Tomo. I, pp. 360-361. En la relación de alcabalas de la Merindad de Santo Domingo de Silos de 1492 Alcozar figuraba dentro de los dominios de Juan Delgadillo y en un pleito de 1543 se identificaba a Gutierre Delgadillo como su señor (ARChV, PLEITOS CIVILES, Fernando Alonso (F), Caja 271, doc. 1552; y AGS, EH, leg. 11).

${ }^{2166}$ En el primero de los casos las presiones del privado de Juan II consiguieron sus propósitos tras negociar con el obispo Carrillo. No ocurrió lo mismo con la estrategia de los Mendoza que no pudieron impedir que D. Francisco de Santillán se hiciera con el obispado. Para ello tuvo que recurrir al apoyo del obispo de Segovia que ...no quiso usar de las armas espirituales para personas de tan alta condición; y así resolvió juntar la gente de armas que pudo, y puesto en Osma, le quitó la posesión, y dexó la Iglesia desembarazada (LOPERRÁEZ CORVALÁN, Descripción histórica..., Tomo I, pp. 335-339 y 369-370).
} 
Esta pugna por el control de beneficios eclesiásticos también se proyectó por otros ámbitos de la sociedad feudal más modestos. Antes de comenzar el análisis pormenorizado creemos conveniente llamar la atención sobre el origen de casi todos los ejemplos que hemos documentado en la comarca. Es significativo que la mayor parte de las disputas tuvieron su punto de partida en la intervención de la curia vaticana en el nombramiento de beneficiados que sistemáticamente colisionaban con los intereses de las instituciones diocesanas que habían dispuesto de esos beneficios al margen de la autoridad episcopal residente por lo general en Roma. Aspecto este que es una evidencia más de la capacidad de injerencia del Papado en los asuntos de la iglesia castellana ${ }^{2167}$.

Un ejemplo expresivo de esta situación fue la disputa por el beneficio curado de las Alcobas, origen del enfrentamiento entre los miembros de la oligarquía urbana arandina, si bien es cierto que se mezclaron otros intereses como eran las luchas internas en el concejo arandino o, incluso, la disputa entre los linajes nobiliarios comarcanos.

En junio de 1490, Juan de Aranda, clérigo residente en la corte romana, consiguió del cardenal de San Jorge y obispo de Osma, Rafael Sansoni Riario, la concesión del beneficio curado de las Alcobas que incluía las iglesias de Alcoba de la Torre y Alcubilla de Avellaneda, tras la muerte del anterior cura, Ruy González. En julio el vicario general de Osma ordenó a los concejos de estos lugares y a los receptores de los frutos y rentas de este beneficio que se los entregaran a Pedro de Mora, hermano de Juan de Aranda y regidor arandino. Sin embargo, desde hacía un tiempo estas iglesias estaban en manos de Francisco García de Quemada, Deán de Logroño y hermano del también regidor arandino Gonzalo González de Quemada ${ }^{2168}$.

El 29 de julio Pedro de Mora tomó posesión primero de la iglesia de Santa María Magdalena de Alcubilla de Avellaneda para posteriormente hacer lo mismo en la de San Román de Alcoba de la Torre, confirmando en sus cargos de capellanes a los que ocupaban el cargo con anterioridad. El problema surgió cuando Mora pretendió cobrar los frutos y rentas del beneficio, incluidas las minucias de lana, queso y corderos. El provisor de Osma ordenó al arcipreste de San Esteban que acompañara a Mora para facilitarle la percepción de las rentas. Pero los delegados del Deán de Logroño ya se habían hecho con las rentas y además habían ocupado la iglesia de Alcoba. Mora decidió en-

\footnotetext{
${ }^{2167}$ AZCONA, "Reforma del episcopado..., pp. 115-210.

2168 Todos los datos que se expondrán sobre este conflicto han sido obtenidos de AGS, CC PUEBLOS, leg. 1, docs. 226-233.
} 
tonces pasar a la acción y reclutar entre su parentela de Aranda a más de medio centenar de hombres armados que se unieron a la veintena de Vadocondes y Fresnillo. Por su parte Gonzalo de Quemada y Martín de Durango reunieron a más de un centenar de hombres de las localidades de Coruña y Aranda para, acto seguido, encastillar la iglesia de Alcoba. Cuando Mora llegó a Alcoba le salió al paso Durango que le solicitó que abandonara las tierras del Deán. Mora rehusó el enfrentamiento y se dirigió a Alcubilla. Tras un intento de asalto de Alcubilla por parte de los hombres del Deán, tanto el arcipreste de San Esteban como un criado del Conde de Miranda pusieron paz entre ambas partes y les conminaron a abandonar las iglesias y dejarlas en manos del arcipreste hasta que los padres hicieran justicia.

Mora se dirigió a Peñaranda y pidió ayuda al conde de Miranda que se la denegó argumentando que se mantenía neutral en la disputa pues contaba en su casa con parientes de ambos contendientes. Por su parte Quemada pasó la noche en Alcoba. Al día siguiente cuando se dirigía a Aranda tuvo noticia de que Pedro de Salazar e Íñigo de Barahona, también regidores arandinos, trataban de prenderle acompañados por hombres armados del marqués de Denia. Quemada dio media vuelta y se refugió en Peñaranda. Allí el conde de Miranda lo acogió bajo su amparo y protección.

El 16 de agosto el conde de Miranda intervino intentando poner paz entre los contendientes mediante la firma de un asiento. El conde propuso nombrar un letrado imparcial y un secuestrador de los bienes del beneficio hasta que se solucionara la controversia. El día señalado para firmar el acuerdo acudieron a Peñaranda Pedro de Mora y Gonzalo García de Quemada. Este último se negó a confirmarlo alegando que debía consultarlo con su hermano. Por su parte Mora aceptó el trato y solicitó traslado de la negativa $^{2169}$.

Finalmente el Consejo Real intervino directamente para poner fin a esta disputa que había generado un verdadero conflicto de orden interior. Con la intención de evitar mayores problemas, el Consejo accedió a trasladar el procedimiento a Burgos y allí comenzó en septiembre la recepción de las declaraciones de los testigos presentados por los implicados ${ }^{2170}$. No sabemos cómo concluyó el proceso pero sí que tenemos la certeza de que el Deán mantuvo su posesión del beneficio de las Alcobas y que las disputas

\footnotetext{
${ }^{2169}$ AGS, CC PUEBLOS, leg. 1, doc. 232.

${ }^{2170}$ AGS, RGS, 149009, fol. 60; y CC PUEBLOS, leg. 1, doc. 233;
} 
entre los regidores arandinos se mantuvieron durante bastante tiempo, así como la tensión entre las casas de Zúñiga y Sandoval.

Las repercusiones de este conflicto sobrepasaron las vinculadas a la simple disputa por un beneficio eclesiástico pues intervinieron actores con un destacado peso en la vida política de la villa arandina en primer lugar, pero también de la Ribera pues se vieron implicados tanto el conde de Miranda como el marqués de Denia. La repercusión en el ámbito popular también fue notable por la alta implicación de los vecinos en uno $\mathrm{u}$ otro bando y por la toma de conciencia de la repercusión violenta que pudo generar este conflicto. Así lo muestra la declaración de uno de los testigos en el proceso que aseguraba que ...en lo faser de la manera que lo hiso que fue maravilla non morir harta gente segund estava aparejado ansi de la una parte como de la otra ${ }^{2171}$. Este episodio violento sobrepasó el ámbito comarcal y ha de ser encuadrado dentro del contexto del conflicto que en el seno de la diócesis oxomense enfrentó al obispo absentista Rafael Sansoni Riario, sobrino del Papa Sixto IV, y a su provisor el arcediano de Haza con el Cabildo catedralicio $^{2172}$.

Episodios similares, pero no tan complicados ni violentos, tuvieron lugar en Roa, Aranda, Zayas de la Torre y Caleruega.

En 1489 el bachiller Fernando Recio, clerigo e familiar del nuestro muy Santo Padre y residente en la corte romana, solicitó el amparo real para tomar posesión del priorazgo de Roa ante las amenazas recibidas por Bartolomé de Montalvo, intruso que dis que esta en el dicho priorazgo. El problema se remontaba a años atrás cuando Montalvo mantuvo un pleito en Roma con Miguel Ruiz, clérigo de Córdoba, que perdió. Parece que tras la muerte de Ruiz, Montalvo ocupó el priorazgo a la vez que el Papa concedía el beneficio a Recio. No disponemos de más información sobre este episodio por lo que no conocemos la trascendencia que tuvo sobre los habitantes de la comarca, máxime cuando ambos litigantes eran de origen foráneo y parece evidente su carácter absentista $^{2173}$.

Más escuetas son las noticias que tenemos sobre los temores del clérigo Andrés de Ulloa que solicitó el amparo real porque recelaba de algunas personas que de fecho e

\footnotetext{
${ }^{2171}$ AGS, CC PUEBLOS, leg. 1, doc. 233.

2172 DIAGO HERNANDO, Estructuras de poder..., pp. 297-299.

2173 AGS, RGS, 148907, fols. 234 y 237.
} 
por fuerça le despojaran de sus beneficios de Santa María de Aranda, Pinillos y Gumiel de Izán en $1493^{2174}$. De nuevo en 1503 la iglesia de Santa María de Aranda fue objeto de la disputa por uno de sus beneficios entre Juan Daza y Diego de Aranda. La documentación sobre este asunto es bastante escasa pero parece que finalmente Diego de Aranda se hizo con el beneficio pues se tiene noticia de su actividad como arcipreste de la villa a comienzos del Quinientos. Se puede pensar que este clérigo estaba emparentado con la familia de los Mora-Aranda por su relación con algunos de sus componentes y porque decidió ser enterrado en la iglesia de Santa María ${ }^{2175}$.

Zayas de la Torre también fue escenario de un conflicto por su beneficio curado, aunque este caso no siguió la dinámica habitual en las disputas entre clérigos. En 1498 el señor de Castrillo envió a su alcaide para que despojara a Juan de Villafañe, clérigo de León y familiar del Santo Padre, del beneficio curado de este lugar. Lo cierto es que no tenemos muchas noticias sobre la causa de esta intervención pues tan solo sabemos que el alcaide encastilló la iglesia parroquial ante la presencia de las autoridades eclesiásticas $^{2176}$.

A comienzos del siglo XVI tuvo lugar un nuevo conflicto por el disfrute de un beneficio, en este caso el de la iglesia parroquial de Caleruega. La disputa la protagonizaron la priora y el convento de Santo Domingo por una parte, y Juan de Santo Domingo, clérigo residente en la corte romana, de la otra. Éste clérigo fue nombrado por el Papa contraviniendo los privilegios de los que gozaba la comunidad dominica, pues era competencia de la priora el nombramiento del beneficiado de la iglesia de San Sebastián ${ }^{2177}$. A raíz de este nombramiento papal comenzó un largo proceso en la Corte romana y ante el tribunal de la Rota. Tras quince años de probanzas, sentencias, recursos y excomuniones, la comunidad dominica recuperó su privilegio y, por lo tanto, las rentas derivadas de la parroquia.

${ }^{2174}$ AGS, RGS, 149305, fol. 64. No parece que la situación pasara de un simple temor pues nada hemos encontrado en otras fuentes sobre este asunto. Ulloa también se vio implicado en la reclamación de otros beneficios en el obispado de Almería por lo que suponemos que fue un clérigo absentista (CC CÉDULAS, Libro 1, leg. 106, doc. 2).

${ }^{2175}$ AGS, CR, leg. 755, doc. 8; y VELASCO PÉREZ, Aranda. Memorias..., p. 210.

${ }^{2176}$ AGS, RGS, 149809, fols. 23 y 203. Ante esta situación los monarcas comisionaron al corregidor de Aranda para que investigara sobre lo sucedido y, si fuera oportuno, auxiliara a las autoridades eclesiásticas.

${ }^{2177}$ Todos los detalles del conflicto, aunque presentados desde un punto de vista parcial, los describe GONZÁLEZ GONZÁLEZ, Real Monasterio..., pp. 167-172. 
Este último ejemplo nos sirve para confirmar la premisa planteada al comienzo de esta exposición. A pesar del aparente conflicto entre convento y Papado por la capacidad de nombrar al párroco y la evidente disputa por la enajenación de una importante fuente de ingresos, cabe destacar en este caso la constatación de un nuevo episodio del enfrentamiento más general que tenía como protagonistas a las instituciones eclesiásticas castellanas que rechazaban la injerencia del Papado, como elemento extranjero que era. Esta circunstancia se muestra más evidente en la medida en que la propia Corona amparaba la pretensión dominica aceptando la denuncia del monasterio ante el Consejo Real y comenzando un proceso judicial paralelo al que desarrollaba la jurisdicción eclesiástica $^{2178}$. En definitiva, este episodio es un ejemplo más de la tensión mantenida entre la autoridad real y la principal institución eclesiástica del Occidente cristiano.

\subsubsection{La proyección reformista en las órdenes religiosas de la Ribera del Duero burgalesa.}

Al igual que ocurría con el clero secular, las diferentes órdenes religiosas emprendieron desde finales del siglo XIV un proceso de reforma interna para intentar luchar contra la relajación de comportamientos en la que habían caído casi todas las comunidades religiosas, tanto femeninas como masculinas ${ }^{2179}$. En el anterior capítulo ya hemos abordado cómo las órdenes de cistercienses, dominicos y franciscanos ribereños experimentaron de manera desigual este espíritu reformista. En este apartado nos proponemos hacer especial hincapié en aquellos episodios ligados a la implantación de las propuestas reformistas que ocasionaron conflictos violentos. Éstos no se produjeron sólo entre los religiosos, sino que además desbordaron los muros de los cenobios y se proyectaron sobre algunos ámbitos de la sociedad ribereña.

El final de la Edad Media en el monasterio de San Pedro de Gumiel estuvo marcado por la disputa entre el Capítulo General del Císter y la Congregación de la Observancia. Como ya hemos señalado anteriormente, la reforma cisterciense comenzada en el primer cuarto del siglo XV tuvo un episodio teñido de violencia en el cenobio gomellense varios años después, en la década de los $80^{2180}$.

\footnotetext{
${ }^{2178}$ AGS, CC PUEBLOS, leg. 5, doc. 67; y CR, leg. 66, doc. 2.

${ }^{2179}$ BONACHÍA HERNANDO, “La Iglesia de Castilla..., pp. 276-282.

${ }^{2180}$ PÉREZ EMBID, El Císter..., pp. 656 y ss.
} 
El incidente se produjo en febrero de 1486 cuando fray Andrés, anterior abad de Gumiel y miembro de la facción observante según Pérez Embid, junto a varios criados del arandino Martín Vázquez de Acuña asaltó el monasterio y consiguió la renuncia del abad fray Juan de Ocio. Una sentencia del abad de Palazuelos, comisionado por Citeaux en calidad de visitador de la orden ${ }^{2181}$, confirmó los derechos de fray Andrés. Sin embargo, la justicia real apresó al agresor y restituyó en su posición a fray Juan de Ocio en julio de ese año ${ }^{2182}$.

Aunque este episodio tuvo paralelismos con otros coetáneos en los que el recurso a la violencia era habitual entre las dos facciones cistercienses, no encontramos en la documentación ningún indicio que identifique a fray Andrés como miembro de la Observancia, máxime cuando él mismo argumentaba en su apelación que había estado ejerciendo como abad durante los últimos 25 años. No obstante, coincidimos con Pérez Embid en la afirmación de que fray Juan de Ocio no pertenecía a la Observancia pues se perpetuó en el cargo por lo menos hasta 1496 y su sucesor, fray Roberto, tampoco fue abad trienal. Por otra parte, el abad de Palazuelos que avalaba los derechos de fray Andrés tampoco pertenecía a la Observancia pues regentó su abadía entre 1469 y $1502^{2183}$. La permanencia de Gumiel entre los claustrales en este periodo se confirma con la facultad que concedió el Capítulo General en 1502 a los monasterios que se mantenían fieles de poderse reunir en un Capítulo Provincial bajo la presidencia de los abades de Gumiel y Rioseco ${ }^{2184}$.

Por lo tanto, y a tenor de los datos de los que disponemos, creemos que este episodio violento en San Pedro de Gumiel no debe encuadrarse en la dinámica del enfrentamiento entre Observancia y Capítulo, sino más bien como una manifestación de las pugnas internas dentro de la familia cisterciense por hacerse con el control de una aba223.

${ }^{2181}$ AGS, CC PUEBLOS, leg. 17, doc. 171; y PÉREZ CELADA. "El mundo monástico..., p.

${ }^{2182}$ PÉREZ EMBID, El Císter..., pp. 646-647 y 677-678. Como ya hemos indicado, a pesar de utilizar la misma fuente (AGS, CC PUEBLOS, leg 17, docs. 169-173) nuestra lectura identifica los hechos a mediados del mes de febrero de 1486 mientras que Pérez Embid los sitúa en septiembre de 1485. La sentencia de la Audiencia está fechada en julio de 1486 sin especificar el día.

${ }^{2183}$ No obstante, en el conflicto que se desarrolló hacia 1485 en el monasterio de Santa María de la Espina, en el que actuó como visitador, parece apoyar la opción reformista. Por otra parte, todo hace pensar que dejó encomendado al abad de La Espina que, tras su muerte, el monasterio de Palazuelos pasara a la Observancia (PÉREZ EMBID, El Císter..., pp. 679, 684 y 685).

${ }^{2184}$ La incorporación definitiva de San Pedro de Gumiel a la Congregación de la Observancia no se produjo hasta la segunda mitad del siglo XVI (PÉREZ EMBID, El Císter..., pp. 678 y 710 ). 
día, aspecto al que no eran ajenos los intereses de una nobleza comarcana que trató de ampliar sus influencias sobre las instituciones eclesiásticas. En este sentido, tiene lógica la carta de seguro que se concedió a fray Andrés en 1482 porque recelaba de que ciertos caballeros de la comarca le hicieran mal a él, sus monjes y sus haciendas. De igual manera se entiende la colaboración que recibió para asaltar el monasterio por parte de don Martín Vázquez de Acuña ${ }^{2185}$.

La comunidad dominicana femenina de Santo Domingo de Caleruega también se vio implicada en un proceso de reforma a finales del siglo XV con episodios concretos de violencia en su seno. A pesar de que el proyecto reformista dentro de la orden de Predicadores tuvo su origen a principios del Cuatrocientos, los primeros frutos no se produjeron hasta mediados de siglo gracias a la actividad reformadora que se emprendió desde el convento de San Pablo de Valladolid. Este proceso reformador alcanzó un gran desarrollo en los años setenta gracias a la promoción y protección de la reina Isabel, y fue precisamente en este contexto en el que documentamos los primeros indicios de actividad reformista en el convento calegorano ${ }^{2186}$.

La implantación de la Observancia en el convento de Santo Domingo de Caleruega se llevó a cabo a finales de la década de los 70. Por aquellas fechas se generalizó la labor de los frailes de San Pablo de Valladolid que impusieron la reforma en diferentes casas dominicas y eliminaron de sus claustros a aquellas monjas que no quisieron $\operatorname{aceptarla}^{2187}$. Esta circunstancia provocó en los primeros meses de 1479 la respuesta de las claustrales expulsadas que, según denunciaba la priora, ...andan procurando e buscando favores para se volver a la dicha casa e la tener e ocupar e lançar fuera della a las dichas monjas observantes. La respuesta de la Reina fue comisionar a las justicias de Aranda y Caleruega para que defendieran a las inquilinas del convento reforma$\mathrm{do}^{2188}$. No disponemos de más noticias sobre este asunto en particular pero la ausencia

${ }^{2185}$ AGS, RGS, 148503, fol. 78. Se trata de una sobrecarta de seguro emitida en marzo de 1485 que contiene otra de 1482. La intervención de Acuña en RGS, 148603, fol. 56.

${ }^{2186}$ GARCÍA ORO, “Conventualismo y Observancia..., pp. 263-266; BELTRÁN DE HEREDIA, Historia de la Reforma..., pp. 18-19; y RÍOS DE LA LLAVE, Mujeres de clausura..., pp. 217-219.

${ }^{2187}$ GARCÍA ORO, “Conventualismo y Observancia..., p. 265.

2188 AGS, RGS, 147908, fol. 81, documento transcrito parcialmente por GONZÁLEZ GONZÁLEZ, Real Monasterio..., p. 152. 
de más noticias sobre este aspecto nos inclina a pensar que la Observancia se asentó en Caleruega sin más contratiempos.

No obstante, en 1492 el Vicario General de la Congregación de la Observancia, fray Luis de Toro, solicitó ayuda a la Reina porque la comunidad de Caleruega pretendía sustraerse a la obediencia de la Orden ${ }^{2189}$. El General alegaba indefensión pues las religiosas del convento tienen muchos parientes en la comarca. No sabemos a ciencia cierta si este episodio supuso un capítulo más en el contexto de la disputa interna en el seno de la familia dominica, quizá como resultado de la pretensión claustral de ocupar el convento y expulsar a la facción observante; o si más bien respondió a la política generalizada de injerencia de la nobleza comarcana que ya hemos percibido en otros cenobios. El vacío documental no nos permite profundizar más en lo sucedido pero constatamos que en 1498 las monjas ya estaban de nuevo sometidas a la autoridad de la Congregación de la Observancia como lo certifica una licencia emitida por el mismo fray Luis de Toro ${ }^{2190}$.

La otra gran orden mendicante, los franciscanos, también se vio inmersa en un proceso reformista de gran calado que causó significativos problemas internos.

Como ya hemos visto anteriormente, la creación y consolidación del convento Domus Dei de La Aguilera estuvo íntimamente vinculada a la disputa entre conventuales y observantes. En el capítulo dedicado al convento aguilereño hemos visto cómo su origen estuvo marcado por este enfrentamiento por lo que nos remitimos a lo ya expuesto, constatando en este punto que esta continua disputa fue uno de los conflictos más significativos y con mayor proyección que se produjeron en el seno de la familia franciscana.

Derivado evidentemente del anterior se plantea el enfrentamiento entre la provincia franciscana de Castilla y la de Santoyo a propósito de la jurisdicción sobre la nueva comunidad franciscana creada en Aranda a finales del siglo XV. La provincia de Santoyo alegaba que Aranda estaba bajo su jurisdicción, en concreto del guardián del convento de San Francisco de Silos, como se había estipulado en unos estatutos y pactos

${ }^{2189}$ El Vicario General denunció que esta situación de desobediencia se llevaba reproduciendo desde hacía más de un año (AGS, RGS, 149208, fol. 214).

${ }^{2190}$ MARTÍNEZ LIÉBANA, Colección Diplomática ..., doc. CCCXV, p. 399. Para RÍOS DE LA LLAVE este episodio de insubordinación es una prueba que confirma la total implantación de la Reforma en Caleruega pues, argumenta, "de haber subsistido la división entre observantes y claustrales, éstas últimas se hubieran mostrado favorables al prior provincial" (Mujeres de clausura..., p. 219). 
previos. El Capítulo General de 1499 nombró un mediador para tratar de solucionar el problema. En noviembre se reunió éste, respaldado por la reina, con los implicados: de una parte, el ministro provincial de Castilla, el padre guardián de Valladolid y el Custodio del Domus Dei de La Aguilera; y de la otra, el ministro provincial de Santoyo y el padre guardián de Silos. En este encuentro se decidió paralizar las obras de construcción del cenobio arandino y buscar una solución. Mientras ésta llegaba los enfrentamientos entre los seguidores de San Francisco se materializaron en un episodio de violencia acaecido en Gumiel de Izán. A principios del mes de octubre de 1500 los frailes de los conventos arandino y silense coincidieron recogiendo limosna en esta villa. Los frailes de Silos amonestaron a los de Aranda pues Gumiel siempre había estado bajo la influencia del cenobio de Silos. El problema se agravó cuando los frailes de Silos fueron prendidos por varios vecinos de Gumiel que además los insultaron y agredieron. Posteriormente llegó a Gumiel el guardián del convento de Aranda acompañado de un alcalde, su alguacil y dos hombres armados a caballo que intentaron arrestar al limosnero de Silos, arrastrándole para ello de la capucha del hábito. Finalmente las autoridades arandinas solicitaron a los alcaldes de Gumiel que mantuvieran a los frailes silenses en prisión alegando unos mandamientos reales que no mostraron ${ }^{2191}$. No sabemos cómo concluyó este episodio de violencia pero poco tiempo después la Corona ordenó a las autoridades civiles de Gumiel y Aranda que se inhibieran en este caso y no permitieran la intromisión de legos en asuntos de jurisdicción eclesiástica ${ }^{2192}$.

La solución definitiva no llegó hasta la celebración de la Junta General celebrada en Madrid el 7 de octubre de 1502 en la que se acordó agregar el convento de Aranda a la custodia del Domus Dei de La Aguilera y reafirmar a Santo Domingo de Silos dentro de la provincia de Santoyo ${ }^{2193}$.

Por otra parte, la condición fraternal del Domus Dei de La Aguilera y el convento de San Francisco de Aranda no evitó que se produjeran roces a causa de la cercanía y el solapamiento de las dos comunidades sobre las dádivas de los vecinos de la villa de Aranda. Esta problemática tardó unos años en solventarse pues hasta 1525 no se firmó una concordia entre ambos monasterios. En ella se establecía que los frailes de La Agui-

${ }^{2191}$ AGS, RGS, 150010, fol. 51.

${ }^{2192}$ AGS, RGS, 150011, fol. 333.

${ }^{2193}$ CARRIÓN GONZÁLEZ, Historia documentada..., pp. 110-112; y ABAD LICERAS, "El ocaso de la presencia..., p. 209. 
lera podían seguir pidiendo limosnas en Aranda, excepto mosto en bendimias. Además el guardián de San Francisco creó un aposento independiente para estos menesteres en el que los frailes vecinos tenían cierta autonomía ${ }^{2194}$.

\subsubsection{Problemas de competencia entre clero secular y regular.}

Las órdenes religiosas tampoco se mantuvieron al margen de los conflictos con la sede episcopal oxomense. En este apartado analizaremos algunos de los enfrentamientos más significativos que enturbiaron las relaciones entre el clero secular y el regular en la comarca ribereña. Por lo general los roces entre ambos tuvieron su origen en un problema de competencia en la cura de las almas que, evidentemente, también tenía su vertiente económica ${ }^{2195}$.

A finales de la decimoquinta centuria se constata que tanto dominicos como franciscanos habían aumentado considerablemente su misión predicadora en las tierras ribereñas, especialmente en la villa de Aranda. Ante esta situación las autoridades diocesanas reaccionaron aplicando las disposiciones conciliares redactadas en Aranda en 1473 en las que se establecía que ningún religioso o seglar pudiera predicar sin la correspondiente licencia del obispo ${ }^{2196}$. En aplicación de esta normativa, el domingo a XI de jullio (1491) vino a esta villa un honbre del provisor de Osma con bara con mucho alvoroto e prendio al dotor fray Françisco, el que predicaba la cuaresma pasada en Aranda. Esta detención provocó un tumulto que se saldó con la liberación del dominico por los vecinos de Aranda. Tal actuación generó inquietud en la sociedad arandina que temía la sanción del provisor $^{2197}$.

Parecida situación se reprodujo en 1501 cuando varios clérigos de San Juan denunciaron ante la Inquisición a fray Antonio de Marchena, provincial de los franciscanos de Castilla, por supuestas herejías contenidas en un sermón. Le acusaban de haber

${ }^{2194}$ ABAD LICERAS, “El ocaso de la presencia..., pp. 209-210.

${ }^{2195}$ Esta conflictividad entre instituciones religiosas se puede observar en otros espacios castellanos. En este sentido, nos parece muy ilustrativo el trabajo de PEÑA PÉREZ que, además de analizar la disputa entre la comunidad benedictina del monasterio de San Juan en Burgos y el arzobispo burgales por la parroquia de San Lesmes, describe perfectamente la proyección que sobre los parroquianos tuvo este conflicto ("Protesta popular y violencia institucional en la ciudad e Burgos a comienzos del siglo XVI: ingredientes de un conflicto sociorreligioso", en Castilla y el mundo feudal. Valladolid, 2009, pp. 189199).

${ }^{2196}$ PÉREZ GONZÁLEZ, El Concilio de Aranda..., canon XIII, p. 158.

${ }^{2197}$ AGS, RGS, 149109, fol. 217; y CC PUEBLOS, leg. 2, doc. 62. 
dicho ...palabras escandalosas e feas en la predicación que hizo desde el púlpito de San Juan en el mes de julio de $1501^{2198}$. Desconocemos por el momento si el fraile sufrió alguna consecuencia por estas denuncias, aunque la calidad del implicado nos hace sospechar que no ${ }^{2199}$.

Por otra parte, la implantación de un nuevo establecimiento religioso en el núcleo urbano de Aranda provocó un reajuste muy significativo en los usos y costumbres del fervor popular, pues hasta ese momento contaba con tan solo dos parroquias. Ya desde los primeros años de su existencia se apreció un trasvase de fieles de las parroquias al nuevo convento. Rápidamente muchos arandinos abandonaron las parroquias de Santa María y San Juan y trasladaron su asistencia y plegarias al atractivo monasterio de San Francisco, y con ellos se fueron también sus limosnas y donaciones. Ambos déficits, el de fieles y el de sus aportaciones económicas, provocaron la pronta respuesta del clero secular que utilizó todas sus armas para recuperar los feligreses, su capacidad de control social y, por qué no, su fuente de ingresos. Su respuesta se concretó en aplicar la pena de censura sobre aquellos parroquianos que no acudieran a oir misa a sus parroquias los domingos y fiestas de guardar ${ }^{2200}$. La rivalidad llegó a tal extremo que el capellán de San Juan, Juan Martínez, y uno de sus clérigos, Mateo Sánchez de Sacramenia, llegaron a denunciar, como acabamos de ver, al provincial de la orden de San Francisco, fray Antonio de Marchena, ante el Tribunal de la Santa Inquisición instalado en Aranda.

La tensión entre clérigos y frailes trató de solventarse con la búsqueda de una solución a través de la redacción de una sentencia arbitral en 1515. En ella se establecía la supresión de las restricciones impuestas a la asistencia a las misas y la administración

${ }^{2198}$ Le acusaban de haber tildado a los Santos Padres de ignorantes, de haber calificado a San Juan y Santiago el Mayor como herejes, de asegurar que uno de los salmos de David respondía a los desvaríos del monarca, al que calificó de loco; por último también le acusaban de poner en duda que María Magdalena era hermana de Lázaro. La denuncia también fue confirmada por el bachiller Juan de Aranda (CARRETE PARRONDO, Fontes Iudaeorum..., docs. 192, 206 y 230, pp. 93, 98 y 107).

${ }^{2199}$ Este fraile franciscano fue uno de los protagonistas de los primeros años de Colón en Casti1la. Marchena y fray Juan Pérez le acogieron y protegieron en el convento de La Rábida preparando el proyecto del famoso viaje que llevó al descubrimiento de América. Fray Bartolomé de las Casas indica en su obra sobre Cristóbal Colón que el Almirante escribió una carta a los reyes en la que relataba: ...ya sabe vuestras altezas que anduve siete años en su corte importunándoles por esto; nunca yo hallé ayuda de nadie, salvo de fray Antonio de Marchena, después de Dios Eterno (DE LAS CASAS, B., Vida de Cristóbal Colón. Edición Biblioteca Ayacucho, 1992, p. 28). Fray Antonio fue guardián del convento de San Esteban de Olmos en 1473 y en 1499 fue nombrado Vicario Provincial de Castilla (MANZANO MANZANO, J., "Fray Antonio de Marchena, principal depositario del gran secreto colombino", en Andalucía y América en el siglo XVI. 1983, vol. II, pp. 501-516).

${ }^{2200}$ AGS, CC PUEBLOS, leg. 2, doc. 107. 
de la comunión, regulaba los enterramientos y repartía las ofrendas y exequias fúnebres entre los párrocos y el convento ${ }^{2201}$.

Por lo visto hasta el momento, parece evidente el conflicto generalizado entre un poder real en expansión que luchaba por extender su influencia y control sobre el ámbito eclesiástico. Como hemos visto, esta dinámica se canalizaba en tres frentes. Por una parte, la Corona intentó generalizar una justicia homogeneizadora que, si bien respetaba la excepcionalidad de la jurisdicción eclesiástica, trató de poner límites a la ambigua delimitación de competencias y a la generalización del abuso del privilegium fori por parte de los laicos. Por otra parte, también trató de imponer su control sobre el gran patrimonio de la iglesia castellana, no sólo a través de la consecución del privilegio de patronato, sino también minimizando la injerencia del papado en el control de los beneficios eclesiásticos. Y en tercer lugar, la Corona fomentó la consolidación de la reforma religiosa en el seno de la iglesia castellana, tanto en el ámbito diocesano como entre las principales comunidades regulares. En otro orden de cosas, los beneficios eclesiásticos y las disputas entre las distintas corrientes de las familias monásticas también se convirtieron en el campo de batalla en el que dirimieron sus diferencias, evidentemente a diferente escala, tanto los linajes de la aristocracia como destacados miembros de la oligarquía urbana ribereña, como hemos constatado en el caso de la disputa por el benefício de las Alcobas.

\subsection{Enfrentamientos derivados del control social de la Iglesia.}

Como ya hemos comentado anteriormente, las autoridades eclesiásticas utilizaron algunos instrumentos para hacer llegar el mensaje pastoral y, sobre todo, imponer una forma de vida acorde con la moral cristiana establecida. Mediante los sermones y los entredichos se procuraba mantener la ortodoxia, pero sobre todo se establecían los principios básicos sobre los que se asentaba su control social sobre los fieles. Asimismo debemos tener en cuenta que el Tribunal de la Inquisición reforzó este mismo papel de

${ }^{2201}$ El 9 de febrero de 1515 se reunieron los 16 frailes del convento de San Francisco de Aranda, con el párroco de Santa María y cinco de sus beneficiados más el párroco de San Juan. Ante ellos Fray Francisco de Evan, comendador del monasterio de Santa Catalina de Toledo de la orden de la Merced y nombrado por ambas partes juez ejecutor, presentó una sentencia arbitral que garantizaba los intereses de ambas partes y ponía fin al conflicto (AGS, CC PUEBLOS, leg. 2, doc. 107). 
control social, no sólo al servicio de la ortodoxia cristiana, sino también, como afirman algunos autores, al servicio de los intereses uniformizadores de la Corona. En este punto no insistiremos sobre este tema que ya ha sido abordado en un apartado anterior ${ }^{2202}$. Evidentemente esta dinámica generó múltiples conflictos que abordaremos a continuación.

Entre los sermones destacaban sobre todo los practicados por los frailes, ya fueran dominicos o franciscanos, que de manera itinerante se desplazaban por los pueblos de la comarca y realizaban sus prédicas en los templos parroquiales. En los días señalados del calendario cristiano los predicadores utilizaban su púlpito para conmover de tal manera que provocaban arrebatos de emoción colectiva, sobre todo entre el público femenino, aunque también ciertos rechazos. Así ocurrió el Viernes Santo de 1502 en Gumiel de Izán: ...aquel dia avia predicado la Pasyon un frayle e echo como remembrança, y lloravan muchas mugeres. Aunque una de las vecinas se quejaba de que se trataba de un engaño y que Nuestro Señor avia pasado muerte y pasyon que qué menester hazía nada de aquello. Evidentemente tal comentario le costó una denuncia ante el Tribunal de la Inquisición ${ }^{2203}$.

En ocasiones, la asistencia a las predicaciones se hacía obligatoria como en el caso de la comunidad mudéjar de Aranda que fue obligada a acudir en 1500 a un sermón que un fraile pronunció en Santa María de Aranda bajo la amenaza de predicar en su propia mezquita ${ }^{2204}$. Pero tampoco los cristianos se libraban de estas coacciones pues los comisarios de la bula de Cruzada obligaban a los vecinos a acudir contra su voluntad a la predicación de la bula. En 1500 un vecino de Roa decía que ...vinieron a esta villa a predicarse unas bullas e pusieron pena dexcomunion, que todas las personas fuesen a la yglesia a oyr el sermon. Uno de sus convecinos, Pedro Platero, prefirió ir de pesca ese domingo y esto le acarreó una denuncia ante el Santo Oficio. Más explicitas fueron las quejas de las autoridades arandinas que en 1526 denunciaban ...que cuando los predicadores de la bulla van a la villa que les hacen muchos agravios tanto para que vayan a oyr los sermones como para tomar las bullas ${ }^{2205}$.

${ }^{2202}$ PÉREZ, "Los Reyes Católicos..., p. 158; ALCALÁ, "La política religiosa... pp. 117-56; NETANYAHU, "Causas y fines..., pp. 315-31.

${ }^{2203}$ CARRETE PARRONDO, Fontes Iudaerum..., doc 154, p. 80.

${ }^{2204}$ AGS, RGS, 150002, fol. 52.

${ }^{2205}$ CARRETE PARRONDO, Fontes Iudaeorum..., doc 359, p. 147; y AMA, leg. 43, doc. 49. 
La otra herramienta de extraordinario alcance para los intereses de la Iglesia fue la censura eclesiástica, que se concretó en la excomunión y el entredicho ${ }^{2206}$. Por lo que nos muestra la documentación podemos deducir que ambas situaciones se reprodujeron en la Ribera del Duero, al igual que en toda Castilla, con bastante frecuencia y ocasionaron serios conflictos tanto individuales como colectivos. No en vano, una de las quejas más repetidas que presentaron las ciudades ante los monarcas en este periodo fue precisamente el excesivo y arbitrario uso de la excomunión ${ }^{2207}$.

Si bien la imposición de la excomunión estaba en manos de obispos o en quien ellos delegaran, lo que nos parece más significativo y de mayor trascendencia es el recurso sistemático a la amenaza de excomunión en todas aquellas situaciones de conflicto entre laicos y eclesiásticos o entre los propios miembros del clero. Esta amenaza se convirtió en una herramienta muy útil en lo que se percibe como una política activa de defensa de un determinado orden social. Como veremos a continuación, los episodios en los que individuos o colectivos eran sancionados con la excomunión o el entredicho fueron bastante frecuentes. Pero lo fue más aún la amenaza que se convirtió en algo cotidiano y supuso, en cierta medida, la institucionalización del miedo. Precisamente la potencialidad de este arma para imponer y reproducir el orden establecido, junto al peligro de provocar indiferencia por su exceso, obligó a la jerarquía eclesiástica a configurar un corpus legitimador que revestía a la excomunión de un carácter sagrado, funcional y efectivo ${ }^{2208}$.

${ }^{2206}$ Brevemente, y a riesgo de no ser del todo precisos, podemos definir la excomunión como la separación o expulsión de la Iglesia con todo lo que ello conlleva. El entredicho puede ser local o personal: el local consiste en la prohibición de celebrar oficios divinos en los lugares puestos en entredicho, sea ciudad o iglesia, salvo algunos días señalados; y el personal prohíbe a un individuo participar en los oficios divinos y en los sacramentos. Ambas, junto a la suspensión que afecta exclusivamente a los clérigos, son censuras eclesiásticas. Las causas y los castigos ya aparecen reflejados en el Título IX de la Primera Partida del Rey Sabio (VOGEL, C., "Penitencia y excomunión en la Iglesia antigua y en la alta Edad Media", en Concilium. 107, 1975, pp. 9-21; y BEAULANDE, V., Le malheur d'être exclu? Excommunication, réconciliation et société à la fin du Moyen Âge. Paris, 2006).

2207 ARRANZ GUZMÁN, A., "El Clero", en Orígenes de la Monarquía Hispánica. Propaganda y legitimación (1400-1520). Madrid, 2004, pp. 141-175; y RAMOS, N., "La Iglesia a través de las Cortes castellanas. Uso y abuso de la excomunión (siglos XIII-XIV)”, en Cuadernos de Historia de España. 69, 1987, pp. 97-108.

${ }^{2208}$ En este sentido, en el territorio peninsular cabe destacar la producción del franciscano Álvaro Pelayo que, rechazando las acusaciones de provocar el miedo o el ánimo de lucro, identificaba como hereje a todo aquel que negara la legitimación que otorgó Cristo a la Iglesia para imponer la excomunión (Mateo, 18, 15-17). Por otra parte, también se revistió a la excomunión de un carácter medicinal, curativo, y no tanto punitivo. La imbricación entre la ideología que mantenía el orden y la realidad imperante se 
El primer entredicho del que tenemos noticia en tierras ribereñas recayó sobre la villa de Aranda que recibió este castigo por haber asaltado el cercano lugar de Castrillo de Duero en $1487^{2209}$. No sabemos a ciencia cierta por qué se sancionó con el entredicho pero sí que tenemos noticias de los 35.000 maravedíes que costó alzarlo.

Más datos proporciona el siguiente episodio que comenzó con la imposición del entredicho sobre la misma localidad en septiembre de 1503 y se prolongó algo más de cuatro meses. Durante tan largo tiempo ...la dicha villa e vezinos e moradores reciben agrabio e a los defuntos que en ella mueren nin se dan los sacramentos que la madre Santa Yglesia manda, por lo que las autoridades municipales solicitaron la intervención de los monarcas para que se alzara la sanción. Lo curioso del asunto es que la villa era simplemente el agente paciente de este conflicto pues el arcediano de Osma la sancionó a causa de un problema interno en torno a la provisión del beneficio curado de Santa María. Todo comenzó a finales del verano de 1503 cuando murió el párroco de Santa María, Pedro Sánchez de la Riba, y la vacante se proveyó en dos clérigos: por una parte en Juan de Daza, que contaba con el favor de Osma, y por la otra, en Diego de Aranda, residente en Roma y apoyado por la Santa Sede. En definitiva el conflicto entre los procuradores de ambas partes requirió la intervención del Provisor de Osma que evidentemente se pronunció a favor de Juan Daza. El problema, lejos de arreglarse, se complicó pues unos vecinos de Aranda habían arrendado a Diego de Aranda los frutos del beneficio y se negaban a cederlos. Ante esta situación el representante del obispo decidió castigar a toda la comunidad arandina imponiendo el entredicho. Finalmente, el 25 de enero de 1504 el arcediano, tras la petición formal por parte de los monarcas, alzó el entredicho a condición de que los vecinos implicados fueran desterrados de la villa. Esta resolución se hizo efectiva el 31 de enero cuando el teniente de corregidor, en esta ocasión brazo ejecutor, expulsó de la villa y sus arrabales a los implicados a pesar de sus apelaciones $^{2210}$.

hacía visible en el recurso de la autoridad eclesiástica al poder temporal para aplicar sus sanciones más extremas (ARRANZ GUZMÁN, "El Clero..., pp. 145-146; y BEAULANDE, Le malheur..., pp. 23 y ss.).

${ }^{2209}$ El asalto, como veremos más adelante, se produjo en el contexto del enfrentamiento entre la villa de Aranda y el Conde de Miranda. El detonante fue la agresión que sufrió un alcalde de la Hermandad a su paso por Castrillo. Los vecinos de Aranda se organizaron y se desplazaron hasta el lugar quemando algunas de sus casas mientras la población local se refugiaba en la iglesia (AGS, CC MEMORIALES, leg. 149, doc. 230).

${ }^{2210}$ AGS, CC PUEBLOS, leg. 2, doc. 96. 
También por motivos económicos esta villa estuvo en entredicho durante buena parte del año 1516. La documentación proporciona noticias un poco confusas que no aclaran si se trató de un entredicho de larga duración o si bien fueron dos el mismo año. Por una parte, contamos con una carta de la reina Juana fechada el 15 de mayo por la que se comprometía a pagar los 187.000 maravedíes de las rentas desa dicha mi villa para que el obispo levantara el entredicho y absolviera a los excomulgados ${ }^{2211}$. Por otro lado, existe una abundantísima documentación sobre un conflicto que se remonta al menos a 1514 y enfrentaba a micer Bernardino, abad de Medina y estante en la Corte Romana, y los propietarios de las heredades sitas en Revilla de Olleros. El motivo de este enfrentamiento era que estos arandinos se negaban a pagar el diezmo alegando tener un contrato con el monasterio de La Vid que les eximía de ello ${ }^{2212}$. En julio de 1516 sabemos que la villa ya estaba bajo el entredicho y que no fue hasta finales de año cuando se levantó después de haber desterrado de la villa y su tierra a siete de los vecinos que se negaban a pagar el diezmo ${ }^{2213}$. Insistimos en que no sabemos si se trata del mismo entredicho o si por el contrario estaríamos asistiendo a dos entredichos encadenados en el mismo año.

De igual manera los entredichos colectivos afectaron a otras localidades de la comarca como Quintana del Pidio que en 1490 sufrió esta pena, en este caso por iniciativa del señor del lugar, el abad de Santo Domingo de Silos. El detonante fue que algunos vecinos se negaron a pagar ciertas rentas alegando su condición de hidalgos ${ }^{2214}$. También hemos documentado un entredicho en los años noventa del siglo XV sobre la villa de Gumiel de Mercado a causa de los desmanes cometidos por un grupo de vecinos sobre un clérigo. En esta ocasión incluso se consiguió una dispensa para que se pudiera celebrar la fiesta de Todos los Santos y Difuntos ${ }^{2215}$.

${ }^{2211}$ AMA, leg. 43, doc. 28, transcrito por HURTADO QUERO, Documentos Reales..., doc. 40, pp. 71-72.

${ }^{2212}$ El término de Revilla de Olleros fue adquirido por la villa de Aranda al monasterio de La Vid a través de un censo perpetuo en 1426 (AMA, leg. 43, fol. 4).

${ }^{2213}$ AGS, CC PUEBLOS, leg. 2, docs. 73 y 107.

${ }^{2214}$ AGS, CC PUEBLOS, leg. 20, doc. 17.

${ }^{2215}$ Esta era una de las fechas señaladas en las que se podía celebrar los oficios en situación de entredicho (CARRETE PARRONDO, Fontes Iudaeorum..., docs. 361 y 362, pp. 147-148). 
A estos entredichos locales o colectivos debemos sumar aquellos episodios en los que la sanción recayó sobre individuos concretos. Generalmente estas censuras tenían como objetivo a los agentes de la justicia y fueron varios los ejemplos de amenazas o condenas que recibieron los oficiales reales como el corregidor, los pesquisidores o incluso los alcaldes ordinarios cuando alguno de los implicados en sus pesquisas era un clérigo. Este aspecto de los conflictos jurisdiccionales entre la Corona y la Iglesia ya ha sido abordado con anterioridad por lo que creemos que no es necesario insistir.

No obstante, con ser numerosos los entredichos, la censura individual que más se utilizó por las autoridades eclesiásticas fue la excomunión. Como ya hemos comentado anteriormente, la casuística de este tipo de castigo estaba perfectamente tipificada en la época y se utilizaba sistemáticamente para imponer un orden social determinado. La función edificante de esta pena se potenciaba con la exposición pública de todas las personas excomulgadas en la iglesia parroquial ${ }^{2216}$. Las parroquias de la Ribera también realizaban esta publicación como lo vemos reflejado en el caso concreto de San Juan de Aranda de Duero que en los años noventa del siglo XV hacía público los nombres de aquellos parroquianos que estaban excomulgados por ...que no eran confesados e no amostravan çédulas con quién se avían confesado ${ }^{2217}$. Efectivamente la ausencia de confesión era causa de excomunión y eso llevaba a que alguno de los fieles se las ingeniara para falsificar las cédulas de confesión y librarse del escarnio público, aunque esta solución podía acarrear ciertos inconvenientes si se descubría el engaño ${ }^{2218}$.

Como en el caso del entredicho, una buena parte de los reos de excomunión fueron las autoridades judiciales de cualquiera de los ámbitos: corregidor, alcaldes de la

${ }^{2216}$ En todas las diócesis era obligatorio dar a conocer los nombres de las personas excomulgadas mediante la publicación de las cartas de excomunión. En algunas de ellas, como la de Burgos, se elaboraron libros de registro en los que se indicaba el tipo de sentencia, quién la pronunció, dónde se leyó y, en su caso, la fecha de absolución (DÍAZ IBÁÑEZ, J., "Simbología y ritual en torno a las relaciones y conflictos sociales del clero burgalés durante la baja Edad Media", en Espacio, Tiempo y Forma, Historia Medieval. 22, 2009, pp. 91-121).

\section{${ }^{2217}$ CARRETE PARRONDO, Fontes Iudaeorum..., doc. 317, p. 133.}

2218 ...vio este testigo cómo venía un moço a dar su çedula al cura; y a esto Alonso Sanchez Traspaso le dixo "Amostra, amostra, amostra la çedula”; e vio este testigo cómo tomó la çédula e fizo otra çedula para amostrar al cura. E vio este testigo cómo luego suvió a darle al cura la çedula fecha por su mano. Estas palabras se incluían en la denuncia que Pedro García de Lagunilla presentó en noviembre de 1501 ante el Tribunal de la Inquisición instalado en Aranda. Las repercusiones de la denuncia fueron nulas pues Traspaso ya había sido quemado por hereje unos años antes (CARRETE PARRONDO, Fontes Iudaeorum..., docs. 203 y 317, pp. 97-98 y 133; y PERIBÁÑEZ OTERO, "Violencia y espacio..., p. 34). 
Hermandad, de la Merindad o los ordinarios locales. Y la causa también estaba relacionada con la aplicación de la justicia laica sobre miembros del clero.

En la Ribera, como en todo el orbe cristiano, estas censuras tuvieron una significativa proyección sobre los diferentes grupos humanos, condicionando en gran medida los comportamientos sociales. Sin embargo, también encontramos excepciones a esta regla general. Una de ellas se produjo en la villa de Gumiel del Mercado en los años finales del siglo XV, siendo su protagonista Juan de Hontoria, hombre de confianza del Marqués de Denia y su alcaide en la fortaleza de la villa ${ }^{2219}$. Este individuo fue sancionado con una excomunión a mediados de los años ochenta cuando ... estando Juan Sanchez de la Parra, clérigo, en la yglesia de Santa María desta villa, entró Juan de Hontoria ..., e echo mano del dicho clerigo de los pechos para le sacar fuera, para le acuchillar, e le rasgó la camisa. El historial de este sujeto es bastante extenso pues unos años después se ganó una nueva excomunión ...porque tomó una mula a un clérigo. Estando excomulgado se presentó en la iglesia de la villa y no atendió a las reclamaciones del párroco para que abandonara el lugar sagrado, por lo que ...cesó el clérigo de desir la misa e se desrebistió e asý se fue el pueblo sin oyr la misa. El pulso continuó. Como su nombre no estaba entre los excomulgados que habían recibido la absolución en la lista que se publicó antes de la celebración de Todos los Santos, Hontoria se tomó la revancha acudiendo casa por casa con una partida de cuadrilleros para incitar a los vecinos a que no se hicieran ofrendas para la misa de Todos los Santos, provocando con esta actitud un importante descenso en los ingresos de la parroquia en tan señalado día. Desconocemos qué repercusiones tuvieron estos hechos, pero lo cierto es que Hontoria fue absuelto de la excomunión algún tiempo después. Bien es cierto que no se libró de la denuncia ante el Santo Oficio, aunque varios años después de los hechos ${ }^{2220}$.

En definitiva, todo esto no es más que un ejemplo del férreo control que ejerció la Iglesia como institución sobre la mayor parte de los aspectos cotidianos de la vida de la sociedad medieval. Los hombres y mujeres de la Ribera del Duero no fueron una excepción y así vemos cómo su vida estaba completamente imbricada y revestida de un

${ }^{2219}$ AGS, RGS, 149301, fols. 25 y 27.

${ }^{2220}$ Los testigos aseguraban que Juan de Hontoria contaba con el favor del Marqués de Denia y que gracias a ello había conseguido su absolución (CARRETE PARRONDO, Fontes Iudaeorum..., docs. 361 y 362 , pp. 147-148). 
sentido religioso que se mantenía rígidamente dentro de una ortodoxia que justificaba el orden social imperante.

\section{4. Conflictos con las minorías religiosas.}

Para terminar con el capítulo dedicado a los conflictos religiosos nos vamos a centrar en los roces que se produjeron entre la mayoría cristiana y las minorías religiosas de judíos y musulmanes, con sus correspondientes implicaciones violentas. Evidentemente el carácter marginado de las minorías religiosas imprimió a sus relaciones con la mayoría una posición de clara desventaja que se plasmó con cierta frecuencia en abusos, conscientes o no, que tuvieron como víctimas a judíos y mudéjares ${ }^{2221}$.

\subsubsection{Evidencias de violencia contra la comunidad judía.}

No son pocos los conflictos que tuvieron como protagonistas a los judíos ribereños y de ellos ha dado buena cuenta la historiografía bajo la denominación de "el problema judio", que después evolucionó en el problema converso al que ya hemos hecho referencia. A continuación trataremos de analizar los más significativos que tuvieron como protagonistas a los judíos en la Ribera del Duero, centrando nuestra atención en aquellos en los que se aprecia violencia en razón de su condición religiosa y racial.

El primer indicio de segregación de la comunidad hebrea lo encontramos en su emplazamiento dentro de la villa de Aranda. Antes del confinamiento establecido tras el Ordenamiento de Toledo, la comunidad judía ya daba muestras de concentrarse en un espacio urbano diferenciado del resto del hábitat cristiano como hemos podido ver en el capítulo dedicado a la aljama judía arandina. Evidentemente la configuración de la judería en el Hocino tras las Cortes de Toledo sancionó esta segregación espacial por razones de religión. Precisamente en la primitiva judería se sitúa una de las primeras noticias sobre un episodio de violencia contra individuos de esta comunidad. Sabemos que en los años convulsos previos a la llegada al poder de los Reyes Católicos se produjo el asesinato de un judío en la judería de la villa de Aranda, en la calle del Pozo,

${ }^{2221}$ Sobre los problemas de convivencia de las minorías religiosas IZQUIERDO BENITO ha presentado un estado de la cuestión en su artículo "Los conflictos socio-religiosos en las ciudades medievales castellanas", en La convivencia en las ciudades medievales. Logroño, 2008, pp. 81-111. 
sin que tengamos más detalles sobre el suceso ${ }^{2222}$. Más datos aporta el caso de Mosén Soriano, zapatero vecino de Roa, que fue herido de muerte por unos vecinos de la tierra de Roa en el tramo del camino real que discurría entre Roa y Guzmán en noviembre de 1489. El judío, después de ser asaltado y robado, recibió trece o catorce cuchilladas y finalmente fue enterrado junto al camino ${ }^{2223}$. A buen seguro que algunas de las agresiones que sufrieron los miembros de la comunidad judía pudieron deberse a la violencia estructural que padecían los habitantes de la comarca independientemente de su credo, pero lo cierto es que se ha documentado un elevado número de incidentes que tuvieron a los judíos como víctimas, lo cual -creemos- es revelador del cariz religioso de las agresiones. Así se puede observar en otros episodios de atropellos, asaltos y vejaciones que han sido recogidos por la historiografía en los lugares comarcanos de Arauzo de Salce y de Miel, Huerta del Rey, Tubilla del Lago, Valdeande o Baños de Valdearados $^{2224}$.

Sin llegar a estos extremos de violencia, también hemos documentado en la villa de Aranda algún episodio de discriminación de las justicias ordinarias arandinas hacia vecinos judíos $^{2225}$. Fue el caso de Ysar Taicaça y su hermano Yuçe. Ambos fueron detenidos en 1486 por orden de los alcaldes de la villa de Aranda por bien poca cosa que, aunque no se hace referencia expresa en el documento, se intuye que se trataba de una pequeña deuda. El proceso judicial que se siguió contra Ysar estuvo lleno de irregularidades pues estuvo en prisión por más de dos meses sin motivo suficiente y cuando Taicaça acudió ante los alcaldes para solicitar traslado de la declaración de testigos, uno de ellos le dio ...un quitichon con la vara y le dijo ... andad y de puta judio que en mala hora aveys tomado esta empresa que nunca mediareis con ella. La situación se complicó más todavía porque los alcaldes alteraron la declaración de los testigos del proceso

${ }^{2222}$ Así lo describía Pedro García de Sacramenia cuando declaraba como testigo: ...que sabe que mataron un judio en la calle del Pozo (AGS, CR, leg. 39, doc. 3, transcrito por PERIBÁÑEZ OTERO y ABAD ÁlVAREZ, Aranda de Duero..., p. 185).

${ }^{2223}$ AGS, RGS, 148912, fol. 172. Fueron acusados del asesinato Juan Ortega y Diego de Santoyo, vecinos de Guzmán (AGS, RGS, 149002, fol. 166).

${ }^{2224}$ BLÁZQUEZ MIGUEL, J., Inquisición y criptojudaismo. Madrid, 1988, p. 39. Toma la información de BAER, F., Die Juden im Christlichen Spanien. 1929, vol. II, pp. 350-351.

${ }^{2225}$ Esta misma dinámica ha sido documentada en otros espacios urbanos castellanos como en La Rioja (GOICOLEA JULIÁN, F. J.,’Los judíos y mudéjares de Haro a finales de la Edad Media: análisis del proceso de exclusión social de ambas comunidades en el siglo XV", Historia, instituciones, documentos. 23, 1996, pp. 317-332). 
además de coaccionarles con amenazas, violencia y prisión. Uno de estos testigos, el judío León, declaraba ante el escribano: ...vos no pongays nada de lo que yo no dixe, que yo no dixe eso que vos decis. Ay que sy yo lo viera escrevir yo lo firmara de mi nombre que también se leer e escribir como vos. Ante este comentario el alcalde ...dio con el cuento (punta de metal) de la vara en los pechos del judio y le dijo ...anda para puto judio que bien oy lo dixistes y eso mismo escribio el escribano. En represalia a la negativa de firmar la declaración, el alcalde mandó encarcelar al judío que se encaminó hacia la prisión diciendo ...aunque me hagais piezas yo no dejo de decir verdad, que aquello que esta escrito yo nunca lo dije $e^{2226}$. En definitiva, este incidente de abuso de autoridad de las justicias arandinas no fue aislado ni limitado a los judíos pero sí que es cierto que la condición de marginación de los acusados incrementaba su indefensión ante la manifiesta parcialidad.

En los momentos previos a la expulsión se observa un recrudecimiento de la violencia contra los judíos lo que provocó la solicitud de varias cartas de seguro y de provisión de escolta para algunos judíos ribereños mientras abandonaban el reino, aunque en ocasiones no les sirvieron de mucho. En este contexto, el bachiller Alonso de Torres recibió la comisión real de acompañar y proteger a la familia Soto en su salida hacia Portugal $^{2227}$. De la misma manera Abrahem Garço obtuvo de los reyes una carta de seguro que, sin embargo, no fue respetada por los alcaides de Haza y Torre del Monte que obedecían las órdenes de su señor, el Conde de Miranda ${ }^{2228}$. También maestre Luis, físico vecino de Aranda, se quejaba de que el conde de Monteagudo había obligado a su padre a cederle todos sus bienes de Almazán cuando decidió salir del reino con otros judíos ${ }^{222}$. Años más tarde Tomás Méndez, converso vecino de Berlanga, denunciaba que sus bienes habían sido robados por un vecino de Guzmán cuando, siendo judío, se concertó con él para trasladarse hasta Portugal ${ }^{2230}$.

${ }^{2226}$ AGS, CC MEMORIALES, leg. 161, doc. 122.
${ }^{2227}$ AGS, RGS, 149205, fol. 526.
${ }^{2228}$ AGS, RGS, 149203, fol. 77; 149310, fol, 141; y 149410, fol. 441.
${ }^{2229}$ AGS, RGS, 149304, fol. 450. El maestre Luis se había convertido al cristianismo y trasladado a la villa de Aranda para ejercer su oficio. Argumentaba que los bienes recibidos por el conde de Monteagudo le pertenecían a él pues su padre se los había traspasado antes de iniciar el camino a Portugal.

${ }^{2230}$ AGS, RGS, 149606, fol. 24. 
No obstante, aunque las anteriores incidencias fueron las más llamativas sí que conviene destacar que desde los años 70 se multiplicaron los pequeños pero continuos enfrentamientos entre individuos cristianos o comunidades enteras contra algunos miembros destacados de la comunidad hebrea. Estos conflictos se referían sobre todo a asuntos relativos al arrendamiento y cobro de las rentas, préstamos, denuncias y pleitos por deudas y usura ${ }^{2231}$. Otros problemas de carácter económico repercutieron sobre toda la comunidad judía. Así, por ejemplo, en 1486 las autoridades municipales arandinas decidieron reducir el número de cabezas que la carnicería judía podía llevar libremente a los pastos de la villa. Desde tiempo inmemorial la aljama de los judíos de Aranda había tenido carnicero y existía la costumbre de traer 120 cabezas de ganado por los pastos de la villa, disfrutando del mismo derecho que el resto de los carniceros de la villa. Pero ese año los regidores decidieron permitir la entrada de tan solo 50 cabezas, con lo que se ocasionaba gran perjuicio económico a los usuarios de esta carnicería ${ }^{2232}$.

La violencia cotidiana de baja intensidad no desapareció tras la expulsión sino que se mantuvo aunque cambió de sujeto sobre el que se ejercía. Esta situación es la que la historiografía ha definido como el paso “del problema judío al problema converso" 2233 , o lo que es lo mismo, dos manifestaciones de una misma realidad. Tras la conversión, sincera u oportunista, la mayoría de los nuevos cristianos emprendieron su camino hacia la integración y para ello utilizaron cuantas armas estuvieron al alcance de su mano: emparentamiento con familias cristianoviejas, preferiblemente con miembros de las oligarquías urbanas o de la hidalguía local; acceso a los oficios concejiles; especialización en la realización de servicios a la Corona; desarrollo de negocios con la participación de cristianos; etc.

El paradigma de ese proceso de integración lo encontramos sin lugar a dudas en la figura de Pedro de Santa Cruz, del que ya hemos hablado en el apartado dedicado a la oligarquía arandina.

2231 Baste como ejemplo los múltiples casos que recogen CADIÑANOS BARDECI y CANTERA MONTENEGRO en los artículos anteriormente citados.

${ }^{2232}$ AGS, RGS, 148607, fol. 72.

2233 BENITO RUANO, E., Los orígenes del problema converso. Barcelona, 1976. Se ha consultado para la realización de este trabajo la edición digital de la Biblioteca Virtual Miguel de Cervantes. RÁBADE OBRADÓ, M., "Los judeoconversos en tiempos de Isabel la Católica”, en Sociedad y Economía en tiempos de Isabel la Católica. Valladolid, 2002, pp. 201-228. 
Otro ejemplo de intento de integración de un converso en la sociedad cristiana lo podemos apreciar en el caso de Fernando de Ayllón. Probablemente de origen segoviano, sabemos que era hijo de judía bautizada e hidalgo y que casó en Aranda con una cristiana vieja sin que sus parientes supieran que era converso ${ }^{2234}$. Su instalación como vecino de Aranda debió ser previa al conflicto sucesorio pues sufrió cuantiosas pérdidas cuando la villa fue tomada para el partido de la Princesa por don Diego de Rojas en $1473^{2235}$. Por el inventario de los bienes que le arrebataron en aquellos días podemos intuir que contaba con una notable fortuna, aunque en los años posteriores sufrió ciertas penurias económicas y tuvo que recurrir al préstamo ${ }^{2236}$. A finales de los ochenta su hacienda se había recuperado y desarrolló una importante actividad como comerciante de paños y puercos. Además se integró sin dificultad dentro de la clientela de la oligarquía local pues en 1489 recibió la vara de la justicia como alcalde del Concejo arandino. Pero la llegada de la Inquisición a Aranda en los meses finales de 1489 provocó su huida a tierras extremeñas con idea de irse a Portugal o incluso al Norte de África ${ }^{2237}$. Esta iniciativa le ocasionó alguna denuncia ante el Tribunal de la Inquisición pero desconocemos por el momento las penas que le pudo imponer, si es que las hubo. Poco después Ayllón optó por volver a la Ribera y retomar de nuevo sus negocios, actuando como arrendador de alguna de las rentas de la villa en 1494 y 1502 . Asimismo participó en otros muchos negocios dentro de la órbita de la familia Santa Cruz. También recuperó su actividad política pues en 1493 fue nombrado Mayordomo del Concejo ${ }^{2238}$.

A pesar de estos intentos de integración por parte de los conversos, en el otro lado estaba la mayoría cristiana que creó una serie de instrumentos para "protegerse" ante la irrupción de este nuevo grupo social: exclusión de cofradías, inhabilitación de

${ }^{2234}$ CARRETE PARRONDO, Fontes Iudaeorum... docs. 413 y 414, pp. 171-172.

2235 ... al tiempo que la dicha villa de Aranda fue tomada e redusida a nuestro servicio al tiempo que eramos prinçipes el fue preso e le fueron tomados asaz bienes suyos que tenia en la dicha villa e tierra: es a saber viñas e cubas e vino encubado e trigo e farina (AGS, RGS, 147702, fol. 349).

${ }^{2236}$ Entre los bienes que le incautaron se especifican tres viñas - por cada una de las cuales se estima una renta anual de 8.000 maravedíes-, siete cubas, doce fanegas de trigo, dos cargas de trigo y ciento sesenta cántaras de vino (AGS, RGS, 147702, fol. 271; 148003, fols. 15 y 104; 148407, fol. 31; y 148408, fol. 56).

\footnotetext{
${ }^{2237}$ CARRETE PARRONDO, Fontes Iudaeorum... docs. 413 y 414, pp. 171-172.

${ }^{2238}$ AGS, EH, leg. 4; y EMR, leg. 683, doc. 2.
} 
cargos públicos, estatuto de limpieza de sangre,... ${ }^{2239}$. Fue precisamente el origen judío, y por lo tanto un componente evidentemente racista, el que configuró el principal elemento de rechazo a través de una proyección imaginaria y colectiva que marginó de forma secular a los nuevos cristianos ${ }^{2240}$. Por otra parte, también cabe destacar el matiz sociopolítico de este conflicto y así algunos autores definen la Inquisición como un instrumento del poder político para imponer un determinado orden social al servicio de los intereses de la Corona ${ }^{2241}$.

Los primeros síntomas de esta situación ya se observan en el trato que recibieron las decenas de judíos ribereños que, tras marchar al exilio, optaron por convertirse y volver a su hogar ${ }^{2242}$. Entre éstos destaca el caso de Pedro Núñez de Santa Fe, antes llamado Yuçe de Valladolid y después apodado el "Ronquillo" o "Pero Embudo". Sabemos que tras el Decreto y después de intentar ajustar sus cuentas pendientes, Yuçe y toda su familia abandonaron Coruña del Conde y se dirigieron a tierras portuguesas. Tras llegar a su destino decidió iniciar junto a su hermano Alonso el camino de vuelta a Castilla, previa conversión en Zamora. A principios de agosto de 1492 ya había conseguido una carta real para que se le devolvieran todos sus bienes. Regresó a Portugal para retornar con su mujer y familiares. Cuando regresó definitivamente se encontró con múltiples problemas financieros, pero sobre todo con numerosas acusaciones de sus clientes, conocidos y vecinos ante la Inquisición. Finalmente se le abrió un proceso inquisitorial que le condenó a ser reconciliado y condenado a cárcel perpetua en 1502. Su mujer, Constanza Martínez y su criado Alonso de Soria fueron

${ }^{2239}$ EGIDO, "El problema histórico..., pp. 170-171. Este autor los define muy acertadamente como los instrumentos para la discriminación.

2240 VALDEÓN BARUQUE señala que esta mentalidad arranca de los estereotipos antijudíos configurados a lo largo del siglo XIV ("Motivaciones socio-económicas de las fricciones entre viejocristianos, judíos y conversos", en Judios. Sefarditas. Conversos. La expulsión de 1492 y sus consecuencias. Valladolid, 1995, pp. 69-88, en concreto p. 72).

${ }^{2241}$ CONTRERAS, J., “Judíos, judaizantes y conversos en la península Ibérica en los tiempos de la expulsión”, en Judios. Sefarditas. Conversos. La expulsión de 1492 y sus consecuencias. Madrid, 1995, pp. 457-477.

${ }^{2242}$ CANTERA MONTENEGRO ha documentado al menos una decena de judíos que huyeron a Portugal pero que poco después retornaron a distintas localidades de la Ribera ("Notas acerca de la expulsión..., pp. 75 y ss.). 
asimismo reconciliados. El sambenito de los tres todavía hoy se puede ver en la iglesia de Coruña del Conde ${ }^{2243}$.

Además de los retornados de Portugal también hemos documentado en 1495 la iniciativa del arandino Tristán de Arcilla de promover el retorno de un grupo de judíos exiliados desde el puerto africano de Larache. La empresa pasó grandes dificultades pues un oficial de la Armada castellana llegó al puerto y le robó dinero, bienes y joyas por una cuantía de 25.000 maravedíes $^{2244}$.

La tensión provocada por la vuelta de estos conversos se tradujo en el aumento considerable de los pleitos que hacían referencia al cumplimiento de los contratos anteriores a la expulsión, la usura y las deudas pendientes. Pero también se produjo un incremento de la violencia, heredera de la que anteriormente comentábamos en los momentos previos a la expulsión. Quizá una de las más llamativas manifestaciones de esta violencia fue la que narraba un vecino de Villanueva de Gumiel: ...luego como vinieron los christianos nuevos de Portogal, este testigo estava en la villa de Coruña e vio un dia como en la dicha villa quemavan en la plaça las Toras e otras escripturas de judios ${ }^{2245}$.

Las razones que impulsaron a estos hombres y mujeres a volver fueron muchas y variadas: bien porque no superaron el drama del desarraigo, bien porque sus pérdidas económicas pesaban más que la renuncia a la fe de sus mayores, etc. Sean unas u otras las causas lo cierto es que a su vuelta encontraron más de lo mismo: una situación de animadversión hacia sus personas, aunque el fundamento de este rechazo ya no era por ser infieles y asesinos de Cristo. El oprobio y la perdición se encontraba en sus venas y este estigma racial no se eliminaba con las aguas del bautismo.

Ante estos antecedentes no es de extrañar que la presencia del Tribunal de la Inquisición en la comarca ribereña durante la década de los noventa y en los primeros

2243 CANTERA MONTENEGRO, "Notas acerca de la expulsión..., pp. 81 y ss. Otros autores también transmiten información acerca de este personaje. Entre ellos destacan los numerosos testimonios recogidos por CARRETE PARRONDO en sus Fontes Iudaeorum...; y el material gráfico aportado por CADIÑANOS BARDECI, “Judíos y moros..., pp. 70-72.

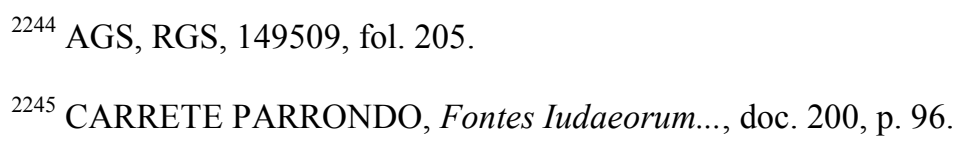


años del Quinientos sembrara el temor entre los nuevos cristianos de forma específica, pero también entre la población en general ${ }^{2246}$.

La violencia, persecución y exclusión social de los conversos no fue monopolio de la Inquisición. Los grupos de cristianoviejos ribereños también crearon y utilizaron mecanismos que, con el argumento de la pureza de sangre, apartaron del camino de la integración social a los nuevos cristianos. Uno de estos mecanismos se observa en la expulsión de dos cofrades ordenada por las autoridades de la Cofradía de San Pedro en aplicación de sus estatutos que prohibían que sus miembros fueran descendientes de judíos. Esta decisión acarreó importantes enfrentamientos y gastos como denunciaba el concejo en 1503: ay una cofadria de la adbocacion de San Pedro que en ella no pueden reçebir a ninguna persona que benga de sangre de judios; de que a cabsa dello se han recreçido muchas enemistades y aun oy dia las ay que aunque sea un onbre ydalgo de padre e habuelos sy en alguna manera toca en qualquier parte de confeso non lo reçiben; e sy por caso lo han reçebido y despues lo saben lo hechan fuera; y sobre semejante caso se an gastado muchas cuantias de maravedies; y hizose con mala yntencion para robarlos y fueron a la chançelleria y los quisieron punir y castigar y queman las ordenanças 2247 .

Ante esta situación no es de extrañar que muchos de estos conversos, cansados de buscar la integración por cualquier medio, optaran por emigrar a tierras lejanas donde su pasado o, mejor dicho, el de sus antepasados no condicionara su futuro. Conocemos varios casos como el ya mencionado de Fernando de Ayllón que huyó de la Inquisición cuando se presentó en la villa a finales de 1489 y se refugió en Extremadura ${ }^{2248}$. También sabemos de la exitosa singladura de Gaspar de Santa Cruz, hijo de Pedro de Santa Cruz, que se desplazó a Sevilla desde donde continuó el negocio de su padre ampliándolo con su participación en el comercio americano ${ }^{2249}$. Y en esta misma línea

${ }^{2246}$ La implantación de una fase inicial de terror institucional se constata perfectamente en otras partes de la geografía peninsular como por ejemplo en Andalucía (CARRASCO GARCÍA, G., "Judeoconversos de Jerez y el obispado de Cádiz a fines del siglo XV”, en En la España Medieval. 29, 2006, pp. 311-345).

2247 AGS, CC PUEBLOS, leg. 2, doc. 94; y ARChV, RRE, Caja 150, doc. 50.

${ }^{2248}$ CARRETE PARRONDO, Fontes Iudaeorum..., docs. 413 y 414, pp. 171-172.

${ }^{2249}$ Algunas noticias sobre la actividad financiera del hijo de Pedro de Santa Cruz, y sobre todo su relación con Francisco Fernández Coronel, las aporta DIAGO HERNANDO en "Arrendadores arandinos..., p. 78. Gaspar de Santa Cruz destacó además en el arrendamiento de rentas en tierras americanas 
encontramos a dos vástagos de conversos que optaron por incorporarse a la aventura americana. Rodrigo de Salazar ${ }^{2250}$, hijo de Sancho de Salazar y a la sazón nieto del converso Pedro de Santa Cruz, partió hacia el Perú en 1534. En este viaje le acompaño el comendador Gregorio Meléndez, hijo de Juan de Gumiel, uno de los colaboradores habituales de Pedro de Santa Cruz y posiblemente también de condición conversa ${ }^{2251}$. Una semana después, Luis de Calahorra, nieto del reconciliado y después rehabilitado García Sánchez de Calahorra, se embarcó rumbo a Santo Domingo ${ }^{2252}$. Estos últimos casos son bastante ilustrativos de la pervivencia en la memoria colectiva del pasado supuestamente impuro de sus abuelos aunque, bien es cierto, no podemos afirmar con total rotundidad que este pasado converso fuera el detonante de la salida hacia tierras americanas.

Como hemos visto en estas últimas líneas, la violencia sobre judíos y conversos fue una constante en la sociedad ribereña bajomedieval. Pero tal vez no fuera la violencia explícita -asesinatos, abusos, robos, autos de fe, sambenitos, multas,...-, la más contundente. Fue la otra, la de baja intensidad, continua y perenne, la que fijó el devenir de muchas familias que siempre estuvieron marcadas por ser diferentes.

\subsubsection{Conflictos con la comunidad mudéjar.}

El carácter modesto de las actividades que desarrollaban los musulmanes que vivían en tierras ribereñas ha sido el argumento más utilizado para explicar por qué esta

como lo muestra la abundante documentación que sobre sus actividades está depositada en el Archivo General de Indias (INDIFERENTE, leg. 419, L-6 y 7; y leg. 420, L-8 y 10).

${ }^{2250}$ AGI, CATÁLOGO DE PASAJEROS DE INDIAS, libro 1, exp. 4893. Rodrigo de Salazar nació el 11 de noviembre de 1500 y era hijo de Sancho de Salazar y de Isabel de Berlanga, hija de Pedro de Santa Cruz. Él junto a sus hermanos, Cristóbal y Francisca, estuvieron bajo la tutela de Pedro de Salazar hasta 1515 (AGS, CR, leg. 3, doc. 3). En 1519 se vio envuelto en una reyerta junto a su hermano Cristóbal (AGR, CR, leg. 518, exp. 2 y leg. 544, exp. 10).

2251 AGI, CATÁLOGO DE PASAJEROS DE INDIAS, libro 1, exp. 4894. Juan de Gumiel era vecino de Gumiel de Izán (AGS, EMR, leg. 560). Participó de varios negocios de arrendamiento de rentas como receptor (CMC, leg. 41) y en 1512 formó parte de la compañía que Santa Cruz creó para arrendar la renta del almojarifazgo de Sevilla. En el contrato se establecía que Gumiel debía residir en Sevilla (EMR, leg. 121, doc. 1). Tras su vuelta a la Ribera se avecindó en Aranda continuando con sus negocios tradicionales a los que incorporó el comercio de esclavos (ARChV, RRE, Caja 420, doc. 7).

${ }^{2252}$ AGI, CATÁLOGO DE PASAJEROS DE INDIAS, libro 1, exp. 5148. Su padre, García Sánchez de Calahorra, fue un notable miembro de la comunidad arandina, protagonista del pleito sobre la apertura de la calle de Barrionuevo en 1503 (PERIBÁÑEZ OTERO y ABAD ÁLVAREZ, Aranda de Duero..., p. 123.). Su abuelo, con el mismo nombre que el padre, fue condenado por la Inquisición por el delito de herejía en los primeros años noventa y parte de sus bienes fueron confiscados. Tras la apelación de sus herederos fue rehabilitada su memoria con anterioridad a 1495 (AGS, RGS, 149507, fol. 324). 
comunidad no provocó animadversión entre sus conciudadanos ${ }^{2253}$. No obstante, esta menor conflictividad no es incompatible con la existencia de unas férreas diferencias entre esta minoría y la sociedad mayoritariamente cristiana. Lo apreciamos claramente en el argumento utilizado por unos vecinos cristianos en 1488 para desechar el testimonio de maestre Abdalá: ser moro enemigo de nuestro Señor ${ }^{2254}$. De igual manera se aprecia un incremento de la presión sobre la comunidad mudéjar al insistir en la prohibición de que los musulmanes ejercieran sus profesiones los días festivos del calendario cristiano ${ }^{2255}$. Más contundente fue la medida que impuso en 1486 el concejo arandino cuando ordenó cerrar la morería para evitar la competencia que los negocios mudéjares ejercían sobre los de los cristianos del arrabal de Allendeduero, pues ...la morería esta en calle pública muy principal caminante y por estar abierta por delante y por detrás la mayor parte del trato del arrabal se hace en esa calle y se pierde el trato en el resto ${ }^{2256}$. Después de unos años la medida debió relajarse porque de nuevo en 1490 el concejo prohibió que hubiera en todo el arrabal de Allendeduero ...tiendas de cosas de comer y de aver tiendas de barberos y sastres y zapateros, provocando ...muchos agravios e mal e dapno a los moros que viben e moran en el dicho arrabal e tienen su morería destinta e apartada ${ }^{2257}$.

La situación empeoró a partir de 1500 pues se observa un progresivo distanciamiento entre las comunidades cristiana y mudéjar que se materializa en un ambiente bastante tenso que preconiza la conversión forzosa que se produjo dos años después. Por ejemplo, en este momento los moros arandinos manifestaron su queja por que no podían vender sus propiedades ya que corría el rumor de que iban a ser expulsados y los posibles compradores tenían miedo de tener los mismos problemas que surgieron cuando se produjo el exilio hebreo ${ }^{258}$. Este rumor ya se había manifestado a renglón seguido de la salida

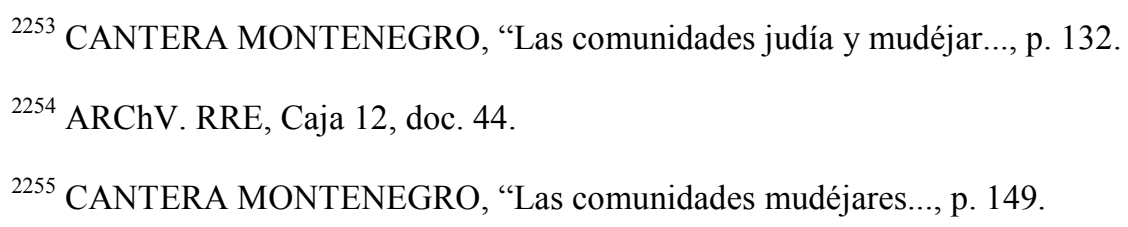

${ }^{2256}$ AGS, CC MEMORIALES, leg. 163, doc. 57. La prohibición de realizar actividades comerciales a los mudéjares ya se estableció en la normativa promovida por la reina Catalina de Lancaster en 1412 (VILLANUEVA ZUBIZARRETA, "Regulación de la convivencia..., pp. 358-361).

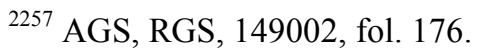

2258 AGS, RGS; 150003, fol. 49, transcrito por LADERO QUESADA, Los mudéjares..., doc. 100, pp. 251-252. Después de la expulsión de los judíos, los provisores del Obispado de Osma requisaron muchas propiedades que los cristianos habían comprado a los judíos, alegando que no tenían pruebas o que debían ser tomadas para la Corona como bienes de herejes. 
de los judíos pues ya en 1493 los monarcas ordenaron a todos sus corregidores que prohibiesen que se manifestara públicamente su intención de expulsar a los mudéjares del reino ${ }^{2259}$. Esta crispación finisecular también se manifestó en 1500 cuando se produjeron conatos de violencia al ser obligados los musulmanes a escuchar los sermones de un fraile franciscano en Santa María o San Francisco o cuando este fraile amenazó con predicar su sermón en la mezquita arandina. Todo ello provocó que alguno de los miembros de la comunidad mudéjar abandonara el reino y emigrara a tierra de infieles ${ }^{2260}$.

A esta conflictividad con los vecinos cristianos debemos añadir también la propia que se desarrolló en el seno de la aljama mudéjar. Recordemos que durante los últimos años del siglo XV se observa una lucha interna entre los diferentes clanes de esta comunidad centrada en el control del oficio de alcalde de la aljama. Para más detalles nos remitimos al apartado dedicado a la comunidad mudéjar en el capítulo anterior.

En conclusión, la Ribera del Duero a finales de la Edad Media no se libró del ambiente hostil que caracterizaba a las relaciones entre la mayoría cristiana y las comunidades marginadas por razón de su religión. Tras los procesos de expulsión-conversión, la dinámica de violencia cotidiana de cariz religioso no cesó de ejercerse aunque de manera unidireccional hacia los judeoconversos. Realmente el hostigamiento que sufrieron los judíos se mantuvo y las justificaciones ideológico-religiosas fueron similares -antes infieles, ahora falsos fieles-; aunque en el trasfondo se aprecia un componente netamente racista, si utilizamos la terminología contemporánea. En el caso ribereño, y en particular en el arandino, se observan evidencias de esa violencia cotidiana que puntualmente se intensificaron y radicalizaron, pero que sobre todo creó en los individuos que la sufrieron una sensación de continua inseguridad. Por contra, la situación de la comunidad morisca formada tras la conversión forzosa de 1502 ha pasado completamente desapercibida para la historiografía hasta el momento, en buena medida debido a la ausencia de noticias que hagan referencia a sus problemas de convivencia, lo que en absoluto quiere decir que no existieran.

${ }^{2259}$ AGS, RGS, 149312, fol. 15, transcrito por LADERO QUESADA, Los mudéjares..., doc. 62, pp. 203-204.

${ }^{2260}$ AGS, RGS, 150002, fol. 52, transcrito por LADERO QUESADA, Los mudéjares..., doc. 97 , pp. $245-246$. 


\section{EL PODER DE LA NOBLEZA COMARCANA.}

Un buen número de los conflictos que hemos documentado en la Ribera del Duero a finales de la Edad Media está relacionado con las pretensiones de la nobleza comarcana de expandir sus estados señoriales. El hecho de que la posición de poder de la nobleza castellana feudal se asentara sobre una base territorial implicó que los linajes que a lo largo del siglo XV se asentaron en este espacio buscaran en los últimos decenios de la Edad Media configurar primero y consolidar después un importante dominio señorial que les permitiera acceder al escalón superior de la aristocracia castellana. En un territorio fuertemente señorializado como la Ribera en la Baja Edad Media esta dinámica expansiva de las principales familias nobiliarias fomentó la proliferación de enfrentamientos intranobiliarios. De igual manera, los elementos más débiles dentro del sistema de poder, monasterios y behetrías fundamentalmente, se vieron sometidos a la fuerte presión derivada de las ansias de crecimiento de los grandes señores. Asimismo, otro poder emergente en la zona, la villa de Aranda, se vio inmersa en esta vorágine expansiva, provocando el incremento de la tensión sobre el control del territorio ribereño.

El apartado que ahora comenzamos analiza pormenorizadamente los conflictos que tuvieron como protagonistas a los linajes nobiliarios con una destacada presencia a finales de la Edad Media en la Ribera del Duero burgalesa. Para ello, en primer lugar, estudiaremos los principales conflictos que enfrentaron a miembros del estamento nobiliario. Posteriormente analizaremos los distintos episodios en los que la nobleza proyectó su política expansiva sobre los grandes cenobios ribereños. Por último, dedicamos un breve apartado a la presión que ejerció la nobleza territorial sobre las behetrías.

\subsection{La política expansiva de los grandes señores y los conflictos intranobi- liarios .}

En este apartado se aborda el análisis de los enfrentamientos más significativos que tuvieron lugar entre los nobles de la comarca ribereña. Para ello presentaremos sucesivamente los distintos conflictos que posibilitaron a los diferentes clanes nobiliarios asentados en la comarca configurar y consolidar verdaderos estados señoriales a semejanza de lo que paralelamente ocurrió en otros espacios castellanos. Si bien es cierto que 
estos episodios muestran líneas generales de expansión de las casas nobiliarias, creemos más oportuna la exposición de la problemática concreta de cada enfrentamiento en un primer momento, para después identificar y definir las dinámicas expansivas de cada una de las familias de la nobleza comarcana.

\subsubsection{El enfrentamiento entre los linajes Sandoval y Téllez-Girón: la villa de Gumiel de Izán y el valle del Esgueva.}

A mediados de los años ochenta del siglo XV las tensas relaciones entre el conde de Urueña y el marqués de Denia se tradujeron en varios altercados violentos en tierras ribereñas.

Este enfrentamiento tuvo su origen en la pugna por el señorío de la villa de Gumiel de Izán ${ }^{2261}$. El punto de partida en nuestro análisis es la compra de la villa que realizó el I conde de Castro en $1421^{2262}$. Los avatares de los enfrentamientos entre el rey castellano y los Infantes de Aragón a mediados del siglo XV provocaron que don Diego de Sandoval perdiera su villa al serle requisada junto a otras posesiones por Juan II. Posteriormente fue cedida en 1452 al marqués de Santillana y finalmente en 1459 Enrique IV se la entregó a Pedro de Girón ${ }^{2263}$.

Lo que en principio parece una mera disputa por la posesión de una villa en el contexto de las numerosas disputas internas del reino de Castilla realmente enmascara una situación bastante más compleja. En 1440 el primer conde de Castro cedió a su hijo Pedro de Sandoval una parte del señorío de Gumiel de Izán, junto a sus derechos sobre Bahabón, Oquillas y Cilleruelo, como aportación a su matrimonio con Leonor de Zúñiga. El resto de los derechos del conde de Castro sobre Gumiel fueron asimismo repartidos entre el resto de sus hijos como parte de su herencia ${ }^{2264}$. Después del secuestro del

${ }^{2261}$ Esta disputa ha sido estudiada por VIÑA BRITO, “Gumiel de Izán, una villa..., pp. 501-513.

${ }^{2262}$ CADIÑANOS BARDECI, Arquitectura fortificada..., p. 267.

${ }^{2263}$ SNAHN, OSUNA, Caja 4135, doc. 1. En este documento se encuentra la donación realizada a favor de Pedro de Girón el 7 de octubre de 1459 y la posterior restitución al conde de Castro el 12 de julio de 1465, que no parece ser efectiva. El 21 de noviembre de 1459 el alcaide Diego de San Pedro tomó posesión de la villa para don Pedro Girón (OSUNA, Caja 79, doc. 6). Esta donación se produjo como compensación a la negativa de los vecinos de Fregenal de la Sierra, apoyados por el concejo de Sevilla, a someterse a la jurisdicción del maestre de Calatrava (OSUNA, Caja 96, doc. 16; y VIÑA BRITO, "Gumiel de Izán, una villa..., p. 502).

${ }^{2264}$ Esto se deduce de las sucesivas compras de derechos que realizó el conde de Urueña a los herederos del conde de Castro para hacerse con la jurisdicción de la villa. En 1462 Inés de Sandoval cedió al conde de Urueña la quinta parte de la villa de Gumiel de Izán, con sus vasallos y su fortaleza, a cambio 
condado de Castro y la posterior donación a los Téllez-Girón, los sucesivos condes de Castro reclamaron sus derechos sobre la villa comenzando así una larga disputa entre las familias Girón y Sandoval, pero también paralelamente entre los propios herederos del I conde de Castro.

A nuestro entender, las donaciones reales enmascaraban una compraventa de la villa ya que el propio monarca la había comprado, o mejor dicho, parte de los derechos sobre ésta a Fernando de Rivadeneyra ${ }^{2265}$. Todo ello apunta al pasado como behetría de la villa y su conversión definitiva en señorío de la mano de los Téllez-Girón, no sin antes mantener una disputa con el marqués de Denia, candidato también por herencia de su abuelo a ostentar el señorío singular de la villa.

La tensión aumentó en el contexto del conflicto sucesorio y la posterior guerra contra Portugal. El conde de Castro participó al lado de los Reyes Católicos bajo la promesa de recuperar sus antiguos estados mientras que el conde de Urueña era partidario de la princesa Juana. Como agradecimiento a la ayuda prestada por el conde de Castro, los nuevos monarcas confirmaron en julio de 1475 sus derechos sobre la villa de Gumiel de Izán, que había sido confiscada poco antes al conde de Urueña ${ }^{2266}$. Sin embargo, la política de reconciliación emprendida por los monarcas alteró significativamente la anterior merced, pues en mayo de 1476 el conde de Urueña consiguió el perdón real, en buena medida gracias a la intercesión de su suegro el Condestable de Casti$11 a^{2267}$. En las negociaciones entre los monarcas y el conde de Urueña uno de los puntos conflictivos fue el retorno de la villa de Gumiel de Izán. En las capitulaciones se estableció que la villa quedaría en manos del Condestable, quien se encargaría de devolverla

de 5.000 doblas de oro, pago que no se hizo efectivo hasta 1468 (SNAHN, OSUNA, Caja 79, docs. 3134). En 1477 los otros tres hermanos, Pedro, Diego y Juan de Sandoval, todavía tenían derechos sobre la villa (Caja 79, docs. 46-48). También Leonor de Zúñiga, hija del conde de Montemayor, alegaba en 1481 tener derechos sobre la villa por la herencia recibida de su abuela María de Barba (Caja 79, docs. 53-54).

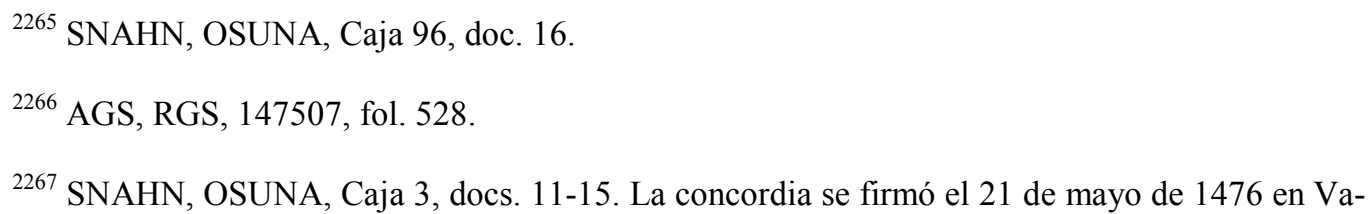
lladolid. El conde prestó obediencia y servicios a los monarcas y recibió de éstos la confirmación de las mercedes hechas a sus antecesores. Llama la atención que entre estas mercedes se mantuviera la exención del pago de alcabalas y tercias a los vasallos del conde como se puso de manifiesto en algunas comunicaciones a los arrendadores (Caja 79, docs. 72-78). 
a Girón en el plazo de tres meses ${ }^{2268}$. Lejos de llevarse a cabo lo estipulado en las capitulaciones de mayo ${ }^{2269}$, el propio monarca tomó partido por don Diego de Rojas y participó en la toma de la plaza a mediados de octubre de ese mismo año ${ }^{2270}$. Finalmente, en febrero de 1477 Girón recuperó definitivamente su villa de Gumiel de Izán ${ }^{2271}$.

A finales de la década de los setenta la política pacificadora emprendida por los reyes tras la contienda permitió a don Juan Téllez recuperar la jurisdicción de Gumiel de Izán tras su sumisión a los nuevos monarcas. Sin embargo, esta circunstancia no significó en modo alguno el final de las disputas entre los Sandoval y los Téllez-Girón como se deduce de las sucesivas prórrogas de tregua de seguro que tuvieron como protagonistas a ambos contendientes ${ }^{2272}$.

Las diferencias se mantuvieron sin mayor trascendencia hasta que en la primavera de 1486 estalló la tensión en un primer asalto a la villa de Gumiel de Mercado por parte de las tropas del de Urueña, capitaneadas por don Pedro de Sandoval, que ...entro e tomo la dicha villa de Gomiel de Mercado e la fortalesa della; e aportillaron la çerca de la dicha villa, e por el dicho don Pedro e por la gente del dicho conde fueron aportillados çiertos cortijos de otros lugares del dicho marques e fueron tomados e robados muchos bienes muebles de los bienes e vasallos del marques ${ }^{2273}$. La respuesta de la otra parte no se dejó esperar y en los últimos días de mayo de ese mismo año ...çierta gente de cavallo e de pie de don Dyego de Rojas, marques de Denia, venieron al dicho lugar

${ }^{2268}$ En febrero de 1476 el Condestable dio garantías al conde de Castro de que el conde de Urueña o sus partidarios se comprometían a no entrar en Gumiel durante los 70 días que la reina había fijado para ajustar los debates sobre la villa (ADM, ARCHIVO HISTÓRICO, leg. 197, 11, nº 1).

${ }^{2269}$ En el compromiso se establecía que: en el caso de Gomiel de Yçan se aya de entregar y entregue al dicho conde de Urueña desde oy de la fecha desta escritura en tres meses primeros syguientes apoderandose en lo alto y baxo della... el conde haga seguridad por esta escritura que durant los dichos tres meses no tomara la dicha villa e fortaleza por trato o furxo ni en otra manera y que durant este tiempo el rey e reina nuestros señores paguen la gente que estuviere en la guarda de la dicha villa y fortaleza y ponga el alcaide en ella ... e que a los vecinos de la dicha villa no les sea tomado el vino que tienen en la Villanueva ni otras cosas...(SNAHN, OSUNA, Caja 3, docs. 24-29). A tenor de lo pactado la plaza debería ser devuelta a finales de agosto.

${ }^{2270}$ PALENCIA, Crónica de Enrique IV, Tomo IV, pp. 304-305. Ya hemos reproducido en el apartado dedicado al reconocimiento de la autoridad real este épico episodio relatado en la crónica.

${ }^{2271}$ Martín de Acuña, alcaide nombrado por los monarcas, hizo entrega de la villa de Gumiel al conde el 17 de febrero y, a petición del conde, se mantuvo en ese puesto (SNAHN, OSUNA, Caja 79, docs. 44-45).

${ }^{2272}$ VIÑA BRITO, “Gumiel de Izán, una villa..., p. 505. La autora ha documentado al menos dos treguas: una que se prolongó hasta 1479 y otra de 20 meses a partir de diciembre de ese año.

${ }^{2273}$ SNAHN, OSUNA, Caja 79, docs. 79-80. 
de Bahavon armados con sus lanças e espadas e coraças e otras armas... e achuchillaron e firieron çiertos vesynos del dicho lugar e llevaron presos a çiertos omes... e tomaron e robaron çierto ganado e bestyas e bueyes. Finalmente, ...tomo la villa de Gomiel de Yçan e tomo prestadas çiertas quantias de maravedies a çiertos vesinos ${ }^{2274}$.

La intervención del Consejo de la Hermandad no consiguió poner fin al litigio y fue el propio monarca el que se vio obligado a actuar como mediador. El 30 de marzo de 1489 dictó una sentencia de reconciliación entre ambos. En ella se estipulaba una serie de capítulos entre los que destaca una indemnización de 750.000 maravedíes que el conde de Urueña debía abonar al marqués de Denia por los daños causados en su villa de Gumiel del Mercado y que, en el fondo, parece una compensación por la renuncia a los derechos sobre Gumiel de Izán ${ }^{2275}$.

No obstante, la renuncia del marqués de Denia no significó que la posesión de la villa fuera completa para los condes de Urueña pues para confirmarla tuvo que llegar a acuerdos con los herederos del I conde de Castro y otros personajes, que se materializaron en la venta de los posibles derechos que sobre Gumiel pudieran tener ${ }^{2276}$.

En esta misma línea expansiva del linaje Téllez-Girón podemos encuadrar una serie de adquisiciones en el valle del Esgueva, que se produjeron en este contexto del enfrentamiento con los Sandoval y que consolidaron la posición de poder del II conde de Urueña en la comarca.

En el contexto de esta dinámica expansiva, el primer episodio tuvo como protagonista a la behetría de Santa María del Mercadillo. Este lugar fue señorío de don Juan de Avellaneda, hijo bastardo del noveno señor de Avellaneda, de quien lo heredó su hija

${ }^{2274}$ AGS, RGS, 148606, fol. 136. El asalto lo dirigió Lope Ochoa de Avellaneda, hombre de confianza del marqués de Denia.

2275 SNAHN, OSUNA, Caja 80, doc. 1; y CADIÑANOS BARDECI, Arquitectura fortificada..., pp. 266-267. Llama la atención que en la sentencia se fijó claramente la cantidad que tenía que abonar Urueña, así como los plazos en que se debía de entregar el dinero al conocido financiero burgalés Diego de Soria. Este dato contrasta con la laxitud con la que se establecía que don Diego de Rojas estaba obligado a devolver el dinero que tomó prestado a algunos vecinos de Gumiel de Izán y la reparación de los daños de Bahabón, a pesar de contar con una sentencia condenatoria del Consejo de la Hermandad. También llama la atención que los únicos condenados a destierro en esta sentencia fueran algunos hombres del conde de Urueña.

${ }^{2276}$ Además de las sucesivas compras de derechos a los hijos del I conde de Castro desde los primeros años sesenta, en 1481 compró los de doña Leonor de Zúñiga (SNAHN, OSUNA, Caja 79, docs. 55-58) y en 1491 adquirió los de Alfonso de Sandoval (Caja 80, docs. 7-9). Todavía en 1503 el mayordomo del conde de Urueña tuvo que demostrar que doña Mencía de la Vega, mujer de Don Fernando de Granada y también descendiente del I conde de Castro, ya había sido pagada por sus derechos sobre la villa de Gumiel (Caja 97, doc. 62). 
Constanza. Tanto ella como su marido, don Martín Vázquez de Acuña, recibieron en 1473 el reconocimiento del señorío y vasallaje por parte de los vecinos de Santa María del Mercadillo ${ }^{2277}$. En 1486, en este caso utilizando medios más o menos amistosos, el conde de Urueña consiguió que doña Constanza y don Martín le vendieran las propiedades que poseían en Santa María del Mercadillo y acto seguido, debido a su condición de behetría, le cedieron sus privilegios sobre la behetría y le traspasaron su señorío ${ }^{2278}$.

Un segundo avance en el control del valle medio del Esgueva se produjo a lo largo de los primeros años ochenta cuando el conde de Urueña se hizo con los lugares de Bahabón, Oquillas y Cilleruelo que fueron comprados a don Pedro de Sandoval, hijo del I conde de Castro, aunque la venta no se confirmó hasta $1488^{2279}$. Años después, en 1508, el conde consolidó su posición en el valle del Esgueva con la compra del señorío de Santibáñez de Esgueva a Alonso Muñoz de Acuña ${ }^{2280}$.

En definitiva, el desarrollo del conflicto entre los linajes de los Sandoval y Téllez-Girón por la villa de Gumiel de Izán supuso la consolidación de la presencia de los señores de Urueña en tierras ribereñas. Esta realidad se vio notablemente reafirmada con posteriores operaciones que permitieron crear un importante estado señorial en la comarca, si bien es cierto que con escaso peso en el contexto del importante patrimonio territorial que poseía esta familia en otros espacios castellanos.

\subsubsection{Las disputas entre los Zúñiga y los Acuña por el señorío de la villa de Hoyales y Fuentelisendo.}

El control de la jurisdicción de la villa de Hoyales y Fuentelisendo fue un punto significativo en la política de expansión territorial de los sucesivos condes de Miranda a lo largo del último tercio del siglo XV. En principio, estas dos localidades pertenecieron a don Juan de Avellaneda, hijo ilegítimo del noveno señor de esta casa, que las transmitió en herencia a su hija doña Constanza. Como ya hemos visto, doña Costanza contrajo

${ }^{2277}$ SNAHN, OSUNA, Caja 36, doc. 76 y 77.

${ }^{2278}$ El mismo día, 20 de enero de 1486, se realizó primero la venta de la hacienda (SNAHN, OSUNA, Caja 36, docs. 72 y 73), para después traspasar el señorío (docs. 74 y 75).

${ }^{2279}$ SNAHN, OSUNA, Caja 36, docs. 42-44; y Caja 80, docs. 7-9.

${ }^{2280}$ SNAHN, OSUNA, Caja 36, docs. 100-102. 
matrimonio con un noble de segunda fila, don Martín Vázquez de Acuña, señor de Villaester $^{2281}$.

En el contexto de la guerra civil don Juan de Avellaneda y don Pedro de Zúñiga, tío y sobrino, intervinieron muy activamente en los acontecimientos que se sucedieron en la comarca y especialmente en la villa de Aranda ${ }^{2282}$. El primero actuó como corregidor en nombre de la reina Juana y el segundo como su tenente efectivo, por lo que deducimos que eran aliados. Esta vinculación se confirma a tenor de la cláusula que don Juan incluyó en su testamento en la que establecía que a su muerte don Pedro se hiciera cargo de la fortaleza de Hoyales y se la transmitiera a sus herederos. Efectivamente, tras la muerte de Avellaneda, Pedro de Zúñiga tomó bajo su protección esta fortaleza, pero después de ocuparla y expoliarla se negó a entregársela a doña Constanza. Tras una tensa disputa entre ambas partes, la herencia de don Juan de Avellaneda pasó definitivamente a su hija ${ }^{2283}$.

Lejos de finalizar las disputas entre la casa de Miranda y doña Constanza de Avellaneda, a partir de 1477 se desarrolló un litigio entre ambas partes por la jurisdicción civil y criminal de Hoyales y Fuentelisendo. Zúñiga, que había heredado los señoríos de su madre doña Aldonza de Avellaneda, argumentaba que este señorío pertenecía a su progenitora como única heredera legítima del último señor de Avellaneda. Por su parte, Constanza hacía valer sus derechos como descendiente directa de don Juan de Avellaneda, hermanastro de doña Aldonza. El pleito tuvo una primera sentencia favorable a los intereses de doña Constanza de Avellaneda pero se prolongó hasta $1500^{2284}$.

Paralelamente al pleito jurisdiccional se desarrollaron también una serie de conflictos entre los oficiales del conde en la cercana villa de Haza y los vecinos de Hoyales. Incluso don Martín de Acuña, esposo de doña Constanza, se vio implicado en el asesi-

${ }^{2281}$ DOMINGO ZAPATERO, La Comunidad de villa y tierra de Haza..., pp. 57-59.

${ }^{2282}$ Recordemos que doña Aldonza de Avellaneda, madre de don Pedro de Zúñiga, era hermanastra de don Juan de Avellaneda.

${ }^{2283}$ Pedro de Zúñiga aprovechó la muerte de Avellaneda para ocupar la torre de Hoyales. En el proceso judicial se presentó una relación de los bienes que tenía el difunto en la fortaleza que se tasaron en más de 200.000 maravedíes. A esta cantidad había que sumar 200 carneros que se encontraban en los alrededores y que fueron tomados por los hombres de Zúñiga (ARChV, RRE, Caja 166, doc. 2).

2284 ARChV, PLEITOS CIVILES, FERNANDO ALONSO, Caja 1198, doc. 2. Existe también copia en el Archivo municipal de Fuentelisendo. En 1501 se solicitó la ejecución de la sentencia (ARChV, RRE, Caja 166, doc. 2). 
nato del alcaide de Haza en $1480^{2285}$. Durante la década de los 90 el siguiente alcaide de Haza emprendió una campaña de acoso y abusos contra los vecinos de Hoyales que contemplaba robos, retenciones, confiscación de bienes e incluso el asesinato ${ }^{2286}$. Este ambiente hostil se incrementó con el desarrollo de varios pleitos por la delimitación de términos y uso de los mismos ${ }^{2287}$.

Esta dinámica de enfrentamiento señorial también tuvo sus repercusiones económicas entre los vecinos de los lugares de uno y otro protagonista. En 1503 el conde de Miranda prohibió a sus vasallos acudir a moler a los molinos de Hoyales con lo que tuvieron que recurrir a otros emplazamientos más alejados. Evidentemente esta medida mermó la rentabilidad del trabajo de los campesinos de las tierras de Haza pues aumentó los costes de desplazamiento. Igualmente repercutió negativamente en la economía de los molineros de Hoyales que sufrieron un descenso considerable en la actividad molturadora $^{2288}$.

A pesar de las sentencias favorables a doña Constanza, la situación de constante enfrentamiento y el gran coste que suponía la tenencia de su señorío llevaron a la señora de Hoyales a tomar la decisión de vender el señorío a la Reina Isabel en 1504 por un cuento de maravedíes ${ }^{2289}$. La compraventa se realizó el 7 de marzo de ese año y fue confirmada por don Martín de Acuña, en nombre de su esposa, el 15 de abril ${ }^{2290}$. Sin embargo, los roces entre los Acuña y los Zúñiga continuaron por lo menos hasta $1508^{2291}$.

Los problemas con la posesión de la villa de Hoyales no terminaron con esta compra por parte de la Corona. Tras el fallecimiento de la reina y la llegada a Castilla de

${ }^{2285}$ AGS, RGS, 148010, fol. 257.

${ }^{2286}$ AGS, RGS, 149310, fol. 141; 149407, fol 121; 149410, fol. 441; y 149910, fol. 238.

${ }^{2287}$ ARChV, RRE, Caja 132, doc. 37; y Caja 141, doc. 13.

${ }^{2288}$ AGS, EMR, leg. 689.

${ }^{2289}$ En los años finales del reinado de doña Isabel se intuye una dinámica tendente a incrementar el patrimonio real en la comarca. En concreto, esta tendencia se plasmó en la compra de la villa de La Ventosilla en noviembre de 1503 y la ahora abordada de Hoyales. No sabemos si estas dos iniciativas responden a una política planificada más general o simplemente se trató de dos hechos puntuales coincidentes en el espacio. En el caso de que fuera la primera de las opciones, lo cierto es que tras la muerte de la reina sus sucesores no tardaron mucho en deshacer el camino andado y, como veremos a continuación, pusieron a la venta rápidamente estos territorios.

${ }^{2290}$ La compraventa la reproduce DOMINGO ZAPATERO, La Comunidad de Villa..., pp. 9396. La confirmación se encuentra en AGS, EMR, leg. 689.

${ }^{2291}$ ARChV, RRE, Caja 195, doc. 27; y Caja 229, doc. 60. 
sus herederos este señorío se convirtió en un apreciado bien con el que obtener recursos para las maltrechas arcas reales. Así se puede apreciar en la merced que el archiduque Felipe hizo al conde de Miranda de la tenencia de Hoyales, Fuentelisendo y La Ventosilla en 1506, ya que tal merced no era sino una venta valorada en 1.600 .000 maravedí$\mathrm{es}^{2292}$. La temprana muerte del donante hizo que las pretensiones de los Zúñiga de afianzar su posición de poder en el curso bajo del Riaza se vieran truncadas pues este señorío retornó a la Corona, a buen seguro por la iniciativa de don Fernando que tenía en gran consideración la finca de La Ventosilla y era conocedor de la gran presión señorial que soportaba la comarca. El montante pagado por el conde de Miranda le fue devuelto en los años sucesivos con los ingresos provenientes de las alcabalas de la villa de Aranda $^{2293}$.

Finalmente, las necesidades de liquidez de la Corona propiciaron que el 18 de mayo de 1510 el señorío de Hoyales y Fuentelisendo, esta vez sin La Ventosilla, fuera vendido definitivamente al Conde de Miranda por la nada despreciable cantidad de cuatro cuentos de maravedíes ${ }^{2294}$. La diferencia de precio entre la compraventa promovida en 1506 por don Felipe y la definitiva llevada a cabo por don Fernando puede considerarse una clara evidencia del clima de oportunismo político que rodeó a la corte del príncipe borgoñón en su breve paso por el reino castellano.

Esta compra fue el último eslabón que permitió a la familia Zúñiga consolidar uno de los principales ejes de su política de expansión territorial pues completaba así el dominio sobre el valle del Riaza que se extendía desde las tierras de la Comunidad de Villa y Tierra de Montejo al Sur hasta las proximidades de su desembocadura en el Duero por el Norte 2295 .

2292 ...mi mandado y voluntad es que don Francisco de Zúñiga y Avellaneda, conde de Miranda, del mi Consejo, tenga las dichas fortalezas y lugares (BRAH, SALAZAR Y CASTRO, M-59, fol. 63, citado por QUINTANILLA RASO, "Élites de poder..., nota 71, p. 977).

${ }^{2293}$ DIAGO HERNANDO “Cambios políticos..., p. 323. En las libranzas de las alcabalas de la villa de Aranda de 1516 se establecía la devolución de 400.000 maravedíes del total ... que sus altezas le mandaron librar por los lugares de Hoyales, Fuentelisendo y La Ventosilla, los cuales se averiguó que le había dado al rey don Felipe, que en Santa Gloria haya, por los dichos lugares al tiempo que le hizo merced dellos e despues se tornaron a restituir (AGS, CMC, leg. 41, doc. 13).

${ }^{2294}$ DOMINGO ZAPATERO, La Comunidad de Villa..., pp. 97-105.

${ }^{2295}$ Esta expansión por la cuenca del bajo Riaza tan solo se vio interrumpida por el pequeño enclave de Torregalindo que, después de pasar por muchas manos -incluso las del conde de Miranda (ARChV, RRE, Caja 154, doc. 2)-, finalmente, tras sumarse al patrimonio del ducado de Alburquerque, pasó a pertenecer a los condes de Siruela. 


\subsubsection{El conflicto por un río: los Zúñiga y su villa de La Aguilera contra los Sandoval y su villa de Gumiel del Mercado.}

Como viene siendo habitual entre comunidades vecinas, los conflictos entre las villas de La Aguilera y Gumiel del Mercado han sido bastante frecuentes a lo largo de su historia. Ya en el primer cuarto del siglo XV se advierten roces entre sus respectivos señores, don Diego González de Avellaneda, señor de Gumiel, y don Juan de Villacreces, señor de La Aguilera y obispo de Burgos. En este caso la disputa se centró en el aprovechamiento ilícito que hacían los vecinos de Gumiel de un monte propiedad del concejo aguilereño $^{2296}$.

Recordemos que a principios del Cuatrocientos la villa de Gumiel pasó a la familia Sandoval mientras que La Aguilera fue adquirida por la casa de Miranda. Durante las décadas finales del siglo XV un conflicto entre estas dos comunidades por el aprovechamiento de las aguas del río Gromejón provocó un enfrentamiento directo entre el conde de Miranda y el marqués de Denia. Si bien es cierto que las desavenencias entre vecinos fueron bastante habituales en este periodo, lo que ya no era tan habitual fue la intervención directa y violenta de los señores en disputas menores ${ }^{2297}$. En el fondo, lo que revela este episodio es una tensión previa que aprovechó una determinada coyuntura para estallar en un conflicto mayor. Esta disputa se desarrolló en dos fases pero con las mismas causas, evolución y resolución.

La primera de ellas comenzó en julio de 1487 cuando algunos vecinos de Gumiel de Mercado, armados con lanças e vallestas e otras muchas armas, dellos a caballo e dellos a pie se presentaron en La Aguilera ...con yntençion e proposito de los injuriar e matar, para acto seguido ...çerrarades una presa que ellos tenían fecha en el rio que se dise de Gomejon por donde llevan el agua para regar sus heredades ${ }^{2298}$. Esta

${ }^{2296}$ Se conserva un documento que recoge un interrogatorio de 1420 sobre el aprovechamiento de un monte de La Aguilera que lindaba con Gumiel de Mercado. En este interrogatorio los testigos informan de que en el pasado, sin especificar más, el señor de Gumiel hacía uso de dicho monte a pesar de las denuncias del obispo de Burgos (AMA, leg. 1199, doc. 19).

${ }^{2297}$ Las disputas entre vecinos por el aprovechamiento del agua de los ríos fueron bastante habituales. Sin ir más lejos, apenas unos años después los cercanos concejos de Quintana del Pidio y Gumiel de Izán se enzarzaron en una disputa por el aprovechamiento de las aguas del Gromejón. El problema lo intentó solucionar la justicia ordinaria, aunque problemas de jurisdicción obligaron a la intervención del Consejo Real (AGS, CR, leg. 391, doc. 3).

${ }^{2298}$ AGS, RGS, 148709, fol. 198. 
iniciativa gomellana contó con el beneplácito y apoyo del señor de la villa, el marqués de Denia. El argumento esgrimido por los agresores, representados por los dueños de los molinos de Gumiel del Mercado, era que los vecinos de La Aguilera habían roto el cauce del Gromejón para regar sus campos, por lo que no les llegaba agua suficiente para mover sus ingenios ${ }^{2299}$. El concejo de La Aguilera denunció la agresión y finalmente el Consejo Real falló que el concejo de Gumiel del Mercado y el marqués de Denia debían pagar una multa de 2.000 doblas de oro y estableció que el agua del río se debía aprovechar como se hacía hasta antes de comenzar el conflicto ${ }^{2300}$.

Durante unos años el conflicto del agua bajó en intensidad aunque la tensión entre los linajes de Sandoval y Zúñiga se mantuvo sobre todo a raíz de la transferencia de vasallos de un pueblo al otro ${ }^{2301}$.

El conflicto se reprodujo de nuevo en 1496 con los mismos protagonistas y resultado. En mayo de ese año los monarcas comisionaron al bachiller Gonzalo Sánchez de Castro y al alguacil Juan de Cuero para que proveyeran lo necesario sobre la diferencia existente entre el marqués de Denia y la condesa viuda de Miranda a propósito del aprovechamiento de las aguas del Gromejón. Cuando los comisionados llegaron al escenario del conflicto para realizar su pesquisa se encontraron con que ambas partes ya habían organizado sendos grupos armados que se habían enfrentado. Los delegados reales disolvieron a las gentes armadas como primer paso para pacificar la situación. A continuación investigaron lo sucedido y tomaron la decisión de imponer una solución provisional hasta que se resolviera de forma definitiva el pleito que se había iniciado ante la Audiencia Real ${ }^{2302}$.

${ }^{2299}$ Las propias características del río con un caudal reducido y sometido a un fuerte estiaje invitan a pensar que precisamente en el verano se producirían conflictos por el aprovechamiento de sus aguas pues las necesidades molturadoras tras la siega coincidían con la mayor demanda de agua para riego de ortalisas e cañamos e linos (AGS, RGS, 148708, fol. 160). No obstante, de las denuncias planteadas por los vecinos de Gumiel se concluye que los de La Aguilera habían aumentado sustancialmente su superficie de cultivos de riego y que además habían construido nuevas infraestructuras de regadío (nueva açequia e caño).

${ }^{2300}$ AGS, RGS, 148709, fol. 198. Poco después se inició un nuevo proceso judicial pues en el verano de 1488 se ordenó la recepción de testigos (148807, fol. 40).

${ }^{2301}$ AGS, RGS, 149301, fol. 27 y 149404, fol. 425. En 1493 Martín Cuesta y Domingo Sotillo abandonaron Gumiel del Mercado por el hostigamiento al que les sometía el alcaide de esa villa. Se refugiaron en La Aguilera al amparo del conde de Miranda pero solicitaron una carta de seguro a los reyes pues temían la respuesta del marqués. Un año después ocurrió lo mismo con Rodrigo Mañero.

${ }^{2302}$ AGS, RGS, 149605, fol. 124, 142, 190 y 191. La solución provisional aportada por el pesquisidor no fue respetar el reparto tradicional de agua que se realizaba con anterioridad al incidente. Aun- 
De nuevo en la primavera de 1497 volvieron a reproducirse los altercados. Ya en abril se comisionó al corregidor de Aranda para que hiciera cumplir lo establecido el año anterior por el pesquisidor, pero la escalada de violencia continuó ${ }^{2303}$. El 19 de mayo varios hombres armados se dirigieron a La Aguilera y derribaron la acequia y la regadera que había sido construida para regar ciertas heredades ${ }^{2304}$. La respuesta de la parte contraria no se hizo esperar y el conde e condesa de Miranda e sus valederos fasiendo guardas e asonadas e ayuntamiento de gentes armados a pie e a cavallo e puestos en batalla e a punto de guerra vinieron al dicho rio e ronpieron e quebraron la ribera del e sacaron la dicha agua de su alveo antiguo e lo echaron por donde quisyeron; e non contentos de aquello derocaron un molino de la dicha villa de Gomiel e fisieron otras fuerças e violencias e ynjurias gravisymas reales e verbales ${ }^{2305}$. El corregidor arandino intentó pacificar la situación e imponer a las partes la resolución provisional del pesquisidor pero da la impresión, a tenor de los continuos requerimientos de los monarcas para que cumpliera su cometido, que sus resultados no fueron muy positivos. Todo hace suponer que los enfrentamientos directos continuaron bastante tiempo pues al año siguiente se prorrogó al corregidor su misión y además se le encomendó realizar una nueva pesquisa ${ }^{2306}$.

Todavía en el verano de 1500 seguía la misma dinámica y los monarcas se vieron obligados a conminar al marqués de Denia para que guardase la sentencia de paz emitida por el pesquisidor y renovada por el corregidor hasta que finalizara el pleito sobre el aprovechamiento de las aguas ante las instancias judiciales. Esta nueva orden estuvo motivada por informaciones que les habían llegado sobre los preparativos que estaba haciendo el marqués y sus gentes para llevar a cabo una nueva incursión violenta contra La Aguilera ${ }^{2307}$.

que no se señala de manera explícita, todo aparece apuntar a que con anterioridad al conflicto los vecinos de La Aguilera disponían del agua del río según sus necesidades.

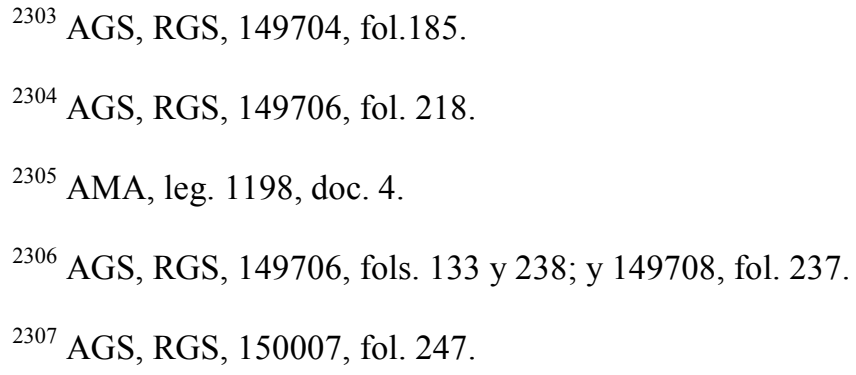


Paralelamente, en el plano judicial se dictó una primera sentencia que certificaba el derecho de La Aguilera a sacar agua del Gromejón para regar sus heredades. La villa de Gumiel evidentemente apeló dicha sentencia. En octubre de 1500 la Audiencia propuso a ambas partes llegar a un acuerdo a través de un compromiso arbitrario. El concejo de Gumiel se opuso en un primer momento, aunque finalmente se comprometió a aceptar lo estipulado en el arbitraje. El compromiso era bastante favorable para La Aguilera pues proponía un reparto equitativo de las aguas del Gromejón estableciendo turnos alternativos diarios para los periodos en los que los vecinos de La Aguilera tuvieran necesidad de regar: un día con su noche para La Aguilera y al día siguiente lo mismo para Gumiel. Los alcaldes de ambos concejos eran los encargados de fijar los periodos en los que había necesidad de regar. Este arbitraje reconocía asimismo el derecho inmemorial a utilizar las regaderas viejas que tenían los vecinos de La Aguilera ${ }^{2308}$.

A partir de esta sentencia no tenemos más noticias sobre enfrentamientos entre los vecinos de estas localidades a propósito de las aguas del Gromejón, aunque sí que es cierto que surgieron otros propios de la convivencia entre vecinos que no tuvieron tanta repercusión, debido sobre todo a la escasa implicación de sus señores. Parece evidente por lo tanto que este incidente por el control de las aguas de un río encubría una situación de confrontación entre dos potencias nobiliarias de la comarca que ya habían estado enfrentadas en el pasado y que intentaron marcar férreamente su territorio con el recurso a la fuerza que en ocasiones evolucionó en violencia explícita.

\subsubsection{Quintanilla de Nuño Pedro y Alcubilla de Avellaneda.}

Además de los enfrentamientos entre los miembros de la nobleza más relevante, la Ribera también fue el escenario de conflictos que tuvieron por protagonistas a la nobleza de segunda fila asentada en la comarca o a miembros de las grandes familias con una presencia bastante residual en la zona. En el episodio que nos ocupa ahora aparece un nuevo protagonista, don Pedro de Zúñiga, señor de Galve y Baides. La proximidad de algunas de sus posesiones, más la coincidencia del nombre con el II conde de Miranda, y la circunstancia de que su sucesor también se llamó Francisco de Zúñiga complican su identificación en la Ribera provocando frecuentes confusiones. Este Zúñiga tam-

${ }^{2308}$ ARChV, RRE, Caja 161, doc. 9. En el Archivo Municipal de Aranda se encuentra una copia de la ejecutoria (leg. 1198, doc. 4) que ha sido parcialmente transcrita por HURTADO QUERO y PERIBÁÑEZ OTERO, Los Reyes Católicos..., pp. 116-119). 
bién tenía su origen en la rama mayor del linaje de los señores de Béjar ya que era hijo de don Diego López de Zúñiga, primer señor de Monterrey. Su patrimonio se encontraba bastante disperso por Castilla: entre los lugares que le pertenecían se encontraba Baides, en tierras de Guadalajara, o Hacinas, en la Demanda burgalesa. La presencia en la Ribera fue bastante marginal pues se limitaba a Moradillo y Aldehorno más Quintanilla de Nuño Pedro ${ }^{2309}$.

Ya desde la década de los setenta el señor de Baides disputó a un conocido miembro de la nobleza comarcal de segunda fila, don Juan González de Avellaneda señor de Valverde, el control territorial de un pequeño enclave del Noroeste de la comarca. La discusión se centró en los lugares de Quintanilla de Nuño Pedro, propiedad de don Pedro y pretendido por don Juan, y de Alcoba, vinculados al señorío de Valverde y pretendidas por don Pedro ${ }^{2310}$.

Esta disputa tuvo un primer capítulo del que tan solo conocemos un frustrado intento de acuerdo a través de una comisión de jueces árbitros. Después de este fallido arbitraje, ambas partes recurrieron a la violencia de forma generalizada ${ }^{2311}$. En 1475 don Juan de Avellaneda acudió a Quintanilla con gente armada de pie e de cavallo; e por fuerça de las dichas armas ... entraran en el dicho lugar e tomaran e ocuparan la fortalesa del dicho lugar e se apoderaran en ella e mataran e fisyeran al alcayde Pedro de Quintanarraya $^{2312}$. Algunos años después los papeles se intercambiaron y en 1479 fue don Pedro quien asaltó y usurpó el lugar de Alcoba del Camino a don Juan, derribando su fortaleza ${ }^{2313}$. Por esas mismas fechas don Pedro de Zúñiga e los vesinos del dicho

${ }^{2309}$ CALDERÓN ORTEGA, J. M., "En torno al origen y las causas de los primeros pleitos del Estado de Monterrey en Galicia”, en Hispania. 168, 1988, pp. 49-78; y OLIVERA SERRANO, C., "Los señores y el estado de Monterrey”, en Cuaderno de Historia de España. LXXX, 2006, pp. 147-170. Quintanilla de Nuño Pedro fue adquirida en marzo de 1406 por don Diego López de Zúñiga a doña Juana, hija de Alfonso de Montemayor (SNAHN, OSUNA, Caja 320, docs. 1-3). No hemos logrado identificar fehacientemente estos lugares de Moradillo y Aldehorno con sus homónimos ribereños.

2310 En la documentación se hace referencia a Alcoba la Yerma y Alcoba del Camino. MARTÍNEZ DÍEZ identifica estas dos denominaciones con un despoblado que se encuentra en las proximidades de Alcubilla de Avellaneda (Pueblos y alfoces..., p. 223). No obstante, la información que transmite la documentación nos hace pensar que Alcoba del Camino quizá deba identificarse con Alcoba de la Torre.

${ }^{2311}$ En 1479 don Juan de Avellaneda se quejaba de que una comisión arbitral le había otorgado la posesión de Quintanilla de Nuño Pedro pero que el señor de Moradillo la había usurpado (AGS, RGS, 147911, fol. 60).

\footnotetext{
${ }^{2312}$ AGS, RGS, 147511, fol.743.

${ }^{2313}$ AGS, RGS, 147911, fol. 60 .
} 
lugar de Quintanilla e otros por su mandado... quemaran e fisieran quemar e derribar honse pares de casas de Alcubilla de Pinilla ${ }^{2314}$. El mismo método fue aplicado por don Juan de Avellaneda que ordenó poco tiempo después quemar las casas de algunos vecinos de Quintanilla ${ }^{2315}$.

Los enfrentamientos y pleitos continuaron durante los años ochenta a propósito del dominio sobre el lugar de Alcoba la Yerma, despoblado que se encontraba entre Alcubilla y Quintanilla ${ }^{2316}$. En noviembre de 1484 varios vecinos de Alcubilla que estaban labrando en Alcoba la Yerma fueron atacados y apresados por los hombres de don Pedro de Zúñiga que irrumpieron armados desde la fortaleza de Quintanilla ${ }^{2317}$. Los monarcas enviaron como pesquisidor al bachiller Alonso Téllez que presentó su pesquisa ante el Consejo Real. No conocemos el contenido de dicha pesquisa pero el reparto de su coste, 7.500 maravedíes, entre denunciantes -2.500 - y denunciados -5.000 - da una idea de las conclusiones a las que llegó ${ }^{2318}$.

Desgraciadamente no contamos por el momento con más datos sobre este enfrentamiento que nos permitan llegar a conclusiones significativas. Lo cierto es que a partir de finales de los años ochenta parece que los sucesivos señores de Monterrey centraron su atención en sus amplios dominios occidentales, quedando relegados sus intereses sobre el territorio ribereño a la mínima expresión. No ocurrió lo mismo con el señor de Valverde que, como ya hemos visto, siguió desarrollando su actividad por tierras ribereñas e incluso se hizo con un importante lugar en el seno de la oligarquía arandina.

\subsection{Usurpación de bienes de la Iglesia.}

A finales de la Edad Media las instituciones monásticas fueron los agentes pasivos de las ansias de expansión de señores y concejos. En este apartado abordaremos las

${ }^{2314}$ AGS, RGS, 148605, fol. 103. En la documentación aparece identificada Alcubilla de Avellaneda como Alcubilla de la Pinilla.

${ }^{2315}$ AGS, RGS, 148605, fol. 166.

${ }^{2316}$ Alcoba la Yerma es un despoblado localizado en el término municipal de Alcubilla de Avellaneda (MADOZ, Diccionario geográfico..., Tomo 7 -Soria-, p. 40; y MARTÍNEZ DÍEZ, Pueblos y alfoces..., p. 223).

${ }^{2317}$ AGS, RGS, 148411, fol. 50; y 148501, fol. 88.

${ }^{2318}$ AGS, RGS, 148503, fol. 90. 
diferentes estrategias que utilizó fundamentalmente la nobleza comarcal para ampliar sus dominios, sus ámbitos de influencia y sus fuentes de riqueza.

\subsubsection{Las pretensiones de la nobleza comarcana sobre el monasterio de San Pedro de Gumiel de Izán.}

Como ya hemos visto anteriormente, el monasterio de San Pedro de Gumiel de Izán fue una de las instituciones religiosas más importantes de la comarca ribereña. El cenobio había configurado un importante patrimonio a lo largo de la Edad Media pero a finales del siglo XV se encontraba en un momento de franca recesión.

A la secular injerencia de la nobleza sobre los bienes del monasterio se sumó a comienzos de 1486 su intromisión también en las cuestiones de organización interna del cenobio, posiblemente al amparo de la disputa entre el Capítulo General del Císter y la Congregación de la Observancia, a la que ya hemos hecho referencia. Tan solo recordemos que en el proceso de renovación del cenobio gomellense a mediados de la década de los ochenta se produjo la intervención armada de un grupo de laicos vinculados a don Martín Vázquez de Acuña ${ }^{2319}$ que ayudó al anterior abad, fray Andrés a despojar de su cargo a fran Juan de $\mathrm{Ocio}^{2320}$. Finalmente la intervención de la justicia real restituyó al abad despojado en julio de $1486^{2321}$. Insistimos en concluir que este incidente está más relacionado con la injerencia de la familia Acuña sobre este cenobio que no en las disputas internas relacionadas con la reforma cisterciense. En este sentido es necesario recordar que don Martín fue el tenente de la villa durante los años conflictivos de la guerra con Portugal y que a buen seguro pudo establecer cierta relación con fray Andrés, abad del cenobio ya en aquella época ${ }^{2322}$.

Sin embargo, el asunto más sangrante para esta comunidad de monjes fue la situación de su lugar de Milagros. Se trataba de una antigua donación que siempre estuvo

${ }^{2319}$ La acción estuvo encabezada por los hermanos Lisas, criados de don Martín y vecinos de Aranda (AGS, RGS, 148603, fol. 56). Uno de ellos, Juan, fue posteriormente el procurador del abad fray Andrés (AGS, CC PUEBLOS, leg. 17, docs. 169 y 171). $677-678$.

${ }^{2320}$ AGS, CC PUEBLOS, leg. 17, docs. 169 y 173; y PÉREZ EMBID, El Císter..., pp. 646-647 y

${ }^{2321}$ El monasterio debió estar varios meses en posesión de los asaltantes pues, a pesar de los requerimientos al alcalde Juan Alfonso de Toro en marzo y Juan Valera en abril, el monasterio no fue desencastillado hasta que lo hizo en mayo don Pedro de Sandoval (AGS, CC PUEBLOS, leg. 17, docs. 170 y 172; RGS, 148604, fol. 41; y 148605, fol. 68).

${ }^{2322}$ SNAHN, OSUNA, Caja 79, docs. 44 y 45. 
en el punto de mira de los intereses de la nobleza comarcana. Ya Ramir Flórez de Guzmán en 1380 tomó la granja a pesar de las quejas del monasterio ante los merinos reales $^{2323}$. La situación de inestabilidad se reprodujo durante todo el siglo XV y alcanzó su culmen cuando los condes de Miranda iniciaron un pleito por la jurisdicción del lu$\operatorname{gar}^{2324}$. El monasterio buscó una solución definitiva con la venta del lugar a la villa de Aranda, que por entonces se encontraba ansiosa por aumentar su término. Ambas partes llegaron a un acuerdo el 3 de julio de 1495 en el que se establecieron unas cláusulas bastante reveladoras de la situación que vivía cada uno de los firmantes ${ }^{2325}$ :

- El abad y monjes del monasterio de San Pedro de Gumiel cedían a la villa de Aranda el lugar de Milagros en censo perpetuo. El monasterio obtenía un censo anual 156 fanegas de pan, mitad trigo y mitad cebada, y dos pares de gallinas que pagaban como renta los vecinos del lugar. La villa se comprometía a pagar esta renta en el caso de que no lo hicieran los vecinos de Milagros.

- La villa de Aranda se obligaba a pagar al monasterio la cantidad de 35.000 maravedíes en dineros contados. Se establecían dos plazos: el primero el día de Santiago y el segundo el día de Pascua de Navidad del año 1496.

- El monasterio se quedaba con todos los frutos, diezmos, primicias, usos y costumbres del lugar de Milagros y su iglesia.

- La villa de Aranda se comprometía a no cargar más censo sobre el lugar y vecinos, salvo si obtenían el consentimiento de los vecinos del lugar. Se establecía la excepción en el caso de que los moradores de Milagros pasaran a ser solariegos y vasallos de la villa de Aranda, en la medida en que participarían de los pechos, derramas y martiniegas como el resto de los vecinos de Aranda y su tierra ${ }^{2326}$.

- La villa se comprometía a no enajenar, trocar o vender el lugar de Milagros sin el expreso consentimiento del abad de San Pedro.

${ }^{2323}$ MORAL GARCÍA, Milagros..., p. 71.

${ }^{2324}$ Este pleito se encuentra recogido en un amplio expediente del Consejo Real (AGS, CR, leg. 22, doc. 1).

${ }^{2325}$ AGS, CC PUEBLOS, leg. 13, doc. 3. Tierra.

${ }^{2326}$ Aspecto que evidencia claramente la intención del concejo arandino de sumar el lugar a su 
- Asimismo la villa de Aranda asumía el coste del pleito que trataba el monasterio con el Conde de Miranda por la jurisdicción del lugar de Milagros.

- Finalmente, el monasterio se comprometía a realizar todas las gestiones necesarias ante sus superiores y ante el Papa para conseguir los tratados y bulas pertinentes que ratificaran este acuerdo. Se estableció asimismo que si el cenobio no consiguiera las licencias se anularía el censo y el monasterio devolvería a la villa todo el dinero que se hubiera gastado en la compra, proceso y mejoras.

Tras la firma del documento y su registro las autoridades de Aranda tomaron posesión solemne del lugar el 24 de septiembre de ese mismo año ${ }^{2327}$. Sin embargo, el acuerdo no evolucionó como esperaban ambas partes pues el pago de la venta no siguió sus cauces, tampoco se consiguió la aprobación papal y para más complicación los condes de Miranda presentaron una reclamación ante el Consejo Real estimando que la jurisdicción del lugar les pertenecía. Así comenzó un largo proceso que duró más de cuarenta años y que mermó considerablemente las arcas y las expectativas de expansión de la villa arandina ${ }^{2328}$.

La dilatada duración de pleito fue directamente proporcional al aumento de la tensión entre las partes que en ocasiones desembocó en episodios violentos que protagonizaron las gentes de Aranda y los vasallos del conde ${ }^{2329}$.

La comunidad gomellense también sufrió en sus carnes un asalto violento del cenobio. Lo cierto es que apenas tenemos noticias de este episodio y tan solo lo conocemos de forma indirecta a través de una de las cláusulas del testamento de don Íñigo López de Mendoza: Ytem mando que si quando esto se executase no se hubiere fecho alguna satisfaccion a los herederos de un labrador que murió cuando el alcayde de Aça tomo la posesión de San Pedro; se les de treynta ducados ${ }^{2330}$. El asalto no estaba vincu-

${ }^{2327}$ AGS, CC PUEBLOS, leg. 13, doc. 3.

${ }^{2328}$ En 1510 el concejo estimaba que había gastado 300.000 maravedíes en el pleito (AGS, CC PUEBLOS, leg. 13, doc. 7).

${ }^{2329}$ En el proceso judicial se incluyen varios episodios de encontronazos entre vecinos, requisamientos de cargas de vino y leña o ganados y altercados de diversa consideración. Estos altercados afectaron sobre todo a los vecinos de los lugares cercanos a la zona de conflicto: Milagros, Fuentespina y Valdeherreros. Todos estos incidentes fueron de escasa entidad pero bastante frecuentes (AGS, CR, leg. 22, doc. 1).

${ }^{2330}$ GARCÍA RÁMILA, El INEM Cardenal..., p. 72. 
lado directamente con la disputa por la posesión de lugar de Milagros, sino más bien a las pretensiones del segundón de los Zúñigas que pretendía asumir el abadengo de Gumiel. Tras el incidente violento ambas partes iniciaron un proceso de negociación que culminó en 1508 con un acuerdo entre el Conde de Miranda y el nuevo abad del monasterio de San Pedro, fray Roberto. Por una parte, el primer día de septiembre el abad vendió la jurisdicción y derechos del lugar de Milagros al conde de Miranda. El acuerdo recoge cinco capítulos en los que se expresan las condiciones económicas y la renuncia total del monasterio a sus derechos sobre el lugar ${ }^{2331}$. Unos días después, el 2 de octubre, se firmó una iguala entre el monasterio de San Pedro de Gumiel y el conde de Miranda, que actuaba en nombre de su hermano don Íñigo López de Mendoza. El contenido de la misma se resume en cuatro puntos:

1. Fray Roberto, que era religioso y natural de la abadía de San Pedro y estaba informado de su funcionamiento, mantenía pacíficamente la posesión de dicha abadía.

2. Don Íñigo de Mendoza cedía a favor de fray Roberto todos los derechos que le pertenecieren sobre la abadía.

3. Para evitar conflictos se estipulaba la creación de una pensión de 25.000 maravedíes sobre la tercera parte de los frutos que pertenecían al monasterio de San Pedro para don Íñigo de Mendoza. Como el monasterio no disponía de liquidez en esos momentos se establecía que esa cantidad se pagaría en fanegas de trigo y cebada situadas sobre el diezmo de distintos lugares que estaban bajo la jurisdicción del Conde de Miranda (Peñaranda, Milagros, Linares, etc.).

4. Además se establecían otras compensaciones para don Íñigo por los gastos que le había supuesto este proceso y se fijaban los plazos para el pago de la pensión. Finalmente se estipula que si don Íñigo fuera promovido a un obispado perdería esta pensión.

Para más seguridad, el Conde se comprometía en junio de 1509 a dar protección jurídica al abad, pues la justicia real había prohibido cualquier venta de Milagros mientras se desarrollara el pleito con la villa de Aranda $^{2332}$. Este acuerdo no hizo más que

2331 AGS, CC PUEBLOS, leg. 13, doc. 6. El documento ha sido transcrito íntegramente por MORAL GARCÍA, Milagros..., pp. 421-423.

${ }^{2332}$ AGS, CC PUEBLOS, leg. 13, fol. 6. 
sancionar una realidad pues las evidencias apuntan a que el lugar se encontraba en ese momento bajo el control efectivo del conde de Miranda.

Suponemos que en el seno de la comunidad cisterciense hubo cierta disensión en torno a este asiento pues el acuerdo fue ratificado por diez de sus monjes reunidos en el capítulo celebrado más de dos años después, el dos de octubre de $1510^{2333}$.

Aunque el proceso judicial se prolongó en el tiempo ${ }^{2334}$, la firma de este acuerdo, la política de hechos consumados y la situación interna del concejo arandino restaron tensión a este conflicto. No obstante, esta disputa todavía se mantuvo en el imaginario colectivo de la comunidad arandina durante mucho tiempo: todavía en 1567 un testimonio de las actas del concejo de Aranda recogía el reconocimiento por parte del monasterio de San Pedro de Gumiel de la propiedad del lugar de Milagros a favor de la villa de Aranda, aunque la aldea se mantenía bajo el dominio conda2 ${ }^{2335}$.

\subsubsection{La proyección del linaje Zúñiga sobre Santa María de la Vid.}

La fase expansiva que el cenobio vitense había experimentado a lo largo de los siglos medievales se vio truncada en el siglo XV. Siguiendo la tónica ya observada en San Pedro de Gumiel, también la comunidad premostratense de La Vid se vio inmersa en múltiples enfrentamientos durante el periodo que nos ocupa. Aunque fueron varios los nobles que intentaron aprovecharse del rico patrimonio del monasterio, en este caso destaca sobre todo la iniciativa emprendida por la familia Zúñiga que consiguió convertir a esta institución en uno de los emblemas del linaje.

El primero de los conflictos con los nobles comarcanos del que tenemos noticia tuvo lugar en sus posesiones en el Cerrato. Se trata del monasterio filial de San Pelayo del Cerrato que se encontraba en las proximidades de Cevico Navero, al Sur de la actual

2333 AGS, CC PUEBLOS, leg. 13, doc. 6. Estos acuerdos económicos no fueron ajenos a la familia cisterciense pues en muchas ocasiones las renuncias de derechos sobre ciertas abadías se compensaban con la creación de pensiones para los renunciantes. Fue el caso de Matallana donde el Papa impuso un abad comendatario y concedió unas pensiones a ciertos individuos para que cesaran en sus pretensiones sobre la abadía. En el monasterio de Sandoval los visitadores reformistas siguieron la misma dinámica concediendo una pensión al antiguo abad para que renunciara a la perpetuidad (PÉREZ EMBID, El Císter..., pp. 590 y 677).

${ }^{2334}$ Todavía en 1529 la Chancillería instaba a que se continuara el pleito porque ...se ha extraviado el rollo (ARChV, CÉDULAS Y PRIVILEGIOS, Caja 1, doc. 1).

${ }^{2335}$ Acta de 13 de febrero de 1567. La información la ofrece VELASCO PÉREZ, Aranda. Memorias..., pp. 257-258. 
provincia de Palencia ${ }^{2336}$. A pesar de que en principio fue una fundación benedictina, desde la segunda mitad del siglo XII pasó a depender de Santa María de la Vid. El periodo más convulso de su historia medieval se desarrolló entre 1400 y 1486 cuando los sucesivos abades, muchos de ellos relacionados estrechamente con la Ribera como Fernando de Aranda y su sobrino Sancho, se dedicaron a enajenar los bienes de este priorato. Precisamente al final de este periodo, en 1485, Juan Delgadillo, señor de Castrillo, usurpó los derechos que el abad de La Vid tenía sobre este monasterio de San Pelayo de Cerrato $^{2337}$. A partir de 1486 otro ribereño, el abad Francisco de Peñaranda, comenzó la abrumadora tarea de recuperar los bienes enajenados por la nobleza, tarea que no concluyó hasta 1578.

El cenobio vitense también tuvo problemas con la jurisdicción de su lugar de Fuentelcésped que le fue disputada por el Conde de Miranda. Esta situación dio paso al inicio de un proceso en 1494 que continuó largos años. No obstante, este lugar estuvo durante todo el periodo que nos ocupa bajo el dominio efectivo de los sucesivos condes de Miranda, y así se plasmó incluso en la Averiguación que a mediados de los años veinte del siglo XVI encargó el monarca, en la que Fuentelcésped se incluye sin ningún tipo de complejo dentro de los dominios de la familia Zúñiga junto a sus posesiones de Peñaranda, Haza, Montejo o Íscar ${ }^{2338}$. En el ámbito jurídico este lugar no dejó de ser jurisdicción del monasterio hasta 1551 cuando, junto a Fresnillo, se escindió para pasar al dominio de la Corona ${ }^{2339}$. En 1564 Fuentelcésped fue comprado por la villa de Aranda e integrado en su Tierra ${ }^{2340}$.

Pero el principal problema que vivió el Monasterio de Santa María de la Vid fue su cerco y asalto por parte de tropas del Conde de Miranda en mayo de 1515. Ya en el otoño de 1514 la comunidad de frailes había tenido serios problemas tras la muerte del abad Sancho de Aranda. Como era su costumbre, el capítulo se reunió junto al abad de Retuerta y eligieron como nuevo abad a fray Francisco de Moradillo. Pero don Íñigo

${ }^{2336}$ LÓPEZ DE GUEREÑO SANZ, Monasterios medievales premostratenses..., Vol. II, pp. 454476.

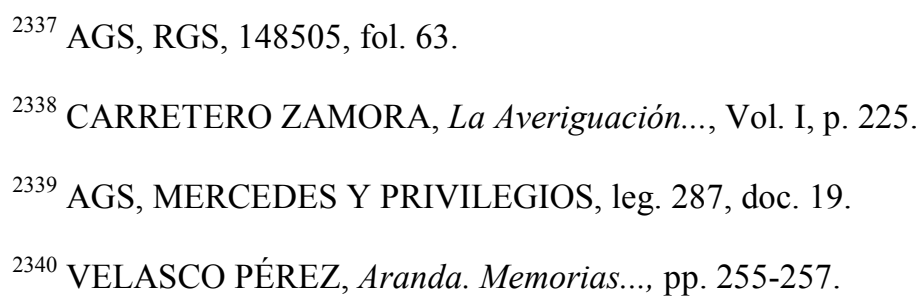


López de Mendoza, hermano del Conde de Miranda, que había conseguido previamente una bula papal para ser nombrado abad comendatario, intentó despojar al nuevo abad de su cargo. Para este fin solicitó la ayuda de su hermano que reunió gentes en La Vid. El corregidor de Aranda fue comisionado para acudir al monasterio, disolver a los reunidos y canalizar las exigencias de estos personajes. Por su parte, el rey Fernando ordenó a sus embajadores ante la corte papal que comunicaran al Papa que no se entrometiera en los asuntos propios de Castilla, haciendo especial mención a este episodio ${ }^{2341}$.

El primer día de mayo de 1515 murió el abad Francisco de Moradillo, posiblemente por yervas o ponçoña. Siguiendo el procedimiento habitual fue elegido como nuevo abad fray García de la Vid. Por estas mismas fechas el prior se quejaba ante la reina de que se había hecho presentación de don Íñigo López de Mendoza por parte de la Corona para ocupar el cargo, cuestión que entendía que no era correcta pues no se trataba de un patronato real, con el agravante de que don Íñigo no era de la orden premostratense ${ }^{2342}$.

Pocos días después, el 14 de mayo, el alguacil Blasco de Vallejo dirigía las tropas del conde de Miranda que cercaron el monasterio. Solicitó al nuevo abad que hiciera entrega del lugar. Fray García de la Vid aceptó la situación pero apeló y pidió un tiempo de espera al alguacil. Vallejo rechazó la demora e inmediatamente después, junto a los alcaides y capitanes, entró por la fuerza en el monasterio rompiendo con azadones la cerca, puerta del corral y la puerta de la iglesia ...y entraron dentro del con gran tropel de gente armados de espingardas e vallestas e alabardas e lanzas e espadas e otras muchas armas e azuelas e petos e coraças e capacetes. El abad y los frailes que con él estaban abandonaron el cenobio y se refugiaron en el monasterio de Retuerta, donde fueron apresados y trasladados a Aranda. Desde allí el abad García solicitó el perdón de la reina ${ }^{2343}$. Finalmente, como no podía ser de otra forma, don Íñigo López de Mendoza tomó posesión del monasterio de Santa María de la Vid como abad comendatario perpe-

${ }^{2341}$ AGS, CC PUEBLOS, leg. 22, doc. 95.

${ }^{2342}$ AGS, CC PUEBLOS, leg. 17, doc. 467. Sin embargo, en una carta sin fechar del abad García de La Vid se solicitaba a la reina su protección argumentando precisamente que el monasterio estaba bajo el patronato de la Corona y, por lo tanto, no debía permitir que se presentara un candidato extranjero, que en este caso era Luiso Rojas Florentín (leg. 17, s. f.).

2343 AGS, CC PUEBLOS, leg. 17, docs. 463-468; y CR, leg. 587, doc. 1. 
tuo. De fray García de la Vid tenemos noticias varios años después cuando ejercía como prior de Fresnillo en $1527^{2344}$.

A partir de ese momento el cenobio premostratense se convirtió en uno de los emblemas del poder de la familia Zúñiga pues tanto el conde como el cardenal dispusieron ser enterrados en su capilla mayor. Con este propósito ambos hermanos invirtieron una considerable fortuna para acondicionar la iglesia con la intención de convertirla en el espejo que reflejara la pujanza social, política y económica de este linaje. Gracias a esta iniciativa el conjunto monástico de Santa María de La Vid se convirtió en uno de los más bellos ejemplos de arquitectura renacentista en tierras castellanas ${ }^{2345}$.

En conclusión, gracias a estas maniobras el linaje de los Zúñiga-Avellaneda aumentó su patrimonio territorial y material a costa de los dos monasterios más representativos de la comarca, a la vez que extendieron sus lazos clientelares sobre los principales responsables de las mismas.

\subsubsection{Otras agresiones de la nobleza comarcana sobre instituciones religio-} sas.

La casa de Miranda no fue la única que estableció estrechos lazos con instituciones monásticas. Otras familias nobiliarias ribereñas también siguieron su ejemplo, aunque las comunidades religiosas sobre las que ejercieron su influencia se encontraban en la periferia de nuestro ámbito de estudio ${ }^{2346}$.

Uno de estos episodios tuvo como protagonistas al monasterio de Santa María la Real de Tórtoles de Esgueva y a los señores de Castrillo. Las primeras noticias sobre su enfrentamiento se centra en pequeños conflictos de vecindad en la década de los setenta entre las comunidades de Castillo y Tórtoles, villa bajo la jurisdicción del monasterio benedictino. Aunque no tenemos constancia de los motivos, sí que parece que el enfrentamiento se revistió de cierto grado de violencia a tenor de las mutuas acusaciones de ...fuerças e robos e males e danos ...que aviades entrado poderosamente con gente de

\footnotetext{
${ }^{2344}$ AGS, CR, leg. 427, fol. 9.

${ }^{2345}$ ZAPARAÍN YÁÑEZ, M. J., El monasterio de Santa María de la Vid: arte y cultura, del medievo a las transformaciones arquitectónicas de los siglos XVII y XVIII. Madrid, 1994; y PORRAS GIL, M. C., "Estética y humanismo en la Familia Zúñiga-Avellaneda", en Biblioteca 18. Estudio e Investigación. 2003, pp. 117-141.

${ }^{2346}$ Recordemos que en el capítulo anterior ya hemos hecho referencia a los monasterios periféricos que ahora abordamos.
} 
cavallo ... armados e con çiertos tyros de polbora feriendo e matando a los que fallarades e poniendo fuego a los panes de las heras e fasyendo escarnio ${ }^{2347}$. Algún tiempo después, en el año 1487, don Juan Álvarez Delgadillo usurpó ciertos heredamientos, prados y abrevaderos del cenobio tortolés con lo que comenzó una disputa judicial que motivó la intervención de la Hermandad ${ }^{2348}$. Tras un arbitraje se emitió una sentencia por la que se condenaba al señor de Castrillo a devolver lo tomado a la abadesa de Santa María, además de imponerle el pago de las costas procesales que ascendía a 35.307 maravedíes $^{2349}$.

Por su parte, los señores de Valverde proyectaron sus intereses sobre la comunidad femenina cisterciense de Fuencaliente. La documentación apunta a un conflicto de intereses entre el monasterio y los diferentes señores de Valverde a causa de compartir la jurisdicción de la villa de Fuentearmegil y su valle ${ }^{2350}$. Ya desde principios de 1489 la presión de don Juan de Avellaneda, señor de Valverde, se dejó notar de forma explícita sobre algunos de los lugares dependientes de esta comunidad cisterciense femenina. Avellaneda se presentó en ellos con un grupo de hombres armados para amedrentar a los vasallos del monasterio prohibiéndoles labrar la tierra sin su licencia y obligándoles a obedecer sólo sus órdenes. Evidentemente esta situación causaba graves perjuicios al monasterio pues los vasallos se negaban a cumplir sus obligaciones con el monasterio amparándose en el temor a las amenazas del señor de Valverde ${ }^{2351}$. Todo parece indicar que la tensión entre ambas partes se mantuvo durante todo el periodo que nos ocupa ${ }^{2352}$. Finalmente en 1518 don Bernardino, heredero de don Juan, llegó a un acuerdo con la abadesa de Fuencaliente para realizar un trueque: el señor de Valverde cedía al monasterio los derechos que le pertenecían sobre Fuentearmegil y a cambio recibía el lugar de Ravanera más unos heredamientos en Arandilla e Hinojar ${ }^{2353}$.

\footnotetext{
${ }^{2347}$ AGS, RGS, 148010, fol. 216; y 148011, fol. 150.

${ }^{2349}$ AGS, RGS, 148802, fol. 148. (ESTEPA DÍEZ, Las Behetrías... Vol. I, pp. 81 y 194-195).

${ }^{2351}$ AGS, RGS, 148902, fol. 298.

${ }^{2352}$ AGS, RGS, 149303, fol. 262.

${ }^{2353}$ SALAZAR Y CASTRO, Historia genealógica..., vol. III, p. 405.
}

${ }^{2348}$ AGS, RGS, 148702, fol. 19; 148709, fol. 212; 148710, fol. 181; y 148712, fol. 169.

${ }^{2350}$ AGS, RGS, 150007, fol. 321. Estas jurisdicciones compartidas tuvieron su origen en el pasado como behetría de estos lugares que evolucionaron en abadengos y solariegos, en este caso compartido 
Parecido al anterior fue el conflicto que mantuvieron la casa condal de Coruña con el monasterio de San Jerónimo de San Marcelino. En este caso los contendientes se disputaban los derechos sobre la villa de Espeja y el lugar de Espejón. En este caso el enfrentamiento también se asentaba en el ejercicio de una jurisdicción compartida con origen en la condición previa de behetría de estos lugares ${ }^{2354}$. Los roces ya se manifestaban en 1488 cuando varios criados de monasterio fueron apresados por las autoridades de Coruña y encarcelados durante algún tiempo ${ }^{2355}$. Al igual que hemos visto con el caso de Fuencaliente y el señor de Valverde, la presión que ejerció el conde de Coruña sobre los vasallos de Espeja y Espejón repercutió directamente sobre el monasterio jerónimo pues sus vasallos querían eximirse de cumplir con sus obligaciones respecto al monasterio $^{2356}$. A lo largo de la primera mitad de los noventa el monasterio vio reconocidos sus derechos fiscales al conseguir el amparo real para percibir de los vecinos de esas localidades el pago de ciertos servicios e igualas antiguas ${ }^{2357}$. Pero el enfrentamiento derivó en un pleito sobre la jurisdicción ante la Chancillería Real que culminó en 1496 con varias sentencias favorables para el conde de Coruña que avalaban sus derechos sobre estos lugares ${ }^{2358}$.

En definitiva, estos ejemplos que hemos analizado muestran claramente cómo las instituciones monásticas de la comarca se convirtieron a finales de la Edad Media en atractivos objetivos para la nobleza ribereña que veía en ellos sobre todo un rentable medio para incrementar su patrimonio. Con este fin la mayor parte de las iniciativas nobiliarias se centraron en la usurpación de las rentas monásticas o directamente la enajenación de parte de su patrimonio territorial. Sin lugar a dudas, la casa de Zúñiga fue la que mayor rentabilidad obtuvo de la aplicación de esta estrategia consiguiendo un importante paso cualitativo al alcanzar el objetivo de controlar una buena parte de estas instituciones y sus recursos. El balance final muestra cómo este linaje logró sus objeti-

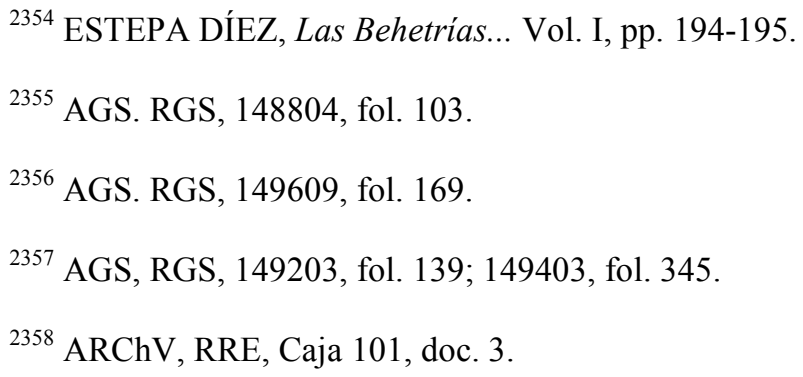


vos parcialmente en San Pedro de Gumiel y de manera completa en el monasterio premostratense de Santa María de La Vid.

\subsection{Apropiación de behetrías.}

Un paso más de la dinámica expansiva de los diferentes actores que pujaron por el control del territorio ribereño tuvo como objetivo a las escasas behetrías de la comarca. Algunas antiguas behetrías como Guzmán, Gumiel de Izán o Caleruega ya sufrieron con anterioridad al periodo estudiado su transformación en solariegos o abadengos. En este apartado nos centraremos en aquellas que mantuvieron su condición de behetría pero padecieron el acoso tanto señorial como concejil. Esta dinámica tenía como objetivo final la anexión a sus respectivos patrimonios territoriales.

\subsubsection{Hontoria de Valdearados.}

En el célebre Becerro de las Behetrías el lugar de Hontoria de Valdearados aparece como behetría. Poco sabemos de ella hasta que hacia 1450 don Diego de Zúñiga, señor de la cercana villa de Peñaranda, tomó por la fuerza este lugar y se hizo con todas sus rentas. Con la llegada al poder de los Reyes Católicos, la Hacienda regia solicitó a las autoridades del lugar el pago de los tributos reales que no se abonaban desde 1460 . El concejo se quejó ante los monarcas argumentando que los tributos habían sido tomados por don Diego primero, y su hijo, don Pedro, después ${ }^{2359}$. La Corona solicitó al segundo conde de Miranda el reembolso de las cantidades enajenadas, situación que desencadenó el comienzo de un pleito por la jurisdicción del lugar entre el conde y el concejo de Hontoria. Este pleito comenzó a principios de los noventa y tuvo una primera sentencia en 1502 que daba la razón a Hontoria tanto sobre su condición de behetría de mar a mar, como sobre el uso de los comunales. Sin embargo, el conde hizo suplicación de las 1.500 doblas, lo que permitió dilatar el proceso en el tiempo, pues aún continuaba en la Chancillería en $1510^{2360}$.

El conflicto afectó a las relaciones entre los habitantes de la behetría y los vasallos del conde de Miranda que habitaban en la cercana villa de Peñaranda. Así, paralelamen-

\footnotetext{
${ }^{2359}$ AGS, RGS, 148010, fol. 127.

${ }^{2360}$ AGS, CR, leg. 6, doc. 5; y ARChV, RRE, Caja 245, doc. 30.
} 
te al desarrollo del litigio judicial, se multiplicaron los episodios de violencia y robos que las autoridades y vecinos de Peñaranda realizaron sobre bienes y vecinos de Hontoria. Como ejemplo valga el acaecido un día del mes de junio de 1498 cuando el alcaide de Peñaranda con 300 hombres armados entró en el lugar de Hontoria. Los vecinos se refugiaron en la iglesia y durante bastante tiempo estuvieron allí cercados, siendo agredidos con ballestas y lanzas. Los asaltantes entraron en las casas, derribando puertas cerradas, y robaron sus pertenencias. Cuando encendieron fuego para quemarlo todo salieron los alcaldes de la Hermandad a requerirles que no lo hiciesen; los asaltantes se burlaron de ellos, los apresaron y se los llevaron a la fortaleza de Peñaranda ${ }^{2361}$.

Por esta misma época se acrecentó el interés de la villa de Aranda por incluir Hontoria dentro de su Tierra, interés que parecían compartir los vecinos del lugar. Esta pretensión se materializó en varias peticiones realizadas por el concejo arandino ante las instancias reales para que se concediera licencia que permitiera incluir el lugar dentro de la jurisdicción de la villa ${ }^{2362}$. No parece que se tomara ninguna medida al respecto pero sí se observa que a partir de 1499 el corregidor de Aranda intervino directamente en todos los asuntos relacionados con el orden público y la justicia que afectaban a la behetría $^{2363}$. No obstante, una sentencia dictada en 1502 establecía que Hontoria no fuera entregada a la villa de Aranda hasta que no se resolviera el conflicto de la behetría con el conde de Miranda, circunstancia que no se produjo en el periodo estudiado.

\subsubsection{Las otras behetrías.}

El resto de las behetrías ribereñas tampoco se escaparon del proceso señorializador que se impuso en Castilla a finales de la Edad Media como podemos apreciar a través de varios ejemplos.

Santa María del Mercadillo no aparece nombrada en el Becerro de las Behetrías pero la documentación bajomedieval atestigua esta condición por lo menos hasta los años ochenta del siglo XV. En el periodo que abordamos los vecinos del lugar, usando de su privilegio de behetría, eligieron sucesivamente como su señor a don Juan Álvarez

${ }^{2361}$ AGS, RGS, 149806, fol. 5.

${ }^{2362}$ Dar primeramente fin en lo del logar de Ontoria de Valdearados para que sea solariego desta villa como los veçinos del dicho logar lo tienen pedido e suplicado a sus altezas (AGS, CC PUEBLOS, leg. 2, doc. 94).

${ }^{2363}$ AGS, RGS, 149909, fol. 165; y 150002, fols. 365 y 387. 
Delgadillo, señor de Castrillo; a don Juan de Avellaneda; y después a su hija doña Constanza de Avellaneda junto a su marido don Martín Vázquez de Acuña. Finalmente, en 1485, don Juan Téllez-Girón, conde de Urueña, fue el elegido ${ }^{2364}$. Al menos en este último caso tal elección enmascaraba una compraventa de los derechos de behetría que hizo el conde de Coruña al matrimonio Avellaneda-Acuña. La adquisición de estos derechos fue el paso previo para la transformación definitiva del lugar en solariego, objetivo que lograron finalmente los condes de Urueña. Mercadillo se convirtió así en una pieza más dentro de la política de expansión emprendida por los Girón en la zona que incluía a la ya analizada villa de Gumiel de Izán, más Santibáñez de Esgueva, Bahabón y Ciruelos.

Más sutil fue la presión del conde de Coruña sobre ciertas behetrías cercanas a sus territorios en la comarca ribereña. Con la excusa de la gestión de la justicia civil que la villa de Coruña ejercía sobre los territorios aledaños ${ }^{2365}$, la presencia del conde se fue imponiendo en algunas behetrías como Quintanarraya, Arauzo de Salce, Arauzo de Torre, Pinilla Trasmonte, Cilleruelo y Baños de Valdearados ${ }^{2366}$.

En el caso de Quintanarraya la presión fue mayor pues en el momento de recibir don Lorenzo Suárez de Figueroa la villa de Coruña ya se incluían ciertos heredamientos más una torre en este lugar. A finales de los setenta el conde vendió estas propiedades a cambio de un censo anual de 110 fanegas de pan. Pero en 1496 el nuevo conde reclamó a los vecinos que al censo le añadieran un derecho anual de un maravedí por hogar. Con el fin de convencer a los vecinos de la idoneidad de esta nueva tasa, el conde envió a su alcaide con un grupo de hombres armados ${ }^{2367}$.

${ }^{2364}$ SNAHN, OSUNA, Caja 36, docs. 76-81. La elección del conde como señor lo justificaba el concejo aludiendo a su condición de behetría y a la necesidad de protección por la amenaza de otros pueblos y señores comarcanos que se aprovechaban de sus términos y montes.

${ }^{2365}$ Este derecho se fundamentaba en la antigua demarcación territorial y judicial del Alfoz de Clunia (MARTÍNEZ DÍEZ, Pueblos y alfoces..., pp. 212 y ss.).

${ }^{2366}$ ARChV, RRE, Caja 186, doc. 1. Se trata de un pleito resuelto en 1503 que mantuvo el conde de Coruña contra algunas de estas localidades y contra el Condestable de Castilla que desde su villa de Santo Domingo de Silos trató de imponer justicia en los lugares implicados. Finalmente la Audiencia Real confirmó los derechos del conde de Coruña.

${ }^{2367}$ AGS, RGS, 149612, fol. 232. El alcaide que se cita era el de la fortaleza de Quintana, lugar que no logramos identificar pues no existe en las cercanías un topónimo similar, salvo la propia Quintanarraya. Todo ello nos lleva a concluir que se trataba del alcaide de la vieja torre vendida por el conde a la villa en los años setenta. 
Esta presión de la nobleza comarcana sobre las behetrías también se manifestó en la participación de este grupo privilegiado sobre las rentas reales de las behetrías. Así el conde de Miranda y la familia Salazar poseían las tercias de Vadocondes y Pinilla Trasmonte $^{2368}$. En este mismo sentido, algunos nobles trataron de ampliar sus dominios adquiriendo propiedades en lugares de behetría como lo intentó el marqués de Denia en Pinilla Trasmonte en 1500. Si embargo, la aplicación de la normativa vigente obligó a Sandoval a vender sus propiedades en esta behetría ${ }^{2369}$.

No solo la nobleza trató de imponer sus intereses sobre las behetrías. En ocasiones fueron los agentes de la justicia los que cometieron irregularidades con los vecinos de estas localidades imponiéndoles multas impropias o cometiendo abusos como denunciaron en múltiples ocasiones $^{2370}$.

A pesar del acoso señorial, muchas de las behetrías mantuvieron su privilegio como muestran los repartimientos de galeotes de los años 1508 y 1531, aunque bien es cierto que no dejaron de estar sometidas a las presiones e intereses de sus poderosos vecinos $^{2371}$. Esta circunstancia revela la discordancia entre la teórica situación legal y la realidad de muchos de estos pequeños lugares que de facto estaban sometidas al control de los grandes señores comarcanos.

\subsection{Presión señorial sobre sus vasallos y respuestas antiseñoriales.}

La conflictividad antiseñorial ha sido un campo notablemente estudiado por la historiografía reciente, tanto en su vertiente rural como urbana ${ }^{2372}$. En este apartado ana-

${ }^{2368}$ AGS, RGS, 149908, fol. 40; y CR, leg. 3, doc. 3.

${ }^{2369}$ AGS, RGS, 150001, fol. 122.

${ }^{2370}$ A modo de ejemplo señalemos el caso del concejo de Arauzo de Miel que en 1489 se quejaba de los abusos cometidos por los alcaldes de Silos (AGS, RGS, 148909, fol. 191 y 384).

${ }^{2371}$ ESTEPA DÍEZ, Las Behetrías..., vol. II, pp. 360 y 368.

${ }^{2372}$ VALDEÓN BARUQUE, J. Los conflictos sociales en el reino de Castilla en los siglos XIV y $X V$. Madrid, 1975; del mismo autor "Resistencia antiseñorial en la Castilla medieval", en El chivo expiatorio. Judios, revueltas y vida cotidiana en la Edad Media. Valladolid, 2000, pp. 132-161; VAL VALDIVIESO, "Resistencia al dominio..., pp. 53-104; y OLIVA HERRER, H. R., Justicia contra señores. El mundo rural y la política en tiempos de los Reyes Católicos. Valladolid, 2004; y de este mismo autor "Conflictos antiseñoriales en el reino de Castilla a fines de la Edad Media: viejas preguntas, ¿nuevas respuestas?", en Historia, instituciones, documentos. 36, 2009, pp. 313-331. 
lizaremos los principales episodios ocurridos en el territorio ribereño al final de la Edad Media.

Por regla general, estos conflictos tuvieron como detonantes dos situaciones que se reprodujeron en Castilla con mucha frecuencia. Por una parte, las pretensiones de buena parte de la nobleza de aumentar sus estados señoriales a costa de la enajenación de villas o lugares ajenos al dominio señorial fueron el detonante de alguno de estos conflictos. En capítulos anteriores ya hemos abordado la frustrada iniciativa promovida por don Pedro de Zúñiga a comienzos de la década de los setenta para hacerse con el dominio de la villa de Aranda y las constantes maquinaciones de diferentes miembros de la familia Zúñiga y Sandoval durante todo el periodo que abarca nuestro estudio para ampliar su influencia sobre los órganos de gobierno arandinos. Dentro de este mismo epígrafe podríamos encuadrar también las presiones ejercidas por los distintos linajes nobiliarios sobre las behetrías como los enunciados en el apartado inmediatamente precedente.

El otro detonante de los enfrentamientos antiseñoriales tuvo como protagonista a la resistencia de los propios vasallos a aceptar el incremento de la presión, sobre todo fiscal, por parte de sus señores. Para el caso ribereño llama la atención que los conflictos de este tipo que hemos documentado se refieren fundamentalmente a la oposición de los vecinos de lugares de abadengo, lo que se puede interpretar como una evidencia más de la clara decadencia en la que se encontraban las instituciones monásticas de la comarca en este periodo.

El episodio de resistencia al dominio señorial más complejo que hemos documentado tiene que ver con las dificultades que tuvo el convento dominico de Santo Domingo para hacer efectiva su jurisdicción sobre sus propios vasallos en la villa de Caleruega. Recordemos que Caleruega fue behetría hasta la donación efectuada por Alfonso $\mathrm{X}$ después de haberse hecho con buena parte de las divisas de la misma. La adquisición de divisas continuó también con posterioridad. Quizá este pasado como behetría sea el origen del conflicto que se produjo en la década de los 40 del siglo $\mathrm{XIV}^{2373}$. A falta de información más precisa, este enfrentamiento entre señor y vasallos se centró en tres aspectos básicos. El primero de ellos concernía a la autonomía política del concejo frente a su señor. Los vasallos alegaban que poseían privilegio de Fernando III que les

2373 MARTÍNEZ LIÉBANA, Colección Diplomática..., doc. CCLXXXIV, pp. 370-375; y GONZÁLEZ GONZÁLEZ, Real Monasterio..., pp. 122-125. 
concedía la facultad de nombrar a los oficiales del concejo, custodiar las llaves de las puertas de la muralla y disponer del sello del concejo. El segundo aspecto en disputa era de carácter fiscal y se centra en el rechazo de los vasallos a aceptar el incremento de los impuestos, no tanto por el aumento cuantitativo, sino porque el monasterio compró muchas propiedades en la villa que pasaban a estar exentas del reparto de pechos y además eximió de contribuir a sus colonos. Ambas circunstancias derivaron en una mayor presión fiscal sobre el resto de vecinos. El tercer y último elemento controvertido fue la creciente actividad reguladora que ejercía la abadesa sobre las actividades económicas de los vecinos.

A tenor de una primera sentencia arbitral fechada en 1346 podemos afirmar que este conflicto no debe identificarse con la negación del señorío del convento sobre la villa, sino más bien la contestación por parte del vecindario a la imposición de una serie de nuevas normas por parte de la priora, doña María Rodríguez de Aza, que chocaban frontalmente contra los usos y costumbres heredados del anterior periodo ${ }^{2374}$. La sentencia confirmó la limitación de la autonomía concejil a la hora de nombrar sus oficiales, custodiar llaves y realizar derramas ${ }^{2375}$. Asimismo se configuraban ciertos derechos señoriales como eran el monopolio de los ejidos y encinar, los trabajos para el convento a través de sernas y transportes o la regulación del uso de las aguas para riego. Finalmente también se impuso la prioridad del convento en la vendimia. Como ya hemos apuntado anteriormente, un aspecto importante que reclamaba el concejo era que la priora no pudiera eximir del pago de impuestos a ciertos vecinos del lugar vinculados al convento, pues suponía una carga mayor para el resto de vecinos. La sentencia, sin embargo, confirmó la exención de molineros e pastores e ortolanos e yeguerizos e colmeneros e paniaguados del dicho monesterio. De entre las reclamaciones de las monjas tan sólo fueron rechazadas las exigencias de prohibir las ventas de bienes entre vecinos sin su autorización y la posesión del sello de la villa.

${ }^{2374}$ Ante la visión planteada por la historiografía tradicional de rechazo a la jurisdicción y autoridad de la priora (GONZÁLEZ GONZÁLEZ, Real Monasterio..., pp. 122-125), el propio documento transmite la idea contraria en la propia voz del procurador del concejo que afirmaba ...que nunca fue nin es desapoderada de la posesión, nin del señorio, nin les fueran enbargados pechos, nin derechos, nin señorio, nin retenido por el dicho conçejo (MARTÍNEZ LIÉBANA, Colección Diplomática..., doc. CCLXXXIV, pp. 370-375).

${ }^{2375}$ Es significativo que se impuso al concejo la elevada cantidad de 20.000 maravedíes de multa ...por quanto el dicho conçeio pusieron alcalles e ofiçiales contra defendimento de las dichas piora e convento, con una clara finalidad persuasiva. 
Por lo tanto, este conflicto muestra la confirmación del aumento de la presión señorial sobre los vasallos de Caleruega, que bien podría encuadrarse como un episodio temprano de la ofensiva señorial que se desarrolló en Castilla a lo largo del siglo XIV y buena parte del $\mathrm{XV}^{2376}$. Esta presión señorial se consolidó en nuevos episodios de contestación y posteriores concordias entre 1410 y $1430^{2377}$. El proceso culminó con la sentencia arbitral de 1435 en la que se fijaba definitivamente que el conçejo e omes buenos del dicho logar de Caleruega que agora son e seran de aquí adelante son vasallos solariegos del dicho monasterio e priora e monjas y además, prueba evidente de las reminiscencias del señorío de behetría del pasado, se estipulaba que non pueden tomar comendero para que los tenga en encomienda ... antes mandamos que tomen e puedan tomar el dicho comendero la dicha priora ${ }^{2378}$. La sentencia mantenía las cargas y monopolios establecidos en el pasado, aunque ajustaba la martiniega y el número de exen$\operatorname{tos}^{2379}$. Asimismo se puntualizaban las limitaciones a la autonomía del concejo, estableciendo que la villa podía presentar ocho candidatos entre los que la priora escogería dos alcaldes y dos jurados. No obstante, la priora se reservaba el derecho a nombrar sus merinos entre los vecinos ${ }^{2380}$.

La consolidación del señorío jurisdiccional fue confirmada a través de las cláusulas que se establecieron en la Real Ejecutoria de 1510 que sancionaba la autoridad jurisdiccional del convento sobre sus vasallos de Caleruega, consagrando a la priora como máxima autoridad judicial en el señorío y asegurando los ingresos provenientes

${ }^{2376}$ La conversión de los señoríos de behetrías en señoriales, en este caso abadengo, fue uno de los instrumentos utilizados por la nobleza para mantener su nivel de ingresos, transformando las estructuras señoriales hacia formas más eficientes (OLIVA HERRER, “La crisis del siglo XIV..., pp. 105-120). 391.

2377 MARTÍNEZ LIÉBANA, Colección Diplomática..., docs. CCC y CCCIV, pp. 387-389 y

${ }^{2378}$ A pesar de este precepto, Caleruega figuraba en 1480 como una de las behetrías que habían estado bajo la encomienda del conde de Villahermosa (AGS, RGS, 148003, fol. 36).

${ }^{2379}$ Si bien el monasterio percibía 600 maravedíes de martiniega, la villa se quejaba de que el cenobio había adquirido muchas propiedades en la villa que habían pasado a estar exentas de contribución con lo que la carga fiscal había aumentado sobre los vecinos. La priora aceptó reducirla a 450 maravedíes con el compromiso de que las propiedades que se incorporaran al patrimonio del convento a partir de ese momento pasaran con el correspondiente cargo de martiniega. En 1510 se pagaba de martiniega 1.200 maravedíes. En este sentido, también se limitó la posibilidad de eximir fiscalmente a sus trabajadores, pues tan solo se contemplaba la exención de dos colonos y un hortelano, aunque se refería exclusivamente al impuesto de la moneda.

${ }^{2380}$ MARTÍNEZ LIÉBANA, Colección Diplomática..., doc. CCCVII, pp. 393-396. 
de las multas ${ }^{2381}$. En el plano de la autonomía concejil se confirmaron las limitaciones anteriores y además se añadió la obligatoriedad de rendir cuentas a la priora una vez al año de los ingresos y gastos del concejo. De igual manera se introdujo una nueva cláusula por la que se prohibía al concejo realizar acuerdos con otras localidades en asuntos de pastos y montes. También se incrementaba la presión fiscal sancionando la actualización de los tributos existentes, retomando algunos que habían desaparecido en los anteriores arbitrios y añadiendo dos peonadas anuales a cuenta del concejo. Por último, la sentencia rechazó las demandas de la comunidad dominica para traspasar los términos concejiles al convento y eliminaba alguno de los malos usos, como la necesidad de licencia para realizar compraventas de bienes inmuebles o para casarse.

A pesar de esta ventajosa sentencia judicial, las religiosas dominicas tuvieron serios problemas para imponer su autoridad sobre el concejo durante las primeras décadas del siglo XVI. La contestación vecinal ante la reafirmación del poder señorial obligó a la priora a utilizar una concesión regia que le permitía solicitar la ayuda de los oficiales reales para imponer justicia. Fueron varias las ocasiones a lo largo de estos años en los que la priora demandó intervención del corregidor de Aranda para tratar de imponer su autoridad sobre sus vasallos de Caleruega, y así continuó durante buena parte del si$\mathrm{glo}^{2382}$. Tal situación provocó que la priora recurriera desde 1522 a un nuevo instrumento, el juez de residencia, que se utilizó para fiscalizar y penar las actuaciones de los oficiales municipales e impartir justicia en momentos puntuales ${ }^{2383}$.

La misma dinámica de contestación a la autoridad señorial parece que se reprodujo entre el monasterio cisterciense de Fuencaliente y sus vasallos del concejo de Fuentearmejil en los años a caballo entre el siglo XV y el XVI. En esta ocasión la disputa se centró también en cuestiones políticas relativas a la autonomía política del concejo y económicas derivadas de la explotación de ciertos heredamientos que ambas partes reclamaban como propias. La escalada de la tensión, a la que no fueron ajenas algunas de la familias comarcanas con intereses en la zona ${ }^{2384}$, motivó que la abadesa solici-

\footnotetext{
${ }^{2381}$ MARTÍNEZ LIÉBANA, Colección Diplomática..., doc. CXLIV, pp. 174-179.

2382 MARTÍNEZ LIÉBANA, Colección Diplomática..., docs. CL y CLIII, pp. 187-198; y AGS, CCP, leg. 5, doc. 67.

${ }^{2383}$ MARTÍNEZ LIÉBANA, Colección Diplomática ..., doc. CCCXXI, pp. 406-408.

${ }^{2384}$ Recordemos que los señores de Valverde compartían el señorío de esta villa y fomentaron la desobediencia de los vecinos para con el monasterio.
} 
tara la intervención de la justicia real ${ }^{2385}$. El corregidor arandino fue comisionado para investigar el asunto y tan solo sabemos que emitió una sentencia favorable a la restitución de unas heredades y montes reclamados por el monasterio cisterciense ${ }^{2386}$.

Un episodio con los mismos ingredientes tuvo como protagonistas al monasterio jerónimo de Nuestra Señora de Espeja de San Marcelino y el concejo de su villa de Espeja de San Marcelino, en este caso sobre la posesión y aprovechamiento de térmi$\operatorname{nos}^{2387}$.

En lo referente a la presión señorial de los grandes señores nobiliarios sobre sus vasallos estamos ante una cuestión que apenas ha dejado huella sobre la documentación consultada. Son muy reducidas las noticias a propósito de la sublevación antiseñorial que tuvo lugar en la villa de Roa en la primavera de 1493 y que debemos poner en relación con el periodo de inestabilidad que vivió el linaje De la Cueva tras el fallecimiento del I duque de Alburquerque. En mayo de ese año los raudenses se rebelaron contra la autoridad del nuevo duque y solicitaron el amparo de los reyes para retornar a la jurisdicción real. No tenemos muchos datos sobre la sublevación en sí, ni tampoco del papel que pudo jugar la duquesa viuda -doña María de Velasco- en la iniciativa de la villa, pero lo cierto es que los reyes actuaron con prontitud y ordenaron a los raudenses su inmediata vuelta a la obediencia de don Francisco de la Cueva. La inestabilidad debió mantenerse durante algún tiempo pues el concejo de Roa solicitó la protección real por el temor a las represalias del duque y su alcaide ${ }^{2388}$. Como ya hemos visto en el capítulo precedente, las posteriores negociaciones en el seno de la familia De la Cueva concluyeron con el traspaso del señorío de la villa raudense y su tierra a los hijos de doña María, finalizando así la vinculación con el ducado de Alburquerque ${ }^{2389}$.

Otro episodio del que apenas tenemos información es el tímido intento de contestación antiseñorial de los vecinos de Quintanarraya que en 1496 se opusieron a las pretensiones de su señor, el conde de Coruña, de aumentar la presión fiscal ${ }^{2390}$.

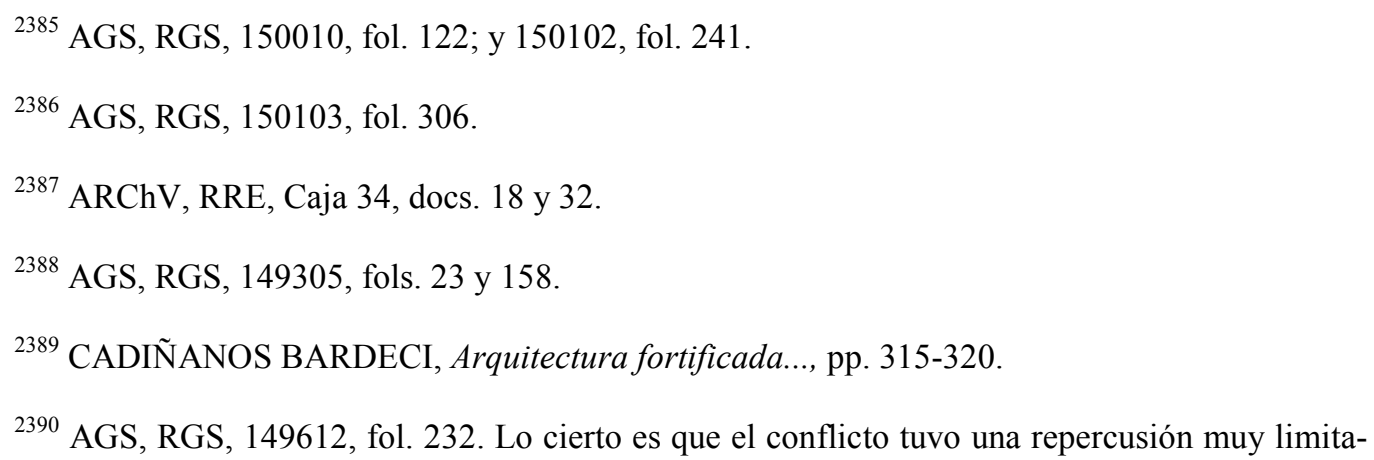
da pues se concretó en la incautación de una mula a un vecino por parte del alcaide de Quintanarraya. El 


\subsection{Balance: la realidad señorial en la Ribera del Duero burgalesa a princi- pios del siglo XVI.}

A través de todos estos conflictos que hemos analizados podemos concluir las principales líneas de expansión de los más destacados linajes nobiliarios con presencia en la comarca.

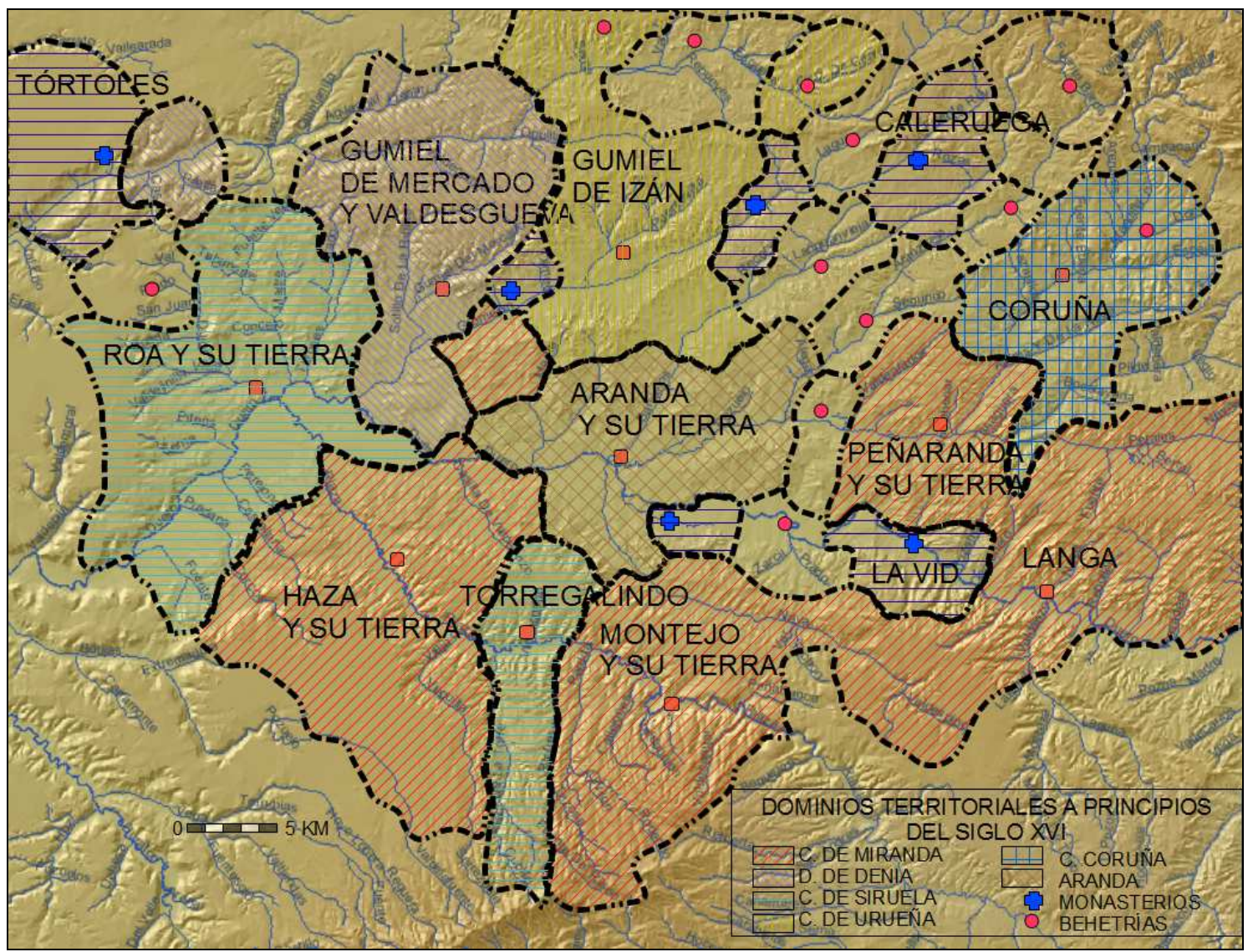

Mapa 22: La realidad señorial en la Ribera del Duero burgalesa a fines de la Edad Media.

En el panorama señorial del área ribereña a finales de la Edad Media podemos concluir que la familia más activa fue la de los Zuñiga Avellaneda. A su importante patrimonio territorial en la comarca heredado de los señores de Avellaneda se fue sumando diferentes lugares que permitieron la consolidación del mayor estado señorial de la comarca. Como ya hemos señalado en su momento, este señorío no gozó de continui-

oficial del conde argumentaba que el valor de la mula compensaba el incremento de un maravedí por hogar que los vasallos se negaban a abonar. 
dad espacial por lo que tuvo varios frentes de expansión abiertos a la vez. Uno de los más importantes fue el curso bajo del río Riaza. A las originales posesiones de las Comunidades de Villa y Tierra de Montejo de la Vega y Haza se sumaron mediante diferentes mecanismo a lo largo del periodo estudiado otros términos como Pardilla, Valdeherreros, Milagros, Hoyales o Fuenlisendo. Se configuró así un espacio casi continuo que dominaba este tramo del Riaza y que sólo se vio interrumpido por la villa de Torregalindo que terminó formando parte del condado de Siruela.

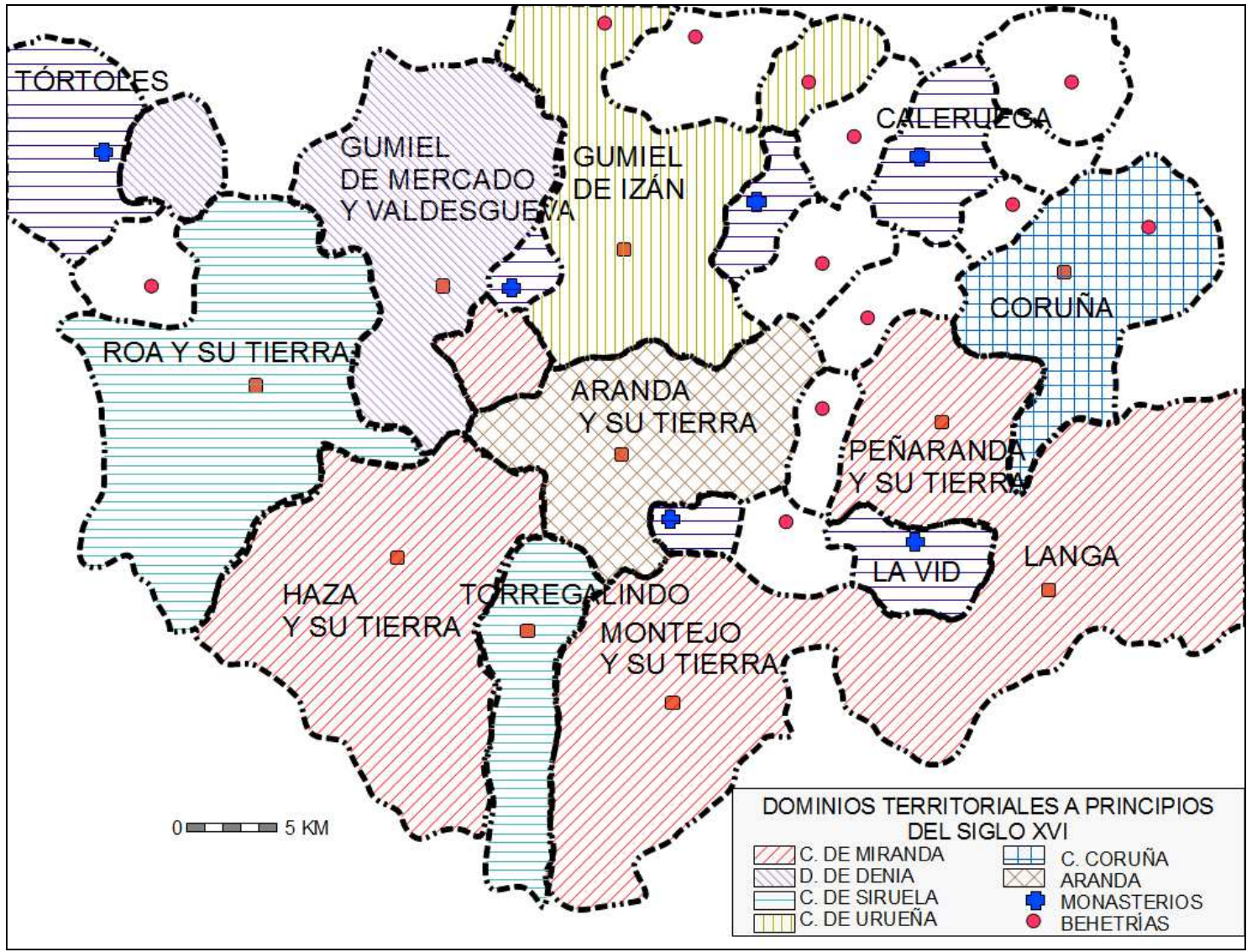

Mapa 23: Esquema de la realidad señorial en la Ribera burgalesa a fines de la Edad Media.

El otro gran foco de expansión de la casa de Miranda se localizó entorno a la villa que ejerció la capitalidad en el espacio ribereño: Peñaranda de Duero. Desde este punto la expansión se dirigió hacia el Norte con la enajenación de hecho de la behetría de Hontoria. Más significativa para los intereses de este linaje fue la inclusión del monasterio de Santa María de La Vid bajo su amparo con el nombramiento de don Íñigo López de Mendoza como abad y la conversión del cenobio en la capilla funeraria de la familia. Esta incorporación supuso la comunicación espacial más directa del centro neurálgico del linaje con sus posesiones del valle de Riaza a través de los lugares de Fresni- 
llo y Fuentelcésped, que si bien eran abadengos de La Vid, ya hacía bastantes años que estaban controlados por los sucesivos condes de Miranda ${ }^{2391}$. De igual manera permitió unir de forma más compacta los territorios más orientales del linaje, Bocigas de Perales, Langa de Duero y Castillejo, con los puntos centrales de su señorío. Esta conexión territorial tiene su excepción en el caso de la villa de La Aguilera, aunque eso no fue impedimento para reforzar su posición frente a los territorios del marqués de Denia con la excusa del control y aprovechamiento de las aguas del Gromejón.

Por último, tampoco debemos olvidar las intensas relaciones que a comienzos del Quinientos estableció el III conde de Miranda con las máximas dignidades de las comunidades religiosas de San Pedro de Gumiel y de Santo Domingo de Caleruega.

La Averiguación encargada por Carlos I a mediados de la década de los años veinte revela a este linaje como el más importante de toda de la comarca en cuanto a número de núcleos de población bajo su jurisdicción pues contaba con nueve villas y más de 30 lugares que agrupaban a más de 1.600 vecinos pecheros ${ }^{2392}$. A tenor de la información recogida por los encuestadores y las propuestas fiscales que realizaron, se concluye que algunos de estos territorios gozaron durante estas primeras décadas del Quinientos de una estupenda salud económica. Así lo manifiestan los informes que argumentan las propuestas fiscales: Y por razon de la dicha vezindad e de las calidades de los dichos pueblos, que en los mas dellos ay muy buenas labranças de pan, e vino e cañamo, e cojen los vezinos mucho açafran, espeçialmente en la dicha villa de Aça e su tierra, e ansymismo tienen ganados e colmenas en mediana cantidad, e comunmente los mas de los dichos vezinos tienen medianas haziendas. Parecidos comentarios se incluyen de las haciendas y vecinos de Hoyales o Moradillo ${ }^{2393}$.

Por lo tanto, el patrimonio territorial de la casa de Miranda se configuró en el periodo que analizamos como el principal estado señorial de la comarca ribereña y fue la base material sobre la que se asentó su posición de élite de poder. En definitiva, a lo largo de apenas sesenta años el linaje de los Zúñiga Avellaneda fue capaz de configurar

${ }^{2391}$ CARRETERO ZAMORA, La Averiguación de la Corona..., Vol. I, p. 225.

${ }^{2392}$ CARRETERO ZAMORA, La Averiguación..., Vol. III, pp. 1400-1407 y 1508-1509.

${ }^{2393}$ CARRETERO ZAMORA, La Averiguación..., Vol. III, pp. 1416-1418. De Hoyales y Fuentelisendo se afirma que...por razon de la dicha vezindad, puesto que los dichos vezinos tienen medianas haziendas e cojen razonablemente pan e açafran... Igualmente se dice de Moradillo y Aldehorno ...porque comunmente los dichos vezinos tienen medianas haziendas, e cojen mucho açafran e razonable pan, e vino e cáñamo en heredades suyas propias, e alguna miel. 
y consolidar un dominio señorial con fuerte protagonismo en las tierras ribereñas que permitió que sus miembros se encumbraran en una posición que les permitió el acceso a nuevas alianzas. Éstas sobrepasaron el ámbito de las inercias familiares, los Béjar, para enlazar con otros grandes personajes del reino, los Velasco y los Cárdenas, y así situarse en una posición privilegiada en el momento en el que irrumpió en Castilla una nueva dinastía y su novedoso concepto de Estado Moderno.

Cuadro 15: Dominio del conde de Miranda según la Averiguación de la Corona de Castilla.

\begin{tabular}{|c|c|c|c|c|}
\hline Territorio & Localidad & Vecinos & $\begin{array}{l}\text { Servicio } 1527 \\
\text { (maravedíes) }\end{array}$ & $\begin{array}{c}\text { Propuesta } \\
\text { (maravedíes) }\end{array}$ \\
\hline \multirow[t]{3}{*}{ Hoyales y Fuentelisendo } & & 52 & 9.500 & 8.500 \\
\hline & Hoyales & 38 & & \\
\hline & Fuentelisendo & 14 & & \\
\hline \multirow{3}{*}{$\begin{array}{l}\text { Moradillo y Aldea del } \\
\text { Horno }\end{array}$} & & 91 & 11.230 & 15.500 \\
\hline & Moradillo & 54 & & \\
\hline & Aldea del Horno & 37 & & \\
\hline \multirow[t]{10}{*}{ Haza y su Tierra } & & 372 & & 57.000 \\
\hline & Haza & 43 & & \\
\hline & Fuentecén & 58 & & \\
\hline & Valdezate & 71 & & \\
\hline & Fuentemolinos & 36 & & \\
\hline & Torre de Corcos & 37 & & \\
\hline & La Sequera de Aza & 27 & & \\
\hline & Hontangas & 23 & & \\
\hline & Castrillo de la Vega & 17 & & \\
\hline & Adrada de Haza & 60 & & \\
\hline \multirow[t]{6}{*}{ Peñaranda y su Tierra } & & 262 & & 38.000 \\
\hline & Peñaranda de Duero & 150 & & \\
\hline & Aldea del Monte & 60 & & \\
\hline & Aldea de Santa María & 37 & & \\
\hline & Casanueva & 15 & & \\
\hline & Cuzcurrita & & & \\
\hline Bocigas de Perales & & 80 & & 10.500 \\
\hline \multirow[t]{14}{*}{ Montejo y su Tierra } & & 336 & & 48.000 \\
\hline & Montejo & 19 & & \\
\hline & Valdevacas & 16 & & \\
\hline & Villaverde & 19 & & \\
\hline & Villalvilla & 16 & & \\
\hline & Pradales & 18 & & \\
\hline & Milagros & 12 & & \\
\hline & Pardilla & 66 & & \\
\hline & Valdeherreros & 30 & & \\
\hline & Tamarón & 6 & & \\
\hline & Casuar & 8 & & \\
\hline & Santa Cruz de la Salceza & 72 & & \\
\hline & Honrubia de la Cuesta & 51 & & \\
\hline & La Nava & 3 & & \\
\hline La Aguilera & & 97 & & 13.500 \\
\hline Fuentelcésped & & 21 & & 2.500 \\
\hline Valverde & & 12 & & 500 \\
\hline
\end{tabular}




\begin{tabular}{|l|r|r|r|r|}
\hline $\begin{array}{l}\text { Langa de Duero y Orade- } \\
\text { ro }\end{array}$ & 143 & 18.210 & 15.300 \\
\hline Rejas de San Esteban & & 78 & 12.550 & 8.000 \\
\hline Castillejo de Robledo & & & \\
\hline TOTAL & 1544 & - & 217.300 \\
\hline
\end{tabular}

La presencia territorial de la casa Sandoval en la Ribera apenas sufrió variación a lo largo del periodo estudiado. A la herencia recibida por el I conde de Castro basada sobre todo en la villa de Gumiel del Mercado y Valdesgueva tan solo se añadió muy tardíamente la villa de La Ventosilla que fue comprada a la Corona por el II marqués de Denia en $1521^{2394}$. Sin embargo, fueron muchos los conflictos que mantuvo en la Ribera relacionados sobre todo con el mantenimiento de su situación más que con la intención de expandirse. Entre estos destaca el enfrentamiento continuo que mantuvo con el linaje de los Téllez-Girón por la jurisdicción de la villa de Gumiel de Izán y por el control de algunos lugares en el valle del Esgueva. Tampoco fue menor la rivalidad con la familia Miranda que se materializó al principio del periodo en el abierto enfrentamiento en el contexto del conflicto sucesorio y en concreto en la disputa por la villa de Aranda. Poco después de esta primera colisión de intereses se produjo otro episodio en el ya señalado enfrentamiento por el control de las aguas del río Gromejón.

Cuadro 16: Dominio del Marqués de Denia según la Averiguación de la Corona de Castilla.

\begin{tabular}{|c|c|c|c|c|}
\hline Territorio & Localidad & Vecinos & $\begin{array}{l}\text { Servicio } 1527 \\
\text { (maravedíes) }\end{array}$ & $\begin{array}{c}\text { Propuesta } \\
\text { (maravedíes) }\end{array}$ \\
\hline \multirow{3}{*}{$\begin{array}{l}\text { Gumiel del Mercado y su } \\
\text { Tierra }\end{array}$} & & 256 & 33.720 & 39.400 \\
\hline & Sotillo & & & \\
\hline & Monzón & & & \\
\hline La Ventosilla & & 42 & 7.580 & 5.250 \\
\hline \multirow{6}{*}{$\begin{array}{l}\text { Santibáñez de Esgueva y } \\
\text { Cabañes }\end{array}$} & & 314 & 41.300 & 39.250 \\
\hline & Cabañes & 56 & & \\
\hline & Santibáñez & 103 & & \\
\hline & Pinillos & 52 & & \\
\hline & Villatuelda & 48 & & \\
\hline & Terradillos & 55 & & \\
\hline Villovela de Esgueva & & 57 & 8.620 & 6.840 \\
\hline TOTAL & & 669 & 91.220 & 90.740 \\
\hline
\end{tabular}

En definitiva, según nos permite ver la documentación asociada a la Averiguación de Castilla, el señorío del linaje de los Sandoval en la Ribera del Duero se limitaba

${ }^{2394}$ DÁVILA JALÓN, V., Historia y nobiliario de Gumiel de Mercado, Sotillo de la Ribera y Ventosilla. Madrid, 1958, p. 188. 
a principios del siglo XVI a una villa relativamente importante, Gumiel del Mercado, más una decena de pequeñas villas y lugares que se situaban a su alrededor enlazando con la cuenca media del Esgueva. Este territorio contaba con un modesto capital humano pues los pecheros que allí habitaban apenas superaban los 600 vecinos $^{2395}$. No obstante, ha de tenerse en cuenta que la capital de sus estados, Lerma, se encontraba a escasa distancia de las posesiones ribereñas lo que provocó sin lugar a dudas el eclipse de éstas en favor de la villa del Arlanza.

Al igual que hemos observado en el caso de la casa de Miranda, el linaje Sandoval también participó de la misma dinámica que los Zúñiga pues su origen modesto no impidió que los sucesivos miembros de esta familia consolidaran un importante patrimonio territorial que les sirvió de base para avanzar hacia una situación más destacada, si bien es cierto que las posesiones territoriales de los Sandoval en la comarca fueron bastante más modestas y menos significativas dentro del conjunto de los estados de la casa de Denia.

Más significativa fue la dinámica expansiva del linaje de los condes de Urueña en la comarca. Desde el punto de partida con la adquisición de la villa de Gumiel de Izán comenzó una rápida y eficaz expansión hacia el Norte que se materializó en la compra de una serie de lugares en la cuenca alta del Esgueva. Tanto la consolidación de su posesión sobre Gumiel, como la posterior fase expansiva hacia el Esgueva, colisionaron con la posición de la familia Sandoval, propiciando un duro enfrentamiento entre ambos protagonistas. Finalmente los Téllez-Girón lograron consolidar un modesto pero eficaz señorío territorial en la comarca que tuvo en la dinámica villa de Gumiel de Izán su centro, que le permitió gozar de un importante patrimonio humano que contaba a comienzos del siglo XVI con casi 800 vecinos $^{2396}$.

A pesar de este notable potencial territorial y humano en la comarca, la evolución de este linaje fue prácticamente antagónica de los anteriores pues su punto de partida, como uno de los más firmes colaboradores y partidarios de Enrique IV, sufrió un importante retroceso durante el reinado de los Reyes Católicos, circunstancia que en absoluto impidió que consolidara su posición como uno de los importantes linajes aso-

2395 CARRETERO ZAMORA, La Averiguación..., Vol. III, pp. 969-972. En concreto, los vecinos pecheros avecindados en los territorios del marqués de Denia eran 669.

${ }^{2396}$ CARRETERO ZAMORA, La Averiguación..., Vol. III, pp. 967-971. 
ciados a la aristocracia castellana. Al final del periodo estudiado la polémica posición mantenida por el heredero del condado en el contexto de la Revolución Comunera propició que de nuevo este linaje se viera postergado a una posición secundaria durante un corto periodo de tiempo.

Cuadro 17: Dominio del Conde de Urueña según la Averiguación de la Corona de Castilla.

\begin{tabular}{|c|c|c|c|c|}
\hline Territorio & Localidad & Vecinos & $\begin{array}{l}\text { Servicio } 1527 \\
\text { (maravedíes) }\end{array}$ & $\begin{array}{c}\text { Propuesta } \\
\text { (maravedíes) }\end{array}$ \\
\hline \multirow{3}{*}{$\begin{array}{l}\text { Gumiel de Izán y su } \\
\text { Tierra }\end{array}$} & & 705 & 85.580 & 98.700 \\
\hline & Villanueva de Gumiel & & & \\
\hline & Villalbilla de Gumiel & & & \\
\hline \multirow{4}{*}{$\begin{array}{l}\text { Bahabón de Esgueva y } \\
\text { Oquillas }\end{array}$} & & 81 & 4.260 & 10.130 \\
\hline & Bahabón & 29 & & \\
\hline & Oquillas & 17 & & \\
\hline & Cilleruelo de Arriba & 35 & & \\
\hline $\begin{array}{l}\text { Santa María de Merca- } \\
\text { dillo }\end{array}$ & & 12 & 2.610 & 1.200 \\
\hline TOTAL & & 798 & 92.450 & 110.030 \\
\hline
\end{tabular}

Situación similar presenta la trayectoria del linaje de la Cueva en la Ribera. Su posición protagonista durante el reinado de Enrique IV fue un lastre demasiado pesado sobre la trayectoria del duque de Alburquerque durante el reinado de los Reyes Católicos. Sin embargo, esta situación no fue óbice para que se convirtiera en el señor que mayor número de vasallos tuvo en la Ribera y el que, casi con toda seguridad, consiguió un mayor beneficio económico debido tanto al potencial demográfico como a la riqueza de recursos naturales asociados a la Tierra de Roa fundamentalmente ${ }^{2397}$. Sin embargo, el protagonismo de Alburquerque en la comarca fue muy reducido, en parte por su especial vinculación con otras tierras castellanas. Además los dominios ribereños se vieron envueltos en las disputas sucesorias en la casa ducal que culminaron con la escisión y asentamiento en la comarca de la casa Siruela de la mano de las alianzas matrimoniales entre de la Cueva y Velasco.

Por lo tanto, la presencia del linaje de la Cueva en la comarca se limitó a la rica y pujante Villa de Roa y los numerosos lugares de su Tierra. Los herederos de este señorío, los Siruela, consolidaron su presencia en la Ribera con la incorporación de la villa de Torregalindo. Las escasas referencias documentales a conflictos con sus vecinos evi-

${ }^{2397}$ Roa y sus aldeas contaban a principios del siglo XVI con 1.602 vecinos pecheros y en Torregalindo, Campillo y Fuentenebro habitaban 102 vecinos (CARRETERO ZAMORA, La Averiguación..., Vol. III, p. 972). 
dencian que al menos en el territorio ribereño los Velasco de la Cueva no se inclinaron por una dinámica expansiva.

Más modesto fue el significado de la presencia de los representantes del clan de los Mendoza en la comarca. Los estados de los condes de Coruña se situaban en el extremo Noreste de la Ribera, extendiendo su influencia hacia tierras sorianas, monasterio de San Jerónimo de Espeja incluido. La documentación apenas nos ha mostrado alguna iniciativa expansiva de consideración. El dominio señorial de los Suárez de Mendoza en la Ribera se limitaba a exiguo territorio limitado a la villa de Coruña más una serie de aldeas y la villa de Espeja con Espejón. Entre todas ellas apenas sobrepasaban los cuatrocientos vasallos ${ }^{2398}$.

Algo más activos se mostraron los representantes de la nobleza de segunda fila. Los Acuñas se vieron implicados en varios episodios conflictivos pero finalmente optaron por desprenderse de sus posesiones territoriales para configurarse como miembros de primer orden dentro de la oligarquía urbana arandina. Este clan familiar ejemplifica claramente a la nobleza hidalga que forjó su identidad como hábiles peones al servicio de la nueva monarquía e idea del Estado.

La integración en la oligarquía del principal núcleo urbano de la comarca también fue lograda por los señores de Valverde al final del periodo que nos ocupa pero sin renunciar a su patrimonio territorial que se limitaba a los modestos lugares de Alcoba de la Torre y Alcubilla de Avellaneda ${ }^{2399}$. Al igual que los Acuña se vieron envueltos en varios conflictos territoriales con otros nobles y con el monasterio de Fuencaliente de los que salieron con una posición reforzada, aunque no podemos olvidar el carácter modesto de sus estados.

Los señores de Castrillo tuvieron un relativo protagonismo en la relación de fuerzas de la comarca aunque sus dominios territoriales estaban muy fragmentados y situados en los extremos occidental, Castrillo de Luis Díaz en tierras del Cerrato; oriental, con Alcozar y Zayas de la Torre en tierras sorianas; y septentrional pues poseía Te-

${ }^{2398}$ Coruña del Conde y su tierra contaba en la década de los veinte del siglo XVI con 288 vecinos pecheros y Espeja alcanzaba los 148 (CARRETERO ZAMORA, La Averiguación..., Vol. III, p. 969).

${ }^{2399}$ Alcoba tenía 23 vecinos y Alcubilla 56 CARRETERO ZAMORA, La Averiguación..., Vol. III, pp. 970). 
jada y Ciruelos de Cervera en las estribaciones de la Sierra de la Demanda ${ }^{2400}$. Posiblemente esta dispersión fue lo que en buena medida provocó que los sucesivos señores de Castrillo mantuvieran frecuentes enfrentamientos tanto con sus vecinos, sobre todo con el monasterio de Tórtoles de Esgueva, como con sus vasallos. Al igual que los anteriores, esta rama de los Avellaneda también proyectó sus intereses sobre la villa de Aranda donde fraguó un importante patrimonio y una posición destacada dentro de la oligarquía local.

Podemos concluir, por lo tanto, que a finales de la Edad Media se configuró en la actual comarca de la Ribera del Duero un espacio fuertemente señorializado, con la presencia de miembros de la nobleza emergente que buscaban consolidar su posición dentro del contexto nobiliario castellano. Con la intención de alcanzar este objetivo el primer paso que dieron fue configurar y consolidar un patrimonio territorial sobre el que asentar las bases de su poder. Las crecientes ansias de expansión territorial de cada uno de estos linajes, más el evidente carácter finito del espacio, generaron necesariamente conflictos que dieron como resultado un determinado reparto del territorio y una relación de fuerzas que sufría reajustes de manera constante, generando nuevos conflictos. Desde nuestro punto de vista, esta conflictividad tuvo su plasmación física sobre el espacio que se definió con unas determinadas características jurídicas, sociales y económicas. Todo ello, en el fondo, fue el resultado de la dinámica propia del feudalismo en la Castilla medieval.

\section{CONFLICTIVIDAD URBANA: LA VILLA DE ARANDA.}

La historiografía reciente es muy prolija en la identificación de los principales conflictos que tuvieron como protagonistas a los habitantes de los principales núcleos urbanos castellanos. Nuestro estudio se hace partícipe de todos estos trabajos y muestra un esquema ya clásico de la conflictividad del principal centro urbano de la Ribera: la villa de Aranda de Duero.

\footnotetext{
${ }^{2400}$ Los lugares del señor de Castrillo contaban a comienzos del siglo XVI con el nada despreciable número de 629 vasallos de los cuales 325 estaban avecindados en sus posesiones palentinas de Cevico Navero y Castrillo de Luis Díaz (CARRETERO ZAMORA, La Averiguación..., Vol. II, p. 628 y Vol. III, p. 970).
} 
En nuestro análisis de la situación hemos optado por estudiar en un primer momento aquellos conflictos internos que tuvieron por protagonistas a los miembros de la sociedad arandina. Un segundo apartado lo dedicaremos a identificar aquellos episodios que tuvieron que ver con las pretensiones expansionistas del concejo arandino y su evidente colisión con los intereses de los grandes señores territoriales de la comarca.

\section{1. Conflictos internos.}

Al igual que ocurrió en otros espacios urbanos de la Castilla bajomedieval ${ }^{2401}$, la conflictividad interna de la villa de Aranda tuvo como protagonistas a una clase dominante u oligarquía que impuso paulatinamente su posición privilegiada sobre una mayoría de vecinos con cada vez menor poder de decisión pero que experimentó una evolución en sus estrategias de acceder al poder municipal, que trataremos de identificar en estas páginas.

La documentación disponible nos muestra dos niveles de conflictividad en el seno de la sociedad arandina. Por una parte, se observa un ambiente de tensión entre los diferentes grupos que configuraban la oligarquía local y que evolucionaron hacia enfrentamientos violentos puntuales pero con gran repercusión en la villa y la comarca. Por otra parte, las diferencias entre la oligarquía y la gran masa vecinal de la Comunidad se perciben como una constante en la vida política arandina, degenerando en una situación de permanente enfrentamiento que trataremos de analizar pormenorizadamente.

\section{1. 1. Conflictos entre los miembros de la clase dominante.}

Los enfrentamientos protagonizados por miembros del patriciado urbano fueron una constante en la Castilla medieval como se puede apreciar en diferentes núcleos

${ }^{2401}$ Son muchos los trabajos sobre este aspecto por lo que sería imposible citarlos todos. Recomendamos sendos trabajos de la profesora VAL VALDIVIESO que sintetizan la identificación del grupo social urbano que se consolida como una clase dominante ya desde el siglo XIV en contraposición a la gran masa del Común ("Oligarquía versus Común..., pp. 41-58.); así como su evolución y la multiplicidad de conflictos que se generan entre estos dos grupos durante las últimas décadas de la Baja Edad Media ("Ascenso social y luchas por el poder en las ciudades castellanas del siglo XV”, En la España Medieval. 17, 1994, pp. 157-184). También cabe destacar las aproximaciones de MONSALVO ANTÓN, J. A., “Aspectos de las culturas políticas de los caballeros y los pecheros en Salamanca y Ciudad Rodrigo a mediados del siglo $\mathrm{XV}$ : violencias y debates sobre el poder en los concejos", en Lucha política: condena y legitimación den la España medieval. Lión, 2004, pp. 237-296; y SOLORZANO TELECHEA, J. A., "Linaje, comunidad y poder: desarrollo y consolidación de identidades urbanas contrapuestas en la Castilla bajomedieval", en Familia y sociedad en la Edad Media (siglos XII-XV), Zaragoza, 2007, pp. 71-94. 
urbanos como Cuenca, Valladolid, Salamanca, Ciudad Rodrigo, Alba de Tormes, Medina del Campo o las villas vascas ${ }^{2402}$.

La escasa documentación con la que contamos para los años anteriores al conflicto sucesorio no nos permite conocer a la clase dominante de la villa de Aranda previa al periodo estudiado, así que mucho menos sus posibles conflictos. A pesar de la constatación de la existencia de dos linajes en la villa desde comienzos del siglo XV, el de don Romero y el de don Pedro García de la Puente, no hemos logrado identificar enfrentamientos entre ambos, aunque es fácil deducir que su origen esté en la disputa de estas agrupaciones clientelares por controlar el gobierno municipal ${ }^{2403}$.

En el contexto de la crisis sucesoria se intuye la existencia de dos bandos que se enfrentaron abiertamente en la villa como describía un vecino afirmando ...que en tiempo del señor don Enrique las partes contrarias, con todos sus parientes amigos e valedores, atentaron muchas veces con robar, ferir y matar a mi e a mis parientes y valedores, e lo pusieron en obra y todavia lo fecieran e acabaran, salvo por que plogo a Dios nuestro Señor de me dar fuerzas con mis parientes, señores e amigos para me defender de todos ellos; y todos los escandalos, heridos y muertos que han sucedido en esta villa desde entonces se han debido a la otra parte, siendo ellos los agresores; y ellos siempre se han resistido y solo han actuado en legítima defension ${ }^{2404}$.

As se constata que en este delicado periodo se produjo el enfrentamiento entre dos destacadas familias vinculadas a los linajes que tuvo su punto álgido en el contexto de la toma de la villa para la princesa Isabel por parte de las tropas de don Diego de Rojas. Entre los partidarios de la princesa Isabel se encontraba Rodrigo de Salazar, encuadrado dentro del linaje de don Romero, que causó importantes daños sobre las haciendas de los parientes de Pedro García de Aranda, del linaje de don Pedro García de la Puente. Como ya hemos visto, ambos tuvieron un papel muy destacado en la consolidación de la villa dentro del bando isabelino y sus sucesores fueron gratificados por este servicio con la

${ }^{2402}$ MONSALVO ANTÓN, J. M., "En torno a la cultura contractual de las élites urbanas: pactos y compromisos políticos (linajes y bandos de Salamanca, Ciudad Rodrigo y Alba de Tormes)", en $E l$ contrato político en la Corona de Castilla: cultura y sociedad políticas entre los siglos X y XVI. Madrid, 2008, pp. 159-209; del mismo autor "Luchas de bandos en Ciudad Rodrigo durante la época Trastámara", en Castilla y el mundo feudal. Valladolid, 2009, vol. III, pp. 201-221; y VAL VALDIVIESO, "La revuelta comunera..., p. 633.

2403 MONSALVO ANTÓN, "Parentesco y sistema concejil..., pp. 937-969; y ASENJO GONZÁLEZ, “Acerca de los linajes urbanos..., pp. 52-84.

${ }^{2404}$ AGS, CC MEMORIALES, leg. 149, doc. 173. 
concesión de sendos regimientos perpetuos al amparo de la reforma de esta institución a principios de los años ochenta ${ }^{2405}$.

Pocos años después las disensiones entre los dos linajes se volvieron a reproducir con la disputa entre los regidores Pedro de Mora y Gonzalo García de Quemada a propósito del beneficio eclesiástico de las Alcobas. Ya hemos visto en un capítulo anterior cómo en el verano de 1490 ambos tuvieron sus diferencias a propósito de este beneficio en nombre de sus respectivos hermanos clérigos. Lo que en principio pudiera ser una disputa de carácter personal, se convirtió en algo más complejo debido a la calidad de los contendientes $^{2406}$.

El hecho de que Mora perteneciera al linaje de Don Pedro García de la Puente, mientras que Gonzalo García de Quemada era miembro del linaje de don Romero, provocó la implicación de sus respectivas redes clientelares tanto en la villa de Aranda como en algunos pueblos de la comarca. Mora contó con el apoyo de otro de los regidores de su linaje, el comendador Íñigo de Barahona, pero también, por extraño que parezca, con la ayuda de Pedro de Salazar, regidor del linaje de Don Romero ${ }^{2407}$. Quemada estuvo apoyado por la poderosa familia Durango.

Más evidente fue la rápida capacidad de movilización de las clientelas. Por una parte, el regidor Mora reclutó entre su parentela de Aranda a más de medio centenar de hombres armados. A éstos se añadió una veintena de Vadocondes y Fresnillo ${ }^{2408}$. Por su parte Gonzalo de Quemada reunió a más de un centenar de hombres entre el vecindario de las localidades de Coruña y Aranda.

Esta disputa provocó importantes altercados en la capital de la Ribera lo que motivó que los alcaldes pregonaran la prohibición de prestar ayuda a cualquiera de los con-

${ }^{2405}$ AGS, CASA Y SITIOS REALES, leg. 3, docs. 123 y 124. Recordemos que Pedro García de Aranda fue uno de los honrados homes que actuó como testigo en el juramento de los privilegios que doña Isabel hizo en 1473 en el Allendeduero (AMA, leg. 42, doc. 6).

${ }^{2406}$ AGS, CC PUEBLOS, leg. 1, docs. 226-233. Juan de Aranda, hermano de Mora, y Francisco García de Quemada, hermano de Gonzalo, se disputaron el beneficio curado de Alcubilla de Avellaneda y Alcoba de la Torre.

${ }^{2407}$ Pedro de Mora era hijo de Pedro García de Aranda y Pedro de Salazar lo era de Rodrigo de Salazar. Ambos progenitores se habían enfrentado como cabezas visibles de los dos bandos que se enfrentaron durante la crisis sucesoria.

${ }^{2408}$ Posiblemente el origen de la familia Mora estuviera en Vadocondes pues al padre del regidor se le conocía indistintamente como Pedro García de Aranda o de Vadocondes. 
tendientes $^{2409}$. Sin embargo, el celo con el que actuaron no debió ser el esperado pues los regidores de la Comunidad les acusaron de pasividad, denunciando asimismo la implicación de algunos vecinos en la bandería. Como consecuencia de la denuncia, dos de los alcaldes detuvieron a los implicados y los pusieron al recaudo del alguacil. Sin embargo, el tercer alcalde rápidamente se encargó de ponerlos en libertad ${ }^{2410}$. Desconocemos a qué bando pertenecían los inculpados pero parece evidente la implicación de los representantes de la justicia en el litigio, lo cual es en cierta medida lógico pues debemos recordar que dos de los alcaldes eran nombrados por los regidores de los linajes.

La situación se complicó todavía más con la intromisión en el asunto de las dos potencias nobiliarias comarcanas. En un primer momento el conde de Miranda se declaró neutral y negó la ayuda solicitada por Mora, argumentando que contaba en su casa con parientes de ambas partes. Sin embargo, la intervención de los hombres del marqués de Denia en favor de Mora provocó la rápida respuesta de Zúñiga otorgando su protección a Quemada que rápidamente se refugió en Peñaranda. Prueba de la gran influencia que la familia Zúñiga Avellaneda tenía sobre la oligarquía arandina fue el hecho de que ambos contendientes acudieran ante el conde: primero Mora le hizo partícipe de sus planes para tomar posesión del beneficio; después Quemada le solicitó directamente ayuda, consiguiendo finalmente su protección ${ }^{2411}$. No obstante, los infructuosos intentos del conde de propiciar una concordia entre las partes dejó el conflicto en una situación de inestabilidad y tensión entre las partes que se proyectó tanto en el ámbito urbano arandino como entre la nobleza comarcana. Llama bastante la atención que, a pesar de la impresionante movilización de recursos y personas que provocó este incidente y la evidente tensión que generó, el conflicto no evolucionó en un enfrentamiento abierto entre las partes sino que se mantuvo en una tensa manifestación de fuerza y capacidad de aglutinar aliados de cada una de las partes. Esta circunstancia también extrañó a los contemporáneos y así lo declaraba uno de los protagonistas del incidente, Pedro Sán-

${ }^{2409}$ Esta prohibición fue propuesta a los alcaldes por Gonzalo García de Quemada mientras Mora estaba reclutando a sus familiares y amigos. Tras la salida de la villa de la gente de Mora, Quemada procedió igual que Mora y consiguió que varios vecinos le siguieran (AGS, CC PUEBLOS, leg. 1, doc. 233).

${ }^{2410}$ AGS, CC PUEBLOS, leg. 1, doc. 231.

2411 AGS, CC PUEBLOS, leg. 1, doc. 233. Blaso, maestresala del conde de Miranda y presente en las conversaciones entre los implicados y el conde, declaró que Mora acudió primero a Peñaranda, no tanto para pedir ayuda, sino para conseguir el beneplácito del conde. Al día siguiente llegó Quemada que solicitó su ayuda aunque el conde se la negó alegando que ambos estaban entre sus aliados. Finalmente dio su protección a Quemada ante la llegada de caballeros vinculados al marqués de Denia. 
chez de Prado: ...en lo faser de la manera que lo hiso que fue maravilla non morir harta gente segund estava aparejado ansi de la una parte como de la otra ${ }^{2412}$.

Ante este panorama el Consejo Real se vio obligado a intervenir y al principio del otoño ordenó la recepción de testigos previa al proceso judicial que suponemos puso fin a la disputa aunque no a la tensión ${ }^{2413}$. Así parece ponerlo en evidencia la disputa que mantuvieron poco tiempo después Íñigo de Barahona, aliado como hemos visto de Mora, y el propio Gonzalo García de Quemada en 1492. No conocemos las causas de la disputa pero sí que ambos llegaron a agredirse y que Barahona fue sancionado con el destierro, aunque existían evidencias de la provocación previa de Quemada ${ }^{2414}$.

Independientemente de los motivos y el desarrollo de los acontecimientos, el episodio violento entre Mora y Quemada es revelador de una situación evidente de interrelación entre los distintos grupos de poder de la comarca. Ante un asunto de carácter netamente particular entre dos individuos, Juan de Aranda y Francisco García de Quemada, se implicó inmediatamente la familia, en el sentido amplio que este término tenía en las sociedades feudales. La intervención familiar suponía la rápida implicación de toda una red clientelar, no sólo del ámbito urbano próximo, sino también del espacio rural inmediato. Asimismo al conflicto se sumó un escalón más amplio de las redes clientelares pues implicó a las principales familias nobiliarias íntimamente relacionadas con los grupos oligárquicos urbanos.

Esta implicación de la nobleza comarcana también la apreciamos en el enfrentamiento que tuvo lugar en 1520 entre el regidor arandino Bernardino del Valle y Antonio Nieto, criado del conde de Miranda. El temor a que este conflicto generará violencia en el seno de la sociedad arandina motivó la intervención de la Corona que impuso una tregua entre ambos contendientes y sus respectivas clientelas ${ }^{2415}$.

Las divergencias entre los miembros de los linajes también se transmitieron a las reuniones del concejo generalizando una sensación de desgobierno que fue denunciada por los representantes del Común. A principios del siglo XVI, momento en el que el peso de la Comunidad en el ayuntamiento estaba limitado exclusivamente a sus dos procurares, la

${ }^{2412}$ Prado era vecino de Aranda y formó parte de las huestes que Quemada reunió para defender el beneficio de su hermano (AGS, CC PUEBLOS, leg. 1, doc. 233).

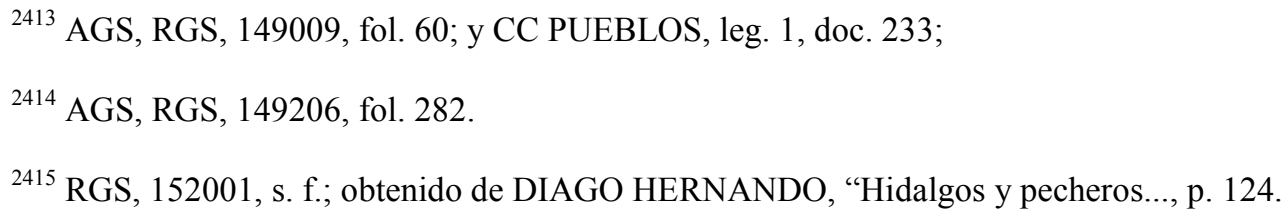


reina Juana I se vio obligada a intervenir por las disensiones internas de la oligarquía arandina. En el seno del Regimiento, que tenía por costumbre reunirse dos días por semana para tratar los asuntos de gobernación de la villa, existía tal diversidad de pareceres que no se llegaba a ningún acuerdo, lo que suponía gran perjuicio para la villa. La reina impuso que se votara como se hacía en otras ciudades y villas y que se acordara lo que decidiera la mayoría del regimiento. En realidad esta pragmática real tan solo recordaba el procedimiento que ya se utilizaba en Aranda desde hacía bastante tiempo y que derivó en fuertes discrepancias internas ${ }^{2416}$.

\section{1. 2. Enfrentamientos entre oligarquía y Comunidad.}

Los conflictos surgidos entre los miembros de la oligarquía no fueron impedimento para que se presentaran como una clase bien coexionada en el momento en que su posición era amenazada por cualquier agente exterior a su grupo, papel que habitualmente representaba el Común ${ }^{2417}$.

Como ya hemos visto anteriormente, la villa de Aranda contaba con dos linajes que copaban los oficios del gobierno municipal. Por su parte, el grueso de los vecinos se encontraba representado por la Comunidad. A pesar de la escasez de la documentación, ya se aprecian en los años 60 de la decimoquinta centuria enfrentamientos entre los linajes y la Comunidad. Durante el señorío de la reina Juana sobre la villa se produjeron ciertas tensiones en el seno del concejo provocadas por que algunos miembros de los linajes cambiaban de linaje, o incluso se pasaban a la Comunidad. La estabilidad también se vio mermada por la incipiente organización de la Comunidad que pretendía convertirse en órgano representativo autónomo, además de contar con fuentes de ingresos al margen del concejo y la autoridad real ${ }^{2418}$.

${ }^{2416}$ AMA, leg. 1222, doc. 17, transcrito por HURTADO QUERO, Documentos reales..., $\mathrm{n}^{\mathrm{o}} 33$, pp. 60-61.

${ }^{2417}$ Esta circunstancia ya ha sido identificada en varias ciudades castellanas como pone de manifiesto el trabajo de VAL VALDIVIESO, “Oligarquía versus Común..., p. 48.

${ }^{2418}$ AGS, RGS, 148002, fol. 256. Los procuradores de la comunidad denunciaban el incumplimiento por algunos vecinos de dos capítulos de las ordenanzas impuestas por la reina Juana que establecían por una parte,...que ningún vecino o morador de la villa que fuese de los linajes que dise de don Pedro García e de Don Romero e permanesciese en el linaje e una vez oviese entrado e entrase que no se mudase al otro ni entrase en el cuento de la comunydad so ciertas penas e destierros e perdimiento de bienes...; y por otra, ...que la dicha comunidad e omes buenos no puedan faser derrama ni repartimiento de mas e alla de tres mill maravedis syn nuestra liçençia. En el documento también se recogía la denuncia de los regidores que acusaban a los hombres buenos de la Comunidad de intentar tener campana e la repicar para reunirse sin pedir permiso al concejo. 
En los últimos años de la década de los 70 esta tendencia se mantuvo y degeneró en la ingobernabilidad de la villa a causa de ...debates e cuestiones que en esa dicha villa en cada un año ay sobre la eleçion de los ofiçios de alcaldias e regimientos e fieles $e$ escribano del conçejo e de la que se pone por el día de año Nuevo de cada año ${ }^{2419}$. Ante esta situación los representantes de la Comunidad solicitaron la intervención de la autoridad real bien a través de un pesquisidor con carácter puntual o bien con un corregidor permanente. Los miembros de los linajes se opusieron rotundamente a esta última opción apelando a los consabidos privilegios de la villa ${ }^{2420}$.

Como ya hemos visto anteriormente, a partir de 1480 la intervención de la Corona en la villa fue cada vez mayor: comenzó con el envío de pesquisidores para abordar problemas concretos, siguió con nombramientos intermitentes de corregidores y culminó con la reforma de todo el sistema concejil, implantando el sistema del regimiento perpetuo. Esta decisión se justificó por ... apartar e quitar las dichas diferençias e porque asy cunplia a nuestro serviçio e al bien e pro comun de la dicha villa e buen regimiento e governaçion della $^{2421}$.

Lejos de calmarse los ánimos entre linajes y comunidad, lo cierto es que se multiplicaron las denuncias recíprocas entre ambas partes. La situación llegó a su cenit a finales de la década de los ochenta cuando los regidores de la comunidad emprendieron una ofensiva contra los abusos de los regidores de los linajes y los alcaldes. La Corona accedió a enviar un pesquisidor y así en el verano de 1487 el bachiller Diego de Encinas comenzó sus investigaciones acompañado del escribano Pedro Rodríguez del Pulgar ${ }^{2422}$. La respuesta de los linajes no se hizo esperar y denunciaron a su vez los desmanes cometidos por los representantes de la Comunidad. Finalmente el pesquisidor presentó su memorial y como

\footnotetext{
${ }^{2419}$ AGS, RGS, 147803, fol. 37.

${ }^{2420}$ AGS, RGS, 148002, fol. 256; y 148006, fol. 138.
}

${ }^{2421}$ AGS, RGS, 148312, fol. 56; y AMA, leg. 43, doc. 15, transcrito por HURTADO QUERO, Documentos Reales..., no 15, pp. 31-33; y DIAGO HERNANDO, “Cambios políticos..., pp. 314-315. Esta misma dinámica se repitió en varios núcleos urbanos castellanos como, por ejemplo, en Laredo y otras villas cántabras (SOLÓRZANO TELECHEA, “De ‘Todos los más del pueblos’..., pp. 62-63).

${ }^{2422}$ AGS, RGS, 148707, fol. 59. En la orden se establecía un salario de 250 maravedíes por cada uno de los 30 días para el pesquisidor y 70 para su escribano. El plazo debió prorrogarse algunos días más pues a principios de septiembre los monarcas enviaron un oficial para que evaluara la necesidad de prorrogar su comisión (148709, fol. 201). Finalmente el 17 de septiembre se solicitó al bachiller que cobrara su salario y acudiera con la pesquisa realizada ante el Consejo Real (AGS, CC PUEBLOS, leg. 2, doc. 86; y RGS, 148709, 133). 
consecuencia de este informe el Consejo Real sancionó a varios de los implicados, entre los que se encontraban tanto de los regidores de los linajes como los representantes de la Comunidad $^{2423}$.

Sin embargo, ni las sucesivas intervenciones de los oficiales de la Corona ni la implantación definitiva del corregimiento lograron poner fin a este clima de crispación. Esta situación era perfectamente percibida por el resto de vecinos como lo expresan las declaraciones de varios testigos que afirmaban: ...que mas se deshonestan los regidores de la comunidad contra los de los linajes que no los de los linajes contra los de la comunidad; ...e que si mala se la daba el uno, que tan mala se la vuelve al otro; ...desde que estan juntos en el ayuntamiento, que si mala se la dice el uno, que mala se la vuelve el otro $^{2424}$.

La desaparición de los regidores de la Comunidad a mediados de la década de los noventa no supuso ningún cambio en esta oposición entre linajes y Común pues los procuradores de la Comunidad tomaron el relevo en la tarea de denunciar los desmanes de los regidores. Esta misma dinámica continuó hasta el estallido de la revolución comunera, momento en el cual buena parte de estos procuradores tomaron el control del poder municipal.

Si bien es cierto que los enfrentamientos se produjeron por multitud de causas, muchas de ellas coyunturales, se aprecia una serie de puntos específicos sobre los que giraba la mayor parte de los conflictos. Hemos intentado agrupar éstos bajo seis epígrafes genéricos que exponemos a continuación.

\section{a. Funcionamiento del concejo.}

La principal fuente de conflictos entre linajes y Comunidad en la villa de Aranda fue la ausencia de representación de alguna de las partes, generalmente de la Comunidad, en la toma de decisiones que se producían en el seno del concejo arandino. La mayoría de las denuncias que transmite la documentación delatan la prepotencia empleada por los

${ }^{2423}$ Sabemos por testimonios indirectos que los regidores de los linajes y alcaldes fueron obligados a reponer en las arcas del concejo las cantidades que habían gastado indebidamente, aunque no conocemos su cuantía (AMA. leg. 43, doc. 1, transcrito por HURTADO QUERO, Documentos Reales..., $\mathrm{n}^{\circ}$ 20, pp. 40-41). También sabemos que el regidor de la Comunidad Juan Fernández Mejías fue condenado a pagar 2.000 maravedíes de multa, mientras que su aliado Diego de Roa recibió la pena de 3.000 maravedíes (AGS, RGS, 148803, fol. 108).

${ }^{2424}$ AGS, CC MEMORIALES, leg. 161, doc. 122. 
regidores de los linajes en la toma de decisiones, relegando a los representantes de la Comunidad a la marginación o incluso impidiendo su asistencia a las reuniones. Pero esta circunstancia fue recíproca, pues los delegados del Común también actuaban de la misma manera siempre que tenían ocasión, aunque bien es cierto que esta circunstancia se produjo en muy contadas ocasiones.

Las ordenanzas que regulaban la actividad concejil tras la reforma efectuada por los monarcas a principios de los ochenta eran bastante claras al respecto:

Ytem puedan faser e fagan regimiento o conçejo todos los dichos regidores si se fallaren presentes en la dicha villa con los alcaldes o con uno dellos a lo menos la mayor parte de los dichos regidores con el dicho alcalde. Sy todos al dicho regimiento non vinieren o sy non pudieren venir e estovieren ausentes, que lo que todos o la mayor parte de los que asy venieren al dicho regimiento con el alcalde o alcaldes que ende se de acaescyeren, hordenaren o mandaren que aquello vala como sy fuese fecho por todo el dicho conçejo e regimiento, con tanto que en la dicha mayor parte aya regidor o regidores de amos los dichos linajes e de la comunidad e non en otra manera ${ }^{2425}$.

Los representantes de la Comunidad denunciaban sistemáticamente la situación de ingobernabilidad en la que se encontraba la villa y el despotismo con el que actuaban los regidores de los linajes. Argumentaban que éstos no contaban con los regidores de la Comunidad para tomar sus acuerdos contraviniendo lo establecido por los monarcas, llegando incluso a imponer decisiones municipales sin tan siquiera asistir a las sesiones del concejo, amparándose en su mayor número (seis contra tres) ${ }^{2426}$.

En ocasiones eran todos los regidores, tanto los de los linajes como los de la Comunidad, los que marginaban al resto de oficiales del concejo. En 1491 los alcaldes y cuadrilleros, por sy e en nombre de toda la republica de la dicha villa, denunciaron ...que por algunos de los dichos regidores dizen que los libramientos en que entendieren e consyntieren regidores de los tres estados que estos han de pasar syn ser vistos nin estimados

${ }^{2425}$ AGS, CC PUEBLOS, leg. 2, doc. 78. Los regidores de la Comunidad fueron un poco más allá e interpretaron la posibilidad de ejercer el derecho de veto por alguna de las partes: ...que mandamos que en el ayuntamiento que fesieses oviese de aver regidores de todos estados, que de otra guisa no valiese cosa alguna de los que se feçiese no consintiendo alguno de los tres estados (RGS, 148707, fol. 59).

${ }^{2426}$ AMA, leg. 43, doc. 1, transcrito por HURTADO QUERO, Documentos Reales..., no 20, pp. 40-41. Se trata de una sobre carta de los monarcas a petición de los regidores de la Comunidad por la que recuerdan la obligación de todos los regidores presentes en la villa de asistir a las reuniones del concejo. 
por los alcaldes de cuentas que sus altesas costituyeron e fundaron en esta villa ${ }^{2427}$.

Algunos meses después los monarcas respondieron ordenando a los regidores que permitieran la entrada de los procuradores de la villa y tierra como era costumbre para que pudieran controlar las actuaciones de los regidores, sobre todo en todos aquellos aspectos relacionados con la fiscalidad municipal ${ }^{2428}$.

También los regidores de la Comunidad ejecutaron decisiones sin tener en cuenta a los regidores de los linajes. Así ocurrió durante el verano de 1486 cuando los regidores de la Comunidad Martín Sánchez de Casasola, Juan Sánchez del Prado y Llorente González decidieron realizar ciertas contrataciones y modificar la puja de las carnicerías aprovechando que los otros regidores estaban ausentes de la villa a causa de un brote de peste $^{2429}$.

Además de la falta de representatividad en el seno del concejo, otro aspecto bastante conflictivo en el ayuntamiento arandino fue la asistencia a las sesiones y la dinámica que en ellas se seguía. En las ordenanzas se establecía la obligación de asistir a las reuniones municipales de todos los regidores que se encontraran en la villa. Sin embargo, existía un alto índice de absentismo y era bastante habitual la ausencia de un número elevado de regidores ${ }^{2430}$. De hecho, en todo el periodo estudiado tan solo hemos identificado una ocasión en la que estuvieran presentes todos los representantes municipales y se remonta ni más ni menos que a 1473 cuando la princesa Isabel acudió a la

${ }^{2427}$ AGS, CC PUEBLOS, leg. 2, doc. 88. El alcalde de cuentas fue un oficial creado con la reforma del regimiento. Era nombrado por la Comunidad y su función era fiscalizar la hacienda municipal.

${ }^{2428}$ Pedro del Castillo, representante de los procuradores de la villa y su tierra, denunciaba en 1491 que los regidores no permitían la entrada de los procuradores en las sesiones del ayuntamiento desde que se habían convertido en perpetuos. Argumentaba que antes de la reforma era costumbre que asistieran ...y estavan al hazer de los repartimientos y miravan en que se gastava e destribuia, e asy mismo en las contribuciones e gastos de la guerra y de la Hermandad, e en todas las otras cosas que se fazian (AGS, RGS, 149106, fol. 107).

${ }^{2429}$ Los regidores de la comunidad contrataron a un letrado para asesorar al concejo y a un clérigo para que espantara los nublados. También modificaron la puja de la carnicería y cambiaron los precios de la pescadería. Asimismo concedieron licencia a Pedro de Santa Cruz para que pudiera sacar madera de un monte comunal (AGS, CC MEMORIALES, leg. 149, doc. 230).

${ }^{2430}$ Bien es cierto que buena parte de los regidores perpetuos de la última década del XV o primeros años del XVI fueron hombres de negocios que tenían que atender sus numerosas compañías, como Pedro de Santa Cruz, Francisco de Mena o Gaspar de Santa Cruz. Otros estuvieron ocasionalmente al servicio de la Corona, como Pedro de Mora, Pedro de Salazar, los Acuña o los Avellaneda. Algunos formaron parte de las clientelas de la nobleza comarcana como el comendador Barahona o los Durango y se debían a las obligaciones para con sus señores. 
villa para jurar sus privilegios y tomar posesión de la misma ${ }^{2431}$. Este absentismo fue denunciado por la Comunidad que observó cómo los regidores no acudían a las sesiones o se ausentaban antes de terminar éstas. También denunciaban que los escribanos del concejo no hacían constar en el acta estas ausencias ${ }^{2432}$. Asimismo los representantes de la Comunidad objetaban que los regidores no cumplían sus funciones pero que, sin embargo, sí que cobraban su salario. Ante esta situación la reina ordenó que el escribano del concejo tomara nota de las ausencias y que cada cuatro meses, cuando los regidores cobraban su salario, se diera cuenta al mayordomo de las ausencias e impusiera un real de pena a descontar del salario por cada ausencia no justificada ${ }^{2433}$. También desde el Consejo Real se recordó a los regidores que debían cumplir con lo estipulado en las cortes de Toledo del año 1480 por lo que debían residir al menos cuatro meses al año en la villa, bien de forma continua o a intervalos. Establecía también que tan sólo podían justificar su ausencia de las sesiones, y por lo tanto seguir cobrando su salario, si estaban enfermos, estuvieran en la corte, al servicio de los reyes, o tuvieran licencia real para ello ${ }^{2434}$.

Pero los problemas no se limitaron al absentismo pues antes de comenzar las reuniones los regidores se enzarzaban en disputas sobre la posición que cada uno debía ocupar en la sesión causando grandes alborotos que repercutían en el orden público de la villa. Esta situación obligó a los monarcas a intervenir de nuevo ordenando a los regidores que se asentaran en el ayuntamiento por el orden en que fueron proveídos y recibieron el oficio de regidor perpetuo ${ }^{2435}$. El desarrollo de las reuniones del ayuntamiento tampoco estuvo libre de polémica pues en muchas ocasiones las inflexibles posturas encontradas de los

${ }^{2431}$ AMA, leg. 42, doc. 6, transcrito por HURTADO QUERO, Documentos Reales..., nº 11, pp. 24-26. El hecho de no conservar las actas del concejo limita en gran medida esta afirmación, pero lo cierto es que en raras ocasiones se reunían más de seis regidores. Así, por ejemplo, en la sesión que en 1518 debía nombrar a un nuevo escribano del número asistieron cinco de los nueve regidores y se justificaron varias ausencias por estar en la Corte -Antonio Miranda-, ante el Consejo Real -Bernardino del Valle-, como corregidor de Soria -Íñigo de Zúñiga- o al servicio del marqués de Denia en Tordesillas -Rodrigo de Durango- (AGS, CR, leg. 453, doc. 5).

${ }^{2432}$ AGS, RGS, 150102, fol. 356.

${ }^{2433}$ AMA, leg. 1222, doc. 18, transcrito por HURTADO QUERO, Documentos Reales..., $\mathrm{n}^{\circ}$ 28, pp. 53-55. $55-56$.

${ }^{2434}$ AMA, leg. 43, doc. 33, transcrito por HURTADO QUERO, Documentos Reales..., nº 29, pp.

2435 AGS, RGS, 150109, fol. 163; y AMA, leg. 43, doc. 34, transcrito por HURTADO QUERO, Documentos Reales..., $\mathrm{n}^{\circ} 30$, pp. 56-58. Aunque la carta estaba fechada en septiembre de 1501, es significativo que los regidores no se comprometieron a cumplir esta misiva hasta el 23 de junio de 1502. 
diversos bandos dentro del concejo provocaron la falta de acuerdos en gran perjuicio de la villa. De nuevo tuvo que intervenir la autoridad real para tratar de poner orden en el gobierno municipal $^{2436}$. Como vemos los pequeños problemas de orden dentro del concejo se convirtieron en la excusa perfecta que permitió que afloraran las tensiones que existieron entre los diferentes grupos instalados en el seno de la sociedad arandina.

En ocasiones estas discrepancias dentro del concejo dieron un paso más y provocaron enfrentamientos directos y violentos entre algunos regidores. Así ocurrió en 1487 cuando los regidores de los linajes Pedro de Salazar e Íñigo de Barahona insultaron y amenazaron a Martín Sánchez de Casasola y Juan Fernández Mejías, regidores de la comunidad. El motivo fue que estos últimos habían denunciado a una panadera, vecina de Salazar, por vender el pan a mayor precio del establecido. Como consecuencia de esta agresión los alcaldes apresaron a Pedro de Salazar que estuvo preso durante ocho días y después fue desterrado. Por las mismas fechas un escribano del concejo declaraba que ...estando los regidores todos juntos en la Plaça de Santa María, los regidores de los linajes dijeron que darian de palos a los de la comunidad. Asimismo vio ...como en el ayuntamiento se deshonestaban diciendo palabras feas a Juan Mejías ${ }^{2437}$.

Otro motivo de conflicto entre oligarquía y comunidad fue el nombramiento de los oficiales del concejo. En este periodo fue una práctica habitual que los regidores nombraran a estos entre sus parientes y allegados, sin que se tuviera en consideración su capacidad para el desempeño de las funciones encomendadas. Así lo denunciaba ya la Comunidad en 1478:

...por cabsa de los debates e cuestiones que en esa dicha villa en cada un año ay sobre la eleçion de los ofiçios, ...que los dichos oficiales son puestos por afeçion e favores e por que las personas que para ello se eligen tengan que tomar e non por los que ayan serviçio e a la buena governacion e regimiento desa dicha villa cumple, e por que las personas que en los dichos oficios se ponen no son ydonios ni pertenescientes para ello no lo saben governar como deven e las tales personas que asy se nombran para los tales oficios han fecho fasta muchos

${ }^{2436}$ AMA, leg. 1222, doc. 17, transcrito por HURTADO QUERO, Documentos Reales..., n 33 , pp. 60-61.

${ }^{2437}$ Estos testimonios están recogidos en el memorial presentado por el pesquisidor Diego de Encinas ante el Consejo Real en septiembre de 1487 (AGS, CC MEMORIALES, leg. 161, doc. 122). 
desafueros e agravios e synrazones a los mercaderes e oficiales e tratantes e otras personas vesinos de la dicha villa e su tierra ${ }^{2438}$.

A pesar de la reforma del regimiento desarrollada a principios de los ochenta, la elección de los oficiales menores siguió siendo anual y los regidores perpetuos continuaron eligiendo a los oficiales en función de sus intereses clientelares, dejando en un segundo plano sus capacidades para gestionar el oficio. Esta situación se reprodujo con cierta frecuencia con los nombramientos de alcaldes, como veremos más adelante, pero sobre todo con los oficios menores que, no obstante, tenían gran repercusión sobre la actividad económica.

En 1497 la Comunidad manifestó su preocupación porque los dos fieles nombrados eran incompetentes en su trabajo pues permitían a los regidores que fijaran los precios de los mantenimientos que se vendían en la villa, que impusieran las penas y que las cobraran para sí. Consideraban que esta desidia de los fieles generaba múltiples conflictos en la actividad económica de la villa y por lo tanto repercutía en sus haciendas y negocios ${ }^{2439}$. Las órdenes que enviaron los monarcas para poner freno a esta situación no consiguieron su objetivo pues un año después el procurador de Común, Alonso Daza, denunció que el regidor Pedro de Santa Cruz había nombrado como fiel a un vecino de su entera confianza, el zapatero Pedro de la Torre. El procurador consideraba que Torre no estaba capacitado para realizar correctamente el trabajo ...de andar sobre los oficiales sastres e zapateros e candeleros e tenderos e recatones e carniceros para que vendan las cosas buenas e sin macula e sin engaño de la republica e poner las viandas e castigar e penar los que no vendieren e medieren e pesaren las cosas bien e fielmente, pues él mismo participaba en negocios de compraventa de pellejos y cueros y además había arrendado junto a otros la renta de las varas y corambres. Añadía además que al ser zapatero difícilmente se impondrá a sí mismo las penas de ...quemar suelas ni pieças si las toviese falsas o quemadas como algunas vezes suele acaesçer. Ante estas denuncias los regidores, también los de la Comunidad, aseguraban que las denuncias de Alonso Daza no debían ser tenidas en consideración pues el procurador junto a otros vecinos de la villa provocaban alborotos inducidos por personas que querían hacer mal a los regidores ${ }^{2440}$.

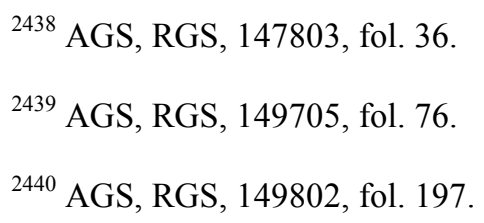


Así pues, se puede concluir que la organización interna y funcionamiento del concejo fue un motivo recurrente para el enfrentamiento entre la oligarquía dominante y la mayor parte de la vecindad representada por los regidores o procuradores de la Comunidad. Esta enconada situación trascendió de las relaciones personales y derivó en la parálisis del ayuntamiento con las correspondientes repercusiones sobre la actividad socioeconómica de la villa.

\section{b. Aplicación de la justicia.}

Los alcaldes ordinarios eran los encargados de administrar la justicia en primera instancia. Recordemos que hasta principios de los ochenta cada uno de los linajes elegía a su alcalde. Con la reforma emprendida por los monarcas se aumentó a tres su número, estableciéndose que el tercer oficial fuera elegido por la Comunidad. Poco después, con la implantación definitiva del corregimiento en la villa, el corregidor y su teniente monopolizaron la administración de la justicia.

Durante todo el periodo estudiado se observa como una constante las quejas de la Comunidad o de particulares que denunciaban la parcialidad de la justicia aplicada por los alcaldes. El principal argumento presentado por la Comunidad era que ...ningund alcalde de los que en la dicha villa se ponen no fasen otra cosa ninguna, salvo lo que le manda aquel que le nombro por alcalde ${ }^{2441}$. Algunos vecinos también se quejaban de esta situación como Juan de Aranda que en 1478 fue objeto de la agresión de Luis, hijo de Diego de Roa y declaraba ante los monarcas que ...las justicias de esa dicha villa han seydo del vando e parentela del dicho Luys. Este comentario no tendría más relevancia si no fuera porque Roa era un reconocido miembro de los linajes arandinos con un importante papel en la vida política de la villa en aquella época ${ }^{2442}$. En otras ocasiones los vecinos no eran tan explícitos y tan solo se quejaban de los atropellos de la justicia y la arbitraria imposición de penas, que además iban a engrosar directamente las haciendas de alcaldes y regidores ${ }^{2443}$.

${ }^{2441}$ AGS, RGS, 148707, fol. 59.

${ }^{2442}$ AGS, RGS, 148006, fol. 157. En el capítulo dedicado a los hidalgos urbanos ya hemos abordado la figura de Diego de Roa. El detonante del enfrentamiento entre Juan de Aranda y Luis de Roa fue que Aranda se encontró en la puerta de su casa al hijo de Roa jugando a las tablas con otras personas de manera que no le dejaban pasar. Aranda les solicitó que se retirasen pero el tal Luis le injurió y le tiró el tablero a la cabeza, después entró en su casa y le dio unos puñetazos y bofetadas. Suponemos que este episodio esconde un problema más importante pues ambos contendientes pertenecen a familias destacadas de la villa. Por el momento la documentación consultada no nos ofrece más pistas.

${ }^{2443}$ AGS, RGS, 148509, fol. 89. 
La constante denuncia de falta de justicia obligó en varias ocasiones a los monarcas a intervenir directamente a través del envío temporal de pesquisidores. El episodio que nos parece más relevante se produjo en 1487 cuando los reyes comisionaron por un mes al bachiller Diego de Encinas junto al escribano Pedro Rodríguez del Pulgar para que investigara sobre la situación real de la justicia en la villa ${ }^{2444}$. Previamente el Condestable había establecido que los tres alcaldes se presentaran ante él para dar explicación de los abusos de los que se les acusaba. El Condestable ordenó asimismo que se pregonara en Aranda esta decisión y se invitara a los vecinos agraviados a que presentaran sus quejas ante él ${ }^{2445}$. Durante este periodo se retiró la vara de la justicia a los alcaldes y fue el pesquisidor quien actuó como juez ordinario en numerosos litigios, mientras acometía la tarea encomendada por los monarcas ${ }^{2446}$. Precisamente su actuación como juez ordinario se vio inmersa en la polémica pues tanto él como su escribano fueron acusados también de parcialidad en numerosas ocasiones $^{2447}$.

El memorial que finalmente entregó Encinas al Consejo Real recogía un notable número de irregularidades que habían cometido los regidores y alcaldes de la villa ${ }^{2448}$. Entre otras cosas, acusaba a los alcaldes de cometer cohecho al liberar a una mujer acusada de manceba de fraile a cambio de 30 reales y en atención a que el fraile con el que estaba era el administrador del cercano monasterio de Santa María de La Vid. Igualmente fueron imputados por haber utilizado la violencia para conseguir la confesión de varias mujeres acusadas injustamente de mancebía de clérigo.

${ }^{2444}$ AGS, RGS, 148707, fol. 59; 148709, fols. 133 y 201; y CC PUEBLOS, leg. 2, doc. 86.

${ }^{2445}$ AGS, CC PUEBLOS, leg. 2, doc. 82. El pregón se leyó en la Plaza de Santa María el 25 de julio. Ese mismo día los alcaldes y regidores de los linajes, en nombre del concejo, dieron su poder a varios vecinos para que acudieran a Burgos y representaran al concejo en cuantos pleitos fuera necesario.

${ }^{2446}$ AGS, RGS, 148708, fols. 59 y 118.

${ }^{2447}$ Alonso de Guadalajara informó al Consejo Real de que Francisco de la Vega quebró su casa de la Plaza Nueva cerca de la media noche con la intención de matarle o robarle y cometer adulterio con su mujer. Pudo evitarlo porque estaba despierto pero resultó herido en un brazo. Lo denunció ante los alcaldes pero cuando éstos iban a proceder llegó el pesquisidor y sacó a De la Vega de la cadena porque era su pariente. El Consejo ordenó a Encinas que tomara declaración a los implicados e hiciera justicia acompañado de dos regidores (AGS, RGS, 148708, fol. 118). Por su parte, Pulgar fue acusado por el regidor Gonzalo García de Quemada de no querer recoger las declaraciones de los testigos presentados por su parte para la elaboración del memorial del pesquisidor (CC PUEBLOS, leg. 2, fol. 64).

${ }^{2448}$ AGS, CC MEMORIALES, leg. 161, doc. 122. Las acusaciones y testimonios presentados a continuación han sido obtenidos de este amplio documento. 
En el informe también señalaba que los alcaldes Juan Fernández del Concejo y Pedro García Ortuño habían cometido varias irregularidades en el proceso contra el judío Caicaza. Por una parte, mantuvieron preso a este judío por más de 50 días sin motivo; alteraron la declaración de los testigos en su proceso además de coaccionarles con amenazas, violencia y prisión; $y$, por último, se negaron a entregarle el traslado de la declaración de los testigos ${ }^{2449}$. Otra declaración aseguraba que el alcalde Juan Fernández del Concejo cometió injusticia con unos pleiteantes sobre una parte de una casa, dando sentencia sin los otros alcaldes y condenando a quien mejor lo había probado. Esta última declaración estaba libre de toda sospecha de parcialidad pues el testigo era el escribano ante el que había pasado el proceso y fue presentado por la defensa de los regidores de los linajes y los alcaldes ${ }^{2450}$.

Con la implantación definitiva del corregimiento en la villa y la asunción por este agente real de la justicia ordinaria se puso fin casi definitivamente a la presencia extraordinaria de oficiales de justicia. Pero siguió siendo una práctica habitual que la parte condenada en cualquier proceso adujera parcialidad del juez en su perjuicio e incluso solicitara de los monarcas la intervención de un pesquisidor. Generalmente esta solicitud no era aceptada y el procedimiento pasaba por la apelación ante el Consejo Real o el recurso a la Audiencia ${ }^{2451}$. La figura del pesquisidor se limitó a situaciones muy concretas relativas a problemas de jurisdicción eclesiástica ${ }^{2452}$.

Todo parece indicar que la situación de la justicia en la villa de Aranda a finales de la Edad Media fue una fuente constante de conflictos entre los oficiales que la ejercieron y los vecinos como sujetos pacientes de su ejercicio. A tenor de las denuncias de los vecinos, pero también de los informes de los pesquisidores reales, podemos concluir que la justicia administrada por los alcaldes ordinarios estuvo marcada por cierto grado de parcialidad y

${ }^{2449}$ Este episodio ya ha sido desarrollado en el apartado dedicado a la violencia contra las minorías religiosas.

${ }^{2450}$ Desgraciadamente no conocemos el nombre del escribano pues en la probanza aparece identificado como número siete y no se incluye la relación de testigos.

${ }^{2451}$ Así ocurrió en el conocido pleito de la apertura de la calle de Barrionuevo de 1503 en el que los propietarios de las casas de la Calle del Pozo solicitaron el envío de un pesquisidor ante el informe favorable del corregidor que apoyaba el derribo de sus casas para crear la nueva calle (AGS, CR, leg. 39, doc. 3$)$.

${ }^{2452}$ Es 1510 se nombró como pesquisidor al licenciado Francisco Velázquez para que investigara ciertos altercados entre la justicia ordinaria de la villa de Aranda y unos estudiantes y clérigos vinculados al convento de San Francisco (AGS, CC PUEBLOS, leg. 2, doc. 100). 
vinculada a los intereses de la oligarquía dominante que, no lo olvidemos, poseía la facultad de nombrar a estos alcaldes. El carácter colegiado del ejercicio de la justicia y la inclusión de un alcalde nombrado por la Comunidad no parece que fuera un obstáculo insalvable para el mantenimiento de esta parcialidad. Tan solo la asunción de la justicia por parte del corregidor parece frenar en cierta medida esta situación.

\section{c. Gestión de los ingresos concejiles.}

No tenemos constancia documental sobre los recursos propios de la villa. Las noticias sobre estos ingresos están muy fragmentadas ${ }^{2453}$. Una de las principales partidas se obtenía del arrendamiento de la pescadería y carnicería ${ }^{2454}$. Asimismo la villa era propietaria de varios solares en el núcleo urbano que arrendaba a los vecinos por unas cantidades variables según la situación de las viviendas o la actividad económica que albergara ${ }^{2455}$. Otro de los ingresos provenía de las licencias que otorgaba el concejo para la extracción de madera de los montes comunales ${ }^{2456}$ y también se obtenían recursos por determinados usos de los pastos comunales ${ }^{2457}$. A buen seguro que existían otras fuentes de ingresos pero desconocemos por el momento su naturaleza. Lo cierto es que a finales del siglo XV se estimaba que los propios de la villa rentaban al año más o menos 150.000 maravedíes $^{2458}$. A pesar de que se trataba de una cantidad significativa, se percibe entre el vecindario la sensación generalizada de que estos ingresos eran muy escasos en comparación de las necesidades de la villa, como muestran las declaraciones de diferentes vecinos que insisten en asegurar que ...la dicha

${ }^{2453}$ Dentro de este concepto de ingresos se incluyen aquellos que provenían de los bienes de propios, bienes comunales y los derivados de la hacienda concejil. Con carácter extraordinario también se recurría al préstamo (AGS, CC PUEBLOS, leg. 2, doc. 104).

${ }^{2454}$ AGS, CC PUEBLOS, leg. 2, doc. 104; y CC MEMORIALES, leg. 149, doc. 173.

2455 AGS, CC PUEBLOS, leg. 2, doc. 104. La villa arrendó en los años sesenta un solar a una familia burgalesa que lo utilizó para desarrollar un negocio de tintorería (RGS, 148711, fol. 36).

${ }^{2456}$ AGS, CC MEMORIALES, leg. 161, doc. 122.

${ }^{2457}$ En principio los vecinos podían hacer uso de los comunales de la villa para pastar siempre que respetaran panes y viñas. En1486 se impuso una renta a los carniceros judíos para el ganado que excediera de las cincuenta cabezas anuales (AGS, RGS, 148607, fol. 72). Esta misma carga se aplicó sobre todos los vecinos en 1497 (149705, fol. 133).

2458 Esta suma es la que se estimaba había rentado para el ejercicio del año 1495 (AGS, RGS, 149512, fol. 31). A este montante seguramente se sumaban otros ingresos provenientes de comunales o impuestos extraordinarios 
villa tiene pocos propios e muy grand gasto. Estos recursos fiscales eran utilizados por el concejo para hacer frente a los gastos ordinarios como eran el pago de los sueldos de los oficiales concejiles y del corregidor, el abono del censo sobre Revilla de Olleros que se debía pagar al abad de La Vid y ...las guardas de los montes e pan e vino desa dicha villa, como en otras muchas cosas de gastos que estas dicha villa tiene de nescesidad de se guardar. La precariedad de los recursos propios obligaba en muchas ocasiones a solicitar autorización para echar sisa sobre los mantenimientos y así satisfacer la fiscalidad regia, como era el caso de los servicios ${ }^{2459}$.

En principio era el mayordomo el encargado de llevar el control de los ingresos y gastos relacionados con los propios, pero eran los regidores los que marcaban las directrices tanto para regular los ingresos como para decidir los gastos. También tenemos constancia de que, al menos en algunas ocasiones, se enviaba un informe al Consejo Real con el montante de los ingresos y gastos de estas rentas de propios ${ }^{2460}$.

La gestión de los ingresos de la villa fue otro motivo de discrepancia entre oligarquía y Comunidad. Cierto era que estos recursos eran muy limitados, pero su control era codiciado por ambas partes. Y los dos grupos se denunciaron mutuamente, acusando a la parte contraria de utilizarlos en beneficio propio y no en el de la villa.

Habitualmente los representantes de la Comunidad justificaban sus denuncias alegando que ...visto que tenemos jurado el byen e parte e comun de la dicha villa e vesinos della, e visto que esto non es en bien ni en parte de la dicha villa, salvo en su dapno, e que non es serviçio de sus altesas quel dinero de la republica sea gastado en afavoresçer a ningunos regidores nin alcaldes en sus propias cabsas por vias yudideras $^{2461}$. Pero lo cierto es que la malversación de los fondos de la villa y su utilización para la defensa de intereses privados de los miembros del concejo fue una práctica habitual en el seno del ayuntamiento arandino.

${ }^{2459}$ AGS, CC PUEBLOS, leg. 2, doc. 92. La petición se hizo en 1503 alegando que la villa tiene debdas del servicio de las señoras ynfantas.

${ }^{2460}$ No conocemos ninguno de estos informes pero en 1513 el procurador del Común envió un memorial a la reina en el que decía ...que la quentas quel escribano del concejo de la dicha villa embio a vuestra alteza dexo de poner en ellos los maravedies que valieron las cortas que se dieron de los montes de la dicha villa. Suplico a vuestra alteza mande al dicho escribano embie el valor dello e quien lo rescibio para que por vuestra alteza visto se provea lo que sea justicia (AGS, CC PUEBLOS, leg. 2, doc. 104). No tenemos la certeza de que este procedimiento fuera algo habitual o si más bien respondió a una circunstancia excepcional vinculada a las denuncias de los representantes de la Comunidad y a la apertura de un proceso judicial.

${ }^{2461}$ AGS, CC PUEBLOS, leg. 2, doc. 78. 
El ejemplo más elocuente nos lo muestra el proceso del derribo del batán construido a principios de 1487 sobre la presa de la aceña de los hermanos Mejías. Esta aceña se encontraba derruida a mediados de los años setenta cuando los Mejías la adquirieron y repararon $^{2462}$. Algún tiempo después se construyó el batán por iniciativa de Pedro de Santa Cruz que había comprado la mitad del negocio de la aceña a los hermanos Mejías ${ }^{2463}$. A principios de marzo el concejo consideró que esta nueva construcción violaba el espacio público de la villa y propuso como ...es costumbre en la villa buena y laudable que si algun vecino de fuera entrare y tomare o ocupare cosa concejil como exido, campo, termino o ribera sin licencia o merced de la villa que esto sea derrocado y el edificador pague a la villa el valor de aquello que entró y no goce de ello; y si otra vez torna asimismo pague lo que le tasaren y no se quede con ello, sino que lo derribaren ${ }^{2464}$. En una sesión del concejo los regidores presentes decidieron por unanimidad derribar el batán ...porque lo hedificava en lo de la villa e que se esperava de alli grande daño por que un monte suyo que estava çerca de alli se perderia e otros ynconvenientes ${ }^{2465}$. Además amenazaron a los Mejía con derribar también la aceña si en el plazo de diez días no presentaban sus títulos de propiedad. Rápidamente los Mejías recurrieron a la justicia real y consiguieron del Condestable una carta por la que se ordenaba al concejo que paralizara los derribos y compareciera ante él para justificar las medidas ${ }^{2466}$. Además los monarcas comisionaron a Alonso de Valladolid, ejecutor de la Hermandad de Valladolid, para que investigara lo sucedido y enviase su pesquisa al Consejo ${ }^{2467}$. Comenzaba así un proceso que se complicó por la negativa de los regidores de la comunidad, Martín Sánchez de Casasola y Juan Fernández Mejías, a que se financiara con dinero público los sucesivos recursos del concejo contra la decisión del Condestable de pa-

${ }^{2462}$ Pedro y Francisco Mejías, propietarios de la aceña, eran hermanos del regidor de la Comunidad Juan Fernández Mejías. Esta aceña fue construida durante el primer cuarto del siglo XV (AGS, CC PUEBLOS, leg. 2, doc. 80).

${ }^{2463}$ Pedro de Santa Cruz compró la participación de Juan Fernández Mejías que suponía el 50\% de la aceña por un montante aproximado de 200.000 maravedíes (AGS, RGS, 148711, fol. 53).

${ }^{2464}$ AGS, CC MEMORIALES, leg. 161, doc. 122.

${ }^{2465}$ AGS, CC PUEBLOS, leg. 2, doc. 60. En la sesión estuvieron presentes los tres alcaldes, los regidores de los linajes Fernando de Covarrubias, Íñigo de Barahona, Pedro de Mora y Pedro de Salazar, más los de la Comunidad Juan de Aranda y Martín Sánchez de Casasola. Todos ellos decidieron demoler el batán.

\footnotetext{
${ }^{2466}$ AGS, CC PUEBLOS, leg. 2, doc. 80.

${ }^{2467}$ AGS, CC PUEBLOS, leg. 2, doc. 60.
} 
ralizar los derribos. Por ello solicitaron al mayordomo que no proveyera el dinero necesario para proseguir este pleito. No obstante, los regidores de los linajes se opusieron a esta medida y mantuvieron la provisión de fondos para seguir el proceso $^{2468}$. Efectivamente los regidores de los linajes tomaron el dinero de la sisa sobre la carnicería para pagar los gastos derivados de llevar a Burgos el problema del batán ${ }^{2469}$. Este episodio culminó en primera instancia con una resolución de los monarcas por la que se ordenaba reconstruir el batán y además se condenaba a los alcaldes y regidores de los linajes a restituir el dinero que habían tomado de los propios de la villa de manera irregular ${ }^{2470}$.

Pero realmente detrás de este episodio se escondían intereses contrapuestos de algunos de los oficiales del concejo que estaban directamente afectados por este asunto. En primer lugar, es evidente la relación de los propietarios del batán con el regidor de la comunidad Juan Fernández Mejías. Por otra parte, los representantes de la Comunidad advertían al Condestable de la implicación de algunos oficiales del concejo en el proceso, los cuales ...querian meter el pleito de la dicha açeña en ello para proseguir la dicha causa junto con lo del batan Avasdevilla porque el açeña que con la dicha açeña y batan del dicho Santa Crus de los Mexias tiene el dicho pleyto y pendencia es del dicho Yñigo Barahona regidor e de Diego Sanches, suegro del dicho Juan de Revenga, e por el uno ser alcalde y el otro regidor querian faser lo uno y lo otro, vos y pleyto de los bienes de la dicha villa ${ }^{2471}$. Y es que previamente al episodio del batán los propietarios de las aceñas de la Sinovilla, situadas inmediatamente aguas abajo del batán, habían denunciado la reconstrucción del aceña de los Mejías argumentando que causaba gran daño a su negocio molturador ${ }^{2472}$.

No obstante, la postura más contradictoria e interesada en este episodio fue la del regidor de la Comunidad Martín Sánchez Casasola. Precisamente Casasola fue el que presentó ante el concejo la denuncia que motivó el derribo del batán y el que emitió el pri-

\footnotetext{
${ }^{2468}$ Los regidores de la Comunidad solicitaron esta medida el 13 de abril y los de los linajes mostraron su negativa el 10 de mayo (AGS, CC PUEBLOS, leg. 2, doc. 78).

${ }^{2469}$ AGS, CC MEMORIALES, leg. 161, doc. 122.

${ }^{2470}$ AGS, RGS, 148707, fol. 63; y AMA. leg. 43, doc. 1, transcrito por HURTADO QUERO, Documentos Reales..., n ${ }^{\circ} 20$, pp. 40-41.

${ }^{2471}$ AGS, CC PUEBLOS, leg. 2, doc. 83.

${ }^{2472}$ Parece ser que en 1487 el proceso ya llevaba dos años ante la justicia real, pero todavía en octubre se estaba emplazando a los implicados (AGS, RGS, 148710, fol. 39).
} 
mer voto a favor de la demolición ${ }^{2473}$. Sin embargo, rápidamente cambió de opinión y se convirtió en defensor de los intereses de los propietarios del batán, denunciando las ocultas pretensiones de los regidores de los linajes y la utilización de los fondos públicos para conseguir sus fines. Sus enemigos le acusaron de haberse convertido en el instrumento de Pedro de Santa Cruz para imponer sus intereses en el concejo pues éste le proporcionó dinero para enviar mensajeros al Condestable y le habría garantizado 100.000 maravedíes en caso de que perdiera su regimiento por el radical cambio de opinión ${ }^{2474}$. Fueran o no ciertas estas acusaciones, lo cierto fue que la relación entre Casasola y Santa Cruz fue muy estrecha en el futuro inmediato pues recordemos que Santa Cruz obtuvo su regimiento en 1494 gracias a la renuncia a su favor realizada por Casasola, maniobra que no fue más que la fórmula legal que escondía una compraventa del regimiento ${ }^{2475}$.

Todo este cúmulo de intereses contrapuestos culminó definitivamente en marzo de 1488 cuando Barahona y sus socios solicitaron la ejecución de la sentencia definitiva de la Audiencia Real por la que se ordenaba derribar el aceña y batán de los Mejías ${ }^{2476}$. También supuso la desvinculación de Santa Cruz de este asunto pues meses antes, temiendo la resolución contraria a sus intereses, reclamó a Juan Fernández Mejías los 200.000 maravedíes abonados $^{2477}$.

Paralelamente al proceso del batán, salieron a la luz una serie de irregularidades cometidas por algunos de sus protagonistas. Así, los representantes de la Comunidad denunciaron que el regidor Íñigo de Barahona había tomado prestados hacía más de tres años 4.000 maravedíes del mayordomo del concejo, sin que por el momento los hubiera devuelto. Además también había asignado 50 reales de los propios de la villa para el mantenimiento de uno de sus hijos ${ }^{2478}$.

${ }^{2473}$ Así lo reconoce él mismo en la declaración que hizo ante Alonso de Valladolid (AGS, CC PUEBLOS, leg. 2, doc. 79).

${ }^{2474}$ AGS, CC MEMORIALES, leg. 149, doc. 230.

${ }^{2475}$ AGS, RGS, 149406, fol. 74; y 149910, fol. 125.

${ }^{2476} \mathrm{ARChV}$, RRE, Caja 12, doc. 44. El pleito tiene una primera sentencia de las justicias ordinarias de Aranda por la que se ordenaba detener las obras de reconstrucción de la aceña de los Mejías. A pesar de la apelación de los Mejías ante la Audiencia, la sentencia definitiva ordenó derribar la aceña.

${ }^{2477}$ AGS, RGS, 148711, fol. 53.

${ }^{2478}$ AGS, CC PUEBLOS, leg. 2, doc. 83 
Los regidores de la Comunidad tampoco se libraron de las denuncias de irregularidades. En concreto, se acusaba a Martín Sánchez de Casasola de haber concedido licencia para cortar madera en el monte de Quemada a Pedro de Santa Cruz cuando éste no era todavía vecino de la villa y a sabiendas de que era necesaria la firma de tres regidores para que fuera válido el permiso. Asimismo fue acusado de haber contratado sin necesidad ni acuerdo del concejo a un letrado escasamente cualificado. También se le recriminaba, como ya se ha indicado, haber pagado 4.000 maravedíes a un clérigo para que espantase los truenos e relampagos e nublos ${ }^{2479}$.

En ocasiones puntuales el conjunto del regimiento fue denunciado por los vecinos de atribuirse ciertas prebendas sobre los propios de la villa. En 1491 los representantes de las cuadrillas denunciaron ante el Consejo Real que los regidores habían impuesto ...los dichos yantares por su propia autoridad sobre las rentas e propios del dicho concejo e sobre los ofiçiales de la dicha villa en grand dapno de la republica della cargandose sobre los vecinos della en los precios de las cosas lo que se libra por los dichos yantares e a menguando del precio que darian por las tales rentas lo que se les paga por los dichos yantares ${ }^{2480}$.

Otras veces simplemente disponían arbitrariamente de los propios de la villa. Así ocurrió en 1496 cuando los regidores y otros oficiales tomaron jerga y luto por la muerte de la reina madre de los propios de la villa a pesar de cierta carta real que lo prohibía. Los monarcas enviaron una amonestación a los oficiales, obligándoles a restituir lo tomado y entregárselo al mayordomo del concejo. Pero este mandamiento nunca fue cumplido $^{2481}$.

En 1498 Juan Daza, procurador de la villa, informó a los monarcas de que la justicia y regidores cobraban las penas para sí y no para las obras pías y reparos de la villa en gran perjuicio de ésta. La respuesta de los monarcas no hizo más que recordar disposiciones y penas que ya se habían enviado en varias ocasiones anteriores sobre este mismo asunto ${ }^{2482}$. Todo ello hace pensar que ésta era una práctica muy extendida y que

${ }^{2479}$ AGS, CC MEMORIALES, leg. 149, doc. 230.

${ }^{2480}$ AGS, CC PUEBLOS, leg. 2, doc. 88.

${ }^{2481}$ AGS, RGS, 149802, fol. 283. Aunque los hechos ocurrieron en 1496, la denuncia no se tramitó hasta más de un año después. $50-52$.

${ }^{2482}$ AMA. leg. 42, doc. 3, transcrito por HURTADO QUERO, Documentos Reales..., n 26, pp. 
el efecto de las denuncias de la Comunidad y de las misivas reales fue más bien limitado.

Las irregularidades en la gestión del dinero público sobrepasaron en ocasiones los propios de la villa y afectaron a las rentas de la Corona. En 1513 el procurador del Común, Miguel Sánchez de la Torre, denunciaba que el concejo pidió prestado dinero a Pedro de Santa Cruz para comprar pan para la villa. El pan se tajo ...e los regidores e justicias de la dicha villa vendieron el dicho pan e cobraron los maravedies que valia e los gastaron en lo que quisieron e pagaron al dicho Pedro de Santa Cruz veinte e seis mill maravedies de los maravedies del cabezamiento y esto no lo enbiaron a vuestra alteza por que no se supiese $^{2483}$.

Todos estos ejemplos ponen claramente de manifiesto el uso particular que de manera habitual hacían de los recursos públicos de la villa los miembros del gobierno municipal, fuera cual fuera su adscripción y condición. En definitiva, la clase dominante arandina participaba de la misma dinámica que se percibe en otros núcleos urbanos castellanos en este periodo.

\section{d. Exención fiscal.}

Tal y como ocurre en otras ciudades de la Corona de Castilla, en la villa de Aranda a finales de la Edad Media se produjo un incremento de la conflictividad entre el Común de pecheros y los grupos de hidalgos instalados en ella como consecuencia de la negativa de estos últimos a contribuir en algunos impuestos concretos. Esta problemática fiscal fue bastante habitual en núcleos urbanos en crecimiento y estaba en relación con la progresiva aristocratización y el cerramiento de la clase dominante ${ }^{2484}$.

En el caso concreto de Aranda el conflicto se planteó a causa de que un pequeño grupo de familias hidalgas, casi todas ellas instaladas en la villa durante la década de los setenta del siglo $\mathrm{XV}$, se negaba a pagar la martiniega, alegando la exención por su condición de hidalgos.

La martiniega era una renta o censo sobre heredades que se pagaba al señor del lugar, en este caso al rey. Este censo se pagaba en Aranda por lo menos desde mediados del siglo XIV y en el siglo XV se encuadraba dentro de la recaudación de las alcaba-

\footnotetext{
${ }^{2483}$ AGS, CC PUEBLOS, leg. 2, doc. 104.

${ }^{2484}$ VAL VALDIVIESO, “Oligarquía versus Común..., p. 49.
} 
las $^{2485}$. Recibe su nombre de la fecha de pago, el día de San Martín (11 de noviembre $)^{2486}$. La cantidad fijada para este censo era bastante modesta pues ascendía a 4.920 maravedíes anuales y se mantuvo estable durante todo el periodo que nos ocupa ${ }^{2487}$.

En principio, la villa poblada a fuero contaba con un privilegio desde tiempo inmemorial que implicaba que ...qualesquier personas que han byvido e vibieren e moraren en la dicha villa diz que fueron e son obligados de pechar e cotribuyr en todos los pechos e derramas que la dicha villa e su tierra ovieren de repartyr en las martiniegas para los gastos e neçesidades de la dicha villa e su tierra; ... e que en otra manera no podrian ser vecinos de la dicha villa ni aver parte en los ofiçios della. Insistían en que no había excepción pues ...siempre desde que la dicha villa se poblo e ay vezinos e moradores en ella, aunque fuesen fidalgos notorios, pagaron syempre en las dichas martyniegas ${ }^{2488}$. Añadían que en el pasado nobles tan ilustres como don Juan, rey de Navarra y Aragón, y el Condestable Álvaro de Luna tuvieron casa en la villa y contribuyeron a la martiniega por guardar la costumbre ${ }^{2489}$.

Los argumentos de una y otra parte eran bastante simples. Los hidalgos aseguraban que cualquier imposición fiscal era incompatible con su condición de privilegiado y por lo tanto su actitud de no contribuir a la martiniega no iba contra derecho. Por su parte, el concejo argumentaba que la imposición de la martiniega tenía condición censual y además no se echaba por la condición de la persona, sino por los bienes que poseían en la villa, siendo un tributo continuo e invariable en la villa. Finalmente el concejo aseguraba que la villa poseía ordenanza antigua confirmada por los reyes que establecía ...que si cavalleros e omes fijosdalgo comprasen bienes algunos de los bienes llanos de pecheros de la dicha villa que pasasen con su $\operatorname{cargo}^{2490}$. Evidentemente, al ser un

${ }^{2485}$ AMA, leg. 40, doc. 2.

${ }^{2486}$ En Aranda esta fecha coincidía con el momento en el que salía a la venta el vino de la cosecha de ese año.

${ }^{2487}$ En 1478 ya estaba establecida en 4.920 maravedíes y así se mantuvo por lo menos hasta principios del siglo XVI (AGS, EH, leg. 4; y CMC, leg. 41).

${ }^{2488}$ AGS, RGS, 148811, fol. 176; y 148901, fol. 261. Asimismo en la cercana localidad de Quintana del Pidio los hidalgos también estaban exentos del pago de impuestos a su señor el abad de Silos, salvo los pechos concejiles y la martiniega (AGS, CC PUEBLOS, leg. 16, doc. 5).

2489 ...en las quales avian contribuydo el señor rey don Juan tenyendo hazienda en la dicha villa e el maestre de Santiago don Álvaro de Luna e Juan Álvarez Delgadillo e Gutierre Delgadillo su padre e otros muchos cavalleros e fijosdalgo (ARChV, RRE, Caja 259, doc. 5).

${ }^{2490}$ ARChV, RRE, Caja 259, doc. 5. 
impuesto que se repartía entre todos los propietarios, la negativa de los hidalgos repercutía directamente sobre el resto de los propietarios pecheros, circunstancia que explica perfectamente la movilización de éstos.

El conflicto tuvo su punto álgido a finales de la década de los ochenta y se dilató durante todos los noventa. El primer incidente del que tenemos noticia se produjo en 1488 cuando Pedro de Salazar, García de Salazar, Juan de Revenga, por sí y en nombre de Diego Fernández de Valladolid, Pedro de Mora, Íñigo de Barahona y Martín de Acuña, se negaron a pagar la martiniega aludiendo a su condición de hidalgos. Ante esta situación los regidores de la Comunidad los denunciaron por incumplimiento de la costumbre inmemorial argumentando que ...los susodichos, que por se fallar emparentados e favorecidos e nuevos regidores, quieren quebrantar la posesión y costumbre anti$\mathrm{gua}^{2491}$. A continuación ordenaron a los alcaldes que tomaran ciertos bienes de los implicados en concepto de fianzas. Evidentemente esta medida provocó la apelación de los hidalgos ante la justicia real que comisionó al bachiller Francisco de Vargas como pesquisidor para que pusiera orden en la villa. El pesquisidor dio cuenta ...de la división e estado en que estava esa dicha villa y envió un informe a los monarcas. Éstos optaron por ordenar en octubre que no se tomaran prendas, que se devolvieran las ya tomadas y que se mandasen las pruebas para que el Consejo dictara lo conveniente. Finalmente insistían en la imperiosa necesidad de que cesasen los escándalos. Pero esta decisión no fue aplicada por el concejo a tenor de las sobrecartas insistentes que se volvieron a enviar en noviembre y diciembre; es más, las autoridades municipales decidieron desterrar a los hidalgos que se negaban a pagar ${ }^{2492}$.

Una nueva carta de los monarcas a principios del año 1489 provocó un nuevo brote de violencia. En esta carta se ordenaba, por una parte, que los hidalgos pagaran la martiniega mientras seguía su curso el proceso judicial y, por otra, que el concejo alzase el destierro de los implicados ${ }^{2493}$. El concejo cumplió el mandato real y levantó el destierro, pero la mayoría de los hidalgos siguieron negándose a pagar. Esta situación enardeció la ira popular que se materializó el día de San Blas cuando un numeroso grupo de

${ }^{2491}$ AGS, RGS, 148811, fol. 176.

2492 AGS, RGS, 148912, fol. 129; y AMA. leg. 41, doc. 5, transcrito por HURTADO QUERO, Documentos Reales..., no 21, pp. 41-43.

${ }^{2493}$ AGS, RGS, 148901, fol. 261. 
vecinos ...fueron a las casas de los susodichos (don Martín de Acuña, el comendador Íñigo de Barahona, Pedro de Salazar y García de Salazar) sin armas e les requirieron que se saliesen de la dicha villa e no se tyraron delante sus puertas fasta que ovieron salido de la dicha villa ${ }^{2494}$.

Ante esta situación, los más perjudicados por la exención fiscal de los privilegiados optaron por plantear a la Corona un cambio en el formato de esta renta. En este sentido, Juan Muñoz, procurador de la Comunidad, solicitó en 1497 a los monarcas que se estudiara la posibilidad de cambiar la martiniega por una sisa sobre los mantenimientos porque ...muchas veses se siguen discordias e diferençias, e algunas veses muchos pleitos e contiendas. Los monarcas comisionaron al corregidor para que estudiara la viabilidad de esta solución pero nada sabemos sobre su informe ${ }^{2495}$

La resolución del conflicto de la exención fiscal tardó bastante tiempo en llegar. La mayor parte de los hidalgos arandinos optaron por emprender pleitos de forma individual contra el concejo que finalmente ganaron ${ }^{2496}$, con lo que el concejo no tuvo más remedio que aceptar la extensión de la condición de privilegiado sobre los bienes inmuebles propiedad de los hidalgos. De esta manera la justicia real confirmó una situación de privilegio que se impuso de forma definitiva sobre la tradición foral de la villa.

Quizá fuera esta negativa de los hidalgos a pagar la martiniega el motivo por el que en algunas ocasiones el concejo denegó el avecindamiento de ciertos nobles como fue el caso de Lope Ochoa de Avellaneda en $1485^{2497}$.

Como ya hemos comentado, este impuesto estaba asociado a las propiedades y el modesto montante global se repartía entre todos los vecinos propietarios. Por lo tanto, aunque la exención de unos repercutía sobre las aportaciones del resto, no parece que en la

${ }^{2494}$ AGS, RGS, 148902, fol. 132. Ante las acusaciones de agresión por parte de los hidalgos, los monarcas mandaron llamar al regidor Gonzalo García de Quemada para que informara sobre los sucesos. Es significativo que Quemada, regidor pero también pechero, además de informar conforme a la solicitud real, también rogó a los monarcas que no se permitiera la exención de los hidalgos.

2495 AGS, RGS, 149705, fol. 137.

${ }^{2496}$ Fue el caso de Martín Vázquez de Acuña en 1496 o de su hijo, Juan Vázquez de Acuña, en 1511. El mismo camino siguieron Pedro y García de Salazar y Martín de Durango (ARChV, RRE, Caja 106, doc. 6; y Caja 259, doc. 5).

${ }^{2497}$ A Lope Ochoa de Avellaneda se le impidió en 1485 avecindarse en Aranda a causa, según él mismo argumentaba, de ciertas enemistades con los alcaldes de la villa (AGS, RGS, 148504, fol. 93). Esta misma dinámica también se observa en algunas villas riojanas argumentando, además de la cuestión fiscal, que así se evitaban conflictos sociales y por temor a la posible injerencia nobiliaria en la autonomía concejil (GOICOLEA JULIÁN, F. J. El gobierno urbano en La Rioja en época medieval e inicios de la Edad Moderna (s. XIII-mediados del XVI. Logroño, 2004, pp. 97-103). 
disputa entre pecheros e hidalgos tuviera un peso determinante el aspecto económico. Nos inclinamos a pensar que fue sobre todo el significado simbólico de esta exención el que encendió la mecha del enfrentamiento. Se planteaba por lo tanto una disputa entre dos formas muy diferentes de entender el espacio en que se desarrollaba su vida. Por una parte, un reducido grupo de hidalgos, muchos de ellos recientemente instalados en la villa, que reivindicaban su exención amparados en su condición de privilegiados. Frente a ellos se situaba la masa social de los vecinos de la villa que esgrimía una legitimidad que hundía sus raíces en la tradición foral que, al fin y al cabo, parece erigirse en el principal emblema que dotaba al colectivo urbano de identidad propia. La evolución de este conflicto y el triunfo final de la posición hidalga sobre las tesis del resto de los vecinos evidencia claramente la marcada distancia que existía entre el concepto de ciudad, entendido como comunidad de vecinos, que desarrollaron uno y otro grupo.

\section{e. Regulación de la actividad económica.}

La proyección de la autoridad concejil sobre la actividad económica de la villa fue uno de los más importantes generadores de conflictos, puesto que las decisiones que tomaban los oficiales municipales repercutían directamente y de manera constante sobre el conjunto de los vecinos. No debemos olvidar que esta capacidad de intervención sobre la vida productiva de los vecinos estaba estrechamente vinculada al ejercicio del poder concejil y, por lo tanto, todas las decisiones de los regidores o sus oficiales estaban legitimadas en el principio de la defensa del bien e parte e comun de la dicha vi$l l a^{2498}$. Entre las prerrogativas de los oficiales concejiles se encontraba la de velar por el abastecimiento de la villa, controlando los precios, pesos y mediadas; vigilar el desarrollo de actividades económicas que entrañaban cierto peligro; garantizar la seguridad;... En fin, un largo etcétera tan amplio como lo era la diversidad económica de un núcleo urbano medieval.

Ante tal diversidad la casuística de los conflictos fue necesariamente muy variada. En algunos momentos el problema surgía cuando las decisiones de las autoridades chocaban con los intereses de algunos particulares porque, en principio, se anteponía el provecho de la colectividad por encima del particular. Pero en otras ocasiones, fueron

${ }^{2498}$ ASENJO GONZÁLEZ, "Las ciudades..., pp. 105-140; y BONACHÍA HERNANDO, J. A., "La justicia en los municipios castellanos bajomedievales", en Edad Media. Revista de Historia. 1, 1998, pp. 145-182. 
los intereses propios del grupo dominante los que marcaron la pauta en la toma de decisiones que afectaban a la colectividad. Cuando se daba esta circunstancia, los poderosos utilizaron una serie de recursos para convencer a la comunidad de la idoneidad de su actuación. Si lo conseguían, su posición de poder y control social se veía reforzada; en caso contrario, la sociedad urbana se sumía en un nuevo enfrentamiento. Cierto es que los conflictos que se generaron fueron de escaso calado, aunque constantes en el tiempo, circunstancia que contribuyó inevitablemente a potenciar la dicotomía social en el seno del colectivo urbano.

Absolutamente todos los aspectos de la vida económica de la villa de Aranda estaban inmersos en esta dinámica de confrontación de intereses. A continuación haremos un breve análisis de aquellas actividades e incidencias que nos parecen más significativas para ilustrar el continuo fluir de conflictos que se produjo en el seno de la sociedad arandina durante los últimos decenios del siglo XV y los primeros años del Quinientos.

Frente a la idea generalmente difundida sobre la prevalencia de la actividad agraria en la villa, conviene tener en cuenta que su principal actividad económica fue el comercio. Sin lugar a dudas, su posición estratégica como cruce de caminos y la venta del producto de la principal actividad agrícola, el vino, convirtieron a Aranda en un activo mercado de carácter comarcal, que también tuvo cierta proyección en el ámbito regional $^{2499}$. Conocedores de esta situación, tanto las autoridades como los vecinos trataron de preservar y fomentar esta actividad. Para ello demandaron en primer lugar seguridad y, todavía con mayor intensidad, la eliminación de trabas e impedimentos para el desarrollo de la actividad. Entre estas trabas destacó sobre todo la imposición de nuevos impuestos o sisas. Cuando el impositor fue la Corona, la villa se mostró unánime en su discurso como lo muestra la información trasmitida por el concejo a la reina en 1516 ...si demas de todo esto se oviese de hechar otra (sisa) para complir lo delas armas, el preçio de los mantenimientos se acreçienta ya de manera que los del pueblo apenas los pudiesen comprar y el transito desta villa, que es el mayor bien que tiene, se perdiera totalmente por que visto los estrangeros la cabeça de los mantenimientos e las ynposiçiones de las mercaderias no abria ni honbre que aquí beniese a gastar ni a comprar ni a vender y aun seria mucha causa de menoscabar las rentas de Vuestra Alteza $a^{2500 .}$

\footnotetext{
${ }^{2499}$ IGLESIAS BERZOSA, "Importancia del vino..., pp. 75-116.

${ }^{2500}$ AGS, CC PUEBLOS, leg. 2, doc. 55.
} 
Pero, como veremos a continuación, esta unanimidad se rompía cuando eran las autoridades municipales las que imponían y gestionaban los impuestos sobre los mantenimientos.

Siendo el comercio del vino el de mayor calado en la economía arandina no es de extrañar que todos los vecinos trataran de obtener el máximo provecho de esta actividad. En 1491 los representantes de las cuadrillas denunciaban que los regidores habían promovido un incremento de los impuestos sobre la venta del vino a través de los corredores del vino. A pesar de lo establecido en las Cortes de Toledo que permitía gravar al comprador una blanca para la carga y un maravedí para la carreta de vino, las autoridades permitieron que los corredores cobraran el doble de lo establecido. Además se debía añadir el medio real que cobraban al propietario del vino vendido. Ante esta queja el Consejo Real ordenó al concejo que se cumpliera la legislación vigente ${ }^{2501}$. Las autoridades, a pesar de argumentar que el montante del impuesto no lo habían fijado ellos sino que estaba así dispuesto en la villa desde hacía al menos treinta años, procedieron a cumplir con lo dispuesto por los monarcas ${ }^{2502}$. Finalmente en 1491 los arrendadores de la renta del vino se vieron obligados a devolver a más de doscientos vecinos cerca de 45.000 maravedíes que fueron repartidos entre los afectados por el excesivo cobro entre los años 1487 y $1490^{2503}$.

Precisamente la modificación de las condiciones del arrendamiento de la correduría del vino provocó un nuevo conflicto entre corredores y oficiales, además de la constatación de un claro caso de corrupción en el seno del concejo. Tras la aplicación de las medidas impuestas por los monarcas, los corredores argumentaron que las nuevas condiciones perjudicaban notablemente su negocio. Pero además acusaban a los regidores de coaccionarles para que aceptaran esta nueva situación bajo la amenaza de prisión. En la posterior investigación también se constató que los regidores impusieron a los

${ }^{2501}$ AGS, CC PUEBLOS, leg. 2, doc. 88. Realmente lo que solicitaba el procurador de las cuadrillas era la supresión del impuesto en sí, reclamación que evidentemente no se concedió.

${ }^{2502}$ AGS, CC PUEBLOS, leg. 2, doc. 89. El procurador de los regidores expuso en su defensa que los corredores cobraban a los vecinos 10 maravedíes si vendían una cuba de menos de 100 cántaras y medio real si superaba esa capacidad. Si la cuba no era vendida por ellos no cobraban nada. También confirmó que la blanca que se cobraba a los forasteros por sacar de la villa una bestia cargada de vino era un impuesto vigente desde tiempos inmemoriales y que desde hacía tres decenios se había añadido otra blanca.

${ }^{2503}$ AGS, CC PUEBLOS, leg. 2, doc. 77. Fueron 224 los vecinos a los que se les devolvió dinero. Las cantidades oscilaban entre las varias decenas y el millar de maravedíes. 
corredores un yantar en su propio provecho y que era una práctica habitual el ofrecimiento de regalos a las autoridades como medio para mejorar las condiciones del arrendamiento de la correduría del vino ${ }^{2504}$.

También la venta del pan se vio afectada por estas irregularidades. Como ya hemos apuntado, en 1487 el regidor Pedro de Salazar trató de evitar que una panadera vecina suya fuera detenida por aumentar fraudulentamente el precio del pan. Cuando los regidores de la comunidad acudieron a detener a la panadera acompañados de los alcaldes y pregonero se produjo un intercambio de insultos y amenazas: Salazar se dirigió a Casasola y le dijo ...pese a tal con este teso (terco) y continuó ....tanto podeis vos volver que lo lleveis encima de la cabeça a palos. Barahona, que acompañaba a Salazar, añadió ...palos no mas cuchilladas al que se desonestare. Este enfrentamiento le supuso a Salazar el destierro de la villa durante una temporada ${ }^{2505}$.

Más problemas presentó la venta del pescado. Desde los tiempos en que don Juan de Navarra era señor de Aranda los tratantes mercaderes de pescado e sardina y aseites, vesinos de la dicha villa gozaban de un privilegio que permitía a los vecinos de esa villa vender libremente pescado, congrio e sardina y otras mercaderías, entendiendo esta libertad como exención de impuestos extraordinarios. Pero en 1483 el concejo impuso una ordenanza por la que anulaba dicho privilegio e imponía a los tratantes de pescado una nueva renta, denominada con el genérico postura, por la que cada uno de ellos debía abonar 2.000 maravedíes al concejo. Evidentemente tal resolución soliviantó al gremio de pescaderos que reclamó ante los monarcas. Éstos ordenaron al concejo que restituyera y guardara el privilegio, además de devolver las prendas que ya había tomado a los mercaderes de pescado para abonar el nuevo impuesto. Con la intención de que no hubiera problemas con la justicia local, los reyes emplazaron al concejo a que dirimiera este asunto ante la justicia del Consejo Real ${ }^{2506}$. No obstante, esta determinación de la autoridad real no tuvo el efecto solicitado por los tratantes de pescado pues en 1491 los representantes de las cuadrillas volvieron a denunciar que ...los regidores dela dicha villa lieban de los pescados frescos que a ella se vienen a bender çiertas pieças e çiertas libras lo qual avian

${ }^{2504}$ AGS, CC MEMORIALES, leg. 150, doc. 45. La denuncia la presentó Pedro de Ortega, corredor del vino en 1490. Uno de los testigos presentados en la información aseguró que García de Buitrago, arrendador de la correduría en 1489, entregó çiertos zamarros a los regidores para que le dejaran la correduría abierta.

${ }^{2505}$ AGS, CC MEMORIALES, leg. 161, doc. 122.

${ }^{2506}$ AGS, RGS, 148311, fol. 140. 
e han por muy molesto e por cosa de gran fatiga los pescadores; e que por esta cabsa muchas veses se pasan syn vender aqui sus pescados, e sy los venden cargan en los precios lo que les lieban de los dichos derechos a que llaman ellos posturas. En su denuncia recuerdan los cuadrilleros que el Consejo Real ya había enviado una sentencia ...por donde se manda que las dichas posturas non se lieben so çiertas penas, lo qual non enbargante los dichos regidores las han lebado e lieban. La respuesta del Consejo fue ratificarse en el anterior mandamiento y prohibir al concejo el cobro de la postura, aunque realmente desconocemos la efectividad de tal medida ${ }^{2507}$.

El soborno también se contemplaba como medio para conseguir cierta flexibilidad a la hora de fijar los precios. En 1487 fueron los regidores de los linajes los que denunciaron al regidor de la comunidad Martín Sánchez Casasola por permitir que su sobrino pudiera vender las sardinas a mayor precio de lo establecido. La acusación mantenía que Casasola fue sobornado por su sobrino pues el regidor se había encontrado en la escalera de su casa una banasta de besugos, aunque bien es cierto que nadie sabía quién la había dejado allín 2508 .

La actividad de los carniceros se vio asimismo afectada por las irregularidades de los regidores tanto de los linajes como de la comunidad. De nuevo en 1487 los regidores de la comunidad alteraron el precio de la carne aumentándolo en una blanca por libra. A tenor de los carniceros, la medida se tomó para evitar perder dinero por la subida del precio del vacuno a causa de la peste. Pero también era cierto que el regidor Casasola tenía mucha confianza con los carniceros pues entraba en la carnicería, partía un pedazo de carnero, lo pesaba y lo llevaba para su casa, previo pago a los carniceros. Evidentemente este aumento del precio causó un gran malestar entre la vecindad, generando grandes alborotos e incluso amenazas de muerte a uno de los regidores ${ }^{2509}$. En 1498 fue Alonso Daza, procurador de la villa de Aranda, el que informó de que los regidores de la villa ponían el precio de la carne de forma arbitraria sin acordarlo con el concejo. Comunicaba además que había un regidor, al que no nombra, que tenía hecha

${ }^{2507}$ AGS, CC PUEBLOS, leg. 2, doc. 88. En este documento se encuentra un resumen de las quejas que los cuadrilleros de Aranda enviaron a los monarcas en la primavera de 1491.

${ }^{2508}$ AGS, CC MEMORIALES, leg. 149, doc. 230. Este documento es una probanza realizada por los regidores de los linajes en la que recogen varias conductas irregulares de los regidores de la comunidad.

${ }^{2509}$ AGS, CC MEMORIALES, leg. 149, doc. 230. 
iguala con los carniceros para no controlar su negocio ni imponerles multas. El regidor en cuestión recibía a cambio cierto género todas las semanas ${ }^{2510}$.

Otro tipo de conflicto fue el que se vivió la segunda mitad de los años ochenta en el arrabal de Allendeduero con la actividad comercial como trasfondo. En 1486 los vecinos y moradores del arrabal informaron al pesquisidor Juan Alonso de Toro que desde hacía algunos años la morería había sido instalada en este arrabal y esta nueva situación les causaba gran daño y perjuicio pues ...los moros estan muy publicos y desonestos viviendo en una calle tan publica y caminanta, donde el trato de los vecinos y pueblo se pierde por estar la dicha calle abierta como esta, y los que pasan por alli se abastecen primero en los moros de esa calle y no en la villa y cristianos. Tras recoger las informaciones oportunas, el pesquisidor resolvió cerrar la morería con dos portones e impedir que los mudéjares tuvieran negocios comerciales en ella ${ }^{2511}$. Pero la situación se complicó un poco más a principios del año 1490 cuando los regidores, a buen seguro a instancias de los comerciantes vecinos de la villa pero esta vez intramuros, prohibieron que hubiera en el arrabal de Allendeduero ...tiendas de cosas de comer y de aver tiendas de barberos y sastres y zapateros. A pesar de la oposición de los vecinos del arrabal, las autoridades hicieron cumplir esta resolución y cerraron los establecimientos, además de confiscar los productos que en ellos se encontraban. Los representantes de los vecinos alegaron que tal decisión iba en contra de la costumbre inmemorial y además suponía un perjuicio tanto para sus haciendas como para los muchos caminantes que llegaban al arrabal y ya no iban a encontrar lo que necesitasen. Por último, exponían su temor a que el arrabal se despoblara y, no sin cierto cinismo, advertían de que esta medida provocaría ...muchos agravios e mal e dapno a los moros que viben e moran en el dicho arrabal e tienen su morería destinta e apartada ${ }^{2512}$.

La intervención de los regidores también se extendió sobre la comercialización de otros productos artesanales con el objetivo de controlar tanto su mercado como la actividad de determinados sectores.

La actividad de los tratantes y mercaderes de paños en Aranda experimentó un importante desarrollo durante las últimas décadas de la decimoquinta centuria como

${ }^{2510}$ AGS, RGS, 149802, fol. 283.

2511 AGS, CC MEMORIALES, leg. 163, doc. 57.

${ }^{2512}$ AGS, RGS, 149002, fol. 176. Idéntica medida tomaron las autoridades de Bilbao prohibiendo la venta fuera de sus murallas (VAL VALDIVIESO, "La identidad urbana..., pp. 17-18). 
muestran las crecientes referencias a este oficio pero, sobre todo, el aumento notable y constante de la renta de los paños que pasó de 40.000 maravedíes anuales en 1478 a 161.000 en 1497. A comienzos del Quinientos, incluso antes de las crisis de subsistencia de 1504, se observa un descenso significativo en la venta pues la renta se contrajo hasta los 90.000 maravedíes en 1502 y siguió descendiendo hasta 1506 que sumó 78.780 maravedíes $^{2513}$.

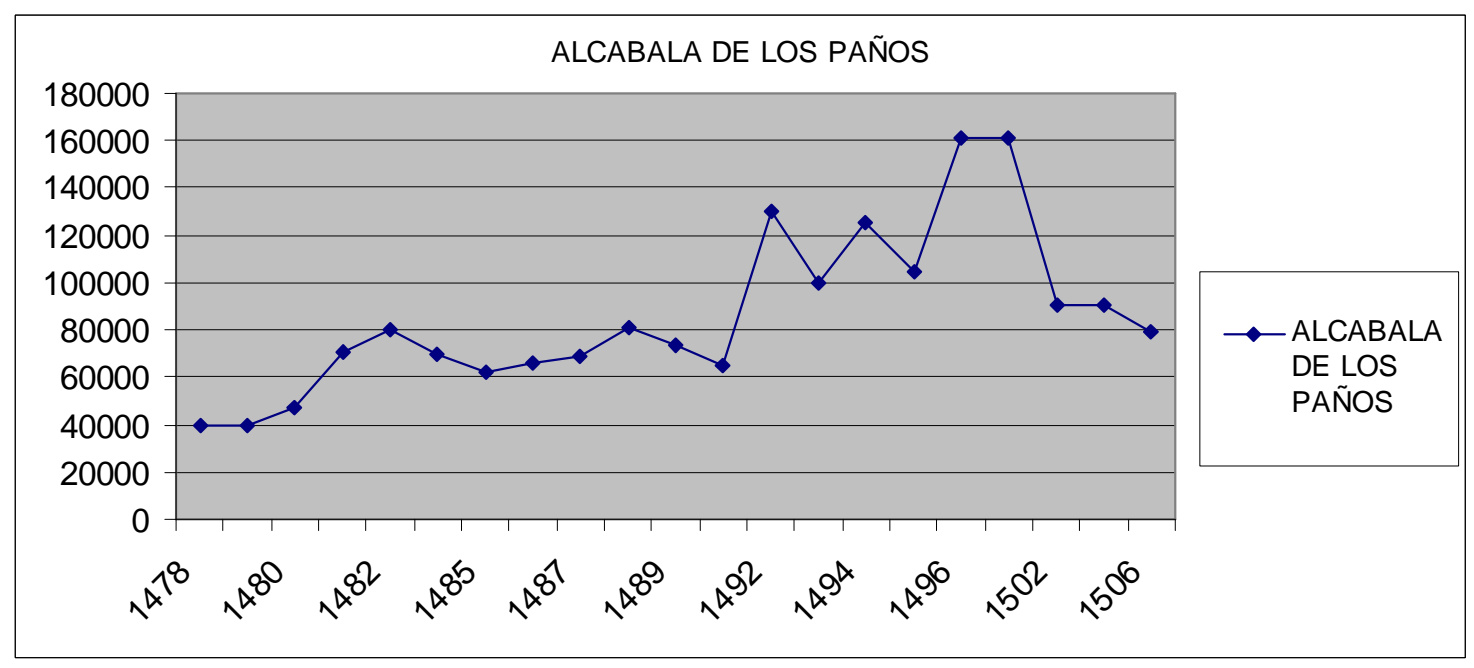

Cuadro 18: Evolución de la alcabala de los paños en Aranda (1478-1506).

Esta actividad estaba regulada como en el resto de Castilla a través de las pragmáticas reales que establecían las condiciones específicas de la venta de tejidos. Así se pone de manifiesto en la misiva que se envió a Aranda y otras muchas villas y ciudades en octubre de $1494^{2514}$. Las autoridades locales se comprometieron a hacer cumplir las normas y a intervenir en caso de observar irregularidades. Esta intervención podía ser efectuada por mandato real o por iniciativa propia, a través de los fieles del concejo. Ejemplo del primer caso lo encontramos en la comisión que recibió el juez de residencia de Aranda en 1494. En ella se le ordenaba que investigara las irregularidades cometidas en las pasadas ferias de noviembre de San Esteban de Gormaz cuando mercaderes de Soria, Aranda, Almazán y San Esteban vendieron los paños ...vareados al pulgar, e juntos sin tundir, e sin mojar, a todo mojar, contraviniendo precisamente la ordenanza enviada el mes anterior. La justicia real puso su acento en la gravedad del hecho de que los

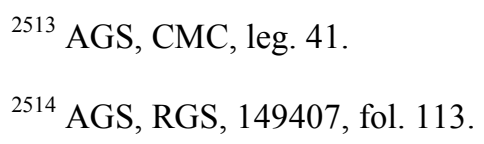


mercaderes se concertasen con los alcaldes ordinarios y con el alcaide de San Esteban para que les permitieran infringir las ordenanzas a cambio de cierta cantidad de maravedíes $^{2515}$. No obstante, aparte de casos puntuales como el anterior, el procedimiento más habitual fue la actuación ordinaria de los oficiales del concejo que se encargaban de velar por el cumplimiento de la normativa y solucionar los problemas habituales en este tipo de transacciones. Así ocurrió, por ejemplo, en 1502 cuando los veedores de la villa, Diego de Gumiel, Francisco de Guadalupe y Pedro González, denunciaron ante el teniente de corregidor que Marcos de Burgos, mercader de paños y vecino de Dueñas, había vendido siete paños negros a unos mercaderes arandinos, ...los quales estavan por mojar e por tundir e tarados e, aun lo que peor hera, que estavan teñidos falsamente e con falsas tintas de que heran avidos por falsos. El mercader palentino fue multado, aunque su recurso prosperó en la Audiencia de Valladolid ${ }^{2516}$.

La actuación de estos oficiales en ocasiones sobrepasaba lo estipulado por la norma como tuvo lugar en 1498 cuando varios tratantes de paños locales denunciaron que las justicias y regidores de la villa habían acudido a sus tiendas y tomado ciertos paños so especie, con el argumento de que no podían tener ni vender paños berníes ${ }^{2517}$. A juicio de los mercaderes esta prohibición no se encontraba en la pragmática real y respondía más bien a los intereses personales de las autoridades locales ${ }^{2518}$.

De igual manera en 1501 el mantero Juan González denunciaba ante los monarcas que las autoridades locales le impedían desarrollar su trabajo. En concreto le prohibían dar tintura a sayales y demás obras gruesas en lana castellana, a pesar de que cumplía rigurosamente la pragmática real. En consecuencia el Consejo Real ordenó al corregidor que restableciera la legalidad y defendiera los intereses del artesano ${ }^{2519}$.

La actividad de los zapateros era bastante más modesta en cuanto a volumen de negocio pero fueron bastante numerosos los artesanos que se ganaron la vida con este oficio en la villa de Aranda. Esta actividad, como veremos a continuación, también se

${ }^{2515}$ AGS, RGS, 149412, fol. 402.

${ }^{2516}$ ARChV, RRE, Caja 180, doc. 12.

${ }^{2517}$ El paño berní o bernés era un tejido basto de lana con el que se hacían las capas.

2518 AGS, RGS, 149810, fol. 293. Los mercaderes arandinos eran Francisco Mejías, Diego Sánchez de Mansilla, Gonzalo del Rincón, Juan Esteban, Pedro Cendero, Francisco de Peñafiel, Francisco de Maderuelo y Juan González.

${ }^{2519}$ AGS, RGS, 150101, fol. 30. 
vio afectada por el creciente intervencionismo de las autoridades locales sobre la actividad económica.

En el verano de 1501 comenzó el enfrentamiento entre el regimiento y el gremio de zapateros arandino a causa de la imposición por parte de las autoridades locales de unas nuevas ordenanzas que regulaban la actividad, producción y precios ${ }^{2520}$.

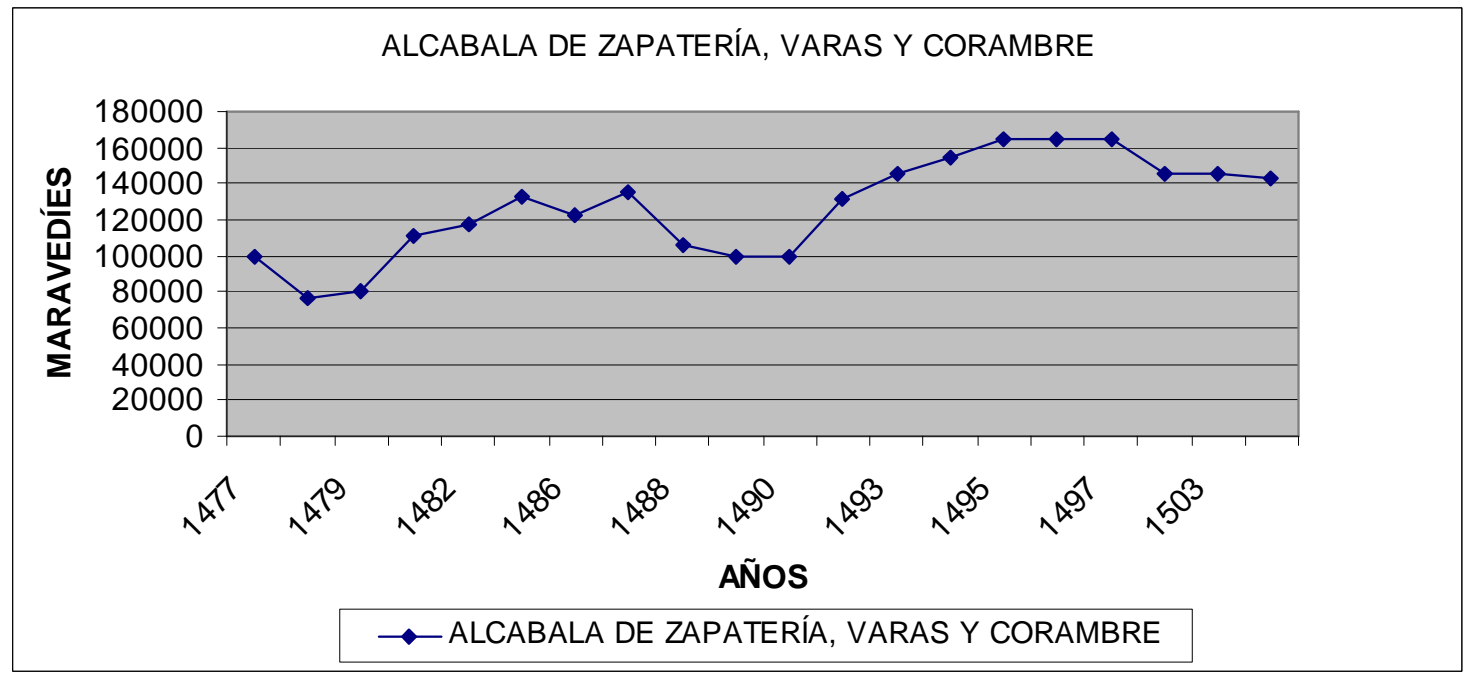

Cuadro 19: Evolución de la renta de cueros y corambre en Aranda (1477-1505).

Las ordenanzas contenían veinticuatro artículos que establecían una tasación muy precisa de calidades, características y precios máximos de cada uno de los productos elaborados por los zapateros arandinos. Además imponía la elección anual de dos veedores entre los miembros del gremio para que, siempre acompañados de dos regidores, se encargaran de hacer cumplir lo establecido en las nuevas ordenanzas. Llama la atención que el segundo y tercer capítulos de estas ordenanzas establecían una serie de medidas encaminadas a evitar el acaparamiento de materia prima por parte de los zapateros, lo que hace pensar que existía cierto problema de especulación con el cuero que salía de las carnicerías arandinas. Y es que ya en 1488 el gremio de zapateros, de la mano de su procurador Martín Delguera, ya había presentado una queja ante los monarcas denunciando que los carniceros de la villa vendían sus corambres y cueros de las carnes

${ }^{2520}$ Toda la información a la que nos vamos a referir ha sido obtenida de ARChV, PLEITOS CIVILES, PÉREZ ALONSO (F), Caja 676, doc. 6. Estas ordenanzas fueron publicadas y pregonadas con trompeta el 18 de julio de 1501 en la plaza y gradas de Santa María de la villa de Aranda por Juan de Oyales. Estaban presentes el alcalde de corregidor, Alfonso de la Cadena, los regidores Pedro de Mora, Martín de Durango y Antonio de Quemada, y el procurador del común Diego García de Fuentenebro, entre otros. 
que mataban a personas de fuera de la villa $y$, aunque les habían requerido que se los vendieran, persistían en su actitud por lo que se causaba gran perjuicio a sus negocios y a las rentas reales ${ }^{2521}$. En este sentido, no es de extrañar la notable competencia que se aprecia en el control de los cueros que se producían en la villa pues no debemos olvidar que Aranda debía contar con una importante industria de curtidores y pellejeros que aprovisionaba a la importante actividad vinculada al transporte del vino ${ }^{2522}$.

La imposición de estas nuevas ordenanzas provocó el rechazo del gremio de zapateros que celebró una reunión como era costumbre en la casa de Pedro de Salinas. A la reunión acudió un buen número de zapateros y estuvo presidida por el alcalde, Julián Borceguilero, acompañado del mayordomo, Juan de Vallejo. Tras un corto debate, la asamblea comisionó a su alcalde para que presentara una apelación ante la Audiencia Real. El primer argumento de la apelación se basaba en que las ordenanzas eran injustas porque ...de derecho es prohibida e denegada la tasaçion en los tales ofiçios e cosas de mercadurias, afirmación que si estuviera fechada un par de siglos más tarde identificaríamos sin dudarlo con la defensa de los principios del libre mercado si no fuera porque finalmente se añadía que ...hacer tales estatutos solamente compete a los reyes. Aludía también al agravio comparativo pues en la ciudad de Burgos, caveça de la probinçia dondes esta sytuada la dicha villa de Aranda, y en otras villas y lugares cercanos no se había impuesto esta tasación. Finalmente los oficiales mostraron su disposición a guardar los capítulos que se referían a la ...forma y calidad de la hechura de las obras para que en ellas no haya falsedad, pero solicitaban que se revocaran las ordenanzas. Petición que confirma la incomodidad que sintieron los zapateros al ver controlado su oficio por veedores y regidores, sobre todo en aquellos aspectos relacionados con la fijación de los precios. También se deduce de sus quejas la constatación de la existencia de un negocio especulativo con el cuero. En este sentido es bastante revelador el significativo peso que tuvo en la villa el comercio del cuero pues la renta que generaba era la tercera en valor, después del vino y el peso, experimentando un crecimiento sostenido hasta

${ }^{2521}$ AGS, RGS, 148811, fol. 177.

${ }^{2522}$ Son muy numerosas las menciones a vecinos arandinos vinculados a oficios relacionados con el cuero, aunque la documentación se muestra muy parca en cuanto a detalles sobre esta actividad y su significado en la villa. Sobre las tenerías y el trabajo del cuero puede consultarse el estudio de VILLANUEVA ZUBIZARRETA, O., "Agua y patrimonio en Castilla: el puente de Itero del Castillo en Burgos y las tenerías de la ciudad de Zamora", en Musulmanes y Cristianos frente al Agua en las Ciudades Medievales. Santander, 2008, pp. 17-45. 
finales de siglo, y apenas sufrió descenso a principios del siglo $\mathrm{XVI}^{2523}$. Como en otras muchas ciudades, fueron algunos de los zapateros de la villa los que arrendaron durante bastantes años la renta de las varas, corambres y zapatería de la villa ${ }^{2524}$. Todo ello nos lleva a pensar que alguno de estos zapateros compaginaba su actividad original con el comercio del cuero a gran escala.

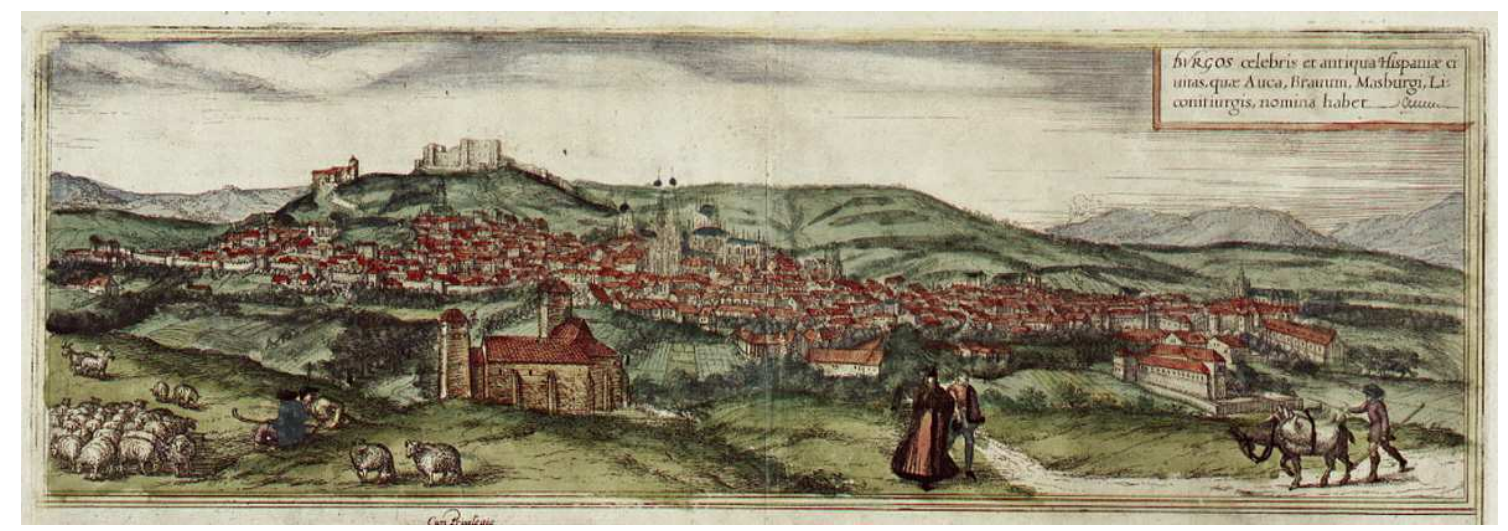

Imagen 52: Representación del Burgos en Civitates Orbis Terrarum y detalle del transporte de pellejos de vino.

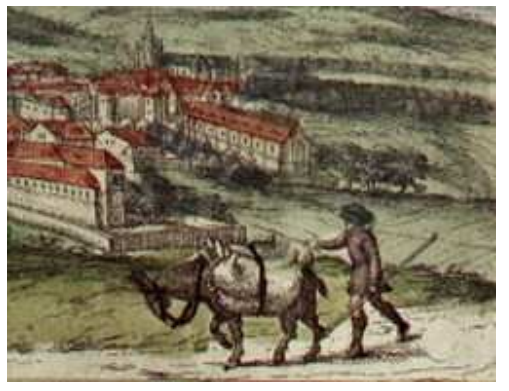

A pesar de la apelación, los veedores acompañados de los regidores hicieron su primera inspección el 16 de agosto con el resultado de la incautación de varias decenas de zapatos en un total de trece establecimientos. Esta circunstancia soliviantó los ánimos de los zapateros que respondieron con el envío de una nueva apelación a Valladolid. Acto seguido la Audiencia solicitó a las partes que presentaran sus probanzas y en este punto dejamos de tener información que nos permita saber cómo concluyó el enfrentamiento. No obstante, este episodio permite comprobar la pretensión intervencionista de la autoridad local sobre una actividad económica concreta y la tensión que generó sobre el colectivo socioeconómico afectado ${ }^{2525}$.

${ }^{2523}$ En 1478 la renta de varas, corambres y zapatería generaba 76.000 maravedíes y en 1497 alcanzaba los 165.000. En 1503 se arrendó por 145.000 y en 1506 se obtuvieron 142.915 maravedíes (AGS, CMC, leg. 41). EH, leg. 4).

${ }^{2524}$ Fue el caso de Álvaro López Daza en 1484 y Rodrigo del Portal entre 1487 y 1492 (AGS,

${ }^{2525}$ MONSALVO ANTÓN, J. M., “Aproximación al estudio del poder gremial en la Edad Media castellana. Un escenario de debilidad”, en En la España Medieval. 25, 2002, pp. 135-176. 
Asimismo la actividad financiera se vio afectada por el intervencionismo de los gestores municipales. En 1491 los regidores impusieron una nueva renta a los cambiadores de la villa. Éstos llevaron el asunto ante el Consejo Real y obtuvieron una sentencia a su favor por la que se eliminó este nuevo impuesto ${ }^{2526}$. Un año después uno de los cambiadores implicados en el proceso, García Sánchez de Calahorra, denunciaba que de nuevo los regidores le obligaban a pagar una sisa injustamente por lo que entabló un pleito contra el concejo. El proceso se pasó ante el alcalde Alonso García de Muriel ...el qual dicho alcalde por faser plaser a los dichos regidores dio sentencia contra my en que me condeno a que pagase la dicha sisa, mostrando contra my odio e por me faser mal e daño ${ }^{2527}$. Por el momento no sabemos cómo terminó este asunto pero sí que se advierte en este capítulo la constancia con la que las autoridades municipales aplicaron nuevas iniciativas recaudatorias.

El negocio de la hostelería también sufrió las irregularidades de los oficiales municipales. En 1497 Diego Martínez de Roa, contino de la Casa Real y titular de un mesón en el arrabal de Allendeduero que tenía arrendado, informaba a los monarcas de que los regidores le enviaban muchos huéspedes sin que luego le pagaran. Además denunciaba cierta parcialidad pues su establecimiento era requerido por los oficiales con mayor frecuencia que otros mesones de la villa. Por todo ello solicitaba la intervención de la justicia. Los reyes ordenaron que se ejecutara lo dispuesto en las Cortes de Toledo de 1480, prohibiendo a los oficiales del concejo que mandaran huéspedes a la posada bajo multa de 10.000 maravedíes, mitad para la cámara real y la otra mitad para el dueño de la $\operatorname{casa}^{2528}$.

Como parece lógico en un núcleo urbano como el arandino donde la actividad agropecuaria tuvo un notable peso, la conflictividad entre las autoridades y los vecinos también tuvo su proyección en estas actividades propias del medio rural. Como en otros lugares de Castilla, los enfrentamientos entre ganaderos y agricultores por la utilización de espacios y el aprovechamiento del agua también se reprodujo en la tierra arandina, interviniendo el concejo en favor de los intereses de los agricultores y penalizando fiscalmente a los ganaderos. Así lo denunciaron en 1497 varios ganaderos de la villa que

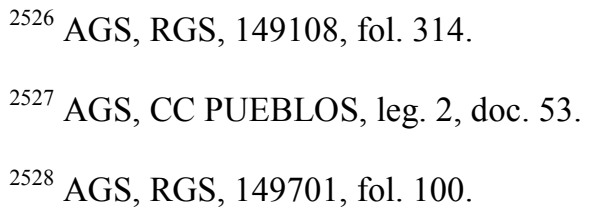


se sintieron agraviados por la nueva ordenanza que el concejo y regidores habían hecho, en la que se fijaba una nueva renta para todo vecino que tuviera más de 50 cabezas de ganado. Los ganaderos argumentaban que desde tiempo inmemorial todos los vecinos habían llevado pacíficamente sus ganados, paciendo las yermas, bebiendo las aguas y guardando panes y viñas por todos los términos de la villa y su tierra sin pagar nada por ser términos comunes ${ }^{2529}$.

Asimismo, se observan disputas relativas a los trabajos agrícolas como la recolección del cereal, las vendimias o, incluso, el estercolado de las viñas ${ }^{2530}$. Sin embargo, es necesario destacar que estas incidencias eran bastante reducidas en comparación con las identificadas en las actividades mercantiles y artesanas, evidente indicio de la creciente entidad urbana de la villa arandina. Esto se percibe mejor todavía si comparamos las ordenaciones realizadas por el concejo arandino, que conocemos de manera muy parcial, con las que tuvieron en otras localidades de la comarca en las que primaba por encima de todo la regulación de las actividades agrarias. Es el caso de las ordenanzas de La Aguilera, otorgadas por los condes de Miranda a principios del siglo XVI ${ }^{2531}$, en las que se regulaban todos los aspectos de la vida cotidiana de un núcleo rural. También conocemos las ordenanzas que otorgó el conde a su villa de Peñaranda que se centran en la administración de la justicia en todos los lugares de su señorío, prestando especial atención a los juegos de azar y sus consecuencias ${ }^{2532}$.

Todos estos ejemplos ofrecen una completa imagen del marcado carácter intervencionista sobre la actividad económica de las autoridades locales arandinas que paulatinamente fueron proyectando su poder sobre los diferentes sectores productivos. Esta dinámica respondía desde nuestro punto de vista a dos factores fundamentalmente. Por una parte, la más obvia, al incremento del patrimonio material, bien fuera el del concejo con el sistemático recurso al aumento de rentas o imposición de nuevos tributos, o bien al

${ }^{2529}$ AGS, RGS, 149705, fol. 133.

${ }^{2530}$ AGS, CC PUEBLOS, leg. 2, doc. 100.

${ }^{2531}$ CALVO PÉREZ, J. J., "Las ordenanzas de la villa de La Aguilera”, en Biblioteca 11. Estudio e Investigación. 1996, pp. 137-159. Las ordenanzas transcritas en este estudio están fechadas en 1569 pero recogen textos de principios del siglo XVI que se conservan parcialmente. De los 69 capítulos que contienen sólo tres se dedican al nombramiento de oficiales, uno a las procesiones y otro a la venta del vino, el resto abordan situaciones de la vida agraria de la villa.

${ }^{2532}$ Estas ordenanzas fueron redactadas en 1515 y conocemos su contenido por un traslado que se presentó ante el concejo de La Aguilera en 1518 (AMA, leg. 1172, docs. 4 y 5). 
personal gracias a sobornos o actuaciones irregulares. Por otra parte, parece evidente que esta dinámica respondió a la intención de la oligarquía arandina de consolidar su posición de primacía política sobre el conjunto de la sociedad, que veía cómo sus estrategias de subsistencia estaban profundamente vinculadas a las decisiones políticas. Esta vinculación se tradujo en muchas ocasiones en afinidad y dependencia, pero en otras, las menos, en abierto enfrentamiento.

No es de extrañar por lo tanto que algunos grupos sociales con una actividad económica destacada procuraran sistemáticamente tratar de alcanzar su participación en los órganos decisorios municipales a través de los medios más o menos tradicionales. Cuando lo conseguían su posición socioeconómica no sólo se consolidaba, sino que ganaba peso; pero cuando sus pretensiones políticas se vieron cercenadas, algunos de estos individuos y sus clientelas recurrieron a otros mecanismos mucho más directos para acceder al poder.

\section{f. Vinculación con los nobles comarcanos.}

El encuadramiento de la oligarquía local dentro de las redes clientelares de la nobleza territorial castellana fue un hecho sobradamente contrastado en las ciudades de la Corona de Castilla a finales de la Edad Media ${ }^{2533}$. La villa de Aranda, a pesar de tener la consideración de realengo, también participó de esta característica. Como veremos, la expansión de la influencia señorial sobre la villa fue un hecho consumado durante todo el periodo que nos ocupa, incluso a pesar de las constantes disposiciones de los diferentes monarcas para impedir esta situación.

Es comprensible que uno de los puntos de la política general de los Reyes Católicos de reafirmación del poder regio se centrara en el intento de impedir o limitar que los grandes señores extendieran sus redes clientelares por aquellos territorios de realengo próximos a sus dominios señoriales. Por lo tanto, no es de extrañar que a principios de los años ochenta, en el contexto de la reforma del regimiento, se estipulara en uno de los capítulos: ...que los regidores e alcalldes e ofiçiales que ha de aver en la dicha villa sean vesinos della e que non vivan nin lleven acostamiento de personas algunas salvo de nos e que de otra manera non puedan aver los dichos ofiçios ${ }^{2534}$.

${ }^{2533}$ Así lo pone de manifiesto, por ejemplo, QUINTANILLA RASO en su estudio de la ciudad de Cuenca ("Política ciudadana y jerarquización del poder. Bandos y parcialidades en Cuenca", en En la España Medieval. 20, 1997, pp. 219-250). $38-39$.

${ }^{2534}$ AMA, leg. 43, doc. 2, transcrito por HURTADO QUERO, Documentos Reales..., $\mathrm{n}^{\circ}$ 19, pp. 
A pesar de estas medidas, la realidad era que los estrechos lazos clientelares entre oligarquía local y nobleza comarcana ya se habían establecido previamente, sobre todo durante la crisis sucesoria de los años setenta. En este sentido, la configuración de los regimientos perpetuos no hizo más que consolidar en su posición de poder a la oligarquía, pero también confirmaba la participación de los nobles vecinos en los asuntos de la villa a través de sus criados.

Así a finales de los años ochenta se observa cómo casi todos los cargos concejiles de primer orden estaban copados por hombres de confianza, en la documentación criados, del conde de Miranda, del marqués de Denia o, incluso, del duque de Alburquerque.

Un rápido recorrido por los personajes que ocuparon el regimiento perpetuo de los linajes durante la segunda mitad de los años ochenta permite constatar esta circunstancia: el comendador Íñigo de Barahona fue la mano derecha del marqués de Denia ya desde $1480^{2535}$; el padre de Pedro de Salazar, Rodrigo de Salazar, capitaneó las tropas de don Diego de Rojas cuando tomó la villa para la princesa Isabel ${ }^{2536}$; otro de sus hijos, García de Salazar, fue depuesto en 1485 de su cargo como alcalde del linaje de don Romero por su vinculación con el duque de Alburquerque ${ }^{2537}$; Fernando de Covarrubias era yerno del contador del conde de Miranda ${ }^{2538}$; Pedro de Mora recibió el apoyo del marqués de Denia en 1490 en sus pretensiones sobre el beneficio de las Alcobas; y precisamente durante este enfrentamiento, Gonzalo García de Quemada obtuvo la ayuda del conde de Miranda ${ }^{2539}$. Más adelante, otro miembro de la clientela del conde de Miranda ocupó otro de los regimientos, Martín de Durango ${ }^{2540}$; y otro Durango, Rodrigo, fue el alcaide del marqués de Denia en su villa de Gumiel del Mercado ${ }^{2541}$. Con el paso del tiempo los sucesivos

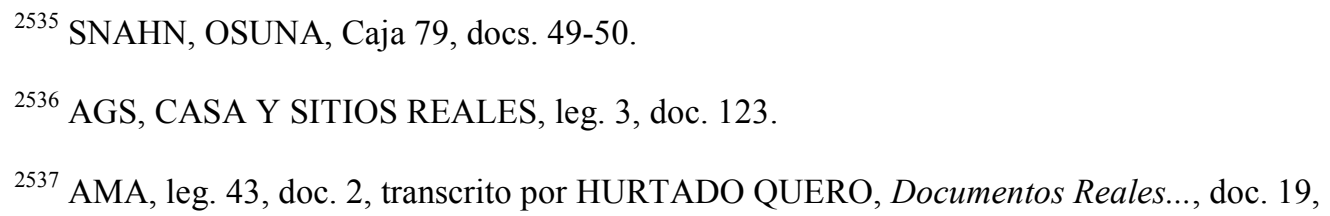
pp. 38-39.

2538 AGS, PR, leg. 28, doc. 73, transcrito por CARRETE PARRONDO, Fontes Iudaeorum..., doc. 148, p. 78 .

${ }^{2539}$ Tanto el caso de Mora como el de Quemada se recogen en AGS, CC PUEBLOS, leg. 1, docs. 226-233.

${ }^{2540}$ AGS, CC PUEBLOS, leg. 1, docs. 233. Ya era criado del conde desde 1490 y sabemos que actuó como regidor al menos desde 1498.

${ }^{2541}$ AGS, CC PUEBLOS, leg. 22, doc. 82. 
condes de Miranda ganaron adeptos entre la oligarquía local hasta el punto de que a principios del siglo XVI contaba entre sus fieles con la gran mayoría de los nueve regidores perpetuos.

Por lo tanto, a pesar de las disposiciones regias, la presencia del poder de los nobles comarcanos en el concejo arandino era una realidad desde la nueva organización política propuesta por los propios monarcas.

Por su parte, los regidores de la Comunidad, en cierta medida al margen de esta vinculación, se encargaron de denunciar esta situación con bastante frecuencia. En 1485 ya se tomó una medida ejemplar con García de Salazar que perdió su condición de alcalde porque vivia con el duque de Alburquerque ${ }^{2542}$. Pero la situación evidentemente se mantuvo y así lo recogían en un informe los regidores de la Comunidad en 1487: ...aun fallaran vuestras altesas algun regidor vebir con algund señor comarcano y llebar acostamiento del, y segund ley y ordenança del dicho provimiento por vuestras altesas a nosotros dado, el tal es (falta) ha perdido y pierde el dicho regimiento ${ }^{2543}$.

Tras la crisis dinástica de principios del siglo XVI la Comunidad volvió a denunciar la evidente connivencia entre los regidores perpetuos y los nobles de la comarca. La reina Juana respondió enviando en febrero de 1507 una provisión real por la que se recordaba a los regidores la prohibición de vivir con nobles ${ }^{2544}$.

De nuevo en 1515 los vesinos e moradores de la villa denunciaron ante la reina que la mayor parte de los regidores perpetuos ...biven con el marques de Denia o con el conde de Miranda, directa o indirectamente por raçion o quitaçion, alegando que tenían para ello licencia del rey don Fernando. Para los vecinos esta circunstancia había propiciado que los regidores ...an sydo muy favorables a los señores con quien an bivido y biven y la Comunidad e vesinos de la dicha villa muy desfavoresçido e que con este atrevimiento les hazen mucha fuerças e synrazones. La reina revocó las supuestas cédulas de su padre y ordenó de nuevo que ningún regidor viviera con nobles. Finalmente, para que nadie argumentara no conocer el contenido de esta orden real mandó que fuera pregonada en la

${ }^{2542}$ AGS, RGS, 148507, fol. 193; y AMA, leg. 43, doc. 2.

2543 AGS, CC PUEBLOS, leg. 2, doc. 83. La acusación se refería a los regidores Íñigo de Barahona, Pedro de Salazar, Gonzalo García de Quemada y Fernando de Covarrubias, pero no se concreta nada más.

${ }^{2544}$ AMA, leg. 43, doc. 38. 
plaza y mercados de la villa ${ }^{2545}$. Pero la realidad era otra bien distinta pues buena parte de los regidores aunque no vivían físicamente con los nobles, tenían bien definida su posición dentro de la parentela de los Zúñiga y Sandoval. Esta vinculación estaba perfectamente asumida en el contexto social arandino pues, a pesar de las disposiciones reales, dos miembros de la oligarquía se declaraban abiertamente deudos de ambas familias: por una parte, Martín de Durango, regidor desde 1508 por renuncia de su padre era contador del conde de Miranda; y por otro lado, Rodrigo de Durango se encontraba al servicio del marqués de Denia, residiendo intermitentemente en Gumiel de Mercado y Tordesillas.

Esta participación de los intereses de los nobles comarcanos se hizo también visible a lo largo del proceso que desde 1517 arrastró el concejo arandino contra la decisión del nuevo monarca de conceder el alguacilazgo de la villa a don Francisco de Zúñiga, hermano del conde de Miranda ${ }^{2546}$. Hasta tal punto la vecindad arandina tenía conciencia de esta connivencia entre los regidores y la nobleza comarcana que el procurador del Común, Sebastián de Ventosilla, solicitó la colaboración del corregidor para proseguir el pleito, sugiriéndole que no lo comunicara a los regidores porque ...biben con el conde de Miranda y buscan le servir ${ }^{2547}$.

Durante la Revolución Comunera se percibió también esta estrecha relación entre alguno de los regidores y el conde de Miranda, sobre todo en los primeros compases del conflicto. Así se observa cuando en el verano de 1520 el conde y los regidores consiguieron apaciguar los ánimos de la mayoría de los vecinos que pretendían seguir los pasos de la ciudad de Burgos. Más tarde, varios de ellos participaron activamente en el conflicto tanto reclutando soldados para el conde como directamente en los enfrentamientos contra los comuneros ${ }^{2548}$.

Finalmente, la evidente vinculación de la oligarquía local con la poderosa nobleza comarcana quedó definida dentro de la legalidad en septiembre de 1522 mediante la

${ }^{2545}$ AMA, leg. 43, doc. 41, transcrito por HURTADO QUERO, Documentos Reales..., no 39, pp. $70-71$

${ }^{2546}$ En el próximo apartado abordaremos este asunto con mayor profundidad.

${ }^{2547}$ AGS, CC MEMORIALES, leg. 129, docs. 43 y 55.

${ }^{2548}$ En estos acontecimientos destacan los regidores Juan de Acuña, Martín de Acuña, Íñigo de Zúñiga y Bernardino del Valle. Las referencias documentales aparecen en el capítulo dedicado a la Revolución Comunera en la Ribera del Duero que desarrollaremos más adelante. 
licencia real que emitió Carlos I por la que se permitía a los regidores perpetuos vivir con señores ${ }^{2549}$.

Por lo visto en este punto, podemos deducir la estrecha relación que hubo entre las principales familias de la nobleza comarcana y diferentes miembros de la oligarquía local que se tradujo en una clara proyección de los intereses de la nobleza sobre uno de los pocos territorios que en la comarca estaban fuera del dominio señorial. Si bien es cierto que la villa permanecía jurídicamente vinculada al realengo, la situación de facto era que el control de la nobleza comarcana se proyectaba sobre la villa a través de unos intensos lazos clientelares de los que participaba plenamente el patriciado urbano. En consecuencia, podemos afirmar que esta situación confirma la progresiva señorialización que se produjo en Castilla en el contexto del tránsito hacia la Modernidad.

La conclusión final a este apartado no puede ser otra que la constatación de la existencia en la villa de Aranda a finales de la Edad Media de un ambiente de conflictividad constante que se evidenció en la continua tensión mantenida entre la oligarquía local y el resto del vecindario, encabezado en este momento por un grupo de vecinos con una posición socioeconómica destacada pero que fueron marginados de los órganos decisorios del gobierno municipal ${ }^{2550}$. Si bien es cierto que no hemos documentado enfrentamientos violentos de consideración en todo el periodo estudiado ${ }^{2551}$, lo cierto es que la conflictividad de baja intensidad se mantuvo como una constante, creando una situación de tensión entre dos bloques más o menos definidos. Inevitablemente las pretensiones del grupo que capitalizaba las inquietudes de la mayor parte de los vecinos chocaron contra los intereses de la oligarquía que tenían una posición dominante consolidada. Desde nuestro punto de vista, la incompatibilidad de ambas

${ }^{2549}$ AMA, leg. 43 , doc. 46.

${ }^{2550}$ En este mismo sentido, después de analizar la situación de las ciudades castellanas en los primeros años del Quinientos, la profesora ASENJO GONZÁLEZ señala que el clima de inestabilidad en el mundo urbano castellano debe ponerse en relación con "la incapacidad del sistema político local y del reino para saber canalizar las inquietudes y demandas de un nuevo conjunto social que se ubica en la sociedad urbana, en particular, y canalizaban a través de los posicionamientos de los llamados pecheros del común" ("Las ciudades castellanas al inicio del reinado de Carlos V", en Studia Historica. Historia Moderna. 21, 1999, pp. 49-115).

${ }^{2551}$ A pesar de este evidente enfrentamiento, en el caso arandino no hemos constatado reacciones drásticas por parte del común ante los abusos de poder de los privilegiados como las señaladas por VAL VALDIVIESO, "Oligarquía versus Común..., pp. 41-58. 
opciones abocó irremisiblemente hacia un estallido de grandes dimensiones que puso en cuestión las relaciones de fuerzas que hasta el momento se habían pergeñado.

\section{2. Conflictos externos.}

Además de los problemas que se desarrollaron en el seno de la sociedad arandina y que acabamos de analizar, también se perciben una serie de enfrentamientos derivados de las relaciones del concejo arandino con sus vecinos, ya fueran éstos nobles, monasterios o lugares.

Estrechamente relacionado con el proceso de señorialización que experimentó la comarca a finales de la Edad Media, el concejo arandino siguió una dinámica de expansión territorial cuajada de éxitos y fracasos. Al igual que hemos apreciado en el caso de las pugnas entre nobles por el control del territorio, la irrupción en escena de otro actor, el concejo arandino, ocasionó nuevos conflictos que se materializaron en una constante tensión salpicada de pequeños episodios violentos.

Relacionado con la presencia de las clientelas nobiliarias en la villa, los enfrentamientos entre el concejo y los nobles comarcanos invadieron el campo de la autonomía política del ayuntamiento, en lo que podríamos considerar una nueva vuelta de tuerca en la áspera relación entre el vecindario urbano arandino y los miembros de los linajes nobiliarios asentados en la comarca.

\section{2. 1. La pretensión de expansión y hegemonía comarcal.}

La creciente actividad económica de la capital de la Ribera, la consolidación de una sociedad cada vez más compleja en la que se fueron definiendo poco a poco los rasgos de un núcleo propiamente urbano, y su situación geoestratégica en el contexto de la política castellana generaron entre los habitantes de la villa de Aranda un anhelo de engrandecimiento, capitalizado y dirigido por las oligarquías urbanas, que tuvo su principal manifestación en el deseo de incrementar su vecindario y, sobre todo, su territorio. En este sentido, es evidente que las diferentes maniobras que llevaron a cabo los principales linajes nobiliarios de la comarca para ampliar sus estados señoriales sirvieron de modelo y acicate a la villa para tratar de conseguir la ansiada expansión territorial. Buena prueba de esta circunstancia se aprecia en una carta de los representantes del concejo a los reyes en 1503 en la que manifestaban ...la gran nescesidad que esta villa tiene de tierra e terminos por que los muchos lugares de señores que la tienen çercada alderre- 
dor; e los grandes señores comarcanos se meten en las dichas behetrias e lugares abadengos e dañan e molestan a esta villa por muchas maneras ${ }^{2552}$.

Evidentemente la limitación física del territorio y la confluencia de intereses expansivos del concejo y de los señores comarcanos propició serios enfrentamientos, algunos de los cuales ya hemos analizado ${ }^{2553}$.

El instrumento más utilizado por el concejo arandino para conseguir la expansión fue la compra de términos, sobre todo a los grandes monasterios de la comarca. Recordemos que este fue el procedimiento mediante el cual la villa incorporó a su tierra los lugares de Quemada y Revilla de Olleros. Esta misma opción fue la que se utilizó con el lugar de Milagros que fue comprado en 1495 al monasterio de San Pedro de Gumiel y, como ya hemos visto en un apartado anterior, se caracterizó por generar graves problemas y una escasa rentabilidad ante la inversión realizada.

La villa también pretendió comprar Fresnillo, Fuentelcésped y Tubilla, en este caso al monasterio de Santa María de la Vid. En 1503 el concejo pidió a los reyes que solicitaran del Papa licencia para permutar estos lugares por un censo. Además de argumentar el beneficio que generaría a la villa, los procuradores urbanos también denunciaban que estos lugares estaban siendo sistemáticamente usurpados por los nobles de la comarca, en una explícita alusión a la presión que el conde de Miranda ejercía sobre el patrimonio del monasterio vitense. La actitud de los monarcas fue bastante positiva ante esta propuesta pues instaron al comendador Francisco de Rojas, su embajador en Roma, para que consiguiera del Papa esta licencia. Sin embargo, la muerte de la reina en 1504 y de don Felipe en 1506, el periodo de crisis económica que comenzó en 1504 y el posterior control del monasterio de La Vid por don Íñigo López de Mendoza frenaron la posibilidad del censo, independientemente del permiso papal que no sabemos por el momento si se consiguió ${ }^{2554}$.

A mitad de camino entre la compra y la donación se encontraba el caso de la villa de La Ventosilla que perteneció a doña Francisca de Castañeda y a los condes de

${ }^{2552}$ AGS, CC PUEBLOS, leg. 2, doc. 94.

${ }^{2553}$ La colisión de los intereses expansivos de los núcleos urbanos y la nobleza también se constata en otros espacios castellanos como, por ejemplo, La Rioja (GOICOLEA JULIÁN, "Expansión territorial..., pp. 293-331).

${ }^{2554}$ AGS, CC CÉDULAS, leg. 7, docs. 13-4; y AGS, CC PUEBLOS, leg. 2, doc. 94. 
Cabra $^{2555}$. El término de esta villa era colindante con la Tierra de Aranda y los vecinos de la cercana aldea de Villalba alegaban derechos inmemoriales para disponer de la madera y caza de los montes de esta villa, lo que ocasionó durante muchos años diversos $\operatorname{conflictos}^{2556}$.

En 1503 la villa de Aranda solicitó que La Ventosilla se incluyera en su Tierra. La reina contestó prohibiendo a cualquier otro la compra del lugar y otorgando un derecho preferente a la villa de Aranda para su adquisición. Sin embargo, el concejo, que pensaba más en una donación que en una compra, no pudo hacerse cargo de la cuantía y definitivamente fue la reina quien compró la villa en noviembre de 1503 al conde de Ribadeo por un montante total de 2.286.333 maravedíes ${ }^{2557}$.

En 1506, por iniciativa del rey Felipe, la tenencia de la villa pasó al conde de Miranda por medio de una merced que disfrazaba una compraventa. En la operación se incluían además la villa de Hoyales y el lugar de Fuentelisendo. Por todo ello el conde abonó 1.600 .000 maravedíes ${ }^{2558}$. Este negocio es una buena muestra de la política despilfarradora del monarca austriaco que vendió estos territorios por la mitad de lo que

${ }^{2555}$ En la documentación de los años ochenta aparece como señora de la villa doña Francisca de Castañeda (AGS, RGS, 148712, fol. 132 ) y en la carta de la reina prohibiendo la compra se dice que era propiedad de los condes de Cabra (AGS, CC PUEBLOS, leg. 22, doc. 80). Doña Francisca de Castañeda fue la tercera hija de Juan Rodríguez de Castañeda, señor de Fuentidueña y Hornazas. En 1453 recibió en herencia la villa de La Ventosilla, además de otros muchos lugares. Contrajo matrimonio con don Luis de la Cerda, señor de Villora, Cubas y Griñón, y tuvieron una hija, Juana, que casó con Diego de Zúñiga, II Duque de Béjar. Fruto de este matrimonio nacieron Francisco de Zúñiga y Francisca de Castañeda. Esta última se casó con don Diego Fernández de Córdoba, III conde de Cabra. En enero de 1503 murió doña Francisca y legó sus heredades a sus nietos, Francisco y Francisca. Los condes de Castro cedieron los dominios a cambio de dinero, pero al no abonarse comenzó un largo litigio entre los hermanos. Posiblemente en este contexto fue en el que se puso a la venta la villa de La Ventosilla (SALAZAR Y CASTRO, L., Historia genealógica de la casa de Haro. Madrid, 1959, Tomo XV, pp.132-142). Lo que todavía no conseguimos explicar es cómo la venta final a la reina la realizaron el conde de Ribadeo y un regidor de Valladolid (AGS, PR, leg. 33, doc. 28. Este documento se encuentra transcrito por QUINTANILLA RASO en la obra coordinada por NIETO SORIA, J. M., Orígenes de la Monarquía Hispánica. Propaganda y Legitimación (ca.1400-1520). Madrid, 1999, doc. 33, pp. 453-457).

${ }^{2556}$ AGS, RGS, 148709, fol. 18; 148711, fol. 46; y AMA, leg. 1222, doc.14.

${ }^{2557}$ AGS, CC PUEBLOS, leg. 2, docs. 56 y 94; leg. 22, doc. 80; CC CÉDULAS, leg. 7, docs. 133; y PR, leg. 33, doc. 28.

${ }^{2558}$...mi mandado y voluntad es que don Francisco de Zúñiga y Avellaneda, conde de Miranda, del mi Consejo, tenga las dichas fortalezas y lugares (BRAH, SALAZAR Y CASTRO, M-59, fol. 63). En las libranzas de las alcabalas de la villa de Aranda de 1516 se establecía la devolución de 400.000 maravedíes del total ... que sus altezas le mandaron librar por los lugares de Hoyales, Fuentelisendo y La Ventosilla, los cuales se averiguó que le habia dado al rey don Felipe, que en Santa Gloria haya, por los dichos lugares al tiempo que le hizo merced dellos e despues se tornaron a restituir... (AGS, CMC, leg. 41 , doc. 13). 
poco tiempo atrás había pagado la Corona $^{2559}$ y de la actitud medrosa de algunas familias de la nobleza castellana que aprovecharon la llegada de los nuevos reyes para incrementar su patrimonio a costa del realengo.

Tras la prematura muerte del monarca la villa retornó al realengo y el marqués de Denia recibió la tenencia de la villa por delegación del rey Fernando. El monarca convirtió los montes de La Ventosilla en uno de sus enclaves favoritos para el disfrute de su pasión venatoria y la convalecencia de la enfermedad que le causó la muerte ${ }^{2560}$. Definitivamente las aspiraciones de la villa de Aranda por anexionar La Ventosilla se vieron truncadas pues la tenencia del marqués de Denia devino definitivamente en propiedad en $1521^{2561}$.

Como ya hemos visto más arriba, otra de las aspiraciones del concejo arandino fue la de convertir en solariego de la villa las behetrías vecinas. A esta intención de los arandinos también debemos sumar la difusión de una imagen de solvencia y seguridad que ofrecía la villa frente a otros poderes comarcanos, lo que explicaría que algunos lugares de behetría prefirieran perder su condición y convertirse en solariegos del concejo arandino ${ }^{2562}$. No obstante, ya hemos visto en el capítulo referido a Hontoria de Valdearados el enfrentamiento que mantuvo frente a los intereses del conde de Miranda y el vano resultado para las aspiraciones arandinas.

Otro episodio paralelo a éste comenzó con la solicitud para incorporar a la jurisdicción arandina la behetría de Castrillo de Solarana, lugar situado en las inmediaciones de Lerma y que, por lo tanto, se salía de su ámbito natural de expansión.

Sabemos que Castrillo de Solarana estuvo bajo la encomienda del conde de Villahermosa hasta su fallecimiento en 1480. En ese momento esta behetría junto a otras de la comarca solicitaron seguro para poder elegir a su señor, aunque no sabemos a quién eligieron. En 1497 el corregidor de Aranda fue enviado a mediar ante las autori-

${ }^{2559}$ Recordemos que en 1504 la reina Isabel había comprado la villa de Hoyales y Fuentelisendo a doña Constanza de Avellaneda por un millón de maravedíes, que se sumaron a los más de dos que se pagaron por La Ventosilla.

${ }^{2560}$ En 1514 el rey envió una cédula al alcaide de Gumiel de Mercado, Rodrigo de Durango, para que ... la montería e caza del monte de Ventosilla se guarde para mi recreación. Además dictó una serie de prohibiciones y castigos para quien osase utilizar el monte para cazar (AGS, CC PUEBLOS, leg. 22, doc. 79). En los últimos años de su vida el rey Fernando pasó temporadas en La Ventosilla disfrutando de la caza o convaleciente (VAL VALDIVIESO, "El reinado de los Reyes Católicos..., pp. 20-21).

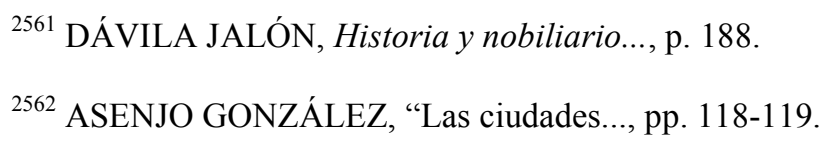


dades de la Merindad de Santo Domingo de Silos que pretendían imponer su autoridad sobre Castrillo a pesar de ser behetría. Como ya hemos señalado, poco más tarde, el 22 de agosto 1498, la princesa Isabel, reina de Portugal, tomó bajo su protección al lugar. Un día después la princesa murió tras el parto de su hijo Miguel. En enero de 1499 los reyes solicitaron al corregidor que asumiera la encomienda de Castrillo en nombre del Príncipe Miguel y velara por su bienestar a pesar de la lejanía. Se hizo un nuevo requerimiento el 27 de agosto de 1500, pocos días después de la muerte del Príncipe, para que se hiciera cargo de la encomienda ${ }^{2563}$.

En 1503 el Concejo arandino solicitó de nuevo licencia para pasar el lugar de behetría a solariego, argumentado que en esta solución confluían los intereses tanto de la monarquía, ...quanto es su serviçio e acreçentamiento de sus rentas reales, como de Aranda por ...la grand nesçesidad que esta villa tiene de tierra e terminos ${ }^{2564}$. Por el momento no tenemos más noticias sobre estas pretensiones, pero todo hace pensar que esta iniciativa no llegó a materializarse.

Podemos concluir que el concejo arandino promovió en la medida de sus posibilidades, que ciertamente eran escasas, una política de expansión territorial que permitiera su consolidación como un poder comarcal importante. Trataba de emular, salvando las distancias, el importante señorío colectivo de la ciudad de Burgos ${ }^{2565}$. Esta situación le hubiera posibilitado mantener su relativa autonomía y hacer frente a los otros poderes comarcanos que, como hemos visto, estaban capitalizados por alguno de los linajes nobiliarios más significativos. Sin embargo, las carencias de propios de la villa, la crisis económica y dinástica de este periodo y la creciente fortaleza y posición de la nobleza comarcana impidieron que esta política expansiva concluyera con éxito. En consecuencia, esta situación creó tensiones que se materializaron en frecuentes conflictos con los otros actores que pretendían ampliar su control sobre los mismos territorios de la comarca ribereña.

${ }^{2563}$ AGS, RGS, 148003, fol. 36; 148708, fol. 184; 149808, fol. 1; y 150008, fol. 263.

${ }^{2564}$ ASENJO GONZÁLEZ, M., “Las ciudades..., pp. 118-119.

${ }^{2565}$ BONACHÍA HERNANDO, J. A., El Señorío de Burgos durante la Baja Edad Media (12551508). Valladolid, 1988. 


\section{2. 2. Injerencia de los poderes vecinos y conflictos.}

Como ya venimos apreciando a lo largo de este capítulo, la relación entre la villa de Aranda, único vestigio de realengo en la comarca, y la nobleza comarcana fue bastante tensa durante el periodo que nos ocupa. Esta tensión se explica sobre todo por las pretensiones nobiliarias de controlar el núcleo urbano y la riqueza que en él se generaba. La convivencia también se vio alterada por la incompatibilidad de las políticas expansivas de la villa y los grandes señores comarcanos pues todos ellos pujaban por anexionarse los escasos territorios que escapaban a su poder como las behetrías, los bienes de las instituciones eclesiásticas o los señoríos de la nobleza comarcal de segundo orden.

El primer conflicto dentro de este contexto del que tenemos noticia tuvo como protagonista a don Diego de Zúñiga que pretendía en 1456 iniciar la construcción de una fortaleza, la Torre del Monte, en el cercano paraje de Valdemontejo localizado en la comunidad de Villa y Tierra de Haza, no lejos del límite con la Tierra de la villa.

Ante el comienzo de la construcción de la fortaleza, el concejo arandino denunció el daño que este castillo suponía para los intereses de la villa y el evidente desacato a las leyes del reino que prohibían realizar construcciones de este tipo. Don Diego argumentó por su parte que no se trataba de una fortaleza sino una casa llana en una heredad suya, e invitó al monarca a que uno de sus delegados lo contrastara. Acto seguido el monarca comisionó al oidor Alonso Vélez de Guevara para que iniciara la investigación $^{2566}$. No sabemos si por exceso de trabajo del oficial o por que Zúñiga ejerció sus influencias, lo cierto es que el comisionado se dilató bastante tiempo en cumplir su comisión $^{2567}$. Finalmente, y a pesar de las quejas del concejo arandino, la fortificación acabó por construirse y supuso un importante punto de control estratégico, pues estaba localizada a las puertas de la villa de Aranda, y de control de las comunicaciones tanto

${ }^{2566}$ La carta de Enrique IV ordenando investigar la posible construcción se encuentra en AMA, leg. 42, doc. 5 y ha sido transcrita por HURTADO QUERO, Documentos Reales..., doc. 9, pp. 19-21.

${ }^{2567}$ Ante la inactividad del comisionado el concejo acudió en septiembre de 1456 a las cercanías de Segovia para solicitar al oidor que acudiera para dar cumplimiento a la orden del rey. Guevara se negó en un primer momento aduciendo que no se había establecido salario y que tenía muchas tareas que realizar en Segovia antes de partir a tierra de moros. Finalmente el oidor se comprometió a consultar con el rey y acercarse hasta Aranda tras terminar unos asuntos en Segovia (AMA, leg. 43, doc. 31). Desconocemos si finalmente se hizo cargo de la comisión real. 
de personas, como de mercancías y ganados debido a su emplazamiento junto al camino real del corredor del Duero que conducía a Peñafiel y Valladolid ${ }^{2568}$.

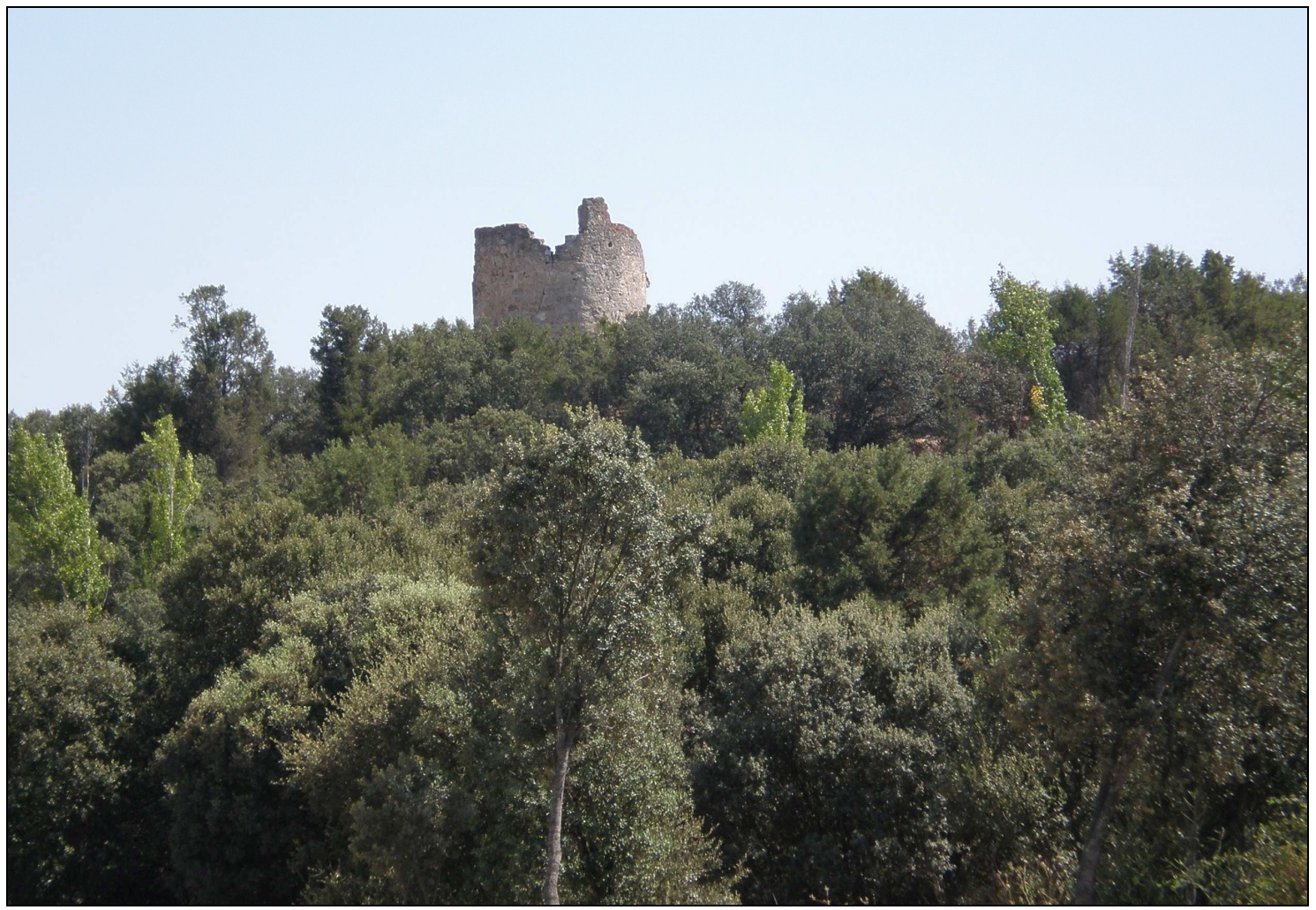

Imagen 53: Restos del castillo de la Torre del Monte o Aunqueospese.

El I Conde de Miranda invirtió en su construcción alrededor de tres cuentos de maravedíes y el epíteto con el que fue bautizado, aunqueospese, muestra muy a las claras la finalidad con la que fue construida dentro de la política de afianzamiento territorial del primer Zúniga en la comarca ribereña ${ }^{2569}$. No en vano, el castillo fue en varias ocasiones el punto de partida de algunas de las algaradas que los alcaides de Haza y Torre del Monte realizaron sobre los transeúntes del camino real ${ }^{2570}$.

${ }^{2568}$ Hoy tan solo se conservan los restos de un cubo y un lienzo de un pequeño castillo de planta cuadrada flanqueada por cuatro cubos en sus esquinas (CADIÑANOS BARDECI, Arquitectura fortificada..., pp. 241-243).

${ }^{2569}$ Aunque parezca más leyenda que realidad, este era el nombre con el que se conocía a la Torre del Monte en la comarca y así lo pone de manifiesto la declaración de doña Constanza de Arellano, hija del I conde de Miranda, cuando reclamaba su parte de la herencia a su sobrino, don Francisco de Zúñiga, en el año 1500 (ARChV, RRE, Caja 154, doc. 2). Además la tradición señala que sobre la desaparecida puerta de la fortaleza se podía leer una inscripción que decía aunqueospese soy del conde de Miranda (CADIÑANOS BARDECI, Arquitectura fortificada..., pp. 241-243).

${ }^{2570}$ AGS, RGS, 149312, fol. 124; y 149410, fol. 441. 
El enfrentamiento también se desarrolló en torno al uso del mismo monte sobre el que estaba emplazada la fortaleza, Valdemontejo. Según el concejo de Aranda, desde tiempo inmemorial los vecinos de la villa y su Tierra tenían ciertos derechos de aprovechamiento de madera y pastos sobre este pago. Sin embargo, el conde de Miranda consideraba que se trataba de abusos sobre un término de su jurisdicción por lo que emprendió un pleito que se desarrolló desde finales de los años ochenta y buena parte de los noventa del siglo XV. El pleito no impidió que durante este periodo se reprodujeran múltiples enfrentamientos entre vecinos y autoridades de ambas partes ${ }^{2571}$.

El episodio más significativo fue el asalto del lugar de Castrillo de Duero por parte de una multitud de vecinos de Aranda encabezados por el regidor de la Comunidad Martín Sánchez Casasola. Los hechos ocurrieron en 1487 y arrancaron con la agresión sufrida en Castrillo por un alcalde de la Hermandad al que quebraron la vara de la justicia, además de propinarle una paliza. Cuando volvió a Aranda, el regidor Casasola soliviantó a los vecinos para que acudieran a Castrillo para vengar la afrenta. Algunos regidores de los linajes se adelantaron a la multitud y trataron de calmar los ánimos pero fracasaron en su intento. Los vecinos del lugar se refugiaron en la iglesia mientras que la muchedumbre asaltó el pueblo, tomó algunas casas e incendió otras. Imaginamos que los daños materiales fueron cuantiosos pero no tenemos constancia de su cuantía. También suponemos que este incidente dio lugar al inicio de un pleito pero lo cierto es que tan solo tenemos noticia de que las autoridades religiosas impusieron un entredicho a la villa de Aranda ${ }^{2572}$.

La tensa relación entre la villa de Aranda y la familia Zúñiga se mantuvo durante los años finales del siglo XV y los primeros del Quinientos con la ya comentada disputa por el lugar de Milagros.

El punto álgido en esta tensa relación entre Aranda y la casa de Miranda tuvo lugar con el conflicto surgido por el nombramiento de don Juan de Zúñiga como alguacil de la villa.

Según los privilegios confirmados en 1473 por la princesa Isabel, correspondía al concejo el nombramiento de los oficiales de la villa y, en principio, el alguacilazgo

2571 AMA, leg. 43, doc. 6; AGS, RGS, 148809, fol. 114; 149208, fol. 215 y 233; 149209, fol. $270 ; 149305$, fol. $122 ;$ y 149306, fol. 198.

${ }^{2572}$ AGS, CC MEMORIALES, leg. 149, doc. 230. La noticia la conocemos por la denuncia interpuesta por los regidores de los linajes a los de la comunidad acusándoles de gastar 35.000 maravedíes en la algarada y los posteriores costes para levantar el entredicho. 
era uno de estos cargos ${ }^{2573}$. Sin embargo, en una fecha que no conocemos la villa delegó en Juan de Cuero, vecino de Madrid, para que ejerciera como alguacil y cobrara la renta a él asociada de por vida. Cuero tenía el cargo arrendado en un vecino de la villa, Vallejo, que era quien realmente ejercía las competencias de alguacil. Hacia 1506 o 1507 falleció Juan de Cuero aunque sus familiares lo ocultaron para seguir cobrando la renta. En 1510 el concejo denunció esta situación, a la vez que acusaba de arbitrariedad al alguacil que actuaba en lugar de Cuero ${ }^{2574}$. Posteriormente el concejo, asumiendo sus privilegios, nombró como alguacil a Francisco de Mazuela ${ }^{2575}$.

Tras la muerte del rey Fernando la situación se complicó. Parece que el regente Cisneros otorgó el alguacilazgo de Aranda al capitán Juan de Angulo, comisionado por él para que recogiera gentes de armas por tierras de Soria, la Merindad de Silos, Aranda y Sepúlveda. Cuando Angulo llegó a Aranda a principios de noviembre de 1516 envió una comunicación al regente en la que señalaba: Tanbien hago saber a vuestra merced como ayer en consistorio los regidores y justicias y procuradores quitaronme la vara que (entre líneas: haya el alguasil) estava puesta por Juan de Cuero y la dieron a otro, hasi que su reverendisima señoria provea della, vale de renta cerca de veinte mill maravedies $^{2576}$.

Poco después, el 29 de enero de 1517 se presentó el caballero Juan de Acuña ante el concejo con un poder de Juan de Zúñiga, hermano del conde de Miranda, para tomar posesión del oficio de alguacil en virtud de la merced otorgada por Carlos I el 27 de noviembre de 1516 en Bruselas ${ }^{2577}$. Los miembros del concejo se negaron a aceptar esta imposición y apelaron ante el corregidor. Éste aceptó la demanda y decidió nombrar un tercer alguacil para que ejerciera el oficio hasta que resolviera el Consejo Real.

Ante esta situación los procuradores de la comunidad solicitaron de los regidores que se pronunciaran al respecto y les propusieron que presentasen ante las autoridades un requerimiento en el que se reivindicara el privilegio de la villa para nombrar el al-

${ }^{2573}$ AMA, leg. 43, doc. 32, transcrito por HURTADO QUERO, Documentos Reales..., doc. 10, pp. 21-24.

${ }^{2574}$ AGS, CC PUEBLOS, leg. 2, doc. 53.

2575 AGS, CC PUEBLOS, leg. 2, doc. 102. Mazuela ejerció como alguacil por lo menos desde abril de 1515 .

${ }^{2576}$ AGS, CC PUEBLOS, leg. 2, doc. 107.

2577 AGS, RGS, 151611, s. f. (DIAGO HERNANDO, “Cambios políticos..., p. 324). 
guacil y se rechazara la imposición de don Juan de Zúñiga en el oficio por no ser vecino de la villa y por el daño que le vendría a la colectividad. De los cinco regidores presentes en la sesión del 29 de enero tres de ellos se manifestaron a favor de tramitar este requerimiento de la comunidad; uno se negó y solicitó que se cumpliera la orden real del nombramiento de Zúñiga; y el quinto solicitó que el letrado mayor del concejo viera previamente la legalidad de este requerimiento. En el transcurso de esta reunión hicieron acto de presencia los diputados de las cuadrillas que también mostraron su apoyo al requerimiento presentado por los procuradores de la comunidad ${ }^{2578}$.

Ante esta apelación, el Consejo emitió en febrero de 1517 un informe para el monarca en el que reconocía las razones esgrimidas por el concejo. Además recomendaba al rey que gratificara de otra forma a Juan de Zúñiga pues lo que podía ganar con este oficio era poco, 15.000 maravedíes anuales. Estimaba asimismo que el perjuicio que podía causar al servicio del rey era mucho pues la villa de Aranda era el único lugar de realengo, junto a Sepúlveda, en la comarca y estaba rodeado por las tierras del conde de Miranda. Concluía el informe alegando que, nombrando alguacil a Juan de Zúñiga, el conde poco a poco se iría ganando la villa, en claro detrimento de la autoridad real. Por último, recuerdan al nuevo monarca que su abuela prohibió rotundamente que los miembros del concejo habitasen con nobles para evitar precisamente la injerencia de la nobleza sobre el realengo. Por todo ello, los miembros del Consejo Real determinaban que lo más acertado, incluso si la villa no disfrutaba realmente de ese derecho, sería dar otra gratificación a Juan de Zúñiga y sobreseer su nombramiento como alguacil ${ }^{2579}$.

Si bien es cierto que en principio, como hemos visto, el regimiento de la villa se opuso a este nombramiento, el peso del mantenimiento del pleito fue llevado por los procuradores de la comunidad. En esta tarea destacó sobre todo el futuro comunero Sebastián Martínez de Ventosilla que se encargó de seguir este pleito ante el Consejo Real a pesar de la falta de apoyo financiero del concejo y de las trabas de algunos de los regidores partidarios del conde de Miranda ${ }^{2580}$. Parece ser que el pleito fue dado por conclu-

${ }^{2578}$ Los regidores Diego de Aranda, Rodrigo de Durango y Pedro de la Plaza apoyaron la moción de los procuradores de la comunidad; Fernando de Sepúlveda se negó; y Martín de Durango solicitó el informe previo del letrado. En este sentido llama la atención la postura ambigua de Martín de Durango pues era conocida su estrecha vinculación con la familia Zúñiga. Es posible que la gran presión popular a la que se vieron sometidos los regidores en esa reunión le empujara a optar por un voto de compromiso (AGS, CC DIVERSOS, leg. 41, doc. 35).

${ }^{2579}$ AGS, CC DIVERSOS, leg. 41, doc. 35.

${ }^{2580}$ AGS, CC MEMORIALES, leg. 129, docs. 43, 55 y 70. 
so en 1520, en vísperas del estallido comunero, y que todavía a comienzos de 1522 no se había dado sentencia definitiva ${ }^{2581}$. Sin embargo, los significativos cambios que se produjeron en el ámbito concejil tras la derrota comunera provocaron que la comunidad no prosiguiera con su apelación. Como consecuencia de esta situación a mediados de 1522 el Consejo Real emitió una sentencia definitiva en la que se reconocían los derechos de don Juan de Zúñiga sobre el oficio de alguacil de la villa de Aranda ${ }^{2582}$.

En conclusión, esta sentencia no fue más que la confirmación definitiva de la situación de hegemonía absoluta del linaje de los Zúñiga sobre la villa arandina que ya se había pergeñado durante las dos últimas décadas y consolidado tras la victoria realista sobre los sublevados comuneros.

Por lo visto hasta ahora podemos concluir que la conflictividad en el seno del núcleo urbano arandino participó de la misma dinámica que se advierte en otras muchas ciudades castellanas. Hemos comprobado cómo los enfrentamientos entre la oligarquía y la comunidad fueron una constante durante todo el periodo estudiado y que generaron un ambiente de tensión que presagiaba un inminente reajuste traumático. Por otra parte, la confluencia de intereses territoriales entre la política expansiva de la villa de Aranda y la necesidad de consolidar los dominios de los grandes linajes comarcanos, sobre todo la familia Zúñiga-Avellaneda, provocaron una serie de fricciones que desembocaron en episodios puntuales de violencia. Esta situación también generó en el imaginario colectivo de los grupos más populares de la sociedad arandina la identificación de estas familias nobiliarias con la dominación y la ausencia de autonomía, materializada no solo en la lucha por el territorio, sino también en la proyección de los intereses nobiliarios sobre los sujetos que controlaban el poder municipal, cuando no en el control efectivo de algunos de los oficios concejiles como fue el caso concreto del alguacilazgo.

\footnotetext{
${ }^{2581}$ AGS, CC MEMORIALES, leg. 141, doc. 272.

${ }^{2582}$ AGS, RGS, 152207, s. f.; y DIAGO HERNANDO, “Hidalgos y pecheros..., pp. 118-119.
} 


\section{COLOFÓN: LAS COMUNIDADES.}

Para concluir con este capítulo dedicado a los conflictos creemos apropiado centrar la atención en uno de los episodios más generalizados y violentos que afectaron a Castilla en el tránsito hacia la Modernidad. Nos referimos por supuesto a la Revolución de las Comunidades.

Desde nuestro punto de vista, este singular acontecimiento fue resultado de una situación caracterizada por las tensiones de tipo económico, social y político que durante los últimos decenios tuvieron como escenario el reino de Castilla, sobre todo en su ámbito urbano. Evidentemente son muchos los estudios que han analizado este complejo movimiento desde una perspectiva más general por lo que nuestro estudio se centrará exclusivamente en aquellos aspectos relacionados con nuestro ámbito espacial, sin perder por ello la conexión con lo sucedido en el resto del reino de Castilla.

Este capítulo lo iniciaremos con el análisis de la situación previa al estallido comunero dentro de un ámbito más general. Posteriormente nos centraremos en los protagonistas y acontecimientos más significativos que se desarrollaron en la comarca ribereña. Finalmente concluiremos con el análisis del significado de la victoria realista y las posibles conclusiones que tuvo dentro de la dinámica histórica de la comarca ribereña.

\section{1. Cambio de tendencia desde 1504.}

Varios autores ya han señalado que la crisis sucesoria que sobrevino tras la muerte de la reina Isabel ya se vislumbraba con las muertes del príncipe heredero Juan y de la princesa Isabel en los últimos años del siglo XV. Las grandes familias de la aristocracia castellana vieron en doña Juana y don Felipe la posibilidad de reproducir pasadas estrategias de injerencia política y aumentar sus patrimonios a costa de la debilidad de carácter y facilidad de manipulación de los herederos ${ }^{2583}$.

La inestabilidad generada tras la muerte de la reina Isabel fue el fértil caldo de cultivo sobre el que se reprodujeron una serie de pactos nobiliarios que dieron paso a la configuración de dos bloques antagónicos: los fernandinos capitaneados por el Duque de Alba y los antifernandinos o felipistas encabezados por el duque de Nájera. Don

${ }^{2583}$ LÓPEZ PITA, “Nobleza y monarquía..., pp. 163 y ss; y QUINTANILLA RASO, "Élites de poder..., pp. 969 y ss. 
Francisco de Zúñiga, tercer conde de Miranda, siguiendo la misma línea que ya habían pergeñado sus antecesores, rápidamente se significó en el bando contrario a los intereses que antaño se denominaban aragonesistas y prestó su apoyo a los nuevos reyes. Esta adhesión a la causa borgoñona se materializó en el embarque del conde con sus familiares para acudir a Inglaterra y recibir a sus señores, todo ello a pesar de la prohibición expresa de don Fernando ${ }^{2584}$. Siguiendo el compromiso de merced tras recibir muestras de servicio ${ }^{2585}$, don Felipe gratificó al conde con la concesión el 21 de julio de 1506 de la tenencia de las disputadas fortalezas de Hoyales y Ventosilla, merced que, como ya hemos visto, escondía una ventajosa compraventa ${ }^{2586}$. Este hecho confirma la confluencia de intereses entre el nuevo monarca, que buscaba confirmar su posición en Castilla y obtener recursos económicos, y la aristocracia, que trataba de medrar a costa de los bienes de la Corona. También el conde de Urueña se encontraba entre los partidarios de don Felipe. Por su parte, don Bernardino de Sandoval, marqués de Denia, fue de los pocos que se mantuvieron siempre fieles al regente don Fernando.

Un nuevo periodo de inestabilidad se abrió en septiembre de 1506 con el fallecimiento de don Felipe. En este contexto las más importantes familias de la aristocracia castellana volvieron a dividirse entre los partidarios de la opción austriaca, que pretendía que fuera regente del reino Maximiliano, y los que proponían la vuelta de don Fernando. Finalmente se impusieron los fernandinos y sus más fieles partidarios acudieron a Valencia para recibir al rey de Aragón en 1507. El rey Católico asumió de nuevo la regencia, contando para ello con el apoyo de un sector de la alta nobleza que en 1510 juró su reconocimiento como administrador y gobernador de los reinos y señoríos de Castilla, León y Granada. Entre los firmantes se encontraba su fiel marqués de Denia y el conde de Coruña. Asimismo volvió a la obediencia fernandina don Juan Téllez de Girón, conde de Urueña. Sin embargo, dicho juramento no incluyó a ninguno de los miembros del clan de los Zúñiga ${ }^{2587}$. En contraposición al triunfo del bloque aragonesis-

\footnotetext{
${ }^{2584}$ PADILLA, Crónica de Felipe..., pp. 140-141.

${ }^{2585}$ QUINTANILLA RASO, “Élites de poder..., p. 974.

${ }^{2586}$ BRAH, SALAZAR Y CASTRO, M-59, fol. 63: ... mi mandado y voluntad es que don Fran-
} cisco de Zúniga y Avellaneda, conde de Miranda, del mi Consejo, tenga las dichas fortalezas y lugares. Citado por QUINTANILLA RASO, "Élites de poder..., nota 71, p. 977; y transcrito por SOLER NAVARRO, Los Duques de Peñaranda..., doc. 10, pp. 25-26.

${ }^{2587}$ LÓPEZ PITA, “Nobleza y monarquía..., p. 169-174 y doc. VIII, pp. 325-333. 
ta, algunos de los felipistas más significados se exiliaron en Gante, al amparo de la corte del príncipe don Carlos. Entre estos exiliados se encontraban don Juan Manuel, Diego de Guevara y Alonso Manrique ${ }^{2588}$. Uno más entre estos personajes fue don Juan de Zúñiga, hermano del conde de Miranda, que fue nombrado chambelán de cámara en la Grand Chapelle de Gante ${ }^{2589}$. En el ámbito comarcal, el cambio en el trono supuso que el conde de Miranda perdiera la tenencia de las villas de La Ventosilla y Hoyales que poco antes le había concedido don Felipe ${ }^{2590}$. A esta inestabilidad generada por cuestiones puramente políticas debemos añadir asimismo las repercusiones socioeconómicas que propició la crisis que comenzó en 1504 como han señalado algunos autores. ${ }^{2591}$

A comienzos de 1516 la inestabilidad política volvió a instalarse en el reino tras la muerte del rey Fernando y la incapacidad manifiesta de doña Juana, reina titular, de hacerse con las riendas del reino. La ausencia de don Carlos obligó a tomar la decisión de nombrar un regente que preparase la llegada del nuevo rey. Para esta misión fue elegido el cardenal Jiménez Cisneros. De todos es conocida la vinculación que tuvo el cardenal con la comarca ribereña en los meses en que fue regente del reino, aunque menos conocida fue la negativa de las autoridades arandinas a hacer cumplir algunas de las decisiones que tomó el regente en este corto periodo. La política de movilización de efectivos militares emprendida por Cisneros no fue muy bien acogida en la villa de Aranda que se mostró reticente a colaborar y dilató todo lo que pudo la movilización de hombres a la espera de lo que hicieran Burgos y Valladolid ${ }^{2592}$. El concejo decidió enviar un memorial al Consejo Real en el que mostraba su preocupación por los problemas que podía acarrear para el desarrollo de la actividad económica en la villa la subida

${ }^{2588}$ MARTÍNEZ MILLÁN, J., "La evolución de la corte castellana durante la segunda regencia de Fernando (1507-1516)", en La Corte de Carlos V. Madrid, 2000. Vol. I, pp. 110-111; y MARTÍNEZ MILLÁN y DE CARLOS MORALES, Felipe II..., pp. 25-26.

${ }^{2589}$ DOMÍNGUEZ CASAS, Arte y etiqueta..., pp. 564-574.

${ }^{2590}$ AGS, CC CÉDULAS, libro 7, leg. 220, doc. 1.

${ }^{2591}$ Los aspectos relacionados con las malas cosechas y el aumento de los precios han sido abordados por YUN CASALILLA, B., "El mercado del vino en Córdoba durante la crisis de 1504-1508: Aproximación al estudio de las bases económicas de un grupo social", en Investigaciones históricas: Época moderna y contemporánea. 1, 1979, pp. 7-42; OLIVA HERRER, H. R., "Reacciones a la crisis de 1504 en el mundo rural castellano", en Crisis de subsistencia y crisis agrarias en la Edad Media. Sevilla, 2007, pp. 259-276.

${ }^{2592}$ AGS, CC PUEBLOS, leg. 2, doc. 107. Cisneros retomó la idea del rey Fernando de crear una milicia permanente. La oposición a esta medida por parte de la villa de Valladolid ha sido estudiada por ASENJO GONZÁLEZ “Las ciudades castellanas al inicio..., pp. 106-110. 
de impuestos y la movilización para la guerra, solicitando asimismo la confirmación de sus privilegios $^{2593}$. El obispo Mota se hizo portavoz del rey y otorgó seguridades a los regidores arandinos con un argumento válido para todo el reino: ...el rrei nuestro señor dize que no bino a estos reynos para quebrantar los buenos privillegios e buenos usos e costumbres de las ciudades, villas e lugares dellos syno para los guardar e mandar guardar e mantener a todos en justicia ${ }^{2594}$.

La alta nobleza, retomando la vieja división entre felipistas y fernandinos, se aprestó de nuevo a colocarse en posición ventajosa ante la llegada del nuevo monarca, sucediéndose los movimientos de acercamiento a la corte de Bruselas y las solicitudes de intercesión ante don Carlos a través de Cisneros o de Alfonso de Aragón, regente de Aragón $^{2595}$. En este contexto se podría encuadrar la modesta prebenda del oficio del alguacilazgo de Aranda otorgada a Juan de Zúñiga por el monarca el 27 de noviembre de 1516 todavía en Bruselas. Sin lugar a dudas, esta prebenda tenía un valor insignificante en Flandes pero se incrementaba exponencialmente en la comarca ribereña. Esta merced se convirtió en una pieza fundamental en la consolidación de la posición del conde de Miranda y, por contra, fue un episodio clave en la merma de la autonomía concejil arandina que ya se venía arrastrando desde las últimas décadas del siglo XV.

El conde de Miranda se encontraba en este momento de inestabilidad política en una posición privilegiada pues, por una parte, su hermano don Juan formaba parte del círculo de confianza del joven rey y, por otra, don Francisco estaba perfectamente integrado dentro del clan del Condestable de Castilla que capitaneaba las confederaciones nobiliarias que apoyaban a don Carlos. Observamos, por lo tanto, que el linaje de los Zúñiga tenía una posición muy bien acomodada al comienzo del reinado de don Carlos dentro de la órbita de los servidores más próximos del monarca.

La casa de Sandoval se ganó también el favor del rey Carlos pues en marzo de 1518 don Bernardo de Sandoval y Rojas, marqués de Denia, recibió como prebenda el cargo de gobernador y administrador de la casa de la reina Juana ${ }^{2596}$. La misión del

2593 AGS, CC PUEBLOS, leg. 2, doc. 55

${ }^{2594}$ AHN, CONSEJO, leg. 37870, nº 1, obtenido de ALONSO GARCÍA, Fisco, poder..., p. 433.

2595 MARTÍNEZ MILLÁN, J., "Inestabilidad política y conflictos en Castilla tras la muerte del rey Fernando. La regencia del Cardenal Cisneros", en La Corte de Carlos V. Madrid, 2000. Vol. I, pp. 147-149.

${ }^{2596}$ LÓPEZ PITA, “Nobleza y monarquía..., nota 43, p. 175. 
marqués era la de mantener a doña Juana bajo un estrecho régimen de vigilancia e impedir que se utilizara su persona como bandera de cualquier intento de sublevación contra el rey. En este sentido, es bastante revelador el comentario que hizo el propio marqués en el verano de ese mismo año cuando se planteó trasladar la Corte de la reina a la villa de Aranda ...pareceme que aquel seria el lugar donde Su Alteza podria estar mejor asi porque no es grand lugar como porque no ay en el personas que puedan poner enbaraço en nada ${ }^{2597}$.

Con el fin de evitar problemas, don Carlos encomendó a Cisneros aplicar la misma estrategia seguida con la reina en la figura de su hermano don Fernando. Precisamente la capital de la Ribera fue el escenario en septiembre de 1516 de la aplicación de estas órdenes pues en Aranda fue privado el infante de sus más estrechos servidores $^{2598}$. La villa ribereña también fue el marco en el que se dio un paso más en esta dinámica política cuando en la Semana de Pascua de 1518 desde Aranda fue el propio monarca el que despachado a su hermano a Flandes ${ }^{2599}$. La despedida entre los dos hermanos la relata el cronista Vital y la dota de un valor moral y sentimental muy propio de la época pues señala que el rey quiso acompañar a su hermano a su salida de Aranda durante media legua y una vez llegados a un cruce de caminos, sin descabalgar, se encomendaron a Dios y se despidieron con un abrazo ...con pocas palabras, porque sus corazones estaban anegados en lágrimas ${ }^{2600}$.

Como hemos podido apreciar, tanto en Castilla como en la Ribera del Duero se aprecia desde los primeros años del Quinientos la configuración de una nueva relación de fuerzas que con el tiempo dio como resultado una nueva realidad en el ámbito político, la configuración del Estado Moderno, que también tuvo sus derivaciones mucho más significativas en las esferas social y económica. No obstante, esta nueva relación de

2597 AGS, ESTADO, leg. 5, doc 308, transcrito por BERGENROTH, Calendar of Letters..., pp. $171-174$, doc 36 .

${ }^{2598}$ ALVAR EZQUERRA, A., Fernando I (1503-1564): socialización, vida privada y actividad pública de un Emperador del Renacimiento. Madrid, 2004, p. 32. Más información sobre la figura del infante en EGIDO LÓPEZ, T. (Coord.), Fernando I. Un infante español Emperador. Valladolid, 2004.

${ }^{2599}$ DE CARLOS MORALES, C. J., "La llegada de Carlos I y la división de la Casa de Castilla", en La Corte de Carlos V. Madrid, 2000, vol. I, pp. 170-171.

${ }^{2600}$ VITAL, Relación del primer viaje..., p. 360. Sobre el significado de la visita del rey a Aranda SANZ ABAD, P., “Aranda de Duero en la primera mitad del siglo XVI”, Boletín de la Institución Fernán González. Burgos, 1967, pp. 5-25. 
fuerzas no fue realidad sino tras las consecuencias que tuvo, tanto en el reino como en la comarca, la última revuelta medieval o la primera revolución moderna.

\section{2. El desarrollo del movimiento comunero en Aranda.}

Entre 1520 y 1521 la villa de Aranda de Duero experimentó uno de los capítulos más intensos de su historia. Si bien es cierto que durante los primeros momentos del desarrollo del movimiento comunero en Castilla la capital de la Ribera mantuvo una postura vacilante, con el transcurso de los acontecimientos la comunidad arandina se decantó por las posiciones de la Junta y así continuó casi sin interrupción hasta la primavera de 1521. En el punto contrapuesto se situó la mayor parte de los señores comarcanos que se alinearon en el bando realista a excepción, en un primer momento, de don Pedro de Girón, hijo del conde de Urueña.

A pesar de contar con extraordinarios trabajos historiográficos que han abordado el conflicto de manera global, los acontecimientos que tuvieron lugar en la villa arandina no han sido abordados de manera concreta sino más bien se emplean ocasionalmente para ilustrar tendencias generales. Los estudios de ámbito local que hasta el momento se han realizado ofrecen una serie de datos recopilados de distintas fuentes aunque no explican suficientemente los motivos por los que se vivió con tal intensidad la experiencia comunera ni tampoco la dinámica interna del movimiento en Aranda ${ }^{2601}$.

Uno de los aspectos que mayor discrepancia ha provocado entre los historiadores de las Comunidades ha sido el debate sobre las causas del fenómeno. Todos ellos han tratado de identificar los motivos que explicaron el estallido de este movimiento pero hasta el momento no se puede dar el debate por concluido. En ocasiones los argumentos esgrimidos son complementarios aunque también se observan posiciones contradictorias

${ }^{2601}$ A lo largo de este apartado haremos referencia a los principales autores y obras que han abordado el fenómeno de las Comunidades en Castilla de manera general. La primera referencia que debemos destacar es la impresionante obra de DÁNVILA COLLADO, Historia Crítica y documentada de las Comunidades de Castilla que en sus seis volúmenes transcribe e interpreta los principales documentos depositados en el Archivo General de Simancas, sección Patronato Real. En cuanto a los estudios locales destaca la obra de VELASCO PÉREZ que dedica un capítulo entero a las Comunidades de Castilla y que se basa casi exclusivamente en los datos publicados por Dánvila Collado (Aranda. Memorias..., capítulo XXI, pp. 146-154); SANZ ABAD también aborda este conflicto en un capítulo específico (Historia de Aranda..., capítulo XXIII, pp. 157-163); y por último, destaca el reciente estudio de DIAGO HERNÁNDO en el que asocia el movimiento comunero a la restauración del régimen de gobierno previo a la reforma de los Reyes Católicos y por lo tanto con una orientación eminentemente conservadora (“Cambios políticos..., pp. 299-342). 
e incompatibles: nacionalismo, tradicionalismo, pactismo, crisis dinásticas, aspectos socioeconómicos,... No es nuestro objetivo avivar el debate y mucho menos desde una perspectiva local como la que presenta este trabajo. No obstante, creemos conveniente tener en cuenta ciertos aspectos previos que condicionaron desde nuestro punto de vista el desarrollo del fenómeno comunero en la Ribera del Duero.

En primer lugar, parece evidente que las sucesivas crisis dinásticas que se desarrollaron en 1504, 1506 y 1516 tuvieron su incidencia en la comarca pues la inestabilidad propia de estos momentos se plasmó de forma significativa en el seno de una sociedad urbana que aprovechó la coyuntura para solicitar el reconocimiento de una determinada situación: ya fuera la de la oligarquía que quería consolidar y reforzar su posición de poder; o la del Común que aspiraba a la participación efectiva en los órganos de gobierno municipales. Aspecto curioso es el hecho de que los dos bandos contendientes en ocasiones confluyeron en argumentos presentando el reconocimiento de los fueros y privilegios como elementos legitimadores de sus aspiraciones.

También en estos periodos de inestabilidad la nobleza comarcana trató de conseguir de los nuevos monarcas el reconocimiento de su posición privilegiada que en el marco de la Ribera se tradujo en el incremento de la presión señorial sobre un territorio sumido en un intenso proceso de señorialización y que tuvo su principal foco de intensidad en el aumento de esta presión sobre el realengo de la villa de Aranda.

Por otra parte, como ya hemos visto en apartados anteriores, a comienzos del Quinientos ya estaba perfectamente configurada una verdadera polarización sociopolítica en el seno de la sociedad arandina. Un primer grupo estaba compuesto por una oligarquía de fuerte base privilegiada y monopolizadora del gobierno urbano. En el polo opuesto se situaba la Comunidad que englobaba a la gran masa pechera de la villa dirigida por un selecto grupo de vecinos que disfrutaban de una situación económica destacada. Los continuos roces entre ambos grupos que hemos identificado a lo largo del periodo bajomedieval culminaron definitivamente en el contexto de la revuelta comunera. Ahora bien, la escala local de nuestro trabajo no nos permite concluir si esta tensión sociopolítica interna fue una de las causas de la revolución comunera o, por el contrario, la revolución fue el detonante que hizo colapsar una situación previa extremadamente tensa. Fuera una u otra posibilidad, lo cierto es que entre el verano de 1520 y la primavera de 1521 se visualizó de forma violenta la conflictividad que se venía desarrollando en el seno de la sociedad urbana arandina durante la Baja Edad Media entre la minoría 
oligárquica que monopolizaba los resortes del poder político local y una mayoría, dirigida por un grupo económicamente potente, que aspiraba a participar en las decisiones que afectaban a la vida de la vecindad.

Por lo tanto, en nuestra opinión las sucesivas crisis dinásticas del principio del Quinientos, la creciente presión nobiliaria y la conflictividad interna de Aranda fueron la base del estallido comunero en la Ribera del Duero burgalesa. No obstante, también debemos tomar en consideración, aunque no hayamos detectado nada que lo justifique, la idea mantenida por Sanz Abad que veía en la figura del infante Fernando, frecuentemente instalado en la villa junto a su consejo hasta 1518 , la explicación de la afiliación de los arandinos hacia la causa comunera ${ }^{2602}$.

\section{2. 1. Antecedentes.}

A nivel general del reino, el detonante de las primeras revueltas se produjo incluso antes de la aprobación del servicio solicitado por el monarca en las Cortes de Santiago, pues en mayo de 1520 ya tuvieron lugar serios altercados en la ciudad de Toledo que se reprodujeron poco después en Segovia, Guadalajara o Ávila.

A buen seguro que los acontecimientos desarrollados en la influyente ciudad de Burgos a principios de junio tuvieron su inmediata repercusión en Aranda. A partir del 10 de junio se sucedieron en esa poderosa urbe una serie de revueltas que primeramente tuvieron carácter antifiscal pero que acto seguido posicionaron a la Cabeza de Castilla en el contexto del movimiento comunero. El temor a la subida de impuestos encendió la ira de los burgaleses que se plasmó en la destrucción de los recipientes que servían para calcular la alcabala del vino. Seguidamente ocuparon la fortaleza, expulsaron a las autoridades municipales y asaltaron varias mansiones de algunos notables, entre los que se encontraba un procurador de Cortes y varios recaudadores. Finalmente el aposentador real de origen francés, Joffre de Cotannes, fue ejecutado en respuesta a su nombramiento como tenente de la fortaleza de Lara que había conseguido de los asesores flamencos del monarca en contra de los intereses del concejo burgalés ${ }^{2603}$. La rápida intervención del Condestable de Castilla en la ciudad no impidió que las asambleas populares se postularan por los ideales comuneros, aunque manteniendo notables discrepancias con los

\footnotetext{
${ }^{2602}$ SANZ ABAD, Historia de Aranda..., p. 158.

${ }^{2603}$ PÉREZ, La revolución..., p. 166.
} 
principios rectores de la Santa Junta. Sin lugar a dudas, la continua presencia del Condestable en la ciudad, así como su intensa actividad "diplomática" sobre los notables burgaleses, lograron prolongar la indefinición del cabildo burgalés que no se decidió a comprometerse con la Comunidad y se mantuvo en una cómoda ambigüedad.

En este contexto encontramos la primera noticia sobre el posicionamiento de la villa de Aranda prestando su apoyo a la sublevación de la Cabeza de Castilla. Si bien los primeros datos apuntan a que la villa se sublevó en los primeros días de septiembre ${ }^{2604}$, ciertos indicios nos llevan a pensar que quizá el movimiento comenzó antes o éste fue escalonado. Así, en la documentación emitida tanto por las autoridades burgalesas como por el propio Condestable se relata la prontitud con la que las autoridades de Aranda enviaron socorro a la revuelta burgalesa. Otra evidencia de una temprana adhesión de la capital de la Ribera a la causa comunera es la comisión que las autoridades municipales encargaron al capitán Miguel Daza, al bachiller Ventosilla y al alcalde Sebastián de Sinovas de ir a Ávila con el cometido de poner la villa al servicio de la Santa Junta, aunque bien es cierto que la documentación original se muestra parca en datos que demuestren la presencia de los arandinos en Ávila ${ }^{2605}$. Por otra parte, en el perdón que el monarca concedió a la ciudad de Burgos y su provincia se hacía expresa mención a los desórdenes cometidos en Aranda tras relatar los que tuvieron lugar en Burgos en los primeros días de junio ${ }^{2606}$. La evidencia más clara de una pronta implicación de la villa en el movimiento comunero la encontramos en una misiva enviada el 21 de julio de

${ }^{2604}$ Para DIAGO HERNANDO el estallido de la revuelta comunera en Aranda se produjo con cierto retraso respecto a la mayoría de las ciudades de su entorno, pues no tuvo lugar hasta el 11 de septiembre de 1520 (“Cambios políticos..., p. 328).

2605 DÁNVILA COLLADO, vol. II, p. 398. El dato de Ávila lo aporta VELASCO PÉREZ (Aranda. Memorias..., p. 147-148). La Santa Junta se creó el 29 de julio en Ávila y se trasladó el 11 de septiembre a Tordesillas. Este testimonio también es refrendado por SANZ ABAD (Historia de Aranda..., p. 159). No obstante, en la documentación original con la que hemos trabajado se hace referencia al envío de los representantes ante la Junta pero en ningún caso se confirma que fuera a Ávila.

${ }^{2606}$ AGS, PR, leg. 4, doc. 25. El monarca hace un relato de los principales acontecimientos: ...en la ciudad de Burgos hubo algunos levantamientos y alborotos, y a nombre de comunidad muchos vecinos de la dicha ciudad tomaron las varas de nuestra justicia al nuestro corregidor y sus oficiales y pusieron otros a su voluntad y tomaron por fuerza el castillo y fortaleza de la dicha ciudad al alcaide que por nos lo tenía e derribaron y robaron algunas casas de la dicha ciudad y mataron a Jofre de Cotannes nuestro aposentador; y alli y en otros lugares de la provincia e partido de la dicha ciudad, especialmente en la villa de Aranda, se han cometido desde el dicho tiempo acá otros muchos delitos. El documento ha sido transcrito íntegramente por SALVÁ, A., Burgos en las Comunidades de Castilla, Burgos, 1895 (red. 2002), pp.154-161. 
1520 por el monarca al Conde de Miranda en la que le agradece su papel en la pacificación de $\operatorname{Aranda}^{2607}$.

Por lo tanto, podemos intuir que en la villa de Aranda, siguiendo el eco de los disturbios acaecidos en Burgos, se inició un conato de rebelión que se vio sofocado por la intervención de don Francisco de Zúñiga. A buen seguro que el conde no dudó en utilizar sus influencias sobre la oligarquía local y posiblemente su fuerza militar.

Sin lugar a dudas, en el verano de 1520 los vecinos de Aranda se hicieron eco de las noticias que venían de las ciudades comuneras y tomaron ciertas iniciativas. A falta de la documentación original que se guardaba en el Libro de los Oficios del Concejo y que desapareció tras las Comunidades, hemos reconstruido el proceso que con toda seguridad se siguió en los últimos días del mes de agosto o primeros de septiembre de 1520 y que desembocó en el estallido de la revuelta el 11 de septiembre de $1521^{2608}$. Suponemos que, como era costumbre en la villa siempre que se producía algún acontecimiento relevante, los procuradores del común solicitaron al corregidor que se reunieran las cuadrillas para discutir sobre el asunto ${ }^{2609}$. El corregidor en compañía de regidores y escribanos convocaron a las cuadrillas por separado: la del Duero en San Llorente, la cuadrilla de Hisilla en la ermita de San Roque, la cuadrilla de Cascajar junto al monasterio de San Francisco y la de San Juan junto a la iglesia del mismo nombre. Después de la discusión entre los vecinos, se nombró a uno o dos de ellos como procuradores para que trasladaran la opinión de la cuadrilla a la reunión del Ayuntamiento. Allí debería haberse tomado la decisión final, aunque posiblemente no llegaran a esta reunión a tenor de los acontecimientos que se desarrollaron después. En esta ocasión las cuadrillas nombraron ocho diputados, además de sus procuradores. La figura del diputado de la Comunidad no suponía una novedad pues ya estaba presente en la villa de

2607 ARCHIVO DUCAL DE ALBA, MONTIJO, Caja 50, doc.1. Referencia obtenida de MARTÍNEZ MILLÁN (coord.), "Los consejeros de Calos V”, La corte..., Vol. IV, p. 473, notas 37453749 .

${ }^{2608}$ Las declaraciones realizadas por varios de los encausados en mayo de 1522 señalaban que sus nombramientos como diputados estaban recogidos en el Libro de los Oficiales del Ayuntamiento. En la recopilación que hace DÁNVILA COLLADO se indica que a mediados del siglo XIX en el Ayuntamiento de Aranda se conservaban los libros de actas de los años previos y posteriores a 1520 pero no los de ese año (Historia crítica..., vol. II, p. 397).

${ }^{2609}$ El procedimiento lo conocemos perfectamente a través de la documentación conservada. En el pleito que emprendió la villa contra el nombramiento de don Juan de Zúñiga como alguacil de la villa, se narra con todo tipo de detalles el proceso de elección de procuradores por las cuadrillas y la posterior reunión de corregidor, regidores, justicias y procuradores en el Ayuntamiento para tomar las decisiones oportunas (AGS, CONSEJO Y JUNTAS DE HACIENDA, leg, 4, doc. 20). 
Aranda al menos desde 1478 actuando como representante de las cuadrillas ${ }^{2610}$. Por el momento no sabemos la fecha en la que se reunió el corregidor, regidores, procuradores y diputados. Es posible que la reunión tuviera lugar el mismo 11 de septiembre o tal vez el comienzo de la revuelta en Aranda hizo inviable este ayuntamiento.

\section{2. 2. El estallido de la Revolución en Aranda.}

Como ya hemos venido anunciando, el 11 de septiembre de 1520 tuvo lugar en la villa el estallido de la revolución comunera. La primera iniciativa de los diputados elegidos previamente por las cuadrillas fue la toma de las varas de la justicia al corregidor, Juan Manrique de Luna, y sus alcaldes ${ }^{2611}$. Asimismo fueron expulsados de sus oficios los regidores perpetuos e impuesto un nuevo gobierno municipal que administraba la villa a boz de regidor ${ }^{2612}$. En este sentido, el nuevo gobierno de la Comunidad no hizo más que imitar lo que ya se había hecho en la capital burgalesa en junio. Pero además en Aranda se tomó una decisión que no tuvo paralelismos en otras ciudades: la destitución de los ocho escribanos del número de la villa y el nombramiento de otros doce que los sustituyeron ${ }^{2613}$.

No sabemos a ciencia cierta por qué se produjo la insurrección en este preciso momento pero sí que hay dos acontecimientos que podrían ayudarnos a entender la situación. El primero de ellos fue el incendio de la villa de Medina del Campo el 21 de agosto por las tropas fieles al monarca comandadas por el alcalde Ronquillo que cumplía las órdenes del regente Adriano de Utrech. Fue tal la indignación que causó este hecho que "la llama de la Comunidad se extendió por todos los rincones de Castilla", provocando asimismo la expulsión del Condestable de la ciudad de Burgos ${ }^{2614}$. El otro aconteci-

${ }^{2610}$ Alonso de Aranda afirmaba que ...fue puesto por deputado por toda la cuadrilla y justicia y regidores de la villa antes que se alçase la villa como paresçe por el libro de los ofiçiales del ayuntamiento desta villa y del Corregidor y regidores e escribano del ayuntamiento. Lo mismo declaraba Miguel Sánchez de la Torre (AGS, CR, leg. 450, doc. 8). La primera mención a la figura del diputado la encontramos en marzo de 1478 (AGS, RGS, 147803, fol. 37; CC MEMORIALES, leg. 121, doc. 236; y AMA, leg. 43, fol. 25, transcrito por HURTADO QUERO, Documentos Reales..., doc. 13, pp. 27-28). Esta figura también aparece asociada a los gremios y cofradías de la localidad (ARChV, RRE, Caja 150, doc. 50; y PLEITOS CIVILES, PÉREZ ALONSO (F), Caja 676, doc. 6).

\footnotetext{
2611 AGS, RGS, 152108, s. f. (DIAGO HERNANDO “Cambios políticos..., p. 328).

${ }^{2612}$ AGS, RGS, 152101, s. f. (PÉREZ, La Revolución..., p. 510).

${ }^{2613}$ AGS, RGS, 152108, s. f. (DIAGO HERNANDO “Cambios políticos... p. 332).

${ }^{2614}$ BERZAL DE LA ROSA, E. Los Comuneros: de la realidad al mito. Madrid, 2008, pp. 8189. Este autor relaciona la revuelta arandina con la respuesta al incendio de Medina del Campo y además
} 
miento que pudo interferir en el estallido de la revuelta en Aranda fue la presencia del obispo Acuña por tierras burgalesas. El dirigente comunero llevaba a cabo el desesperado intento de controlar a la indecisa ciudad de Burgos, justo en el momento en que parecía decidirse por la Comunidad tras la expulsión del Condestable ${ }^{2615}$. Posiblemente la combinación de ambos factores, más otros que no logramos descifrar por el momento, llevaron a la incorporación de la villa de Aranda al movimiento comunero.

\section{2. 3. Los protagonistas.}

La gran cantidad de documentación que ha aportado la posterior represión sobre los comuneros arandinos nos ha permitido recomponer el cuadro de gobierno de la Comunidad en Aranda ${ }^{2616}$ :

- Alcaldes: estos oficiales asumieron las competencias judiciales del depuesto corregidor y se encargaron de administrar justicia, retomando el número y las funciones que ostentaban los alcaldes ordinarios con anterioridad a la reforma de los Reyes Católicos efectuada a principios de los años ochenta. Fueron nombrados para este oficio García Ximeno y Sebastián de Sinovas.

- Regidores: tras la destitución de los regidores perpetuos fueron nombrados nuevos regidores, recobrando así el carácter electivo previo a la reforma de los monarcas. En esta misma línea se retomó el número de cuatro y casi seguro que también su carácter anual, aunque el desarrollo de los acontecimientos no permitió corroborarlo. A buen seguro que sus funciones se centraron en el gobierno del municipio, aunque es posible que tuvieran que compartir esta tarea con los diputados. Conocemos el nombre de los cuatro nombrados por la Comunidad: Alonso de Moradillo, Pedro Sánchez de Mendoza, García Tomillo y Alonso Jiménez Daza.

lo sitúa dentro del movimiento antiseñorial que se produce en la provincia de Burgos y que pone en jaque los dominios de los Velasco en el Norte burgalés. Desde nuestro punto de vista poco tiene que ver el aspecto antiseñorial con los acontecimientos desarrollados en Aranda que, no lo olvidemos, era una villa de realengo.

${ }^{2615}$ GUILARTE, A. M., El obispo Acuña. Historia de un comunero. Valladolid, 1983, pp. 66-70. Los intentos de Acuña por entrar en Burgos se produjeron entre el 12 de septiembre y los primeros días de octubre. La empresa fracasó y Acuña tuvo que retirarse precipitadamente.

${ }^{2616}$ La mayor parte de la identificación de los oficios la proporciona un memorial sin fechar enviado por algún vecino realista a los Gobernadores. En él se enumeran los vecinos con su cargo, 42 en total, más una larga lista, otros 34, de implicados en la revuelta (AGS, PR, leg. 4, doc. 16). A través de otras fuentes hemos identificado a otros vecinos como oficiales de la Comunidad. 
- Alguaciles: recordemos que se trata del oficial que se encargaba de ejecutar las sentencias y cobrar las multas. Hasta 1520 sólo había uno pero la Comunidad nombró a dos vecinos para este cometido: Alonso de Aranda el de San Juan, alias el Bermejo, y Francisco de la Plaza.

- Diputados: como ya hemos visto era una figura de larga tradición entre los representantes del Común y respondía a las exigencias de los vecinos por encontrarse representados en el concejo. Es significativo que aparecieran citados como Diputados a boz de regidores lo que lleva a identificar ambos oficiales. De esta afirmación se puede colegir que regidores y diputados formaban un único cuerpo de oficiales equiparable al Regimiento, asumiendo las tareas de gobierno del municipio $^{2617}$. Ya hemos comentado anteriormente el proceso por el que fueron elegidos por las cuadrillas con el beneplácito de corregidor y regidores. Tenemos noticias de ocho diputados: Miguel de la Gallega, que además aparece identificado como Presidente ${ }^{2618}$, Martín García de Anguix, Alonso de Aranda Tundidor, Miguel Sánchez de la Torre, Miguel García de Fuentelcésped, Sebastián de Gumiel, Miguel Díez del Prado, Bernaldino de Arauzo y Alonso de Halcona$\mathrm{da}^{2619}$.

- Escribanos del Concejo: como ya hemos visto en su momento, eran los encargados de dar fe de los acuerdos del Ayuntamiento, por lo que parece lógica la sustitución de al menos el escribano de los caballeros. No obstante, también fue destituido el escribano de la Comunidad. Ambos fueron sustituidos por Francisco de Torquemada, que también aparece como Presidente del concejo ${ }^{2620}$, y el bachiller Ventosilla.

${ }^{2617}$ Esta circunstancia ha llevado a PÉREZ a señalar que los diputados expulsaron a los regidores y los sustituyeron en sus tareas de gobierno municipal (La revolución..., p. 510). Sin embargo, como afirma DIAGO HERNANDO ("Cambios políticos..., p. 329), la documentación confirma que ambos oficios convivieron en el gobierno de la Comunidad. El Diccionario de la Lengua Española de la Real Academia Española indica en la octava acepción de la palabra voz: Poder, facultad, derecho para hacer alguien, en su nombre, o en el de otro, lo conveniente ( $22^{\mathrm{a}}$ Edición).

${ }^{2618}$ DÁNVILA COLLADO, Historia crítica..., vol. II, p. 398.

${ }^{2619}$ Éste último aparece identificado junto a los anteriores en un emplazamiento del Condestable a los oficiales de la villa en febrero de 1521 (RGS, 152102, s. f.; y DIAGO HERNANDO, "Cambios políticos..., p. 331).

${ }^{2620}$ DÁNVILA COLLADO, Historia crítica..., vol. II, p. 398. 
- Capitanes: eran el brazo armado de la Comunidad y los responsables de las milicias urbanas. Entre sus misiones estaba defender la villa de las agresiones externas pero también fueron enviados a otros puntos de Castilla como Burgos, Tordesillas o Villalar al mando de entre 200 y 300 soldados. Cabe destacar su elevado número y alto grado de compromiso a tenor de las penas que les fueron impuestas posteriormente ${ }^{2621}$. Conocemos los nombres de algunos de estos capitanes: Gaspar de Mansilla, Miguel Daza, Miguel de Alcozar, Sancho de la Peña, Alonso Martínez, Pablo Fresnillo y Juan Sánchez de Quemada. Además los capitanes contaban con personal subalterno como un lugarteniente o alguacil, Juan de Tubilla, y un correo, Martín de Zárate, que se encargaba de mantener la comunicación entre las milicias destacadas fuera de la villa y las autoridades arandinas.

- Procuradores: con esta figura se designaba tanto a los representantes del concejo en cuanto institución como a los representantes de las cuadrillas elegidos directamente por los vecinos. Como ya hemos visto, este oficio aparece continuamente en el concejo arandino antes y después de la existencia de los regidores de la comunidad. Durante el periodo comunero parece que mantienen sus funciones tradicionales centradas en la defensa de los intereses generales del vecindario y la representación del concejo. Desempeñaron este cargo durante el periodo comunero Juan Esteban Mercader, Francisco de la Puerta, Sebastián de Ventosilla y Juan del Rincón, mesonero. Posiblemente también ocupara el oficio de procurador Juan de Alameda, aunque muy pronto renunció a él por desavenencias con el resto de los oficiales comuneros ${ }^{2622}$.

${ }^{2621}$ El grado de implicación de los capitanes con la causa comunera parece evidente. Sin embargo, el hecho de que la mayor parte de los capitanes fueran represaliados es posible que tuviera más relación con su participación en episodios bélicos significativos y no tanto con una mayor significación en la revuelta.

${ }^{2622}$ En el memorial citado anteriormente no figuraban Sebastián de Ventosilla ni Juan del Rincón como procuradores pero otros documentos los confirman como tales (DÁNVILA COLLADO, Historia crítica..., vol. III, pp. 653-654; y DIAGO HERNANDO, "Cambios políticos..., p. 331; AGS, RGS, 152102, s. f.; y 152210, s. f.). En el caso de Ventosilla no aparece en los memoriales porque ya había fallecido cuando comenzó la represión (ARChV, RRE, caja 361, doc. 8). El caso de Alameda aparece recogido en AGS, CCM, leg. 141, doc. 206. 
- Otros oficiales del concejo: asimismo la Comunidad nombró a los oficiales menores del Ayuntamiento. Entre éstos tan solo hemos identificado a Miguel Sánchez Hermoso que actuó como mayordomo ${ }^{2623}$.

- Escribanos del Número: aunque no se trataba estrictamente de un oficio de carácter político, las autoridades de la Comunidad destituyeron a los ocho escribanos del número y nombraron otros doce, siguiendo la tradición de finales del siglo XV. Los nuevos escribanos fueron: Sancho de la Peña, Francisco de Quemada, Bartolomé del Rincón, Pedro de Pedraza, Santiago de Calahorra, Antonio de Prado, Antonio de Mari Quemada, Rodrigo de Aranda, Juan de Santo Domingo, García Sánchez Calahorra, Pedro Sánchez Guerra y Miguel Sánchez Campillo.

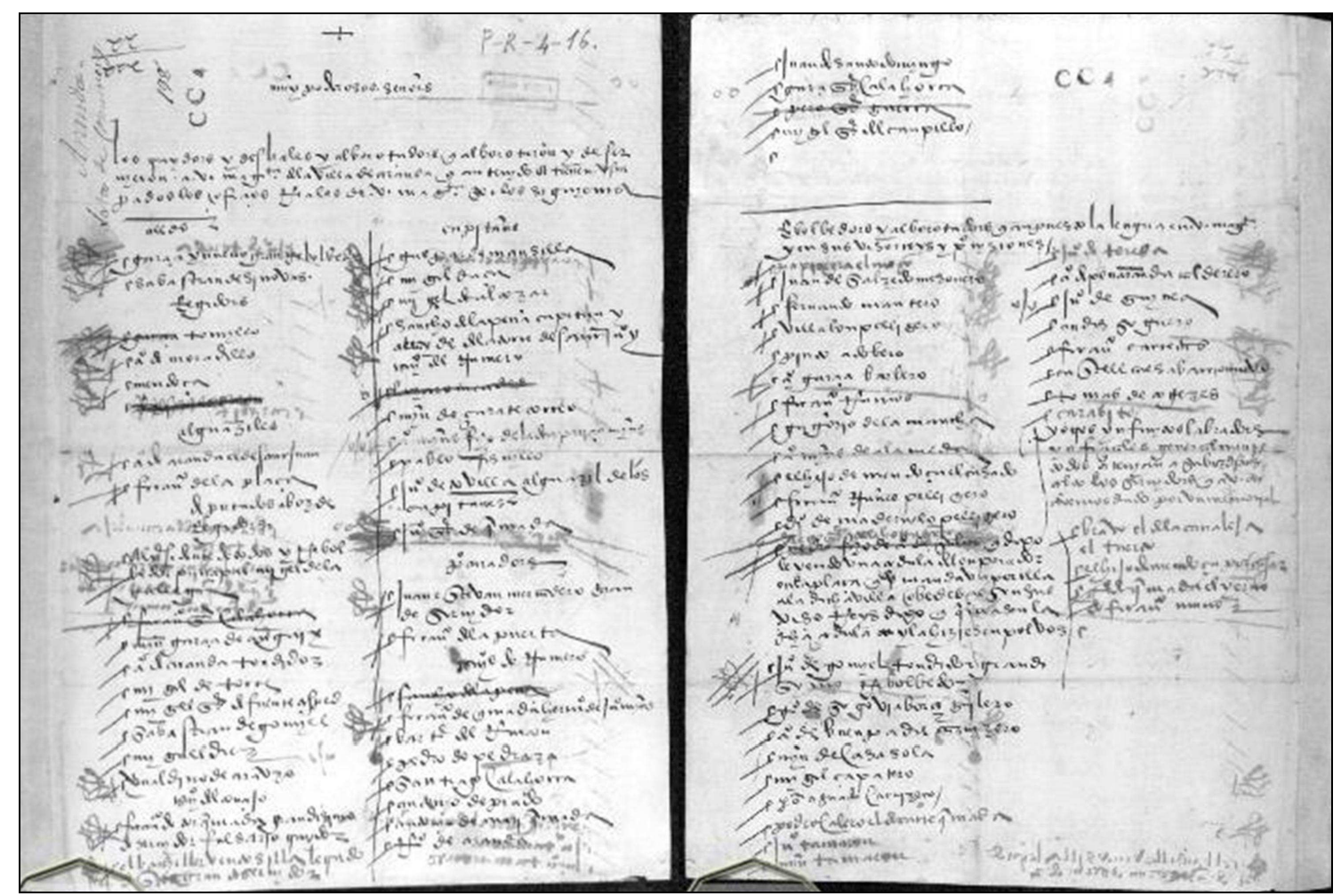

Imagen 54: Listado de los implicados en el movimiento comunero en Aranda (AGS, PR, leg. 4, doc. 16).

En este punto de nuestro análisis nos preguntamos quiénes fueron estos vecinos que tomaron la bandera de la revolución y el peso socioeconómico que tuvieron en la

${ }^{2623}$ AGS, CR, leg. 450, doc. 8 . 
villa arandina antes de la revolución. Las fragmentarias noticias de las que disponemos nos permiten reconstruir a grandes trazos las vidas de algunos de estos protagonistas ${ }^{2624}$.

La primera característica de este grupo de individuos es su gran heterogeneidad. El único punto que compartían era su condición de pecheros y su gran vinculación a la tierra, que era de forma directa o indirecta su principal medio de vida, aunque desarrollaran paralelamente otras actividades que les aportaban importantes ingresos. Efectivamente todos podían encuadrarse dentro de la categoría de labradores y, como no podía ser de otra manera, relacionados de una u otra forma con el mundo del vino. Todos ellos, salvo el bachiller Ventosilla ${ }^{2625}$, eran propietarios, y la mayor parte de su patrimonio se concentraba en aranzadas de viñedo. En este sentido cabe destacar las haciendas de Alonso de Moradillo, Miguel Daza o García Ximeno que contaban con más de 40 hectáreas de viñedo; entorno a la treintena poseían Gaspar de Mansilla, Bernaldino de Arauzo y Juan Esteban Mercadero; y entre 10 y 20 se encontraban Alonso de Aranda, Miguel de la Gallega, Pedro Sánchez de Mendoza, Francisco de Quemada y Sebastián de Sinovas. Todos ellos además eran propietarios de suelos en alguna de las bodegas arandinas y se dedicaban a vender su vino, y alguno de ellos el ajeno ${ }^{2626}$.

Pero el negocio del vino no era el único entre los comuneros arandinos. Alonso de Aranda, además de ser propietario de más de 16 hectáreas de viñedo, poseía más de ocho pares de casas en la villa además de varios censos sobre otras, y tenía arrendadas diversas rentas de la villa y comarca. Gaspar de Mansilla era vendedor de cerdos y tenía depositados en préstamos más de 100.000 maravedíes en buena parte de la comarca y

${ }^{2624}$ Los datos que aportamos aquí están obtenidos en gran medida de AGS, CMC, leg. 355, complementados por otras fuentes. Este documento recoge un pleito iniciado por los comuneros a los que se les confiscaron sus bienes. Los condenados denunciaron haber sido objeto de abusos por parte de las autoridades municipales restituidas tras Villalar.

${ }^{2625}$ En el expediente de los bienes confiscados al bachiller Ventosilla se especifica que no poseía bienes. A pesar de esta carencia de hacienda, hemos constatado que disfrutaba de una posición económica muy acomodada pues incluso fue uno de los pocos arandinos que disponía de un esclavo (ARChV, RRE, Caja 556, doc. 20). Suponemos que o bien en el momento de la rebelión era soltero y sin ningún bien, algo bastante improbable por edad y sentido común, o bien su hacienda estaba vinculada exclusivamente a su esposa. Esta última posibilidad indicaría cierta premeditación y consciencia de las consecuencias que su intervención en la revuelta podrían acarrearle.

${ }^{2626}$ A Bernaldino de Arauzo le confiscaron a principios de junio más de 1.700 cántaras de vino. En el inventario de los bienes confiscados aparecen casi en todos los exceptuados utensilios propios de la venta del vino (un embudo, una escalera de cubas, una gamella de vender vino, un embasador,...). También señalan en varias ocasiones los factores que deben devolver cierto vino que estaba en las bodegas de los exceptuados pero pertenecía a otro vecino. 
sobre todo en la Tierra de Cuéllar y Madrigal de la Altas Torres ${ }^{2627}$. Sus préstamos adquirieron la sutil forma de un depósito de empeños al que acudían destacados miembros de la oligarquía local para obtener liquidez dejando como prenda ricas telas o productos exóticos $^{2628}$. Juan Esteban Mercader pertenecía al gremio de comerciantes de paños de la villa y participaba en varias compañías con mercaderes burgaleses. García Ximeno actuó buena parte de su vida como arrendador de propios de la villa y receptor de rentas reales. También es sintomático que varios de los exceptuados tenían en sus casas importantes cantidades de diversos tejidos que nos dan una idea de una actividad mercantil complementaria de las ocupaciones agrarias. Asimismo entre los desterrados se hace mención a numerosos artesanos y comerciantes como tundidores, adoberos, cereros, zapateros, carniceros, caldereros, sogueros, cesteros o mesoneros.

Alguno de los implicados, como Francisco de Quemada, pasó una parte de su vida como hombre de armas en la capitanía del Marqués de Denia. En el caso de Quemada se aprecia cierto interés particular en el seguimiento de la causa comunera pues parece responder al despecho por haberle negado el regimiento el acceso a la plaza de escribano que dejó vacante su hermano, Juan Martínez de Quemada, en $1518^{2629}$.

Una evidencia más del alto poder adquisitivo del que disfrutaban algunos de los comuneros se extrae del hecho de que varios de ellos eran propietarios de esclavos: Gaspar de Mansilla poseía una esclava; el esclavo de Francisco de Torquemada era granadino y se llamaba Domingo; y el bachiller Ventosilla también fue propietario de un esclavo $^{2630}$.

${ }^{2627}$ Se trata de muchos pequeños préstamos hechos a los vecinos de las aldeas de estas dos villas. El escribano que hizo el recuento señalaba que estos maravedíes ...se los debian a Mansilla de puercos que le habian comprado fiados. Resulta curioso que cuando se embargaron las propiedades de Mansilla no apareció ni un solo cerdo. Esta circunstancia hace pensar que los puercos posiblemente fueran la tapadera de un negocio de préstamo.

${ }^{2628}$ ARChV, RRE, Caja 229, doc. 60.

${ }^{2629}$ Francisco de Quemada presentó ante el concejo la renuncia de su hermano en su persona, pero los regidores la rechazaron argumentando que su hermano no había vivido el tiempo necesario para que tuviera valor la renuncia. Posteriormente regidores y corregidor no se pusieron de acuerdo pues los regidores querían nombrar a otro vecino y el corregidor había recibido la orden del monarca de conceder el oficio a un tercero (AGS, CR, leg. 453, doc. 5).

${ }^{2630}$ AGS, CMC, leg. 355; y ARChV, RRE, Caja 556, doc. 20. 
Otro elemento en común entre los implicados era que ninguno de ellos formó parte del Regimiento ${ }^{2631}$, aunque alguno ocupó algún cargo de oficial menor del concejo en los años anteriores al estallido de la Revolución:

- Alonso de Aranda fue mayordomo el año 1491 y procurador del concejo al menos en 1501, 1502 y 1510. Además fue representante de su cuadrilla, la de San Juan, en varios asuntos importantes en 1517.

- Miguel Sánchez de la Torre fue procurador del Común entre 1509 y 1515, aunque de forma intermitente.

- Alonso Ximeno Daza fue procurador de la villa en 1498 y 1515.

- Sebastián de Ventosilla fue procurador de la villa entre 1516 y 1518.

- Francisco de Torquemada fue nombrado alguacil provisional por el corregidor en 1517 en el contexto del pleito por el alguacilazgo entre la villa de Aranda y don Juan de Zúñiga.

- García Ximeno también fue en 1518 alguacil de la villa.

Asimismo, y a pesar de la fragmentada información de la que disponemos, es perceptible la existencia de ciertos lazos familiares o de clientelismo entre los principales protagonistas de la Comunidad. En este sentido Alonso de Moradillo era el que aglutinaba un mayor número de afiliaciones: por una parte era tío de Sancho de la Peña (...es primo, hijo de hermanos); Alonso Ximeno Daza era su primo segundo; y Alonso de Aranda... llama primo a Alonso de Moradillo e Alonso de Moradillo a él pero que non sabe sy son parientes e que cree que non lo son ${ }^{2632}$. Por su parte, los dos yernos de Bernaldino de Arauzo, Santiago de Calahorra y Juan de Alameda, se vieron implicados en la Comunidad ${ }^{2633}$. Asimismo Juan de Mansilla, hijo de Gaspar de Mansilla, fue el heredero de Miguel Sánchez de la Torre en $1523^{2634}$.

${ }^{2631}$ Creemos que equivocadamente PÉREZ (La revolución..., p.476) atribuye a Alonso de Moradillo la condición de regidor con anterioridad a la revuelta comunera. A pesar de las numerosas noticias que tenemos sobre este personaje no poseemos ninguna sobre su condición de regidor anterior o posterior a las Comunidades.

${ }^{2632}$ AGS, CR, leg. 39, doc. 3. Se trata del pleito por la apertura de la calle Barrionuevo a la Plaza de Santa María. Todos los citados aparecen como testigos de la parte de Alonso de Moradillo (PERIBÁÑEZ OTERO y ABAD ÁLVAREZ, Aranda de Duero..., pp. 167 y ss.).

${ }^{2633}$ AGS, CMC, leg. 355.

${ }^{2634}$ AGS, CR, leg. 450, doc. 8. 
Por último, nos parece reseñable que alguno de los implicados ostentó algún oficio relacionado con la Corte pues García Tomillo fue entre 1518 y 1519 portero de cámara al servicio de la reina Juana, circunstancia que implica asimismo alguna relación con el marqués de Denia; y Alonso Jiménez Daza era despensero de la reina de Portugal $^{2635}$. A buen seguro que sus influencias en la Corte les fueron muy útiles para eliminar su nombre del listado de los excluidos del perdón general a pesar de haber ocupado el cargo de regidores en el gobierno comunero.

En conclusión, percibimos que se trata de un grupo de vecinos con una posición socioeconómica destacada a los que unía una cierta relación de parentesco o clientela. En este sentido, la mayor parte de los dirigentes del movimiento comunero en Aranda pueden encuadrarse dentro de ese grupo de destacados miembros de la Comunidad que ya hemos descrito en un capítulo anterior. Por otra parte, también se constata que ninguno de los implicados en el movimiento comunero había conseguido con anterioridad a la revuelta acceder a los órganos de gobierno municipal. Tan solo habían alcanzado a ocupar alguno de los oficios menos importantes, generalmente vinculados a la representatividad de la Comunidad, y que habitualmente se mantenían al margen de las decisiones más importantes del Regimiento.

\section{2. 4. Aranda Comunera.}

Volviendo al desarrollo de los acontecimientos de la revolución comunera en Aranda, observamos que rápidamente las nuevas autoridades tomaron importantes decisiones. En concreto, el nuevo concejo aprobó enviar 2.000 doblas de oro y doscientos soldados a Burgos para participar en los gastos y defensa de la capital frente a la posible reacción realista ${ }^{2636}$. De la misma manera se determinó mandar gente a Tordesillas ...para la libertad de la Reina nuestra señora ${ }^{2637}$.

${ }^{2635}$ MARTÍNEZ MILLÁN, “Los servidores de las Casas Reales”, en La Corte de Carlos..., vol. IV, p. 365; AGS, leg. 450, doc. 8. Posiblemente entre ambos exista un lazo familiar pues Francisco Tomillo se casó con Catalina de León, hermana de Alonso Jiménez Daza. Francisco y García Tomillo eran padre e hijo o tío y sobrino.

2636 En una carta de respuesta enviada a finales de abril de 1521 por las autoridades de Aranda a las de Burgos se dice: ...e a esta villa de la prymera tyxera hezistes pagar dos mill doblas por seguir vuestra opinion y en galardon de aquesto la gente que ynbiamos en vuestro favor les hizistes pagar las posadas. Y bien complys el ofreçimiento que nos hizistes que procuradyades nuestro bien como el propio vuestro e ansy es que lo procurastes consyntiendo que dentro del baso desa çibdad por seguir vuestra opinión dentro della nos llamaban traydores. (AGS, CC, MEMORIALES, leg. 140, doc. 68). El 8 de abril el Condestable envió una misiva afirmando ...me pesa mucho de ver la diligencçia que ay se puso 
Todos los recursos económicos de la villa se pusieron al servicio de la Comunidad y así se dispuso de los propios de la villa e incluso de las rentas reales para reparos de la cerca y se fiçieron fuertes, comprasen de armas, y faziendo cabas y garitas y comprando muniçion y tiros, e incluso los arrabales se rodearon de una cerca. Todas estas disposiciones culminaron con el establecimiento de las habituales guardas de tiempos de guerra ${ }^{2638}$.

Paradójicamente, y en contraposición a las hipótesis que califican a la Comunidad de revuelta antifiscal, es significativo que las nuevas autoridades municipales no cambiaron un ápice de la fiscalidad previa y mantuvieron en sus cargos a los receptores de las rentas reales. Se siguieron recaudando las rentas reales y las de propios e incluso se percibió ...la sisa que feron para pagar el serviçio a sus altezas. Asimismo recurrieron a los ingresos de las bulas de cruzada, el terzuelo de Santa María y a fuentes de ingresos extraordinarios mediante la autorización de la corta de leña del monte de Allende Aranda $^{2639}$.

Por otra parte, también conocemos algunas iniciativas encaminadas a impedir que los fieles al monarca pudieran conseguir hombres de guerra en la villa o la comarca. En este sentido, el comunero Ramón Cestero se encargó de echar la mujer e hijos del Capitan del Valle porque hacía la gente para el Rey ${ }^{2640}$. Dentro de estas iniciativas también se produjo el embargo de armas a los fieles realistas ${ }^{2641}$. Por su parte, el Condestable se quejaba el 30 de octubre de las grandes dificultades que encontró el conde de Miranda para reclutar soldados que apoyaran a la causa realista en la comarca aran-

para enviar gente a Burgos quando aquí huvo alguna alteraçion y la poca que se pone agora (PR, leg. 1, doc. 105).

${ }^{2637}$ Declaraciones de Alonso de Aranda y Miguel Sánchez de la Torre (AGS, CR, leg. 450, doc.

${ }^{2638}$ El corregidor Juan Manrique de Luna afirmaba que ...en tiempo de su reinado (el de la Comunidad) cerraron los arrabales ... lo cercaron todo y pusieron puertas (AGS, CC MEMORIALES, leg. 141, doc. 98; y CR, leg. 450, doc. 8).

${ }^{2639}$ Los receptores de las rentas reales del año 1520 fueron Diego de Curiel y Luis de Quemada. De la sisa se utilizaron 21.926 maravedíes y de la corta de leña se obtuvieron otros 8.481 (AGS, CR, leg. 450, doc. 8). Se recaudaron para la causa comunera las bulas de cruzada (AGS, PR, leg. 1, doc. 22) y cerca de 20.000 maravedíes del terzuelo de la parroquia de Santa María (ADB, LIBRO DE FÁBRICA DE SANTA MARÍA, vol. I, año 1529, s. f.).

2640 DÁNVILA COLLADO, Historia crítica..., vol. II, p. 398.

${ }^{2641}$ Las noticias son muy fragmentarias e imprecisas pero tenemos constancia de que el regidor Miguel Daza requisó una escopeta al vecino Rodrigo Platero (AGS, CMC, leg. 355). 
dina y las amenazas realizadas por las autoridades comuneras de destruir las casas de quienes se alistaran en el ejército de los Gobernadores ${ }^{2642}$.

En el otoño de 1520 se produjeron asimismo importantes movimientos al Sur de la comarca, en tierras de Sepúlveda, donde estaban acantonados los soldados de la tropa de los Gelves ${ }^{2643}: 800$ lanzas experimentadas que hasta el momento se habían mantenido al margen del conflicto. Tanto realistas como comuneros enviaron a sus delegados para tratar de atraerse a los mercenarios. El Condestable, por su parte, envió a mediados de octubre al Conde de Miranda para tratar de convencer a los oficiales de esta tropa para que secundaran la causa realista ${ }^{2644}$. Paralelamente don Carlos de Arellano, apoyado por don Pedro de Girón, fue comisionado por la Junta para hacer lo propio para la Comunidad $^{2645}$. Finalmente los efectivos militares se repartieron entre uno y otro bando, no tanto por los grandes ideales que movían a cada una de las partes, sino más bien por el convencimiento de seguir a quien garantizara el cobro de sus soldadas. En este contexto, la situación estratégica de la villa de Aranda y su posicionamiento a favor de la Comunidad sirvió de base para las iniciativas de don Carlos de Arellano. El concejo arandino se puso de inmediato a disposición del capitán pues ...vino a esta villa con una carta diziendo y publicando que era de la serenísima reyna nuestra señora e que por ella nos requeria e mandava que le diesemos todo el fabor e ayuda para bolver a la gente que llevaba don Francés de Viamonte para el servicio de la serenísima reina. En consecuencia, el concejo arandino envió una carta al capitán realista, don Francés de Beaumont, requiriéndole ...que no pasase adelante de donde estava aposentado (Sepúl-

${ }^{2642}$ AGS, CC CÉDULAS, Libro 46, doc. 54 (PÉREZ, La Revolución..., p. 435). El conde de Miranda rápidamente se situó al lado de su tío el Condestable y jugó un importante papel en el control militar de la ciudad de Burgos y su comarca, como aparece reflejado en la correspondencia del Gobernador (AGS, PR, leg. 1, doc. 105).

${ }^{2643}$ Fuerza expedicionaria enviada en 1519 para ocupar la isla de Djerba (actual Túnez) a las órdenes de Hugo de Moncada que finalizó con éxito en 1520. Tras la victoria, las tropas desembarcaron en Cartagena en junio de 1520. En su camino hacia el Norte se negaron a sofocar la rebelión comunera en Madrid y levantar el sitio del alcázar madrileño asediado por los rebeldes. En otoño se acantonaron en la tierra de Sepúlveda (PÉREZ, La Revolución de las comunidades..., pp. 232-233).

${ }^{2644}$ En carta del Condestable al rey el 21 de octubre de 1520 éste relataba: ...el conde de Miranda esta muy bien en lo que debe al servicio de vuestra magestad, yo le envie a su tierra para que travaje de sacar la gente que quedo de los Gelves bolberse luego aqui (AGS, PR, leg. 1, doc. 105).

2645 Pedro Girón se movió en octubre por tierras ribereñas como lo atestigua una carta enviada a la Junta el 26 de octubre en la que hace referencia a ciertos dineros recibidos en la villa de Haza que calificaba de totalmente insuficientes para convencer a la gente de los Gelves (AGS, PR, leg. 2, doc. 14). Girón consiguió el 28 de octubre que la villa de Sepúlveda se sumara a la causa comunera (PÉREZ, La Revolución de las comunidades...., pp. 232 y 434). 
veda) syno que se bolvyese y acudiese donde estava la serenisima reyna doña Juana nuestra señora, syno que esta villa le saldria a ynpedir el camino ${ }^{2646}$.

No obstante, y a pesar de esta manifiesta determinación, se produjo una nueva contradicción en las decisiones del concejo arandino que benefició a la causa realista. En los primeros días de noviembre, no sabemos si por incapacidad o por omisión intencionada, se permitió el paso del grupo de mercenarios de los Gelves capitaneados por Beaumont que se había unido a los realistas gracias a las negociaciones realizadas por el Conde de Miranda. Incluso parece que se les dispensa algún trato de favor pues ...estovieron posentados dellos en tierra de esta villa y a legua y media della ${ }^{2647}$. Además, y seguramente vinculado a este hecho, las autoridades de la capital de la Ribera se mostraron muy receptivas ante la petición del Condestable de enviarle çiertas tiendas de campo que pertenecían al rey. Junto a las tiendas, el concejo arandino remitió una carta que no conocemos pero que resultó tan grata al Condestable que decidió reenviarla al monarca, instándole a que escribiera a la villa graciosamente porque desta manera es bien que se restituya lo que esta tan malo contra vuestro servicio y obediencia. Por su parte, la Junta envió a la Ribera a sus propios receptores de rentas para conseguir recursos con los que mantener a la Comunidad. Rápidamente la red de espías locales comunicaron la nueva al Condestable que mandó apresar a los delegados comuneros, aunque no tenemos noticia de que lo consiguiera ${ }^{2648}$.

Sin atisbo de duda, podemos afirmar que entre los meses de octubre y noviembre las autoridades arandinas alzadas en nombre de la Comunidad mantuvieron una más que interesada posición de ambigüedad que trataba de complacer a ambas partes. Sin ningún tipo de complejos atendieron a las pretensiones de la Comunidad dando apoyo a los delegados comuneros que buscaban tanto soldados como dinero y, simultáneamente, se plegaron a las exigencias realistas permitiendo el paso de militares y proporcionando material de campaña. Cierto es que la docilidad y rapidez con la que respondieron a las

${ }^{2646}$ AGS, PR, leg. 1, doc. 22.

${ }^{2647}$ Sabemos que el Conde de Miranda estaba ya de vuelta junto al Condestable el 15 de noviembre acompañado de las tropas que había conseguido (AGS, PR, leg. 1, doc. 105). El reducido tamaño de la Tierra arandina nos hace pensar que, aunque parte de la tropa acampara en este territorio, la mayoría debió hacerlo en los amplios dominios señoriales del Conde de Miranda que rodeaban Aranda (AGS, PR, leg. 1, doc. 22).

${ }^{2648}$ Carta del Condestable al rey fechada el 14 de noviembre de 1520: ...de Aranda me han escripto oy que han ydo alli personas de parte de la Junta con provisiones a cobrar las rentas, luego provey sobre ello conforme a lo de Vitoria y de Santo Domingo (AGS, PR, leg. 1, doc. 105). 
demandas del Gobernador bien se pudiera explicar por la proximidad del conde de Miranda con su séquito de mercenarios veteranos.

La situación cambió drásticamente en los primeros días de diciembre cuando la villa de Aranda comunicó a Valladolid ...que estavan en la provynçia de Burgos e que la cibdad avia respondido y que lo mysmo respondian ellos ${ }^{2649}$. Evidentemente la aceptación de las reclamaciones de la ciudad de Burgos por parte del Condestable en octubre y su entrada en la ciudad en noviembre, sancionando el evidente cambio de bando de la Cabeza de Castilla, tuvo mucha influencia en esta decisión ${ }^{2650}$. Algo más improbable es que la derrota comunera de Tordesillas tuviera algo que ver con esta decisión, pues la carta está fechada el mismo día que tuvo lugar la batalla, el 5 de diciembre.

En este mes de diciembre el monarca, bien directamente o a través de su Virrey, mandó dos cartas a la villa arandina. La primera fue su real perdón el día 17, en el que tras recordar los levantamientos e alborotos producidos en los días pasados en Burgos y en otros lugares de la provincia e partido de la dicha ciudad, especialmente en la villa de Aranda, ... por la presente perdonamos e remitimos a todos los vecinos y moradores de la dicha ciudad, y por su respeto a los de los otros pueblos de su provincia y partido todas las penas asi civiles como criminales ${ }^{2651}$.

La segunda comunicación real pudo recibirse con el anterior perdón o bien ser algo posterior, llegando a la villa a finales del mes de diciembre o en los primeros días del año 1521. En esta carta el monarca recriminaba a la villa, en un tono afable, los movimientos acaecidos y concedía su perdón a los vecinos que se mostraban muy agradecidos por la concesión de esta merced ${ }^{2652}$. El 9 de enero las autoridades comuneras en-

${ }^{2649}$ AGS, PR, leg. 3, doc. 104. Esta información viene recogida en una relación de cartas. En el catálogo aparece como Relación de extractos de cartas de Pedro Girón, pero más bien parece contener un inventario de distintas cartas dirigidas a los protagonistas del movimiento comunero.

${ }^{2650}$ PÉREZ, La Revolución de las comunidades..., p. 204. No en vano, el propio Gobernador justificó la aceptación de los capítulos concedidos a Burgos porque ... quanto mas que de Burgos cuelgan todas las montañas y Vizcaya y Guipuzcoa y Alava y Encartaciones y otra ciudades y villas de su provincia y fuera della que estan en su opinion, que si no se hiciera fuera de acabar de perder el Reino (AGS, PR, leg. 1, doc. 105).

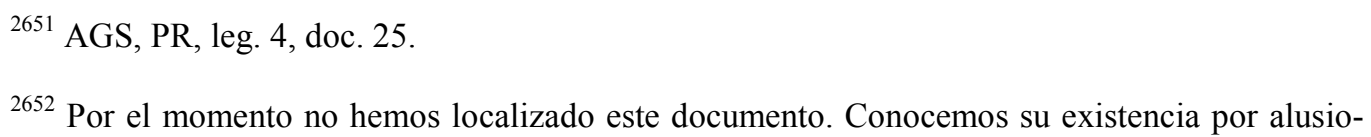
nes en una carta que envió el concejo al monarca en enero de 1521. Sabemos que esta carta se pregonó en la villa y, siguiendo la retórica del momento, fue muy bien acogida pues ... todos reçibieron mucha consolaçion como era razon; y esta fue señalada merçed de Vuestra Católica Magestad hizo a esta villa en acordarse della, por tanto donde los pequeños hasta los medianos e grandes y los niños de los que maman a una boz e diçentes a una boz clamante dan gracias a Dios (AGS, PR, leg. 1, doc. 22). 
viaron al rey una carta de agradecimiento por el perdón recibido. Cabe destacar en esta carta que, aparte de los consabidos formulismos, los oficiales trataron de justificar su rebelión y solicitaron del monarca ...pluguiese de la oyr y dar audiençia, y así ...no la echaria tanta culpa por como quiera que nuestra intençion ni el movimiento que ovo no fue de deservir a Vuestra Magestad, mas antes fue endereçado a su real serviçio y para acreçentamiento de este su pueblo. Además, anticipándose a posibles represalias, se defendían de un supuesto memorial del capitán Francés de Beaumont en el que se les acusaba de colaborar con el comunero Carlos de Arellano e impedir el paso de las gentes de los Gelves. Los de Aranda argumentaban que ...por le amansar al dicho don Carlos de Arellano e por le despedir, no con intención de deservir a Vuestra Magestad, esta villa escrivio al dicho don Françes de Viamonte rogandole que se volviese en serviçio de la serenisima reyna ${ }^{2653}$.

Con el paso de la villa arandina al bando realista, el Condestable se aseguraba el dominio de la Ribera. Los amplios estados del conde de Miranda en la zona (Peñaranda, Montejo y Haza), los del Marqués de Denia (Gumiel del Mercado y la cercana Lerma) y la obediencia del conde de Siruela, encargado de proteger Roa ${ }^{2654}$, garantizaron este control clave en la política de freno a la expansión comunera en el valle del Duero oriental. No olvidemos que en Peñafiel instaló su cuartel el capitán comunero Pedro Girón (además Gumiel de Izán era señorío de su padre, el conde de Urueña), la ascendencia de Carlos de Arellano en Soria y la adhesión de la villa de Sepúlveda a la Comunidad a finales de octubre. Se trataba pues de un importante hito en la política de contención del Virrey.

Suponemos que durante el mes de enero y parte del de febrero la situación se mantuvo estable a tenor de algunos documentos emitidos por la cancillería real ${ }^{2655}$. Sin

${ }^{2653}$ AGS, PR, leg. 1, doc. 22.

${ }^{2654}$ El 16 de diciembre el conde de Siruela se disculpaba ante el monarca por no haber participado en la batalla de Tordesillas pues ...el Condestable me ha escrito muchas vezes que este en esta villa para tener este paso y tierra aparejado al servicio de vuestra alteza para quando menester sea... (AGS, PR, leg. 3, doc. 47). Buena prueba de la importancia que concedió el Condestable al control de la villa de Roa la encontramos en la carta que envió al monarca el 25 de mayo, una vez terminada la guerra: La villa de Roa es cosa muy importante para el tiempo en que estamos y porque aquella estuviese cierta para el servicio de vuestra magestad yo no he consentido que el conde de Syruela saliese della hasta agora (leg. 1, doc. 105).

2655 Entre estos destaca la concesión de una escribanía del número para Alonso de Huete (AGS, RGS, 152101, s. f.). Llama la atención este nombramiento, sobre todo teniendo en cuenta que todavía no habían sido repuestos los escribanos a los que la Comunidad removió de sus oficios. Huete, como vere- 
embargo, a pesar de los insistentes reclamos del Condestable, el orden anterior a septiembre no se restableció y siguieron ocupando sus puestos en el gobierno de la villa los mismos oficiales nombrados a voz de Comunidad. Esta situación exasperó al Gobernador que reclamó insistentemente a las autoridades arandinas que se presentaran en Burgos para solucionar la situación ilegal y así atender las denuncias de los regidores y escribanos depuestos por la rebelión ${ }^{2656}$. La ausencia de respuesta del concejo arandino motivaría la del monarca que, esta vez con tono vehemente, exhortaría a la villa a restituir la legalidad y amenazaría con importantes castigos si persistía en su desobedien$\mathrm{cia}^{2657}$.

A principios de febrero el movimiento comunero trató de atraerse de nuevo a la villa arandina y para ello las cuadrillas de Valladolid solicitaron a las autoridades comuneras que enviaran una carta a Aranda y Roa instando a que acudieran ante la Junta con sus antiguos privilegios para que fueran confirmados al amparo de su política de promoción de las libertades municipales y la defensa del patrimonio real frente a las imposiciones foráneas y los privilegios señoriales ${ }^{2658}$.

Posiblemente las amenazas del bando realista, los intentos de acercamiento de la Junta de Valladolid y las repercusiones de la victoria comunera de Torrelobatón a finales de febrero inclinaron la balanza por la causa comunera. Así comprobamos cómo a partir de marzo y hasta el final de la contienda la villa arandina se mostró, ya sin ambigüedades, partidaria de la causa de la Comunidad.

Prueba de este nuevo rumbo en la postura arandina es la presencia en la capital de la Ribera de Alonso de Encinas, receptor de la Junta. Su actividad en la villa se documenta al menos desde los primeros días del mes de marzo de 1521. Tanto el cargo que ostentaba como las referencias documentales señalan que la función del receptor estaba enfocada sobre todo al campo fiscal. Y efectivamente desempeñó su papel con

mos más adelante, jugó un significativo papel en la posterior represión (CR, leg. 450, doc. 8; y CMC, leg. $355)$.

${ }^{2656}$ AGS, RGS, 152102, s. f. (DIAGO HERNANDO, “Cambios políticos..., p. 330).

2657 Tanto VELASCO PÉREZ (Aranda. Memorias..., p. 150) como SANZ ABAD (Historia de Aranda..., p. 159) hablan de estas amenazas imperiales pero no hemos encontrado por el momento ningún documento que las acredite.

${ }^{2658}$ AGS, PR, leg. 4, doc. 54. No tenemos certeza de que la Junta decidiera enviar esta carta a Aranda y Roa, tan solo es una sugerencia de la Junta de cuadrillas de Valladolid a su procurador en la Santa Junta, Alonso de Vera. Una visión general de la política comunera de defensa del patrimonio real la podemos encontrar en PÉREZ, J. Los Comuneros. Madrid, 2001, pp. 229 y ss. 
gran diligencia a tenor de los testimonios de las propias autoridades locales que comunicaron a la Junta que ...el recebtor nos a ynportunado en tanta manera e nos ha apuntado las çinchas que casy no nos ha dexado resollar para que le diesemos dineros ${ }^{2659}$.

Encinas también se ocupó de aplicar las órdenes de la Junta referentes a bienes requisados a los realistas: ...que qualquier cosa que se tomase por qualesquier personas que sygan el santo proposyto a qualesquier personas de los enemigos e contrarios sea de aquel que lo tomase. Y así él como otros vecinos de la villa requisaron ...çiertas escripturas e otras cosas e un macho a un criado de Pedro de Santa Cruz, vezino e regidor de Aranda, que estava y esta con los cavalleros e como arrendador que a sydo. El receptor comunicó lo sucedido a la Junta porque el macho estaba depositado en un mesón y ...come mas que vale, por lo que solicitaba que se le permitiera venderlo ...porque no se acabe de comer del todo. El 7 de marzo desde Valladolid se determinó que ...se venda el macho e los dineros se depositen en el jurado Pedro Ortega y se vea lo que estos an de aver e se provehera ${ }^{2660}$.

Pero además de sus cometidos fiscales, el receptor también actuó como interlocutor entre Junta y villa, transmitiendo las instrucciones de la primera y las demandas de la segunda. Precisamente Alonso de Encinas fue el encargado de comunicar las órdenes de la Junta para organizar la defensa de la villa a principios de abril ante el temido e inminente ataque de las tropas realistas que desde Burgos se desplazaban a Valladolid y estaban acantonadas en la cercana villa de Torresandino ${ }^{2661}$.

De la implicación de la villa de Aranda con la Comunidad da cumplido testimonio la carta que Pedro Girón envió el 4 de abril a la Junta en la que informaba de ...que un Miguel Daça, que es mucha parte alli en el pueblo, nos enbio a desir como el estava mucho a servicio de vuestra señoría y para lo que a esta vylla tocase muy çierto, e que sy tuvyesemos alguna neçesidad que a la ora vernian mil ombres en nuestro socorro $^{2662}$.

En este sentido, es bastante revelador de la situación el incesante intercambio de correspondencia que se generó entre la ciudad de Burgos y la villa de Aranda. A finales

${ }^{2659}$ Carta de la villa a la Santa Junta el 19 de abril de 1521 (AGS, PR, leg. 1, doc. 22).

${ }^{2660}$ AGS, PR, leg. 5, doc. 129. Pedro Ortega era procurador y jurado de Toledo, muy activo en la Santa Junta.

\footnotetext{
${ }^{2661}$ AGS, PR, leg. 1, doc. 22.

${ }^{2662}$ AGS, PR, leg. 2, doc. 14
} 
de marzo el concejo burgalés solicitó al arandino el envío de 200 hombres para participar en el ejército realista que se preparaba en esta ciudad para iniciar su marcha hacia el territorio dominado por la Comunidad en Tierra de Campos y Valladolid. Por su parte el Condestable también realizó sus gestiones en estas mismas fechas para reducir la villa a la obediencia real ${ }^{2663}$, pero ésta le contestó ...que no tuvyese que haser con ellos por que ellos estavan a servicio del rey y muy prestos para lo que los señores de la Junta les mandasen ${ }^{2664}$. Finalmente, el 8 de abril el rey envió una cédula a las autoridades arandinas exigiendo ...que luego sin dilaçión alguna envieys los dichos dozientos ombres al dicho Condestable, mi gobernador, o la paga dellos por dos meses, lo qual vos mando lo asy agays e cumplays so la pena en que cahen los que en tales tiempos faltan a los mandamientos de sus reyes e señores naturales y de perder esta dicha villa todas las franquezas e libertades que tiene ${ }^{2665}$. Los arandinos no parece que acogieran esta reclamación con mucho respeto y así, después de la lectura pública que se hizo de la cédula en la plaza, uno de los vecinos comentó sin pudor ...que quemasen la dicha cedula y la hiziesen polvos ${ }^{2666}$.

Ante la contundencia del mensaje y la evidente amenaza militar que suponía la presencia de las tropas realistas en las inmediaciones de la villa, los oficiales arandinos solicitaron el 9 de abril la ayuda de la Junta: ... el dicho Condestable se a endinado e asy amenazandonos, ...son salidos de Burgos quatro mill hombres, los quales estavan posentados en el valle de Torresandino; tememonos que es para venir sobre esta villa. Por ende suplicamos a vuestra señoría, si en algo nos puede afaboreçer, nos socorra por que no sean destruydos los bienes del patrimonio real. Esta carta se envió esa misma

${ }^{2663}$ En la carta que la villa remitió a la Junta el 9 de abril se decía que ...esto mas ha venido por que por otra carta antes desta (8 de abril) nos avia escripto (el Condestable) como dicho es que le enviasemos la dicha gente (AGS, PR, leg. 1, doc. 22).

${ }^{2664}$ AGS, PR, leg. 2, doc. 14.

2665 AGS, PR, leg. 4, doc. 44. Este documento es un traslado de una cédula real ordenada por el Condestable en nombre del monarca (AGS, PR, leg. 1, doc. 105).

${ }^{2666}$ AGS, PR, leg. 4, doc. 16. Se trata del Memorial que recoge los nombres de los implicados arandinos en la Comunidad. Al redactor no le quedaba claro quién pronunció esas palabras pues en primer lugar se las atribuyó a Juan, hijo de Alonso de Salas, y posteriormente a Diego Sánchez de Calahorra, cerero. El cambio de atribución también pudo deberse a la posición realista de Alonso de Salas como parece confirmar su participación en la posterior represión y su designación como uno de los depositarios de los bienes secuestrados a los exceptuados (AGS, CMC, leg 355). 
noche por medio de al menos dos mensajeros para garantizar su recepción en Vallado$\operatorname{lid}^{2667}$.

La respuesta de la Santa Junta no se hizo esperar y el jueves 18 el receptor Encinas presentó una provisión por la que ordenaba a las autoridades municipales que ...para la defensa desta villa agamos doszientos hombres de guerra, escopeteros e piqueros y para esto nombrasemos un capitan. Sin embargo, en la respuesta de los arandinos ya no se observa la urgencia por defender la villa, pues en el impás entre el envió de la misiva y la respuesta de la Junta, las tropas del Condestable habían pasado de largo sin que la villa sufriera su asedio. Los oficiales, aunque no creían oportuna la creación de la milicia, aseguraron que en caso de peligro responderían ...no dezimos con doszientos hombres, pero con myll sy los oviere menester. Por si acaso, solicitaron de la Junta que se les proveyera de dos tiros de artillería y un artillero para la defensa de la villa $^{2668}$.

Lo cierto es que en estos días del comienzo de la primavera se sucedieron una serie de acontecimientos con cierta relevancia que muestran la intensidad con la que se vivió el movimiento comunero en la Ribera.

Por una parte, los responsables comuneros de Aranda, conocedores de ...como pasavan çierto metal para hazer çierta artelleria, lo qual hera para el duque del Ynfantazgo, y porque esta villa penso que no se servia vuestra señoría, ynvio gente a la traviesa por donde yva desviado desta villa e lo tomo que abra fasta noventa quintales que heran para tiros. Es de suponer que este metal tendría su origen en Burgos o Vizcaya y que se dirigía por su camino natural hacia las tierras de los Mendoza en Sigüenza o Guadalajara, circunstancia que aprovechó la milicia arandina para incautar la mercancía. Lo que no sabemos es el destino final que se dio al metal tras ser requisado ${ }^{2669}$.

El episodio más violento que se vivió en la capital de la Ribera tuvo lugar pocos días antes de la derrota de Villalar, cuando varios vecinos se enfrentaron con el trágico

${ }^{2667}$ AGS, PR, leg. 1, doc. 22. Se conservan dos copias de esta carta. La primera llegó a su destino el 10 de abril y la segunda el 11 .

${ }^{2668}$ AGS, PR, leg. 1, doc. 22.

${ }^{2669}$ AGS, PR, leg. 1, doc. 22. A pesar de la ambigüedad y aparente neutralidad del Duque del Infantado durante buena parte del desarrollo de la revuelta, desde mediados de marzo sus maniobras de reclutamiento atemorizaron a los comuneros de Madrid que temían el inmediato asalto de la villa. Asimismo, los Gobernadores animaron el 9 de abril a Mendoza a hostigar a la villa del Manzanares (PÉREZ, La Revolución de las comunidades..., pp. 423-424). A buen seguro que este metal incautado tenía mucho que ver con estos movimientos realistas sobre el Madrid comunero. 
resultado de una muerte, la del procurador de la Comunidad Sebastián de Ventosilla. Por el testimonio de un vecino sabemos que ...por el prinçipio del año pasado de quinientos e veinte e un años el dicho Pedro García (Ortuño), sin tener cabsa justa, trabo question con Sebastian de Ventosilla, ... en la Plaça de Santa María de la dicha villa; y en la dicha question por el dicho Pero García e por un Cristobal de Cendrera, su cuñado hermano de su mujer, fueron dadas çiertas cuchilladas (a Ventosilla) malamente en la cabeça de las quales murio ${ }^{2670}$. Tras el incidente, los agresores se refugiaron en la iglesia de Santa María, acogiéndose a sagrado, y, ...estando abrazado con una imagen de Nuestra Señora en el altar mayor, la Justicia de la Comunidad sacó a Ortuño y Cendrera de allí utilizando para ello la violencia, los encarceló y amenazó con la horca. La violación del espacio sagrado provocó la intervención de los jueces eclesiásticos y una mayor complicación del asunto ${ }^{2671}$.

En definitiva, este episodio es una prueba más de la tensión que se vivió en la villa entre los partidarios de uno y otro bando en vísperas de la resolución del conflicto. No en vano, los principales protagonistas de este conflicto estaban muy identificados con las dos causas: Ventosilla fue procurador de la Comunidad años antes de estallar la revuelta y continuó como tal con el gobierno comunero; Ortuño por su parte era uno de los escribanos depuestos por la Comunidad que además intervino de forma activa en la posterior represión ${ }^{2672}$.

\section{2. 5. La represión.}

Así pues encontramos en los albores del desenlace final de la contienda una situación bastante complicada en la villa de Aranda. La tensión derivada del seguimiento mayoritario de la causa Comunera y la situación de los sectores realistas eclosionó en

${ }^{2670}$ ARChV, RRE, Caja 361, doc. 8. El testimonio lo proporciona Diego Sánchez de Calahorra, el mozo, en el contexto del pleito que interpuso Pedro García Ortuño contra María García, viuda de Sebastián de Ventosilla, acusándole de injurias. Evidentemente la declaración de Calahorra era parcial pues, además de testigo, actuaba en el pleito como procurador de la acusada y, seguramente, era hijo de uno de los implicados en la Comunidad, Diego Sánchez de Calahorra, cerero (AGS, PR, leg. 4 doc. 16).

${ }^{2671}$ Esta información se deduce de la declaración de uno de los agresores, Cristóbal de Cendrera, cuñado de Ortuño (DÁNVILA COLLADO, Historia crítica..., Vol. III, pp. 653-654).

${ }^{2672}$ Ventosilla fue el procurador de la villa al menos entre los años 1516 y 1518 (AGS, CC PUEBLOS, leg. 2, doc. 107; y CCM, leg. 129, doc. 55). En el verano de 1521 se realizaron ante Pedro García Ortuño varios de los inventarios de los bienes secuestrados a los exceptuados del perdón real (AGS. CMC, leg. 355). 
una gran convulsión como consecuencia del devenir de los acontecimientos en los últimos días del mes de abril de 1521 .

De todos es conocido el desenlace y consecuencias que tuvo para la Comunidad la batalla de Villalar el 23 de abril de 1521. Hemos podido constatar cómo un número indeterminado de arandinos armados acudió a la llamada de la Junta o formó parte del ejército realista. Tanto los unos como los otros participaron de forma activa en los acontecimientos bélicos que tuvieron lugar en Villalar aquel fatídico domingo ${ }^{2673}$.

La repercusión de la jornada de Villalar en la Ribera fue inmediata, pues rápidamente los mensajeros comunicaron el desastre en los días siguientes. El 24 de abril fueron ejecutados Padilla, Bravo y Maldonado y los virreyes recibieron en Simancas la capitulación de Valladolid. Pero ese mismo día también se recibió la solicitud de ayuda del Conde de Nájera que advertía de la entrada en Navarra de un ejército invasor.

A partir de ese momento los acontecimientos se sucedieron vertiginosamente. El 27 de abril la ciudad de Burgos envió una carta a Aranda en la que acusaba a la capital ribereña de no haber seguido a la cabeza de la provincia. Le reprochaba que no enviara los doscientos hombres que solicitaron, aunque sí que mandó trescientos a la Junta y además impidió la ayuda de otros. Por último, amenazaba con enviar un ejército para asediar la villa, aunque se mostraba indulgente y prometía interceder por ella ante el Condestable y el monarca si abonaba ocho mil ducados para pagar los gastos ocasionados a la ciudad ${ }^{2674}$.

La villa contestó con una retórica misiva rebosante de altivez y cruel ironía. El inicio no puede ser más provocador, pues critica de manera ácida la capacidad comuni-

${ }^{2673}$ Por el bando comunero sabemos que ciertos hombres fueron enviados al servicio de la Junta, aunque no sabemos cuántos. En el perdón emitido por el monarca el 15 de mayo se decía literalmente que quedaban excluidos del mismo ...los capitanes que participaron y fueron detenidos en Villalar (AGS, $\mathrm{CMC}$, leg. 355). Suponemos que el capitán Sancho de la Peña participó en la batalla y después huyó como otros tantos a refugiarse en Toledo (DÁNVILA COLLADO, Historia crítica..., Vol. IV, p. 554). Por el bando realista sabemos por el Memorial del Conde de Haro de la participación en las batallas de Tordesillas y Villarlar de don Martín y don Juan de Acuña, así como de Íñigo de Zúñiga (AGS, PR, leg. 4, doc. 64). También los acompañó Martín de Torquemada, que resultó herido por dos golpes de escopeta (DÁNVILA COLLADO, Historia crítica..., Vol. V, p. 451). Este Torquemada era primo del regidor Diego de Durango.

${ }^{2674}$ Tanto la carta de Burgos como la de Aranda se encuentra en AGS, CC MEMORIALES, leg. 140, doc. 68. Han sido varios los autores que han regestado estas cartas o han hecho referencia a ellas. Recientemente hemos publicado la enviada por el concejo arandino en "La Revolución comunera..., pp. 77-78. 
cadora de Burgos, citando para ello a Avicena y Séneca ${ }^{2675}$. A continuación denunciaba, con la retórica propia de la época y los circunloquios acostumbrados, la actitud hipócrita de Burgos que indujo a otros lugares a la rebelión, con el ya citado aporte de gentes de armas y dineros, y después se vendió al bando realista por la tenencia del castillo de Lara y un mercado franco. Finalmente respondía a las amenazas de saco y la petición de dinero con una invitación a recogerlo, advirtiendo que ...os reçibamos con muy buena boluntad y estamos determinados de hazer lo que hazieron los de Jerusalem, que es que quemaron sus byenes para que con mayor ánimo osasen morir en su defensión ${ }^{2676}$.

Fácilmente se puede deducir que dicha respuesta no debió causar muy buena impresión en Burgos. No es de extrañar, por lo tanto, que entre las peticiones que la ciudad de Burgos reclamó al monarca el 11 de mayo se incluyera en último lugar la siguiente $^{2677}$ : Asimismo suplica a su magestad que no se tome conçierto con Aranda sino que de liçençia a la dicha çibdad para que ella les castigue. Afortunadamente para la villa, las negociaciones con los delegados reales para su rendición ya se habían puesto en marcha.

Si la presión de Burgos no era suficiente, las tierras ribereñas también sufrieron la presencia de un importante contingente militar que desde tierras vallisoletanas se dirigía hacia Navarra. El conde de Haro informaba en un Memorial de la división del ejército real en dos bloques tras la victoria de Villalar: uno de ellos se encaminó con los Gobernadores a Valladolid y de allí a Navarra, mientras que... por aca por Aranda va toda la otra gente y artillería ${ }^{2678}$. La presencia de semejante amenaza seguramente ocasionó una gran presión sobre la vecindad que a buen seguro se aprestó a negociar la su-

${ }^{2675}$ La respuesta de la villa de Aranda comienza así: Magnificos señores; recibymos la carta de vuestras mercedes y no nos marabyllamos de la deshorden de vuestro escribyr la qual dexamos desplycar por nuestra onestydad, que como dize el Abyçena: quando la cabeça duele, los miembros no tyenen su lyvertad ni el coraçon reçibe alegria; e asymesmo en otra parte dyze Séneca que todo onbre declyna a su natural (AGS, CC MEMORIALES, leg. 140, doc. 68).

${ }^{2676}$ Este recurso literario parece hacer referencia al asedio de Jerusalén por las tropas de Saladino que culminó con la pérdida de la Ciudad Santa para la Cristiandad en 1187. En las negociaciones previas a la rendición parece ser que los cristianos rechazaron en un primer momento la oferta del sultán y aseguraron preferir destruir la ciudad antes que rendirse. El valor simbólico de este paralelismo entre la Aranda comunera y la Jerusalén a punto de sucumbir ante el infiel es bastante evidente.

${ }^{2677}$ Las peticiones fueron pocas, siete, pero de lo más ambicioso pues entre ellas se encontraban las de trasladar la Chancillería de Valladolid y las ferias de Medina del Campo a la Cabeza de Castilla (AGS, PR, leg. 4, doc. 30).

${ }^{2678}$ AGS, PR, leg. 1, doc. 106. El conde de Haro argumentaba que el hecho de que parte del ejército fuera por Valladolid era una estrategia de los Gobernadores para obtener más milicianos de esta villa. 
misión a la Corona. Además esta tropa presentaba un problema añadido pues ...mas toda o la mas va muy descontenta porque con todas las diligençias que el liecenciado Vargas a hecho no tienen lo que seria menester para pagalla.

Con toda seguridad podemos afirmar que en los primeros días de mayo se estaban negociando en Segovia las condiciones de la inevitable rendición de la villa arandina. La notable desigualdad entre las partes motivó que estas negociaciones concluyeran rápidamente con un acuerdo que se vio materializado en la redacción de un asiento. Mediante este documento el rey accedía a perdonar a la villa por su implicación en la rebelión comunera pero se exceptuaba del perdón a ciertos vecinos que se habían significado como oficiales municipales o capitanes en Villalar ${ }^{2679}$. La creciente inestabilidad del Norte motivó que se impusiera a la villa el envío de 200 hombres de armas a Navarra equipados con 200 coseletes, 300 escopetas, 300 picas y toda la artillería que tuvie$\operatorname{ran}^{2680}$. Finalmente el 16 de mayo de 1521 se emitió el Perdón Real que fue pregonado en la villa ${ }^{2681}$. No obstante, podemos deducir que con anterioridad al 12 de mayo la villa estaba bajo el control realista pues a partir de ese día se procedió al secuestro de bienes y el mismo 16 se ordenó el destierro de los vecinos exceptuados ${ }^{2682}$. Al menos desde el 23 de mayo ya se había restablecido la legalidad anterior a septiembre de 1520 pues encontramos al corregidor Juan Manrique de Luna y a los regidores perpetuos ejerciendo sus oficios precisamente para fiscalizar las cuentas de los propios y las rentas reales $^{2683}$.

${ }^{2679}$ Los vecinos exceptuados del perdón fueron 15 . Se les secuestraron todos sus bienes que pasaron a depositarse en manos de algunos vecinos claramente identificados con el bando realista. Éstos se encargaron de administrarlos hasta que el monarca nombró un factor para que determinara su destino final. Una treintena de vecinos fue condenada al destierro de la villa, además de pagar ciertas multas (AGS, PR, leg. 3, doc. 141; y CMC, leg. 355).

${ }^{2680}$ Este asiento no lo hemos localizado por el momento pero ha sido posible reconstruir su contenido a través de otros documentos: AGS, CMC, leg. 385; PR, leg. 3, doc. 141; y AMA, leg. 43, doc. 42.

${ }^{2681}$ Conocemos este documento por un traslado sacado el 24 de mayo de 1522 que se recoge en un proceso entre algunos de los vecinos implicados en la revuelta y el escribano de rentas al que acusaban de llevarles más dinero del que debía en el proceso de subasta de sus bienes para hacer frente al pago de las multas impuestas (AGS, CMC, leg. 355).

${ }^{2682}$ DÁNVILA COLLADO, Historia crítica..., Vol. IV, pp. 52 y 110.

${ }^{2683}$ La fecha del 23 de mayo la aporta un acta recogida en el proceso de los antiguos comuneros contra el escribano Alonso de Huete (AGS, CMC, leg. 355). Sin embargo, DIAGO HERNANDO señala que la vuelta del corregidor se produjo el día 25 según consta en un documento del Registro General del Sello ("Cambios políticos..., pp. 328-329). Quizá la restitución de las autoridades realistas fuera anterior pues ya hemos visto cómo desde el día 12 se procede a al secuestro de los bienes de los implicados (DÁNVILA COLLADO, Historia crítica..., Vol. IV, p. 110). Sea una u otra fecha, lo importante es que 
También por estas fechas la villa tuvo que hacer efectivo el compromiso adquirido en el asiento con la Corona: el día 20 se ordenó desde Segovia que se preparara el material bélico que se determinó y se entregara al segoviano Fernando de Aguilar para ser trasladado a Navarra donde se necesitaba. El día 30 desde Torquemada se solicitó que se prepararan 100 de los 200 hombres que se habían comprometido a enviar. Por fin el 5 de junio, después de que los regidores confiscaran las armas en la villa, se hizo entrega a Aguilar de varios barriles de pólvora y piedras de azufre, falconetes, escopetas, munición, picas y coseletes. El capitán y regidor arandino Bernaldino del Valle fue el encargado de trasladar a Navarra a los 100 soldados con su correspondiente armamento. La gran cantidad de pertrechos militares que se requisaron en la villa en apenas quince días es prueba evidente de las medidas que las autoridades comuneras habían preparado, bien para participar en la contienda o bien para resistir el asalto de las tropas realis$\operatorname{tas}^{2684}$. Todavía en febrero de 1522 el rey Carlos solicitaba al concejo desde Bruselas que tuviera preparados los hombres de a caballo y a pie necesarios para su servicio, ante la inmediatez de su retorno a Castilla ${ }^{2685}$. Entre lo requerido se incluían ciertas mulas necesarias para el transporte de la artillería que traía el monarca y que era necesario trasladar desde el puerto de Santander hasta la ciudad de Burgos ${ }^{2686}$. Por su parte el conde de Siruela partió de Roa hacia el Norte con 50 lanzas para ponerse a disposición del ejército de los Gobernadores ${ }^{2687}$.

Como ya había ocurrido en nuestra historia, y desgraciadamente volvió a ocurrir, tras la contienda se sucedió un momento de gran inestabilidad en Aranda donde, a pesar de la restitución de las autoridades, se impuso en cierto sentido un clima de revanchismo y ajuste de cuentas. La documentación es muy parca en detalles, sobre todo porque

ya desde mediados de mayo se constata el restablecimiento del orden y, por lo tanto, el final de la aventura comunera en Aranda.

2684 AMA, leg. 43, doc. 42. El inventario de lo entregado a Aguilar es muy prolijo en detalles: un tonel de piedra azufre de 10 arrobas; otro tonel de piedra azufre de 11 arrobas; un tonel de pólvora de tiros gruesos de falconetes de cinco arrobas; otro tonel de pólvora de 6 arrobas; 6 servidores de tiros falconetes; un tiro falconete con carretón; más 4 tiros falconetes con sus cureñas; un tacón en una cureña; 80 pelotas de hierro de los dichos tiros; 35 coseletes; 51 escopetas; y 160 picas. El capitán del Valle se llevó los 100 hombres armados con 50 escopetas, 50 picas, 50 fiascos y 100 coseletes.

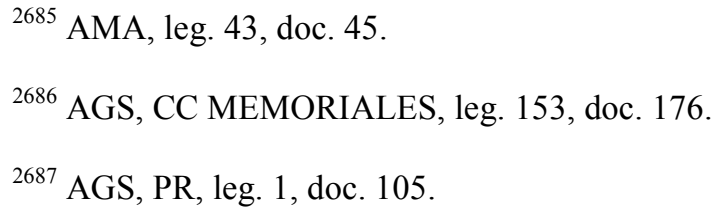


los productores de documentos pertenecían al bando vencedor, pero aún así se puede percibir este tenso ambiente.

La primera medida que tomaron las autoridades restituidas fue el embargo de las haciendas de los principales implicados en la rebelión. Así, entre los días 13 y 15 de mayo se ordenó a través de varias cédulas reales el secuestro de los bienes de los exceptuados del perdón ${ }^{2688}$. Estas órdenes fueron ejecutadas por ciertos vecinos ilustres, encabezados por personajes muy implicados con el bando realista como don Martín y don Juan de Acuña, Bernardino y Pedro de Avellaneda, Íñigo de Zúñiga o el escribano Alonso de Huete. Estos realistas confiscaron los bienes de los exceptuados sin rendir cuentas ni a las autoridades locales ni tampoco a la Corona. Así lo observamos en los diferentes inventarios de bienes que se hicieron entre mayo y septiembre de 1521 y en el informe que se envió al monarca en el que se ponía de manifiesto la situación de los bienes embargados:

De las hasiendas desta villa (Aranda) no ay çierta relación a causa de embaraços que uvo alli con vnos cavalleros que alli biven que antes tenyan secrestados los bienes de los exceptuados por provision de los governadores y han tomado y gastado de la hazienda y no han querido dar quenta. Y el uno es corregidor de Madrid, don Martín de Acuña, y otro de Avellaneda que estan en Pamplona. Converna que su Magestad cometa a una persona que vaya alli y haga justicia.

Dizese que pueden valer las dichas haziendas a vender XII V ds (12.000 ducados) 2689

En este sentido cabe destacar que los principales realistas se hicieron con la administración de las haciendas más importantes, pero también los bienes de aquellos que, no teniendo gran riqueza, se significaron con mayor protagonismo en el movimiento comunero arandino. En principio estos vecinos actuaron como depositarios de bienes confiscados por la Corona pero realmente dispusieron de ellos a su antojo ${ }^{2690}$. Fue tal su

${ }^{2688}$ DÁNVILA COLLADO, Historia crítica..., Vol. IV, p. 110. Los inventarios de los secuestros comenzaron el día 19 de mayo con los bienes de Bernaldino de Arauzo y Miguel de la Gallega.

${ }^{2689}$ AGS, PR, leg. 3, doc. 139.

${ }^{2690}$ Pedro Martínez de Avellaneda fue el depositario de la gran fortuna de Alonso de Aranda; don Martín de Acuña dispuso de la hacienda de Bernaldino de Arauzo; Íñigo de Zúñiga se ocupó de los bienes del capitán Miguel de la Gallega; Bernardo de Avellaneda se hizo cargo del importante negocio de Gaspar de Mansilla; don Juan de Acuña gestionó los bienes de Pedro Sánchez de Mendoza; y Alonso de Huete se encargó del patrimonio más importante de todos los exceptuados que era el de Alonso de Mora- 
arbitrariedad en el manejo de estos bienes que en mayo de 1523 el monarca se vio obligado a concederles una merced de 500 ducados de oro para así solventar el problema que se encontraron los factores reales a la hora de contabilizar los bienes de los exceptuados que pertenecían a la Corona ${ }^{2691}$.

Cuadro 20: Algunos datos sobre los bienes de los exceptuados del perdón general en Aranda.

\begin{tabular}{|l|c|r|r|}
\hline $\begin{array}{l}\text { Nombre de los exceptua- } \\
\text { dos del Perdón General }\end{array}$ & $\begin{array}{c}\text { Hectáreas } \\
\text { de } \\
\text { viñedo }\end{array}$ & $\begin{array}{r}\text { Renta que producen todos } \\
\text { sus bienes entre mayo de } \\
\mathbf{1 5 2 1} \text { y1522 (en maravedíes) }\end{array}$ & $\begin{array}{c}\text { Cantidad final que } \\
\text { percibe la Corona } \\
\text { (en maravedíes) }\end{array}$ \\
\hline $\begin{array}{l}\text { ALONSO DE ARANDA } \\
\text { (53 años) }\end{array}$ & 16 & 205.044 & -32.930 \\
\hline GASPAR DE MANSILLA & 27 & 184.597 & -90.000 \\
\hline $\begin{array}{l}\text { BERNALDINO DE } \\
\text { ARAUZO (61 años) }\end{array}$ & 34 & 102.544 & Deudas \\
\hline $\begin{array}{l}\text { ALONSO DE } \\
\text { MORADILLO (70 años) }\end{array}$ & 40 & 77.516 & 45.042 \\
\hline $\begin{array}{l}\text { MIGUEL DAZA } \\
\text { SANCHO DE LA PENA }\end{array}$ & 3 & 76.758 & 26.000 \\
\hline 42 años)
\end{tabular}

El 16 de mayo el monarca ordenó también el destierro de aquellos vecinos que estaban incluidos en un memorial del secretario Castañeda que citaba, además de los quince exceptuados, otros treinta vecinos. En definitiva se castigaba a cuarenta y cinco arandinos, cifra muy inferior a los más de setenta y cinco vecinos denunciados por un memorial anterior ${ }^{2692}$. Al igual que ocurrió en otras ciudades implicadas en la revuelta comunera, algunos de los denunciados, como estrategia para ganarse o agradecer el perdón real, se enrolaron en el ejército realista. El caso más significativo fue el del capitán Sancho de la Peña que tras la derrota de Villalar buscó refugio en Toledo pero contra-

dillo (AGS, CMC, leg. 355). Estos primeros depositarios se hicieron cargo de los bienes entre mayo y junio de 1521. A lo largo de 1522 los bienes pasaron a Gutierre Velázquez, factor del obispo de Oviedo, que a principios de 1523 los traspasó a Antón García y Alonso de Azofra, factores reales.

${ }^{2691}$ El 20 de mayo de 1523 desde Valladolid se expidió una cédula real por la que se concedía la merced de 500 ducados de oro a don Juan de Acuña, Bernardo de Avellaneda, don Martín de Acuña, Pedro Sanz de Avellaneda, Diego de Puelles y Martín de Torquemada ...que ellos confesaron averse aprovechado de los bienes de çiertos eçebtados de Aranda (AGS, CMC, leg. 355).

2692 DÁNVILA COLLADO, Historia crítica..., Vol. IV, p. 110; el memorial de Castañeda se encuentra en AGS, PR, leg. 3, doc. 141; el primer memorial de fecha desconocida está en AGS, PR, leg. 4, doc. 16 . 
dictoriamente acabó formando parte del ejército del Prior de San Juan que cercaba la sede metropolitana. El 16 de octubre fue enviado por el Prior ante los Gobernadores como mensajero con una carta en la que, entre otras cosas, solicitaba el perdón para el arandino exceptuado ${ }^{2693}$. Suponemos que esta recomendación no tuvo el efecto deseado pues sus bienes fueron confiscados y él desterrado. Otros arandinos también recurrieron al alistamiento para pagar su implicación en la revuelta pues el corregidor denunciaba en junio de 1521 que algunos soldados de los que marcharon a Navarra habían desertado, práctica bastante generalizada en los ejércitos reales enviados al Norte ${ }^{2694}$.

El destierro que sufrieron los comuneros fue bastante laxo pues muchos de ellos se mantuvieron en las aldeas de la tierra arandina, se acomodaron en los mismos arrabales de la villa, en sus casas o fincas cercanas, en el monasterio de San Francisco o, como fue el caso de García Tomillo, en la ermita de la Virgen de las Viñas ${ }^{2695}$. Algunos otros manifestaron su arrepentimiento y solicitaron al monarca un plazo para permanecer en la villa y mostrar su inocencia A tenor de la prontitud con la que se concedieron algunos perdones, seguramente lo consiguieron. Pero lo más significativo lo transmite el corregidor de Aranda que se veía incapaz de impedir que los desterrados se pasearan libremente por las calles de la villa y transmitieran malas influencias sobre el resto de veci$\operatorname{nos}^{2696}$. Una prueba más de esta peculiar situación la encontramos en el hecho de que Juan de Alameda solicitara en junio un seguro de armas para él y su criado argumentando que se sentía amenazado por los comuneros a causa de que durante la insurrección se negó a ocupar el cargo de procurador de la Comunidad ${ }^{2697}$.

Sin embargo, y a pesar de esta situación realmente ambigua, las medidas represoras contra los comuneros continuaron. El siguiente paso fue revisar las cuentas de las

\footnotetext{
IV, pp. 354-355. ${ }^{2694}$ AGS, CC MEMORIALES, leg. 141, doc. 98.

${ }^{2695}$ PÉREZ, La Revolución..., p. 579; AGS, CC MEMORIALES, leg. 141, doc. 98; CMC, leg. 355.

${ }^{2696}$ Esta denuncia la envió el corregidor arandino al Consejo Real en junio de 1521. Es bastante revelador el comentario que el secretario escribe por la parte posterior de la carta advirtiendo de que esta situación era representativa de lo que sucedía en el resto de las ciudades y villas del reino que fueron de esta calidad por lo que recomendaba al presidente del Consejo que proveyera lo que conviniera para solucionarlo (AGS, CC MEMORIALES, leg. 141, doc. 98). el solicitante.

${ }^{2697}$ AGS, CC MEMORIALES, leg. 141, doc. 206. Finalmente se lo concedieron, pero sólo para
}

${ }^{2693}$ AGS, PR, leg. 3, doc. 92, carta transcrita por DÁNVILA COLLADO, Historia crítica..., Vol. 
rentas reales y de los bienes de propios de la villa. El 23 de mayo el corregidor junto a los regidores tomaron las cuentas de los receptores de las rentas y del mayordomo concejil. En su resolución estimaron que los oficiales comuneros habían malgastado 310.812 maravedíes y medio de las rentas reales y 298.064 y medio de los propios. Posteriormente Juan Esteban Mercader devolvió 42.000 de las rentas reales y 30.000 de los propios. En definitiva, se condenó a ciertos comuneros a pagar con sus bienes la deuda que ascendía a 536.877 maravedíes. Tras las consiguientes apelaciones y reclamaciones, el 27 de julio de 1521 el corregidor ordenó ejecutar la sentencia y pregonar la subasta de los bienes de los implicados para pagar la deuda. Los bienes se subastaron públicamente en agosto $^{2698}$. Esta subasta no estuvo exenta de irregularidades pues algunos de los postores aprovecharon su posición política para hacerse con los bienes más apreciados por un precio muy inferior a su valor. Fueron varios los casos: el alcaide de Gumiel del Mercado y regidor arandino, Rodrigo de Durango, pagó 35.000 maravedíes por unas viñas y fincas de Bernaldino de Arauzo tasadas en 60.000; el regidor Gaspar de Santa Cruz consiguió por menos de la mitad de su tasación, 104.000 maravedíes, una inmensa viña de 18 hectáreas propiedad de García Ximeno; también el prior de Roa y el escribano Alonso de Huete adquirieron unas casas de Sebastián de Sinovas y unas tierras que pertenecían a Pedro Sánchez de Mendoza, respectivamente, por un precio inferior al marcado en la tasación. Pero el caso más espectacular fue el del bachiller Borja que pagó 10.000 maravedíes por una viña de más de seis hectáreas propiedad de Miguel de la Gallega valorada en 30.000 y además compró por 35.000 maravedíes tres pares de casas en la calle de la Miel valoradas en 80.000 que fueron de Alonso de Moradillo. Ante esta situación, tanto los multados como el Fisco presentaron una denuncia que se resolvió en primera instancia de forma favorable para los intereses de los demandantes pero que fue posteriormente apelada por lo que la resolución final se dilató bastantes años ${ }^{2699}$. Además de estas circunstancias, los exceptuados fueron objeto de varios abusos, entre los

${ }^{2698}$ Todo el proceso se recoge en AGS, CR, leg. 450, doc. 8. PÉREZ indica que el monto de las rentas reales ascendía a 283.500 maravedíes y no hace referencia a las rentas de propios (La Revolución..., p. 651).

${ }^{2699}$ En 1524 un juez ya había determinado que los citados anteriormente debían devolver a la Corona los bienes obtenidos de esta manera, pero su apelación ante la Chancillería hizo que la medida perdiera efectividad para las arcas reales (AGS, CMC, leg. 355). La viuda de Bernaldino de Arauzo, Catalina de Quemada, seguía pleiteando ante la Chancillería en 1527 (ARChV, RRE, Caja 401, doc. 32). Alonso de Moradillo hizo lo propio con el bachiller Borja en el mismo lugar entre 1523 y 1527 (PLEITOS CIVILES, FERNANDO ALONSO (F), Caja 161, doc. 1). 
que destacaron la venta de bienes dotales o la obligación de pagar más tasas de las que estipulaba la normativa municipal ${ }^{2700}$. Además del destierro y la confiscación de sus bienes, desde principios del año de 1522 los exceptuados tuvieron que hacer frente al comienzo de sus respectivos procesos judiciales ${ }^{2701}$.

Pese a todo, el "espíritu" de la Comunidad parece que mantuvo en la villa cierta presencia moral más que real ${ }^{2702}$. En agosto de 1522 el bachiller Velasco denunciaba que los procuradores elegidos para ese año habían participado activamente en la revuelta comunera del año anterior: se trataba de Alonso Daza y Juan de Alameda ${ }^{2703}$. El primero de ellos realmente estuvo implicado en la rebelión pues aparece identificado como regidor en uno de los memoriales, aunque su nombre fue posteriormente tachado, y tuvo que pagar una multa por el uso indebido de las rentas reales y concejiles ${ }^{2704}$. El segundo, Alameda, ya lo hemos mencionado, sabemos que fue propuesto por la Comunidad como su procurador pero no aceptó el cargo, enemistándose con los comuneros ${ }^{2705}$. Asimismo en 1535 volvió a repetir como procurador Juan de Alameda y le acompañó Francisco de Torquemada, escribano del Concejo en el gobierno comunero ${ }^{2706}$. Aparte de esta evi-

${ }^{2700}$ En el proceso seguido ante el Consejo Real entre los exceptuados, como parte demandante, y el escribano Alonso de Huete entre 1522 y 1524 se concluye que el escribano cobró una cantidad abusiva en concepto de derechos. Era costumbre en la villa que cuando se ejecutaban bienes por impago se aplicara un máximo de 150 maravedíes. Cuando se subastaron los bienes de los exceptuados para hacer frente a las rentas que habían sido utilizadas por la Comunidad, Huete cobró la cantidad de un maravedí de cada diez. Finalmente el Consejo Real resolvió a favor de los demandantes (AGS, CR, leg. 450, doc. 8).

${ }^{2701}$ Los primeros en ser llamados a declarar fueron Sebastián de Sinovas, Sancho de la Peña y Miguel de Alcocer el 17 de enero de 1522 (PÉREZ, La Revolución..., p. 583).

${ }^{2702}$ Algo similar ocurrió en otras ciudades de pasado comunero como Ávila, Valladolid o Murcia (PÉREZ, La Revolución..., pp. 584 y ss.).

${ }^{2703}$ DIAGO HERNANDO, “Cambios políticos..., pp. 337-338. El autor deduce de esta situación la persistencia de un fuerte movimiento de contestación al régimen oligárquico basado en los regimientos vitalicios.

${ }^{2704}$ AGS, PR, leg. 4, doc. 16; y CR, leg. 450, doc. 8. Sobre este personaje ya hemos hablado en el capítulo dedicado a los miembros más destacados de la Comunidad. Recordemos que en los últimos años del siglo XV y primeros del XVI tuvo una importante actividad como procurador de la villa y se caracterizó por denunciar las irregularidades cometidas por los regidores. En 1522 ostentaba el título de Despensero de la Reina de Portugal.

2705 AGS, CC MEMORIALES, leg. 141, doc. 206. El documento que aporta DIAGO HERNANDO lo identifica como escribano de la Comunidad ("Cambios políticos..., p. 337; AGS, RGS, 152208 , s. f.).

${ }^{2706}$ VELASCO PÉREZ, Aranda. Memorias..., p. 171. 
dencia, no hemos logrado identificar la presencia de ninguno de los protagonistas comuneros en puestos relacionados con el concejo arandino.

No obstante, la documentación sí que transmite cierta información que evidencia claramente que el espíritu de la Comunidad seguía tímidamente vivo. Y así, el escribano Pedro García Ortuño denunciaba ante el corregidor que María García, la viuda de Sebastián de Ventosilla, ...va diziendo ...en çiertos dias... de abril e junio de los mesos del año pasado de mill e quinientos e veynte e un años y en el mes de henero de quinientos e veynte y dos años en unas casas en que la dicha María García morava que eran en la dicha villa en la calle que dizen Toledano; ...e la dicha calle publica, e por las otras partes de las calles de la dicha villa, y la iglesia de Santa María, e en otras partes e logares de la dicha villa ... se avia hallado en grado ynjuria enfamia suya, muchas vezes dijo en publico que el era un traydor e que el avia vendido la villa por dos rreales, y a sus hijos los llamavan hijos del traidor; en lo qual le avia injuriado disfamado grabemente por ser como el era escribano publico de la dicha villa del numero della y persona onrrada y enparentado y hezendado en ella ${ }^{2707}$.

En este punto nos parece lógico concluir este apartado con una valoración sobre las causas del fracaso de la revolución comunera. Si bien es cierto que el análisis microhistórico de este fenómeno en la Ribera del Duero no permite llegar a conclusiones generales, sí que creemos percibir ciertas evidencias que pueden aportar algo de luz sobre este aspecto. Es obvio que la explicación del fracaso de la experiencia comunera en Aranda participa en líneas generales de las causas planteadas por investigadores especialistas en el tema. Desde nuestro punto de vista se observan una serie de factores tanto puntuales como estructurales. Entre los primeros nos parece determinante la deserción de la ciudad de Burgos del bando comunero, aspecto que por otra parte ya denunciaron en su momento las autoridades comuneras arandinas ${ }^{2708}$. También nos parece

${ }^{2707}$ ARChV, RRE, Caja 361, doc. 8.

${ }^{2708}$ En la carta que el concejo comunero arandino envió a la ciudad de Burgos el 30 de mayo se reprocha este comportamiento: ...pues que a su cavsa en los primeros prinçipios fue publicadora que en lo cavsado hera para servicio de Dios e de sus magestades y bien del Reino en general e partycular e ansy nos lo hezistes creer e a este vuestro apellido byendo que hera natural todo el reyno os seguio ... E a las otras çibdades del reyno yzo sacar su hexerçito en el campo conbocandolas, pidyendoles su fabor las dexastes en el campo e bolbystes vuestro hexerçito a vuestra çibdad. Los arandinos también apuntan el motivo de la deserción y la responsabilidad en la revuelta: ... Y porque os dyeron la tenençia del castyllo de Lara y un mercado franco dystes la buelta en mucho perjuizio del Reyno. De donde, sy byen lo mirais, nosotros no somos los culpados y vuestras mercedes si los causadores (AGS, CC MEMORIALES, leg. 140, doc. 68). 
reseñable en este sentido la división interna en el seno de las autoridades de la Santa Junta que se puso de manifiesto por ejemplo en la rivalidad entre Padilla y Girón. Sin embargo, fueron mucho más importantes a nuestro entender los factores estructurales. De todos es conocido el planteamiento mantenido por Joseph Pérez que atribuye la causa de la debacle comunera a la evidente alianza de intereses entre monarquía y noble$\mathrm{za}^{2709}$. Como ya han apuntado otros investigadores y hemos visto nosotros en el caso de la villa arandina, el posicionamiento del patriciado urbano en el bando realista fue absoluto por lo que es bastante acertado incluir en esta alianza a las oligarquías urbanas ${ }^{2710}$.

En nuestra modesta opinión, aceptando plenamente las anteriores cuestiones, participamos de la idea de que uno de los principales problemas que presentaba la propuesta comunera era la ausencia de sintonía entre la ideología surgida de los intelectuales que articularon el programa comunero y la mentalidad predominante caracterizada por una estructura ideológica anclada en siglos de feudalismo ${ }^{2711}$. Desde nuestro punto de vista este problema se tradujo en la práctica en un movimiento muy dinámico pero que dio muestras de una notable indefinición ideológica. Varios autores han analizado muy acertadamente el programa comunero en el que se aprecia claramente los objetivos pretendidos por los intelectuales comuneros ${ }^{2712}$. Sin embargo, somos de la opinión de que la Santa Junta fue incapaz de transmitir a la mayor parte de la población del reino su propuesta innovadora. Bien por falta de capacidad, o bien porque sus planteamientos, claramente emanados del ámbito urbano, rebasaban ampliamente la realidad y las nece-

${ }^{2709}$ PÉREZ, J., "Las comunidades de Castilla", en Entorno a las comunidades de Castilla. Cuenca, 2002, pp. 133-145.

${ }^{2710}$ CASADO ALONSO concluye que la monarquía, la aristocracia y el patriciado urbano unieron sus fuerzas para conseguir una estabilidad que garantizara sus inversiones e intereses ("El movimiento comunero antes de la Revolución de las Comunidades", en Introducción a la Historia de Castilla. Burgos, 2001, pp. 711-729, en concreto pp. 728-729).

${ }^{2711}$ LADERO QUESADA señala que la mentalidad de la población rural castellana a principios del XVI se asentaba en el conservadurismo donde los principios básicos eran la ley (religión), el rey, la tierra y los fueros. La adhesión a la personalidad del rey es total pues es visto como el vicario de Dios, el hacedor de justicia y el defensor frente a las agresiones exteriores. La configuración de esta figura parternalista fue perfectamente fomentada durante el reinado de los Reyes Católicos ("Castilla a comienzos del siglo XVI..., pp. 41-42).

2712 PÉREZ, La revolución..., pp. 532 y ss.; DÍAZ MEDINA, A. (Ed.), Relación del discurso de las Comunidades. Valladolid, 2003; y JERÉZ CALDERÓN, J. J., Pensamiento político y reforma institucional durante la Guerra de las Comunidades de Castilla (1520-1521). Madrid, 2007. 
sidades de una población eminentemente rural $^{2713}$. Esta situación se percibe perfectamente en la comarca ribereña donde el movimiento comunero solamente fue seguido por la villa de Aranda mientras que el entorno rural permaneció sumido en un absoluto silencio y se mantuvo sin problemas controlado por los linajes nobiliarios.

\section{3. La nueva realidad tras 1521 .}

Tras el fracaso de la experiencia comunera se asistió en la comarca al restablecimiento del orden establecido que tenía su origen en la dinámica social, política y económica de los últimos decenios. Observamos pues que por encima de los hechos concretos que supuso la derrota comunera destacan dos aspectos fundamentales que derivan de la misma.

La consecuencia más inmediata sobre el panorama político de la comarca ribereña fue el resultado obvio derivado de la clara implicación del principal núcleo urbano de la comarca apoyando a los insurgentes. En definitiva, la derrota comunera supuso para la villa de Aranda la confirmación de la pérdida total de la escasa autonomía política que en su momento garantizaran sus privilegios.

Tras 1521 se reafirmó la creciente injerencia sobre la villa de los dos poderes superiores. Por una parte, la Corona consolidó con su victoria su avance centralizador con la imposición sobre la villa del Corregimiento, ya no sólo como árbitro, sino como exclusivo ejecutor de la voluntad de la Monarquía, con la complicidad y aquiescencia de la oligarquía local.

Derivado de esta primera consecuencia, la derrota comunera supuso también la consolidación de la posición de dominio de la oligarquía dentro del municipio, sancionando su monopolio en el ejercicio del poder urbano y potenciando la patrimonialización de los cargos públicos en unas clientelas cada vez más permeables a la incorporación de nuevos efectivos, sobre todo ligados a la nobleza de segundo orden. En contraposición, se advierte el final definitivo de las aspiraciones de los grupos de pecheros enriquecidos que, marginados políticamente, se erigieron en representantes de la Comunidad y optaron no tanto por la violencia como por la ruptura con lo anterior para alcanzar su objetivo de participar en los órganos del poder local.

${ }^{2713}$ A modo de ejemplo baste recordar la propuesta comunera que pretendía reconducir la relación entre reino y rey a través de unas Cortes con representatividad exclusiva de las ciudades en un contexto en el que el $80 \%$ de la población habitaba en el medio rural. 
Al contrario de lo que ocurrió en otras grandes ciudades, la hidalguía urbana arandina se identificó de forma casi unánime con la opción realista, convirtiéndose en adalides de la resistencia anticomunera. Esta actitud fue recompensada convenientemente tras la contienda por el Monarca con dádivas de todo tipo. Esta identificación entre los intereses de la Corona y el patriciado local ayudó a consolidar la tendencia a la aristocratización de la oligarquía local pues la tendencia a la concentración de los regimientos en las familias hidalgas se convirtió tras la contienda comunera en una realidad. Baste como ejemplos los casos de los Acuña, Avellaneda, Durango, Zúñiga o Salazar.

En segundo lugar, se produjo la reafirmación de la posición de élite de poder de la nobleza comarcana que vio reforzada su posición política mediante su perfecta integración en la nueva configuración del Estado moderno que impuso poco a poco el nuevo monarca. Como hemos visto a lo largo de los anteriores capítulos, la relación de la nobleza comarcana con los monarcas había sido ya bastante estrecha, pero casi siempre en relación con las disputas entre bandos nobiliarios que trataban de intervenir sobre los diferentes monarcas. Esta situación la hemos identificado en el caso de la crisis sucesoria que permitió a doña Isabel hacerse con el reino de Castilla y, tras un periodo en el que estuvo bastante mitigada, se reprodujo de nuevo de la mano de las crisis sucesorias de principios del Quinientos. Esta dinámica se vio claramente superada como consecuencia de la revolución comunera pues, aunque no dejaron de existir tensiones intranobiliarias, la materialización de un enemigo común provocó la identificación de intereses entre monarca y alta nobleza. A efectos prácticos y tangibles encontramos dos perfectos ejemplos en la comarca. El marqués de Denia, cuyo linaje estuvo férreamente ligado a los intereses aragonesistas desde los tiempos del primer conde de Castro, jugó un importante papel en la represión de la conjura comunera, primero haciendo todo lo posible por impedir la utilización de la reina Juana como elemento de legitimidad para los insurrectos comuneros, y después aportando su potencial bélico en la recuperación de Tordesillas. Asimismo el conde de Miranda, procedente de un linaje antiaragonesista y él mismo declarado felipista, se posicionó sin ambigüedades del lado del monarca durante la contienda civil y se convirtió en su delegado ante la difícil situación de Navarra después de la contienda civil. No obstante, la evolución de ambos magnates fue desigual. Los Zúñiga tuvieron un puesto privilegiado en la esfera próxima del Emperador, pues el titular del condado actuó como virrey de Navarra y ejerció como destacado miembro de los Consejos del emperador; el Cardenal don Íñigo López de Mendoza fue embajador en 
Italia e Inglaterra; y a otro de los hermanos, don Juan, estuvo al lado del príncipe Felipe como su ayo y hombre de confianza. Por su parte, Bernardino de Sandoval se vio relegado a una dorada marginación como gobernador de la casa de la reina Juana en Tordesillas $^{2714}$.

En el contexto de esta nueva relación planteada entre la Corona y la emergente nobleza se aprecia lo que algunos autores han denominado el auge de la señorialización de la aristocracia ${ }^{2715}$. Tras 1521 se consolidó una nueva relación de fuerzas de la que salió ciertamente reforzada la nobleza. El conflicto comunero no fue más que el último escollo para concluir un proceso que durante el último tercio del siglo XV y los primeros años del XVI permitió definir y consolidar una importante red de dominios territoriales nobiliarios que se extendió más allá de sus competencias jurisdiccionales condicionando la dinámica de la comarca. En la Ribera burgalesa esta situación se personalizó en la Casa de Miranda, pues su dominio señorial se asentó, incrementó y consolidó a lo largo del periodo que hemos estudiado recurriendo habitualmente al conflicto con la Corona, ya fueran los monarcas, el realengo o las behetrías, o con sus iguales, fueran otros nobles o las instituciones eclesiásticas vecinas. Todo ello concluyó con el afianzamiento de su posición de élite de poder en la comarca, consolidando su dominio señorial e imponiendo su influencia sobre aquellos espacios que mantenían su autonomía. En definitiva, sus redes clientelares se expendieron por aquellos territorios que, aun no siendo de su jurisdicción -realengo, abadengos y behetrías-, cayeron en su implacable tela de araña ${ }^{2716}$. Sirvan como ejemplos la adquisición de los lugares de Hoyales y Fuentelisendo, el nombramiento de don Juan de Zúñiga como alguacil de Aranda, el asalto del monasterio de Santa María de la Vid por las gentes del Conde o la entente firmada con el abad Roberto de San Pedro de Gumiel de Izán a propósito de la jurisdicción de Milagros.

\footnotetext{
${ }^{2714}$ FEROS, El Duque de Lerma..., p. 85.

${ }^{2715}$ MARTÍN CEA y BONACHÍA HERNANDO, “Oligarquías y poderes concejiles..., pp. 2628.

${ }^{2716}$ Baste como ejemplo el comentario realizado en 1515 por el prior de La Vid advirtiendo a la Reina del peligro de conceder al hermano del conde de Miranda la posesión de La Vid pues con ello ...tenía cercada a la redonda a la vuestra villa de Aranda” (AGS, CC PUEBLOS, leg. 17, fol. 467). También son ilustrativas las palabras del procurador de la Comunidad Sebastián de Ventosilla que afirmaba que los regidores de la villa ...biben con el conde de Miranda y buscan le servir (CC MEMORIALES, leg. 129, docs. 43 y 55).
} 
En conclusión, el triunfo de la contrarrevolución supuso la consolidación de un nuevo orden político, nada original pues sus bases se asentaron ya desde finales del siglo XV, en el que se reafirmaron los privilegios y su condición de élite de poder de una nobleza comarcana totalmente imbricada en la estructura de poder del nuevo estado que se pergeñaba y una oligarquía local al servicio del monarca e integrada perfectamente en las estructuras clientelares de la nobleza comarcana. La revolución comunera, lejos de alterar una dinámica de afianzamiento de los órganos y grupos que controlaban los resortes del poder económico y político, se convirtió en el detonante de su consolidación. 



\section{CONCLUSIONES.}

Una de las características más significativas de las sociedades preindustriales es la íntima relación e interdependencia entre el medio natural y los grupos humanos que en él desarrollan su vida. Nuestro estudio ha pretendido ampliar el conocimiento de esta interacción en un espacio concreto, la comarca natural de la Ribera del Duero burgalesa, en el contexto de un breve periodo temporal que discurre entre la segunda mitad del siglo XV y las primeras décadas del Quinientos.

En consonancia con lo anteriormente expuesto, nuestro punto de partida necesariamente debía comenzar por la identificación de los principales protagonistas de nuestro estudio. Por lo tanto, en primer lugar hemos intentado, siendo conscientes de las grandes limitaciones y dificultades que esto supone, reconstruir la imagen del medio natural sobre el que se desarrolló la actividad de la sociedad feudal del momento. El siguiente paso se ha centrado en constatar la apropiación social que ese espacio experimentó a lo largo de los siglos medievales. Si bien es evidente que esta tarea implica una labor eminentemente descriptiva, no es menos cierto que nuestro planteamiento, motivado sobre todo por la precariedad de fuentes de todo tipo, ha pretendido obtener de este proceso unas conclusiones que nos han permitido reconstruir la realidad socioeconómica de los grupos humanos que transformaron ese espacio.

En este sentido, una de nuestras primeras conclusiones certifica que la red de poblamiento de la comarca ribereña en la Baja Edad Media es heredera de un largo proceso de configuración que comenzó en los siglos precedentes y que, a finales del siglo XV y principios del XVI, mostraba una organización del territorio muy bien definida. Al igual que ocurre en otros espacios vecinos, esta estructura de ocupación del suelo perduró sin apenas modificaciones significativas a lo largo del periodo preindustrial.

En este apartado de la configuración del territorio destaca sobre todo el espacio que sufrió el mayor proceso de antropización de la comarca a lo largo de la Baja Edad Media. El proceso de urbanización que experimentó la villa de Aranda de Duero durante el periodo estudiado permite concluir que este núcleo se consolidó al final del medievo como un centro urbano de segundo orden capaz de articular el territorio de su entorno comarcal. Asimismo, y como consecuencia de su dinamismo y vitalidad tanto social 
como económica, la villa arandina proyectó su influencia más allá de los límites comarcales, integrándose perfectamente en el sistema urbano de la Castilla septentrional.

Como ocurre en otras muchas partes, la apropiación social del espacio estuvo en sintonía con las relaciones de diferente tipo que se establecieron entre los grupos humanos que habitaron la comarca en este periodo concreto. Estas complejas relaciones, que definimos desde el punto de vista social, económico y político, respondieron a una serie de principios ideológicos que se perfilaron a lo largo de los siglos medievales. En el plano político, como no podía ser de otra manera, las mismas bases ideológicas en las que se asentaba la organización social feudal fueron las que fundamentaron el ejercicio del poder. Por lo tanto, la Monarquía, la nobleza, las instituciones religiosas y los concejos no fueron más que la plasmación política de la concepción ideológica del mundo feudal.

Teniendo en cuenta estas premisas, nuestro objetivo en la segunda parte de este estudio ha sido identificar los diferentes actores políticos y definir sus interrelaciones sociales y económicas. Derivado del gran peso que tuvo el dominio del territorio en todas las sociedades preindustriales europeas, se atisba en la comarca ribereña una pugna por el control del espacio que se materializó en numerosos conflictos que enfrentaron a los protagonistas de nuestro estudio. Desde nuestro punto de vista, el desarrollo y resolución de estos conflictos condicionaron, con la intervención de otros muchos factores, la evolución de esta sociedad hacia una nueva realidad histórica que nos atrevemos a definir como una fase desarrollada del modo de producción feudal en la que se integran y conviven algunos elementos de un nuevo modo de producción que, con el paso del tiempo, cristalizaron en el capitalismo.

A nuestro modo de ver, el protagonismo que tuvieron los diferentes actores que interactuaron sobre el territorio ribereño a finales de la Edad Media fue necesariamente desigual. Los monarcas, los linajes nobiliarios comarcanos, las instituciones eclesiásticas, la oligarquía urbana o el resto de la población gozaron de una mayor o menor implicación en el desarrollo histórico en función de su capacidad para ejercer el control sobre este territorio y sus gentes. Este control se concretó no sólo en la expansión del tradicional dominio jurisdiccional o la generalización de oficiales e instrumentos de control político, sino también mediante el establecimiento de densas redes clientelares, el ejercicio de la violencia física o psicológica, la imposición de determinados comportamientos sociales o el establecimiento de vínculos económicos. 
Como consecuencia de esta situación, a lo largo del periodo estudiado se observa el reforzamiento de la posición de poder de tres de los protagonistas más significativos del panorama ribereño: la Corona, la oligarquía urbana y los linajes de la nobleza comarcana.

Por una parte, la Corona consiguió, tras una primera etapa conflictiva ligada a la crisis sucesoria del último tercio del siglo XV, imponer su autoridad en el reino. Asimismo el reinado de los Reyes Católicos supuso en el espacio ribereño la culminación de la política centralizadora e intervencionista emprendida años atrás y que tuvo su máximo exponente en las medidas tomadas en la villa de Aranda, prácticamente la única pervivencia del realengo en la comarca. La progresiva eliminación de los privilegios forales, la reforma del regimiento, la imposición definitiva del corregidor y la reforma de las escribanías fueron las principales manifestaciones de la creciente limitación de la autonomía municipal y, en consecuencia, de la subordinación de la villa a los intereses de la Corona. Por todos es conocido que la fortaleza de la Monarquía se vio afectada por motivos biológicos y de género bien aprovechados por las fuerzas políticas a principios del Quinientos. Desde nuestro punto de vista, las crisis sucesorias de este periodo, lejos de ser una muestra de debilidad, fueron la prueba final que confirmó el éxito de la política autoritaria de los Trastamara castellanos sobre la que se asentó el Estado Moderno de la mano de la nueva dinastía austriaca.

Íntimamente ligado al poder de la Corona se situaba el creciente protagonismo de la oligarquía local, que en nuestro estudio se singulariza en la clase dirigente de la villa de Aranda de Duero. A pesar de la tradicional organización basada en los linajes, hemos comprobado cómo la oligarquía arandina experimentó una importante renovación en el último tercio del Cuatrocientos con la incorporación de un nutrido grupo de hidalgos foráneos vinculados en su mayor parte a las principales familias nobiliarias de la comarca. Esta circunstancia llevó a una progresiva aristocratización de la clase dirigente arandina que se confirmó definitivamente en las primeras décadas del siglo XVI. Por otra parte, la simbiosis entre Corona y oligarquía fue total pues la política intervencionista de los monarcas contó con el apoyo de los dirigentes locales que vieron como su posición de élite de poder se perpetuaba a través de la transformación de los regimientos electivos en mercedes reales de carácter vitalicio. Asimismo los monarcas favorecieron la patrimonialización de los regimientos, confirmando en varias ocasiones el carácter hereditario de estos cargos municipales. La posición de poder de la oligarquía 
también se vio reforzada con la incorporación de destacados hombres de negocios que habían forjado sus notables fortunas en el ámbito del comercio del dinero y el arrendamiento de las rentas reales. La entrada de estos ricos burgueses en la clase dirigente fue posible sin lugar a dudas gracias a su poder económico y el visto bueno de la Corona. Asimismo la incorporación de estos elementos no privilegiados a una realidad cada vez más privilegiada fue refrendada por una práctica matrimonial que ejemplificó el arrendador Pedro de Santa Cruz. El hacendado converso consiguió que sus tres hijos se casaran con miembros destacados de la nobleza local y que sus nietos consolidaran su posición privilegiada en el seno de la oligarquía arandina.

Por su parte, los principales linajes de la nobleza comarcana comparten una serie de características. La primera de ellas es que casi todas las familias nobiliarias tuvieron algún tipo de vinculación con la casa de Avellaneda que se instaló en la Ribera gracias a las mercedes concedidas por el primer Trastamara. De igual manera, prácticamente todos los linajes bajomedievales ribereños pueden encuadrarse en lo que la historiografía ha denominado la "nobleza nueva", que se desarrolló al amparo de la dinastía recién llegada y necesitada de apoyos. Dentro de este rango de la nueva nobleza, los linajes ribereños podrían definirse, en los momentos iniciales de su presencia en la comarca, como una nobleza de segundo orden que se mantenía de una manera u otra vinculada a la aristocracia castellana. En este sentido, todos ellos iniciaron estrategias conducentes a encuadrarse dentro de la aristocracia que dominaba el escenario político y social de Castilla. En algunos casos fue la proximidad a los monarcas lo que les permitió adquirir una posición preponderante, como ocurrió con Beltrán de la Cueva o la familia Girón en distintas fases del reinado de Enrique IV. En muchas ocasiones fueron los enlaces matrimoniales los que permitieron emparentar con la aristocracia. Así se aprecia en la vinculación de la casa de Miranda con los Velasco y Cárdenas; los Sandoval con los Manrique de Lara; o los de la Cueva con los Velasco. En determinados momentos de inestabilidad se generalizó el recurso a los pactos nobiliarios que, además de promover la injerencia de la nobleza en los asuntos del reino, también sirvieron para estrechar los lazos entre diferentes familias aristocráticas. No obstante, hubo un recurso que destacó por encima de todos los demás y que fue necesario desarrollar como paso previo a los anteriores: la formación y consolidación de un importante dominio señorial que les permitiera equipararse a otros señores y que, sobre todo, se definía como la base de la cual obtener unos recursos acordes a sus aspiraciones de promoción sociopolítica. 
En este sentido, nuestro trabajo ha tratado de estudiar la realidad de cada una de estas familias analizando su evolución y las bases de su poder. El proceso de señorialización que se configuró en Castilla a lo largo de la Edad Media tuvo una plasmación muy gráfica en la Ribera del Duero, pues fue un escenario en el que, con mayor o menor intensidad, las principales familias nobiliarias comarcanas trataron de aumentar sus dominios territoriales a expensas de otros nobles, de las instituciones religiosas o de los territorios de realengo. Evidentemente esta presión sobre el territorio se materializó en numerosos y persistentes conflictos entre los distintos actores sociopolíticos.

Sin lugar a dudas, el ejemplo más significativo de esta dinámica se observa en la trayectoria de la casa de Miranda. El modesto bagaje territorial que obtuvo el I conde de Miranda del mayorazgo creado por el señor de Béjar fue rápidamente incrementado por los estados que aportó al matrimonio Aldonza de Avellaneda. Las vicisitudes familiares provocaron que el centro del señorío se afianzara en los territorios ribereños de la mano del II conde de Miranda. Finalmente, el tercero de los Zúñiga Avellaneda se encargó de consolidar un importante dominio señorial en la comarca que, junto a su posición próxima a los Velasco, le permitió ocupar un puesto de confianza al lado de los monarcas de la nueva dinastía a comienzos del Quinientos.

La casa Sandoval también compartió el origen modesto y la llegada a las tierras ribereñas a través de un enlace matrimonial con otra descendiente de los Avellaneda. La configuración de sus dominios se vio gravemente alterada por su implicación en los conflictos que a lo largo de los años centrales del siglo XV enfrentaron a los monarcas castellanos con sus primos aragoneses, a los que apoyaba incondicionalmente el primer Sandoval. El activo respaldo del primer marqués de Denia a la causa de los Reyes Católicos en el conflicto sucesorio posibilitó la vuelta de este linaje al ámbito de la confianza real, sobre todo de don Fernando. No obstante, la definición de la capitalidad de sus estados señoriales en la cercana villa de Lerma provocó que la presencia y actividad de este linaje sobre la comarca ribereña fuera en cierta medida limitada al final del periodo analizado.

En el servicio prestado a Enrique IV por don Beltrán de la Cueva se encuentra el origen de la presencia de este linaje en tierras ribereñas mediante la concesión del señorío de la villa de Roa y su Tierra. No obstante, la caída en desgracia de este personaje en los años finales del reinado de don Enrique, la capitalidad de sus estados en la cercana villa de Cuéllar y los problemas hereditarios que provocaron el paso de este territorio al 
emergente condado de Siruela restaron bastante protagonismo a la presencia de este clan en la vida política y social de la comarca ribereña en los años finales de la Edad Media.

Un origen similar tuvo el linaje de los Téllez-Girón, que también formó un notable señorío en tierras ribereñas. El punto de partida estuvo ligado al servicio real y la proximidad del maestre Pedro de Girón al monarca, vinculada sobre todo a la iniciativa de su hermano, el marqués de Villena. Los sucesivos condes de Urueña siguieron el proyecto emprendido por el patriarca. No obstante, los dominios de esta familia tuvieron un gran desarrollo en territorios próximos, como la cercana villa de Peñafiel, y en otros más lejanos, por lo que sus posesiones ribereñas jugaron un papel secundario en su dinámica expansiva general.

En definitiva, todos estos linajes nobiliarios con vinculación más o menos estrecha con la comarca ribereña configuraron a lo largo de los últimos decenios de la Baja Edad Media unos significativos estados señoriales, recurriendo para ello a diversos métodos. Esta situación, junto a las alianzas familiares y los buenos servicios a los monarcas en tiempos de inestabilidad, les permitió a todos ellos situarse en una posición destacada que, si bien no era de primer orden, sí que les posibilitó entrar dentro del reducido número de los servidores más próximos al monarca. A partir de ese momento algunos de los actores de nuestra historia, o sus sucesores, adquirieron el protagonismo que habían pretendido durante todo el periodo que hemos estudiado. Tras la última de las crisis sucesorias de principios del siglo XVI, la posición destacada de estos personajes estuvo legitimada por el servicio real y sustentada en las numerosas dádivas y mercedes concedidas por los monarcas en forma de rentas y juros. Valga como ejemplo el importante papel que jugó el III conde Miranda como Virrey de Navarra, miembro del Consejo de Guerra y mayordomo de la Casa de la Emperatriz; el cargo de ayo del Príncipe Felipe que desempeñó don Juan de Zúñiga y su participación en los Consejos de Estado y de Guerra de Carlos V; las misiones como embajador de don Íñigo López de Mendoza; o el cargo de Gobernador de la Casa de la reina Juana que ocupó don Bernardino de Sandoval.

Desde nuestro punto de vista, en el contexto de este cambio, el patrimonio territorial dejó de tener el peso fundamental que tuvo en el pasado reciente de estos linajes. Pero esta circunstancia de ningún modo implicó que dejaran de tener una fuerte presencia e influencia en la comarca ribereña que, lejos de atenuarse, se incrementó de manera exponencial. 
De esta misma dinámica participaron también los miembros de la nobleza urbana de la villa de Aranda, que consolidaron su posición de élite de poder mediante su total identificación con los intereses de la Corona y la prestación de servicios sobre todo en los momentos más delicados de la crisis comunera. Ante la pérdida de sus patrimonios territoriales o la insignificancia relativa de los mismos, muchos de los miembros de las familias Acuña, Avellaneda o Delgadillo, encontraron acomodo y fortuna en el servicio a la Corona, formando parte del extenso cuerpo de capitanes, corregidores, letrados y eclesiásticos que configuraron el engranaje del Estado Moderno.

Dentro del sector privilegiado se encontraba también el clero. Si bien es cierto que la gran influencia del clero sobre el resto de la sociedad ribereña se mantuvo firme a lo largo del periodo estudiado, sobre todo en aquellos aspectos que tuvieron que ver con todo lo referente al control de los comportamientos sociales, lo cierto es que su capacidad e influencia sobre las decisiones políticas y territoriales se vieron significativamente mermadas a lo largo del periodo estudiado. Esta situación se percibe en la débil proyección del poder episcopal en este territorio y en el discreto papel del clero secular. En este mismo sentido, la pérdida de peso geopolítico se aprecia nítidamente en el caso de las comunidades regulares, que durante las últimas décadas de la Baja Edad Media experimentaron la confirmación de la decadencia comenzada años atrás. Por una parte, sus recursos se vieron seriamente comprometidos por los intereses de algunos de los señores comarcanos que usurparon sus propiedades, derechos y vasallos. Buena prueba de esta situación es la influencia que la familia Zúñiga Avellaneda proyectó sobre los cenobios de Santa María de La Vid o San Pedro de Gumiel. Por otra parte, las instituciones monásticas se vieron inmersas en este periodo en una situación de inestabilidad generada por los conflictos derivados del proceso reformista que afectó a la iglesia castellana.

Para abordar el estudio de la gran masa social de los no privilegiados nuestro estudio se ha centrado en la sociedad urbana de la villa de Aranda de Duero. El carácter mediano de esta localidad nos ha permitido identificar elementos netamente urbanos pero también percibir las características propias del campesinado castellano. A lo largo del periodo analizado hemos comprobado cómo, en la villa de Aranda, la Comunidad se configuró como una fuerza política y una instancia de poder que aspiraba a defender sus intereses y adquirir una cuota de participación dentro del organigrama del poder local. La gran masa social de la Comunidad estaba formada por un conjunto heterogéneo de 
pequeños artesanos y comerciantes urbanos más un numeroso grupo de pequeños y medianos labradores. Aparte de su condición de pecheros, todos ellos soportaron con mayor o menor dignidad la marginación política a la que fueron sometidos por la oligarquía dominante. Dentro de esa heterogeneidad, hemos identificado al frente de la Comunidad un grupo de vecinos con una notable solvencia económica e intelectual que capitalizó las iniciativas encaminadas a fiscalizar las medidas creadas por la oligarquía para controlar los procesos productivos y mercantiles. Esta misma élite entre los pecheros fue la que en el verano de 1520 tomó la bandera de la Comunidad y puso en práctica sus aspiraciones mediante la toma violenta de las instituciones concejiles.

En nuestra opinión, la estructura del poder que se asentaba en la Castilla bajomedieval, y en la comarca ribereña en particular, estaba amparada en unos principios legitimadores creados y consolidados a través de los siglos por aquellos que monopolizaban este poder. No obstante, la estructura feudal no era estática, sino que evolucionó y se adaptó a las nuevas realidades derivadas de una sociedad dinámica. En consecuencia, cuando la estructura política no fue capaz de asimilar los cambios internos de la sociedad se generó una contradicción que necesitaba de un reajuste traumático, bien rompiendo la estructura de poder previa -revolución- o bien eliminando o reconduciendo el elemento social distorsionador -represión-. Desde nuestro punto de vista, el nuevo elemento que no fue asimilado por la estructura de poder fue esa élite dentro de la Comunidad que no consiguió canalizar sus inquietudes e intereses a través de las vías tradicionales de acceso al poder. Ante esta situación, el grupo dirigente de la Comunidad optó por una respuesta violenta mediante la cual se apropió de los resortes del poder político local, bien es cierto que sin tener muy claro -a nuestro entender- los pasos a seguir para dotar de contenido y futuro a esta iniciativa.

Evidentemente el fracaso de la experiencia comunera supuso un duro golpe para las aspiraciones de este grupo cuya opción política, y no tanto sus personas o haciendas, fue duramente reprimida. A partir de ese momento la única posibilidad que tuvo la incipiente burguesía para acceder al poder político fue mediante su integración en una oligarquía cada vez más aristocratizada; es decir, la proyección política de esta burguesía pasaba necesariamente por obtener y asimilar el estatus de privilegiado y, por lo tanto, abandonar definitivamente una posible identidad de clase burguesa. 


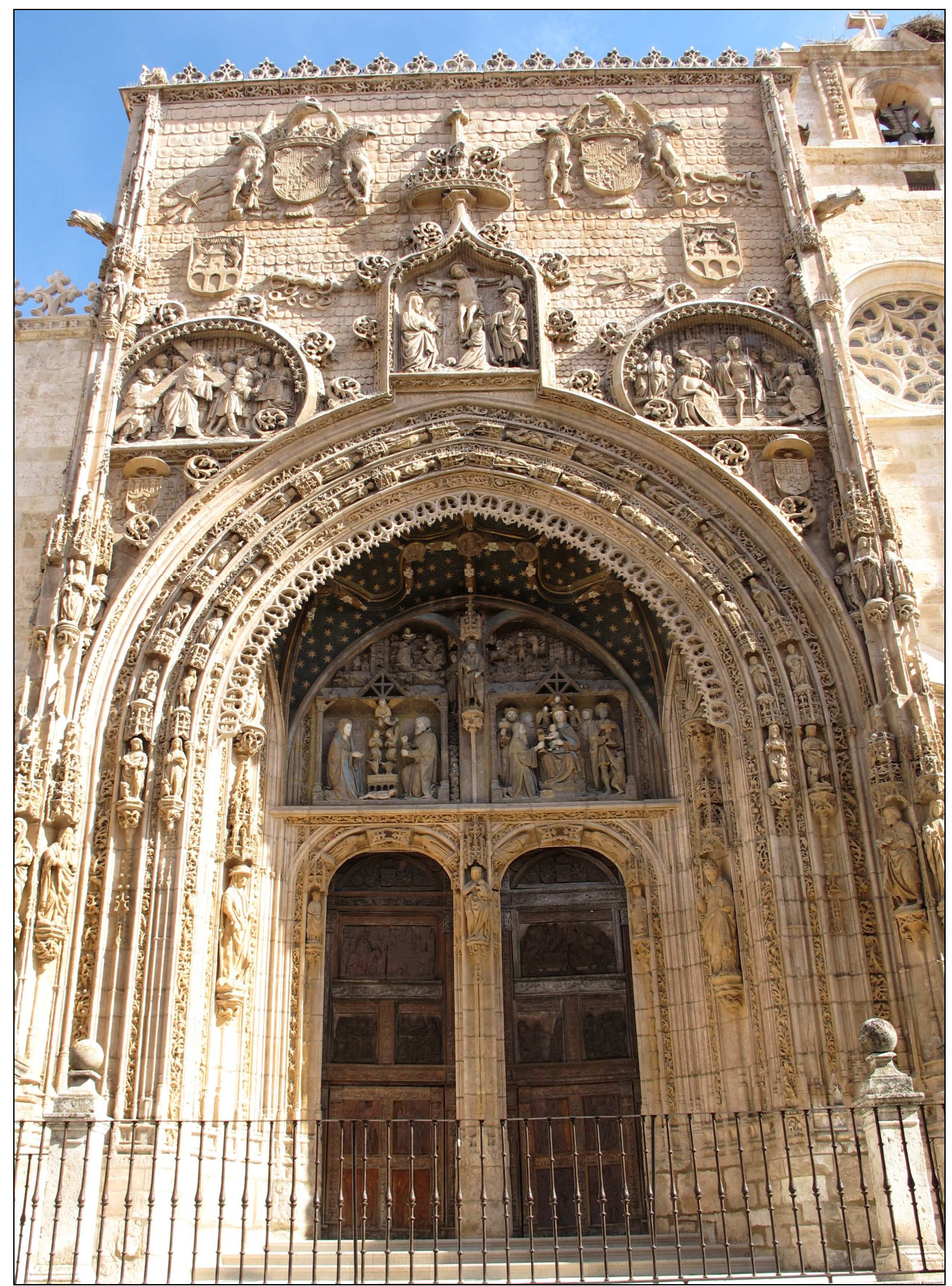

Imagen 55: Fachada de Santa María la Real de Aranda de Duero.

La evolución histórica de la Ribera del Duero burgalesa en el periodo analizado también tuvo una proyección espacial. Uno de los ejemplos paradigmáticos es la iglesia de Santa María la Real de Aranda. En su magnífica fachada retablo se puso de manifies- 
to físicamente el poder de la Corona, cuyos emblemas culminan y destacan sobre todo el conjunto. En una posición secundaria, subordinada por lo tanto a la Monarquía, se encuentra el concejo, que aparece representado mediante el escudo municipal. Por último, en un sector marginal, y con claras evidencias de haber sido añadido con posterioridad, se contempla el emblema del obispo oxomense de turno en representación del poder episcopal pues, al fin y al cabo, el edificio que servía de soporte para realzar la figura de monarquía y concejo era la iglesia cabecera del arciprestazgo.

Como ya hemos señalado anteriormente, la poderosa nobleza comarcana consiguió culminar este periodo con la consolidación del control de un vasto territorio, bien a través de la ampliación de la jurisdicción mediante compras u otros instrumentos, o bien por la imposición de facto sobre ciertos lugares. Esta dinámica plenamente medieval alcanzó su cénit en el periodo inmediatamente posterior al estudiado en este trabajo. A partir de los años treinta del siglo XVI, y durante buena parte de esa centuria, los principales linajes ribereños construyeron sobre el terreno espléndidos edificios que se convirtieron en emblemas físicos del poder y magnificencia que alcanzaron estas familias. En este sentido, es paradigmático el monumental conjunto construido por los condes de Miranda en la villa ducal de Peñaranda formado por un espectacular palacio y una grandiosa colegiata. Asimismo el monasterio de Santa María de La Vid, muy próximo a la capital del condado, experimentó una notable reforma para convertir su iglesia en el panteón funerario de la familia. De igual manera, otro de los centros de religiosidad más señalados de la Ribera, el convento del Domus Dei de La Aguilera, fue significativamente engrandecido bajo el patronato de los Zúñiga Avellaneda ${ }^{2717}$. En definitiva, los profundos cambios que experimentó el panorama territorial de la Ribera en este periodo son perfectamente percibidos de manera gráfica en el contraste entre las arcaicas fortalezas medievales de Haza y Peñaranda, redefinidas por el I conde de Miranda a mediados del siglo XV, y los exuberantes palacios e iglesias renacentistas construidos unas décadas después por su nieto y bisnieto.

De igual manera la comarca ribereña se convirtió en el escenario para la ostentación de otros importantes linajes nobiliarios. Un buen ejemplo de ello, aunque algo más tardío, es el palacio construido por la familia Sandoval en la villa de La Ventosilla destinado a albergar a los monarcas en sus frecuentes estancias cinegéticas en tierras ribe-

${ }^{2717}$ La implicación de la casa de Miranda en estas construcciones modernas, así como las que comentaremos más adelante relacionadas con las otras familias nobiliarias, han sido estudiadas por ZAPARAÍN YAÑEZ, Desarrollo artístico..., Vol. II, pp. 251 y ss. 
reñas. Este pabellón de caza fue construido en consonancia con el monumental conjunto patrocinado por la casa ducal en la cercana villa de Lerma.

La nobleza de segundo orden también plasmó sobre el espacio su creciente poder. De esta manera los condes de Castrillo, resultado de la unión de la casa Avellaneda y Delgadillo, promocionaron el traslado del monasterio de Fuencaliente a la villa de Aranda y construyeron un palacio cortesano en el lugar de Valverde, cuna de uno de sus ancestros. De igual manera los Acuña fueron los patronos, como ya hemos visto, de la implantación de la comunidad franciscana en la villa de Aranda. Poco después, otro de los miembros de esta familia fue el promotor del Colegio de la Vera Cruz en la capital de la Ribera. De igual manera los Avellaneda perpetuaron su memoria con la reforma del monasterio jerónimo de Espeja y la construcción de un palacete de la mano del patronazgo de don Diego de Avellaneda, obispo de Tuy y presidente de la Chancillería de Granada.

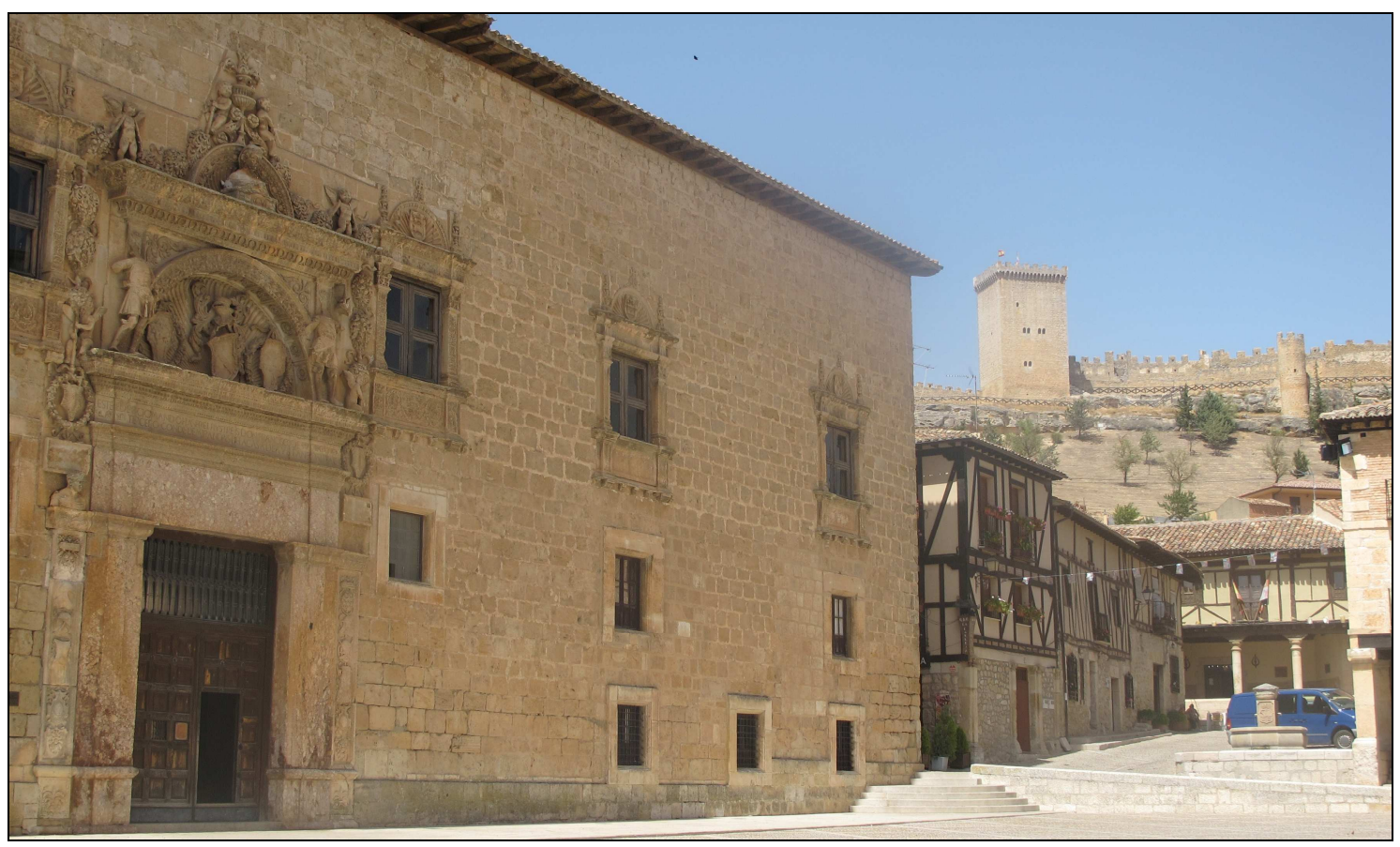

Imagen 56: Palacio renacentista de los condes de Miranda en Peñaranda de Duero.

A esta dinámica se sumó también un importante número de hidalgos urbanos que hicieron ostentación de su posición privilegiada en el seno de la oligarquía mediante la construcción de señoriales palacios urbanos, de los que en la actualidad tan solo se conserva en la villa de Aranda el de la familia Durango-Tamayo. No obstante, tenemos la certeza de que otras familias como los Salazar, Acuña, Aranda, Ortiz de Zárate o Mi- 
randa también construyeron importantes residencias durante la primera mitad del siglo XVI.

En contraposición a estas muestras de poder ligadas a los privilegiados, las evidencias físicas sobre el espacio de la actividad de la mayor parte de la población fueron bastante efímeras y apenas tenemos constancia de su existencia en la actualidad. Sin lugar dudas, una de las más importantes fue la propia configuración urbana de la villa de Aranda, que vemos representada en el Plano de 1503, y que todavía hoy pervive sin apenas modificaciones significativas. Otra evidencia material del gran dinamismo socioeconómico que experimentó la comarca a finales de la Edad Media está asociada a construcciones de carácter negativo fruto de la principal actividad económica de la villa: la elaboración y comercialización del vino. Evidentemente, el impresionante conjunto de bodegas subterráneas que horadan el subsuelo de la villa de Aranda y de otros muchos pueblos de la comarca es una de las escasas pervivencias materiales de la intensa actividad que desarrollaron los hombres y mujeres que poblaron la Ribera del Duero burgalesa a finales de la Edad Media.

Precisamente el final del periodo que hemos analizado estuvo protagonizado por esta gran masa social de pecheros que, ciertamente dirigidos por un grupo enriquecido gracias a la economía del vino, apostó decididamente por una ruptura brusca con el sistema de poder vigente en el que la Comunidad ocupaba una posición marginal. La trascendencia de la experiencia comunera se fundamenta en que durante un corto periodo de tiempo los representantes de los pecheros se situaron al frente del gobierno municipal, circunstancia que hasta ese momento nunca se había conseguido de forma generalizada. La expansión de este movimiento puso en jaque toda la estructura de poder tradicional y puso en guardia a todos los grupos que participaban del poder establecido. Corona, aristocracia y oligarquía local utilizaron todos los instrumentos a su alcance para frenar la insurrección. Desde nuestro punto de vista, la propuesta comunera comportaba, por lo tanto, un rotundo cambio en el modelo ideológico que sustentaba las relaciones de poder en la Baja Edad Media. En lo que toca al caso arandino es evidente que, a falta de una base teórica innovadora ${ }^{2718}$, la propia evolución de los acontecimientos exteriores y la iniciativa del grupo que controlaba la representatividad de la Comunidad hicie-

${ }^{2718}$ Es evidente la presencia del pensamiento humanista en la propuesta comunera pero no debemos olvidar que el argumento básico esgrimido por las autoridades comuneras se remitía constantemente a un principio bastante arcaico: hera para servicio de Dios e de sus magestades y bien del Reino en general e partycular (AGS, CC MEMORIALES, leg. 140, doc. 68). 
ron posible la puesta en práctica de una propuesta política revolucionaria que legitimaba y otorgaba el poder a quien detentaba la representatividad de la población, retirándoselo a quien lo ostentaba por delegación de una autoridad superior. Evidentemente el cuestionamiento de la autoridad superior no fue nada innovador, pues a lo largo de la Edad Media se produjeron numerosas y variadas insurrecciones antiseñoriales y, en múltiples ocasiones, la nobleza provocó y promovió situaciones que generaban la inestabilidad de la monarquía y el reino. Sin embargo, en ninguna de estas iniciativas anteriores se pretendió cambiar la estructura misma que otorgaba legitimidad al sistema de poder.

En este sentido, estimamos que uno de los principales problemas que presentaba el movimiento comunero en general fue la ausencia de sintonía entre las propuestas planteadas y la realidad y las necesidades de la mayor parte de la población del reino. Esta situación se plasmó sobre todo en un movimiento muy dinámico pero en el que se evidenciaba en la práctica una notable falta de definición ideológica. Es evidente que el ejemplo arandino no puede servir como modelo, pero observamos que la misma indefinición ideológica que se aprecia en Aranda se planteó también en el seno del grupo dirigente de la Santa Junta que fue incapaz, no tanto de articular un programa concreto, sino sobre todo de hacer llegar a la gran masa social del reino su propuesta innovadora. Desde nuestro punto de vista, este aspecto es primordial a la hora de explicar la evolución negativa del movimiento comunero, pero somos conscientes de que hubo otras muchas causas puntuales y estructurales.

El fracaso de la iniciativa comunera supuso precisamente la consolidación de la estructura ideológica y política que se había pergeñado desde mediados del siglo XV y que culminó con el triunfo de la monarquía autoritaria. Paralelamente al preponderante papel de la Corona, también se confirmó el intenso proceso de señorialización que se impuso sobre el territorio castellano, y en particular el ribereño. Este proceso tuvo como protagonista a una nobleza comarcana que reforzó su posición a través de alianzas con la aristocracia castellana y el servicio a la Corona. Paralelamente, las oligarquías urbanas vieron consolidada su posición de élite de poder local con una progresiva aristocratización del grupo y la reafirmación de la patrimonialización de los cargos municipales, ambos aspectos derivados de su perfecta imbricación dentro del servicio a los intereses de la Monarquía Autoritaria. 



\section{ÍNDICE TOPONÍMICO.}

Alcoba de la Torre, 117, 123, 299, 376, 389, $541,548,647,689,717,721$

Alcubilla de Avellaneda, 123, 376, 389, 538, $564,647,688,689,690,717,721$

Aldehorno, 85, 95, 97, 123, 558, 689, 712

Allendeduero, 152, 183, 187, 188, 200, 216, $241,244,245,246,256,258,260,367,374$, $384,414,428,440,443,607,674,721,750$, 756

Alojería, 212, 260, 261

Aranda de Duero, 11, 18, 19, 22, 23, 28, 29, 30, $32,33,34,36,39,40,41,42,43,44,45,51$, $52,54,55,57,58,59,63,67,70,73,74,77$, $78,81,82,84,93,94,95,111,113,114,120$, $122,124,125,126,127,130,132,135,137$, $141,146,147,148,152,154,155,162,164$, $166,167,168,169,170,171,177,179,182$, $193,203,210,211,219,223,224,228,236$, $237,247,249,254,256,257,258,260,262$, $273,275,280,281,286,289,295,308,309$, $311,312,315,325,329,348,350,361,381$, $383,387,403,411,418,420,421,422,429$, $432,433,434,458,544,560,570,596,603$, $606,611,615,628,663,666,673,718,778$, $779,791,818,820,824,826$

Arandilla, 18, 81, 82, 83, 87, 101, 128, 129, $176,184,203,224,236,248,252,254,256$, $263,361,367,381,384,390,394,407,518$, $536,564,614,699$

Aranzuelo, 34, 82, 83, 87, 157, 158, 159, 198, $207,213,217,255,258,261,293,295,361$, $368,381,390,391,395,407,419,613,614$

Arauzo de Miel, 83, 84, 117, 123, 385, 449, $546,548,704$

Arauzo de Salce, 117, 123, 295, 299, 522, 546, $548,593,594,666,703$

Arauzo de Torre, 101, 117, 123, 522, 548, 703

Ávila, 56, 70, 124, 223, 267, 283, 291, 298, $358,434,460,461,494,499,510,529,619$, $781,782,811$

Bahabón, 123, 452, 487, 512, 568, 677, 680, 681, 703, 716

Baños de Valdearados, 101, 102, 117, 121, 123, $299,548,550,551,556,586,593,596,641$, 666, 703

Bañuelos, 82, 83, 137, 138, 140, 143, 159, 162, $176,183,184,186,204,238,248,252,254$, 255, 260, 261, 537, 573, 593, 594

Barrionuevo, 141, 147, 163, 164, 167, 168, 179, $181,198,219,220,230,231,235,237,238$, $239,255,288,295,361,363,383,384,387$, 407, 421, 434, 491, 571, 603, 615, 673, 734, 791

Boticas, 141, 209, 220
Burgo de Osma, 31, 38, 45, 56, 94, 113, 184, 253, 428, 439, 443, 554, 557, 559, 566

Burgos, 27, 28, 31, 32, 33, 34, 35, 36, 39, 40, $42,44,45,46,49,50,51,54,55,56,58,59$, $62,63,65,66,67,72,74,78,82,84,88,90$, $91,93,94,97,99,101,102,103,104,107$, $108,110,111,112,115,124,125,127,128$, $129,130,132,137,154,155,161,162,170$, $171,184,185,186,191,200,203,210,211$, $213,219,224,248,252,253,256,258,267$, 269, 271, 272, 280, 283, 286, 287, 290, 293, 296, 309, 341, 354, 358, 359, 371, 381, 382, 391, 393, 394, 424, 428, 429, 432, 437, 443, 450, 459, 460, 472, 477, 478, 479, 480, 508, $532,543,552,554,555,556,557,558,569$, $575,576,577,593,595,599,604,606,611$, $618,625,626,648,663,685,733,738,752$, 754, 755, 761, 767, 776, 778, 781, 782, 783, $784,785,787,792,794,796,798,799,800$, $801,803,804,806,812,813$

Canaleja, 132, 177, 220

Carraquemada, 85, 178, 183, 185, 252

Casasola, 120, 123, 201, 204, 205, 262, 263, $320,324,325,332,342,343,398,415,416$, $417,630,728,730,737,738,740,748,749$, 770

Cascajar, 140, 141, 162, 164, 166, 167, 168, $169,179,181,182,183,186,213,220,221$, $228,253,255,318,320,403,435,531,614$, 616,783

Castrillejo, 18, 80, 84

Castrillo de la Vega, 128, 713

Castrillo de Luis Díaz, 538, 643, 717, 718

Castrillo de Solarana, 123, 549, 551, 766

Cerrato, 18, 19, 111, 298, 397, 467, 538, 541, $548,551,580,618,695,717$

Clunia, 35, 81, 101, 102, 105, 106, 107, 109, $111,112,118,554,556,703$

Comadre, 167, 177, 247

Conchuela, 184, 203, 252, 428

Corcos, 18, 80, 713

Coruña del Conde, 174, 298, 303, 368, 432, 433, 436, 437, 438, 439, 558, 560, 670, 717

Domus Dei, 42, 379, 552, 575, 598, 599, 600, $601,602,603,604,605,609,644,654,655$, 827

Espeja, 83, 123, 517, 521, 619, 700, 709, 717, 828

Espejón, 80, 123, 517, 521, 700, 717

Fresnillo, 103, 116, 123, 143, 211, 216, 265, $299,367,576,577,579,648,696,698,712$, $721,764,787$

Fuencaliente, 122, 263, 296, 331, 536, 618, 619, $699,700,708,717,828$ 
Fuentelcésped, 123, 143, 216, 265, 272, 299, $448,450,459,467,468,569,577,579,580$, $581,696,712,713,764,786$

Fuentelisendo, 45, 123, 178, 467, 525, 529, 600, $681,682,684,712,713,765,766,816$

Fuenteminaya, 183, 186, 199, 215, 252, 256, 573,618

Fuentenebro, 439, 440, 577, 716, 753

Fuentespina, 120, 123, 176, 201, 204, 205, 217, $262,320,540,565,635,693$

Gromejón, 81, 82, 83, 86, 87, 98, 269, 459, 466, $491,685,686,688,712,714$

Gumiel de Izán, 62, 67, 72, 80, 112, 119, 121, $123,131,144,284,309,316,331,354,359$, $365,452,478,484,485,487,488,491,506$, $509,510,511,512,526,528,546,547,560$, $573,577,581,582,583,584,589,596,635$, $650,655,659,673,677,678,679,680,681$, $685,691,701,703,714,715,716,797,816$

Gumiel del Mercado, 80, 87, 94, 97, 111, 114, $119,123,206,270,284,346,372,420,449$, $452,466,484,487,535,538,548,556,577$, $603,664,680,685,686,714,715,759,797$, 810

Guzmán, 34, 58, 62, 89, 114, 117, 118, 263, $309,365,448,455,456,457,459,463,467$, $477,511,514,515,520,535,537,538,540$, $543,544,548,549,553,559,560,573,590$, $597,617,666,667,692,701$

Haza, 45, 101, 108, 110, 112, 115, 118, 121, $123,144,151,200,210,261,265,270,272$, $273,285,310,331,346,377,395,433,449$, $452,456,458,459,460,464,468,525,535$, $555,558,560,561,562,649,667,682,683$, $696,711,713,768,769,794,797,827$

Hesilla, 158, 159, 162, 164, 167, 169, 177, 181, $183,184,185,188,190,198,201,202,220$, $229,230,231,252,255,256,355,380,383$, $421,428,614,643$

Hocino, 137, 138, 145, 158, 162, 168, 177, 178, $207,211,236,237,238,239,253,261,427$, 665

Honrubia, 80, 81, 459, 569, 713

Hontoria de Valdearados, 117, 123, 265, 284, $459,467,468,548,550,551,577,701,766$

Hospital, 256, 542, 574

Hoyales, 45, 94, 123, 178, 259, 285, 467, 471, $524,525,529,627,681,682,683,684,711$, $712,713,765,766,775,776,816$

Huerta del Rey, 80, 83, 123, 184, 275, 296, 448, $549,560,666$

Judería, 234

La Aguilera, 40, 42, 85, 87, 97, 121, 123, 129, 144, 204, 217, 269, 331, 372, 374, 379, 420, $450,459,466,538,552,553,575,598,599$, $600,601,602,603,604,605,606,607,609$, $644,654,655,685,686,687,688,712,713$, 757,827

La Calabaza, 96, 143, 185

La Nava, 260, 713
La Ventosilla, 98, 123, 265, 270, 275, 403, 603, $683,684,714,764,765,766,776,827$

La Vid, 36, 54, 57, 93, 94, 101, 112, 118, 120 , $122,260,264,331,352,448,450,460,477$, $480,552,559,576,577,578,579,580,581$, $583,585,591,597,604,662,695,696,697$, $698,701,711,733,736,764,816,824,827$

Langa, 101, 123, 619, 641, 712, 714

Lerma, 19, 27, 47, 94, 95, 116, 275, 296, 358, $362,371,373,387,483,484,487,488,489$, $491,492,604,631,715,766,797,816,822$, 828

Medina del Campo, 124, 267, 274, 298, 312, $326,341,505,510,592,720,784,804$

Milagros, 59, 80, 97, 101, 120, 161, 178, 191, 265, 266, 283, 404, 419, 448, 460, 468, 540, $564,565,572,584,585,587,589,627,691$, $692,693,694,695,711,713,764,770,816$

Montejo, 79, 82, 108, 118, 123, 161, 265, 282, $440,456,459,468,535,540,553,555,560$, $569,570,572,578,684,696,711,713,797$

Moradillo, 84, 123, 210, 216, 218, 229, 274, $299,420,421,422,436,580,636,689,696$, $697,712,713,785,789,791,808,810$

Morería, 240, 241

Palencia, 39, 46, 65, 71, 124, 129, 133, 139, $147,162,186,244,252,267,283,288,296$, $303,463,464,465,483,494,495,501,541$, $542,553,600,601,628,629,630,634,635$, 696

Pardilla, 84, 327, 459, 564, 565, 569, 711, 713

Pedraja, 137, 194, 195

Peñafiel, 19, 36, 78, 94, 255, 313, 344, 357, $365,377,403,405,438,460,484,505,509$, $510,516,548,593,643,752,769,797,823$

Peñaranda, 40, 68, 98, 109, 111, 123, 128, 184, $215,255,272,284,329,336,434,440,449$, $450,452,453,454,455,456,457,458,459$, $460,463,464,465,467,468,469,471,473$, $475,476,477,479,535,556,560,575,584$, $587,596,648,694,696,701,711,713,722$, $757,775,797,827,828$

Pescadería, 207, 209, 211

Plaza de la Resina, 177, 185, 215

Plaza del Trigo, 144, 167, 175, 209, 220, 231, 237,337

Plaza Nueva, 141, 144, 145, 156, 158, 161, 167, $169,170,173,174,181,184,190,192,207$, $209,212,226,227,229,233,237,248,261$, $337,406,428,491,615,733$

Plaza Pública, 147, 158, 165, 167, 171, 172, $175,189,190,206,209,337$

Pontecilla, 138, 177, 211, 220, 227, 253

Postas, 33, 153, 155, 158, 159, 185, 256

Pradales, 18, 79, 80, 84, 569, 713

Puerta Nueva, 33, 155, 159, 160, 163, 164, 169, $170,220,238,258,351,615$

Quemada, 50, 101, 119, 120, 129, 143, 164, 176, 203, 204, 213, 236, 251, 255, 262, 263, $266,320,327,331,337,355,357,361,363$, 
$368,372,375,377,383,384,385,386,387$, $388,389,390,391,392,394,395,403,409$, 411, 415, 430, 446, 546, 582, 647, 648, 721, $722,723,733,740,744,753,759,760,764$, 787, 788, 789, 790, 793, 810

Quintana del Pidio, 40, 85, 110, 123, 270, 295, $304,448,544,552,555,585,662,685,742$

Quintanarraya, 117, 123, 517, 520, 521, 522, $546,548,549,550,551,556,689,703,709$

Quintanilla de Nuño Pedro, 536, 688, 689

Revilla de Olleros, 143, 172, 263, 264, 265, $331,383,413,577,578,579,662,736,764$

Riaza, 48, 56, 81, 82, 83, 84, 86, 97, 106, 108, $269,525,584,684,711$

Roa, 18, 19, 46, 66, 73, 82, 83, 84, 85, 89, 95, $101,102,103,105,106,108,111,112,113$, $114,115,118,123,127,135,150,156,174$, $189,191,206,252,265,269,270,283,286$, $303,310,312,313,380,410,416,433,434$, $437,439,464,465,493,494,499,500,501$, $502,503,504,539,544,558,559,560,562$, $563,567,568,577,583,586,587,631,634$, $641,649,659,666,709,716,726,732,756$, $797,798,806,810,822$

Ronda, 155, 158, 169, 177, 227, 233, 247, 532

Salas de los Infantes, 34, 102, 184, 396, 405

San Andrés, 84, 110, 182, 183, 186, 204, 215, $216,251,258,303,329,428,429,555$

San Esteban de Gormaz, 19, 106, 113, 184, 253, $274,275,442,558,562,590,591,593,596$, 600,751

San Francisco, 34, 85, 87, 164, 169, 182, 183, $184,185,188,195,197,198,199,238,252$, $256,257,272,288,295,360,368,371,373$, $381,401,402,403,419,529,530,531,533$, $534,552,599,600,602,607,608,610,611$, $612,613,615,616,617,640,644,654,655$, $657,658,675,734,783,809$

San Gregorio, 185, 202, 256, 428

San Juan, 32, 33, 51, 54, 84, 111, 127, 128, 130, $132,133,137,138,140,158,162,167,175$, $177,178,180,182,183,186,189,190,195$, 203, 204, 213, 220, 224, 227, 230, 231, 238, $241,247,249,251,253,261,318,320,352$, $362,418,421,428,431,435,440,534,556$, $570,573,574,614,633,656,657,658,663$, 783, 786, 791, 809

San Lázaro, 177, 188, 200, 246, 260, 406, 428, 429, 607

San Llorente, 138, 158, 177, 178, 179, 181, 193, 220, 226, 227, 238, 261, 320, 428, 555, 783

San Martín de Rubiales, 12, 95, 454

San Pedro, 31, 62, 65, 110, 111, 112, 114, 116, $118,119,121,122,128,131,179,191,203$, $263,265,288,304,309,359,419,426,427$, $429,448,460,468,478,491,506,528,539$, $546,552,555,556,558,559,562,564,575$, $578,581,582,583,584,585,586,587,588$, $589,591,594,597,627,642,644,651,652$,
$672,677,691,692,693,694,695,701,712$, $764,816,824$

San Pedro de Gumiel, 62, 65, 112, 114, 116, $119,121,122,131,179,191,263,265,288$, $309,359,419,448,460,468,478,528,552$, 559, 564, 578, 581, 582, 583, 587, 588, 589, $591,594,597,627,642,651,652,691,692$, $694,695,701,712,764,816,824$

San Roque, 177, 181, 185, 201, 320, 428, 429, 783

San Sebastián, 30, 36, 186, 199, 215, 216, 222 , $428,429,633,650$

Santa Ana, 162, 163, 164, 177, 178, 179, 180, $182,194,195,202,229,239,240,260,351$, $373,418,421,426,427,428,532,564$

Santa Catalina, 185, 203, 216, 257, 428, 430, 658

Santa Cruz de la Salceda, 18, 359

Santa Isabel, 199, 616

Santa Lucía., 429

Santa María, 17, 27, 32, 36, 55, 57, 71, 73, 94, $110,112,116,122,123,131,138,140,141$, $143,144,147,165,168,170,171,172,174$, $175,177,182,189,190,191,201,204,206$, $207,208,209,210,211,219,220,223,237$, $265,274,303,329,332,334,337,346,352$, $355,361,370,376,377,383,388,391,392$, 394, 401, 402, 429, 430, 450, 478, 480, 501, $512,522,524,525,528,529,539,541,544$, $547,555,558,562,563,564,569,570,571$, $572,573,574,575,576,578,581,585,587$, 590, 591, 594, 597, 601, 604, 608, 612, 615, $618,619,643,647,650,652,657,658,659$, $661,664,675,680,695,696,697,698,701$, $702,711,713,716,730,733,753,764,791$, $793,802,812,816,824,826,827$

Santa María de Roma, 201

Santa María del Mercadillo, 94, 123, 512, 522, 524, 525, 529, 547, 680, 702

Santiago de la Encina, 355

Santibáñez, 492, 506, 509, 681, 703, 714

Santo Cristo, 130, 138, 178, 193

Segovia., 37, 78, 233, 236, 323, 434, 553, 634

Sepúlveda, 19, 40, 43, 55, 92, 98, 105, 135, 211, 282, 290, 291, 318, 346, 397, 444, 480, 550, $560,629,630,771,772,794,797$

Sinovas, 40, 50, 99, 100, 120, 121, 123, 202, $204,205,262,266,320,361,427,428,539$, $564,782,785,789,810,811$

Soria, 18, 29, 38, 41, 44, 48, 64, 78, 82, 88, 91, $97,113,171,178,184,187,253,258,267$, $271,296,303,306,349,360,377,378,397$, 403, 405, 406, 432, 443, 553, 554, 558, 562, $600,670,680,690,729,751,771,797$

Sotillo, 44, 274, 483, 492, 636, 686, 714

Tenerías, 182, 183, 186, 204, 251, 428

Torregalindo, 85, 114, 121, 123, 144, 439, 459, $493,499,500,501,502,504,555,577,636$, $684,711,716$

Tórtolas, 290 
Tubilla del Lago, 84, 116, 123, 577, 579, 580, $582,583,641,666$

Vadocondes, 94, 117, 123, 217, 253, 260, 299, $332,352,366,367,374,421,448,548,549$, $550,551,577,578,583,630,642,643,648$, 704,721

Valdeande, 80, 117, 123, 450, 454, 548, 549, $550,551,552,555,577,593,595,596,641$, 642,666

Valdeherreros, 440, 459, 540, 565, 693, 711, 713

Valladolid, 11, 16, 23, 27, 30, 31, 34, 35, 36, $37,38,39,42,44,46,48,50,51,53,54,55$, $56,57,59,60,61,62,63,64,65,66,67,69$, $70,71,73,74,78,82,84,86,88,93,100$, $101,102,103,107,111,115,117,119,120$, $124,125,133,134,164,169,170,171,175$, $183,185,187,190,200,206,213,224,228$, $234,240,243,244,245,249,252,253,256$, 258, 263, 267, 269, 271, 272, 283, 286, 296, 297, 298, 302, 303, 305, 306, 308, 314, 331, $341,348,349,354,356,362,377,378,383$, $396,409,439,443,447,455,457,458,460$,
476, 477, 479, 481, 492, 504, 505, 511, 522, $529,542,544,582,596,597,600,619,625$, $637,653,655,668,670,678,704,720,737$, $739,743,752,755,765,767,769,776,778$, $785,796,798,799,800,801,803,804,808$, 811,813

Valverde, 123, 459, 524, 531, 533, 535, 536, 537, 538, 543, 544, 563, 689, 690, 699, 700, $708,713,717,828$

Vega Duero, 120, 123, 262

Villalar, 172, 361, 364, 378, 422, 472, 504, 787, $789,801,803,804,805,808$

Villalba, 120, 123, 204, 205, 262, 266, 303, $320,456,465,539,765$

Villovela, 210, 449, 483, 487, 488, 535, 542, 714

Virgen de las Viñas, 86, 186, 193, 198, 573, 617,809

Zayas de la Torre, 123, 540, 541, 544, 649, 650, 717

Zazuar, 117, 119, 121, 123, 144, 548, 550, 551, 586

Zuzones, 123, 576, 577 


\section{ÍNDICE DE CUADROS Y GRÁFICOS:}

Cuadro 1: La población de la Ribera del Duero a principios del siglo XVI.

Cuadro 2: Evolución de la alcabala del vino en Aranda (1478-1506).

Cuadro 3: Relación de los corregidores de Aranda entre 1480 y 1524. 290

Cuadro 4: Evolución de las alcabalas en la villa de Aranda (1477-1523). 300

Cuadro 5: Los señores de la villa de Aranda de Duero (s. XIII-XV).

Cuadro 6: Esquema genealógico de la familia Santa Cruz. 398

Cuadro 7: Esquema genealógico de los señores de Avellaneda en la comarca. 451

Cuadro 8: Esquema genealógico de los condes de Miranda. 462

Cuadro 9: Esquema genealógico de la familia Sandoval y Rojas. 486

Cuadro 10: Esquema genealógico de los duques de Alburquerque y los condes de Siruela

Cuadro 11: Esquema genealógico de la familia Téllez-Girón. 507

Cuadro 12: Esquema genealógico de los condes de Coruña. 519

Cuadro 13: Descendientes del IX señor de Avellaneda. 526

Cuadro 14: Esquema genealógico de la familia Vázquez de Acuña. 527

Cuadro 15: Dominio del conde de Miranda según la Averiguación de la Corona de Castilla.

Cuadro 16: Dominio del Marqués de Denia según la Averiguación de la Corona de Castilla.

Cuadro 17: Dominio del Conde de Urueña según la Averiguación de la Corona de

Castilla.

Cuadro 18: Evolución de la alcabala de los paños en Aranda (1478-1506).....

Cuadro 19: Evolución de la renta de cueros y corambre en Aranda (1477-1505).

Cuadro 20: Algunos datos sobre los bienes de los exceptuados del perdón general en Aranda. 


\section{ÍNDICE DE IMÁGENES:}

Imagen 1: Detalle del barrio de San Juan según el plano de 1503.

Imagen 2: La calle del Pozo en el plano de 1503.

Imagen 3: Plano de Imola de Leonardo Da Vinci.

Imagen 4: Detalle del lienzo identificado en la calle Santa Lucía n ${ }^{\circ} 6$.

Imagen 5: Fotografía de Las Traseras en la que se aprecia un cubo de la muralla.....

Imagen 6: Detalle del cubo localizado en Puerta Nueva $\mathrm{n}^{\circ} 38$.

Imagen 7: Detalle de los lienzos de la muralla que aparecen en el plano de Coello.... 157

Imagen 8: La Puerta de Duero.

Imagen 9: La Puerta de Duero a mediados del siglo XX........................................... 160

Imagen 10: Remodelación del Arco en 1971 ............................................................. 161

Imagen 11: Restos del cubo meridional de la Puerta Nueva........................................ 163

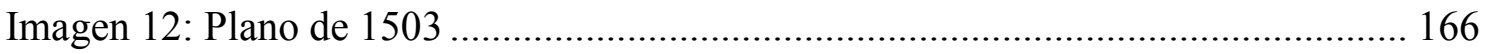

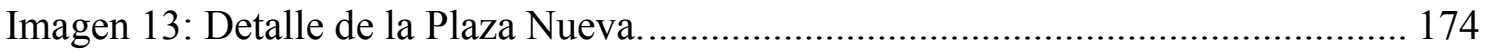

Imagen 14: Detalle de la Plaza Pública o de Santa María y de la Plaza del Trigo....... 175

Imagen 15: Plaza Pública, cementerio e iglesia de Santa María. .................................. 190

Imagen 16: Las gradas de Santa María a principios del siglo XX............................ 191

Imagen 17: Puerta y ermita de Santa Cruz. ............................................................... 192

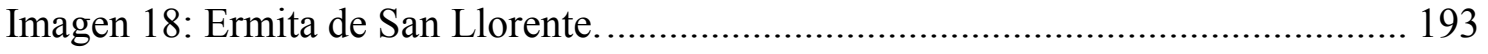

Imagen 19: Ermita de San Lorenzo poco antes de su derrumbe ................................. 194

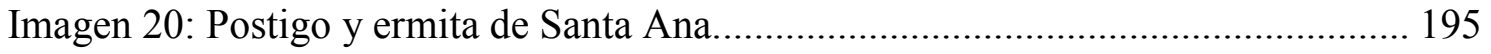

Imagen 21: Detalle del convento de San Francisco según el plano de Coello............. 197

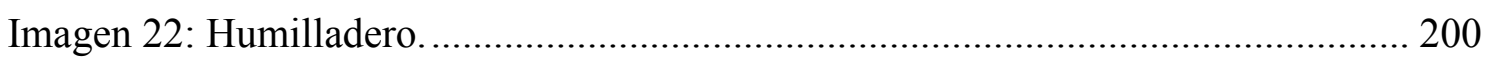

Imagen 23: La Plaza del Obispo o de la Resina a principios del siglo XX................. 202

Imagen 24: Iglesia parroquial de San Nicolás de Bari de Sinovas.............................. 205

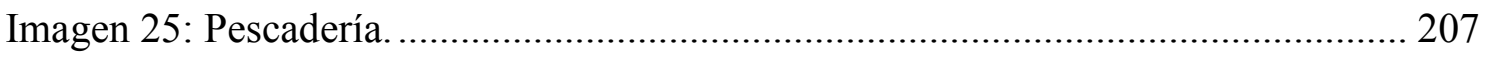

Imagen 26: Interior de la bodega Tierra Aranda o Requejo ........................................ 218

Imagen 27: Detalle del caserío en el plano de 1503................................................... 225

Imagen 28: Alzado de las traseras de unas casas del XVIII de la calle Empedrada .... 226

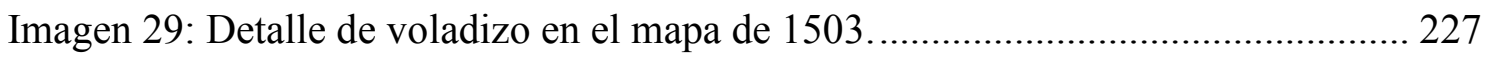

Imagen 30: Detalle de las casas de Pedro de Santa Cruz. ......................................... 230

Imagen 31: Detalle de las casas de don Martín Vázquez de Acuña............................ 231 
Imagen 32: Detalle de las casas del Ayuntamiento. 232

Imagen 33: Detalle de la cubierta en forma de cúpula. 233

Imagen 34: Detalle de la calle de la Morería Vieja. 241

Imagen 35: Detalle de la calle de la Comadre Vieja. 247

Imagen 36: Grabado de Salneuve, s. XVIII 250

Imagen 37: Puente e iglesia de San Juan. 251

Imagen 38: Detalle de la fuente de Hesilla y su recorrido en el plano de Coello. 256

Imagen 39: Fuente de Santo Domingo o del Torillo. 257

Imagen 40: La calle Béjar o Alojería a comienzos del siglo XX. 260

Imagen 41: Sambenito de maestre Juan. 303

Imagen 42: Claves de la iglesia de San Juan Bautista y primitivo escudo de Aranda. 352 Imagen 43: Escudo de la villa de Aranda de la fachada de Santa María..... 352

Imagen 44: Palacio de los Berdugo en la actualidad. 366 Imagen 45: Sepulcro de Pedro de Salazar (izq.) y de sus padres (der.) en la capilla ... 370 Imagen 46: Escudo localizado en el palacio de los Berdugo e imagen de Diego de Curiel en el Libro de los caballeros de la Cofradía de Santiago de Burgos. 382

Imagen 47: Carretero a principios del siglo XX. 430

Imagen 48: Castillo de Peñaranda. 458

Imagen 49: Escudo de don Martín Vázquez de Acuña en San Francisco de Aranda... 529

Imagen 50: Puerta de la capilla de los Acuña Avellaneda en San Francisco.

Imagen 51: Restos del antiguo convento de San Francisco de Aranda. 610

Imagen 52: Representación del Burgos en Civitates Orbis Terrarum 755

Imagen 53: Restos del castillo de la Torre del Monte o Aunqueospese. 769

Imagen 54: Listado de los implicados en el movimiento comunero en Aranda...... 788

Imagen 55: Fachada de Santa María la Real de Aranda de Duero.

Imagen 56: Palacio renacentista de los condes de Miranda en Peñaranda de Duero. .. 829 


\section{ÍNDICE DE MAPAS:}

Mapa 1: La Ribera del Duero burgalesa en la actualidad.......................................... 17

Mapa 2: Principales elementos del relieve en la Ribera del Duero................................ 79

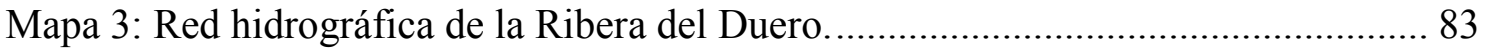

Mapa 4: Detalle del Sur de la provincia de Burgos según Tomás López....................... 94

Mapa 5: Representación del monte de La Calabaza en el siglo XVIII........................... 96

Mapa 6: El alfoz de Clunia según Martínez Díez........................................................ 107

Mapa 7: Las Comunidades de Villa y Tierra en la Ribera del Duero. ......................... 109

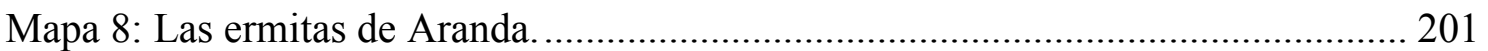

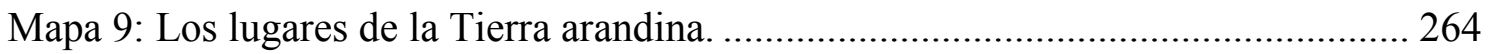

Mapa 10: La red de caminos de la villa de Aranda a finales de la Edad Media........... 268

Mapa 11: Señorío territorial de los condes de Miranda.................................................475

Mapa 12: El señorío territorial de los marqueses de Denia ......................................... 490

Mapa 13: El señorío territorial de los De la Cueva-Siruela......................................... 503

Mapa 14: Señorío territorial de los condes de Urueña. ................................................. 513

Mapa 15: Señorío territorial de los condes de Coruña. ................................................. 521

Mapa 16: Las behetrías en la Ribera del Duero burgalesa según Estepa Díaz............. 547

Mapa 17: Dominios monásticos y behetrías en la Ribera a finales de la Edad Media. 552

Mapa 18: Zona occidental del Obispado de Osma según Loperráez Corvalán............. 561

Mapa 19: Posesiones del monasterio de Santa María de La Vid en la Ribera............. 578

Mapa 20: Posesiones del monasterio de San Pedro de Gumiel en la Ribera. .............. 583

Mapa 21: Trazado del proyecto de canalización del río Aranzuelo. ............................. 613

Mapa 22: La realidad señorial en la Ribera burgalesa a fines de la Edad Media......... 710

Mapa 23: Esquema de la realidad señorial en la Ribera a fines de la Edad Media...... 711 


\section{ÍNDICE DE PLANOS:}

Plano 1: Topografía del terreno sobre el que se asienta Aranda de Duero.................... 126

Plano 2: Hipotético trazado del núcleo de nueva fundación arandino. ......................... 136

Plano 3: Esquema de la primera cerca según Abad Zapatero...................................... 140

Plano 4: Esquema de la primera ampliación de la cerca según Sáinz Guerra.............. 142

Plano 5: La villa de Aranda de Duero a finales del siglo XV. .................................... 146

Plano 6: Aranda y sus arrabales a principios del siglo XVI. ....................................... 184

Plano 7: Localización de las eras arandinas. ............................................................... 215

Plano 8: Plan de las bodegas subterráneas de Aranda según Iglesias y Villahoz......... 219

Plano 9: Emplazamiento de la antigua y nueva judería................................................ 235

Plano 10: Modificaciones urbanísticas en Barrionuevo a finales de la Edad Media.... 238

Plano 11: Hipotético emplazamiento de las morerías vieja y nueva y el fonsario....... 242

Plano 12: Trazado del proyecto de canalización del río Aranzuelo en Aranda............ 255 